DEPARTMENT OF THE INTERIOR UNITED STATES GEOLOGICAL SURVEY CHARLES D. WALCOTT, DIRECTOR

\title{
GEOGRAPHIC DICTIONARY OF ALASKA
}

BY

MARCUS BAKER

SECOND EDITION

PREPARED BY

JAMES MCCORMICK

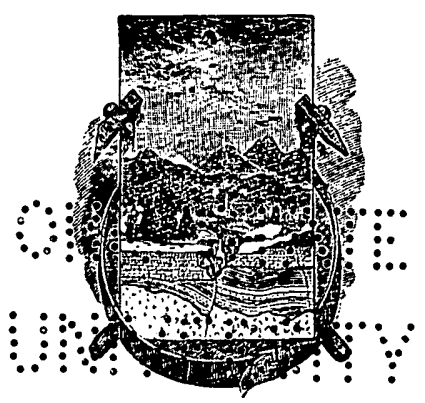

WASHINGTON

GOVERNMEN'T PRINING OFFICE

1906 


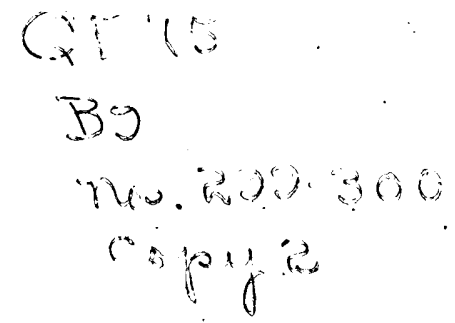

\section{CONTENTS.}

Preface

United States Board on Geographic Names

Executive order of September 4, 1890

Executive order of January 23, 1906

Members and officers, June, 1906

Adoption of dictionary

Introduction

Origin of dictionary

Plan and scope

Origin of names

Principles employed and reforms attempted

Authorities

In chronologic order

In alphabetic order

Dictionary

2

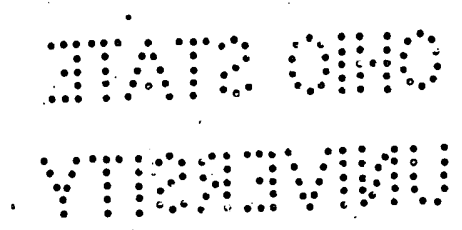




\section{PREFACE.}

The first edition of this dictionary, published in 1902 as Bulletin No. 187 of the United States Geological Survey, proved a most useful work to map makers, writers, and editors, and was soon exhausted. Since its publication the wonderful development of Alaska's resources has continued at an accelerated rate. Ocean cables have been laid, relegraph lines built, light-houses and railroads constructed, and mail routes established; old mining fields have been developed and new ones discovered and prospected; mining camps of that day have grown to populous cities, and new towns and camps have sprung up.

The Government has generously contributed of its resources to encourage, promote, and aid this development. In this work many of its bureaus and organizations have been employed. The Army made explorations, established the telegraph, and built posts and roads; the Geological Survey has continued its explorations, surveys, and investigations of the geology and mineral resources; the Coast Survey has continued to survey the coasts and harbors; the Fish Commission and its successor, the Bureau of Fisheries, have proceeded with their investigations of the fisheries and have established hatcheries and fish-culture reserves; the Agricultural Department has made investigations of the agricultural resources, established agricultural experiment stations, and studied the animal and plant life; the Revenue-Cutter Service, the Light-House Board, the General Land Office, the Post-Office Department, the Bureau of Education, have all been active in their respective spheres.

One of the results of these activities is a great body of maps, charts, and reports which have added vastly to our knowledge of Alaskan geography and resources. Each of these contains its quota of geographic names, there first published, obtained from the natives or given by old settlers, miners, prospectors, pilots, fishermen, or the explorers and surveyors themselves. While a gratifying proportion of these new geographic names, like the old, especially those of the larger and more important natural features, are of Eskimo or Indian origin, it is regrettable that so large a proportion of the names given by miners and prospectors, repeated in the various diggings, are 
the same as names met at every turn in the mining regions of the West. The first edition of this dictionary contained about 6,300 names and 2,800 cross references. The present volume contains about 9,300 names and 3,300 cross references. These numbers may be taken as a rough indication of Alaskan growth.

To compile and describe the application of the new names has required constant comparison with the older maps and literature, to discover whether other names had been adopted for the same features. Such duplications, discovered in the first edition, have been eliminated, and doubtless, despite the care taken to avoid it, still others have been introduced. Many names, probably several hundred in the aggregate, have been taken from older maps and publications not consulted in the original compilation, and earlier usage than that cited in the first edition has been discovered for still other names. In numerous instances original descriptions have been amended or rewritten and made to conform with the more accurate maps of the present day. Excepting obvious errors, however, decisions of the United States Board on Geographic Names, and a few instances in which present usage unquestionably required a change, the names and forms adopted in the first edition have been scrupulously retained. The principles adopted for guidance in the original compilation have been followed in the new, and the same letter values; those adopted by the Board on Geographic Names, have been employed in transliterating foreign and writing native names whenever a choice has been offered.

This revision has made manifest to a degree not before appreciated the great labor involved in the original compilation, as well as its thoroughness and accuracy. Mr. Baker had planned a revision of. his work, but was not spared to undertake it.

The writer would here acknowledge his indebtedness to his colleagues in the office of the editor of topographic maps for valuable assistance rendered; to Mr. S. J. Kübel, the responsible head of that office, for facilities provided; and to Mr. Alfred Hulse Brooks, geologist in charge, division of Alaskan mineral resources, and the geologists and topographers of that division, for helpful suggestions, information, and facilities. 


\section{UNITED STATES BOARD ON GEOGRAPHIC NAMES. ${ }^{a}$

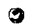 \\ EXECUTIVE ORDER OF SEPTEMBER 4, I8go.}

As it is desirable that uniform usage in regard to geographic nomenclature and orthography obtain throughout the Executive Departments of the Government, and particularly upon the maps and charts issued by the various departments and bureaus, I hereby constitute a Board on Geographic Names, and designate the following personș, 'who have heretofore cooperated for a similar purpose under the authority of the several Departments, bureaus, and institutions. with which they are connected, as members of said Board:

Prof. Thomas C. Mendenhall, United States Coast and Geodetic Survey, chairman.

Andrew H. Allen, Department of State.

Capt. Henry L. Howison, Light-House Board, Treasury Department.

Capt. Thomas Turtle, Engineer Corps, War. Department.

Lieut. Richardson Clover, Hydrographic Office, Navy Department.

Pierson H. Bristow, Post-Office Department.

Otis T. Mason, Smithsonian In'stitution.

Herbert G. Ogden, United States Coast and Geodetic Survey.

Henry Gannett, United States Geological Survey.

Marcus Baker, United States Geological Survey.

To this Board shall be referred all unsettled questions concerning geographic names. which arise in the Departments, and the decisions of the Board are to be accepted by these Departments as the standard authority in such matters.

Department officers are instructed to afford. such assistance as may be proper to carry on the work of this Board.

The members of this Board shall serve without additional compensation, and its organization shall entail no expense on the Government.

Benj. Harrison.

Executive Mansion,

September 4, 1890.

\section{EXECUTIVE ORDER OF JANUARY 23 , 1906.}

It is hereby ordered that there be added to the duties of the United States Board on Geographic Names, created by Executive order dated September 4,1890 , the duty of deternining, changing, and fixing

a Official title changed to United States Geographic Board by Executive order of August $10,1906$. 
place names within the United States and insular possessions, and it is hereby directed that all names hereafter suggested for any place by any officer or employee of the Government shall be referred to said Board for its consideration and approval before publication.

In these matters, as in all cases of disputed nomenclature, the decisions of the Board are to be accepted by the Departments of Government as the standard authority.

Theodone Roosevìlt.

The White House,

January 23, 1906.

MEMBERS AND OFFICERS, JUNE, Igo6.

HENRY GanNETT, Chairman,

United States Geological Survey.

C'Harles S. Sloane, Secretary,

Bureau of the Census.

Maj. William D. Beach, General Staff, War Department.

I'RANK Bown,

General Land Office.

Andreiv Braid,

Coast and Geodetic Survey.

Chardes Denbi,

Department of State.

ArNold B. JoHnson,

Light-House Board.

O'Is 'T. Mason,

Smithsonian Institution.

C. Hart Merriam,

Department of Agriculture.

JoHN S. Milds,

Treasury Department.

C. M. Robinson,

Government Printing Office.

Commander C. C. Rogers. U. S. N.,

Navy Department.

ADó́PH VON HAAKE,

Post-Office Department.'

\section{ADOPTION OF DICTIONARY.}

\section{FIRST EDITION.}

At a special meeting of the United States Board on Geographic Niames held July 29, 1901, the following resolution was adopted.

Whereas the United States Board on Geographic Names some ten years ago determined to prepare a dictionary of Alaska geographic names and appointed a committee which began the work of collecting the material therefor; and

Whereas such committee, consisting of Messrs. H. G. Ogden and Marcus Baker, entered upon the work and prosecuted it for two or three years, collecting the names from all published and original sources; and

Whereas Mr. Marcus Baker has since collected and discussed the evidence relating to the names and alternatives, in connection with his official duties, and has written the dictionary: Therefore,

Resolved, That the Board approve this dictionary, thus prepared, and provisionally adopt the approved forms contained therein.

\section{SECOND EDITION.}

At the regular meeting of the United States Board on Geographic Names held June 6, 1906; the following resolution was adopted.

Resolved, That the Board approve the second edition of the Dictionary of Aliska Geographic Names, which has recently. been prepared by the United States Geological Survey, and provisionally adopt the approved forms contained therein. 


\title{
GEOGRAPHIC DICTIONARY OF ALASKA.
}

\author{
By Marcus Baker. \\ Second edition, prepared by JAmes McCormick.
}

INTRODUCTION.

ORIGIN.

This dictionary is the outgrowth of work undertaken by the Board on Geographic Names in 1892. Shortly after the Board was organized there was submitted to it a list of two or three hundred names of geographic features in Alaska which were variously spelled or which bore two or more names. The Board studied these names, sought information and advice from experts, and finally decided all the cases. But the studies made in order to ascertain the facts and to establish principles for guidance in the determination of cases made it plain that nothing short of a complete revision of all the geographic names in Alaska could yield satisfactory results. Accordingly the Board, after full discussion, decided to undertake such revision and to prepare a geographic dictionary. For this purpose it appointed a committee to collect and arrange the material. The committee consisted of Messrs. H. G. Ogden, of the Coast and Geodetic Survey, and Marcus Baker, of the Geological Survey. The territory was divided, Mr. Ogden undertaking to catalogue the names in Alexander archipelago and Mr. Baker those in the remainder of the Territory.

In September, 1893, the committee reported that about 4,300 names had then been entered upon cards-about 2;400 in southeastern Alaska, by Mr. Ogden, and 1,900 in central, western, and northern Alaska, by .Mr. Baker. For some years thereafter comparatively little progress was made in this work. The cataloguing had been carried on as incidental to other duties, and with increasing demands the dictionary work came to a standstill. Thus it remained for several years, save for a little time given to it now and then.

Meanwhile the gold discoveries had quickened public interest in Alaska. Prospectors swarmed into the-Territory, and there were 
numerous exploring and surveying expeditions sent out by the War, Treasury, and Interior Departments. From these resulted large additions to geographic knowledge and to the list of names, especially of features in the interior. The United States Geological Survey took an active part in this interior exploration, and thus the Director found urgent need of the dictionary as an aid in preparing and publishing reports on Alaska. Accordingly in June, 1900, he directed Mr. Baker to complete it." From that time the work progressed with little interruption to completion, and it was adopted by the Board on Geographic Names on. July 29, 1901. The second edition was adopted by the Board June 6, 1906.

\section{PLAN AND SČOPE.}

The plan of this dictionary is to show in one alphabetical list all the published names which have been applied to geographic features in Alaska. This includes obsolete as well as current names, and also a . few not previously published. It aims to show the origin, history, modes of spelling, and application of each name, and: in the cases of Indian, Eskimo, and foreign names, their meaning also. And finally it shows, in bold-faced type, the forms approved by the United States Board on Geographic Names.' Rejected, doubtful, and obsoleteforms are printed in italic.

So comprehensive a scheme as this could not, from the nature of the case, be completely realized. . The attempt to discover and record every name that has been used would require an expenditure of time - ind energy far beyond the value of the result; and would, moreover, fall short of:absolute success. Nevertheless, thoroughness and completeness as well as accuracy have been steadily kept in view. The work is brought down to about 1905 . . While it is an Alaskan dictionary, a few names of featurès near but outside of Alaska are included. Also, elevations are given, when known.

The difficulties in executing this plan are deeper than the names.

... In many cases the question is not What is the name? but, To what does or should the name apply? In the beginning, of exploration there is generally confusion and uncertainty as to the names and their .. application, growing, out of imperfect geographic knowledge. It is $\therefore:$ certain that: many of the recent names included herein will not sur-

$\therefore$ vive; and that local usage will have established other forms. Thus complete revision of this work will be needed from time to time. Meanwhile, it is hoped that this dictionary, will be found helpful in establishing uniformity in the use of Alaska proper names.

ORIGIN OF NAMES.

The geographic names of any region may be likened to the coins circulating in a great seaport. As these coins are stamped by various nations, so geographic names are stamped by a conquering, colonizing, 
or exploring people upon the regions they visit, colonize; or conquer. As.some coins are by long use worn till their origin is unrecognizable, so . some geographic names, well: known and most useful, are of so uncertain origin that men disagree and dispute about them. Other coins and other geographic names are less worn, and their origin and history can be traced. Alaskan geographic names comprise a comparatively small number either so old or so corrupted as wholly to conceal their origin or meaning. They are derived almost exclusively from six.sources, which may be briefly characterized as follows: $\because$ 1. Names bestowed by the. Russians.-Prior to about 1750 Russian America, now Alaska, was a blank on our maps. Beginning with Bering's first expedition, in 1725, dim and obscure outlines began to appear: on this blank space, and as, they appeared the Russians who were filling this space applicd names to the geographic features which they discovered and explored., First came the fur hunter, then the - official explorer, and later: they worked side by side. On the part of the Russians the work continued till the purchase of Alaska by the United States in 1867. Thus the period of Russian nomenclature is about one hundred and twenty-five years, dating from Bering's second voyage, in 1741 , and ending with the cession of the territory to the - United States in 1867.

2. Names bestowed by the Spaniards.-There are few names in Alaska of Spanish origin. All of them were bestowed in the interval between 1774 and about 1800. The exploratory work of the Spaniards was all coastwise and extended from the southern boundary of Alaska to and including Prince William sound. One expedition, indeed, went as far west as Unalaska and named a few points along this stretch of -.coast. Most of these names, owing to tardy and obscure publication; have disappeared from the maps.

:3... Names bestowed by the English. - English names in Alaska date from Cook's voyage thither in 1778. From time to time during the seventy-five or eighty years following Cook's voyage, and to a limited extent to the present time, English traders and naval vessels have contributed to a knowledge of Alaskan geography and to its nomenclature.: "Noteworthy in the last century, after Cook, are the voyages of Dixon, Meares, and Portlock, British fur traders, but especially are we indebted to the incomparable Vancouver for his masterly exploration and survey of the coast from Kodiak eastward and southward to lower California. Vancouver named many features. At the same time the features named were so fully described, mapped, and published that most of these names remain unchanged on our maps to-day. The more important additions by Englishmen after Vanconver. were those by Captain Beechey, R. N., in 1826-27; by Sir Edward Belcher, R. N.; in 1836-1842, and more especially, by the so-called Franklin search expeditions during the period 1848-1854. 
The work of Cook in 1778, of Beechey and Franklin in 1826-27, and of Dease and Simpson in 1837 gave to the world the main outlines. of the Arctic coast of Alaska and the names of nearly all its large or important features.

4. Names bestowed by Frenchmen.-The explorations by the French on the Alaskan coast are small and are confined almost wholly to southeastern Alaska. The ill-fated expedition of La Perouse, in 1786 , is almost the only one which has left its impress on the nomenclature of the country, and that wholly in the southeastern part.

5. Names bestowed by Americans.-American whaleships first entered the Arctic ocean through Bering strait in 1848 and began a contribution to Alaskan geographic names. This naming of geographic features has been continued by private citizens and by Government officers of the United States to the present time. The earliest large contribution was made by the North Pacific Exploring Expedition of 1855, whose Alaskan names are found chiefly in the Aleutian islands and in Bering sea. Beginning with the cession of the Territory to the United States in 1867, numerous official expeditions have explored, surveyed, mapped, and named many features. The largest contributions, till recently, have come from the numerous surveying expeditions of the Coast Survey. At the same time, the Revenue Marine Service, the naval vessels, the military garrisons and reconnaissances, the Census Office, the Bureau of Education, the missionaries, the traders, miners, and prospectors, have each taken a part in spreading names over Alaska. In recent years the Geological Survey has given many names, especially in the interior of the country.

6. Native names.-Last in order, but first in importance, are native names. The various native tribes, occupying Alaska for an indefinite period before the advent of the whites, had applied names to various features. For certain great features each tribe would have its own name. Thus even before the advent of the whites there was duplication of names. The great river of Alaska which we call the Yukon was called by the Eskimo Kweek-puk (kweek river and puk big), and from them the Russians obtained their name, which through various transliterations into roman characters has appeared as Kwitchpak, Kwikhpak, etc. Some of the Indian tribes of the interior called it Yukon (the river), it being too great and well known to need a name, while the Tanana tribes call it, according to Lieutenant Allen, Niga To. It doubtless bears and has borne other names.

Explorers and geographers visiting new lands and peoples are always prone to ascertain and use the native names of places, mountains, rivers, lakes, etc. But this is attended with difficulty, as everyone who has tried knows. Dealing with tribes whose lan- 
guage is strange and often wholly unknown, the strange sounds are often imperfectly understood, and the application of the name is uncertain. Hence, as a rule, no native name is preserved, but rather some faint imitation or corruption of it. Potomac, Kalamazoo, Massachusetts, and Mississippi are accepted as Indian words, but it is very doubtful whether any Indian past or present would recognize these as words of his native tongue.

A large part of the Alaskan native names which, up to a few years back; had appeared on our maps were gathered by the Russians, and these names, when independently gathered and published, differ from one another more or less, as we should expect them to do. Again, these names in Russian characters have been transliterated into Roman characters by persons unskilled in Russian, and this has served to produce yet wider divergence and some extraordinary. and unpronounceable forms.

The native names as a whole fall into two great groups: $(a)$ The Eskimo, covering the Arctic coast, the eastern shore of Bering Sea, extending some distance up the various rivers, the Aleutian Islands, and Alaska peninsula as far east as Kodiak; and (b). the Indian tribes of the interior and of 'southeastern Alaska:

PRINCIPLES EMPLOYED AND RETORMS ATTEMPTED.

The generai principles followed are those adopted by the Board on Geographic Names and published in its reports, viz:

(a) The avoidance, so far as seems practicable, of the possessive form of james.

(b) The dropping of the final $h$ in burgh.

(c) The spelling of the word center as here given.

(d) The discontinuance of the use of hyphens in connecting parts of names.

(c) The simplification of names consisting of more than one word by their combination into one word.

(f) The avoidance of the use of diacritic characters.

(g) The dropping of the words city and town as parts of names.

(7l) 'The uniform rendering of the Russian termination oв's by of, not off, ov, nor ou.

The rules of orthography adopted by the United States Board on Geographic Names for the spelling of geographic names which require transliteration into Roman characters and for the writing of native names are exemplified by the following alphabet, reprinted from the second report of the Board. It is here reproduced in the hope that it may be more generally adopted by explorers, prospectors, surveyors, missionaries, and others who have occasion to reduce to writing the Eskimo and Indian names of places and features in Alaska. This system is in practical accord with that devised by the Royal Geographical Society and adopted by the British Government offices, the 
Geographic.Board of Canada, and other organizations in Englishspeaking countries. The French and German systems also apparently agree with this as closely as the differences in language permit.

An approximation only to the true sound is aimed at in this system. The vowels are to be pronounced as in Italian and on the Continent of Europe generally, and the consonants as in English:

a has the sound of a in father. Example: Java, Banana, Somali, Bari.

$\mathrm{e}$ has the sound of e in men. Examples: Tel el Kebir, Medina, Peru.

$i$ has the sound of $i$ in ravine, or the sound of $e \theta$ in beet. Examples: Fiji, Hindi.

o has the sound of o in mote.

u has the sound of oo in boot. Examples: Umnak, Unga.

ai has the sound of $i$ in ice. Example: Shanghai.

au has the sound of ow in how. Example: Fuchau.

ao is slightly different from above: Example: Nanao.

ei has the sound of the two Italian vowels, but is frequently slurred over, when it is scarcely distinguishable from ey in the English they. Examples: Beirut, Beilul.

c is always soft, and has nearly the sound of s; hard $\mathrm{c}$ is given by $\mathrm{k} . \quad E x$ ample: Celebes.

ch is always soft, as in church. Example: Chingchin.

$f$ as in English; ph should not be used for this sound. Thus, not Haiphong, but Haifong.

$\mathrm{g}$ is always hard (soft $\mathrm{g}$ is given by $\mathrm{j}$ ). Example: Galapagos:

$\mathbf{h}$ is always pronounced when inserted.

$\mathrm{j}$ as in English; dj should never be put for this sound. Examples: Japan, Jinchuen.

$\mathbf{k}$ as in English. It should always be used for the hard c. Thus, not Corea, but Korea.

$\mathrm{kh}$ has the sound of the oriertal guttural. Example: Khan.

gh is another guttural, as in the Turkish: Dagh, Ghazi.

ng has two slightly different sounds, as in finger, singer.

$\mathrm{b}, \mathrm{d}$,
$\mathrm{l}, \mathrm{m}$,
$\mathrm{n}, \mathrm{p}$,
$\mathrm{r}, \mathrm{s}$,
$\mathrm{t}, \mathrm{v}$,
$\mathrm{w}, \mathrm{x}$,
and
$\mathrm{z}$.

$\mathrm{q}$ should never be employed; $\mathrm{qu}$ is given by kw. Example: Kwangtung.

$y$ is always a consonant, as in yard, and should not be used for the vowel $i$. Thus, not Mikindany, but Mikindani.

All vowels are shortened in sound by doubling the following consonant. Examples: Yarra, Tanna, Jidda, Bonni.

Doubling a vowel is only necessary where there is a distant repetition of the single sound. Example: Nuulua.

Accents should not, generally, be used; but where there is a very decided emphatic syllable or stress which affects the sound of the word it should be marked bý an acute accent. Examples: Tongatábu, Galápagos, Paláwan; Saráwak. 
In addition to following the foregoing principles, certain reforms have been herein attempted with reference to some native names. One of the most noteworthy is the omission of the generic parts of such names. The Eskimo termination miut, or mut, or mute; meaning people, is found with wearisome frequency in those parts of Alaska occupied by the Eskimo. Unless local usage or euphony required its retention this termination has been omitted. For example, an Eskimo village on an island in the Kuskokwim has been written Kikkhtagamute, Kik-Khtagamute, and Kikikhtagamiut; meaning big island people. Kikhtak (whence by corruption Kodiak) means a big island. In this case the Board has adopted Kiktak. The form Ikogmut, however, the name of an old and well-known mission on the lower Yukon, is retained because it is old and well known; otherwise it would be Ikok: How far this attempted reform can be profitably carried is a matter of judgment and discretion. While all agree as to the principle, differences arise in its application. Even with theshortening of some long Eskimo names by such cutting off of their generic termination the remainder is so long and unpronounceable that it is certain it will not, and ought not, to survive as a geographic name.

In the interior are many rivers bearing native names ending in kakat (also written chargut and changut), meaning mouth of a river or confluence, such is Melozikakat (mouth of Melozi), Batzakakat (mouth of Batza), etc. In the interest of brevity and simplicity this termination kakat has been omitted: The same rule would reduce Mississippi river to Misis river, which is obviously impracticable, since both the word and its spelling are well established. Such does not, however, appear to be the case with many of the Alaskan names. Among the different tribes the syllable na, no, nu, meaning water, and hini, river, are suffixed to Indian names of rivers. These short and characteristic terminations are generally retained, though in a few instances they also have been dropped.

Wherever and whenever it appeared practicable to use a simple spelling this was done. When a native name had been reported by different persons, with different spellings, as is the almost invariable rule, the Board has not felt bound merely. to select from among these, but has from time to time adopted a form of its own derived from study and comparison of these and the rules adopted for writing native names.

When features have been named after persons the spelling used by those persons has been followed, always excepting corruptions and changes too well established to make this practicable. Thus Thomson, not Thompson; Ruhamah, not Ruhama, etc. In the case of Russian proper names the application of this rule is impossible, because the names are to be expressed in Roman and not in Russian letters. 
Thus we have Romanzof, a well-established name derived from Count Rumiantsof. Most Russian proper names when transliterated into Roman characters have peculiarities of form due to the views held and knowledge possessed by the transliterator. The Board has not followed a fixed system of rules in these cases. Practically the transliteration of all such names had been made, and in divers ways, before the Board began its work. It therefore dealt with cases as it found them and selected such form as, all things considered, gave promise of being generally acceptable.

The Board has given little attention or weight to either purity or priority. The guiding principle has been to discover, record, and follow the names by which features are now known, irrespective of when or how they got those names. Many features, especially the great ones, once bore names they do not now bear. To return to these first names is neither possible nor desirable. Bering sea and Bering strait will continue to be so called despite their other names earlier given.

Again, simplification of the spelling of names, whenever practicable, has been kept steadily in mind. Early in the Board's work it dropped, from native names, silent letters whenever, in its judgment such omission would generally commend itself as an improvement. Thus Atka, not Atkha; Sitka, not Sitkha; Kitkuk, not Khitkouk. Certain Russian proper names begin with the Russian X (equivalent to a guttural $K$ ); this letter has been transliterated by $K h$. Thus Khromchenko, Khwostof, etc. The Board has not felt warranted in dropping the $h$ in all these cases.

The sound of oo in food often occurs in Aleut and Eskimo names and has been variously rendered by oo, ou, and $u$. Thus, Oonalaska, Ounalaska, and Unalaska. For this sound the letter $u$ has been generally though not universally used. Thus, Unga, Umak, Ugalgan, etc., but not Chilkut. Chilkoot is a popular and wellestablished spelling and pronunciation of an Indian word which is unpronounceable by most white men and which might be written T'sl-kūt.

In the older literature were many names from the Russian which in transliteration began with $T c h$ or $T s c h$, as Tschitschagow, which is now written Chichagof. As far as usage would permit, the simple form $C h$ has been used in such cases.

Curiosities of nomenclature abound. There have been strange transformations due to carelessness, ignorance, or bad writing. Thus, Gain became Cain; Hound, Round; Miller, Mitten; Chornie became Torno; Traitors, Traders; Andrew, Lidrejana; Sutwik, Zutchwik, etc. Numerous illustrations of transformation and corruption will be found throughout the dictionary. 


\section{$\triangle$ U'THORI'TIES.}

Many maps, charts, books, and persons have been consulted in preparing this work. Scattered through the dictionary are references to such persons and publications. These constitute the chief original sources of Alaskan names. Below is given a list of the principil ones. It does not aim to be exhaustive. First is given a chronologic list. This is followed by the same authorities arranged alphabetically, and after each entry follows a brief account of the individual, a statement of the work by which he became an authority, and references to publications containing his results. These references are to the publications chiefly used in preparing this work.

\section{AOTHORITIES IN CHRONOLOGIC ORDER.}

In the following list are given, in chronologic order, the names of the principal authorities used in the preparation of this dictionary. An account of each, arranged alphabetically, follows on pages 16-77.

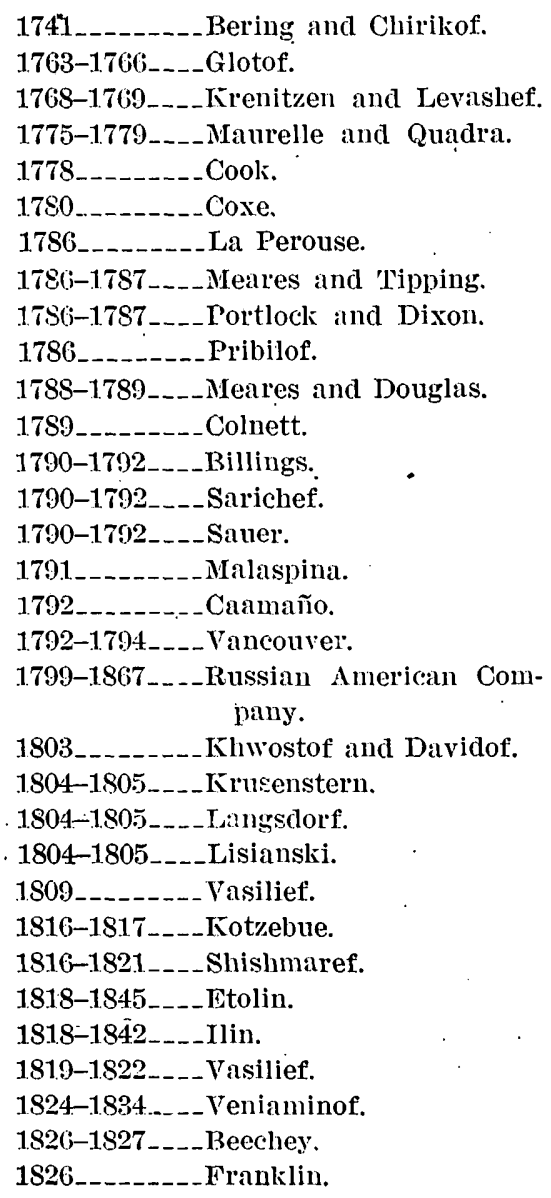

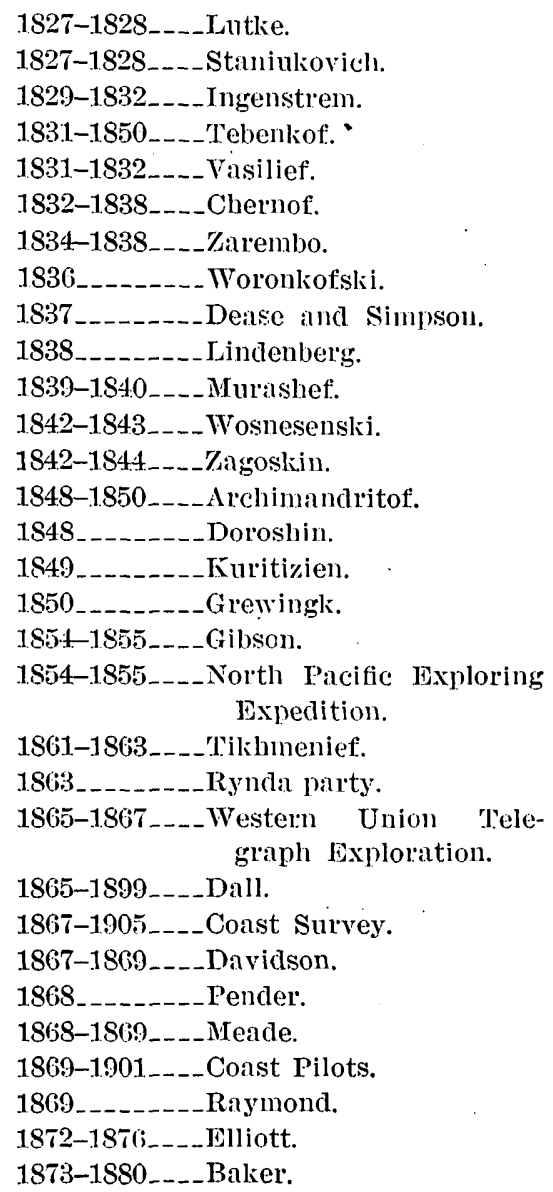



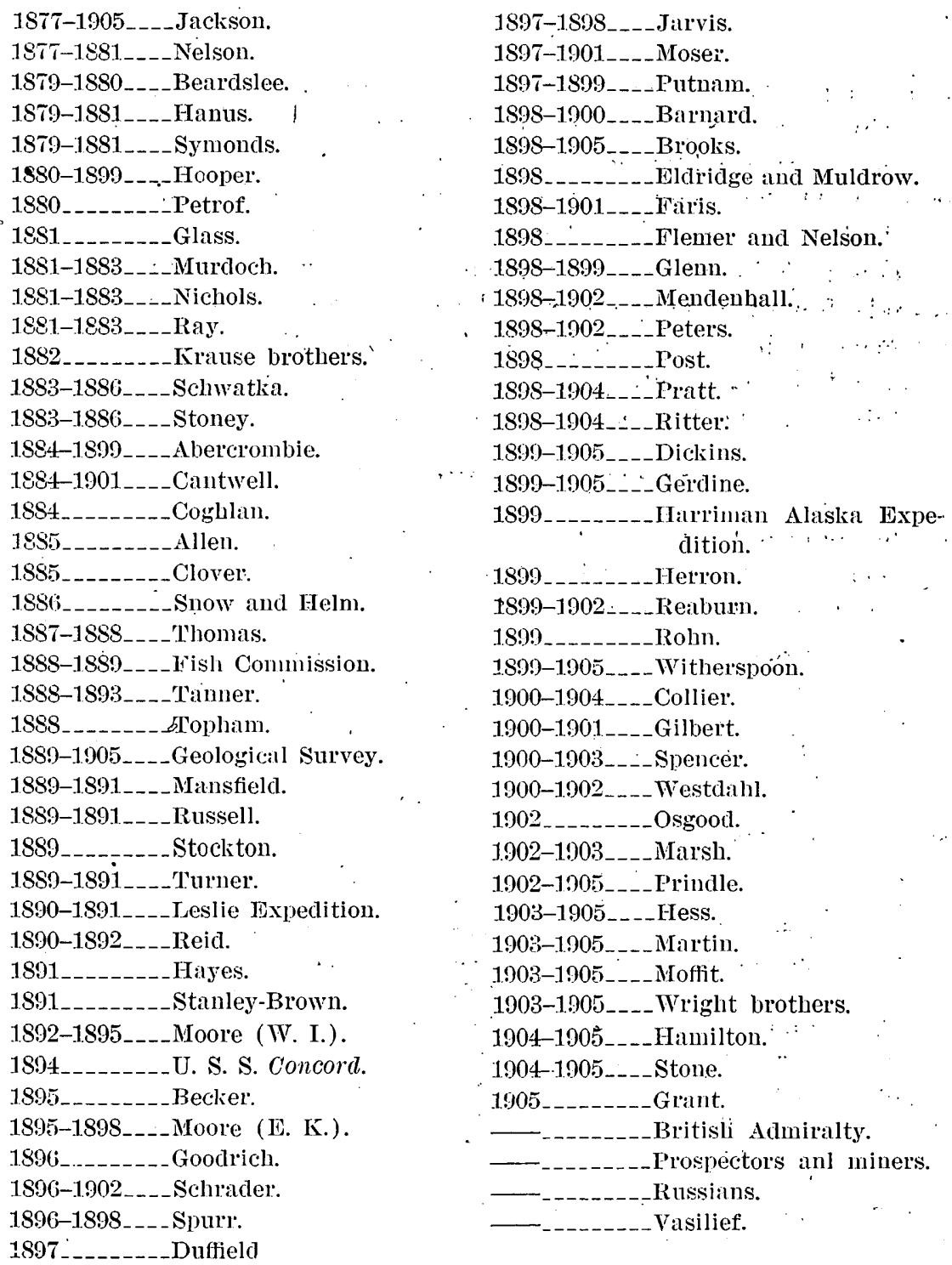

AUTHORITIES IN ALPHABETIC ORDER.

The following is an alphabetic list of the principal authorities used in the making of this dictionary. Concerning each one a brief statement is made as to the reasons for accepting him as an authority. References are also given to such publications, by himself or by others, concerning his work, as have been used.

ABErcrombie, 1884, 1898-99.

In the spring of 1898 , by direction of the Secretary: of War, three military expeditions were organized for exploring the interior of Alaska. The second of these expeditions was under the command of. 
Capt. William R. Abercrombie, U. S. A., who had in 1884 ascended. Copper river to latitude $60^{\circ} 41^{\prime}$ and afterwards visited Port Valdez, in Prince William sound. Abercrombie was directed to organize his party at Valdez and then explore the valley of Copper river and its tributaries and the country northward to the Tanana. Mr. F. C. Schrader, of the United States Geological Survey, was attached to his party as geologist. Schrader's report was published in 1900 in the 'Twentieth Annual Report of the Geological Survey, Part VII, pp. 341-423. Abercrombie's report was published in July, 1899, in War: Department, Adjutant General's Office, No. XXV, Report of Explorations in 'Alaska,"pp. 295-351. It was also published in 1900 in a $4^{\circ}$ volume entitled Compilation of Narratives of Explorations in Alaska, Washington, Government Printing Office, 1900, a work which seems to have come from the Senate Committee on Military Affairs.

Captain Abercrombie continued the work of exploration in 1899 under instructions, inter. alia, to construct a military road from Valdez to Fort Egbert, on the Yukon. Mr. Oscar Rohn accompanied the party as topographer and geologist. For Abercrombie's report see the above-cited compilation, pp. 755-766; also separately printed, with numerous illustrations, Washington, Government Printing Office, 1900. Rohn's report was published in 1900 in the Twenty-first Annual Report of the Geological Survey, Part II, pp. 393-440.

AI.LEN, 1885.

Lieut. (now Brigadier-General commanding the Philippine Scouts) Henry Tureman Allen, U. S. A., who was graduated from West Point in 1882, made a journey of exploration through central Alaska in 1885. Leaving Nuchek on March 20, he ascended Copper river, crossed to and descended the Tanana to its mouth, thence traveled north to the Koyukuk, ascended it some distance, and then descended to its mouth and arrived August 29 at St. Michael, whence he returned to San Francisco. His report, with accompanying maps, was published in 1887 as Senate Ex. Doc. No. 125, Forty-ninth Congress, second session.

\section{ARCHIMANDRTTOF, $1848-1850$}

Toward the close of the Russian occupation of Alaska, Captain Archimandritof commanded one of its vessels in the colonies. $\mathrm{He}$ made surveys in Kenai peninsula and around Kodiak in about 1850, but published nothing. It is probable that some of his results were used in Tebenkof's atlas. Copies of his manuscript maps were in use by the Russian skippers and others at the time of the purchase, and

Bull. 299-06 $\mathrm{M}-2$ 
some fragments reached the Coast Survey. A survey by him of Graham harbor (Port Graham), in Cook inlet, was published in the Coast Survey atlas of Harbor Charts, 1869.

Arteaga, 1779 . See Maurelle and Quadra.

BAKER, 1873-1880.

Marcus Baker, the author of this dictionary, in the employ of the Coast Survey, surveyed in the Aleutian islands and along the Alaskan coast from Dixon entrance to Point Belcher, Arctic ocean, in the seasons of 1873,1874 , and 1880 in the party of Dr. William H. Dall. In May, 1880, through the courtesiy of Captain Beardslee, he made a boat journey from Sitka to Chilkat and return. The very few names given during that journey are recorded in the Coast Pilot, 1883. Mr. Baker died in Washington, D. C., December 12, 1903.

\section{BARNARD, 1898-1900.}

Mr. Edward Chester Barnard, topographer of the United States. Geological Survey, surveyed the Fortymile district, in eastern Alaska, in the summer of 1898, and also made surveys in Seward peninsula in the summer of 1900 . The Fortymile atlas sheet was published in April, 1899, in a Congressional document (Public Resolution No. 25, Fifty-fifth Congress, second session), entitled Maps and Descriptions of Routes of Exploration in Alaska in 1898; and also as an atlas sheet of the United States Geological Survey. The maps resulting from the Seward peninsula surveys appeared in a special report of the Geological Survey, published in 1901, entitled Reconnaissances of the Cape Nome and Norton Bay Regions, Alaska, in 1900, and Barnard's report appears on pages 174-177 of that volume.

\section{BEARDSLEE, 1879-80.}

Capt. (afterwards, Rear-Admiral). Lester Anthony Beardslee, U. S. N., was in 1879-80 stationed in southeast Alaska in command of the U. S. S. Jamestown. Among his officers was Lieut. Frederick M. Symonds and Master Gustavus C. Hanus, both of whom had served in the Coast Survey and were enthusiastic surveyors. These officers and their associates utilized their opportunity to increase our imperfect knowledge of the Alexander archipelago. They surveyed Sitka harbor and various coves and harbors and brought back information as to Glacier bay, which, while not absolutely the first, was the first to attract much notice. Their map of Sitka was published by the Coast Survey. Most of the geographic information, except that, is contained in Beardslee's report on affairs in Alaska, which 
was published in 1882 as Senate Ex. Doc. No. 71, Forty-seventh Congress, first session. This contains several maps, including reprints of United States Hydrographic Office charts 882 and 883.

BECKER, 1895.

Mr. George Ferdinand Becker, geologist of the United States Geological Survey, accompanied by Mr. Chester Wells Purington, visited Alaska in the summer of 1895 for the purpose of examining and reporting on its gold resources. Their examination was, in accordance with instructions, confined to the coast, and embraced points from Sitka westward to Unalaska. It included several localities in Alexander archipelago, about Kodiak and Cook inlet, and along Alaska peninsula, and the trip ended with a visit to Bogoslof.

Becker's report on this work is published in the Eighteenth Annual Report of the Geological Survey, Part III, pp. 1-86.

BeEchey, 1826-27.

In 1824 the British Government determined to send a ship to Bering strait to cooperate with Franklin and Parry in a search for the Northwest Passage. Capt. Frederick William Beechey, R. N. was on January 12, 1825, selected for the task and placed in command of H. M. S. Blossom. On May 11, 1825, he received his instructions, and eight days later, May 19, set sail from Spithead, sailed round Cape Horn, and on June 28, 1826, reached Petropavlovsk. Thence he sailed to Kotzebue sound, arriving on July 22. Sailing northward he made surveys on the Arctic coast as far as Point Barrow, and tinen returned to Kotzebue sound. ' On October 13 he quit the sound and, passing Unimak strait, reached San Francisco on November 7 ; where he stayed till the end of the year, and then proceeded to the Hawaiian islands, touching en route at Monterey. He arrived at Honolulu on January 26, 1827. Thence he went to China, and on July 3 was back in Petropavlovsk.

Quitting the harbor on July 18, he returned to Kotzebue sound, arriving on August 5. The rest of the season was spent in surveys about Seward peninsula, till October 6, 1827, when he took his final departure and, rounding Cape Horn, returned to England in September, 1828.

A fuli and satisfactory account of this voyage was published by authority of the Admiralty in 1831, entitled "Narrative of a Voyage to the Pacific and Beering's Strait," by F. W. Beechey, 1825-1828, 4, London, 1831.

Bering and ChIRIKof, 1741.

The first Russian voyage to bring definite tidings as to northwest America dvas made by Capt. Commander Ivan Ivanovich (otherwise Vitus) Bering and Capt. Alexie Ilich Chirikof in 1741. It was an 
official voyage ordered by the government to be made for exploration and discovery. Bering in the St. Paul, with whom was Steller, and Chirikof in the St. Peter, with whom went Croyere, sailed from Avacha bay on June 4, 1741, and together they cruised eastward. On the 20 th they were separated by a storm and did not meet again. The courses kept were generally eastward. Bering reached the vicinity of the mouth of Copper river and landed there on July 20. The next day he turned back, touched at the Shumagins, saw a number of the Aleutian islands, and was finally driven ashore and died on December 8,1741 , on the island which now bears his name.

Chirikof made land July 15, 1741, at Bucareli bay, Alexander archipelago. He landed two boat crews somewhere in the archipelago, perhaps near Sitka.' Neither of these was seen again, and Chirikof, sailing away, arrived in Avacha on October 9.

Concerning this voyage, which was the first of the Russian official voyages to bring back any definite knowledge of America, much has been written. A good account of it, compiled from original sources, is concained in Journal of Russian Hydrographic Department, 1851, Vol. IX, pp. 190-469. A detailed track chart accompanies this account. See also Petrof's account in Bancroft's History; pp. 63-98.

Bullings, $1790-1792$.

Commodore Joseph Billings commanded a Russian exploring and surveying expedition in Bering sea and the North Pacific ocean in 1791-1792. He appears not to have made or published any account of it. For the results, see Sauer and Sarichef.

\section{Bodega, 1775-1779. See Maurelle and Quadra.}

\section{British Admiralty.}

The British Admiralty has published various charts relating to Alaska, most of them being compilations or reproductions of other maps. Almost always the source of information is clearly indicated. Occasionally, however, bits of information have been found here and there on the British Admiralty charts which have not been traced to any other source; in such cases reference is simply made to the British Admiralty. The region about Glacier bay on British Admiralty chart 2431 is an illustration.

\section{Brooks, 1898-1905.}

Mr. Alfred Hulse Brooks, of the United States Geological Survey, as geologist in the party of Mr. W. J. Peters, in 1898, made geologic studies in Tanana and White river basins in Alaska. Again, in 1899, with Peters's party, he made a reconnaissance from Pyramid harbor 
at the head of Lynn canal to Eagle on the Yukon. In the autumn of 1899 he spent a few weeks on Seward peninsula. In the season of 1900 Brooks had charge of a geologic party on Seward peninsula, having as geologic assistants Messrs. George B. Richardson and Arthur J. Collier. In 1901 he made a geologic examination of the Ketchikan mining district, southeastern Alaska, and a more hasty reconnaissance of the northern belt of southeastern Alaska.

In 1902 Brooks conducted an exploring expedition, composed of 7 men, with 20 pack horses, from the head of Cook inlet to Rampart, on the Yukon. Mr. D. L. Reaburn was the topographer of the expedition and Louis M. Prindle was geologic assistant. The expedition started from Tyonek, on Cook inlet, June 2. The route lay northwest across the Skwentna to the Kichatna, up this stream and through Rainy pass to the Kuskokwim, down the Kuskokwim a short distance, and thence northeasterly for 200 miles along the northwest base of the Alaska range to the head of Yanert fork of Cantwell river. From there they traveled northwest, and thence north along the one hundred and forty-ninth meridian across Tanana and Tolovana rivers, and thence northwest to Rampart, on the Yukon, which was reached on September 16. Reaburn carried a continuous plane-table survey over the 800 miles of this journey, from Cook inlet to the Yukon.

Since July, 1903, Mr. Brooks' has been in charge of the division of Alaskan mineral resources, United States Geological Survey, and has directed the topographic and geologic surveys of that Territory. For reports on his work see Twentieth Annual Report of the United States Geological Survey, Part VII, pp. 425-494; also Twentyfirst Annual Report, Part II, pp. 331-391. The report on the work of 1900 on Seward peninsula was published in a special report of the United States Geological Survey in 1901, entitled, Reconnaissances of the Cape Nome and Norton Bay Regions, Alaska, in 1900, pp. 1-180. The report for 1901 was published as Professional Paper No. 1, United States Geological Survey, 1902, 120 pp. and 8 maps. The report on the 1902 expedition may be found in the Twenty-first Annual Report of the United States Geological Survey, pp. 94-102. Concerning this see, also, an article by Brooks and Reaburn in the National Geographic Magazine, January, 1903, entitled Plan for Climbing Mt. McKinley, and articles by Brooks in Science, vol. 16, 1902, pp. 985-986, and Journal of Geology, vol. 2, 1903, pp. 441-469, map. Reaburn's map was published as Pl. XI, opposite p. 36, in a volume written by Brooks and published as Professional Paper No. 45 of the United States Geological Survey, 1906, entitled Geography and Ceology of Alaska. Brooks is writing a detailed report of this expedition and its results, which will be published as a Professional Paper of the Geological Survey. 
Caamaño, 1792.

Lieut. Don Jacinto Caamaño, in the corvette Aranzazu, was sent out in 1792 by Count de Revillagigedo, Viceroy of Mexico, to explore the northwest coast about Juan de Fuca strait and northward with a view to determining the truth about de Fonte's reported Northwest Passage. Sailing from San Blas on March 20, 1792, he arrived in Bucareli bay on July 12, and then surveyed southward along the southern Alaska coast and British Columbia. He returned to San Blas on February 6, 1793. No general report on this work was published till long afterward. Vancouver met him in the field and apparently obtained copies of some of his maps, especially of places just north of Dixon entrance, which he incorporated in his atlas. For an account of this voyage see Salva (Miguel) y Baranda (Pedro Sainz de), Coleccion de documentos ineditos, etc., $8^{\circ}$, Madrid, 1849, Vol. XV, pp. 323-363.

CANTWELL, 1884-1885 and 1899-1901.

On July 8, 1884, Lieut. John C. Cantwell, Revenue-Cutter Service, with a small party, was detached from the revenue cutter Corwin, Capt. Michael Healy, at anchor off Cape Kruzenstern, to explore Kobuk river. Between that date and August 30, he ascended the Kobuk 185 miles, returned and explored Selawik lake and vicinity.

On July 2, 1885, two parties disembarked from the Corwin off Hotham inlet, to explore Kobuk and Noatak rivers. Between that and August 27 Cantwell explored the Kobuk to Walker lake, which he discovered and sketched. At the same time Second Asst. Engineer S. B. McLenegan, Revenue-Cutter Service, with one man, explored Noatak river for about 250 miles from its mouth.

The reports of these explorations may be found in Report of the Cruise of the Revenue Marine Steamer Corwin in the Arctic Ocean in the year. 1884, by Capt. M. A. Healy, U. S. R. M., Commander, Washington, Government Printing Office, 1899, pp. 47-128; and Report of the Cruise of the Revenue Marine Steamer Corwin in the Arctic Ocean in the year 1885, by Capt. M. A. Healy, U. S. R. M., Commanding, Washington, Government Printing Office, 1887, pp. 21-102, 3 maps.

Lieutenant Cantwell commanded the U. S. revenue steamer Nunivak on Yukon river from the summer of 1899 to the summer of 1901, both inclusive. The two intervening winters he spent with his ressel in winter quarters in the mouth of Dall river. From information gathered while on this station, sketch charts of Yukon and Koyukuk rivers were constructed, but not published. His report-Report of the U. S. Revenue Steamer Nunivak on the Yukon River Station, Alaska, 1899-1901, by First Lieut. J. C. Cantwell, Commanding, 
Washington, Government Printing Office, 1902, pp. 325-contains much geographic information.

\section{Chernof, 1832-1838.}

Ivan Chernof was a pilot in the employment of the Russian American Company and made surveys here and there in Alaska. He surveyed Sviechnikof harbor, in Amlia island, in 1832, and made other surveys in the Rat Island group of the Aleutian islands at about the same period. Lutke, in his Voyage, Partie nautique, 1836, p. 327, informs us that knowledge of the Rat Island group at that time, though very incomplete, was due to Ingenstrem and Chernof. The latter collected detailed information about all the islands and rocks of the group, and even wrote out some of these notes. It does not appear that these were ever published. Tebenkof in his notes several times refers to Chernof's work. He is doubtless the same Ivan Chernof who, as a lad, was given by the Indians to the Russians as a hostage in 1804 and returned to them in 1805. He attended the navigation school at Sitka and afterwards was long.in the service of the Russian American Company as a pilot. In 1838 he was skipper of the Russian American Company's brig Polyfem, in which Kashevarof explored the Arctic coast. He died in 1877, and his descendants live on Afognak island. See Russian Hydrographic Charts 1378 and 1400 for some of his results.

Chirikof, 1741. See Bering and Chirikof.

Clover, 1885.

Lieut. Commander Richardson Clover, U. S. N., in command of the Coast and Geodetic Survey steamer Patterson, made surveys in southeastern Alaska in 1885. The field season was from May 17 to September 16, 1885, during which surveys were made of Clarence strait from Cape Chacon and Dall Head on the south to Narrow point and Union bay on the north, also of the north shore of Dixon entrance from Cape Chacon to Cape Muzon, except Cordova bay. Extracts from his reports were published in Coast Survey report, 1886, pp. 80-81. Coast Survey chart 709, issued in 1886, shows the results of his work. Some of it also appears on Coast Survey charts 706 and 707 .

Const Pilots, 1869, 1883, 1891, 1901.

Four Coast Pilots of Alaska have been prepared and published by the Coast Survey. The first one, prepared by Assistant George Davidson, was published in 1869 . See Davidson for an account of this. The second was prepared by Assistant William H. Dall, assisted by Marcus Baker, between 1875 and 1882 and was published by the Coast Survey in 1883 under the title Pacific Coast Pilot, 
Alaska, Part I. An Appendix to this Pilot, devoted to meteorology and bibliography, was also prepared by Dall and Baker and published by the Coast Survey in 1879, the edition being 250." The meteorological tables, the diagrams, the biblography, and the cartography were prepared by Baker. They were edited by Dall, who wrote the discussions and put the whole through the press.

The third edition was published by the Coast Survey, in 1891. It was prepared by Lieut. Commander H. E. Nichols, who was assigned to this work in 1888. In the summer of that year Nichols visited: Alaska and gathered notes for.it. $\mathrm{He}$ was at Kodiak and Unalaska and visited various points between, also several of the Aleutian islands, the Pribilof islands, and points in Bristol bay. (See Coast Survey Report, 1888, p. 77.) He-also visited Alexander archipelago in the autumn of 1888 on the same errand. The manuscript of the new edition was completed before July, 1890, and the volume was issued in 1891. The eritical and historical notes in the Pilot of 1883, or "Dall's Coast Pilot," has made it more useful for this dictionary than the edition of 1891 , or, as it is often called, "Nichols's Coast Pilot."

In the fourth edition, published in 1901, "the arrangement has been changed and the text revised and brought up to date by $\mathrm{Mr}$. Herbert C. Graves and Pilot E. H. Francis, assisted and directed ini the final arrangement by Mr. John Ross, under the general direction of Herbert G. Ogden, assistant, Coast and Geodetic Survey, inspector of hydrography and topography." This volume treats of the coast waters and inland passages from Dixon entrance to Yakutat bay, and is based mainly on the work of the Coast and Geodetic Survey, supplemented by special field examinations and investigations made by Mr. Graves in 1900, and the thirty-two years' experience in those waters of Pilot Francis. An account of Mr. Graves's field operations may be found in the report of the Superintendent' of the United States Coast and Geodetic Survey, 1901, pp. 152 and 161.

Additional Coast Pilot material has been published by the Coast and Geodetic Survey: Bulletins 37 and 38 of that Survey were prepared by Lieut. Commander J. F. Moser and publishëd in 1899. These relate, the first to Alexander archipelago, the second to Prince William sound, Cook inlet, Kodiak, and westward to Unalaska. Bulletin 40, published in 1900, prepared by the Coast and Geodetic Survey and revised by Lieutenant Jarvis, U. S. Revenue Cutter Service, relates to Bering sea and the Arctic. This bulletin has been through five editions, the last published in 1904 .

Const SüveY, 1867-1905.

Geographic work in Alaska by the Coast Survey began in the summer of 1867 , prior to the purchase of Alaska, made in that year, and with more or less interruption it has continued to the present. The 
results are set forth in the reports, maps, charts, and other publications of that organization. So far as practicable, in making this dictionary names are accredited to the particular individual who applied them. It has not been possible to do so in all cases, however, and accordingly some of the names are simply recorded as having been applied or given by the Coast Survey.

Coghtian, 1884.

Commander (now Rear-Admiral) Joseph Bullock Coghlan, U.S. N., in command of the U. S. S. Adams, was stationed in southeastern Alaska in 1884 and with. his officers made reconnaissance surveys at some of the places where the need was especially great. His surveys were principally in the interior passages north and east from Sitka sound, through Peril strait to Chatham strait, and in and about Barlow cove at the south end of Lynn canal.

For his results see Coast and Geodetic Survey charts 727 and 728, published in $18 \mathrm{~s} 5$.

CoLtuer, 1900-1904:

Arthir James Collier, of the United States Geological Survey, was geologic assistant to Brooks in the Cape Nome region, Seward peninsula, in 1900. For an account of his work see special report of the Geological Survey, Reconnaissances of the Cape Nome and Norton Bay Regions, Alaska, 1900, p. 15. The notes on climate and vegetation in that report were written by Collier.

In 1901 he was attached as geologist to Gerdine's party in a reconnaissance of the northwestern portion of Seward peninsula. His report, Professional Paper United States Geological Survey No. 2, $1902,70 \mathrm{pp}$. and 4 maps, contains also Gerdine's topographic map of the northwestern portion of Seward peninsula, Pl. XII.

In $1902^{\circ}$ Collier, with two assistants, made an examination of the coal deposits along Yukon river from Dawson to the delta. His report is Bulletin United States Geological Survey No. 218, 1903, pp. 71 and 5 maps.

In 1903 Collier, with F. C. Hess as assistant, detailed to continue the investigations of the mineral resources of Seward peninsula, visited nearly all the important placer-mining camps on the peninsula. He also examined the tin deposits in the York region. His report on the placer mines is in preparation, and that on the tin deposits was published as Bulletin United States Geological Survey No. 229,1904, pp. 61 and 4 maps.

In 1904 he spent forty-six days in making supplementary observations on the gold and tin deposits of Seward peninsula, and then sailed for Cape Lisburne, where he spent a month in a reconnaissance of the Cape Lisburne coal fields. He made a geologic and topographic reconnaissance along the coast and several miles inland, from 
Cape Beaufort to Cape Thompson, a distance of 140 miles. An account of these operations may be found in the Twenty-second Annual Report of the United States Geological Survey, 1905, pp. 65-67. His report on the geology and coal resources of the Cape Lisburne region, Alaska, is.Bulletin United States Geological Survey No. 278, 1906.

Colnett, 1789.

James Colnett, an English fur trader, sailed under instructions from Captain Meares, from China, in command of the Princess Royal and Argonaut, in April and May, 1789, on a trading voyage to northwest America. Colnett did not publish any account of his voyage, but information concerning it is contained in the Appendix to Meares (John) Voyages; etc., $4^{\circ}$, London, 1790.

\section{U..S. S. CONCORD, 1894.}

The U. S. S. Concord, in 1894, made surveys in the islands of the Four Mountains, in the Aleutian chain. The results are shown on United States Hydrographic Office chart No. 8, edition of February, 1895 .

Cook, 1778.

Eight days after the American colonies had declared themselves free and independent, Capt. James Cook, R. N., the great English navigator, sailed from Plymouth, England (July 12, 1776), on his third and last voyage of discovery. He had two ships, the Resolution and Discovery. He commanded the Resolution and Capt. Charles Clerke the Discovery. The ships proceeded to Teneriffe, Cape of Good Hope, Kerguelen Land, Van Dieman's Land, New Zealand, Friendly isles, Tahiti, Christmas island, Hawaiian islands, and to Nootka sound, in Vancouver island, where they arrived on March 30, 1778. Between this date and October 3, 1778, Cook cruised northward and westward along the American coast to Icy cape, in the Arctic ocean, and sketched the chief outlines of this coast, hitherto practically unknown. Leaving Unalaska on October 27, 1778, he returned to the Hawaiian islands, where he was killed by the natives on February 14, 1779. The British Admiralty published in 1784-85 an account of this voyage in three quarto volumes and a large atlas.

Coxe, 1780.

Rev. William Coxe, archdeacon of Wilts, spent some time in St. Petersburg prior to 1780 and while there specially interested himself in the discoveries made by the Russians between Asia and America between 1741 and the date of his writing. His results were published 
in 1780 under the title Account of the Russian Discoveries between Asia and America, etc. This passed through several editions, the third appearing at London in 1787 and the fourth in 1803. Two French translations appeared in 1781 and a German one in 1783. This is an important work for the student of Alaskan exploration and geography. In it are the first published accounts of the voyages of Shalaurof, 1761-1763; Sind, 1764-1768; and Krenitzin and Levashef, $1764-1771$.

\section{DALL, 1865-1899.}

Dr. William Healey Dall first went to Alaska in 1865, in the employment of the Western Union Telegraph Company, and from that beginning has become one of the foremost students, explorers, writers, and authorities on Alaskan matters. His book Alaska and Its Resources, published in 1870 , remains to this day the most useful handy reference book on Alaska.

He came back to San Francisco in the autumn of 1865 , returned to Alaska in the spring of 1866, and remained in the Yukon country till 1868, when he came back and published Alaska and Its Resources. In 1871 he entered the Coast Survey and from August, 1871, to the end of 1874 was engaged in reconnaissance surveys along the coast from Sitka westward to the end of the Aleutian chain and northward in Bering sea as far as Nunivak and the Pribilof islands. With him, as assistant, in 1871-72 was Mark Walrod Harrington. Dall returned to Washington at the end of 1874 and was employed in the Coast Survey Office on Alaskan matters from 1875 to 1880 ; in this interval was written the Alaska Coast Pilot and its Appendix. Marcus Baker was associated with him in this and other Alaskan work as an assistant from March, 1873, till July, 1882. In 1880 another season of Alaska field work was had, the cruise extending along the coast from Sitka to Unalaska and northward nearly to Point Barrow. The principal sources of geographic information as to all this is a series. of some fifty charts and plans issued by the Coast Survey and the Alaska Coast Pilot with its Appendix.

In 1884 Dr: Dall resigned from the Coast Survey and entered the Geological Survey, with which organization he has been connected ever since. In the summer of 1895 , in company with Mr. G. F. Becker, he revisited Alaska for the purpose of studying and reporting on its coal resources. The cruise made was coastwise from Sitka to Unalaska. The results are published in the Seventeenth Annual Report of the United States Geological Survey, 1896, Part I, pp. 763-908. He was a member of the Harriman Alaska Expedition in 1899 and wrote The Discovery and Exploration of Alaska, in Vol. II, pp. 185-204 of its report, and Neozoic Invertebrate Fossils in Vol. IV, pp. $99-120$. 
Tavidor, 1803 . See Khwostof and Davidof.

Davidson, $1867-1869$.

George Davidson, assistant in the Coast Survey, accompanied by Alonzo Tyler Mosman, G. Farquhar, and Stehman Forney, made a cruise in the waters of Russian America just prior to its purchase and change of name to Alaska, in 1867. They sailed on the revenue cutter Lincoln from Victoria on July 29 and returned there October 27, 1867, having visited and made observations at Sitka, Chilkat, Kodiak, and Unalaska. Davidson wrote a voluminous report on this work, including a description of the southeast coast of Alaska, from Dixon entrance to Cook inlet. This report was published in Coast Survey Report, 1867, Appendix 18, pp. 187-329. This description was afterwards revised and published by the Coast Survey under the title Coast Pilot of Alaska (First Part) from Southern Boundary to Cook's inlet.

Charts were made of Sitka, of St. Paul harbor, Kodiak, and of Captains bay, Unalaska, and published by the Coast Survey. These are in a small atlas issued by the Coast Survey in 1869 and entitled Harbor Charts of Alaska. Davidson visited Alaska again in 1869 and observed the total solar eclipse of August 7 of that year at Kohklux, on the Chilkat river. On his journey thither and back he did a little reconnaissance surveying in Alexandria archipelago. For an account of this see Coast Survey Report, 1869, pp. 177-181.

Dease and Simpson, 1837.

Peter Warren Dease and Thomas Simpson, factors of the Hudson Bay Company, in the summer of 1837 made an exploring journey along the Arctic coast from the mouth of Mackenzie river to Point Barrow. Prior to their journey the coast line from Return reef to Point Barrow was'a blank on the maps. They left the Mackenzie mouth on July 9 in two open boats and arrived at Point Barrow on August 4, the last part of the journey being overland. For an account of their work see Simpson (Thomas), Narrative of Discoveries on the North Coast of America, $8^{\circ}$, London, 1843; also Journal Royal Geog. Soc., $8^{\circ}$, London, 1838, Vol. VIII, pp. 213-225.

DICKINS, 1899-1905.

Edmund Finlay Dickins, assistant, United States Coast and Geodetic Survey, commanded the Coast Survey steamer Gedney, 18991905. In 1899 he triangulated the southern end of Chatham strait and the western end of Sumner strait, thus connecting the two systems. In 1901 and 1902, in cooperation with Pratt, he executed the hydrography and topography of Icy strait, from Chatham strait to 
Inian islands, including Port Frederick, Idaho inlet, and Mud bay on the south shore and Dundas bay on the north. In 1903-4 he executed the triangulation, hydrography, and topography of Davidson inlet and Sea Otter sound, Iphigenia bay, and the adjacent islands and passages. In 1905 he surveyed the north arm of Moira sound, south- eastern Alaska, Dolomi bay and Port Johnson, on the éastern shore of Prince of Wales island, and Cordova bay, Alexander archipelago. Accounts of these operations are published in United States Coast and Geodetic Survey Reports, 1900, pp. 208-209; 1902, pp. 134-135; 1903 , p. $103 ; 1904$, pp. $97-100 ; 1905$, pp. 58-59. The Icy strait surveys are incorporated on Coast and Geodetic Survey charts 8302 and 8304. The other results have not yet been published otherwise than as corrections to the more general charts of those waters.

Dixon, 1785-1788.

Capt. George Dixon, commanding the ship Queen Charlotte, made a trading voyage from England to northwest America and around the world in 1785-1788 in company with Portlock. (See Portlock.) Dixon published an account of this voyage entitled A Voyage Round the World, etc.; $4^{\circ}$, London, 1789.

\section{DoRoshrn, 1848.}

Peter P. Doroshin, a mining engineer, was sent out from Russia in 1847 by the Russian American Company to their American possessions with Captain Riedell in the ship Atka, to examine and report on the gold resources of the colony. He visited Baranof island and Cook inlet and examined these places, and also visited California. His results were published in the Russian Mining Journal for 1866, No. 1 (Part V), p. 136 ; No. 2 (Part VI), pp. 277-282; also No. 3 (Part III), pp. 365-401. The last contains descriptions of Prince William sound and Copper river.

Douglas, 1788-89. See Meares.

DUFFIELD, 1897.

Will Ward Duffield, assistant, United States Coast and Geodetic Survey, was in charge of a party from the Coast Survey in 1897, which made a topographic survey of the Pribilof islands, Bering sea. Of this party were Fremont Morse, G. R. Putnam, and G. L. Flower. The resulting topographic maps-United States Coast and Geodetic Survey Miscellaneous maps Nos. 3214 and 3224-were published in 1.898 on a scale of $1: 20,000$, contour interval 20 feet. At the same time Inore detailed surveys were made of the various seal rookeries, and maps of these were published on a scale of $1: 2,000$, contour interval 10 
feet. They are miscellaneous maps of the United States Coast and

- Geodetic Survey 3215 to 3223 , inclusive, and 3225 to 3228 , inclusive, issued in 1898.

Eldridge and Muldrow, 1898.

Mr. George Homans Eldridge, geologist of the United States GeoIogical Survey, made a reconnaissance of the Susitna basin in the summer of 1898 . He was accompanied by Mr. Robert Muldrow, topographer. Their explorations extended from the head of Cook inlet up the Susitna nearly to latitude $64^{\circ}$. For their results see Twentieth Annual Report of the United States Geological Survey, Part VII, pages 1-29, and the special report of the United States Geological Survey, 1899, entitled Maps and Descriptions of Routes of Fixploration in Alaska in 1898. Mr. Eldridge died in Washington, D. C.; June 29, 1905.

ELLIOTT, 1872-1876.

Mr. Henry Wood Elliott was, in 1872-73, an assistant agent of the 'T'reasury Department on the Pribilof islands. In the summer of 1874 he was a special agent of the Treasury Department, and with I.ieut. Washburn Maynard, U. S. N., visited in the U. S. revenue cutter Reliance, Captain Baker commanding, Sitka, Kodiak, Unalaska, the Pribilof islands, St. Matthew, and St. Lawrence. In November, 1874, he submitted a report, which was printed by the Treasury Department in 1875 and by Congress in 1876. He also wrote a monograph on the Pribilof islands, which was published in the Tenth Census, 1880, Vol. VIII, and also separately in two editions, one in 1881 and the other in 1882. These contain the maps of St. Paul and St. George made by Elliott and Maynard in 1874.

\section{Etolin, 1818-1845.}

Adolph Karlovich Etolin, who was governor of the Russian American colonies in 1841-1845, first went to the colony from Russia with Golofnin in the Kamchatka, leaving Cronstadt on August 26, 1817, and arriving in Petropavlovsk on May 3, 1818. At least Grewingk so states, and is followed by Dall; but Golofnin in his Voyage gives a list of all his ship's company, to the number of 138, and Etolin's name is not in that list. (Golofnin's Voyage Round the World (in Russian), $4^{\circ}$, St. Petersburg, 1822, Vol. I, supplement, pp. i-viii.) Etolin, Khromchenko, and Vasilief were engaged in surveying and exploring Bering sea in 1822-1824. (Bancroft, History, p. 546.) In 1839 he sailed from Cronstadt for the colonies, in command of the Russian American Company's ship Nikolai. With him went Kupreanof, Woewodski, and Dr. Blashke. (Journal Russ. Hyd. Dept., 1850, Vol. VIII, pp. 187-188.) From 1841 to 1845 Etolin was gov- 
ernor of the Russian American colonies. In 1833 he surveyed Tamgas harbor and Kaignai strait. (See Russ. Hyd. Chart, 1396, published in 1848.)

\section{FARIS, 1898-1901.}

Robert Lee Faris, assistant, United States Coast and Geodetic Survey, during the seasons 1898-1900 was engaged with Pratt in surveys about St. Michael, Yukon delta, and the north shore of Norton sound. In 1901 he was engaged with Westdahl in the survey of the Sannak islands. The references in this dictionary are confined to his work during the season of 1899 , when he was in charge of a subparty engaged in the survey of the Kwikpak and Kawanak passes and channels, and Apoon pass, Yukon delta. An account of this may be found in United States Coast Survey Annual, 1900, pp. 196-203, and the results are embodied on charts 9370 and 9373 .

Fish Commission, 1888-1905.

From time to time since 1880 the United States Fish Commission has made investigations in Alaskian waters and contributed to a knowledge of its geography. Special use has been made in this dictionary of the maps of Alaska peninsula and the eastern Aleutians contained in the Bulletin of the Commission, Vol. VIII, for 1888, and of a map covering part of the same region, together with Bristol bay, in Vol. IX, for 1889. The new names appearing on these maps are said to be chiefly due to Mr. Samuel Applegate. See also Tanner and Moser.

Flemer and Nelson, 1898.

In 1898 two parties from the Coast and Geodetic Survey, one under John Adolph Flemer, ássistant, Coast and Geodetic Survey, who had general charge of both parties, and the other under John Nelson, assistant, Coast and Geodetic Survey, made a topographic reconnaissance of the country about the head of Lynn canal. Their surveys covered the valleys of Chilkat, Tsirku, Klehini, Katzehin, Skagway, and Taiya rivers. An account of their operations was published in United States Coast and Geodetic Survey Report for 1899, pp. 206-208. The resulting maps were not published, excepting that lithographs were made of the Chilkat River sheet. The more general charts of the region, 8000, 3089, etc., show changes and additions resulting from these surveys.

Franklin, 1826.

Sir John Franklin made explorations along the extreme eastern part of the Arctic coast of Alaska in July and August, 1826. After wintering at Fort Franklin, Sir John descended the Mackenzie to its 
mouth and explored along the coast westward as far as Return reef. For an account of this see his Narrative of a Second Expedition to the Shores of the Polar Sea, 1825-1827, $4^{\circ}$, London, 1828, pp. 124-159.

\section{Geological Survey, 1S89-1905.}

Geologic investigations in Alaska by the Geological Survey began with the work of Mr. I. C. Russell in Yukon valley in 1889. These investigations were continued by Russell in 1890 and 1891 in the St. Elias region. In 1895 Messrs. Becker and Dall investigated and Jater reported on the gold and coal resources of the Territory. Since that time topographic and geologic work has been actively prosecuted by the Geological Survey. The results are set forth in its annual reports and in special reports, bulletins, and profëssional papers, as follows:

Map of Alaska, with Descriptive Text. Prepared in accordance with Public Resolution No. 3, Fifty-fifth Congress, second session. $\mathrm{s}^{\circ}$, Washington, 1899, $44 \mathrm{pp}$.

Maps and Descriptions of Routes of Exploration in A'laska in 1898. Prepared in accordance with Public Resolution No. 25, Fifty-fifth Congress, third session. $8^{\circ}$, Washington, $1899,138 \mathrm{pp}$.

Preliminary Report on the Cape Nome Gold Region, Alaska, By F. C. Schrader and A. H. Brooks. $8^{\circ}$, Washington, $1900,56 \mathrm{pp}$.

Reconnaissances in the Cape Nome and Norton Bay Regions, Alaska, in 1900. By Alfred H. Brooks, George B. Richardson, Arthur J. Colier, and Walter C. Mendenhall. $\mathrm{s}^{\circ}$, Washington, 1901, $222 \mathrm{pp}$.

The Geology and Mineral Rescurces of a Portion of the Copper River District. Alaska. By Frank Charles Schrader and Arthur Coe Spencer. $8^{\circ}$, Washington, 1901, $94 \mathrm{pp}$.

Preliminary Report on Ketchikan Mining District, Alaska, with an Introductory Sketch of the Geology of Southeastern Alaska, by Alfred Hulse Brooks : Professional Paper United States Geological Survey No. 1, 1902, 120 pp.

A Reconnaissance of the Northwestern Portion of Seward Peninsula, Alaska, by Arthur J. Collier: Professional Paper United States Geological Survey No. 2, 1902, $170 \mathrm{pp}$.

A Reconnaissance from Fort Hamlin to Kotzebue Sound by way of the .Dall, Kanuti, Allen, and Kowak Rivers, by Walter C. Mendeṇhall : Professsional Paper United States Geological Survey. No. 10, 1902, 68 pp:

Coal Resources of the Yukon, Alaska, by Arthur. J. Collier: Bulletin United States Geological Survey No. 218, 1903, 71 pp.

The Mineral Resources of the Mount Wrangell District, Alaska, by Walter C. Mendenhall and Frank C. Schrader: Professional Paper United States Geological. Survey No. 15, 1903, $71 \mathrm{pp}$.

Tin Deposits of the York Region, Alaska, by Arthur J. Collier: Bulletin United States Geological Survey No. 229, 1904, 61 pp.

A Reconnaissance of Northern Alaska, Across the Rocky Mountains, Along Koyukuk, John, Anaktuvuk, and Colville Rivers and the Arctic Coast to Cape $\because$ Uisburne; 1901, by Frank C. Schrader and W. J. Peters: Professional Paper $\therefore$ U̦ited States Geological Survey No. 20, 1904, $139 \mathrm{pp}$.

The Porcupine Placer District, Alaska, by Charles W. Wright: Bulletin United Státes Geological Survey No. 236, 1904, 35 pp. 
The Fairbanks Gold Placers of Seward Peninsula, Alaska, by Fred H. Moffit: Bulletin United States Geological Survey No. 247, 1905, 85 pp.

The Petroleum Fields of the Pacific Coast, with an Account of the Bering River Coal Deposits, by George C. Martin: Bulletin United States Geological Survey No. 250, 1905, (i4 pp.

The Gold Placers of the Fortymile, Birch Creek, and Fairbanks Regions. Alaska, by Louis M. Prindle: Bulletin United States Geological Survey No. 251, $1905,89 \mathrm{pp}$.

The Geology of the Central Copper River Region, Alaska, by Walter C. Mendenhall: Professional Paper United States Geological Survey No. 41, 1905, $133 \mathrm{pp}$.

Report on the Progress of Investigations on the Mineral Resources of Alaska in 1904, by Alfred Hulse Brooks, Chester Wells Purington, F. E. Wright. Chas. W. Wright, Arthur C. Spencer, Geo. C. Martin, Fred H. Moftit, Arthur J. Collier, Louis M. Prindle, F. L. Fless, and Ralph W. Stone: Bulletin United States Geological Survey No. 259, $1905,196 \mathrm{pp}$.

The Geography and Geology of Alaska, a Summary of Existing Knowledge, by Alfred Fulse Brooks, with a Chapter on Climate by Cleveland Abbe, jr., and il Topographic Map' and Description Thereof by Richard U. Goode: Frofessional Iaper: United States Geological Survey No. 45, 1906, :327 pp.

The Geology and Gold Resources of the Cape Lisburne Region, Alaska, by Arthur .T. Collier: Bulletin United States Geological Survey No. 278, 1906, $54 \mathrm{pp}$.

Gold Placers of the Riampart Region, Alaska, by Louis M. Prindle and F. I. Hess: Bulletin United States Geological Survey No. 280, 1906, $54 \mathrm{pp}$.

The Juneau Gold Belt and a Reconnaissance of Admilalty Island, Alaska, by Arthur C. Spencer and Charles W. Wright: Bulletin United States Geological Survey No. 2S7, $161 \mathrm{pp}$.

Gerdine, $1899-1905$.

Thomas Golding Gerdine, topographer, United States Geological Survey, began his Alaskan service in 1899 as topographer in Schrader's party on Chandlar and Koyukuk rivers. D. C. Witherspoon also assisted in the topographic work. Again, in 1900, he was topographic assistant to Schrader in the Copper River region. (See Schrader.)

In 1901 Gerdine was in charge of a Geological Survey party engaged in making a reconnaissance of the northern portion of Seward. peninsula. To this party Collier was attached as geologist and D. C. Witherspoon as topographic assistant. An account of these operations will be found in the Twenty-third Annual Report of the United States Geological Survey, pp. 73-75. The result was a topographic reconnaissance map covering nearly 5,000 square miles of the northwestern portion of Seward peninsula, on a scale of $1: 250,000$, and a report on the geology by Collier (Professional Paper United States Geological Survey No. 2, 1902), in which this map was published.

In 1902 Gerdine had charge of a party in the Copper River region, to which Walter C. Mendenhall was attached as geologist, in a topographic and geologic reconnaissance of the Chistochina gold fields and the central portion of Copper River valley. During this season

Bull. 299-06 $\mathrm{M} \longrightarrow 3$ 
4,500 square miles were mapped. An account of these operations will be found in the Twenty-fourth Annual Report of the United States Geological Survey, pp. 79-94. Preliminary maps were published in Professional Paper United States Geological Survey No. 15,1903 , and the final map, on a scale of $1: 250,000$, contour interval 200 feet, as Pl. XIX in Professional Paper United States Geological Survey No. 41, 1905.

In the summer of 1903 Gerdine had charge of the combined topographic and geologic parties in the Yukon-Tanana region. R. B. Oliver was topographic assistant and L. M. Prindle special geologic assistant. During this season a strip extending east and west from the Fortymile quadrangle to Tanana river was mapped, and also another strip from the Fairbanks placer district to Circle on the Yukon-about 6,000 square miles in all-on a scale of $1: 250,000$. An account of these operations will be found in the Twenty-fifth Annual Report of the United States Geological Survey, pp. 76-77, and the maps, so far as published, are contained in Prindle's report, Bulletin United States Geological Survey No. 251, 1905.

In the summers of 1904 and 1905 Gerdine, assisted by R. B. Oliver and W. R. Hill in the former'year, was engaged in making more detailed topographic surveys of the Cape Nome mining region and the region to the eastward. In 1904 about 500 square miles were surveyed, and the resulting maps were engraved and published by the United States Geological Survey in 1906 as two atlas sheets entitled Nome Special Map and Grand Central Special Map. These are on a scale of $1: 62,500$ and the contour interval is 25 feet. In 1905 similar detailed surveys were made, covering about the same area in the Solomon River region to the eastward of Cape Nome. The resulting maps will also be published in the form of atlas sheets.

GIBSON, 1854-55.

Lieut. William Gibson, U. S. N., commanded the U. S. schooner Fenimore Cooper in 1854-55. This vessel was one of those composing the North Pacific Exploring Expedition, "Lieut. John Rodgers commanding," sometimes known as the Ringgold and Rodgers expedition. Gibson cruised through the Aleutian islands in the summer of 1855 , correcting the charts and surveying harbors here and there, especially at Attu and Adak. No report of the work has been published. The geographic results are shown on United States Hydrographic charts 8 and 55 .

GiLbert, 1900-1901.

John Jacob Gilbert, assistant, United States Coast and Geodetic Survey, commanded the Coast Survey steamer Pathfinder in Alaskan waters during the seasons of 1900-1901. In 1901 he triangulated and 
surveyed the shore line of Norton sound, western Alaska, and executed the hydrography and topography along the shore from and including St. Michael harbor to and including Golofnin sound. In 1901 the Fox islands and passes, eastern Aleutians, were surveyed, and the triangulation, hydrography, and topography were extended. from and including the eastern shore of Unalaska island to and including the southwestern shore of Unimak island. Accounts of these operations are published in United States Coast and Geodetic Survey Reports, 1901, pp. 148-151, and 1902, pp. 136-139, and the results are shown on charts $9370,9375,9380$, and 9382 for Norton sound and 8860 for the Fox islands.

Glass, 1881.

Commander Henry Glass, U. S. N., succeeded Captain Beardslee on the Sitka station in 1881, in command of the U. S. S. Wachusett. The surveying done by Symonds and Hanus under Beardslee was continued under Glass and was published by the Coast Survey. See Coast Survey chart 726.

Glave, 1990. See Leslie Expedition.

GLenN, 1898-99.

By direction of the Secretary of War, three military parties were to be organized in the spring of 1898 for exploring the interior of Alaska. The third, known as Expedition No. 3, was placed under the command of Capt. Edwin F. Glenn, of the Twenty-fifth infantry, who was instructed to establish a camp at Port Wells, Prince William sound, about April 1, 1898, and explore northeastward for routes toward the Copper and Susitna rivers, and on, about May 1, to go to Cook inlet and explore northward to the Tanana and Yukon. With this party went, as geologist, Mr. W. C. Mendenhall, of the United States Geological Survey. Glenn's report was published in 1899 by the Adjutant-General's Office of the War Department, as (Bulletin) No. XXV, Reports of Explorations in Alaska, and also in a quarto volume emanating from the Senate Committee on Military Affairs and entitled Compilations of Narratives of Explorations in Alaska; Washington, Government Printing Office, 1900, pp. 627648. Mendenhall's report was published in 1900 in the Twentieth Annual Report of the Geological Survey, Part VII, pp. 265-340.

Glenn's explorations were continued in 1899. For report on these see the above-cited compilation, pp. 711-724.

GLOTоF, 1763-1766.

Stephen Glotof, a Russian fur trader, after wintering, 1762-63, on Copper island, sailed away on July 26 and, cruising eastward, discovered several of the Aleutian islands. He went as far eastward as 
the island of Kodiak, which he discovered. He wintered there and returned to Umnak in 1764 and to Kamchatka in 1766. He published nothing. For some account of his travels see Coxe, Account cf Russian Discoveries, 1780; Berg, Chron. Hist. of Discovery of Aleutian Islands, St. Petersburg, 1823; also Dall's Alaska and Bancroft's History.

Goodrich, 1896. See Spurr, Goodrich, and Schrader.

Grant, 1905.

In the summer of 1905 Prof. Ulysses Sherman Grant, of Northwestern University, in the employ of the Geological Survey, and assisted by Mr. Sidney Paige, investigated the copper deposits of Prince William scund and made detailed stratigraphic studies along the coast. In the early part of the season Mr. Paige made a reconnaissance survey of the Herendeen Bay coal field. A preliminary report of these investigations, illustrated by sketch maps, has been published in Bulletin United States Geological Survey No. 284, 1906, pp. 78-87, 101-108, and a final report is in preparation.

Grewingk, 1850.

1)r. Constantin Grewingk published in Verhandlungen der Russisch-Tíaiserlichen Mineralogischen Gesellschaft zu St. Petersburg, Jahrgang, 1848 und 1849, a contribution to our knowledge of Northwest Ancrica and its adjacent islands. This work, in German, is a veritable storehouse of information and has been freely used in this dictionary. Its arrangement, however, and the lack of an index make its use for dictionary purposes both laborious and unsatisfactory.

Hamilton, 1904, 1905.

In 1904, Ernest G. Hamilton, of the Geological Survey, was detailed as topographer with Moffit on Kenai peninsula. During this season a topographic reconnaissance map was made, covering 1,600 siquare miles of the northwestern portion of Kenai peninsula abont Kenai lake and on the south shore of Kachemak bay. (See Moffit.) In 1905, as topographer under Martin and assisted by W. R. Hill, he made a topographic map of the region about Controller bay. (See Martin.)

Hanus, 1879-1881. See Beardslee and Glass.

Harber, 1892. See Moore (W. I).

Harriman Alaska Expedition, 1899.

In the summer of $1899 \mathrm{Mr}$. Edward Henry Harriman, of New York, visited Alaska for health and recreation. For this purpose he chartered the steamer George W. Elder, and invited as his guests 
about 30 scientific men from various parts of the United States, a considerable number being from Washington. The party sailed from Seattle on July 1 and cruised northward and westward along the British Columbian and Alaskan coasts to Bering strait, and returning reached Seattle on August 31, having been gone just two months. At various points collections were made by his guests, photographs secured, and a little surveying and exploration done. The results are being published by Mr. Harriman and the Washington Academy of Sciences. Mr. Harriman's publication has now grown to six large volumes, edited by C. Hart Merriam.

HAYES, 1891.

In the spring of 1891 Lieut. Frederick Schwatka conducted an exploration, organized by a syndicate of newspapers, in the region lying between Lynn canal and Copper river. Dr. Charles Willard. Hayes, of the United States Geological Survey, was detailed to accompany the expedition as geologist. He published his results, including 3 maps, in 1892, in the National Geographic Magazine, Vol. IV, pp. 117-162. The route was up Taku inlet, down the Teslin and Lewes, up the White, over Skolai pass and down the Chitina and Copper. The party left Juneau on May 25 and arrived at Eyak, in Prince William sound, just in time to miss the August mail steamer.

HeLm, 1886. See Snow.

Herron, 1899.

In April, 1899, Lieut. Joseph S. Herron, U. S. A., was detailed for duty with the Cook Inlet Exploring Expedition, commanded by Capt. Edwin F. Glenn. The expedition sailed from Seattle, Wash., April 30, and while the main expedition continued to Tyonek, Herron was detailed at Orca with a small party to explore a reported portage between Passage canal, Prince William sound, and Turnagain arm of Cook inlet. He made the exploration and arrived at Tyonek on May 31.

Later he was placed in command of a detachment to explore a route to the Yukon, which was landed at the head of steamboat navigation on Kichatna river, a branch of the Yentna, on July 1. His route lay up the Kichatna, across the mountains to the Kuskokwim (south fork), down that river and up the valley of the East fork of the Kuskokwim, across Minchumina lake and the mountains to the head of Cosna river, down that stream and Tanana river to Fort Gibbon on the Yukon, where he arrived December 11, 1899.

His report, Explorations in Alaska, 1899, for an All-American Route from Cook inlet, Pacific Ocean, to the Yukon, by First Lieutenant Joseph S. Herron, 8th Cavalry, Commanding Expedition, 
March, 1901, is No. XXXI, Adjutant-General's Office, War Department, pages 77 , and 3 maps, Washington, Government Printing Office, 1901.

Hess, 1903-1905. See Coliter, Prindle, Moffit.

Hooper, 1880-1899.

Capt. Calvin Leighton Hooper, of the United States Revenue-Cutter Service, was born in Maine on July 7, 1842, and entered the United States Revenue-Cutter Service as a third lieutenant on June 6, 1866. In this service he remained continually till his death of Bright's disease in San Francisco on April 29, 1900. He was promoted to second lieutenant on June 24, 1868, to first lieutenant on July 20, 1870, and to captain on October 23, 1879 . He served six years on the North $\Lambda$ tlantic coast of the United States, three years on the Great Lakes, while his last twenty-five years were spent on the Pacific coast, chiefly in Alaskan waters, where for many years he patrolled in and about Bering sea. His annual reports to the Treasury Department have contributed to our knowledge of Alaskan geography.

ILIN, 1818-1.842.

- Staff-Capt. Peter Ivanovich Ilin, of the Pilot Corps, sailed from Cronstadt for the Russian American colonies with Golofnin in the Kamchatka on August 26, 1817. In 1831, in a skin boat (bidarka) 23 feet long, he surveyed the eastern coast of Kamchatka from Avacha bay northward to Cape Shipunski (Journal Rus. Hyd. Dept., 1852, Vol. X, pp. 125-135). This man is supposed to be the one who surveyed, at an unknown date, a bay on the western shore of Chichagof island, a bay which after him has been called Ilina-i. e., Ilin's. His sketch is contained in Sheet XXIII of Sarichef's atlas, published in 1826. Ilin died in Okhotsk (one account says Kamchatka) in 184\%. (Journal Rus. Hyd. Dept., 1850, Vol. VIII, p. 169.)

INGENSTREM, 1829-1832.

Ingenstrem was a pilot in the employment of the Russian American Company and often visited Atka, where he twice wintered and made various surveys on Atka and Amlia. He did not publish anything. His results are, incorporated in Tebenkof, Lutke, and on Russian Hydrographic chart 1400. Very little information is on record about him. Even the spelling of his name is uncertain. Grewingk says that he made surveys in the western Aleutians in 1829. In 18301832, in company with Chernof, he did surveying in Prince William sound and at the mouth of Kenai river, Cook inlet. 
Rev. Sheldon Jackson, Presbyterian missionary and since 1885 general agent for education in.Alaska, first visited Alaska in August, 1877, in the interest of schools and missions. He made a second trip on the same errand in 1879. Other visits followed, and since his government appointment ị 1885 he has made annual visits to the Territory, traveling. extensively in various parts on inspecting tours. Reports on this work are published annually in the Report of the Commissioner of Education, and in the Report on Introduction of Domestic Reindeer into Alaska.

JARVIS, $1897-98$.

In the winter of 1897-98, Lieut. Daniel H. Jarvis, Revenue-Cutter Service, conducted an overland expedition for the relief of the whaling fleet imprisoned by the ice in the vicinity of Point Barrow. On December 16, 1897, he, with three companions, was landed on Nunivals island, Bering sea, near Cape Vancouver, by the revenue cutter Bear.

From Nunivak island the expedition traveled by dog teams across the delta and lake country to Andreafski, on the Yukon, thence down the Yukon and along the coast to St.. Michael. From St. Michael the route lay along the coast of Norton sound to Cape York, by one section, and across the base of Seward peninsula to Kotzebue sound by another. From the various stations on the shore of Norton sound a herd of 448 reindeer was collected and driven across Kotzebue sound on the ice and thence along the Arctic coast to Point Barrow, which was reached on March 29, 1898.

This expedition is remarkable rather for the enterprise, endurance, and heroism displayed by the officers and men engaged than for its contriblutions to geographic knowledge. A detailed account was published in Report of the Cruise of the U. S. Revenue Cutter: Bear and the Overland Expedition for the Relief of the Whalers in the Arctic Ocean from November 27, 1897, to September 13, 1898. Washington, Government Printing Office, 1899, pp. 144 and 1 map.

\section{Khwostor and Davidor, 1803.}

Two Russian naval officers, Nikolai Alexandrovich Khwostof and Gavril Ivanovich Davidof, were in the employ of the Russian American Company in 1802-1804. They left St. Petersburg in April, 1802, and went overland to Okhotsk, arriving in August "of the same year." a Thence they sailed to Kodiak, conferred with Baranof, and

a Bancroft, F. H., History of Alaska, $8^{\circ}$, San Francisco, 1886, p. 458. 
returned to Olkhotsk, whence they returned overland to St. Petersburg, arriving there in January, 1804. Davidof published in Russian an account of this journey, in 2 volumes, St. Petersburg, 1810-1812. See also Journal of the Russian Hydrographic Department, 1852, Vol. X, pp. 391-433; also Bancroft's History, pp. 458-459.

\section{Kotzeiue, . 1816-17.}

By the liberality of Count Rumiantzof, Russian counselor of state, in 1815 the brig Rurik was fitted out for exploration in America with reference to a Northwest Passage. Lieutenant Otto von Kotzebue, son of the distinguished author, and who had accompanied Krusenstern on the Neva in 1803-1806, was placed in command. Accompanied by the savants Choris, Chamisso, and Eschscholtz, he sailed from Cronstadt on July 30, 1815, and, rounding Cape Horn, arrived in Petropavlorsk on June 19, 1816. Sailing from there on July 18, he landed on St. Lawrence island on the 27th, passed through Bering strait on the 31st, and on August- 3 entered the. sound which now bears his name. This he explored and mapped, as also the region about Bering strait and St. Lawrence island. He then sailed to Unalaska, San Francisco, and the Hawaiian islands. From here he returned to Unalaska the following year (1817), refitted, and went to St. Lawrence island. Through ill health he gave up further exploration and returned to Russia, arriving in Cronstadt on August 3,1818 . A full account of this voyage was published in 1821, both in Russian and in German. An English translation by H. E. Lloyd was published the same year.

Kotzebue was born at Revel on December 19, 1787, and died there on February 13, 1846.

Krause Brothers, 1882.

Two brothers, Dr. Arthur Krause and Dr. Aurel Krause, were sent out by the Bremen Geographical Society in 1881 to make ethnographic and geographic studies in Alaska. In the summer of 1881 they visited and mapped a district about the head of Lynn canal and Chilkat river. Later they visited and worked in Bering strait, making a map of the country about East cape. Accounts of this have appeared in various journals. A summing up of all the work was published in 1885, entitled Ergebnisse einer Reise nach der Nordwest Küste von Amerika und der Berings-Strasse, etc., $8^{\circ}$, Jena, 1885, $16+420$ pp., with illustrations.

In this dictionary Krause's names have all been taken from a map of the Chilkat region, from surveys by Arthur Krause in 1882, which was published in Zeitschrift der Ges. für Erdk. zu Berlin, 1883, Vol. XVIII, plate 9. 
Krentrzin and Levaseef, 1768-69.

On May 4, 1764, the Tzarina of Russia issued an ukase ordering a secret naval expedition to explore between Asia and America. In charge of it was placed Capt.-Lieut. Peter Kuzmich Krenitzin, whose principal assistant was Lieut. Michael Levashef. Leaving St. Petersburg on July 1, 1764, the party went to Okhotsk and there built two vessels, repaired two others, and with the four sailed from Okhotsk on October 10, 1766. Shipwreck soon followed and the shipwrecked crews wintered at Bolsheretsk in Kamchatka. The following summer they repaired their boats, sailed to Nizhnikamchatsk, and there passed the winter. Finally, on June 21, 1768, all was ready and the party sailed eastward, Krenitzin commanding the galiot St. Catherine and Levashef the hooker St. Paul. They cruised through the eastern part of the Aleutian chain and wintered, Levashef in the poit in Unalaska which now bears his name, and Krenitzin in the strait between Unimak and Alaska peninsula.

The following year (1769) both ships returned to Kamchatka, Krenitzin arriving on July 29 and Levashef on August 24. They wintered at Kamchatka. On July 4, 1770, Krenitzin was drowned, whereupon Levashef assumed command and returned to St. Petersburg, arriving on October 22, 1771. Coxe published in 1780 the first account of this voyage. An official account of it, in Russian, was published in the Journal of the Russian Navy Department in 1852, Vol. X, p. 70-103. Petrof drew largely from this official report for the accoant written by him in Bancroft's (H. H.) History of Alaska, pp. 157-168.

Krusenstern, 1804-05.

Admiral Adam Johann von Krusenstern, in the ship Nadezhda (Hope), and accompanied by Lisianski in the ship Neva, made the first of a long series of Russian voyages from Cronstadt to the Russian American colonies.

Prior: to 1799 there were several Russian companies in Alaska. They derived their supplies overland through Siberia. In 1799 a new company - the Russian American Company - was organized and given very large powers. This company completely supplanted all previous ones, and it adopted the policy of sending to the colonies an annual supply ship-or rather two of them, for they sailed, after the custom of the time, in pairs for mutual assistance. Krusenstern commanded the first one sent out, the Nadezhda, which, sailing from Cronstadt on July 26, 1803, rounded Cape Horn and arrived in Petropavlovisk on July 31, 1804. Refitting here, Krusenstern sailed on August 27, 1804, on a diplomatic mission to Japan. The winter, one of disappointment and failure, was spent in Japan, and on April 5, 1805, Krusenstern 
sailed away and, cruising northward along the Japanese coast and Kurile islands, arrived in Petropavlovsk in June. On board the Nadezhda were, among others, the chancellor Resanof, Kotzebue, Langsdorf, and Shemelin. Resanof and Langsdorf left the Nadezhda at Petropavlovsk, and on June 23, 1805, Krusenstern sailed for home, arriving in Cronstadt on August 7, 1806.

Both Krusenstern and Lisianski had served in the English navy. Krusenstern became an admiral in the Russian navy and published extensively respecting the hydrography of the North Pacific. In 1809-10 he published, in Russian, an account of this voyage. This appeared in German in 1810-1812, in French in 1821, and in English in 1831. He also published an atlas of the Pacific ocean in 1827, accompanied by a collection of hydrographic memoirs explanatory thereof. For a brief account of the voyage see Journal of the Russian Hydrographic Office, 1849, Vol. VII, pp. 6-26. The accounts by Langsdorf, Lisianski, and Shemelin cover parts of the voyage.

Kunitzien, 1849.

Full-Pilot Kuritzien made a survey of Umnak island in or before the year 1849. His map is reproduced as a subsketch in Tebenkof's atlas sheet xxv. No particulars concerning him are known to the writer.

\section{LANGSDORF, $1804-05$.}

Georg Heinrich von Langsdorf accompanied Krusenstern during part of his voyage around the world, in 1803-1806, and published in two volumes an account of his voyages and travels, which appeared in German in 1812 and in English in 1813-14. Apparently also there was a Russian edition in 1811. Langsdorf was a member of the Russian embassy to Japan, of which embassy Resanof was chief. Resanof and Langsdorf parted company with Krusenstern at Petropavlovsk on June 24, 1805, and together visited the Pribilof islands, Unalaska, Kodiak, Sitka, and California, and afterwards returned to Russia.

\section{La Perouse, 1786.}

In 1785 Louis XVI of France organized a scientific exploring expedition on a lavish scale and placed it under the command of Commander Jean François de Galaup de la Perouse.

Two vessels were fitted out for the purpose-La Boussole, commanded by La Perouse, and L'Astrolabe, commanded by Captain de Langle. Sailing from Brest on August 1, 1785, via Cape Horn and the Hawaiian islands, they arrived on June 24 in sight of the northwest coast of America in the vicinity of Yakutat. From this point they cruised southward, surveying as they went as far as Monterey, 
California, arriving there on September 15. .Here they remained till the 24th and then took final leave of the American coast.

La Perouse was an unfortunate navigator. At Lituya bay, which he entered and surveyed, 26 of his ship's company were drowned in the tide bore at its entrance. Both ships with all hands were lost in 1788 or 1789, and for many years their fate was a mystery. It has been solved, however, and some of the wreckage of the ships has been recovered and recently placed on exhibition in the French Naval Museum in Paris.

An elaborate report upon this expedition, in 4 quarto volumes, with an atlas, was published by the French Government in 1797, entitled Voyage de La Perouse autour du monde.

Lestite EXPEDITION, 1890-91.

In the spring of 1890 Frank Leslie's Illustrated Newspaper sent an expedition to Alaska. It was conducted by E. H. Wells, E. J. Glave, and Alfred B. Schanz, with Wells in command. John Dalton and Franklin B. Price, of San Francisco, were employed as helpers. The expedition was transported from San Francisco by the Coast Survey steamer Patterson and landed at Pyramid harbor, Lynn canal, early in May. Convoyed by Chilkat Indians, the expedition ascended the Chilkat river, crossed the divide through Chilkat pass, and descended Takhini river to the north.

At Kusawa lake Glave and Dalton separated from the main expedition and crossed to the headwaters of the Alsek river, which they explored to the ocean, descending it in a canoe. The main expedition, consisting of Wells, Schanz, Price, and Indiank, a Chilkat, after surveying Kusawa lake and its outlet, floated on a raft down the Yukon to Fortymile creek.

Here Schanz was detained by illness, and Wells, having obtained the services of another white man, De Haas, with the rest of the party, pushed on in an attempt to reach Mount Wrangell. He ascended Fortymile creek and its south fork, crossed the Tanana at Tanana crossing, and, continuing north, reached a point well up Tok river. Here he was forced by want of food to turn back. The party descended Tok river, the Tanana, and the Yukon to Nulato, and crossed the portage to St. Michael, which was reached on September $18,1890$.

Meanwhile Schanz, having recovered, departed from Fortymile with a companion, James A. French, and descended the Yukon to St. Michael, where he arrived September 8. Between this date and October 10, 1890, Schanz, accompanied by William C. Greenfield and some Eskimos, made a bidarka trip from St. Michael to Ikogmut, portaged thence to the Kuskolswim, descended that river, and coasted 
to Nushagak, on Bristol bay. Between September 22 and November 12 Wells followed over the same route to Nushagak.

Later Wells crossed Alaska peninsula with dog teams to Katmai. Between January 29 and February 25, Schanz, accompanied by John W. Clark (the trader at Nushagak), Innokente Shishkin (a young Russian), and Eskimos, with dog teams, ascended Nushagak, Mulchatna, and Kakhtul rivers, crossed to the head of Chulitna river, and descended that stream to Lake Clark, which he named. From Lake Clark the route lay down its outlet, across Illiamna lake, and down Kvichak river to Bristol bay. He then followed Wells across the peninsula to Katmai.

Narratives by Wells, Schanz, and Glave may be found running through the numbers of Frank Leslie's Illustrated Newspaper, contained in vols. $70,71,72$, and $73,1890-91$. In addition to these, the writer has seen an article by Glave in the Century Magazine for October, 1892, also the chapter on the Nushagak district in the Eleventh -Census volume on Alaska, pp. 91-97, written by Schanz. The map results appeared on the general maps and charts of the Coast Survey and on the map of Alaska in the above-named Census report.

Levashef, 1768-69. See Krenitzin and Levasher.

Lindenberg, 1838.

In 1838 a survey and chart was made of the head of Lynn canal and the lower reach of Chilkat river by a Mr. Lindenberg. This chart was published as an inset or subsketch on Russsian Hydrographic chart 1396, published in 1848. It does not appear who this Lindenberg was. Perhaps it was the Captain Lindenberg who was in command of the Russian American Company's ship Prince Menshile of in 1852. Grewingk records (p. 418) that Lindenberg surveyed Admiralty island and Chilkat river in 1838 .

LISTANSKI, 1804-5.

Krusenstern (Admiral A. J. von) and Lisianski (Capt. Urey), in the ships Nadeahda (Hope) and Neva, sailed from Cronstadt around Cape Horn and thence to the North Pacific on a voyage to carry supplies to the Russian American Company and to make exploration and discovery. This was the first of a series of circumnavigations by the Russians. Sailing from Cronstadt on October 6, 1803, Lisianski reached the Hawaiian islands on June 4, 1804, and proceeded thence to St. Paul, Kodiak, arriving on July 14, 1804. Here he heard that the Indians had destroyed the Russian settlement at Sitka. Accordingly he sailed thither (August 15-20), and on October 1, 1804, bombarded and destroyed the Indian village which was located on Indian river near the present site of Sitka. On November 10-15 he returned 
to Kodiak and wintered there. The next year (June 14-22, 1805) he returned to Sitka and remained there till September 1, when he set sail for Canton and thus ended his work in Alaska. He published in English an account of the voyage in 1814, entitled Voyage Round the World in 1803-1806, by Urey Lisianski, $4^{\circ}$, London, 1814.

LUTKE, 1827-28.

One of the important authorities used in preparing this dictionary is Capt. Feodor Petrovich Lutke, who, in command of the Russian corvette Seniavine and accompanied by Capt. Mikhail Nikolaievich Staniukovich in command of the sloop Moller, made a voyage around the world in 1826-1829.

An account of the voyage was published in Russian in 1834-1836, in 3 octavo volumes, a folio atlas, and another volume called Nautical part. It appeared at the same time in French. The nautical part is a rare book. The two copies of it in the Library of Congress, one in French, the other in Russian, are the only ones known to the writer. This Partie naitique contains hydrographic and geographic information as to Bering sea, Alaska peninsula, etc., derived not merely from Lutke's own work, but also from various Russian sources previously unpublished. Pressing public duties delayed the preparation and publication of this work, and finally it appeared in a crude form far from satisfactory to its author. Despite its defects, however, the work is of first importance in dealing with the evolution of our geographic knowledge of Alaska. An index to this book was: prepared by Dall and published by the Coast Survey in 1883 in the Coast Pilot of Alaska.

Lutke and Staniukovich sailed from Cronstadt on September 1, 1826, and, rounding Cape Horn, arrived at Sitka on June 24, 1827. Here Lutke remained till July 31 and then sailed to Unalaska, arriving on August 22. After a stay of eight days in Unalaska he cruised northward and westward in Bering sea to the Pribilof islands, St. Matthew, the Commander islands, and to Petropavlovsk. From here he cruised southward and returned to Petropavlovsk on June 9, 1828. After a stay of sixteen days he cruised and surveyed along the Siberian coast to St. Lawrence bay in Bering strait and returned on September 4, 1828, to Petropavlovsk. He took final leave of this place on November 9, 1828, and, rounding the Cape of Good Hope, returned home, arriving at Cronstadt on September 6, 1829.

McGrath, 1889-1892. See 'Turner and Moore. (W. I.)

McLenegan, 1885. See Cantwell.

Malaspina, 1.791.

Capt. Alessandro Malaspina, an Italian navigator in the service of Spain, in command of the Descubierta and accompanied by Bustamente in the Atrevida, arrived on the Alaskan coast on June 2, 1791, near 
Sitka and surveyed along the coast to Prince William sound, looking for the Northwest passage reported by Maldonado. The journals of the voyage were long suppressed. A sketch of the voyage was published in the Introduction to Galiano's Relacion del viage hecho por los goletas Sutil y Mexicana, etc.; de orden del rey, $8^{\circ}$, Madrid, 1802; yet, strange to say, the name of Malaspina, whose work is highly praised, can not be found in the book. On his return to Spain, the infamous Godoy, known as the Prince of the Peace, confined him in a dungeon at Corunna and there kept him till the peace of Amiens in 1802, when, at the express desire of Napoleon, he was liberated. An account of his work was published in Salvá (Miguel) y Baranda (Pedro Sainz de), Coleccion de documentos ineditos, etc., $8^{\circ}$, Madrid, 1849, Vol. XV, pp. 268-320.

Mansfield, 1889-1891.

Lieut. Commander Henry Buckingham Mansfield, U. S. N., succeeded Thomas as commander of the Coast and Geodetic Survey steamer Patterson in the spring of 1889, and remained in command until succeeded by Moore, on February 2, 1892; thus he made surveys in Alexander archipelago during the seasons of 1889, 1.890, and 1891. In 1889 , April 27 to September 29, his work was chiefly or wholly in Frederick sound, where surveys were made of Cleveland passage, Steamboat bay, Eliza harbor, Gambier bay, Mole harbor, Windfall harbor, Holkham bay, etc. The season's work of 1890 began at Port Simpson on April 28 and ended at Juneau on September 17. During this season 14 harbor and large-scale charts were made, chiefly in and about Lynn canal. This included Barlow cove, William Henry harbor, Pyramid harbor, Portage cove, Gastineau channel, Juneau harbor, etc. Work during the season of 1891 began on April 30 at Burroughs bay and ended on September 18 at Thorne arm. The surveys of this season were chiefly or wholly in the waters surrounding Revillagigedo island, southeastern Alaska. For an account of his work see Coast and Geodetic Survey Reports, 1890, pp. 75-77; 1891, pp. $78-81$; 1892, pp. 82-83; also Coast Survey charts $8075,8170,8216$, $8218,8224,8235$, and 8302 .

MARSH, 1902-3.

S. J. Marsh, of Nome, Alaska, in the winter of 1902-3, made a remarkable journey from Camden bay on the Arctic coast to Fort Yukon, via Kuselik creek, Barter river, Canning river, East Fork Chandlar river, and Chandlar river. He made notes of his route and a sketch map. The notes have been included by Brooks in his report on The Geography and Geology of Alaska: Professional Paper United States Geological Survey No. 45, 1906, pp. 260-262. 
MaRTIN, 1903-1905.

Since 1903 Dr. George Curtis Martin, of the Geological Survey, has been engaged each season in studying the petroleum and coal fields on the south coast of Alaska. In 1903 he studied the petroleum and coal fields of Controller bay and Bering river, the petroleum fields on. the southwest coast of Cook inlet, and the Cold bay field on the southeastern coast of Alaska peninsula.

In 1904, with the assistance of $\mathrm{R}$. W. Stone, a reconnaissance of the Kachemak bay coal field was made, and a reconnaissance of the southwestern shores of Cook inlet and thence southwesterly as far as Cold bay on Alaska peninsula. Martin also made a study of the ore deposits on Unga island and spent two weeks in a supplementary reconnaissance of the Controller bay coal and petroleum fields.

In 1905 Martin conducted the operations of a larger party in making a more detailed topographic and geologic survey of the Controller bay region. With him were Mr. A. G. Maddren, geologic assistant, and Mr. E. G. Hamilton, topographer, assisted by Mr. W. R. Hill. During this season Martin also made a reconnaissance of the Matanuska coal fields north of Cook inlet.

Accounts of these operations may be found in the annual reports of the United States Geological Survey-Twenty-fifth Annual, pp. 72-75, and Twenty-sixth Annual, pp. 61-64. The results appear in Bulletin United States Geological Survey No. 225, 1904, pp. 365-382, and Bulletin No. 259, pp. 88-89, 100-101, 128-137, 140-150, 167-168. Bulletin No. 250, published in 1905, 64 pp. and 6 maps, entitled The Petroleum Fields of the Pacific Coast of Alaska, with an Account of the Bering River Coal Deposits, gives the results of the investigations in 1903 and 1904. A preliminary report of the 1905 investigations appears in Bulletin No. 284, 1906, 157 pp. Bulletin No. 289, 1906, $36 \mathrm{pp}$. and 4 maps, is Martin's report on A Reconnaissance of the Matanuska Coal Field in 1905. Hamilton's topographic map has not yet been published.

\section{MaUrecte and Quadra, 1775-1779.}

Spanish exploration on the northwest coast of America north of California began in 1774. In that year Perez and Martinez reached and anchored in Nootka sound, Vancouver island.

In 1775 , by command of the Mexican Viceroy Bucareli, there was despatched the royal galiot Sonora, under command of Don Juan Francisco de la Bodega y Quadra, to make explorations north of California. With Quadra went the pilot Francisco Antonio Maurelle. On this voyage they discovered, named, and in part surveyed Bucareli bay. Four years later a second voyage was undertaken by the Spaniards. Quadra, in command of La Princesa, and Don Ignacio Arteaga, in command of La Favorita, with Maurelle as pilot, sailed 
from S̄an Blas, Mexico, on February 11, 1779, and cruised northward as far as the mouth of Copper river, whence they returned to San Blas, arriving on November 21, 1779. In this voyage they revisited Bucareli bay and made additional surveys there. The published results of these voyages, so far as this dictionary is concerned, relate chiefly to Bucareli bay.

A copy of their map was secured by La Perouse and published in 1798, in the atlas accompanying his Voyage, plate 26. Also Daines. Barrington, in his Miscellanies, $4^{\circ}$, London, 1781, published Maurelle's journal, yet without the map. The Spaniards were secretive about their explorations, avoided publication, and thus have left little impress on the geography of the region they visited. For references to publications touching this work see Grewingk, pp. 392-393.

MEADE, $1868-69$.

Commander (afterward Rear-Admiral) Richard Worsam Meade, U. S. N., cruised through Alexander archipelago in the winter of 1868-69 in the U. S. S. Saginaw and made reconnaissance sketches of various places there. An account of this cruise was published by the Navy Department on July 26, 1869, as Hydrographic Notice No. 13 of 1869 , a pamphlet of 29 pages. The map results were incorporated on United States Hydrographic chart No. 225, a chart of rough and crude appearance, but which has been very useful in making this dictionary.

Meares and Dougglas, 1788-89.

Capt. John Meares, in January, 1788, in connection with several British merchants resident in India, bought and fitted out two vessels, the Felice and the Iphigenia. Meares commanded the Felice and Capt. William Douglas the Iphigeria. The two ships sailed together from Typa, near Macao, China, on January 22, 1788, cruised around the Philippines, and, parting company, Meares reached Nootka on May 13, 1788, and Douglas arrived in Cook inlet on June 16, 1788. From Cook inlet Douglas voyaged east and south and joined Meares at Nootka on August 27, 1788. Meares cruised and traded about Vancouver island and what is now Washington, and later both officers sailed to the Hawaiian islands. They returned and again traded on the northwest coast of America and then sailed to China.

For an account of their voyage and its results see Meares ( $\mathrm{John}$ ), Voyages in 1788-1789 from China to Northwest America, $4^{\circ}$, London, 1790 .

Meares and Tipping, $1786-87$.

Capt. John Meares, in the Nootka, sailed from Bengal, India, on March 2, 1786, on a trading voyage to Malacca and northwest America. About the same time sailed also Lieut. William Tipping, R. N., 
in command of the Sea Otter. The two vessels were owned by the same company of merchants and were to cooperate. Meares made the land at Atka, in the Aleutian islands, on August 1, 1786, anchored there, and met both Russians and natives. He then cruised eastward through the Aleutian islands to Unalaska, the Shumagins, Kodiak, Cook inlet, and Prince William sound, where the Sea Otter had preceded him and departed with a cargo of peltries. Meares thereupon decided to winter in Prince William sound. He spent a very uncomfortable winter, many of his crew dying of scurvy. On May 17, 1787, he was visited by Capt. George Dixon, another English trader, just arrived in Prince William sound. Of Meares's ship's company 23 had died during the winter, and on June 21, 1787, he sailed away with his company reduced to 24 . Ten days later he was at Sitka and sailed thence for the Hawaiian islands and thence to China, arriving on October 20,1787. Nothing was ever heard of Lieutenant Tipping in the Sea Otter after he left Prince William sound.

For an account of these voyages see Meares (John), Voyages in 1788-1789 from China to Northwest America, $4^{\circ}$, London, 1790, pp. i-xl.

\section{Mendenhall, 1898-1902.}

Mr. Walter Curran Mendenhall, geologist, of the United States Geological Survey, was attached to a military exploring expedition under the command of Capt. E. F. Glenn, known as Military Expedition No. 3, which in the summer of 1898 explored east of Cook inlet and thence northeastward up the Matanuska and across to Tanana river. Mendenhall's results are published in the Twentieth Annual Report of the Geological Survey, Part VII, pp. 265-340.

In 1900 Mendenhall was attached as geologist to a party in charge of W. J. Peters, working in the eastern part of Seward peninsula. His report, A Reconnaissance in the Norton Bay Region, Alaska, in 1900 , is a part of a special report of the United States Geological Survey, 1901, entitled Reconnaissances of the Cape Nome and Norton Bay Regions, Alaska, in 1900, pp. 181-222.

In 1901 a party, of which Mendenhall was geologist and Reaburn was topographer, made a topographic and geologic reconnaissance from Fort Hamlin on the Yukon, by way of Dall, Kanuti, Alatna, and Kobuk rivers, to Kotzebue sound. An account of this exploration may be found in the Twenty-third Annual Report of the United States Geological Survey, pp. 75-77, and the results in Professional Paper United States Geological Survey No. 10, 1902, pp. 68 and 4 maps.

In 1902 Mendenhall was geologist to a party in charge of T. G. Gerdine, which made surveys in the Chistochina gold field and the central Copper River valley. An account of these surveys will be

Bull. $299-06 \mathrm{M}-4$ 
found in the Twenty-fourth Annual Report of the United States Geological Survey, pp. 79-93; a preliminary report in Professional Paper United States Geological Survey No. 15, 1903, pp. 71 and 8 maps; and a final report in Professional Paper No. 41, 1905, pp. 133 and 7 maps. The latter publication contains the reconnaissance maps of the Copper River region made by Gerdine and Witherspoon in 1902.

\section{Mofrit, 1903-1905.}

Mr. Fred Howard Moffit, of the United States Geological Survey, has been engaged each season since 1903 in an investigation of Alaskan geology and mineral resources. In 1903 he was assigned as geologist to Witherspoon's party in a reconnaissance of the northeastern portion of Seward peninsula. In 1904 Moffit, assisted by E. G. Hamilton, topographer, conducted a reconnaissance of the northern part of Kenai peninsula, including the Kenai Lake region and a small area on the south shore of Kachemak bay. About 1,600 square miles were mapped. In 1905 Moffit, assisted by F. L. Hess, was engaged in a detailed geologic survey of the region adjacent to Cape Nome, of which Gerdine had made a detailed topographic survey the year before.

For an account of Moffit's work see the Twenty-fifth Annual Report of the United States Geological Survey, pp. 79-81, and the Twenty-sixth Annual, pp. 59-61. His report on the Fairhaven Gold Placers, Seward peninsula, Bulletin United States Geological Survey No. $247,1905,85 \mathrm{pp}$. and 4 maps, contains Witherspoon's map of that region. A preliminary report of his work on Kenai peninsula was published in Bulletin United States Geological Survey No. 259, 1905, pp. 90-99, illustrated by sketch maps. A final report, entitled The Gold Placers of Kenai Peninsula, by F. H. Moffit and R. W. S.tone, 80 pp. and 6 maps, is Bulletin No. 277, 1906. This contains IIamilton's map. Except for a preliminary report in Bulletin No. 284,1906 , the results of the field work in 1905 have not been published.

Moore (U. K.), 1895-1898.

Lieut. Commander Edwin K. Moore, U. S. N., succeeded W. I. Moore in command of the Coast and Geodetic Survey steamer Patterson on March 15, 1895, and remained in command until recalled in the spring of 1898 to participate in the Spanish war. Thus he had three surveying seasons in Alaska, all in Alexander archipelago; the first from May 13 to October, 1895, spent chiefly in Chatham and Peril straits; the second from August 8 to October 6, 1896, in Peril strait, and the last from April 30 to October 9, 1897, chiefly in and to the north of Sitka sound. 
For an account of his work see Coast and Geodetic Survey Reports, I895, pp. 50-52; 1896, pp. 43-45; 1897, pp. 39-40;1898, pp. 49-50; also Coast Survey charts $8170,8281,8283$.

Moone (W. I.), 1.892-1895.

Lieut. William I. Moore, U. S. N., succeeded Mansfield in command of the Coast and Geodetic Survey steamer Patterson on February 2, 1892, and remained in command till March 15, 1895, when he was relieved by Lient. Commander E. K. Moore, U. S. N. During the season of 1892, which began at Vixen bay, in Boca de Quadra, on May 12 and ended at Security bay on September 19, surveys were made in Dixon entrance, Bocit de Quadra, Clarence strait, Revillagigedo channel, and Kelku strait. In this season's work Lieut. W. P. Ray, U. S. N., commanding the McArthur, cooperated, and Lieut. Giles B. Harber, U. S. N., in command of the Coast Survey steamer Hassler, besides transporting McGrath's party, engaged in determining the geographic position of Mount St. Elias, and, cooperating with that party, made a hydrographic survey of De Monti bay, Port Mulgrave, and Rurik harbor, Yakutat bay.

The season's work of 1893 began at Port Simpson on May 3 and ended at Sitka on September 1. A survey was made of Sitka harbor and approaches, and the ship was used for transporting boundary parties.

The season of 1894 began on May 27 and ended on August 14, during which surveys were made chiefly in Chatham strait, between Peril strait and Icy strait.

For an account of his work see Coast and Geodetic Survey Reports, 1893, Part I, pp. 54-56: 1894, Part I, pp. 50-51; 1895, pp. 50-51; also Coast Survey charts 8075, 8214, 8240, 8283.

Moser, 1897-1901.

Lieut. Commander Jefferson Franklin Moser, U. S. N., commanded the Fish Commission steamer Albatross during her cruises in Alaska in 1897 and 1898. Moser, in the cruise of 1897, collected hydrographic notes and made sketches of harbors and anchorages here and there. These notes and maps were published by the Coast and Geodetic Survey in 1899 as Bulletins 37 and 38. Moser's report for 1897-98 was published in 1899 in Fish Commission Bulletin for 1898, pp. $1-178$; this was also issued separately.

In 1900-1901 Moser also commanded the Albatross, cruising in Alaskan waters, and visited most of the canneries and important salmon streams on the Alaskan coast from Dixon entrance to Nushagak river, Bristol bay. He made sketch maps of many of these streams with their tributary lakes, added to the reconnaissance chart 
of Nushagak bay made by Tanner in 1890, made reconnaissance charts of Alitak bay, southwestern coast of Kodiak, and Afognak bay. He also made a topographic reconnaissance of the Alsek delta and the shore and streams between that and Yakutat bay. Moser's reports for 1900-1901, with sketches and charts, was published in 1902 in Fish Commission Bulletin, Vol. XXI, pp. 173-398. It was also published separately.

Muldrow, 1898. See Eldridge and Muldrow.

MurasheF, 1839-40.

Sub-Lieut. Mikhail Murashef sailed with Tebenkof in the Russian American Company's ship Elena from Cronstadt on August 5, 1835, and, rounding Cape Horn, arrived at Sitka on April 16, 1836. The ship was kept in the colonies. Murashef made surveys, apparently very good ones, along the strait separating Afognak and Kodiak in 1839-40. The results are shown on Russian Hydrographic chart No. 1425, published in 1849 .

MURDOCH, 1881-1883.

John Murdoch was a member of Ray's party at Point Barrow, 1881-1883, as naturalist and observer. The natural history in Ray's report (pp. 89-200) was written by him. Murdoch also studied the Eskimo, acquired some knowledge of their language, and published, in 1892, Ethnological Results of the Point Barrow Expedition, in the Ninth Annual Report of the Bureau of Ethnology, 1887-88, pp. 1-441.

NELSON, 1877-1881.

Mr. Edward William Nelson was stationed for about four years (June, 1877 to 1881) at St. Michael, Norton sound, in the employment of the United States Signal Service, and as a collector for the Smithsonian Institution. During that period he made sledge journeys in the vicinity, and one, especially noteworthy, of about 1,200 miles through the Yukon delta. This journey, made in December, 1878, and January, 1879, yielded considerable geographic knowledge of the region traversed. The map results were incorporated in the maps of the Tenth Census, and a special map with a description of the journey was published in the Proceedings of the Royal Geographical Society for 1882, Vol. IV, pp. 660 to 670 .

Nichols, 1881-1883.

Lieut. Commander Henry E. Nichols, U. S. N., in command of the Coast and Geodetic Survey steamer Hassler, made surveys in Alexander archipelago during three seasons, 1881-1883. In 1881 he made surveys in Kaigani and Wrangell straits and magnetic observations 
at various places. In 1882 , from July 6 to November 20, his work was in and about Revillagigedo channel and northward to Wrangell. In 1883, from May 16 to October 13, he surveyed several harbors just north of Dixon entrance. He was relieved of his command by Lieut. Commander A. S. Snow on March 6, 1884.

In 1888-1890 he again served in the Coast Survey and wrote a revised edition of the Alaska Coast Pilot, which was published in 1891.

For an account of his work see Coast and Geodetic Survey Reports, 1882 , pp. 52-53; 1883, pp. 59-60; 1884, pp. 70-71; also Coast Survey charts $707,709,710,713,8072,8074$.

\section{North Pactfic Exploring Expedition, 1854-55.}

Exploration and surveys were made in the North Pacific, Aleutian islands, Bering sea, and on the Siberian coast by United States naval officers in 1854 and 1855. The expedition was under the command of Capt. Cadwalader Ringgold, U. S. N. Owing to ill health he gave up the command to Capt. John Rodgers, who commanded the U. S. S. Vincennes, while Lieuts. William Gibson and Beverly Kennon were on the U. S. schooner Fenimore Cooper. The expedition is referred to as the North Pacific Exploring Expedition and also as the Ringgold and Rodgers Exploring Expedition. The resulting maps were published by the United States Hydrographic Office, but the journals exist only in manuscript and no general account or report, so far as the writer knows, has ever been published. See United States Hydrographic Office charts $8,54,55,60$, and 68 .

\section{OLtver, 1903-1905. See Gerdine and Wrtherspoon.}

OsGoon, 1902.

In the summer and fall of 1902 Wilfred H. Osgood, of the Biological Survey, Department of Agriculture, conducted a biological survey of the base of Alaska peninsula. Travel was chiefly by canoe, and work was done on both coasts and in the interior.

Starting from Iliamna bay, Kamishak bay, west shore of Cook inlet, on July 10, the route lay over the mountains to Lake Iliamna and thence to Lake Clark. From Lake Clark the party traveled by way of Chulitna and Nushagak rivers to Nushagak on Bristol bay. In a sailboat they crossed the head of Bristol bay to the mouth of Ugaguk river, which they ascended to Becharof lake. Proceeding up Becharof lake to the head of its southern arm, they crossed the mountains to Portage bay, Shelikof strait, and skirted the coast to Cold bay, which was reached on October 13.

From sketches and notes made en route a map of the region was constructed, which was published with Mr. Osgood's report. (U. S. 
Department of Agriculture, Division of Biological Survey, North American Fauna, No. 24, A Biological Reconnaissance of the Base of the Alaska Peninsula, by Wilfred H. Osgood, Assistant, Biological Survey, Washington, Government Printing Office, 1904, 86 pp. and 2 maps.)

Pender, 1868.

Staff Commander David Pender, R. N., made a survey of Portland canal and vicinity in 1868 . This was a survey along the boundary of the then newly purchased Alaska. The resulting map was published as a fly leaf attached to British Admiralty chart 2431.

\section{Peters, 1898-1902.}

In the summer of $1898^{\circ}$ a party of the United States Geological Survey in charge of Mr. William John Peters, topographer, with whom went Mr. Alfred Hulse Brooks as geologist, made a reconnaissance of parts of the White and Tanana river basins. A report on this work was made by Mr. Brooks and published in the Twentieth Annual Report of the.Geological Survey, Part VII, pp. 425-494.

In 1899 Peters and Brooks continued their explorations, going from the head of Lynn canal northwestward and northward to Eagle, on the Yukon. The report on this work was written by Brooks and published in the Twenty-first Annual Report of the Geological Survey, Part II, pp. 331-391.

In 1900 Peters, with Mendenhall as geologist, made a reconnaissance of the southeastern part of Seward peninsula, about Norton bay. An account of his operations was published in the Twentysecond Annual Report of the United States Geological Survey, Part I, pp. $97,98,167$, and 168, and his maps were published with Mendenhall's report, contained in a special report of the United States Geological Survey, entitled Reconnaissances in the Cape Nome and Norton Bay Regions, Alaska, in 1900.

In 1901 Peters conducted a party, with Schrader as geologist, on a reconnaissance in northern Alaska, across the Rocky mountains, along Koyukuk, John, Anaktuvuk, and Colville rivers and the Arctic coast to Cape Lisburne. An account of this trip may be found in the Twenty-third Annual Report of the United States Geological Survey, pp. 77-80, and the results, written by Schrader and Peters, in Professional Paper United States Geological Survey No. 20, 1904, pp. 139, and 4 maps.

In 1902 Peters made a topographic map of about 100 square miles on Douglas island and the mainland in the vicinity of Juneau. This was engraved and published by the Geological Survey in 1904 in the form of an atlas sheet.entitled Juneau Special Map, Scale 1:62,500, contour interval 100 feet. 
Petrof, 1880.

Ivan Petrof was special agent of the Tenth Census (1880) for Alaska and prepared i Report on the Population, Industries, and Resources of the Territory, which forms 189 pages of Volume VIII of the Tenth Census of the United States, published in 1884. This report and two general maps of Alaska issued by the Census Office, one dated 1880, the other 1882, have been most useful and helpful in making this dictionary. The references to Petrof are chiefly to these two maps. References to Bancroft's History of Alaska are usually credited to Petrof, who wrote that work.

A preliminary report on the population, industries, and resources of Alaska was published early in 1881 as House of Representatives Executive Document No. 40, Forty-sixth Congress, third session. In this report is a general map of Alaska showing Petrof's route of travel in his census work. He was at. Kodiak, the Shumagins, Sannak, Belkofski, Unalaska, Unimak, Atka, Pribilof islands, and St. Michael, and traveled in western Alaska from St. Michael to Kodiak, including journeys for considerable distances up Yukon and Kuskokwim rivers.

Por'tlock and Dixon, 1786-87.

The King George's Sound Company, organized as a commercial partnership in May, 1785, fitted out two vessels for trading on the northwest coast of America and China. One of these, the King George, was placed under the command of Capt. Nathaniel Portlock, the other, the Queen Charlotte, under the command of Capt. George Dixon. Both of these officers had served under Cook in his voyage on the Alaskan coast in 1778. The vessels departed from England on September 16, 1785, rounded Cape Horn, touched at the Hawaiian islands, and on July 16, 1786, arrived at Cook inlet. Leaving this anchorage, the two vessels cruised eastward and southward along the coast as far as Nootka and went thence to the Hawaiian islands, arriving on December 1, 1786. Here both remained until March 15, 1787, and then sailed together for Prince William sound, arriving on April 25, and remaining there till July 31, when the ships parted company and Portlock cruised east to the vicinity of Sitka and thence via the Hawaiian islands and China back to England. He made a few additions to the geographic knowledge of the then almost unknown Alaski coast, sketched a few harbors, and named a few places. Both Portlock and Dixon wrote accounts of their royages, which were published in London in 1789. Portlock's is entitled A Voyage Round the World, etc., $4^{\circ}$, London, 1789. 
Post, 1898. Sbe Spurr and Post.

Pratt, 1898-1904.

John Francis Pratt, assistant, United States Coast and Geodetic Survey, commanded the Coast Survey steamer Patterson in Alaskan waters during the seasons 1899-1904. In 1898-99 Pratt had general supervision of all the Coast Survey parties on the coast of Bering sea. Under his immediate direccion his own party made a reconnaissance of the passes of the Yukon and surveyed St. Michael harbor and approaches. In 1899 he made offshore soundings from St. Michael to Cape Dyer and examined the approach to Cape Dyer and Scammon bay. He also surveyed the entrance to Port Safety and made a hydrographic survey of Golofnin bay. In 1900 the north shore of Norton sound from Golofnin bay to Sledge island was surveyed, and also a detailed survey made of Port Clarence, Grantley harbor, Imuruk passage, and Imuruk basin. In 1901 Pratt was in charge of the survey of Icy strait and Cross sound. He carried the triangulation through from Chatham strait and executed the hydrography and topography of Cross sound from the Inian islands to the Pacific. In 1902 he was again in Bering sea with the Patterson to determine the longitude of points on Nunivak and St. Lawrence islands, and incidentally carried lines of soundings between these points and Dutch harbor. In 1903, to facilitate the laying of the army cable, deepsea soundings were made from the entrance to Juan de Fuca strait to Cape St. Elias, the triangulation was extended from the Copper river delta to Kayak island near Controller bay, and the hydrography and topography of Controller bay executed in part.

In 1904 Pratt was in charge of the survey of Kiska harbor and approaches, including Kiska island and Little Kiska island. An account of these operations may be found in the United States Coast and Geodetic Survey Reports, 1899, pp. 212-217; 1900, pp. 181-184; 1901, pp. 153-158; 1902, pp. 139-141; 1903, pp. 105-109; 1904, pp. 101-105; 1905, pp. 61-62. The results of the Bering sea work appear on charts $9302,9370,9372,9373,9380,9381,9382$, and 9385 . The Cross sound and Icy strait surveys are embodied on charts 8302 and 8304 and the Controller bay work on chart 8513. The Kiska harbor surveys, executed at the request of the Navy Department, are held confidential.

Pribilof, 1786.

Gerassim Gavrilovich Pribilof, master in the Russian navy, was the son of one of the sailors who accompanied Bering in 1741 . $\mathrm{He}$ entered the service of the Lebedef-Lastochkin Company in 1778. In 1786 he sought for and discovered in Bering sea the breeding place of the fur seals, the group of islands that now bear his name. He died in Sitka in March, 1796. It does not appear that he published anything. 
Louis Marcus Prindle, of the United States Geological Survey, has been engaged since 1902 in the investigation and study of Alaskan geology and mineral resources. He was geologic assistant to Brooks in 1902 in his exploration of the Mount McKinley region. Each season since that date he has been engaged in the Yukon-Tanana region, which includes the Fortymile, Eagle, Birch Creek, Fairbanks, and Rampart gold fields.

In 1903 he was attached as Geologist to Gerdine's party and made cxaminations in the Fortymile, Birch Creek, and Fairbanks gold diggings. In 1904, assisted by F. L. Hess, he continued his investigations of this region and made a geologic reconnaissance from Eagle to Fairbanks and thence to Rampart. In 1905, with an assistant, he made a foot traverse and geologic reconnaissance from Dawson westward to Fairbanks, over a hitherto unmapped area, and studied recent developments in the Fairbanks region.

For accounts of his work see the Twenty-fifth Annual Report of the United States Geological Survey, pp. 76-77, and the Twentysixth Annual, pp. 67-68. A preliminary report made hy him was published in Bulletin United States Geological Survey No. 225, 1904, pp. 64-73, and by Prindle and Hess in Bulletin No. 259, 1905, pp. 104-119, illustrated by sketch map, and Bulletin No. 284, 1906, pp. 1-157. Bulletin No. 251, 1905, 89 pp. and 5 maps, is a complete report on the gold placers of the Fortymile, Birch Creek, and Fairbanks regions, and contains Gerdine's reconnaissance map of the Fairbanks and Birch Creek districts. Bulletin No. 280, 1906, 54 pp. and 2 maps, by Prindle and Hess, is a detailed report on the Rampart gold placer region.

\section{Prospectors and Miners.}

Ever since the purchase of Alaska, in 1867, prospectors and miners have visited it and gone from time to time here and there. Within the last ten years there have been several gold excitements, and prospectors and miners have gone to Alaska in great numbers. 'These prospectors and miners have named many features, though rarely in print. Subsequently government explorers and surveyors have obtained these names from prospectors' stakes or by word of mouth and have published them. In this dictionary such names are, as far as practicable or known, accredited to the prospectors and miners.

\section{Putnam, $1897-1899$.}

George Rockwell Putnam, assistant Coast and Geodetic Survey, was in Duffield's party, engaged in making topographic surveys of the Pribilof islands and seal rookeries, in 1897. In Coast Survey Report for 1903, Appendix No. 7, pp. 1013-1015, Putnam published 
a list of Native Names for Localities on St. George Island, Bering Sea, collected at that time.

During the seasons of 1898-99 Putnam was in charge of a subparty in the Yukon delta, and made a topographic and hydrographic survey of Scammon bay, mouth of Black river, Kwikluak channels and mouth, Kwikluak pass, and Yukon river to Andreafski; the coast line of the delta also was surveyed from Scammon bay north to the Apoon mouth. An account of these operations will be found in Coast and Geodetic Survey Reports, 1899, p. 218; 1900, pp. 185195 ; and the results are embodied in Coast Survey Charts 9370, 9372, and 9373 .

Quadra, 1774-1779. See Mauretle and Quadra.

$\mathrm{RAY}, 1881-1883$.

Early in the eighties the leading nations of the world undertook simultaneous exploration of the North Polar regions. The plan was for each participating nation to establish as far north as practicable a station for meteorologic and magnetic observations and to maintain it for three years. In this work the United States participated by establishing two stations, one under Gen. Adolphus Washington Greely, U: S. A., at Lady Franklin bay, the other under Capt. Patrick Henry Ray, U. S. A., at Point Barrow, Alaska. With Ray, as observers, assistants, etc., were, among others, John Murdoch, Middleton Smith, Edward Perry Herendeen, and Sergie Smolianinof, a Russian, who is called in the records A. C. Dark. Smolianinof died in Washington on February 11, 1901.

The party sailed from San Francisco on July 18, 18s1, on the schooner Golden Fleece and reached Point Barrow on September 8. Here a permanent station was established and maintained till August 27,1883 . On the 29th the party sailed away on the schooner Leo, reached San Francisco on October 7, and was disbanded on the 15th. Between March 28 and April 7, 1883, Ray made a sledge journey into the interior, and he published a map resulting from this exploration. Ray's report with accompanying papers was published in 1885 as House of Representatives Ex. Doc. No. 44, Forty-eighth Congress, second session.

\section{RAYMOND, 1869.}

Capt. (now Brig. Gen. retired) Charles Walker Raymond, U. S. Engineers, was in 1869 directed to go to Fort Yulion and determine its geographic position. At that time there was doubt in some minds whether Fort Yukon was in British or American territory. Raymond went up the river in the summer of 1869, found that the fort was in American territory, and made a report on the work assigned him, entitled Report of a Reconnaissance of the Yukon River, Alaska 
Territory, July to September, 1869. This was published in 1871 as Senate Ex. Doc. No. 12, Forty-second Congress, first session. The map of the river accompanying this report is the one cited in this dictionary. The map was also issued separately.

Reaburn, 1899-1902. See Barnard, Mendenhal., and Brooks.

REID, 1890-1892.

Prof. Harry Fielding Reid, formerly of the Case School of Applied Sciences at Cleveland, Ohio, and now of Johns Hopkins University, visited Muir glacier in the summer of 1890 and made a study of it and the surrounding region. He returned to it again in 1892 and made further studies there. An account of the work of 1890, accompanied by sketch maps, was published in the National Geographic Magazine in 1892, Vol. IV, pp. 19-84. 'Later studies were published in 1896 in the Sixteenth Annual Report of the United States Geological Survey, Part I, pp. 415-461. The map results are incorporated in map No. 3095 of the Coast and Geodetic Survey.

RITTER, 1898-1904.

Homer Peter Ritter, assistant, Coast and Geodetic Survey, during the seasons 1898-1903 was in charge of a party engaged in triangulating and making topographic and hydrographic surveys of the Copper River delta and the eastern portion of Prince William sound to and including Port Valdez. In this work he had the use of the small steamer Taku. In 1904, in command of the steamer $M c A r t h u r$, he cooperated with Pratt in the survey of Kiska harbor, western Aleutians. The accounts of these operations are published in United States Coast and Geodetic Survey Reports, 1899, pp. 209-211; 1900, pp. 204-206; 1901 , pp. $159-160 ; 1902$, pp. 142-144; 1903, pp. 110-112; 1904, pp. 106-108; 1905, pp. 62-63. The results of the Copper River delta and Prince William sound surveys, so far as published, appear on United States Coast and Geodetic Survey charts 8500, 8513, 8520, and 8521. The Kiska harbor surveys, made at the request of the Navy Department, are still held confidential.

RoHN, 1899.

In the summer of $1899 \mathrm{Mr}$. Oscar Rohn, who was attached to a military exploring expedition under the command of Capt. W. F. A.bercrombie, had charge of a detachment which explored the region south and east of Mount Wrangell. A preliminary report on this work was submitted to the War Department and a later and fuller report to the Geological Survey. The last is published in the Twenty-first Annual Report of the Geological Survey, Part II, pp. $393-440$. 
RUSSELL, 1889-1891.

Prof. Israel Cook Russell, then of the United States Geological Survey, visited the Yukon valley in 1889 and the Mount St. Elias region in 1890. In the latter year he explored Malaspina glacier and Yakutat bay under the auspices of the National Geographic Society and the United States Geological Survey. This work he continued in 1891. For an account of the work of 1890, see National Geographic Magazine, Vol. III, pp. 53-203; and for that of 1891 see Thirteenth Annual Report of the United States Geological Survey, Part II, pp. 1-91. Professor Russell died at Ann Arbor, Mich., May 1, 1906.

\section{RUSSIAN AMERICan COMPany, 1799-1867.}

The Russian American Company was chartered on June 8, 1799, for twenty years. On September 23, 1821, its charter was renewed for twenty years. In 1844 it was again renewed for twenty years, to date from January 1, 1842. The unchartered company after 1862 continued on sufferance, till the purchase of Alaska by the United States, in 1867. Much geographic information was gathered and published by officers of the company. Information cited in this dictionary is credited to such officers when known, but otherwise to the company. The principal reference to the company's results are to a map of Baranof island, contained in its report for 1849.

\section{Russtans.}

In this dictionary there are a considerable number of names accredited to the Russians without being more specific. This was unavoidable because more specific information was lacking. The names so accredited come chiefly from charts issued by the Russian Hydrographic Department. Between 1844 and 1854 a dozen (more or less) charts of northwest America, Bering sea, and the Arctic were issued as parts of a Pacific ocean series and subsequently given new numbers.

The principal charts in this series, with their dates of publication, current numbers, and the old Pacific ocean series numbers, are as follows:

\begin{tabular}{|r|r|r||r|r|r|}
\hline Date. & Number. & Old number. & Date. & Number. & Old number. \\
\cline { 1 - 5 } 1844 & 1345 & $\ldots . . . .$. & 1849 & 1427 & 5 \\
1.847 & 1378 & 9 & 1850 & 1441 & $10 b$ \\
1847 & 1379 & 8 & 1851 & 1454 & 4 \\
1848 & 1396 & 10 & 1852 & 1455 & 6 \\
1848 & 1397 & 10 & 1853 & 1493 & $10 d$ \\
1848 & 1400 & 7 & 1853 & 1494 & $1.0 c$ \\
1849 & 1425 & 9 & 1854 & 1495 & 13 \\
\hline
\end{tabular}


RYNDA PARTY, 1863.

Russian naval officers on board the corvette Rynda in 1863 visited Wrangell and Stikine river and made surveys there, especially of the Stikine. The surveyors were Butirkin and Kadin. Prof. William P. Blake, of New Haven, was also a member of the party and published an account of the work done and results obtained, in the American Journal of Science, New Haven, July, 1867, vol. 44, pp. 96-101; also in House of Representatives Ex. Doc. No. 177, part 2, Fortieth Congress, second session.

The Russian Hydrographic Department in 1867 published a chart of the Stikine resulting from this survey.

SARICHEF, $1790-1.792$.

Lieut. (afterwards Vice-Admiral and Hydrographer) Gavrila Andreevich Sarichef, of the Russian navy, made explorations in the Arctic in 1787, and later was an officer under Commodore Joseph Billings during the latter's explorations of Bering sea and Alaska (1790-1792). He appears to have been an excellent sailor and geographer. - No satisfactory account of his life or works has been found by the writer. Sarichef published in Russian in 1802 an account of the Billings expedition, in 2 volumes, accompanied by a folio atlas of 50 sheets. This work the writer has never seen. (There is a copy of each in the District Historical Library and Museum at Sitka.) In 1826 the Russian Hydrographic Office published a large folio atlas, comprising 33 double-page sheets, of which 26 are charts and 7 are views, entitled Atlas of the Northern Part of the Pacific. Occan, Compiled in Sheets by the Imperial Navy Department from the Latest Reports and Maps, 1826, under the Direction of Vice-Admiral and Hydrographer Sarichef first. As indicated in the title, this appears to be a collection of separate sheets issued from time to time and first collected into an atlas in 1826. Sheet 3 contains corrections obtained in 1829. Several of Sarichef's surveys in 1792 appear in this atlas, notably those of the Aleutian islands, Unalaska, etc. Separate charts from this atlas are to be found in the Coast Survey Office and the Hydrographic Office in Washington.

A copy of this atlas, owned by Prof. George Davidson, of San Francisco, was kindly placed at Mr. Baker's disposal during the preparation of this dictionary. References to Sarichef refer mainly to this atlas.

SAUER, 1790-1792.

The publication in 1784 of Cook's explorations of northwest America made in 1778 stimulated other nations to like work. La Perouse was despatched by France in 1785 ; and the same year, by 
order of the Empress of Russia, was organized "A secret astronomical and geographical expedition for navigating the frozen sea, describing its coasts and ascertaining the situation of the islands in the seas between Asia and America." This was placed under the command of Commodore Joseph Billings, who, according to Sauer, "said he had been astronomer's assistant in Captain Cook's last voyage." Martin Sauer accompanied this expedition as its secretary and translator, and in 1802 published an account of it, entitled Account of a Geographical and Astronomical Expedition, etc., performed by Commodore Joseph Billings in 1785-1794, $4^{\circ}$, London, 1802.

Leaving St. Petersburg in the autumn of 1785 , the party went overland to Okhotsk and there built two vessels, the Slava Rossie (Glory of Russia) and the Dobraia Namerenia (Good Intent), which were launched in August, 1789. The latter vessel was wrecked on the bar at Okhotsk, and another vessel, the Chornie Orel (Black Eagle), was built to take its place. This vessel was under the command of Captain Hall, while Billings commanded the Slava Rossie. The party wintered at Petropavlovsk and in May, 1790, sailed eastward somewhere near the Aleutian islands, saw Amchitka, landed at Unalaska, and thence continued on past Sannak and the Shumagins to Kodiak and Afognak, visiting Cook inlet and Prince William sound and then returning and wintering at Petropavlovsk. On May 19 of the following year (1791) the ships again set sail to the eastward, passed Bering island, touched at Tanaga, and went thence to Unalaska. From here they went northward in Bering sea, passed near the Pribilof islands and St. Matthew island, landed on St. Lawrence island and later at Point Rodney, Seward peninsula, and on August 3 anchored in St. Lawrence bay, Bering strait. Here Billings left the party for an overland journey in the Chukchi country, and Sarichef (see Sarichef) on August 14 set out to return to Iliuliuk, Unalaska, arriving August 28, 1791. Here Sarichef wintered. (1791-1792). In May, 1792, the party left Unalaska and went back to Petropavlovsk and thence to St. Petersburg.

Schanz, 1890-91. See Lestite ExpedtTon.

SCHrader, 1896-1902.

Mr. Frank Charles Schrader, of the United States Geological Survey, in 1896 accompanied Spurr and Goodrich on a geologic reconnaissance from the head of Lynn canal over Chilkoot pass to the Yukon and down the Yukon to St. Michsel. En route they made side trips and investigations into the Fortymile, Eagle, Birch Creek, and Rampart regions. (See Spurr.)

In 1898 Schrader was attached to a military exploring expedition under command of Capt. W. R. Abercrombie, known as Military 
Expedition No. 2, which made explorations from Valdez northeastward to and along Copper river. For an account of this see the Twentieth Annual Report of the United States Geological Survey, Part VII, pp. $341-423$.

In 1899 Schrader, in charge of a party with Gerdine as topographer and Witherspoon among the assistants, made explorations along Chandlar and Koyukuk rivers, northeastern Alaska. The results were published in the Twenty-first Annual Report of the United States Geological Survey, Part II, pp. 441-486.

Again in 1900, in the latter part of the summer and in the fall, Schrader, assisted by Arthur Coe Spencer, geologist, and T. G. Gerdine and D. C. Witherspoon, topographers, investigated the geology and mineral resources of the Copper River region and the shores and islands of Prince William sound.' The results were published in 1902 in a special report of the United States Geological Survey, written by Schrader and Spencer, entitled The Geology and Mineral Resources of a Portion of the Copper River District, Alaska, 99 pp. and 5 maps.

In 1901. Schrader was attached as geologist to the party of Peters on a reconnaissance in northern Alaska from the Koyukuk, up John river, across the Rocky mountains, down Anaktuvuk and Colville rivers, and along the Arctic coast to Cape Lisburne. His report is Professional Paper United States Geological Survey No. 20, 1904.

In 1902 Schrader, with Witherspoon as topographic assistant, made a topographic and geologic reconnaissance of the upper Copper River basin and adjacent parts of the Tanana basin. An account of this work may be found in the Twenty-fourth Annual Report of the United States Geological Survey, pp. 79-93. A preliminary report, The Mineral Resources of the Mount Wrangell District, Mlaska, by Walter C. Mendenhall and Frank C. Schrader, was published as Professional Paper United States Geological Survey No. 15, 1903, 71 pp. and 8 maps; while the topographic reconnaissance map made by Witherspoon was published as Pl. XX of Professional Paper.No. 41, 1905 .

\section{SCHWATKA, 1883-1886.}

Lieut. Frederick Schwatka; U. S. A., made a military reconnaissance in 1883 along Yukon river from source to mouth on a raft. He made an official report on this military reconnaissance in. Alaska, in 1883, which was printed in 1885 as Senate Ex. Doc. No. 2, Fortyeighth Congress, second session. A fuller account of the same journey, in popular form, was published by Cassel \& Co., in 1885, under: the title Along Alaska's Great River. This has an index. He made a second trip to Alaska in 1886 under the auspices of the New York Times and explored in the St. Elias region. Schwatka was born on 
September 29, 1849, in Galena, Ill., and died in Portland, Oreg., on November 2, 1892.

SFIS H M AREF, $1816-1821$.

Capt. Lieut. Glieb Semenovich Shishmaref accompanied Kotzebue on his voyage to Alaska and round the world in 1815-1818, and in 1817 made surveys in Kotzebue sound and on the east and south coast of St. Lawrence island.

In 1821 he again returned to the colonies, this time in command of the ship Blagonamierennic (Good Intent), and in company with Vasilief on the Otkrietie (Discovery). Sailing from Cronstadt on July 3, 1819, and rounding Cape Horn, he arrived at Unalaska on June 4, 1820. With him went Dr. Stein and astronomer Tarkanof. Afterwards he cruised through the Aleutian islands to Amchitka, Semisopochnoi, Gareloi, and Bogoslof. He also entered the Arctic, went as far as Icy cape, visited St. Lawrence bay, and completed in 1821 the survey of the shore line of St. Lawrence island, partially surveyed by the Kotzebue expedition in 1817. (See Grewingk, p. 413; Krusenstern Mémoires hydrographiques, Vol. II, p, 36 ; Journal of the Russian Hydrographic Office, 1849, Vol. VII, pp. 106-116.)

\section{Simpson, 1837. See Dease and Simpson.}

SNow ANd Helm, 1886.

Lieut. Commander Albert S. Snow, U. S. N., relieved Lieut. Commander Richardson Clover of the command of the Coast and Geodetic Survey steamer Patterson in February, 1886, and made surveys in southeastern Alaska during the summer of 1886 , beginning the season early in May in the vicinity of Wrangell, and ending it on September 15 at Port Simpson. Snow was succeeded in the command of the Patterson by Lieut. Commander Charles M. Thomas on April 30, 1887. Associated with Snow was Lieut. James M. Helm, U. S. N., in command of the MCArthur. Snow and Helm surveyed and charted part of Clarence strait, Sumner strait, Wrangell strait, St. John harbor, Dewey anchorage, Ratz harbor, Coffman cove, Wrangell harbor, Steamer bay, Red bay, Shakan strait, Port Protection, and Port McArthur. Charts of these places, issued by the Coast Survey, have been used in the preparation of this dictionary.

Spencer, 1900, 1903.

Arthur Coe Spencer of the United States Geological Survey, in 1900 was with Schrader in the Copper River region, and wrote the greater part of the special report of the United States Geological Survey entitled The Geology and Mineral Resources of the Copper River District, Alaska, 1901, 94 pp. and 5 maps. (See Schrader.) 
In 1903 Spencer, assisted by C. W. Wright, made a detailed study of the geology and mineral resources of the mining country about Juneau, and a reconnaissance of all the mining camps of the mainland. portion of southeastern Alaska from Windham bay to and including the Porcupine placer district. Mr. Wright made the study of the Porcupine district. For an account of his work see the Twenty-fifth Annual Report of the United States Geological Survey, pp. 69-72. A preliminary report on the Juneau gold belt by Spencer was published in Bulletin United States Geological Survey No. 225, 1.904, pp. 28-42, and of the Porcupine belt by Wright, pp. 60-63. Bulletin No. 236, 1904, 35 pp. and 3 maps, is Wright's report on the Porcupine placer district. Bulletin No. 287, 1906, 161 pp. and 23 maps, is a combined report by Spencer and Wright on the Juneau gold belt and a reconnaissance of Admiralty island.

Spurk, Goomrich, and Schrader, 1896.

Mr. Josiah Edward Spurr, geologist of the United States Geological Survey, assisted by Messis. Harold B. Goodrich and F. C. Schrader, in the summer of 1896 made a geologic reconnaissance from the head of Lynn canal over Chilkoot pass to the Yukon and thence down that river to $\mathrm{St}$. Michael. Examinations and investigations were made in the gold fields of Fortymile, Birch Creek, Eagle, and Rampart. For report on this work see"Eighteenth Annual Report of the Geological Survey for 1896-97, Part III, pp. 87-392.

\section{Spurr ANd Post, 1898.}

Mr. Josiah Edward Spurr, geologist, accompanied by Mr. William Schuyler Post, topographer, both of the United States Geological Survey, in the summer of 1898 made a reconnaissance in southwestern Alaska. They began at the head of Cook inlet, went northwest across. the Tordrillo range, descended the Kuskokwim, crossed from its mouth to Nushagak, and thence crossed Alaska peninsula to Katmai. The party landed at Tyonek on April 26 and arrived at Katmai on October 17, 1898, whence they sailed (October 31) on the Alaska Commercial Company's steamer Dora for San Francisco.

For an account of this expedition see Twentieth Annual Report of . the Geological Survey, Part VII, pp. 31-264.

STANIUKOVICh, $1.827-28$.

Capt. Mikhail Nikolaievich Staniukovich, commanding the sloop Moller, accompanied Lutke on his voyage around the world. He made a survey of the north shore of Alaska peninsula in the summer of 1.828. The geographic results of this voyage were incorporated by

Bull. 299-06 $\mathrm{M} \longrightarrow \mathbf{5}$ 
Lutke in the Partie nautique of his Voyage Around the World. For an account in Russian of Staniukovich's voyage see Journal of the Russian Hydrographic Department, 1850, Vol. VIII, pp. 63-75.

\section{Stanley-Brow N, 1891.}

Joseph Stanley-Brown, geologist, United States Geological Survey, was in April, 1891, detailed as special agent for the Treasury Department to visit the Pribilof islands for the purpose of studying the seal life thereon. While so engaged, between June 10 and September 22, 1891, he made contour maps of St. Paul and St. George islands on a scale of $1: 80,000$, contour interval 20 feet. He also made detailed maps, not contoured; of the various seal rookeries, on a scale of 528 feet to the inch. These maps are published in the Proceedings of the Fur Seal Arbitration Tribunal of 1893, vol. 3; Appendix II, Case of the United States. They are maps 2, 7, 8, 9, 10, 11, and 12 of that volume.

\section{Stockiton, 1889.}

Lieut. Commander Charles Herbert Stockton; U. S. N., commanding the U. S. S. Thetis, cruised in Alaskan waters in the summer of 1889. This cruise covered the whole coast from Dixon entrance to Unalaska, and thence through Bering sea to the Arctic and eastward to Mackenzie river. Stockton published an account of this voyage in 1890 in the National Geographic Magazine, Vol. II, pp. 171-198. His geographic results are shown on United States Hydrographic Office chart 1189, edition of 1890 .

\section{STONE, 1904-5.}

Ralph Walter Stone, of the United States Geological Survey, spent the summers of 1904 and 1905 in the study of Alaskan geology and mineral resources. In the former season, as a member of Martin's party, he gave special attention to the coal beds and coal-bearing rocks. In the latter season he was detailed as geologist with Wither-, spoon's party in the region south of the Yukon flats, between Circle and Rampart.

Stone contributed a paper on the Coal Resources of Southwestern Alaska, published in Bulletin United States Geological Survey No. 259, 1905, pp. 151-171, and with Moffit wrote a report on the gold placers of Kenai peninsula, published in Bulletin 277, in 1906. His 1905 report is in preparation.

SToney, 1883-1886.

Lieut. George Morse Stoney, U. S. N., in 1883 was detailed to carry presents to the natives of St. Lawrence bay, Siberia. These natives had been especially kind to the shipwrecked officers and men 
of the relief ship Rodgers, of whom Stoney was one. He took passage from San Francisco in the spring of 1883 on the U. S. revenue cutter Corwin, Capt. M. A. Healy, U. S. Revenue Marine, with the presents on board. The Corwin arrived at St. Lawrence bay in July, and the distribution was soon after made.

As the Corwin was bound farther north, Stoney determined to employ the time till her return in looking for Kobuk river, a large affluent of Hotham inlet, Kotzebue sound. He was landed at the entrance to the inlet with one white man, an Eskimo from Norton sound, a boat, and seven days' provisions. Employing another Eskimo as guide, he ascended the Kobuk about 85 miles-45 miles to the head of the delta and 40 miles up the main river-which he found to be a very large river, as reported. Fifteen days after landing he was picked up again by the Corwin, and landed in San Francisco on October 8, 1883.

Reporting his discoveries to the Secretary of the Navy, Stoney requested that he be ordered to make further exploration of the river. His request was granted, and the schooner Ounalaska, of 49 tons, was fitted out for a six months' trip. The Ounalaska sailed from San Francisco on April 13, 1884, and reached the mouth of Hotham inlet on July 10. Between July 16 and August 27 the Kobuk was explored for 200 miles from its mouth, Lake Selby discovered and named, Selawik and Inland lakes explored, and the expedition landed in San Francisco on October 26, 1884.

The results of these explorations were embodied in a report to the Secretary of the Navy, accompanied by a chart. At the same time, Stoney requested that he be sent back " to accurately triangulate the rivers and country, and explore as much as possible the interior of Arctic Alaska." Accordingly, in addition to the steam cutter Helena, used in the 1884 expedition, a 60-foot, flat-bottomed, stern-wheel steamboat was constructed for river navigation and named the $E x$ plorer. The two-masted schooner Viking, 390 tons, M. Danevig, master; was chartered to convey the expedition to Hotham inlet and leave it. On May 3, 1885, the Viking sailed from San Francisco, and on July 9 anchored off Hotham inlet. Winter quarters were built on the right bank of Kobuk river 150 miles above its mouth, and named Fort Cosmos, after the Cosmos Club of San Francisco. During the following winter and summer a system of triangulation was extended over the valleys of Kobuk, Noatak, and Selawik rivers and the intervening mountains; and the region drained by these rivers, the upper Alatna, Chandler lake, and upper Colville river was explored and mapped. During the winter Ensign A. V. Zane, U. S. N., made a trip from Fort Cosmos to St. Michael and return by way of Kobuk, Pah, Dakli, Koyukuk, Yukon, and Unalaklik rivers; and in the spring and summer of 1886 Ensign W. L. Howard crossed from Fort 
Cosmos to the upper Noatak and thence by way of upper Colville and Chipp rivers to the Arctic coast and Point Barrow, where he embarked on the U. S. revenue cutter Bear and returned to Kotzebue sound. On August 26, 1886, the expedition sailed on the Bear from Kotzebue sound and landed in San Francisco on October 21.

Stoney made a full report of his explorations, accompanied by maps and illustrations, to the Secretary of the Navy, who transmitted it to Congress for publication. It was ordered printed, but the manuscript in some way was lost or disappeared and the report was never published. Ten years later Stoney wrote an account of these explorations, which was published by the United States Naval Institute, Annapolis; Md., 1900, in a volume entitled Naval Explorations in Alaska: An account of two naval Explorations in Alaska with. Official Maps of the Country Explored, by Lieutenant George M. Stoney, U."S. Navy, in Command of the Expedition, pp. vIII+105 and 3 maps.

Commander George Morse Stoney, U. S: N., died at Annapolis, Md., April 29, 1905.

Symonds, 1879-1881. See Beardslee and Guass.

TANNer, $1888-1893$.

Lieut. Commander Zera Luther Tanner, U. S. N., was in command of the Fish Commission steamer Albatross from 1888 to 1893, inclusive. Each season the Albatross cruised in Alaska waters, making investigations of the fisheries and fishing grounds.

In 1890 the work was in Bristol bay. During this season the Albatross sounded out the fishing banks in Bristol bay, and the officers made reconnaissance charts of Port Moller and Herendeen bay and of lower Nushagak river (Nushagak bay). These charts and a preliminary report by Tanner were published in Bulletin of the Fish Commission for 1899 , Vol. IX, pp. 279-288, 3 maps. The references to Tanner in this dictionary are to these maps.

Tebenkof, 1831-1850.

Capt. Mikhail Dmitrievich Tebenkof was director of the Russian American Company and governor of Russian America during 18451850. As early as 1831 he was in Norton sound, and in that year discovered the bay that now bears his name. (Lutke, Partie nautique, p. 220.) In 1833 he surveyed and mapped it. His map is reproduced by Lutke. In 1835 he was in St. Petersburg, and on August 5 of that year sailed in command of the Russian American Company's ship Elena from Cronstadt for Sitka, where he arrived via Cape Horn on April 16, 1836. He appears to have remained in the colonies thenceforward till the close of his term as director and then 
returned to Russia. To him more than to any other Russian are we indebted for geographic knowledge of the Alaskan coast. Himself a surveyor and interested in surveying, he gave much attention to improving charts of the coast in the interests of the company. In 1848 and 1849 there was compiled, drawn up, and engraved at Sitka his Atlas of the Northwest Coast of America. This atlas of 39 maps shows the entire coast line of North America from Bering strait to Lower California, with adjacent islands and parts of the Siberian coast. It embodies the results of the various surveys made by Russian naval officers, officers of the Russian American Company, etc. The maps were engraved at Sitka by Terentief, a creole, and for the most part are dated 1849. It is probable that they were dated from time to time during 184.8 to 1850 as engraved and afterwards put together as an atlas in 1852. With it was issued by Tebenkof a little book of Notes and Explanations. There appear to be two editions of this book of Notes, both very rare, at least in the United States. In the making of this dictionary 'Tebenkof's atlas has been consulted more than any other single work.

Thomas, $1887-88$.

Lieut. Commander Charles M. Thomas, U. S. N., succeeded Lieut. Commander Snow in command of the Coast and Geodetic Survey steamer Patterson on April 30, 1887, and remained in command till relieved by Mansfield on April 1, 1889. During the season of 1887, which began at Port Simpson on May 21 and ended there on October 13, his party surveyed and mapped in whole or in part Frederick sound, Duncan canal, Brown cove, Thomas bay, Farragut bay, and Portage bay. In the following season, which began on April.27, 1888 , he made surveys until June 26 in the vicinity of Taku inlet, in this time mapping 'Taku harbor, Limestone inlet, Port Snettisham, and Oliver inlet. Between July 3 and October 14, 1888, Thomas made surveys asked for by the Department of State in and about Portland canal. For an account of his work see Coast and Geodetic Survey Reports, 1888, pp. 73-76; 1889, pp. 78-82, and Coast Survey charts 704,733 , and 8227 .

Thismenief, 1861-1863.

P. Tikhmenief has been called the historian of the Russian American Company. He published in Russian a work in two volumes, the first dated 1861, the second 1863, entitled Historical Review of the Russian American Company. This is a useful work, compiled from original sources, and. gives information on Alaskan matters not to be found elsewhere. 
'Tipping, 1786-87. See Meares and Tipping.

T'Topham, 1888.

Mr. Harold W. Topham and his brother Edwin, of London, with George Broka, of Brussels, and William Williams, of New York, left Sitka on a little schooner on July 3, 1888, and went to Mount St. Elias for the purpose of climbing it. They reached an altitude of 11,460 feet and then turned back. Topham read an account of this trip before the Royal Geographical Society on April. 8, 1889. This account, with a map, was published in the Society's proceedings in July, 1889, Vol. XI, pp. 424-435. See also the National Geographic Magazine, 1890, Vol. III, pp. 73-74. Williams published an article, "Climbing Mount Saint Elias," in Scribners Magazine of April, 1889 , pp. 387-403, and one small map.

TURNer, 1889-1891.

Mr. John Henry Turner, assistant in the Coast and Geodetic Survey, was engaged on the Alaskan boundary survey from June, 1889, to July, 1891. In the summer of 1889, with Mr. McGrath, he ascended Yukon river to Fort Yukon, where the party divided. On August 12, Turner began his journey up Porcupine river to the boundary. On the 19 th he landed at the site of an abandoned camp near the one hundred and forty-first meridian, and there began the building of quarters for officers and men and the erection of an observatory. This camp was named Camp Colonna. Longitude was determined by moon-culmination observations in March and April, 1890.

On March 27, 1890, he set out upon a sledge journey from Camp Colonna northward to the Arctic ocean, where he arrived on April 8. The next day he started back and reached Camp Colonna on April 17. Later he left Camp Colonna, descended Porcupine and Yukon rivers, and proceeded to St. Michael, Norton sound, where he was compelled to remain until July, 1891, when he departed for Washington. He returned to Alaska in 1892 on boundary work, but owing to ill health was obliged to give it up. During his stay in Alaska he made a valuable collection of bird and animal skins, which he presented to the University of California. The expenses of this collection he bore personally. He died in Washington on June 13, 1893. An account of his work was published in the National Geographic Magazine in 1893, Vol. IV, pp. 189-197; see also Coast and Geodetic Survey Report 1890-1891, Part I, pp. 86-88.

\section{VANCOUVER, 1792-1794.}

Capt. George Vancouver, R. N., in command of the sloop of war Discovery, accompanied by the armed tender Chatham under the command of Lieut. William R. Broughton, R. N., made a surveying and 
exploring voyage from England to Northwest America and around the world in 1790 to 1795 . An account of this voyage was published by the British Government in 1798 in 3 quarto volumes accompanied by a folio atlas.

This is an admirable account of an admirable piece of work and is one of the standard works for the region it covers.

On April 1, 1791, the two vessels departed and, rounding the Cape of Good Hope, arrived off the coast of California on April 17, 1792. Thence Vancouver cruised northward, surveying and mapping the coast as far as Fitzhugh sound, whence he went to Nootka. He then cruised southward to San Francisco and Monterey, and about the beginning of 1793 went to the Hawairan islands.

Leaving these on March 30,1793, he returned to the north, arriving off Cape Mendocino on April 26, whence he proceeded to Fitzhugh sound, joined the Chatham there, and resumed his surveys. During the season of 1793 he carried these northward along what is now British Columbia and in Alexander archipelago to Sumner strait. Quitting Alaska and returning southward, he surveyed the California coast from Monterey southward to San Diego and down to latitude $30^{\circ}$ on the coast of Lower California, finishing on December 15,1793 , and going thence to the Hawaiian islands. Quitting these on March 15, 1794, Vancouver returned on his last voyage to northwest America, arriving off Chirikof island, just west of Kodiak, on April 2. He then surveyed eastward; in Kodiak, Cook inlet, Prince William sound, and so on, to a junction with his surveys of the preceding year. This work ended at Port Conclusion, from which he took his final departure on August 22, 1794, and returned via Cape Horn to England, arriving off the Irish coast on September 12, 1795 . Vancouver's work in the field and the admirable presentation of results in his published report constitute his monument. After more than a century it remains a standard work of reference.

Vancouver had had previous experience in exploring. Captain Cook selected him in 1771 as one of his officers, and thus he accompanied that distinguished navigator during his second voyage. $\mathrm{He}$ also assisted Cook in outfitting and equipping for his third and last voyage. On December 9, 1780 , he was made a lieutenant and served under Rodney in the West Indies till the middle of 1783. From 1784 to 1789 he served on the Europa, stationed at Jamaica. In 1790 he was made master and commander of the Discovery. In August, 1794, he was made a post-captain. After his return to England he worked continually on his report till his death, in May, 1798. The work, nearly but not quite complete at the time of his death, was finished by his brother, John Vancouver. 
VASILIEF.

Several Russian naval officers known for their work in Alaska have borne this name (Williams). Krusenstern, in his Receuil de mémoires hydrographiques, 1827 , Vol. II, p. 76, says:

It is much to be regretted that the hydrographic works of a naval officer, vasilief, who was in the employment of the American Company, were lost. I have already had occasion to speak of bim in the preceding article. Provided with a sextant and chronometer and with much zeal and attachment for his profession, he had during his sojourn in our American colonies made a complete survey of all of the Aleutian islands without hiving had specific instructions to do so. Unfortunately he was drowned in Okhotsk barbor on his return from America to Russia, and what became of his precious papers and drawings is unknown. He is not to be confounded with the Captain (Mikhail Nikolaievich) Vasilief who was sent in 1819 to explore the northern parts of the Pacific ocenn and particularly Bering strait.

\section{VASILIEF, 1809.}

Ivan Vasilief the first, pilot or mate in the Russian navy, went with Hagemeister in the ship Neva to Russian America in 1806. In 1809 he surveyed the western shore of Baranof island and at an unknown date " died in the service."

VASILIEF, 1819-1822.

Capt. Lieut. Mikhail Nikolaievich Vasilief sailed on July 3, 1819, from Cronstadt on a voyage to the Russian American colonies. With him went Shishmaref on the Blagonamierennie (Good Intent). Vasilief arrived in Petropavlovsk on June 4, 1820. Leaving there late in June, he went to Kotzebue sound, where he joined his consort the Good Intent (Captain Shishmaref), and together they cruised northward along the coast to Icy cape, and, returning via St. Lawrence and the Pribilof islands, reached Unalaska on August 19, 1820. Thence he went to Sitka and southward to San Francisco and the Hawaiian islands, and on the 7th of April, 1821, was back in Sitka, whence he went to Unalaska, arriving on June 12. He then cruised northward as far as Cape Lisburne, explored the eastern part of Bering sea, discovered Nunivak island, and arrived at Petropavlovsk on September 8, 1821. Thence he returned to Cronstadt, arriving on August 2, 1822.

During this cruise Vasilief and Shishmaref explored the mainland coast of Bering sea from Cape Newenham to and including Norton sound, and the Arctic coast from Cape Lisburne to Icy cape. (See Journal of the Russian Hydrographic Department, 1849, Vol. VII, pp. 106-116.)

\section{VASILIEF; $1831-32$.}

Ensign Vasilief, of the corps of pilots, in 1831-32 surveyed and mapped a part of Alaska peninsula from Cook inlet westward nearly to Chignik bay. The map resulting from this survey is published 
by Lutke in his Partie Nautique, p. 274. Of this survey and map Lutke says:

Vasilief's mạp of the northeastern part of Alaska contains all possible details as to the situation of the coast, and appears worthy of confidence, but in his journals which we have had in our hands we have found absolutely nothing except the data on which the construction of the map was based. Relative to places they contained no remark as to their configuration, properties, peculiarities, or their advantages, details so important for the navigator. We are therefore able to add but few observations supplementaly to his map hereto annexed.

Vasilief began his reconnaissance in 1831 at Cape Douglas, andi from there in the course of the same summer went as far west as Calpe Kubugakli, in latitude $57^{\circ} 52^{\prime} 30^{\prime \prime}$. The following year he extended it as far: as Cape Kumliun, in latitude $56^{\circ} 32^{\prime} 12^{\prime \prime}$. . Circumstances prevented him from pursuing his work farther. The reconnaissance was made in three-holed bidarkas, a circumstance which, on the one hand, made it possible for him to explore all the windings of the coast in the greatest detail, but, on the other hand, prevented him from seeing the coast and judging of its appearance at any great distance. His chronometer stopped in the first days of the reconnaissance, so that it is based only on survey and latitude observations.

1 Veniaminor, 1824-1834.

Rev. John Veniaminof, a Russian priest of Irkutsk, went to Unalaska as a missionary in 1824. Of this devoted and noble man all writers speak in terms of the highest praise. The writer has sought unsucessfully for any satisfactory account of his life and labors.

He resided at Unalaska from the time of his arrival there in 1824 till 1834, when he was made a bishop. He then went, after the custom of his church, to Irkutsk and was there invested with his sacred office, taking the name of Innokenti or Innocentius. Returning, he went to Sitka and labored successfully among the Indians there for a time, and later returned to Russia, where he reached the highest office in the Russo-Greek church, becoming Metropolite of Moscow. He became blind and died at an advanced age some time prior to 1880 .

Veniaminof was not merely a noble and successful.missionary, but is known for his ethnologic and linguistic studies as well. There was published at St. Petersburg, in Russian, in 1840 his Notes on the Islands of the Unalaska District, in two volumes, with a supplementary or third part on the Atkans and Koloshians. These books are standard works, and it is regrettable that they are accessible only in Russian. He learned the Aleutian language and wrote a grammar and dictionary of it, which was published in 1846 . In the same year he also published a sketch of the Koloshian and Kodiak languages. All these works have been used in preparing this dictionary. 
WeLLS, 1890-91. See LesLie Expedition.

WeștDahL, 1900-1902.

During the seasons of 1900, 1901, and 1902, Ferdinand Westdahl, assistant, United States Coast and Geodetic Survey, commanded the Coast Survey steamer McArthur in Alaskan waters. In 1900 the $M c A r t h u r$ was engaged in Coast Pilot work in southeastern Alaska. In 1901 the Sannak islands, harbors, and anchorages were charted and a reconnaissance was made of the south shore of Unimak island. In 1902 the hydrography of Hinchinbrook entrance, Prince William sound, was executed, and the topography of the adjacent shores of Hinchinbrook and Montague islands. Accounts of these operations were published in the Coast and Geodetic Survey Reports, 1901, pp. $161-162 ; 1902$, pp. 144-147; 1903, pp. 113-115, and the results published on Coast Survey charts 8841, 8860, and 8881 for the Sannak islands, and chart 8520, Prince William sound.

Western Union 'Telegraph Exploration, 1865-1867.

After the failure of the second Atlantic telegraphic cable, the Western Union Telegraph Company, believing that an ocean cable could not succeed, undertook to construct an overland telegraph to Asia and Europe via Bering strait. For this purpose preparations were made on a large scale and parties worked, explored, and built some line in British Columbia, Alaska, and Siberia in 1865 and 1866. When the third Atlantic cable proved, in 1866, to be a success the whole enterprise was abandoned and the geographic information collected by it was scattered. No satisfactory general account of this venture has been published. Several manuscript maps were made but not published. A photograph of one, of these is the authority chiefly used and cited in this dictionary.

Williams, 1888 . See Topham.

Witherspoon, 1899-1905.

David Columbus Witherspoon, topographer, United States Geological Survey, has been employed from 1899 to the present time in making topographic surveys in Alaska. In 1899 he assisted Gerdine in Schrader's party in the topographic work on Chandlar and Koyukuk rivers. In 1900 he was again with Schrader in the Copper River country. (See Schrader.) In 1901 he assisted Gerdine in his reconnaissance of the northern portion of Seward peninsula. (See Gerdine.) Again, in 1902, he was with Schrader in the upper Copper River country, and made a topographic reconnaissance map of the headwater regions of Copper, Nabesna, and Chisana rivers, on a scale 
of 1:250,000, contour interval 200 feet, published as Pl. XII in Professional Paper United States Geological Survey No. 41, 1905.

In 1903 Witherspoon was in charge of a party, to which F. H. Moffit was attached as geologist and C. R. Hill as field assistant, executing a reconnaissance of the northeastern portion of Seward peninsula. That season he made a topographic map covering about 800 square miles, on a scale of $1: 250,000$, contour interval 200 feet, which was published as Pl. II in Bulletin United States Geological Survey No. 247, 1.905.

In 1904. and 1905 Witherspoon was engaged in making topographic surveys in the Yukon-Tanana region. In the former year, with one assistant, he surveyed about 4,500 square miles in the region between Eagle and the head of Birch creek, including the headwaters of Birch creek, Charley river, Seventymile and Fortymile creeks, and Salcha and Chena rivers. In the latter year, with $\mathrm{R}$. W. Stone as geologic assistant and R. B. Oliver as topographic assistant, about 4,300 square miles south of the Yukon flats, extending from Circle to Fort Hamlin, were mapped. These maps will be published on a scale of $1: 250,000$, contour interval 200 feet.

WORONKOFSKI, 1836.

Lieutenant Woronkofski, of the pilot corps, by direction of the Russian American Company, surveyed in 1836 the southern shore of Alaska peninsula from the vicinity of Chignik bay, where Vasilief's work ended in 1832, westward to Unimak pass, connecting with Staniukovich's survey of the north shore in 1828. He sailed from Sitka on this errand on March 6,1836, in command of the company's transport Kadiak. The survey was carried on in bidarkas and his assistants were Aleuts. He returned to Sitka on August 30. Baer and Helmersen speak in high praise of this work in the brief account given of it in their Beiträge zur Kentniss des Russischen Reiches, $8^{\circ}$, St. Petersburg, 1839, Vol. I, pp. 323-325. He also surveyed about Unga and Popof islands in the Shumagins in 1837. See Russian Hydrographic chart 1379 for his map.

Wosnesenski, $1842-43$.

Ilia G. Wosnesenski was sent in 1839 to Alaska, by and at the cost of the Imperial Academy of Sciences of St. Petersburg, to make collections. He sailed with Etolin, who was succeeded in command by Kadnikof, on the Russian American Company's ship Nikolai, from Cronstadt on August 19, 1839, and reached Sitka on May 1, 1840. In $1840-41$ he was on the coast of lower and upper California, in 1842-43 in the Aleutian islands, in Bering sea and Kotzebue sound, in 1844 
in the Kurile islands, and in $1845-1845$ about the Okhotsk sea and in Kamchatka. He returned to Sitka at the end of July, 1849, and sailed thence for St. Petersburg with Captain Riedell on the ship Atka. Mining engineer Doroshin returned on the same voyage. (Grewingk, pp. 419-420.)

Wrtght BRothers, 190?-1905.

Charles Will Wright, of the United States Geological Survey, in 1903 made a study of the mining conditions and general geology of the Porcupine Placer district, southeastern Alaska, and assisted Spencer in the Juneau region. (See Spencer.) Wright made a preliminary report on the Porcupine district, published in Bulletin United States Geological Survey No. 225, 1904, pp. 60-63, and a final report, published as Bulletin No. 236, 1904, containing 35 pages and 2 maps.

In 1904 Fred Eugene Wright, assisted by Charles W. Wright, made geologic studies in southeastern Alaska. Together they studied a cross section from Taku inlet to Sitka. F. E. Wright made a detailed investigation of the Sitka mining district, while his brother examined the coal and metalliferous deposits of Admiralty island; the shore exposures from Sitka to Wrangell, and thence to Cleveland peninsula; the mainland coast from Stikine river and Wrangell to Windham bay, and the copper and gold deposits of the Ketchikan district. For an account of these operations see the Twenty-sixith Annual Report of the United States Geological Survey, pp. 57-59, and C. W. Wright's report on the reconnaissance of Admiralty island, published in Bulletin United States Geological Survey No. 287, 1906.

Again in 1905 the Wright brothers, with Fred E. Wright in charge, were in southeastern Alaska investigating the geology and mineral resources of the Ketchikan district, the islands, and mainland. Their report, Mineral Resources of the Wrangell and Ketchikan Mining Districts, Alaska, is in preparation.

ZAGoskin, 1842-1.844.

Lieut. Laurenti Alexief Zagoskin made explorations on the lower Yukon, the Kuskokwim, and in Norton sound in 1842-1844, under a commission from the Russian American Company. Of this exploration he published an account, in Russian, in two volumes, at St. Petersburg, 1847-48. An account of it, and also an extract from Zagoskin's diary, accompanied by a map, was published by. S. I. Zelanie in the Journal of the Russian Geographic Society, 1849, Vol. I., pp. 211-266. 
ZAREMBO, 1834-1838.

Capt. Lieut. Dionysius Fedorovich Zarembo, in command of the Russian American Company's ship Prince Alescander, sailed from Cronstadt on August 14, 1840, and, going via Cape Horn, arrived at Sitka on April 3, 1841. With him on the voyage went Lieutenant Zagoskin. Zarembo had previously been in the Russian colonies, having first gone out as pilot in 1816 with Ponafidin in the Suworof and again in 1819. with the same officer in the Borodino. He surveyed Wrangell harbor in 1834 and Woewodski harbor in 1838 . His maps are shown as insets on Russian Hydrographic chart 1396, published in 1848. For a very brief and unofficial account of his voyage see Journal Russian Hydrographic Department, 1850, Vol. VIII, pp. 139-140. Zarembo, in command of the brig Chichagof, founded the present town of Wrangell in the spring of 1834, building there a stockade or fort, which after him was named Dionysius. 



\section{I C T I N A R Y.}

Nore.-Adopted forms are in black-face type; rejected, obsolete, und doubtful forms in italic.

Aantlen; glacial stream near the St. Elias Alps, debouching on the coast 15 miles southeast of Yakutat, near longitude $139^{\circ} 20^{\prime}$. Indian name; so written by Tebenkof. in 1849. Glave, 1890, wrote Arn Klane, and Moser, 1901, Ahrn-klin.

Aaron; island, in Favorite channel, Lyun canal, Alexander archipelago. So. named by Beardslee, 1.880.

Aats; bay and harior, on northern shore of Coronation island, Alexander archipelago. Niative name, reported by Snow in 1886. Nichols calls the western cove of this bay Aats harbor.

Aats; point, on northern shore of Coronation island, Alexander archipelago. Native name, reported by Snow in 1886.

Abaknakik, lake; see Aleknagik.

Abbe; gulch, 10 miles north of Nome, Seward peninsula, at the head of Glacier: creek, near longitude $165^{\circ} 22^{\prime}$. Local name, published in 1903.

Abdallah; mountain, at head of Glacier bay, southeastern Alaska. So named by Reid, 1892 .

Abercrombie; canyon, in the lower part of Copper river. So named by Allen, in 1885, after Capt. William R. Abercrombie, U. S. A. See Abercrombie rapids.

Abcrcrombic, lake; see Klutina.

Abercrombie; mountain, on headwaters of White river near longitude $142^{\circ}$. Named by the Geological Survey, 1899, after Capt. William R. Abercrombie, U. S. A.

Abercrombie; rapids, in Copper river just above Miles glacier. So called by Mendenhall and Schrader, 1903. "Synonomous with Abercrombie canyon and Copper River rapids. The term canyon, as used by Allen, is a misapplication, as there is no canyon here, so we have retained the name Abercrombie by applying it to the rapids."

Abermabby; creek, Kenai peninsula, a left-land tributary of Resurrection creek near its source. Local name, from Moffit, 1904.

Ablun, pass; see Apoon.

Abraham; islet, northwest from Point Stanhope, Clarence strait, Alexander archipelago. Named by Snow, 1886, after President Abraham Lincoln. This islet has been reserved for light-house purposes by Executive oirder dated January 4, 1901.

Abre-el-ojo, islet; see Eye Opener.

Acaponeta; point, on north end of St. Ignace island, Bucareli bay, Prince of Wales archipelago. Named Punta d'Acaponeta by Maurelle and Quadra, 1775-1779.

Achaiak, island ; see Aghiyuk.

Acharon; channel, leading to Krvikluak and Kwemeluk passes, in the Yukon delta, near latitude $62^{\circ} 30^{\prime}$. Called Acharon by the Coast Survey in 1898. Probably the Eskimo achirinun (a slough). 
Achek, island; see Middleton.

Achenchik, river; see Chandlar.

Acheredin; point, the southwest point of Unga island, Shumagin group. The word means turn or turning. Doubtless it was named after mate Atb. Acheredin, a Russian fur trader, who wintered at Kodiak in 1779. Has been written Atcheredina and Otcheredin. The bight east of it is also called Acheredin.

Acherk; harbor, indenting the northwestern shore of Sannak island, near latitude $54^{\circ} 30^{\prime}$, longitude $162^{\circ} 50^{\prime}$. 'Tebenkof, 1849 , published a sketch (acherk) of this harbor, which was republished by the Coast Survey in 1875, with the name Acherk. Thus the designation "Sketch of a harbor in the NW. part of Simnak" became Sketch (acherk) harbor.

Acherun; see Azacharum.

Achilles; mountain (3,027 feet high), on Revillagigedo island, near Tongass narrows, Alexander archipelago. So named by Nichcls, 1883.

Achirun; see Acharon and Azacharum.

Achteedeedung, creek; see Akhtidung.

Aclullik, island; see Ayakulik.

Ackan-ungta; see Dalnoi point.

Ackiagmute, Eskimo village; see.Akiak.

Aclek, cape; see Aklek.

Acootan, island; see Akutan.

Acorn; peak, near mouth of Nushagak river. So named by the Fish Commission, 1890 .

Acouan, island; see Akun.

Acpalliut, village; see Alpaliut.

Acutan, island; see Akutan.

Adagdak; cape, the northernmost point of Adak island, Andreanof group, middle Aleutians. Aleut name from Tebenkof, 1849. Has also been written Adachdach.

Adak; island $(5,678$ feet high), one of the principal islands of the Andreanof group, middle Aleutians, near longitude $176^{\circ} 25^{\prime}$. This is apparently the Ayagh or Kayaku island of Lazaref in 1761. Also written Ajaga or Kejachu. It is Adak and Adach of Billings, 1790, and often written Adakh. According to Dall, adák is the Aleut word for crab, while adak means fattucr.

Adak; strait, between Adak and Kanigil islands, Andreanof group, middle Aleutians. Apparently so named by the British Admiralty on chart 2460.

Adamagan, bay; see Morzhovoi.

Adams; anchorage, at south end of Shelter island, Stephens passige, Alexander archipelago. Named by Coghlan, 1884, after the U. S. S. Adams, which anchored here in that year.

Adams; channel, in Northern rapids, Peril strait, Alexander archipelago. Named by Coghlan, 1884, after the U. S. S. Adams.

Adams; creek, tributary to middle fork of the Koyukuk from the north, near longitude $150^{\circ}$. Named by prospectors, 1899 .

Adams; creek, tributary to Shovel creek from the west, near its headwaters, Seward peninsula. Name from Barnard, 1900.

Alams, fort; see Fort Aủams.

Adams; glaciei, east of Glacier bay, southeastern Alaska. Named by Reid, in 1896, after C. A. Adams, a member of his party in 1890 . In Reid's first publication (Nat. Geog. Mag. Vol. IV, map, 1892) this is called the Southeast tributary (of Muir glacier). 
Adams; mountain peak (7,600 feet high), and also cluster or range of mountains, west of Portland cantl. Named by Fender, 1868 .

Adams; peak (3,100 feet high), on Woronkofski island, Alexander archipelaro. Named by Snow, 1886, after the U. S. S. Adams.

Adams; point, the north point of entrance to Moira sound, Clarence strait, Alexander archipelago. So named by the Coast Survey in 1891.

Adams Channel, rock; see Rose Isiand rock.

Adamson, cape ; see Bartolome.

Addington; cape, on Noyes island, Alexander archipelago. So named by Vanconver, 1794, after the speaker of the House of Commons. Fis been written Adington; also named Barnett by Meares, 1788.

Admiral; creek, tributary to Tubutulik river, near its source, Seward peninsula. Prospector's name, from Peters, 1900.

Admiral; range of mountains, on the mainland east of 'thomis bay, southeastern Alaska. So named by Thomas, 1887.

Admiralty; bay, on the Arctic coast, east of Point Barrow, forming the head of Dease inlet. So named by the British Admiralty, 1850 .

Admiralty, bay; see Yaliutat.

Admiralty; island and group of. islands, in northern part of Alexander archipelago. .. So named by vancouver in 1794 (11I, p. 276). It is Khutsnoi (bear) islind of Tebenkof in 1848 .

Adolphus; point, the most northerly point of Chichagof island, Icy strait, Alexander archipelago, near longitude $135^{\circ} 4 \bar{i}^{\prime}$. So named by vancouver, 1794. Has also been called Adolph point on some charts.

Adugak; islet, north of the west end of Umnak, eastern Aleutians. Native name from Veniaminof. Fas been written Adougakh. Ferhaps from the Aleut Adudak (rather long).

Aektok, island and strait; see Rootok.

Affleck; canal, indenting southern shore of Kuiu island, Alexander archipelagio. Named Affleck's chamnel by Vancouver, 1793, after. Admiral Affleck, R. N.

Afognak; bay, indenting the southeastern coast of Afognak island, Kodiak group. So called by Tebenkof, 1849. According to Moser, 1900, Litnik, a corruption of the Russian word Elitnik (or Lietnik), meaning a place where fish are dried, is the name locally given throughout the Kodiak district to the body of water known to us as Afognak bay; while the name Afognak bay is applied to a small shallow, foul cove, about $1 \frac{1}{2}$ miles westward of the village, on, the northern side of Afognak strait.

Afognak; cape, the northarmmost point of Affognak island, Kodiak group. So called on the Russian American Company's map of 1.849 . Tebenkof the same year uses the name Sievernoi (north).

Afognak; cape, the southernmost point of Afognak island, Kodiak group. So called by Murashef, 1839-40.

Afognak; forest and fish culture reserve. The island of Afognak was by proclamation of President Harrison dated December 24, 1892, set apart as a forest and fish culture reserve.

Afognak; island, northeast of-Kodiak, and, after Kodiak, the largest in the Kodiak group. Native name, which Coxe, 1780, wrote Afagnalk and Afagnack. Portlock, 1786, calls it Kodiac. Vancouver speaks of the land "which the Russians call Fogniak." Langsdorf has Aphoknak and Appoknak. By error it has been called Afgonak. The form Afognak is well established by usage. It was named Isla de Estuardo by the Spaniards.

Bull. 299-06 $\mathrm{x}-6$ 
Afognak; river, in western part of Afognak island, tributary to Afognak bay. So called by Murashef, 1839-40. According to Moser, 1900, it is locally called Litnik river.

Afognak; post-office and village, or row of scattered dwellings, on shore of Afognak bay, in southwestern part of Afognak island. Population in 1890, 409. The post-office was established in 1904. In the Eleventh Census, 1890 , pp. $73-74$, it is stated that "Afognak village $* * *$ really consists of a series of settlements lining the long curving beach. * * $*$ The creole village of Afognak extends in a single row of dwelliugs, somewhat widely scattered, about three-fourths of a mile along the beach. This settlement was founded during the first quarter of the present century under the nime of Rutkorsky village by super:annuateã and pensioned employees of the Russian American Company." Rutkorsky, in the passage just cited, seems to be an error. Written also Ratkorsky. 'Tebenkof' (Ch. XXIII) has Rubertz and the Russian American Company's map, 1848, Rubtzovskaia. See Litnik.

Afognak; straits between Afognak island and Whale island, Kodiak group, near latitude $58^{\circ}$, longitude $152^{\circ} 45^{\prime}$. So described by Moser, 1897 .

Agadak, island; see Rat.

Agaiak; islet, in Krestof 'sound, north of Sitka, sound, Alexander arcbipelago. Apparently an Aleut name, first applied by Vasilief in 1833. Has also been written Agayak and Agiak.

Agalitnal, river; see Haliknuk.

Agamgik; bay, indenting the northern shore of Beaver bay, Unalaska island, eastern Aleutians, about latitude $53^{\circ} 52^{\prime}$, longitude $166^{\circ} 21^{\prime}$. Aleut name, from Sarichef, 1790. Called Food bay by the Fish Commission in 1888. Veniaminof writes it Agringik.

Agamsik; cape, the northern point of entrance to Tanaga bay, Tanaga island, middle Aleutians. Aleut name, from Tebenkof, 1849. Has also been written Agamsikh.

Agaschagoch, island; see Bogoslof.

Agassiz; glacier, in the St. Elias alpine region. So named by Libbey, 1886, after Prof. Louis Agassiz. See also Malaspina.

Agassiz; mountain (2,241. feet high), near Tamgas harbor, Annette island, Alexander archipelago. So named by Nichols, 1883. Has been erroneously printed Aggassiz.

Agassiz; peak (5,931. feet high), on the mainland, near .Thomas bay, southeastern Alaska. So named by Thomas, 1887.

Agassiz; point, on the mainland in Frederick sound, Alexander archipelago, near latitude $56^{\circ} 55^{\prime}$, longitude $132^{\circ} 52^{\prime}$. So named by Dall, 1877 , after Prof. Louis Agassiz.

Agattu; island, one of the Near island group, near Attu, western Aleutians. Called Agattu or: Krugloi (round) by the early Russians. Lutke says it is usually called Krugloi (round) by the Russians; also that Attu and Agattu are said to have been called St. Etienne and St. Abraham Bering in 1741. Coxe, 1780, writes it Agataku. Variously written Agatu, Agattou, etc. Native name.

Agayak, islet; see Agaiak.

$A-g \bar{a}^{\prime}-z h u k$, island ; see Aghiyuk.

Agee-ee-pul, river; see Agiapul.

Ageklarok; Eskimo village, Yukon delta, on the right bank of Kwikluak pass at its mouth, near latitude $62^{\circ} 37^{\prime}$, longitude $164^{\circ} 45^{\prime}$. Native name obtained by Putnam, 1899, and written Ageklarokamint-i. e., Agelclarok folks: 
Ageklekak; Eskimo village, Yukon delta, on the south bank of Kawanak pass at its mouth, near latitude $68^{\circ} 00^{\prime}$, longitude $164^{\circ} 30^{\prime}$. Native name Ageklekakamiut, obtained by Faris in 1899. Miut means people.

Aghik; islet (250 feet high), one of the Semidi group. Native name from Dall, 1874, who wrote it A'ghik. Agik is Aleut for liver.

Aghileen; pinnacles, a remarkable row or series of black castellated rocks west of Pavlof volcano, on Alaska peninsula, northeast of Belkofski, near longitude $162^{\circ}$. Native name, obtained by Dall in 1880 .

Aghiyuk; island (1,500 feet high), one of the Semidi islands, nenr latitude $56^{\circ} 12^{\prime}$, longitude $156^{\circ} 52^{\prime}$. Native name as obtained by Dall in 1874 . Tebenkof, 1849, has Agayak. Has also been written Aghiyukh and Aghi yukh. Achaiak of Langsdorf is probably this island. It is. the Aleut name of the cormorant (graculus bicristatus). The Eskimo name of: the violet-green cormorant is, according to Nelson, A-ga'-'zhuk. Apparently this is known locally as North Semidi, upon which there is a fox farm. See also Chowiet.

Agiak, islet; see Agaiak.

Agiapuk; river, tributary to Grantley harbor; from the north, Seward peninsula. Niskimo name, from Beechey, 182i, who wrote it Agee-ee-puk. Has also been written. Ageepuk, Agiopul, and Ahgeeapuk, the last syllable puk meaning big.

Agisam; hill (570 feet high), on the north shore st. George island, Bering sea, near longitude $169^{\circ} 37^{\prime}$. According to Putnam, called by the Aleuts Agīs'äm-kōvěrūishk:̈̈' (watch place hill), the Russian word kovrishka, a little loaf, being used to mean hill.

Agisogh; bluff, to the south of and overlooking zapadni rookery, southwestern coast St. George island, Bering sea. Aleut name, meaning watch place, reported by Duffield, 1897 .

Agisogh; bluff, on the west side and overlooking Staraya Artil rookery, north shore of: St. George island, Bering sea, near longitude $169^{\circ} 36^{\prime}$. Aleut name, the watch place, reported by Putnam in 1897 .

Agiukchuk; Essimo village, on the mainland, east of Nunivak island, Bering sea. Visited by Nelson in December, 1878 , and its native name reported by him to be Agiukchugamute, i. e.. Agiulschuk people.

Agivavik; Eskimo village, on right bank of Nushagak river. Native name, from Fetrof, 1880.

Agligadak; small island, off the east end of Amlia, Andreanof group, middle Aleutians. Native name from Tebenkot. It means a gull half a fathom long, i. e., the albatross. Has also been written Aglidakb.

Agnate, rocks; see Aiugnak.

Ago, bay ; see Hallo.

Agoo, lake; see Agu.

Agoocharuk, river; see Agucharuk.

Agoulouikatuk, lake; see Aleknagik.

Agouloukpak, lake; see Agulukpak.

Agonyak, river; see Ugaguk.

Agre; creek; just south of Port Clarence, Seward peninsula. Name from Barnard; 1900.

Agripina; bay, on the southern shore of Alaska peninsula near the Semidi islands. So named by Vasilief, 1832. Has been variously written Agrepin, Agripin, Agrippine, etc.

Agu; lake, Yukon delta, near latitude $61^{\circ} 15^{\prime}$, longitude $163^{\circ}$. Eskimo name from Jarvis, 1897, who wrote it Agoo.

Aguada, Rio de la; see Watering. 
Agucharuk; river, Yukon delta, an affluent of Naniwuknuk lake, or of Lake Agu, near latitude $61^{\circ}$, longitude $164^{\circ}$. Eskimo name reported by Jarvis in 1897 as Àgoocharuk.

Aguchik; island, in Kukak bay, Shelikof strait. Aleut name, reported by Vasilief in 1831.

Agueda; point, the northeastern point of San Juan Bautista island, Bucareli bay, Prince of Wales arehipelago. Named Punta de Santa Agueda by Maurelle and Quadra, 1775-1779. Has also been written San Ageda.

Agugsiak, islet; see Asuksak.

Agugum uda; see Northwest bay:

Aguirre; point, on the northwestern coast of San Fernando island, Gulf of Esquibel, Prince of Wales archipelago. Named Punta de Aguirre by Maurelle and Quadra, 1775-1779. Aguirre is a Spanish proper name.

Aguligik; island, in Kukak bay, Shelikof strait. Aleut name, meaning hawk. Name reported by Vasilief in 1831 . Has been written Aguligat. Pronounced Ah-goo-líg-ik.

Aguliuk; cape, on the northern coast of Umnak, eastern Aleutians. Native name from Kuritzien, 1849. Said to be the Aleut name for goshawk. Tebenkof calls it Chidak, on his Chart $\mathrm{XXV}$, and Aguliuk on a subsketch on same chart. Chidak is the Aleut name for the young of wild birds and animals.

Agulogak, lake; see Bechạrof.

Agulogak, lake and river; see Naknek.

Agulukpak; large lake, north of Bristol bay, near head of Wood river. Eskimo name, obtained by Spurr and Post in 1898 from trader A. Mittendorf. Spurr and Post write it Agouloúkpak, i. e., Aguluk big.

Agumsadak; cape, the southern point of Umak island, Andreanof group, middle Aleutians. Native name, apparently from United States North Pacific exploring expedition, 1855; also written Agumsadakb.

Agunalaksh, island; see Unalaska.

Agusta, glacier and mountain; see Augusta.

Ahguliagamiut, village; see Aklut.

Ahkiok, native village; see Akhiok.

Ahklun; range of mountains north of Bristol bay, between the Togiak and Kanektok rivers. Eskimo name, from Spurr, 1898, who wrote it Oklune.

Ahkoseagewick, creek ; tributary of Kobuk ; see Beaver.

Ahlashok, river; see Alatna.

Ahluckeyak, hill ; see Ulakaia.

Ahluegawil, spring; see Hot.

Aho, bay; see Hallo.

Ahpolagamiut, village; see Apiokak.

Ah-quay, river; see Akwe.

Ahrnklin, glacial stream; see Aantlen.

Ahtell; creek, tributary to Slana river from the west, near its junction with Copper river. Native name from Mendenhall and Schrader, 1903.

Aiachagiuk; Eskimo village, 20 miles below Andreafski, on the right bank of the lower Yukon, near head of delta, about latitude $62^{\circ} 15^{\prime}$, longitude $163^{\circ} 55^{\prime}$. Name from Coast Survey officers, in 1898 , by whom it is written Ayachaghayuk.

Aiacherul. Petrof in the Tenth Census, 1880, shows an Eskimo village, population 60, at Cape Nome, Seward peninsula. He spells it Aiacheruk on his map and Ayacheruk in his text.

Aiaialgutak, island; see Avatanak. 
Aiaiepta, island; see Rootok.

Aiak; cape, on the southern shore of Unalaska, near its western end. Called Aiak by Tebenkof, 1849, and by the Fish Commission, in 1888, Lake point.

Aialetak, island; see Rootok.

Aiaktalik; village, on one of the Goose islands, near Kodiak. Population in 1890, 106. Native name, from Petrof, 1880, who writes it Aiekhtalik and Ayakitalik. Sauer, 1790, has Anayachtalik, which, he says, is by Shelikof called Lgichtalik.

Aialik; bay, indenting the southern shore of Kenai peninsula, near longitude $149^{\circ} 45^{\prime}$. Native name, from the. Russians, who called it Aialikskaia. Has been written Ajalik and generally Ayalik.

Aialki, islands ; see Chiswell.

Aielihtalik, village; see Aialitalik.

Aieval; native village 18 miles southwest of Cape Douglas, Shelikof strait. Native name so given to Martin in 1904 by Nikolai Kalmakof, of Katmai. (May be the same as Ashivak of Petrof, which see.) 'Called Douglas village by the whites.

Aiken; cove, at the head of North arm Moira sound, western shore Clarence strait, southeastern Alaska, near latitude $55^{\circ} 8^{\prime}$, longitude $132^{\circ} 12^{\prime}$. Local navigators' name reported by H. C. Fassett, Bureau of Fisheries, 1904. Named Clara Marie bay by Brooks, 1901, after his launch.

Aik.tak; islet, one of the Krenitzin group near Ugamak island, Unimak pass, eastern Aleutians, near longitude $164^{\circ} 50^{\prime}$. So called by Tebenkof, 1849. On recent maps called Ashmiahk. Probably from the native word Aikak (passage).

Ainslie; gulch; 15 miles north of Cape Nome, Seward peninsula, draining from the east: into New Eldorado creek at the headwaters of Osborn creek, near longitude $165^{\circ} 9^{\prime}$. Local name, published in 1904 .

Airs; hill, near the international boundary line in latitude $62^{\circ} 30^{\prime}$. Named in 1898 by Peters and Brooks, after A. R. Airs, a member of their party.

Aishihik; lake, and village on its shore, in the southwestern part of Yukon district, Canada. Apparently Ta-ku-ten-ny-ee of Davidson. Glave, in 1890 , reported the name as I-she-ik. It has also been written Ishiih and I-shi-ih, and, erroneously, Ashink. The above form, Aishihik, has been adopted by the Canadian Board on Geographic Names.

Aiu, bay; see Hallo.

Aiugnak; group of columns or rocks near the Semidi islands. Also written Augnak, and, erroneously, Akgnak. Native name, from the Russians.

Aja, bay; see Hallo.

Ajaga, island; see Adak.

Ajagisch, volcano; see Makushin.

$A j a k$, island; see Sledge.

Ajalik, bay; see Aialik.

Ajaliki, islands; see Chiswell.

Ajax; reef in Felice strait near eastern entrance to Tamgas harbor, Annette island, Alexander archipelago. So named by Nichols, 1883.

Ajugadach, island; see Rat.

Akagowik; pass or slough, Yukon delta, one of the outlets of Kwiguk pass on the south, near latitude $62^{\circ} 46^{\prime}$, longitude $164^{\circ} 50^{\prime}$. Eskimo name, obtained by Putnam in 1899 .

Akalok; Eskimo village on the Arctic coast, 25 miles north of Hotham inlet. This may be the same as Tikizat or Sheshalek or Anyok; most likely another spelling of the latter name. Eskimo name taken from Reindeer Rept.. 1900 , p. 137 . 
Akamok, island; see Chirikof.

Akeit, cape; see Aksit.

Akgnak, island; see Aiugnak.

Akha, lake; see Chilkopot.

Akhiok; native village, on the northwestern shore of Alitak bay, Kodiak. According to Moser, it had over 100 inhabitants in 1890 . Native name, from Petrof, 1880. Apparently identical with. Oohaiack of Lisianski in 1805. Erroneously Abkiok.

Akhtidung; creek, tributary to Lake Clark from the nortb, near latitude $60^{\circ}$ $30^{\prime}$, longitude $154^{\circ}$. Native name reported by Osgood in 1902 (p. 13), who writes Achteedeedung or Portage. Called Portage by the prospector's.

Akhun, island; see Akun.

Akiachak; Eskimo village, on right bank of the Kuskokwim about 15 miles åbove Bethel. Its Eskimo name, as obtained by Spurr and Post from missionary J. H. Kilbuck, in 1898, is Akiatshágamut, i. e., Akiachak people. The name has been published as Akiachagamut.

Akiak; Eskimo village, on the right bank of the Kuskokwim, about 30 miles above Bethel. Petrof, 1880, wrote its name Ackiagmute, i. e., Akiak people. Spurr and Post, 1898, write Akiágmut, following missionary J. H. Kilbuck.

Aklek; cape, the western point of entrance to Cold bay, Shelikof strait. Apparently a native name. Lutke, 1835, has Aklek and Aclek. Vasilief, 1831, has Aklek. Tebenkof, 1849, has Yaklek. It has been called Iaḳlek, Taklek, Yaklak, and generally Yaklek.

Aklut; Eskimo village, on the eastern shore of Kuskokwim river at the mouth of Eek river. Its Eskimo name as obtained by Spurr and Post from missionary J. H. Kilbuck, in 1898, is Aklukwágamut, from Ak-klut (ammunition, provisions, belongings). This place is almost certainly identical with Akooligamute of Nelson, in 1878-79, and Petrof, in 1880, and Abguliagamiut of the Eleventh Census.

Akmagan, village; see Starichkof.

Akmute; Eskimo village, on left bank of the Kuskokwim, about 10 miles above Kolmakof. So called by Petrof in the Tenth Census, 1880, on his map, but it is not in his text. Spurr and Post, who passed its site in 1898, do not mention it. Akmute means Als people.

Aloblueik, river; see Aluluik.

Akogpak; slough, Yukon delta, a cut-off between Kivikluak and Akularak passes, 10 miles below the head of the delta; near latitude $62^{\circ} 42^{\prime}$, longitude $164^{\circ} 10^{\prime}$. Eskimo. name, obtained by Putnam in 1899.

Akoi; glacial stream, in the St. Elias Alps, debouching through the same mouth owith the Akwe, between the Alsek delta and Yakutat bay. Name pub- lished by 'Tebenkof in 1849. According to Moser's sketch, 1901, this stream might be either the Akwe or Italio, which see. Apparently Akoi and Akwe are variant forms of a native word, Ak. Tebenkof shows two native settlements here, the one nearest Yakutat bay being called Akoi blizhn (Near Akoi); the other Akoi daln (Far Akoi). In Materials for the History of the Russian, American Company (IV, p. 51) we find "Akoi, a place about 40 miles from Yakutat, visited by Kuskof in 1802."

Alkom-uda, settlement; see Ucomude.

Akooligamute, village; see Aklut.

Akoolukpugamute, Eskimo village; 'see Akulukpak.

Akoun, island; see Akun. 
Aloutan, harbor and island; see Akutan.

1.l.kpaliut. The Western Union Telegraph Expedition map of 1867 shows an Eskimo village called Acpalliut a little west of Golofnin bay, Norton sound. It is near or possibly identical with Chiukak of recent maps.

Aksit; cape; near Cape Lazaref, the western point of entrance to otter cove, on the southenstem shore of Unimak island, eastern Aleutians, near latitude $54^{\circ} 40^{\prime}$, longitude $163^{\circ} 25^{\prime}$. So called by Tebenliof in 1849 . Called Akeit by Woronkofski in 1826 . Veniaminof says that the ship Okenna (Is this O'Kenna?) " having perhaps an American skipper" was wrecked near here. Aksit is obviously from Akeit. Can Akeit have been an attempted rendering of the name of the ship? And what was the name of the ship? It is sometimes called West Cape Lazaref. Akuaine, cape; see Akuyan.

Akula; according to Father Barnum, this is the Eskimo term for the tundra or Arctic moorlands. It may be the root of some of the following names.

Akularak; pass or slough, Yulson delta, connecting Kivikluak with Kwemeluk pass near latitude $62^{\circ} 35^{\prime}$, longitude $164^{\circ} 20^{\prime}$. Iskimo term akúlīrok, the root meaning in between, and applied to a streain connecting two lakes or other bodies of water. Name from Putnam, 1899, who wrote Akúlarak.

Akulik; river, tributary to Nolton bay, from the east, Seward peninsula. Native name, from Peters, 1900. See Akula.

Alullik, village; see Aklut.

Akuliukhpak, lake; see Famiek.

Akuliukpak; Iskimo settlement on the shore of Pamiek lake, between the Nushagak and Kuskokwim rivers. Native mane, from Petrof, 1.880, who writes it Akuliulhpak. The termination pak means big, large, great; see Akula.

Akulivikchuk; Eskimo village, on right bank of Nushagak river. Native name, from Petrof, 1880. See Akula.

Akulogak, lake; see Naknek.

Akuluik; river, tributary to Alatna river from the east, latitude $67^{\circ} 20^{\prime}$, longitude $153^{\circ} 45^{\prime}$. Native name, reported in 1886 by Stoney, who wrote it A-koo-loo-ik. Mendenhall and Reaburn, 1901, wrote Akoblueik.

Akulukpak; Eskimo village, Yukon delta, described by Jarvis in 1.897 as "situated on the banks of the Azoon.river a few miles to the northward of where the Nuguiachuk empties into it" and written Akoolukpugamute. Near latitude $61^{\circ}$, longitude $164^{\circ}$. Maybe the big tundra folks, from aküla, Eskimo for the Arctic moorlands or tundra.

Akun; cove, indenting the eastern shore of Akun island, Krenitzin group, eastem Aleutians. So named by the Fish Commission in 1888. 'Tebenkof calls it Riecheshnoi (little river) bay.

Akun; island, on the western shore of Unimak pass in the Krenitzin group, eastern Aleutians, near longitude $165^{\circ} 30^{\prime}$. Native name, from Krenitzin, 1768. Variously written Akhun, Akoon, Akoun, Akouna, and Acouan. Akun is Aleut for distant.

Akun; strait, separating Akun and Akutan islands of the Krenitzin group, eastern Aleutians. So called by Veniaminof and Lutke about 1830 .

Akun Head; the northern point of Akun island, Krenitzin group, eastern Aleutians. Named Sievernoi (north) by Tebenkof, 1849, and recently designated Akun Head by the Coast Survey.

Akutan; bay, between Akun and Akutan islands, Krenitzin group, eastern Aleutians, near longitude $165^{\circ} 45^{\prime}$. So named by the Fish Commission in 1888. 
Akutan; harbor, indenting the eastern shore of Akutan island, Krenitzin group, eastern Aleutians. Called Chinchan bay by Tebenkof, 1849, and Akoutan harbor by the Fish Commission in 1888.

Akutan; island, northeast of Unalaska, being the 1argest island in the Krenitzin group, eastern Aleutians, near longitude $166^{\circ}$. Native name, from Krenitzin and Levashef, 1768. Cook spelled it Acootan. Variously written Akoutan, Acutan, etc.

Akutan; pass, separating Akutan and Unalga islands, Krenitzin group, eastern Aleutians. So called by Lutke and Veniaminof, 1828. Perhaps identical with Paso de Sanganoac of Galiano's atlas, 1802.

Akutan; peak (4,100 feet high), active volcano, on Akutan island, Krenitzin group, eastern Aleutians. Tebenkof gives its height as 3,332 feet, and the Coast Survey -as 3,888, and later 4,100.

Akuyan; cape, the westernmost point of Great Sitkin island, Andreanof group, middle Aleutians. Native name, from Tebenkof, 1849. Has also been written Aluaine.

Akwe; glacial stream in the St. Elias Alps debouching between the Alsèk delta and Yakutat bay. So called by Tebenkof in 1849. Indian name. It was written Ar Qualy by Glave in 1890 and Alh-quay by Moser in 1901, who sketcied the stream more like the Akoi of Tebenkof. See Akoi and Ustay.

Alachs-chak, peniusula; see Alaska.

Alaeksa, peninsula; see Alaska.

Alaganik; slough, the most westerly pass or outlet of Copper River delta. Name from Ritter, 1898. Moser, 1899, wrote Algonek.

Alaganik; native village at mouth of Copper river. Called by its native name, Alagnik and Alaganik, by Serebrenikof in 1848. Allen, who visited its site in 1885, calls it Alaganik (Anabantik), and thinks the site has been moved. A place near by is called Skatalis by the natives. This, Allen thought, was the site of Serebrenikof's Alaganik.

Alagnak; river, Alaska peninsula, draining Kukaklek lake west to the hend of Bristol bay, longitude $156^{\circ}$. Native name, from Tebenkof, 1849. Has been written Aliknuk and Lockenuck.

Alai; mountain, on the southern shore of Alaska peninsula south of Becharof lake. Apparently a native name from Vasilief, 1831-32, who wrote it Alai. Fas been variously written Alay, Olai, Olav, and Otai.

Alaid; island ( 818 feet high), the westernmost of the Semichi islands, western Aleutians. So named by the Russians from its resemblance to Alaid island, one of the Kuril islands, near Cape Lopatka and sometimes called Little Alaid, presumably to distinguish it from that island. The whalemen call it Alída. Grewingk says Alaid or Herzfels (German)= Serdtse Kamen (Russian), Heart Rock or Navel of Alaid (Alaidskaia pupka).

Alakanuk; slough or pass, Yukon delta, an outlet of Kwikluak pass on the right bank, near latitude $62^{\circ} 42^{\prime}$, longitude $164^{\circ} 45^{\prime}$. Eskimo name, obtained by Putnam in 1899.

Alakanuk; Eskimo village at the, head of Alakanuk slough, Yukon delta. Written Alakanukamiut by Putnam in 1899.

Alaksa, cape; see Kabuch point.

Alakshak, peninsula and territory; see Alaska.

Alaksu, territory; see Alaska.

Alamos, Punta de los; see Poplar.

Alanzo, point; see Alonzo.

Alargate-alla, rock; see sheer-off-there. 
Alasca, territory; see Alaska.

Alaschka, peninsula and territory; see Alaska.

Alashuk, river; see Alatna.

Alaska, Gulf of; this name has for the last two or three decades been applied to that part of the North Pacific ocean lying, approximately, to the north of a line from sitka to Kodiak.

Alaska; peak, on the mainland west of Farragut bay, southeastern Alaskit. So named by Thomas, 1887 .

Alaska; peninsula stretching from southwestern Alaska southwestward to the Aleutian islands.

Lutke, 1836, wrote it Aliaska and adds "Some write it Aliaksa. We follow the orthography generally adopted in the colonies. The natives pronounce it Aliakskha."

Veniaminof says "Aliaksa or Aliaska, by the Aleuts called Alakskak."

- Cook, 1778 (II, 504) says, "I have already observed that the American continent is here called by the Russians, as well as by the islanders, Alaschka; which name, though it properly belong only to the country adjoining to Oonemak, is used by them when speaking of the American continent in general, which they know perfectly well to be a great land."

Berg, 1823, calls it the Aliaksa peninsula (pp. 43-44, 66).

Grewingk, 1849, says the usual designation of the peninsula in the Russian American colonies is Alaeksa, and adds as variant forms, Aljaksa, Aljaska, Aläska and in Aleut, Alachs-chak (p. 116).

Dall, 1870 , says the natives of Unalaska told the earliest Russian explorers of a great land to the eastward which they call Al-ak-shak or Al-ayek-sa (p. 529).

Alaska; range of mountains, separating the Kuskokwim and Yukon drainage on the north from the coastwise drainage on the south. Name Alaska apparently given by Dall in 1869. On some earlier maps called Chigmit mountains. See Chigmit.

Alaska; territory, formerly Russian America. This word is a corruption of some native word or phrase the meaning. of which is uncertain.

In 1762 Bechevin, a Russian fur trader, wintered in what we now call Isanotski strait, at the western end of Alaska peninsula. The land constituting the eastern end of the peninsula was regarded by him as an island and called Alaksu or Alakshak. (Coxe, p. 146.)

In 1768 Krenitzin wintered in the same place and calls the strait and land to the eastward Alaxa. (Same, p. 251.)

In 1788 Cook reports, "I have already observed that the American continent is here called by the Russians, as well as the islanders, Alaschka, which name, though it properly belong only to the country adjoining to Oonemak, is used by them when speaking of the American continent in general, which they know perfectly well to be a great land." (II, p. 504.) He also writes it Alashka.

In 1803 Coxe speaks of this country "which is now called Alaska" (p. 101).

In 1805 Lisianski refers to the peninsula as Alaska and also Alasca (pp. $153,196-7)$.

In 1818 Kotzebue speaks of the "peninsula of Alaska" and also peninsula of Alashka. (III, 262, 263.) He also says that the natives of St. Lawrence call the great country to the eastward Kililack. (Same, p. 193.)

Prior to the acquisition of Alaska by the United States in 1867 , it was on English and American maps designated Russian America. The Russians always referred to it as their Possessions in America. 
Alatna; river, large northwest fork of Koyukuk river at the Arctic Circle. Called Allenkikat (kakat meaning moith of) by Allen, who discovered its mouth in 1885. Stoney, the same year, crossed the divide from the Kobuk and explored the headwaters of this river, whose Eskimo name he wrote Al-lash-ook. Cantwell, 1885, wrote the Eskimo name Ahlash-ok and Oklashok. Schrader and Gerdine, 1899, obtained the Indian name Allatna, and Peters and Schrader, 1901, Alatna. Mendenhall and Reyburn's explorations in 1901 showed the Alatna or Allen, and Alishuk, which since 1885 had been represented as different rivers, to be the same. Thus this river is called by three different namesAlashuk by the Eskimo, Alatna by the Indians, Allenkakat by Allen, and each written in various ways. Locally, the miners and traders have adopted the Indian nime Alatni.

Alava; bay, indenting the southeastern shore of Revillagigedo island 4 miles northeast of Point Alava, southern entrance to Behm canal, near latitude $55^{\circ} 15^{\prime}$, longitude $131^{\circ} 07^{\prime}$. Name so applied by local navigators, reported by H. C. Fassett, Bureau of Fisheries, 1904.

Alava; point, the south end of Revillagigedo island, Revillagigedo channel, Alexander archipelago. So named by Vancouver, 1793, in compliment to the Spanish governor at Nootka.

Alava; ridge of mountains near the southern end of Revillagigedo island, - Alexander archipelago. So named by Nichols, 1883.

Alaxa, territory; see Alaska.

Alay, mountain; see Alai.

Alayeksa, peninsula; see Alaska.

Albatross; anchorage in Portage bay, Alaska peninsula, north of the Shumagins. Surveyed and named by officers of the Fish Commission steamer Albatross in September, 1893 .

Albatross; fishing bank, southeast from Kodiak. Named by the Fish Commission in 1888, after its steamer Albatross.

Albert; creek, in the Birch Creek region, tributary to Crooked creek from the left, near latitude $65^{\circ} 35^{\prime}$, longitude $144^{\circ}, 50^{\prime}$. Frospector's name, reported by Spurr, Goodrich, and Schrader, 1896.

Alberto; islands. Three islands near the eastern shore of San Alberto bay, Bucareli båy, Prince of Wales archipelago, near latitude $55^{\circ} 30^{\prime}$. So named by Moser, 1897.

Albion; creek, 8 miles north of Nome, Seward peninsula, tributary from the north to Rock creek, an east branch of Snake river, near longitude $165^{\circ} 25^{\prime}$. Local name, published in 1904 .

Alchichna, river; see John. .

Alder; creek, Kenai peninsula, a left branch of Sixmile creek, near latitude $60^{\circ} 50^{\prime}$, longitude $149^{\circ} 25^{\prime}$. Local name, from Moffit, 1904 .

Alder; creek, tributary to Gold run from the east, Seward peninsula. Name from Barnard, 1900.

Alder; creek, Seward peninsula, tributary to the north fork of Kougarok river, near latitude $65^{\circ} 40^{\prime}$, longitude $164^{\circ} 25^{\prime}$. Local name, from Gerdine, 1901.

Alder; creek, Seward peninsula, flowing into Kotzebue sound west of Spafarie: bay. Longitude $162^{\circ} 15^{\prime}$. Local name, reported by Witherspoon in, 1903.

Alder; creek, tributary to Fairbanks creek from the north, near latitude $65^{\circ} 05^{\prime}$, longitude $147^{\circ} 15^{\prime}$. Prospectors' name, from Gerdine, 1903.

Alder; creek, in the Fairbanks region, tributary to Kokomo creek from the south, near latitude $65^{\circ} 10^{\prime}$, longitude $147^{\circ} 15^{\prime}$. Prospectors' name, from Gerdine, 1903. 
Alder; creek; 10 miles west of Fairbanks, tributary to Cripple creek from the north, near longitude $148^{\circ}$. Prospector's' name, from a local map, 1905.

Alder; creek, on the south bank of the Yukon, 20 miles above Rampart (city), near longitude $150^{\circ}$. Prospectors' name, reported by Lieutenant Erickson, U. S. A., 1902.

Alder; creek, tributary to North fork of Koyukuk river. Prospectors' name, mentioned by Cantwell in 1902 . Not found on any map.

Alder; creek, eastern Alaska, on the south bank of Seventymile creek, near latitude $65^{\circ}$, longitude $142^{\circ} 20^{\prime}$. Prospectors' name, from sketch map compiled by Major Glassford, Signal Corps, U. S. A., 1905.

Alder; creek, tributary to O'Brien creek from the west, in the Fortymile mining region. Prospector's' name, from Baruard in 1898.

Alder; creek, tributary to South fork of Fortymile creek, from the west, in the Fortymile mining region. Prospectors' name, from Barnard, 1898.

Alder-Nest, mountain; see Eagle Nest.

Alecks; lake and stream, Kuiu island, Tebenkof bay, "on the eastern side of the inner bay, about the middle of its length" near latitude $56^{\circ} \cdot 32^{\prime}$. So described by Moser in 1900, who says that they are also called Kuiu lake and stream.

Aleknagik; Jake, north of Bristol bay, draining through Wood river to Bristol bay. Variously spelled Alaknakik, Aliaknagik, etc. Eskimo name published in Sarichef's atlas, 1826. According to Spurr and Post, deriving their information from trader A. Mittendorf, in 1898, the native name is Agoulouikatuk. It appears also to be the lake described by Sheldon .Jackson as well studded with beautiful pine-covered islands and called Abaknakik.

Aleknagik, river; see Wood.

Aleks; sunken rock, about 15 miles southwest from Sannak, near latitude $54^{\circ}$ $.20^{\prime}$, longitude $163^{\circ} 10^{\prime}$. Reported by Capt. William Paterson, of the schooner Alexander, in 1890. Name derived from the name of his vessel.

Aleksashkina; a former native settlement on Wood island, St. Paul harbor, Kodiak, near what is now called Ice House point. In 1849 Tebenkof called it the Chiniak settlement (Aleksashkina), while the Russian American Company map of the same year calls it the Aleut settlement Tanignag-miut.

Alentkina, bay ; see Aleutkina.

Alert; creek, a branch of Casadepaga river; see Willow.

Aleutian; islands, the long chain of 70 treeless islands stretching westward 1,000 miles from Alaska peninsula. "The word Aleutian seems to be derived from the interrogative particle allix, which struck strangers in the language of that people.". (Kotzebue, III, p. 312.) Alik-u-a-ia?= What is this? (Veniaminof, II, p. .2.) Allik?=-What dost thou want? (Bancroft's History of Alaska, p. 106.) Have been called Aleutian, Aleoutiennes, etc. Usually called the Fox islands by seaffaring people. Aleutian; mountains, on Alaska peninsula northeast of Becharof lake. So named by Spurr, 1898 .

Aleutian, sea; see Bering.

Aleutkina; bay, indenting the eastern shore of Sitka sound, Alexander archipelago. So named by Vasilief, 1809. Has also been called Leesia (fox) and Leesoffskaia bay. Also erroneously Alentkina. The name Leesia (fox) appears to be used by Tebenkof as a synonym for Aleutkina (Aleut woman), referring to the Unalaskan or Fox Island Aleuts. The bay just north of this is named by Tebenkof, Kadiak, referring to another branch of the Aleuts. 
Aleutski; island, SE. of the wharf in Sitka harbor, Sitka sound, Alexander archipelago. Named Aleutski (Aleutian) by the Russians. Has also been written Aleyoutski. Also named Ball, by Beardslee, 1880.

Alexander; archipelago in southeastern Alaska, comprising the great group of coastwise islands between Dixon entrance and Lynn canal. So named by the Coast Survey in 1867 , after the Russian Tsar.

Alexander; creek, on the western bank of Susitna river, about 10 miles from its mouth. Named after an old. Indian chief who lived a quarter of a mile above the mouth. Published by the Geological Survey in 1899.

Alexander; island, on the eastern side of Afognak bay, between Afegnak and

' Kodiak islands, near latitude $58^{\circ}$, longitude $152^{\circ} 41^{\prime}$. Local name, reported by Moser in 1900.

Alexander; point, the southeastern point of entrance to Wrangell strait, Alexander archipelago. So named by Lindenberg, 1838.

Alexander; port at the south end of Chatham strait, Baranof island, Alexander archipelago. Name published by 'Tebenkof, 1849 .

Alexander; rock, near Middle channel into Sitka harbor, sitka sound, Alexander archipelago. Name published on Coast Survey chart 725 in 1881. Origin of name not discovered.

Alexander Archipelago Forest Reserve; reservation, established by Presidential proclamation August 20, 1902. It includes Chichagof and adjacent islands to seaward, Kuprianof, Kuiu, Zarembo, and Prince of Wales and adjacent islands to seaward.

Alexandra; point, in Kupreanof harbor, Ivanof bay, Alaska peninsula. Named Alexandra by Woronkofski, 1837. Sometimes erroneously Alexander.

Alexandrovsk; settlement on Graham harbor; Cook inlet. Nämed Alexandrovsk (Alexander) by the Russians in the last century.

Alexandrovsk, trading post; see Nushagak.

Alexeief; very small village in the Yukon delta. Name from Nelson, who passed through it in December, 1878. Hé shows it on his map but does not mention it in his text. It appears on the census map of 1880 but not in the text, unless, indeed, it may be "Village (name unknown )."

Alfield; creek, 30 miles north of Cape Nome, Seward peninsula, a fork of Sulphur creek, which is tributary to Nome river from the east, near longitude $165^{\circ} 10^{\prime}$. Miners' name, reported by Gerdine, 1904:

Alga-anatorolog; see North rookery.

Alganuda; bay, the small bight in the southeastern end of Zapadni bay, southwestern' shore St. George island, Bering sea, near longitude $169^{\circ} 40^{\prime}$. Aleut name, meaning seal bay and written Äl'gän-ūdä by Putnam in 1897.

Alger; peak $(7,500$ feet high $)$ in the Tordrillo raige, northwest of Cook inlet. So named by Spurr and Post, 1898.

Algonek, river: or slough; see Alaganik.

Aliagnagik, river; see Wood.

Aliaknagik, lake; see Aleknagik.

Aliaksin; cape or promontory forming the western head of Portage bay, Alaska peninsula, north of Unga. Called Aliaksinskie and Aliaksin by the Russians.

Alias7a, peninsula; seè Alaska.

Aliaskinskoi, strait; see Shelikof.

Alice; creek, Seward peninsula, a small tributary on the east bank of Casadepaga river, near latitude $64^{\circ} 50^{\prime}$, longitude $164^{\circ} 18^{\prime}$. Prospectors' name, reported by Gerdine, 1905 . 
Alice; island, one of the Japonski group, Sitka sound, Alexander archipelago. So named by United States naval officers, 1880 .

Alice; peak (3,623 feet high) in the northern part of Etolin island, Alexander archipelago. So named by Snow, 1886.

Alice; port (Fort Alice) indenting the northwestern shore of Heceta island on the south side of Davidson inlet, Prince of Wales archipelago, near latitude $55^{\circ} 50^{\prime}$, longitude $133^{\circ} 36^{\prime}$. So named by Dickins, $1903-4$.

Alida. island; see Alaid.

Alihack, cape; see Alitak.

Aliksemit; island ( 300 feet high), one of the Semidi group of islands. Has been called Alikbsemit and Ali'khsemit. Native name, obtained by Dall in 1874 .

Alikinuk, river; see Alagnak.

Aliknuk, lake; see Kukaklek.

Alilok, bay; see Alitak.

Alimuda; bay, indenting the nortbern shore of Unalaska, immediately west of Kashega bay. Sarichef, 1792, calls it Kismaliuk. Veniaminof, however, about 1830, calls it by its Aleut name, Alim uda (Alim bay), which bay he says is also called Mikhailovskaia, after the ship Michael, which was wrecked there. Sarichef applies this name Alimuda to the bay just west of this one and which is in this dictionary called Middle bay.

Alimvoak; bay, indenting the northwestern shore of Afognak island, Kodiak group. Native name, from the Russian American Company in 1848.

Alinchak; bay, indenting the south shore of Alaska peninsula, Shelikof strait, between Cold bay and Katmai bay, near latitude $57^{\circ} 50^{\prime}$. Native name; so written for Martin in 1904 by Nikolai Kalmakof, of Katmai.

Alitak; bay, indenting the southwestem end of Kodiak. Corruption of some native term obtained by the early Russians. The old Russian charts call the bay Yagelstaliek and the cape Alitok. Petrof has Kaniat (Alitak) bay. Also called Aluta and Alutak by Archimandritof in 1849.

Alitak; cape, the western point of entrance to Alitak bay, on western coast of Kodiak. Native name, from the early Russian explorers. Has been written Alihack, Alitack, and Alutak.

Alitak; native village on the northern shore of Alitak bay, west shore of Kodiak. The Russian American Company map of 1849 shows an Aleut and a Russian settlement here called Kashukvag-miut, i. e., Kashukvak people.

Aliluya, bay; see Lituya.

Aliuksuk, bay; see Fumicestone.

Aliutik, cape; see Trinity.

Aljaska, peninsula; see Alaska.

Allan; point, the eastem point of Halleck island, Nakwasina passage, Alexander archipelago. So named by Moore, 1897 , after W. S. Allan, recorder in his party.

Allashook, river; see Alatna.

Allatna, river; see Alatna.

Allen; creek, tributary to headiwaters of Topkok river, Seward peninsulit. Name from Barnard, 1900.

Allen; creek, on the north bank of Tamanil river, neill longitude $147^{\circ}$. So named in 1902 by Lient. George S. Gibbs, U. S. A., probably after Britg. Gen. Henry Tureman Allen, U. S. A. 
Allen; glacier, and mountain (10,000 feet high) near the headwaters of Tanana river. So named by Peters and Brooks, 1898, after Maj. Henry Tureman Allen, U. S. A. Spurr has proposed to change this to Stoney glacier and mountain, after Lieut. Geo. M. Stoney, U. S: N., an Alaskay explorer.

Allen, Allenkakat, river; see Alatna.

Allene; creek, Seward peninsula, north of Grantley harbor; tributary from the west to North creek, near latitude $65^{\circ} \cdot 20^{\prime}$, longitude $166^{\circ} 05^{\prime}$. Prospectors' name, from Gerdine, 1901 .

Allgold; creek, Seward peninsula, in the Casadepaga drainage basin, tributary on the north bank of Canyon creek, near latitude $64^{\circ} 52^{\prime}$, longitude $164^{\circ} 28^{\prime}$. Prospector's' name, reported by Gerdine, 1905.

Alma; creek, Seward peninsula, in the Casadapega drainage basin; tributary to the head of Birch creek, near latitude $64^{\circ} 48^{\prime}$, longitude $164^{\circ} 10^{\prime}$. Prospectors' name, reported by Gerdine, 1905.

Alma; gulch, on the south shore of Seward peninsula, $2 \frac{1}{4}$ miles west of Cape Nome, near longitude $165^{\circ} 04^{\prime}$. Local name, from Gerdine, 1904.

Almiralty, bay; see Yakutat. .

Almirantazgo, bay; see Yakutat.

Alogh-koverushka; see Sealion hills.

Alonzo; point, on the southern shore of Port Asumcion. Bucareli bay, Prince of Wales archipelago. Named Punta de Alonzo by Maurelle and Quadra, 1775-1779. Erroneously Alanzo.

Alookuk, village; see Ulukuk.

Alpha; creek, 9 miles north of Nome, Seward peninsula, tributary to Snake river from the west, near longitude $165^{\circ} 28^{\prime}$. Local name, published in 1900.

Alpha; small creek draining the southern slope of the divide between Tanana river and the headwaters of Minook creek, near latitude $65^{\circ}$, longitude $150^{\circ} 15^{\prime}$. Prospectors' name from Prindle; 1903:

Alsek; glacier, southeastern coast of Alaska, on the left bank of Alsek river, near longitude $138^{\circ} 10^{\prime}$. So named by Moser:; 1901 .

Alsek; river, in the St. Elias region, debouching between Lituya and Yakutat bays. Called Riviere de Behring by: La. Perouse in 1786, Alsekh by Tebenkof in 1849, Jones by the New York Times Expedition of 1856, and Harrison by the Coast.Survey in 1890. Variously written Alseck, Alsekh, Altsekh, Alzech, etc. The above form, Alsek, was adopted by both the United States and the Canadian Boards on Geographic Names. The form Alseck, in the first report of the Canadian Board, was a typographical error.

Alsentia, bay; see Kaguyak.

Althorp; port (Port Althorp), indenting the northwestern shore of Chichagof island, Cross sound, Alexander archipelago, near latitude $58^{\circ} 10^{\prime}$, longltude $136^{\circ} 20^{\prime}$. So named by Vancouver, 1794. Erroneously Altorp and Apthorp.

Althorp; rock (15 feet high) in Port Althorp, eastern shore of Cross sound. So named by Pratt, 1901.

Altona, baý; see Lituya.

Altselkh, river; see Alsek.

Altua, bay; see Iituyn.

Allukeyak, hill : see Ulakaia.

Alukuk, village; see Ulukuk.

Alutak, bay and cape; see Alitak. 
Alvin; bay, indenting the eastern shore of Kuiu island, Sumner strait, Alexander archipelago, near latitude $56^{\circ} 26^{\prime}$, longitude $133^{\circ} 53^{\prime}$. Local navigators' name reported by H. C. Fassett, Bureau of Fisheries, 1904.

Alzane; island, in Lynn canal; the northermmost of the Chilkat islands. Native name, obtained by. Dr. Arthur Krause in 1882, who writes it Alzáne.

Alzech, river; see Alsek.

Amagalik; cape, on the southwestern shore of Tanagal island, Andreanot group, middle Aleutians. Aleut name, from 'Jebenkof, 1.549. Has also been written Ámagalikli.

Amagat; island (1,030 feet high), near the southem shore of Alaska peninsula at east side of entrance to Morzhovoi bay, near latitude $54^{\circ} 54^{\prime}$, longitude $162^{\circ} 53^{\prime}$. According to Lutke, quoting Kudiakof, the Aleut name is Amagadak. Tebenkof, who has been generally followed, calls it Amagat.

Amagul, bay; see Amugul.

Amak; island (1,682 feet high), off the northern shore of Alaska peninsula, near its western end, about longitude $163^{\circ} 09^{\prime}$. Once much frequented by walrus and known as Walrus island, though this name does not appear on maps. The Aleut name is Amak (blood).

Amakagagvak; lake, near to and connected with Nushagak lake. Native name, from 'Tebenkof, 1849 .

Amalulktuli, cape; see Eagle.

Amaknak; cave, or hollow, under Cave rock, Amaknak island, Unalaska bay. An ancient burying place of the Aleuts.

Amaknak; island (1,640 feet highl), in Unalaska bay, eastern Aleutians, near longitude $166^{\circ} 31^{\prime}$. Native name, from Sarichef. Has also been written Amakhnak and Amoknak.

Amalga; post-office established October, 1905, southeastern Alaska, on the mainland, eastern shore of Lyni canal, near latitude $58^{\circ} 30^{\prime}$.

Amalik; harbor, south shore Alaska peninsula, near latitude $58^{\circ} 05^{\prime}$. So described by Dall, 1895.

Amanat, point; see Hostage.

Amanka; lake, near the northern shore of Bristol bay, drained by the Igushik river. Native name, obtained by Spurr and Post, of the Geological Survey, 1898. Petrof, 1880, reports its name to be Pogakhluk, while Tobenkof, 1849, calls it Kagata (source.) Written also Amankal.

Amargura; cape, the southern point of San Fernando island, Bucareli bay, Prince of Wales archipelago, near latitude $55^{\circ} 25^{\prime}$. Named I'unta de la Amargura (point of sorrow) by Maurelle and Quadra, 1775-1779. Has also been written erroneously Amatgura.

Amatignak; island $(1,921$ feet high), the southwesternmost of the Andreanof group, middle Aleutians. Aleut name, from early Russian explorers. Billings, 1790, has Amatignas, while Lutke has Amatignak and Amatygnak, which he says is the Aleut word for chip. Variously written Amatiegnak, Amatignake, etc.

Amatuli; island, one of the Barren islands at entrance to Cook inlet. Native name, from the Russians.

Amawak; promontory, on the northern coast of Kukak bay, Alaska peninsulat. Native name, from Langsdorf, 1805, who wrote it Amawack.

Amber; bay, on the southern coast of Alaska peninsula, north of Sutwik island. So named by the Russians from the reported occurrence here of amber. Bernstein (amber) bucht of Grewingk and 'Iantarni (amber) of the Russians. 
Amber; lake, on Unalaska island, eastern Aleutians. Veniaminof, getting his information from the natives, says ( $I, 171)$ : "There is, near Mokrovski bay, between the mountains above, a lake, which has an islet in the middle, on the eastern precipitous shore of which excellent amber occurs."

Amber; small stream tributary to the estuary of Nushagak river from the east, near Etolin point.' Named Iantar (amber) on Russian Hydrographic Chart 1455 (ed. of 1852).

Ambler; peak (3,058 feet high), on Lindenberg peninsula, Kupreanof island, Alexander archipelago. So named by Thomas, in 1887, after Dr. James M. Ambler, surgeon of the ill-fated Arctic expedition under De Long, $1879-80$.

Ambler; river, tributary to the Kobuk from the north, near longitude $158^{\circ}$. Named by Stoney, in 1885 , after Dr. James M. Ambler, U. S. N., surgeon of the ill-fated Arctic expedition under De Long. Published by the Coast Survey in 1890. Stoney writes the native name, Nut-vuck-towo-ark or Nuck-vuck-to-ark, and Cantwell Not-mok-to-way-ok, Notmoktowoak, and Notmoktowaoh.

Amchik, point; see Eagle.

Amchitka; island (1,281 feet high), one of the principal islands of the Rat island group, western Aleutians, near. longitude $179^{\circ}$. Said to have been seen by Bering, in 1741, and called St. Makarius. Its native name is Amchitka, which has been variously written Amtatka, Amtchitka, Amtschitka, ete.

Amelia; point, on the western shore of Kruzof island, Alexander archipelago, near latitude $57^{\circ} 13^{\prime}$, longitude $135^{\circ} 50^{\prime}$. So named by Vancouver, 1794 .

Amelius; point, on the southeastern shore of Kuiu island, Sumner strait, Alexander archipelago. So named by Vancouver, 1793.

American; bay, on the eastern shore of Dall island, at Howkan narrows, Kaigani strait, Alexander archipelago. Named Amerikanskaia by Etolin, 1833.

American; creek, Kenai peninsula, a left-hand tributary of Resurrection creek near its source. Local name from Moffit, 1904.

American; creek, tributary to Niukluk river from the west, Seward peninsula. . Name from Barnard, 1900.

American; creek, tributary to sinuk river from the west, Seward peninsula. Name from Barnard, 1900.

American; creek, tributary to Snake river from the east, in the Cape Nome mining region, Seward peninsula. Prospectors' name, published in 1900 .

American; creek, Seward peninsula, tributary to old Glory creek, near latitude $65^{\circ} 50^{\prime}$, longitude $163^{\circ} 10^{\prime}$. Local name, from Witherspoon, 1903.

American; creek, tributary to Preacher creek from the south, near latitude $65^{\circ}$ $30^{\prime}$, longitude $146^{\circ} 15^{\prime}$. Prospectors' name, from Gerdine, 1903.

American; creek, tributary to Mission creek from the south, a mile west of Eagle. Prospectors' name, reported by Sppurr's party of the Geological Survey, 1896.

American; gulch, $4 \frac{1}{2}$ miles north of Nome on the western slope of Newton peak, draining into Dry creek, near longitude $165^{\circ} 20^{\prime}$. Local name, from Gerdine, 1904.

American; range of mountains, on the mainland north of Farragut bay, southeastern Alaska. So named by Thomas, 1887.

American; river, tributary to Agiapuk river, from the north, Seward peninsula. Name from Brooks, 1900. 
American Mouth, pass; see Kwikluak.

Amerikanstaia, bay; see American.

Amherst; glacier, tributary from the east to College fiord, Port Wells, Prince William sound. So named by the Harriman Expedition, 1899, after Amberst College.

Amlia; island (1.900 feet high), the ensternmost of the principal islands of the Andreanof group, middle Aleutians. Native name, from 'Tolstyk, 1761 , who wrote it Amlak. Has also been written Amlii, Amli, Amlja, Amlya, Amlag, Amluk, etc. The southern part of Atka island has been called the Amlia peninsula.

Ammak, point; see Aspid.

Ammolialoolitok, river; see Black.

Amnak or Amnuk, island; see Bogoslof and Umnik.

Amolincli, island; see Amaknak.

Amoukhta, island; see Amuktal.

Amtagis; islet, or group of islets, off the southern shore of Atka, middle Alentians. Native name, from 'Tebenkof, 1849.

Amtatka, island; see Amchitka.

Amtchitlia, island; see Anchitka.

Amtschitla, island; see Amchitka.

Amugul; bay, indenting the southern shore of Beaver bay, Unalaska, eastern Aleutians, near latitude $53^{\circ} 45^{\prime}$, longitude $166^{\circ} 24^{\prime}$. Aleut name, from Sarichef, 1792. Veniaminof cills it Amugulik. Perhaps from the Aleut word Amuk (lightning). Into it flow two small streams. One of these is doubtless the Amagui creek of Langsdorf (II,'28). It has been called Fourth, of July bay.

Amukta; volcanic island (3,738 feet high), forming the westernmost of the group of islands of the Four Mountains as classified by Veniaminof. Native name, from the earliest Russians. Coxe, 1780, writes it Amuckta and Amukta, taking the name from Krenitzin and Levaşhef, 1768. Variously written Anoghta, Amoukhta, etc.

Amukta; pass, about 40 miles wide, in the Aleutian islands, between Amulta island on the east and Seguam island on the west, near the one hundret and seventy-second meridian of west longitude and known to the whalers as the Seventy-Second rass.

Amy Landing; place on Klutina river about 6 miles below the outlet of Klutina lake, where the river enters The Gorge. So named by Abercirmbie in 1.898, after W. S. Amy, of Copper Center.

Anagaksik; islet, south of Great Sitkin, Andreanof group, middle Aleutians. Aleut name, from Tebenkof, 1.849. Has also been written Anagilkhsikh.

Anagnak; Eskimo village near moutl of Wood river, a little above the head of Nushagak bay. Native name, from Petrof, 1880.

Analıánuk, village; see Alaganik.

Ancialktak, islands; see Geese.

Anaiuliak, islet; see Ananiuliak.

Anatovil, creek; see Anikovik.

Anakshek; slough or pass, Yukon delta, connecting Kwemeluk pass and Black river near latitude $62^{\circ} \cdot 20^{\prime}$, longitude $164^{\circ} 40^{\prime}$. Eskimo name, obtained by Putnam in 1899 .

Anaktuvuk; pass, norther'n Alaska, on the divide between the Arctic and Yukon drainage, at the headwaters of John and Anaktuvuk rivers, near - latitude $68^{\circ} 10^{\prime}$, longitude $152^{\circ}$. Crossed by Peters and Shrader in 1901. Eskimo name.

Bull. $299-06 \mathrm{M}-7$ 
Anaktuvuk; river, on the Arctic slope, a large tributary of the Colville river from the south, near longitude $151^{\circ}$. Explored by Peters and Shrader in 1901. Eskimo name. Mendenball wrote it Auukturuk.

Anan; bay, south of Blake island, indenting the southern shore of Bradfield canal, Alexander archipelago. So called by Snow in 1886. Written An-An on plats in General Land Office. Name wrongly placed on Coast Survey chart $\$ 200$.

Anan; creek, tributary to Humpback bay, Bradfield canal, Ernest sound, southeasteru Alaska, near latitude $56^{\circ} 10^{\prime}$, longitude $131^{\circ} 52^{\prime}$. So called by the fisheries, probably after an Indian, and reported by Moser in 1897.

Ananakeik, island; see Dolgoi.

Anangusik, islands; see Gareloi.

Ananiuliak; islet, near the northwestern shore of Umnak, eastern Aleutians. Native name, from Veniaminof. Lutke wrote it Anangouliak and Kuritzien Anaiuliak.

Ananongutka; bluff, prominent isolated bluff, near the west end of the north coast of St. George island, Bering sea, about longitude $169^{\circ} 43^{\prime}$ Aleut name (Ananong's shelf), written-Ănăn'ŏng-ūtc'ha by Putnam in 1897.

Anavinguk; river, tributary to the Togiak river from the east, near!Togiak lake, north shore Bristol bay. Native name, reported by Post, of the Geological Survey, in 1898, who writes it Anavínguk. Tebenkof, 1849, calls it Anvaniek.

Anayachtalik, village; see Aiaktalik.

Ancau; see Ankau.

Anchor; cové, indenting the shore of Admiralty island, near north end of Stephens passage, Alexander archipelago. So named by Coghlan, 1884.

Anchor; cove, indenting the southern shore of Olga bay, Alitak bay, southwestern coast of Kodiak. Local name; reported by Moser in 1900.

Anchor; mountain, near Nats river, Fortland inlet. So named by the British Admiralty.

Anchor; passage, in Behm canal, between Bell island and the mainland. Alexander archipelago. Name published by the Coast Survey in 1894. Has also been called Anchorage pass.

Anchor; point, in Wrangell strait, Mitkof island, Alexander archipelago. So named by Meade, 1869 .

Anchor; point, on the eastern shore of Cook inlet. So named, in 1778, by Cook, who lost an anchor here. Also called Laidennoj (icy), Jakorny (anchor), and Kasnatchin, a native name.

Anchorage; bay, about 12 miles from Tuliumnit point, indenting the southern shore of Chignik bay, Alaska peninsula. It is the anchoring place for all the canneries in Chignik bay. Local name, reported by Moser in 1897.

Anchorage; cove, in American bay, Kaigani strait, Alexander archipelago. So named by Dall, 1882 .

Anchorage; cove, in and near the mouth of Lituya bay, southeastern Alaska. So called by Dall in the Coast Pilot, 1883 (p. 203).

Anchorage; point, on Hamilton island in Shakan bay, Sumner strait, Alexander archipelago. Local name, published in the Coast Pilot, 1883.

Anchcrage; point, the southern point of entrance to Pyramid harbor, Chilkat inlet, Lynn canal, southeastern Alaska, near latitude $59^{\circ} 10^{\prime}$, longitude $135^{\circ} 28^{\prime}$. Named Anchorage (Yakorni) by Lindenberg, in 1838. It is Sandy pọint of Meade in 1869.

Ancon; peak (3,300 feet high), on Woronkofski island, Alexander arçhipelago, Named by Snow, in 1886, after the steamship Ancon. 
Ancon; rock, at east point of entrance to Glacier bay, Cross sound, southeastern Alaska, near longitude $135^{\circ} \mathbf{5 5 ^ { \prime }}$. Named in 1891 or earlier after the S. S. Ancon.

Ancou, creek; see Ankau.

Anderson; bay, on south side of Port Valdez, 6 miles west of Fort Liscum, Prince William sound, near latitude $61^{\circ} 05^{\prime}$, longitude $146^{\circ} 30^{\prime}$. Local name, reported by Grant in $\mathbf{1 9 0 5 .}$

Anderson; bay, indenting the western shore of Makushin bay, Unalaska, eastern Aleutians. So named by the Fish Commission in 1888. Its native rame, says Veniaminof, 1840 , is Iksiaktak (? burning). It is, at jts head, divided into two arms, the southern one called Udamak and the northern one Naginak (sick).

Anderson, cape; see Northeast.

Anderson; creek, Seward peninsula, tributary from the east to Don river, near latitude $65^{\circ} 30^{\prime}$, longitude $166^{\circ} 50^{\prime}$. Prospector's' name, from Gerdine, 1901.

Anilerson, island; see St. Lawrence.

Anderson; point, southeast point of entrance to Clover bay, western shore Clarence strait, southeastern Alaska, near latitude $.55^{\circ} 18^{\prime}$, longitude $1.32^{\circ}$ $10^{\prime}$. So called by the local navigators and reported by H. C. Fassett, Bureau of Fisheries, 1904.

Anderson; suriken rock, reported in 1883 and still uncharted, about 25 miles south of Sannak island, near latitude $54^{\circ} 03^{\prime}$, longitude $162^{\circ} 45^{\prime}$. So called by the Fish Commission in 1888.

Andreafski; fort or stockaded post established by the Russians on the right bank of the Yukon, near the head of the delta, in or about 1853. In August, 1855, the natives killed its two inmates. It has been variously written Andreafski, Andreaivsky, Andreievsky, i. e., Andrew's, etc. 'The place appears on the latest maps as Old Andreafski, and Andreafski appears at a new site 5 miles farther up the river. This is now the most important trading post on the lower Yukon, is situated on the right bank of Clear river, about 2 miles above its junction with the Yukon and 120 miles above the mouth of the latter, longitude $163^{\circ} 15^{\prime}$. Here are located the warehouses, stores, and dwellings of the Northern Commercial Company. A mile above on the same side of. Clear river is the extensive winter quarters of the Nortbern Commercial Company, where the company has established machine shops, a marine railway for hauling out its vessels, a large hotel, and an electric plant to light the buildings.

Andreafski; mountain, on the right bank of the Yukon dnear Andreafski, latitude $62^{\circ} 03^{\prime}$, longitude $163^{\circ} 15^{\prime}$. So called by Putnam, 1899 .

Andreafslci, river; see Clear.

Andreanof; group of islands in the middle of the Aleutian chain, extending from Seguam pass on the east to (but not including) Amchitka on the west. These islands were first explored by Andreian Tolstyk with Peter Vasiutkin and Maxim Lazaref in 1761. Tolstyk owned the vessel which is usually called the Andreian and Natalia. Berg calls it the Adrian and Natalia (p. 53); Coxe, the St. Andrean and Natalia (p. 155), and Dall the Andrean and Nathalia (p. 302).

Coxe says: "The first certain account was brought by this yessel, the $s t$. Andrean and Natalia, from whence they are called the Andreanoffskie ostrova, or the islands of St. Andrean" (p. 155). 
Andreanof-Continued.

Berg says: "Tolstyk, Lazaref, and Vasiutkin furnished the authorities with an exact account of the six islands discovered by them, and accordingly they were thereafter called the Andreianofski islands" (p. 55).

Petrof, speaking of Tolstyk's stay on these islands, adds, "Named after him the Andreianorski" (Banc. Hist., 129), and Dall in his Alaska, p. 302, says: "In 1761, Lazeroff explored the islands which have since borne the name of Andreanoffsky, from the owner of the vessel." Tolstyl's . vessel was called the Andreian and Natalia after himself and wife, hence St. Andrean is an error. See also Fox islands.

Andrew; bay, indenting the northern shore of Adak island, Andreanof group, middle Aleutians. Apparently named by Tebenkof, 1849, presumably after Andreiana (Andrew) Tolstyk, the first explorer of Adak, in 1761. By a double error this has been rendered Lidrejana bay. 'The Russian $\mathbf{L}(\mathrm{s})$ differs from $\mathrm{A}$ by the omission of the cross mark. This cross mark: was omitted by the Russian engraver. The Russian I (и) differs but slightly from the Russian $\mathrm{N}(\mathrm{H})$. Hence the strange form Lidrejana.

Andrew; Learnard, of Glenn's expedition, 1898, gives this as the name of a river coming into the Susitna from the left but the exact location is uncertain.

Andrews, port; see Resurrection.

Andrews, river; see Chuiu.

Andronica; island, one of the Shụmagin group, between Korovin and Nagai, near latitude $55^{\circ} 40^{\prime}$, longitude $160^{\circ}$. Now occupied for the propagation of blue foxes (vulpus lagopus). So named by the Russians after the apostle Andrew (Andronika). Dall gives Yasni (clear) or Foggy as alternative names.

An-e-la-gag-e-rack, river; see Tieed.

Anemuk; Eskimo village, on the left bank of the Anvik river about 30 miles above its junction with the Yulson. Native name, from Riymond, 1869.

Aneskett; point, the most easterly point of Kosciusko island, Prince of Wales archipelago, near latitude $56^{\circ} 09^{\prime}$. longitude $1.33^{\circ} 16^{\prime}$. Apparently a native name, obtained by Dickins in 1903-4.

Aneyuk, Eskimo village; see Aniuk.

Angeles; creek, Seward peninsula, tributary to Garfield creek from the north, latitude $65^{\circ} 30^{\prime}$, longitude $164^{\circ} 30^{\prime} \therefore$ Name from Gerdine, 1901 .

Angle; point, on the southwestern shore of Bold island, Revillagigedo channel, Alexander archipelago. So named by the Coast Survey in 1886.

Anglice, island; see Martin point and Fox islands.

Angoon; Indian village, on the western shore of Admiralty island, $2 \frac{\pi}{2}$ miles north of Killisnoo, Chatham strait, Alexander archipelago, near latitude $57^{\circ} 30^{\prime}$, longitude $134^{\circ} 35^{\prime}$. Native name, reported by Moore in 1895.

Angoyaktoli; creek, tributary to the Kuskokwim from the east, near its mouth. Native name, obtained by Spurr and Post in 1898 from missionary J. H. Kilbuck and by them written Angoyáchtoli. Erroneously published Augoyaktoli.

Anguilla; a supposed island in the Gulf of Esquibel, Prince of Wales archipelago, was named Anguilla (eel) by Maurelle and Quadra in 17751779 .

Angutikada; peak, in the Sheklukshuk range, northwestern Alaska, south of Kobuk river, latitude $66^{\circ} 40^{\prime}$, longitude $156^{\circ} 30^{\prime}$, elevation about 4,100 feet. Native name reported by Mendenhall in 1901 . Stoney made a station on this peak, which he called Ounalima. 
Anguvik; islet, in Chignik bay, Alaska peninsula. Native name, from Russian Hydrographic chart 1379 , published in 1847 .

Aniakchak; bay, indenting the southern shore of Alaska peninsula north of Sutwik island. Native name from the Russians, who wrote it Aniakshak.

Anihitsk. Near the beginning of this century there was a settlement on Sitkalidak island of the Kodiak group, which Lisianski (map, p. 169) called Onibitsk. Name not found elsowhere.

Anikovik; river, debouching at Cape York, in western part of Seward peninsula. Eskimo name, from Brooks, of the Geological Survey, 1900. Published by the Coast Survey and on local maps as Ono-ko-ruk and Onokovuk. Pronounced An-y-kón'-vik. It is Youp-nut of Beechey, 1827, and Up-nut of Lutke (p. 244). Has also been written Anakovik.

Animak, island; see Deer.

Anim-algera, lake, St. George island; see Seal.

Animas; island and point, San Fernando island, Gulf of Esquibel, Prince of Wales archipelago. Named Ysla y punta de las Animas by Maurelle and Quadra, 1775-1779.

Animatchoutchkok, cape; see Tachilni.

Anita; bay, in Jtolin island, opening into Zimovia strait, Alexander archipelago. So named by Snow in 1886.

Anita; creek, tributary to Kougarok river from the west, Seward peninsula. Name from Brooks, 1900.

Anita; gulch, 10 miles north of Cape Nome, Seward peninstula, draining into Osborn creek from the east near longitude $165^{\circ} 05^{\prime}$. Local name, published in 1904.

Aniuk; Eskimo village, on the upper Noatak river, northwestern Alaska. Latitude $68^{\circ}$, longitude $157^{\circ}$. Visited by Howard of Stoney's expedition in spring, 1886, and written An-e-yuk.

Aniyak; Eskimo village, on the Arctic coast between Cape Krusenstern and Point Hope. Eskimo name, from Petrof, 1880, who writes it An-iyakh. Population in $1880,25$.

Ankachak; Eskimo village, on the right bank of the lower Yukon, about 20 miles above Andreafski. Not given in the Tenth Census, 1880. In tine Eleventh Census called Ankahchagmiut (population 103). By Raymond, 1.869 , by the Coast Survey, and by the Geological Survey called Ankachagamuk, ạ obvious error for Ankachagamut, i. e., Ankachak people. Perhaps this place is identical with Kenunimik of al recent Coast Survey chart.

Ankau; creek or river, and inlet, in the peninsula south of Port Mulgrave, Yakutat bay, near longitude $139^{\circ} 40^{\prime}$. Named Estero del Ancau by Malaspino in 1791, after a Tlinkit chief. Dixon says Ancou means friend or chief. Spelled variously Ancau, Ancou, Ankau, Ankow, and erroneously Aukon (pronounced Ŏn'-cow). Moser, 1901, describes two streams here having the same source, the Tawah flowing westward into De Monti bay and the Ankau flowing southeastward and debouching on the coast 9 miles southeast of Ocean cape. (See Tawah.)

Ankau; head, forming the eastern point of entrance to Ankau creek, Yakutat bay, southeastern Alaska. Called Punta Gorda (broad point) by Malaspina, in 1791, and Ankau Head by Harber in 1892.

Ankitaktuk; creek or river, tributary to the Kuskokwim from the north, near longitude $162^{\circ}$. Eskimo name obtained, in 1898 , by Spurr and Fost of the Geological Survey, from missionary J. H. Kilbuck. See also Kvichivak. 
Anman; small stream, tributary to the Chilkat river near its mouth. Native word reported by Dr. A. Krause in 1882 as Anmā'n.

Anmer; point, the southern point of entrance to Port Snettisham, Stephens passage, Alexander archipelago. So named by Vancouver, 1794.

Annelagaggerack, river; see Reed.

Annette; bay, indenting the northern end of Annette island, Gravina gloup, Alexander archipelago. So named by Dall, 1879.

Annette; island, the largest of the Gravina group, Alexander archipelago, near latitude $55^{\circ} 10^{\prime}$, longitude $131^{\circ} 30^{\prime}$. Named in 1879 by W. H. Dall, after * his wife, Annette Whitney Dall. By act of March 3, 1891, this island was reserved for the use of the Tsimshian Indians.

Annette; point, the southeasternmost of Annette island, Felice strait, Alexander archipelago. So named by Nichols, 1883.

Annin; glacier, near Port Valdes, Prince William sound. So called by Abercrombie, 1898.

Annoksek; creek, said to be a lake outlet, southesatern coast of Alaska, 7 miles north of Cape Spencer, near longitude $136^{\circ} 45^{\prime}$. Indian name, reported by Moser in 1901, who wrote An-nock-seck.

Annuk, river and village; see Atnuk.

Anoghta; island; see Amukta.

Anogok; Eskimo village, on the mainland shore just west of Kuskokwim bay, Bering sea. Visited by Nelson in December, 1878, and its name reported by him as Anogogmute, i. e., Anogok people.

Anook, river; see nuk.

Anowik; island ( 650 feet high), one of the Semidi islands. "Native name, obtained by Dall in 1874.

Ansley; island, in Swanson harbor, Icy strait, Alexander archipelago, near latitude $58^{\circ} 12^{\prime}$, longitude $135^{\circ} 07^{\prime}$. Apparently so named by Meade in 1869. Perhaps this is an error for Astley.

Anthracite; ridge, on the north bank of Matanuska river, 60 miles northeast of Knik arm of Cook inlet, near latitude $61^{\circ} 50^{\prime}$, longitude $148^{\circ}$. Local náme, reported by Martin in 1905.

Antler; creek, Seward peninsula, in the Solomon river basin, tributary on the north bank Tributary creck, near latitude $64^{\circ} 40^{\prime}$, longitude $164^{\circ} 10^{\prime}$. Prospectors' name, from a local map, 1904.

Antone; lake, on the southwest coast of St. Paul island, Bering sea, near longitude $170^{\circ} 21^{\prime}$. Local name, reported by Stanley-Brown in 1891.

Anuk; river, tributary to the Stikine river from the east, near the international boundary line. Native name, obtained by the Coast Survey. Has also been written Anook.

Anuk; river, an affluent of the Yukon on the right near latitude $62^{\circ} 20^{\prime}$, longitude $163^{\circ} 50^{\prime}$. Eskimo name, obtained by Putnam in 1899 .

Anulcusilokh; lake, St. George island, Bering sen, just north of Ulakaia hill, near longitude $169^{\circ} 34^{\prime}$. Aleut name, obtained by Putnam in 1897, and written Änŭckäsēl'ogh.

Anukturuk, pass and river; see Anaktuvuk.

Anvaniek, river; see Anavinguk.

Anvik; Indian village, post-office, and mission, on the right bank of the Anvik river a mile above its junction with the Yukon. Here in January, 1834, Glazunof found a village of several hundred people. Population in 1880,95 ; in 1890,101 . The Episcopalian mission located here was established in 1887. Raymond, 1869, calls it Anvic (American station). Has also been written Anvig, Anwig, and Anvick. The post-office was established here in September, 1898. 
Anvik; river, tributary to the Yukon from the west, near longitude $160^{\circ}$. Explored by Glazunof in 1833 . Called by the Russians Anvich, Anvig, Anvik, and sometimes Anwig.

Anvil, city; see Nome.

Anvil; creek, 4 miles northwest of Nome, Seward peninsula, tributary to Snake river, from the northeast, near longitude $165^{\circ} 30^{\prime}$. Prospectors' name, published in 1900 .

- Anvil; mountain (2,157 feet high), at the northern end of Annette island, Alexander archipelago. So named by Nichols, 1883 .

Anvil; peak (1,050 feet high), 5 miles north of Nome, Seward peninsula, near: longitude $165^{\circ} 23^{\prime}$. Local name, from Witherspoon, 1.899 .

Anvil Head; broad promontory, forming the western point of entrance to Annette bay, Annette island, Nichols passage, Alexander archipelago. So called in the Coast Pilot, 1883 (p. 80).

Anwig, village; see Anvik.

Anxiety; point, on the Arctic coast, east of Point Barow, near longitude $147^{\circ}$ $50^{\prime}$. So named by Franklin, in 1826 , in commemoration of his state - $\quad$ of mind when there.

Anyaguk; river, tributary to the Kuskokwim, from the south, neall longitude $160^{\circ}$. Eskimo name, obtained by Spurr and Post in 1898.

Anyok; Eskimo village, on the north shore of Kotzebue sound between Cape Kruzenstern and the mouth of Noatak river. Visited by Jaĩvis and the Overland Expedition in 1898. See also Sheshalek, Tikizat, and Aniyak.

Apakshau; sloùgh or river, Yukon delta, opening on the left bank of: Apoon pass $2 \frac{1}{2}$ miles above Okwega pass; near latitude $63^{\circ} 02^{\prime}$, longitude $163^{\circ} 45^{\prime}$. Eskimo name, obtained by Faris in 1.899 .

Ape; point, on the southern shore of Revillagigedo island, near southern entrance to Behm canal. So named by the Coast Survey in 1891. Erroneously Cone Island point of British Admiralty chart 2431.

Apholcnak, island; see Afognak.

Apilctalluk, Eskimo village; see Opiktulik.

Apoka; river, tributary to Kuskokwim bay, between the Eek and Kanektok rivers. Called Apoga by Spurr and Post, who obtained this name from missionary J. H. Kilbuck in 1.898.

Apokak; Iskimo village, on the eastern shore of Kuskokwim bay, at mouth of Apoka river. According to Nelson, 1878-79, its native name is Apokagamute, i. e., Apokak people. In the Eleventh Census, 1.1890, it is called Abpokagamiut.

Apollo; post-office established in May, 1899, on the south shore of Unga island, Shumagin group.

Apoon; mouth and pass, the northernmost in the Yukon delta. Called by Tebenkof, 1849, Abkun, and by later Russians Apkun. Dall calls it. Uphoon, the Coast Survey Apoon, Aphoon, and Aphroon, and others Aproon. Father Baruum gives "ắprūn, main trail, regular passage." Dr. William Hamilton, of the Bureau of Education, in Reindeer Re-

- port, 1904, page 39, writes: "The natives compare the delta of the Yukon with its mouths to a human hand and have given the name Aphoon (thumb) to its northernmost channel." This, however, is not verified by the Eskimo vocabularies at hand. 
Apple; group of islands, in the northern part of Sitka sound, Alexander archipelago. Named Sredini (middle) by Vasilief in 1809, and Iablochnic(apple) on later Russian maps, where it is also written Iabloshnle. Thus it has been variously called Apple, Iablosb, Iablochnie, Middle, and Srednl.

Apple, islands; see Watch.

Applegate; cove, indenting the southeastern shore of Izembek bay, north shore Alaska peninsula, near longitude $162^{\circ} 50^{\prime}$. So named by the Fish Com- * mission, in 18s8, after Mr. Samuel Applegate.

Appleton; cove, in Rodman bay, Peril strait, Alexander archipelago. Named by Moore, in 1895, after W. G. Appleton, a member of his party.

Approach; point, the extreme southeasterly point of Grindall island, northeast point of entrance to Kasaan bay, western shore Clarence strait, southeastern Alaska, near latitude $55^{\circ} 27^{\prime}$, longitude $132^{\circ} 06^{\prime}$. Local navigators' name, reported by H. C. Fassett, Bureau of Fisheries, 1904.

Aproka; pass or channel, Yukon delta, a cut-off between Kwikluak and Kwikpak passes, 20 miles below their junction, near latitude $62^{\circ} 45^{\prime}$, longitude $164^{\circ} 07^{\prime}$. Eskimo name (probably the same as áprūkã, little passage or trail), reported by Faris in 1899.

Aproon, mouth and pass; see Apoon.

Apruka; see Aproka.

Apthrop, port; see Althorp.

Arboles; island, in Portillo channel, Bucareli bay, Prince of Wales archipelago. Named Ysla de los Arboles (island of the trees) by Maurelle and Quadra, 1775-1779.

Arboleda; point, the northwestern point of Suemez island, Bucareli bay, Prince of Wales archipelago. Named Arboleda (grove) by Maurelle and Quadra, $1775-1779$.

Arch; point, "a rocky projection, 40 feet high, with an arch through the extremity of the point" on the southern shore of Unimak island, 3 miles northeastward from seal cape, near longitude $164^{\circ} 34^{\prime}$. So described by Westdahl in 1901.

Arch; rock, near Sand point, I'opof strait, Shumagins. Descriptive name, given by Dall in 1872.

Arch; rock, on the northwestern shore of Amaknak island, the eastern point of entrance to Captains bay, Unalaska bay, near longitude $166^{\circ} 34^{\prime}$. De scriptive name, given by Dall in 1871 . The rock is perforated.

Archangel Gabriel, fort; see Sitka.

Archer, creek or river; see 'Tonsina.

Archimandritof; rocks, in Kachemak bay, Cook inlet. Named by Dall, 1880, after Captain Archimandritof, of the Russian American Company.

Archimandritof, islands; see Geese.

Arctic; creek, tributary to Cripple creek from the east, in the Cape Nome mining region, Seward peninsula. Local name, published in 1900. Erroneously Artic.

Arctic; creek, eastern Alaska, on soutb bank of Seyentymile creek, near Arctic Dome and tributary to I'lume creek, about latitude $64^{\circ} 55^{\prime}$, longitude $142^{\circ} 40^{\prime}$. Prospector's' name, from sketch map compiled by Major Glassford, Signal Corps, U. S. A., 1905.

Arctic; mining camp, on the Koyukuk river, near the Arctic circle in longitude $153^{\circ}$. Called Arctic City by the miners in 1899 .

Arctic; river, Seward peninsula, flowing north into Shishmaref inlet, near longitude $165^{\circ} 41^{\prime}$. Prospector's' name, from Gerdine, 1901. 
Arctic Dome; mountain (4,800 feet high) in eastern Alaska, on south bank of Seventymile creek, near latitude $64^{\circ} 55^{\prime}$, longitude $142^{\circ} 40^{\prime}$. Prospectors' name, reported by Witherspoon, 1905.

Arcy, creek; see Carey.

Arden; point, the northeastern point of Admiralty island, Stephens passage, Alexander archipelago. So named by Vancouver, 1.794 .

Ardigaen; rookery, one of the seal rookeries on Reef point, St. Paul island, Bering sea, near longitude $170^{\circ} 18^{\prime}$. Probably native name, reported by Duffield in 1897.

Argonaut; mining camp, now deserted, eśtablished in 1899, and called Argonaut City, on the right bank of the Koyukuk, 15 miles above Huggins island, near latitude $66^{\circ} 10^{\prime}$, longitude $154^{\circ} 20^{\prime}$. Reported by Cantwell, 1900 .

Arie, point; see Murre.

Ariswaniski; Eskimo village, on the right bank of the lower Yukon, about 25 miles above Andreafski, longitude $162^{\circ} 45^{\prime}$. Name published by the Coast Survey, in 1899, as Ariswániski.

Arizona; creek, Seward peninsula, tributary to Kougarok river "from west, 5 miles below the mouth of 'Taylor creek, near latitude $65^{\circ} 35^{\prime}$ ', longitude $164^{\circ} 50^{\prime}$. Miners' name, from Gerdine, 1901.

Arizona; creek, Seward peninsula, tributary to Inmachuk river from the east, near latitude $65^{\circ} 50^{\prime}$, longitude $163^{\circ}$. Miners' name, published by the Geological Survey in 1902 .

Arkansas; creek, in the Fortymile region, tributary to the headwaters of Champion creek from the right near latitude $64^{\circ} 35^{\prime}$, longitude $141^{\circ} 40^{\prime}$. Prospector's' name, found on a MS. map by E. F. Ball, 1898, in the Coast Survey archives.

Arliell, lake; see Kunsawa.

Arko-sher-wak, Ark-o-sherwik, creek; tributary of Kobuk; see Benver.

Arm; mountain (2,177 feet high), just west of Nakat inlet, Dixon entrance, Alexander archipelago. So named by Nichols, 1883.

Armstrong; port, near the southern end of Baranof island, Chatham strait, Alexander archipelago. So named by Vancouver, 1794.

Army; peak (612 feet high), 10 miles northwest of Cape Nome, at the junction of Osborn creek and Nome river near latitude $64^{\circ} 32^{\prime}$, longitude $165^{\circ}$ 11'. Local name, reported by Pratt, 1.900.

Arnkil; island, north shore Afognak bay, Kodiak group, near latitude 58 $02^{\prime}$, longitude $152^{\circ} 46^{\prime}$. Local name, reported by Moser in 1900 .

Arn Klane, river; see Aantlen.

Arolokovik; Eskimo village, on right bank of Yukon river at the head of the deltal, near latitude $62^{\circ} 22^{\prime}$, longitude $163^{\circ} 50^{\prime}$. Lskimo name written Arolokôvik by Putnam in 1899. "Vik" is often a locative termination in Eskimo, meaning place of.

Ar. Quay, river; see Akwe.

Arre; rocks, off the southern shore of Hall island, Bering sea. Apparently so named by Elliott, in 1874, who says Arrie, a sea bird, the Murre, was so named by the Russians from its harsh cry Arra-arra. It is the Uria lomvia arra of some of the ornithologists. Sarichef. says, "The atar, or ara torda alca, is the name of a Kamtschadale water fowl, of the species of the Gagara (colymbus arcticus) or water-hen. At Kola it is called Gegarka."

Arrecifes; point, on the mainland in Yakutat bay, opposite Port Mulgrave. Named Punta de Arrecifes (point of reefs) by Malaspina in 1791.

Arriaga; passage, in the northern part of Bucareli bay. Named Bocas de Arriaga by Maurelle and Quadra in 1775-1779. 
Arricife, Punta del ; see Reef.

Arrowsmith, island; see Rat.

Arroyo Blanco; see White.

Arroyo de la Cruz; see Cross gulch.

Artelnof. On the rocky southwestern coast of Akun island, Krenitzin group, eastern Aleutians, existed, in 1830, a small village named Artelnofskie. The bidarshik or foreman for the Krenitzin group lived here.

Arthur; island, northwest shore Peril strait, between Northern and Southern rapids, Alexander archipelago, at.Arthur point below, near latitude $57^{\circ} 27^{\prime}$, longitude $135^{\circ} 35^{\prime}$. So named by Moore, 1885 .

Arthur; peak (3,434 feet high), on the mainland, near Limestone inlet, southeastern Alaska. So named by Thomas in 1888.

Arthur; point, on Chichagof island, Peril strait, between Northern and Southern rapids, Alexander archipelago. So named by Coghlan in 1884.

Artic, creek; see Arctic.

Arucenas; point, the eastern point of entrance to Port Dolores, Bucareli bay, Prince of Wales archipelago. Named Punta de Arucenas by Maurelle and Quadra in 1775-1779.

Arvesta; creek, in the Controller bay region, tributary to Katalla slough. Local name, from Martin, 1904.

Arvesta; creek, Alaska peninsula, tributary to Becharof lake. So named by J. L. McPherson, deputy mineral surveyor, 1903.

Ascheeshna, river; see John.

Ashby; mountains (5,200 to 5,500 feet high), east of Portland canal. So named by Pender, 1868.

Ashiiak; island, between Port Wrangell and Agripina bay, Alaska peninsula. Native name, from Tebenkof, 1849.

Ashington; range of mountains, between Portland canal and Observatory inlet. So named by Pender, 1868.

Ashink, lake, and village; see Aishihik.

Ashishik; cape, on the northern shore of Umnak island, near its eastern end. Native name, from Kuritzien, 1849.

Ashivak; native village (population 46 in 1880), near Cape Douglas, Cook inlet. Native name, reported by Petrof in 1880.

Ashmiahk, islet; see Aiktak.

Asiak, island; see Sledge.

Asiutchak, point; see Romanof.

Askinak. The Eleventh Census, 1890, includes an Eskimo village called Askinaghamiut in the Kuskokwim district. Population 138. Not found on any map and its location unknown.

Askinuk; Eskimo village, on the southern shore of Hooper bay, Yukon delta. Native name, from Nelson, who visited it December 14, 1878, and was welcomed by its entire population of nearly 200 people.

Askinuk; range of mountains, Yukon delta, on the north of Askinuk river and terminating at Cape Romanzof; about latitude $61^{\circ} 45^{\prime}$, longitude $165^{\circ}$ $50^{\prime}$. The highest point, about 5 miles from Cape Romanzof, is 2,363 feet. So called by Nelson, 1878 .

Askinuk; river, in the Yukon delta, debouching into Hooper bay. Native name, from Nelson, who crossed it December 15, 1878.

Asko; Eskimo village, on the right bank of the Yukon, below Anvik. Native name, from Nelson, 1878-79, who wrote it Askhomute, i. e., Asko or Askh people.

Aslik; cape, the northern head of Inanudak bay, on the northern coast of Umnak, eastern Aleutians. Native name, from Kuritzien, 1849. 
Aspid; bay, indenting the northern shore of Unalaska, immediately enst of Chernofski harbor. . So called by Veniaminof, 1840.

Aspid; cape, on the northern shore of Unalaska, between Chernofski harbor and Aspid bay. Called Ammak by Sarichef, in 1792, which is Aleut for night. Veniaminof calls it Aspid (slate) and says (I, 169): "It obtained the name Aspid (slate) not from the presence of slate rock, but from a chief, who formerly dwelt near by and was so called by the Russians." The Fish Commission, in 1888, called it Nellie Juan, presumably after the schooner Nellie Juan, belonging to Mr. Samuel Applegate.

Aspid, islets; see Slate.

Asses Ears; mountain, south of Goodhope bay, Kotzebue sound, on Seward peninsula. So named by Kotzebue, in 1816, because "its summit is in the form of two asses' ears."

Asses Head; cape, on the northern coast of Unalaska, near Chernofski village. So named in a pencil memorandum on Sarichef's chart of 1.792 .

Assamption, port; see Asumcion.

Assurance, bay; see Disenchantment.

Astley, island; see Ansley.

Astley; point, the southern point of entrance to Holkham bay, Stephens passage, Alexander archipelago. So named by Vancouver in 1794.

Aston; island, in Tlevak strait, Cordova bay, Dixon entrance. Named by Nichols, in 1881, after Chief Engineer Ralph Aston, U. S. N., a member: of his party. Has also been called Wright island by Sheldon Jackson.

Astrolabe; point, on the mainland between Cross sound and Lituya bay. Named, in 1883, by Dall, after one of the Fremch exploring ships under La Perouse.

Astronomical; point, the eastern point of entrance to Halibut bay, Portland canal, southeastern Alaska, near latitude $55^{\circ} 13^{\prime}$, longitude $130^{\circ} 04^{\prime}$. So named by the Coast Survey.

Asuksak; islet, southwest of Great Sitkin, Andreanof group, middle Aleutians. Aleut name from Tebenkof, 1849. Has also been written Agugsiak. Perhaps it is from the Aleut word 'asuk (kettle).

Asumcion; port, in Bucareli bay. Named by Maurelle and Quadra, in 1775, Puerto de nuestra Señora de la Asumcion. Published as Puerto de nostra Señora de la Asumcion in La Perouse's voyage, 1797. Copied by the Russians thus: "Nuesta Sensor"i de la Asimsion" harbor. Also written Port Asuncion and Port Assumption.

At, island; see Attu.

Atalion, island; see Attu.

Ataku; island, one of the Necker islands, Sitka sound, Alexander archipelago. Apparently a native name; reported by Vasilief in 1809. Has been written Atakou.

Atayak; mountain, at the headwaters of the Kanektok river, western Alaska. Native name, obtained by Spurr and Post, of the Geological Survey, in September, 1898. More exactly perhaps it might be written Ah-tah-ai-ak.

Atcha, island ; see Atka.

Atchaka, island; see Middleton.

Atcheredina, point; see Acheredin.

Atcho-koverushka, St. George island; see Gull bill.

Atherton; mountain (1,700 feet high) on south shore of Wrangell island, Arctic ocean. So named by the British Admiralty, 1884. 
Atka; lake, near the south coast St. George island, Bering sea, about longitude $169^{\circ} 39^{\prime}$. According to Putnam, 1897, called Nārō'am-än'yi (Atka natives' lake) by the Aleuts because some people from Atka island lived near it. Called Atka by the Coast Survey in 1898.

Atka; island (4,988 feet high), one of the principal islands of the Andreanof group, middle Aleutians; near longitude $174^{\circ} 30^{\prime}$. Native name, from early Russian traders. Coxe calls it Atchu, and Cook, 1778, Atghka. Also written Atcha, Atchka, and Alcha.

Atkins; island (about 800 feet high), northeast of Litle Koniuji island, Shumagin group. So named by Dall, 1872, after the fishing schooner Minnie G. Atkins. Erroneously Atkin.

Atkritoi, rock ; see Discovery.

Atkritoi, rock; see Open.

Attroi-glaza, rock; see Eye Opener.

- Atkulik; island, near the entrance to Chignik bay, Alaska peninsula. Native name, from the Russians. Erroneously Atkunk.

Atlin; lake and river, northeast from Lynn canal. This name has been adopted by the Canadian Board on Geographic Names.

Atmugiak; creek, tributary to Kagati lake from the east, near source of Kanektok river. Native name, obtained by Spurr and Post, of the Geological Survey, who passed near it September 7, 1898.

Atna, river; see Copper.

Atnik; Eskimo village, on the Arctic coast at or near Point Belcher. Called Ataniek by Tikhmenief in 1861. The Eleventh Census map has Attanak and the text Atnik. Perhaps it is Pinoshuragin of Petrof, 1880, or Nunaria of Ray, 1885. See also Sedaru.

A.tnilial. This is the native name of one of the smaller Shumagins, which one is not known. So givèn by Veniaminof and Lutke. Perhaps Aniliak and Animak are other forms of the same name.

Atnuk; river, and Eskimo village at its mouth, on the northern shore of Norton bay, Norton sound. Tebenkof, 1849, calls the river Atniek and Tikhmenief, in 1861, calls the settlement Atniek-miut. Petrof, 1880, writes it Atnuk. Erroneously Annuk.

Atonisuk, river; tributary to the Yukon from the north, about 50 miles above Rampart. Native name, from Raymond, 1869, who wrote it Atonisonik. Petrof, 1880, wrote it Ahtonisuk. This may be identical with Ray river of Allen, 1885, and of recent maps. See Ray.

Atrevida; glacier, near the head of Yakutat bay, southenstern Alaska. Named Atrevida (intrepid) by Russell, in 1890, after one of Malaspina's vessels.

Atroic, village; see Stebbins.

Attanak, village; see Atnik.

Atten; Eskimo village, near the headwaters of Buckland river. Its name is given by Dall, 1869, as Attenmut, i. e., Atten people.

Attiunik; point, southern point of entrance to Selawik lake, near the Arctic circle and longitude $161^{\circ} 25^{\prime}$. Eskimo name, written by Stoney, 18S6, At-tiu-nick.

Attu; island (3,084 feet high), the westernmost large island of the Aleutian chain of islands, near east longitude $173^{\circ}$. Native name, from the early Russian explorers, which has been written At, Atako, Atakon, Ataka, Attak, Attou, Otma, etc. According to Petrof it is St. Theodore of Chirikof, in 1741, and according to Lutke, St. Abraham or St. Etienne of Bering, 1741 . 
Atushagvik; cape, in Shelikof strait, on the southern shore of Alaska peninsula, east of Katmai. Native name, from the Russians. Lutke, 1835 , writes it Atouchagvik.

Atutsak; river, tributary to the Yukon from the south, just below Nuklukyet. Its native name was reported by Raymond, in 1869, as Atutsakulakushchargut; Allen, in 1885, wrote it Atutsakulakushakakat, and Petrof, in 1880, Atutsakulakushchakat, while a recent Coast Survey chart has Atutzehbuilcusten creek. See Kakat.

Atwater; creek, tributary to South Fork of Fortymile creek. Prospectors' name, published by the Geological Survey in 1899.

$A^{\prime}-u$-(ln, island; see Unalaska.

Auburn; creek, Seward peninsula, in the Casadepaga drainage basin, tributary to the head of Birch creek, near latitude $64^{\circ} 48^{\prime}$, longitude $164^{\circ} 111^{\prime}$. Prospectors' name, reported by Gerdine, 1905.

Auburn; creek, Seward peninsula, in the Niukluk valley, tributary to American creek, from the southeast, near latitude $64^{\circ} 566^{\prime}$, longitude $164^{\circ} 27^{\prime}$. Frospectors' name. Called Auburn Ravine creek on a local map, 1901.

Aueruk; creek, tributary to Norton bay from the northwest, between the Tubutulik and Kwiniuk rivers, Seward peninsula. Native name, from the Davidson Blakeslee map of 1900 , where it is spelled Oweruk.

Augoyaltoli, creek; see Angoyaktoli.

Augusta; glacier and mountain (13,918 feet high) in the St. Elias region; named, in 1891, by Prof. I. C. Russell, after his wife. Has been printed erroneously Agusta.

Augusta; point, the northeastern. point of Chichagof island, Chatham strait, Alexander archipelago. So named by Vancouver, 1794 .

Augustin; peak, in the McKinley range, near latitude $62^{\circ} 10^{\prime}$, longitude $153^{\circ}$. So named by Herron, 1899.

Augustine; bay, indenting the western coast of Quadra island, Prince of Wales archipelago. So named by Dall, 1883 . Has since been written St. Augustine bay.

Augustine; cape, near the above. Named in 1775, by Maurelle, Cabo de $s$. Augustin. Also called cape St. Augustine.

Augustine; island (about 3,000 feet high) in Kamishak bay, Cook inlet. Named Mount St. Augustin by Cook, 1778. It is Chernoburi or Chernabura (black-brown) of the Russians.

Auke; bay, indenting the mainland at the northeastern end of Stephens passage, Alexander archipelago, just north of Fritz cove, near latitude $58^{\circ} 23^{\prime}$. Local name, reported by Spencer and Wright, 1903.

Auke; cove, indenting the northern shore of Admiralty island, Stephens passage, Alexander archipelago, near latitude $58^{\circ} 11^{\prime}$; longitude $134^{\circ} 34^{\prime}$. Called Auke bay by Meade in 1S68, after a poor tribe of Indians living near it.

Auke; creek, north shore of Admiralty island, Alexander archipelago, tributary to Auke cove, above. Local name, reported by Spencer and Wright in 1903.

Aukcon, river; see Ankau creek.

Aurora; creek, Seward peninsula, tributary to the west fork of the Noxapaga river from the west, near latitude $65^{\circ} 38^{\prime}$, longitude $164^{\circ} 10^{\prime}$. Miners' name, from Gerdine, 1901.

Aurora; creek, 25 miles north of Cape Nome, Seward peninsula, tributary to Eldorado river from the west near longitude $165^{\circ}$, Miners' name, from Gerdine, 1904. 
Aurora; mountain (2,115 feet high), 20 miles northwest of Nome, Seward peninsula, on the left bank of Cripple river, near latitude $64^{\circ} 43^{\prime}$, longitude $165^{\circ} 40^{\prime}$. Prospector's' name, published on a local map in 1901.

Aurora; village, or settlement, on the eastern shore of Kachemak bay, Kenai peninsula, near latitude $59^{\circ} 40^{\prime}$. Local name, from Stone, 1904.

Ausana; see Hosiana river, Beaver creek, and Beaver slough.

Auto; river, tributary to the Yukon from the north, about 20 miles below the mouth of Kaiyuh river. Name from Allen, 1885, who calls it Autokokakat on his map and Autokakat in his text, i. e., Auto mouth. Raymond, 1869, shows this stream without name, but has a yillage called Yakutsklitnik. From its mouth Allen followed the summer trail to Unalaklik on . Norton sound. 'Tikhmenief, 1861, shows a village here (on the opposite bank of the Yukon) called Ttutaho.

Avatanak; island (from 1,200 to 1,700 feet high), between Akutan and Tigalda of the Krenitzin group, eastern Aleutians, near longitude $165^{\circ} 20^{\prime}$. Native name, from the Russians. Has also been written Avatanok and Awatanok. Apparently identical with Aiaialgutak of Krenitzin and Levashef in 1768 .

Avatanak; strait, separating Akun island from Avatanak and other islands, Krenitzin group, eastern Aleutians. So called by Veniaminof and Lutke, 1828. Has also been called Pathfinder channel, which name was -published in Coast Survey Magnetic Declination Tables for 1902.

Avaterat; lake, north of Lake Selby, drained by the Mauneluk river into the Kobuk near latitude $67^{\circ}$, longitude $156^{\circ}$. Native name reported by Mendenhall in 1901. It may be Car-le-ok-shuk of Cantwell, 188; (p. 41).

A-vi-lu-legorack, creek; see Cosmos.

Avinof; cape, on the mainland southeast from Nunivak island, Bering sea. Presumably so named by Vasilief, in 1821, after Lieut. Alexander: Avinof, a member of lis party. See also Shoal Ness.

Avogon; channel, between two small islands on the north side of the mouth of Kwikluak pass, Yukon delta, near latitude $62^{\circ} 37^{\prime}$, longitude $164^{\circ} 52^{\prime}$. Probably an Eskimo name, obtained by Putnam in 1899.

Avon; islet, in McHenry anchorage, Clarence strait, Alexander archipelago. Name published by the Coast Survey in 1891.

$A w$-aw, lake and stream; see Thoms.

Ayachaghayuli, village; see Aiachagiul.

Ayacheruk, village; see Aiacheruk.

Ayagh, island; see Adak.

Ayaghish, volcano; see Makushin.

Ayrak, island; see sledge.

Ayakhtalik, village; see Aiaktalik.

Ayakulik; island, off the west coast of Kodiak, near the mouth of Ayakulik river. Native name, from Tebenkof, 1849. Erroneously Achulik.

Ayakulik; river, on the west coast of Kodiak. Among the local cannery men it is known as Red river. Native name, from Tebenkof, 1849. Erroneously Ayakulih.

Ayalik, bay; see Aialik.

Ayalik, islands; see Chiswell.

Ayou, bay; see Hallo.

Ayugadak, island; see Rat.

Ayutka; cape, in Aniakchak bay, Alàska peninsula. Native name, as published by the Coast Survey in 1900 . 
Azacharak; Eskimo village and hill, on the left bank of the YYukon, near Azacharum slough below. Eskimo name, obtained by Putnam in 1.899 .

Azacharum; slough, on the right bank of the Yukon at the great bend 25 miles below Andreafski, latitude $62^{\circ} 05^{\prime}$, longitude $163^{\circ} .55^{\prime}$. Eskimo name, obtained by Putnam in 1899. The Eskimo word ăchérŭn (achirun) means slough.

Azaik, island; see Aziak.

Azamis; cape, the eastern point of Little Tanaga island, Andreanof group, - middle Aleutians. Name from Tebenkof, 1849. Has also been written Azimis.

Aziachak, point; see Romanof.

Aziak, island; see Sledge.

Aziak; islet, southwest of Great Sitkin, Andreanof group, middle Aleutians. Native name, from the Russians. Lutke says 'Tebenkof calls it Azki, but Tebenkof's chart XXVIII has Aziak. Has also been written Azik, and, erroneously, Azaik.

Aziavik; river, tributary to Hagemeister strait on northern shore of Bristol bay. Native name, from Tebenkof, 1849 , who writes Azvichvak.

Aziavik; Eskimo village, on northern shore of Bristol bay. Name from Petrof, 1880 , who wrote it Aziavigamute, i. e., Aziavik people. Population in $1880,132$.

Azimuth; point, on the eastern shore of Portland canal. So named by the Coast Survey.

Azimuth; point, on the northern coast of Kodiak, near Spruce island. Named Pelenga (magnetic asimuth) by Murashef, who in 1839-40 took bearings here.

$A \approx k i$, island; see Aziak.

Azun; river, in the Yukon delta. Usually witten Azoon. Native name, from Nelson, who crossed it in December, 1878.

Babbler; point, on mainland, northern shore of Lastern passage, southeastern Alaska, near latitude $56^{\circ} 28^{\prime}$, longitude $132^{\circ} 17^{\prime}$. Local name, probably after Mr. Babbler, superintendent of the cannery at Wrangell, and reported by H. C. Fassett, Bureau of Fisheries, 1904.

Babbling; brook, northern shore Olga bay, Kodiak, tributary to North olga stream, from the left. Local name, reported by Moser, 1900.

Babe; islands, southern shore Cholmondeley sound, Clarence strait, southeastern Alaska, near latitude $55^{\circ} 13^{\prime}$, longitude $132^{\circ} 08^{\prime}$. Locall navigators' name, reported by H. C. Fassett, Bureau of Fisheries, 1904 .

Baby; creek, tributary to Chandlar river from the west, near longitude $148^{\circ} 30^{\prime}$. So named by prospectors, 1899.

Baby; creek, tributary to Squaw creek from the south, in the Fortymile mining district. Prospector's' name, from Barnard, 1898.

Baby; islands, a groụp of six small islands in Akutan pass, off the northeast shore of Unalga island, Krenitzin group, eastern Aleutians, near latitude $54^{\circ}$, longitude $166^{\circ} 04^{\prime}$. Local name, from Gilbert, 1901.

Baby; pass, between Unalga island and Baby islands, Krenitzin group, eastern Aleutians. Local name, reported by Gilbert, 1901.

Bachelor; creek, tributary to Preacher creek from the south, near latitude $65^{\circ}$ $30^{\prime}$, longitude $146^{\circ} 05^{\prime}$. Prospectors' name, reported by Gerdine, 1.903.

Back; bay, at head of Afognak bay, south shore of Afognak island, Kodiak group, near latitude $58^{\circ} 03^{\prime}$, longitude $152^{\circ} 47^{\prime}$. Local name, reported by Moser in 1900 .

Back; island, in Behm canal, near Betton island, Alexander archipelago. Name pụblished by the Coạst Survey in 1886. 
Back; point, between Gwydyr bay and the mouth of Colville river, on the Arctic coast, east of Point Barrow. So named by Franklin, in 1826, "after my excellent companion, Lieut. [afterwards Captain] George Back," R. N.

Backbone; mountain (2,525 feet bigh), on the mainland, near Revillagigedo channel. So named by Nichols, 1885.

Backhouse; river, on the Arctic coast near and east of the international boundary, about longitude $140^{\circ} 30^{\prime}$. So named by Franklin, 1826, after Mr. Backhouse, one of the under secretaries of state for foreign affairs.

Bacon; hill, on the right bank of the Yukon, 12 miles above Ikogmut or Russian Mission. Name taken from Edwards's 'Track Chart of the Yukon, 1899.

Badger; bay, indenting the northern shore of Boca de Quadra, southeastern Alaski. So named by the Coast Survey in 1891.

Bagial; cove, in Bucareli bay, Prince of Wales archipelago. Named P'uerto Bagial by Maurelle and Quadra in 1775-1779. On Sarichef's map called cape Bagial.

Bahia de las Islas; see Salisbury sound.

Batuia de las Islas; see Bay of Islands.

Baht; harbor, indenting the northern shore of Zarembo island, Alexander archipelago. So named by the Russians after Engineer Baht, of the steamer Alexander. Erroneously Bath harbor.

Baie de Monti; see Yakutat.

Baikron; creek, tributary to Kanektok river from the north near its northernmost bend. Native name (pronounced By-krốn), obtained by Spurr and Post, of the .Geological Survey, who passed its mouth September 5,1898 .

Bailey; bay, indenting the mainland north of Revillagigedo island, Behm canal, Alexander archipelago. So named by Dall, 1879, in the Coast Pilot (p. 73). Erroneously Baily.

Bailey; harbor, in northern part of Belkofski bay, Alaska peninsula, near longitude $162^{\circ} 07$ '. Surveyed by Capt. George W. Bailey, U. S. R. M.. in 1879 , and named after him by the Revenue-Marine Service. Captain Bailey was lost overboard on the return voyage to San Francisco, Octoler 16, 1879.

Bailey; sunkèn ledge, off Obernoi point, Captains bay, Unalaska bay, near longitude $166^{\circ} 34^{\prime}$. Shown an the earliest charts, then omitted and rediscovered in 1872 by Silvanus Bailey, mate of the Coast Survey schooner Humboldt, after whom it is named.

Bainbridge; glacier, on west shore of Port Bainbridge, Prince William sound. Local name, reported by Grant in 1905.

Bainbridge; passage, in southwestern part of Prince William sound. Local name, reported by Grant in 1905.

Bainbridge; peak (3,467 feet high), on the mainland, near Thomas bay, Frederick sound. So named by Thomas, $188^{i} i$, presumably after Commodore William Bainbridge, U. S. N.

Bainbridge; port (Port Bainbridge), at extreme southwest corner of Prince William sound. . So named by Vancouver, 1794.

Baird; bank, off the northern shore of Alaska peninsula. Named by Tanner, 1890, after Prof. Spencer F. Baird, of the Smithsonian Institution.

Baird; canyon, tributary to Copper river from the east, just north of Miles glacier. So named by Allen, 1885, after Prof. Spencer Fullerton Baird, Secretary of the Smithsonian Institution. 
Baird; glacier, at head of Thomas bay, southeastern Alaska. So named by Thomas, 1887, after Prof. Spencer F. Baird, Secretary of the Smithsonian Institution.

Baird; glacier, near headwaters of Lowe river, about 25 miles east of valdez. So named by the Geological Survey after a prospector who, in the spring of 1898 , lost his life while exploring it.

Baird; inlet, on the western coast of Alaska, northeast of Nunivak. So named by Petrof, 1880, after Prof. Spencer F: Baird, Secretary of the Smithsonian Institution.

Baird; mountain, near Mount Augusta, St. Elias alps, southeastern Alaska. So named by Russell, 1890, after Prof. Spencer Ir. Baird, Secretary of the Smithsonian Institution.

Baird; mountains, northeast of Kotzebue sound between Kobuk and Noatak rivers. Named by Stoney, 1886, in honor of Prof. Spencer F. Baird, Secretary of the Smithsonian Institution.

Baird; peak $(3,260$ feet high), on the northeastern coast of Prince of Wales island, Alexander archipelago. So named by Snow, 1886.

Baituk; creek, in western end of Seward peninsula, debouching a few miles southeast of Cape Prince of Wales. Eskimo name, which has been written Bituk and Botuk. Pronounced Bye-took. Name published by the Coast Survey in 1900.

Bajo Pamplona; see Pamplona.

Baker; creek, tributary to Tanana river, right bank, about $60^{\circ}$ miles above mouth of latter, near longitude $151^{\circ}$. So named by Allen, 1885. Apparently identical with Saklekageta of Petrof., 1880.

Baker; creek, tributary to Middle fork Koyukuk river. See Hammond.

Baker; inlet, in Kasaan bay, Prince of Wales island, Alexander archipelago: This name was given by Dall, in 1880, to a supposed inlet indenting the southern shore of Kasaan bay. When Clover surveyed Kasaan bay, in 1885, and found the inlet did not exist he applied the name to a point near by.

Baker; island, in Bucareli bay, Prince of Wales archipelago. Named by Dall, 1879, "after Marcus Baker, of the Coast Survey, engaged 1873-1881 in surveys and office work relating to Alaska." Professor Davidson identifies this island as the landfall of Chirikof, July 15, 1741.

Baker; mountain, on west bank of White river, near latitude $63^{\circ}$. So named, 1898, by Peters and Brooks, after H. B. Baker, a member of their party.

Baker; point, being the northwestern point of Prince of Wales island, Sumner strait, Alexander archipelago. Named by Vancouver, 1.793, after Lieat. Joseph Baker, R. N., of Vancouver's party, who drew the maps in Vancouver's atlas. Has also been called North Point Baker.

Baker; point, on the southern shore of Kasaan bay, Prince of Wales island, Alexander archipelago, near latitude $55^{\circ} 31^{\prime}$, longitude $132^{\circ} 25^{\prime}$. Named by Clover, 1885 , after Marcus Baker.

Baker; telegraph station, on the Tanana, at or near the mouth of Baker creek, 80 (?) miles abòve Fort Gibbon. So named by the United States Signal Corps in 1903.

Bakewell; arm, of Smeaton bay, Behm canal, southeastern Alaska, near latitude $55^{\circ} 18^{\prime}$, longitude $130^{\circ} 40^{\prime}$. Local navigator's' name, reported by H. C. Fassett, Bureau of Fisheries, 1904.

Balaena, island; see Ballena.

Bull..299-06 $\mathrm{M} \longrightarrow 8$ 
Balandra; island, in Bucareli bay, Prince of Wales archipelago. Named La Balandra (the sloop) by Maurelle and Quadra, 1775-1779. See also Fish Egg.

Balandra; shoal, Bucareli bay, Prince of Wales archipelago, a mile and a half northwest of Balandra island. So named by Moser, 1897.

Bald, cape; see Chacon.

Bald; mountain, on Heceta island, Prince of Wales archipelago, near latitude $55^{\circ} 43^{\prime}$, longitude $133^{\circ} 34^{\prime}$. So named by Dickins, $1903-4$.

Bald; mountains, near laku river. Probably so called by the exploring parties of the Western Union Telegraph Company in 1865.

Bald; ridge of mountains (2,241 feet high), east of Tamgas harbor, on Annette island, Alexander archipelago. So named by Nichols, 1883.

Bald Head; promontory, on the northern side of Norton bay, Norton sound, Bering sea. So named by Cook, September, 1778. Quite recently it bas been called Point Inglestat, and also Isaacs point, by the minei's and prospectors. Some part of it was also called Point Ennis by the Western Union Telegraph expedition of 1867. Has also been written Bald-Head.

Baldwin; creek, tributary to Fish river from the east, Seward peninsula. Local name, 1900.

Baldwin; post-office (established January, 1906, or December, 1905), Prince of Wales island, Alexander archipelago, on the north side of the north arm of Moira sound near its head, about latitude $55^{\circ} \cdot 10^{\prime}$.

Baldy; creek, Seward peninsula, tributary to north fork of Kougarok river from the south, near latitude $65^{\circ} 35^{\prime}$, longitude $164^{\circ} 35^{\prime}$. Local name, from Gerdine, 1901.

Baldy; mountain, on east bank of Kougarok river, Seward peninsula. Name from Brooks, 1900.

Ball; creek, Seward peninsula, Solomon River drainage, tributary on east bank of Shovel creek, near latitude $64^{\circ} 43^{\prime}$, longitude $164^{\circ} 25^{\prime}$. Prospectors' name, from a local map, 1904.

Ball; group of islets, forming eastern part of the Galankin group, Sitka sound, Alexander archipelago. So named by United States naval officers, 1.579, after Col. Mottrom Dulany Ball, at that time collector of customs at Sitka.

$B a l l$, island; see Aleutski.

Ballarat; creek ${ }_{2}$ Seward peninsula, tributary from the south to Humboldt creek, which is a tributary to Goodhope river. Latitude $65^{\circ} 50^{\prime}$, longitude $164^{\circ} 10$. Local name, from Gerdine, 1901.

Ballast; island, in Portage bay, Alaska peninsula. So named by the Fish Commission in 1893.

Ballena; islands, in Bucareli bay, Prince of Wales archipelago. Named La Ballena (the whale) by Maurelle and Quadra in 1775-1779. Has been written erroneously Balaena and Balena.

Balls; pass, between the headwaters of Fortymile creek and the Tanana river on the west side of Sixtymile butte, near latitude $63^{\circ} 50^{\prime}$, longitude $142^{\circ} 30^{\prime}$. Probably named after E. F. Ball, a prospector, and written Ball's on a manuscript map made by him in 1898 and deposited in the Coast Survey archives.

Balto; creek, 10 miles north of Nome, Seward peninsula, tributary to Snake river from the east, near longitude $165^{\circ} 27^{\prime}$. Local name, published in 1900. Erroneously Batto. 
Balween; mountain, Annette island, Alexander archipelago, on north shore Tamgas lake, west shore Tamgas harbor, $1 \frac{1}{2}$ miles north of Davison mountain, near latitude $55^{\circ} 04^{\prime}$. Name from Moser, 1901.

Bamdoroshni; island, one of the Galankin group, Sitka sound, Alexander archipelago. So named by Vasilief, 1809. Has been written Bamdorotchnoi. Has also been called Russian island. According to George Kostrometinoff, United States court interpreter at Sitka, this is a corruption of the Russian Podorozbnie, meaning on the roud.

Bamer; creek, tributary to Casadepaga river from the east, Seward peninsula. Name from Barnard, 1900.

Ban; island, in Paramanof bay on the northwestern coast of Afognak island, Kodiak group. Named Ban (? of baths) by the Russians. On a map by the Russian American Company, 1849, it is Bok (side) island.

Bancas, Bahia de las; see Disenchantment.

Bancas; point, the north point of entrance to Disenchantment bay, Yakutat bay. C.lled Punta de las Bancas (point of the banks or shoals) by Malaspina in 1791.

Band; cove, just south of entrance to Security bay, Kuiu island, Alexander archipelago. So named by Glass, 1881.

Bander, bay ; see Banner.

Bangor; creek, 15 miles north of Nome, Seward peninsula, tributary to Snake river from the west, near longitude $165^{\circ} 27^{\prime}$. Name from Barnard, 1900.

Banks; point, the north point of Shuyak island, Kodiak group. So named by Cook in 1778; also erroneously Benkes. Called El Lovo (the wolf) by the Spaniards, 1779.

Banks; port, an arm of Whale bay, Baranof island, Alexander archipelago. Called Port Banks by Dixon in June, 1787, "in honour of Sir Joseph Banks." It is Zakritoi (closed) bay of Tebenkof and others.

Banks, port; see Whale bay.

Banner; bay, indenting the northern shore of Atka, middle Aleutians. Named by Lutke, about 1830, after the Dane, Ivan Ivanovich Banner, long the Russian American Company's agent at Kodiak. Variously written Baner, Bander, etc. Perhaps this bay is identical with Glubokoi (deep) of some charts.

Banner; creek, 12 miles north of Nome, Seward peninsula, tributary to Nome river, from the west, near longitude $165^{\circ} 18^{\prime}$. Prospector's' name, pub- . lished by the Coast Survey in 1900 .

Banner; creek, Seward peninsula, tributary from the northeast to Anikovik creek, about 2 miles northeast of York. Local name, from Gerdine, 1901.

Banner; railroad station, and mining camp, 5 miles north of Nome, Seward peninsula, near longitude $165^{\circ} 23^{\prime}$. Name published in 1904 as Banner Station.

Baptist, bay; see St. John Baptist and San Juan Bautista.

Bar; creek, tributary to Nome river from the west, in the Nome mining region, Seward peninsula. Prospector's name, published by the Coast Survey in 1900 . Has also been printed Barr.

Bar; point, on Revillagigedo island, Tongass narrows, Alexander archipelago, near latitude $55^{\circ} 22^{\prime}$, longitude $132^{\circ} 40^{\prime}$. So called by Capt. W. L. George, a pilot in southeastern Alaska. 
Baralof; bay, on the eastern coast of Unga island, Shumagin group. Called by Veniaminof, Vavilofskaia, and by Dall, in 1872, New harbor. Later it was called Baraloff bay and Barloff harbor. Apparently a corruption of Vavilof.

Barani, island; see Sheep.

Baranof; large island, in Alexander archipelago. Variously written Baronoff, Baranov, Baranow, etc. Also called Sitka island. Named by Lisianski, 1805, after Alexander Andreievich Baranof, then Governor of the Russian American colonies. It, with the adjacent islands, has been called the Baranof archipelago.

Baranof Packing Company; cannery, on Redfish bay, Baranof island, Alexander archipelago.

Baranovich; fishing station, at the head of Kasaan bay, Prince of Wales archipelago, established by Philip Baranovich in or about 1878. Variously written Baronovitch, Baronovich, etc. See Karta.

Baranovich's bay; see Karta.

Buranow, island; see Baranof.

Barber; point, near Nuchek, Prince William sound. So named by Portlock, 1787.

Barca; point, on the western shore of Port Refugio, Bucareli bay, Prince of Wales archipelago. Named Punta de la Barca (boat point) by Maurelle and Quadra in 1775-1779.

Barclay; valley, on the eastern shore of Portland canal, back of Belle bay. So named by the Coast Survey in 1891.

Bare; gulch, 9 miles north of Nome, Seward peninsula, on the southeast slope of Mount Brynteson, draining into Glacier creek from the west near longitude $165^{\circ} 21^{\prime}$. Local name, published in 1904.

Bare; islet, near edge of flat in Port Krestof, Kruzof island, Alexander archipelago. Named Goloi (bare) by Vasilief, 1809.

Bare; island, in Kupreanof strait, Kodiak group. Named Goloi (bare) by Murashef, 1839-1840.

Bare; islet, in Funter bay, Chatham strait, Alexander archipelago. So named by. Mansfield, 1890.

Bare; islet; in Mitchell bay, Kootznahoo inlet, Admiralty island, Alexander archipelago. So named by Meade, 1869.

Bare; islet, in. Wrangell strait, Alexander archipelago. Either this or an islet near it was named Goloi (bare) by Lindenberg in 1838. There seems to be confusion of names here.

Bare; mountain, on the mainland of Alaska, east of Admiralty island. So named by the British admiralty in or about 1865 .

Bare; point, on the eastern side of McClellan flats, at mouth of Chilkat river, southeastern Alaska. Named Goloi (bare) by Lindenberg in 1838. The name is obsolete.

Bare; point, north shore Afognak bay, Afognak island, Kodiak group, near latitude $58^{\circ} 01^{\prime}$, longitude $152^{\circ} 46^{\prime}$. Descriptive name, from Moser, 1900.

Bare; rock, about half a mile westerly from Sentinel rock in Sitka sound, Alexander archipelago. Name apparently derived from the descriptive phrase golia kameñnia ostrofki (bare rocky islets), applied by Vasilief, 1809. The Passage islets in Sitka sound have also been called Bare islets.

Bare; rock, in Hawk inlet, Chatham strait, Alexander archipelago. So named by the Coast Survey in 1891. 
Bare; rock, in Hot Springs bay, Sitka sound, Alexandér archipelago. Named Goloi (bare) by Vasilief, 1809.

Bare; see Goloi and Naked.

Barigon; cape, on the western shore of Port Dolores, Bucareli bay, Prince of Wales archipelago. On La Perouse's copy (1798) of the Spanish map by Maurelle and Quadra, 1775-1779, it bears the designation El Barigon.

Barlow; cove, in northern end of Admiralty island, Stephens passage, Alexander archipelago. Named by Whidbey, of Vancouver's party, in 1794 . Also written Barlow's, Barlows, and erroneously Burlow.

Barlow; islets, forming the east side of Barlow cove, above.- Also called Barlow islands. Named by the Coast Survey in 1884.

Barlow, mountain; see Lone.

Barlow; point, on east side of Barlow cove, above. So called by Dall in the Coast Pilot, 1883.

Barnabas; cape, the eastern point of Sitkalidak island, on the southeast coast of Kodiak. Called by Cook, in 1778, cape St. Barnabas and also cape Barriabas. Has also been written Barnaba.

Barnard; island, in Koyukuk river, near longitude $155^{\circ} 30^{\prime}$. So named by Allen, in 1885, presumably after Lieut. J. J. Barnard, of H. M. ship Interprise, who was killed by the Koyukuk Indians, February 16, 1851.

Barnett, cape ; see Addington.

Barney; creek, tributary to Seventymile creek from the west, near latitude $65^{\circ}$, longitude $142^{\circ}$. Prospectors' name, from Gerdine, 1903.

Barometer; mountain (2,310 feet high), near St. Paul, Kodiak. Apparently so named by the Coast Survey, in 1867, from its reputed power as a weather indicator. On the old Russian chart of 1809 it is called Ostraia (steep) mountain. Tebenkof calls it Skotnik (cow keener).

Barometer; mountain, on the south side of Kuskokwim river, near longitude $157^{\circ}$. So named by Spurr and Post, 1898.

Bar Point; flat, mostly bare at low water, extending $1 \frac{1}{2}$ miles along the northwest shore of Tongas narrows at Bar point above. So described in the Coast Pilot of 1901 .

Barr; creek, 15 miles north of Nome, Seward peninsula, a small tributary of Nome rivel from the west near longitude $165^{\circ} 18^{\prime}$. Local name, from a local map of 1900 .

Barren, island; see Long.

Barren; islands, at entrance to Cook inlet. So named.by Cook, in 1778, "from their very naked appearance." Also called Bairen isles. Islas Esteriles of the Spaniards, Bezplodnie (sterile) of the Russians, Bareninseln of the Germans, etc. Peregrebni of Tebenkof and Russian Hydrographic chart, 1378.

Barren; rock (20 feet high), in Dixon entrance, 7 miles south of Cape Northumberland. Called Barren rock by Dall in the Coast Pilot, 1883. Also called Barren island.

Barrie, island; see Strait.

Barrie; point, the southwestern point of Kupreanof island, Sumner strait, Alexander archipelago. So named by Vancouver, in 1793. after Mr. Barrie, a member of his party.

Barrier; group of islands, in southeastern part of Cordova bay, Alexander archipelago. So called by the Coast Survey in 1899.

Barrier; two islands and numerous adjacent rocks and reefs, marking the north point of entrance to Shakan bay, Sumner strait, Alexander archipelago, near latitude $56^{\circ} 13^{\prime}$, longitude $133^{\circ} 40^{\prime}$. So designated by Dall in the Coast Pilot, 1883. At high water they appear like two islands. 
Barrow; point (Point Barrow), the northermmost point of Alaska, near latitude $71^{\circ} 25^{\prime}$, longitude $156^{\circ} 20^{\prime}$. So named by Beechey in September, 1826, after Sir John Barrow. Dease and Simpson, in 1837, called it Point Barrow or Cape North. The Eskimo name is Náwŭk, meaning the point; variously written Noowook, Noowooh, etc.

Barrow; post-office (established in 1901), at Point Barrow, the northernmost point of Alaska.

Barry; arm of Port Wells, Prince William sound. So named by Glenn, 1898, after Col. Thomas Henry Barry, assistant adjutant-general, U. S. A.

Barry; glacier, tributary to Harriman fiord, Port Wells, Prince William sound. Named Barry by Glenn, 1898, after Col. Thomas H. Barry, assistant adjutant-general, U. S. A. Was also named Washington glacier by the Harriman Expedition, in 1899, before the prior naming was published.

Bart; island, in Nakwasina passage, west coast Baranof island, Alexander archipelago, near latitude $57^{\circ} 15^{\prime}$, longitude $135^{\circ} 29^{\prime}$. 'So named by Moore, 1896.

Barter; island, near Camden bay, on the northern coast of Alaska, about longitude $144^{\circ}$. So named by Franklin, 1826 , on account of the annual trading carried on there between the natives. The Eskimo name is said to be Nooboo'a.

Barter; river, Arctic coast, debouching in Camden bay, at Barter island, near longitude $144^{\circ}$. So called by S. J. Marsh, a prospector, 1902.

Bartlett; bar, on the left bank of Koyukuk river, east of Red mountain, latitude $66^{\circ} 20^{\prime}$, longitude $153^{\circ} 45^{\prime}$. Miner's' name, given in 1899. From Cantwell, 1900.

Bartlett; cove or bay, in Glacier bay, southeastern Alaska. So named by the pilot, Capt. W. E. George, in or about 1881.

Bartlett; point, between Surprise harbor and Murder cove, near the southern extreme of Admiralty island, at junction of Chatham strait and Frederick sound. So called in the Coast Pilot (1891, p. 141).

Bartlett; point, on northwest shore of Whitney island, Fanshaw bay, Frederick sound, Alexander archipelago. So named by Mansfield, 1891.

Bartlett; point, the westernmost point of Wales island, Dixon entrance. Name published by the Coast Survey in 1891.

Bartolome; cape, being the north point of entrance to Bucareli bay, Alexander arcipelago. Named by Maurelle, in 1775, Cabo de S. Bartholome (Co. Bartolomo on his chart), or Cape of St. Bartholomew, which has appeared under various forms since, such as St. Bartolom, St. Bartolome, Bartholomew, etc. In 1778 Meares called it Adamson, and Lisianski, in 1805 , called it Cheericoff or C. de St. Bartolome.

Barwell; island (472 feet high), at Resurrection cape, Resurrection bay, Kenai peninsula, near latitude $59^{\circ} 51^{\prime}$, longitude $149^{\circ} 17^{\prime}$. So named June 6 , 1906 , by the U. S. Board on Geographic Names. Portlcsk, 1787, called. the cape, Point Barwell.

Barwell, point; see Resurrection.

Basalt; rock (30 feet high), off the northern shore of Avatanak island, Krenitzin group, eastern Aleutians, near longitude $165^{\circ} 22^{\prime}$. Descriptive name, from Gilbert, 1901.

Basargin; mountain, on mainland on rorth bank of Stikine river, near Popof. glacier. Named Bassarguine by Hunter, 1877, after Lieut. Vladimil Basargin, I. N., commanding the Russian corvette Rynda, which explored the Stikine in 1863.

Base, point; see Cliff.

Basin; creek, tributary to Klokerblok river from the south, Seward peninsula. Name from Barnard, 1900. 
Basin; creek, tributary to Melsing creek from the east, Seward peninsulat. Name from Barnard, 1900.

Basin; creek, 15 miles north of Nome, in the Nome mining region, Seward peninsula, tributary to Nome river, from the east, near longitude $165^{\circ} 17^{\prime}$. Prospectors' name, published in 1900 .

Basin; gulch, at the headwaters of Chititu creek. Prospectors' name; first appears on map by George M. Esterly, of Valdez, 1902.

Basin (The); in Kelp bay, Chatham strait, Alexander archipelago, near latitude $57^{\circ} 17^{\prime}$, longitude $134^{\circ} 55^{\prime}$. " On the south side of the bay west or." South point are several low wooded islands, south of which is line Busin." So described in the Coast Pilot of 1901. Descriptive name given by Moore in $\mathbf{1 8 9 5}$.

Basket; bay, on the eastern shore of Chichagof island, Chatham strait, Alexander archipelago. Has been called Kakagin inlet. Its Indian name is Kook. The name Basket was given by the Alaska Oil and Guano Company's employees at Killisnoo.

Basket, lake and stream; see Kook.

Bass; point, on south shore of Revillagigedo island, near entrance to Behm canal. Named by the Coast Survey in 1891.

Bassarguine, mountain; see Basargin.

Bat; point, near head of George inlet, Revillagigedo island, Alexander archipelago. Named by the Coast Survey in 1891.

Batan; point, on west shore of Fort Caldera, Bucareli bay, Prince of Wales archipelago. Named Punta de Batan by Maurelle and Quadra, 1.7751779. Batan is Spanish for fulling-mill.

Batareinoi, ișland; see Battery.

Bates; creek, in the Birch Creek district, tributary to Ptarmigan creek from the east, latitude $65^{\circ} 28^{\prime}$, longitude $145^{\circ} 30^{\prime}$. Prospector's' name, reported by Gerdine in 1903 .

Bates; pass, over Valdez glacier.. So named by Abercrombie, 1898.

Bates; rapids, in middle part of Tanana river, central Alaska. So named by Allen, in 1885, after an Englishman of that name, wbo is reported to have descended the Tanana. Also called Bates rapid.

Bath, harbor; see Baht.

Battery; island, between Whiting harbor and the western anchorage of Sitka harbor, Sitka sound, Alexander archipelago. Named Batareinoi (battery) by Vasilief, 1809 . It was once occupied by an earthwork, now obliterated.

Battery; islets, in southern part of Wrangell strait, Alexander archipelags. So named by Lindenberg, 1838. They are the Clear islets of Meade in 1869.

Battery; point, on Seduction tongue on west shore of Chilkoot inlet, Lynn canal, Alexander archipelago. So named by the Coast Survey; in 1891, from its resemblance to an earthwork fortification. According to the Krause brothers its native name is Ketlrachtii. 'I'his point has been reserved for light-house purposes by executive order dated January 4, 1901.

Battery; point (1,600 feet high), the eastern head of Sarana bay, on soutl. shore of Akutan island, Krenitzin group, eastern Aleutians, near longitude $164^{\circ} 53^{\prime}$. So named by Veniaminof, about 1830 , who describes it as a perpendicular cliff of volcanic rock, and the southernmost part of the island. It is also said to be pierced at the base by caverns and passages, and that the booming of the waves in these gave origin to the name Battery. Possibly. identical with South Head of the Fish Commission, in 1.885, which is in turn identical with Cape Kaianal, of Tebenkof, 1849. It was called Liberty Cap by Gilbert's party in 1.901. 
Battle; creek, Seward peninsula, a west branch of Pine creek, on Norton Sound coast, near longitude $164^{\circ} 20^{\prime}$. Prospector's' name, Bob or Battle creek, from a local map, 1904.

Batto, creek; see Balto.

Batza; mountains, village, and river of central Alaska, tributary to the Koyukuk from the north, near longitude $154^{\circ}$. The native name, Batzakákat, was reported by Allen in 1885, kákat meaning mouth of. See Kákat.

Batzulnetas; post, on north bank of Copper river, in latitude $62^{\circ} 37^{\prime}$. Apparently a native name. Published by the Coast Survey in 1898. Has also been printed Batzulnatos.

Baum; cape, near Belkofski, Alaska peninsula, west of the north end of Dolgoi island. Named by the traders after one of the employees of the Alaska Commercial Company. The name has also been applied to the northwesternmost point of Dolgoi island.

$B a y$, anchorage; see Ray.

Bay; creek, tributary to Grantley harbor from the north, Seward peninsula. Name from Barnard, 1900.

Bay; group of four wooded islets, in American bay, near Dixon entrance, Alexander archipelago. So named by Nichols, 1881.

Bay; island, in Koyukuk river, near longitude $157^{\circ}$. So named by Allen, 1885.

Bay; islet on eastern shore of Portland canal. So named by Pender, 1868.

Bay; point, on the northeastern shore of Prince of Wales island, Clarence strait, southeastern Alaska, 1 mile southeast of Point Colpoys, near latitude $56^{\circ} 20^{\prime}$, longitude $133^{\circ} 10^{\prime}$. Local navigators' name, reported by H. C. Fassett, Bureau of Fisheries, 1904.

Bay; point, the northwestern point of Unga island, Shumagin group. Named Zaliva (bay) by the Russians. Lutke, 1835, calls it Tonkoi (narrow) point.

Bay; point, the western point of entrance to Farragut bay, Frederick sound, southeastern Alaska. So named by Dall, 1879.

Bay of Islands; bay, on the southeast side of Point Urey, northwest coast of Chichagof island, Alexander archipelago, near latitude $57^{\circ} 57^{\prime}$. Said to be called Bahia de las Islas on Galiano's chart, 1792.

Bay of Islands, Adak; see Islands, Bay of.

Bay of Islands; see Salisbury sound.

Bay of Pillars; see Pillars, Bay of.

Bay of Starrigavan; see Old Harbor bay.

Bay of Waterfalls; see Waterfalls, Bay of.

Bay Point Knoll; mountain (2,108 feet high), on the mainland, near Bay point, the western point of entrance to Farragut bay, southeastern Alaska. So named by Thomas, 1887.

Bayou; point, on the western shore of Wrangell strait, Alexander archipelago. So named by Meade, 1869.

Bazan; point, the south point of entrance to Port Bazan, Prince of Wales archipelago. So called by Tebenkof, 1849.

Bazan; port, on west coast of Dall island, Alexander archipelago. Visited by Caamaño in July, 1792, and named Puerto del Baylio Bazan. Has been called Bazan bay or harbor.

Bazhi; Eskimo village, on left bank of the Yukon, at upper mouth of the Innoko or Shagaluk slough. Name from Tikhmenief, 1861, who writes it Bazhigagat (mouth of the Bazhi). 
Bazil; point, on the northwestern coast of Montague island, the northeast point of entrance to Hanning bay, Prince William sound. So named by Vancouver, 1794 .

Beacon; rock, in entrance to Mole harbor, Seymour canal, Alexander archipelago. So named by Mansfield, 1889.

Beacon, rock; see Makhnati.

Bean; creek, Seward peninsula, tributary to Candle creek from the east, latitude $65^{\circ} 50^{\prime}$, longitude $162^{\circ} 05^{\prime}$. Local name, from Witherspoon, 1903.

Bean; island, in Dixon entrance just west of Cape Chacon. So named by Dall, in 1880, after Dr. Tarleton Hoffman Bean, of the Fish Commission.

Bean; ridge, on north bank of the Tanana, near longitude $151^{\circ}$. Named, 1898 , by Feters and Brooks, after the first trader to establish a post on the Tariana. The post was at Harper bend, and here Mrs. Bean was murdered by the Indians.

Bear; bay or cove, indenting the northern shore of Silver bay, Sitka sound, Alexander archipelago, near latitude $57^{\circ} 01^{\prime}$, longitude $135^{\circ} 10^{\prime}$. A stream tributary to this small bay was named Medviezhia (bear) by Vasilief, 1809.

Bear; bay, indenting the northwestern shore of Baranof island, Peril strait, Alexander archipelago. So called by Coghlan, 1884.

Bear; bay or cove, on the eastern shore of Kachemak bay, Cook inlet. So called by Dall, 1880.

Bear; bay, indenting the southern shore of Alaska peninsula, north of Belkofski. Named Medvednikova (bears) by the Russians, presumably from the abundance of brown bears found in its vicinity.

Bear, bay, Kamishak bay; see Bruin.

Bear; cape, the northwestern point of entrance to Port Etches, Prince William sound. Named Medviezhi (bear) by Chernof, 1830.

Bear; cape, the northern point of entrance to Bear bay, Alaska peninsula, near Belkofski, Iongitude $162^{\circ}$. Called Medviednik (bear) by Tebenkof,

- 1849. Has also been called Middle point.

Bear, cove, Kamishak bay; see Ursus.

Bear; creek, tributary to Chilkat river from the west, near latitude $59^{\circ} 30^{\prime}$, longitude $136^{\circ} 10^{\prime}$. Local name, obtained by Wright in 1903. Its Indian name, written Jelchitni by Krause brothers in 1882, was written Yelchthini by Flemer in 1898.

Bear; creek, falling into the Gulf of Alaska at Cape Yaktag, near longitude $142^{\circ} 30^{\prime}$. So called by pioneers in 1897 . Obtained by Martin, 1904 .

Bear; creek, 20 miles north of Controller bay, Gulf of Alaska, tributary to Trout creek from the east, near longitude $144^{\circ}$. Prospector's' name, reported by Martin, 1905.

Bear; creek, and small glacier at its head, tributary from the south to Tanana river near its head. So named by Schrader, 1902, who one afternoon saw four large bears on its headwaters.

Bear; creek, Kenai peninsula, tributary to Tustumena lake from the west, near longitude $150^{\circ} 30^{\prime}$. Local name, from Moffit, 1904.

Bear; creek, Kenai peninsula, near Hope city, tributary to Turnagain arm of Cook inlet, from the south, one-half mile east of Resurrection creek. Prospectors' name, reported by Becker, 1.895 .

Bear; creek, tributary to Kantishna river on the east (right), 25 miles above Bearpaw creek, near latitude $64^{\circ}$, longitude $150^{\circ} 30^{\prime}$. So named by prospectors in 1905, and reported by Prindle.

Bear; creek, Alaska pẹninsula, tributary to Becharof lake from the east. Named by prospector in 1901, and reported by Martin, 1904. 
Bear; creek, 5 miles north of Nome, Seward peninsula, draining the eastern slope of Anvil peak into the head of Dry creek, near longitude $165^{\circ} 21^{\prime}$. Local name, published in 1904.

Bear; creek, Seward peninsula, tributary to the west fork of Bucklin river from the west, latitude $65^{\circ} 30^{\prime}$, longitude $161^{\circ}$. Prospectors' name, from Witherspoon, 1903.

Bear; creek, in the Fairbanks region, tributary to Fish creek from the north, near latitude $65^{\circ} 05^{\prime}$, Kongitude $147^{\circ} 10^{\prime}$. Name from Gerdine, 1903.

Bear, creek; see Sajek.

Bcar, creek; Ramparts of the Yukon; see Dwyer.

Bear; creek, on the south bank of the Yukon, 20 miles above Rampart (City), and just below Alder creek. Prospectors' name, reported by Lieutenant Erickson, U. S. A., 1902.

Bear; creek, tributary to the head of Hess creek, Rampart region, near latitude $65^{\circ} 40^{\prime}$, longitude $147^{\circ} 30^{\prime}$. Local name, from Lieutenant Erickson, U. S. A., 1902.

Bear; creek, tributary to Champion creek, an affluent of the North fork of Fortymile creek from the east, near latitude $64^{\circ} 30^{\prime}$, longitude $142^{\circ}$. Prospectors' name, from Barnard, 1898.

Bear; creek, tributary to South fork of the Koyukuk from the south, near latitude $67^{\circ}$. Prospectors' name, published in 1900.

Bear, creek; see Lime.

Bear; gulch, at the hendwaters of Chititu creek. Prospectors' name; first appears on map of Nizina mining district by George M. Esterly, of Valdez, 1902.

Bear, gulch; see Washington creek.

Bear; harbor; in Affleck canal, Kuiu island, Alexander archipelago. So named. by Helm, 1886.

Bear; island, near or in Uyak anchorage, Uyak bay, northern coust of Kodiak. So called by Moser, 1897.

Bear, island; see Woewodski.

Bear; lạke, on north coast St. George island, Bering sea, nèar longitude $169^{\circ} 34^{\prime}$. Called Těnrä'rŭm-än'yi (bear lake) by the Aleuts, according to Putnam, 1897.

Bear; mountain, about 40 or 50 miles north, by compass, from Mount St. Elias. So named by Russell, 1891, after the U. S. revenue çutter Bear.

Bear; mountain, on right bank of upper Anvik river, western Alaska, near latitude $63^{\circ} 20^{\prime}$, longitude $160^{\circ} 20^{\prime}$. Prospectors' name, published in 1900.

Bear; mountain, on right bank of Tanana river, near latitude $62^{\circ}$. So named by Peters, 1898.

Bear; river, tributary to the head of Portland canal. Apparently so named by Pender, 1868.

Bear; river, tributary to Niukluk river, from the west, Seward peninsula. Name from Barnard, 1900.

Bear; slough, on the eastern shore of Kvichak bay, Bristol bay, southwestern Alaska, 6 miles below Koggiung, near latitude $58^{\circ} 50^{\prime}$. So called by the fisheries, and reported by Moser, 1900 .

Bear Bay; island, in Bear bay, Peril strait, Alexander archipelago. So named by Coghlan, 1884.

Beardslee; group of islands, in Glacier bay, southeastern Alaska. So named by United States naval officers, 1880, after Rear-Admiral Lester Anthony Beardslee, U. S. N. Have also been called Sand islands. 
Beardslee; group of islands, forming part of the Galankin group in Sitka sound, Alexander archipelago. So named by United States naval oflicers, 1880 , after Rear-Admiral Beardslee. Has been erroneously printed Beardsley.

Beardslee, island; see Kayak.

Beardslee; river, on the mainland, tributary to William Henry bay, Lynn canal, Alexander archipelago. So named by United States naval officers, 1880. after Rear-Admiral Beardslee.

Bear: Fort; see Kootznahoo.

Bearpaw; creek, a right or east branch of Kantishna river, 120 miles above its mouth, near latitude $64^{\circ}$, longitude $150^{\circ}$. Prospectors' name, reported by Frindle, 1905.

Bearpaw; mining town, on Kantishna river at mouth of Bearpaw creek, 120 miles south of the Tanana, near latitude $64^{\circ}$, longitude $150^{\circ}$. Camp established in the summer of 1905 and called Bear Paw City by the prospectors. Reported by Prindle, 1905.

Beaton; creek, Seward peninsula, a northwest branch of Cache creek, north coast of Norton sound, near longitude $164^{\circ} 10^{\prime}$. Prospectors' name, from a local map, 1900.

Beaton, island; see Betton.

Bcattic, creek; see Slate.

Beauclerc; island, near the entrance to Port Beauclerc, Sumner strait, Alexander archipelago. Also, erroneously, Beauclere. Named by Dall, 1879.

Beauclerc; mountain peak (2,500 feet high), on Kuiu island, near Port Beauclerc. So named by Helm, 1.885 .

Beauclerc; port, in Kuiu island, Sumner strait, Alexander archipelago. So named by Vancouver, 1793. Also, erroneously, Beauclere.

Beaufort; bay, on the Arctic const of Alaska, near the international boundary line. So named by Franklin, in 1826, after his friend, Capt. Francis Beaufort, R. N.

Beaufort; cape, on the Arctic coast of Alaska, near Cape Lisburne. Named, in 1826, by Beechey, "in compliment to Captain Beaufort, the present hydrographer to the Admiralty." Has also been written Bophor.

Beautems, cape and mountain; see Fairweather.

Beaver; bay, gulf or inlet indenting eastern shore of. Unalaska island, eastern Aleutians. Named Bobrovoi (sea otter) by Sarichef in 1792. Sauer, 1802, has Bobrovoi guba or Bay of Otters; Langsdorf has "Sea-Otters bay of Cook, Sarichef, and, others."

Beaver; bay, indenting the southern shore of: Alaska peninsula, northwest of: the Shumagins. Named Bobrovoi (sea otter) by the Russians. The maps are confused in this locality. Perhaps this is identical with Otter bay of some maps.

Beaver; bay, indenting the southern shore of Atka island, middle Aleutians. Named by the Russians Bobrovaia (sea otter).

Beaver; cove, just north of Cape Providence, in Port Wrangell, Alaska peninsula. So called by the Russians, before 1831, because parties of sea. otter hunters from Katmai usually stopped there. Lutke calls it Port Bobrovoi (des loutres).

Beaver; creek, on Mary island, Gravina group, Alexander archipelago. \$o named by Nichols, 1883.

Beaver; creek, tributary to Matanuska river from the west, a few miles north of Knik river, Cook inlet. Local nạe, from Glenn, 1898.

Beaver; creek, tributary to Eldorado river from the east, near its: mouth, Seward peninsula. Name from Barnard, 1900. 
Beaver; creek, tributary to the Yukon, from the south, a little below the mouth of Tozi river. Name published by the Coast Survey in 1898.

Beaver; creek, tributary to the Yukon from the south, near latitude $66^{\circ}$, longitude $146^{\circ} 15^{\prime}$. Name published by the Coast Survey in 1897. This may be the stream called Nocotocargut by the Western Union Telegraph Company explorers in 1867. Called also She Beaver.

Beaver; creek, tributary to Kobuk river from the north, near longitude $155^{\circ} 15^{\prime}$. Called Ah-ko-se-a-ge-wick on Stoney's map, 1885. Ark-o-sherwik, Arkosher-wak or Beaver by Cantwell, 1885, and Beaver by Mendenhall, 1901.

Beaver, island; see Sea Otter.

Beaver, islet; see Sea Otter.

Beaver; lake, Revillagigedo island, Alexander archipelago, on the eastern shore of Thorne arm near its head, about latitude $55^{\circ} 24^{\prime}$, longitude $131^{\circ}$ 10'. Local name, reported by Brooks, in 1901.

Beaver; lake, between the headwaters of Unalaklik and Yukon rivers, draining into the latter. "An open tundra known as Beaver lake, as it is covered with water in the spring." Local name from Dall, 1866.

Beaver; mountain, near Beaver bay, Unalaska, eastern Aleutians. Called Bobrovskoi (sea otter) by Lutke, 1836.

Beaver; mountain range, in central Alaska. Is so indicated on map of Alaska, published by Parliament in 1855. (Arctic papers III, 916.). Probably the 'Tanana mountains. The name also appears on a map issued by the United States General Land Ofirce in $\mathbf{1 8 6 9 .}$

Beaver; point, the southern point of entrance to Shelikof bay, on western coast of Kruzof island, Alexander archipelago. Probably named Bobrovie (sea otter) by Rikord, 1810.

Beaver; slough on the south shore of Yukon river at the mouth of Beaver creek, near longitude $148^{\circ}$. Name from Mendenball and Reaburn, 1901. Edwards's Track Chart of the Yukon, 1899, has She Beaver (Ausana) here and He Beaver on the opposite bank of the Yukon at the mouth of Hosiana river.

Beaver; village, or native settlement on northern shore of and near entrance to Beaver bay, Unalaska. Called Bobrova and Bobrovo (sea otter) by Sarichef in 1792. In about 1830 it consisted of 4 huts (yourts) and 41 people. Its native name is Uguióg.

Beaver City; mining camp, on Alatna river, latitude $67^{\circ}$. Name from Mendenhall, 1901.

Beaver Creek Range; mountains, indefinite, south of the Yukon flats, near Beaver creek. So' named on Edwards's Track Chart of the Yukon, 1899. See also Beaver mountains.

Beavertail; island, in Big Branch bay, Baranof island, Alexander archipelago. So named by Moser, 1897.

Becharof; creek, Alaska peninsula, tributary to Becharof lake from the east. So named by McPherson, deputy mineral surveyor, in 1903, and reported by Martin, 1904.

Becharof; lake, on Alaská peninsula. The lake was named at an early day by the Russians after Becharof, a master in the Russian navy, who was at Kodiak in 1788. It has been variously written Becharoff, Betchareff, Bocharof, Bochonoff, Botcharoff, Rochanoff, etc. The Eskimo name appears to be Igiagiuk, or Ugiagwik; etc. It has also been known as Tugat or Ninuan-Tugat, etc., while Agulogak of Sarichef is probably this .lake. 
Becharof; mountain, on Alaska peninsula. Name as above, recently applied.

Becher; point, the westeri head of Gwydyr bay on the Arctic const, near Beechey point. This name has resulted from confusion. Franklin, in 1826, named a point near here Beechey. In 1837 Dease and Simpson transferred Franklin's name to another point a little farther east, viz, to the one here called Becher, and to Franklin's Beechey point they gave the name Berens. Later maps retain the name Beechey as applied by Franklin and give to this cape a new name, Becher.

Bechevin; bay, in Isanotski strait, indenting the western end of Alaska peninsula, near latitude $55^{\circ}$, longitude $163^{\circ} 20^{\prime}$. Called Port Betchevinskoi, by Lutke, in 1836. Named presumably after Bechevin, a wealthy merchant of Irkutsk, Siberia, who in 1760 dispatched the largest vessel sent out up to that time to the Aleutian islands-the Gavril or Gabriel. The bay has also been called Isanotski.

Bechevin; bay, indenting the northern coast of Atka, Andreanof group, middle Aleutians. Apparently so named by Billings about 1790. On Billings's track chart in Sauer's account it is Belshevinskoi. Named doubtless after the Irkutsk merchant Bechevin. Variously written Betchevinskoi, Bichevina, etc.

Bechevin; cape, near Bechevin bay, on the north shore of Atka, middle Aleutians. Called Betchevinskoi by Lutke, who seemingly took it from the pilot Ingenstrem.

Beck; hills, or mountains, on right bank of Koyukuk below the junction of John (Fickett) river. So named, 1885, by Allen, " in honor of Senator James B. Beck, of Kentucky. 'The Indians seemed to have no names for these."

Beck; point, in Hiassler harbor, Annette island, Alexander archipelago. So named by the Coast Survey in 1883.

Bede; point, on the eastern side of entrance to Cook inlet. So named by Cook in 1778. "In naming this (Cape Bede) and Mount St. Augustin, Captain Cook was directed by our calendar."

Bedennoi, islets; see Watch.

Bedrock; creek, Kenai peninsula, on the left bank of Resurrection creek, 4 miles above Hope city. Local name, from Moffit, 1904.

Bedrock; creek, 20 miles northeast of Fairbanks, at the head of Cleary creek, an aftluent of Chatanika river, from the south, near latitude $65^{\circ} 05^{\prime}$, longitude $147^{\circ} 30^{\prime}$. Prospectors' name, from a local map, 1905 .

Bedrock; creek, in the Birch Creek region, tributary to Crooled creek from the right, 5 miles above Boulder creek, near latitude $65^{\circ} 30^{\prime}$, longitude $145^{\circ} 05^{\prime}$. Prospectors' name, reported by Spurr, Goodrich, and Schrader, of the Geological Survey, 1896.

Bee; rocks (10 feet high), in Dixon entrance, southern entrance to Clarence strait, south of the Percy islands, Alexander archipelago. So named by Nichols, 1883.

Beecher; pass, between Woewodski and Kupreanof islands, Alexander archipelago, near latitude $56^{\circ} 35^{\prime}$, longitude $133^{\circ}$. So named by Thomas, in 1887, after Ensign Albert Morrison Beecher, U. S. N., a member of his party. It is Duncan passage of Meade in 1869.

Beechey; point, near mouth of Colville river, Arctic coast, east of Point Barrow. Named by Franklin, in 1826, after his friend, Capt. Frederic William Beechey, R. N. Called Berens by Dease and Simpson in 1837. Erroneously Beechy.

Beehive; creek, tributary to Budd creek from the north, Seward peninsula. Name from Brooks, 1900. 
Beehive; island, in southern entrance to Nakwasina passage, Baranof island, Alexander archipelago. So named by Baker, in 1880, from its fancied resemblance, seen from the west, to the conventional straw beehive.

Beering; see.Bering.

Beering's, bay ; see Dry.

Behm; canal, in southern part of Alexander archipelago. Named by Vancouver, 1793, after Maj. Magnus Carl von Behm, commandant of Kamchatka in 1779 .

Behm; mountain (2,867 feet high), on the mainland, near southern entrance to Behm canal. So named by Nichols, 1883.

Behm; narrows or strait, in Behm canal, separating Bell and Revillagigedo islands. Named by the Coast Survey in 1891.

Behring, Riviere de; see Alsek.

Behring; see Bering.

Belcaro; post-office (established in August, 1899), about 50 miles north of Valdez, Prince William sound. It was discontinued in 1900.

Belcher; point, on the Arctic coast, between Icy cape and Point Barrow. So named by Beechey, 1827, after Lieutenant (afterwards Sir Edward) Belcher, who accompanied him during his explorations here.

Belknap; islands, forming the eastern part of the Eckholms group; Sitka sound, Alexander archipelago. So named by United States naval officers in 1880 , presumably after Capt. (afterwards Rear-Admiral) George Eugene Belknap, U. S. N.

Belkofski; bay, cape, and village, on south coast of Alaska peninsula, near latitude $55^{\circ}$, longitude $162^{\circ}$. Named by the Russians, as early as 1835, and probably earlier. Derived from bielka (squirrel). Variously written Belkoffski, Belkoffisky, Belkovsky, etc.

Bell; arm, in northern part of Behm canal, north of Bell island, below. So named by the Coast Survey in 1883.

Bell; island $(2,500$ feet high), in Behm canal, north of Revillagigedo island. Called Bell's island by Vancouver, in 1793, after a member of his party.

Bell; island, in entrance to Red bay, Prince of Wales island, Alexander archipelago. Named by Helm, 1886, after Lieut. John Arthur Bell, U. S. N., a member of his party.

Bell; river, tributary to Gwydyr bay, Arctic coast of Alaska. Named Bell's by Dease and Simpson, 1837.

Bella; creek, Seward peninsula, tributary from the south to Schlitz creek, which is a tributary of Serpentine river, near latitude $65^{\circ} 50^{\prime}$, longitude $164^{\circ} 50^{\prime}$. Prospectors' name, from Gerdine, 1901.

Belle; bay, on the eastern shore of Portland canal. So called by the Coast Survey.

Belle Isle, village; see Eagle.

Bellevue; river, in northernmost Alaska, tributary to Elson bay, near Point Barrow. Named Belle Vue by Dease and Simpson, in 1837, commemorating their pleasure at seeing the end of their exploratory journey from Mackenzie river mouth to Point Barrow.

Beloi, rock; see Bieli.

Belshevinstooi, bay; see Bechevin.

Belt; creek, tributary to Kuzitrin river from the east, Seward peninsula. Name from Brooks, 1900.

Beluga; lake, on the eastern shore of Cook inlet and the northern shore of Kachemak bay, 7 miles southeast of Bluff point, Kenai peninsula. Local name, reported by Stone in 1904. Russian, bieluga (white whale). 
Beluga; mountain (3,580 feet high), near the head of Cook inlet, about latitude $61^{\circ} 45^{\prime}$, Jongitude $151^{\circ} 15^{\prime}$, Local name, published by the Geological Survey in 1898. Russian, bieluga (white whale). Ferron, 1899 , reports the Indian name of what appears to be the sime mountain as Snee-dee. See Snidi.

Beluga; river and lake, tributary to Cook inlet from the north, near longitude $151^{\circ}$. Apparently a local name, published in 1899. Russian, bieluga (white whale).

Ben; creek, eastern Alaska, at the head of Slate creek, tributary from the west to North fork Fortymile creek, near latitude $64^{\circ} 40^{\prime}$, longitude $142^{\circ} 45^{\prime}$. Prospectors' name, from sketch map compiled by Maj. W. A. Glassford, Signal Corps, U. S. A., 1905.

Ben, lake; on Kẹnai peninsula, tributary to Kenai river. May be identical with Cooper lake. See Cooper. So called on Russian Hydrographic chart 1378 , edition of 1847 .

Bence; mountain $(4,800$ feet high), near the lead of Klutina lake. So named by Abercrombie, 1898, after Private Bence, of his party.

Bench; creek, at the head of east fork Sixmile creek, Kenai peninsula. Prospectors' name, from Mendenhall, 1898.

Bend; mountain $(5,000$ feet high), on east bank of Chandlar river, near latitude $68^{\circ}$. Descriptive name given by Schrader in 1899 . There is a Jarge bend in the river near this mountain.

Bendel; cape, the northwest point of Kupreanof island, Frederick sound, Alexander archipelago. So named by Dall, 1877, after Mr. Bernhard Bendel, formerly of Bremen, an Alaskan pioneer, to whom the early Coast Survey parties were indebted for valuable information and generous hospitality.

Bendel; island, between Big Koniuji and Nagai islands, Shumagin group. So named by Dall, after Bernhard Bendel, a trader in Alaska in 1871-72. Has also been called Morse island.

Bendeleben; mountain, north of Golofnin bay, Norton sound. Named in 1866, after Baron Otto von Bendeleben, who made explorations in this vicinity while a member of the Western Union Telegraph exploring expedition. Erroneously Berdeleben.

Bendeleben; mountains, Seward peninsula, 50 miles north of Golofnin bay, extending east from Mount Bendeleben. So named by Brooks, 1900 . They were called Greenhorn mountains by Schrader in 1899 .

Benelaracher, mountain; see Koyukuk.

Benham; point, the eastern point of entrance to Rodman bay, Peril strait, Alexander archipelago. Named by Moore, 1895, after linsign Henry Kennedy Benham, U. S. N., a member of his party.

Benjamin; island, in southern part of Lynn canal, Alexander archipelago. So named by Beardslee, 1880.

Renkes, point; see Banks.

Bennett; creek, tributary to Niukluk river from the south, Seward peninsula. Name from Barnard, 1900.

Bennett; island, in the Arctic ocean, north of the New Siberian islands. Discovered by De Long, 1881, and named by him, after Mr. James Gordon Bennett.

Bennett; lake, north of Chilkoot pass. Named by Schwatka, in 1883 , after James Gordon Bennett. Has been erroneously written Bennet.

Bennett; town, at head of Bennett lake, the present terminus of the railroad from Skagway. 
Bentera; island, in Bucareli bay, Prince of Wales archipelago. Named La Bentera by Maurelle and Quadra, 1775-1779.

Bentinck; point (Point Bentinck), the point at the eastern end of Hinchinbrook island, Prince William sound, near latitude $60^{\circ} 25^{\prime}$, longitude $146^{\circ} 05^{\prime}$. Portlock, 1787, named the eastern end of Hinchinbrook island Point Steele, and Vancouver, 1794, named it Point Bentinck. Both names have been preserved by applying them to different capes. See Steele.

Berdeleben; mountain; see Bendelebeñ.

Berens, point; see Beechey.

Berezhnoi, island; see Caution.

Berezovaia, cove; see Birch.

Berg; bay or inlet, on the southwestern shore of Glacier bay. So called in the Coast Pilot (1883, p. 169).

Berg, creek, on Snake river near Nome; see Borg.

Berg; lake, on the eastern border of Muir glacier. So named by Reid, 1890, because of the large number of icebergs found floating in it that year.

Berg; lakes (four small lakes, called locally First, Second, Third, and Fourth Berg lakes), in the Controller bay region, on the northwest margin of Bering glacier, near latitude $60^{\circ} 25^{\prime}$, longitude $143^{\circ} 45^{\prime}$. Descriptivé name, given by prospectors, and reported by Martin in 1905 .

Bergman; settlement and trading post, on Koyukuk river, near the Arctic circle, about longitude $153^{\circ}$. So named by prospectors, 1899 , after the owner of the post.

Bergstrom; gulch, 7 miles north of Nome, Seward peninsula, draining into Glacier creek from the north, near longitude $165^{\circ} 25^{\prime}$. Local name, published in 1904 .

Bering. Several geographic features in and adjacent to Alaska have been named after Commander Bering, the pioneer explorer of northwest America. So applied the name has been variously spelled Bebring, Bhering, Beering, etc. Nearly all are now agreed that the spelling should be that used by Bering himself, viz, Bering. Capt. Commander Iran Ivanovich Bering, selected by the Tsar, Peter the Great, for the work of exploring eastern Asia and western America, was the son of Jonas Svendsen by his second wife, Anne Pedersdatter Bering, and was born at Horsens, in Jutland, in the summer of 1681 . On his mother's side he was descended from the distinguished Bering family which, during the seventeenth and eighteenth centuries, flourished in various parts of Denmark, and included a number of ministers and judicial officers. Baptized the 12th of August, 1681, he received the baptismal name Vitus Jonassen Bering. On entering the Russian havy, however, he took, as was the custom of the Danish and Norwegian officers serving in Russia, a new or Russianized form of name. This form is Ivan Ivanovich Bering. The name Ivanovich is an exact translation of Jonassen; in English, Johnson or John's son. All the Russian and Danish records agree as to the spelling of the family name; both in Danish and in Russian it is Bering. His autograph is always Bering.

The insertion of an $h$ in the name, giving the form Behring, appears to have been made in Germany.

In 1748 was published Harris's Collection of Voyages, in two folio volumes. In the second volume, pages 1016-1041, is contained "A distinct account of part of the northeast frontier of the Russian Empire, commonly called the country of Kamschatka or Kamschatska, including the voyages of Captain Behring for discovering toward the east, etc., 
Bering-Continued.

collected from the best anthorities, both printed and manuscript." This account was prepared by Doctor Campbell, who made use of the form Behring. From this it may be inferred, as pointed out by Mr. William H. Dall, that Doctor Campbell did not have access to original documents, but got his material from German sources or from German translations of the original. As Harris's Voyages is an elaborate work, long accepted as a standard, the use of the form Behring gained. wide adoption among linglish-speaking people. That the form Bering should be adopted, however, appears (1) becaluse it is the form always used by Bering himself, by his ancestors for five grenerations at least, and by his descendants; (2) because it is the form almost, though not quite, universilly adopted in all non-English works, and (3) because even in English works it is gradually superseding the form Behring.

On this subject see note by Dr. 'T. $N$. Gill in report upon the condition of affairs in Alaska, by F. W. Elliott, Washington, 1875 , p. 246; also in report on the seal islands of Alaska by same, pp. 151-152, this being. contained in Tenth Census of the United States, Washington, 1884.

For information touching Bering and his family see Vitus J. Foring og de Russiske opdagelsestejser fra, 1725-1743, af P. Lauridsen, 12mo, K.j $\phi$ benlitvn, Hegel \& S $\$$ n, 1SS5, pp. 4-6. See also translation of same, entitled, "Russian Explorations, 1725-1.743, Vitus Bering, the Discoverer" of Bering Strait, by Peter Lauridsen; etc., translated from the Danish by Julius W. Olson," 12mo, Chicago, Griggs \& Co., 1.899, pp. ix, xii, 10, 11. See also note on Bering's name by W. F. Dall in The National Geographic Magazine, $s^{\circ}$, Washington, 1S90. Vol. II, No. 2, p. 122.

The Encyclopredia Britannica, ninth edition, has Behring's island and Behring's strait. Johnson's New Universal Cyclopedia, New York, 1877, has Behring or Beering (Vitus). The American Cyclopedia, 1883, vol. 2, p. 480, has Behring or Bering (Vitus). Appleton's Cyclopedial of American Biography, New York, 1857, vol. 1, p. 245, has Vitus Bering.

Bering, bay ; see Yakutat.

Bering; glacier, northeast of: Controller bay, between Mount St. Elias and Copper River, near longitude $143^{\circ} 30^{\prime}$. So named by the Coast Survey in 1880 .

Bering, haven; see Controller bay.

Bering; island, one of the Commander group, Bering sea. Bering died and was buried here December $8,1741$.

Bering, river; see Alsek.

Bering; river and like. 'The river rises in Bering glacier and flows into Controller bay; the lake is on Bering river, 5 miles north of Controller bay. The Spaniards called the river Rio Lagartos (lizards). Davidson (Coast Pilot, p. 146) calls this river and lake Chilkaht. It has since been published Chilcat and Chilkat. Pratt, 1908, and G. C. Martin, 1903 , each calls them Bering, which is the local usage.

Bering; sea, between Alaska and eastern Siberia. First so called after Commander Bering. by Captain Golofnin, in 1822. Before this date it was for the most part called the Sea of Kamchatka (variously spelled). On a very old map it is called the Mei d'Ormante and on another the Sleepy sea. It has also been called the Sea of Otters (Bobrovoi) and also the Sea of Alaska (variously spelled) or Aleutian sea. Also the Eastern (i. e., Pacific) ocean. For very full account of this name see Fur Seal Arbitration.

Bull. $299-06 \mathrm{M}-9$ 
Bering; strait, separating Asia from North America. Variously written as strait and straits, and also variously written sometimes in the possessive form, as Bhering, Belring, Beering, etc. As early as 1572, it is shown on a map with the name Strets de Anian. Cook, in 1778 , called it Bhering's straits.

Bering; village, on the eastern shore of Port Clarence, Seward peninsula. Name from Brooks, 1900. Locally called Bering City.

Bernard; creek, tributary to Tonsina river from the southeast. Name from Gerdine, 1900.

Berners; bay, indenting the eastern shore of Lymn canal, Alexander archipelago, near latitude $58^{\circ} 45^{\prime}$. Named by Vancouver, 1794.

Bernstein; bay; see Amber.

Berry; arm; of Port Frederick, Chichagof island, Alexander archipelago. So called in the Coast Pilot of 1883, p. 192.

Berry; creek, Seward peninsula, tributary to the west fork of Noxapaga, river, near latitude $65^{\circ} 40^{\prime}$, longitude $164^{\circ}$. Prospectors' name, obtained by

- Witherspoon, 1903.

Berry, inlet; see Tenakee.

Berry; island, in Kasalan bay, Prince of Wales group, Alexander archipelago. So named by Clover, 1886.

Berry; island, one of the Kutchuma group, Sitka sound, Alexander archipelago. Named Yagodnoi (berry) by Valsilief in 1809 . Has al'so been called Johnson island:

Berry; knoll (894 feet high), east of Tamman harbor, on Annette island, Alexander archipelago. Called Berry Knoll by Nichols, 1883.

Berry, passage ; see Tenakee.

Berry; peak (2,500 feet high), on Wlangell island, Arctic ocean. So named by the United States Navy in 1.881, after Lieut. Robert Mallory Berry, U. S. N., whose party was the first to lind upon this island.

Berry; point, the end of a sandy shoal forming the northernmost point of Wrangell island, Arctic ocean. Named after Lient. Robert M. Berry, U. S. N., who discovered it in 1881 .

Bertha; glacier, on the mainland near the head of Chilkat inlet, southeastern Alaska. So named by United States naval officers, 1880.

Bert Millar; cutoff, entrance to Nichols bay west of Cape Nunez, Dixon entrance, southeastern Alaska, near latitude $54^{\circ} 40^{\prime}$, longitude $132^{\circ} 08^{\prime}$. Named after a local sea captain and reported by H. C. Fissett, Bureau of Fisheries, 1904.

Besboro; island, in eastern part of Norton sound, Bering sea. Named Besborough by Cook, September, 1778 .

Besimenny, cape; see Nameless.

Bessie; peak $(4,130$ feet high $)$, in the northern part of Etolin island, Alexander archipelago. So named by Snow, 1886.

Betchareff, lake; see Becharof.

Betchevinskoi, bay, cape, etc.; see Bechevin.

Bethel; mission (Moravian) and reindeer station, on the lower Kuskokwim near or at the native village Mumtrelega. The missionaries, William $\mathrm{H}$.' Weinland and John H. Krilbuck, founded the mission in 1885.

Betrug, cape; see Deceit.

Bettles; mining camp, supply station, and post-office, at the head of steamboat navigation on Koyukuk river at the mouth of John river, near latitnde $67^{\circ}$. The post-office was established in 1901. Named after members of the firm who own the trading post. 
Bettles; river, tributary to Middle fork of the Koyukuk, from the east, near longitude $150^{\circ}$. Named by the miners, 1899 , after $\mathrm{Mr}$. Bettles, of the firm Pickarts, Bettles \& Pickarts, owners of the post Bergman.

Betton; cape, on the western coast of Betton island. Called Betton Head by the Coast Survey in 1886.

Betton; island, in the northern entrance to Behm canal, Alexander archipelago. Named by Vancouver, in 1793 , after Mr. Robert Betton, one of lis party, who was wounded in a fight with the natives. 'The name occurs several times in Vancouver's text, but in the atlas is erroneously Beatons. This erroneous form has been widely copied.

Between; cape, between Spruce and Inner Spruce cape, Chiniak bay, Kodiak. Named Promezhutochnie (between) by Murashef in 1839-40.

Between; mountain (1,526 feet high), near 'ramgas harbor, on Annette island, Alexander archipelago. Named by the Coast Survey in 1886.

Beulah; island, northeast of St. Michael island and a little north of Whale island, Norton sound, near latitude $63^{\circ} 30^{\prime}$, longitude $162^{\circ}$. So called by the Coast Survey parties, 1898-1900.

Beverly; creek, eastern Alaska, tributary to Charley river from the west, near latitude $65^{\circ}$, longitude $143^{\circ} 40^{\prime}$. Prospector's' name, reported by Witherspoon, 1905 .

Beziemiannoi, islet; see Nameless.

Bezplodnie, islands; see Barren.

Bhering; see Bering.

Bibb; shoal, in the entrance to Security bay, Kuiu island, Alexander archipelingo. So nimed by Glass, in 1881, perhaps after one of the Coast Survey vessels.

Bibora; reef, off the northeru end of St. Ignace islind, Bucureli bay, Prince of Wales archipelago. Named La Bibora by Maurelle and Quadra, 17751.779. Apparently intended for la bilaro (beaver).

Bichevina, bay; see Bechevin.

Bidarka; point; see Copper Mountain point.

Bieli; rock, near Middle island, Sitka sound, Alexander archipelago. Named Bieloi (white) by Vasilief, 1809. Called White by Dall in the Coast Pilot (1883, p. 140). Erroneously Beloi.

Bieli, rock, Chatham strait; see White.

Big; bowlder, near Danger point in Wrangell strait, Alexander archipelago. So called by Nichols, 1881.

Big; creek, tributary to Chandlar river from the east, near longitude $149^{\circ}$. Prospector's' name, given in 1899 .

Big; creek, tributary to Grouse creek from the north, Seward peninsula. Name from Barnard, 1900.

Big; creek, tributary to Red bay, Prince of Wales island, Alexander archipelago. So named by Helm, 1886.

Big; island, at entrance to Deep bay, Peril strait, Alexander archipelago. Named Bolshoi (big) by Vasilief, 1833.

Big; island, in Yukon river just below the mouth of Melozi river. Descriptive name, published by the Coast Survey in 1898.

Big, island; see Big Gavanski.

Big; lake, in northeast part of St. Paul island, Pribilof group, Bering sen, near longitude $170^{\circ} 10^{\prime}$. Elliott, 1874, calls it Great lake. According to Jiliott, its Aleut name is Mee-sulk-mah-nee, i. e., very shallow.

Big; mountain (8,750 feet high), on the mainland, east of Stikine river and near the international boundary. So called on recent Coast Survey charts. 
Big; rock, at entrance to Afognak bay, Kodiak group. Named Bolshoi (big) by Murashef, $1839-40$.

Big Arrow, bay; see Big branch.

Big Bar; creek, Seward peninsula, tributary to Koyuk river from the north, latitude $65^{\circ} 25^{\prime}$, longitude $162^{\circ} 10^{\prime}$. Prospectors' name, obtained by Witherspoon, 1903.

Big Bend; in Koyukuk river near latitude $65^{\circ} 25^{\prime}$, longitude $157^{\circ}$. Descriptive name, firom schrader, 1899.

Big Black, river; see Blick and also Rat.

Big Bonunzu, creek ; see Bonanza.

Big Branch; bay, indenting the southwestern shore of Balanof island, Alexander archipelago. Named Bolshoi strelka (Big arrow or Big offshoot) by the Russians. Has been called Great Strelki bay; also Bolshoi Rukaly (big sleeve.)

Big Branch; rock, oft Bir Branch bay, Baranof island, Alexander archipelago. So named by Moser, 1897.

Big Diomede; island (1,759. feet high), the westernmost and largest of the Diomede islands, Bering strait. It is the easternmost land of eastern Siberial, Asia. For name of the group see Diomede. Commonly known as Big Diomede. Saluer, 1802, calls it Inalin and Inellen; Lutke has Inilik, while Beechey, 1830, has Ratminnoff (Noo-nall-book). In the Alaskil purchase treaty, 1867 , it is called Ratmanoff or Noonalbook. Tebenkof, 1849, has Inaklit, while Nordenskjold has I-ma-ltn. Beechey, 1826, salys that he transfered to this island the name Ratmanoff, which hald been bestowed upon the supposed discovery of Kotzebue.

Big Eldorado; creek, in the rairbanks region, tributary to Goldstrean creek from the north, near lititude $\left(\mathrm{j}-t^{\circ} 55^{\prime}\right.$, longitude $147^{\circ} 50^{\prime}$. Prospectors' name, from Gerdine, 1908 .

Big Fort; islet, on southeastern shore of Shuyak island, Kodiak group. Named Bolshoi Kriejosti (Big fort) by the Russian American Company, 1849.

Big Four; areek, tributary to Casaldepaga river from the soutl, Seward peninsula. Name from Barmard, 1900.

Big Gavanski; island, one of the Gavanski group, immediately in front of Starrigalvan baly, Sitka sound, Alexander. archipelago. Named Gavanski Bolshoi (big harbor) by Vasilief, 1809. Has also been called Big island and Gavanski island.

Big Goosc, island ; see Goose.

Big Hurrah; creek, tributary to Solomon river from the east, Seward peninsula. Name from Barnard, 1900.

Big Thiut, river; see Niukluk.

Big Iliazhek, island; see Outer Mliasik.

Big Koniuji; island, one of the Shumagin group. Named by the Russians Bolshoi Koniuhi, a word derived from Koniughka (crested auk). Also written Konioujii, Koniugi, etc. See Koniuji.

Big Lake. A region of flat country abounding in lakes, between the lower Yukon and the Kuskokwim rivers, was, as early as 1878 and probably earlier, known to the fur traders as the Big Lake country.

Big Naked, island; see Naked.

Big Rivor; slough, in the Copper River delta, reported by Moser, 1897. It may be Catstle 1sland slongh, which see.

Big Rose; island, one of the Opasni islinds in Northern rapids, Peril strait, Alexander archipelago. Named by Coghlan, 1884, doubtless after the little steamer Rose. 
Big Sskookum; creek, at the head of Walker fork of Fortymile creek, tributary from the left near latitude $64^{\circ}$ and the international boundary. Prospectors' name, obtained by 12. F. Ball, a prospector, 1898 .

Big Whitefish; island, in Yukon river, at the Pallisates. Called Big White Fish islind by the Coast Survey in 1898 .

Big Windy; creek, eastern Alaska, tributary on south bank of South fork Birch creek, near latitude $65^{\circ} 15^{\prime}$, longitude $144^{\circ} 30^{\prime}$. Prospectors' name, reported by Witherspoon, 1905.

Bill; point, the north point of Whitney island, Fanshaw bay, Frederick sound, Alexinder archipelago. Named by the Coast Survey in 1891.

Bill Moores; landing, on right bank of Apoon pass, Yukon delta, 12. miles above Kotlik, near latitude $62^{\circ} 57^{\prime}$, longitude $163^{\circ} 46^{\prime}$. Local name, reported by Faris, 1899, who wrote the Eskimo name Konog'kelyokamiut.

Billy; creek, tributary to Hicks creek from the north, near longitude $147^{\circ} 30^{\prime}$. Local name, from Glenn, 1898. Named after the Indian, Billy, one of: the guides of: Glenn's expedition.

Billy; lake, the westerly of the two Yokneda lakes on the left bank of Copper river, near latitude $62^{\circ} 25$. Tocal name, reported by schrader, 1902 .

Billy's Hole; lake, north shore l.rince William sound at the head of Jong bay, near longitude $147^{\circ} 10^{\prime}$. So named by the fisheries, and reported by Moser in 1897.

Bimiut; laskimo camp or village on the onter const of the Yukon deltil, 13 miles south of Black river, near latitule $\left(i 2^{\circ} 10^{\prime}\right.$. Bskimo name, obtained by Putnam in 1.899; may be the same as Paimiut=mouth (of the river) follis.

Bingham; cape, the northwestein point of Yakobi island, Alexander archipelago, neal latitude $58^{\circ} 05$, longtude $136^{\circ} 35$. Named by Vancouver in 1794. Tebenkof calls it Thakhinis, while Cook and La Pernuse call it Cape Cross. Vanconver located Cape Cross 7 miles from this.

Bingo; mountain, in northern part of Annette islaud, Alexander archipelizo. So named by Nichols, 1883 .

Biorka; cape, the northeasternmost point of Biorka island near: Unalaska, eastern Aleutians. Called Burka by the Jish Commission in 1888.

Biorka; island, the northwestermost of the Necker islands, at entrance to sitka sound, Alexander atchipelago. So named by Vasilief, 1809. It is South island of Lisianski in 1805 .

Biorka; islind, near the east end of: Unaliska, eastern Aleutians, near latitude $53^{\circ} 45^{\prime}$, longitude $16\left(i^{\circ} 15^{\prime}\right.$. Its Aleut name is Siginak (braided, curled.), which Samer wrote Sithanal. Sarichef, in 1792, called it Spirkin; Veniaminof: has Borka or Spirkin, while Lutke silys Spirkine, otherwise called Borkal. Now commonly written and pronounced Biórka. Frroneously Burka. It is from the Norwegian Bjerk $\ddot{O}$, or Swedish B.jörk $\ddot{0}$, meaning Binch island.

Biorka; sunken reef. in Sitka sound, westward from Biorka island. So named by Dill in the Coast Pilot, 1883. Hals also been called Biorkat rock.

Biorka; village (population in 1890, 58); on the eastern end of Biorka islind, eastern Aleutians. Has been written Borka and Burka. Its native name, according to Veniaminof, is Ugiń-ugr, but Samer, 1790, salys it is called Sidankin, while Sarichef, in the same party with Satuer, has Sedanka and Sedanki.

Biougam, island; see Bushy.

Birch; cove, east of Pyramid island, Chilkat inlet, southeastern Alaska. Named Berezovail (birch) bay by Lindenberg, 1838. The name is obsolete. 
Birch; creek, Kenai peninsula, tributary to Tustumena lake from the northwest, near longitude $150^{\circ} 40^{\prime}$. Local name, from Moffit, 1904.

Birch; creek, tributary to Big Four creek from the south, Seward peninsulit. Name from Barnard, 1900.

Birch; creek ; tributary to the Yukon from the north, about 15 miles below the mouth of 'Tozi river. Name published by the Coast Survey in 1898 .

Birch; creek, affluent to the Yukon on the left bank about 30 miles below Fort Yukon. The source of this creek is in the mountains 60 miles southwest. of Circle, and in this region is the Birch Creek gold field, discovered in 1893. It flows to within 12 miles of the Yukon at Circle and thence through the Yukon flats parallel to the Yukon for nearly a hundred miles. Named by traders of the Hudson Bay Company. Its Indian name is reported to be Tohwun-nukakat. Fither this creek or the next below it is Nocotocargut of the Western Union Telegrapb expedition, 1867.

Birch; hill, Seward peninsula, on the south side of Kuzitrin river, near latitude $65^{\circ} 10^{\prime}$, longitude $164^{\circ} 55^{\prime}$. Prospectors' name, from Gerdine, 1901.

Birch; lake, near 'Tetling river, between Copper and Tamana rivers. So named by Lowe, 1898, after Stephen Birch, a member of his party.

Birch Creek; trail, from Tanana river, near longitude $147^{\circ}$, to the headwaters of Birch creek. Local usage. Apparently identical with Circle City trail of some maps.

Birches; telegraph station, on the Yukon, 55 miles below Fort Gibbon (at the mouth of Birch creek may be). Name and description from the Signal Corps map, 1904. The Northern Commercial Company's folder, 1905, gives distance from Birches to Tanana (store) as 81 miles.

Bird; cape, on southern shore of Whale island, Kodiak group. Named Ptichie (bird) by Murashef in 1839-40.

Bird; cape (1.,088 feet high), at western end of Amchitka is!and, western Aleutians. Lutke says the Aleuts call it Satinna, i. e., des oiseaux (of birds). The Russians called it I'itchie (bird) cape.

Bird; creek, tributary to Turnagain arm of Cool inlet from the north, opposite the mouth of Sixmile creek, near longitude $149^{\circ} 25^{\prime}$. Prospectors' name, reported by Becker, 1895 .

Bird; creek, debouching on the south shore of Seward peninsula, $6 \frac{1}{4}$ miles west of Calpe Nome, near longitude $165^{\circ} 10^{\prime}$. Local namé, from Gerdine, 1904 .

Bird; island, in Favorite channel, Iynn canal, Alexander archipelago. So named by Beardslee, 1880 .

Bird; island, in St. Paiul harbor, Kodiak island. Named Ptichie (bird) by the Russians, 180 .

Bird; island, in southern part of the Shumagin group. Named Ptichnie or: Ptichnoi (bird) by the early Russians. Has also been written Petitski and Ptitchny.

Bird; island, off south shore of Ikatan peninsula, near east end of Unimak island. Named Ptichie (bird) by Tebenkof, 1849.

Bird; point, on the north shore of Turnagain arm, Cook inlet, 5 miles east of Bird creek, near latitude $61^{\circ}$, longitude $149^{\circ} 20^{\prime}$. Local name, from Glenn, 1898. Herron, 1899, calls it Hunter's point.

Bird; rock, in eastern part of Cordova bay, Alexander archipelago. Name from Moser, 1897.

Bird; rock, in Fanshaw bay, Frederick sound, Alexander archipelago. Named by the Coast Survey in 1891. 
Birthday; gulch, 8 miles northwest of Cape Nome, Seward peninsula, on the southeast slope of Army peak, draining into St. Michael creek, near longitude $165^{\circ} 08^{\prime}$. Local name, published in 1904.

Bishop; point, the western point of entrance to Taku inlet, Stephens passage, Alexinder archipelago, near latitude $58^{\circ} 12^{\prime}$, longitude $134^{\circ} 09^{\prime}$. Originally named Salisbury by Vancouver, in 1794, after: the Bishop of Salisbury. The name Salisbury having been accidentally transferred to a point about 3 miles farther west, the name Bishop was given to this point by Dall in the Coast Pilot (1883, p. 171).

Bishop; rock, a rocky bluff on the right bank of the Yukon 10 miles above the mouth of the Koyukuk, near longitude $157^{\circ} 15^{\prime}$. Local name, reported by Collier, 1902. Called also Bishop's mountain.

Bissell; lake, tributary to Chuitna river, near the head of Cook inlet. Name published by the Coast Survey in 1898 .

Bituk, creek; see Baituk.

Bitzishtini; mountains, on the right bank of the Wast fork of Kuskokwim river, near its sonrce, and on the left bank of the Cosna; near latitude $64^{\circ} 30^{\prime}$, longitude $151^{\circ} 30^{\prime}$. Indian name, probably from bitzish (caribou), reported by Ferron, 1899, and written Bitz-ish-ti-nee.

Bitzla; river, tributary to the Koyukuk from the eist, near longitude $157^{\circ} 30^{\prime}$. Part of a native name reported in 1885 by Allen, who has Bitzlatoilocta on his map and Bitzlatoiloeta in his text.

Black; bluffs, east of St. Paul village, St. Paul island, Pribilof group, Bering sea, near longitude $170^{\circ} 16$. Apparently a local descriptive name, published by the Coast Survey in 1875 . "A symmetrical remuant of a cinder cone mostly dissected away by erosion of the waves." (Emerson, Farriman expedition, vol. 4, p. 31.)

Black; cape, forming the eastern head of Driftwood bay on the southern shore of Umnak island, eastern Aleutians. Named Choinoi (black) by Kuritzien, 1849 .

Black; cape, on northern shore of Afognik island, Kodiak group. Named Chernoi or Chornoi (black) by the Russians as early as 1848. Hals also been written erroneously Torno. Presumably a descriptive name.

Black; cape, on southeastern coast of Spruce island, Kodiak group. Named Chernie (black) by Murashef, 1839-40.

Black, cape; see Newenham.

Black; glacier, in the Mount: St. Elias region, near Disenchantment bay. Descriptive name, given by Russell in 1890 .

Black; gulch, on the north side of Noxalatga liver, 3 miles above the town of Noxilpaga, near latitude $65^{\circ} 30^{\prime}$, longitude $164^{\circ} 10^{\prime}$. Prospectors' name, obtained by Gerdine, 1901.

Black; head, on the east side of Dease inlet, Arctic const. near longitude $155^{\circ}$. So named by reters and Schrader, 1901.

Black; island, in Behm canal, northwest of Revillagigedo island, Alexander archipelago. Named by the Coast Survey in 1891.

Black; islet, in Revillagigedo channel, north of the southern entrance to Behm canal. So named by Nichols, 1883. Descriptive term.

Black; small wooded island, near Cape Edward, western coast of Chichagof island, Alexander archipelago, near latitude $57^{\circ} 35^{\prime}$, longitude $136^{\circ}$ 46'. Descriptive name, given by Moore in 1897 .

Black; lake, near Black peak, on Alaska peninsula. So called by Petrof, 1880.

Black; mountain (5,130 feet high), in the Muir glacier, southeastern Alaska. So named by Muir, 1882. 
Black; mountain (1,883 feet high), in the southern part of Revillagigedo island, Alexander archipelago. So named by Nichols, 1883.

Black; mountain (5,000 feet bigh), northeast of Valdes glacier. So named by Abercrombie, 1898.

Black; peak, on Alaska peninsula, northwest of Chignik bay. Named Chornaia (black) by Tebenkof, 1.849. Also called Black volcano.

Black; point, on the northern shore of Moira sound, western shore Clarence strait, southeastern Alaskil, near latitude $55^{\circ} 03^{\prime}$, longitude $132^{\circ} 04^{\prime}$. Navigator's' name, reported by H. C. Fassett, Bureatu of Fisheries, 1904.

Black; point, on northern shore of Whitewater bay, Admiralty island, Alexander archipelago. So named by Glass, 1881.

Blsck; point, the southwesternmost point of Sitkalidak island, Kodiak group. Descriptive name, given by Tanner in 18ss. It is Miesofski or Miesof of Tebenkof and Mizofek of Archimandritof, 1849.

Black; reef, in Port Frederick, west of Green island, Chichagof island, Alexander archipelago. Descriptive name, given by United States naval officers in 1880.

Black; river, in the Yukon delta, near latitude $62^{\circ} 20^{\prime}$, longitude $165^{\circ}$; called by Dall, Kipníuk or Black. Russian Hydrographic Chart 1455 (ed. of 1852) calls it.Kipnaiak, and late Coast Survey charts Kripniyuk. Nelson says the native-name is Kipniaguk, spelled Kipniuk on most maps, and shows it as a river distinct from and to the north of Black river. It is Kipunatiak pass of Tebenkof, 1849.

Black; river, tributary to Porcupine river from the southeast, about 20 miles above Fort Yukon, called Big Black by the Coast Survey in 1898 . There has been confusion in the placing of Big Black, Little Black, and Rat rivers on the maps. See also Little Black and Rat.

Black; river, tributary to the Kobuk from the south, near latitude $66^{\circ} 45^{\prime}$, longitude $157^{\circ} 30^{\prime}$. So named by Stoney, 1885. Its Eskimo name according to Cantwell, 1884 and 1885, is Umakalookta, Am-mok-a-looktok (or tah) or Um-ok-a-look-tok, and a fishing village on its banks, Um-nok-a-luk-ta.

Black; rock ( 25 feet high), in Revillagigedo channel, south of entrance to Boca de Quadra, Alexander al'chipelago. Presumably a descriptive name, given by Nichols, 1883.

Black; rock, off the southwestern end of Kosciusko island, Ipluigenia bay, Prince of Wales archipelago, near latitude. $55^{\circ} 52^{\prime}$, longitude $133^{\circ} 45^{\prime}$. Descriptive name, given by Dickins, 1903-4.

Black: rock, in Sitka sound, Alexander archipelago, less than a mile westerly from Sentinel rock. This may be the Makbnak or the golia kamennya ostrovki (bare rocky islets) of Vasilief in 1809. The early and later representation and nomenclature here is confused.

Black; rock, in Kasaan bay, 2 miles north of Kasaan point, Clarence strait, Alexander archipelago, near latitude $55^{\circ} 28^{\prime}$, longitude $132^{\circ} 16^{\prime}$. Descriptive name, given by the local navigators and reported by Fassett, Bureau of Fisheries, 1904.

Black; rock (150 feet high), east of Crooked issland, in the Walrus Island group, Iristol hay. So named by the Fish Commission, 1890.

Blackbird; island, one of the Necker group, Sitka sound, Alexander archipelago. Named Diozdof (blackbird) by Vasilief, 1809.

Blackburn; coal mine, station, or landing, on the right bank of the Yulion, 57 miles above Anvik. Local name, from Cantwell, 1900. 
Blackburn; mountain (16,140 feet high), near Copper river. Named by Allen, iil 1385, after Hon. Joseph Clay Styles Blacikburn, of Kentucky.

Blackiburn; river, tributary to Copper river from the east, a little south of lattitude $62^{\circ}$. So named by Abercrombie in 1.898. This river is not shown on later maps.

Black Crag; peak (5,895 feet high), on the mainland, on the international boundary, about 8 miles south of Stikine river. Name published by the Coasi Survey in 1895 .

Black Crook; creek, tributary to Igloo creek from the north, Seward peninsula. Name from Brooks, 1900.

Black Diamond; creek, tributary to headwaters of Mission creek, in the Dagle Mining region. Local name, published in 1899 .

Black Head; point, on the eastern shore of Dease inlet, Arctic coast. So named by Dealse and Simpson, 1837.

Black River; settlements. The Eleventlı Census, 1890, sperks of the Black River settlements in the Yukon district. I suppose this refers to Eskimo villages along Black river in the Yukon delta.

Black Sand; island, on the const, 11 miles southeast of Yakutat, near longitude $139^{\circ} 30^{\prime}$. Descriptive name from Moser, 1901:

Blackstone; bay and glacier, in Prince William sound, opposite Port Wells, near latitude $60^{\circ} 40^{\prime}$, longitude $148^{\circ}$. $20^{\prime}$. Named after a miner who with two companions lost his life there in the winter of $1896-97$. From Glenn, 1898.

Blackthorn; peak $(4,010$ feet high $)$, on the western shore of Glacier bay, southeastern Alaska. Named Black 'I'hom by Reid, 1896.

Blaine; bay, a small bight in l\%embek bay, Alaskal peninsula. Named by the Fish Commission, 18S8, atter Hon. Tames Gillespie Blaine.

Blaine; point, on the mainland, near north end of Pearse camal, southeastern Alaskat. Named by the Coalst Survey, 1891, after Hon. James G. Blaine.

Blaine; point, the western point of entrance to Blaine bay in Izembek bay, Alaska peninsula. Named by the Fish Commission, 1.888, after Fon. James G. Blaine.

Blake; channel, separating southern part of Wrangell island from the mainland, Alexander airchipelago. Named by Dall, 1879, after Prof. William P'hipps Blatke, of New Halven, Conn., who mate explorations in this region in 1860 ?

Blake; island, at junction of Blake channel and Bradfield canal. Named Ham by Snow in 1886, and Blake by Nichols in $1899^{\circ}$.

Blaker, point; see Blitquiere.

Blanche; (white) rock (10 feet high), in Ernest sound, between Etolin and Deer islands, Alexander archipelago. So named by Snow, 1886 .

Blank; creek, Seward peninsula, tributary to Candle creek from the enst, latitude $65^{\circ} 50^{\prime}$, longitude $162^{\circ} 00^{\prime}$. l'rospector's' name, obtained by Witherspoon, 1903 .

Blank; inlet, indenting southeastern coist of Gravina island, Alexander archipelago. So named by Nichols, 1883.

Blank; two islets, at entrance to Blink inlet, above.

Blank; point, the southern point of entrance to Blank inlet, Nichols passage, southern Alaska, near latitude $55^{\circ} 15^{\prime}$, longitude $131^{\circ} 40^{\prime}$. Above name is applied to point by local navigators, and was reported by H. C. Fassett, Bureatu of lisheries, 1904.

Blanquizal; point, on west coast of Prince of Wales island. Named by Maurelle and Quadra, 1775-1779, and first published by La Perouse. 1798, as Pta. del Blanquizal. Also has been written Blanquisal. Blanquizal is Spanish for pipcclay. 
Blaquiere; point, the southeastern point of Mitkof island, Alexander archipelago. So named by Vanconver, 1793. By the Russians written Blaker.

Blashke; island, one of the Kashevarof group, Clarence strait, Alexander archipelago. Named by the Russians after Dr. Edward Leontief Blashke, surgeon on the ship Nikolai, Capt. A. K. Etolin, commanding, 18391841. Has also been written Blaschke and Bloshke.

Blassom, point; see Blossom.

Blatchford; coal mine on the right bank of the Yukpn below Nulato. Local name, from Collier in 1902.

Blatchford; creek, 12 miles north of Nome, Seward peninsula, tributary to Snake river from the east, near latitude $64^{\circ} 40^{\prime}$, longitude $165^{\circ} 25^{\prime}$. Local name, published in 1900.

Blei; gulch, on the south side of Chititu creek. Prospector's' name, reported by Schrader in 1903.

Bligh; island, in Prince William sound. Named Bligh's island, by Vancouver, 1794. Has also been written Blighs.

Blind; creek, Seward peninsula, small tributary on west bank of Casadepaga river, near latitude $64^{\circ} 46^{\prime}$, longitude $164^{\circ} 28^{\prime}$. Prospectors' name, reported by Gerdine, 1905.

Blind; gulch, 2 miles northeast of Nome, seward peninsula, on the east bank of Dry creek, near longitude $165^{\circ} 21^{\prime}$. Local name, from Gerdine, 1904.

Blind, inlet or passage; see Tenakee.

Blind; islind, near mouth of Blind river, in Wrangell strait, Alexinder archipelago. So named by Nichols, 1881 .

Blind; passage, between Black island and Hassler island, in Behm canal, Alexander archipelago. Named by the Coast Survey in 1891.

Blind; point, neir mouth of Blind river, Mitkof island, Wrangell strait, Alexander archipelago. Called Blind Passage point by Nichols, 1881.

Blind; river, in Mitkof island, tributary to Wrangell strait, Alexander archipelago. Before this region was explored it was supposed that a choked or obstructed passage existed here and connected with Blind slough, on the south shore of Mitkof island. Lindenberg, in 18:38, calls it Sukhoi malif (dry strait). Meade, in '1868, has Blind passage, said to lead to Clarence strait. This supposed channel which has been variously called Dry or Blind passage or channel does not exist.

Blind Slough. An indentation of the southern shore of Mitk of island, Sumner strait, Alexander archipelago, was, prior to the surveys by the Coast Survey, supposed to connect with Blind passage in Wrangell strait. The western part of this supposed (but nonexistent) Blind passage is now known as Blind river and its southern end Blind slough.

Bliskie, island; see Near.

Blizhni; point, on northern shore of Yakutat bay, southeastern Alaska. Named Blizhnie (near) by 'Tebenkof, 1849. Has also been called Blitzhni and Nearer.

Block; island, in Tlevak narrows, Prince of Wales archipelago. So named by Nichols, 1881.

Bloshke, island; see Blashke.

Blossom; cape, on eastern shore of Kotzebue sound, opposite Cape Espenberg. So named by Beechey, 1827, after his ship Blossom.

Blossom; island, a rocky mass, protruding through the Malaspina glacier in the St. Elias region, was found by the National Geographic Society exploring party, of 1890 , to be covered with flowers and accordingly named Blossom island. 
Blossom; point, the end of a sandy shorl on soutbwestern shore of Wrangell island, Arctic ocean. So named by Berry, 1881. Erroneously Blassom point.

Blossom; shoals, off Icy cape, Arctic ocenn. Described by Beechey, in 1.826, and named by him after his ship. In September, 1889, Commander $\mathrm{C}$. H. Stockton, of the U. S. S. I'hetis, erected a beacon on Icy calpe to mark the beginning of Blossom shoals.

Blue, island; see Crow.

Blue; point, on eastern shore of Portland canal. Descriptive name, given by Pender in 1868.

Blue; river, on the mainland, southeastern Alaska, the largest tributary of: Unuk river, on the north side, between Burroughs bay and the international boundary, near latitude $56^{\circ} 17^{\prime}$, longitude $130^{\circ} 50^{\prime}$. Local name. So described by Fremont Morse, of the Coast Survey, in 1905.

Blue Fox; bay, indenting the northern shore of Atka island, middle Aleutians. Named Pestsovaia (blue fox) by Ingenstrem about 18:30.

Bluestone; creek, eastern Alaska, on south bank of Gold creek, an affluent of: North fork Salcha river, near latitude $64^{\circ} 50^{\prime}$, longitude $145^{\circ} 45^{\prime}$. Prospectors' name, reported by Witherspoon, 1905.

Bluestone; river, tributary to Tuksuk chammel from the south, Seward peninsula. Name from Barnard, 1900.

Bluff; cape, on the eastern shore of Kizhuyak bay, Kodiak island. Named Otrubistoi (bluff) by Murashef, 1839-40.

Bluff; cape, the sonthwestern head of Afognak bay, Afognak island. Kodialk group. Named Otrubistoi (cut around, i. e., abrupt, perpendicular, bluff) iy Murashef, 1839-40.

Bluff; cape, the northernmost point of Dolgoi island, near Belkofski, south shore Alaska peninsula, near longitude $161^{\circ} 50^{\prime}$. Named by Dall, 1880.

Bluff; creek, Seward peninsula, tributary from the north to Arctic river near longitude $165^{\circ} 57^{\prime}$. Name from Gerdine, 1901.

Bluff; creek, Seward peninsula, tributary to headwaters of 'Turner creek, which is a tributary of Noxapaga river on the west; latitude $65^{\circ} 35^{\prime}$, longitude $164^{\circ} 25^{\prime}$. Name from Gerdine, 1901.

Bluff; creek, tributary to American creek from the east in the Bagle mining region. Local name, obtained by Barnard in 1898 .

Bluff; island, in entrance to Shipley bay, Sumner strait, Alexander archipelago. near latitude $56^{\circ} 06^{\prime}$, longitude $133^{\circ} 40^{\prime}$. Descriptive name, given by Dall in 1879.

Bluff; island, one of the Kashevarof group, Clarence strait, Alexander archipelago. Named by Snow, 1886 .

Bluff, jsland ; see Buyan.

Bluff; islet, on the southesatern edge of the Sandman reefs northeast of Siannak. So called by Dall, 1880.

Bluff; point, on the enstern shore of Portland canal. So called by Pender, 1.868 .

Bluff; point, on the northern shore of Woewodski harbor, Frederick sound, Alexander archipelago. Named by Mansfield, 1889.

Bluff; point, the northeastern head of Kootznahoo roads, Admiralty island. Alexander archipelago. Named published, 1881, on United States Hydrographic chart 882.

Bluff; point, the northern point of entrance to Wachusett cove, Freshwater bay, Chichagof island, Alexander archipelago. So named by Glass, 1881.

Bluff; point, the western point of entrance to Yes bay, Cleveland peninsula, Alexander archipelago. Named by the Coast Survey in 1891. 
Bluff; point, on the northern shore of Kachemak bay, Cook inlet. Descriptive name, given by Dall in 1880.

Bluff; point, the eastern point of entrance to Stepovak bay, Alaska peninsula. So named by Dall, 1880.

Bluff; point, north shore Mine harbor, Herendeen bay, north shore Alaska peninsula, near longitude $160^{\circ} 43^{\prime}$. Descriptive name, given by Tanner, 1890 .

Bluff; point, on the right bank of the Yukon, about 20 miles below Nulato. So called on recent maps.

Bluff; post-office (established in 1901) and settlement, noith shore Norton sound between Nome and Golofnin bay. Locally called Bluff City.

Blume; creek, tributary to Johnston creek from the north, Seward peninsula. Named from Barnard, 1900.

Blunt; mountain, on eastern shore of Annette island, Alexander archipelago. Named by Nichols, 1883.

Blunt; point, in Wrangell strait, near its northern end. Named by Lindenberg, in 1838 , Zhila (vein or lode), and a place about 1 mile farther north was named, also by Lindenberg, Tupoi (blunt) point. This Blunt point of Lindenberg was, in 1869 , called Cone point by Meade and, in 1881, Turn point by Nichols, by which name it is now known. This name Blunt is now applied to Lindenberg's Zhila point.

Blunt; point, on the western shore of Stepoval bay, Alaska peninsula. Named by Dall, 1880 .

Blant; point, the northern point of entrance to Letnikof cove, Chilkat inlet, Lynn canal, southeastern Alaska. Named Tupoi (blunt) by Lindenberg, 1838. Name obsolete.

Blying; sound, or open bay, on the southeastern shore of Kenai peninsula. According to Vancouver; it was so called by the Russians, before 1794, and called by Portlock, in 1.7\$7, Port Andrews. Also written Blyings and Blying's and Canal Blyings.

Boat; channel, in Red bay between Danger island and Prince of Wales island. So called by the Coast Survey in 1888. May not be intended for: a name, but only designed to indicate that here exists a channel for boits.

Boat; harbor, a little west of Golofnin bay on northern shore of Norton sound. Apparently so named by the Coast Survey in 1899.

Boat; harbor, in Peninsula ridge at south end of Revillagigedo channel. Visited but not named by Vancouver, in 1798 , who describes it as "a very commodious well-sheltered little cove about half a league to the westward of Cape Fox."

Boat; harbor, on western coast of Lynn canal, just north of. St. James bay. Described in Coast Pilot as "a boat harbor" and on Coast survey chart 8300 (edition of 1893 ) called Boat harbor.

Boat; rock, in Cordova bay, Alexander archipelago, near latitude $54^{\circ} 49^{\prime}$. so named by Moser, 1897.

Boat; rock, in entrance to Nakat inlet, near Cape Fox, Dixon entrance, Alexander archipelago. Named by Nichols, 1883.

Boat Extreme. This name was given by Dease and Simpson, in 1837 , to the westernmost point (longitude $154^{\circ} 23^{\prime}$ ) , reached by them, by boat, in their journey from Mackenzie river mouth to I'oint Barrow.

Boat Harbor; point, being one of the heads of Boat harbor, near Cape Fox, Alexander archipelago. So called by Meade, 1869.

Bob; creek, Seward peninsula, tributary to Bear creek from the west, latitude $65^{\circ} 30^{\prime}$, longitude $161^{\circ} 05^{\prime}$. Prospectors' name, from Witherspoon, 1903.

Bob; creek, tributary to Pine creek, Seward peninsula; see Battle. 
Bob; gulch, at the hendwaters of Chititu creek. 1'rospectors' name, reported by Schrader in 1903.

Bobrof, bank, etc.; see Seil Otter.

Bobrof, island, between Kanaga and Tanaga; see Sea Otter.

Bobrof, island; see Beaver.

Bobrovie, point, Kruzof island; see Beaver.

Bolrovoi, laly ; see Otter.

Botrovor, bay, cove, etc.; see Beaver.

Bobrovoi; point, near south end of Barranof island, the southern point of entrance to Lalreh bay, Alexander archipelago. Named Bobrovoi (sea otter) by the Russians.

Bobrotskoi, mountain; see Beaver.

Boca de Quadra; canal or fiord, indenting the mainland coast of southeastern Alaski, east of: Reviliagigedo chamel, Alexander archipelago, near latitude $55^{\circ}$. Apparently so named by Calamaño in 1792 . Has also been called Quadra bay, Quadra channel, and often Bokay inlet. Boca de Quadra is Spanish for chamnel or passige of Quadra, i. e., Quadra's channel.

Boca Fina; see Bocas de Finas.

Bocas; point, in Port Refugio, Bucareli bay, Prince of Wales archipelago. Named Puntit de las Bocas (point of the mouths) by Maurelle and Quadra, 1775-1779.

Bocus de Arriagu; see Arriagil.

Bocas de Finas. A nime alplied by Qualdra and Artengi, 1779, to the unexplored inlets or bays at the extreme northern part of Bucareli bay, where their explorations ended. The name appears to have intended the commemoration of the fact. 'Termination bays or inlets would seem to be the meaning. According to Davidson it is Boca de Finas on the original Spanish chart. Hals also been called Boca Fina.

Bocas del Almirante. Some unexplored inlets on the north shore of Bucareli bay, Prince of Wales irchipelago, were so designated by Maurelle and Qualdr: $1775-1779$.

Bocharoff, lake; see Becharof.

Bochonoff, lake; see Bechirof.

Bock; bight, in Thomas bay, eastern coast of Frederick sound, Alexander archipelago. So named by Thomas, 1.887.

Boer; creek, 25 miles north of Nome, Seward peninsula, tributary from the south to Fudson creek, an affluent of Buffalo creek at the headwaters of Nome river, near longitude $165^{\circ} 17^{\prime}$. Miners' name, reported by - Gerdine, 1904.

Bog; calpe, between Protection bay and Three Islind bay, on southeastern shore of Unilaska, eastern Aleutians, near longitude $166^{\circ} 36^{\prime}$. So called by the Fish Commission in 1.858. It is Ianaliun or Yanaliun of Tebenkof, 1849, and Alexander, of the Const Survey, in 1900.

Boga Slov, hill; see Bogoslof.

Bogert; point, on eastem shore of Port Snettishim, Stephens passage, Alexander archipelago. So named by 'Thomas, 1888 .

Bogoslof; hill (591 feet high), on St. Paul island, Pribilof group, Bering sea. Called Bogosloff mountain by the Coast Survey. H. W. Elliott calls it Boga slov and adds Boga slor (word of God), indefinite in its application to "the place, but is, perhaps, due to the fact that the pious Russians, immediately after landing at Zapadnie, in 1787, ascended the hill and erected a huge cross thereon." 
Bogoslof; volcanic island, in Bering sea, about 25 miles north of the western end of Unalaska, near latitude $53^{\circ} 55^{\prime}$, longitude $168^{\circ}$. This island rose from the sea May 18, 1796, St. John's day, and received from the Russians the name Joanna Bogoslova, or John the Theologian's island. It has been called Bogoslov, Johamn Bogoslow, St. Jean Bogosloff, etc. Its native name, according to Grewingk, is Agaschagoch, or, is it may be written, Agashagok. Beechey (pp. 563 and 639) refers to it as Amnuk and Amnak, probably variant forms of Umnak, to which island Bogoslof was thought to be joined and was so shown on some early maps. In 1883 a new volcano rose near this one, which is accordingly now called Old Bogoslof. From 1884 to 1890 the two, connected by a spit, formed a single island.

Bohemian; range of mountains $(2,000$ to 2,500 feet high), on the north shore of Kupreanof island, Alexander archipelago. So named by Thomas, 1887.

Boidarkin; island, one of the Kutchuma group, Sitka sound, Alexander archipelago. So named by Vasilief, 1809. Has also been called Boidarka and Hawley. It is a corruption of bidarka, the Aleut name of their skin canoe.

Boil, cape; see Mohican.

Boil; creek, tributary to Skookum river, near its source, Seward peninsula. Name from Barnard, 1900.

Boise; creek, tributary to Coal creek from the north, Seward peninsula. Name from Barnard, 1900.

Bok, island; see Bin.

Bokay, inlet; see Boca de Quadra.

Bold; cape, the western point of entrance to Belkofski bay, Alaska peninsula. near longitude $162^{\circ} 13^{\prime}$. Named Stolb (pillar) by the Russians, and usage divided between Pillar and Bold. Descriptive name.

Bold; cliff, on northeastern shore of Hood bay, Admiralty island, Alexander archipelago. Descriptive name, said to have been given by Meade in 1.869 .

Bold; island, in Revillagigedo channel, northeast of Annette island, Alexander. archipelago. Named by Nichols, 1883.

Bold Bluff; point, on the south shore, near the hend of Herendeen bay, Alaska peninsula, about longitude $160^{\circ} 45^{\prime}$. Descriptive name, given by 'Tanner in 1.890 .

Boldrin; creek, 27 miles north of Cape Nome, Seward peninsula, tributary to Eldorado river, from the west near longitude $165^{\circ}$. Name from Barnard, 1900 .

Bolivnoi, rocks; see Surf.

Bolles; inlet, indenting western shore of Long island, Kaigani strait, Alexander archipelago. Named by Dall, in 1882, after Lieut. T. Dix Bolles, U. S. N.

Bolles; ledge in Ward cove, Tongass narrows, Alexinder archipelago. Discovered and named after Lieut. Timothy Dix Bolles, U. S. N., about 1882.

Bolshoi, island, Peril strait; see Big.

Bolshoi; mountain peaks; see Foraker and McKinley.

Bolshoi, point; see Manby.

Bolshoi Krieposti, islet; see Big Fort.

Bolshoi Malinof, island; see Raspberry.

Bolshoi rukav or Great sleeve; see Great.

Bolshoi Rukav, bay; see Big Branch.

Bolshoi Strelki or Big Arrow bay; see Big Branch. 
Bolshoiger. Petrof, on his census map of 1850, gives this as the name of a village on the right bank of the Yukon, about 25 miles above the mouth of the Koyukuk. Name not found in his text nor anywhere else.

Bomb; point, west point of entrance to Simpson bay, north shore Orca bay, l.rince William sound, near latitude $60^{\circ} 37^{\prime}$, longitude $145^{\circ} 50^{\prime}$. ₹ Written Rom by Moser in 1897, and Bomb by Abercrombie in 1898.

Bomohoi, islind; see Lalrge.

Bonanza; bar, on Fortymile creek, near the international boundary line. Prospectors' name, reported by Wells in 1890.

Bonanza; creek, tributary. to Casadepaga river from the west, Seward peninsula. Nime from Barmard, 1900.

Bonanza; creek, 30 miles north of Cape Nome, Seward peninsuliı, tributary to Silnon like, from the south, longitude $1\left(6^{\circ}\right.$. Name from Barnard, 1900.

Bonanza; creek or river, tributary to l'ort Safety, Seward peninsulit. Local name published in 1900. Also called Bonanza Cal. A late malp malkes California creek a principal tributary of this stream. According to Brooks, the Eskimo name is Ki-ul-uk.

Bonanza; creek, Seward peuinsula, tributary to Kuzitrin river from south, latitude $65^{\circ} 20^{\prime}$, longitude $164^{\circ} 00^{\prime}$. Prospectors' name, from Gerdine, 1901 .

Bonanza; creek, Seward peninsula, tributary to Kiwalik river from the west, latitude $65^{\circ} 42^{\prime}$, longitudè $162^{\circ} 00^{\prime}$. Prospectors' name, obtained by Witherspoon, 1.903.

Bonanza; creek, eastern Alaskil, Salcha River drainage, tributary on south barnk of Gold (reek; near latitude (it. ${ }^{\circ} 0^{\prime}$, longitude $1455^{\circ} 3 y^{\prime}$. l'rospector's' nilme, reporte? by Witherspoon, 1905.

Bonanza; creek, eastern Alaska, a right branch of Charley river, an affluent of the lukon on the south, nealr longitude $142^{\circ} 45$. P'rospectors' name, reported by Collier in 1902. Called also Big Bonanzal and Fish creek.

Bonanza; creek, in the Birch Creek region, tributary to Porcupine creek from the right, neal latitude $65^{\circ} 30^{\prime}$, longitude $145^{\circ} 20^{\prime}$. Frospectors' name, reported by Spurr, Goodrich, and Schrider, 1896.

Bonanza; gulch, 7 miles north of Nome, Seward peninsula, draining into Glacier creek from the south near longitude $165^{\circ} 25^{\prime}$. Local name, publisher in 1903.

Bond; bay, inside Caamaño point at northern entrance to Behm canal, southeastern Alaska, near latitude $55^{\circ} 30^{\prime}$, longitude $131^{\circ} 57^{\prime}$. Tocal navigators' name, reported by H. C. Fassett, Burean of Fisheries, 1904.

Bond; creek, tributary at the headwaters of Nabesna river from the east. Suggested to Schrader in 1902 by the native name 'Is-um-bon-da.

Bonita; creek, 15 miles north of Cape Nome, Seward peninsula, tributary from the west to the head of Osborn creek, near latitude $64^{\circ} 38^{\prime}$, longitude $105^{\circ} 10^{\prime}$. Local name, published in 1901.

Bonita; creek, Sewird peninsula, Casadepagil drainage, tributaly on south bank of Canyon creek, near latitude $64^{\circ} 51^{\prime}$, longitude $164^{\circ} 23^{\prime}$. P'ospectors' name, reported by Gerdine, 1905.

Bon-i-thaw-yate-le-ne; mountain, on the right bank of the Yukon at the mouth of the 'Tanana, near latitude $65^{\circ} 20^{\prime}$, longitude $152^{\circ}$. Herion got this from the Indians in 1899. For use it might be reduced to Bonithaw.

Bonnerfield, mining district; see Bonnifield.

Bonncrville, mining district; see Bonnifield.

Bonnot, creek; see Slate.

Bonneville, mining district; see Bonnifield.

Bonnie; point, on southern shore of Whitewater bay, Chatham strait, Admiralty island, Alexander archipelago. Named by Giass, 1881. 
Bonnifield; mining district, the foothill region of the Alaska range, south side of Tanana valley, about 50 miles south of Fairbanks, near longitude $149^{\circ}$. So named by the miners after John $\mathrm{E}$. Bonnifield, one of the first to prospect here, and reported by Prindle, 1904. Erroneously Bonnerfield, Bonnerville, and Bonneville.

Bonton; creek, in the Fortymile region, tributary to Champion creek from the left, near latitude $64^{\circ} 30^{\prime}$, longitude $142^{\circ}$. Prospector's' name, reported by E. F. Ball, a mospector, 1898 .

Boomer; creek, Seward peninsula, tributary to Big Bar creek, which is a tributary to Koyuk river. Latitude $65^{\circ} 30^{\prime}$, longitude $162^{\circ} 20^{\prime}$. Prospectors' name, from Witherspoon, 1903.

Boomer; creek, eastern Alaska, on the left batnk near the mouth of Beaver creek, an affluent of the Yukon river, near longitude $147^{\circ} 20^{\prime}$. Prospectors' name, reported by Lieutenant IRrickson, U. S. A., 1902.

Boothby; creek, north of Baker flats on the Tanana, tributary to Pioneer creek, from the Northwest. Frospector's' name, obtained by L'rindle, 1904.

Bophor, cape; see Beaufort.

Border; two rocks, forming part of the Gavanski (barbor) group of islands, Starrigalvan bay, Sitka sound, Alexander archipelago. Named Griada (border) by Vasilief, 1809.

Bore; rock, in entrance to Duncan canal, Kupreanof island, Alexander archipeligo. Nimed by Thomas, 1857.

Boreas; point, the north point of entrance to Breezy bay, Dall island, Alexander archipelago, Named by Dall, 1882.

Borg; creek, 15 miles north of Nome, Seward peninsula, tributary to Snake river from the ealst, near longitude $165^{\circ} 23^{\prime}$. Local name, written Burg by Schrader, 1899, and Berg on a local map of 1900 .

Borlia, island ; see Biorka.

Borka, village; 'see Biorki.

Borlase; point; on the northwestern shore of Warren island, Sumner strait, Alexander archipelago. Named by Vancouver, 1793, after Capt. Sir John Borlase Warren.

Boroshlit, bay; see No Thorofire.

Boston; creek, at headwaters of Baker creek, lower Tanani valley, tributary to Eureka creek from the west. Prospectors' name, published in 1902.

Boston; creek, Seward peninsula, on west bank of Shovel creek, a tributary of Solomon river from the west, near latitude $64^{\circ} 38^{\prime}$, longitude $164^{\circ} 25^{\prime}$. Prospectors' name, from a locai map, 1904.

Boston; gulch, 8 miles north of Nome, Seward peninsula, on the south side of Glacier creek, near longitude $165^{\circ} 21^{\prime}$. Local name, published in 1.904.

Boston; gulch, eastern Alaska, on the north bank of Bonanzal creek, a tributary of Charley river, from the east, near latitude $65^{\circ} 10^{\prime}$, longitude $142^{\circ} 50^{\prime}$. Prospectors' name, from sketch map compiled by Major Glassford, Signal Corps, U. S. A., 1.905.

Boston; islands, near the southwestern shore of Wales island, Dixon entrance, Alexander archipelago. So named by Pender, 1868.

Bostwick; inlet, iudenting the soutbeastern shore of Gravina island, Alexander archipelago. Named by Nichols, 1883, presumably after Lieut. Frank Matteson Bostwick, U. S. N., a member of his party.

Bostwick; sunken reef, in Felice strait, Gravina group, Alexander archipelago Named by Nichols, 1883.

Boswell; bay, in eastern end of Hinchinbrook island, Prince William sound, near latitudes $60^{\circ} 25^{\prime}$, longitude $146^{\circ} 05^{\prime}$. Name from Ritter, 1899 .

Botcharoff, lake; see Becharof. 


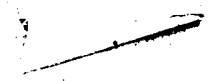

Botinski; island, not identified, near Unihak pass; mentioned by Langsdorf (Voyage, 11, 54).

Bottomless; lake, near Portage bay, Alaska peninsula. Named by the Russians Bezdonuoi (without bottom).

Botuk, creek; see Baituk.

Boulder; bay, indenting the northeastern shore of Prince William sound, east of Bligh island, near latitude $60^{\circ} 50^{\prime}$, longitude $146^{\circ} 35^{\prime}$. Fublished by the Coast Survey in 1900 ; probably reported by Ritter, 1899 .

Boulder; bay, indenting eastern shore of Stepovak bay, Alaska peninsula. Named by Dall, 1880 .

Boulder; cape, on north coast of Kodiak. Named by the Russians Mies pokatago utesu (cape of the rolling rock). Descriptive term.

Boulder; creek, tributary from the north to Klehini river, in the Porcupine mining region. Prosiectors' name, published in 1900. Krause brothers, 1882, wrote the Indian name Jockeấch.

Boulder; creek, tributary to the Copper river from the east, north of Mount Sanford. Named by Abercrombie, 1898.

Boulder; creek, tributary to Kanata river from the west. Name from Schrader, 1900.

- Boulder; creek, tributary to Chickaloon creek, about 40 miles northeast of Knik arm of Cook inlet. Prospector's' name, reported by Lieutenant Castner, of Glenn's party, in 1898. Named Schoonhoven by Glenn, 1S98, after George W. Van Schoonhoven, a member of his party. Erroneously Schoonoven.

Boulder; creek, 10 miles north of Nome, Seward peninsula, tributary to Suake river, from the west, near longitude $165^{\circ} 28^{\prime}$. Prospectors' name, published in 1900 and spelled Bowlder and Boulder.

Boulder; creek, 20 miles north of Nome, Seward peninsula, tributary to Stewart river, from the south, near longitude $165^{\circ} 25^{\prime}$. Name from Barnard, 1900.

Boulder; creek, Seward peninsula, tributary to 'Turner creek, which is a tributary of Noxapagal river. Ialtitude $65^{\circ} .35^{\prime}$, longitude $164^{\circ} 20^{\prime}$. Iro : pectors' name, from Gerdine, 1901.

Boulder; creek, tributary to Sinuk river from the west, Seward peninsulit. Nime from Barnaird, 1900.

Boulder; creek, Seward peninsula, Casadepaga drainage. tributary to Canyon creek from the north, near latitude $64^{\circ} 52^{\prime}$, longitude $164^{\circ} 23^{\prime}$. Prospector's' name, from a locil maly, 1901.

Boulder; creek, tributary to Vulcan creek from the west, southeast of Omalik mountain, Seward peninsula. Prospectors' name, from Peters, 1900.

Boulder; creek, in the Birch Creek region, tributary to Crooked creek from the right, near latitude $65^{\circ} 30^{\prime}$, longitude $145^{\circ}$. Prospectors' name, reported by Spurr, Goodrich, and Schrader, of the Geological Survey, 1896.

Boulder; creek, tributary to the Yukon from the west, 4 miles below Eagle. Prospectors' name, obtained by Barnard in 1898.

Boulder, creek, near Eagle; see Colorado.

Boulder; creek, tributary from the west to South fork of Koyukuk river, near latitude $67^{\circ} 15^{\prime}$. Local name, ontained by Peters and Schrader, 1901.

Boulder; extensive flat of mud and boulders near Vexation point, in Wrangel! strait, Alexander archipelago. So called by Dall in the Costst Pilot, $188: 3$.

Boulder; gulch, on the south side of Young creek, which in turn is tributary to Nizina river. Prospectors' nime, first appears on map of Nizina mining district by George M. Esterly, Valdez, 1902.

Bull. $299-06 \mathrm{M}-10$ 
Boulder; hill, in the Birch Creek region, 17 miles southwest of Circle city. Prospectors' name, obtained by Gerdine, 1903.

Boulder; island, in Camden bay, Arctic coast. So named by Franklin, in 1826, because it appeared "to be a collection of boulder stones" (p. 148).

Boulder, island; see Karpa.

Boulder; mountain (3,790 feet high), on the mainland, near junction of Katete and Stikine rivers. Name published by the Coast Survey in 1895.

Boulder; point, in Tlevak narrows, Prince of Wales island, Alexander archipelago. So named by Dall in the Coast Pilot, 1883.

Boulder; point, on the eastern shore of Kuiu island, Sumner strait, Alexander archipelago. So named by Helm, 1886.

Boulder; point, the eastern point of entrance to Portage bay, Kupreanof island, Alexander archipelago. So named by Nichols, 1882.

Boulilyr, island ; see Buldir.

Boundary; butte or peak (about 2,500 feet high), near junction of Seventymile creek and the Yukon at the international boundary. Named Boundary Butte by Schwatka, 1883, who says its native name is 'Ta-tót-lee.

Boundary; creek, tributary to White river from the south, near the international boundary line. Descriptive name, publisbed by the Geological Survey in 1900 .

Boundary; creek, tributary to the Yukon from the west at the international boundary, in latitude $64^{\circ} 40^{\prime}$. Local name, published in 1898.

Boundary; mountain, on south bank of Porcupine river, at the international boundary. So named by the Coast Survey about 1890 . Erroneously Boundry.

Boundary; mountain $(4,805$ feet high), on west bank of Stikine river, near international boundary line. Name published by the Coast Survey in 1895 .

Boundary; rock, on the international boundary, about 15 miles north of Porcupine river. So called by the Coast Survey about 1890 .

Boundary, strait; see Dixon entrance.

Boundary; telegraph station, on the Yukon at the international boundary. Called Boundary and Boundary Fost on the Signal Corps map of 1904.

Bourbon; creek, at Nome, Seward peninsula, tributary to the mouth of Snake river, from the north. Prospector's' name, published in 1900.

Bourdieus; bay; in Vancouver's atlas this name is applied to the part of Kamishak bay south and southwest of Augustine isalnd. On the map in the second edition of Vancouver's Voyage it is Bourdiens. Not discovered which is correct, nor after whom named. Name now obsolete.

Boussole, Point de la; see Manby.

Bove, lake ; see Tagish.

Bow; cape, on north coast of Alaska peninsula, a little east of Irembek bay, near longitude $162^{\circ} 30^{\prime}$. So named by the Fish Commission in 1888.

Bow; creek, tributary to Chisana river at its source, near latitude $62^{\circ} 04^{\prime}$, longitude $142^{\circ} 10^{\prime}$. Descriptive name, given by Schrader in 1902 .

Bowhead; creek, 12 miles northwest of Nome, Seward peninsula, a tributary on the left bank of Cripple river near its moutb, about longitude $165^{\circ} 45^{\prime}$. Prospector's name, published in 1900. Has been written Bowheads and Bowherd.

Bovie, bay; see Two Moon.

Bowlder, creek; see Boulder.

Bowser; creek, tributary to Oil bay on the west side of Cook inlet, near latitude $59^{\circ} 40^{\prime}$. Named after August Bowser, an oil operator. Reported by Martin, 1903 . 
Bozman, mountain; see Seattle.

Brad; rock, submerged, 175 yards from the west shore of Kakul narrows, Peril strait, Alexander archipelago, near latitude $57^{\circ} 22^{\prime}$, longitude $135^{\circ} 41^{\prime}$. So named by Moore, 1898, probably after Ensign G. B. Bradshaw, U. S. N., a member of his party.

Bradfield; canal, penetrating the mainland north of Cleveland peninsula, Alexander archipelago. Called Bradtield channel by Vancouver, 1793.

Bradford. The Eleventh Census, 1890, reports a village of this name in the Nushagak enumerating district, with a population of 166 . Location not shown on any map consulted.

Bradley; river, tributary to Tanana river, from the south, near longitude $149^{\circ}$. So named by Allen, 1885.

Bradshaw; cove, north shore Peril strait, just inside the western entrance, near: latitude $57^{\circ} 23^{\prime}$, longitude $135^{\circ} 40^{\prime}$. So named by Moore, 1896 , after: Ensign G. B. Bradshaw, U. S. N., a member of his party.

Brady; glacier, at head of Taylor bay, Cross sound, southeastern Alaska, near longitude $136^{\circ} 40^{\prime}$. Named by the Coast Survey, 1883, after Rev. (afterwards Governor) John G. Brady, missionary and teacher who iwent to Sitka and began work in 1878.

Brady, island ; see Polnoi.

Branch; creek, tributary to South fork of the Koyukuk, from the enst, near latitude $68^{\circ}$. Prospectors' name, published by the Coast Survey in 1899.

Brandon; gulch, 8 miles north of Nome, Seward peninsula, on east bank of Glacier creek, near longitude $165^{\circ} 20^{\prime}$. Local name, publisbed in 1904.

Breakers, cape; see Burunof.

Breast; island, one of the Galankin group, Sitka sound, Alexander archipelago. Named by United States naval officers, 1880.

Breed, isliand ; see Tanginak.

Breezy; bay, in Tlevak strait, Dall island, Alexander archipelago. So named by Nichols, in 1.881, on account of the strong winds encountered there.

Breezy; point, on the western shore of Portland canal, southeastern Aláska. So named by Pender, 1868.

Bremner; river, tributary, from the east, to the lower part of Copper river. So named by Allen, in 1885, after John Bremner, a miner who, in 1884, ascended the Copper as far as Taral and wintered there 1884-85. Allen reports its native name to be Tetahena, i. e., Teta river. Often miscalled Brenner.

Brennan; bay, indenting the south shore of Cholomondeley sound, southeastern shore Prince of Wales island, Alexander archipelago, near latitude $55^{\circ} 12^{\prime}$, longitude $132^{\circ} 08^{\prime}$ : Prospectors' name, reported by Brooks in 1901.

Brian, islands; see Inian.

Brickyard; harbor, in Long island, near St. Paul, Kodiak. Name not before published, so far as known. Old Russian charts indicate the existence of a brickyard on the shores of this unnamed harbor.

Bride; point, in Port Snettisham, Stephens passage, on the mainland, Alexander archipelago. Named by Thomas, 1888 .

Bridge; point, on northern shore of Kootznahoo. inlet, Admiralty island, Alexander archipelago. So named by Meade, 1869, after Midshipman (afterwards Lieutenant) Edward W. Bridge, U. S. N., one of his oflicers.

Bridget; cove, in Lynn canal, near Bridget point. Named by the Coast Survey in 1893 .

Bridget; point, the south point of entrance to Berner's bay, Lynn canal, Alexander archipelago. So named by Vancouver in 1794. 
Brightman; point, the south point of entrance to Herring bay, Frederick sound, Alexander archipelago. Named by the Coast Survey in 1899. 'This point may be identical with Townshend of Vancouver.

Brinterson, mountain; see Brynteson.

Bristol; bay, indenting the southeastern shore of Bering sea. So named by Cook, in 1778, "in Lonour of the admiral Warl of Bristol." Grewingk hats Bristol or Kwitschak.

Bristol, river; see Nushlilgalk.

Bristolski, point; see Etolin.

British; chain of mountains, on northern coast of Alaska, near international boundary. So named by Franklin, 1826 .

British; point, on the eastern shore of Portland canal, near its head. Name published by the Coast Survey in 1897.

Broad; bay, on western shore of Unalaska bay, eastern Aleutians, near longitude $166^{\circ} 38^{\prime}$. Called Shirokaia (broad) by Veuiaminof. Descriptive name.

- Broad; bight, indenting the northeastern shore of Sarana bay, southern shore of Akutan island, Krenitzin group, eastern Aleutians, near longitude $165^{\circ} 55^{\prime}$. Descriptive name given by Gilbert, 1901.

Broad, cape, in Sitka sound; see Burunof.

Broad; cape, the eastern point of entrance to Pavlof bay, near Belkofski, Alaska peninsula. Named by. the Russiaus Tolstoi (broad), and variously called Broad or 'Tolstoi. Descriptive term.

Broad; island, near junction of IIooniah sound and Peril strait, Alexander archipelago. Named Poperechnoi (across on the other side, crosswise, transverse, lying across, "tlwart-ship," etc.) by Vasilief, 1833 . Has been translated Broad and has appeared as Poperetch or Broad island.

Broad, pass; see Caribou.

Broad; point, between Kalsin and Middle balys, in Chiniak bay, Kodiak. Named 'Tolstoi (broad) by Russian naval officers, 1809.

Broad, point; see Tolstoi.

Broad; point, on the northern shore of St. Michael island, Norton sound, near latitude $63^{\circ} 32^{\prime}$, longitude $162^{\circ} 09^{\prime}$. Descriptive name, given by Coast Survey parties, 1898-1900.

Broken Neck; creek, eastern Alaska, on the north bank of Seventymile creek, near latitude $65^{\circ}$, longitude $141^{\circ} 45^{\prime}$. Prospectors' name, from sketch map compiled by Major Glassford, Signal Corps, U. S. A., 1905.

Bronaugh; islands, off Dall Head, Gravina island, Alexander archipelago. Named by Nichols, 1883, after Lieut. William Venable Bronaugh. U. S. N., a member of his party.

Bronson; creek, tributary to Middle fork of the Koyukuk, from the north, near longitude $150^{\circ} 30^{\prime}$. Prospector's' name, published in 1900 .

Brools, harbor; see Nuchek.

Brooks; mountain (2,918 feet high), in York mountains, Seward peninsula, near latitude $65^{\circ} 30^{\prime}$, longitude $167^{\circ} 10^{\prime}$. Named by Gerdine in 1901 after Alfred Hulse Brooks, of the Geological Survey.

Brothers (The); group of islands and rocks off Point Pybus, Frederick sound, Alexander archipelago. Named by Nichols, 1882.

Brothers (The); islets, in Gulf of Esquibel, Prince of Wales archipelago. Named Los Hermagos by Maurelle and Quadra, 1775-1779. Los Hermagos is here assumed to be an error for Los Hermanos (the brothers).

Brothers (The); islets, in San Christoval channel, Bucareli bay, Prince of . Wales archipelago. Named Los Hermanos (the brothers) by Maurelle and Quadra, 1775-1779. 
Brothers (The); see Lynn Brothers.

Brow; point, in Behm calnal, the south point of entrance to Gedney passage. Named by the Coast Survey in 1891. Nose and Chin points are near by.

Brown; cove, in mainland, northeast of north end of Wrangell strait, Alexander: archipelago. So named by Thomas, 1887 .

Brown; creek, tributary to Dry bay, west shore Cook inlet, near latitude $59^{\circ}$ 40 '. Named ifter "Andrew Brown, a pioneer," and reported by Martin in 1.903.

Brown; creek, Seward peninsula, tributary to Taylor creek on the south, near: latitude $65^{\circ} 04^{\prime}$, longitude $164^{\circ} 40^{\prime}$. Local name, from Gerdine, 1901.

Brown; glacier, at head of Fords 'Terror, Endicott arm, IIolkham bay, Alexander archipelago. Name published by the Coast Survey in 1895 .

Brown; mountatin, in western part of Revillagigedo island, Alexander archipelago. Named by Clover, 1.885.

Brown; mountain (5,800 feet high), on the eastern shore of Portland canal. Named by Pender, 1868.

Brown; peak $(1,300$ feet high) on the southern shore of Unimak island, 6 miles west of: Cape Lazaref, near: longitude $163^{\circ} 45^{\prime}$. So called by Westdihl, 1.901.

Brown; point (Point Brown), eastern shore Kruzof island, Fayward strait, Sitka sound, Alexander archipelago, near latitude $57^{\circ} 09^{\prime}$. So named by Moore, 1897.

Brown and Johnson; salmon stream, Prince of Wales island, soutleastern Alaska, on the western shore of Skowl arm, Kasaan bay, near latitude $55^{\circ} 25^{\prime}$, longitude $132^{\circ} 27^{\prime}$. So known in the fisheries and reported by

- Moser, 1897.

Brownlow; point, the western head of Camden bay, Arctic coast. So named by Franklin, 1826.

Brownson; bay, indenting the southern shore of Prince of Wales island, Alexander archipelago, about 8 miles west of Cape Chacon, Dixon entrance. Named by the Coast Survey after Commander Willard Herijert Brownson, U. S. N.

Brownson; island, separated from Ntolin island by Canoe passage, in Einest sound, Alexander archipelago, near latitude $56^{\circ}$, longitude $182^{\circ} 10^{\prime}$. Named ly the Coast Survey, in 1891, after Commander Brownson.

Bruch; spit, off northeastern coast of Wrangell island, Arctic ocean. So named by Berry, $1.8 s 1$.

Bruin; bay, on west shore of Kamishak bay, Cook inlet, near latitude $59^{\circ} 23^{\prime}$. Local name Bear bay, reported by Martin in 1904. Named Bruin by the U. S. Board on Geographic Names, June $6,1906$.

Brumeux, cape; see Foggy.

Brumez, point; see Foggy.

Brundage; head, on the eastern shore of Unalaska island, Unalga pass; being the north point of entrance to Beaver inlet, near longitude $166^{\circ} 12^{\prime}$. Named, presumably, after F. H. Brundage, of the Coast Survey, one of - Gilbert's party in 1901.

Brundige; reef or ledge, in south end of Clarence strait, designated in the Coast. Filot (1883) after Capt. J. C. Brundige, R. N., who reported it. This' reef or one near it has since been located and named, by the Coast Survey, Hassler reef. It is now established that these are different names of the same thing. See Hassler. 
Brunn; point, on the eastern shore of Carroll inlet, Revillagigedo island, Alexander archipelago, near latitude $55^{\circ} 22^{\prime}$, longitude $131^{\circ} 23^{\prime}$. Local navigators' name, probably after Captain Brunn, a local master and pilot, and reported by H. C. Fassett, Bureau of Fisheries, 1904.

Brush; hill, on Revillagigedo island, near Ward cove, Alexander archipelago. Named by Nichols, 1883. Erroneously Bush hill.

Bryan; creek, Seward peninsula, tributary to the headwaters of. Serpentine river, latitude $65^{\circ} 50^{\prime}$, longitude $164^{\circ} 58^{\prime}$. Local name, from Gerdine, 1901.

Bryan; creek, eastern Alaska, on the south bank Slate creek at the head of North fork of Fortymile creek, about latitude $64^{\circ} 35^{\prime}$, longitude $142^{\circ} 35^{\prime}$. Prospectors' name, from sketch map compiled by Major Glassford, Signal Corps, U. S. A., 1905.

Bryan; creek, tributary to Seventymile creek; see Bryant.

Bryant; creek, tributary to Seventymile creek, from the south, north of the Fortymile mining region. Local name, reported by Barnard in 1898. Erroneously Bryan.

Bryant; point, in Kootznahoo inlet, Admiralty island, Alexander archipelago. . Named by Meade, in 1869, after Mr. Charles Bryant, for several years United States Treasury Department agent on the Pribilof islands.

Bryant; point, the south head of McLeod harbor, Montague island, Prince William sound. Was so named by Portlock, 1787.

Bryn Mawr; glacier, tributary from the west, to College fiord, Port Wells, Prince William sound. So named by the Harriman expedition, 1899, after Bryn Mawr College.

Brynteson; mountain, 10 miles north of Nome, Seward peninsula, on east side of Snake river, near latitude $64^{\circ} 38^{\prime}$, longitude $165^{\circ} 23^{\prime}$. Named after John Brynteson, one of the first to stake claims near Nome in 1898. Erroneously Brinterson.

Bubb; creek, tributary to Tazlina river, from the north, near latitude $62^{\circ}$. Proper name, given by Glenn in 1898 , who gives its native name as Taiklano.

Bucareli; bay, on the western side of Prince of Wales archipelago. Discovered by Maurelle, in 1775, and surveyed and named by-him Puerto del Baylio Bucareli, in honor of Don Antonio Maria Bucareli y Ursua, viceroy of Mexico. Varigusly called a bay, gulf, harbor, port, or sound and its name variously written Bucarelli, Buccarelli, Bukarelli, etc.

Buccleugin; sound. The eastern part of Dixon entrance was named Buccleugh's by Meares in 1789. Spelled, erroneously, on his charts Bucclugh. Name obsolete.

Buck; creek, in the Mentasta mountains, tributary to Little Tok river at its source. So named by Schrader in 1902 from the dense growth of buck brush in its valley.

Buck; creek, Seward peninsula, tributary to Grouse creek from the northwest, near latitude $65^{\circ} 38^{\prime}$. Name, from Gerdine, 1901.

Buck; creek, eastern Alaska, on west bank of North fork of Fortymile creek, near latitude $64^{\circ} 40^{\prime}$, longitude $142^{\circ} 10^{\prime}$. Prospector's' name, from sketch map compiled by Major Glassford, Signal Corps, U. S. A., 1905.

Buck; mountain, on Revillagigedo island, near Nichols passage, Alexander archipelago. Named by Nichols, 1883. Doe and Fawn nountains are near by.

Buckeye; creek, tributary to the Yukon from the west, near Eagle, eastern Alaska. Prospectors' name, published in 1899. 
Buckland; mountains, on the Arctic coast, near the international boundary. So named by Franklin, 1826, "in honour of Professor Buckland."

Buckland; river, in the Seward peninsula, tributary to Iischscholtz bay. So named by Beechey in September, 1826, "in compliment to Dr. Buckland, the professor of geology at Oxford." Its Eskimo name, according to the Russians is Kaniek or Kotsokotana; according to Dall, 1869, Kúng-uk; according to Petrof, 1880, Konguk, and according to otbers, Kongalk.

Bucks; house and stope, on the lower: Stikine, of which the name is Choquett's or Choquette's, but is commonly called Buck's. Was so called, in 1877, and presumably earlier.

Buckskin; creek, tributary to South fork of Fortymile creek, from the west, near latitude $64^{\circ} 10^{\prime}$. Prospectors' name, reported by Spurr, Goodrich, and Schrader, of the Geological Survey, in $\mathbf{1 8 9 0 .}$

Budd; creek, tributary to American river, from the east, Seward peninsula. Name from Brooks, 1900 .

Buen-ticmpo, cape and mountain; see Fairweather.

Buffalo; creek, at headwaters of Nome river, Seward peninsula, near latitude $64^{\circ} 53^{\prime}$, longitude' $165^{\circ} 18^{\prime}$. Name from Barnard, 1900 .

Bug; island, in Seymour canal, Admiralty island, Alexander archipelago. So named by Mansfield, 1890 .

Bug; islet, in Neets bay, Behm canal, Alexander archipelago. Named by the Coast Survey in 1891.

Bugomowik; slough or pass, Yukon delta, one of the outlets of Kwikluak pass on the north, near latitude $62^{\circ} 55^{\prime}$. Eskimo name reported by Putnam, 1899, and written also Pagomawik.

Buhner; creek, tributary to Anikovik river, near Cape Prince of Wales, Seward peninsula. Prospectors' name, published in 1900.

Bukarelli, bay; see Bucareli.

Bukti, point; see Cove.

Buldir; island (1,145 feet high), between Kiska and Attu, western Aleutians. So called by the early Russian explorers. Langsdorf calls it Buldir, or the round island. Variously written Bouldir, Bouldyr, etc. Buldier is the Russian word for hut or hovel.

Bull; island, near head of George inlet, Revillagigedo island, Alexander archipelago. Named by the Coast Survey in 1891.

Bullen; point, on the Arctic coast, near Point Barrow. Named by Franklin in 1.826.

Bullion; creek, on northeastern shore of Douglas island, Alexander archipelago. Presumably a miner's name in use prior to 1890 .

Bullion; creek, tributary to the north fork of Fortymile creek from the west. Latitude $64^{\circ} 30^{\prime}$, longitude $142^{\circ} 05^{\prime}$. Prospector's' name, obtained by Gerdine, 1903.

Bullion; creek, an affluent of Mosquito fork of Fortymile creek on the right, near latitude $64^{\circ} 10^{\prime}$, longitude $142^{\circ} 05^{\prime}$. Prospector's' name, reported by $\mathrm{E}$. F. Ball, a prospector, in 1898 .

Bulshaia, mountain; see McKinley.

Bunker; hill, on worth bank of Kuzitrin river, Seward peninsula. Name from Brooks, 1900.

Burg, ereek, Nome region; see Borg.

Burka, cape; see Biorka.

Burke; creek, Seward peninsula, tributary from the east to American river near latitude $65^{\circ} 41^{\prime}$. Prospector's' name, from Gerdine, 1901. 
Burlow, cove; see Barlow.

Burls; creek, tributary to Controller bay from the north. So named by J. L. McPheison, deputy mineral surveyor, after H. T. Burls, the London petroleum expert. Reported by Martin in 1908. Erroneously Burrs.

Burls; mountain, 9 miles southeast of Mount Feulik, on the western side of the southeastern extremity of Becharof lake, Alaska peniusula. Named by J. L. McPherson, deputy mineral surveyor, after H. T. Burls, F. G. S., F. R. G. S., who was on this mountain in 1903 . Reported by Martin in 1904 .

Burnett; inlet, in Etolin island, opening into Clarence strait, Alexander archipelaggo. Named by snow in 1.886 .

Burnett; lake, Ftolin island, Alexander archipelago, probably on the east side of Burnett inlet and tributary thereto. Local name, reported by Moser in 1900 , but not found on any map,

Burniston; range of mountains, east of Portland canal. So named by Pender, 1868.

Burns; gulch, 10 miles north of Nome, Seward peninsula,-at the bead of Glacier creek, near longitude $165^{\circ} 21^{\prime}$. Local name, from a local map of 1901 .

Burnside; creek, Seward peninsula, tributary from the north to Eldorado creek, which is a tributary of Kiwalik river, latitude $65^{\circ} 45^{\prime}$, longitude $161^{\circ}$ 55'. Local name, reported by Witherspoon, 1903.

Burnt; islet, near Keene island, in Wraingell strait, Alexander archipeligo. Named Obgorielie (burnt off) by Lindenberg, 183S. It is Captitin's island of Meade in 1869 .

Burnt; point, just south of Anchorage point, Chilkat inlet, southeastern Alaska. Named Obgorielie (burnt off) by Lindenberg, 1838. The name is obsolete.

Burnt Islet; reef, near Burnt islet, in Wrangell strait, Alexander archipelago. So called in the Coast Pilot, 1883.

Burroughs; bay, in the mainland north of Revillagigedo island, Alexander archipelago, near latitude $56^{\circ}$, longitude $131^{\circ} 05^{\prime}$. Named Burrough's bay by Vancouver in 1793 . Renderea Burrong (burrower) on one Russian chart.

Burroughs Bay; cannery and village, at junction of Unuk river with Burroughs bay, southeastern Alaska. Population in 1890, 134. A saltery was operated here by James Miller in 1886 or 1887. Cannery built here, in 18s8, by Andrew and Benjamin Young, of Astoria, known as the Cape Lees Packing Company. It was dismantled and abandoned in 1894.

Burrs, creek; see Burls.

Burun, rocks; see Surf.

Burunof; cape, on eastern shore of Sitka sound, Baranof island, Alexander archipelago. Named Burunof (breakers) by Vasilief in 1809, and variously written Bouronor, Burunoff, Breakers, etc. Tebenkof calls it Tolstoi (broad) cape.

Busby; bay, indenting the northwestern shore of Bligh island, northeastern coast Prince William sound, near latitude $60^{\circ} 52^{\prime}$, longitude $146^{\circ} 44^{\prime}$. Local name, from Ritter, 1903.

Bush, hill; see Brush.

Bush; islets, near: Kell bay, on western shore of Affleck canal, Kuiu island, Alexander archipelago. Named by Snow, 1886.

Bush; island, in Tlevak narrows, Prince of Wales archipelago. So named by Nichols, 1881. 
Bush; mountain (1,805 feet high), in northern part of Annette island, Alexander archipelago. Descriptive name, given by-Nichols in $188 \%$

Bush; rock, in Redfish bay, Baranof island, Alexander atchipelago. Named by Moser, 1897.

Bush; rock, off the northeastern shore of Stevenson island, Kashevarof passige, Clarence strait, Alexinder archipelago, near latitude $56^{\circ} 03^{\prime}$, longitude $132^{\circ} 54^{\prime}$. Local navigators' name, reported by H. C. Fassett, Burenu of Fisheries, 1904.

Bushtop; islet, in Wrangell strait, Alexander archipelago. Named Bush Top by Nichols, 1881. It is Goloi (bare) of Lindenberg in 1838 .

Bushy; islind, in Tlevak strait, Prince of Wales archipelago. So named by Nichols, 1881. It is "smill and covered with bushes:"

Bushy; island, the northernmost of the large islands of the Kashevarcf g:oup, Clarence strait, Alexander archipeliso. So named by Vancouver, 1793. Erroneously Biugam on some charts.

Bushy; islets, in Endicott arm of Holkham bay, Stephens passage, Alexander archipelago. So named by Meade, 1869 .

Bushy; point, between Neets bay and 'Traitors cove, on Revillagigedo island, in Behm canal, Alexander archipelago, near latitude $55^{\circ} 43^{\prime}$, longitude $131^{\circ} 42^{\prime}$. Named by the Coast Survey in 1891 .

Bushy Point; cove, on the north side of Bushy point, western shore Revillagigedo island, Behm cinal, southeastern Alaskil. Usage of locil navigators, reported by Fassett, Bureau of Fisheries, 1.004 .

Buskin; river and village, near St. Paul, Kodiak. Named Sapozhkova (little boot) by Russian naval officers, 1808-1810.

Buster; creek, 8 miles northeast of Nome, Seward peninsula, tributary to Nome river, from the east, near longitude $165^{\circ} 15^{\prime}$. Prospectors' name, published in 1900.

Butler, creek ; see Butter.

Butler; peak (1,163 feet high), on the mainland near Slocum inlet, soutlieastern Alaska. So named by Thomas, 1888 .

Butte (The); mountain (4,586 feet high) in eastein Alaska, between upper Salcha and Chena rivers, near latitude $64^{\circ} 45^{\prime}$, longitude $145^{\circ} 40^{\prime}$. Prospectors' name, reported by Witherspoon, 1906 .

Butte; creek, tributary to headwaters of Birch creek, Jatitude $65^{\circ} 25^{\prime}$, loagitude $145^{\circ} 35^{\prime}$. Prospectors' name, obtained by Gerdine, 1903.

Butte; creek, easstern Alaska, on west bank of Washington creek, an affluent of the Yukon, from the south; near latitude $65^{\circ} 10^{\prime}$, longitude $142^{\circ} 20^{\prime}$. Prospector's' name, from sketch map compiled by .Major Glassford, Signal Corps, U. S. A., 1905.

Butte; creek, tributary to Fortymile creek from the east, latitude $61^{\circ} 40^{\prime}$, longitude $142^{\circ}$. Prospectors' name, obtained by Gerdine in $190: 3$.

Butte; creek, tributary to South fork of Fortymile creek, from the west. Prospectors' name, published by the Geological survey in 1899 .

Butte; creek, eastern Alaska, tributary on north bank of Salcha river, near latitude $64^{\circ} 40^{\prime}$, longitude $146^{\circ}$. Prospectors' name, reported by Witherspoon, 1905.

Butte; creek, Seward peninsula, tributary on west bank of Solomon river, near latitude $64^{\circ} 43^{\prime}$, longitude $164^{\circ} 20^{\prime}$. Prospectors' name, from a local map, 1905.

Butter; creek, small tributary of the Yukon from the south ahout 10 miles above Washington creek, near longitude $142^{\circ}$. Tocil name, reported to Collier in 1902 by E. J. Chamberlain, deputy mineral surveyor at Eagle. It is uncertain whether it is not Butler. 
Butterfield; canyon or gulch, 15 miles north of Nome, Seward peninsula, on right bank of Bangor creek, a tributary of Snake river from the west, near longitude $165^{\circ} 30^{\prime}$. Miner's' name, from a local map of 1901 .

Buyan; island, south of the Iliasik islands, in the Sandman reefs. So called by the Fish Commission in 18s8. Ferhaps this is. Blutf island of others. Buyan is a Russian feminine noun meaning a turbulent, noisy fellow; also a masculine noun meaning wharf or lauding place.

Buzzard; creek, Seward peninsula, tributary to Noxapaga river from north, 4 miles above the town of Noxapaga, latitude $65^{\circ} 30^{\prime}$, longitude $164^{\circ} 10^{\prime}$. Prospector's' name, reported by Gerdine, 1901.

Caamaño; point, the southernmost point of Cleveland peninsula, Clarence strait, Alexander archipelago. Named by Vancouver, 1793, after Don Jacinto Caamaño, who had made a chart of this region prior to Vancouver's survey.

Cabin; creek, tributary from the northwest to Passage canal, Prince William sound. It is at the east end of the portage to Turnagain arm of Cook inlet. Latitude $60^{\circ} 55^{\prime}$, longitude $148^{\circ} 50^{\prime}$. So named by Glenn. 1898 .

Cabras; islets or rocks, in Bucareli bay, Alexander archipelago. This name does not appear on La Perouse's chart of Bucareli bay, which was the first publication of the Spanish surveys, of 1775 and 1779 . On all the later charts it appears as here written, being variously called islands, island, and rock. In the late Coast Pilot erroneously Cabas. Cabras is Spanish for goats.

Cabras Head; see Cobras Head.

Cache; creek, Arctic slope, a tributary on the right bank of Canning river, near latitude $69^{\circ} 15^{\prime}$, longitude $146^{\circ}$. So named by S. J. Marsh, at prospector, $1902-3$.

Cache; creek, on north shore of Norton sound, between the mouths of Solomon and Topkok river's, near longitude $164^{\circ} 10^{\prime}$. Prospector's' name. Its Eskimo name, reported by Barnard, 1900, to be Orobuktulak, is on King's map of 1900 Opatulik. Gerdine, 1905 ; reports the local name to be Spruce creek. Near it the Davidson-Blakeslee map of 1900 locates the Eskimo camp called Opiktulik, written also Opiktolik, Okpiktalik, Opiktillik, and Apiktalluk.

Cache; island, in Koyukuk river, a little below the mouth of Batza river. So named by Allen, 1885.

Cache; island, in Naha bay, Behm canal, Alexander archipelago. So named by the Coast Survey in 1886.

Cache; lake, northeastern Alaska, near the source of Anaktuvuk river. So named by Peters and Schrader, 1901.

Cactus; point, on Revillagigedo island, in Behm canal, opposite entrance to Rudyerd bay, Alexander archipelago. Named by the Coast Survey in 1891.

Cadiack, island; see Kodiak.

Cadilla, Entrada de; see Castilla.

Cadillac; creek, Seward peninsuli, in Solomon River basin, tributary on east bank of Shovel creek, near latitude $64^{\circ} 39^{\prime}$, longitude $164^{\circ} 24^{\prime}$. Prospectors' name, from a local map, 1905.

Caetani; lake, in the St. Elias region. Named Lake Caetani by Prof. William Libbey, of Princeton College, in 1886, "in honor of the Duke of Sermoneta, president of the Italian Geographical Society." (Jour. Am. Geogr. Soc., vol. 18, 1886, p. 149.) All references except the one here cited have the name, erroneously, Castani.

Cahill; creek, Seward peninsula, Casadepaga drainage, tributary on north bank of Willow creek, near latitude $64^{\circ} 49^{\prime}$, longitude $164^{\circ} 27^{\prime}$. Prospectors' name, from local map, 1901. 
Cahoon; creek, in the Forcupine district, southeastern Alaska, tributary to McKinley creek from the south, near latitude $59^{\circ} 21^{\prime}$, longitude $136^{\circ} 18^{\prime}$. Prospector's' name, obtained by Wright, 1903.

Caiganee, cape; see Muzon.

Cain, island; see Gain.

Caines Head; a bluff point ( 680 feet high), on the western shore of Resurrection bay, Kenai peninsula, near latitude $59^{\circ} 59^{\prime}$, longitude $149^{\circ} \quad 24$. Local name, Caine's Head, reported by Denson of the Coast Survey in 1905.

Cairn; hill (313 feet high), Yukon delta, on the left bank of Kun river near the head of Scammon bay and one-half mile west of Castle hill. Lattitude $61^{\circ} 50^{\prime}$, longitude $165^{\circ} 30^{\prime}$. So named by Putnam, 1899.

Cairn; point, in Albatross anchorage, Portage bay, Alaska peninsula. So named by the Fish Commission in 1893.

Cairn; island, near entrance to Snag cove, Gambier bay, Admiralty island, A'exander archipelago. Named by the Coast Survey in 1.889 .

Calahonda; creek, on the east side of Disenchantment bay, Yakutat bay, just below Haenke island. Called Cala Honda (deep creek) by Malaspina in 1791, because off its mouth " no bottom was found at 120 fathoms."

Calamity; gulch, on the north side of Young creek, which in turn is tributary to Nizina river. So named by disappointed prospectors, and reported by Schrader, 1902.

Calder; bay, near Mount Calder, in Prince of Wales island, Alexander archipelago. Named by Helm, 1886.

Calder; mountain $(3,371$ feet high), in the northwestern part of Prince of Wales işland, Alexander archipelago. Named by Vancouver, 1793, after Captain Calder, of the British navy.

Calder; rocks, westerly from Mount Calder, in Sumner strait, Alexander archipelago. Named by Dall, 1879.

Caldera; port, in Malaspina island, Bucareli bay, Prince of Wales archipelago. Named Puerto de la Caldera by Maurelle and Quadra in 1775-1.779, presumably on account of the rough (or boiling) water in its vicinity. Has also been called a harbor and the name spelled, erroneously, Caldero and Coldera.

Ca.ldwell; glacier; at the head of the Kichatna river near latitude $62^{\circ}$, longitude $153^{\circ}$. So named by Ferron, 1899 .

Cerlifornia; bay, indenting north end of Prince of Wales island, near Point Colpoys, Alexander archipelago. Named by Dall in the Coast Pilot, 1883 (p. 90), after the steamer California.

California; boulder or boulder patch, near Blind point, in Wrangell strait, Alexander archipelago. Presumably so named by Nichols, 1881, after: the steamer California.

California; cove, on the east side California head, Carroll inlet. Revillagigedo island, southeastern Alaska. Name applied by local navigators, and reported by H. C. Fassett, Bureau of Fisheries, 1904.

California; creek, tributary to Bonanza river from the east, Seward peninsula. Name from Barnard, 1900.

California; creek, Seward peninsula, tributary to Kougarok river from the west, 3 miles below 'Taylor creek, néar latitude $65^{\circ} 37^{\prime}$, longitude $164^{\circ} 50^{\prime}$. Local name, obtained by Gerdine, 1901.

California; creek, Seward peninsula, tributary from the southeist to Kugrupaga river, near its mouth, about latitude $65^{\circ} 59^{\prime}$. longitude $166^{\circ} 42^{\prime}$. Prospectors' name, from Gerdine, 1901. 
California; creek, Rampart Placer region, flowing west from near the hend of Minook creek. Latitude $\left(55^{\circ}\right.$, longitude $150^{\circ} 10^{\prime}$. 'Local name, obtained. by Prindle, 1.904.

California; gulch and creek, on the right bank of Giacier creek, north shore Turnatgain arm, Cook inlet. Local name, from Mendenhall, 1898.

California; gulch, on the upper Nabesna river, near the foot of the Nabesna glacier, southern Alaska. So named by prospectors in 1899, and reported by Schrader, 1902.

California; gulch, in the Failbanks region, on the right bank of Pedro creek, near latitude $65^{\circ}$, longitude $147^{\circ} 30^{\prime}$. Prospectors' name; obtained by Prindle, 1903.

California; head, a bluff point on southwest shore of Revilligigedo islind, separating George inlet from Carroll inlet, near latitude $55^{\circ} 20^{\prime}$, longitude $131^{\circ} 29^{\prime}$. Named by the Coast Survey, 1880 , presumably after the steamer California.

California; ridge or lange of mountains, in eastern part of Gravina island, Alexander archipelago. Named by Nichols, 188:, presumably after the steamer California.

California; river, Seward peninsula, flowing south and emptying into a lagoon on north shore of Port Clarence. Prospectors' name; from Gerdine, 1901.

California; rock, near southern end of Tongass narrows, Alexander archipelago. Named by the Coast Survey, in 1885, after the steamer California, which touched upon it. Has also been called Wayanda (misspelled Wyanda), from the U. S. revenue cutter Wayanda having touched upon it.

Calm, point; a high point somewhere on the north shore of Bristol bay was so named July 13, 177s, by Cook, who had cailm water wheu off it. Tebenkof, 1849, identifies it with the soutli point of Hegemeister island, which he calls Shtilia (calm), and this usage is followed by the Fish Commission and Coast Survey. Possibly identical with reirce. See Peirce. .

Calming; islet, in southeastern part of Sitki sound, Baranof island, Ale::ander archipelago. Name published by Nicliols in the Coast Pilot, 1891. It is Utichi (escape) island of Vasilief, 1809, or perhaps this is intended for some derivative of Utikat (to grow calm).

Calton, point; see Catton:

Cam; islet, in Port Camden, Kuiu island, Alexander archipelago. So named by Moore, 1892.

Camacho, Isla de; see Marmot island.

Cambon; cape, on northwestern coast of San Juan Bautista island, Prince of Wales archipelago. So named by Maurelle and Quadra, 1775-1779.

Camden; bay, on the Arctic coast, about $4^{\circ}$ west of the international boundary. So named by Franklin, in 1826, " in honour. of Marquess Camden."

Camden; point, the eastern point of entrance to Port Camden, Kuiu island, Alexander archipelago. So named by Moore, 1892.

Camden; port, indenting the northeastern shore of Kúiu island, Alexander archipelago. So named by Vancouver, 1794 .

Cameron; point, near Halkett point, on the Arctic coast, east of Point Barrow. So named by Dease and Simpson, 1837.

Camp; creek, tributary to Canyon creek, from the east, in the Fortymile mining region. Local name, obtained by the Geological Survey in 1898.

Camp; creek, tributary at the headwaters of Nabesna river on the east. So named by Schrader, 1902, from the good camping ground at its mouth. 
Camp; creek, Seward peninsula, tributary from the east to American river, about latitude $65^{\circ} 32^{\prime}$. Local name, from Gerdine, 1901.

Camp; creek, tributary to Kotzebue sound from the south neir longitude $162^{\circ}$ $30^{\prime}$. So named by Mendenhall and Reaburn, 1901.

Camp; creek, Seward peninsula, tributary to Bear creek from the east, near latitude $65^{\circ} 38^{\prime}$, longitude $161^{\circ} 05^{\prime}$. Name from Witherspoon, 1903.

Camp; creek, 8 miles north of Nome, Seward peninsuli, drinining the northenst slope of King mountain to None river, near longitude $165^{\circ} 18^{\prime}$. Local name, published in 1900. Called also Upper Canup.

Camp; creek, tributary to Niukluk river, from the south, Sewaril peninsula. Name from Barnard, 1900.

Camp; creek, tiributaly to Sinuk river, from the north, Seward peniusula. N $\mathrm{N}$ me from Barnard, 1900. .

Camp; island, in Dry strait, near entrance to I.e Conte baly, sontheastern Alaska. So named by Thomas, 1.857.

Camp; mountin $(5,300$ feet high), northeast of Valdez glacier. So named by Abercrombie, 1898. Sawmill camp was at the foot of this mountain.

Camp; point, near the Indian village Kutkwutlu, on left bank cf Chilkat river, a few miles above its mouth. So named by United States naval officers in 1880 .

Camp; point, on the western shore of Portland cant. So named by Pender, 1.868.

Campbell; creek, tributary to the yukon on the left bank 20 miles below Rampart (city), near longitude $150^{\circ} 40^{\prime}$. Local name, from Edwards's Track Chart of the Yukon, 1899.

Campbell; mountain, 10 miles northeast of Controller bay. - So called by rratt in 1903. Named after a petroleum operator.

Campbe:li; point, at head of Cook inlet. Named by Vancouver in 1794.

Campbell; river, tributary to the Porcupine, from the south, near the international boundary line. So called by the Coast Survey in 1895 .

Campbell; river, tributary to Controller Bay from the northeast. Local nume, after a petroleum operator, reported by Martin, 1908.

Camp Coogan; bay, indenting the eastern shore of: Sitka sound, Baranof islant, Alexander archipelago. Named after Michat Coogan, of Battery I, Second United States Artillery, who, in Angust, 1871, was reported "on extra duty in Quartermaster's Department in charge of wood party." Coogin had a wood-cutting camp here and the bay was named after him. Erroneonsly published as Camp Kogan and Camp Cogan. From the description, it is not certain what bay is intended. It may be either Kidlak bay of Tebenkof, 1849) (Nachlezhnaia of Vasilief, 1809), or Lisefskialia bily of Tebenkof, 184!) (Aleutkina of Vasilief, 1809). Sec A.leutkinal.

Camp Koyan, bay; see Camp Coogan.

Camp Taylor; fishing station on Sarkar inlet; Dry pass, western shore of Prince of Wales island, near latitude $56^{\circ} 02^{\prime}$, longitude $133^{\circ} 15^{\prime}$. Locil name, from Dickins, 1903-4.

Canal (The). About 15 miles below Bethel in the lower Kuskokwim is a large island. The slough or channel which separates it from the river's south bank is known locally as The Canal.

Canal; point, at western entrance to St. Michiel canal, Norton sound, nerr latituile $63^{\circ} 04^{\prime}$. Named by the Coast Survey in 1897 .

Canal; point, behind St. Ignace island, Bucareli bay, Prince of Wales archipelago. Named Punta de la Canal by Mamelle and Quadra, 1775-1779.

Canal de Portillo; see Portillo and similarly for this kind of names. 
Canas; islet, in eastern part of Bucareli bay, Prince of Wales archipelago. Named Ysla de Canas by Maurelle and Quadra, 1775-1779.

Canas, Punta de; see St. Elias.

Candle; creek, Seward peninsula, tributary to Kiwalik river from the southwest near longitude $162^{\circ}$. So named by the miners, and reported by Mendenhall and Reaburn, 1901.

Candle; island, between Smeaton and Rudyerd bays, in Behm canal, Alexander archipelago. So named by Dall, 1879.

Candle; mining town, and post-office established in 1902, on Candle creek, Seward peninsula.

Cane, mountain; see Cone.

Cangrejo; point, the western point of entrance to Port Refugio, Bucareli bay, Prince of Wales archipelago. Named Punta Cangrejo (crab point) by Maurelle and Quadra in 1775-1779. Has been called, erroneously, Grego.

Canivus; banks, the north bank of Yentna river, about longitude $150^{\circ} 45^{\prime}$. Indian name, obtained by Herron, 1899, who wrote it Can-i-vus.

Cannery; cove, in the northern shore of Olga bay, Alitak bay, southwestern coast of Kodiak, Local name, reported by Moser, 1900.

Canning; river, extreme northern Alaska, debouching in Camden bay, rear longitude $146^{\circ}$. So named by Franklin in 1826, after "the late $\mathrm{Mr}$. Canning." Another, close by, he named Sir 'T. Staines river. These are now thought to be two mouths of the same river, of which the Eskimo name given by S. J. Marsh, a prospector, 1902-3, is Kooguru or (better) Kuguru.

Cannon; island, at entrance to Jamestown bay, Sitka sound, Alexander archipelago. Named Pusbki (cannon) by Vasilief, 1809.

Cannonball; creek, Kenai peninsula, on the left bank of Resurrection creek 10 miles above Hope city. Local name, from Moffit, 1904.

Canoe; bay, at the head of Pavlof bay, Alaska peninsula. So named by Dall, 1880.

Canoe; cove, on the southwestern coast of Annette island, Gravina group, Alexander archipelago. So named by Nichols, 1883. It is a stopping place for the natives when waiting for good weather and affords excellent shelter for their canoes; hence the name.

Canor, island, in Peril strait; see Povorotni.

Canoe; passage, separating Brownson island from Etolin island, in Ernest sound, Alexander archipelago. So named by Snow, 1886. Descriptive term.

Canoe; passage, through Hawkins island, Prince William sound, near latitude $60^{\circ} 30^{\prime}$, longitude $146^{\circ}$. So called by Ritter, 1899 .

Canoe; point, in eastern part of Bucareli bay, Prince of Wales archipelago. Named Punta de la. Canoa (canoe point) by Maurelle and Quadra, $1775-1.779$.

Canoe; point, near south point of entrance to Fanshaw bay, Frederick sound, Alexander archipelago. Named by Mansfield, 1889.

Canoe Landing; camp, on Shepherd creek, 10 miles north of Controller bry, near longitude $144^{\circ} 10^{\prime}$. Local name; reported by Martin, 1904.

Canon, creek near Nome; see Canyon.

Canon. creek; see Canyon.

Canooskie, island ; see Koniuji.

Cantishna, river; see Kantishna.

Cantisna, river; see Kantishna. 
Cantwell; river, tributary to the Tanana, from the south, near longitude $149^{\circ}$. Nimed by Allen, 1885, presumibly after Lieut. John C. Cantwell,

. U. S. R. M., who explored Kobuk river in 1S84 and 1885. According to Peters and Brooks, the native name is 'Tutlut; according to Lieutenant Castner, it is Nananil, and according to Lieutenant Herron and others, Nenana ; also written Neenana.

Canwell; glacier, tributary to Delta river, from the east, near latitude $63^{\circ} 30^{\prime}$. So named by Glenn, 1898, after Private Canwell, of the Hospital Corps, a member of his party.

Canyon; creek, tributary to Tsirku river from the north. Latitude $59^{\circ} 1 \mathrm{~S}^{\prime}$, longitude $136^{\circ} 20^{\prime}$. Local name, reported by Wright, 1903 .

Canyon; creek, tributary to Fortymile creek, from the south, at Deadman riffle, near longitude $141^{\circ} 10^{\prime}$. Local name, reported by Spurr, Goodrich, and Schrader, of the Geological Survey, 1896. Has also been written Canon.

Canyon; creek, 20 miles north of Controller bay, tributary to Bering river from the north, near latitude $60^{\circ} 25^{\prime}$, longitude $143^{\circ} 55^{\prime}$. Prospectors' name, from Martin, 1903.

Canyon; creek, tributary from the west to Delta river, an aftluent of the 'Tanana from the south, near latitude $63^{\circ} 15^{\prime}$, longitude $145^{\circ} 46^{\prime}$ '. Local name, obtained by Gerdine, 1902 .

Canyon; creek, Arctic slope, an aftluent on the right bank of Canning river, near latitude $69^{\circ}$, longitude $145^{\circ} 30^{\prime}$. So named by S. J. Marsh, a prospector, 1903.

Canyon; creek, in the Talkeetna mountains, northeast of Cook inlet, on the left bank near the head of Chickaloon creek, about latitude $62^{\circ} 20^{\prime}$, longitude $148^{\circ} 20^{\prime}$. So called by Glenn, 1898 .

Canyon; creek, tributary to Skwentna river from the south, 50 miles north of the head of Cook inlet, near longitude $151^{\circ} 45^{\prime}$. Descriptive name, from Brooks, 1902.

Canyon; creek, Kenai peninstila, tributary from the south to Sixmile creek, a tributary to 'Turnagain arm, Cook inlet, from the soutb. Prospectors' name, from Becker, 1895.

Canyon; creek, 12 miles north of Nome, Seward peninsula, emptying into Nome river from the west through Slate and Banner creeks, near latitude $64^{\circ} 45^{\prime}$, longitude $165^{\circ} 20^{\prime}$. Local name, from Gerdine, 1904. Called also Canon.

Canyon; creek, tributary to Casadepaga river from the west, Seward peninsuliı. Name from Barnard, 1900.

Canyon; creek, tributary to Imuruk basin from the west, Seward peninsulí. Name from Barnard, 1900.

Canyon; creek, tributary to Iron creek from the south, Seward peniusula. Name from Barnard, 1900.

Canyon; mining camp, north of Skagway on Taiya river, near the international boundary, southeastern Alaska. Called Canyon City by prospectors, and reported by Flemer, 1898.

Canyon Creek, glacier; see Shoup.

Cap; islind, off the northwestern shore of Tuxekan island, Sea Otter sound, Prince of Wales archipelago, near latitude $55^{\circ} 53^{\prime}$, longitude $133^{\circ} 21^{\prime}$. So named by Dickins, 1903-4.

Capaloa, cape; see Dyer.

Capaloa; creek, falling into the Arctic ocean on the south side of Cape Dyer. Eskimo name of Cape Dyer, given by Collier to the creek, 1904.

Capaloa; Eskimo village, abandoned, at Cape Dyer, Arctic coast, near latitude $68^{\circ} 40^{\prime}$. Native name, written by Doctor Driggs, of Point Hope, Capaloah, 
Cape, bay, indenting southwestern shore of Sitkalidak island, near Kodiak. So named by Lisianski, 1804 . Name apparently now obsolete.

Cape, island, in Sitka sound; see Lazaria.

Cape; mountain $(2,300$ feet high $)$, at Cape Prince of Wales, Seward peninsula. Name from Brooks, 1900.

Cape Douglas, village; see Kaguyalk.

Cape Elizabeth; island, the most westerly of the Chugach group, near enstern entrance to Cook inlet. Now occupied as a fox farm.

Cape Fox; Indian village at Kirk point, Foggy bay, Revillagigedo channel, Alexander archipelago. Name published by the Coast Survey in 1899 . Petrof, in the Tenth Census, 1880, has a Cape Fox village on Cape Fox.

Cape of the straits; see Strait.

Cape Seppings; Eskimo village, at Cape Seppings, of which the Eskimo name is given by 'Tikhmenief, 1S61, as Kivalinag-miut, and by U. S. Hydrographic chart 68 as Kechemudluk.

Capital; mountain (7,697 feet high), north of Mount Sanford, southern Alaska, near latitude $62^{\circ} 26^{\prime}$, longitude $144^{\circ} 08^{\prime}$. Local name, from Gerdine, 1902.

Capones; point, near St. Ignace island, Bucareli bay, Prince of Wales archipelago. Named Punta de Capones by Maurelle and Quadra, 1775-1779.

Captain; creek, in the Fairbanks region, tributary to Tolovana (Chatanika) river from the south, near latitude $65^{\circ} 10^{\prime}$, longitude $147^{\circ} 20^{\prime}$. Local name, obtained by Gerdine, 1903 :

Captains; bay, the most southerly arm of Unalaska bay between Iliuliuk bay and Nateekin bay, eastern Aleutians, near latitude $53^{\circ} 52^{\prime}$, longitude $166^{\circ} 34^{\prime}$. At the head of this bay is Port Levashef. Capt. Lieut. Michael Levashef wintered in this bay, September 18, 1768, to June, 6, 1769, and named it St. Paul harbor after his vessel. In 1790 Sarichef surveyed in this locality, and named this place Captains harbor after Levashef. Krusenstern, in 1827 , salys of this place that it is properly called Captains, but to distinguish it from others it will be convenient to call it Port Levalshef. It has generally been called Captains harbor. In 1840, Veniaminof applied the name Captains to the whole of Unalaska bay in memory of Levalshef's visit.

Captains; harbor; see Port Levashef.

Captains, island, in Wrangell strait; see Burnt.

Car; point, on eastern shore of Portland canal. Name published by the Coast Survey in 1899.

Caracol, point; see Snail.

Carbon; creek, tributary to Shepherd creek from the east, 10 miles north of Controller bay. Prospectors' name, obtained by Martin, 1903.

Carbon; creek, on the south bank of Matanuska river; opposite Chickaloon creek and just below Coal creek, near latitude $61^{\circ} 40^{\prime}$, longitude $148^{\circ}$ $30^{\prime}$. Local name, reported by Martin, 1905.

Carbon; mountilin, on the north side of Bering river, near latitude $60^{\circ} 25^{\prime}$, longitude $143^{\circ} 50^{\prime}$. Local name, obtained by Martin, 1903.

Carbon; ridge, 15 miles north of Controller bay, Gulf of Aliskia, a spur of Kushtaka mountain, near latitude $60^{\circ} 23^{\prime}$, longitude $144^{\circ} 08^{\prime}$. Prospector's' name, reported by Martin, 1905.

Carey; creek, Arctic slope, tributary from the right to Canning river, near latitude $69^{\circ} 30^{\prime}$, longitude $147^{\circ}$. So named by S. J. Marsh, a prospector, in 1903, after Ned Carey, a companion prospector. Erroneously Arcy creek.

Caribou; creek, the chief tributary of Matanuska river, northeast of Cook inlet. Local name, published in 1899. 
Caribou; creek, Kenai peninsula, on the right bank of Resurrection creek, 5 miles above Palmer creek. Local name, from Moffit, 1904.

Caribou; creek, in the Kantishna region, a left branch of Bearpaw creek, near latitude $64^{\circ}$, longitude $150^{\circ}$. So named by prospectors, in 1905, and reported by Prindle.

Caribou; creek, eastern Alaska, tributary on north bank to Salcha river, near latitude $64^{\circ} 40^{\prime}$, longitude $145^{\circ} 40^{\prime}$. Prospector's' name, reported by Witherspoon, 1905 .

Caribou; creek, tributary to Walker fork of Fortymile creek from the right, near latitude $64^{\circ}$, longitude $141^{\circ} 30^{\prime}$. Prospectors' name from a manuscript map in the Coast Survey archives drawn by E. F. Ball, a prospector, 1898.

Caribou; creek, eastern Alaska, on south bank of Seventymile creek, and tributary to Flume creek, near latitude $64^{\circ} 55^{\prime}$, longitude $142^{\circ} 30^{\prime}$. P'rospectors' name, from sketch map compiled by Major Glassford, Signal Corps, U. S. A., 1905.

Caribou; creek, tributary to Igloo creek, from the east, Seward peninsula. Name from Brooks, 1900.

Caribou; gulch, at head of Walker fork Fortymile creek, on right bank of Cherry creek near international boundary and latitude $64^{\circ}$. Prospectors' name, from a map drawn by E. F Ball, a prospector, in 1898,' now in the Coast Survey archives.

Caribou.; islands, in Skilak lake, Kenai peninsula. Local name, from Moflit, 1904.

Caribou; mountain, in the Koyukuk region, near the headwaters of Kanuti river, about latitude $69^{\circ}$. So named by Mendenhall and Reaburn, 1901.

Caribou; mountain, on west bank of White river, near latitude $63^{\circ}$. Named by Peters and Brooks, who ascended it in 1898.

Caribou; pass, between Chulitna and Cantwell rivers. So named by Glenn, 1898. Muldrow calls it Broad pass and applies the name Caribou to another pass immediately east of this.

Caribon, river; see Cutler.

Car-ilt-mu, creek; see Kariltna.

Carl; creek, tributary to Eldorado river, from the east, Seward peninsula. Name from Barnard, 1900.

Car-le-ok-shuk, lake; see Avaterat.

Carlile; bay, shown on United States Hydrographic chart 225, made by Commander Meade in 1869, in Dry strait. So named by the Coast Survey, 1883, after Carlile P. Patterson, the superintendent. Later surveys disprove the existence of the bay indicated.

Carlisle; rapids, in Tanana river, between the mouths of Johnson and Gerstle rivers. So named by Allen, 1885, presumably after Hon. Jobn Griffin Carlisle, of Kentucky.

Carlisle; volcanic island $(7,500$ feet high), one of the group of islands of the Four Mountains. So named by officers of the U. S. S. Concord, in 1894, after Hon. John G. Carlisle, Secretary of the Treasury.

Car-loog-ah-look-ta, lake; see Walker.

Carlook, village; see Karluk.

Carlson; creek, tributary to Sunny cove, northwestern shore Taku inlet, southeastern Alaska, near latitude $58^{\circ} 20^{\prime}$, longitude $134^{\circ} 10^{\prime}$. Local name, reported by Spencer and Wright, 1903.

Bull. 299-06 M- -11 
Carlton; island, in Dewey anchorage, Clarence strait, Alexander archipelago. So named by Snow, 1886.

Carmack; mountain (Mount Carmack, 6,700 feet high), north of Skagway between Taiya and Skagway rivers. So called by Flemer, 1898.

Carmel; Moravian mission and school; established in 1886, at Kanulik, an Eskimo village, near the mouth of Nushagak river. Nushagak postoffice is located here. Population in 1890, 189.

Carmen, island ; see Kayak.

Carol, inlet; see Carroll.

Caroline; shoal, in Muir inlet, Glacier bay, Alaska. Origin of name not known. First appears on British Admiralty chart 2431, corrected to February, - 1890.

Carolus; point, the western point of entrance to Glacier bay, Cross sound, near longitude $136^{\circ} 03^{\prime}$. So named by Dall, 1879.

Carolyn; island, in Golofnin bay, Norton sound. Named by the Coast Survey in 1900 .

Carp; island, in entrance to Smeaton bay, Behm canal, Alexander archipelago. Named by the Coast Survey in 1891.

Carr. hills; see Karr.

Carr; range of mountains $(4,000$ to 4,500 feet high), on eastern shore of Portland canal. Named by Pender, 1868.

Carrero, cape; see Carrew point.

Carrew; point, the south point of entrance to De Monti bay, Yakutat bay, southeastern Alaska, vear latitude $59^{\circ} 34^{\prime}$, longitide $139^{\circ} 50^{\prime}$. So, named by Dixon; 1787. According to Davidson, called Carrero on Malaspina's manuscript chart, 1791. There has been confusion in the application of the name Phipps, Carrew, and Ocean. See Phipps.

Carrie; small creek, Seward peninsula, tributary to Quartz creek from west, which in turn is tributary to the Kougarok river, near latitude $65^{\circ}$ $20^{\prime}$, longitude $164^{\circ} 40^{\prime}$. Prospectors' name, from Gerdine, 1901.

Carrizales, Punta de; see Reedgrass.

Carroll; anchorage, on north shore of Prince of Wales island, at entrance to Red bày, with which it connects by a narrow passage, dry at low water. Named by the Coast Survey, in 1883 , after Capt. James Carroll, of the steamer California, who had anchored bere and found the anchorage good.

. Carroll; glacier, at head of Glacier bay, southeastern Alaska. So named by Reid; 1892, after Capt. James Carroll, who in that year was the first to take a ship into the upper part of Glacier bay. Erroneously Woods.

Carroll; inlet, indenting southern shore of Revillagigedo island, Alexander archipelago. Named by the Coast Survey, in 1880, after Capt. James Carroll, long in command of steamships in these waters. It was then called a channel, being unexplored. It has since been shown to terminate and constitute a canal or inlet. Erroneously Carrol and Carol.

Carroll; island, about 3 miles east of Murder cove, at south end of Admiralty island, Alexander archipelago. Named after Capt. James Carroll and published by the Coast Survey in 1898.

Carroll, point; see Walker.

Carroll; point, at entrance to Carroll inlet, Revillagigedo island, Alexander archipelago. Named by the Coast Survey, 1880, after Capt. James Carroll.

Carroll, straits; see Gastineau channel. 
Carry; inlet, off the northern end of Shuyak island, Kodiak group. Named by the Jussians Carry (perewalnoi ; from perewal, a dragging over or across, a portage). Has been called, erroneously, Perewamno and Perevainoy.

Carter; lake, and creek tributary to Trail lakes, Kenai peninsula.. Local name, reported by Mendenhall, 1898.

Carter; mountain (4,700 feet high), near the outlet of Klutina lake. So named by Abercrombie, 1898.

Carter; pass (4,000 feet high), in the Endicott mountains, northeastern Alaska, between the headwaters of East Fork Chandlar river and Canning river, near latitude $68^{\circ} 10^{\prime}$, longitude $146^{\circ}$. Named Carter by Marsh, 1903 , after F. G. Carter, a companion prospector, who preceded him through this pass by two months.

Casaan, bay ; see Kasaan.

Casaclepaga; creek, Seward peninsula, tributary to Niulkluls river from the south. Native name, variously written Casa-de Parga, Kassdeparka, Koshotok, Kosoktok, Koksuktapaga, Koksukdeparga, etc.

Cascade; bay, in Baranof island, west of Point Gardner, Chatham strait, Alexander archipelago. So named by Moore, $\mathbf{1 8 9 5}$.

Cascade; bight, indenting the northwestern shore of Sarana bay, southern shore of Akutan island, Krenitzin group, eastern Aleutians, near longitude $165^{\circ} 59^{\prime}$. So named by Gilbert, 1901.

Cascade; creek, about 2 miles northwest of Sitka, on Baranof island, Alexander archipelago. Named by United States naval officers in 1880 .

Cascade; glacier, at head of Valdez glacier. So named by Abercrombie in 1898.

Cascade; glacier, in the St. Elias region. So named by Prof. I. C. Russell in 1890 , "on account of its splendid ice fall."

Cascade; glacier, near Harriman fiord, Port Wells, Prince William sound. So named by the Harriman expedition in 1899.

Cascade; inlet, on eastern coast of Annette island, Alexander archipelago. Local descriptive name, published by the Coast Survey in 1883. There is a large cascade near its southern point of entrance.

Cascade; point, the southeasternmost point of St. George island, Pribilof group, Bering sea. Called Iuzhnie (south) by Tebenkof, 1849, and generally Southeast point. On a recent Coast Survey map it is called Cascade. There is a waterfall near it.

Cascade, point; see Waterfall Head.

Cascade; stream, on the eastern shore of Wrangell narrows, Alexander archipelago, opposite Finger point, near latitude $56^{\circ} 41^{\prime}$. So called by the fisheries, and reported by Moser, 1900.

Case; mountain (5,509 feet high), near the head of Glacier bay, southeastern Alaska. Named by Reid, 1890, after the Case School of Applied Science, Cleveland, Ohio.

Casernent; glacier, tributary to Muir glacier, southeastern Alaska. Reid, in 1890, called this the first north tributary (of Muir glacier) and later Casement, after R. L. Casement, a member of his party in 1890.

Cash; creek, 15 miles northwest of Fairbanks, on the right bank of Keystone creek, a tributary to Goldstream creek from the north, near longitude $148^{\circ}$. Prospectors' name, from a local map, 1905.

Cask; creek, eastern Alaska, on the east bank of Charley river, which is affluent to the Yukon from the south, near longitude $143^{\circ}$. Prospectors' name, from sketch map compiled by Major Glassford, Signal Corps, U. S. A., 1905. 
Cass, creek, near None; see Cuss.

Cassiterite; creek, Seward peninsula, 15 miles northeast of Cape York, tributary from the northeast to Lost river, near latitude $65^{\circ} 28^{\prime}$, longitude $167^{\circ} 10^{\prime}$. So named by Collier, 1903 , from the occurrence of the mineral cassiterite in its valley.

Castalia; creek, tributary to the Yukon, from the west, near Eagle. Local name, obtained by the Geological Survey in 1898.

Castani, lake; see Caetani.

Castigo, Punta de; see Punishment.

Castilla; a supposed bay on the mainland coast a few miles north of Lituya bay ; was called Enta ${ }^{a}$. de Castilla, by Malaspina, in 1792. According to Professor Davidson, on the Sutil y Mexicana manuscript chart (Galiano) the name is written Cadilla. In this place Tebenkof shows no bay, but has a river called Katagini.

Castle; bay, indenting the southern shore of Chignik bay, Alaska peninșula. Local name. Tuliumnit point is turreted like a castle, and this bay near it takes its name from this circumstance.

Castle, cape or point; see Tuliumnit.

Castle; creek, in the Mount. Wrangell district, tributary to Elliott creek from the north. Prospectors' name, reported by Mendenball, 1902.

Castle; creek, Seward peninsula, Casadepaga drainage, tributary from the northwest to Big Four river, near latitude $64^{\circ} 52^{\prime}$, longitude $164^{\circ} 05^{\prime}$. Prospectors' name, reported by Gerdine, 1905. It is apparently Gold run of a local map, 1901.

Castle; hill (433 feet high), Yukon delta, on the left baik of Kun river, near the head of Scammon bay, about latitude $61^{\circ} 50^{\prime}$, longitude $165^{\circ} 30^{\prime}$. So named by Putnam, 1899 .

Castle; island, a knoll rising out of the marsh or tidal flats in Coppər Rivcr delta, on the east shore of Castle Island slough, near latitude $60^{\circ} 20^{\prime}$, longitude $145^{\circ} 15^{\prime}$. "The knoll is about 30 feet high and covered with alder bushes. There are five large cottonwood trees on this knoll and from a distance they resemble the tower of a castle." So described by Ritter, 1898.

Castle; islands, in Duncan canal, Kupreanof island, Alexander archipelago. So named by Thomas, 1887.

Castle; mountain, on the mainland west of the Stikine river, on the international boundary, near latitude $57^{\circ}$. Name published by the Coast Survey in 1895.

Castle; mountain (4,500 feet high), in the Talkeetna range, about 40 miles from Knik arm of Cook inlet, near latitude $61^{\circ} 50^{\prime}$, longitude $148^{\circ} 30^{\prime}$. Local and descriptive name, published by the Geological Survey in 1899.

Castle; peak (10,314 feet high), about 12 miles south of Mount Blackburn, near Kuskulana pass. Prospectors' name, reported by Gerdine, 1900.

Castle; rock, off the north end of Big Koniuji island, Shumagin group. So called by the fishermen. Descriptive name, reported by Dall, 1872.

Castle Island; slough, one of the passes through the delta of Copper river, near latitude $60^{\circ} 20^{\prime}$, longitude $145^{\circ} 15^{\prime}$. Name. from Ritter, 1898. This may be Big river of Moser, 1897.

Castner; glacier, tributary to Delta river, from the east, near latitude $63^{\circ} 30^{\prime}$. So named by Glenn, 1898, after Lieut. Joseph C. Castner, U. .S. A., a member of his party.

Cat; island, between Duke and Mary islands, Gravina group, Ạlexander archipelago. So named by ${ }^{\star}$ Nichols in 1883. 
Catalina; island, in San Alberto bay, Bucareli bay, Prince of Wales archipelago. Named Ysla Catalina (Catalina island) by Maurelle and Quadra, 17751779.

Catalla, bay, river, town, etc.; see Katalla.

Cataract; bight, in Bay of Waterfalls, Adak island, middle Aleutians. Descriptive name, given by United States naval officers in 1893.

Cataract; glacier, tributary to Harriman fiord, Port Wells, Prince William Sound. Descriptive name given by the Harriman expedition, 1899.

Catella, bay, river, town, etc.; see Katalla.

Cathedral; bluff and rapids, on Tanana river, near longitude $144^{\circ}$. Descriptive name, given by Allen, 1885 .

Cathedral; mountain, in the Tordrillo range, between the headwaters of the Skwentna and Kuskokwim rivers. So named by Spurr, 1898.

Catherina. "That great series of islands extending from the mouth of Cook's inlet to the end of the Aleutian chain, and perhaps properly including the Commander's islands, was nomed by Forster, in 1786, the Catherina archipelago, in honor of Catherine the Great, Empress of all the Russias." Name obsolete.

Cathul, mountain; see Kathul.

Cathut, mountain ; see Kathul.

Caton; harbor, between Caton island and Elma island, Sannak group. Local name, reported by Westdahl, 1901.

Caton; island, the easternmost of the Sannak group, near latitude $54^{\circ} 25^{\prime}$, longitude $162^{\circ} 25^{\prime}$. So called by the Fish Commission in 1888.

Caton; shoal, in Popof strait, Shumagin islands. Reported to the Coast Survey, in 1880 , by Mr. Caton and named after him.

Catton; point, on the Arctic coast, near Herschel island. So named by Franklin, 1826. Erroneously Calton.

Caution; island, on the northern shore of Redoubt bay, Sitka sound, Alexander archipelago. Named Berezbnoi (cautious) by Vasilief, 1809.

Caution; point, the southern point of entrance to Whitewater bay, Admiralty island, Chatham strait, Alexander archipelago, near latitude $57^{\circ} \mathbf{1 5}^{\prime}$, longitude $134^{\circ} 38^{\prime}$. So named by Meade in 1869. This name is erroneously transferred to another point, farther south, on British Admiralty chart 2431.

Cave; point, the southwestern head of Oksenof bay, on western coast of Unimak island, eastern Aleutians, near latitude $54^{\circ} 45^{\prime}$, longitude $164^{\circ} 38^{\prime}$. Named Shishkova (Shishkof's) by Lutke in 1828, who wrote it in French Chichkoff. Veniaminof calls this Pogromnoi second, and the next one west from Sarichef he calls Pogromnoi first. Tebenkof gives Pogromnoi as an alternate name, the cape being near Pogromnoi volcano. The Fish Commission, in 1890, called it Cave point, taking the name from Samuel Applegate who reports it as local usage. "Cave point takes its name from a cave on its face."

Cave; point, on the southeastern shore of Katalla bay, Gulf of Alaska, near longitude $144^{\circ} 25^{\prime}$. Local name, obtained by Pratt, 1903.

Cave; rock, on Amaknak island, Unalaska bay, near longitude $166^{\circ} 33^{\prime}$. Under it is a burial cave which Dall investigated in 1872-73, and which he has called Amaknak care.

Cawtaskakat, river; see Kautas.

Caymas; point, in North bay, Tlevak strait, Dall island, Alexander archipelago. So named by Dall, 1882, from its fancied resemblance to an alligator's head. 
Cecelia; lake (Lake Cecelia), on the eastern shore of Port Wells, Prince William sound, near latitude $61^{\circ} 10^{\prime}$, longitude $148^{\circ}$. Described by Mendenhall, 1898.

Cedar; bay, indenting the northern shore of Prince William sound, the first bay east of Unakwik bay, near longitude $147^{\circ} 30^{\prime}$. Local name, reported by Grant, 1905.

Cedar; bay or bight, indenting the northern shore of Hawkins island, Orca.bay, Prince. William sound, near latitude $60^{\circ} 33^{\prime}$, longitude $145^{\circ} 58^{\prime}$. Name published by the Coast Survey in 1900 .

Cedar; bight, in Security bay, Kuiu island, Alexander archipelago. Named by Meade, 1869.

Cedar; cove, in Freshwater bay, Chichagof island, Chatham strait, Alexander archipelago. Name published by the Coast Survey in 1899.

Cedar; island, in Security bay, Kuiu island, Alexander archipelago. So named by Meade, 1869.

Cedar; island, in Naha bay, at mouth of Moser bay, western shore Revillagigedo island, Behm canal, southeastern Alaska, near latitude $55^{\circ} 35^{\prime}$, longitude $131^{\circ} 40^{\prime}$. Local navigator's' name, reported by $H$. C. Fassett, Bưreau of Fisheries, 1904.

Cedar; point, in Kootznahoo archipelago, Admiralty island, Alexander archipelago. So named by Meade, 1869.

Cedar; point, near the entrance to Security bay, Kuiu island, Alexander archipelago. So named by Meade, 1869.

Cedar; point, the northern head of Smuggler cove, Annette island, Alexander archipelago. So named by Nichols, 1883.

Celenic, lake; see Selenie.

Cement Belt; creek, tributary to Dennison fork Fortymile creek from the right, near latitude $63^{\circ} 50^{\prime}$, longitude $142^{\circ}$. Prospector's name, from map in Coast Survey archives drawn by E. F. Ball, a prospector, 1898.

Cenotaph; island, in Lituya bay. So named by La Perouse in memory of 26 officers and men, constituting two of his boats' crews, who were caught in the bore or boiling ebb tide at the entrance to Lituya bay and drowned July 13, 1786. A cenotaph then erected on the southeastern end of this island to commemorate the event was sought for by a Coast Survey party; in 1874, and no trace of it found. The island has since been called Egg (Yaichnoi) by the Russians.

Cenotaph; point, the southeastern extreme of Cenotaph island above, where the cenotaph was erected. So named by Dall, 1874.

Center; creek, $1 \frac{1}{2}$ miles northwest of Nome, Seward peninsula, tributary to Snake river from the north, near longitude $165^{\circ} 25^{\prime}$. . Local name, published in 1900. Has also been called Wonder creek.

Center; island, in Dewey anchorage, Clarence strait, southwestern coast of Etolin island, Alexander archipelago. So named by Snow, 1886. Descriptive term.

Center; island, in the southern entrance to Wales passage, Portland canal. Named by the Coast Survey in 1891. The island lies in the middle of the entrance.

Center; island; on the southeastern shore of Cordova bay, Alexander archipelago. So named by Moser, 1897.

Central; creek, eastern Alaska, tributary on east bank to Goodpaster river, near latitude $64^{\circ} 20^{\prime}$, longitude $145^{\circ}$. Prospector's' name, reported by Witherspooin, 1905. 
Central; river, of eastern Alaska, which unites with South river to form the Chitina. First called by Allen, 1885, "Central branch (of the Chittyna)."

in 15

Central; telegraph station, on Goodpaster river, latitude $64^{\circ}, 20^{\prime}$, longitude $145^{\circ}$. So named by the Signal Corps, U. S.:A., 1903.

Central House; tavern or locality, on Crooked creek; in the Birch Creek regin, latitude $65^{\circ} 35^{\prime}$, longitude $144^{\circ} 45^{\prime}$. Local name, obtained by Gerdine, 1903.

Chacktoole, bay; see Shaktolik.

$\cdots$,

Chacon; breakers or reef, in Dixon entrance, off Cape çhacon. Reported by Captain Carroll, of the steamer Idilio, April 13, 1883. Called also Chacon reef and Chacon breaker.

Chacon; cape, the southeastern point of Prince of Wales island, Alexander archipelago. Named Cabo de Chacon by Caamaño, 1792. It is Cape Murray of Douglas, 1789, and Bald cape.of Rowan (ship Eliza) in 1799.

- According to Rowan, the native name is Intankoon. Tebenkof has the name Shakon. "Sometimes known locally as Musatchie Nose." - (Coast Pilot, 1891, p. 86.)

Chagafka, cove; see Shahafka.

Chagak; cape, on the northern shore of Umnak, eastern Aleutians. Native name, from Kuritzien, 1848. It means ditch or trench.

Chagak, bay, Adak island; see Shagak.

Chagamil, island; see Kagamil.

Chagavenapuk; river, tributary to the Kuskokwim, from the east, near latitude $62^{\circ}$. Eskimo name, obtained by Spurr and Post, in 1898, from trader A. Lind.

Chageliuk, slough; see Shageluk.

Chagulak, island; see Chugul.

Chaguliak, island; see Herbert.

Chagvan; bay, indenting mainland coast just north of Cape Newenham, Bering sea. Native name, published by Sarichef, 1826. It is called Portage bay on a recent Coast Survey map. On its shores Petrof, 1880, locates a settlement which he calls Tzahavagamute, which has been copied on some maps as Tzaharagamute.

Chaiagaguk; river, tributary to Togiak river. Not shown on any map. Name from Spurr, 1898, who wrote it Tshayagíguk. An Eskimo village, presumably at the junction of this river with the Togiak, is called by Spurr Tshayagágamut.

Chaichei; islands; south of Middle island, Sitka sound, Alexander archipelago. . Named Chaichei (gull) by Vasilief, 1809.

Chaichie, islet, point, etc.; see Gull.

Chaik; bay, indenting the southwestern shore of Admiralty island, Alexander archipelago. Native name, published by the Coast Survey, in 1896, as Cha-ik. Supposed to be identical with Chaqua cove of Eliza, 1799, and Chaque bay of Meade, 1869.

Chailki, islet; see Gull.

Chaitna, river ; see Chuit.

Chaix; bills, back of Icy bay, in the St. Elias region. Named, in 1886, by Prof. William Libbey, of Princeton College, after Prof. Paul Chaix, president of the Geneva Geographical Society.

Chakik; cape, the northwest point o. Umnak island, middle Aleutians. Native name, apparently from officers of the United States North Pacific exploring expedition, 1855, by whom it was written Tchakhikh. 
Chakina; river, tributary to the Chitina river from the south. Native name, from a manuscript map made by prospectors in 1900 .

Chakok; small stream on Kenai peninsula, debouching near Anchor point; Cook inlet. Apparently a native name, reported by Wosnesenski, about 1840 , and printed by Grewingk as Tchakoch.

Chakwa; bay, or cove in Hood bay, Chatham strait. Native name, first mentioned by Captain Rowan, of the ship Eliza, in 1799. Has been called Chaque bay and Chaque cove. See also Chaik.

Chalit; Eskimo village, of about 60 people in 1878, on left bank of the Kuguklik river, northwest of Kuskokwim bay. Visited by Nelson in December, 1878, and its name reported by him to be Chalitmiut, i. e., Chalit people.

Chaliuknak. An Aleut village bearing this name existed, in 1790, on the northern shore of Beaver bay, Unalaska, eastern Aleutians.

Chaljchnikikaljslun. Grewingk, following Wosnesenski, 1840, gives this string of letters as the native name of a small stream on Kenai peninsula debouching a little south of the Kaknu river, Cook inlet. Perhaps it sounds like Kal-ik-nik-ik-al-is-lun.

Chalmers; port, in Montague island, Prince William sound. Named Chalmer's harbour. by Portlock, 1787.

Chalzekahin, river; see Kicking Horse.

Chamberlain; glacier, southeastern coast of Alaska, 32 miles southeast of Yakutat, near longitude $138^{\circ} 45^{\prime}$. So named by Moser, 1901, after F. M. Chamberlain, a member of his party.

Chamisso; island (231 feet high), in Kotzebue sound, at entrance to Eschscholtz bay, near latitude $66^{\circ} 13^{\prime}$, longitude $161^{\circ} 50^{\prime}$. So named by Kotzebue, 1816, after Dr. Louis Adelbert von Chamisso, who accompanied him dur. ing his explorations here. The native name, according to Beechey, 1827, is E-ow-ick.

Champagne; gulch, in Copper River region, on the south side of Young creek, which in turn is tributary to Nizina river. Prospectors' name. First appears on map of Nizina mining district, 1902, by George M. Esterly, of Valdez.

Champion; creek, Seward peninsula, tributary to Mina creek, which is tributary to Kugruk river, near latitude $65^{\circ} 45^{\prime}$, longitude $162^{\circ} 20^{\prime}$. ' Prospectors' name, obtained by Witherspoon, 1903.

Champion; creek, tributary to North fork Fortymile creek, from the east, near latitude $64^{\circ} 30^{\prime}$. Local name, reported by Barnard, 1898 .

Chandelar, river ; see Chandlar.

Chandik, river; see Klondike.

Chandlar; lake; and river tributary to the Yukon, from the north, near the Arctic circle. Locally known as the Chandlar and said to be named after John Chandlar, a factor of the Hudson Bay Company. Has also been called Gens de Large. Apparently identical with Achenchik river of Raymond (1869) and Petrof (1880), and with Tadrandike of recent Coast Survey maps.

Chandler; lake, at the source of Colville river, latitude $68^{\circ} 10^{\prime}$, longitude $153^{\circ}$ $1^{\prime}$. Visited and named by Stoney, 1886 , in honor of William E. Chandier, Secretary of the Navy.

Chandos; point, the eastern point of entrance to Yarboro inlet, on the Arctic coast, east of Colville river. So named by Franklin, 1826.

Chanceliut, slough; see Chaniliut. 
Chaniliut; slough,. Yukon delta, opening on the right bank 1 mile above Apoon mouth, near latitude $63^{\circ} 02^{\prime}$, longitude $163^{\circ} 25^{\prime}$. Eskimo name, written Chineeliut by Farris, 1899. The census enumerator for the 4 th enumeration district, 1900, writes the name of a village in his district Chineleat.

Chankliut; island, near Chignik bay, south shore of Alaska peninsula, near longitude $158^{\circ} 10^{\prime}$. Native name, from the Russians. Has been written Chankluit.

Channel; creek, in the Koyuluk region, tributary to Wild river from the west, near latitude $67^{\circ} 15^{\prime}$. Local name obtained by Peters and Schrader, 1901.

Channel; island, northeastern shore Wrangell island, Eastern passage, Alexander archipelago, near latitude $56^{\circ} 22^{\prime}$, longitude $132^{\circ} 10^{\prime}$. Local navigators' name, reported by H. C. Fassett, Buieau of Fisheries, 1.904.

Channel; island, in Howkan strait, Cordova bay, Alexander archipelago. So named by Nichols, 1881. They appear like two islands, but are connected by a sand spit. Rev. Sheldon Jackson has named the northern part Sheldon island and the southern Jackson island.

Channel; island, in Tongass narrows, near Ward cove, Alexander archipelago. Presumably so named by pilot Capt. W. I. George, about 1880 . Descriptive term.

Channel; islands, in Behm canal,onear Walker cove, Alexander archipelago. So named by the Coast Survey in 1891.

Channel; islands, in the upper part of Orca bay, Prince William sound. Gulf of Alaska, near latitude $60^{\circ} 37^{\prime}$, longitude $145^{\circ} 45^{\prime}$. So named by Moser, 1897.

Channel; point, in Kootznahoo inlet, Admiralty island, Alexander archipelago. Named by Meade, 1869. Descriptive term.

Channel; rock, in entrance to Hassler harbor, Annette island, Alexander archipeligo. So named by Nichols, 1882 . Descriptive term.

Channel; rock, in middle of the entrance to the western anchorage, Sitka harbor. So named by Beardslee, 1880. Descriptive term.

Channel; rock, in entrance to St. Paul harbor, Kodiak. Named by the Coast Survey in 1.869 . Descriptive name.

Channel; rocks, in Kakul narrows, Peril strait, Alexander archipelago. So named by Coghlan, 1884. Descriptive term. Have been called indiscriminately islets and rocks.

Chanriel Bar; creek, tributary to the Yukon on left bank a few miles below Fort Hamlin. Local name, from Edwards's Track Chart of the Yukon, 1899.

Chapeau; mountain (2,000 feet high), a spur of Davison mountain, east of Tamgas harbor, Annette island, Alexander archipelago. Named by Nichols, 1883.

Chapel; cove, indenting eastern side of Bay of Waterfalls, Adak island, middle Aleutians. So named by Gibson, 1855.

Chapel; islet, near south point of entrance to Gambier bay, Admiralty island, Alexander archipelago. So named by Mansfield, 1889.

Chapeluk; slough, Yukon delta, opening on the left bank of Apoon pass 5 miles above Okwega pass, near latitude $63^{\circ}$, longitude $163^{\circ} 48^{\prime}$. Eskimo name, obtained by Farris, 1899.

Chapin; bay, indenting the southern shore of Admiralty island, Alexander archipelago. So named by Moore, in 1892, after Ensign Frederick Lincoln Chapin, U. S. N., a member of his party. 
Chapman; creek, tributary to Middle fork of the Koyukuk, from the east, near longitude $150^{\circ} 30^{\prime}$. Prospectors' name, published by the Coast Survey in 1899.

Chapman; creek, tributary to Minook creek, from the east. Prospectors' name, published by the Coast Survey in 1898.

Chapman, point; see Entrance.

Chaqua, bay; see Chhakwa.

Charcoal; island, one of the Japonski group, Sitka sound, Alexander archipelago. Named Ugolnoi (stone coal) by Vasilief, 1809.

Chariot (The). A spur of the peak of Mount St. Elias was so named by Russell, 1890. This may be identical with The Hump of Topham, 1889.

Charity; creek, in the Fairbanks region, tributary to Faith creek from the west, latitude $65^{\circ} 25^{\prime}$, longitude $146^{\circ} 20^{\prime}$. Prospectors' name, obtained by Gerdine, 1903.

Charleetna, river; see Chulitna.

Charles; point, on the Arctic coast, east of Point Barrow. So named by Dease and Simpson, 1837. Not found on any map and its exact location unknown.

Chanley; creek, 25 miles north of Nome, Seward peninsula, tributary to Sinuk river, from the south, near longitude $165^{\circ} 30^{\prime}$. Name from Barnard, 1900.

Charley, creek ; see Kandik river:

Charley; river, tributary to the Yukon from the south 12 or 15 miles below Washington creek, near longitude $142^{\circ} 45^{\prime}$. Local name, published as early as 1898 . Written also Charlie.

Charley Village; Indian village, on the upper Yukon at the mouth of Kandik river. Locally called Charley's Village.

Charlie, creek; see Washington.

Charlotte; lake, 20 miles north of Controller bay, at head of Shepherd creek, near longitude $144^{\circ} 10^{\prime}$. So named by Martin in 1904 .

Charlotte; ridge, 20 miles north of Controller bay, Gulf of Alaska, a spur on the northwest side of Kushtaka mountain, and on the east side of Lake Charlotte, near latitude $60^{\circ} 25^{\prime}$, longitude $144^{\circ} 07^{\prime}$. Prospectors' name, reported by Martin in 1905.

Charm, point; see Chasina.

Charpentier; glacier, on the southern shore of Hugh Miller inlet, western shore Glacier bay, southeastern Alaska. So named by Reid, 1892, after a Swiss glacialist. This is the southern branch of the original Hugh Miller glacier of Muir, 1879. 'See Hugh Miller.

Chasen, point; see Chasina.

Chasil, island, in Cook inlet; see Chisik.

Chasina; anchorage, at entrance to Cholmondeley sound, Clarence strait, Alexander archipelago. Surveyed and named by Clover, 1885.

Chasina, bay; see Cholmondeley sound.

Chasina; point, in Clarence strait, near southern point of entrance to Cholmondeley sound, Alexander archipelago." Apparently a native name adopted from the Russians and in some cases erroneously transliterated Charm. It is Chasen of Tebenkof and Chasina of Russian Hydrographic chart 1493. Has also been written Tchaseni. The settlement near it is Chasintsef of the Russians, written Chasintzeff on United States Hydrographic chart 225 . 
Chasina; island, in Chasina anchorage, Cholmondeley sound, western shore Clarence strait, southeastem Alaski, near latitude $55^{\circ} 16^{\prime}$, longitude $132^{\circ} 03^{\prime}$. So applied by local navigators, and reported by H. C. Fassett, Bureatu of Fisheries, 1904 .

Chastie. Lutke, 1836, applied the name Tchastie (serrees) to a group of 1.3 rugged islets and 5 large isolated rocks lying between Atka and Adak, middle Aleutians. Also written Tschastiji. It means crowded together, close-set, etc.

Chastie. Tebenkof, 1849, applies this name Chastie (compact, crowded together) to some islets and rocks lying very near the south shore of Adak, while Lutke applies it to a group lying farther east between Atka and Great Sitkin.

Chatanika; river, the upper part of the Tolovana river, which is a north branch of the Tanana river, latitude $65^{\circ} 10^{\prime}$, longitude $147^{\circ} 30^{\prime}$. "The Chatanika, which lower down is called the Tolovana" (Bull. U. S. Geol. Survey, No. 225, p. 68). Indian name, obtained by Gerdine, 1903. Written also Chataneka and Chatinka.

Chatham; creek, in the Fairbanks region, tributary to Cleary creek from the east, near latitude $65^{\circ} 05^{\prime}$, longitude $147^{\circ} 25^{\prime}$. Local name, from Gerdine, 1903.

Chatharn; port (Port Chatham), immediately behind Cape Elizabeth, at eastern point of entrance to Cook inlet. Surveyed by Vancouver, 1794, and named after. one of his vessels.

Chatham; post-office (established in February, 1906), near Point Thatcher, western shore of Chatham strait, south side of entrance to Peril strait. Alexander archipelago, near latitude $57^{\circ} 25^{\prime}$.

Chatham; strait, in Alexander archipelago. Named by Vancouver, in 1794, after Lord Chatham. "It was also called Menzies' strait by the fur traders as late as 1799." To its expanded southern end Colnett gave the name Christian sound in 1789. La Perouse had, 1786, called this part Chirikof (Tschirikow) bay, while the Spaniards, 1791, called it Ensenada del Principe.

Chathenda; creek, tributary from the east to. Chisana river, near its source. Native name, reported by Witherspoon, 1902.

Chatinak; Eskimo village, on right bank of Yukon river, a little below Andreafski. Native name; from Nelson, 1878, who writes it Chatinakh.

Chatinka, river; see Chatanika.

Chatlaknuk; creek, tributary to Yentna river from the north, 15 miles below the Skwentna, near latitude $62^{\circ}$, longitude $151^{\circ}$. Native name, obtained by Flerron, 1899, who wrote it Chat-lak-nuk.

Chauik; mountain (3,510 feet high), a little east of Mount Bendeleben, Seward peninsula. Native name, from Peters; 1900, who wrote it Chowik.

Chavolda; creek, tributary from the east to Chisana river, near its source. Native name, reported by Witherspoon, 1902.

Chayagagul, river; see Chaiagaguk.

Checats; cove, lake, and salmon stream, on the mainland, eastern shore of southern entrance to Behm canal, southeastern Alaska, near latitude $55^{\circ}: 30^{\prime}$. Apparently a native name in use by the fisheries, reported by Moser, 1897 and 1901.

Checats; point, the south point of entrance to Checats cove (above), eastern shore of southern entrance to Behm canal. Name reported by $\mathrm{H}$. C. Fassett, of the Burenu of Fisheries, in 1904.

Chechitno, peak; see Wrangell Mount. 
Chechitno, river; see Chitina.

Chechotlin, inlet; see Linnet.

Checkers; camp, on Kuzitrin river, Seward peninsula. So called by the prospector's, 1900, after one of their comrades, nicknamed Checkers.

Checkers; creek, on Seward peninsula, tributary to Quartz creek from the east, near latitude $65^{\circ} 20^{\prime}$, longitude $164^{\circ} 40^{\prime}$. Prospectors' name, obtained by Gerdine, 1901.

Chedotlothna; river, tributary to East fork Kuskokwim river from the east; near its mouth, about latitude $63^{\circ} 10^{\prime}$, longitude $153^{\circ} 45^{\prime}$. Native name, from Herron, 1899, who wrote it Chedotlothno and Che-dot-loth-no.

Cheechocna, river; see Chichokna.

Cheenik; village and mission at head of Golofnin bay, Norton sound. This is said to be a native name and has been written Chee-nik, Chenik, Chinick, Chinik, etc. Pronounced Chee'nik. Tikhmenief, 1861, shows an Eskimo village here called Ikaligvig-miut. It is also called Dexter post-office, though no post-office has been established there by the Government.

Cheerful; cape, the western head of Unalaska bay, eastern Aleutians, near longitude $166^{\circ} 36^{\prime}$. Called Veselofski (cheerful) by Kotzebue in 1817. Sarichef, 1792, shows a village near here called Veselofski. Lutke, 1836, has Vécélovskoi cape and mountains. An unnamed cascade near it is a landmark for Captains bay.

Cheerful. Sarichef, 1792, shows a native village, Veselofski (cheerful), near

- Cape Cheerful, Unalaska. Veniaminof says this village lies on the left side of Cape Cheerful, in the left corner of a bight of the same name, on a spit. Population about 1830 was 15 .

Cheericoff, cape; see Bartolome.

Cheericoff, island; see Chirikof.

Chefoklak; Eskimo village of 4 huts in the Yukon delta, near Kusilvak mountain, visited by Nelson in December, 1878. He reports its name to be Chefokhlagamiut, i. e., Chefoklak people.

Chegoula, island; see Chugul:

Chelekhoff, strait; see Shelikof.

Chena; river and slough, on the right bank of Tanana river, near longitude $147^{\circ} 30^{\prime}$. Native name, reported by Schrader, 1898, as Che-na, i. e., Chee river. The town of Fairbanks is situated on the right bank of Chena slough, which is said to be pronounced, locally, Chĕnō'a.

Chena; town, post-office, and telegraph station on Tanana river, 15 miles below Fairbanks, at west end of Chena slough, near longitude $148^{\circ} 25^{\prime}$. The town was incorporated December, 1903, and the post-office established in 1904.

Chena Dome; mountain $(4,450$ feet high), in the Fairbanks region, near the source of Chena river, about latitude $65^{\circ} 05^{\prime}$, longitude $146^{\circ} 30^{\prime}$. Local name, from Gerdine, 1903.

Chenango; mountain $(2,987$ feet high), in the northern part of Annette island, Alexander archipelago. So named by Nichols, 1883.

Chenega; glacier, entering Icy bay, western side of Prince William sound, near latitude $60^{\circ} 20^{\prime}$. Local name, reported by Grant, 1905 .

Chenega; island, on the western shore of Prince William sound. Apparently. a native name. On Petrof's map, 1882, in the Tenth Census this name is given for an Indian village (population, 80) on Knight island. On late maps this village is shown on an island called Chenega, immediately west of Knight island. Written also Cheniga. 
Chenega; lake and stream, west shore Prince William sound, at the head of the bay, on the north side of Point Nowell ; near latitude $60^{\circ} 30^{\prime}$, longitude $148^{\circ}$. Indian name, so applied by the fisheries, reported and written Cheniga by Moser, 1897 and 1901. This-is not far from Chenega island, above.

Chenega; Indian village, on south end of Chenegil island, Prince William sound. Cheniga, lake, island, stream, village; see Chenega.

Chenik, mission; see Cheenik.

Chenik, village; see Chimekliak.

Chenoa, river and slough; see Chena.

Chentansitztan; village, on north bank of the Yukon, about 80 miles below the mouth of Melozi river. Native name, published by the Coast Survey in 1898.

Chepp, river; see Chipp.

Chernabura; island, the southernmost of the Shumagin group. Named Chernoburie (black-brown, whence also a priest thus clad) by the Russians. The native name is Nunik (porcupine). Has been variously written Chernabour, Chernobour, Chernabur, Niunak, Niunyak, Niuniak, Nuniak, etc. Lutke has an island Tounak in his list of the Shumagins, apparently a typographical error for Nounak. Now occupied for raising blue foxes.

Chernabura, island, Cook inlet; see Augustine.

Chernabura; islet (100 feet high), and surrounding rocks, on the western edge of the Sandman reefs, northeast of Sannak, near latitude $54^{\circ} 38^{\prime}$, longitude $162^{\circ} 22^{\prime}$. Called Chernabura (black-brown, or a priest clad in black-brown garb) by the Russians. Lutke says, Tagamak, called by the Russians Tchernoboury, while Veniaminof says the Aleut name is Kagak Unimak, i. e., East Unimak. Sarichef has Taganak. Variously written, Chernabour, Chernabur, Chernobura, Chernaboor, Tchernobour, etc.

Chernieshef, mountains; see Devil's Prongs.

Chernof; cape, in Kupreanof strait, on northern shore of Kodiak. So named by Murashef, in 1839-40, presumably after Ivan Chernof, who made explorations and surveys in the Russian American colonies, 1832-1838.

Chernofski; harbor, indenting the northern coast of Unalaska near its western end. Named Chernofski, by Sarichef, 1792, presumably from Chernof, a Russian family name. Variously written Tchernovskaia, etc.

Chernofski; native village, in Chernofski harbor, Unalaska. So called by Sarichef in 1792 . In 1831 it consisted of 4 huts (yourts) and 44 people. Population in 1880,101 ; in $1890,78$.

Cherry; creek, in the Fortymile mining region, tributary to Walker fork. Local name, from Barvard, 1898.

Cheshnina; river, and glacier, tributary to Copper river, from the east, near latitude $62^{\circ}$. Native name, from Abercrombie, 1898, who writes Cheshnena, i. e., Cheshni river.

Chesloknu, bay; see Seldovia.

Cheslotta; " town or station," Copper River region; in the Slana valley, near Suslota creek and lake. . So named by the Signal Corps, U. S. A., 1903. Probably another writing of Suslota.

Chesnik; mountains, south of the Skwentna river, near latitude $61^{\circ} 30^{\prime}$, longitude $152^{\circ} 15^{\prime}$. Indian name from Herron, 1899, who wrote it Ches-nic.

Chestakof, island; see Chistiakof.

Chestalena, river; see Chetaslina.

Chester; lake, near Port Chester, Annette island, Alexander archipelago. Named by the Coast Survey in 1897. 
Chester; port, on the western coast of Annette island, Gravina group, Alexander archipelago. Named by Nichols, 1883, after Commander Colby Mitchell Chester, U. S. N.

Chestochina, river; see Chistochina.

Chestolnu, bay; see Seldovia.

Chetaslina; glaciei, on the southern flank of Mount Wrangell and drained by Chetaslina river. Native name from Schrader, 1900.

Chetaslina; river, draining Chetaslina glacier and tributary to Copper river, from the east, near latitude $61^{\circ} 45^{\prime}$. Indian name, reported by Abercrombie, 1898. On Abercrombie's map, as published by the Geological Survey in 1899, it was printed Chetastena creek; on the same map published in Bulletin 25, Adjutant-General's Office, it appeared Chestalena; and on the same, Twentieth Annual Report U. S. Geological Survey (map 20) Chetasleni. Schrader, 1900, wrote Chetaslina. Apparently this is the river which Allen, 1885, named Liebigstag.

Chetastena, creek; see Chetaslina river.

Chetaut; river, tributary to the Yukon, from the noith, at the Lofyer Ramparts. Native name, given by Dall as Tseétoht and by Raymound. as Chetaut. Schwatka has Che-taut and Petrof Chetaht. Has also been written Seet-oht. The present tendency is to call this Ray piver and the river 10 miles below, Salt river. The latter is the one griginally named Ray.

Chetchitno, river; see Chitina.

Chetierek, mountain ; see Fourpeaked.

Chetlechuk; river, tributary to the Yukon, from the north, 6 miles below Dail river, near longitude $149^{\circ} \cdot 15^{\prime}$. Native name, from Raymond, 1869, who wrote it Chetletchuk. Petrof, 1880, wrote it Chetlechuik. It has alsò been called Toolitzkakat.

Chettyna, river; see Chitina.

Cheukee, river; see Chiuki.

Cheval; island, on the southwestern shore of Resurrection bay, Kenai peninsula, near latitude $59^{\circ} 46^{\prime}$, longitude $149^{\circ} 31^{\prime}$. Named Cheval (horse), June 6,1906 , by the U. S. Board on Geographic Names.

Chewaulee, river; see Chiwaki.

Cheyenne; creek, Seward peninsula, tributary to Solomon river from the west, near latitude $64^{\circ} 45^{\prime}$, longitude $164^{\circ} 20^{\prime}$. Prospectors' name, from a local map, 1904.

Chezum; mountain (Mount Chezum, 2,600 feet high), on Cunningham ridge, north of Controller bay, near latitude $60^{\circ} 26^{\prime}$, longitude $143^{\circ} 58^{\prime}$. Probably native name, reported by Martin, 1905 .

Chiachi; cape, on western shore of Whale island, Kodiak group. Named Cliaiachie (guii) by Murashef, 1839-40.

Chiachi; islands, northeast of the Shumagins, on south shore of Alaska peninsula, near longitude $159^{\circ}$. So called by Tebenkof, 1849. Has been written Chiache (gull) and Chaicht.

Chiachi; islet, near the southeastern coast of Unimak island, eastern Aleutians. Called Chaiachie (gull) by Tebenkof, 1849.

Chibukak; cape (Cape Chibukak), the northwesternmost point of St. Lawrence island, Bering sea. Called Northwest by Tebenkof, 1849, who shows a settlement on the cape. In copying his map the name of the village was taken as the name of the cape. Written also Sivukuk, Seevookuk, Tchibukak, Tchiboukoukak, etc. According to Kotzebue the native name of the island is Tschibocki, or, as it may be written, Chiboki. See Gambell village. 
Chibukak, Eskimo village; see Gạmbell.

Chicago; creek, draining the southem slope of the divide between 'Timana river and the beadwaters of Minook creek, near latitude $\left(55^{\circ}\right.$, longitude $150^{\circ}$ 15'. Prospector's' name, obtained by Prindle, 1904.

Chicago; creek, tributary to the Yukon, on tḷe left bank between Minook and Hess creeks, about 5 miles above Minook creek near longitude $150^{\circ}$ 10'. Local name from Edwards's 'Track Chart of the Yukon, 1899.

Chicago; creek, Seward peninsula, a northeast branch of Kugruk river, near longitude $163^{\circ}$. Prospector's' name, obtained by Mendenhall, 1901.

Chicagos, island, see Chichagof.

Chicaloon, creek; see Chickaloon.

Chican, village; see Shakan.

Chic Cloon, bay and river; see Chickaloon.

Chichagof; bay, in Clarence strait, on southeastern coast of Prince of Wales island, Alexander archipelago. So named by the Russians and variously spelled Chichagoff, Chitchagoff, and erroneously 'Tehitchanoff. It is not an uncommon Russian proper name. Admiral Vasili Ialkob Chichagof, with a fleet of three ships, made explorations in the Arctic regions in 1765-1766. One of the vessels of the Russian American Company, an armed brig, was named Chichagof. 'The name of this bay has been misplaced on some charts. On 'Tebenkof's map it is very obscurely printed, making it difficult to say whether it is Chichagof or Chigatz. Also called a harbor.

Chichagof; cape, on the northern coast of Alaska peninsula, at mouth of Ugaguk river. Named Chichagova (Chichagof's) by Lutke, 1828, after Admiral Chichagof, of the Russian navy. Variously written Chichagov, Chichagow, Tchitchagow, etc.

Chichagof; cove, valley, and peak (3,000 feet high), Alaska peninsula, between Stepovak bay and Port Moller, near longitude $160^{\circ}$. Chichagof, after: the Russian Admiral, is the local name of the cove, and was reported in 1899 by the Harriman expedition, which gave the name to the valley and peak.

Chichagof; harbor, indenting north shore of Attu island, western Aleutians, near east longitude $173^{\circ} 14^{\prime}$. Surveyed and presumably named by Etolin, 1827, after one of the early Russian Arctic explorers. Sometimes written 'T'schitschagoff.

Chichagof; island, or group of islands, Alexander archipelago. Named by Lisianski, 1805, after Admiral Chichagof. First known to the Russians as Yakobi or Jakobi, a name restricted by Lisianski, in 1805, to am island at the northwestern angle of the group, and the name Chichagof applied to the remainder. It forms the northern part of King George the III's archipelago of Vancouver. The native name is Khuna or Hooniah. Variously called Chichagcv, Chichagoff's, etc., and erroneously Chicagos.

Chichagof; passage, between Etolin and Woronkofski islands, Alexander archipelago. Named by the Russians and variously spelled as above. Called also pass and strait.

Chichagof; peak $(2,600$ feet high ), in the northwestern part of Wrangell island, Alexander archipelago. Named by Snow, 1886. Erroneously Chicagoff on Coast Survey chart 706.

Chichaldinskoi, volcano; see Shishaildin.

Chichinak; Eskimo village on the mainland, east of Nunivak island, Bering sea. Visited by Nelson in December, 1878, and its name reported by him as Chichinagamiut, i. e., Chichinak people. 
Chichnareff, inlet; see Shishmaref.

Chichokna; river, on the west slope of Mount Wrangell, tributary from north to Chetaslina river, near longitude $144^{\circ} 32^{\prime}$. Indian name, written Cheechocna by Gerdine, 1902.

Chickaloon; bay, indenting the south shore of 'Turnagain arm, Cook inlet, near longitude $150^{\circ} 10^{\prime}$. Local name, published by the Geological Survey in 1899.

Chickaloon; creek and glacier at its head, tributary to Matanuska river, from the west, near latitude $62^{\circ}$, longitude $148^{\circ} 30^{\prime}$. Said by Mendenhall, 1898 , to be a proper name in local use and the spelling as above well established. Glenn, 1898, writes it Chicaloon.

Chickaloon; river, tributary to Chickaloon bay from the south. Reported by Becker, 1895, who wrote it Chic Cloon.

Chickamin; river, of southeastern Alaska, flowing into Behm canal, near latltude $55^{\circ} 50^{\prime}$, longitude $131^{\circ}$. Native name, reported by the Coast Survey in 1891.

Chicken; creek, in the Fortymile mining district, tributary to Mosquito fork, from the north, near latitude $64^{\circ} 05^{\prime}$; longitude $141^{\circ} 55^{\prime}$. So named by prospectors because the gold found here is about the size of chicken feed (corn). Reported by Spurr, Goodrich, and Schrader, 1896.

Chicken; creek; tributary to Cache creek, from the north, Seward peninsula. Name from Barnard, 1900.

Chicken; creek, tributary to North fork Koyukuk river: Prospectors' name, reported by Cantwell, 1900. Not found on any map.

Chicken; post-office (established in 1904), in the Fortymile region, located on or near Chicken creek, on Mosquito fork, Fortymile creek.

Chick-ka'u-kay-lent-nu, river; see Chikak.

Chidak, cape; see Aguliuk.

Chief; gulch, 10 miles northeast of Nome, Seward peninsula, on the south bank of Buster creek, a tributary to Nome river from the east, near longitude $165^{\circ} 13^{\prime}$. Local name, published in 1904.

Chief, island, Sitka sound; see Nachlezhnoi.

Chief, mountain ; seé 'Tyee.

Chief Stephen; Indian village, on right bank of Copper river, near latitude $62^{\circ}$. Name from Abercrombie, 1898, who wrote it Chief Stephan. Is also written Stiphan and Stiphan or Stick. Apparently it is the English name Stephen, derived through Russian pronunciation and spelling.

Chigatz, bay; see Chichagof.

Chiginagak; bay and mountain, on southern coast of Alaska peninsula, north of the Semidis. Native name, reported by Vasilief, 1831-32. Usually spelled as above. Has been written Tchighinagak and, erroneously, Tiginagak.

Chigmit; Grewingk, 1849, applies the name Tschigmit to the high range of mountains between Cook inlet and the Kuskokwim river. Dall, 1869, calls this the Alaskan range, and says the portion of them immediately northwest of Cook inlet has been termed Chigmit mountains on some maps. A map made by the United States Land Office, 1869, calls the southwestern part of the Alaska range Chigmit mountains and the northeastern part Beaver mountains. Eldridge, 1898, adopts the name Chigmit for a range west of Cook inlet, in which are the volcanoes Iliamna and Redoubt; Martin, 1903-4, applies the name to the unbroken range extending from above Mount Redoubt on the north to Bear bay in the northwest coast of Kamishak bay on the south. See also Alaska, range of mountains. 
Chignik; bay, on the south shore of Alaska peninsula, near latitude $56^{\circ} 20^{\prime}$, longitude $158^{\circ} 20^{\prime}$. Probably a native name, from the Russians. Also, erroneously, Tiznik.

Chignik; lagoon, at head of Chignik bay, Alaska peninsula. Local name, published by the Fish Commission in 1899 .

Chignik; lakes, Alaska peninsula, drained by Chignik river, into Chignik lagoon, near longitude $159^{\circ}$. Local name, published by the Geological Survey in 1905.

Chignik; post-office (established in 1901), on Chignik bay, south shore Alaska peninsula.

Chignik; river (about 6 miles long), tributary to Chignik lagoon, Chignik bay, Alaska peninsula. Local name, published by the Fish Commission in 1899.

Chignil Bay; fishing station on Chignik bay, Alaska peninsula. Population in $1890,193$.

Chigul, island; see Chugul.

Chikak; river, tributary to Skwentna river from the south near longitude $152^{\circ}$ 15'. Abbreviation of the Indian name, which Herron, 1899, wrote Chickkaw-kay-lent-nu.

Chikalan. Grewingk, following Wosnesenski, 1840, gives Tschichkalïnsk or Tschichkän Tan as the native name of a point on the eastern shore of Cook inlet just south of Kenai. Name apparently obsolete.

Chilcat; see Chilkat.

Chilcoot; see Chilkoot.

Childs; glacier, tributary to Copper river from the west, opposite Miles glacier. Só named by Abercrombie, 1884, after George Washington Childs, of Philadelphia.

Chilga; an island of this name between Adak and Great Sitkin, middle Aleutians, is mentioned by Lutke. Not identified.

Chilkat; creek, a small stream on north shore of Controller bay between Bering river and Burls creek, near longitude $144^{\circ} 12^{\prime}$. Indian name, given to this creek by prospectors in 1903 or 1.904 , and reported by Martin, 1904.

Chilkat; group of islands near entrance to Chilkat inlet. So named by Beardslee, 1880. According to Dr. Arthur Krause, the native names of the four isląnds cnustituting the group are Alzane, Katagáne, Nechrajê, and Schikosseán.

Chilkat; inlet, at head of Lynn canal, Alexander archipelago, near latitude 59 ${ }^{\circ}$ $10^{\prime}$, longitude $135^{\circ} 25^{\prime}$. Name of a native tribe obtained by the Russians and first applied to the inlet by United States naval officers in 1880. It has had various spellings, Chilcat being most common. Also written Chilkaht, Tchillkat, T'silkat, etc. The native word is a difficult one for an American to spell or pronounce. Perhaps Tsl-kaht pronounced explosively is as near as it can be rendered.

Chilkat; lake, near the head of Chilkat inlet, southeastern Alaska, draining through 'Tsirku river into Chilkat river. So called by United States naval officers in 1880. It is Tschilkat of the Krause brothers.

Chilkat, mountains; see Chilkoot.

Chilkat; pass (3,100 feet high), about 60 miles northwest from the head of Lynn canal; southeastern Alaska. Local name.

Chilkat; peak $(6,580$ feet high), near west bank of Chilkat river, near latitude $59^{\circ} 30^{\prime}$, longitude $136^{\circ} 10^{\prime}$. So called by Beardslee in 1880 . It is Tschilkat (Chilcat Pik) of the Krause brothers, 1882. See also High point.

Bull. $299-06 \mathrm{M}-12$ 
Chilkat; point, near the Chilkat Indian village, Klukwan, Chilkat river. So named by United States naval officers in 1880.

Chilkat; river, flowing into Chilkat inlet at the head of Lynn canal. Named Chilkat by the Russians, after the Indian tribe inhabiting its banks. Spelled variously Chilcat, Chilkaht, Tchillkat, T'silkat, etc., and Tschilkathin by Krause.

Chilkat; native village, on Controller bay. According to Martin, 1904, the village of this name is and always has been at the mouth of Bering river on the right bank. Earlier maps locate it on the southeastern shore of Controller bay. Native name, published in 1898 or earlier.

Chilkat, village; see Klukwan.

Chilkoot; inlet, at head of Lynn canal, near latitude $59^{\circ} 20^{\prime}$, longitude $135^{\circ} 30^{\prime}$. So named from a tribe of Indians which has a village near its head. Also written Chilcoot and cailed by Meade False Chilkaht or Tschillkat inlet. See also Dyea ind Taiya.

Chilkoot; lake, near the head of Chilkoot inlet. Named from the Chilkoot Indian village on its shores. Also written Chilcoot and Tschilkut. Has also been called Akha lake.

Chilkoot; mountains or range of mountains near the head of Lynn canal. Variously called Chilkat, Chilkoot, and Tschil-kut. Called Kotusk mountains on a recent map.

Chilkoot; pass, (3,500 feet high), 20 miles from Skagway, between the drainage into Lynn canal and the Yukon basin. Variously spelled. Has also been called Perrier by Schwatka, and Dejail (Dyea) by Ogilvie. Identical with Shasheki of Dall in the Coast Pilot (1883, p. 200); also written Shaseki, which is the native name.

Chilkoot; river, tributary to head of Chilkoot inlet, Lynn canal, s̀oụtheastern Alaska. Native name, variously spelled. Its lower part, between Chilkoot lake and Chilkoot inlet, has been called Deyea, and the upper part, above the lake, Krause calls Katschkabín; also written Kachkahin.

Chilkoot; village, or settlement of Chilkoot Indians, at outlet of Chilkoot lake. Fis been called Tschilkut and Tananei or Chilcoot.

Chimekliak; Eskino village, on the eastern shore of Kuskokwim bay, near mouth of Kuskokwim river. This may be identical with Chenik of a Russian Admiralty chart of 1802. Petrof in the Tenth Census, 1880, calls it Chimiagamute, i. e., Chimiak people, while the Eleventh Census, 1890, has Chimingyangamute. Spurr and Post, 1898, obtained from Missionary Kilbuck the name Chim-e-kliág-a-mut.

Chimiagamute, village; see Chimekliak.

Chimingyangamute, village; see Chimekliak.

Chimiudi, islands; see Kudiakof.

Chimney; creek, in the Koyukuk region, tributary to Wild river from the west, near latitude $67^{\circ} 30^{\prime}$. Prospector's' name, obtained by Peters and Schrader, 1901.

Chin; point, the northern point of entrance to Neets bay, in Behm canal, on northwestern shore of Revillagigedo island. Named by the Coast Survey in 1891. Brow and Nose points are near by.

China, river'; see Tsina.

Chinaldna, creek; see Chunilna.

Chinalno, river; see Chunilna.

Chinana, river; sce Kuskokwim.

Chinchan, bay; see Akutan harbor.

Chineeklk, hill or mountain; see Stephens. 
Chineleat, slough and Eskimo village; see Chaniliut.

Chiniak; bay, indenting the eastern end of Kodiak, near latitude $57^{\circ} 40^{\prime}$, longitude $152^{\circ} 15^{\prime}$. Native name, obtained by the early Russian explorers and variously written Chiniak, Chiniatskoi, and even, by error, Tuniak. Chiniak is Aleut for a rocky, impassable, wretched sea.

Chiniak; cape, on Alaska peninsula, northwest of Afognilk island, near latitude $58^{\circ} 30^{\prime}$. Native name, from early Russian explorers; written Chiniakskie, Chiniatskoy, Thineyak, and even Tuniak.

Chiniak; cape, the easternmost extremity of Kodiak. Has been written Chinik. Named Greville by Cook, 1778. Langsdolf identifies it with Cape Hermogenes of Bering, 1741. The Russians usually called it Tolstoi (broad). It has also been called Elovoi (spruce) and Chiniatskoy. According to Tanner, 1888, it is locally known as Chiniak.

Chinial, cape; see Shakmanof.

Chiniak; islet, off Cape Chiniak, Chiniak bay, Kodiak. Langsdorf, who accompanied Krusenstern in his voyage round the world, 1803-1806, says (II, 56) Cape Chiniak " is bounded to the north by two small islands, one of which, in the language of the country, is called Giniak, the other Ugak."

Chiniak; islet, near the northern coast of Afognak island, Kodiak group. Native name, published by the Russian American Company, 1849, as Chiniakskoi.

Chiniak, settlement; see Aleksashkina.

Chinick, village; see Cheenik.

Chiniklik; peak, in the Ilivit mountains, south of Anvik. Native name, from the Russians. Not shown on recent maps.

Chinitna; bay, indenting the western shore of Cook inlet, south of Iliamna peak, near latitude $59^{\circ} 50^{\prime}$, longitude $153^{\circ}$. Name published by the Coast Survey, 1898, by mistake as Chinitua.

Chiolvuk, village; see Chiukak.

Chipp; peak $(2,532$ feet high), in the northeastern part of Kupreanof island, Alexander archipelago. Named by Thomas, 1857, after Lieut. Charles Winans Chipp, U. S. N., who perished in the Lena delta in November, 1881.

Chipp; river, in northernmost Alaska, tributary to Admiralty bay at the head of Dease inlet, near longitude $155^{\circ}$. Ray, 1.883, reported its Eskimo name Ik-pik-pung, which has also been written Ikpikpung, Ikpekpung, Ikpikpuk, etc. It was traversed by Ensign Howard of Stoney's expedition in May and June, 1886, and named Chipp by Stoney in honor of Lieut. Charles Winans Chipp, U. S. N., who perished in the ill-fatedDe Long expedition November, 1881. According to the map of Howard's route the main river is Ik-pik-puk, and a west branch 20 miles. above Meade river, Ik-pik-pung.

Chips; cove, in the western side of the strait comnecting Alitak bay with Olga bay, southwest coast of Kodiak. Name from Moser, 1900.

Chiriliof; bay, the south end of Chatbam strait (Christian sound of Colnett in 1789), was named "Baie Tschirikow" by La Perouse, 1786 , in honor of the distinguished Kussian navigator, who visited this part of the coast in 1741. Name obsolete. See Chatham strait.

Chirikof, cape; see Bartolome and Ommaney.

Chirikof; island, southwest of Kodiak, near latitude $55^{\circ} 50^{\prime}$, longitude $155^{\circ} 40^{\prime}$. Usually called Ukamok or Chirikof island and spelled most diversely. Ukamok is said to be a native name of the marmot, but this is not verified. The island appears to be the Tumannoi (foggy) island of 
Chirikof-Continued.

Bering, 1741. Cook so. identified it in 1778. Sarichef, according to Sauer, called it Ilkamok; and Vancouver, 1794, in honor of Bering's companion, Capt. Alexie Chirikof, called it Tscherikow's island. It is variously written Akamok, Ookamok, Oukamok, Ukamok, Ugamok, and Yukamak, while Chirikof appears variously as Chirikoff, Chirikov, Tchirikoff, Tscherikow, Tschirikoff, etc.

Chisana, creek; see Cross.

Chisana; glacier, on the northeast slope of the Wrangell mountains at the head of Chisana river, near latitude $62^{\circ}$, longitude $142^{\circ} 30^{\prime}$. So called by Schrader, 1902.

Chisana; mountain (3,200 feet high), on left bank of the Tanana, near Tetling river. Name from Peters and Brooks, $189 \mathrm{~S}$.

Chisana; river, one of the two main branches at the head of Tanana river. The other is the Nabesua. They drain the northeast slope of the Alaska range and unite to form the Tanana near longitude $142^{\circ}$. Indian name, meaning Chisa river, reported by Allen, 1885. Has since been written Chusana.

Chishelnoi, islet; see Sushilnoi.

Chisik; island, on western shore of Cook inlet, at entrance to Tuxedni harbor, near Iliamna volcano. Native word, given by Tebenkof, 1849, as Khazik and in Eichwald's German text Chasik. Commonly now called Chisik. Has been printed Chisick.

Chislechina, river; see Chistochina.

Chisna; post-office (established in 1901), and river tributary to the Chistochina near its source. Indian nime, reported by Mendenhall, 1902.

Chistiakof; island, in Heiden bay, on north shore of Alaska peninsula. Named Chestaliof by the Fish Commission, 1890, presumably after Peter Egorovich Chistiakof, who was director of the Russian American Colonies, $1826-1831$.

Chistochina; river, tributary to Copper river from the north, near latitude $63^{\circ}$. Native name, obtained, 1885 , by Allen, who has Chistotchina on his map and Chitslétchiná in his text (pp. 65, 66). Hás also been written Chestochina, Chislechina, Chitsletchina, Tieschenni, etc. According to Spencer, of the Geological Survey, Chistochina represents local usage.

Chistochina; telegraph station, at the crossing of Chistochina river, 66 miles north of Copper Center. So named by the Signal Corps, U. S. A., 1903.

Chiswell; islands, off the southern coast of Kenai peninsula. Named Chiswell's islands by Portlock, 1786. Also, erroneously, Chisswell's. They are the Aialiki islands of Tebenof, which may be a native name. Has also been written Ajaliki.

Chitanana; river, tributary to Tanana river from the south 20 miles from its mouth, near latitude $65^{\circ}$, longitude $151^{\circ} 30^{\prime}$. Indian name, obtained by Herron, 1899, who wrote it Chit-an-ana.

Chitanatala; mountạins, 40 miles south of Fort Gibbon, near latitude $64^{\circ} 30^{\prime}$, longitude $152^{\circ}$. Indian name, obtained by Herron, 1899, and by him written Chit-an-at-ala, may be for Chitanadlela, i. e., Chitana mountain.

Chitchagoff, bay; see Chichagof.

Chitina; river, tributary to Copper river, from the east, near latitude $62^{\circ}$. Native name. Dall, 1869 and 1870 , wrote Chetchitno and Chechitno, and Allen, 1885, spelled it Chittyna, from chitty (copper), and na (river). Hayes wrote it Chittenah; Brooks, Chittena; and Abercrombie, Chettyna. 
Chitistone; river, tributary to the Chitina. Named Chittystone by Allen, $\mathbf{1 8 8 5}$, from chitty (copper) and stone, the English word, i. e., Copperstone river, on account of copper discolorations on the bowlders and rocks of the river's bed.

Chititu; creek, tributary to the Nizina, from the south. Called Chitty Too (copper water) by Allen, 1885. Hayes, 1891, says too means river and dek means creek, and that he has usually omitted these generic endings. The water of this stream is reported to be of a dark copper color.

Chitna; creek, in the Matanuska valley north of Cook inlet, tributary from the northwest to Caribou creek, near latitude $62^{\circ}$, longitude $148^{\circ} 10^{\prime}$. Indian name, from Glenn, 1898 , who wrote it Shitna.

Chitnak; native village and cape, on the southern shore of St. Lawrence island, Bering sea. Native name, from Tebenkof, who wrote it Shitnak. Has also been written Chitnak, Sshitnak, and T'chitnak.

Chitnashuak, village; see Sitnazuak.

Chitsia; mountain (3,675 feet high), 65 miles nortliwest of Mount McKinley, near latitude $64^{\circ}$, longitude $150^{\circ} 20^{\prime}$. Native name, from Brooks, 1902, who called it Chitsiah or Heart.

Chitsletchina; see Chistochina.

Chittenah; see Chitina.

Chittyna, river; see Chitina.

Chittystone; see Chitistone.

Chitty Too, creek; see Chititu.

Chiukak; Eskimo village near Golofnin bay, on north shore of Norton sound, Bering sea. Eskimo name called Chiuksak-miñt by the Russians, Chiokuk by Petrof in 1880, and Seookuk by Jaryis in 1898. This appears to be the same as that called Knecktakimut by the Western Union Telegraph expedition, 1867 , and Scookuk on a late Coast Survey chart. See also Akpaliut.

Chiuki; river, debouching on the const of the Gulf of Alaska 12 miles west of Cape Yaktag and 1 mile west of Kulthith river, near longitude $142^{\circ} 45^{\prime}$. Native name, reported by Martin, 1904, who wrote it Cheukee.

Chiwaki; river, 15 miles northwest of Cape Yaktag, Gulf of Alaska, a lower fork of Kaliakh river, near longitude $142^{\circ} 45^{\prime}$. Native 'name, reported by G. C. Martin, 1904, who wrote it Chewaukee. This is probably the stream called Myhote river on the Land Oftice map, 1898.

Chkazehin, river; see Katzehin.

Chlachatsch, island; see Pyramid.

Chlanak; cape, on the southeastern coast of Kanaga island, middle Aleutians. Probably a native name, from 'Tebenkof, 1849. Erroneously Ulanach.

Chlebnikoff, cape; see Khlebnikof.

Chnikchak, creek or river; see Ninilchik.

Chock; island, near entrance to 'Snug cove, Gambier bay, Admiralty island, Alexander archipelago. So named by Mansfield, 1889.

Choginng, Eskimo village; see Kanakanak.

Chokagtaligamute, native village; mentioned in Reindeer Report, 1901 (p. 83). It may be another writing of Shokfaktolik.

Chokfoltoleghagamint, lake and village; see Shokfaktolik.

Chokosna; river, tributary to Kuskulana river, from the south. Native name, from a manuscript map made by prospectors in 1900 .

Chokotonk; river, tributary to Clark lake at the extreme northeast end near latitude $61^{\circ}$, longitude $153^{\circ}$. Native name, reported by Osgood, 1902, as Chokotonkna, 1, e, Cholsotonk river. 
Chokoyik; island, in Yukon river, about 15 miles above the mouth of Nowi river. Native name, from Raymond, 1869, who shows a fishery on the island.

Chok-voay-chok, river; see Pah.

Cholmondeley; sound, indenting the eastern shore of Prince of Wales island, opposite Gravina island, Alexander archipelago. So named by Vancouver, 1793. Erroneously Colmondeley. It is Chasina bay of Tebenkof. Pronounced Chum-ly.

Chomly; post-office (established July, 1.900), on the north shore of Cholmondeley sound.

Choris; peninsula, partly separating Kotzebue sound from Eschscholtz bay, Arctic ocean. Apparently so named by Beechey, 1826, after Louis Choris, who accompanied Kotzebue on his voyage round the world.

Chornoi, cape ; see Black.

Chortof, island; see Devil.

Chouyak, island; see Shuyak.

Chowiet; island (1,200 feet high), one of the largest of the Semidi group. Native name, obtained by Dall, 1874, and spelled at first Chowee-et. This and Aghiyuk are of about equal size, are the two largest islands of the group, and are now both occupied as blue-fox farms. Billings speaks of " Evdokeeff, the largest Simedan," and Lutke also says " Semidin, the largest of the Evdokeevskies." This name, applicable to either, probably refers to Aghiyuk.

Chraalch. The Krause brothers, 1882, show on their map a supposed river, draining from a glacier southward to Tahini river (of their map), which in turn debouches into Chilkat river. They write it Chraalch.

Christian; creek, 25 miles north of Cape Nome, Seward peninsula, tributary to Nome river from the east, near longitude $165^{\circ} 12^{\prime}$. Local name, from Gerdine, 1904.

Christian; sound, the southern end of Chatham strait, Alexander archipelago. . So named by Capt. James Colnett, of the Argonaut, an English fur trader on this coast, 1789. Also called Christians, Christian's, and, erroneously, Christiana.

Christie; point, the western point of entrance to Dease inlet, on the Arctic coast, just east of Point Barrow. So named by Dease and Simpson, 1837, after Chief Factor Christie, of the Hudson Bay Company. Er-roneously Christy.

Christina, islet; see Cristina.

Christmas; island, in Security bay, Kuiu island, Alexander archipelago. So named by Glass in 1881.

Christoval, channel; see San Christoval.

Chuarlitilik; a deserted Eskimo village on Kanektok river, north bank, about 55 miles from the Kanektok's mouth. Is called by Spurr and Post, of the Geological Survey, who passed by it September 3, 1898, Chwarlitilígamut, i. e., Chu-ar-li-til-ik people.

Chuck, river; see Shuck.

Chuck-a-uvon-ugh-toly, river; see Chukawon.

Chudnoi, island ; see Queer.

Chudoelkow, islands ; see Kudiako.

Chugach; islands, at Cape Elizabeth, near eastern entrance to Cook inlet. Native name, from the Russians, who wrote it Chugatskie, or Chugatzkiia. Has also been written Chugatz. The westernmost large island, Cape Elizabeth, is occupied as a blue-fox farm; the eastern island formerly so occupied has been abandoned. 
Chugach; mountains (5,000 to 7,000 feet high), on the coast of the Gulf of Alaska, extending from Kenai peninsula eastward on the north coast of Prince William sound and across Copper river. A native name, obtained by early Russian traders, and by them written Chugatz and Tchougatskoi. Now usually Chugach or Chugatch.

Chugach, gulf; see Prince William sound.

Chugachile, bay; see Kachemak.

Chugachik; island at head of Kachemak bay, Cook inlet. Native name, from Tebenkof, 1848.

Chugatch, mountains; see Chugach.

Chugatz, islands ; see Chugach.

Chugiginak; rock (123 feet high) between Amukta and Yunaska, in the group of islands of the Four Mountains, eastern Aleutians. Native name, from Veniaminof, 1840.

Chuginadak; island, the largest of the group of islands of the Four Mountains, eastern Aleutians. Discovered by Stepan Glottof in 1764. Called by the natives Tanak-angunak (land-big), and variously called Tana, Tano, Tana-unok, Tanakh-Angounakh, etc. In 1849 Tebenkof called it Chuginadak, variously written Tchoughinadokh, Chuginok, etc. Tradition has it that there were formerly two islands which were united by a volcanic eruption filling the strait which separated them.

Chuginok, island; see Chuginidak and also Herbert.

Chugul; island $(2,696$ feet high), east of Kiska, Rat island group, western Aleutians, near east longitude $178^{\circ}$. Apparently a native name, from early Russian. explorers. Variously written Chugal, Segula, Sigoola, Tschechovla; also Tchougoule or Iron island of the North Pacific exploring expedition, 1855 .

Chugul; island, southenst of Great Sitkin, Andreanof group, middle Aleutians, near longitude $176^{\circ}$. Native name, from early Russians. Billings, 1790, wrote it Tshugulla. Has also been written Chigul, Tchigul, Tchougoul, Tchougoulak, etc.

Chugul; volcanic island (4,300 feet high), one of the group of islands of Four Mountains, middle Aleutians, as classified by Veniaminof. It is between Amukta and Yunaska, near longitude $171^{\circ}$. Native name, from Sarichef, about 1790 , who wrote it Chugula. Variously written Chegoula, Chagulak, Tchougoulok, etc.

Chuit; river, tributary to Cook inlet, from the northwest, near its hend. Native name reported as Shuitna and Chuitna, i. e., Chuit river. Also has been written Chaitna, Chuitan, and Shuitna. Called Chuitan by the Coast Survey, in 1898, i. e., Chui cape.

Chuitna; river; see Chulitna.

Chuiu; bay and river, tributary to south shore of Kamishak bay, Cook inlet. Native name, published by Tebenkof, 1849. Has been written Tschuiou and Tschuiow. Martin, 1904, says it is now called Douglas river or Andrews river by prospectors.

Chukajak; creek, tributary to the Tubutulik river, from the east, Seward peninsula. Prospector's' name, from Peters, 1900.

Chukawon; river, the left fork near the head of Chulitna river, a branch of the Kuskokwim, near longitude $157^{\circ}$. Eskimo name, written Chuck-awon-ugh-toly on an unpublished map drawn by W. R. Buckman, who prospected the Chulitna valley in 1902-3.

Chukchuk; Eskimo viliage on the right bank of the lower Yukon, 5 miles above Ingrakak, near latitude $61^{\circ} 45^{\prime}$, longitude $161^{\circ} 30^{\prime}$, called Chukchukamute, i. e., Chukchuk jeople, by Raymond, 1869. Perhaps identical with Takshak. See Takshak. 
Chukwoktulik; Eskimo village, Yukon delta, on the right bank of Kashunuk river, 20 miles southwest of Andriafski. Visited by Jarvis in 1897.

Chukwoktulik; Eskimo village on Lake Agu in the Yukon delta, visited by Jarvis in 1897 and by him written Chukwoktuliugamute and Chukwo. ktulik. Another writing may be Shokfaktolik, which see.

Chuligmiut, villages; see Upper Chulik.

Chulik: The Eleventh Census, 1890 (p. 114), speaks of two Eskimo villages on the easetrn shore of Nunivak, together containing 62 people, and called Upper Chuligmiut and Chuligmiut, i. e., Chulik people. Not found on any map.

Chulitna; pass, between the Susitna and Chulitna rivers. So called by Eldridge, 1898.

Chulitna; river, the principal southern tributary of the Kuskokwim, near longitude $157^{\circ}$. The first white man to visit it was the Russian creole Lukeen, who descended it in 1832. According to Spurr, 1898, deriving his information from A. Lind, a trader, it is Chulitna, i. e., Chulit river of the Indians, and Holiknuk of the Eskimo. These two have been confounded and written variously, Chulitna, Holitno, Hoiiknuk, Hulitna, Hulitnak, or Hulitno, and by transliteration from the. Russian Hoolitna, Khulitno; Kulitnak, etc. The name first appears on sheet 3 of Sarichef's atlas, corrected to 1829, as Hulitna. The east branch of this river is here called Haliknuk river.

Chulitna; river, tributary to Clark lake from the west near latitude $60^{\circ} 30^{\prime}$, longitude $155^{\circ}$. Indian name, reported by Schanz, 1890. According to Osgood it is pronounced Charleetna by the prospectors and others. Erroneously Chuitna, Chultina, and Chutina.

Chulitna; river, one of the principal western tributaries of the Susitna river. Native name, from Eldridge, 1898, who says it is often pronounced Chulitno. Chulitna or Chulitno means Chulit river.

Chuliun; lake, south of Nushagak lake. So called by Tebenkof, 1849.

Chultina, river; see Chulitna.

Chunak; cape, on the northeastern coast of Unimak island, at entrance to Isanotski strait, near longitude $163^{\circ} 30^{\prime}$. Native name, reported by Lutke, who wrote it Tchounok. Tebenkof, 1849, wrote Chunak and Dall, Chunnok. Veniaminof in his notes (I, 214) writes it Chunnak.

Chuniksak; cape, on the southwest coast of Attu island, western Aleutians. Native name, published by Tebenkof, 1848.

Chunilna; creek, tributary to the Talkeetna, from the north, near longitude $150^{\circ}$. Name from Eldridge and Muldrow, 189S. On one map they have Chunilna, on another Chinaldna. Different members of Glenn's expedition write it Chinalno, Chinaldna, and Chinaltno.

Chunnok, cape; see Chunak.

Chunu; cape, the southwesternmost point of Kanaga island, middle Aleutians. So called by Tebenkof, 1849. Has also been written Tchuna.

Chupador, cape; see Suckling.

Church; peak, on mainland, east of Frederick sound, southeastern Alaska. Named by Thomas, 1887.

Church; point, on the southern coast of Gambier bay, Admiralty island, Alexander archipelago. So named by Mansfield, 1889.

Chusana, river; see Chisana.

Chustielena, lake; see Tustumena.

Chuyal, island and strait; see Shuyak.

Chutina, river; see Chulitna. 
Chvilnuk; river, tributary to the Yukon, from the north, a little above Andreafski. Called Chvilnuk by the Russians and Milavanoff (a Russian proper name) by Dall. Possibly identical with Clear river. See Clear. Chwarlitiligamut, village; see Chuarlitilik.

Cipres, Punta de; see Cypress.

Circle; creek, Seward peninsula, tributary to Holtz creek from the west near latitude $65^{\circ} 30^{\prime}$, longitude $162^{\circ} .35^{\prime}$. Prospectors' name, obtained by Witherspoon, 1903.

Circle; islet, in or near Revillagigedo channel, Alexander archipelago. So called by the Coast Survey in Coast Pilot, 1883. Not found on any map.

Circle; point, the south point of entrance to Slocum inlet, Stephens passage, Alexander archipelago. Descriptive name given by Thomas, 1888 .

Circle; trail, mining camp, and post-office (established in 1899), on west bank of the Yukon, near latitude $66^{\circ}$. Called Circle City by the miners from its supposed location on the Arctic circle. See Birch Creek trail.

Cirquet, lake; see Sirkwet.

Cirquet, river; see Takhini.

City of Topeka; rock, in Highfield anchorage, north end Wrangell island, Sumner strait, Alexander archipelago, near latitude $56^{\circ} 29^{\prime}$, longitude $132^{\circ} 23^{\prime}$. Described in the Coast Pilot of 1.901 and named after Pacific: Coast Steamship Company's steamer City of Topeka, which reported it, perhaps.

Clahona, river; see Klahini.

Clam; island, in Neets bay, Behm canal, Alexander archipelago. Named by the Coast Survey in 1891.

Clam; island, in northenstern part of Prince William sound. Name publishe: by the Coast Survey in 1900.

Clam; island, Bucareli bay, Prince of Wales archipelago, at north side of entrance to Klawak inlet, near latitude $55^{\circ} 30^{\prime}$. So called by Moser, 1897 .

Clam; reef, Bucareli bay, Prince of Wales archipelago, near the southwest shore of Fish Egg island at entrance to Klawak inlet, near latitude $55^{\circ} 30^{\prime}$. So called by Moser, 1897.

Clara; creek, 20 miles north of Nome, Seward peninsula, tributary to Nome river from the west, near longitude $165^{\circ} 13^{\prime}$. Name from Barnard, 1900 .

Clara; creek, tributary from the east to Middle fork Koyukuk river, near latitude $67^{\circ} 20^{\prime}$, longitude $150^{\circ} 1.5^{\prime}$. Prospector's' name, obtained by Peters and Schiader in 1901.

Clara Marie, bay; see Aiken cove.

Clare; island, at the entrance to Niblack anchorage, Moira sound, western shore Clarence strait, southeastern Alaska, near latitude $55^{\circ} 04^{\prime}$, longitude $132^{\circ} 05^{\prime}$. Local navigator's' name, reported by H. C. Fassett, Bureau of Fisheries, 1.904.

Clarence; port, indenting wéstern end of Seward peninsula, Bering strait, near latitude $65^{\circ} 15^{\prime}$. Long known to the Russians under the name of Kaviaiak bay. First described by Beechey, who visited it in Septem. ber, 1827 , and named it Clarence, after the Duke of Clarence. According to Sauer its native name is Imagru.

Clarence; strait, in Alexander archipelago. Surveyed and named by Vancouver in 1793, " in honour of His Royal Highness Prince William Henry * * The Duke of Clarence's strait." Also written Clarence sound. 
Clark; bay, indenting the western shore of Twelvemile arm of Kasaan bay, eastern shore Prince of Wales island, Alexander archipelago. Local name, from Brooks, 1901.

Clark; creek, southwestern Aliski, tributary to Nushagak bay, eastern shore, on the north side of Clark point. Local name, reported by Moser, 1901.

Clark; island, the westernmost large island cf the Siginaka group in extreme northern part of Sitka sound. Named Kliarkof (Clark) by Vasilief, 1809.

Clark; lake, between 50 and 60 miles long and from 2 to 10 miles wide, west of and near Cook inlet, about latitude $60^{\circ} 30^{\prime}$, longitude $154^{\circ}$. Supposed to have been discovered by John W. Clark, chief of the Nushagak trading post, in 1891, and on late charts named after him. It is, however, shown on a Russian government map of 1802 with the name Ilima, while Iliamna lake is called Shelikof.

Clark; point, near mouth of Nushagak river, latitude $58^{\circ} 49^{\prime}$, longitude $158^{\circ}$ 32'. Named Clark's point by the Fish Commission, in 1890 , perhaps after Prof. Samuel Fessenden Clark, of Williams College. See also Ekuk cape.

Clark Point, Eskimo village; see Stagarok.

Clashmore; mountain (5,502 feet high), east of Portland canal. Named by Pender, 1.868.

Clate-ech-li-nich, mountains; see Kletekhlinik.

Claude; point, on the northern shore of Revillagigedo island, Behm canal, Alexander archipelago. Named by the Coast Survey in 1891.

Clear; creek, tributary to the Kotsina from the north. Prospectors' name reported by Gerdine, 1900 .

Clear; creek, tributary to the Tubutulik river from the west, Seward peninsula. Prospector's' name, from Peters, 1900.

Clear; creek, 20 miles north of Controller bay, Gulf of Alaska, tributary on the north bank of Stillwiter creek, near longitude $144^{\circ}$. Prospectors' name, reported by Martin, 1905.

Clear; creek, tributary to Bear creek, which is tributary to the Chilkat river, near latitude $59^{\circ} 30^{\prime}$, longitude $136^{\circ} 10^{\prime}$. Local name, reported by Wright, 1903. Krause brothers, 1882, wrote the Indian name Katschadélch.

Clear, creek; see Deep.

Clear, islets; see Battery.

Clear; point, the north point of entrance to Funter bay, near south end of Lynn canal, Alexander archipelago. So named by Mansfield, 1890.

Clear; river, tributary to the Yukon, right bank, at Andreafski, near head of Yukon delta. The name is a translation of the Russian name Swetla Rechka. Called Andreafski by the Coast Survey in 1898, and very commonly so called. Raymond, 1869 , calls it Konnekova or Clear river. On several maps called Clear river. Its native name as used by the Russians is Niegieklik.

Clear, river; see Chvilnuk.

Cleare; cape, the southern end of Montague island, Prince William sound. So named by Portlock in 1789. Also called Cape Clear and Southwest cape.

Cleary; creek, in the Fairbanks region, tributary to Chatanika river from the south, near latitude $65^{\circ} .05^{\prime}$ longitude $147^{\circ} 30^{\prime}$. Local name, from Gerdine, 1903.

Cleary; mining camp and post-office (established in September, 1905), on Cleary creek, in the Fairbanks region. Called Cleary City by the miners, and reported by Prindle in 1905. 
Cleave; creek, tributary to Copper river from the west, near latitude $61^{\circ}$. Local name, from Schrader, 1898.

Cleft; island, in Security bay, Kuiu island, Alexander archipelago. Descriptive name, given by Meade in 1869.

Clem; mountain, Seward peninsula, 15 miles southeast of Spafarief bay, near latitude $65^{\circ} 59^{\prime}$, longitude $161^{\circ} 21^{\prime}$. Prospectors' name, obtained by Witherspoon, 1901.

Clerlee's, island ; see St. Lawrence.

Cleveland. A mountain near Mount St. Elias was so named by the New York Times expedition of 1886, after President Grover Cleveland.

Cleveland; mountain (Mount Cleveland) 6,170 feet high, between Skagway and Taiya ivers, southeastern Alaska, near latitude $59^{\circ} 37^{\prime}$, longitude $135^{\circ}$ 15'. So named by Flemer: in 1898 , but not hitherto published.

Cleveland; passage, between Whitney island and the mainland, Frederick sound, Alexander archipelago, near latitude $57^{\circ} 14^{\prime}$, longitude $133^{\circ} 30^{\prime}$. So named by Thomas, in 1887 , after President Grover Cleveland.

Cleveland; peninsula, a projection of the mainland between Behm canal and IEnest sound. Named by the Const Survey, in 1886, after President Grover Cleveland.

Cleveland; volcanic peak $(8,150$ feet high), on Chuginadak island, one of the group of islands of the P.'our Mountains, enstern Aleutians. So named by officers of the U. S. S. Concord, in 1894, after President Grover Cleveland.

Cliff; islet, in entrance to Womens bay, Chiniak bay, Kodiak. Named Utesistoi (cliffy) by Russian naval ofticers, 1808-1810.

Cliff; point, between Middle and Womens bays, in Chiniak bay, Kodiak. Named Utesof. (cliff) by Russian naval officers in 1808-1810.

Cliff; point, on the eastein shore of Port Frederick, Icy strait, Alexander archipèlago. Named by United States naval officers in 1880 .

Cliff; point, on the southeastern shore of Pearse island, Portland inlet, Alexander archipelago. So called by Pender in 1868. Has also been called Base point and Rose point.

Clifford; creek, tributary to Mission creek, from the southwest, in the Earle mining region, Local name, published in 1899 .

Clifford; creek, Seward peninsula, tributary to Goodhope bay from the sout?, near longitude $163^{\circ} 30^{\prime}$. Prospector's name, obtained by Mendenhall and Reaburn, 1901.

Clifford; island, off the southwest shore of and near to Sannak island, near latitude $54^{\circ} 25^{\prime}$, longitude $162^{\circ} 50^{\prime}$. So named by the Fish Commission in 1890. Sometimes called Long islind.

Clifford; mountain (Mount Clifford, 5,820 feet high), between Taiya and Skagway rivers, sontheastern Alaska, about a mile southwest of Mount Carmack, near latitude $59^{\circ} 33^{\prime}$, longitude $135^{\circ} 15^{\prime}$. So named by Flemer, 1898, but not hitherto published.

Clinker; plateau, in western part of St. George island, Pribilof group, Bering sea. Descriptive name, published by the Coast Survey in $\mathbf{1 8 7 5}$.

Clondyke, river; see Klondike.

Close; bay, on outer coast of Baranof iṣland, Alexander archipelago. Named Close (dushnaia) by the Russians before 1850. Has been called Close or Dushnaia (close) and Doushnai.

Close, island; see Near.

Closed, bay; see Banks harbor. 
Cloudman; bay, indenting the southeastern shore cf Bligh island, Prince William sound, near latitude $60^{\circ} 50^{\prime}$, longitude $146^{\circ} 40^{\prime}$. Local name, from Schrader, 1900.

Clover; bay, indenting eastern shore of Prince of Wale; island, just north of Cholmondeley sound, Alexander archipelago. Surveyed and named Thomas by Commander Richardson Clover, U. S. N., in 1885. Afterwards the name was changed to Clover by direction of the Superintendent of the Coast and Geodetic Survey to prevent confusion with another Thomas bay in the Alexander archipelago.

Clover; island, in Clover passage, northern entrince to Behm canal, southeastern Alaska; near latitude $55^{\circ} 30^{\prime}$, longitude $131^{\circ} 48^{\prime}$. Name so applied by local navigators, and reported by H. C. Fassett, Bureau of Fisheries, 1904.

Clover; passage, in northern entrance to Behm canal, separating Betton and other islands from Revillagigedo island. Named by the Coast Survey, in 1886, after Commander Richardson Clover, U. S. N.

Clover; point, north point cf entrance to Clover bay, western shore Clarence strait, southeastern Alaska, near latitude $55^{\circ} 18^{\prime}$, longitude $132^{\circ} 10^{\prime}$. So applied by the local navigators, and reported by H. C. Fassett, Bureau of Fisheries, 1904.

Club; point, on Liesnoi island, Eliza harbor, Frederick sound, Alexander arch:pelago. Named by Mansfield in 1889.

Club; rocks, two in number ( 15 feet ligh), 3 miles south of Cape Northumberland, Dixon entrance. So named by Nichols, 1883.

Clubokoi, lake; see Deep.

Clums; fork of Birch creek, eastern Alaska, on south side, near latitude $65^{\circ} 15^{\prime}$, longitude $145^{\circ} 15^{\prime}$. Prospectors' name, reported by Witherspoon, 1905.

Coagalga, island; see Tigalda.

Coal; bay, on the northern shore of Kachemak bay, Cook inlet, inside Homer spit, near latitude $59^{\circ} 40^{\prime}$, longitude $151^{\circ} 20^{\prime}$. Called Ugolnoi (stone coal) by Tebenkof, 1849. Coal abounds here and mines are in operation.

Coal; bay, on the southern shore of Alaska peninsula, northwest from the Shumagins. So named by Dall in 1880. Near it is Ugolnoi (stone coal) island of the Russians.

Coal; bay, on the southern shore of Kasaan bay, Prince of Wales island, Alexander archipelago. Apparently so named by Nichols, in 1891, who reports outcrops of coal here.

Coal; bluff, on the eastern shore of Herendeen bay, Alaska peninsula, 6 miles south of Point Divide, near longitude $160^{\circ} 45^{\prime}$. Descriptive name, given by Tanner, 1890 .

Coal; bluffs, northern Alaska, on the west bank of Colville river, about latitude $69^{\circ} 30^{\prime}$. Descriptive name, given by Peters and Schrader, 1901.

Coal; cape, on southern coast of Alaska peninsula near the Chiachi islands. So named by the Coast Survey in 1882.

Coal; cove or harbor, in Port Grahnm, Cook inlet. Named Coal harbor by Dixon, in 1786 , who found "a vein of coals" there. Also called Coal bay.

Coal; creek, in the Cepper river region, tributary to Chisna river at its source. So named by prospectors, from the coal found on the stream, and reported by Mendenhall, 1902 .

Coal; creek, Alaska peninsula, tributary to Mine harbor, Herendeen bay, from the east, near latitude $55^{\circ} 45^{\prime}$, longitude $160^{\circ} 40^{\prime}$. Prospectors' name, reported by Sidney Paige of the Geological Survey, 1905. 
Coal; creek, tributary to Dall river, near Dall City, about longitude $150^{\circ}$. Prospectors' name, reported by Mendenhall and Reaburn, 1901.

Coal; creek, tributary to the Yukon from the south, near longitude $143^{\circ}$. Local name, from Cantwell, 1900.

Coal; creek, about 5 miles east of Bluff point, north shore at entrance to Kachemak bay, Cook inlet. I_ocal name, obtained by Stone, 1904.

Coal; creek, tributary to Matanuska river from the south, opposite the mouth of Chickaloon creek, near longitude $148^{\circ} 30^{\prime}$. Local descriptive name, from Mendenhall, 1898.

Coal; creek, tributary to Solomon river from the east, Seward peninsula. Name from Barnard, 1900.

Coal; glacier, tributary to Tyndall glacier near Mount St. Elias, southeasteru Alaska. So named by Topham in 1888.

Coal; harbor, at the head of Zachary bay, Unga island, Shumagin group. Probably so named by the Western Union 'Telegraph expedition in 1865. The name has also been applied to Zachary bay. Also called North harbor of Unga.

Coal, harbor, Herendeen bay ; see Mine.

Coal; point, the end of Homer spit, projecting from the northern shore of Kachemak bay, Cook inlet, near latitude $59^{\circ} 36^{\prime}$, longitude $151^{\circ} 24^{\prime}$. Called Ugolnoi (stone coal) by Tebenkof, in 1849, from the presence of coal upon and near it.

Coal; valley, Alaska peninsula, on the eastern shore of Herendeen bay, 3 miles southeast of Point Divide, near latitude $55^{\circ} 50^{\prime}$, longitude $160^{\circ} 40^{\prime}$. Descriptive name, published by the Coast Survey in 1900 .

Coal Harbor; post-office (established in 1903), on Coal harbor, Zachary bay, Unga island, Shumagin group:

Coarse Gold; creek, tributary to the Kougarok river from the west, Seward peninsula. Name from Brooks, 1900.

Coarse Gold; gulch, Seward peninsula, in Solomon River basin, on left bank of Penny creek, near latitude $64^{\circ} 40^{\prime}$, longitude $164^{\circ} 20^{\prime}$. Prospectors' name from a local map, 1901.

Cobb; island, near Silver point in Sitka sound, Alexander archipelago. So named by United States naval officers in 1880.

Cobblestone; river, tributary to Imuruk basin from the south, Seward peninsula. Name from Barnard, 1900.

Coblura. This word Coblura appears on British Admiralty chart 2164, of Point Barrow, published in 1854, near a small sand spit in the northern part of Elson bay, Arctic coast.

Cobolunuk, Eskimo village; see Kobolunuk.

Cobras Head; some feature, not discovered what, on the Mosquito fork of South fork Fortymile creek. Name from. Wells, 1890. Written also Cobra's Head and Cabras Head.

Cochrane; point, opposite Port Wells, on the northwestern shore of Prince William sound. So named by Vancouver, 1794. Erroneously Cochran.

Cochranes, trading post and telegraph station; see Kokrines.

Cocos; point, on south end of St. Ignace island, Bucareli bay, Prince of Wales archipelago. Named Punta de Cocos (cocoa point) by Maurelle and Quadra in 1775-1779.

Cod; point, west shore Revillagigedo island, on the east side of Moser bay, Naha bay, Behm canal, southeastern Alaska, near latitude $55^{\circ} 35^{\prime}$, longitude $13.1^{\circ} 40^{\prime}$. Local navigators' name, reported by H. C. Fassett, Bureau of Fisheries, 1904. 
Codiac, island; see Kodiak.

Coffee; creek, tributary to Kougarok river from the west and just north of Coffee Dome, Seward peninsula. Latitude $65^{\circ} 18^{\prime}$. Local name, from Gerdine, 1901.

Coffee, creek; see Slate.

Coffee; point, near the mouth of the Nushagak river. Traders' name, published by the Fish Commission, 1891.

Coffee; point, on north shore of Kasilof river, Kenai peninsula, 4 miles above its mouth. Name from Moffit, 1904.

Coffee Dome; mountain (2,400 feet high), in the Fairbanks region, near latitude $65^{\circ} 05^{\prime}$, longitude $147^{\circ} 10^{\prime}$. Probably Iocal name, from Gerdine 1903.

Coffee Dome; mountain, Seward peninsula, near latitude $65^{\circ} 18^{\prime}$, longitude $164^{\circ}$ 44'. Local name, obtained by Gerdine, 1901.

Coffman; cove, indenting the northeastern shore of Prince of Wales island, at southern. entrance to Kashevarof passage, Alexander archipelago. Named by Snow, 1886, after Lieut. Dewitt Coffman, U. S. N., a member of his party.

Coffman; island, near Coffman cove, at southern entrance to Kashevarof pass-

: . age, Alexander archipelago. Named by Snow, 1886.

Coghlan; island ( 436 feet high), near the western entrance to Gastineau channel, Alexander archipelago. Named by the Coast Survey, 1885, after Commander Joseph Bullock Coghlan, U. S. N. Erroneously Coglan.

Cogrua, river; see Kugrua.

Cogtua, river; see Meade.

Cohen; island, in Favorite channel, Lynn canal, Alexander archipelago. Named by the Coast Survey in 1893.

Cohen; island, on southern shore of Kachemak bay, Cook inlet. Named by Dall, in 1880 , after a trader of that name stationed in Cook inlet at that time.

Cohen; reef, in Favorite channel, Lynn canal, Alexander archipelago. So named by Coghlan, 1884.

Coho; cove, indenting the southern shore of Revillagigedo island, Revillagigedo channel, Alexander archipelago, near latitude $55^{\circ} \cdot 16^{\prime}$, longitude $131^{\circ}$ 22 . . Name reported by local navigator's to H. C. Fassett, Bureau of Fisheries, 1904. Coho (a species of salmon.)

Cohoes; creek, in the southern part of the St. Elias alps, southeastern Alaska. Name published by the Coast Survey in 1889.

Coke; point, the northern point of entrance to Holkham bay, Stephens passage, Alexander archipelago. Named by Vancouver, 1794.

Cold; baly, indenting the southern shore of Alaska peninsula, just west of Belkofski, longitude $162^{\circ} 30^{\prime}$. Named Morozovskie or Morozova (cold, frozen) by the Russians. Has been called Cold, Frozen, Morozoffski, etc.

Cold; bay, on southern shore of Alaska peninsula, west of Kodiak, near latitude $57^{\circ} 45^{\prime}$. Named Studenaia (cold, freezing) by the Russians on account of the cold winds which draw through a deep ravine or gorge from Becharof lake. The native name appears to be Puale. Variously called Studenaja, Puale, Pouale, and, erroneously, Stulchena.

Cold; creek, 20 miles north of Nome, Seward peninsula, an east branch of Grouse creek, draining through Goldbottom creek into Snake river, near latitude $64^{\circ} \overline{45^{\prime}}$, longitude $165^{\circ} 21^{\prime}$. Local descriptive name, from Gerdine, 1904. 
Colder $u$, port; see Caldera.

Coldfood, post-oftice; see Coldfoot.

Coldfoot; mining camp, and post-office (established in 1903), on Middle forl: Koyukuk river, at the mouth of Slate creek, near latitude $67^{\circ} 15^{\prime}$. Erroneously Coldfood.

Coleen; mountain, on north bank of the Yukon, near mouth of the Coleen river. So called by the Coast Survey in $\mathbf{1 8 9 5}$.

Coleen; river, tributary to the Porcupine, from the north, between the upper and lower Ramparts of the Porcupine, near longitude $142^{\circ} 30^{\prime}$. So called by the Coast Survey in 1895 .

Coleman, point; see Thateher.

Coleman; reef or shoal in Chatham strait, off Thatcher point, near the eastern end of Peril strait, Alexander archipelago. So named by Dall in the Coast Pilot in 1883 . The name Coleman had been given by Homfray, in 1867 , to the adjacent point, now called Thatcher.

College; fiord, in Port Wells, Prince William sound. So named by the Harriman expedition in 1899.

Collie; point, on the Arctic coast, at entrance to Wainwright inlet. Named by Beechey, in 1.826, after his surgeon, Alex. Collie. Called Kalidge on Russian Hydrographic chart 1495. Perhaps this comes from an erroneous transliteration of Collie into Russiau.

Colling; mountains (3,000 to 4,000 feet high), on the eastern shore of Portlind canal. Called Colling range by Pender, 1868.

Collins; creek, Seward peninsula, tributary from the west to Hannum creek, which is a tributary to Inmachuk river, near latitude $65^{\circ} 52^{\prime}$, longitude

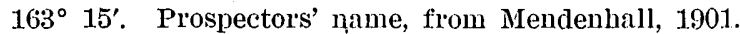

Collinson; point, near Camden bay, on the Arctic coast, about $4^{\circ}$ west of the international boundary. Capt. Richard Collinson, R. N., of Her Majesty's ship Enterprise, wintered here in 1853-54, whence the name.

Colmondeley, sound; see Cholmondeley.

Colorado; creek, tributary to Cripple creek, in the Nome mining region, Seward peninsula. Frospector's' name, published in 1900. Identical with Dog creek or Ryan creek of the Davidson-Blakeslee map of 1900 .

Colorado; creek, tributary to Klokerblok river, from the south, Seward peninsula. Name from Barnard, 1900.

Colorado; creek, Kenai peninsula, a left branch of Canyon creek, near its head. Local name, from Moffit, 1.904.

Colorado; creek, tributary to Mission creek, from the south, 7 miles west of Eagle. Local name, reported by Barnard, 1898. Spurr, Goodrich and Schrader, 1896, called it Boulder creek. See also Montana.

Colpas, Isla de; see Hawkins island.

Colpoys; point, at northeast angle of Prince of Wales island, Sumner strait, Alexander archipelago. Named by Vancouver, 1793, after Admitral Colpoys, R. N.

Colt; island, west of Douglas island, in Stephens passage, Alexander archipelago. Named by the Coast Survey in 1891.

Columbia; bay, immediately west of Port Valdes, indenting northern shore of Prince William sound, near latitude $61^{\circ}$, longitude $147^{\circ}$. So called by the Harriman expedition in 1899. It is Glacier bay of Abercrombie, 1898 .

Columbia; creek, tributary to O'Brien creek, from the west, in the Fortymile mining region. Loçal name, obtained by the Geological Survey in 1898. 
Columbia; glacier, discharging into Columbia bay, Prince William sound. So named by the Harriman expedition in 1899.

Columbia; peak $(7,500$ feet high), in the Tordrillo range. So named by Spurr and Post, 1898.

Columbia; point, on the eastern shore of Portland canal. Name published by the Coast Survey in 1891.

Columbine; rock (3 feet out of water), southwest shore Neva strait, Alexander archipelago, near latitude $57^{\circ} 16^{\prime}$, longitude $135^{\circ} 35^{\prime}$. Named after the U. S. light-house tender Columbine, and described in the Coast Pilot of 1901.

Column; point, the northeast headland of Lisianski strait, Chichagof island, Alexandèr archipelago, near latitude $5 S^{\circ} 07^{\prime}$, longitude $136^{\circ} 26^{\prime}$. Descriptive name, given by Dall, 1880 . Vaucouver's name Lucan has been accidentally applied to this point.

Colville; river, northern Alaska, draining to the Arctic ocean, near longitude 151. ${ }^{\circ}$. Named by Dease and Simpson, 1837, after Andrew Colvile, of the Hudson Bay Company. On Dease and Simpson's map it was spelled Colville. The Eskimo name is reported to be Or-kim-ya-nook. Ray (Report, 1885, p. 55) says: "The Colville river was always spoken of as 'Neg-a-len-mi-ku (the river at Negalek),' and we did not obtain the name." John W. Kelly (Eskimo Vocabularies, Bureau of Education, 1896-97) has Negáleh. Stoney, 1886, wrote Kun-ya-nook and Kungyanook; and Cantwell, 1885, Kar-n'yer-nok.

Colwell; bend, in Koyukuk river, near longitude $157^{\circ}$. So named by Allen in 1885, " in honor of Mr. Colwell, of the Adjutant-General's Office, who gave me such conscientious work in working up my observations and making my maps."

Comet; creek, an affluent of North fork, Fortymile creek, from the left, near latitude $64^{\circ} 30^{\prime}$. Local name, obtained by the Geological Survey in 1898. It is Count creek of Aber'crombie's map.

Comet; mining camp and landing, on the eastern shore of Lynn canal, southeastern Alaska, just north of Point Sherman, near latitude $58^{\circ} 52^{\prime}$. 'This is the place formerly called Seward City. Prospector's' name, reported by Spencer and Wright, 1903.

Comfort; point, near Cape Halkett, on the Arctic coast east of Point Barrow, near longitude $152^{\circ} 14^{\prime}$. So named by Dease and Simpson, in 1837, " in gratitude for seasouable comforts."

Composite; island, near the head of Glacier bay. Descriptive name, given by Reid in 1892.

Conbert; creek, north of the Tanana, tributary to Preacher creek, near its source, about latitude $65^{\circ} 30^{\prime}$, longitude $146^{\circ} 20^{\prime}$. Prospectors' name, obtained by Gerdine, 1903.

Conclusion; island, in southern part of Keku strait, Alexander archipelago. Named by Vancouver, who concluded his season's work of 1793 at this point.

Conclusion; point, on the southeastern shore of Baranof island, Chatham strait. It forms the northeast extreme of the peninsula between Port Alexander and Port Conclusion. So described in the Coast Pilot of 1901.

Conclusion; port, near the south end of Baranof island, Alexander archipelago. So named, 1794, by Vancouver, who here concluded his survey of the northwest coast of America.

Concord; creek, $6 \frac{1}{2}$ miles north of Cape Nome, Seward peninsula, tributary to Fox lake from the west, near longitude $165^{\circ}$. Name from Gerdine, 1904. 
Concord; point, the southenstern point of Chuginidak island, islands of the Four Mountains group, eastern Aleutians. So named, 1894, by officers of the U. S. S. Concord, who made surveys here at that time.

Cone; bay, indenting the northwestern shore of Heceta island, Prince of Wales archipelago, near latitude $55^{\circ} 47^{\prime}$, longitude $133^{\circ} 40^{\prime}$. So named by Dickins, 1903-4.

Cone; hill (551 feet high), in the western part of St. Paul island, Pribilof group, Bering sea. Descriptive name, published by the Coast Survey in 1875.

Cone; hill, at the head of East Fork Kuskokwim and Cosna rivers, near latitude $64^{\circ} 20^{\prime}$, longitude $151^{\circ}$. Descriptive name, from Herron, 1899.

Cone, hill ; see Potato mountain.

Cone; island (300 feet high), in Revillagigedo channel, at entrance to Thorne arm, Alexander archipelago. Descriptive name, given by Nichols, 1883.

Cone; mountain (2,7.18 feet high), in the northern central part of Annette island, Alexander archipelago. Named by Nichols, 1883.

Cone; mountain (3,800 feet high), on the mainland, about 14 miles northeast of Cape Fox, Dixon entrance. So named by Nichols, 1883.

Cone; mountain, on the mainland, about 10 miles south of Stikine river. Name published by the Coast Survey in 1895 .

Cone; mountain $(6,100$ feet high), on the mainland, on east bank of the Stikine and near Scud river. Erroneously Cane mountain. Name published by the Coast Survey, in 1891, as Cane, and, in 1899, as Cone.

Cone; mountain, Kodiak island, west of Chiniak. Descriptive name, from Harriman expedition, 1899.

Cone; mountain (1,390 feet high), on the left bank near the mouth of Cripple river, Seward peninsula, about longitude $165^{\circ} 45^{\prime}$. So called by the prospectors in 1898 .

Cone; mountain, prominent landmark on north bank of Koyukuk river, near latitude $66^{\circ} 10^{\prime}$, longitude $156^{\circ} 10^{\prime}$. Descriptive name, given by Allen, 1885.

Cone; peak, on Heceta island at the head of Cone bay. Descriptive name, given by Dickins, 1903-4.

Cone; point, the southern head of Thorne arm, Revillagigedo channel, Alexander archipelago. Named by Nichols in 1883. Also called Cone Island point. Descriptive term.

Cone, point, in Clarence strait; see Grindall.

Cone, point, in Wrangell strait; see Blunt and Turn.

Cone, point; see Red Head.

Cone Hill, river; see Fortymile creek.

Cone Island, point; see Ape.

Coney; island, near the junction of Dry strait and Frederick sound, Alexander archipelago. So named by 'Thomas, 1887.

Conference, creek; see Humbug.

Conical, hill; see Potato.

Conical; volcano, on the northwestern shore of Atka island, middle Aleutians. Called Konícheskaia by Ingenstrem, 1829, and Chernof, 1832.

Coning; inlet, indenting the eastern shore of Long island, western shore Cordova bay, Alexander archipelago, near latitude $54^{\circ} 50^{\prime}$, longitude $132^{\circ}$ $40^{\prime}$. Name from Dickins, 1905.

Connecticut; creek, Seward peninsula, Casadepaga drainage, tributary on south bank of Canyon creek, near latitude $64^{\circ} 51^{\prime}$, longitude $164^{\circ} 26^{\prime}$. Pros'pector's' name, reported by Gerdine, 1905 .

Bull. $299-06$ M -13 
Connor; creek, in the Fairbanks region, tributary to the headwaters. of Kokomo creek, near latitude $65^{\circ} 10^{\prime}$, longitude $147^{\circ} 10^{\prime}$. Prospector's' name, obtained by Gerdine, 1903.

Consa, telegraph station; see Cosna.

Constantine; anchorage, near Ilin bay, on western shore of Chichagof island, Alexander archipelago. So named by the Russian pilot Ilin near the beginning of the century.

Constantine; bay, indenting eastern shore of Unalaska bay, eastern Aleutians, near longitude $166^{\circ} 26^{\prime}$. So called by Veniaminof, 1830. Said to derive its name from the Russian American Company's ship Comstantine, which was wrecked in attempting to enter it.

Constantine; cape, the western point of entrance to the estuary at mouth of the Nushagak river, Bristol bay,.Bering sea. So named by Ustiugof,. 1818. Also written Constantin and Konstantina.

Constantine; harbor, indenting north shore of Amchitka island, Rat Island group, western Aleutians, near east longitude $179^{\circ} 23^{\prime}$. So named, apparently, by Klinkofstrem prior to 1849 . Also written Constantin and Konstantina.

Constantine and Helena, Fort; see Nuchek:

Contact; creek, in the Koyukuk region, tributary to John river at its source, near latitude $68^{\circ} 10^{\prime}$, longitude $152^{\circ}$. So named by Peters and Schrader, 1901.

Contaythno, river; see Kantishna.

Convenient; cove, in Hassler island, Behm canal, Alexander archipelago. Named by the Coast Survey in 1891.

Controller; bay, near the mouth of Copper river. Named Comptroller's bay by Cook in 1778. Has also been called Bering haven.

Coogalga, island; see Tigalda.

Coogrock, river; see Kougarok. .

Cook; bend, in Klutina river about 12 miles above its mouth. Name from Abercrombie, 1898.

Cook; inlet, on south coast of the Alaskan mainland. First explored and mapped by Capt. James Cook in 1778. Not having in his journal applied any name to it "Lord Sandwich. directed that it should be called Cook's River." Vanconver calls it Cook's inlet, and also refer's to it as Groosgincloose or Cook's inlet. The Russians call it Kenai bay. It has been called an arm, bay, gulf, inlet, and river, and the name Kenai has been rendered Kenaiskoi, Kenaiskaia, Kenaiskischer. According to Grewingk, quoting Zagoskin, the correct name is "Ttunaiskysch" bay.

Cook; mountain (13,758 feet high), in the St: Elias alps, southeastern Alaska. Named by Dall, 1874, after: the great English navigator, Capt. James Cook.

Cook, strait; see Etolin.

Cook's rock; see Signals (The).

Cool, bay; see Graham harbor.

Coon; cove, on the east side of George inlet, Revillagigedo island, Alexander archipelago, near latitude $55^{\circ} 30^{\prime}$, longitude $131^{\circ} 30^{\prime}$. Local navigator's' name, reported by H. C. Fassett, Bureau of Fisheries, 1904.

Coon; island, in George inlet, Revillagigedo island, Alexander archipelago. So named by the Coast Survey in 1891 .

Cooney; cove, indenting the southwestern shore of Etolin island, Rocky bay, Clarence strait, Alexander archipelago, near latitude $56^{\circ} 05^{\prime}$, longitude $132^{\circ} 35^{\prime}$. Local navigators' name, reported by H. C. Fassett, Bureau of Fisheries, 1904. 
Cooper; creek, draining northwest from Cooper pass into Nabesna river. Local name from Schrader, 1902, who says the native name is Thekonda.

Cooper; creek and lake, near the west end of Kenai lake, and tributary to Kenai river, from the south, Kenai peninsula. Local name, from Mendenhall, 1898. Ben lake of Russian Hydrographic chart 1378, ed. of 1.847 , is probably this one.

Cooper; creek, on eastern shore of Cook inlet, 6 miles east of Bluff point, north shore at entrance to Kachemak bay. Local name, obtained by Stone, 1904.

Cooper; creek, Seward peninsuli, tributary from the south to Nuluk river, near latitude $65^{\circ} 52^{\prime}$, longitude $166^{\circ} 43^{\prime}$. Prospector's' name, from Gerdine, 1901.

Cooper; gulch, 4 miles north of Nome, Seward peninsula, on the south slope of Anvil peak, near longitude $165^{\circ} 23^{\prime}$. Local name, published in 1904 as Cooper's gulch.

Cooper; island, near entrance to Chichagof harbor, Attu island, western Aleutians. So named, in 1.855 , by Gibson, of the North Pacific exploring expedition, after the U. S. schooner Fenimore Cooper.

Cooper; island, near Dease inlet, just east of Point Barrow, Arctic ocean. Apparently so named by the British Admiralty, 1855 .

Cooper; pass, between the Nabesna and Chisana rivers, near latitude $62^{\circ} 20^{\prime}$, longitude $142^{\circ} 35^{\prime}$. Local name, from Peters, 1899.

Cooper; point, on the mainland, on western shore of Taku inlet, southeastern Alaska. So named by Mansfield, 1890 .

Coopers; whạling station, about 5 miles southeast of Point Hope, Arctic coast, near latitude $68^{\circ} 20^{\prime}$. Local name, Cooper or Cooper's. According to Collier, the village at this place is commonly called Jabbertown.

Cooselik, creek; see Kuselik.

Coot; cove, on the northern shore of Funter bay, Admiralty island, Alexander archipelago. So named by Mansfield, 1890.

Copleston; mountain, near: Camden bay, on the Arctic coast. So named by Franklin, in 1826, "in honour of Dr. Copleston, provost of Oriel College, now Bishop Landaff." Erroneously Coplestone and Coppleston.

Cop?y; reef, near Keene island, Wrangell strait, Alexander archipelago. Name published by the Coast Survey in 1.898 .

Coposo; island, in Port Real Marina, Bucareli bay, Prince of Wales archipelago. Named Ysla Coposo (tufted) by Maurelle and Quadra, 1775-1779.

Copper; bay, in the northeastern part of Prince William sound. Name published by the Coast Survey in 1900.

Copper; creek, tributary to the Kotsina, from the south. Prospectors' name, from Gerdine, 1900.

Copper; creek, 35 miles north of Cape Nome, Seward peninsula, tributary to Nugget creek, from the sonth, near longitude $165^{\circ} 10^{\prime}$. Name from Barnard, 1900 .

Copper; creek, tributary to the headwaters of Dan creek, which, in turn is tributary to Nizina river. Prospectors' name; first appears on map of the Nizina mining district by George M. Esterly, of Valdez, 1902.

Copper; creek, eastern Alaska, an east branch of Charley river, near latitude $64^{\circ} 50^{\prime}$, longitude $143^{\circ} 30^{\prime}$. Prospector's' name, reported by Witherspoon, 1905.

Copper; glacier, the source of Copper river, southern Alaska. So named by Schrader, 1902. 
Copper; harbor, on the east side of Hetta inlet, Cordova bay, Prince of Wales island, near latitude $55^{\circ} 13^{\prime}$, longitude $132^{\circ} 38^{\prime}$. Local name, from Brooks; 1901.

Copper; lake, on Unalaska island, eastern Aleutians. Veniaminof, getting his information from the natives, says ( $I, 171)$ : "Near Maliushin bay, between a long isthmus and Tarasof bay, in the mountain, is a lake on whose shores native copper occurs." Name not heretofore used.

Copper; mountain peak (3,830 feet high), and range on eastern shore of Prince William sound. So named by Abercrombie, 1898.

Copper; mountain (3,850 feet high), on the eastern shore of Hetta inlet, Cordova bay, Prince of Wales island, on the north side of Copper harbor. Local name, published by Coast Survey in 1901.

Copper; point, in Port Chester, Annette island, Alexander archipelago. So named by Nichols, 1883.

Copper; river, in central Alaska. Discovered by Nagaief, in 1781, and named Copper (miednaia), on account of the reported existence of copper in its vicinity. Called Rio de los Perdidos by the Spaniards. The native name is Atna or Aetna, i. e.; At river. Often called the Atna or Copper.

Copperas, island; see Hawkins.

Copper Center; mining camp or village, post-office and telegraph station, on Copper riverr, near latitude $62^{\circ}$. Prospectors' name, first published in 1898. About 300 miners and prospectors wintered here in 1898-99. The post-office was established in 1902.

Copper City; see Valdez.

Copper City; mining camp, on the eastern shore of Hetta inlet, Cordova bay, Alexander archipelago, 6 miles south of Coppermount. Prospectors' name, reported by Dickins, 1905 .

Coppermount; post-office (established in 1901) and mining settlement, on Copper harbor, Hetta inlet, Cordova bay, Prince of Wales island.

Copper Mountain; point, on the northeastern shore of Prince William sound, between Boulder and Landlocked bays. So named by Abercrombie, 1898. Grant, 1905 , says the local name is Bidarka.

Copper River; plateau between Copper and Susitna rivers, about latitude $62^{\circ}$. Named by Abercrombie, 1898.

Copper River, rapids; see Abercrombie.

Coqenthena, Indian village, island, and slough; see Kokinhenik.

Cora; creek, debouching between capes Douglas and Woolley, Seward peninsula. Name from Barnard, 1900.

Cora; point, the northeastern point of Coronation island, Alexander archipelago. So named by Snow, 1886.

Coral; rocks off the southwest end of Montague island, Prince William sound. This name appears to have been first applied by the Coast Survey in 1868.

Corbin; glacier and pass, near Valdez, Prince William sound. Named by Abercrombie, 1898, after Adjt. Gen. Henry Clark Corbin, U. S. A.

Corbin; point and mine on the eastern shore of Hetta inlet, Cordova bay, Alexander archipelago, near latitude $55^{\circ} 15^{\prime}$, longitude $132^{\circ} 41^{\prime}$. Local name, reported by Dickins, 1905.

Cordova, bay, Prince William sound; see Orca.

Cordova; bay, on the northern shore of Dixon entrance in Prince of Wales island, Alexander archipelago, near latitude $54^{\circ} 50^{\prime}$, longitude $132^{\circ} 40^{\prime}$. The name Puerto Cordova y Cordova appears to have been first applied by Caamaño, in 1792, and published by Vancouver in 1798. 
Cork; islet, in Security bay, Kuiu island, Alexander archipelago. So named by Glass, 1881.

Corlies; group of two islets, on eastern shore of Tlevak strait, opposite View cove, in Dall island, Alexander archipelago: Named by Dall, 1.852, after Rev. W. H. R. Corlies, of Philadelphia, a missionary who began work in Alaska in 1.879. Sheldon Jackson has named the north one Rankin and the south one Young.

Corlies; point, the north point of entrance to Sawmill cove, Howkan strait, Cordova bay, Alexander archipelago. Named by Sheldon Jacisson, after Rev. William Fenry Richards Corlies.

Cormorant; rock, near the entrance to Lituya bay, southeastern Alaska. Named Cormorants by La Perouse, 1786.

Cormorant; rock, on the south side of Uyak anchorage, northern shore of Kodiak. So named by Moser, 1897.

Corner; mountain, on south side of Silver bay, at the corner or angle where the bay turns to the southeast, Baranof island, Alexander archipelago. Named Uglovaia (corner) by Vasilief, 1809.

Cornwall; ridge, on east side of Copper river, north of Mount Sanford. Nameil by Lowe, 1898, after John Cornwall, a member of his party. Inroneously Corwells and Cornwell.

Cornwallis; point, the north head of Liscome bay, Dall island, Alexander archipelago. Name published by the Fydrographic Oftice in 1882 and perhaps earlier.

Cornwallis; point, the north point of entrance to Saginaw bay, Kuiu island, Frederick "sound, Alexander archipelago. So named by Vancouver, 1794.

Coronados; group of islands, in eastern part of Bucareli bay, Prince of Wales archipelago. Named Los Coronados (tonsured priests), by Maurelle and Quadra, 1775-1779.

Coronation; island, at junction of Sumner and Chatham straits, southeast of Cape Ommaney, Baranof island, Alexander archipelago. So named by Vancouver in September, 1793, "the day of our passing it having been the anniversary of that happy event" (II, 423). Koronatsie of the Russians.

Coronation, islands; see Spanish.

Corvells, ridge; see Cornwall.

Corwin; bluff, at the so-called Corwin coal mine on the Arctic coast, west of Cape Sabine, near longitude $165^{\circ}$. So called by Peters and Schrader, 1901.

Corwin; cape, the southeasternmost point of Nunivak island, Bering sea. Callẹd Vasilief by Tebenkof, 1849, after Capt. Mikhail Nikolaevich Vasilief, I. N., of the Otkrietie (discovery), who, in 1821, discovered Nunivak island. The Russian hydrographic office, 1852, called it Etolin and the Coast Survey has recently (1899) called it Corwin, probably after the U. S. revenue cutter Corvin.

Corwin; cliffs, in the St. Elias region. So named by. I. C. Russell, in 1890, after the U. S. revenue cutter Corwin.

Corwin; coal mine, on Arctic coast, east of Cape Lisburne. Definitely located and used by Captain Hooper, of the U. S. revenue cutter Corwin, in July, 1880 , and named after his vessel.

Corwin; lagoon, on the Arctic coast, between Cape Seppings and Cape Krusenstern. Named by the Coast Survey, in 1884, after the U. S. revenue cutter Corwin. 
Corwin; rock, in the group of islands of the Four: Mountains, eastern Aleutians. So named, in 1894, by officers of the U. S. S. Concord; after the U. S. revenue cutter Corwin.

Cosacoots, river; see Kosakuts.

Coschaget, Indian village; see Coskakat.

Cosinas; point, on the southern shore of Port Asumcion, Bucareli bay, Prince of Wales archipelago. . Named Punta de Cosinas by Maurelle and Quadra, 1775-1779.

Coskakat; Indian village at the mouth of the Cosna river, near latitude $64^{\circ} 55^{\prime}$, longitude $151^{\circ} 10^{\prime}$. Native name, obtained by Ferron, 1899, who wrote Cos-chaget and Coschaget.

Cosmos; cove, on the northeastern shore of Baranof island, Chatham strait, Alexander archipelago. Named by Moore, 1895, after the surveying steamer Patterson's steam launch Cosmos.

Cosmos; creek, a tributary of Kobuk river from the north, near latitude $66^{\circ} 45^{\prime}$, longitude $157^{\circ} 15^{\prime}$. So.named by Mendenhall, 1901, after Stoney's winter camp, 1885-86, Fort Cosmos, which was located at the mouth of this creek. The Eskimo name, according to Stoney, is A-vi-lu-legorack.

Cosmos; pass, Davidson inlet, Prince of Wales archipelago, near latitude $55^{\circ}$ $58^{\prime}$, longitude $133^{\circ} 42^{\prime}$. Named by Dickins, 1903-4, after the Coast Survey launch Cosmos, in which he first explored the passage.

Cosmos; point, on the southwest shore of Kuiu island, Chatham strait, Alexander archipelago, between Gedney harbor and Point Harris, near latitude $56^{\circ} 21^{\prime}$, longitude $134^{\circ} 17^{\prime}$. Named after the Coast Survey launch Cosmos, and described in the Coast Pilot of 1901.

Cosmos; point, on the northeastern shore of Mitkof island, Alexander archipelago. So named by Thomas, 1887, after the steam launch of the Coast Survey steamer Patterson.

Cosmos; range of mountains (3,900 feet high), on the' mainland near Thomas bay, Frederick sound. Named by Thomas, 1887, after the steam launch Cosmos attached to the Coast Survey steamer Patterson.

Cosna; river, between the Chitanana and Kantishna, tributary from the south to Tanana river, 30 miles above its mouth, near latitude $65^{\circ}$, longitude $151^{\circ} 30^{\prime}$. Indian name, obtained by Herron, 1899. Erroneously Goschacket.

Cosna; telegraph station on the Tanana, at confluence with Cosna river, 45 miles above Fort Gibbon. Erroneously Consa. So named by the Signal Corps, U. S. A., 1903. See Coskakat.

Cotillakakat, river; see Kateel.

Cottonwood; bay, a small indentation in the west side of Iliamna bay, southwestern shore of Cook inlet, about latitude $59^{\circ} 40^{\prime}$. Name from Osgood, 1902 (p. 11).

Cottonwood; creek, tributary to Tsirku river from the north near latitude $59^{\circ}$ $19^{\prime}$, longitude $136^{\circ} 06^{\prime}$. Prospectors' name, reported by Wright, 1903.

Cottonwood; creek, on the eastern side of Cook inlet, tributary from the north to Kachemak bay, about 12 miles northeast of Homer. So called by Dall, 1898.

Cottonwood; creek, Seward peninsula, tributary to Goodhope river from the east, near latitude $65^{\circ} 45^{\prime}$, longitude $163^{\circ}, 30^{\prime}$. Name from Mendenhall and Reaburn, 1901.

Cottonwood; group of low wooded islands, at mouth of Stikine river. So named by Thomas, 1887. 
Cottonwood; point, the eastern point of entrance to the most easterly moutl of Copper river, near latitude $60^{\circ} 17^{\prime}$, longitude $144^{\circ} 53^{\prime}$. So named by Abercrombie, 1898.

Cottonwood Point; slough, in the eastern part of Copper River delta, presumably near Cottonwood point, above. Local name, reported by Moser, 1897.

Couden, island, Salisbury sound; see Round.

Council; mining camp and post-oftice, on Niukluk river, at mouth of: Ophir creek, Seward peninsula. Called Council City by the prospectors. A post-oftice was established here in September, 1899, and named Council.

Count, creek; see Comet.

Countess; point, on the western shore of Prince William sound. Named by Vancouver, 1794, "after Captain Countess, of the navy."

Course; point, in Narrow strait, on northern shore of Kodiak. Named Kursa (course, of a ship) by Murashef in 1839-40.

Course, point; see Turn.

Couverden; island, at junction of Lynn canal and Chatham and Tcy straits, Alexander atchipelago, near latitude $58^{\circ} 12^{\prime}$, longitude $135^{\circ} 04^{\prime}$. Apparently so named by Meade, 1869 .

Couverden; point, the southern point of Couverden island, forming the southwestern point of entrance to Lynn canal, Alexander archipelago. Named by Vancouver, 1794, after the seat of his ancesters (III, 245).

Cove (The); cove, in San Antonio bay, Bucareli bay, Prince of Wales archipelago. Called "The Cove" (I Puertezuelo) by Maurelle and Quadra, 1775-1779.

Cove; hill (619. feet high), on the mainland, nearly enst of Cape Fox, Dixon . entrance. So named by Nichols, 1883.

Cove; islet, near Applegate cove, in Izembek bay, Alaska peninsula. So named by the Fish Commission in 1888.

Cove; mountain, near Ward cove, in the western part of Revillagigedo island, Alexander archipelago. Named by the Coast Survey in 1886 .

Cove; point, on Raspberry island, on the northern shore of Kuprennof strait, Kodiak group. Named Bukti (bight or cove) by Murashef, 1839-40.

Cove; point, on the northeastern shore of Glass peninsula, Admiralty island, Stephens passage, Alexander archipelago. Name published by the Coast Survey in 1893. Deseriptive term.

Cove, point, the southern point of entrance to Kah Shakes cove, Revillagigedo channel, Alexaner archipelago. Named by the Coast Survey in 1883. Name not found on any map and presumably obsolete.

Cove, point, Wrangell strait; see Mountain.

Covearak, tract and river; see Kaviruk.

Covina; gulch, 10 miles north of Nome, Sewird peninsula, on the east bank of Glacier creek, near longitude $165^{\circ} 20^{\circ}$. Lecal name, published in 1908. Erroneously Govina.

Cov-vee-arak, tract and river; see Kaviruk.

Cow; island, between Annette and Percy islands, Gravina group, Clarence strait, Alexander archipelago. Named by the Coast Survey in 1886.

Cowee; creek, on Douglas island, tributary to Gastineau channel, nearly opposite Juneau. Local name, obtained by Peters, 1903.

Cowee; creek, on the mainland, eastern shore Lynn canal, southeastern Alaska, tributary to Berners bay from the southeast, near latitude $58^{\circ} 45^{\prime}$. Prospectors' name, reported by Spencer and Wright; 1903 .

Cowpack; river, Seward peninsula, debouching on the Arctic coast near longitude $164^{\circ} 55^{\prime}$. Name from Gerdine, 1901. 
Cowpen; bay and river, on the northern shore of Prince William sound. Local name, reported by Glass, 1898.

Cox; landing, on Klutina river, at or near foot of "The Gorge." Name from Abercrombie, 1898.

Coyote; creek, tributary to Grantley harbor from the south Seward peninsula. Name from Barnard, 1900.

Coyuluk, river; see Koyukuk.

Cozian; reef, in Peril strait, Alexander archipelago. Named after Anton George Cozian, a native of Dalmatia, and long a pilot in the employment of the Russian American Company. This reef was discovered by him and named after him by naval officers in 1880 . Said also to have been called Nikolas rock, after the steamer Nikolas, which touched upon it in 1854. The name has also been erroneously written Cozain and Kozian.

Crab; cove, at the head of Funter bay, near the junction of Lynn canal and Chatham strait, Alexander archipelago. Named by Mansfield, 1890.

Crab; point, on the western shore of Tamgas harbor, Annette island, Alexander archipelago. Apparently so named by the Coast Survey in 1891.

Crafton; island, northwest of Knight island, in western part of Prince William sound. Name from. Schrader, 1900. Erroneously Grafton:

Crag; peak, in the upper Koyukuk region, on the west side of John river, near latitude $67^{\circ} 40^{\prime}$, longitude $152^{\circ} 30^{\prime}$. Name from Peters and Schrader, 1901.

Craig; point, on the northeastern coast of Zarembo island, the northwestern point of entrance to Stikine strait, Alexander archipelago. Named by Vancouver, 1793 (II, 400).

Craig; sunken rock, in entrance to Nakat inlet. Named by Nichols, in 1888, presumably after Commandér Joseph Edgar Craig, U. S. N.

Craigie; pass (5,100 feet high), in the Fortymile region, eastern Alaska, between the beadwaters of Willow creek and Hutchinson creek, near latitude $64^{\circ} 15^{\prime}$, longitude $142^{\circ} 25^{\prime}$. Só called by Lieutenant Mitchẹl, Signal Corps, U. S. A., 1902.

Cranberry; island; near the outlet of Lake Eyak, at western edge of Copper river delta. Local name, reported by Moser; 1897.

Cranberry; peak ( 5,200 feet high), near Cranberry marsh, on the northern shore of Klutina lake. So named by Abercrombie, 1898.

Cranberry Marsh; name used by the prospectors to designate the flat marshy mouth of the valley northwest of Klutina lake. Name published in 1899.

Crane; cove, near Hot Springs bay, Sitka sound, Alexander archipelago. Named Zhuravlina (crane) by Vasilief, 1809.

Crane; creek; tributary to Fairbanks creek from the north, latitude. $65^{\circ} 05^{\prime}$, longitude $147^{\circ} 15^{\prime}$. Local name, from Gerdine, 1903.

Crater; creek, in the Rampart region, tributary to the head of Hess creek from the south, latitude $65^{\circ} 40^{\prime}$, longitude $148^{\circ}$. Local name, from Lieutenant Erickson, U. S. A., 1902.

Crater; creek, tributary to Kruzgamepa river from the north, Seward peninsula. Name from Barnard, 1900.

Crater; hill (525 feet high), an extinct volcanic crater, in western part of St. Paul island, Pribilof islands, Bering sea. Name published, 1875, by the Coast Survey.

Crater; lake, near Chaix hills, in the St. Elias alps, southeastern Alaska. Named by Prof. William Libbey, of Princeton College, 1886. Descriptive term. 
Crater; lake, in Chilkoot pass, southeastern Alaska, draining nortl. Name from Flemer, 1898 .

Crater; mountain (2,240 feet high), 20 miles north of Nome, Seward peninsula, near latitude $64^{\circ} 45^{\prime}$, longitude $165^{\circ}$. Prospectors' name, published in 1901 .

Crater; mountain or hill (633 feet high), about 7 miles south of St. Michael, Norton sound. So named by the Coast Survey in 1898.

Crater; peak, near head of Yakutat bay, southeastern Alaska. Named by Russell, 1890 .

Crater; point, the southeastern point of Otter island, Pribilof group, Bering sen. So named by Elliott, 1874 , who, in his notes accompanying his map of: 'St. Paul, in his Seal Fisheries of Alaska, 1881, says: "A slight mistake of the engraver causes Crater point to appear as a bifurcated tongue. It is not so; but there is a funnel-shaped cavity here plainly emarginated from the sea, and on that extreme point constituting and giving to it this name."

Craven; point, the southeastern extreme of Chichagof island, Alexander archipelago. So named by Meade, 1869, after Admiral Thomas Tingey Craven, U. S. N. Erroneously Graven. Has also been called Point Williams by Homfray and Tliakinikut by 'Tebenkof. The correct native name is said to be Thliankhini.

Crawfish; inlet, indenting the outer coast of Baranof island, Alexander archipelago. Named by the Russians Rakof or Rakovoi, from Rak (crawfish). Has also been called Rokovoy.

Crazy; mountains $(3,000$ to 3,700 feet high), in the Birch creek region, 30 miles west of Circle city, near latitude $65^{\circ} 45^{\prime}$, longitude $145^{\circ}$. Local name, reported by Spurr, Goodrich, and Schrader of the Geological Survey, 1896.

Creadon; river, tributary to Kluane lake from the east, nenr latitude $62^{\circ}$. So called by Peters, 1899.

Creek; point, on the eastern shore of Tamgas harbor, Annette island, Alexander: archipelago. So named by the Coast Survey in 1891. It is at or near the mouth of a creek.

Creek; point, on the southwestern shore of Halleck island, Olga strait, Alexander archipelago. So named by the Coast survey in 1885.

Creig, mountain; see Greig.

Crescent; glacier, on the eastern shore of Port Wells, Prince William sound, near the entrance to College fiord. Descriptive name, given by the Harriman expedition, 1899.

Crescent; low sandy island, in front of Elson bay, Arctic coast, just east of Point Barrow. So named by the British Admiralty in 1853. Descriptive name.

Crete; creek, debouching between capes Douglas and Woolley, Seward peninsula. Name from Barnard, 1900.

Crib; point, on the mainland, near head of Port Snettisham, Stephens passage, Alexander archipelago. So named by Thomas, 1888.

Crillon; glacier, near Mount Crillon, in the southern part of the St. Elias alps, southeastern. Alaska. So named by Dall, 1874.

Crillon; mountain $(15,900$ feet high), in the southern part of the St. Elias region, southeastern Alaska. So named by La Perouse, 1786, after the French minister of marine.

Cripple; creek, Kenai peninsula, a left branch of Resurrection creek at Hope city, on Turnagain arm, Cook inlet. Local name, from Moflit, 1904. 
Cripple; creek, 5 miles west of Fairbanks, tributary to Chena slough, near longitude $147^{\circ} 55^{\prime}$. Local name, from Map of Location, Tanana Mines Railroad, 1904.

Cripple; creek, tributary to Tolovana (Chatanika) river from the north near latitude $65^{\circ} 20^{\prime}$, longitude $146^{\circ} 40^{\prime}$. Prospector's' name, from Gerdine, 1903.

Cripple; creek or river, Seward penibsula, tributary to Goodhope bay from the south, near longitude $163^{\circ} 40^{\prime}$. Prospectors' name, obtained by Mendenhall and Reaburn, 1901.

Cripple; creek, tributary to Mission creek, from the east, in the Eagle mining region. Prospectors' name, published in 1899.

Cripple; creek, tributary to South fork Koyukuk river from the south, hear latitude $67^{\circ}$. Prospector's' name, published in 1900. See also Money.

Cripple; river, in the Nome mining region, Seward peninsula. Named by the prospectors, in 1898, after the famous Cripple Creek in Colorado.

Crist; point; on the west side of entrance to Port Frederick, south shore Icy strait, Alexander archipelago, near longitude $135^{\circ} 30^{\prime}$. Named after F. G. Crist, deck officer of the Coast Survey steamer Gedney, commanded by Dickins, in 1901. This was called Entrance point by the Coast Survey in $\cdot 1899$.

Cristina; islet, in Bucareli bay, Prince of Wales archipelago. So named by Maurelle and Quadra, 1775-1779. Has also been written Christina.

Crooked; creek, a small stream in the St. Elias region, southern Alaska, debouching on the coast 11 miles east of Cape Yaktag. Local descriptive name, obtained by Martin, 1903.

Crooked; creek, tributary to Birch creek from the west, near Circle city, about latitude $65^{\circ} 30^{\prime}$, longitude $144^{\circ} 30^{\prime}$. Descriptive name, published by the Coast Survey in $\mathbf{1 8 9 5 .}$

Crooked; creek, tributary to headwaters of Ophir creek, Seward peninsula. Name from Barnard, 1900.

Crooked; creek, tributary to Seventymile creek from the north, in the Eagle mining region. Local name, published by the Geological Survey in 1899.

Crooked; island, in St. Paul harbor, Kodiak. Named Krivoi (crooked) by the Russians in 1809.

Crooked; island, one of the Walrus island group, in northern part of Bristol bay, Bering sea. So called by the Fish Commission in 1890. Apparently identical with Nizkoi (low) of Sarichef, 1826, and Ugushtu of Tebenkof, 1849.

Crooked, island, Yakutat bay; see Kriwoi.

Crooked, river; see Igushik.

Crooze, island; see Kruzof.

Crosby; creek, Seward peninsula, tributary from the east to Maston creek, near latitude $65^{\circ} 50^{\prime}$, longitude $166^{\circ} 22^{\prime}$. Prospectors' name, obtained by Gerdine, 1901.

Cross; bay, indenting the southeastern shore of Akun island, between Seredka bay and 'Trident bay, near longitude $165^{\circ} 30^{\prime}$. So named by Gilbert, 1901.

Cross; cape, on the western coast of Yakobi island, Alexander archipelago. Described by Cook, 1778, as "a high promontory" and named Cross from having passed it on Holy Cross day, May 3.

Cross; cape, the northeastern point of Unga island, Shumagin group. Named Krest (cross) by the Russians.

Cross, cape; see Bingham. 
Cross; cape; see Theodore.

Cross; creek, tributary to the Chisana river from the west. So named by Schrader, 1902, who reports that the Indians call it Chisana.

Cross; gulch, in Port Santa Cruz, Suemez island, Prince of Wales archipelago. Named Arroyo de la Cruz (gulch of the cross) by Maurelle and Quadra, $1775-1779$.

Cross, harbor, Kiruzof island; see Krestof.

Cross; hill (96 feet high), on Northeast point, St. Paul island, Pribilof group, Bering seil. Called Cross or St. Jolun's hill by Blliott, 1874. Probahly these are local names.

Cross; island and strait, in San Christoval channel, Bucareli bay, Prince of Wales archipelago." Named Canos y Ysla de la Cruz by Maurelle and Quadra, 1.755-1779.

Cross, island, north of: Sitka sound; see Kr:estof.

Cross; island, the westernmost of the Midway islands, on the Arctic coast, east of the mouth of Colville river, near longitude $148^{\circ}$. So named by Lieut. Commander Charles Herbert Stockton, of the U. S. S. I'hetis, in 1889, because a wooden cross has been erected on the island by the whalers.

Cross; islet, "small and wooded," in Portland canal, just north of Halibut bay. So called by Nichols in the Coast Pilot, 1891. (p. 76). Not named on any chart.

Cross; mountain (2,597 feet high), near Sitka, on Baranof island, Alexander archipelago. Apparently so named’by Davidson, 1.869 .

Cross, point, Krestof island; see Kresta.

Cross, port; see Krestof.

Cross; sound, between the mainland and Chichagof island, Alexander archipelago, near latitude $58^{\circ} 10^{\prime}$, longitude $136^{\circ} 30^{\prime}$. Discovered by Cook, May 3, 1778, and named Cross sound, after this day, designated in the calendar as Holy Cross day. By the Russians this has been called Lohtianoi (icy) and Kresta (cross); by the Spaniards, Puerto de la Cruz and Entrada de la Cruz. Various!y called Cross sound or Icy strait. Both names are now in use, Cross sound for the western and Icy strait for the eastern part.

Cross, strait, north of Sitka ; see Krestof.

Cross Cape; rocks, off Cape Cross, Yakobi island, Alexander archipelago. So . . called by Dall, 1.880 .

Crossover (The); channel, in Nushagak bay, Bristol bay, southwestern Alaska, off Clatk point, near latitude $58^{\circ} 50^{\prime}$, longitude $158^{\circ} 30^{\prime}$. Local pilots' name, written The Cross-over and The Cross-Over by Moser, 1900.

Crosswise; island, in southern entrance to Nakwasina passage, Batranof island, Alexander archipelago. Named Foperechnoi (crosswise) by Vasilief, 1809.

Croto, creek; see Deshka river.

Crow; creek, tributary to Glacier creek, on the north side of Turnagain arm, Cook inlet. Local name, from Mendenhall, 1898.

Crow; creek, at the head of Walker fork, Fortymile creek, tributary to Cherry creek from the left, near latitude $64^{\circ}$ and the international boundary. Prospector's' name from map in Coast Survey archives drawn, 1898, by I. F. Ball, a prospector.

Crow; island, Kelp bay, Chatham strait, Alexander archipelago, on the south side of the bay, the westernmost and largest island west of Pond island, near latitude $57^{\circ} 17^{\prime}$, longitude $134^{\circ} 54^{\prime}$. So named by Moore, 1895. 
Crow; island, in Redoubt bay, Sitka sound, Alexander archipelago. So called jy the Coast Survey in 1898. On the old Russian chart of 1809 it is called Korga.

Crow; island, in Sawmill cove, Howkan strait, Dall island, Alexander archipelago. So named by Nichols, 1881 . Sheldon Jackson has named it James.

Crow; island, one of the Middle island group, in Sitka sound, Alexander archipelago. Named Voronie (the raven, corvus cor $a x$ ) by Vasilief, 1809. The Russian dictionaries give voronie as the adjective form of vorón, a raven or crow. Elliott gives Varrone as the Russian for raven, while Dall gives the form Varonie, translating it crow. Has been erroneously called Blue island, while one chart gives Crow, Voroni, or Blue island.

Crow; point, on San Fernando island, Bucareli bay, Prince of Wales archipelago. Named Punta del Cuerbo (crow) by Maurelle and Quadra, $1775-1779$.

Crow; point and reef, on the south side of Mine harbor, Herendeen bay, Alaska peuinsula, near longitude $160^{\circ} 42^{\prime}$. So called by Tanner, 1890 .

Crowley; point, a prominent headland on the eastern shore of Chatham strait, Alexander archipelago, 8 miles north of Cape Decision, near latitude $56^{\circ} 07^{\prime}$, longitude $134^{\circ} 15^{\prime}$. Named in 1900 after B. F. Crowley, first watch oflicer of the Coast Survey steamer McArthur, and described in the Coist Pilot of 1301.

Crowley; rock, lying $1 \frac{1}{2}$ miles off the north shore of Sannak island, south of west end Alaska peninsula, near latitude $54^{\circ} 30^{\prime}$, longitude $162^{\circ} 45^{\prime}$. Named by Westdabl, 1901, presumably after Officer Crowley of the McArthur.

Croyalgu, island; see Tigalda.

Croyère, Isles de la; see Hazy.

Crucifix; mountain, in the pass between the headwaters of Skwentna and Kuskokwim rivers. So called by Spurr, 1898. Not shown on the map.

Cruz, Puerto de la; see Cross.

Crystal; creek, 6 miles northwest of Nome, Seward peninsula, tributary to Snake river from the east, near longitude $165^{\circ} 30^{\prime}$. Local name, published in 1903.

Cub; creek, Seward peninsula, tributary to Bear creek from the west, near latitude $65^{\circ} 30^{\prime}$, longitude $161^{\circ}$. Frospector's' name, obtained by Witherspoon, 1903.

Cub; creek, in the Fortymile region, enstern Alaska, on the south bank of Champion creek, near latitude $64^{\circ} 30^{\prime}$, longitude $141^{\circ} 55^{\prime}$. Prospector's' name, from sketch map compiled by Major Glassford, Sigual Corps, U. S. A., 1905.

Cub; creek, tributary to Sixmile creek from the west, at Sunrise, Kenai peninsula. Prospector's' name, from Becker, 1.895.

Cub; point, between Boulder and Fox bays in Stepovak bay, Alaska peninsula. Named by Dall, 1880 .

Cuban; gulch, on left bank of the Yukon, 6 miles above Eagle, eastern Alaska. Prospectors' name, published by the Geological Survey in 1899 .

Cube; point, the southern head of Square cove, near northern end of Chatham strait, Alexander archipelago. So named by Dall, 1880.

Cudahy: post, on the west bank of the Yukon, near mouth of Fortymile creek. Also called Fort Cudahy. The above form, Cudahy, bas been adopted by the Canadian Board on Geographic Names.

Culebrina; island, in eastern part of Bucareli bay, Prince of Wales archipelago. Named Culebrina (culverin) by Maurelle and Quadra, 1775-1779. 
Culross; island, northwestern shore Prince William sound, on which is Point Culross (below). This island was reported by Graint in 1905, and so named by the U. S. Botrd on Geographic Names, June 6, 1906.

Culross; point, near Port Wells, on the northwestern shore of Prince William sound. So named by Vancouver, 1794. Erroneously Cull Ross and Gulrass.

Cultas; creek, eastern Alaska; on the west bank of Charley river, which is uffluent to the Yukon from the south, near longitude $143^{\circ}$. Prospectors' name, from sketch map compiled by Major Glassford, Signal Corps, U. S. A., 1905.

Cultheeth, river; see Kaliakh.

Cunningham; creek, debouching on the south shore of Seward peninsula, $5 \frac{1}{2}$ miles west of Cape Nome, near longitude $165^{\circ} 10^{\prime}$. Local name, from Gerdine, 1904.

Cunningham; creek, Seward peninsula, tributary from the northwest to Hannum creek, which is a tributary of Inmachuk river, latitude $65^{\circ} 55^{\prime}$, longitude $163^{\circ} 20^{\prime}$. Prospectors' name, obtained by Witherspoon, 1903.

Cunningham; ridge (2,000 to 2,800 feet high), northeast of Controller bay, Gulf of Alaska; near latitude $60^{\circ} 25^{\prime}$, longitude $144^{\circ}$. Prospectors' name, reported by Martin, 1905.

Cupola; peak, near the head of Silver bay, Sitka sound, Alexander archipelago. Named Kupolnaia (cupola) by the Russians.

Curlew; ledge, in Funter bay, Chatham strait, Alexander archipelago. So named by Mansfield, 1890.

Curlew; point, on the northwestern coast of Revillagigedo island, being the southwest point of entrance to Behm narrows, Alexander archipelago. So named by the Coast Survey in 1891 .

Cur-loog-ah-look-tah, lake; see Walker.

Current; cape, on the northern shore of Afognak island, Kodiak group. Strong. currents flow between Shuyak and Afognak islands, and the cape on the Afognak shore of the narrow strait separating the islands was named by Murashef, 1839-40, Silnago techenia (of. strong current). Hence the name, which on all the American charts is erroneously applied to a point farther east.

Curtis; creek, tributary to Casadepaga river from the south, Seward peainsula. Name from Barnard, 1900.

Curtis; gulch, on the western shore of Klutina lake. Apparently a prospectors' name, reported by Abercrombie, 1898.

Curve; mountain, in California ridge, on Gravina islaud, Alexander archipelago. So named by Nichols, 1883 .

Cushaback, river; see Klokerblok.

Cushing; glacier and. plateau, at head of Glacier bay. So named by Reid, after Prof. Henry Platt Cushing, one of his companions, in 1890. In Reid's account, published in 1892 (Nat. Geog. Mag., vol. 4), the glacier is called "Northwest tributary" of Muir glacier.

Cuss; creek, 15 miles north of Cape Nome, Seward peninsula, tributary to Osborn creek from the east, near longitude $165^{\circ} 08^{\prime}$. Local name, published in 1901 as Guss; also called Cass.

Custom House; cove, on the western shore of Mary island, Revillagigedo channel; Alexander archipelago, near latitude $55^{\circ} .06^{\prime}$, longitude $131^{\circ} 14^{\prime}$. A custom-house which existed here for some years was moved to Ketchikan in 1900 . 
Cutler; river, tributary to the Noatak from the south, near longitude $158^{\circ}$, northwestern Alaska. Origin of name not discovered. First applied by the Coast Survey in 1890. Called Caribou by Stoney, 1886.

Cut-na, creek; see Kutna.

Cutoff; channel, of Koyukuk river, about 35 miles long, on the left or south side of Treat island, near latitude $66^{\circ}$, longitude $156^{\circ}$. The channel on the right side of the island is called the 'Suskita channel. River pilots' name, reported by Cantwell, 1900, as Cutoff and Cut Off.

Cutter; two rocks, awash, in Revillagigedo channel, at entrance to Carroll inlet. Alexander archipelago. So named by Nichols, 1883.

Cyane; peak, on the mainland, north of Frederick sound, near Farragut bay. Named by Thomas, 1887, after a vessel of that name.

Cygnet; island, at mouth of Mink bay, Boca de Quadra, Alexander archipelago. So named by the Coast Survey in $\mathbf{1 8 9 1 .}$

Cypress; point, on the eastern shore of Port Refugio, Bucareli bay, Prince of Wales archipelago. Named Punta de Cipres (cypress point) by Maurelle and Quadra, 1775-1779.

Cyrus; cove, indenting the southern shore of Orr island, Sea Otter sound, Prince of Wales archipelago, near latitude $55^{\circ} 55^{\prime}$, longitude $133^{\circ} 25^{\prime}$. So named by Dickins, 1903-4, after Capt. Cyrus Orr of Shakan," who informed me of this anchorage."

Dachlazug; cape, on Seduction tongue, northwest of Seduction point, Lynn canal, southeastern Alaska. Native name, reported by the Krause brothers, 1882, as Dachlazūg.

Dad; rock and anchorage, sonth shore of Inian islands, on the east side of Cross sound, Alexander archipelago, near longitude $136^{\circ} 20^{\prime}$. So named by Pratt, 1901.

Dadina; glacier, on the northwest slope of Mount Wrangell, drained by Dadina river (below). So called by Gerdine and Mendenhall, 1902.

Dadina; river, tributary to the Copper river from the left (northeast), near latitude $61^{\circ} 50^{\prime}$. Indian name, written Tatena by Abercrombie (1898), Tatina in the first edition of this dictionary (1902), and Dadina by Gerdine and Mendenhall (1902).

Dagelet; mountain $(9, \dot{7} 08$ feet high), in the southern part of the St. Elias alps. So named by Dall, 1874, after Lepaute Dagelet, the astronomer of La Perouse's expedition to this coast in 1786. Often written D'Agelet.

Dagetkakat, river; see Dagitli.

Dagitli; river, tributary to the Koyukuk from the north, near longitude $157^{\circ}$. Native name, reported by Allen, 1885, as Doggetlooscat and Doggetlooskat. Schrader writes it Doggetlikakat. Written also Dagetkakat, Dogitskakat, Dogitlikakat, etc. See Kakat.

Dago; creek, Alaska peninsula, tributary on the right bank of Ugashik river, near its mouth, about latitude $57^{\circ} 30^{\prime}$. Local name, reported by Moser, 1900.

Dagorastiapka; mountain, on the north bank of the Yukon, about 25 miles below Koserefski. So called by Raymond, 1869. Not seen on any other map. Perbaps this is an error for Pogoreshapka. Petrof, 1880, has a village Pogoreshapka (burnt hat) near this mountain.

Dahl; creek, on Seward peninsula, tributary to Quartz creek from the west., near latitude $65^{\circ} 20^{\prime}$, longitude $164^{\circ} 45^{\prime}$. Prospectors' name, obtained by Gerdine, 1901.

Dahl; post-office (established September, 1905), Seward peninsula, apparently on Quartz creek, at mouth of Dahl creek, near latitude $65^{\circ} 20^{\prime}$, longitude $164^{\circ} 40^{\prime}$. See Quartz Creek mining camp. 
Dahlgren; peak (3,502 feet high), on the mainland north of Frederick sound and near Farragut bay. Named Dahlgreen by Thomas, 1887, after RearAdmiral John Adolf Dahlgren, U. S. N.

Daisy; creek, Seward peninsula, Solomon River drainage, tributary on north bank of 'Tributary creek, near latitude $64^{\circ} 40^{\prime}$, longitude $164^{\circ} 09^{\prime}$. Prospectors' name, from a local map, 1904.

Daisy; glacier, tributary to Tyndall glacier, near Mount St. Elias, southeastern Alaska. So named by Topham, 1888.

Daisy; island, in Kasaan bay, western shore Clarence strait, southeastern Alaska, near latitude $55^{\circ} 29^{\prime}$, longitude $132^{\circ} 20^{\prime}$. Local nilvigators' name, reported by H. C. Fassett, Bureau of Fisheries, 1904.

Dakavak; bay, indenting eastern shore of Alaska peninsula, Shelikof strait. It is the next bay northeast of Katmai near latitude $58^{\circ}$. Native name, called Tagalack by Krusenstern, 1827. Martin, 1.904, reports that Nikolai Kalmak of of Katmai wrote the name for him Dakavak.

Dakli; river, tributary to the Koyukuk from the north, near longitude $157^{\circ}$. Native name, reported by Allen, 1885 . In his text Allen calls it Dakliakakat and on his map Daklikakat. The latter has been copied by the Coast Survey. See Kakat. According to Stoney the Kobuk Eskimo name for this stream is 'logo-tit-nuk.

Dale; creek, in the Fortymile region, tributary to Dome creek from the left, near latitude $64^{\circ} 20^{\prime}$, longitude $141^{\circ} 20^{\prime}$. Frospectors' name, from map in the Coast Survey archives, drawn in 1.898 by $\mathrm{E}$. F. Ball, a prospector.

Dall; bay, 2 miles northeast of Dall head, southeastern shore Gravina island, Nichols passage, Clarence strait, southeastern Alaska, near latitude $55^{\circ} 08^{\prime}$, longitude $131^{\circ} 45^{\prime}$. So named by Brooks, 1901 .

Dall; head, a promontory at the south end of Gravina island, Alexander archipelago. Named by the pilots prior to 1879 , after Capt. C. C. Dall, of the Pacific Mail Steamship Company's service.

Dall; island, on the northern "side of the mouth of Dixon entrance. Named by the Coast Survey, 1879, after W. H. Dall. Port Bazan indents the western shore of Dall island and (according to present information) nearly, but not quite, cuts it in two. Coast Survey Chart 8050 calls the southern part of the island Dill and the northern part Quadra.

Dall; island, in Koyukuk river, near the mouth of Fuslia river. Named by Allen, in 1885, after William Healey Dall. Has also been written Dolls.s island.

Dall; lake, in the delta coast region between the Yukon and Kuskokwim rivers, east of Cape Vancouver, drained by the Kiniak river. Named by Nelson, 1878, after W. H. Dall.

Dall; mountain (Mount Dall, 9,000 feet high), in the McKinley range, 45 miles southwest of Mount McKinley, near latitude $62^{\circ} 40^{\prime}$, longitude $152^{\circ} 20^{\prime}$.

Named by Brooks in 1902 after Dr. William H. Dall.

Dall; point or cape, on the mainland coast, near Cape Romanzof, south of the Yukon mouth and north of Nunivak. So called, 1869, after W. H. Dall.

Dall; ridge of mountains, on the western coast of Gravina island, Alexander archipelago. Named by Nichols, 1883, after W. H. Dall.

Dall; river, tributary to the Yukon, from the north, at the Lower Ramparts. It is Notokakat or Dall of the Coast Survey in 1869 ; Notochangut or Dall of Raymond, 1871, and Notochargut of Schwatka, 1883.

Dall City; mining camp, on west branch of Dall river, near longitude $150^{\circ}$. Local name, obtained by Mendenhall and Reaburn, 1901.

Dalnie, cape; see Far. 
Dalnie, island, Yakutat bay ; see Knight.

Dalnoi; point, the westerumost point of St. George island, Pribilof islands, Bering sea. Tebenkof and Tikhmenief call it West Konetz (west end). Otherwise known as Dalnoi (distant) point. According to Putnam, the Aleut name is Äck̈̈̈n'-ūng'-tä. (end point).

Dalton, glacier; see 'Turner.

Dalton; post, range of mountaius and trail leading from head of Lynn canal to the interior. As applied to a range of mountains near Dezadeasi lake this name has been adopted by the Canadian Board on Geographic Names.. Dalton trail is a well-known local name. Named after John Dalton, a well-known miner and frontiersman, "justly considered the pioneer explorer of the region."

Dalzell; creek, draining from Rainy pass into Rohn river, a right-hand tributary of the Kuskokwim, near latitude $62^{\circ} 10^{\prime}$, longitude $153^{\circ} 10^{\prime}$. So named by Brooks, 1902, after: Dalzell, a prospector, who discovered this creek while on his way from the Kuskokwim to Tyonek in 1901.

Dan; creek, tributary to Nizina river on the south, between the Chitistone and Chititu. Prospector's' name. "First appears on map of Nizina mining district by George M. Esterly of Valdez." (Mendenhall, 1902.)

Dan; small creek, tributary to Kougarok river from west, near latitude $65^{\circ} 30^{\prime}$, longitude $164^{\circ} 40^{\prime}$. Prospectors' name, obtained by Gerdine in 1901.

Dana; peak (4,260 feet high), on the mainland near Thomas bay, southeastern Alaska. Named by Thomas, 1887, after Prof. James Dwight Dana, of Yale College.

Danaaku, lake; see Silver.

Danger; bay, indenting the southern shore of Afognak island, Kodiak group. Named Opasnaia (dangerous) by Murashef, 1839-40.

Danger; cape, on the northeastern coast of Whale island, Kodiak group. Named Opasnie (dangerous) by Murashef in 1839-40.

Danger; island, in the entrance to Red bay, Prince of Wales island, Alexander archipelago. So named by Helm, 1886. Erroneously Dead Island on one chart.

Danger; island, near Ward cove, in Tongass narrows, Alexander archipelago. So named by Nichols, 1883.

Danger, island; see Dead.

Danger; islet, "small and wooded" at the southern end of Mary island, Revillagigedo channel, Alexander archipelago. So called by Nichols in the Coast Pilot (1891, p. 98). It is now called Danger.

Danger; passage, between Cat island and Mary island, Revillagigedo channel, Alexander archipelago. So named by Nichols, 1883.

Danger; point, on the eastern or Mitkof island shore of Wrangell strait, Alexander archipelago. So named by Dall, 1879.

Danger; point, the southern point of entrance to Kootznahoo inlet, Admiralty island, Alexander archipelago. Descriptive name given by Meade, 1869.

Danger; reef, in Tongass narrows, near Ward cove, Alexander archipelago. Named by the Coast Survey in 1883. Name not found on any chast. Also called Danger Island reef.

Danger; reef, in Afognak bay, southeast coast of Afognak island, Kodiak group, near latitude $58^{\circ}$, Iongitude $152^{\circ} 46^{\prime}$. So described by Moser, 1900 .

Danger; rock, near Danger point, Wrangell strait, Alexander archipelago. So named by Meade, 1869.

Danger; rock, in Narrow strait, between Kodiak and Spruce islands, Kodiak group. Named Opasnie (dangerous) by Murashef, 1839-40. 
Dangerous; cape, the northern point of entrance to Graham harbor, Cook inlet, near latitude $59^{\circ} 24^{\prime}$, longitude $151^{\circ} 53^{\prime}$. Named Opasnoi (dangerous) by Tebenkof, 1849 .

Dangerous; cape, between Kiliuda and Ugak bays, on the southeastern shore of Kodiak. Named Opasnie (dangerous) by lisianski, 1805. Has also been written Onatzino.

Dangerous; channel, separating Biorka from other islands in or near sitka sound. So named by United States naval officers in 1879-80. Nichols, in the Coast Pilot, suggests that this name is premature.

Dangerous; passage, on the western shore of Prince William sound, separating Chenega island from the mainland. So named by Abercrombie, 1898.

Dangerous; river, a glacial stream on the southeastern coast, 20 miles southeast of Yakutat, near longitude $139^{\circ} 15^{\prime}$. Local name, reported by Moser, 1901.

Danger Point; reef, off Danger point, Kootzmahoo inlet, Admiralty island, Alexander archipelago. So named by Meade, 1869.

Daniels; creek, west of Golofnin sound, Seward peninsula. Name from Barnard, 1900 .

Darby; cape, between Golofnin bay and Norton bay, on northern shore of Norton sound, near latitude $64^{\circ} 20^{\prime}$, longitude $162^{\circ} 40^{\prime}$. So named by Cook. 1778. Has also been written Derby.

Darby; mountains, Seward peninsula, extending 40 miles north from Cape Darby. So described by Brooks, 1900.

Dare, creek; see Dora.

Dark, creek ; see Dora.

Dark; island, off north const of Shuyak island, Kodiak group. Named Temnie (dark) by the Russian American Company, 1849.

Dark; point, the southernmost point of the mainland between Nakat and Willard inlets, Dixon entrance. So named by Nichols, 1883 .

Darling; creek, 20 miles north of Nome, Seward peninsula, tributary to Nome river from the east, near latitude $64^{\circ} 45^{\prime}$, longitude $165^{\circ} 13^{\prime}$. Local. name, from Gerdine, 1904.

Dasa Dee Arsh, lake; see Dezadeash.

Dassar-dee-ash, lake; see Dezadeash.

Dave; gulch, Copper River region, at the headwaters of Chititu creek. "Prospectors name, first appears on map of the Nizina mining district by George M. Esterly, of Valdez." (Mendenhall, 1902).

David, creek; see Sheep.

David; creek, 25 miles north of Nome, Seward peninsula, tributary to Nome rNer from the east, near longitude $165^{\circ} 15^{\prime}$. Name from Barnard, 1900.

David; island, in Wrangell harbor, Alaska peninsula. So named by Vasilief, 1831-32. Also called Davidoff.

Davidof, island; one of the Rat islands, western Aleutians. So named in Krusenstern's atlas; 1827, after Gavriil Ivanovich Davidof, a Russian naval officer, who, with Khwostof, made explorations in Alaska in 18021804. The existence of this island, at least in the place it occupies on most charts, is doubtful.

Davidson; bank or fishing ground, near Unimak pass, near" latitude $54^{\circ}$, longitude $164^{\circ}$. Named by the Fish Commission, 1888, after Prof. George Davidson, of the United States Coast and Geodetic Survey.

Davidson; glacier, on the mainland, near head of Lynn canal, Alexander archipelago. Named by the Coast Survey, 1867, after Prof. George Davididson. According to Krause, 1882, the native name is Șsitkajế,

Bull, $299-06 \mathrm{M}-14$. 
Davidson; inlet, south of Kosciusko island, on the western coast of Prince of Wales archipelago. , Named by Dall, 1879, after Prof. George Davidson.

Davidson; mountain, on the south side of Sanborn harbor, Nagai island, Shumagin group. So named by Dall, 1872, after Prof. George Davidson.

Davidson, plateau and mountain range; see Endicott.

Davidson; point, on the east side of Klakas inlet, Cordova bay, Prince of Wales island, southeastern Alaska, near latitude $54^{\circ} 56^{\prime}$, longitude $132^{\circ} 24^{\prime}$. So called by local navigators, reported by H. C. Fasșett, Bureau of Fisheries, 1904.

- Davis; creek, a strait connecting Mitchell bay and Kinalku bay, Kootzmahoo inlet, Admiralty island, Alexander archipelago. Named by Meade, 1869, after Gen. Jefferson C. Davis, U. S. A., then in command of the military division of Alaska.

Davis; creek or gulch, at the head of Walker fork Fortymile creek, across the international boundary near latitude $\left(0 t^{\circ} 05^{\prime}\right.$. Prospectors' name, reported by Spurr, Goodrich, and Schrader, of the Geological Survey, 1896.

Davis, creek; tribut:rry to Fortymile creek; see Smith.

Davis; creek, tributary to South fork Koyukuk river from the south, near lati- tude $67^{\circ}$, longitude $150^{\circ} 30^{\prime}$. Prospectors' name, published by the Coast Survey in 1899.

Davis, fort; see Fort Davis.

Davis; gulch, 10 miles northeast of Nome, Seward peninsula, on the south bank of Buster creek, a tributary to Nome river from the east, near longitude $165^{\circ} 13^{\prime}$. Local name, published in 1903 .

Davişon; creek, Seward peninsula, small tributary on west bank of Casadepaga river, near latitude $64^{\circ} 55^{\prime}$, longitude $164^{\circ} 10^{\prime}$. Prospectors' name, reported by Gerdine, 1905.

Davison; gulch, Seward peninsula, in Solomon River basin, on north bank of Mystery creek, near latitude $64^{\circ} 19^{\prime}$, longitude $164^{\circ} 25^{\prime}$. Prosepctors' name, from a locill map, 1904.

Davison; mountain (2,652 feet high), in the southern part of Annette island, Gravina group, Alexander archipelago. So named by Nichols, 1.883 .

Davison; poiut, the southernmost point of Amette island, Gravina group, Alexander archipelago. Named by Vancouver, 1793, after Alexander Davison, esq., "owner of our storeship."

Dawes; glaciers, two in number, at the head of Endicott arm, Holkham bay, southeastern Alaska. So named by the Coast Survey, 1891, after Hon. Henry Lalurens Dawes, of Massachusetts.

Dawson; creek, 15 miles northwest of Fairbanks, on the left bank of Keystone creek, a tributary of Goldstream creek from the north; near longitude $148^{\circ}$. Prospectors' name, from a locial map; 1905.

Dawson; peak, near Teslin lake, Yukon ;

range of mountains at the confluence of the Lewes, Pelly, and Yukon rivers, Yukon;

town, Government headquarters, and post-office on Yukon river, at mouth . of Klondilie river, Yukon. (Not Dawson City.)

The above entry for Dawson is taken from the first annual report of the Canadian Board of Geographic Names. Named after Dr. George Mercer Dawson, of the Canadian Geological Survey.

Day; harbor, on the southeastern shore of Kenai peninsula. Named Day's by Portlock in 1787.

Dayay, inlet; see Taiya.

Dead; islet, in the entrance to Red bay, Prince of Wales island, Alexander archipelago. So named by Helm, 1886. See Danger. 
Dead Dog; creek, tributary to Alatna river. Prospectors' name, taken from Report of the Operations of the U. S. revenue steamer Nunivak, 18991901, p. 247. Not found on any map.

Deadman; reach, in Peril strait, Alexander archipelago. Named Deadman's bay by Meade, 1869, in memory of the 150 Aleuts killed by eating poisonous mussels in this vicinity. in 1799. Variously written Dendman's, Deadmans, and Deadman.

Deadman; riffle, on Fortymile creek, near the international boundary. Commemorative name given by the miners. Reported by Spurr's party, Geological Survey, 1896.

Dead Pine; island, in Tleval strait, Cordova bay, Alexinder archipelago. Descriptive name, given by Nichols, 1881.

Dead Tree; bluff, in Mitchell bay, Kootsnahoo inlet, Admimalty island, Alexander archipelago. Descriptive name, given by Meade, 1869.

Dead Tree; island, in Hanus bay, Peril strait, Alexander archipelago. Descriptive name, given by Moore, 1895 .

Deadwood; creek, in the Birch creek region, tributary to Crooked creek from the right, near latitude $65^{\circ} 30^{\prime}$, longitude $144^{\circ} 50^{\prime}$. Frospectors' name, reported Hog'em or Deadwood by Spurr, Goodrich, and Schrader, of the Geological Survey, 1896.

Deadwood; creek, in the Fairbanks region, an aftluent of I'edro creek on the left, near latitude $65^{\circ}$, longitude $147^{\circ} 30^{\prime}$. Prospector's' name, reported by L. M. Prindle, of the Geological survey, 1903.

Dearborn; island, "the largest island off the southeastern end of Raspberry island," Kodiak group, between Raspberry island and Whale island, near latitude $58^{\circ}$. So described by Moser, 1900. See also Deranof.

Dease; creek, lake, and river of British Columbia. Named as early as 1867, and perhaps earlier, after Peter Warren Dease, of the Hudson Bay Company.

Dease; inlet, on the Arctic coast of Alaska, near Point Barrow. Named by 'Thomas Simpson, 1837, after his "worthy colleague," Peter Warren Dease.

Death; valley, Seward peninsula, between the headwaters of Fish river and Koyuk river, near latitude $65^{\circ} 15^{\prime}$, longitude $162^{\circ} 30^{\prime}$. Local name, published in 1903.

De Blondeau; glacier, on the south side of Tsirku river, southeastern Alaska, near latitude $59^{\circ} 17^{\prime}$, longitude $136^{\circ} 12^{\prime}$. Prospectors' name, reported by Wright, 1903 .

Deceit; cape, on the southern shore of Kotzebue sound, Arctic ocean, near latitude $66^{\circ} 07^{\prime}$, longitude $162^{\circ} 48^{\prime}$. Nimed Betrug (deceit) by Kotzebue, August, 1816. He writes: "I had double reason to call it Cape Deceit." He was deceived by its appearance, indicating a bay, which he found not to exist, and he found the natives expert cheats.

December; point, on Mitkof island, in southern part of Wrangell strait, Alexander archipelago. So named by Meade, 1S69. Lindenberg, 1.838, called it Zelonoi (green).

Deception; creek, in the Mount Wrangell district, tributary to Elliott creek from the north. Prospector's' name, of obvious origin, reported by Mendenhall, 1902.

Deception, islands; sẹe Near.

Deception; islet, in Kootznahoo inlet, Admiralty island, Alexander archipelago. So named by Meade, 1869. 
Deception; point, on Woewodski island, in Wrangell strait, Alexander archipelago. So named by Meade, 1869. The mariner may be deceived as to which is the main channel.

Decision; cape, the southermost point of Kuị island, Alexander archipelago. So named by Vancouver, 1793 (II, 420), to commemorate his decision against the pretensions of De Fuca, De Fonte, and others to a prior knowledge of this region. In Russian called Rishénia and Razrishénia (decision).

Deep; bay, indenting the southern shore of Chichagof island, Feril strait, Alexander archipelago. Named Glubokoi (deep) by Vasilief, 1833.

Deep; bay, indenting the north side of the entrance to Beaver inlet, Unalaska island, near longitude $166^{\circ} 15^{\prime}$. So named by Gilbert, 1901 .

Deep; bay, near Banner bay, on the northern shore of Atka, middle Aleutians. Called. Glubokaia (deep) by Lutke about 1830. Not shown on any chart.

Deep, bay ; see Kelp.

Deep; creek, near Controller bay, tributary to Katalla river from the right, near longitude $144^{\circ} 27^{\prime}$. Local name, from Pratt, 1903. Said also to be called Clear creek.

Deep; creek, Sewilrd peninsula, tributary to Goodhope river from the south near latitude $65^{\circ} 42^{\prime}$, longitude $163^{\circ} 32^{\prime}$. Prospectors' name, obtained by Mendenhall, 1901.

Deep; creek, tributary to Fairbanks creek from the north, near latitude $65^{\circ} 05^{\prime}$, longitude $147^{\circ} 10^{\prime}$. Local name, from Gerdine, 1903.

Deep; creek, eastern Alaska, on the south bank of Seventymile creek, near latitude $64^{\circ} 55^{\prime}$, longitude $142^{\circ} 25^{\prime}$. Prospectors' name, reported by Witherspoon, 1905. Erroneously, Deer.

Deep; inlet, about 5 miles from Sitka, in Baranof island, opening into sitka sound. Named Glubokaia (deep) by Vasilief in 1809, on account of its great depth. It is Dorokhora (fool's) bay of Tebenkof, 1849.

Deep; lake, about 10 miles from Sitka, Baranof island, Alexander archipelago. Named Gloubokoi (deep) by Vasilief in 1809. Tebenkof calls it Redoubt lake. A fishing station at the lake's outlet was called The Redoubt. Erroneously given also as Clubokoi. Grewingls also calls it Der tiefe see. Fias also been erroneously called Kluchev (springs) bay.

Deep, point; on the western bank of Chilkat river, near its mouth. Named Glubokie (deep). by Lindenberg, 1838. This name is obsolete.

Deep, river; see Klondike.

Deep Canyon; creek, 30 miles north of Nome, Seward peninsula, an affluent at the headwaters of Nome river, from the north, near latitude $64^{\circ} 45^{\prime}$, longitude $165^{\circ} 15^{\prime}$. Local name, reported by Gerdine, 1904.

Deepwater; point, the northern point of entrance to Woewodski harbor, Frederick sound, Alexander archipelago. In 1838, Zarembo made a sketch of Woewodski harbor and named its south point of entrance Glubokoi (deep water). On late charts this name is applied to the north point of entrance.

Deer; bay, on western side of Hetta inlet, Cordova bay, Prince of Wales island, near latitude $55^{\circ} 15^{\prime}$, longitude $132^{\circ} 40^{\prime}$. Local name, published by the Coast Survey in 1904 .

Deer; creek, tributary tọ Anikovik river, near York, Seward peninsula. Name from Brooks, 1900.

Deer; creek, south of Ears mountain, Seward peninsula, tributary from the north to Crosby creek near longitude $166^{\circ} 11^{\prime}$. Name from Gerdine, 1901 . 
Deer; creek, on south bank of Seventymile creek; see Deep.

Deer, creek, tributary to Seventymile creek; see Green.

Deer; gulch, 7 miles north of Nome, Seward peninsula, at the lieal of Dexter creek, a tributary of Nome river from the west, near longitude $165^{\circ} 21^{\prime}$. Local name, published in 1903.

Deer; island, in Ernest sound, Alexander archipelago. So named by Snow, 1886.

Deer; island, southwest from Belkofski, on southern shore of Alaska peninsula, near latitude $54^{\circ} 55^{\prime}$, longitude $162^{\circ} 15^{\prime}$. 'Named Oleny (reindeer) by the Russians, who derived the name from the Aleuts, whose name for reindeer, says Veniaminof, is Itkaiak. Lutke has Animak, and Billings Animok, for the Aleut name.

Deer; island at entrance to Port Moller and Ferendeen bay, northern coast of Alaska peninsula, near longitude $160^{\circ} 50^{\prime}$. So named by Dall, 1882. Apparently this is Kudobin peninsula of Lutke, 1828.

Deer, island, Hetta inlet; see Jumbo.

Deer; mountain, near Tongass narrows, on Revillagigedo island, Alexander archipelago. So named by Nichols, 1883. Has also been called Deer mountains.

Deer; point, on the western shore of Tamgas harbor, Annette island, Alexander: archipelago. Named by the Coast Survey in 1886.

Deer; rocks, off the eastern shore of Stevenson island, Kashevarof passage, Clarence strait, Alexander archipelago, near latitude $56^{\circ} 02^{\prime}$, longitude $132^{{ }^{\prime \prime}} 55^{\prime}$. Local navigator's name, reported by H. C. Fassett, Burean of Fisheries, 1904.

Deer; valley, Alaska peninsula, extending south from Ferendeen bay, near longitude $160^{\circ} 47^{\prime}$. Sंo called by Tanner, 1890 .

Deering; post-office (established in 1901) and village, at the mouth of Inmachuk river, on south shore of Kotzebue sound, east of Cape Deceit.

De Groff; bay, in Krestof island, north of Sitka sound, Alexander archipelago. So named by Moore, 1897, after a prominent merchant of "Sitka.

Deitrick, river; see Dietrich.

Dejah, inlet; see Chilkoot and Taiya.

Dejah, pass; see Chilkoot.

Dejahssanke, harbor; see Taiyasanka.

Dejahssankessit, glacier; see Ferebee.

Dek. Indian word for creek. Used in the Copper river region. It is appended to the name, thus: 'Tatondek ('Taton creek).

Delarof; harbor, in Unga island, Shumagin group. Apparently nemed by 'Tebenkof, 1.848, after Eustrate Ivanovich Delarof, a native of Greece, who was chief director of the Russian American colonies from about 1784 to July, 1791. Also written Delaroff and Delarovskoi. Generally spoken of as Unga harbor, and the village on its shores called Unga. Lutke says the native name of the village is Ougnagok.

Delarof; islands, at western end of the Andreanof group, middle Aleutians. The two islets, Skagul and Ogliuga, are called Delaroft islands by Lutke, who says the group consists of seven islands. They were named after the former superistendent at Kodiak.

Delgada; point, in Portilla channel, Bucareli bay, Prince of Wales archipelago. Named Punta Delgada (narrow or sharp point) by Maurelle and Quadra, 1775-1779.

Dell; island, an islet in the head of Hetta inlet, Cordova bay, Alexander archipelago, near latitude $55^{\circ} 16^{\prime}$, longitude $132^{\circ} 41^{\prime}$. Local name, rejorted by Dickins, 1905 . 
Del Monte; peak (2,482 feet high), on Lindenberg peninsula, Kupreanof island, Alexander archipelago. So named by Thomas, 1887.

Delome; creek, tributary to Garfield creek, from the west, Seward peninsula. Name from Brooks, 1900.

De Long; islands, off the north coast of Siberia. Discovered by the Jeannette exploring expedition, 1881, and named after its commander, De rong.

De Long; islands, in Foggy bay, at south end of Revillagigedo channel, Alexander archipelago. Named by the Coast Survey, 1885, after Lieut. Commander George Washington De Long, U. S. N., of the exploring steamer Jeannette, who perished in the Lena delta in November, 1881.

De Long; mountains, in northwestern Alaska, between Noatak river and Arctic ocean. So named by Stoney, 1886, after the commander of the Jean. nette expedition.

De Long; peak (3,737 feet high), on Lindenberg peninsula, Kupreanof island, Alexander archipelago. Named by Thomas, 1887, after Lieut. Com. mander George W. De Long, U. S. N.

Delta, creek; see Silok.

Delta; river, tributary to the Tanana river, from the south, near longitude $146^{\circ}$. So named by Allen, 1.885. This and silok creek (Delta creek of Allen) are distinct streams, their mouths being alout 22 miles apart. Frroneously Delt on one chart.

Demarcation; point, on the Arctic coast, at the international boundary line. so named by Sir John Franklin, 1826, as marking the boundary between British and Russian possessions. Has also been written Demarkation.

Demidof; island, in Chiniak bay, 6 miles from Kodiak. Has been occupied as a blue-fox farm, but not so at present. Local name; written also Demidoff.

De Monti; bay, between Khantaak island and a peninsula on the eastern side of the entrance to Yakutat bay, southeastern Alaska. Named Bahia de Monti by Malaspina in 1791. La Perouse, in 1786, hald called Yakutat bay or some part of it, not identifiable, Baie de Monti, after Lieutenant de Monti, first officer of the Astrolabe, who first landed and reconnoitered it. Malaspina applied La Perouse's name to the bay above described. The Coast Pilot says: "This modified application has the advantage of preserving an historic name, and also of naming a part of the bay which otherwise would have required a new name."

Denbigh; cape, the southern point of entrance to Norton bay, on eastern shore of Norton sound. So named by Cook, 1778. Erroneously Denbigh. The Eskimo name is Nuklit, written also Nucleet and Noocleet. By executive order of March 20, 1901, the entire peninsula about 15 miles long and 5 miles wide, of which this is the southern extremity, was reserved as a reindeer station.

Denison Creek, station; see Denuison Creek.

Dennis, fork of Fortymile; see Denuison.

Dennison; fork, of South fork, Fortymile creek, near latitude $64^{\circ}$, longitude $142^{\circ}$. Called Dennis by 'Spurr' in 1896 (Eighteenth Ann. Rept. U. S. Geol. Survey, part 3, Pl. XLV), and Denison by Barnard (Fortymile sheet of Geólogical Survey) in 1898. Abercrombie has, also in 1898, Dennison fork of Fortymile creek. Apparently these are three spellings of one name.

Dennison Creek; station, on military telegraph line between Tanana Crossing and Kechumstuk, at the head of Dennison fork of South fork, Fortymile creek. Named Denison Creek by the Signal Corps, U. S. A., in 1903. 
Denslow; lake, tributary to the Chuit river, near the head of Cook inlet. Name published by the Coast Survey in 1898 .

Dent; mountain $(5,057$ feet high), on the eastern shore of Portland canal. Named by Pender, 1868.

Deranof; island, a small island, occupied by Ivan Deranof as a fox farm, in Kupreanof strait, 5 miles west of Whale island, Kodiak group. Local. name, from the Harriman expedition, 1899.

Derbin; strait, separating Avatanak and ITigalda islands of the Krenitzin group, eastern Aleutians, near longitude 165 $15^{\prime}$. Called Derbenskoi by Veniaminof. Lutke has Derbin and Derbinskoi. Perhaps the name is derived from Derábin or Deriabin or Derzhavin, who was massacred at: Nulato in 1.851.

Derby, cape; see Darby.

Derby; : creek, debouching on the south shore of Seward peninsula, $4 \frac{1}{2}$ miles west of Cape Nome, near longitude $165^{\circ} 08^{\prime}$. Local name, from Gerdine, 1904.

Derwent; creek, eastern Alaska, on the south bank of the Yukon, tributary to Bonanza creek, an affluent of Charley river from the east; near latitude $65^{\circ} 10^{\prime}$, longitude $142^{\circ} 40^{\prime}$. Prospectors' name, from sketcl. map compiled by Major Glassford, Signal Corps, U. S. A., 1905.

Desa Dee Ash, lake; see Dezadeash.

Desconocida; point, in Gulf of Esquibel, Prince of Wales archipelago. Named Punta de lat Desconocida (point of the unknown) by Maurelle and Quadra, 1775-1779, whose surveys ended near this point.

Dese; creek, tributary to Grantley harbor from the south, Seward peninsula. Name from Barnard, 1900 .

Inesengaño, Puerto dcl; see Disenchantment.

Desert (T'he). For 12 miles above Point Rothsay, at the mouth of the Stikine river, "the river valley is sandy and almost destitute of regetation. This trict $* * *$ has received the name of the Desert," probably from the prospectors and mineis. (Coast Pilot, p. 109.) Accoiding to Ogden this is a misnomer.

Desgraciada, islet; see Unlucky.

Deshka; river, tributary to Susitna river, from the north, about 35 miles above the mouth of the latter. Apparently a native name, from Muldrow, 1898. Called Croto creek by Learnard of: Glenn's expedition, 1898, who explored it for 15 miles. See Kroto.

Deshu, village; see Haines.

Destruction; point, on the northeastern shore of Security bay, Kuiu island, Alexander archipelago. So named by Meade, who, in February, 1869, destroyed two Indian villages in Security bay.

Detached; rock, near Outer Spruce cape, near St. Paul, Kodiak. So named by the Coast Survey in 1869.

Devastation, volcano; see Pogromnoi.

Deviation; peak, on the mainland east of Kotzebue sound, elevation 2,675 feet, near latitude $67^{\circ} 05^{\prime}$, longitude $161^{\circ} 10^{\prime}$. So named by Becchey, 1827 .

Devil; mountain, in northeru part of Seward peninsula, southwest from Kotzebue sound. Named Teufelsberg by Kotzebue in August, 1816. It is Chortof (devil) mountain of Russian charts.

Devil; rocks, in Dixon entrance. Tebenkof, 1848 , shows a sunken danger called Devil bank. Latter a United States Hydrographic Office chart shows similarly a danger called Devil ridge. The later charts. abandon this name and show two sunken dangers, called, respectively, East Devil rock and West Devil rock. See East Devil and West Devil. 
Devilfish; bay, indenting the eastern shore of Kosciusko island, Dry pass, Prince of Wales archipelago, near latitude $56^{\circ} 05^{\prime}$, longitude $133^{\circ} 18^{\prime}$. Local name, from Dickins, 1903-4.

Devils; creek, Kenai peninsula, at the head of Quartz creek, which is tributary to Kenai lake. Prospectors' name, from Moffit, 1904.

Devils; gulch, on the south shore of Norton sound, a few miles west of Golsova, near longitude $161^{\circ}$. Local name, reported by Dr. C. O. Lind, of Unalaklik. (Reindeer Report 1904, p. 77.)

Devil's Elbow (The); bend, in the Yukon 40 miles above Andreafski, about longitude $161^{\circ} 30^{\prime}$. Name from Cantwell, 1900.

Devils Prongs. This appellation was applied by the Coast Survey, in 1869, to two mountain peaks near St. Paul, Kodiak. Elevation of the north peak, 2,057 feet. Also called Devils mountains. Named by the Russians, in 1809, Chernieshef, a name not found in any Russian dictionary consulted, but which is very suggestive of the Black One.

Devils Thumb; a remarkable pinnacle, on the summit of a mountain, on the mainland east of Frederick sound. So named by Meade, 1869, accordiug to whom it is 400 feet high. According to Nichols the shaft or thumb is 1,662 feet high; the elevation of the whole is 9,077 feet. It marks the international boundary at this point.

Devine; cape, the southeastern point of Korovin island, Shumagin group, near longitude $160^{\circ} 05^{\prime}$. Named by Dall, 1880 .

Dew, point, on the mainland, in Behm canal, near north end of Revillagigedo island. So named by the Coast Surrey in 1891.

Dewey; anchorage, in the southern end of Etolin island, Clarence strait, Alexander archipelago, near latitude $55^{\circ} 55^{\prime}$, longitude $132^{\circ} 20^{\prime}$. Named by Snow, 1886, after Ensign Theodore Gibbs Dewey, U. S. N., a member of his party.

Dewey; creek, tributary to Copper river, from the east, opposite the mouth of Tiekel river, near latitude $61^{\circ} 10^{\prime}$. So named by Abercrombia, 1898, after Admiral George Dewey, U. S. N.

Dewey; creek, tributary to Eureka creek, from the east, Seward peninsula. Name from Barnard, 1900.

Dewey; creek, tributary to Fox river from the south, Seward peninsula. Name from Barnard, 1900.

Dewey; creek, tributary to Grantley harbor from the.north, Seward Peninsula. Name from Barnard, 1900.

Dewey; creek, 10 miles north of Nome, Seward peninsula, tributary to Nome river from the east, near longitude $165^{\circ} 17^{\prime}$. Local name, published by the Coast Survey in 1900 . Near by is Sampson creek and Schley creek.

Dewey; creek, 20 miles north of Nome, Seward peninsula, a tributary from the south to Last Chance creek, an affluent of North fork Snake river, near longitude $165^{\circ} 28^{\prime}$. Miners' name, from Gerdine, 1904.

Dewey, creek, tributary to Casadepaga river; see Squirrel.

Dewey; creek, small tributary of Yukon from south, about 12 miles above Washington creek, near longitude $142^{\circ}$. Local name, reported to Collier, 1902, by E. J. Chamberlain, deputy mineral surveyor at Eagle.

Dewey; creek, in the Fortymile region, eastern Alaska, on the south bank of Hutchinson creek, near latitude $64^{\circ} 20^{\prime}$, longitude $142^{\circ} 15^{\prime}$. Prospectors' name, from sketch map compiled by Major Glassford, Signal Corps, U. S. A., 1905. 
Dewey; creek, eastern Alaska, on the west bank of Charley river, which is affluent to the Yukon from the south, nenr longitude $143^{\circ}$. Irospectors' name, from sketch map compiled by Major Glassford, Signal Corps, U. S. A., 1905 .

Dewey; rock ( 30 feet high), in entrance to Cordova bay, Dixon entrance, Alexander archipelago. Named by Clover, in $\mathbf{1 8 5 5}$, after Ensign 'T. G. Dewey, U. S. N., a member of his party.

Deweyville; fishing station, Sea Otter sound, on the western shore of Prince of Wales island, near latitude $55^{\circ} 57^{\prime}$, longitude $133^{\circ} 15^{\prime}$. Tocal name, reported by Dickins, $1.908-4$.

Dexter; creek, 7 miles north of Nome, Seward peninsula, tributary to Nome river from the west, near latitude $64^{\circ} 30^{\prime}$, longitude $165^{\circ} 17^{\prime}$. Prospectors' name, pnblished in 1900 .

Dexter; point, on the southern shore of Norton bay, Norton sound, Bering sea. Local proper name, published in 1900.

Dexter, post-office; see Cheenik.

Dexter; railroad station and mining camp, 7 miles north of Nome, Seward peninsula, near the head of Dexter creek, near longitude $165^{\circ} 21^{\prime}$. Name published in 1904. Called also Dexter Station.

Deyea, river; see Chilkoot.

Dezadeash; lake, back of the st. Elias range of mountains. Native name reported by Davidson as 'Tots-in-tee-ish and by 12. J. Glave, 1890, as Dalsal Dee Arsh, Desa Dee Ash, and Dassirl-Dee-ash. Variously written Dezade-ash, Dazadeash, etc. The above form, Dezadeash, has been adopted by the Canadian Board on Geographic Names.

Dgak, bay ; see Ugak.

Diamond; fork, of Seventymile creek, eastern Alaska, on the south bank, near latitude $64^{\circ} 55^{\prime}$, longitude $142^{\circ} 50^{\prime}$. Prospectors' name, from sketch map compiled by Major Glassford, Signal Corps, U. S. A., 1905.

Diamond; island, in Mitchell bay, Kootznahoo inlet, Admiralty island, Alexander archipelago. So named by Meade, 1869.

Diamond; point, on the west end of San Juan Bautista island, Bucareli bay, Prince of Wales archipelago. Named Punta de Diamante (diamond point) by Maurelle and Quadra, 1775-1779.

Diamond; post-oftice, central Alaska (established in March, 1906), on the Kantishna river near the mouth of the Toklat, latitude $64^{\circ} 30^{\prime}$, longitude $150^{\circ} 30^{\prime}$.

Diana; mountain, near Ward cove, in the western part of Revillagigedo island, Alexander archipelago. So named by the Coast Survey in 18s6.

Diane, roads; see Tianna.

Di-bot-i-chit-in-da, creek; see Jacksina.

Dick; creek, 12 miles north of Controller bay, Gulf of Alaska, tributary to Bering lake from the north, near latitude $60^{\circ} \cdot 20^{\prime}$, longitude $144^{\circ} 15^{\prime}$. Prospector's' name, reported by Martin, 1.905.

Dick; creek, Seward peninsula, tributary to Bryan creek, an affluent of Serpentine river, near latitude $65^{\circ} 50^{\prime}$, longitude $164^{\circ} 58^{\prime}$. Prospectors' name, obtained by Gerdine, 1901.

Dick, point; see Gore.

Dick; port, on the outer const of Kenai peninsula. Named Dick's harbor by Portlock in 1786. Port Dick of the Russians.

Dickason; mountain, on the southern bank of Skwentna river, near longitude $152^{\circ}$. Named, in 1898, by Post, of the Geological Survey, after Col. L. T. Dickison. Erroneously Dickerson. 
Dick Dale; creek, in the Fortymile region, tributary to Dome creek from the south, near lititude $64^{\circ} 20^{\prime}$, longitude $141^{\circ} 15^{\prime}$. Prospectors' name, obtained by Gerdine, 1903.

Dickens; creek, 27 miles north of Nome, Seward peninsula, tributary to Nome river from the east, near longitude $165^{\circ} 15^{\prime}$. Name from Barnard, 1900 .

Dickens; point, on the eastern shore of Portland canal. Named by Pender, 1868.

Dickman; bay, at the he:a of Moira sound, western shore Clarence strait, southeastern Alaska, near latitude $55^{\circ}$, longitude $132^{\circ} 16^{\prime}$. So called by local navigators and reported by II. C. Fassett, Bureau of Fisheries, 1904.

Dicks; arm and inlet, indenting the northern shore of Cross sound at Cape Spencer; southeastetn Alaskin, near latitude $58^{\circ} 13^{\prime}$, longitude $136^{\circ} 38^{\prime}$. So named by Pratt, 1901.

Dickson; railiond terminus, Seward peninsula, at mouth of Solomon river, ne:tr longitude $164^{\circ} 25$. Loc:il name, given in 1903 or 1904.

Dierovatie, point; see IIoles.

Dietrich; river, tributary to Middle fork Koyukuk river, near its source. Published, in 1809, by the Geological Survey, with the spelling Deitrick; here changed to Dietrich.

Digges's, sound; see Disenchantment.

Dikoi, island; see Wild.

Dillinger; river, tributary to the Kuskokwim from the right, near latitude ( $32^{\circ} 30^{\prime}$, longitude $154^{\circ}$. Named by Herron, 1899 , after Private Gilbert Dillinger, U. S. A., a member of his party.

Dillingham; post-oftice (established August, 1905), southwestern Alaska, at the head of Nushagak bay, Bering sea, near latitude $59^{\circ}$.

Dim, creek, in Fortymile region; see Jim.

Din-az-ee, mountain peaks; see Foraker and McKinley.

Dinsmore; creek, Seward peninsula, tributary from the northeast to Crosby creek, near latitude $65^{\circ} 52^{\prime}$, longitude $166^{\circ} 20^{\prime}$. Local name, from Gerdine, 1901.

Diomede; a group of three islands, in Bering strait, known as the Big Diomede, belonging to Russia, Little Diomede, and Fairway rock, belonging to the United States. The international boundary is the meridian which passes midway between Big Diomede and Little Diomede islands. They, or one of them, appear to have been first discovered by Bering, August 16, 1728, and named by him the island of the holy martyr Diomede. August 16 is st. Diomede's day of the church calendar. It also bore on early maps the name of St. Demetrius. August 14 is St. Demetrius's day of the church calendar. It is jossible that this name was applied by Bering, but usage has established Diomede. Michael Grozdef, surveyor, also explored in Bering strait; in 1730, and after him the islands bave been called by the Russians Grozdef islands. Thus the islands have been called Diomede, Diamed, St. Diomede, St. Diomed, Diomedis, St. Demoid, S. Dimitre, Gwozdeff, and Gwosdew; doubtless several other forms have also been used.

Dirt; glacier, near Muir inlet, Glacier bay, southeastern Alaska. Descriptive name, given by Reid, 1892.

Dirt, glacier; see Mud. 
Discovery; creek, 10 miles north of. Cape Nome, Seward peninsula, tributary to Flambean river from the west, near longitude $165^{\circ}$. So called in the Cape Nome report (Geol. Survey) of 1899, where it is shown as debouching in Port Safety. On a late map called Seattle or Discovery.

Discovery; creek, tributary to Birch creek from the south, near latitude $66^{\circ}$, longitule $146^{\circ}$. I'rospectors' name, fullished by the c'oast Survey in 1898 .

Discovery; fork, of American creek, in the Eagle mining region. Prospectors' nime, published by the Geological survey in 18!)!.

Discovery; rock, in Chiuiak bay, near St. Paul harbor, Kodiak. Named Atkritoi (discovery) by Russian naval officers, 1808-1810.

Disenchantment; bay, at the head of Yalkutat bay, near latitude $\left(i 0^{\circ}\right.$, longitude $139^{\circ} 30^{\prime}$. Nimed I'uerto del Desengaño by Malispinal, in Tuly, 1791, who, looking for a northeast passage, commemolated, by this name, his fallure to find it lere. This name wals not published until 1802, and meanwhile Vincouver hild named it Digges's sound. Malitspinal's Spanish name has been rendered Disenchantment in Wnglish and Razuvirenie in Russian. This name appears to bave been applied by Malaspinat to the head of Yakutat bay, hetween Point Jatouche and Traenke island, while to the ice encumbered arm stretching northeastward was given the name Bahia de las Bancus (bay of shoals). The water is, however, very deep, more thin 120 fathoms, and hence the name may have been applied with reference to the.floating ice, as suggested by Dall. This name appears to have never' come into use. Vancouver's name, Beerings bay, is applied, an his chart, to this part of Yakutat bay. Tebenkof hats the nime Ferrer applied to the entrance of this bay, and says it was given by Malaspina, in 1791, after: his first mate, Ferler. The head of Yakutat bay is here called Disenchantment bay and the long arm extending 30 miles southeasterly from the liead of the biy is called Russell fiord.

Disraeli; mountains (5,000 feet high), near the head of Portland canal. Named by Pender. 1868 .

Distant, island, Peril strait; see Otstoia.

Distant, island, Yakutat bay; see Knnight.

Distant, point. St. George islind; see Dalnoi.

Distant; point, the soutbern point of entrance to IIood hay, Admiralty island, Chatham strat, Alexinder arehipelago. so named by Meade, 1869.

Distin; mountain (2,155 feet high), 20 miles north of Nome, Seward peninsula, at head of Snake river, near latitude $6 t^{\circ} 40^{\prime}$, longitude $165^{\circ} 22^{\prime}$. Nime from Barnard, 1900 .

Distin; peak, on the north bank of Happy river, near latitude $\left(22^{\circ}\right.$. So named by P'ost, 1898 .

Divide; creek, at the head of East fork Sixmile creek, Kenai peninsular. Loc:al name, reported by Mendenlatil, 1899.

Divide; creek, 25 miles north of Nome, Seward peninsula, a small western tributary of Nome river, near latitude $64^{\circ} 50^{\prime}$, longitude $165^{\circ} 16 i^{\prime}$. Mmers' name, reported by Gerdine, 1904.

Divide; creek, Seward peninsula, tributary from the north to Cottonwood creek, an aftluent of Goodhope river, near. latitude $65^{\circ} 42^{\prime}$, longitude $163^{\circ} 15^{\prime}$. Prospectors' name, outained by Mendenhall, 1901. 
Divide; creek, a right tributary of Mosquito fork Fortymile creek, near its head, about latitude $64^{\circ}$, longitude $143^{\circ}$. Descriptive name, reported by Lieutenant Mitchell, Signal Corps, U. S. A., 1902.

Divide; head, at the entrance to South arm Cholmondeley sound, western shore Clarence strait, southeastern Alaska, near latitude $55^{\circ} \mathbf{1 5}^{\prime}$, longitude $132^{\circ} 17^{\prime}$. Name from local navigators, reported by H. C. Fassett, Bureau of Fisheries, 1904.

Divide; island, in Shakan bay, Sumner strait, Alexander archipelago. So named by Helm in 1886 ; it divides an unnamed bay into two parts.

Divide; peak, on the mainland, east of Frederick sound and near Patterson glacier. Named Divide (peak?) by the Coast Survey in 1888 . (See Coast and Geodetic Survey chart 705.)

Divide; point, separating Herendeen bay from Port Moller, Alaska peninsula. So named by the Fish Commission in 1890.

Divining; creek, 12 miles north of Nome, Seward peninsula, tributary to Snake river from the east, near latitude $64^{\circ} 40^{\prime}$, longitude $165^{\circ} 25^{\prime}$. Local name, published in 1900 .

Dix; point, the northern point of entrance to American bay, Kaigani strait, Alexander archipelago. Named by Dall, 18s2, after Lieut. Timothy Dix Bolles, U. S. N. Also named Graham by Sheldon Jackson.

Dixie; creek, Seward peninsula, tributary to Independence creek, near latitude $65^{\circ} 30^{\prime}$, longitude $162^{\circ} 20^{\prime}$. Prospectors' name, obtitined by Witherspioon, 1903.

Dixon; creek, tributary to the Casadepaga river, from the north, Seward peninsula. Name from Barnard, 1900.

Dixon; harbor, on the mainland coast a little north of Cross sound. Name published by the Const Survey in 1889.

Dixon; mountain (4,800 feet high), near the head of Yakutat bay, southeastern Alaska. Named by Russell, 1890, presumably after Capt. George Dixon, who, in 1787, marde the first sketch of Port Mulgrave.

Dixon; mountain (Mount Dixon, 1,713 feet high), Seward Peninsula, on west bank of Casadepaga river, near latitude $64^{\circ} 55^{\prime}$, longitude $164^{\circ} 14^{\prime}$. Local name, reported by Gerdine, 1905. Apparently called Nipple mountain on a local map of 1900 .

Dixon Entrance; a broad open sound or strait, between the Columbian and Alexander archipelagoes, through which passes the southern boundary line between British Columbia and Alaska. It has been variously called an inlet, channel, strait, sound, and entrance. Usage seems to have settled upon the above name. Dixon Entrance was discovered by the Spaniards, in 1774, and called Entrada de Perez. Dixon, in 1787, visited it and named it. after himself, Dixon's straits; the name being applied to the waters east and north of Queen Charlotte islands. Meares at about the same time named it Douglass entrance, after Capt. William Douglass (or Douglas) who commanded his consort ship the packet-boat Iphigenia (Nubiana). To its northeastern part he applied the name Buccleugh sound, which he also spelled Bucclugh. The Russians, 1825, called it Granitsa (boundary) strait, whence we find Dixon entrance or Granitsa channel and Graenz strasse. Tebenkof, using the native name, has Kaigani strait.

Dlinnaia, reef : see Long.

Dobriek Vestei, bay ; see Goodnews. 
Doctor; low sandy island, on the Arctic coast, near Point Barrow. Perhaps this is identical with Crescent island or Martin island or both (called Il-liut-kak by the Eskimos) of British Admiralty chart 2164, published in 1854. (See Martin.)

Doe; mountain (2,976 feet high), on Revillagigedo island, near. Tongass nallrows, Alexinder archipelago. So named by Nichols, 1883. Buck and Fawn mountains are near by.

Doe; point, Herendeen bay, Alaska peninsula, the southeastern point of Deer island, near longitude $160^{\circ} 47^{\prime}$. So named by 'Tanner, 1890 .

Dog; cape, the southeasternmost point of Agattu island, western Aleutians. Called by Tebenkof Southivest or Sabak ( $\log )$.

Dog, creek; see Colorado.

Dog; creek, Seward peninsula, Casadepaga drainage, tributary to Ruby creek from the south, near latitude $64^{\circ} 47^{\prime}$, longitude $164^{\circ} 18^{\prime}$. Prospectors' name, from a local map, 1901.

Dog; creek, 6 miles north of Cape Nome, Seward peninsula, tributary to Concord creek from the south, near longitude $165^{\circ} .02^{\prime}$. Name from Gerdine, 1904.

Dog; island, on the northern shore of Duke island, Gravina group, Alexindria archipelago. So named by Nichols, 1883.

Dog; point, the south point of entrance to Nakwasina passage, Baranof island, Alexander archipelago. Named Sabachi $(\operatorname{dog})$ by Vasilief, 1809.

Dogfish; bay, on the eastern shore of Portland canal, near its mouth. Named by Pender, 1868.

Dogfish; island, at the head of Naha bay, western shore Revillagigedo island, Behm canal, southeastern Alaska, near latitude $55^{\circ} 36^{\prime}$, longitude $131^{\circ}$ 38'. Local navigators' name, reported by H. C. Fassett, Bureau of Fisheries, 1904.

Doggetlooscat; see Dagitli.

Dogitskakat, river; see Dagitli.

Dog Salmon; river, Alaska peninsula, tributary on the left bank of Ugashik river, 20 miles firom its mouth, near latitude $57^{\circ} 30^{\prime}$, longitude $157^{\circ}$. Local name, reported by Moser, 1900.

Dolgay, island ; see Long.

Dolgoi; cape, the south point of Dolgoi island, near Belkofski, Alaskil peninsula. So called by Dall, 1.880.

Dolgoi, cape; see Kukistan.

Dolgoi; harbor, indenting the western coast of Dolgoi island, near Belkofski. Probably a local name, published by the Coast Survey in 1.882 .

Dolgoi, island, Cordova bay; see Long.

Dolgoi; island, in Port Bazan, Dall island, Prince of. Wales archipelago. Named Dolgoi (long) by Zarembo, 1834.

Dolgoi; island, in Yakutat bay, southeastern Alaska. C̣alled Dolgoi (long) by Tebenkof, 1849.

Dolgoi; island, near Belkofski, on southern shore of Alaska peninsula, about longitude $161^{\circ}, 50^{\prime}$. Named Dolgoi (long) by the Russians. Its Aleut name, according to Veniaminof ( $I, 252)$, is Ananakeik.

Dolgoi, island, Sitka sound; see Long.

Dolgoi, lake; see Lower.

Dolomi; post-office (establisbed August, 1.900), between Moira and Cholmondeley sounds, on the eastern shore of Prince of Wales island, Alexander archipelago. 
Dolores; port, in Suemez island, Bucareli bay, Prince of Wales archipelago. Named Inerto de los Dolores. (port of the sorrowing) by Maurelle and Quadra, 1775-1779.

Dolls, island; see Dall.

Dolph; rock (which bares 3 feet), Peril strait, three-fourths mile off the south side at entrance to Ushk bay, Alexander archipelago, near latitude $57^{\circ} 33^{\prime}$, longitude $135^{\circ} 33^{\prime}$. So named by Moore, 1895, after Quartermaster George Dolph, of his ship.

Dolphin; point, the northeast point of Whale island, Afognak strait, between Afornalk and Kodiak islands; neair latitude $57^{\circ} 57^{\prime}$. Name from Moser, 1900. Called Melkowadia (little water or shallows) by Murashef, $1839-40$.

Dome; creek, tributary to Tisuk river from the north, Seward peninsula. Name from Barmard, 1900.

Dome; creek, Seward peninsula, tributary from the east to Americall river; near latitude $65^{\circ} 35^{\prime}$. Local name, from Gerdine, 1901.

Dome; small creek, on Seward peninsula, tributary to Jim creek, which is a branch of 'Taylor creek, near latitude $65^{\circ} 40^{\prime}$, longitude $164^{\circ} 30^{\prime}$. Local name, obtained by Gerdine, 1901.

Dome; creek, Seward peninsula, tributary to Kiwalik river from the west, near latitude $65^{\circ} 40^{\prime}$, longitude $162^{\circ}$. Prospectors' name, obtained by Witherspoon, 1903.

Dome; creek, in the Fairbanks region, tributary to Chatanika river from the south, near latitude $65^{\circ} 05^{\prime}$, longitude $147^{\circ} 35^{\prime}$. Local name, from Gerdine, 1903.

Dome; creek, tributary to O'Brien creek, from the east, in the Fortymile mining region. Local name, reported by Barnard, 1898.

Dome; creek, tributary to American creek, from the soutb, in the Eagle mining region. Local name, reported by Barnard, 1898.

Dome; creek, eastern Alaska, at the head of Washington creek, an affluent to the Yukon on the south bank, near latitude $65^{\circ} 05^{\prime}$, longitude $142^{\circ} 20^{\prime}$. Prospectors' name, from sketch map compiled by Major Glassford, Signal Corps, U. S. A., 1905.

Dome; mountain (2,100 feet high), on the western side of Portland canal, in latitude $55^{\circ} 04^{\prime}$. Named by Pender, 1868.

Dome, mountain ; see Roundtop.

Dome; pass $(4,300$ feet high $)$, in the St. Elias alps. Descriptive name, given by Russell, 1890.

Dome; peak, near the head of Thomas bay, southeastern Aliskil. Descriptive name, given by Thomas, 1887.

Dome; peak (4,420 feet high), on the mainland, west of Lincoln islind, Lynn canal, Alexander archipelago. So named by Meade, 1869 .

Dome; peak $(6,500$ feet high), on the western side of Portland canal, in latitude $55^{\circ} 25^{\prime}$. Descriptive name given by Pender, 1868 .

Dome, peak; see Fortymile dome.

Dome; point, on the western shore of Long island, Port Frederick, Alexander archipelago. Named by United States naval officers, 1880.

Dome; point, on the eastern shore of Stepovak bay, Alaska peninsula. So named by Dall, 1880 .

Dominion; creek, Seward peninsula, tributary from the east to Independence creek, an affluent of Kugruk river near latitude $65^{\circ} 40^{\prime}$, longitude $162^{\circ}$ $50^{\prime}$. Prospector's' name, obtained by Mendenhall and Reaburu, 1901. 
Dominion; creek, tributary to the headwaters of Mission creek from the west, near latitude $64^{\circ} 20^{\prime}$ in the laggle mining region. Local name, published by the Geological Survey in 1899?.

Don; river, Seward peninsula, tributary from the north to the ligoon on the north shore of Port Clarence. Local name, reported by Gerdine, 1901.

Donchelok; river, draining Lake Tukomina into Lake Minchumina, near latitude $63^{\circ} 45^{\prime}$, longitude $152^{\circ}$. Native name written Don-che-loch-no by Herron, 1899.

Donjek; river, tributary to White river from the south, near latitude $62^{\circ}$. Native name; has also been written Donjeck. The above form, Donjek, has been adopted by the Canadian Board on Geographic Names.

Donnelly; point, in Naha bay, Revillagigedo island, on the south side of anchorage at Loring, near latitude $55^{\circ} 36^{\prime}$, longitude $131^{\circ} 39^{\prime}$. Local navigators' name, reported by H. C. Fassett, Bureau of Fisheries, 1904.

Dora; bay, in Cholmondeley sound, Prince of Wales archipeligo. So named by Clover, 1885, presumably after his. wife, formerly Miss Dora Miller.

Dora; creek or xiver, tributary to Chitina river from the nortl, about 25 miles above junction of Chitina and Copper rivers. Nimed Dora by Lientenant Allen, April 14, 1855, after Miss Dora Johnson, of Chicago, afterwards his wife. On map 1. of Allen's report it is printed Dora, but on map 2 of same report it is printed Dare, and this form has been copied on Coast and Geodetic Survey chart 3091. On a late map it is printed Dark.

Dora; harbor, indenting the southern shore of Ikatan peninsuli, Unimak island, near longitude $163^{\circ} 15^{\prime}$. Named Loras by the Fish Commission in 1888. Called Lords by the Coast Survey and known locally as Dora harbor.

Doran; straight, separating the front of Barry glacier from the opposite mainland, and connecting Barry arm with Harrinan fiord, Port Wells, Prince William sound. So named by the Harriman expedition, 1899, after Capt. Peter Doran, of the steamer George W. Elder, which bore the expedition.

Doric; creek, in the Rampart region, tributary to Pioneer creek from the northwest. P'rospector's' name, from Prindle, 1904.

Doris, bay; see Mud.

Dorn; island, in Seymour canal, Alexander archipelago. So named by Mansfield, 1890, after Lieut. Edward J. Dorn, U. S. N., a member of his party.

Dornin; sunken rock, off the western end of Douglas island, Stephens passage, Alexander archipelago. Named by Mansfield, 1890, after J. B. Dornin, a member of his party.

Dorokhova, bay ; see Deep.

Doroshin; glacier, on Kenai peninsula, near Kachemak bay, Cook inlet. So named by Dall, 1880, after Peter P. Doroshin, a Russian mining engineer, who made investigations in Cook inlet in 1.848 .

Dorothy; creek; 25 miles north of Nome, Seward peninsula, tributary to Nome river, firom the west, near longitude $165^{\circ} 15^{\prime}$. Name from Barnard, 1900.

Dorozhnoi, island ; see Road.

Dot, hill, St. Paul island; see Ridge.

Dot; island, very small, off the northwest shore of Tuxekan island, Sea Otter sound, Prince of Wales archipelago, near hatitude $55^{\circ} 54^{\prime}$, longitude $133^{\circ} 20^{\prime}$. So named by Dickins, 1903-4. 
Dot; island, north shore Afognak bay, Kodiak group, near latitude $58^{\circ} 02^{\prime}$, longitude $152^{\circ} 47^{\prime}$. So named by Moser, 1900.

Dot; islet, in the center of McHenry inlet, southwestern shore Etolin island, Clarence strait, Alexander archipelago, near latitude $56^{\circ} 01^{\prime}$, longitude $132^{\circ} 24^{\prime}$. Descriptive name, reported by Moser, 1900.

Double; island, at entrance to Hunter bay, Cordova bay, Prince of Wales island, near latitude $54^{\circ} 53^{\prime}$. Descriptive name, given by Moser, 1897.

Double; island, in Krestof sound, north of Sitka sound, Alexander archipelago. Named Droinoi (twin) by Vasilief, 1809. Called Dwinoi in the Coast Pilot (1883, p. 155) and Double in late Const Survey publications.

Double; island, near Dewey anchorage, Clarence strait, Alexander archipelago. Named by Snow, 1886. The island is double at high water.

Double; island, in St. Paul harbor, Kodiak. . Named Droinoi (double, or twius) by Vasilief, 1809 .

Double; islands, between Cat and Dog islands, in Felice strait, southeast of Annette island, Gravina group, Alexander archipelago. So named by Nichols, 1883.

Double Point; mountain, on the north bank of the Koyukuk, near Arctic city. Descriptive name, given by Allen, 1885.

Doubtful; harbor, on the southern coast of Wrangell island, Arctic ocean. So named by Berry, 1881. Possibly this is a synonym for Selfridge bay.

Doughton; peak (2,700 feet bigh), 20 miles northeast of Controller bay, Gulf of Alaska, near latitude $60^{\circ} 26^{\prime}$, longitude $143^{\circ} 50^{\prime}$. Prospectors' name, reported by Martin, 1905.

Douglas; bay, indenting the southern coast of Kupreanof island, Sumner strait, Alexander archipelago. Named by Helm, 1866, and spelled on various charts Douglas and Douglass indiscriminately.

Douglas; cape, the western head of Cook inlet. So named by Cook, 1778 (II, 385), after Dr. Douglas, canon of Windsor. It is Kamieshatskoi of a Russian chart of 1802 . The native name is given as Kukvak, Koukhat, and Kuchat.

Douglas; cape, on the western shore of Seward peninsula, Bering sea, just south of Port Clarence, near latitude $65^{\circ}$. So named by Beechey, 1826.

Douglas, entrance; see Dixon.

Douglas; island, opposite Juneau, at the north end of Alexander archipelago. Named Douglas's by Vancouver, 1794, after the Bishop of Salisbury. Has sometımes been written Douglass.

Douglas; mountain (Mount Douglas), on Cape Douglas, southwestern shore Cook inlet. Name reported or proposed by Martin, 1904, and adopted by the U. S. Board on Geographic Names, June 6, 1906.

Douglas, river; see Chuiu.

Douglas; town and post-office, on Douglas island, southeastern Alaska. Postoffice established in January, 1888, and town incorporated March 29, 1902. Population, 1890, 402; in 1900, 825. Often called Douglas City.

Douglas, village; see Aievak and Ashivak.

Douglass; bay, in southwestern shore of Hooniah sound, Peril strait, near latitude $57^{\circ} 40^{\prime}$, longitude $135^{\circ} 45^{\prime}$. So named by Moore, 1895, but not heretofore publishẹd.

Douglass; peak, on the mainland, east of Farragut bay, southeastern Alaska. So named by Thomas, 1887 .

Doushnai, bay; see Close.

Dove; islet, at entrance to Jamestown bay, Sitka sound, Alexander archipelago. Named by United States naval officers, 1880, after a Mr. Dove, employed on the U. S. S. Jasnestown in that year, 
Doverspike; gulch, Seward peninsula, Solomon River drainage, on nortl. bank of Adams creek, near latitude $64^{\circ} 43^{\prime}$, longitude $164^{\circ} 28^{\prime}$. Prospector's' name, from a local map, 1901.

Dowling; peak, on the north shore of Klutina lake. So named by Abercrombie, 1.898.

Drake; head, Kodiak island, southwestern shore of Alitak bay, 5 miles northeast of Alitak point. Local name, obtained by Moser, 1900.

Drake; island (about 1,000 feet high), in Glacier bay, southeastern Alaska. Origin of name not discovered. First found on British Admiralty chart 2431 , corrected to 1890 .

Dranishnikof; mountain or peak, near Deep lake, Baranof island, Alexander archipelago. So named by Vasilief, 1809. Has been called Mount Dranish. Locally known as Redoubt mountain.

Dranishnikof. The settlement or fishing station at the outlet of Deep lake, in Sitka sound, was sometimes so called. More commonly it was, and still is, spoken of as The Redoubt.

Draper; mountain (7,546 feet high), near the head of Disenchantment bay, southeastern Alaska. Named by Russell, 1891, after Prof. John William Draper.

Dravnoi, bight; see Kologho.

Dress; point, in Behm canal on the northwestern shore of Revillagigedo island, Alexander archipelago. Named by the Coast Survey in 1.891.

- Drew; point, on the Arctic coast, east of Point Barrow. Named by Dease and Simpson, 1837, after Richard Drew, of the Hudson Bay Company.

Drew, coal mine; see Pioneer.

Drier; bay, indenting the western shore of Knight island, Prince William sound. Name from Schrader, 1900.

Driest; point, the north point of entrance to Port Chester, Annette island, Alexander archipelago. So named by Nichols, 1883. Erroneously Dreist.

Driftwood; small open bay, on the southern shore of Umnak island, eastern Aleutians. Named Drovenaia (firewood) by the Russians on account of the abundance of driftwood found here. On account of its shape the Russians sometimes called it Dvoinoi (double or twin). Also it was known as Staraia gavan (old harbor), because one of the early Russian trading vessels anchored here. Has also been written Drovianatia.

Drop; creek, on the north slope of Mount Sanford, and glacier at its head, tributary to Copper river on the left. Descriptive name, given by Schrader, 1902, from its steep slope and torrential flow.

Drop (The); pass, Copper River region, between Kanata river and the head of Quartz creek, an aftluent of 'Tonsina river; near latitude $61^{\circ} 25^{\prime}$, longitude $145^{\circ} 15^{\prime}$. Prospectors' name, reported by Rohn, 1899.

Drovenaia, bay ; see Driftwood.

Drozdof, island; see Blackbird.

Drum; mountain (12,000 feet high), east of and nenr Copper river, near longitude $144^{\circ}$. Named, by Allen, 1885, åter Adjt. Gen. Richard Coulter Drum, U. S. A.

Drum Head; peak, on the northern coast of Wrangell island, Arctic ocean. Named by Berry, 1881. Also written Dirumhead.

Drunkard; bay, on the southeastern coast of Kodiak. This name was given by Lisianski, 1805, in his text. Name not found elsewhere and the place not identified.

Dry; bay, indenting the eastern shore of Stephens passage, southeastern Alaska, between League point and Point Lookout, near latitude $57^{\circ} 37^{\prime}$. Prospectors' name, reported by Spencer and Wright, 1903.

Bull. 299-06 M- -15 
Dry; bay, on the mainland coast, between Lituya bay and Yakutat bay, near longitude $139^{\circ}$. So called by Davidson, 1869. It appears to be a shallow lagoon where the waters from the melting glaciers contend with the ceaseless surges of the Pacific. Cook saw this place in 1778, and under the supposition that it was the spot where Bering anchored July 20, 1741, named it Beering's bay (II, 347). This name, variously spelled, was adopted by Malaspina, Dixon, and others. La Perouse called it Behring's river. Tebenkof represents it truly as the delta of the Alsek, and shows it debouching through five mouths or rivers, of which four bear the names Tlegan, Taaltsug, Vankahina, and Kakanhina, the fifth being unnamed; whence arose the name Five Rivers or Dry bay. In the Coast Pilot of 1869, Davidson also calls it Shallow bay. Moser, 1901, made a reconnoissance here and reported the delta to cover. 80 to 100 square miles. At that time there were only three outlets, forming three very large basins filled with bars and small islands, and each emptying into the sea through a narrow channel.

Dry; bay, very small, indenting the north shore of Cape Douglas, southwest point of entrance to Cook inlet. Called Sukboi (dry) by Tebenkof, 1849.

Dry; small bay, indenting the north shore of Kamishak bay, southwest shore of Cook inlet, near latitude $59^{\circ} 40^{\prime}$, longitude $153^{\circ} 10^{\prime}$. Prospectors' name, from Martin, 1903.

Dry; open bay, just north of Alitak bay, on the southwestern shore of Kodiak. Named Sukhoi (dry) by Tebenkof, 1849.

Dry; bay, indenting the southem shore of Alaska peninsula, 15 miles southwest of Cold bay. Prospector's' name, from Martin, 1903.

Dry; cove, on the western shore of Portage bay, Kupreanof island, Alexander archipelago. Descriptive name given by Nichols, 1882.

Dry; creek, tributary to Copper river from the east, north of Sanford river. So named by Abercrombie, 1898.

Dry; creek, a small tributary of Cold bay; southeast shore Alaska peninsula, near latitude $57^{\circ} 45^{\prime}$. Prospectors' name, reported by Martin, 1904 .

Dry; creek, Seward peninsula, small tributary on west bank of Casadepaga river, near latitude $64^{\circ} 53^{\prime}$, longitude $164^{\circ} 13^{\prime}$. Descriptive name, given by prospectors and published in 1901 .

Dry; creek, at Nome, Seward peninsula, tributary from the northeast to the mouth of Snake river. Local name, published in 1900.

Dry; creek, tributary to Camp creek from the north, Seward peninsula. Name from Barnard, 1900.

Dry; island (2,461 feet high), in delta at mouth of Stikine river, Alexander archipelago. So named by Thomas, 1887.

Dry; island, near Kodiak, probably in Chiniak bay. Occupied by the Semidi Propagating Company for raising blue foxes. Local name, taken from report of James W. Witten to Secretary of Interior, 1903. (Rept. Sec. of Int., 1903, p. 284.)

Dry; pass, Alexander archipelago, 25 miles long, connecting Shakan strait with Sea Otter sound, and separating Kosciusko island from Prince of Wales island, near latitude $56^{\circ}$, longitude $133^{\circ} 15^{\prime}$. Locally called Dry because in the narrows it runs dry at ebb of every large tide. Called also Klawak passage by the fishermen because it is the beginning of the inside passage taken by the fishing boats from Shakan to Klawak. Dickins, 1904, suggested the name El Capitan passage, after the El Capitan marble quarries located thereon. 
Dry, passage; see. Blind.

Dry. river; see Blind.

Dry; strait, much obstructed by shoals, separating Mitkof island from the mainland. near Stikine river month, Alexander archipelago. Named Sukhoi (dry) by the Russians. Also written Suchoi channei ainu Soukhoi strait.

Dry, strait; see Hayward.

Dry Creek, mountain; see Newton peak.

Drying; point, the western point of entrance to Dry Spruce bay, on the northern shore of Kodiak. Named Obsiekaiushie (drying up round about) by Murashef, $1839-40$. -

Dry Spruce; bay, on the northern coast of Kodiak. Named Sukhoi Elnik (dry spruce) by Murashef, 1839-40. Written erroneously Sucho Emnik bay.

Dry Spruce; peninsula (at high water), in Kupreanof strait, on the northern shore of Kodiak. Named Sukhaho Elnika (of dry spruce) by Murashef, 1839-40. Sucho Emnik on one chart by error of transliteration.

Dschenuteche; a ridge of mountains, near the headwaters of Klehini river, southeastern Alaska. The Krause brothers report this name, Dschenutếche, to be the native name, and give its meaning "as back of the mountain goat.

Dubuque; mountain (2,145 feet high), in the eastern part of Annette island, Alexander archipelago. So named by Nichols, 1883.

Dublikalat, river; see Dulbi.

Duck; bay and settlement, on the southeastern shore of Afognak island, Kodiak group. Named Selezneva (wild duck or drake) by the Russians. Selezni (Russian) is Kalsisgin (Aleut) for a lake bird. Kalágak, according to Veniaminof, is Aleut for Selezen (Russian for duck) and also for a marine fish, Kalaga. Elliott says the Aleuts call all the small cottoid fishes Kalog.

Duck, bay; see Tutka.

Duck; cape, on the northeastern coast of Afognak island, Kodiak group. Named Seleznera (wild duck) by the Russians, 1848 .

Duck; creek; tributary to Red bay, Prince of Wales island, Alexander archipelago. So named by Helm, 1886.

Duck; island, near the head of Bradfield canal, Alexander archipelago. So named by Snow, 1856.

Duck; islet, southeast of Grave point, Duke island, Gravina group, Alexander archipelago. Apparently so named by local pilots. Name not found on any map.

Duck; islet, near Kukak bay, Shelikof strait, west of Afognak island. Named Utinoi (of ducks) by the Russians. Lutke calls it l'îlot Outinoi (des canards).

Duck; point, the south point of Whitney island, Fanshow bay, Frederick sound, Alexander archipelago. So named by the Coast Survey in 1891 .

Ductoth, river; see Duktotb.

Dude; mountain, in the western part of Revillagigedo island, Alexander archipelago. Named by the Coast Survey in 1856.

Duffield; peninsula, forming the northern end of Baranof island, Alexander archipelago. So named by Moore, 1895, after Gen. William Ward Duffield, Superintendent of the Coast and Geodetic Survey.

Duffield, glacier ; see Turner. 
Dugan, river; tributary to Tanana river from the south, near longitude $150^{\circ}$. Named by Allen, 1885, after Lieut. Thomas Buchanan Dugan, U. S. A. See Kantishna.

Duke; hill (540 feet high), on the eastern edge of Duke island, Gravina group, Alexander archipelago. So named by Dall, 1.879 .

Duke; island, the southernmost of the Gravina group, Alexander archipelago. So named by Dall, 1879. The southernmost point of this island had been named Northumberland by Vancouver, 1793, after the Duke of Northumberland.

Duke; point, the easternmost point of Duke island, Gravina group, Alexander archipelago. So named by Dall, 1879.

Duke of Clarence, strait; see Clarence.

I) uke of York, islands ; see York.

Duktoth; river, debouching on the coast of the Gulf of Alaska, 3 miles west of Cape Yaktag, near longitude $142^{\circ} 20$. Indian name, written Ductoth by Martin, 1903, and by error published Quetoth.

Dulbi; river, tributary to the Koyukuk from the east, near longitude $156^{\circ} 30^{\prime}$. Native name, reported by Allen, 1.885, as Dulbikakat, i. e., mouth of the Dulbi. Has also been written Dulebekakat.

Dulebelakat, river; see Dulbi.

Dunbar; inlet, opening into Tlevak strait, Prince of Wales island, Alexander archipelago. Named by Dall, 1882, after Miss Margaret J. Dunbar, of Steubenville, Ohio, who began missionary work in Alaska in 1879.

Dunbar; point, the southern point of entrance to Young cove, Howkan strait, Cordova bay, Alexander archipelago. So named by Sheldon Jackson, after Miss Margaret J. Dunbar.

Duncan; canal, indenting the southern crast of Kupreanof island, Alexander archipelago, near latitude $56^{\circ} 40^{\prime}$, longitude $133^{\circ} 10^{\prime}$. Named by Vancouver, 1793, after Admiral Duncan, R. N. Has also been called Duncan channel and Canal de Dunkan.

Duncan, passage; see Beecher.

Duncan; peaks, two in number, east of Duncan canal, on Kupreanof island, Alexander archipelago. So named by Thomas, 1887.

Dundas; bay, indenting the mainland coast, on northern shore of Cross sound, southeastern Alaska, near latitude $58^{\circ} 20^{\prime}$, longitude $136^{\circ} 20^{\prime}$. So named by Dall, 1879 .

Dundas; point, the eastern point of entrance to Dundas bay, Cross sound, southeastern Alaska. Named by Vancouver, 1794.

Dununak, Eskimo village; see Tanunak.

Dupont; peak (5,794 feet high), on the mainland coast of Frederick sound, southeastern Alaska. Named by Thomas, 1887, after Admiral Samuel Francis Du Pont, U. S. N.

Durelle; mountain (4,300 feet high), east of Klutina lake. So named by Abercrombie, 1898. Also has been written Du Relle.

Durrant; creek, tributary to Stewart river, from the south, Seward peninsula. Name from Barnard, 1900.

Dushistoi, islands; see Fragrant.

Dushkot; islet, near the head of Beaver bay, Unalaska. Probably so named by Sarichef, who made a sketch or reconnoissance of Beaver bay and Captains bay, Unalaska, June 3-10, 1790.

Dushnaia, bay ; see Close.

Dutch; creek, tributary to Ophir creek, from the north, in the Eldorado mining district, Seward peninsula. Local name, published in 1900. 
Dutch; harbor, on the eastern side of Amaknak island, in Unalaska bay, near latitude $53^{\circ} 54^{\prime}$, longitude $166^{\circ} 32^{\prime}$. So named from the tradition that a Dutch vessel was the first to enter it. Veniaminof says that it is called, by old navigators, Dutch (Hollandish) harbor. Sarichef, 1792, calls it Udakta. According to Lutke, Tebenkof calls it Ougadakh. Davidson and Dall wrote Ulakhta harbor. It, and the village on its shores, is now universally known as Dutch harbor.

Dutch Camp; basin, on Lowe river, east of Valdez, Prince William sound. So named by Abercrombie, 1898. Now generally known as Dutch, Flat.

Dutton; post-office (established September, 1905), western coast of Cook inlet, on Iliamna bay, northwestern shore Kamishak bay, near latitude $59^{\circ} 30^{\prime}$.

Dvoini-bratef (twin brothers), Sitka sound ; see Twins.

Dvoinoi, bay ; see Driftwood.

Dvoinoi, island; see Double.

Dwinoi, islet, Krestof sound; see Double.

Dwyer; creek, tributary to the Yukon on the right bank 3 miles above Rampart rapids, about longitude $151^{\circ}$. Name taken from Edwards's Track Chart of the Yukon, 1899.' Cantwell, 1900, calls it Dwyer in his text and Bear on his chart.

Dyea; town, port of entry (post-office established in June, 1.896, and discontinued in 1902), at the head of Lynn canal. The inlet was called Tÿ̈a by Meade (1869), Dejah by Krause (1882), Dayay by Schwatka (1883), and Chilkoot or Taiya by the miners.

Dyer; cape, on the mainland coast, south shore of Scammon bay, Yukon delta, near latitude $61^{\circ} 50^{\prime}$, longitude $165^{\circ} 43^{\prime}$. So named by Dall, 1869, after Joseph Tarbell Dyer, now of Washington, D. C., who explored in this region, in 1865-66, for the Western Union Telegraph Company.

Dyer; cape, on the Arctic coast between Point Hope and Cape Lisburne, near latitude $58^{\circ} 38^{\prime}$. So named by Beechey, 1827. Its Eskimo name is Capaloa.

Dying; glacier, near Muir inlet, Glacier bay, southeastern Alaska. Descriptive name, given by Reid, 1892. "Dying glacier belongs to the past, and is melting away."

Dyke; mountain $(6,700$ feet high), on the western shore of Klutina lake. So named by Abercrombie, 1898 .

Eads; peak (4,636 feet high), on the mainland, north of Frederick sound, southeastern Alaska. Named by Thomas, 1887, after the distinguished engineer, James Buchanan IEads.

Eagle; bay, on the southern coast of Unalaska, immediately east of. Kashega bay, near longitude $166^{\circ} 55^{\prime}$. So named by the Fish Commission in 1888.

Eagle; cape, on the northwestern shore of Shuyak island, Kodiak group. Called Orlinie (eagle) by the Russians, who in turn seem to have taken it from the native name Amakaktuli, supposed to mean eagle.

Eagle; creek, on Douglas island, tributary to Gastineau channel, about 2 miles northwest of Juneatr. Local name, from Peters, 1902.

Eagle; creek, Seward peninsula, tribitary to Bear creek from the west near latitude $65^{\circ} 35^{\prime}$, longitude $161^{\circ} 10^{\prime}$. Locil name, from Witherspoon, 1.901.

Eagle; creek, tributary to the right fork of Bluestone river, Seward peninsula. Name from Barnard, 1900. 
Eagle; creek, tributary to Birch creek at its source. Latitude $65^{\circ} 25^{\prime}$, longitude $145^{\circ} 30^{\prime}$. Prospector's' name, reported by Spurr, Goodrich, and Schrader, of the Geological Survey, 1.896.

Eagle; creek, tributary to the Yukon from the east, near Eagle. Local name obtained by the Geological Survey in 1898 .

Eagle; creek, an áffluent of Mosquito fork Fortymile creek on the left, near latitude $64^{\circ} 05^{\prime}$, longitude $142^{\circ}$. Prospector's' name, taken from a map in the Coist Survey archives drawn, 1898, by E. F. Ball, a prospector.

Eagle; creek, tributary to South fork Koyukuk river from the south, near longitude $150^{\circ} 30^{\prime \prime}$. Prospector'ș' name, obtained by Peters and Schrader, 1901.

Eagle; creek, Arctic slope, a tributary on the right bank of Canning river, near latitude $69^{\circ} 15^{\prime}$, longitude $146^{\circ}$. So named by S. J. Marsh, a prospector, 1902-3.

Eagle; glacier (1,200 feet high), on the mainland, east of Lynn ctnal. Apparently so named by Meade, 1869, from its fancied resemblance to an eagle with outstretched wings.

Eagle; harbor, indenting the western shore of Nagai island, Shumagin group. So named by Dall, 1872.

Eagle; harbor, on the southern [or (?) northern] shore of Ugak bay, on eastern shore of Kodiak. The Eagle Harbor Packing Company, of Kodiak, has an establishment at this harbor, which, on a late Fish Commission map, is located on the north shore of Ugak bay. According to some, Eagle harbor village or settlement is identical with Orlova of the Russians. A post-office was established here in November, 1898. The Kodiak Packing Company established a saltery here prior to 1890 .

Eagle; island, east of Onslow island, near junction of Ernest sound and Clarence strait, Alexander archipelago. So named by Snow, 1886.

Eagle; island, on the east side of Davidson inlet, Prince of Wales archipelago, near latitude $55^{\circ} 53^{\prime}$, longitude $133^{\circ} 30^{\prime}$. So named by Dickins, 1903-4.

Eagle; mountain (about 1,500 feet high), at head of Eagle harbor, Nagai island, Shumagin group. So named by Dall, 1872.

Eagle; point, on the mainland, near head of Portland canal. Apparently so named by the Coast Survey in 1891. May possibly have been named by Pender in 1868.

Eagle; point, on north shore of Chichagof island, Icy strait, Alexander archipelago, midway between Port Frederick and Point Adolphus, near latitude $58^{\circ} 14^{\prime}$, longitude $135^{\circ} 38^{\prime}$. So named by Pratt, 1901.

Eagle; point, on the southern shore of Unalaska, separating Eagle and Kashega bays. Named by the Fish Commission in 1888. From a manuscript note on Sarichef's Chart XIV, 1792, it would appear that the native name of this point is Amtchik. It is East point of the Coast Survey in 1869.

Eagle; reef, in Favorite channel, Lynn canal, Alexander archipelago. So named by Coghlan, 1884.

Eagle; rock, northwest coast of Kruzof island, $1 \frac{1}{4}$ miles south of Cape Georgiana, near latitude $57^{\circ} 18^{\prime}$, longitude $135^{\circ} 53^{\prime}$. " It is 58 feet high, domeshaped, and bare." (Coast Pilot of 1901, p. 195.) So named by Moore, 1897.

Eagle; rock, in Northeast harbor, Sannak island, near latitude $54^{\circ} 27^{\prime}$, longitude $162^{\circ} 35^{\prime}$. So named by Westdahl, 1901.

Eagle; rock, on the enstern shore of Herendeen bay, Alaska peninsula, 4 miles south of Point Divide; near longitude $160^{\circ} 45^{\prime}$. So called by 'Tanner, 1890 . 
Eagle; town, post-office, and telegraph station, on left bank of the Yukon, 10 miles below the international boundary. A trading station, consisting of one $\log$ house, was built here in 1881 and abandoned the next year. This was called Belle Isle. . The military post, Fort Egbert, was established near by in 1889. On the site of the old trading post was established the mining camp locally called Eagle City, about 1898. An United States post-office, called Eagle, was established here in November, 1898. The town was incorporated January 8, 1901, and it is on the military telegraph line completed in 1903 . Population in 1900, 383.

Eagle Cliff; bar (gold-bearing), on South fork Koyukuk river. Prospectors' name, published in 1.902 .

Eagle Crag; mountain (5,705 feet high), on the mainland, enst of Stikine river and near the international boundary. Has also been called Lagle.

Eaglek; bay; indenting the northern shore of Frince William sound. Apparently a native name, published by the War Department, in 1900, as Eagleck.

Eagle Nest; mountain, on north bank of Lewes river, Yukon, a little above the mouth of Nordenskiold river. According to Schwatka, 1883, the Chilkats call it by a name which means Eagle's Nest, the Tahk-heesh by a name which means Otter Tail. To settle the matter he named it Parkman, after the historian, Prof. Francis Parkman. It is Adler-Nest butte of one German publication.

Eananukhto, bluffs and hills; see Einahnuhto.

Earl; cove, indenting the eastern shore of Inian islands, Icy strait, Alexander archipelago, near latitude $58^{\circ} 15^{\prime}$, longitude $136^{\circ} \quad 18^{\prime}$. So called by Dickins, 1902.

Earl; river, draining the west slope of Simpson pass and tributary to Rohn river from the left; near latitude $62^{\circ}$, longitude $153^{\circ} 30^{\prime}$. So named by Herron, 1899.

Ears; two peaks, southwest of Shishmaref inlet, on Seward peninsula, northwester'n Alaska. Descriptive name given by Beechey, 1827.

Ears; two peaks, or rather two pointed bluffs 600 to 700 feet high, on the Arctic coast, between Point Hope and Cape Lisburne, near latitude $68^{\circ} 35^{\prime}$. Descriptive name given by Beechey, 1827 .

East; arm of Uganik bay, Kodiak, opening on the east side of the west branch of that bay. So described by Moser, 1S97.

East; bay, immediately south of Pavlof volcano and near the entrance to Pavlof bay, Alaska peninsula. Presumably a local name, reported by Dall, 1880 .

East, bay; see Nazan.

East; beacon, on the Middle Eckholm, Sitka sound. Frected and named by United States navil officers, 1880.

East; bight of Nagai, a bay or harbor indenting the eastern shore of Nagil island, Shumagin islands. So called by Dall, 1872.

East; cape, on the eastern end of St. Lawrence island, Bering seit. Called Vostochnoi (east) by Tebenkof, 1849 .

East; cape, the easternmost point of Amchitka island, Rat island group, western Aleutians. So called by the North Pacific exploring expedition, 1855.

East; cape, the easternmost point of Attu istand, westem Aleutians. Named Vostochnie (east) by the Russians.

East; cape, the easternmost point of Spruce island, Kodiak group. Named Vostochnie (east) by Murashef, 1839-40. Tikhmenief calls it Ostrovskoi (islets) point. 
East; channel, north of Sitka sound, Alexander archipelago, connecting Hayward strait and Kirestof sound, near latitude $57^{\circ} 10^{\prime}$, longitude $135^{\circ} 33^{\prime}$. Descriptive name, published by the Coast Survey in 1.900 .

East; creek, Kenai peninsula, ạ right branch of Resurrection creek at its head, near latitude $60^{\circ} 45^{\prime}$, longitude $149^{\circ} 45^{\prime}$. Local descriptive name, from Moffit, 1904.

East; fork, Sixmile creek, Kenai peninsula, a southern tributary of Turnagain arm, Cook inlet. Local descriptive name, reported by Mendenhall, 1898.

East; fork, Seward peninsula, a left branch of Solomon river, reported Right branch by Barnard, 1900, and East fork on a local map, 1904. Schrader and Brooks, 1899, misapplied the name Trilby creek to this stream.

East; fork, Chandlar river, near longitude $147^{\circ}$. Prospectors' name, published in 1899.

East; fork, Kusawa river, one of the tributaries of the upper Yukon. Little is known of it. Krause calls it Kussooáchrawathíni (Yukon).

East; fork, of Hess creek, in the Rampart region. Prospectors' name, reported by Lieutenant Erickson, U. S. A., 1902.

East; gulch, 5 miles north of Nome, on the western slope of Newton peak, draining into Dry creek, near longitude $165^{\circ} 20^{\prime}$. Local name, published in 1900.

East; island, near Duke island, in southern entrance to Revillagigedo channel, Alexander archipelago. So named by Nichols, 1883.

East; island, near the entrance to Ward cove, Tongass narrows, Alexander archipelago. Probably so named by pilot W. E. George. Name published by the Coast Survey in 1883.

East; island, one of the Inian group, Cross sound, Alexander archipelago. Apparently so named by Dall in the Coast Pilot, 1883.

East; island, one of the Kashevarof group, Clarence strait, Alexander archipelago. Named by Snow, 1886.

East; island, on eastern shore at entrance to Red bay, Sumner strait, Alexander archipelago, three-fourths mile inside Pine point, near latitude $56^{\circ} 20^{\prime}$, longitude $133^{\circ} 17^{\prime}$. So called by Helm, 1886, and published in the Coast Survey' magnetic declination tables, 1902 .

East; landing, east of St. Paul village, St. Paul island, Bering sea, near Iongitude $170^{\circ} 16^{\prime}$. Local descriptive name, reported by Duffield, 1897.

East; ledge, east of Keene island, on Mitkof shore of Wrangell strait, Alexander archipelago. So called by Nichols in the Coast Pilot, 1891.

East; peak (4,900 feet high), near Valdez, Prince William sound. Named by Abercrombie, 1898.

East; peak (1,406 feet high), near Chichagof harbor, Attu island, western Aleutians. So named by Gibson, July, 1855.

East; point, between Freshwater bay and Tenakee passage, on the eastern coast of Chichagof island, Alexander archipelago. The name was applied by Meade in 1869 to the eastern point of entrance to Freshwater bay. Neither of these names, East and Freshwater, has its original application.

East; point, in the eastern part of Whitewater bay; Admiralty island, Chatham strait, Alexander archipelago. Named by Glass, 1881.

East; point, on the eastern shore of Portage bay, Kupreanof island, Alexander archipelago. Named by Nichols, 1882.

East; point, on the eastern shore of Woronkofski island, Alexander archipelago. Named by Snow, 1886. 
East; point, on the southeastern shore of whale island, Kodiak group. Named Vostochnie (east) by Murashef, 1839-40. It is Uskosti (narrow) of the Russian American Company map of 1849.

East; point, between the two main branches of. Uganik bay, Kodiak, so described by Moser, 1897.

East; point, at entrance to Chichagof cove, Stepovak bay, south shore Alaska peninsula, near longitude $160^{\circ}$. Descriptive name, given by the Farriman expedition, 1899 .

East; point, the eastern point of entrance to Chernofski harbor, Unalaska. So named by the Fish Commission in 1888.

Wast, point; see Eagle.

East; rookery (seal), on the northeast coast of St. George island, Bering sea, near longitude $169^{\circ} 30^{\prime}$ : Called Gieat Eastern by Elliott (1872-1874), Great East and East by Stanley-Brown (1891), and East by Duffield (1897).

East; spit, at the south end of Cleveland passage, Frederick sound, Alexander archipelago. Apparently so named by Nichols, 1891.

East Anchor; cove, indenting the eastern shore of Ikatan peninsula, near southern entrance to Isanotski strait, Unimak island. Named by the Fish Commission in 1888.

East Clump; "a small high-water islet" in Tongass narrows, "called by the pilots East Clump." Dall, in the Coast Pilot (1883, p. 80), calls it Seat island, and says it is so named from a conspicuous and peculiar seatshaped rock at its outer end.

East Devil; rock or reef, bare at low water, in Dixon entrance, 4 miles northwest of Zayas island. Named by Dall in 1883. Prior to that date a sunken rock of doubtful position had been called Devil rock, a name suggesting the sailor's state of mind as to sunken rocks. In 1883 Capt. James Carroll, in the Idaho, found another sunken reef farther west, and this was called by Dall West Devil rock.

Eastern; anchoirage, between the Mission buildings and northern entrance to Middle channel, Sitka harbor, Sitka sound. Old descriptive name.

Eastern; channel, leading into Sitka harbor, Sitka sound, Alexinder archipelago. Named Vostochnie (eastern) by the Russians.

Eastern, ocean; see Bering sea and Pacific ocean.

Eastern; paissage, between the northern part of Wrangell island and the mainland, Alexander: archipelago. So nimed by Dall, 1877.

Eastern; passage, leading from Glacier bay to Muir inlet, southeastern Alaska. Has been called East pass. Origin of nime not discovered.

Eastern; passage, leading into Afognak bay, from the east, between Hog island and Skipwith reefs, Kodiak grbup, near latitude $58^{\circ}$. So named by Moser, 1900.

Eastern; point, the easternmost point of Krestof island, Sitka sound, Alexander archipelago. Apparently so named by Dall in the Coast Pilot, 1883.

Eastern, shoal ; see Southeast.

Hastern Sitkin, island; see Great Sitkin.

East Foreland; "steep, cliffy point" near the head of Cook inlet, so named by Vancouver, 1794. Wosnesenski, about 1840, according to Grewingk, calls it Dast cape and gives its native name as Mikischkin or Tuchan Tan (tan meaning cape), and a nearby stream is called Kantiitschike. Russian Hydrographic chart 1378 (ed. of 1847) calls it East or Katiushkin cape. 
East Fork; village and railroad station, Seward peninsula, on Solomon river at mouth of East fork, near latitude $64^{\circ} 41^{\prime}$, longitude $164^{\circ} 17^{\prime}$. ' Local name, from Gerdine, 1905.

East Francis; sunken rock, in Southern rapids, Peril strait, Alexander archipelago. Discovered and named by Coghlan, 1884, after pilot E. H. Francis, the first person who succeeded in making soundings upon it.

East Glacier; creek, tributary to Cook inlet from the northeast just above Chinitna bay, near latitude $59^{\circ} 50^{\prime}$, longitude $153^{\circ}$. Name from Martin, 1903.

East Head; promontory, between Porpoise and Sanborn harbors, on the western coast of Nagai islaud, Shumagin group. So named by Dall, 1872.

East Head; the northeastern point of entrance to Popof strait, Shumagin islands. Named by Dall, 1872.

East Kusawa; lake, near the headwaters of Yukon river. Native name. Also spelled Kussua and Kussooă. The Canadian Board on Geographic Names has adopted the spelling Kusawa.

Eastland; creek, Kenai peninsula, tributary from the north to Kachemak bay, about 14 miles northeast of Homer. So named by Dall, 1895, probably after one of the officials of the Alaska Coal Company operating there.

East Nagai; strait, separating Big Koniuji and Nagai islands, Shumagin group. Named by Dall, 1872.

East Uganuk, bay; see Uganik.

Easy; cove, inside Jackass point, southern shore of Akun island, Krenitzin group, eastern Aleutians, near longitude $165^{\circ} 33^{\prime}$. So named by Gilbert, 1901.

Eaton; mountain, between Corwin cliffs and Mount Augusta, in the St. Elias alps, southeastern Alaska. So named by Russell, 1890.

Eaton; point, western shore Cleveland peninsula, Ernest sound, southeastern Alaska, near latitude $55^{\circ} 56^{\prime}$, longitude $132^{\circ} 04^{\prime}$. Local navigators' name, reported by H. C. Fassett, Bureau of Fisheries, $\bullet 1904$.

Eaton; reindeer station, on the Unalaklik river, about 10 miles above its mouth, northwestern Alaska. So named after Gen. John Eaton, formerly United States Commissioner of Education.

Eaton; river, tributary to Grantley harbor, Seward peninsula. So called in 1900. Formerly called Fish river, that name including what is here called Niukluk and Eaton.

Echeatnu, river; see Echitna.

Echitna; river. According to Herron, 1899, E-cheat-nu is the Indian name for the south fork of the Kuskokwim near longitude $154^{\circ}$ and which Spurr and Post called the Kuskokwim proper.

Echo; cove, indenting the southeastern shore of Berners bay, Lynn canal, Alexander archipelago, near latitude $58^{\circ} 40^{\prime}$. - Local name, reported by Spencer and Wright, 1903.

Echo; small island, in Clarence.strait, Alexander archipelago, near latitude $56^{\circ} 14^{\prime}$; longitude $133^{\circ} 01^{\prime}$. Lacal navigator's name reported by $\mathrm{H}$. C. Fassett, Bureanu of Fisheries, 1904.

Eckholms (The); group of islets, on the south side of Eastern channel into Sitka harbor, Sitka sound, Alexander archipelago. So named by Vasilief, 1809. Has also been written Eckholm, Eckholmes, and, by error in transliteration, Ekgalit-tch. It has also been called Beacon group. Eckholm is a Swedish family name. 
Eclipse; creek, tributary to Melsing creek, from the enst, in the Eldorado mining district, Seward peninsula. Local name, published in 1900 .

Ecolena, river; see Ekolina.

Elcolik, point; see Ikolik.

Edge; creek, tributary to Chisana river at its source. So named by Schrader in 1902 from its position at the edge of the Nutzotin .mountains and Tanana flats.

lidgecumb, island; see Kruzof.

Edgecumbe; cape, at entrance to Sitka sound. Named Edgecumbe by Cook, 1778, presumably after Mount Edgecumbe, at the mouth of Plymouth harbor, England. It has been variously spelled Edgcumbe, Ldgcombe, Edgecombe, Edjecumbe, and Edgkomb. It was seen and named Cabo del Engaño (deceit or deception) by Maurelle, 1775. This name has been variously spelled Enganno, Engano, and Engario. By the early Russians it was called st. Lazaria or St. Lazarus, on the assumption that Mount Edgecumbe was the peak seen and named St. Lazaria by Chirikof, 1741. Also, it has been called Trubitsina. This name is said to have been given by Baranof, in honor of Boatswain Trubitsin, one of Chirikof's officers. In the official list of Chirikof's officer's and men, however, this name is absent. The name Sitka (spelled Sitkha, Sitcha, etc.) has also been applied to this cape, and on some charts both names are retained and applied to different parts of the same locality. This and adjacent land to the eastward has been reserved for light-house purposes by Executive order dated January 4, 1901. In that order: it is spelled Edgecombe.

Edgecumbe; lake, near Port Chester, Annette island, Alexander archipelago. Named Edgecomb by the Coast Survey in 1897.

Edgecumbe; mountain (3,467 feet high), an extinct volcano, on Kruzof island near the entrance to Sitka sound. Elevation given as $2,676,2,800,2,855$, 3,467 , and 8,000 feet, the last being an estimate by Lisianski, who climbed it in 1805 . The elevation 2,855 is that determined by the Coast Survey in 1867, and 3,467 the determination by the Coast Survey in 1897. Named Edgecumbe by Cook, 1778 , presumably after Mount Edgecumbe, at the entrance to Plymouth harbor, Ingland. It is Mount st. Lazarus or St. Lazaria of eftrly Russian charts, this name, it is said, having been given by Chirikof, 1741. Maurelle, 1775, called it Mount de S. Jacinto, which La Perouse, translating, writes Mount Saint-Hyacinte. Variant spellings of all these forms are found, including the erroneous one San Vacinto.

IEdgecumbe, island; see Kruzof.

Edith; lake, near 'Tanana river, in latitude $62^{\circ} 40^{\prime}$. So named by Abercrombie, 1898.

Edith; point, the north point of entrance to Checats cove, eastern shore of southern entrance to Behm canal, southeastern Alaska, near latitude $55^{\circ} 30^{\prime}$, longitude $130^{\circ} 55^{\prime}$. Local navigators' name, reported by H. C. Fassett, Bureau of Fisheries, 1904.

Edmonds; cove, Yukon delta, indenting the south shore of Scammon bay on the west side of Cape Dyer, nenr latitude $61^{\circ} 50^{\prime}$, longitude $165^{\circ} 05^{\prime}$. So named by Putnam, 1899.

Edna; bay, indenting the southern shore of Kosciusko island, Davidson inlet, Prince of Wales archipelago, near latitude $55^{\circ} 57^{\prime}$, longitude $133^{\circ} 38^{\prime}$. So named by Dickins, 1903-4. 
Edna; creek, $4 \frac{1}{2}$ miles nortbwest of Cape Nome, Seward peninsula, tributary from the west to Saunders creek, a fork of Hastings creek, near longitude $165^{\circ} 07^{\prime}$. Local name, from Gerdine, 1904.

Edna; sulch, in the Copper river region, on the headwaters of Chititu creek. Prospectors' name, first appears on map of the Nizina mining district, 1902, by George M. Esterly, of Valdez.

Edward; cape, on the western coast of Chichagof island, Alexander archipelago. So named by Vancouver, 1794. Tebenkof calls it Illkugu, which is presumably the native name.

Edward; creek, tributary to Cripple river from the east, near its mouth, Seward peninsula. Local name, published in 1900 as Eduards and Edward.

Edward; passage, between Fillmore island and the mainland, southeastern Alaska. Named by the Coast Survey in 1891.

Edward; point. The northern point of Deer island,. Port Moller, Alaska peninsula, was so named by Dall, 1882, after Capt. Edward Perry Herendeen, to whom is due a considerable extension of our knowledge of the geography of Port Moller. This name has been transferred to an adjacent point on Cape Rozhnof, and the north point of Deer island called Fawn point.

Edwardes; river, tributary tó Controller bay from the northeast. Named for Cecil Edwardes (brother of Lord Kensington), who, with Gandil and Campbell, represented the lessees operating property of the Alaska Development Company in 1899. Local name, reported by Martin, 1903. Called also Puffy.

Edwards; island, in Port Beauclerc, Kuiu island, Alexander archipelago. So named by Helm, 1886.

Eegyak; river; see Throat.

Eek; inlet and lake, in southwestern part of Prince of Wales island, Alexander archipelago. Called. Eeke by Moser, 1897.

Eek; river, tributary to the Kuskokwim from the east, near its mouth. Eskimo name, published in Sarichef's atlas, 1826, where it is spelled Ik; on late maps it is Eek.

Eeke, inlet and lake; see Eek.

Eenanulihto; see Einabnuhto.

Eganuta; bluffs (1,012 feet high), on the north coast of St. George island, Bering sea, near longitude $169^{\circ}$. 40,. Called High bluff by Elliott, 1872-73. Putnam, 1897, obtained the Aleut name Ēgănŭt'a (high bluff').

L'ganuta-koverushka; see Maynard hill.

Egashak, river; see Igushik.

Egavik, river and village; see Iguik.

Egawik, Eskimo village; see Iguik.

Egbert, fort; see Fort Egbert.

Dgegak, river and village; see Ugaguk.

Egg; bay, west of Egg cape, on the northwestern shore of Atka island, middle Aleutians. Called Iaitchnoi (egg) by Lutke, 1836.

Egg; cape, the south point of entrance to Korovinski bay, on northwestern coast of Atka, middle Aleutians. Named Iachnoi (egg) by Lutke or Ingenstrem about 1830 . Has been written Iachnoi, Iaitchnoi, Jaichnoi, Yaitchni.

Egg; harbor, on the north shore of Coronation island, Alexander archipelago. So named by Snow, 1.856. "It is a rendezvous for the Indians, who here await favorable weather to go out to the Hazy islands to gather eggs." 
Egg; island, in Moira sound, Clarence strait, Alexander archipelago. So named by Snow, 1886 .

Lyy, island; see Fish Egg.

Egg; island, northeast of St. Michael, in Norton sound. Named Iachnoi (egg) by the Russians. It is L'ile des Oeufs of Lutke. Archimandritof calls it Zliarof.

Egg, island; see Haenke.

Higg, island, Lituya bay; see Cenotaph.

Egg; island, between Whale and Little Raspberry islands, Kodiak group. Named Iachnoi (egg) by Murashef, 1839-40.

Egg; island, in Alitak bay, southwestern coast of Kodiak, at the north point of entrance to Lazy bay, 5 miles northeast of Cape Alitak. Name from Moser, 1900.

Egg, island, Sandman reefs; see.Hunt.

Egg; island (550 feet bigh), near the eastermost point of Biorka island, east of Unalaska, eastern Aleutians, near latitude $53^{\circ} 50^{\prime}$, longitude $166^{\circ}$. $03^{\prime}$. It is apparently Gagalgin of Krenitzin (1768), Kigalgin of Kudiakof (1791), Ugalgan or Iachnoi (egg) of Sarichef (1792). Veniaminof. says its Aleut name is Ugalgan and that it was called in 1830 orieshik (hazel) or iachnie (egg). It is Ugalohan or Jaitschoi (egg) of Langsdorf. This island was reserved for light-house purposes by Executive order dated January 4, 1901. In that order it was called Egg island.

Egg; islands, west edge Copper river delta, 5 miles southeast of Cape Whitshed, near longitude $145^{\circ} 45^{\prime}$. So called by Ritter, 1898. Moser, 1897, showed one island here, which he called Egg Shell.

Egg; islands, in Popof strait, Shumagin islands. So called by Dall, 1872.

Egg; islet ( 300 feet high), near Cape Tachilni, southern shore of Alaska peninsula, near the west end, about longitude $162^{\circ} 55^{\prime}$. So called by Westdahl, 1901.

$E g g$, islets, Necker bay; see Guibert.

Egg Island; passage, between Biorka island and Egg island, eastern Aleutians. So named by Gilbert, 1901.

Egg Shell; island, east of Cape Whitshed, at mouth of the Copper river. So called by Moser in 1897. 'This seems to be one of the ligg islands of Coast and Geodetic Survey chart 8500 (ed. of 1900). See Egg.

Egichtalik, village; see Aiaktalik.

Egilka, island; see Igitkin.

Egoochshac. Cook gives this as the native name of a bay in Unalaska, which one, not determined. He entered it October 2, 1778, and says (II, 492): "As all harbours are alike to me, provided they were equally safe and convenient, I hauled into a bay, that lies 10 miles to the westward of Samganoodha, known by the name of Egoochshac; but we found very deep water ; so that we were glad to get out again."

Egorkovskoi, cape; see Tanak.

Egoushik, river; see Igushik.

Egovolk, creek and village; see Iguik.

Egypt; mountain (2,500 feet high), on the west bank of Kuskokwin river near latitude $62^{\circ} 30^{\prime}$, longitude $154^{\circ}$. So named by Spurr and Post, 1898.

Eidenu; Eskimo settlement, on Cape Prince of Wales. Variously written Eidannou, Iden-noo, etc. It is not an Eskimo word. Can this be an Eskimo rendering of "I don't know?" Beechey, 1826, writes Ei-dannoo and Iden-noo. 
Eider; anchorage and point, on the western shore of Unalaska bay, eastern Aleutians, near longitude $166^{\circ} 35^{\circ}$. Sarichef, 1792, shows a village here called Pestriakovo (eider duck). Kotzebue, 1816, calls it Igognak or Pestriakovo. Thus it has been called Eider, Igognak, Pestriakof, etc. Eider; native village, at Eider point, Captains bay, Unalaska, called by Sarichef, 1792, Pestriakof (eider duck). Veniaminof, about $1830 ;$, says it was composed of 5 huts (yourts) and 37 people.

Eiganuta, bluffs and hills; see Einahnubto.

Eighteenmile, arm, of Kasaan bay ; see Twelvemile.

Eightmile; bend, in Koyukuk river, near longitude $152^{\circ} 30^{\prime}$. Descriptive name, given by Allen, 1885.

Eightmile; creek, tributary to Bettles river from the south, near latitude $67^{\circ}$ $30^{\prime}$, longitude $149^{\circ} 15^{\prime}$. Frospector's' name, obtained by Feter's and Schrader, 1901.

Eightmile, creek, near Cape Suckling; see Kiklukh.

Einahnuhto; bluffs and hills (600 feet high), in the western part of St. Paul island, Pribilof islands, Bering sea. Also written Ein-ah-nub-to and Eenanukbto. According to Elliott this is Aleut for the mamme. Also, according to same, it means the three mamma. Stanley-Brown's map shows three names here: High bluff, Eiganuta, and Rush hills. Coast Survey chart 3214 has High bluffs and, for the highest bill of the group, Rush hill. Ēganuta, according to Putnam means high bluff.

Eivoogiena, island; see St. Lawrence.

Eivugen, island; see St. Lawrence.

Ekgalit-tch, islets; see Eckholms (The).

Ekilik; Eskimo village, on the west bank of Togiak river, about 10 miles from its mouth. Eskimo name obtained by Spurr and Post, 1898, who write it Ekiligamut, i. e., Ekilik people.

Ekolina; river, an aftuent of East fork Chedotlothua river from the left, near latitude $63^{\circ}$ longitude $164^{\circ}$. Indian name, written Ecol-ena by Herron, 1899.

Ekogmute, village; see Ikogmute.

Ekuk; cape, on the eastern shore of Nushagak river, near its mouth. Native name, from Lutke, 1828, who wrote it Ekouk. Clark point of the Fish Commission, 1888, may be a synonym for this. In the Eleventh Census written Yeluk.

Ekuk; Eskimo settlement, near the mouth of Nushagak river. Name from Lutke, 1828, who spelled it Ekouk. Has also been written Yekuk.

Elbow; mountain $(4,111$ feet high), at the first great bend or elbow of Stikine river, on its northern bank. So named by the Coast Survey.

El Capitan, passage; see Dry pass.

El Capitan; marble quarry on Dry pass, western shore of Prince of Wales island, near latitude $56^{\circ} 10^{\prime}$, longitude $133^{\circ} 20^{\prime}$. Local name, from Dickins, 1903-4.

Eldorado; creek, south of Goodhope bay, Seward peninsula, tributary to Noxapaga river at its source, near latitude $65^{\circ} 40^{\prime}$, iongitude $164^{\circ}$. Prospectors' name, obtained by Mendenhall and Reaburn, 1901.

Eldorado; creek, Seward peninsula, tributary to Kiwalik river from the west, near latitude $65^{\circ} 42^{\prime}$, longituce $162^{\circ}$. Prospector's' name, from Witherspoon, 1.903.

Eldorado; creek, tributary to headwaters of Budd creek, Seward peninsula. Name from Brooks, 1900.

Eldorado; creek, tributary to Tisuk river from the east, Seward peninsula. Name from Barnard, 1900. 
Eldorado; creek, in the Fai lbanks region, tributary to Chatanika river from the south, near latitude $65^{\circ} 05^{\prime}$, longitude $147^{\circ} 35^{\prime}$. Prospectors' name, from Gerdine, 1903.

Eldorado; creek, eastern Alaska, on south bank of Gold creek, Sálcha River drainage, near latitude $64^{\circ} 50^{\prime}$, longitude $145^{\circ} 40^{\prime}$. Frospectors' name, reported by Witherspoon, 1905.

Eldorado; creek, tributary to South fork Koyukuk river from the east, near longitude 147'. Prospector's' name, published in 1899.

Eldorado; river, tributary to Port Safety, Seward peninsula. So called by Barnard, 1900. Previously called Eldorado creek.

Eldred; passage, south shore Kachemak bay, Cook inlet, separating Cohen, Hesketh, and Yukon islands from the mainland. Named by Dall, 1880, after Sarah Eldred, wife of Marcus Baker.

Eldred; rock (50 feet high), in Lymn canal, east of Sullivan island. Visited, located, and named, in 1880, by Marcus Baker, after his wife, Sarah Eldred. Krause, 1882, reported the native name to be Nechrajé. Reserved for light-house purposes by Executive order of January 4, 1901.

Eldridge; mountain (Mount Eldridge, 6,000 feet high), in the Fortymile region, eastern Alaskil, the highest peak on Glacier mountain, near latitude $64^{\circ} 45^{\prime}$, longitude $141^{\circ} 50^{\prime}$. Prospectors' name, from sketch map compiled by Major Glassford, Signal Corps, U. S. A., 1905.

Eleanor; cove, in eastern part of Yakutat bay, behind Knight island, near latitude $59^{\circ} 42^{\prime}$, longitude $139^{\circ} 30^{\prime}$. So named by Puget, of Vancouver's party, 1.794 .

Eleanor; lake, on the divide between the Arctic and Yukon drainage at the source of Anaktuvuk river, near longitude $151^{\circ} 50^{\prime}$. So named by Peters and Schrader, 1901.

Eleanor; mountain (Mount Eleanor) on the northeast side of Iniskin bay, Cook inlet, near latitude $59^{\circ} 47^{\prime}$, longitude $153^{\circ} 23^{\prime}$. So named by Martin, 1904.

Eleanor; passage, in the Knight Island group, Prince William sound, along the south side of the island on which is Point Eleanor. Local name, reported by Grant, 1905.

Eleanor; point, the north point of Knight island, Prince William sound. Named by Vancouver, 1.794. Vancouver's Knight island has proven to be three islands, and Eleanor point is the north point of the most northerly. .

Elephant; point, in Eschischoltz bay, Kotzebue sound. So named by Beechey, 1826, " from the bones of that animal being found near it."

Elephants Head; mountain peak, on the eastern shore of Thomas bay, southeastern Alaska. So named by Thomas, 1887.

Eleutak; Eskimo village, Yukon delta on the left bauk of Kwemeluk pass, near latitude $62^{\circ} 29^{\prime}$, longitude $164^{\circ} 52^{\prime}$. IEskimo name obtained by Putnam, 1899, and written by him Eleutakamiut.

Elitnik, bay and village; see Afognak and Litnik.

Eliza; harbor, indenting the southern coast of Admiralty island, Frederick sound, Alexander archipelago. Discovered April 17, 1799, by Mr. Bumstead, of the ship Eliza, from Boston, Captain Rowan, and named "Eliza's Harbour, in compliment to our ship."

Eliza; point, the southern point of entrance to Port Armstrong, Baranof island, Alexander archipelago. So named by Vancouver, 1794 .

Elizabeth; cape, at the southwestern angle of Kenai peninsula, on east side of entrance to Cook inlet. So named by Cook, 1778, because "the discovery of it was connected with the Princess Elizabeth's birth-day" (II, 382). Sauer calls it, erroneously, Cape St. Elizabeth. 
Elizabeth; creek, and mountain (1,300 feet high), 20 miles northwest of Nome, Seward peninsula, on the right bank of Cripple river, near latitude $64^{\circ} 40^{\prime}$, longitude $165^{\circ} 55^{\prime}$. Prospectors' name, published in 1904.

Elizabeth; point, the northwest point of entrance to Rodman bay, Peril strait, Alexander archipelago. So named by Moore, 1895.

Elk; creek, 13 miles northwest of Cape Nome, Seward peninsula, draining from the east through Twin lakes to Nome river, near longitude $165^{\circ} 15^{\prime}$. Local name, published in 1904.

Llkamok, island; see Chirikof.

Elkhorn; creek, tributary to the Niukluk from the south, in the Eldorado mining district, Seward peninsula. Local name, published in 1900. Also, erroneously, Elkorn.

Elkington; creek, Seward peninsula, tributary from the east to Don river, near latitude $65^{\circ} 32^{\prime}$, longitude $166^{\circ} 53^{\prime}$. Local name, obtained by Gerdine, 1901.

Elkugu, cape; see Edward.

Ella; creek, Seward peninsula, tributary to South fork Kuzitrin river from the south, near latitude $65^{\circ} 20^{\prime}$, longitude $163^{\circ} 50^{\prime}$. Prospector's' name, reported by Gerdine, 1901.

Ella; point, on the eastern shore of Revillagigedo island, Behm canal, southeastern Alaska, near latitude $55^{\circ} 30^{\prime}$, longitude $131^{\circ}$. Local navigator's' name, reported by H. C. Fassett, Burean of Fisheries, 1.904.

Ellamar; post-office (established̂ September, 1900), at Gladhaugh bay, between ports Fidalgo and Valdez, on the northeastern shore of Prince William sound.

Ellice; point, on the Arctic coast, east of Point Barrow. Named by Dease and Simpson, 1837, after the Right Hon. Edward Ellice. Erroneously Elice.

Elliott; creek, tributary to the Kotsina from the east. Name from a manuscript map made by prospectors in 1900 . Erroneously Elliot.

Elliott; creek, in the F'airbanks region, tributary to Sorrels creek from the west, near latitude $65^{\circ} 05^{\prime}$, longitude $147^{\circ}$. Local name, obtained by Gerdine, 1903.

Ellis; creek, 8 miles north of Nome, Seward peninsula, on the southeast slope of Mount Brynteson, tributary from the north to Glacier creek, near longitude $165^{\circ} 22^{\prime}$. Local name, published in 1901 .

Ellis; point; the northwestern point of entrance to Tebenkof bay, Kuiu island, Chatham strait, Alexander archipelago. So named by Vaucouver, 1794. An Indian village here has been called Point Ellis village:

Ellsworth Cut; a narrow channel, in Sitka sound, separating Harris island from the Baranof shore. Named Ellsworths Cut by United States naval officers, 1879, after Lieut. Henry G. Elisworth, United States Marine Corps.

Elma; island, one of the Sannak group, between Sannak and Caton islands, longitude $162^{\circ} 30^{\prime}$. So named by the Fish Commission in 1890 .

Elmer; creek, 11 miles north of Cape Nome, Seward peninsula, a right branch of Discovery creek, near longitude $165^{\circ} 02^{\prime}$. Local name, published in 1901.

Elongozhik; slough, Yukon delta, at the mouth of Kwiguk pass, near latitude $62^{\circ} 47^{\prime}$, longitude $164^{\circ} 50^{\prime}$. Eskimo name, reported by Putnam, 1899, and written variously Elongozheek and Elongozhewik.

Elovoi, cape; see Chiniak.

Elovoi, cape; see Spruce. 
Elovoi; island, one of the Necker group, Sitka sound, Alexander archipelago. Named Elovoi (spruce) by Vasilief, 1809. Valriously called Spruce, Yelowoi, etc.

Elovoi, island (Kodiak) ; see Spruce.

Elovoi; islet, opposite Hooniah sound, in Peril strait, Alexander archipelago. Named Elovoi (spruce or fir) by Vasilief, 1833. Has also been written Yelowoi, Firtree, or Spruce island.

Elovoi, strait; see Narrow.

Elovoi vnutrennie, cape; see Inuer Spruce.

Elrington; island, in southwestern part of Prince William sound, at entrance to Port Bainbridge, near latitude $60^{\circ}$, longitude $148^{\circ} 10^{\prime}$. 'This is the island on which is Point Elrington. Local name, reported by Grant, 1905.

Elrington; point, the eastern point of entrance to Port Bainbridge, Prince William sound. Named by Vancouver, 1794.

Elsie; point, the easternmost point of Bell island, Behm canal, Alexander archipelago. So nimed by the Coast Survey in 1891.

Elson; bay, near Point Barrow. So named by Beechey, September, 1826, " in compliment to Master 'Thomas Elson," R. N., a member of' his party. Its Nskimo name, according to English naval ofticers, is 'Tasuk; according to Ray it is 'Tas'ynk, meaning inclosed water (bay); written also 'Tashuk. Compare with 'Techek.

Eluktuk; Eskimo village, Yukon delta, on the left bank of Kwikluak pass, near latitude $62^{\circ} 42^{\prime}$, longitude $164^{\circ} 23^{\prime}$. 'There is or was a Catholic mission here. Eskimo name, obtained by Putnam, 1899, and written Eluktukamiut. On Coast Survey chart 9373 (edition of 1899) this place was nitmed Kogweamnit, and (edition of 1901) Eluktukamiut.

El-yog-o-lok-tok, river; see Kogoluktuk.

Emerald; creek, in the Controller bay region, Gulf of Alaska, tributary to Puffy creek. Prospectors' name, from Martin, 1904.

Emerald; gulch, in the Mount Wrangell district, tributary to Elliott creek on the north. Prospectors' name, reported by Mendenhall, 1903.

Emgeten; island, in northeastern part of Sitka sound, Baranof island, Alexander archipelago. So named by Vasilief, 1809. Has been variously given as Emheleni, Emgayten, etc. It has also been called Luce island. Origin or meaning of name not discovered.

Emheleni, island; see Emgeten.

Emilie; canyon, on Sanford river, 'near latitude $62^{\circ} 30^{\prime}$. So named by 'Abercrombie, 1898.

Emily; island, in Duncan canal, Kupreanof island, Alexander archipelago. So named by Thomas, 1887.

Emily; peak, in eastern part of Mitkof island, Alexander archipelago. So named by 'Thomas, 1887 .

Emma; cape, on the southern shore of Bennett island, Arctic ocean. At this point the shipwrecked crew of the United States arctic exploring steamer.Jeannette landed, in 1881, and De Long named the cape after his wife.

Emma; creek, tributary to Middle fork Koyukuk river from the west, near latitude $67^{\circ} 15^{\prime}$. Local name, obtained by Peters and Schrader, 1901 .

Emma; gulch, in the Copper River region, at the headwaters of Chititu creek. Prospectors' name, first appears on map by George M. Esterly, Valdez, 1902.

Bull. $299-06 \mathrm{M}-16$ 
Emma; lake (Lake Emma), Kenai peninsula, draining through Indian ìver into Tustumena lake from the west. Local name, from Moftit, 1904.

Emmerich; mountain (6,940 feet high), about 6 miles west of Pyramid harbor, Lynn canal, southeast Alaska. So named by the Coast Survey in 1897.

Emmons; island, in Hooniah sound, Peril strait, Alexander archipelago, near latitude $57^{\circ} 36^{\prime}$, longitude $135^{\circ} 32^{\prime}$. So named by Moore, 1895, after Lieut. George Thornton Emmons, U. S. N.

Emmons; point, Hooniah sound, Peril strait, Alexander archipelago; the most easterly point of Emmons island above. Named by Moore, 1895.

Emogarikchoit, lake; see Inland lake and E-mug-ge-row-che-uk village.

Empalizada, Punta de la; see Palisade.

Empinado; cape, on the southeastern shore of Bucareli bay, Prince of Wales archipelago. Named Cabo Empinado (high cape) by Maurelle and Quadra, 1775-1779. Erroneously Etpinado.

Empty; island, one of the Kasiana group, Sitka sound, Alexander archipelago. Named Pustiia (empty) by Vasilief, 1809.

E-mugg-ge-rouv-chu-ulk; Eskimo village, on Selawik river, near Inland lake, at the Arctic circle, about longitude $160^{\circ}$. Such is the name as Stoney got it in 1.884. Cantwell, 1.884, wrote the Eskimo name of Inland lake, Emogarikchoit (little sea).

Emukpun. This Eskimo name appears on Ray's map of 1885 for some feature, perhaps a lagoon near western end of Elson bay at Point Barrow, Arctic coast.

Emuruk, lake; see Imuruk.

Enchantment; cape, on the northwestern shore of Russell fiord, Yakutat bay, southeastern Alaski. So named by Russell, 1891.

Endicott; arm, of Holkham bay, Stephens passage; southeastern Alaska. Named by Mansfield, 1889, after Hon. William .Crowninshield Endicott, Secretary of War, 1885-1889.

Endicott; lake, on the eastern border of Muir glacier. Named by Reid, 18901892. The valley was named Main by Muir, and by Reid changed to Endicott on account of impreved knowledge of its relation to Endicott river.

Endicott; plateau and mountain range in northern Alaska, north of the Arctic circle and constituting the divide between the Yukon and Arctic drainage. It is the Alaskan extension of the Rocky mountains. So named by Allen, 1885 , probably after the Secretary of War. Named Davidson by Turner, 1890 , probably after Prof. George Davidson.

Endicott; river, on the mainland, tributary to Lynu canal from the west, southeastern Alaska. Named by United States naval officers, 1880, after Hon. William C. Endicott, Secretary of War.

Endicott; valley, southeast of Muir glacier. Named Main valley by Muir, and this name changed, by Reid, to Endicott valley on account of improved knowledge of its relations to Endicott river:

Endora, mountain; see Eudora.

Engaño, Cabo del; see Edgecumbe.

Ingayjlen, island; see Fmgeten.

Engelstadt; creek, western Alaska, a south branch of Shaktolik river, near latitude $64^{\circ}$. Prospector's' name, published in 1900 as Engelstad.

Engelstadt; mountain, east of Norton sound, on the headwaters of Anvik river, near latitude $63^{\circ} 30^{\prime}$. Prospectors' name, published in 1900 as Engelstad. 
Engineer; creek, in the Fairbanks region, tributary to Gilmore creek from the south, near latitude $64^{\circ} 55^{\prime}$, longitude $147^{\circ} 40^{\prime}$. Local name, obtained by Gerdine, 1903 .

Engineers; point, on the eastern shore of Portland canal. Name published by the Coast Survey in 1897.

English; bay, indenting the eastern shore of Unalaska, opposite Unalga island, near longitude $166^{\circ} 15^{\prime}$. 'This bay was visited and surveyed by Cook, June 28 to July 2, 1778. He says the natives call it Samganoodha. Written also Simganudia. The termination uda or uddak means bay. Becaluse of this visit by Cook the Russians often cilled it English bay, and this is the present usage.

Jinglish, bay, Cook inlet; see Graham harbor.

English; shallow bay, indenting the southern shore of St. Paul island, Pribilof islands, Bering sea, near longitude $170^{\circ} 18^{\prime}$. Name derived, according to Elliott, from the circumstance that a large British vessel was wrecked here in 1847 .

Ennis, point; see Bald Head.

Enochkin, bay ; see Iniskin.

Enright, creek; see Slate.

Ensenada del Principe; see Chatham.

Entrance; cape, forming the western point of entrance to a small bay on northern shore of Kupreanof strait, Kodiak group. Named Ustia (entrance) by Murashef 1839-40, a name which, in 1849, was applied by the Russian American Company to a point a little farther west.

Entrance; island, at entrance to St. John Baptist bay, in Neva strait, Alexander: archipelago. So named by Coghlan, 1884 .

Entrance; island, at entrance to Swanson harbor, in Icy strait, near southern end of Lymn canal, Alexander archipelago. Descriptive name, given by United States navil officers in 1880 .

Entrance; isliand ( 458 feet high), in mouth of Hobart bay, Frederick sound, Alexinder archipelago. So liamed by the Coast Survey in 1891.

Entrance; island, near the north end of Winstanley island, in Behm canal, Alexander archipelingo. So called by the Coast Survey in 1891.

Entrance; island (45 feet high), at mouth of Symonds bay, Biorka island, Sitka sound. So named by Symonds, 1879.

Entrance; island, south shore of Port Valdez, Irince William sound, just inside Valdez narrows, near latitude $61^{\circ} 05^{\prime}$, longitude $146^{\circ} 34^{\prime}$. So called by Ritter, 1901.

Intrance, island; see Twins (The).

Entrance; islet, the guide to the channel, at entrance to McHenry inlet, Etolin island, Clarence strait, Alexander archipelago, near latitude $56^{\circ}$, longitude $132^{\circ} 27^{\prime}$. So named and described by Moser, 1900 .

Entrance; point, the eastern point of entrance to Sawmill cove, Dall island, Howkan strait, Alexander archipelago. So named by Dall, 1882. Also named Chapman point by Sheldon Jackson, after James E. Chamman, commissioned as a teacher at Howkan village, August, 1881.

Entrance; point, on north shore of Douglas island, marking the western entrance to Gastineatu channel, Alexander archipelago. So named by Symonds, 1880 .

Entrance; point, the north point of entrance to Klawak inlet, Bucareli bay, Prince of Wales archipelago, near latitude $55^{\circ} 30^{\prime}$. 'So named by Moser, 1897. 
Entrance, point, Hooniah harbor; see Hooniah point and bluff:

Eintrance, point, Port Frederick; see Crist.

Entrance; point, the eastern point of entrance to Port Valdez, Prince William sound. So named by Abercrombie, 1898.

Entrance; point, the western point of entrance to Narrow strait (between Kodiak and Spruce islands). Named Nachalnie (entrance) by Murashef, $1.839-40$.

Entrance; point, being the eastern point of Raspberry island, Kodiak group, and marking the beginning of Kupreanof strait. Named Nachalnie (beginning) by Murashef, 1839-40.

Entrance; point, the eastern point of entrance to Port Moller, Alaska peninsula, So named by Dall, 1880.

Entrance; rock, in entrance to Hassler harbor, Annette island, Alexander archipelago. So named by Nichols, 1882 .

Entry; peak (1,400 feet high), on the southern coast of Wales island, Dixon entrance, Alexander archipelago. Named by the Coast Survey in 1891.

Enukelinguk; slough, Yukon delta, opening on the left bank of Kwikpak pass, 20 miles below the head of the delta, near latitude $62^{\circ} 45^{\prime}$, longitude $164^{\circ} 02^{\prime}$. Eskimo name, reported by Faris, 1899, as Enukehlincuk-puk.

Eolus; point, the southern point of entrance to Breezy bay, Tlevak strait. This name, given by Dall, 1882, was suggested by the strong winds enconutered there.

E-oo-vogen, island; see St. Lawrence.

E-ow-ick, island ; see Chamisso.

Epizetka; river, northwest Alaska, debouching in the lagoon on the Arctic coast 20 miles southwest of Foint Lay and just north of the Kukpowruk, near latitude $69^{\circ} 30^{\prime}$. Eskimo name, reported by Collier, 1904.

Equibel, bay or gulf; see Esquibel.

Erickson; creek, in the Rampart region, triputary to Hess creek from the south, near latitude $65^{\circ} 30^{\prime}$, longitude $148^{\circ} 50^{\prime}$. Local name from Lieutenant Erickson, U. S. A., 1902.

Erickson; creek, eastern Alaska, on the west bank of Charley river, which is affluent to the Yukon from the south; near longitude $143^{\circ}$. Prospector's' name, from sketch map compiled by Major Glassford, Signal Corps, U. S. A., 1905.

Erickson; gulch, 8 miles north of Nome, Seward peninsula, on the north bank of Glacier creek, near longitude $165^{\circ} 21^{\prime}$. Local name, published in 1903.

Ericsson; peak (4,296 feet high), on the mainland, northeast of Frederick sound. Named by Thomas, 1887, after the distinguished Swedish engineer John Ericsson, inventor of the Monitor. Erroneously Ericson on some charts.

Ermine; island, on the southeastern shore of Shuyak island, Kodialk group. Named Gornostai (weasel or ermine) by the Russian American Company, 1849.

Eirmoshkinskic, cape; see Kovrizhka.

Ernest; point, the southwesterly point of Onslow island at the north point of entrance to Ernest sound, Clarence strait, southeastern Alaska, near latitude $55^{\circ} 51^{\prime}$, longitude $132^{\circ} 22^{\prime}$. So applied by local navigator's, and reported by H. C. Fassett, Bureau of Fisheries, 1904.

Ernest; sound, east of Prince of Wales archipelago, Alexander archipelago. Named Prince Ernest's sound by Vancouver, 1793, "after His Royal Highness Prince Ernest." 
Ernestine; creek, tributary ${ }^{\circ}$ to the headwaters of Kanata river. Local name, reported by Schrader, 1900.

Error; island, one of the Kutchuma group, Sitka sound, Alexander archipelago. Named Oshibki (error) by Vasilief, 1809. Has also been written Oshinpi and Oshipki. Has also been called White island and Ship island.

Erskine; bay, at head of Beaver bay, Unalaska, eastérn Aleutians, near longitude $166^{\circ} 35^{\prime}$. So named by the Fish Commission, 1888, after Capt. Melzin C. Erskine of the Alaska Commercial Company. Sarichef, 1792, calls it Kikukalen, apparently its native name. Veniaminof calls it Kikukalia.

Erskine; point, the eastern head of Kalekta bay, Unalaska, eastern Aleutians, near latitude $53^{\circ} 59^{\prime}$, longitude $166^{\circ} 16^{\prime}$. So named by the Fish Commission, 1888, after Captain Erskine, of the Alaska Commercial Company.

Escape; cape, on Kruzof island, at junction of Hayward strait and Krestof sound, Alexander archipelago. Named Koloshskoi strechi (Koloshiani escape) by Vasilief, 1809 .

Escape; point, on the western shore of Revillagigedo island, Alexander archipelago. Named by Vancouver, 1798 , in commemoration of his escape from a hostile attack by the natives. Izbavlenia (deliverance) of the Russians.

Escarpment; cape, on the northern shore of Norton sound. Named Utes (cliff or bluff) by 'Tebenkof., 1838 , which is translated cscarpé by Lutke. Descriptive name. Not found on recent maps.

Eschscholtz; bay, an arm of Kotzebue sound. Named by Kotzebue, August, 1816, after Dr. Frederick Eschscholtz, his physician and naturalist. Also has been written Wschholtz, Escholtz.

Eshamey; bay, on western side of Prince William sound. Local name, reported by Grant, 1905, but not locited.

Eska; creek, on the north bank of Matanuska river, 15 miles above the mouth of the latter, between Tsadaka and Granite creeks, near latitude $\left(i 1^{\circ}\right.$ $40^{\prime}$, longitude $149^{\circ}$. Local name, reported by Martin, 1905 .

Esker; glacial stream, from the Malaspina glacier, debouching near the head of Yakutat bay, southeastem Alaska. So named by Russell 1891.

Eskimo; island, in Harricon bay, Arctic const, enst of Point Barrow. Named Esquimaux by Dease and Simpson, 1837.

Esogem-ungu; talus slide in the bluff at the west end of St. George island, Bering sea, a little southeast of Fox Castle, near longitude $169^{\circ} 45^{\prime}$. Aleut name written $\overline{\mathrm{s} s o ̄}$ 'gĕm-ūngii' (hair-seal trail) and so described by Putnam, 1897.

Espada, Funta de; see Sword.

Espenberg; cape, the southern point of entrance to Kotzebue sound. Named by Kotzebue, 1816, after his friend; Dr. Karl Espenberg, who, as surgeon, accompanied Krusenstern on his voyage round the world, 18031806. Erroneously Espenburg and Spanberg. The Eskimo name is given as Toatut and Togotet.

Espenberg; river, Seward peninsula, tributary to Kotzebue sound, near Cape Espenberg. Local name, obtained by Gerdine, 1901.

Esperanza; creek, Seward peninsula, tributary to Goodhope river from the south, near latitude $65^{\circ} 40^{\prime}$, longitude $163^{\circ} 40^{\prime}$. Prospectors' name, obtained by Mendenhall, 1901.

Esperanza, point; see Latouche. 
Esquibel; bay or gulf, on the western coast of Prince of Wales archipelago. So named by Maurelle, 1779. Variously denominated bay and gulf. Misspelled Esquible. The original name is given by Petrof as Bahía de Esquivel. According to Davidson, it is Golfo de Esquibel on the original Spanish chart.

Esquimaux, island; see Eskimo.

Essawa; salmon stream, on Dall island, Alexander archipelago. Probably a native name, reported by Moser, 1897.

Essie; creek, eastern Alaska, on the east bank of Charley river, which is affluent to the Yukon from the south, near longitude $143^{\circ}$. Prospectors' name, from sketch map compiled by Major Glassford, Signal Corps, U. S. A., 1905 .

Estelle; mountain, near headwaters of Kushokwim river, longitude $153^{\circ}$. So named by Post, of the Geological Survey, 1898.

Esteriles, islas; see Barren.

Esther; creek, 10 miles west of Fairbanks, tributary to Cripple creek, from the north, near longitude $148^{\circ}$. Prospectors' name, from a locil map, 1905.

Esther; island, in Port Wells, Prince William sound. So named by Vancouver, 1794.

Estrella; port, in Malaspina island, Bucareli bay, Prince of. Wales archipelago. Named Puerto de la Estrella (port of the star) by Maurelle and Quadra, 1775-1779.

Dstuardo, Isla. de; see Afognak island.

Esuktu, river; see Usuktu.

Esutkwa; small stream, in northernmost Alaska, near the United States refuge station Utkiavi. Eskimo name from Ray, 1885 .

Etches; port (Port Etches), inderiting the western shore of Hinchinbrook island, Prince William sound, Gulf of Alaska, near latitude $60^{\circ} 20^{\prime}$, longitude $146^{\circ} 35^{\prime}$. Visited and named by Portlock, 1787 , after John and Camden Etches \& Co., of London, early fur traders on the Northwest coast. Dixon, 1787 , called it Port Rose. The Russians adopted the native name Nuchek, which has been variously written Noocheck, Nutschek, etc., and even Nooscha.

Etivluk; river, tributary to Colville river from the south, near latitude $68^{\circ} 15^{\prime}$, longitude $156^{\circ}$. Visited by Stoney, 1885, who wrote Etiv-luk and explored by Ensign Howard, of Stoney's party, in the spring of 1886 .

Etivoli; river, tributary to the Colville from the west, and rendezvous village, at the limit of boat navigation on the Colville. Visited by Ensign Howard, of Stoney's expedition, in spring of 1886. Written Etivoli-par and E-tiv-o-li-par by Stoney. Par, probably the same as pah and pai meaning mouth of.

Etivuk; river, tributary to the Colville from the west. Latitude $68^{\circ} 50^{\prime}$, longitude $156^{\circ} 30^{\prime}$. Reported by Howard, of Stoney's expedition, 1886.

Etolin; cape, the northernmost point of Nunivak island, Bering sea, near latitude $60^{\circ} 25^{\prime}$. So named by the Russians after Capt. Adolph Karlovich Etolin, director of the Russian American colonies, 1841-1845, who, with Khromchenko, explored this region in 1821. It has also been called Khromchenko.

Eeolin, cape; see Corwin.

Etolin, harbor ; see Wrangell.

Etolin; island, between Wrangell island and Prince of Wales island, Alexander archipelago. Named by the Russians after Etolin, governor of the Russian American colonies, 1841-1845. Variously written Etholen (Bancroft's Hist., p. 559), Etholine, Etoline, etc. 
Etolin; mountain (3,778 feet high), in the southern part of Etolin island, Alexander archipelago. Șo named by Snow, 1886, after Director Etolin.

Etolin; point, in Bristol bay, the eastern point of entrance to Nushagak river. So called by Lutke, about 1830, after Director Etolin, who made surveys and explorations in this region in 1821. Variously spelled Etholin, Etoline, and also called Bristol and Bristolski.

Etolin; strait, separating Nunivak island from the mainland, Bering sea. Discovered, in 1821, by Etolin, afterwards governor of the Russian American colonies, who named it Cook strat, after: Capt. James Cook. Krusenstern, however, proposed that it be called after its discoverer, Etolin, and accordingly it appenr's variously as Cook or: Dtolin strait.

Etta; creek, Seward peninsula, tributary on north bank of East fork Solomon river, near latitude $64^{\circ} 42^{\prime}$, longitude $164^{\circ} 10^{\prime}$. Prospector's' name, from Gerdine, 1905 .

IEtuleligemute, Dskimo village; see Itulilik.

Euchre; mountain, in the Nutzotin mountains, southern Alaska, about latitude $62^{\circ}$. Named by Brooks, 1899 , after a favorite horse.

Eudocia or Eudokia, islinds; see Semidi.

Eudora; mountain (3,500 feet high), on Prince of Wales island, between Mbira and Cholmondeley sounds, Alexander archipelago. So named by Clover, 1885. Erroneously Ėndora.

Eudoxia, islands; see Semidi.

Eugenia; point, on the northern shore of San Juan Bautista island, Bucareli bay, I'rince of Wales archipelago. Named Punta de lillegible] Eugenia by Maurelle and Quadra, 1775-1779.

Eureka; creek, in the Kantishina region, on the enst (right) bank of Moose creek, which is a left fork of Bearpaw creek, near latitude $63^{\circ} 30^{\prime}$, longitude $150^{\circ} 30^{\prime}$. So named by prospectors in 1905 , and reported by Prindle.

Eureka; creek, tributary to Skookum river from the north, Sewird peninsula. Name from Barnard, 1900.

Eureka; creek, Seward peninsula, on east bank of Solomon river, 4 miles from const of Norton sound, near longitude $164^{\circ} 22^{\prime}$. Prospectors' name, from Gerdine, 1905.

Eureka; creek, Seward peninsula, in Casadepaga valley, tributary on south bank of Canyon creek, near latitude $64^{\circ} 51^{\prime}$, longitude $164^{\circ} 21^{\prime}$.' Prospectors' name, from Gerdine, 1905 .

Eureka; creek, Seward peninsula, tributary to Inmachuk river near its source, about latitude $65^{\circ} 50^{\prime}$, longitude $163^{\circ} 10^{\prime}$. Frospector's' name, obtained by Witherspoon, 1903 .

Eureka; creek, on Seward peninsula, tributary to North fork Kongarok river: near its mouth, about latitude $65^{\circ} 35^{\prime}$, longitude $164^{\circ} 40^{\prime}$. Prospector's' name, from Gerdine, 1.901.

Eureka; creek, flowing sonthwest from near the headwaters of Minook creek. This stream joins Pioneer creek near where it sinks in the Tanana flats, about latitude $65^{\circ}$, longitude $150^{\circ} 10^{\prime}$. Prospectors' name, publisherl in 1902.

Eureka; gulch, 15 miles north of Nome, Seward peninsula, on the west bank of Snake river at its head, near latitude $64^{\circ} 42^{\prime}$, longitude $165^{\circ} 25^{\prime}$. Miner's' name, from Gerdine, 1904.

Eureka, ledge; see Wayanda.

Eva; creek, 8 miles west of Fairbanks, on the north bank of Esther creek, tributary to Cripple creek from the north, near longitude $148^{\circ}$. Prospectors' name, from a local map, 1905. 
Eva; islands, in the eastern part of Peril strait, Alexander archipelago. So named by Moore, 1895.

Eva; islet, near the entrance to Hamilton bay, Keku strait, Alexander archipelago. Named by Moore, 1895 .

Eva; lake, on the north shore of Baranof island, near Hanus bay, Alexander archipelago. So named by Moore, 1895.

Eva; peak, in the divide between the headwaters of the Kuskokwim and Skwentua rivers, near longitude $153^{\circ}$. So named by Post, 1898.

Eva; point, on the mainland, the north point of entrance to Rudyerd bay, Behm canal. So called by the Coast Survey, in 1891 ; also called Slide point by the Coast Survey in 1894 .

Evans; mountain (5,400 feet high), between Valdez glacier and Klutina lake. So named by Abercrombie, 1898.

Evans; point, on the northern coast of Wrangell island, Arctic ocean. Named by Berry, 1881, presumably after Commander (now Rear-Admiral) Robley Dunglison Evans, U. S. N.

Evasha; river, on the Arctic slope, an upper left fork of Sawanukto river, near latitude $68^{\circ} 30^{\prime}$, longitude $150^{\circ}$. Eskimo name, obtained by $\mathbf{S}$. J. Marsh, a prospector, 1901-1903.

Eviokeeff, island; see Chowiet and Semidi.

Evelshearlk, river; see Redstone.

Everell; creek, eastern Alaska, on the east bank of Charley river, which is an attluent to the Yukon from the south, near longitude 143\%. Prospectors' name, from sketch map compiled by Major Glassford, Signal Corps, U. S. A., 1905.

Everett; peak (3,645 feet high), on the mainland, near Port Snettisham, southeastern Alaska. Nimed by Thomas, 1888; after the distinguished orator Edward Everett.

livesheark, river; see Redstone.

Evrashichichie, cape; see Marmot.

Evrashka, bay; see Marmot.

Ewan; bay, on western side of Prince William sound. Local name, reported by Grant, 1905, but not located.

Ewdokijefftian, islands ; see Semidi.

Ewen Nass. Vancouver gives this as the supposed Indian name of Portland inlet and connecting waters. Ewen was by him supposed to mean great, while the meaning of Nass he did not discover.

Excelsior; creek, in the Copper River region, tributary to Gakona river from the north. Prospectors' name, obtained by Mendenhall, 1902.

Excelsior; creek, tributary to Mission creek from the west, 7 miles west of Eagle. Local name, reported by Barnard, 1898. Spurr, 1896, called it Twelve Mile creek.

Exchange; cove, in Prince of Wales island, opening into Kashevarof passage, Clarence strait, Alexander archipelago. Named by Snow, 1886.

Exchange; island, in Kashevarof passage, Clarence strait, Alexander archipelago. Named by Snow, 1886.

Excursion; inlet, on the northern shore of Icy strait, between Lynn canal and Glacier bay, near latitude $58^{\circ} 25^{\prime}$, longitude $135^{\circ} 27^{\prime}$. It was entered by the excursion steamer Idaho, in 1883, and named Excursion inlet by pilot W. E. George. It is said to be known as Hudson Bay inlet, and appears on the charts as Hudson Bay inlet and Hudson Bay or Excursion inlet. 
Expedition; islet, in Iliuliuk harbor, Únalaska bay, near longitude $166^{\circ} 33^{\prime}$. So named by Dall, 1871.

Expedition; point, on the northeastern shore of Security bay, Kuiu island, Alexander archipelago. So named by Meade, 1869.

Extra Dry; creek, 7 miles northeast of Nome, Seward peninsula, tributary to Nome river from the west, near longitude $165^{\circ} 15^{\prime}$. Local name, published in 1900. The neighboring creek is named Dry.

Eyak; lake, native village, and river, at western edge of Copper River delta, near latitude $60^{\circ} 32^{\prime}$, longitude $145^{\circ} 40^{\prime}$. Petrof in the 'Tenth Census, 1880, wrote it Ikhiak. The Eleventh Census, 1890, has Ighiak or Odiak. Recent maps have Eyak. Moser, 1897, calls the village Odialk, the lake and river Eyak. Pronounced Ai-ak. See Odiak.

Eye Opener; islet, in Portillo channel, Bucareli bay, Prince of Wales archipelago. Named Abre-el-ojo (open the eye) by MaurelJe and Quadra, 1775-1779.

Eye Opener (The); a dangerous rock, covered at three-fourths tide, near the middle of Sumner strait, off Red bsy, Alexander archipelago. Named Atkroiglaza (eye opener) by the Russians. Also known locally as Shoo Fly rock.

Fair; island, at junction of Beecher passage and Duncan canal, Alexander archipelago. So named by Thomas, 1887.

Fairbanks; creek, tributary from the north to Fish creek, which is tributary to l.ittle Chena river, near latitude $65^{\circ} 05^{\prime}$, longitude $147^{\circ} 15^{\prime}$. Named after Senator (afterwards Vice-President) Fairbanks.

Fairbanks; town, post-office (established in 1903), and mining district on the Tamana river, near latitude $64^{\circ} 50^{\prime}$, longitude $147^{\circ} 40^{\prime}$. A trading post was established on the site of the town in 1901, and mining operations in this district were begun in 1902 . The town and district were named in honor of United States Senator Charles Warren Fairbanks, of Indiana, afterwards Vice-President.

Fairhaven; mining precinct, northeastern. part of Seward peninsula, on the south shore of Kotzebue sound.

Fairmount; island, north shore of Prince William sound, near mouth of Unakwik bay. Name from Schrader, 1900. This island, 50 or 60 miles southwest of Valdez, is about 4 miles across, and has been occupied since 1897 for the propagation of blue foxes.

Fairplay; creek, tributary to Dennison fork Fortymile creek from the right, near latitude $64^{\circ}$, longitude $142^{\circ} 30^{\prime}$. Prospectors' name, taken from a map in the Coast Survey archives drawn by E. F. Ball, a prospector, is 1.898 .

Fairplay; mountain (Mount Fairplay), in the Fortymile region, eastern Alaska, near latitude $64^{\circ}$, longitude $142^{\circ}$. Name taken from sketch map compiled by Maj. William Glassford, Signal Corps, U. S. A., 1905.

Fairs; island, in Stockdale harbor, on western shore of Montague island, Prince William sound. So named by Portlock, 1787.

Fairview; creek, tributary to Bering sea near Cape Woolley, in western part of Seward peniusulit. Prospectors' name, from Barnard, 1900.

Fairway; island (100 feet high) and reef, in entrance to Affleck canal, Sumner strait, Alexander archipelago. So named by Snow, 1886.

Fairway; island, in the eastern entrance to Peril strait, Alexander archipelago. So named by Meade, 1869 . It has been reserved for light-house purposes by Executive order dated January 4, 1901. 
Fairway; rock, south of Whale island, Redoubt bay, Sitka sound, Alexander archipelago. Named Farvaternoi (fairway) by Vasilief, 1809.

Fairway; rock, forming part of the Diomede group of islands in Bering strait. So named by Beechey, 1826 , because, he says, "it is an excellent guide to the eastern channel." Itş native name has been variously written Okivaki, Oo-ghe-e-ak, Ugiiak, etc.

Fairuay, rocks; see Green.

Fairweather; cape, on the mainland, in the St. Elias region. Named Fair Weather by Cook, Mily, 1778. It is Beautems of La Perouse (1786), Buentiempo of Galiano (1802), Cape de Beautemps of De Mofras (1844), Gutwetter of Grewingk (1849), Horoshi pogodi of the Russians, and L'tua of Tebenkof (1849). : The last is the native name.

Fairweather; mountain $(15,292$ feet high), in the St. Elias region, near latitude $58^{\circ} 55^{\prime}$, longitude $137^{\circ} 30^{\prime}$. So named by Cook, May, 1778, doubtlesss on account of fine weather at the time of his visit; universally called Fairweather by English-speaking people. It is Beautems of La Perouse (1786), Buen-tiempo of Galiano (1802), Horoshi pogodi of the Russians, Phaier-veder of Tebenkof. (1849), Gutwetterberg of Grewingk (1850), and Schönwetter Berg of Justus Perthes, 1882. . This mountain with its neighboring peaks and clest constitute the Fairweather range.

Fairweather; mountains or range, southeastern Alaska, "lie on the mainland from about 20 miles northwestward of Cape Spencer to Cape Fairweather."

Fairweather Ground. The waters of the north Pacific in the vicinity of the Fairweather range was much frequented by the whalemen fifty years ago, and by them called the Fairweather Ground.

Faith; creek, tributary to Chatanika river near its source, about latitude $65^{\circ}$ $20^{\prime}$, longitude $146^{\circ} 20^{\prime}$. Prospector's' name, obtained by Gerdine in 1903.

Fake; pass, Davidson inlet, Prince of Wales archipelago, near latitude $55^{\circ} 52^{\prime}$, longitude $133^{\circ} 41^{\prime}$. So named by Dickins, $1903-4$, because "we thought we had discovered a good passage, but it turned out to be a fake."

Falfan; point, on the southern shore of Port Asumcion, Bucareli bay, Prince of Wales archipelago. Named Punta de Falfan by Maurelle and Quadra, 1775-1779.

Fall; creek, on the north shore of Admiralty island, Alexander archipelago, tributary to Young bay, near latitude $58^{\circ} 10^{\prime}$, longitude $134^{\circ} 40^{\prime}$. Local name, reported by Spencer and Wright, 1903.

Fall; creek, tributary to Kluvesna creek from the north. Prospectors' name, from Gerdine, 1900.

Fall; creek, tributary to the headwaters of Kanata river. Name from Schrader, 1900.

Fall; creek, tributary to Imuruk basin from the south, Seward peninsula. Name from Barnard, 1900.

Falls; creek, southwestern shore Etolin island, Clarence strait, Alexander archipelago, affluent to McHenry inlet at the head of the east cove at its head, near latitude $56^{\circ} .03^{\prime}$, longitude $132^{\circ} 21^{\prime}$ : Local descriptive name, reported by Moser, 1900 .

Falls; creek, Chatham strait, Alexander archipelago. Reported by Moser, 1897, but not located.

Falls; creek, Kenai peninsula, on the north shore of Kachemak bay, near longitude $151^{\circ} 10^{\prime}$. Descriptive name, reported by Stone, 1904. 
Falls, creek ; see Sonickson.

Falmouth; harbor, indenting the western shore of Nagai island, Shumagins. So named by Dall, 1872 , after a vessel of that name driven into it by a gale, which is the first ressel known to have entered it.

False; bay or anchorage, on the eastern shore of Chichagof island, Chatham strait, Alexander archipelago. Name adopted by Meade, 1869, from the fur traders.

False; cape, near Franklin point, Arctic coast. Perhaps it is the easternmost foint of the Seashore islands. So called on British Admiralty chart 593 (ed. of 1882 ).

False; creek, Kenil peninsula, tributary to Trail creek from the east near its junction with Kenai lake, about latitude $\left(60^{\circ} 27^{\prime}\right.$, longitude $149^{\circ} 20^{\prime}$. Local name, from Moftit, 1904.

False; hill, at head of Tamgas harbor, Annette island, Alexander archipeligo. So called by the Coast Survey as early as 1891 and perhaps earlier.

False; island, on the northern shore of Peril strait, opposite Rodman bay, Alexander archipelago. So named by Moore, 1895.

False; point, on the eastern shore of Port Frederick, Icy strait, Alexander' archipelago, near longitude $135^{\circ} 27^{\prime}$. So named by United States naval officers, 1880 .

F'ulse, rock; Sitkit sound; see Liar.

False Channel; bay, in Kootznahoo inlet, Admiralty island, Alexander archipelago. Descriptive name, given by Meade, 1.869.

linke Chilkat, inlet; see Chilkoot.

F'alse Ears; mountain, on Seward peninsula, south of Goodhope bay, Kotzebue sound. So called on British Admiralty chart 598 (ed. of 1882). Perhaps so called by some of the English naval ofticers engaged in the Franklin search expeditions, 1849-1854. See Ears.

False Green; point, on the mainland near the mouth of Stikine river. Called by Durkin and Kadin, who made a survey here in 1863, "Tower limit of Zelonoi (green) cape," whence the names False or South Zelonoi point, False Green point, and False Zelonoi point.

False Island; point, near to and resembling Island point, Lindenberg peninsula, Wrangell strait, Alexander archipeligo. So named by Thomas, 1887.

False Lead; an opening leading from Tlevalk strait to View cove, Dall island, Alexander archipelago. Being liable to be mistaken for the main channel it was named False Lead by Nichols, 1881.

False Lindenberg; rocky bluff, on the northern shore of Peril stritit, on the southeastern shore of Chichagof island. Name probably adopted by the Coast Survey from the pilots.

False Mount Calder; see Red Bay mountaln.

F'alse Pass, strait; see Isanotski.

False Point Pybus; point, the southeasternmost point of Admiralty island, Frederick sound, Alexander archipelago. It has been confused on some charts with the true Point Pybus, which is about 5 miles southwest from it.

False Point Retreat; point, on the western shore of Admiralty island, Alexander archipelago, about 5 miles south of the true Point Retreat. Named from fancied resemblance to Point Retreat.

F'alse Zelonoi, point; see False Green.

Fankuda; island, on the southern shore of Redoubt bay, Sitka sound, Alexander archipelago. So called by Vasilief, 1809.

Fannie; island, in Port Snettisham, Stephens passige, Alexander archipelago. So named by 'Thomas, 1888. 
Fanshaw; bay, indenting the mainland coast on the eastern side of Frederick sound, Alexander archipelago, near latitude $57^{\circ} 12^{\prime}$. So named by Thomas, 1887.

Fanshaw; cape, on the northeastern shore of Frederick sound, Alexinder archipelago. So named by Vancouver, 1794.

Fanshaw; peak (2,818 feet high), on the mainland, near Cape Fanshaw, northeast of Frederick sound. So named by Thomas, 1887.

Fanshaw; range of mountains, on the mainland, northeast of Frederick sound, southeastein Alaska. So named by Thomas, 1887.

Far; cape, on the northern shore of Whale island, Kodiak group. Named Dalnie (far or distant) by Murashef, 1839-40.

Far; mountain (4,752 feet high), eastern Alaska, between headwaters of Chena river and Birch creek, near latitude $65^{\circ} 05^{\prime}$, longitude $145^{\circ} 45^{\prime}$. Prospectors' name, reported by Witherspoon, 1905.

Far; point, the eastermmost of the Barrier islands, Cordova bay, Alexander archipelago. So named by Moser, 1897.

Faraday; gulch, 9 miles nortbwest of Cape Nome, Seward peninsula, draining into St. Michael creek from the north, near longitude $165^{\circ} 08^{\prime}$. Name from Gerdine, 1904.

Farallon; see Kekur.

Farcwell, island, Lynn canal; see Pyramid.

Farewell; mountain, on the left bank of the Kuskokwim river, near latitude $62^{\circ}$ $30^{\prime}$, longitude $154^{\circ}$. So named by Spurr and Post, 1.898 .

Farewell; .point, the southern extreme of Chernabura island and the southernmost point of the Shumagin group. Name supposed to have been adopted by the Coist Survey from the fishermen or Russians. It is the last land seen by the fishermen when setting out from their fishing grounds for: home.

Faris; peak, in the southwestern part of Unimak island, 3 miles south of Pogromni volcano, near latitude $54^{\circ} 32^{\prime}$, longitude $164^{\circ} 40^{\prime}$. Named by Supt. O. H. Tittmann, of the Coast Survey, after R. L. Faris, of Westdahl's party, who determined its geographic position in 1901.

Farm; island, in delta at mouth of Stikine river. So named by Thomas, 1887. The island is low and flat.

Farmer. A cape in Dixon entrance was so named by Douglas, 1789. Identity doubtful 'and name obsolete.

Farnsworth; island, in 'Tanana river, near longitude $143^{\circ} 30^{\prime}$. So called by Lieutenant Mitchell, Signal Corps, U. S. A., in 1902.

Farragut; bay, on the northern shore of Frederick sound, Alexander archipelago. Named by 'Thomas, 1887, after Admiral David Glascoe Farragut, U. S. N.

Fassett; glacier, -southeastern coast of Alaska, on the north side of Diy bay, at the head of Ustay river, near longitude $138^{\circ} 30^{\prime}$. So named by Moser, 1901, after H. C. Fassett, of the Fish Commission, a member of his party.

Fassett; island, in Albatross anchorage, Portage bay, Alaska peninsula. So named by the Fish Commission in September, 1893.

Fassett; islet, in Sitka sound, one of the Kutchuma group. Named by Beardslee, 1880, presumably after Sailmaker Thomas O. Fassett, U. S. N. Has been erroneously written Fasseet and Fasset.

Fassett; point, on north side of Moser bay, Alitak bay, Kodiak. So named by Moser, 1900, after H. C. Fassett, a member of his party. 
Fatigue; bay, between Smith bay and Dease inlet, on the Arctic coast, east of Point Barrow. So named by Dease and Simpson, in 1837, In memory of their tedious and fatiguing walk around it.

Fault; mountain, on headwaters of Koyukuk river, near latitude $68^{\circ}$. So named by Schrider, 1898.

Faust; island, in Seymour canal, Alexander archipelago. So named by Mansfield, 1890, after Ensign William H. Faust, U. S. N., al member of his party.

Faust; sunken rock, in Siginaw channel, Lynn canal, Alexander archipelago. Discovered and named by Mansfield, 1890, after Ensign William Harry Fiaust, U. S. N., a member of his party.

Faustino; point, on the northwestern shore of San Juan Bautista island, Bucareli bay, Prince of Wales archipelago. Named Punta de San Fiaustiuo by . Maurelle and Quadra, 1775-1.779.

Favor; peak, in extreme eastern part of Mitkof island, Alexander archipelago. So named by Thom:is, 1887.

Favorite; anchorage, in Deadman reach, $1 \frac{1}{4}$ miles southward of Otsoi island and one-fourth mile off: shore, Peril strait, Alexander archipelago, near: latitude $57^{\circ} 32^{\prime}$, longitude $135^{\circ} 28^{\prime}$. So named by United States natval ofticers, 1880, after the little steamer Fuvorite, belonging to the Nortlwest Trading Company.

Favorite; bay, at the head of the southermmost arm of Kootznathoo inlet, Admiralty island, Chatham strait, Alexander archipelago, near latitude $57^{\circ} 28^{\prime}$, longitude $134^{\circ} 30^{\prime}$. So named by Moore, 1895 .

Tavorite; channel, at south end of Lynn canal. Alexander archipeligo. Named by United States naval officers, 1880 , after the steamer Fivorite, above. Also, erroneously, Favourite.

Favorite; glacier, on the western shore of Glacier bily. Named by Reid, 1892, after "the little steamer Fravorite, in which Captain Beardslee first entered Glacier bay in 1880."

Favorite; reef, in Saginaw channel, on the southwestern shote of Shelter island, Alexander archipelago. Named by the Coast Survey, 1885, after the little trading steamer fivorite.

Fawn; mountain (2,112 feet high), near the southern end of Revillagigedo island, Alexander archipelago. So named, 1883, by Nichols. Buck and Doe mountains are near by.

Fawn; point and reef, the southernmost point of Deer island, near Belkofski, about longitude $162^{\circ} 17^{\prime}$. So named by Dall, 1880. Called South cape by the Fish Commission in 1888.

Fawn; point, the north point of Deer island, at mouth of Herendeen bay, Alaska peninsula, near longitude $160^{\circ} 47^{\prime}$. So named by Tanner, 1.890 .

Fawn; river, near Return reef, Arctic ocean. So named by Dease and .Simpson, 1837.

Feather; river, in the Cape Nome mining region, Seward peninsula, debouching a little north of Cape Woolley. Local name, from Barnard, 1900.

Feddis, creek; see Fettis.

Fee. One of the glacial streams emerging from the Malaspina glacier was called Fee river by the New York Times expedition of 1.886. Seton Karr calls it Fee Springs.

Felice; strait, separating Annette island from other islands south and east of it, Alexander archipelago. So named by the Coast Survey, 1883, after the Felice, one of Meares's ships, which visited this const in 1788 . Is also called Felice passage. 
Felix; cape, the southenstern point of entrance to Bucareli bay, Prince of Wales archipelago. Named Cabo de San Feliz by Maurelle and Quadra, 1775-1779, and variously called Saint Felix point, Point Saint Feli\%, etc. According to Davidson, on the original Spanish chart, 1779, it is written Co. Sinto Felix.

Ferebee; glacier and river, near the head of Lynn canal, Alexander archipelago. Named by United States naval officers, 1880, after Surg. Nelson Macpherson Ferebee, U. S. N., who visited the region that year. According to $\mathrm{Dr}$. A. Krause, who visited the region in 1882 , . its native name is Dejähsssánkessit.

Ferebee; rocks, in the Galankin group of islands, Sitka sound, Alexander archipelago. Named by United States naval officers, 1880, after Surg. Nelson M. Ferebee, U. S. N. Erroneously Ferabee.

Ferebee; valley, in which Ferebee glacier heads. Named by United States naval officers, 1880.

F'ergusson, point; see Rocky.

Fern; point, the eastern point of San Fernando island, Bucareli bay, Prince of Wales archipelago, near latitude $55^{\circ} 30^{\prime}$. So named by Moser, 1897.

Fern; reef, half a mile east of Fern point, Bucareli bay, Prince of Wales archipelago. So named by Moser, 1897 .

Fern; shoal, a mile east of Fern point, Bucareli bay, Prince of Wales archipelago. So named by Moser, 1897.

Ferrer; passage, the entrance to Disenchantment bay, from Yakutat bay. Variously called elitrance, inlet, passage, and strait. According to Tebenkof it is said to have been so named by Malaspina, 1791, after Ferrer Maldonado. The name is obsolete.

Fetkina; Eskimo village, in the Yukon delta. So called by Nelson, who visited it in December, 1878. Population 30, in 1880. Origin of name not discovered.

Fettis; creek, left fork of Franklin creek in the Fortymile region, near latitude $64^{\circ} 10^{\prime}$, longitude $142^{\circ}$. Frospector's' name, written Feddis by Goodrich, 1896.

Fick; cove, in the southwestern shore of Hooniah sound, Peril strait, Alexander archipelago, near latitude $57^{\circ} 37^{\prime}$, longitude $135^{\circ} 41^{\prime}$. So named by Moore, 1895 .

Frickett; river, tributary to the Koyukuk, from the right. The river to which Allen, 1885, gave this name is now called John river; Schrader, 1899, applied it to a small tributary on the same side, 10 miles below. See John.

Fidalgo; mountain, on the northern shore of Prince William sound. Was called Volcan de Fidalgo by the Spaniards, probably in 1790 , the name being published in 1802.

Fidalgo; port, indenting the eastern shore of Prince William sound. So named by Vancouver, 1794, in honor of Señor Don Salvador Fidalgo, who vis. ited this region in 1790 .

Fiddler; bend, in Kasilof river, Kenai peninsula, near latitude $60^{\circ} 20^{\prime}$, longitude $151^{\circ} 08^{\prime}$. Local name, from Moffit, 1904.

Figarok, village; see Tigara.

Fighting John; peak ( 5,078 feet high), on the mainland, east of Thomas bay, southeastern Alaska. So named by Thomas, 1887.

Figure Four; mountain (about 2,000 feet high), near shore of Bering sea, a little north of Goodnews bay. Local name from missionary Romig and published by the Geological Survey in 1898. 
File; point, the southernmost point of Liesnoi island, Frederick sound, Alexander archipelago. So named by Mansfield, 1859 .

Fillmore; inlet, separating Fillmore island from the mainland, Dixon entrance. Named by the Coast Survey in 1891. Has been erroneously called Nakat inlet.

Fillmore; island, west of Pearse island, Portland canal, Alexander archipelago. Named by the Coast Survey, 1885, presumably after: Ensign John Hudson Fillmore, U. S. N.

Fillmore; peak ( 3,633 feet high), on the mainland, near Port Snettisham, southeastern Alaskal. So named by Thomas, 1888, after President Millard Fillmore.

Fillmore; rock, in Port Chester, Annette island, Alexander archipelago. So named by Nichols, 1.883 .

Final; bay, indenting the southwestern shore of Beaver inlet, Unalaska island, near longitude $166^{\circ} 32^{\prime}$. So named by Gilbert, 1901 .

Finas, Bocas de; see Bocas de linas.

F'ine, cape; see Tonki.

Finegan, point; see Finnegan.

Finger; islets, in Sumuer strait, off Ruins point, Kosciusko island, Frince of Wales archipeligo. So called in the Coast Pilot (1883, p. 101).

Finger; lake, a few miles from the head of Knik arm of Cook inlet. Descriptive name, given by Glenn, 1898 .

Finger; mountain (2,800 feet high), on the northeastern shore of Hooniah sound, Chicagof island, Alexander archipelago, near latitude $57^{\circ} 40^{\prime}$, longitude $135^{\circ} 23^{\prime}$. Descriptive name, given by Moore, 1895 .

Finger; point, on the western shore of Wrangell strait, Alexinder archipelago. Descriptive name, given by Nichols, 1881.

Fink; creek, Seward peninsula, tributary to Inmachuk river from the east near latitude $65^{\circ} 55^{\prime}$, longitude $163^{\circ}$. Prospectors' name, obtained by Mendenhall, 1901.

Finnegan; point, on east bank Taiya rivè, southeastern Alaska, 4 or 5 miles above Dyea. Prospector's' name, written Finegan by Flemer, 1898.

Finneys; bay and island, northeastern shore of Simnak island, near latitude $54^{\circ} 25^{\prime}$, longitude $162^{\circ} 33^{\prime}$. 'So called by Westdahl, 1901 .

Finski; bay, in northeastern part of Glacier island, Prince William sound, near: latitude $60^{\circ} 53^{\prime}$, longitude $147^{\circ} 10^{\prime}$. Local name, reported by Grant, 1905 .

Fir; island, between Ilput and Kangal islands, Sitka sound, Alexander: archipelago. Named Sosnovoi (fir) by Vasilief, 1809.

Fire; island, near Knik (fire) arm, at head of Cook inlet. Name published by the Geological Survey in 1895. It wals named Thumagain, by Vancouver, 1794. It is Mushukli of Russian Hydrograpbic chart 1378 and Fire island of late chitrts.

Fire; 'slet, in the northern end of Kashevarof passige, Clarence strait, Alexander archipelago. So named by Snow, 1886 .

Fire; point, the northern point of entrance to Saks cove, Behm canal, Alexinder archipelago. Named by the Coast Survey in 1891.

Fired; point, on the southern shore of Norton sound, a few miles east of St. Michael. Called Palenoi (fired) by Tebenkof, 1849.

fired, point; see Palonoi.

First, glacier; see I'opof.

First; islet, in Sitka sound, near Whale island. Named Nachalnie (beginning) by Vasilief, 1809. Descriptive term. 
First; narrows, in Redfish bay, Baranof island, Alexander archipelago. So callèd by Moser, 1897 .

First, point, Sitka sound; see Shoals.

F'irst, rapid, Peril strait; see Northern.

First Chance; creek, Seward peninsula, draining from Kiwalik mountain into Koyuk river on the north, near latitude $65^{\circ} 20^{\prime}$, longitude $162^{\circ}$. Prospector's' name, obtained by Witherspoon, 1903.

First Kekur; an isolated rock or rocky islet, on the western shore of Baranof island, Alexander archipelago. So called by the Russians. Also written Kekour. See Kekur.

Firth; river, lying on both sides of the international boundary and falling into the Arctic ocean, near longitude $140^{\circ}$. So named by Turner, 1890 , after John Firth, the Hudson Bay Company's agent at Rampart House, who accompanied 'Turner to the Arctic coast.

Firtree, island; see Slovoi and Spruce.

Fish; bay; indenting the northwestern shore of Baranof island, Peril strait, Alexander archipelago. Named Rieba (fish) by the Russians, and variously called Rubia, Ribnaia, Fisch, and Fishing, and designated as bay or gulf.

Fish; bay, indenting the north shore of Port Fidalgo, eastern shore Prince William sound, near latitude $60^{\circ} 50^{\prime}$, longitude $146^{\circ} 21^{\prime}$. Name from Ritter, 1908.

Fish; creek, on Revilligigedo island, flowing into Tongass narrows, at Ketchikan, near latitude $55^{\circ} 20^{\prime}$. Name probably adopted by the Coast Stirvey from the pilots and published in 1883.

Fish; creek, on northwest part of Douglas island, tributary to Fritz cove. Local name, obtained by Peters, 1902.

Fish; creek, Seward peninsula, tributary on east bank of Solomon river, near latitude $64^{\circ} 43^{\prime}$, longitude $164^{\circ} 18^{\prime}$. Prospectors' name, from a local map, 1904.

Fish; creek, in the Kantishna region, a west (left) branch of Bearpaw creek, near latitude $64^{\circ}$, longitude $150^{\circ}$. Name given by prospectors in 1905 , and reported by Prindle.

Fish; creek, in the Fairbanks region, tributary to Little Chena river from the west, near latitude $65^{\circ} 05^{\prime}$, longitude $147^{\circ}$. Local name, from Gerdine, 1903.

Fish; creek, tributary to Hess creek from the north, near latitude $65^{\circ} 30^{\prime}$, longitude $149^{\circ}$. Local name, from Gerdine, 1903.

Fish; creek, tributary to the Yukon from the south, 3 miles above Rampart rapids, near longitude $151^{\circ}$. Local name, taken from Edwards's Track Chart of the Yukon, 1899.

Fish; creek, tributary to Chandlar river from the east, near latitude $68^{\circ}$. Local name, from Schrader, 1899.

Fish; creek, tributary to Middle fork Fortymile river from the south, near latitude $64^{\circ} 20^{\prime}$, longitude $142^{\circ} 50^{\prime}$. Local name, from Gerdine, 1903.

Fish; creek, tributary to South fork of the Koyukuk from the south, near longitude $151^{\circ} 15^{\prime}$. Prospectors' name, published in 1899.

Fish, creek, near mouth of Tanana; see Guthna.

Fish, creek, eastern Alaska; see Bonanza.

Fish; island, in Koyukuk river, near longitude 15 $6^{\circ}$. So named by Allen, 1885.

Fish; islet, in Felice strait, southeast of Annette island, Gravina group, Alexander archipelago. So named by Nichols, 1883.

Fish; lake, draining through Kijik river into Lake Clark, near latitude $60^{\circ} 40^{\prime}$, longitude $154^{\circ} 30^{\prime}$. Name from Osgood, 1902. 
Fish; mountain, in the southwestern part of Revillagigedo island, near 'Tongass narrows, Alexander archipelago. So named by Nichols, 1883.

Fish; point, on the mainland, on eastern shore of Behm canal, the northern point of entrance to Chickamin river. So named by the Coast Survey in 1891.

Fish; point, the northern point of entrance to Fish bay, in Peril strait, on the northwestern shore of Baranof island. Named Riebnie (fish) by the Russians.

Fish; river, Seward peninsula, which late maps show as one of the eastern affluents of the Niukluk. What is here regarded as the Niukluk bore the name Fish on most maps from 1869 till quite recently. Named by the Western Union Teleglaph expedition, 1865-1867. Its Eskimo name was reported by the Russians as lkeutpak and by the lelegraph expedition as Icathliuk. See also Eaton.

Fish; rock, in Iliuliuk harbor, Unalaska bay. SQ named by Dall, 1871.

Fish; spit, on west side of south entrance to Valdez narrows, Frince William sound. Locil naime, reported by Grant, 1905.

Fish Creek; flat, bare at low water, northwest shore 'Tongass narrows, neur Ketchikan, at mouth of Fish creek above. So described in the Coast Pilot of 1901.

Fish Egg; islets, in San Alberto bay, Bucalreli bay, Alexander archipelago. Northeast of San Juan Bautista island about 1. mile, according to Nichols (Coast Pilot, 1891, p. 121.), is a wooded rocky islet, named by Maurelle and Quadra, 1779, La Balandra (the sloop). Somewhat more than a mile farther, in the same direction, are two more rocky, woody islets, also named by Maurelle and Quadra, Los Mondragones, and called Balena by Moser, 1897. These three islets, says Nichols (Coast Pilot, p. 121), "Lave received the local name of Fish Egg islets." Moser, 1897 , uses the name Fish Egg for a much larger island about a mile north of these, lying across the mouth of Klawak inlet. Mosel's name is here adopted for the island and the islets near it.

Fisher; creek, Seward peninsula, tributary from the north to Burke creek, near longitude $165^{\circ} 35^{\prime}$. Local name, from Gerdine, 1901 .

- Fisher; creek, enstern Alaska, on the south bank of the Yukon, tributary to Bonanza creek, an aftluent of Charley river from the east; near latitude $65^{\circ} 10^{\prime}$, longitude $142^{\circ} 20^{\prime}$. Prospectors' name, from a sketch map compiled by Major Glassford, Signal Corps, U. S. A., 1905.

Fisherman; point, on the eastern shore of Unalaska island, Unalga pass ; being the southern point of entrance to English bay, near longitude $166^{\circ} 14^{\prime}$. So called by Gilbert, 1901, who wrote it Fishermans.

Fishery; point, on the western coast of Admiralty island, Chatham strait, Alexander archipelago. . Name published by the Coast Survey in 1883. There is an Indian fishing station here.

Fish Ranch; baly, in Mitrofania bay, Alaska peninsula, northeast of the Shumagins. So called by the Fish Commission in 1888.

Fitzgerald; island, eastern shore Yakutat bay, southeastern Alaska, between Dolgoy island and the mainland. So named by Harber, 1892, after. C. W. Fitzgerald, one of his party.

Fitzgibbon; cove, in the mainland debouching into Behm canal, near Burroughs bay, Alexander archipelago. So named by the Coast Survey in 1891.

Fitzgibbon; point, on the mainland, in Behm canal, at entrance to Burroughs bay, Alexander archipelago. So named by Vancouver, 1793.

Five Fathom; rocky patch in Redfish bay, Baranof island, Alexander archipelago. So named by Moser, 1897.

Bull. $299-06 \mathrm{M}-17$. 
Five Fingers (The); group of islets and ledges, in Frederick sound, off Port Houghton, Alexander archipelago. Descriptive term given by Meade, 1869. This group, or the southenstern part of it, has been reserved for light-house purposes by Executive order dated January 4, 1901.

Fivemile; islet, in Sumner strait, 5 miles from Wrangell, whence the name Piatimilni (five mile) given by the Russians in 1863. May be Scraggy island of Meade, 1869.

Five Rivers; see Dry bay.

Flag; hill (1,200 feet high), on the eastern bank of Tanana river, near longitude $147^{\circ}$. Descriptive name, given by Peters and Brooks, 1898.

Flag; point, in Whitewater bay, Admiralty island, Alexander archipelago. So named by Glass, 1881.

Flambeau; river, tributary to Port Safety, Seward peninsula, near latitude $64^{\circ} 30^{\prime}$, longitude $165^{\circ}$. Name from Barnard, 1900 .

Flat; bay, on the western shore of Chilkoot inlet, Lynn canal. Said to have been so named by Dr. Arthur Krause in 1882 . He reports its native name to be Náchk, also written Nakh.

Flat; bight, indenting the western shore of Akutan island, Krenitzin group, eastern Aleutians, near longitude $166^{\circ} 04^{\prime}$. Descriptive name, from Gilbert, 1901.

Flat; creek, 3 miles north of Nome, Seward peninsula, tributary to the head of Center creek, near longitude $165^{\circ} 23^{\prime}$. Local name, published in 1904.

Flat; creek, Seward peninsula, tributary from the east to Agiapuk river, near latitude $65^{\circ} 21^{\prime}$ '. Name from Gerdine, 1901.

Flat; creek, Seward peninsula, tributary from the east to Anikovik creek near York. Local name, obtained by Gerdine, 1901.

Flat; creek, in the Kantishna region, a left branch of Glacier creek, near latitude $64^{\circ}$, longitude $150^{\circ}$. Prospectors' namie, given in 1905 , and reported by Frindle.

Flat; creek, eastern Alaska, tributary to Charley river from the east, near latitude $65^{\circ} 10^{\prime}$, longitude $142^{\circ} 45^{\prime}$. Prospectors' name, reported by Prindle, 1903.

Flat; creek, tributary to Chandlar river, from the north, near longitude $148^{\circ}$. Prospector's' name, reported by Schrader, 1899.

Flat; island, in Red bay, Prince of Wales island, Alexander archipelago, So named by Freln, 1886.

Flat; island, in Security bay, Kuiu, island, Alexander archlpelago, Descriptive name, given by Meade, 1869.

Flat, island; see Wolf rock.

Flat; islet, near Graham harbor, Cook inlet. Descriptive name, given, presumably, by Dall, 1880.

Flat; islet, in Wrangell harbor, Alaska peninsula, north of the Semidi group. Named Gladkie (flat) by Vasilief, 1832. Has also been called Platte.

Flat; mountain $(1,800$ feet high), in California ridge, in the southeastern part of Gravina island, Alexander archipelago. Presumably a descriptive term, published by the Coast Survey in $\mathbf{1 8 8 5}$.

Flat; point, on the eastern coast of Pearse island, Portland inlet. Named by Pender, 1868.

Flat; point, on the western shore of Portage bay, Kupreanof island, Alexander archipelago. So named by Nichols, 1882.

Flattop; peak (3,170 feet high), on Akutan island, 2 miles soutbwest of Akutan peak, near longitude $166^{\circ} 02^{\prime}$. Descriptive name, from Gilbert, 1901.

Flat Top, point; see Lava. 
Flaw; point, in Mole harbor, Seymour canal, Admiralty island, Alexander archipelago. So named by Mansfield, 1889 .

Flaxman; island, on the Arctic coast, near Camden bay, east of Point Barrow. So named by Franklin, 1826 (p. 151), "in honour of the late eminent sculptor."

Fleece; rock, about 12 feet above high water, in Dixon entrance, near Cape Fox. So named by Nichols, 1883 .

Fleischmann; glacier, on the north side of Simpson pass in the McKinley range ; latitude $62^{\circ}$, longitude $153^{\circ} 30^{\prime}$. So named by Ferron, 1899 .

Flemming; island, in the southwestern part of Prince. William sound. So called by Schrader, 1900. It is said that the large island to which Schrader applied this name is locally called Foodoo island and that Flemming island is a much smaller island to the north of it-maybe the one here called Gage.

Flemming; passage, in southwestern part of Frince William sound. Local naine, reported by Grant, 1905.

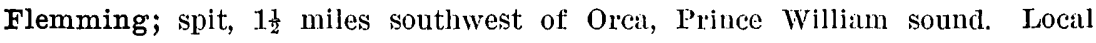
name, reported by Schrader, 1900.

Flock; rock, in Farragut bay, Frederick sound, Alexander archipelago. So named by the Cain st Survey in 1891.

Flood; glacier, on the western bank of the Stikine, near the international boundary. So called by the Coast Survey.

Floral; hills and pass, between Hayden and Lucia glaciers, St. Elias alps, soutleastern Alaska. So called by Russell, 1890, "on account of the luxuriance of the vegetation covering them."

Florence; bar, in Koyukuk river, near the north end of Huggins island, about latitude $66^{\circ}$, longitude $154^{\circ} 20^{\prime}$. Prospector's' name, given in 1899 .

Florence; bay, "inside of Point Fayes," Chatham strait, Alexander archipelago, near latitude $57^{\circ} 30^{\prime}$. So described by Moser, 1897. From this description it appears to be a branch of Sitkoh bay.

Florence; cape, on the northwestern coast of Wrangell islind, Arctic ocean. So named by Beriry, 1881.

Florence; creek, tributary to Eldorado river, from the west, Seward peniusula. Name from Barnard, 1900.

Florence; creek, tributary to North fork Koyukuk river on the right bank, near latitude $67^{\circ} 15^{\prime}$, longitude $150^{\circ} 45^{\prime}$. Prospector's' name, published in 1902.

Florence; gulch, 3 miles east of Nome, Seward peninsula, on the east bank of Otter creek near iongitude $165^{\circ} 17^{\prime}$. Local name, published in 1904.

Florence; group of islands in Koyukuk river, right bank, near latitude $65^{\circ} 50^{\prime}$. longitude $155^{\circ}$. The channel here is between Fry island and the Flor. ence group of islands. Probably river pilots' name, reported by Lieutenant Camden, Revenue-Cutter Service, 1900.

Flores, Canal de; see Shelikof.

Flores; cape, the eastern point of entrance to Port Refugio, in Bucareli bay, Prince of Wales archipelago. Named Cabo de Flores (cape of flowers) by Maurelle and Quadra, 1755-1779.

Florida; creek, in the Rampart region, tributary to Minook creek about 8 miles above its mouth. Prospector's' name, obtained by l'rindle, 1904.

Flume; creek, in the Fairbanks region, tributary to Pedro creek from the north near latitude $65^{\circ}$, longitude $147^{\circ} 35^{\prime}$. Local name, obtained by Gerdine, 1903. 
Flume; creek, eastern Alaska, on north bank of Gold creék, Salcha River drainage, near latitude $64^{\circ} 50^{\prime}$, longitude $145^{\circ} 35^{\prime}$. Prospectors' name, reported by Witherspoon, 1905 .

Flume; creek, eastern Alaska, on south bank of Seventymile creek, near latitude $65^{\circ}$, longitude $142^{\circ} 30^{\prime}$. Prospectors' name, reported by Prindle in 1903. Erroneously Plume.

Flume; gulch, in the Kantishna region, on the east (right) bank of Bearpaw creek, near latitude $64^{\circ}$, longitude $150^{\circ}$. So named by prospectors in 1905, and reported by Prindle.

Flusser; peak, on the mainland, east of Frederick sound, southeastern Alaska. So named by Thomas, 1887.

Flynn; cove, soath shore Icy strait, 7 miles northwest of Port Frederick, near latitude $58^{\circ} 13^{\prime}$, longitude $135^{\circ} 36^{\prime}$. Named after H. F. Flynn, assistant, Coast Survey, with Dickins party in 1901.

Foggy; bay, indenting the mainland, in the southern part of Revillagigedo channel, Alexander archipelago. So named by the Coast Survey, in 1S83, or earlier.

Foggy; cape, the eastern end of Sutwik island, Alaska peninsula, near the Semidis, about longitude $157^{\circ}$. Named by Cook in 1778. 'Exact locality of Cook's Foggy cape uncertain, as might be guessed from the weather conditions prevailing when it was nimed. Lutke identifies it with Cape Kumliun, which see. Lutke also calls it Brumeux.

Foggy; island, between Camden bay and Colville river, Arctic coast, near longitude $148^{\circ}$. So named by Franklin, 1826, who describes (p. 155) " the propriety of designating this dreary place by the nime of lioggy Island."

Foggy, island; see Andronica.

Foggy, islands; see Semidi islands. Vancouver thought Chirikof island was the "Foggy island of Beering." But Cook applied the name Foggy to the present Semidi group and Vancouver named Chirikof ('Tscherikow), after Bering's companion.

Foggy, islet; see Poa.

Foggy; point, on the western shore of Portland canal, southeastern Alaska. Apparently so named by the British Admiralty in 1890.

Foggy; point, on the mainland, in Revillagigedo channel, the south point of - entrance to. Foggy bay. So named by Vancouver in 1793 . The Russians called it Foggy or Brumez (Tumannie). On some charts it is Point Brumez.

Foggy Island; bay, between Camden and Harrison bays, Arctic coast. So named by Dease and Simpson, 1837.

Fogniak, island; see Afognak.

Fohlin; creek, tributary to Lakina creek from the north. So namied by Rohn, 1899 , after a member of his party.

Fontaine; island, in Shakan bay, Prince of Wales archipelago. So named by Helm in 1886 ; has also been written Fontain.

Food, bay; see Agamgik.

Fool; creek, Seward peninsula, a small tributary on west bank Casadepaga river, near latitude $64^{\circ} 56^{\prime}$, longitude $164^{\circ} 10^{\prime}$. Prospectors' name, from Gerdine, 1905 .

Fool; creek, northeastern Alaska, tributary to John river from the west, near latitude $67^{\circ} 30^{\prime}$, longitude $152^{\circ} 15^{\prime}$. Prospectors' name, reported . by Peters and Schrader, 1901.

Fools; inlet, indenting the southern shore of Wrangell island, and opening into Ernest sound, Alexander archipelago. So named by Snow. 1886. 
Fools; point, on the western shore of Portland canal. Apparently so named by the Coast Survey in 1891.

Foraker; mountain (17,100 feet high), 15 miles southwest of Mount Mcíinley, near laititude $63^{\circ}$, longitude $151^{\circ} 30^{\prime}$. Discovered and named by Herron, 1899, after United States Senator Joseph Benson Foraker, of Ohio. Herron says that these two mountains, McKinley and Foraker, are called Bolshoi, the Russian word meaning big, by the Susitna tribe. They are called Din-az-ee by the Kuskokwims and Din-al-ee by the Tanainas and Yukons.

Foot; island, in Steamboat bay, Frederick sound, Alexander archipelago. So named by Mansfield, 1889.

Foot, island; Prince William sound. See Latouche.

Foote; peak $(5,176$ feet high), on the mainland, near Thomas bay, Frederick sound, southeastern Alaska. Named by 'Thomas, 1887, after RenrAdmiral Andrew Hull Foote, U. S. N.

Ford; arm of Khaz bay, indenting the soutbwestern shore of Chichagof island, Alexander archipelago, near latitude $57^{\circ} 34^{\prime}$, longitude $136^{\circ}$. So named by Mopre, 1897, after Farry L. Ford, one of his party.

Ford; cove, on the eastern shore of Portland canal. Named Ford's by the Coast Survey, 1891, after Harry L. Ford.

Ford; rock, 150 yards long, bare only at lowest tides, Peril strait, off the entrance to Ushk bay, near latitude $57^{\circ} 34^{\prime}$, longitude $135^{\circ} 31^{\prime}$. So named by Moore, 1895, after Harry L. Ford, one of his party.

Fords Terror; narrow inlet, on the northern shore of IEndicott arm, Alexander archipelago. It is very narrow at one point. Floating ice from glitciers, with falling tide, jamming in this contracted throat, make it a dangerous place. Named by Mansfield, 1889, after Harry L. Ford, a member of his party.

Forest, river; see Kakhtul.

Fork; penk, norther'n Alaska, on the east side of John river, near latitude $68^{\circ}$, longitude $152^{\circ}$. Descriptive name, from Peters and Schrader, 1901.

Forney, river; see Osar stream.

Forrest, cape; see Icy point.

Forrester; island, off the southwestern coast of Prince of Wales archipelago. So named by Dixon, July, 1787. Perez, in 1774, called it Santa Cristina, which is also written in the journal of his voyage Santa Christina and Santa Catalina (Banc. Hist., vol. 33, pp. 196, 201). Douglas in August, 1788, named it Douglas island (Meares, p. 327); Maurelle, 1775, called it San Carlos island. This name was published in Barrington's Miscellanies in 1781. La Perouse, 1786, called this island and Wolf Rock the San Carlos islands. Vancouver adopted Forrester, and this name has been adopted and used for a century, to the exclusion of all others.

Forss; island, in Helm bay, ivestern shore Behm canal, sontheastern Alaska, near latitude $55^{\circ} 37^{\prime}$, longitude $131^{\circ} 58^{\prime}$. Local navigator's' name, reported by F. C. Fassett, Burenu of Fisheries; 1904.

Fort; point, on the northern shore of Tongass island;" Tongass harbor, eastern part of Dixon entrance. So named by Nichols, 1891.

Fort; point, the north point of entrance to Steamboat bay, Frederick sound, Alexander archipelago. Sa named by Mansfield, 1889.

Fort Adams. An American trading station was established on the north bank of the Yukon, at the mouth of the Tozi river, 1868 or 1869 , and called Fort Adams. St James Mission was near this place.

Fort Alexander; see Nushagak. 
Fortaleza; point, in Bucareli bay, Prince of Wales archipelago. Named Punta de la Forteleza (fortitude) by Maurelle and Quadra, 1775-1779.

Fort Archangel Gabriel, Baranof island; see Sitka.

Fort Cosmos; Stoney's winter quarters on the Kobuk, 1885-86, near longitude $157^{\circ}$. So named in bonor of the Cosmos Club of San Francisco.

Fort Cudahy; see Cudahy.

Fort Davis; military post at moutli of Nome river, 3 miles southeast of Nome, Seward peninsula, near longitude $165^{\circ} 17^{\prime}$. Established in 1899 . It is on the line of the military telegraph near its northwestern terminus. .

Fort Egbert; military post, at Eagle, on the upper Yukon, near the international boundary. Established and so named by the War Department in 1889. and connected with Valdez and St. Michael by the military telegraph completed in 1903.

Fort Gibbon; military post and reservation, on north bank of the Yukon, at mouth of Tanana river. Named after Gen. John Gibbon, U. S. A.

Fort Hamilton; village, in the Yukon delta, on the right bank of Apoon pass, about 25 miles above its mouth. Called Nunapithlugak or Fort Hamilton by the Coast Survey in 1899, and Old Fort Hamilton (Nonapeklowak) in 1901. See New Fort Hamilton.

Fort Hamlin; trading post, on the south bank of the Yukon, 10 miles below the mouth of the Dall, near longitude $149^{\circ} \mathbf{1 5 ^ { \prime }}$. Local name, published by the Coast Survey in 1897.

Fort Liscum; military post, Port Valdez, Prince William sound.

Fort Liscum; post-office (established 1901), Port Valdez; Prince William sound.

Fort Morton; see Morton.

Fort Nicholas, Cook inlet; see Kenai.

Fort Reliance; post, an old trading post of the Hudson Bay Company, now in ruins, on the east bank of the Yukon, a few miles below Dawson, Canada.

Fort St. Michacl; see St. Michnel.

Fort Selkirk; Canadian military beadquarters, at mouth of the Lewes river. T.he site of the old fort of the Hudson Bay Company is on the opposite bank of the river. This name has been adopted by the Canadian Board on Geographic Names.

Fort Tongass. A military post of the United States known as Fort Tongass was maintained on 'Tongass island, from June, 1868, to September, 1870 . Fort Tongass was the official spelling. Variously called Fort Tongas, Fort Tomgas, etc.

Fortuna, island; see Klokachef.

Fortuna; strait, separating Chichagof island from Klokachef island, Salisbury sound, Alexander archipelago. Has also been called a passage or channel. Named by the Russians. The Spanish schooner Fortunt, with seven natives of the Hawaiian islands on board, was found ashore

' here and taken by the Russian American Company's vessels as a prize in 1819. The name has doubtless come from this circumstance.

Fort Wrangell; see Wrangell..

Fort Wrangell; post-office (established in October, -1895), at Wrangell, and changed to Wrangell in 1902. See Wrangell.

Fortyfive Pup; a creek or gulch, in the Fortymile region, eastern Alaska, on the north bank of Buckskin creek, near latitude $64^{\circ} 15^{\prime}$, longitude $142^{\circ}$ 10'. Prospectors' name, from a miap compiled by Major Glassford, Signal Corps, U. S. A., 1905. The term pup is used by the miners to designate small branch gulches. 
Fortyseven Pup; creek, in the Rampart region, tributary from the east to. Hunter creek, a branch of Minook creek. Prospector's' name, obtained by Prindle, 1904, as 47 Pup. Pup is a miners' term for very small branch valleys or gulches.

Fortymile; creek, tributary to the Yukon from the west, nenr latitude $64^{\circ} 30^{\prime}$. Name given, presumably by prospectors, in 1886 , when gold was first found here. It takes this name from being about 40 miles below old Fort Reliance. The native name is Shitando. It was called Cone Hill river by Schwatkil, 1883, "from il conspicuous conical hill in its valley." The Canadian Board on Geographic Names has adopted the name Fortymile.

Fortymile; mining camp, at the mouth of Fortymile creek, near latitude $64^{\circ} 30^{\prime}$. It was started in 1893.

Fortymile; trail, from Fortymile creek to Tanana river. Local name.

Fortymile Dome; peak ( 3,900 feet high), in the Fortymile mining region, near the international boundary, and latitude $64^{\circ} 25^{\prime}$. It is Dome peak of some maps and Fortymile Dome of others.

Fort Yukon; fort and trading post on the upper Yukon, near longitude $145^{\circ} 18^{\prime}$. established by McMurray, of the Hudson Bay Company, in 1847, on the supposition, it may be assumed, that it was in British territory. It was moved 1 mile farther downstream to its present site in 1864. The boundaly line between the British and Russian possessions had been agreed upon in 1825 , but the line hat not been marked on the ground. Shortly after Alaskia had been acquired by the United States, Lient. C. W. Raymond, U. S. Engineers, ascended the river and determined the longitude of this post, which wis found to be on American territosy.

Fort Yukon; post-office (established in 1901), at Fort Yukon (above), at the junction of Yulion and Porcupine rivers.

Fossil; creek, in the Yukon-Tanana region, tributary at the head of: Beaver creek from the east, near latitude $65^{\circ} 30^{\prime}$, longitude $147^{\circ} 40^{\prime}$. So named by Frindle, 1905.

Fossil; creek, a lower fork of Lawrence creek, 13 miles east of Cape Yaktag, Gulf of Alaskil, near longitude $142^{\circ}$. Name reported by Martin, 1904:

Foster; creek, tributary to Camp creek from the west, Seward peninsula. Name from Barnard, 1900.

Froster, creek; see Pine.

Foster, glacier ; see Talku.

Foul; passage, in reril strait, near the Southein rapids. Descriptive name, given by Coghlan, 1884 .

Found; island, in Ernest sound, at the mouth of Zimovia strait, Alexander. archipelago. So named by Snow, 1886 .

Fountain; glacial strcam, from Malaspina glacier, debouching between sitkag! bluffs and Icy bay. So named by Russell, 1891.

Fountain; sunken rock, near Middleton island, Gulf of Alaska. Descriptive name, given by the Russians.

Fourmile; creek, 50 miles northeast of Knik arm of Cook inlet, tributary to Cbickaloon creek from the west, near latitude $61^{\circ} 50^{\prime}$, longitude $148^{\circ}$ 30'. Descriptive name given by Glenn, 1898.

Four Mountains; a group of volcanic islands just west of Umnak, in the eastern Aleutians, was discovered by the Russians at an enrly day and called ostrova chetierek sopochnie, i. e., Islands of the Four Craters, or Islands of the Four Mountains, as they are usually called. The group consists of five principal islands, though on many charts only four are 


\section{Four Mountains-Continued.}

shown. Our knowledge of the group, still very imperfect, has been considerably improved by the work of the U. S. S. Concord, there in 1894. Their Aleut name, according to Veniaminof, is Unigun, or, according to Sauer, 1790, Oone-agun. Sarichef, who was the first to give any details, says (Phillips Voyages, vol. 6, pp. 4-5) on May 30 , 1791, "we fell in with the four volcanic islands which take their names from the four craters which they contain. They lie contiguous to each other and bear distinct names. That to the southwest is called Ulaga ; that northeast, T'schiginsk ; that to the north, Tana; and that to the soucheast, Chagatnil." The names applied by different anthorities are as shown below; but this correlation is to a considerable extent conjectural.

\begin{tabular}{|c|c|c|c|c|c|}
\hline \multirow{2}{*}{ Authority. } & \multicolumn{5}{|c|}{ Names of islands. } \\
\hline & Carlisle. & Herbert. & Chuginadak. & Kagamil. & Kigalgin. \\
\hline $\begin{array}{l}\text { 1768. Krenitzen and Lev- } \\
\text { ashef. }\end{array}$ & Ulaga ...... & Tchagulak : & Kitalga.......... & Kagamila .. & \\
\hline 1791. Billings.. & Ollagn... & 'Tshugidi ... & Tanaguni ..... & Chamil ..... & ... \\
\hline 1791. Sarichef ...... & Uliaga... & Chuginok .. & Tano ......... & Kagamil ... & \\
\hline 1830. Veniaminof:... & Uliagan .... & Chuguliak.. & Tanak-aniunak & Kagamiliak & Kigalga. \\
\hline 1836. Lutke.... & Oulliaghin . & Tchegoulak & Tanakh-angounakh & Kigamiliakh & Kigalga. \\
\hline 1847. Rus. Hyd. chart 1397 & Ulliagin .... & Chegulak... & Tanak-Angunak ... & Kigamiliak. & Kigalga. \\
\hline 1849. Tebenkof :.......... & Ulliagn . & & Chuginadak..... & Kagamil.... & Kagalgin. \\
\hline 1893. Coast Survey..... & Uliaga... & & Chuginadak... & Kagamil.... & Kigalgin. \\
\hline 1895. Hyd. Office chart 8 . . & Carlisle. . & Herbert .... & Chuginadak........ & Kagamil.... & Uliaga. \\
\hline
\end{tabular}

Fourpeaked; mountain, near the western entrance to Gook inlet. Descriptive term, given by the Russians, who called it Gora chetierek glavi.: (mountains with four heads). On one chart Chetierek (four) has been written Tapirag and the peak called Mount Tapirag.

Fourth of July, bay; see Amugul.

Fourth of July; creek, tributary to Yukon river from the south, 2 miles below Nation city, near latitude $65^{\circ} 10^{\prime}$, longitude $142^{\circ}$. Prospector's name, taken from a map in the Coast Survey archives, drawn by E. F. Ball, a prospector, 1898.

Fourth of July; creek, in Fortymile region, tributary to Slate creek on north bank, near latitude $64^{\circ} 40^{\prime}$, longitude $142^{\circ} 40^{\prime}$. Prospectors' name, reported by Wither:spoon, 1905 .

Fox; bay, indenting the eastern shore of Stepovak bay, Alaska peninsula. So called by Dạll, 1880 .

Fox; bay, indenting the north shore of Whale island, between Afognak and Kodiak, near latitude $57^{\circ} 57^{\prime}$. Local name; reported by Moser, 1900.

Fox; cape, on the mainland, at eastern end of Dixon entrance. Named by Vancouver, 1793, after the Right Hon. Charles James Fox.

Fox; cape, on the southern shore of Alaska peninsula, northeast of the Shumagins. Named Leesy (fox) by the Russians.

Fox; cape, the northernmost point of Little Tanaga (or possibly Kagalaska) island, Andreanof group, middle Aleutians. Apparently named (fox) by the Russians, though I have not found this in any Russian map or book. On United States Hydrographic chart 8, made from reports by the North Pacific exploring expedition, 1855, occurs the entry " C. Lises (Fox cape)." 
Fox; creek, Kenai peninsula, tributary from the east to Resurrection creek, near latitude $60^{\circ} 45^{\prime}$, longitude $149^{\circ} 40^{\prime}$. Local name, from Moffit, 1904 .

Fox; creek, Kenai peninsula, tributary to Tustumena lake from the south, near: longitude $150^{\circ} 40^{\prime}$. Local name, from Moffit, 1904.

Fox; creek, Seward peninsula, in Solomon River valley, tributary on south bank of Coal creek, near latitude $64^{\circ} 44^{\prime}$, longitude $164^{\circ} 17^{\prime}$. Pros- pector's' name, from a local map, 1901.

Fox; creek, 25 miles north of Nome, Seward peninsuli, tributary to Eldorado river from the west, near latitude $64^{\circ} 46^{\prime}$, longitude $165^{\circ}$. Name from Barnard, 1900.

Fox; creek, 35 miles north of Cape Nome, Seward peninsula, tributary to Salmon lake from the north, near longitude $165^{\circ}$. Name from Barnard, 1.900 .

Fox; creek, Seward peninsula, tributary from the east at the head of Arctic river, an affluent of Shishmaref inlet, near latitude $65^{\circ} 50^{\prime}$, longitude $165^{\circ} 50^{\prime}$. Name from Gerdine, 1901.

Fox; creek, Seward peninsula, tributary to Goodhope bay, near longitude $163^{\circ}$ $30^{\prime}$. Name from Witherspoon, 1903.

Fox; creek, in the Fairbanks region, tributary to Goldstream creek from the north, near latitude $65^{\circ}$, longitude $147^{\circ} 40^{\prime}$. Local name, from Gerdine, 1903.

Fox; creek, tributary to Seventymile creek from the north, near latitude $64^{\circ}$ $55^{\prime}$, longitude $141^{\circ} 35^{\prime}$. Prospectors' name, obtained by Gerdine, 1903.

Fox; creek, tributary from the east to Rogers creek, a south aftuent of the Yukon, 20 miles above the mouth of the Dall, near latitude $66^{\circ}$. longitude $148^{\circ} 20^{\prime}$. Prospector's' name, reported by Lieutenant Li:ickson, U. S. A., 1902.

Fox; gulch, 3 miles northenst of Nome, Seward peninsula, on the west bank of Otter creek, near longitude $165^{\circ} 18^{\prime}$. Locil name, published in 1904.

Fox; hill (563 feet high), on the mainland, neir Cape Fox, Dixon entrance. So nimed by Nichols, 1883 .

Fox; hill (463 feet high), in the southwestern part of St. Paul island, Pribilof group; Bering sea. Presumably a local name, published by the Coast Survey in 1875. Elliott has this name Fox, and near it in quotation marks "Seethah." Perhaps this is the native name.

Fox; island, on south side of entrance to P'ort Valdez, just north of Bligh island, Prince William sound. Has been occupied since 1897 for the propagation of blue foxes.

Fox, island, Sea Otter sound; see Marble.

Fox, island, Holkhiam bay; see Sumdum.

Frox, island, Resurrection bay ; see Renard.

Fox; islands, the easternmost group of the Aleutian chain of islands. The limits of the application of the name are now rather vague. Veniaminof, the best authority of his time, writing in 1840 , says the islands lying between Amulta and Alaska peninsula, together with the islands near the peninsula, are called the Fox islands. Cook, in 1778, calls them the Fox islands. Frobably named leesy (fox) by early Russian fur traders. They are Fox or Andreanof islands of Langsdorf, Iles aux Renards of: Lutke, etc. The whole Aleutian chain is known to mariners and whalemen as the Fox islands. The Const Survey now restricts this name Fox to include only Unimak, Unaliska, and Unnak with their various associated islands. See also Aleutian islands.

frox, islands ; see Martin. 
Fox; islet, near the north shore of Deer island, between Sannak and Belkofski; near latitude $54^{\circ} 57^{\prime}$, longitude $162^{\circ} 25^{\prime}$. Called Leesy (fox) by 'Tebenkof, 1849.

Fox; lake, near Nome, Seward peninsula. Name from Barnard, 1900.

Fox; point, on the southeastern shore of Revillagigedo island, Alexander archipelago. So named by the Coast Survey in 1891.

Fox; point, on right bank of Yukon river, a little above Hall rapids. So named by Raymond, 1869 .

Fox; river, Kenai peninsula, draining into the head of Kachemak bay, near latitude $59^{\circ} 50^{\prime}$, longitude $151^{\circ}$. Local name, from Dall, 1895 .

Fox; river, tributary to Fish river, from the west, between the Niukluk and Klokerblok rivers, Seward peninsula. Local name.

Fox, river; see Kiaktak.

Fox; rock, on east side Davidson inlet, Prince of Wales archipelago, near latitude. $55^{\circ} 53^{\prime}$, longitude $133^{\circ} 32^{\prime}$. So named by Dickins, $1903-4$.

Fox Cairn; see Fox Castle.

Fox Castle; prominent mass of rocks, on hill $6 \pi 1$ feet high, on west end of St. George island, Bering sea, 1 mile southeast of Dalnoi point, near longitude $169^{\circ} 45^{\prime}$. Called Fox Castle by Stanley-Brown, 1891, and Fox Cairn by Duffield, 1897. Putnam writes the Aleut name Kräd'iggy.

Fox Islands; passes, a general name for all of the passes, straits, and channels among the Fox islands, easteri Aleutians.

Fragrant; island, one of the Necker group, Sitka sound, Alexander archipelago. Named Dushistoi (fragrant) by Vasilief, 1809.

Francais, Port des; see Lituya.

Francis; anchorage, in Farragut bay, Frederick sound, Alexander archipelago. So named by Thomas, 1887 , after pilot E. H. Francis.

Francis; creek, Seward peninsula, tributary to Goodhope bay, near longitude $163^{\circ} 40^{\prime}$. Prospectors' name, obtained by Witherspoon, 1903.

Francis; island, in Glacier bay, southeastern Alaska. Apparently so named by the British Admiralty in 1890.

Francis; lake, Etolin island, Alexander archipelago, probably on the eastern shore of Burnett inlet and tributary thereto. Local name, reported by Moser, 1900, but not found on any map.

Francis; mountain (3,015 feet high), on Kosciusko island, southern shore of Shipley bay, Sumner strait, Alexander archipelago. So named by Snow, 1886, after pilot H. H. Francis.

Francis; mountain (4,800 feet high), near Port Valdez, Prince William sound. So named by Abercrombie, 1898.

Francis; point, in Behm canal, on the eastern coast of Cleveland peninsula, opposite Traitor cove. It is the south point of entrance to Port Stewart. Nanied by the Coast Survey, 1886, after pilot E. H. Francis.

Francis, river; see Stikine.

Francis; sunken rocks, in Southern rapids, Peril strait, Alexander archipelago. Discovered and named by Coghlan, 1884, aftery pilot E. H. Francis, the first person to secure soundings on them.

Francisco; creek, 25 miles north of Nome, Seward peninsula, tributary to Stewart river from the north near longitude $165^{\circ} 28^{\prime}$. Local name, from Gerdine, 1904.

Franklin; creek, tributary from the west to South fork Fortymile creek, near latitude $64^{\circ} 10^{\prime}$. Gold was discovered on this creek in 1886 and it was named in honor of the miner who discovered gold at the mouth of Fortymile creek the year before. Reported by Wells, 1890. Has also been called Franklin gulch. 
Franklin; mountains, in northernmost Alaska, east of the Colville river. So named by Dease and Simpson, 1837, after Sir John Franklin.

Franklin; peaks (3,909, and 4,314 feet high), on the mainland north of. Frederick sound, southeastern Alaska. So named by Thomas in 1887.

Franklin; point, on the Arctic coast, between points Belcher and Barrow. So named by Beechey in September, 1826, after Sir John Franklin.

Franklin; post-oflice (established in 1903), on South fork Fortymile creek, at the mouth of Franklin creek, near latitude $64^{\circ} 10^{\prime}$, longitude $141^{\circ} 50^{\prime}$.

Fred; gulch, 20 miles north of Nome, Seward peninsula, on the south bank of Stewart river; between Boulder and Mountain creeks, near longitude $165^{\circ} 26^{\prime}$. Local name, reported by Gerdine, 1904.

Frederick; cove, at the head of Moira sound, western shore Clarence strait, soutbeastern Alaska, near latitude $55^{\circ}$, longitude $132^{\circ} 16^{\prime}$. Local navigator's' name, reported by Fassett, Bureau of Fisheries, 1904.

Frederick, harbor; see Hooniah.

Frederick; lake, between Kasawa and Dezadeash lakes, in longitude $137^{\circ}$. So named by Glave, 1890, after his dead brother. Adopted by the Geographic Board of Canada.

Frederick; point, on the northeastern shore of Mitlof island, Alexander archipeligo. So named by Thomas, 1887.

Frederick; port (Port Frederick), in the northern end of Chichagof island, Icy strait, Alexander archipelago, near latitude $58^{\circ} 05^{\prime}$, longitude $136^{\circ} 30^{\prime}$. So named by Vancouver, 1794. According to Meade its native name is. Komtok Hon.

Frederick; sound, separating the Admiralty island group from the Kupreanof island group, Alexander archipelago. Named Prince Frederick's sound by Vancouver, 1794 (III, 285), after His Royal Highness Frederick, Duke of York, a name now shortened to Frederick.

Frederika; glacier, tributary to Skolai creek from the north. So named by Hayes, 1891, presumably. after Frederick Schwatka, with whon he visited it.

Freemantle; point, the western point of entrance to Port Valdez, Prince William sound, near latitude $60^{\circ} 56^{\prime}$, longitude $146^{\circ} 56^{\prime}$. Named by Vancouver, 1794, who on his chart has freemantle and in his text Fremantle. In the eighth edition of his voyage, 1801 , it is Freemantle in both text and chart.

Free Silver; gulch, on the right bank of Buckskin creek, an affluent of South fork Fortymile creek, near latitude $64^{\circ} 10^{\prime}$, longitude $142^{\circ}$. Prospectors' name, from map in Coast Survey archives drawn by E. F. Ball, a prospector, 1898.

French; creek, Seward peninsula, tributary on north bank of East fork Solomon river, near latitude $64^{\circ} 42^{\prime}$, longitude $164^{\circ} 05^{\prime}$. Prospector's' name, from Gerdine, 1900 .

French; creek, Seward peninsula, tributary to Holtz creek from the south, near latitude $65^{\circ} 30^{\prime}$, longitude $162^{\circ} 30^{\prime}$. Prospectors' name, obtained by Witherspoon, 1903.

Frronchman's, bay; see Lituya.

Freshwater; bay or inlet, on the eastern shore of Chichagof island, Chatham strait, Alexander archipelago. Nichols says (Coast Pilot, 1891, p. 163) : "Pavlof harbor was sketched by Meade, 1869, and published as a subsketch on Hydrographic Office chart 225, under the name of Freshwater bay ; this latter name is now applied to the whole inlet." It was called Novaia (new) by Vasilief, in 1848, and New harbor on British Admiralty chart 2431 (ed. of 1882). See also Pavlof. 
Freshwater; creek, tributary to Mitchell bay, Kootznahoo inlet, Admiralty island, Alexander archipelago. So named by Meade, 1869.

Fresno; creek, Kenai peninsula, on the west bank of Canyon creek opposite Mills creek. Prospectors' name, from Becker, 1895, but misplaced on his map.

Frezas, Laguna de las; see Strawberry.

Friday; creek, in the Kantishna region, on the east (right) bank of Moose creek, a left branch of Bearpaw creek; near latitude $63^{\circ} 30^{\prime}$, longitude $150^{\circ} 30^{\prime}$. So named by prospectors in 1905 , and reported by Prindle.

Friday; creek, eastern Alaska, on the north bank of Seventymile creek, near latitude $64^{\circ} .55^{\prime}$, longitude $143^{\circ}$. Prospector's name, from sketch map compiled by Major Glassford, Signal Corps, U. S. A., 1905.

Fripo; islet, in Danger passage, between Duke and Mary islands, Alexander archipelago. So named by Nichols, 1883.

Fritz; cove, in the western end of Douglas island, Alexander archipelago. Named, in 1880, by Symonds, after his son Fritz.

Fritz; creek, Kenai peninsula, tributary from the north to Kachemak bay about (; miles north of Homer. Local name, obtained by Stone, 1904.

Fritz; islet, in the Japonski group, Sitka sound. Named by naval officers, 1880, after little Fritz, son of Lieut. F. M. Symonds, U. S. N.

Frocallero, strait; see Trocadero.

Irog; rocks; see Hog.

Frogs (The); group of rocks and islets in Port Real Marinia; Bucareli bay, Prince of Wales archipelago. Named Las Ranas (the frogs) by Maurelle and Quadra, 1775-1779.

Frost; creek, Seward peninsula, tributary to West fork Noxapaga river near its mouth, abont latitude $\left(65^{\circ} 35^{\prime}\right.$, longitude $164^{\circ} 05^{\prime}$. Prospectors' name, obtained by Gerdine, 1901.

Frosty; peak $(5,820$ feet high), on eastern shore of Morzhovoi bay, near the western end of Alaska penınsula, about longitude $162^{\circ} 52^{\prime}$. So named by Dall, 1882.

Frozen, bay ; see Cold.

Fruit; small group of islets in the Japonski group, Sitka sound, Alexander ,archipelago. So named by United States naval officers, 1880 .

Fry; island, in Koyukuk river, left bank, near latitude $65^{\circ} 50^{\prime}$, longitude $155^{\circ}$. The channel here lies between Fry island and the Florence group of islands. Probably river pilots' name, reported by Lieutenant Camden, Revenue-Cutter Service, 1900.

Fryingpan; creek, eastern Alaska, small tributary on north bank of Birch creek, near latitude $65^{\circ} 20^{\prime}$, longitude $145^{\circ} 35^{\prime}$. Prospector's' name, reported by Witherspoon; 1905.

Fugitive. Lisianski, 1805 (Voyage, p. 178), mentions a "thriving village" of this name on Sitkalidak island, Kodiak group. It appears to have been on or near the Port Hobron of recent maps.

Fula; point, on Suemez island, Bucareli bay, Prince of Wales archipelago. Named Punta de Fula by Maurelle and Quadra, 1775-1779.

Full; creek, tributary from the north, to Port Valdez, Prince William sound. So named by Abercrombie, 1898.

Fulton; creek, in the St. Elias region, Southern Alaska, 6 miles east of Cape Yaktag, Gulf of Alaska, near longitude $142^{\circ} 15^{\prime}$. Named after: Walter S. Fulton, one of the first to locate oil lands at Cape Yaktag. and reported by Martin, 1903.

Fulton; peak $(3,252$ feet high), on the mainland, northeast of Frederick sound, southeastern Alaska. So named by Thomas, 1887, after the distinguished engineer, Robert Fulton. 
Funny; river, Kenai peninsula ; a southern tributary of Kenai river, near longitude $150^{\circ} 55^{\prime}$. Name from Moffit, 1904.

Funter; bay, in Admiralty island, near the south end of Lynn canal, about latitude $58^{\circ} 15^{\prime}$, longitude $134^{\circ} 55^{\prime}$. Named by Dall, 1883, after Capt. Robert Funter, one of the very early explorers and surveyors of the northwest coast of America.

Funter; post-office (established 1902), southeastern Alaska, on Funter bay, Admiralty island, at mouth of Lynn canal:

Fur Seal, islands; see Pribilot.

Gable; mountain (4,490 feet high), at the head of Glacier bay, southeastern Alaskí. So named by Reid, 1892.

Gaff; rock (30 feet high), on north side of the entrance to Port Althorp, eastern side of Cross sound, near latitude $58^{\circ} 11^{\prime}$, longitude $136^{\circ} 25^{\prime}$. So named by Pritt, 1901.

Gagalgin, island; see Egg.

Gagara, rocks; see Arre.

Gagarin, island; see Loon.

Gage; island, in Prince William sound, 100 miles southwest of Valdez. Has been occupied since 1896 as a fox farm. Probably somewhere near Flemming island or between Flemming and Knight islands. Nime taken from Report of Secretary of Interior, 1903, p. 281. Not found on any map.

Gain; island, in Gambier bay, Admiralty island, Alexauder archipelago. So named by Mansfield, 1889. Erroneously Cain.

Gakona; post-office (established Januiry, 1906), on Copper river at the mouth of Gakona river.

Gakona; river, tributary to Copper river from the west, near latitude $62^{\circ} 30^{\prime}$. Native name from Allen, 1885, who writes it Gakona, i. e., Gako river.

Galankin; group of islands, between Eastern chamnel and Middle channel, Sitka sound, Alexander archipelago. Name apparently first applied by Dall in the Coast Pilot, 1883. About a dozen islands in the group have been named, the largest of which are Galankin, Whale and Bamdoroshni.

Galankin; island, the principal island in the Galankin group, Sitka sound, Alexander archipelago. So called by Tebenkof, 1850. Was also called Peschani (sandy) by Vasilief, 1809. Has also been called Thompson island by Beardslee, 1880, after the then Secretary of the Navy. The name is derived from Galanka, the Russian name of their brick stove.

Galena; bay, near Port Valdez, Prince William sound. Local name. "Supposed to be named from the occurrence of galena on its shores."

Galera; island, in Bucareli bay, Prince of Wales archipelago. Named La Galera (the gallery) by Maurelle and Quadra, 1775-1779.

Galiano; glacier, near the head of Yakutat bay. So named by Russell, 1891, after Don Dionisio Alcala Galiano, the reputed writer of the report on Malaspina's voyage.

Galsovia, native village; see Golsova.

Cialtzora, village; see Golsova.

Galvin; creek, Seward peninsula, tributary to Kougarok river, from east, near latitude $65^{\circ} 35^{\prime}$, longitude $164^{\circ} 40^{\prime}$. Local name, obtained by Gerdine, 1901:

Gambell; native village, of 300 to 400 Eskimos, on St. Lawrence island, Bering sea, near the northwest cape-Cape Chibukak. It contains a Government school established in 1891, a Presbyterian mission established in 1892. Named in honor of Mr. and Mrs. W. C. Gambell, missionaries 
Gambell-Continued.

and tecchers, on St. Lawrence island from 1894 to 1898 , and who were lost in the schooner Jane Grey. The Eskimo name of the village is Chibukak, variously written Tchibukak, Tchiboukoukak, Seevookak, Sivukuk, etc.

Gambier; bay, in Admiralty island, Stephens passage, Alexander archipelago, near latitude $57^{\circ} 28^{\prime}$, longitude $134^{\circ}$. So named by Mansfield, 1889 .

Gambier; island, at entrance to Gambier bay, Stephens passage, Alexander archipelago. So named by Mansfield, 1889.

Gambier; point, the eastern point of entrance to Gambier bay, Stephens paspassage. Alexander archipelago. So named by Vancouver, 1794.

Gamdil; creek and mountain; see Gandil.

Game; cove, near Marsden point, Admiralty island, near the north end of Chatham strait, Alexander archipelago. So named by Baker, 1880, on account of the abündance of game there.

Game; creek, Seward peninsula, in Niukluk valley, tributary to American creek from the southeast, near latitude $64^{\circ} 58^{\prime}$, longitude $164^{\circ} 22^{\prime}$. Prospectors' name, from Gerdine, 1905.

Game; point and creek, on the east side of Port Frederick, south shore Icy strait, Alexander archipelago, near latitude $58^{\circ} 05^{\prime}$, longitude $135^{\circ} 30^{\prime}$. So named by Dickins, 1901.

Gandil; creek, tributary to Bering river from the east, and mountain 6 or 7 miles north of Controller bay. Erroneously Gamdil. Prospector's' name, obtained by both Martin and Pratt, 1903.

Gannet; island, in Boca de Quadra, at the mouth of Vixen bay, Alexander archipelago. So named by the Coast Survey in 1891 .

Gan-te-gas-tak-heh; Indian village, consisting, in 1867, of 12 large houses and, in 1880 , of 16 houses and 171 people, at mouth of the Chilkat river, southeastern Alaska. Variously called Tondustek, Yendestaka, etc. The name obtained by Baker, in 1880, from an Indian interpreter, was Giante-gas-tak-heh, meaning village on right bank of river. Beardslee, 1.880, has Tondustek; Krause, 1882, Jendestaka, and the Eleventh Census, 1890, Hindasetukee.

Gaolsovia, village, river, etc.; see Golsova.

Gap; mountain $(3,400$ feet high), on the mainland, west of the mouth of Portland canal. Presumably so named by Pender, 1868.

Garbotch, rookery; see Gorbatch.

Garcia; island and point, on the northwestern coast of San Fernando island, Gulf of Esquibel, Prince of Wales archipelago. Named Ysla y Punta de Garcia by Maurelle and Quadra, 1775-1779.

Garden; cove, near the head of Port Etches, Prince William sound. So named by Davidson, 1869.

Garden; cove, on the eastern shore of St. George island, Pribilof islands, Bering sea. Local name. Origin not discovered. Published by the Coast Survey in 1875. According to Putnam, the Aleut name is Krä'känkring'a (facing the east).

Garden; island, in Garden cove, Port Etches, Prince William sound. So named, in 1787 , by Portlock, who, in that year, made a garden upon it.

Garden, island; see. Kutkan.

Garden; point, at the mouth of Indian river, Sitka harbor. Descriptive name, published by the Coast Survey in 1891.

Gardiner; creek, tributary to Tanana river from the north, near longitude $141^{\circ}$ 30'. So named by Peters and Brooks, 1898, after L. D. Gardiner, a - member of their party. Erroneously Gardner on the maps. 
Gardiner; lake, at the head of Anvik river, east of Norton sound, near latitude $63^{\circ} 30^{\prime}$. Prospector's' name, published in 1900 .

Gardner; bay, indenting the southeastern shore of Prince of Wales island, Clarence strait, Alexander archipelago. So named by Kupreanof, 1848. Also called Port Gardner.

Gardner; point, the southernmost point of Admiralty island, Alexander archipelago. So named by Vancouver, 1794.

Gareloi; volcanic island and peak thereon $(5,334$ feet high), near the western end of the Andreanof group, middle Aleutians. Named Gareloi (variously written Goreloi, Gorely, Gorelloi, etc., i. e., burnt, or burning) by early Russian explorers. Its Aleut name, according to Tebenkof, is Anangusik.

Garfield; bay; on the northern shore of Alaska peninsula. So named by the

- Fish Commission, 1888, after President James Abram Garfield.

Garfield; creek, tributary to Kuzitrin river, from the north, Seward peninsula. Name from Brooks, 1900.

Garfield; peak (3,929 feet high), on the mainland, north of Frederick sound, southeastern Alaska. Named by Thomas, 1887, after President Garfield.

Garfield, point; see Lieskof.

Garforth; island, in Muir inlet, Glacier bay, southeastern Alaska. Apparently so named by the British Admiralty in or about 1890 .

Garnet; creek, on the right bank of upper Anvik river, east of Norton sound, near latitude $63^{\circ} 20^{\prime}$. Prospector's' name, published in 1900 .

Garnet; creek, tributary to the Yukon. The second large creek from the south,

.. below Rampart. It heads opposite Ruby creek, a tributary of Minook creek. Reported and described by Prindle in 1904.

Garnet; creek, in the Koyukuk region, tributary to Bettles river fiom the south, near latitude $67^{\circ} 30^{\prime}$, longitude $149^{\circ} 30^{\prime}$. Prospector's' name, obtained by Peters and Schrader, 1901.

Garnet; point, the southernmost point of Kannaghunut island, Dixon entrance. So named by Nichols in 1883. Erroneously Garnot.

Garnet; point, the southwesternmost point of Choris peninsula, Kotzebue sound, Arctic ocean. So called by Beechey in September, 1827.

Garns, point; see Harris.

Garrett; peak (5,700 feet high), between Valdez glacier and Klutina lake. So named by Abercrombie, 1898, after Private Garrett, a member of his party.

Garrison; glaciers, at head of Kicking Horse river, near the head of Chilkat Inlet, southeastern Alaska. So named by Dall in the Coast Pilot, 1883,

Garry; river, emptying into the Arctic ocean near Cape Halkett. So named by Dease and Simpson, 1837, after Nicholas Garry, esq.

Gas; rock, on the south side of Davidson inlet and the east side of the entrance to Port Alice, Prince of Wales archipelago, near latitude $55^{\circ} 50^{\prime}$, longitude $133^{\circ} 34^{\prime}$. So named by Dickins, $1903-4$.

Gassman; creek, tributary to Eldorado river from the east, Seward peninsula. Name from Barnard, 1900.

Gastineau; channel, between Douglas island and the mainland, southeastern Alaska. So named on Homfray's manuscript map of 1867 , furnished to the Western Union Telegraph Company, the name being derived from one of the Hudson Bay Company's steamers, which in turn took its name from the Gastineau or Gatineau river of Quebec, a branch of the Ottawa. Has also been designated Gastineaux channel, Icy channel, and Carroll straits. 
Gastineau, point; see Hobart.

Gates; glacier, an arm of Kennicott glacier, on the southern flank of Mount Regal. So named by Schrader, 1899, after Mr. Gates, a sojourner in the vicinity.

Gatherer; rock, on Hanks shoal, north shore Orca bay, Prince William sound, near latitude $60^{\circ} 36^{\prime}$, longitude $145^{\circ} 55^{\prime}$. So named by Ritter, 18991903, after the ship Gatherer, wrecked here.

Gauge; island, near the middle of Funter bay, Admiralty island, Alexander archipelago. So named by Mansfield, 1890.

Gavanski, islet; see Little Gavanski.

Gavanski, peak; see Harbor.

Gavanski; two islands (Big and Little Gavanski), immediately in front of Old Sitka harbor, Sitka sound, Alexiunder archipelago. Named Gavanski (harbor) by the earliest Russian visitors.

Gavanstii Bolshoi; see Big Gavanski.

Gavarushka, lake, St. George island; see Govorushka.

Gawanka; brook, draining from a lake into Chichagof harbor, Attu island, western Aleutians. So called by Grewingk, 1850 .

Gay; creek, Seward peninsula, tributary from the southeast to Tuttle creek, near latitude $65^{\circ} 54^{\prime}$, longitude $166^{\circ} 25^{\prime}$. Prospectors' name, obtained by. Gerdine, 1901.

Gechiak; creek, tributary to the Togiak river from the west, a few miles above the mouth of the latter. Native name obtained by spurr and Post in 1898. An Eskimo village at its mouth is called Gechiagamut, i. e., Gechiak people.

Gedney; channel, at the western entrance to Fort Frederick, south shore Icy strait, Alexander archipelago, near longitude $135^{\circ} 30^{\prime}$. Sounded in 1901 by Dickins, who named it ifter his vessel, the Coast Survey steamer: Gedney.

Gedney; harbor, in the southwest shore of Kuiu island, east side Chatham strait, near latitude $56^{\circ} 23^{\prime}$, longitude $134^{\circ} 15^{\prime}$. Named after the Coast Survey steamer Gcdney, from which a reconnaissance of the harbor was made in 1899 and 1900.

Gedney; island, in the northwestern part of Behm canal, Alexander archipelago. So named by the Coast Survey, 1891, after one of its vessels.

Gedney; passage, between Hassler and Revillagigedo island, in Behm canal, Alexander archipelago. So named by the Coast Survey, 1891.

Geese; islands, off the southwestern end of Kodiak. Farly Russian maps have the native name Anaiaktak and Anaiaktalik. Archimandritof, in 1849, has Gusinaia (goose). Petrof, 1880, calls it Goose island, and shows a native settlement upon it called Aiakhatalik. Now usually called Geese islands. According to the Eleventh Census they were called Geese islands by the Russians under Solovief, 1762. This must be an error, as the first visit of Russians to Kodiak was in 1763, under Glotof.

Gegarka, rocks; see Arre.

Gehoenda; creek, tributary from the southeast to Chisana river, latitude $62^{\circ}$ $05^{\prime}$, longitude $142^{\circ} 10^{\prime}$. Native name, reported by Witherpoon, 1902.

Geikie; glacier and inlet, western shore of Glacier bay, southeastern Alaska, erroneously Geike. Exploring this inlet in 1879, Muir found it headed by a tidal glacier, to which he gave the name Geikie, after Sir Archibald Geikie. In 1892, Reid found that its front had receded so far as to convert its two branches into distinct glaciers. Retaining the name Geikie for the more northerly, he called the other Wood glacier.

Geissen, mountain; see Ripinski. 
Gèlch. The Krause brothers, in 1882 , report this to be the native name of a hill between the heads of Chilkat and Chilkoot inlets, southeastern Alaska.

Gem; point, the eastern point of entrance to Snug cove, Gambier bay, Admiralty island, Alexander archipelago. So named by Mansfield, 1889.

Genaenda; creek, near the source of Chisana river, tributary to Gehoenda creek from the right, near latitude $62^{\circ}$, longitude $142^{\circ}$. Native name, reported by Witherspoon, 1902.

Gens de Large, lake and river; see Chandlar.

Qens des Buttes, river; see Tanana.

Genunam, island; see Seguam.

George; inlet, in the southern shore of Revillagigedo Island, Alexander "archipelago. Named George arm. or inlet by the Coast Survey, in 1880, after pilot W. E. George, to whom is due the first sketch of Revillagigedo channel and longass natrows.

George; islands and the largest island in the group, in entrance to Port Althorp, Cross sound, Alexander archipelago, near latitude $58^{\circ} 12^{\prime}$, longitude $136^{\circ} 23^{\prime}$. So named by Dall, 1880 .

George; mountains (3,225 feet high), east of Portland canal and west of Fastings arm, British Columbia. Perhaps so named by Pender in 1.868 .

George; reef, nealr Skowl point, in Kasaan bay, Prince of Wales island, Alexander archipelago. Apparently so named by the Coast Survey, 1.883, after pilot W. E. George.

George; rock (covered at spring tide), off the western end of Douglas island, Stephens passage, Alexander archipelago. So named by Beardslee, 1880, presumably.after pilot W. E. George.

George Simpson, cipe; see Simpson.

Georgiana; cape, the northwestermmost point of: Kruzof island, Salisbury sound, Alexander archipelago. So named by Portlock, 1.787. Called Siuchi (sea lion) by Vasilief in 1833, and Olga by Tebenkof in 1848. Also bas been written Siouchi.

Gerard; point, on the mainland, north point of entrance to Bastern passige, southeastern Alaska, near latitude $56^{\circ} 30^{\prime}$, longitude $132^{\circ} 20^{\prime}$. Local name, reported by Moser, 1900.

Geroe; creek, tributary to Chandlar river" from the south, near latitude $68^{\circ}$. Local name, reported by Schrader, 1899.

Gerries; run, eastern Alaska, on west bank of the North fork Fortymile creek, just north of Middle fork, near latitude $\left(44^{\circ} 30^{\prime}\right.$, longitude $142^{\circ} 10^{\prime}$. Prospectors' name, from sketch map compiled by Major Glassford, Signal Corps, U. S. A., 1905.

Gerstle; bily, indenting the northern shore of Alaska peninsula, west of Port Moller. Named by the Fish Commission, 1888, after Lewis Gerstle, president of the Alaska Commercial Company.

Gerstle; point, the northern point of entrance to Gerstle bay, Alaska peninsula. Named by the Fish Commission, 1888, after Lewis Gerstle, president of the Alaska Commercial Company.

Gerstle; river, tributary to Tanana river from the south, near longitude $145^{\circ}$. So named by Allen, 1885, after Lewis Gerstle, president of the Alaska Commercial Company.

Gertrude; creek, tributary from the west to Slana river, near its junction with the Copper river. So named by Lowe, 1.898, after Miss Gertrude Wagner.

Bull. $299-06 \mathrm{M}-18$ 
Ghownarhar; creek, southeastern coast of Alaska, having a lake source, midway between Icy point and Harbor point, near longitude $137^{\circ} 30^{\prime}$. Indian name, reported by Moser, 1901, who wrote Ghow-nar-har.

Giant, island ; see Grant.

Giant; point, the northernmost of Mary island and the western point of entrance to Mary island anchorage, Mary island, Gravina group, Alexander archipelago. Named by Nichols, 1883. Formerly, called Winslow point, which name is now transferred to the eastern point of entrance to Mary island anchorage. See Winslow.

Giant; rocks, in Port Valdez, Prince William sound. So named by Albercrombie, 1898.

Gibbon, fort; see Fort Gibbon.

Gibson; creek, tributary to Dietrich river, from the west, near latitude $68^{\circ}$. Local name, reported by Schrader in 1899.

Gibson; island, near the entrance to Chichagof harbor, Attu island, western Aleutians. Named by the North Pacific surveying expedition of 1855 , after Lieut. William Gibson, U. S. N., commanding the U. S. schooner Fenimore Cooper. Gibson surveyed Chichagof harbor in July, 1855.

Gilahịna; river, tributary to Chitina river from the north. Native name, from a manuscript map made by prospectors in 1900 .

Gilder Head; promontory, between Cape r'bomas and Zanes cliff, on the western end of Wrangell island, Arctir scean. Apparently so named by the Coast Survey, 1890.

Giliskonkok; creek, tributary to Yentna river from the left, 5 miles above the Kichatna, near latitude $62^{\circ}$, longitude $151^{\circ} 45^{\prime}$. Native name, obtained by Herron, 1899, who wrote Gil-is-kon-kok.

Gillett; pass, in the Mentasta mountains, about longitude $144^{\circ}$. Named after Edward Gillett, civil engineer with Abercrombie in 1899.

Gillette; creek, Seward peninsula, tributary to Little Garfield creek from the west, near latitude $65^{\circ} 30^{\prime}$, longitude $164^{\circ} 20^{\prime}$. Prospector's' name, obtained by Gerdine, 1901.

Gillman; creek, eastern Alaska, tributary to 'Trout creek, on the south bank of Yukon river, near latitude $65^{\circ}$, longitude $141^{\circ} 40^{\prime}$. Frospectors' name, from sketch map compiled by Major Glassford, Signal Corps, U. S. A., 1905.

Gillmore; islands, part of the Galankin group, Sitka sound, Alexander archipelago. Named Gilmore by Beardslee, 1880, after Ensign James C. Gillmore, U. S. N.

Gilmer; bay, inside Point Amelia, western shore Kruzof island, Alexander archipelago, near latitude $57^{\circ}, 15^{\prime}$, longitude $135^{\circ} 48^{\prime}$. Named by Moore, 1897 , after Lieut. William Wirt Gilmer, U. S. N.

Gilmer; cove, in the northeastern shore of Partofshikof island, opening into Neva strait, Salisbury sound, Alexander archipelago, near latitude $57^{\circ}$ $18^{\prime}$, longitude $135^{\circ} 38^{\prime}$. Named by Moore, 1897, after Ensign W. W. Gilmer, U. S. N., a member of his party.

Gilmore; creek, in the Fairbanks region, tributary to the headwaters of Goldstream creek, near latitude $65^{\circ}$, longitude $147^{\circ} 30^{\prime}$. Local name, obtained by Gerdine, 1903.

Gilmour. The north point of entrance to Port Chalmers, Montague island, Prince William sound, is so designated on a sketch by Portlock in 1787. Gines, river; see Hines and Stuhinuk,

finiak, islet; see Ugak. 
Girdled; glacier; on the eastern border of Muir glacier, southenstern Alaska. So named by Rejd, 1890 , on account of the moraine, which completely surrounds it.

Gisasa; river, tributary to the Koyukuk, from the west, near latitude $65^{\circ}$. Na. tive name, reported by Allen in 1885. In bis text (p. 106) it is Gissassalkakat; on his map 4 it is Gissakakat. See Kakat.

Glacier; bay, penetrating the Alaska mainland in the Fairweather region and opening into Icy strait, near longitude $136^{\circ}$. Entered by Lieut. Charles I. S. Wood in 1877 , explored by John Muir in 1879, and named by Beardslee in 1880 . Descriptive name.

Glacier, bay, Prince William sound ; see Columbia.

Glacier; creek, Kenai peninsula, tributary to the head of Tustumena lake from the west, near longitude $150^{\circ} 20^{\prime}$ : Local name, from Moflit, 1904.

Glacier; creek or river, tributary to the head of Turnagain arm, Cook inlet, from the southeast, near latitude $61^{\circ}$, longitude $149^{\circ} 10^{\prime}$. Descriptive nime, from Glenn, 1898 .

Glacier; creek, tributary' to Turnagain arm of Cook inlet from the north, near latitude $61^{\circ}$, longitude $149^{\circ} 20^{\prime}$. Locil name, from Mendenball, 1898 .

Glacier; creek, in the Kantishna region, a left branch of Bearpaw creek, near latitude $64^{\circ}$, longitude $150^{\circ}$. So named by prospectors in 1905, and reported by Prindle.

Glacier; creek, Seward peninsula, tributary to Kiwalik river from the west, near latitude $65^{\circ} 40^{\prime}$, longitude $162^{\circ}$. Frospectors' name, obtained by Witherspoon, 1903.

Glacier; creek, 7 miles north of Nome, Seward peninsula, tributary to Snake river from the east, near longitude $165^{\circ} 25^{\prime}$. Prospectors'. name, published in 1900 .

Glacier; creek, tributary to Imuruk basin from the south, Seward peninsula. Name from Barnard, 1900.

Glacier; creek, tributary to the south fork of Chena river, latitude $64^{\circ} 40^{\prime}$, longitude $146^{\circ} 30^{\prime}$. Local name firom Gerdine, 1903 .

Glacier; creek, tributary to the Yukon from the north, 16 miles below Rampart (city) near longitude '150\% $35^{\circ}$ '. River pilots' name, taken from Edwards's Track Chart of the Yukon, 1899.

Glacier; creek, eastern Alaska, tributary on the east bank of Beiver creek, an attluent of Yukon river from the south, near longitude $147^{\circ}$. Prospectors' name, reported by Lieutenant Erickson, U. S. A., 1902.

Glacier; creek, tributilly to Sixtymile creek from the west, near longitude $147^{\circ}$. Local natme.

Glacier; creek, a small tributary of Fortymile creek from the left, near the international boundary. Local descriptive name (probably from a small transient glacier at its head), from mal in Coast Survey archives, drawn by E. F. Ball, 1898.

Glacier; creek, in the Porcupine gold district, southeastern Alaska, tributary to Klehini river from the south, near longitude $136^{\circ} 20^{\prime}$. Local name, published by the Coast Survey in 1900 .

Glacier; creek, tributary to South fork Koyukuk river from the north, near latitude $67^{\circ} 15^{\prime}$, longitude $149^{\circ} 30^{\prime}$. Prospector's' name, reported by Feters and Schrader, 1901.

Glacier, inlet; see Taku.

Glacier; island, off Columbia bay, on the northern shore of Prince William sound, near latitude $60^{\circ} 55^{\prime}$, longitude $147^{\circ}$. So called by Abercrombie, 1898. Has been occupied since 1900 for the propagation of blue foxes. 
Glacier; mountain (about 6,000 feet high), 18 miles west of Tagle, eastern Alaska. Presumably a local name, published. by the Geological Survey in 1899 .

Glacier; mountain (4,769 feet high), on the western bank of Stikine river, near Great glacier.

Glacier; mountains, east of Stikine river, near the international boundary line. Dall, in the coast Pot (1883, p. 111), says: "The miners term the rugged region of this vicinity the Glacier mountains." Also called Stikine mountains.

Glacier; point, on the western shore of Portland canal, near its head, southeastern Alaska. So named by the Coast Survey.

Glacier; point, in front of Davidson glacier, Chilkat inlet, Iynn canal, Alexander: archipelago. So called by Meade, 1869. Lindenberg, 1838, called it Lohtianoi (icy) point.

Glacier; point, on the north bank of the Matanuska river, near Matanuska glacier and latitude $61^{\circ} .45^{\prime}$, longitude $147^{\circ} 30^{\prime}$. Descriptive namé, given by Mendenhall, 1898 .

Glacier; river, in the western part of Copper River delta, draining Sheridan glacier. So named by Ritter in 1898. Schrader, 1900, called it Sheridan river.

Glacier; spit, in front of Grewingk glacier; Kachemak bay, Cook inlet. .So named by Dall, 1880.

Glacier, valley; see Makushin.

Glacier Cone; mountain peak, on Kenai peninsula, near Kachemak bay, Cook inlet. So named by Dall, 1880.

Gladhaugh; bay, indenting the northeastern coast of Prince William sound. An iron and copper mine was found and staked here by a Mr. Gladhaugh in 1897. It is also known locally as Virgin bay.

Gladkie, islet; see Flat.

Gladstone; mountain (4,800 feet high), near the head of Portland canal. Named by Fender, 1868, after the Right Hon. William Wwart Gladstone.

Gladys; gulch, on the south side of Chititu creek. Prospectors' name, taken from map of Nizina mining district by 'George M. Esterly, of Valdez, 1902.

Gladys; small lake, in the valley of Matanuska river, about 85 miles from Knik ar'm of Cook inlet. So named by Mendenhall, 1898 .

Glagolm; islets, near the entrance to Redoubt bay, Sitka sound, Alexander archipelago. So called by Vasilief, 1809.

Gla-luuts, island; see Kochu.

Glass; peninsula, between Seymour canal and Stephens passage, Alexander archipelago. Named by the Coast Survey, after Commander Henry Glass, U. S. N., who made surveys in the Alexander archipelago in 1881.

Glass; point, on the eastern shore of Glass peuinsula, Alexander archipelago. So named by the Coast Survey.

Glass; point, on the left bank of Chilkat river, opposite the moutli of Tlebini river, southeastern Alaska. Named by naval officers, 1880, after Commander Henry Glass, U. S. N.

Glave; river, tributary to Chilkat river, from the west. Named by the Geological Survey, in 1899, after Mr. E. J. Glave, who explored in this region in 1891. According to Wright, 1903, the stream locally called Glave creek is in British territory and on the north bank of Klehini river, the same apparently that Krause brothers, 1882, called by its Indian name Seltathín (Seltat river). 
Glazenap; cape, the western point of entrance to Izembek bay, on northern shore of Alaska peninsula, near longitude $162^{\circ} 58^{\prime}$. So named by Lutke, 1828 , presumábly after two midshipmen, Vladimir Glazenap and Gotlieb Glazenap, members of his party. Has also been called Round point by the Fish Commission.

Glen; creek, in the Kiantishna region, on the east (right) bank of Moose creek, near Jatitude $63^{\circ} 30^{\prime}$, longitude $150^{\circ} 30^{\prime}$. Descriptive name, given by prospectors in 1905 , and reported by Prindle.

Glen; island, the westernmost of the Kudlakof islands, Izembek bay, north shore Alaska peninsula, near longitude $162^{\circ} 54^{\prime}$. So named by the Fish Commission, 1888.

Glen; telegraph station, 30 miles south of Rampart on the divide between Baker and Minook creeks. So named by the Signal Corps, U. S. A., 1903.

Glenn; creek, small tributary of Yukon river from the south, about 9 miles above Washington creek, near longitude $142^{\circ}$. Local name, reported to Collier by E. J. Chamberiain, deputy mineral surveyor at Eagle, 1902. Logan creek of Witherspoon, 1905, appears to be the same. See Logan.

Glenn; creek, flowing south to Baker creek or sinking in the flats along Tanana river, near latitude $65^{\circ}$, longitude $150^{\circ} 10^{\prime}$. Local name, obtained by Priridle, 1904.

Glenn; lalie, drained by Twentymile river into the head of Turnagain arm of: Cook inlet, near latitude $61^{\circ}$, longitude $149^{\circ}$. Named, 1898 , after Cant. Edwin F. Glenn, U. S. A.

Glenora; small town, at head of steam navigation on the Stikine river, near mouth of Great canyon, British Columbia.

Glorious; high point, near I'innacle pass, in the St. Elias alps. So named by Russell, 1890, on account of the view it affords.

Glory of Russia. An extinct Russian penal colony established, in 1795, near: Ankau creek, on the southeastern shore of Yakutat bay. It has been referred to as the Yakutat colony or settlement, New Russia, Novarassi, Slavarassi, Slawa Rossij, etc. Presumably named after Billings's vessel the Slava Rossie (Glory of Russia). The history of the place is very obscure. It appears to have been founded in $\mathbf{1 7 9 5}$, fortified with a blockhouse and stockadê by Polomoshnoi in 1796, and in perpetual trouble ever after till exterminated by the natives in about 1803 or 1804 . Russell visited the site in 1.891, and reports that the cellars marking the site contain spruce trees, some of them 2 feet in diameter.

Glory of Russia, bay; see Tanaga.

Glory of Russia; cape, the northwestern point of St. Matthew island, Bering sea. So named by the Russian Hydrograpinic Oftice after Billings's ship, the slava Rossie (Glory of Russia).

Glubokoi, bay; see Banner.

Glubokoi, bay ; see Partof.

Glubokoi, bay, inlet, lake, etc. ; see Deep and Deepwater.

Gnat; cove, on the eastern shore of Carroll inlet, Revillagigedo island, Alexander archipelago. So named by the Coast Survey, 1891.

Goat; gulch, Copper River region, on the north side of Young creek, which in turn is tributary to Nizina river. Prospectors' name, first appears on map by George M. Esterly, of Valdez, 1902.

Gobler; creek, tributary to Livingston creek from the south, Seward peninsula. Name from Barnard, 1900.

Godfrey; fork of Charley river, eastern Alaska, near latitude $65^{\circ}$, longitude $163^{\circ} 30^{\prime}$. Prospector's' name, on some maps applied to the upper part of 'Charley river, but said not to be known locally. 
Godwin; river, Kenai peninsula, on the west shore of Resurrection bay, near its head, about longitude $149^{\circ} 20^{\prime}$. Local, name, obtilined by Moffit, 1904 .

Gokachin; river, on Revillagigedo island, Alexander archipelago, tributary to Thorne arm from the nortbeast, near latitude $55^{\circ} 21^{\prime}$, longitude $131^{\circ}$ 10'. Native name, from Brooks, 1901, who wrote Gokacheen.

Gold; creek, on the mainland, in edge of the town of Juneau, southeastern Alaska. Miners' name, published in 1883.

Gold; creek, on north shore Port Valdez, Frince William sound, near latitude $61^{\circ} 08^{\prime}$, longitude $146^{\circ} 25^{\prime}$. Local name, reported by Ritter, 1901 .

Gold; creek, tributary to Bluestone river from the east, Seward peninsulai. Name from Barnard, 1900.

Gold; creek, 7 miles north of Nome, Seward peninsula, tributary to Snake river from the east, near longitude $165^{\circ} 27^{\prime}$. Local name, published in 1904.

Gold; creek, 15 miles north of Nome, Seward peninsula, a small tributary from the west to Nome river, near longitude $165^{\circ} 18^{\prime}$. Prospectors' name, published in 1900 .

Gold, creek, 15 miles north of Nome; see Jorosa.

Gold; creek, Seward peninsula, tributary from the west to Grouse creek, near latitude $65^{\circ} 36^{\prime}$, longitude $167^{\circ} 30^{\prime}$. Prospectors' name, obtained by Collier, 1903.

Gold; creek, eastern Alaska, tributary on west bank to North fork Salcha river, near latitude $64^{\circ} 50^{\prime}$, longitude $145^{\circ} 30^{\prime}$. Prospectors's name, reported by Witherspoon, 1905 .

Gold; creek, tributary to Mosquito fork Fortymile creek from the north, near latitude $64^{\circ} 10^{\prime}$, longitude $142^{\circ} 20^{\prime}$. Prospectors' name, found on map iu Coaist Survey archives drawn by E. F. Ball, 1898.

Gold; creek, enstern Alaska, on the left bank of Butte creek, an affluent of North fork Fortymile creek from the northeast, near latitude $64^{\circ} 40^{\prime}$, longitude $142^{\circ}$. Prospectors' name, from sketch map compiled by Major Glassford, Signal Corps, U. S. A., 1905.

Gold; creek, tributary to Middle fork Koyukuk river from the east, near latitude $67^{\circ} 30^{\prime}$, longitude $150^{\circ}$. I'rospector's' name, reported by schrader, 1899.

Gold; gulch, Kenai peninsula, on the left bank of Resurrection creek, 6 miles above Hope city. Local name from Moflit, 1904.

Gold; gulch, 10 miles rorth of Cape Nome, Seward peninsula, draining into Osborn creek from the cast, near longitude $165^{\circ} 05^{\prime}$. Local name, published in 1904.

Gold; hill, a bluff on the right bank of Yukon river 15 miles below the mouth of Tozi river, near longitude $152^{\circ} 45^{\prime}$. 'This is 20 miles farther upstream than the Gold mountain of Allen. Name from Cantwell, 1900.

Gold; islet, southwest of Japonski island, Sitka sound, Alexander archipelago. So named by United States naval officers, 1880 .

Gold; mountain, on north bank of the Yulson, near longitude $153^{\circ} 30^{\prime}$. So named by Allen, 1885. Its native name is given by the Coast Survey as Nubkabllanny.

Gold; run, 16 miles northwest of Cape Nome, draining into New Bonanza creek at the head of Osborn creek, near longitude $165^{\circ} 13^{\prime}$. Local name, published in 1904.

Gold; run, Seward peninsula, tributary to. Kiwalik river from the west, near latitude $65^{\circ} 35^{\prime}$, longitude $162^{\circ}$. Prospectors' name, obtained by Witherspoon, 1903. 
Gold; run, tributary to American river, from the east, Seward peninsula, near latitude $65^{\circ} 40^{\prime}$, longitude $165^{\circ} 30^{\prime}$. Name from Brooks, 1900 .

Gold, run, Seward peninsulat ; see Cistle creek.

Gold; run, eastern Alaskil, on the south bank of Slate creek, tributary from the west to North fork Fortymile creek, about latitude $64^{\circ} 35^{\prime}$, longitude $142^{\circ} 50^{\prime}$. Prospector's' name, from sketch may compiled by Major Glisstord, Signal Corps, U. S. A., 1905.

Gold; run, draining the southern slope of the divide between Tanana river and the headwaters of Minook creek, near latitude $65^{\circ}$, longitude $150^{\circ} 10^{\prime}$. P'rospectors' name, obtained by Prindle, 1904.

Gold Bench; bar, on South fork Koyukuk river, near latitude $67^{\circ}$, longitude $150^{\circ} 30^{\prime}$. Discovered to be gold bearing in 1899 and worked. Name published, 1902 .

Goldbottom; creek, 20 miles north of Nome, Seward peninsula, draining the southern and western slope of Mount Distin, near latitude $64^{\circ} 45^{\prime}$. longitude $165^{\circ} 25^{\prime}$. Name from Barnard, 1900.

Goldbottom; creek, tributary to Niukluk river from the north, in the Eldorado mining district, Seward peninsula. Local name, published in 1900 .

Goldbottom; creek, tributary to Skookum river from the north, Seward peninsula. Name firom Barnard, 1900.

Goldbottom; creek, Seward peninsula, in Solomon River basin, tributary on south bank of Coal creek, near latitude $64^{\circ} 44^{\prime}$, longitude $164^{\circ} 12^{\prime}$. Prospectors' name, Goli Bottom, on a local map, 1904.

Gold Dust; creek, dritining the southwest slope of Mastodon dome and tributary to Birch creek neitr its source, ahout latitude $65^{\circ} 25$, longitude $145^{\circ} 30^{\prime}$. Prospectors' name, reported by Spurr, Goodrich, and schrader, 1896.

Golden, creek, branch of Beaver; see Victoria.

Golden; penk, just east of Mount Bendeleben, Seward peninsula. Local name, published by the Coast Survey in 1900.

Golden City; mining camp, in the Fairbanks region, situated on Ptarmigan creek, near latitude $65^{\circ}$, longitude $147^{\circ} 30^{\prime}$. Local name, obtained by Gerdine, 1.903.

Goldengate; creek, tributary to Kruzgamepa river from the west, Seward peninsula. Name from Bamard, 1900.

Goldengate; creek, debouching on the south shore of Seward peninsula, 1. miles west of Cape Nome, near longitude $165^{\circ} 03^{\prime}$. Local name, from Gerdine, 1904.

Goldpan; gulch, 5 miles northwest of Nome, Seward peninsula, on the east side of Snake river, near longitude $165^{\circ} 30^{\prime}$. Local name, published in 1904.

Gold Run; creek, Seward peninsula, tributary to Kougarok river from east, about 3 miles below the mouth of Taylor creek. Latitude $65^{\circ} 40^{\prime}$, longitude $164^{\circ} 45^{\prime}$. Prospectors' name, obtained by Gerdine, 1901.

Gold Run; creek, in the Fairbanks region, tributary to Goldstream creek from the north, near latitude $65^{\circ}$, longitude $147^{\circ} 40^{\prime}$. Local name, obtained by Gerdine, 1903 .

Gold Run; gulch, Copper River region, on the north side of Young creek, which in turn is tributary to Nizine river. P'rospectors' name, taken from map of Nizina mining district by George M. Esterly, of Valdez, 1902. .

Goldstream; creek, in the Tairbanks region, tributary to Tolovana river, near latitude $64^{\circ} 55^{\prime}$, longitude $147^{\circ} 50^{\prime}$. Local name, obtained by Gerdine, 1903. 
Golofnin; bay and sound, on north shore gf Norton sound, Bering sea. Discovered, in 1821, by Khromchenko, who named it after his vessel, the brig Golofnin, which in turn had been named after Capt. Vasili Mikhailovich Golofnin, of the Russian navy. In Roman letters this name has been written Golovnine, Golofnin, and Golovin. The Eskimo name is said to be Tatchik (bay). A large and shallow sound stretches inland from the bay. This inner bay the Russians, it is reported, called Sun Golovine or Golovine sound. The name Golofnin is here applied to both the inner part, the sound, and the outer part, the bay.

Golofnin, point; see Hope.

Golofnin; village, reindeer station and Presbyterian mission on the northeastern shore of Golofnin bay. A post-offict, Golovin, established here in 1900 was abolished in December, 1905.

Goloi; island, one of the Necker group, Sitka sound, Alexander archipelago. Named Goloi (bare) by Vasilief, 1809.

Goloi; island, between Inner Iliasik and Dolgoi islands, near Belkofșki, south shore of Alaska peninsula, near longitude $162^{\circ}$. Named Goloi (bare) by Veniaminof.

Goloi, island; see Rootok.

Goloi, island; see Kalibri.

Goloi, island; see Iong.

Goloi, island, point, etc.; see Bare.

Goloi: islands, in the northeastern part of Salisbury sound, Alexander archipelago. Named Goloi (bare) by the Russians.

Goloi, islands; see Passage.

Goloi: islet, near Kruzof island, in entrance to Sitka sound, Alexander archipelago. Named Goloi (bare) by Vasilief, 1809.

Goloi, islet; see Bushtop.

Golovi, cape; see Head.

Golora, cape; see Mountain.

Golanin, bay, village, etc.; see Golofnin.

Golovni; island, one of the Necker group, Sitka sound, Alexander archipelago. Named Golomiannoi (sea breeze) by Vasilief, 1809. Has also been written Golomi, which, according to George Kostrometinoff, United States court interpreter at Sitka, is a corruption of the Russian Golovni or Golovniá (firebrand).

Goisan, mountain, east of Norton sound, and south of Unalaklik river, near latitude $63^{\circ} 30^{\prime}$. Also a mining district on Anvik river. Prospectors' name, published in 1900 .

Golsova; river, debouching in the southeastern part of Norton sound. Dall (1866) calls it Golsóva, Nelson (1879) Goltzovaia, obviously two forms of the same word. Perhaps from the German holtz (wood). Tebenkof uses the native name Negvelnuk and Stoney writes. Nuwaynyuk.

Golsova; native village and telegraph station, on the south shore of Norton sound, 35 miles east of St. Michael, probably on or near Golsova river (above). Written variously Goltzovaia, Galsovia, Gaolsovia, Galtzora. Zane, of Stoney's expedition, wrote the native name Nu-wayn-yuk.

Goltsowaiu, bay; see Holt\%.

Goltwovaia, river; see Golsova.

Gonnair; lake; see Gumaer.

Gompertz; hcannel, Cook inlet, between East Foreland and North Foreland. Named after Captain Gompertz, who discovered it, and reported by the Coast Survey parties in 1905. 
Good; island, in Gambier bay, Admiralty island, Alexander archipelago. So named by Mansfield, 1889 .

Good; island, in the Yukon river, about 4 miles below the mouth of Soonkalkat river. Name published by the Coast Survey, in 1898.

Goodall; creek, Seward peninsula, tributary to Noxapaga river, through Boulder' and 'Turner creeks, near latitude $65^{\circ} 35^{\prime}$, longitude $164^{\circ} 20^{\prime}$. Prospectors' name, obtained by Gerdine, 1901.

Goodenough; creek, Seward peninsula, tributary on south bank of Wast fork Solomon river, near latitude $64^{\circ} 42^{\prime}$, longitude $164^{\circ} 10^{\prime}$. Prospectors' name, from a locil map, 1904.

Goodhope; bay, in the southeastern part of Kotzebue sound, Arctic ocean. So named by Kotzebue, August, 1816, because here he had "good hope" of making important geographic discoveries.

Goodhope; river, Seward peninsula, tributary to Goodhope bay from the south. near longitude $164^{\circ}$. Name from Mendenhall and Reaburn, 1901.

Goodlu.ck; gulch, 10 miles northeast of Nome, Seward peninsula, at the head of Buster creek, an east fork of Nome river, near longitude $165^{\circ} 11^{\prime}$. Local name, published in 1904.

Goodluck; gulch, 11 miles north of Nome, Seward peninsula, on the east bank of . Snake river, near longitude $165^{\circ} 27^{\prime}$. Local name, published in 1901.

Goodman, glacier; see Goodwin.

Goodnews; bay, indenting the mainland coast a little south of the mouth of the Kuskokwim river. Called by Sarichef, 1826, Port Dobriek Vestei (good news) or Imakpiguak bay. Lutke, following this, calls it Bonnes Nonvelles baie, and adds, "it might better be called the bay of false reports." It was visited and probably named Good News by the land expedition of Ustiugof and Korsik of of 1818-19.

Goodpaster; river, tributary to the Tamana from the northeast, near latitude $64^{\circ}$, longitude $146^{\circ}$. This river was named Volkmar by Allen in 1885 . The tributary 20 miles farther up the Tanana he named Goodpaster, after the Goodpaster family of Kentucky. Later explorers inadvertently transposed these names, and so they have become fixed by common usage.

Goodpaster; telegraph station at the confluence of Goodpaster: and Tamana rivers. So named by the Signal Corps, U. S. A., 1903.

Goodwin; glacier, tributary to Copper river from the west, just south of Childs glacier. So named by Abercrombie, in 1884, after Maj. W. E. Goodwin, U. S. V. Erioneously Goodman.

Goose; cove, at the head of Portage bay, Kupreanof island, Alexander archipelago. So named by Nichols, 1882.

Goose; creek, on the northern shore of Baranof island, Alexander archipelngo. Named Gusinaia (goose) by Vasilief, 1833. Has also been written Gousna and Gusna.

Goose; creek, tributary to Red bay, Prince of Wales island, Alexander archipelago. So named by Helm, 1886.

Goose; creek, tributary to Casadepaga river from the west, Seward peninsula. Name from Barnard, 1900.

Goose; creek, Seward peninsula, tributary to Noxapaga river from north, 5 miles above Noxapaga village, near latitude $65^{\circ} 35^{\prime}$, longitude $164^{\circ} 05^{\prime}$. Prospectors' name, obtained by Gerdine, 1901.

Goose; creek, Seward peninsula, tributary to Kougarok river from east, 1 mile north of the mouth of Taylor creek, near latitude $65^{\circ} 41^{\prime}$, longitude $164^{\circ}$ 45'. Local name, obtained by Gerdine, 1901. 
Goose; creek, Seward peninsula, tributary to French creek from the east, near latitude $65^{\circ} 30^{\prime}$, longitude $162^{\circ} 30^{\prime}$. Local name, obtained by Witherspoon, $190 \%$.

Goose; creek, in the Rampart region, tributary to a branch of Tolovana river, near latitude $65^{\circ} 20^{\prime}$, longitude $149^{\circ}$. $30^{\prime}$. Prospectors' name, reported by. Prindle, 1905.

Goose; island, at western point of entrance to Mud bay, Cross sound, Alexander archipelago, near longitude $136^{\circ} 03^{\prime}$. So named by Hanus, 1880.

Goose; island, about 1 mile wide and 2 miles long, on the northeastern shore of Prince William sound, about 8 miles from Ellamar. So named by Abercrombie, 1898. Hás been occupied since 1897 for the propagation of blue foxes.

Goose, island; see Geese.

Goose; islands, on the southern edge of the Sandman reefs, near latitude $54^{\circ}$ 41', longitude $162^{\circ} 15^{\prime}$. Named Gusinnoi (goose) by the Russians. . Lutke calls them "Civoutchy (du lion marin) rocher," i. e., sea lion rocks. They are still unsurveyed. Dall's chart of 1882 (Coast Survey, 806) shows two islands, Big Goose and Little Goose.

Goose; point, on the Arctic coast, at mouth of Sinaru creek, just west of Refuge inlet. Presumably so named by British naval officers connected with the Franklin search expeditions, 1849-1853.

Gora, cape; see Mountain.

Gora Chetierel; Glavicia, mountain; see Fourpeaked.

Gorbatch; rookery, o. I Reef Point, southwestern coast of St. Paul island, Bering sea, near longitude $1.70^{\circ} 17^{\prime}$. Local name. Called Gorbatost (hump-

- back) by the Russians. Written also Gorbotch and Garbotch.

Gorbun, rock; see Humpback.

Gorda; point, in Fort Refugio, Bucareli bay, Prince of Wales archipelago. Named Punta Gorda (broad point) by Maurelle and Quadra, 1775-1779.

Gorda; point, on the northwestern shore of St. Ignace island, Bucareli bay, Prince of Wales archipelago. Named Punta Gorda (broad point) by Maurelle and Quạdra, 1775-1779.

Gorla, point; see Ankau.

Gordon; gulch, 6 miles north of Nome, Seward peninsula, on the north slope of Anvil peak, at the head of Anvil creek, near longitude $165^{\circ} 23^{\prime}$. Lucal name, from Gerdine, 1904.

Gordon; mountain (9,100 feet high), about 30 miles north of Mount Wrangell, southern Alaska. Prospector's' name, given in 1899 and reported by Schrader, 1903.

Gore; cape, on the southwestern coast of St. Matthew island, Bering sea. Named Gore by Lutke, 1836, to preserve the name which Cook gave to the island, 1778 .

Gore; point, the eastern point of entrance to Port Dick, Kenai peninsula, Gulf of Alaska. So named by Portlock, 1786. Has also been called Point Dick.

Goreli, island; see Seguam.

Goreloi, islands; see Gareloi.

Goreloi, volcano; see Redoubt.

Gores island; see St. Matthew.

Gorge (The); canyon, in Klutina river, a little below Klutina lake. Name from Abercrombie, 1898.

Gorman; strait, between Andronica and Korovin islands, Shumagin group, near longitude $160^{\circ} 05^{\prime}$. So named by the fishermen prior to 1872 . 
Gornoi; island, one of the Necker group, Sitka sound, Alexander archipelago. Named Gornoi (mountainous) by Vasilief, 1809. Erroneously Cornoi. Gornostai, islind; see Ermine.

Goschacket, river; see Cosua.

Goshanoli, cape; see Aguliuk.

Gould; island, near head of Fetta inlet, Cordova bay, Alexander archipelago, near latitude $55^{\circ} 17^{\prime}$, longitude $132^{\circ} 38^{\prime}$. Local name, reported by Dickins, 1905 .

Goulding; harbor, near Portlock harbor, on the western shore of Chichagof island, Alexander archipelago. . So named by Portlock, 1787.

Gousna, creek; see Goose.

Government Station; see Utkiavi.

Governor Simpson, cape; see Simpson.

Govina, gulch; see Covina.

Govorushechi, cape, point, etc.; see Gull.

Govorushechie, island; see Whale.

Govorushka; lake, about the middle of St. George island, Bering sen, near longitude $169^{\circ} 37^{\prime}$. Local name (Russian for the red-legged gull), written Goverooskie by Stanley-Brown in 1891 and Gavarushka by Duffield and Putnam in 1897. According to Putnam the Aleut name is Kōorījm-iin'yi (red-legged gull likke).

Goyot, glacier; see Malaspina.

Grace; gulch, 10 miles northeast of Nome, Seward peninsula, on the south bank of Buster creek, a tributary to Nome river from the east, near longitude $165^{\circ} 12^{\prime}$. Local name, published in 1.904 .

Grace; point, the northernmost point of Latouche island, Prince William sound. So called in Vancouver's atlas, 1798.

Grafton, island; see Crafton.

Graham; hatbor, in Cook inlet. Called Graham's harbor by Portlock, 1786. It is Cool bay of Meares, 1788, ald English bay of the Russians. Often called Port Gi:aham.

Graham, point; see Dix.

Grand; island, in Stephens passage, Alexander archipelago. So named by Meide, 1869.

Grand; island,-in Tlevak strait, Cordova bay, Alexander archipelago: So named by Nichols, 1881. Has also been named McNair by Sheldon Jackson.

Grand; point, the east point of entrance to Farragut bay, Frederick sound, Alexander archipelago. So named by Thomas, 1887.

Grand Canyon; of Noatak river northwestern Alaska, near longitude $161^{\circ}$; called Grand Cañons of the Noatak by Cantwell, 1885.

Grand Central; river, 40 miles north of Cape Nome, Seward peninsula, tributary to Salmon lake from the west, near longitude $165^{\circ} 10^{\prime}$. Name from Barnard, 1900.

Grand Pacific; glacier, at the head of Reid inlet, Glacier bay, southeastern Alaska. Exploring this inlet in 1879 Muir found it headed by a great glacier, whose ice cliff filled the fiord from wall to wall, and to which he gave the name Grand Pacific. In 1892 Reid found that its front had receded so far as to convert its three branches into distinct glaciers. Retaining the name Grand Pacific for the largest and most northerly, he named the middle one Johns Hopkins, and the Harriman expedition, 1899, named the smallest and most southerly Reid glacier. 
Grand Plateau; glacier, in the Fairweather range, southeastern Alaska. La Perouse, in 1786, called this place Le Grand Plateau and Dall, 1874, called it, as above, Grand Plateau glacier.

Grand Wash, river; see Kwik.

Granichnoi, point; see Telmination.

Granite; cove, in George island, Port Althorp, Cross sound, Alexander archipelago. Descriptive name, given by Dall, 1880 .

Granite; creek, tributary to Gold creek from the north, $2 \frac{1}{2}$ miles northeast of Juneau. Local name, obtained by Peters, 1902.

Granite; creek, Kenai peninsula, tributary to East fork Sixmile creek from the northeast. Local name, from Mendenhall, 1898.

Granite; creek, tributary to Matanuska river from the west, about 25 miles above the mouth of the latter. Prospectors' name, published in 1899.

Granite; creek, tributary to Tisuk river from the east, Seward peninsula. Name from Barnard, 1900.

Granite; creek, tributary to Minook creek from the west, about 16 miles above its mouth. Local descriptive name, obtained by Prindle, 1.904.

Granite; creek, tributary to Seventymile river from the south, near latitude $65^{\circ}$, longitude $142^{\circ} 10^{\prime}$. Local descriptive name, obtained by Gerdine, 1903.

Granite; creek, tributary to North fork Fortymile creek from the west, near latitude $64^{\circ} 20^{\prime}$, longitude $142^{\circ}$. Local descriptive name, obtained by Gerdine, 1903.

Granite; creek, tributary to Chandlar iver from the west, near latitude $67^{\circ}$. 'Prospectors' name, reported by Schrader, 1899.

Granite; creek, tributary to South fork Koyukuk river from the east, near longitude $150^{\circ}$. Prospectors' name, reported by Schrader, 1899.

Granite, fork of Fortymile; see Middle.

Granite; lake, Revillagigedo island, Alexander archipelago on the east shore of 'Thorne arm at its head, near' latitude $55^{\circ} 25^{\prime}$, longitude $131^{\circ} 10^{\prime}$. Local name, reported by Brooks, 1901.

Granite; point, in Redfish bay, Baranof island, Alexander archipelago. So named by Moser, 1.897.

Granite; point (1,500 feet high), forming the south point of entrance to Sanborn harbor, Nagai island, Shumagin group. Name published by Dall, 1875.

Granite Canyon; glacier, on the eastern border of the Muir glacier, southeastern

- Alaska. So named by Reid, 1890, from the crystalline nature of the rock, which, however, turns out to be not a true granite.

Granitza, strait; see Dixon entrance.

Grant; island, in Behm canal, on the western side of Revillagigedo island, near Naha bay. So named by Clover, 1855. Erroneously Giant.

Grant; peak (5,291. feet high), on the mainland north of Frederick sound, southeastern Alaska. Named by Thomas, 1887, after President Ulysses S. Grant.

Grant; point, in Izembek bay, Alaska peninsula. Named by the Fish Commission, 1388, after President Ulysses S. Grant.

Grant, point; see Whidbey.

Grantley; harbor, at head of Port Clarence, Bering strait. Surveyed by Beechey in September, 1827, and named Grantley "in compliment to Lord Grantley."

Graptolite; river, the left fork of Dillinger river, which is a right branch of the Kuskokwim, near latitude $62^{\circ} 40^{\prime}$, longitude $153^{\circ} 15^{\prime}$. So named by Brooks, 1902, to mark the "only place we had found these fossils." 
Grass; creek, $4 \frac{1}{2}$ miles northwest of Cape Nome, Seward peninsula, tributary from the west to Saunders creek, a fork of Hastings creek, near longitude $165^{\circ} 07^{\prime}$. Local name, from Gerdine, 1904.

Grass; gulch, 7 miles north of Nome, Seward peninsula, at the head of Dexter creek, a tributary of Nome river from the west, near longitude $165^{\circ} 21^{\prime}$. Local name, published in 1904.

Grass; island, on the western shore of Orca inlet, Prince William sound, near latitude $60^{\circ} 34^{\prime}$, longitude $145^{\circ} 44^{\prime}$. So named by Moser, 1897 .

Grass; island, in the Copper River delta, near latitude $60^{\circ} 17^{\prime}$, longitude $145^{\circ}$ 09'. Descriptive name, given by Ritter, 1898.

Grass; islet, in Sawmill cove, Howlsan strait, Cordova bay, Alexander archipelago. So called by Sheldon Jackson, 1880 .

Grass; rock, in entrance to Tamgas harbor, Annette island, Alexander archipelago. So named by Nichols, 1883.

Grass; rock, at entrance to Hunter bay, Cordova bay, Prince of Wales island, near latitude $54^{\circ} 52^{\prime}$. So named by Moser, 1897 .

Grass; valley, Alaska peninsula, extending southeast from the head of Herendeen bay, near longitude $160^{\circ} 37^{\prime}$. So called by Tanner, 1890 .

Grass Knoll; islet. This name was applied by Dall, 1883, to that part of Bushtop islet which is detached at high water.

Grasstop; rock, in the entrance to Deep bay, Chichagof island, Peril strait, Alexander archipelago. Named Grass Top by Coghlan, 1884.

Grassy; islet, south of Iliasik islands, in Sandman reefs, northeast of Sannak. So called by Dall, 1880.

Grave; creek, tributary to Middle fork Chandlar river, near longitude $148^{\circ}$. Prospectors' name, reported by Schrader, 1899 .

Grave; point, the north point at entrance to Hunter bay, Cordova bay, Prince of Wales island, near latitude $54^{\circ} 53^{\prime}$. So named by Moser, 1897.

Grave; point, the northeasternmost point of Duke island, Gravina group, Alexunder archipelago. Name published by the Coast Survey in 1882 (map in Coast Pilot, p. 72). Presumably a descriptive name, obtained from the pilots.

Grave; point, the northyestern point of Pitt island, Hooniah harbor, Port Frederick, Alexander archipelago. So named by United States naval officers, 1880.

Grave; point, the western point of entrance to 'Taku harbor, Stephens passige, Alexander archipelago. So named by Meade, 1869. There were a few graves on the point.

Gravè; creek, eastern Alaska, on south bank of Seventymile creek, near latitude $64^{\circ} 50^{\prime}$, longitude $142^{\circ} 50^{\prime}$. Prospectors' name, from sketch map compiled by Major Glassford, Signal Corps, U. S. A., 1905.

Gravel; island, one of the Kutchuma group, Sitka sound, Alexander archipelago. Named Pesiak (gravel) by Vasilief, 1809. Has also been called Martin island.

Gravel; point, Alaska peninsula, the west point of entrance to the most soutlerly cove of Herendeen bay; near longitude $160^{\circ} 42^{\prime}$. Descriptive name, given by Tanner, 1890 .

Graven, point; see Craven.

Graves; harbor, indenting the mainland southeastern Alaska, 4 miles northwest of Cape Spencer, near latitude $58^{\circ} 15^{\prime}$, longitude $136^{\circ} 40^{\prime}$. Named after Herbert $C$. Graves, nautical expert, Coast Survey, and described in the Coast Pilot of 1901. 
Graves; rocks, on east side of entrance to Graves harbor above. "The north end of the group is an islet, wooded on top and about 125 feet high. From the islet a series or group of large bare rocks extend more than a mile SSE." So named and described in the Coast Pilot of 1901.

Graveyard; cape, southwestern shore of Afognak bay, Marmot bay, southern shore of Afognak island, Kodiak group. Named Kladbitsha (graveyard) by Murashef, 1839-40.

Graveyard; point, the east point of entrance to Landlocked bay, Port Fidalgo, Prince William sound. Local name, reported by Grant, 1905.

Graveyard; point, on the shore of Kvichak bay, Bristol bay, north of the mouth of Naknek river. Local name, reported by Moser, 1900.

Graveyard, point; see Station.

Gravina; group of islands, in Clarence strait, Alexander archipelago, of which the principal ones are Annette, Duke, Gravina, and Mary. They were thus designated by the Spaniard Don Jacinto Caamaño in about 1790.

Gravina; island, in Clarence strait, Alexander archipelago, between Revillagigedo island and Prince of Wales archipelago, near latitude $55^{\circ} 15^{\prime}$, longitude $132^{\circ} 45^{\prime}$. It is the northerumost of a group named Gravina by Caamaño in about 1790 .

Gravina; island, at entrance to Port Gravina, Prince William sound. So named by Abercrombie, 1898.

Gravina; point, the easternmost point of Gravina island, Alexander archipelago, being the west point at the southern entrance to Tongass nitrows.

Gravina; point, separating Orca bay and Port Gravina, Prince William sound. So called by Moser, 1897 .

Gravina; port (Port Gravina), indenting the eastern shore of Prince William Sound, near latitude $60^{\circ} 40^{\prime}$, longitude $146^{\circ} 15^{\prime}$. So named by Fidalgo, 1790 .

Gray; peak (4,694 feet high), near the head of Thomas bay, southeastern Alaska. Named by Thomas, 18si, presumably after Prof. Asa Gray, of Harvard College.

Grayling; village and landing, on the right bank of the Yukon, 22 miles above Anvik, near latitude $63^{\circ}$, iongitude $160^{\circ}$. There is a store here; a large wood yard to supply steamers, and an Indian village of about 75 people. So described by Cantwell, 1900.

Graystone; creek, eastern Alaska, on south bank of Gold creek, Salcha River drainage, near latitude $64^{\circ} 50^{\prime}$, Iongitude $145^{\circ} 45^{\prime}$. Frospector's' name, reported by Witherspoon, 1905.

Great; arm, of Whale bay, Baranof island, Alexander archipelago. Nimed Bolshoi roukav (big sleeve) by the Russians.

Great; canyon, about 50 miles long, on Stikine river, British Columbia. This canyon marks the head of steam navigation.

Great; glacier, on the western bank of Stikine river, southeastern Alaska. Hunter, writing in 1877, says: "Great glacier is said to extend northwestwardly to the coast, about 70 miles, from 350 to 400 feet high."

Great, lake, St. Paul island; see Big.

Great Bend; local name for an ox bow in Kuskokwim river, near longitude $158^{\circ}$, obtained by Spuri and Post from missionary J. H. Kilbuck in 1898.

Great Bering; glacier, west of Icy bay, in the St. Elias alpine region. So named by Seton-Karr, 1886.

Great East, Great Eastern, rookery ; see East. 
Great Sitkin; island (5,033 feet high), between Atka and Adak, Andreanof group, middle Aleutians. Native name from the earliest Russian explorers. Called Great Sitkin to distinguish it from Little Sitkin, near Kiska. Has been written Seetien, Sigdak, Sitchin, Sitchini, 'Tschechina, Tsetchina, etc. Lutke calls it Eastern Sitkin, while Dill calls it Sitkin or Great Net island.

Great Strelki, bay; see Big Branch.

Great Unknown; creek, eastern Alaska, small tributary on north bank of Birch creek, near latitude $65^{\circ} 20^{\prime}$, longitude $145^{\circ} 25^{\prime}$. Prospectors' name, reported by Witherspoon, 1905.

Greely; point, on the mainland, in Taku inlet, southeastern Alaska. So named by Mansfield, 1890 , after Gen. Adolphus Washington Greely, U. S. A. Erroneously Greeley.

Green; bight, a small indentation in the southeastern shoie of Akutan island, Krenitzin group, eastern Aleutians, longitude $165^{\circ} 40^{\prime}$. So named by Gilbert, 1901.

Green; creek, tributary to Seventymile creek, from the south. Local name, from Barnard, 1898. Called also Deer creek.

Green; creek, eastern Alaska, tributary to Ruby creek, at the head of Slate creek, an affluent, from the west, to North fork Fortymile creek, near latitude $64^{\circ} 40^{\prime}$, longitude $142^{\circ} 50^{\prime}$. Frospectors' name, from sketch map compiled by Major Glassford, Signal Corps, U. S. A., 1905.

Green; creek, Seward peninsula, in Casadepaga drainage basin, tributary on south bank of Willow creek, near latitude $64^{\circ} 48^{\prime}$, longitude $164^{\circ} 30^{\prime}$. Prospector's' name, from a local map, 1901.

Green; island, in Port Frederick, Icy strait, Alexander archipelago. So named by United States naval officers, 1880 .

Green; island, in Davidson inlet, Prince of Wales archipelago, near latitude $55^{\circ} 55^{\prime}$, longitude $133^{\circ} 37^{\prime}$. So named by Dickins, $1903-4$.

Green; island, 4 miles wide and 15 miles long, northwest of Montague island, in Prince William sound. A group so named in May, 1778, by Cook, who found them "Low, free from snow, and covered with wood and verdure." The name as now used applies to one island ats above. Also called lles Vertes. It is Nikolai island of Russian Hydrographic chart 1378 (ed. of 1847). Occupied since 1.897 for the propagation of blue foxes.

Green; isle, the most southerly of the village islauds, Uganik bay, Kodialk. So named by Moser, 1.597.

Green; islets (at high water), on eastern shore of Portland canil, southeastern Alaskia. So named by Fender, 1868 .

Green; point, on Lindenberg peninsula, Wrangell strait, Alexander archipelago. Apparently so named by Dall in Coast Pilot, 1883. It is point Meli (shoal) of Lindenberg, 1838.

Green; point, on the mainland, a little south of the mouth of the Stikine river. Named Zelenoi (green), 1863, by the Russian surveying party, under: Commander Basargin, on the steamer Rynda. Has been called Zelonoi, Zelony, and Green. The name is descriptive.

Green; point, on the northeastern shore of Hemlock island, Port Chester, Annette island, Alexander archipelago. Name published by the Coast Survey in $\mathbf{1 8 7 6 .}$

Green; point, the northern point of entrance to Pyramid hadrbor, Chilkat inlet, Lynn canal, southeastern Alaska. Named Zelenoi (green) by Lindenberg, 1.838. It is Indian point of Meade in 1869, and Pyramid point of Beardslee in 1880. 
Green; ridge, of wooded hills (about 1,300 feet high), near Cape Fox, Dixon entrance. Named by Nichols, 1888.

Green, river ; see Omalik.

Green; rocks, between Island and Rock points, Wrangell strait, Alexander archipelago. Named Zelenoi (green) by Lindenberg in 1838. Meade, 1869 , called them Fairway rocks.

Greenhorn; gulch, in the Birch creek region, at the head of Boulder creek, near latitude $65^{\circ} 25^{\prime}$, longitude $145^{\circ} 05^{\prime}$. Prospector's' name, reported by Spurr, Goodrich, and Schrader, of the Geological Survey, 1896.

Greenhorn, mountains; see Bendeleben.

Greenough; mountain (4,800 feet high), in extreme northeastern Alaska.; So named by Franklin, 1826.

Grego, point; see Cangrejo (crab).

Gregson; island, Yakutat bay, southeastern Alaska, south of Fitzgerald island. So named by Harber, 1892, after G. S. Gregson, one of his party.

Greig; cape (Cape Greig), on the north shore of Alaska peninsula, the north point of entrance to Ugashik river. Named by Lutke, 1828, after Admiral Greig, of the Russian navy. Variously written Greigh, Grey, etc.

Greig; mountain (6,500 feet high), in the Tordrillo range; between Kuskokwim and Skwentna rivers. So named by Spurr and Fost, 1898. Erroneously Creig.

Greville, cape; see Chiniak.

Grewingk; glacier, on Kenai peninsula, tributary to Kachemak bay, Cook inlet. Named by Dall, 1880, after Dr. Constantin Grewingk, a distinguished writer on Alaskia.

Grewingk; volcanic island near Bogoslof island, Bering sea, about latitude $53^{\circ} 55^{\prime}$, longitude $168^{\circ}$. This island rose from the sea in 1883, and was called New Bogoslot. Dall proposed the name Grewingk, after Dr. Constantin Grewingk, who had previously written on the geology and vulcanism of Alaska. See Bogoslof.

Grey, cape; Bristol bay; see Greig.

Grey; point, on the western shore of Tamgas harbor, Annette island, Alexander archipelago. Name published by the Coast Survey, 1891.

Greyling, village and landing; see Grayling.

Greys; island, on the southern edge of the Stikine flats, Sumner strait, Alexander archipelago. Apparently so named by Meade, 1869.

Griada, rocks; see Border.

Grief; islet, in Duncan canal, Kupreanof island, Alexander archipelago. So named by Thomas, 1887.

Griffin; point, on the Arctic coast, a little west of the international boundary line. So named by Franklin, 1826 .

Griffith; island, in western anchorage of Sitka harbor, Sitka sound, Alexander archipelago. Name published by the Coast Survey, 1885 .

Grimkopf; town or station on the Yukon, 20 miles above the Koyukuk. Written also Grimkop.

Grindall; island, in Clarence strait, at entrance to Kasaan bay, Alexander archipelago. So named by Dall, 1880.

Grindall; passage, between Grindall island and Grindall point, Clarence strait, Alexander archipelago. So called by Nichols (Coast Pilot, p. 90) in 1891. 
Grindall; point, the north point of entrance to Kasaan bay, Clarence strait; Alexander archipelago. Named by Vancouver, 1793, after Captain Grindall, R. N. Sometimes called Cape Grindall. It is Cone point of the traders.

Grindall; post-office, at Grindall point, Alexander archipelago. Established in July, 1900 ; discontinued 1904.

Grisley; creek, eastern Alaska, tributary to Wolf creek, an affluent of Birch creek from the south, near latitude $65^{\circ} 15^{\prime}$, longitude $145^{\circ}$. Prospectors' name, from Witherspoon, 1905. May have been intended for Grizzly.

Griz:ly, creek; see Grisley.

Groosgincloose, inlet; see Cook.

Groundhog; creek, southeastern Alaska, on the mainland, 2 miles east of Juneau, and on the enst side of Icy gulch. Local name, reported by Spencer and Wright, 1903 .

Grouse; creek, tributary to Kruzgamepa river, from the west, Seward peninsula. Name from Barnard, 1900.

Grouse; creek, tributary to Mint river, Seward peninsula. Name from Brooks, 1900.

Grouse; creek, tributary to Tubutulik river, near its source, Seward peninsula. Prospector's' name, from Peters, 1900.

Grouse; creek, 20 miles north of Nome, Seward peninsula, draining the southeastern slope of Mount Distin into Goldbottom creek, an affluent of Snake river, near latitude $64^{\circ} 45^{\prime}$, longitude $165^{\circ} 22^{\prime}$. Local name, from Gerdine, 1904.

Grouse; creek, Seward peninsula, tributary to Noxapaga river, about 2 miles above the village of Noxapaga, near latitude $65^{\circ} 30^{\prime}$, longitude $164^{\circ}$ 10'. Local name, obtained by Gerdine, 1901.

Grouse; creek, Seward peninsula, tributary to Aurora creek, which is a tributary to West forl: Noxapaga river, near latitude $65^{\circ} 37^{\prime}$, longitude $164^{\circ}$ 15'. Local name, obtained by Gerdine, 1901.

Grouse; creek, Seward peninsula, small tributary of: Casadepaga river on east bank, near latitude $64^{\circ} 46^{\prime}$, longitude $164^{\circ} 29^{\prime}$. Prospector's' name, from Gerdine, 1905.

Grouse; creek, tributary to the head of Hess creek from the north, near latitude $65^{\circ} 40^{\prime}$, longitude $147^{\circ} 30^{\prime}$. Local name, obtained by Lieutenant Erickson, U. S. A., 1902.

Grouse; gulch, 7 miles north of Nome, Seward peninsula, on the south slope of King mountain, draining to Dexter creek, near longitude $165^{\circ} 20^{\prime}$. Local name, published in 1903.

Grouse; island, at mouth of Mink bay, Boca de Quadra, southeastern Alaska. So named by the Coast Survey., 1891.

Grouse; lake, Kenai peninsula, 6 miles north of Resurrection bay and just west of Salmon lake. Local name, from Moffit, 1904.

Grub; gulch, 18 miles north of Nome, Seward peninsula, opening on the east bank of Goldbottom creek at the headwaters of Snake river, near longitude $165^{\circ} 23^{\prime}$. Miners' name, from Gerdine, 1904.

Grubstake; gulch, Copper River region, at the headwaters of Chititu creek. Prospectors' name, taken from map of Nizina mining district by George M. Esterly, of Valdez, 1902.

Grubstake; gulch, eastern Alaska, on the right bank of Little Blanche creek, a tributary of Seventymile creek from the south. Prospectors' name, reported by Lieutenant Erickson, U. S. A., in 1902.

Burl. 299-06 м $\longrightarrow 19$ 
Grunt; point, Gambier bay, Admiralty island, Alexander archipelago. So named by Mansfield, 1889.

Guadalipe, Puerto de; see Shelikof.

Guanton; mountains (5,163 feet high), east of Portland canal. So named by Pender, 1868.

Guard, island, Resurrection bay; see Hive.

Guard; islands (25 feet high), at junction of Behm canal, Clarence strait, and Tongass narrows, Alexander archipelago. Name given by local pilots about 1880 . These islands have been reserved for light-house purposes by Executive order dated January 4, 1.901.

Guertin; islet, in Jamestown bay, Sitka sound, Alexander archipelago. So named by United States naval officers in 1880, after Master Frank Guertin, U. S. N.

Guibert; islets, in the entrance to Necker bay, Baranof island, Alexander archipelago. Called Necker isles by La Perouse, 1786. By the Russians called Yaichnia (egg) and by Dall; 1883, Guibert in order "to distinguish them from the host of others which have likewise received from the Russians the title of Egg (Yaichnia) islands." Variously called Egg, Necker, Yaitchny, etc.

Guibert, port; see Whale bay.

Guide; island, in the northern part of Sitka sound, Alexander archipelago. Named Krestofskoi (cross) by Vasilief, 1809. Later it was called Ukazatel (guide) island by the Russians. Has also been called Index island. In the Coast Pilot, 1891, it is called Guide (p. 168) and Unastal (p. 176).

Guide; rocks, in the southeastern part of Cordova bay, Alexander archipelago. So named by Moser, 1897.

Guillemot; island, north of the Shumagins.' Named Iachnoi (egg) by 'Tebenkof in 1849. Renamed Guillemot by Dall, 1880.

Gukyuk; slough, Yukon delta, on the right bank of Kawanak pass, 5 miles below the head, near latitude $62^{\circ} 58^{\prime}$, longitude $164^{\circ} 10^{\prime}$. Eskimo name, reported by Faris, 1899.

Gulch; creek, tributary to East fork Sixmile creek from the east, Kenai peninsula. Local name, obtained by Becker, 1895, but misplaced on his map.

Gulkana; river and lake near its source, tributary to Copper river from the northwest, between Tazlina and Gakona rivers. Native name, adopted by the whites and reported by Mendenhall, 1902.

Gulkana. The Signal Corps map of 1904 shows a "town or station" in Copper River valley, near the mouth of Gulkana river, named Kulkana.

Gull, bay; see Udamat.

Gull; cape, the southern point of entrance to Kaflia bay, on north shore of Shelikof strait. Named Govorushechi or Govorushek (gull) by the Russians. According to Elliott Goverooskie, Russian for gulls, refers to Larus brevirostris and Larus tridactylus.

Gull; cove, at the northeast point of entrance to Idaho inlet, south shore of Icy strait, Alexander archipelago, near longitude $136^{\circ} 10^{\prime}$. So named by Dickins, 1902.

Gull; hill, at east end of St. George island, Pribilof group, Bering sea. Perhaps a local name; used by Elliott, 1873-74. According to Putnam the Aleuts call it Ätchō'-kōvěrūshkä (lower hill)—from Russian kovirishka, a little loaf.

Gull; hill, south coast St. Paul island, Bering sea, on the eastern shore of the narrow neck between St. Paul village and Reef point, near longitude $170^{\circ} 16^{\prime}$. Local name, reported by Duffield in 1897 . 
Gull; island, in Favorite channel, Lynn canal, Alexander archipelago. So named by Beardslee, 1880 .

Gull; island, in Port Chester, Annette island, Alexander archipelago. So named by Nichols, 1883.

Gull; island, eastern shore Prince William sound, inside Goose islind, between Porcupine point and Knowles head, near latitude $60^{\circ} 43^{\prime}$, longitude $146^{\circ} 39^{\prime}$. Name from Ritter, 1903.

Gull; island in Mine harbor, Herendeen bay, north shore Alaska peninsula, near longitude $160^{\circ} 41^{\prime}$. So called by 'Tanner, 1890 .

Gull, island ; see Kutkan.

Gull; islands, on the southeast shore of Kachemak bay, Cook iulet, near longitude $151^{\circ} 20^{\prime}$. Local name, from Dall, 1895 .

Gull; islet, southeast of Long island, Sitka sound, Alexander archipelago. Named Chaiki (gull) by Vasilief in 1809. Called Gull rocks by Nichols in the Coast Pilot $(1891$, p. 173).

Gull; islet, near the northwestern shore of Shuyak island, Kodiak group. Named Chaichi (gull) by the Russian American Company, 1849.

Gull; islet (20 feet high), near the northern coast of Unga islanid, Shumagins, at entrance to Zachary bay, near longitude $160^{\circ} 40^{\prime}$. Presumably so named by the Western Union Telegraph expedition in 1865.

Gull; islet, in western anchorage St. Paul harbor, Kodiak. Named Chaichi (gull) by the early Russians.

Guil, islets, Akutan pass; see Seagull.

Gull; point, the northwestern point of Onslow island, Clarence strait, Alexander archipelago. So named by Snow, 1886.

Gull; point, the south point of entrance to Igak bay, on eastern shore of Kodiak. Named Govorushiche (Kittiwake, a kind of gull) and Chaichi (gull) by the Russians. Lisianski, 1805, calls it Gull's point. Elliott says Chikie is the Russian for the Burgomaster gull (Larus glaucus).

Gull; point, north shore Alaska peninsula, the eastern point at entrance to the most southerly cove of Herendeen bay, near longitude $160^{\circ} 40^{\prime}$. So called by 'Tanner, 1890 .

Gull; rock, off the western shore of Heceta island, Iphigenia bay, Prince of Wales archipelago, near latitude $55^{\circ} 45^{\prime}$, longitude $133^{\circ} 45^{\prime}$. So named by Dickins, 1903-4.

Gull; rock, near Pinnacle island, Bering sea. Apparently so called by Elliott, 1874. Sarichef shows the rock and calls it Rock with gravel.

Gullhead; point, south shore Kotzebue sound, Seward peninsula, 6 miles west of Cape Deceit, "a narrow rocky peninsula stretching a mile into the sea." So named and described by Beechey, 1826. (Vol. 1, p. 326.)

Gulrass, point; see Culross.

Gumaer; lake, near. Tetling river, in about longitude $142^{\circ}$. So named by Lowe, 1898, after John Gumaer, a member of his party. Erroneously Gomair on the maps.

Gunahadetaje. The Krause brothers, 1882, report this to be the native name of a lake in or near the Krotahini pass, southeastern Alaska.

Guray; creek, eastern Alaska, on the east bank of Charley river, which is affluent to the Yukon from the south, near longitude $143^{\circ}$. Prospectors' name, from a sketch map compiled by Major Glassford, Signal Corps, J. S. A., 1905 .

Guria; see Kekur.

Gurney; peak; in the McKinley range, near latitude $62^{\circ} 10^{\prime}$, longitude $153^{\circ}$. So named by Herron, 1899. 
Gusinaia, creek, islands, etc. ; see Goose.

Gusinaia, islands; see Geese.

Gusna, creek ; see Goose.

Guss, creek, near Nome; see Cuss.

Gustavus; point, the easteln point of entrance to Glacier bay, Icy strait, southeastern Alaska, near longitude $135^{\circ} 55^{\prime}$. So named by Dall, 1879.

Gus Wilson; slough, in the eastern part of the Copper River delta. Fisheries' name, reported by Moser, 1897.

Gut; bay, on the southeastern coast of Baranof island, Chatham strait, Alexander archipelago. Name published by the Coast Survey, 1889.

Guthna; creek, tributary to Tanana river from the north, 12 miles above its mouth, near latitude $65^{\circ}$, longitude $151^{\circ} 30^{\prime}$. Native name, reported by Herron, 1899, and witten Guth-na. Has been called Fish creek.

Gutwetter, cape; see Fairweather.

Gutwetterbery; see Fairweather.

Guyot; glacier, between Karr hills and Robinson hills and tributary to Malas-1 pina glacier, near Mount St. Elias. Originally this name was applied by the New York Times expedition, of 1886, to the western lobe of Malaspina glacier. The above description follows Russell's application. Named after Prof. Arnold Guyot, of Princeton College.

Gvozdef, islands ; see Diomede.

Guozdef, cape; see Prince of Wales.

Gwozdeff, islands; see Diomede.

Gwydyr; bay, a little east of the mouth of Colville river, Arctic coast. So named by Franklin, 1826. Erroneously Gwydir.

Hadley, port ; see Lyman anchorage.

Hadley; settlement, on Lyman anchorage, Kasaan peninsula, Prince of Wales island, Clarence strait, Alexander archipelago, near latitude $55^{\circ} 32^{\prime}$, longitude $132^{\circ} 17^{\prime}$ : Name reported by H. C. Fassett, Bureau of Fisheries, 1904.

Hadon; peak, near the head of Libbey glacier, in the St. Elias region. So named by Topham, 1886.

Haenke; island, in Disenchantment bay, Yakutat bay, southeastern Alaska. So named by Malaspina, 1791, after Thaddeus Haenke, botanist and naturalist of his expedition. Accolding to Davidson it is Isla de Hengue on Malaspina's manuscript chart. The name Egg island, said to be in use locally, was published by the Coast Survey in $\mathbf{1 8 9 1 .}$

Hafuache, point; see Kamachi.

Hagemeister; island, in northern part of Bristol bay, Bering sea. So named by the Russians, after Capt. Leontius Vasilevich Hagemeister, who made three voyages to the Russian American colonies and round the world, 1806-7 in command of the Neva, 1816-1819 in command of the Kutuzof, and 1828-1830 in command of the Krotkoi. This name was published in Sarichef's atlas, 1826. Erroneously Hagenmeister.

Hagemeister; strait, separating Hagemeister island from the mainland, Bristol bay. Name published by Sarichef, 1826.

Hague, cape; see Umshaliuk.

Hague; channel, in Port Moller, north shore Alaska peninsula, leading to the entrance of Herendeen bay, near latitude $55^{\circ} 55^{\prime}$, longitude $160^{\circ} 42^{\prime}$. So named by Tanner, 1890.

Hague; rock, between Sannak island and Sandman leefs, near longitude $162^{\circ}$ 24'. Named by the Fish Commission in 1890. Called Midway island by the Coast Survey in 1900. 
Haiden, port; see Heiden.

Haines; village and post-office, on l'ortilge bay, near the head of Chilkoot inlet, soutbeastern Alaska. Prior to 1880 there existed here an Indian village called Kutkwutlu (Deshu or Daschu, according to the Krause brothers). In 1881 a Presbyterian mission school was established here, a trading post having been already established, and called Willard Mission. This name was soon afterwards changed to Haines. The postoffice is called Haines and the whole place known locally as Chilkoot. The post-office was established here in February, 1884.

Faiu; creek, tributary to Yukon river on the right bank, opposite the mouth of Minook creek, near Squaw creek, about longitude $150^{\circ} 10^{\prime}$. Prospector's' name, spelled Hi-u, on Edwards's Track Chart of the Yukon, 1899.

Halcorcins; two stations (old and new) on north bank of Yukon river, about 75 miles below the mouth of the Tanana. Name published by the Coast Survey in 1898. See also Kokrines and Miokniozdok.

Haley; anchorage, in Fish bay, Peril strait, Alexander, archipelago, near latitude $57^{\circ} 22^{\prime}$, longitude $135^{\circ} 37^{\prime}$. Named by Coghlan, 1884, after a miner, Nicholas Haley.

Haley; point, Fish bay, Peril strait, Alexander archipelago, "forming the eastern side" of Haley anchorage above "a sand flat terminating in a high-water island." Named by Moore in 1896 and so described in the Coast Pilot of 1901.

Haley; rock, south side of entrance to Fish bay, Peril strait, on western side of Haley anchorage above. So named by Moore, 1.896.

Halfmile; salmon stream, western coast Prince of Wales island, tributary to Klawak lake on the north shore, one-half mile from the outlet, near latitude $55^{\circ} 27^{\prime}$. Local descriptive name, reported by Moser in 1897 and written Half-mile.

Halfmoon; anchorage, in Wrangell strait, Alexander archipelago. Traders' name, first reported by Meade in 1869 and published by the Hydrographic Office in 1869.

Halftide; rock, on the eastern shore of Herendeen bay, Alaska peninsula, $3 \frac{1}{2}$ miles south of Point Divide, near longitude $160^{\circ} 45^{\prime}$. Descriptive name Half Tide given by Tanner, 1890 .

Half:way; island, in Yukon river, near the Jeft bank and nearly midway between Fort Yukon and Circle, near longitude $145^{\circ}$. So called by the river pilots, and reported by Cantwell, 1900.

Halfway; point, on the southeastern shore of St. Paul island, Pribilof group, Bering seal. It is about midway between " the village and Northeast point." Named Polovinnoi (halfway) by the Russians.

Halibut; bay, on the western shore of Portland canal, southeastern Alaska, near latitude $55^{\circ} 13^{\prime}$. So named by Pender, '1.868.

Halibut; cove, indenting the eastern shore of Kachemak bay, Cook inlet. Apparently so named by Dall, 1880 .

Halibut; creek, on the western shore Clarence strait, southeastern Alaska, near latitude $55^{\circ} 15^{\prime}$, longitude $132^{\circ}$. Local navigator's' name, reported by H. C. Fassett, Bureau of Fisheries. 1904.

Halibut; harbor, indenting the southwestern end of Kosciusko island, Iphigenia bay, Prince of Wales archipelago, near latitude $55^{\circ} 55^{\prime}$, longitude $133^{\circ}$ 47'. Local name from Dickins, 1903-4.

Halibut; island and rock, bare at low water, in the entrance to Port Frederick, Icy strait, Alexander archipelago, near longitude $135^{\circ} 30^{\prime}$. Name of rock published in the Coast Pilot of 1883 , that of the island in the Coast Pilot of 1901. 
Halibut, island ; see Sannak.

Halibut; point, 4 miles northwesterly from Sitka, Baranof island, Alexander archipelago. Named Paltus (halibut) by Vasilief, 1809. Also written Paltoose. Has also been called Peschani (sandy):

Halibut; point, on the western shore of Portland canal, at west of entrance to Halibut bay above. Name published by the Coast Survey.

Halibut Nose; a point on the northenstern shore of Tlevak strait, being the northern point of the west entrance to Sukkwan strait, Cordova bay, Prince of Wales island, near longitude $133^{\circ}$. Local name, published by the Coast Survey in $\mathbf{1 9 0 5 .}$

Haliknuk; river, tributary to the Chulitna river from the east, in longitude $156^{\circ}$ 30'. Eskimo name, obtained by Spurr and Post, 1898, from A. Lind, a trader. It is pronounced Hal-\{k-nook, and said to mean sudden or unexpected. Tikhmenief, 1861, calls it Agalitnak. Written also Ho-holiknuk.

Halkett; cape, between Smith and Harrison bays, on the Arctic coast, east of Point Barrow. So named by Dease and Simpson, 1837, in compliment to one of the directors of the Hudson Bay Company. Has often been written Halket.

Hallin, island ; see Raven.

Hall; cape, the north point of Hall island, Bering sea. So called by Tebenkof, 1849, after Lieut. Robert Hall, who accompanied Billings and visited this locality in 1791. Has also been called North cape.

Hall; cove, indenting the western shore of Duke island, Alexander archipelago, near latitude $54^{\circ} 54^{\prime}$, longitude $131^{\circ} 23^{\prime}$. Local navigators' name, reported by H. C. Fassett, Bureau of Fisheries, 1904.

Hall; creek, tributary to Canyon creek from the east, in the Fortymile mining region. Local name from Barnard in $\mathbf{1 8 9 8 .}$

Hall; island, near the southeastern shore of Big Koniuji island, Yukon harbor, Shumagin group. So named by Dall, 1874, after Captain Hall, sailing master of the Coast Survey schooner Humboldt, 1871-72.

Hall; island (1,500 feet high), of the western end of St. Matthew island, Bering sea. The early Russian hunters called this Morzhovoi (walrus), because they found these animals there. Lutke and Tebenkof follow this, Lutke writing Morjovi (aux morses) and Morjovy. Russian Hydrographic chart 1427 calls it Sindsha, probably after its alleged Russian discoverer, Sind. Billings and Sarichef anchored between it and St. Matthew, July 14, 1791 (o. s.), and on American maps for the last thirty years it has borne the name Hall, presumably after Lieut. Robert Hall, who accompanied Billings.

Hall; peak (3,726 feet high), in the northern part of Kupreanof island, Alexander archipelago. Named by Thomas, 1887, after Capt. Charles Francis Hall, the distinguished Arctic explorer, who died November 8, 1871.

Hall; rapids, in the Yukon river, 25 miles above Anvik. Named Hall's rapids by Raymond, 1869, "in honor of Capt. Benjamin Hall, who first passed this point in a steamer."

Hall; rock, in the Kasiana group of islands, Sitka sound, Alexander archipelago. So named by Vasilief, 1809.

Halleck; harbor, in Saginaw bay, Kuiu island, Alexander archipelago. So named by Meade, 1869, after Maj. Gen. Henry Wager Halleck, U. S. A.

Halleck; island, a little north of Sitka sound, Baranof island, Alexander archipelago, near latitude $57^{\circ} 13^{\prime}$, longitude $135^{\circ} 27^{\prime}$. So named by Meade, 1869, after General Halleck, U. S. A., then in command at Sitka. 
Halleck; point, the western point of Halleck island above, at junction of Nakwasina passage and Olga strait, Alexander archipelago. So named by Moore, 1896.

Halleck; range of mountains (3,500 to 4,000 feet high), west of Portland canal. So named by Pender, 1868 .

Hallet; valley and river, tributary to the head of Klutina lake. So named by Abercrombie, 1898, after Private Hallet, a member of his party. $\mathrm{Er}$ roneously Hallett.

Hallo; bay, on the northern shore of Shelikof strait. Corruption of a native word given by Tebenkof as Ayou or Aiu, and this is said to represent very nearly the native pronunciation. It has appeared as Ago, Ábo, Aja, and Hioo. The local pronunciation by the whites is like the telephone call, hello:

Ham, cove; see Sawmill.

Ham; island, near the eastern shore of Annette island, Revillagigedo channel, Alexinder archipelago. So named by Nichols, 1883.

Ham, island ; see Blake.

Hamilton; bay, in Keku strait, Kupreanof island, Alexander archipelago. So named by the United States Navy, presumably in 1879 or 1880 , after the owner of a sawmill there. Sometimes called Familton harbor.

Hamilton; creek, in St. Elias region, southern Alaska, 5 miles east of Cape Yaktag, Gulf of Alaska. Named after Thos. J. Hamilton, United States marshal, Territory of Washington, and reported by Martin in 1903.

Hamilton; island, in Shakan bay, Sumner strait, Alexander archipelago. So named by Dall in the Coast Pilot $(1883$, p. 101).

Hamilton; landing, on right bank of the Yukon, a little above Kaltag. Called Hamilton's landing on recent maps.

Hamilton; mount, 12 miles north of Controller bay and 2 miles north of Bering lake, southern Alaska, near longitude $144^{\circ} 12^{\prime}$. Local name, reported by Martin in 1904.

Hamilton; mountain peak (about 2,500 feet high), in the Kilbuck range, westel'n Alaska, about 30 miles east-northeast of Bethel. So named by Post, of the Geological Survey, 1898.

Hamilton; point, the southern point of entrance to Hamilton bay, Keku strait, Alexander archipelago. So named by Moore, 1892.

Hamiltons Mill. A sawmill and wharf, on Shakan strait, Kosciusko island, Alexander archipelago; so called after its owner. The post-office Shakan is at this place. See Shakan.

Hamlet; mountain (2,000 feet high), on the Arctic coast, 12 miles south of Cape Lisburne, near latitude $68^{\circ} 45^{\prime}$. Named by Collier, 1904, after Capt. o. C. Hamlet, Revenue-Cutter Service, commanding the Revenue Marine steamer Thetis, that year, in Alaskan waters.

Hammond; creek, tributary to Middle fork Koyukuk river from the north (right), near latitude $67^{\circ} 30^{\prime}$, longitude $150^{\circ} 15^{\prime}$. Prospectors' name, reported both Baker and Nelson by Schrader, 1899, and Hammond by Peters and Schrader, 1901.

Hamond, cape; see St. Elias.

Hanagita; trail, valley, and river, tributary to Tebay river from the east. So named by Gerdine, 1900, after an Indian chief in the vicinity.

Hancock; peak (3,851 feet high), on the mainland, west of Thomas bay, southeastern Alaska. So named by Thomas, 1887, presumably after the first steamship to cross the Atlantic. 
Hanin; rocks, near the northern point of entrance to Chiniak bay, Kodiak island. Named Haninskia (Hanin), by Murashef in 1839-40. Twins of Coast Survey charts.

Hanks; island and shoal, near Sheep point, north shore Orca bay, Prince William sound, near latitude $60^{\circ} 37^{\prime}$, longitude $145^{\circ} 55^{\prime}$. Local name, from Moser, 1897. Ritter, 1903, has in the place of this shoal name, Gatherer rock.

Hanna; creek, eastern Alaska, on the west bank of Charley river, which is aftluent to Yukon river from the south, near longitude $143^{\circ}$. Prospectors' name, from sketch map compiled by Major Glassford, Signal Corps, U. S. A., 1905.

Hanna; glacier, on the northwest slope of Mount McKinley, drained by McKinley fork Kantishna river, near latitude $63^{\circ} 10^{\prime}$, longitude $151^{\circ}$. Named Peters, by Brooks, 1902, after W. J. Peters, of the Geological Survey, and Hanna, by the Board on Geographic Names, Jan. 6, 1904, after the late Hon. Marcus Alonzo Hanna, United States Senator from Ohio.

Hanning; bay, on the northwestern coast of Montague island, Prince William sound. So named by Portlock, 1787, "after the worthy family of the Hannings." Erroneously Hunning. It is Port Bazil of Vancouver's atlas and of Russian Hydrographic chart 1378.

Hannum; creek, Seward peninsula, tributary to Inmachuk river from west, near latitude $65^{\circ} 55^{\prime}$, longitude $163^{\circ} 10^{\prime}$. Prospectors' name, obtained by Mendenhall and Reaburn, 1901.

Hantak, island; see Khantaak.

Hanus; bay, indenting the northern shore of Baranof island, Peril strait, Alexander archipelago. Named by United States naval officers, 1880, after Lieut. Gustavus Charles Hanus, U. S. N. Was called Hanus inlet in the Coast Pilot of 1883.

Hanus; islet, at eastern entrance to Symonds bay, Biorka island, Sitka sound. Named by Symonds, 1879, after Lieut. G. C. Hanus, U. S. N.

Hanus; point, the eastern point of entrance to Hanus bay, Peril strait, Alexander archipelago. Named by Moore, 1895, after Lieut. G. C. Hanus, U. S. N.

Hanus; reef, in the eastern entrance to Icy strait, Alexander archipelago, near latitude $58^{\circ} 08^{\prime}$, longitude $135^{\circ}$. So named by Beardslee, 1880 , after: Lieut. G. C. Hanus, U. S. N., who discovered and surveyed it. Also called Hanus rocks.

Happy; river, tributary to the Skwentna from the north, near its source. So named by Spurr and Post, 1898.

Happy Newyear; creek, in Fortymile region, tributary on south bank to Slate creek, near latitude $64^{\circ} 35^{\prime}$, longitude $142^{\circ} 30^{\prime}$. Prospectors' name, reported by Witherspoon, 1905.

Harbor; island, immediately in front of the wharf at Sitka, Sitka sound, Alexander archipelago. Named Gavanski (harbor) by Vasilief, 1809.

Harbor; island, in Holkham bay, Stephens passage, Alexander archipelago. So named by Meade, 1869.

Harbor; island, in Security bay, Kuiu island, Alexander archipelago. So named by Meade, 1869.

Harbor, island; see Pitt.

Harbor, islet; see Danger.

Harbor; peak (2,200 feet high), near Sitka harbor, Baranof island, Alexander archipelago. Called Gavanski (harbor) mountain by Tebenkof, 1850. Has also been called Gavan. 
Harbor; point, the southern point of Old Sitka harbor, Sitka sound, Alexander archipelago. Named Gavanski by Vasilief, 1809, and called, indifferently, Gavanski and Harbor.

Harbor; point, on Annette island, the southern point of entrance to Hassler barbor; Revillagigedo channel, Alexander archipelago. So named by Nichols, 1882.

Harbor; point, on the eastern shore of Long island, Port Frederick, Icy strait, Alexander archipelago. Named by United States naval officers, 1880.

Harbor; point, the eastern point of entrance to Lituya bay, southeastern Alaska, near longitude $137^{\circ} 40^{\prime}$. Named by Dall in 1874. It is Iuzhnoi (south) point of Tebenkof', 1849.

Harbor; point, a sand spit in Port Moller, Alaska peninsula. So.named by Dall, 1882 :

Harbor; ridge (1,700 feet high), on the mainland, east of Nakat harbor, southeastern Alaska. So named by Nichols, 1883.

Harbor; rock, between the middle and western anchorages, Sitka harbor, Sitka sound, Alexander archipelago. So called by Dall in the Coast Pilot $(1883$, p. 149).

Frarding; point, the extreme northern point of Smeaton island, southern entrance to Behm canal, Alexander archipelago, near latitude $55^{\circ} 23^{\prime}$, longitude $130^{\circ} 56^{\prime}$. Local navigators' name, reported by H. C. Fassett, Bureau of Fisheries, 1904.

Hardscrabble; point, on the western shore of Prince of Wales island, Sumner strait, near latitude $56^{\circ}$, longitude $133^{\circ} 46^{\prime}$. Local navigators' name, reported by H. C. Fassett, Bureau of Fisheries, 1904.

HAarlem; gulch, Seward peninsula, Solomon River drainage, on east bank of: Shovel creek near its source; about latitude $64^{\circ} 43^{\prime}$, longitude $164^{\circ} 25^{\prime}$. Prospectors' name, from a local map, 1904.

Harman; point, the eastern head of Day harbor, Kenai peninsula. So named by Pơrtlock, 1786. Meares calls it Harmon.

Harold; mountain (3,428 feet high), on the mainland, east of Stikine river and near the international boundary line. Name published by the Coast Survey in 1895 .

Harper; bend, in Tanana river, about 20 miles below the mouth of Kantishna river. Locally known as Harper's bend, this designation being derived from Arthur Harper, a pioneer trader on the Yukon. Here, in a log house, was Harper's trading station, the scene of the murder of Mrs. Bean, wife of the agent stationed there.

Harrell; island, in Kuskokwim river, near latitude $63^{\circ}$. So named by Spurr, 1898 , after A. E. Harrell, a member of his party.

Harriet; creek, tributary to the Koyukuk river from the south, near longitude $151^{\circ}$. Prospector's' name, reported by Schrader, 1899.

Harriet; point, on the northwestern shore of Cook inlet, near Redoubt volcano. So called in Vancouver's atlas (1798, chart 10).

Harriman; fiord, opening into Port Wells, Prince William sound. Discovered and nimed by the Harriman expedition, 1899, after Mr. Edward Henry Harriman.

Harriman; glacier, tributary to the head of Harriman fiord, Fort Wells, Prince William sound. So named by the Farriman expedition, 1899.

Harringt 3 ; point, the north point of Observation island, forming the western point of entrance to Steamer bay, Etolin island, Alexander archipelago. So named by Vancouver, 1793.

Harrington; rock, in Portage bay, Kupreanof island, Alexander archipelago. So named by Nichols, 1882 . 
Harris; creek, tributary to North fork Kougarok iver, Seward peninsula. Name from Brooks, 1900.

Harris; island, near the mouth of Tamgas harbor, Felice strait, Alexander archipelago. So named by Clover, 1885.

Harris; islet, near the entrance to Silver bay, Sitka sound, Alexander archipelago. So named by Beardslee, 1880.

Harris; point, the northern point of entrance to Port Malmesbury, Kuiu island, Chatham strait, Alexander archipelago. So named by Vancouver, 1794. By transcription into Russian letters, an error in lettering, and a retranscription into English, this has appeared on some charts as Garns.

Harris; point, the most soutberly point of Smeaton island, southern entrance to Behm canal, near latitude $55^{\circ} 20^{\prime}$, longitude $130^{\circ} 57^{\prime}$. Local navigators' name, reported by H. C. Fassett, Bureau of Fisheries, 1904.

Harrisbuig, city, harbor, etc.; see Juneau.

Harris Dome; mountain (1,800 feet high), on Seward peninsula, near latitude $65^{\circ} 38^{\prime}$, longitude $164^{\circ} 32^{\prime}$. Local name, obtained by Gerdine, 1901.

Harrison; bay, on the Arctic coast, near mouth of Colville river, east of Point Barrow. So named by Dease and Simpson, 1837, in honor of the deputy governor of the Hudson Bay Company.

Harrison; creek, tributary to the North fork Birch creek from the left, near latitude $65^{\circ} 25^{\prime}$, longitude $145^{\circ} 10^{\prime}$. Prospector's name, reported by Spurr, Goodrich, and Schrader, of the Geological Survey, 1896.

Harrison; creek, on the right bank of Beaver creek, an affluent to Yukon river from the south, near longitude $147^{\circ}$. Prospectors' name, reported by Lieutenant Erickson, U. S. A., 1902.

Harrison; mountain (6,955 feet high), on the mainland, near Holkham bay, Stephens passage, Alexander archipelago. So named by Mansfield, 1889, after President Benjamin Farrison.

Harrison; point, on the western shore of Portland canal, southeastern Alaska. So called by the Coast Survey. This is Leading point of British Admiralty chart 2431 (1865-1888).

Harrison, river; see Alsek.

Harry; bay, indenting the mainland north of Tongass, Dixon entrance, southeastern Alaska, near latitude $54^{\circ} 49^{\prime}$, longitude $130^{\circ} 47^{\prime}$. Local navigator's' name, reported by H. C. Fassett, Bureau of Fisheries, 1904.

Harry; island, at the entrance to Flynn cove, south shore Icy strait, Alexander archipelago, near longitude $135^{\circ} 35^{\prime}$. So named by Dickins, 1901 .

Harry Saddle; a mountain (2,086 feet high), just north of Cape Fox, Dixon entrance. Apparently so named by Meade, 1869.

Hart; creek, 8 miles north of Nome, Seward peninsula, on the north slope of King mountain, tributary from the south to Glacier creek, near longitude $165^{\circ} 21^{\prime}$. Local name, published in 1901.

Hartford; range of mountains, on the mainland, north of Farragut bay, southeastern Alaska. Named by Thomas, 1887, after Admiral Farragut's flagship.

Hartman; river, tributary to the headwaters of Kuskokwim river. So named by Spurr, 1898 , after George Hartman, a member of his party.

Harts; lake, draining into Myrtle lake at the head of Niblack anchorage. Moira sound, southeastern shore Prince of Wales island, Alexander archipelago, near latitude $55^{\circ} 05^{\prime}$, longitude $132^{\circ} 07^{\prime}$. Local name; reported by Brooks, 1901.

Hartt; point, on Dall island, Howkan strait, Cordova bay, Alexander archipelago. So named by Sheldon Jackson, 1880. 
Harvard; glacier, tributary to the head of College fiord, Port Wells, Prince William sound. So named by the Harriman expedition, 1899. Near it, to the eastward, is Yale glacier, named by the sime expedition. These two were called Twin glaciers by Captain Glenn, 1898.

Flarvester; island, near or in Uyak anchorage, Uyak bay, northern coast of Kodiak. So named after the bark Harvester, and name published in 1899.

Bassiah; inlet, southwestern shore Prince of Wales island, Alexander archipelago, indenting the eastern shore of Cordova bay, near latitude $55^{\circ}$, longitude $132^{\circ} 37^{\prime}$. Probably native name, so called by the pilots, and reported by Dickins, 1905 .

Hassler; harbor, indenting the northeastern shore of Annette island, Revillagigedo channel, Alexander archipelago. Surveyed and named by Nichols, in the Coast Survey steamer Hassler, 1882.

Hassler; island, in Behm canal, on the northwestern shore of Revillagigedo island, Alexander archipelago. Named by the Coast Survey, 1891, after its surveying steamer Hassler.

Hassler, island. It was supposed, in 1882, that Carroll inlet or arm extended entirely across Revillagigedo island, cutting it in two. The southern part was then named Hassler. The name is, however, inapplicable, there being no such island.

Hassler; passage, separating Hassler island from Revillagigedo island. Alexander archipelago. So named by the Coast Survey in 1891.

Hassler; point, the northern point of entrance to North bay, Tlevak strait, Dall island, Alexander archipelago. Named by Dall, 1882, after the Coast Survey steamer Hassler, which was in this vicinity on a surveying cruise, 1881.

Hassler; reef (10 feet out at low water), 5 miles south of the Percy islands and in the southern entrance to Clarence strit, Alexander archipelago. Named after the Coast Survey steamer Hassler by Nichols, 1883, who says (Coast Pilot, p. 74), "probably identical with Brundige Rock." And again (p. 85), "This is without doubt the reef reported by Captain Brundige, though his bearings would not so confirm it." See Brundige.

Hastings; creek, debouching on the south shore of Seward peninsula, $3 \frac{1}{4}$ miles west of Cape Nome, near longitude $165^{\circ} 05^{\prime}$. Local name, published in 1900 .

Hat; mountain, on Wales island, Alexander archipelago. So named by Nichols, 1888.

Hatan, cape; see Kovrizhka.

Hatay; mountain and pass, 40 miles northwest of Tyonek, Cook inlet, near latitude $61^{\circ} \cdot 30^{\prime}$, longitude $152^{\circ}$. Indian name, reported by Ferron, 1899, written also Ha-tay. See also Spurr.

Hatch; creek, 15 miles north of Nome, Seward peninsula, a small tributary of Nome river from the 'west, near longitude $165^{\circ} 18^{\prime}$. Local name, published in 1900.

Hatchet; pass, between Dolgoi island and Hatchet point, southeastern shore Yakutat bay, southeastern Alaska. So named by Harber, 1892.

Hatchet; point, on the eastern shore of Yakutat bay,. southeastern Alaska. Called Topor (hatchet) by Tebenkof, 1849. Also has been written Tapor.

Hattie; gulch, in the Copper River region, at the headwaters of Chititu creek. Prospectors' name, taken from map of Nizina mining district by George M. Esterly, of Valdez, 1902. 
Hattie; island, in Portland canal, in latitude $55^{\circ} 19^{\prime}$. So named by the Coast Survey in 1891.

Hawaii; cape, the southeastern point of Wrangell island, Arctic ocean. Seen for the first time, August 16, 1867, by Capt. Thomas Long, of the American whaling bark Nile, and by him named Hawaii.

Hawg-heen, river; see Huagin.

Hawk; inlet, indenting the northwestern shore of Admiralty island, Chatham strait, Alexander archipelago. Name published in the Coast Pilot (1883, p. 182).

Hawk, island; see Aguligik.

Hawkins; island, in the entrance to Prince W.illiam sound, near latitude $60^{\circ}$ $30^{\prime}$, longitude $146^{\circ}$. Named Hawkins's by Vancouver in 1794. Has also been printed Hawkin. The Spaniards, 1779, called it Isla de Coipas (Copperas island).

Hawkins, point; see Salmo.

Hawkins Island Cutoff; channel, between Hawkins and Hinchinbrook islands, Prince William sound. So called by Ritter, 1899.

Hawley, island; see Boidarkin.

Hawthorne; peak (4,021 feet high), between Juneau and Taku inlet, southeastern Alaska. So named by Mansfield, 1890.

Hay; islet, on the southeastern edge of Sandman reefs, northeast of Sannak. So called by the Fish Commission, 1888.

Hayden; glacier, tributary to Malaspina glacier, northwest of Yakutat bay, in the St. Elias alps, southeastern Alaska. Named by Russell, 1890, after Prof. Ferdinand Vandiveer Hayden, founder and long director of the Geological Survey of the Territories.

Hayden, port; see.Heiden.

Hayes; glacier, at the source of Hayes river, northwest of Cook inlet. So named by Spurr and Post, 1898, after Dr. Charles Willard Hayes, of the United States Geological Survey.

Hayes; mountain (about 14,000 feet high), near latitude $63^{\circ} 30^{\prime}$ and longitude $147^{\circ}$. So named by Peters and Brooks, in 1898, after Dr. C. Willard Hayes, of the United States Geological Survey.

Hayes; point, the northeastern point of entrance to Peril strait, Chatham strait, Alexander archipelago. So named by United States naval officers, 1880, presumably after President Rutherford Birchard Hayes.

Hayes; river, tributary to the Skwentna from the south, northwest of Cook inlet. So named by Spurr and Post, 1898, after Dr. C. Willard Hayes, of the Geological Survey. Ferron, 1899, gives the native name as Tu-lu-shu-lit-na.

Haystack; island ( 450 feet high), one of the Proctor group, off the southwestern shore of Wales island, at. southern entrance to Tongass passage, Alexander archipelago. Descriptive name, given by Nichols, 1888.

Haystack; rock, south coast St. Paul island, Bering sea, east of St. Paul village, near longitude $170^{\circ} 16^{\prime}$. Descriptive name, from Duffield, 1897.

Haystacks; a group of five large and a number of small rocks, extending about 2 miles southerly from Andronica island, Shumagin group. Name published by Dall, 1875 .

Hayward; point, the northernmost point of Partofshikof island, at junction of Sukoi inlet and Neva strait, Alexander archipelago. So called by Dall (Coast Pilot, 1883, p. 155). On British Admiralty chart 2337 and Coast Survey chart 727 the name is erroneously applied to the north end of Kruzof island. 
Hayward; strait, separating Krestof and Kruzof islands and uniting Krestof and Sitka sounds, Alexander archipelago. This is recent Coast Survey usage. The name Hayward was given by Portlock, 1787, to a body of water which on late Coast Survey charts bears three names, viz, Souhoi inlet, Krestof sound, and Hayward strait, i. e., to the waters batbing the eastern shore of Kruzof island and uniting Salisbury and Sitka sounds. Portlock named his Hayward strait after his mate, who was the first white man to pass through it and thus establish the insularity of Kruzof island. The Russians called it Sukoi (dry), variously written Soukhoi, Soukoi, etc., and erroneously Souhoi.

Hazel; creek, 20 miles north of Cape Nome, Seward peninsula, tributary to Flambeau river from the west, near longitude $165^{\circ} 05^{\prime}$. Prospectors' name, published in 1900 .

Hazel; creek, 10 miles northwest of Cape Nome, Seward peninsula, tributary to Nome river from the east, near longitude $165^{\circ} .12^{\prime}$. Name from Barnard, 1900 .

Hazel; gulch, 20 miles north of Nonie, Seward peninsula, on the south side of Last Chance creek, an aftluent of North fork Snake river, near longi-. tude $165^{\circ} 28^{\prime}$. Local name, published in 1904.

Hazel, island; see Egg.

Hazen; bay, northeast of Nunivalk island, Bering sea. So named by Nelson, December, 1879, after Gen. William Babcock Hazen, Chief Signal Officer, U. S. A.

Hazen; point, in the eastern part of Izembek bay, Alaska peuinsula. So named by the Fish Commission, 1888.

Hazy; group of islands, south of Cape Ommaney and west of Coronation island, Alexauder archipelago. So named by early English fur traders in the eighteenth century. La Perouse, 1786, called them Isles de la Croyere. Maurelle and Quadra, 1779, called them Las Hermanas (the (sisters), but in Galiano's atlas, 1802, they were called Los Hermanos (the brothers). The Russians called them Tumannoi (foggy).

Head; cape, the southern point of Afognak island, Kodiak group. Called Golova (head) by the Russian-American Company, 1849. Apparently identical with Zhila (lode) point of Murashef in 1839-40.

Head, mountain; see Tyee.

Headland, island; see Sebree.

Heald; point, the western point of entrance to Yarboro inlet, on the Arctic: coast, east of the mouth of Colville river. So named by Franklin, 1826.

Healy; creek, a right branch of Cantwell river, near latitude $63^{\circ} 50^{\prime}$, longitude $149^{\circ}$. Named after Capt. J. J. Healy, president of the North American Transportation and Trading Company, and reported by Brooks, 1902. Erroneously Healey.

Healy; river, tributary to Tanana river from the north, near longitude $144^{\circ}$. Prospectors' name, reported by Prindle, 1905.

Healy; rock, in Whitewater bay, Admiralty island, Alexander archipelago. So named by Glass, 1881.

Heart; mountain, on the north bank of Yukon river, a little above the mouth of Melozi river. Name published by the Coast Survey in 1898.

Heart, mountain; see Chitsia.

Heather; island, in Columbia bay, Prince William sound, at the head of the bay and close to the front of Columbia glacier, near latitude $61^{\circ}$, longitude $147^{\circ} 10^{\prime}$. So named by the Harriman expedition, 1899 . 
Heceta; island, on the western border of Prince of Wales archipelago, near latitude $55^{\circ} 45^{\prime}$, longitude $133^{\circ} 30^{\prime}$. Named by Dall, 1879, after Don Bruno Feceta, a Spaniard, who, in the Santiago, explored and surveyed hereabouts in 1775 .

He Beaver, river; see Hosiana.

Heckman; point, on the eastern shore of Cleveland peninsula, Behm canal, southeastern Alaska, near latitude $55^{\circ} 45^{\prime}$, longitude $131^{\circ} 47^{\prime}$. Local navigators' name, probably after J. R. Heckman, superintendent of cannery at Loring, and reported by H. C. Fassett, Bureau of Fisheries, 1904.

Heenan; creek, eastern Alaska, tributary to Glenn creek, on the south bank of Yukon river, near latitude $65^{\circ} 15^{\prime}$, longitude $142^{\circ} 05^{\prime}$. Prospectors' name, from sketch map compiled by Major Glassford, Signal Corps, U. S. A., 1905.

Heesman, point; see Hiesman.

Heiden; canyon, in upper part of Lowe river, east of Port Valdez. So named by Abercrombie, 1898, after Corp. Robert Heiden, a member of his party. Erroneously Hyden.

Heiden; port or bay, indenting the northern shore of Alaska peninsula, north of Chignik bay. Named Heidena (Heiden's) by Lutke, 1828, after Count Heiden. In French, Lutke wrote it Heyden and Krusenstern wrote it Hayden. Has also been written Haiden.

Heim; creek, in the Fairbanks region, tributary to Miller creek from the west, near latitude $65^{\circ} 05^{\prime}$, longitude $147^{\circ}$. Prospectors' name, reported by Gerdine, 1903.

Helen; creek, 7 miles northwest of Nome, Seward peninsula, a small tributary of Nome river, near longitude $165^{\circ} 16^{\prime}$. Local name, published in 1903.

Helen; island, in Hassiah inlet, Cordova bay, Alexander archipelago, near latitude $55^{\circ}$, longitude $132^{\circ} 37^{\prime}$. Name from Dickins, 1905.

Helen; peak $(3,675$ feet high $)$, in the northern part of Etolin island, Alexander archipelago. So named by Snow, 1886.

Helikoff, strait; see Shelikof.

Hell Gate; rapids, in Klutina river, above Copper Center. Prospectors' name, in use during season of 1898 , to denote the extreme rough waters on the Klutina above Copper Center.

Hells Acre; a place of violent tidal currents and rough water in Kootznahoo inlet, Admiralty island, Alexander archipelago. So named by Meade, 1869.

Helm; bay, in Cleveland peninsula, opening into Behm canal, Alexander archipelago. So named by Snow, 1886, after Lieut. James Meredith Helm, U. S. N., a member of his party.

Helm; point, the southernmost point of Coronation island, Alexander archipelago. Named by Snow, 1886, after Lieut. James M. Helm, U. S. N., of his party.

Helm; point, the north point of entrance to Helm bay, Behm canal. Reported usage of local navigators, by Fassett, Bureau of Fisheries, 1904.

Helm; rock, off Point Baker, Sumner strait, Alexander archipelago. Named after Lieut. J. M. Helm, U. S. N., who surveyed this region in 1886.

Helmick; mountain (about 2,000 feet high), near the coast and east of Kuskokwim bay, western Alaska. Named by Post, of the Geological Survey, 1898, after the Moravian missionary, Rev. Benjamin Helmick.

Helpmejack; creek, tributary to Alatna river from the west, near latitude $67^{\circ}$, longitude $153^{\circ} 45^{\prime}$. . Prospectors' name, reported by Mendenhall in 1901. Stoney, who was there in 1885, wrote the Kobul Eskimo name, Ko-taglik-ark. 
Hemlock; island (peninsula at low water), in Port Chester, Annette island, Alexander archipelago. So named by Nichols, 1883.

Hemlock; point, in Kootzuahoo inlet, Admiralty island, Alexander archipelago. So named by Meade, 1869 .

Henderson; island, near the western point of Korovin island, Shumagin group, about longitude $160^{\circ} 20^{\prime}$. Named by Dall, 1872 .

Hendrickson; mountain (4,430 feet high), in the St. Elias alps, southeastern Alaska. Named by Russell, 1890, after the Swedish missionary, Rev. Karl Johan Hendrickson. Erroneously Hendriksen, Hendricksen, etc.

Hengue, Isla de; see Haenke island.

Hennig; sunken rock, west of Sannik island, near latitude $54^{\circ} 25$, longitude $162^{\circ}$ 58'. Named by Dall, 1880, after Capt. E. Hennig. Erroneously Henning.

Henning, rock; see Hennig.

Henrietta; island, in the Arctic ocean, north of the New Siberian islands. Discovered and so named by De Long, 1.881.

Henry; creek, Seward peninsula, tributary to Kugrupaga river from the west, 2 miles below the mouth of 'Taylor creek, near latitude $65^{\circ} 35^{\prime}$, longitude $165^{\circ} 55^{\prime}$. Prospectors' name, obtained by Gerdine, 1901.

Henry; peak (3,386 feet high), on the mainland, near Thomas bay, southeastern Alaska. Named by 'Thomas, 1887, after Prof. Joseph Henry, Secretary of the Smithsonian Institution.

Hepburn; cape (Cape Hepburn), between the two northeastern arms of Alitak bay, southwestern coast of Kodialk. So named by Moser, 1900, after Ensign A. J. Hepburn, U. S. N., a member of his party.

Hepburn; point, on the northwestern shore of Admiralty island, Chatham strait. Alexander archipelago. So named by Homfray, 1867, after James Hepburn, of Victoria, Vancouver island, long a naturalist and explorer in this region, and who died about 1866.

Herald; island ( 856 feet high), east of Wrangell island, Arctic ocean. Discovered and landed upon July, 1849, by Captain Kellett, of H. M. S. Herald and named by him after his ship.

Herbert; glacier, on the mainland, just-south of Lagle glacier, southeastern Alaska. Named by Mansfield, 1890, after Hon. Hilary A. Herbert, Secretary of the Navy.

Herbert; volcanic island $(5,291$ feet high), one of the group of islands of the Four Mountains, eastern Aleutians. So named by officers of the U. S. S. Concord, 1894, after Hon. Hilary Abner Heibert, Secretary of the Navy. This may be the island Tshugidi of Billings, 1791, and variously called since then Chuginok, Chaguliak, Tchegoulak, etc. See Four Mountains islands.

Herbert; port (Fort Herbert), southeastern shore of Baranof island, Chatham strait, Alexander archipelago, near latitude $56^{\circ} 26^{\prime}$, longitude $134^{\circ} 40^{\prime}$. Described in the Coast F'ilot of 1.901.

Herendeen; bay, indenting the northern shore of Alaska peninsula, near or in Port Moller. The bay was first explored and sketched by Capt. L. P. Herendeen, in about 1881, and named after him by the Coast Survey.

Herendeen; island, forming the northern side of Nortbwest harbor, Little Koniuji island, Shumagin group. So named by Dall, 1874, after Capt. Edward Perry Herendeen, sailing master of the Coast: Survey schooner Yukon, 1873-74 and 1880.

Hermanos, Los dos; see Wingham island.

Hermogenes, cape; see Chiniak. 
Herring; bay, on the western shore of Carroll inlet, Revillagigedo island, southeastern Alaska, near latitude $55^{\circ} 20^{\prime}$, longitude $131^{\circ} 32^{\prime}$. Local navigators' name, reported by H. C. Fassett, Bureau of Fisheries, 1904.

Herring; bay, indenting the southern shore of Admiralty island, Frederick sound, Alexander archipelago. Named Seldovaia (herring) by the Russians.

Herring; bay, indenting the western shore of Knight island, Prince William sound, near latitude $60^{\circ} 25^{\prime}$, longitude $147^{\circ} 45^{\prime}$. Local name, reported by Schrader, 1900.

Herring, cove; see Salmon.

Herring; islets, at entrance to Tutka bay, Kachemak bay, Cook inlet. So named by Dall, 1880 .

Herron; glacier, on the north slope of Mount Foraker in the McKinley range and drained by Shisnona river, near latitude $63^{\circ}$, longitude $151^{\circ} 30^{\prime}$. So named by Brooks, 1902, after Lieut. Joseph S. Herron, U. S. A.

Herschel; island (about 500 feet high), on the Arctic coast, near the international boundary line. So named by Franklin, 1826. Has sometimes been written Hershel.

Hery, point ; see Fley.

Herzfels, island; see Alaid.

Hesketh; island, on the southern shore of Kachemak bay, Cook inlet. Named by Dall, 1880, after Sir 'Thomas Hesketh, who in his yacht, the Lancashire Witch, visited Cook inlet that year.

Hess; creek, tributary to Yukon river from the east, near Rampart city. Raymond, 1869, calls it Yokuchargut (Yoku-kakat) or Whymper. Dall calls it Yukutzchárkat, and says Captain Ketchum called it Whymper, after his friend and companion. On recent maps called Mike Hess or Hess creek.

Hessa; inlet, in Prince of Wales island, opening into Cordova bay, Alexander archipelago. Local name, obtained by Moser, 1897.

Hessa; lake, near the southern end of Prince of Wales island, at the head of Hessa inlet, above. So called by the fisheries, and reported by Moser, 1897.

Hetta; cove, between Hetta inlet and Hetta lake, Cordova bay, southeastern Alaska, near latitude $55^{\circ} 08^{\prime}$, longitude $132^{\circ} 34^{\prime}$. So called by local navigators, and reported by H. C. Fassett, Bureau of Fisheries, 1904.

Hetta; inlet and lake, in the southwestern part of Prince of Wales island, Alexander archipelago. Name reported by Moser, 1897. Tliakek bay, of earlier charts, may have been this inlet.

Hetta; mountain, on the eastern shore of Hetta inlet, southwestern coast of Prince of Wales island, Alexander archipelago, near latitude $55^{\circ} 10^{\prime}$, longitude $132^{\circ} 35^{\prime}$. Local name, reported by Wright, 1905.

Hetta; point, the north point of entrance to Hetta cove, eastern shore Hetta inlet, Cordova bay, Alexander archipelago. Local name, reported by Dickins, 1905.

Hetta; stream, Prince of Wales island, the outlet of Hetta lake, above. So called by Moser, 1901.

Hetta; village, on south shore Hetta cove, above. Written Hettah by Dickins, 1905.

Hey; point, on the northwestern shore of Controller bay, Gulf of Alaska, near latitude $60^{\circ} 10^{\prime}$, longitude $144^{\circ} 18^{\prime}$. Named by Vancouver in 1794 . Erroneously Hery.

Hibahibgik; pinnacle rock, off Scotch cap, in Unimak pass. Native name from Veniaminof. Lutke calls it Ounga. 
Hicks; creek, tributary to Matanuska river from the north, near latitude $62^{\circ}$ : So named by Glenn, 1898, after H. H. Hicks, guide of his expedition.

Hicks; point, on Mitkof island, Wrangell strait, Alexander archipelago. Named by Meade, 1869, after a Mr. Hicks, pilot and trader of the Hudson Bay Company, who piloted the U. S. S. Saginaw on her first trip in Alanskan waters in 1868-69.

Hid; l:eef, in Nichols passage, off Canoe cove, western side Annette island, Alexander archipelago. So named by Nichols, 1883.

Hidden; glacier, tributary to Russell fiord, from the east, Yakutat bay, southeastern Alaska. So named by Russell, 1891, who only obtained glimpses of it as he passed.

Hidden; inlet, in the mainland north of Pearse island, southenstern Alaska. Descriptive name, given by the Coast Survey in 1891 .

Hidden; island, at the northern entrance to Dry strait, Alexander archipelago. So named by 'Thomas, 1887.

Hiesman; point, on the southwestern shore of Chichagof island, Alexander archipelago. So called by 'Tebenkof, 1849. Erroneously Heèsman and Heisman.

Higgins; point, the westernmost point of Revillagigedo island, Alexander archipelago. Named by Vancouver, 1798, after " Senr. Higgins de Vallenar, President of Chili." Higgins was an Irishman from Ballenagh, Ireland, and spelled his name O'Higgins.

High, bluffs, St. George island; see Eganuta.

High, bluffs, St. Paul island; see Einahnuhto.

High; island, in the entrance to Kasaan bay, Clarence strait, Alexander archipelago. So named by Dall, 1880.

High; island, one of the Walrus island group, in northern part of Bristol bay: So called by the Fish Commission in 1890. Apparently identical with Ingekvak of Sarichef, 1826.

High; island, in the entrance to Womens bay, Chiniak bay, Kodiak. Named Viesokoi (high) by Russian naval officers, 1808-1810.

High; island, between Korovin and Popof islands, Shumagin group. Named. Viesokoi (high) by Tebenkof, 1849. Has also been written Vesoki and Visokoi.

High; islet, near Kita island, in Sitka sound, Alexander archipelago. . Named Viesokoi (high) by Vasilief, 1809.

High; mountain (2,540 feet high), in California ridge, Gravina island, Alexander archipelago. Name published by the Coast Survey in 1886.

High; mountain, in Peninsula ridge, on the mainland, east of Revillagigedo channel, southeastern Alaska. So named by Nichols, 1883.

High; point, west shore of Woronkofski island, Stikine strait, Alexander archipelago, near latitude $56^{\circ} 24^{\prime}$, longitude $132^{\circ} 33^{\prime}$. Local navigators' name, reported by H. C. Fassett, Bureau of Fisheries, 1904.

High; point, between Port Tongass and Nakat inlet, southeastern Alaska. So named by Nichols, 1883.

High; point, on Dall island, Tlevak strait, Cordova bay, Alexander archipelago, So named by Nichols, 1881.

High, point, on left bank of the Chilkat river, about 10 miles above its mouth; Named Viesokie (high) ly Lindenberg, 1838. The name is obsolete. The place seems to be identical with Chilkat peak (4,000 feet high) ur United States Fydrographic chart 883.

High; rock, off the southwestern end of Near island, Chiniak bay, Kodicis Named Viesoloi (high) by the early Russians: It may be identicas with Inner Humpback; see Inner Humpback.

Bull. 299-06 $\mathrm{m}-20$ 
High; rock, on the north shore of Alitak bay, southwestern coast of Kodiak, at the northeast point of entrance to Moser bay. Descriptive name, from Moser, 1900.

High; rock (123 feet high), near the easternmost point of Chugul island, eastern Aleutians. So called, apparently, by the North Pacific exploring expedition, 1855.

High; rock, off the southeastern coast of Amukta island, eastern Aleutians. So called by the North Pacific exploring expedition, 1855.

Highcliff, bay; see Kachemak.

Highfield; anchorage, off the north end of Wrangell island, Alexander archipelago. Surveyed, 1862 , by F. O. Simpson, master H. M. S. Devastation, and by him called Anchorage off Point Highfield. Meade, 1869, calls it Point Highfield harbor, while the Hudson Bay traders called it Labouchere bay or anchorage, after the steamer Labouchere.

Highfield; point. the northernmost point of Wrangell island, Alexander archipelago. So named by Vancouver, 1793 .

Highland; creek, Kenai peninsula, on the right bank of Resurrection creek, near latitude $60^{\circ} 55^{\prime}$, longitude $149^{\circ} 35^{\prime}$. Local name, from Moffit, 1904.

Highland; creek, eastern Alaska, on the east bank of Charley river, which is aftluent to the Yukon from the south, near longitude $143^{\circ}$. Prospectors' name, from sketch map compiled by Major Glassford, Signal Corps, U. S. A., 1905.

Highland; point, on the mainland on the northern shore of Frederick sound, Alexander archipelago. Descriptive name, given by Meade, 1869.

High Rock, Sitka sound; see Viesoki.

Highwater; islet, in Neva strait, near St. John Baptist bay, Alexander archipelago. So named by Coghlan in 1884. At low water it is not an islet.

Hijosa, Isla de; see Middleton.

Hilda; creek, 15 miles north of Nome, Seward peninsula, a small tributary of Nome river from the west, near longitude $165^{\circ} 18^{\prime}$. Local name, published in 1900.

Hilda; creek, tributary to North fork Fortymile creek, from the east. Prospectors' name, from Barnard, 1898.

Hilda; point, on the southein shore of Douglas island, Stephens passage, Alexander archipelago. So called by the Coast Survey in 1890 .

Hilgard; mountain (1,500 feet high), near Sanborn harbor, Nagai island, Shumagin group. So called by Dall, 1872, after Julius Erasmus Hilgard, afterwards Superintendent of the Coast Survey.

Hill; creek, Seward peninsula, tributary from the north to Arctic river, near longitude $165^{\circ} 59^{\prime}$. Prospectors' name, obtained by Gerdine, 1901.

Hill; gulch, 25 miles north of Nome, Seward peninsula, on the south bank of Stewart river, near. longitude $165^{\circ} 22^{\prime}$. Local name, from Gerdine, 1904.

Hill; island, at entrance to Portlock harbor, Chichagof island, Alexander archipelago. Named Hills by Portlock, 1787.

Hill, islets; see McFarland.

Hinchinbrook; cape, the southwestern point of Hinchinbrook island, Prince William sound. Named, 1778 , by Cook, who spells it Hinchingbroke in his text and Hinchinbrook on his chart. This name, with several variations of spelling, was used by Dixon, Meares, Portlock, and Vancouver. Tebenkof calls it Morskoi (ocean) cape. 
Hinchinbrook; entrance, the principal entrance to Prince William sound, between Hinchinbrook and Montague islands, near latitude $60^{\circ} 20^{\prime}$, longitude $146^{\circ} 45^{\prime}$. Named Meiklejohn by Abercrombie; 1898, after Hon. George D. Meiklejohn, Assistant Secretary of War. The Coast Survey, 1903, called it Hinchinbrook, which appears to be in accordance with the usage of mariners, and this name has been adopted by the U. S. Board on Geographic Names.

Hinchinbrook; island, in Prince William sound, near latitude $60^{\circ} 20^{\prime}$, longitude $146^{\circ} 30^{\prime}$. So called by Vancouver, 1794 . It is Rose island of Meares and Portlock, 1787-88, and Isla de la Magdalena of the Spaniards, 1791. Tebenkof uses the native name Khtagaliuk or Khta-aluk, according to Petrof, while an old Russian chart of 1802 has Thhalka, which has a manuscript French rendering of Tchalka. Abercrombie, in 1898, calls it Nuckek island.

Hindasetukee, village; see Gan-te-gas-tak-heh.

Hines; river, a glacial stream, debouching immediately west of the western mouth of Alsek river, southeastern Alaska. Written Gines by Teben'kof, 1849. Apparently a native word, pronounced Géenes , or Hē-nĕs. See also Stuhinuk.

Hini. An Indian word meaning river, in use in southeastern Alaska. It is appended to the names of rivers, as Klehini, Krotahini, etc.

Hioo, bay ; see Hallo.

Hitchcock; range of mountains, between Marvine and Seward glaciers, St. Elias alps, southeastern Alaska. So named by Russell, 1890, "in acknowledgment of the services to science rendered by the first State geologist of Massachusetts."

Hitzeecolochna, river; see Hitzikolok:

Hitzikolok; river, in the Kuskokwim region, a right branch of the Shisnona, near latitude $63^{\circ} 15^{\prime}$, longitude $153^{\circ}$. Indiain name, reported by Herron in 1899, and written by him Hitz-ee-col-och-na and Hitzeecolochna.

$H i$ - $u$, creek; see Haiu.

Hive; island (1,070 feet high), in entrance to Resurrection bay, Kenai peninsula, near latitude $59^{\circ} 53^{\prime}$, longitude $149^{\circ} 23^{\prime}$. So named by the U. S. Board on Geographic Names, June 6, 1906. Called Guard island by Moffit, 1904. Reported as Sugar Loaf island, by Denson, of the Coast: Survey, 1905.

H'lit-tu-yuh, bay; see Lituya.

Hobart; bay, indenting the mainland coast, Frederick sound, Alexander archipelago. So named by Mansfield, 1889.

JHobart; point, on the mainland coast, Frederick sound, Alexander archipelago. So named by Vancouver, 1794. Has also been called Gastineau point.

Hobron; port, indenting the northeastern shore of Sitkalidak island, near Kodiak. It is " a snug harbor on the north side of Sitkalidak island, in the second deep bay coming from seaward." Apparently so named by Petrof, 1887 or 1888, who at that time established here a fishing station for the Alaska Coast Fishery Company and became its manager. Lisianski, 1805, locates a village, called Fugitive, at or near this place.

Hobson; creek, 20 miles north of Nome, Seward peninsula, tributary to Nome river from the north, near latitude $64^{\circ} 45^{\prime}$, longitude $165^{\circ} 17^{\prime}$. Name from Barnard, 1900. 
Hockley; hills, east of Kotzebue sound and north of Selawik lake. Apparently so named by English naval officers during the Franklin search expeditions, 1849-1854.

Hodatic; river, tributary to the Koyukuk on the right bank between Koteel and Huslia rivers, about latitude $65^{\circ} 30^{\prime}$, longitude $157^{\circ} 30^{\prime}$. Name published in 1900 .

Hoffmann; mountain (Mount Hoffmann, 5,280 feet high), on the west bank of Taiya river, southeastern Alaska, near latitude $59^{\circ} 39^{\prime}$, longitude $135^{\circ}$ $20^{\prime}$. So named by Flemer, 1898 , but not hitherto published.

Hoffnung, point; see Hope:

Hog; island (300 feet high), near Hot Springs bay, Sitka sound, Alexander archipelago. Named Srinoi (hog) by Vasilief, 1809.

Hog; island, in the mouth of Afognak bay, Afognak island, near. latitude $57^{\circ}$ $58^{\prime}$, longitude $152^{\circ} 42^{\prime}$. Name from Moser, 1900. 'This seems to be the island which was called Shayak by Tebenkof.

Hog; island, west of Amaknak island, in Unalaska bay, near longitude $166^{\circ} 34^{\prime}$. Called Swinoi (hog) by Tebenkof, 1849. Its native name as given by Sarichef, 1792, is Uknodok, and by Veniaminof, Uknadak. - Lutke calls it Ouknadok. Veniaminof records that in olden time an Aleut village existed here and that a fight occurred between the Unalaskans and Aleuts from Unimak, in which the latter were exterminated. Hogs were placed on this island by the Russians, whence the name.

Hog, river ; see Hogatza.

Hog; rocks, near the southern end of Revillagigedo island, Revillagigedo channel, Alexander archipelago. So named by Michols, 1883. Erroneously Frog rocks on some charts.

Hogan; island, at the entrance to Portlock harbor, Chichagof island, Alexander archipelago. Named Hogans by Portlock on his sketch of Portlock harbor, made in August, 1787, and published in his Voyage, p. 258. On his general chart it is called vincent Island.

Hogatsikakat, river; see Hogatza.

Hogatza; river, tributary to Koyukuk river from the north, near longitude $156^{\circ}$. Native name, reported by Allen, 1885, as Hogatzakakat. See Kakat. This is the same river as the one called Kokachatna or Kokachutna by Stoney in 1885, and called Hokachatna and Hokuchatna by others. Has also appeared as Hogatiakakat, Hogatsikakat, and Hog.

Hogback; small glacier, a few miles east of Valdez, Prince William sound. So named by Abercrombie, 1898.

Hogback; hill (300 feet high), south shore Pastol bay, 8 miles east of the Apoon mouth of the Yukon, near latitude $63^{\circ} .01^{\prime}$, longitude $163^{\circ} 06^{\prime}$; Named Hog Back by the Coast Survey, 1898.

Hogem, creek; see Deadwood.

Hoggatt; bay, on the southeastern shore of Baranof island, Chatham strait, Alexander archipelago. So named by Moore, 1895, after Ensign Wilford Bacon Hoggatt, U. S. N., a member of his party, and now Governor of Alaska. Erroneously Hoggat.

Hoggatt; reef, one-half mile square, partly bare, in Peril strait off the entrance to Ushk bay, near latitude $57^{\circ} 33^{\prime}$, longitude $135^{\circ} 31^{\prime}$. So named by Moore, 1895, after Ensign Wilford Bacon Hoggatt, U. S. N., a member of his party, and now Governor of Alaska.

Hoholiknuk, river; see Haliknuk.

Hohonilla, mountain; see Totanilla.

Holeachatna, river; see Hogatza. 
Holkotena, river; see Wild and North fork Koyulikk.

Ho-ku-chat-nu, river; see Hogatzil.

Holbrook; fishing station at the head of Davidson inlet, sonthern shore of Kosciusko island, Prince of Wales archipelago, near latitude $56^{\circ} 02^{\prime}$, longitude $133^{\circ} 30^{\prime}$. Local name, reported by Dickins, $1903-4$.

Holbrook; mountain (2,660 feet high), on Kosciusko island, near the heitl of Davidson inlet, about latitude $56^{\circ} 02^{\prime}$, longitude $133^{\circ} 27^{\prime}$. So named by Dickins, 1903-4, after the near-by fishery.

Holden; point, on Dall island, opposite Howkan village, Cordova bay, Alexander archipelago. So named by Sheldon Jackson, 1880.

Hole-in-the-Wall; small cove, in the northwestern part of Prince of Wales island, opening into Sumner strait, Alexander archipelago. So named by Helm, 1886.

Holes; point, on the southern shore of Whale island, Kodiak group. Named Dierovatie (full of holes) by Murashef, 1.839-40.

Holiday, island ; see Praznik.

Holikitsalk. The Eleventh Census, 1890 (p. 165), records a native village of this name in the Yukon enumerating district with a population of $\mathbf{1 1 4 .}$ Location not discovered.

Holiknuk, river; see Chulitna.

Holitno, river; see Chulitna.

Holkham; bay, indenting the mainland and opening into Stephens passage, near latitude $57^{\circ} 45^{\prime}$, southeastern Alaska. So named by Vancouver, 1794. The native name is Sum Dum, and represents in sound and meaning the noise of falling and rising icebergs.

Hollings, cape, Kodiak; see Narrow.

Hollis; cove and post-office (established in 1901.), on Twelvemile arm of Kasaan bay, east shore Prince of Wales island, southeastern Alaska, near latitude $55^{\circ} 28^{\prime}$, longitude $132^{\circ} 40^{\prime}$. Locil name.

Holoöatna, river; see Kobuk.

Holtkagelia, mountain; see Totanilla.

Holtz; open bay, indenting the northern shore of Attu island, just west of , Chichagof: harbor, western Aleutians. Lutke calls this Goltsovaia bay. Perhaps the name comes from the German word holtz (wood). It has also appeared as Goltzeb and even Gotzeb.

Holtz; creek, Seward peninsula, branch of Kugruk river from the south, near latitude $65^{\circ} 35^{\prime}$, longitude $162^{\circ} 30^{\prime}$. Frospectors' name, obtained by Witherspoon, 1903.

Holy Cross; Jesuit mission school, on the northern bank of the Yukon, about 25 miles below Anvik, opposite Koserefski, established in 1886 .

Holyoke; creek, $2 \frac{1}{2}$ miles north of Nome, Seward peninsula, tributary to the headwaters of Bourbon creek, near longitude $165^{\circ} 23^{\prime}$. Local name, published in 1903.

Holyoke; creek, tributary to Niukluk river from the west, Seward peninsula. Name from Barnard, 1900.

Horner; post-office, on Coal point, Kachemak bay, Cook inlet, establisherl in November, 1895.

Horner; spit, Kenai peninsula, extending 5 miles into Kachemak bay from the north shore, and on which the town of Homer is situated. So called by Stone, 1904 .

Hornestake; creek, eastern Alaska, on the north bank of Bonanza creek, a tributary of Charley river from the east, near latitude $65^{\circ} 10^{\prime}$, longitude $142^{\circ} 50^{\prime}$. Prospector's' name, from siketch map compiled by Major: Glassford, Signal Corps, U. S. A., 1905. 
Homestake; creek, tributary to Kruzgamepa river from the west, Seward peninsula. Prospectors' name, from Barnard, 1900.

Homestake; creek, Seward peninsula, tributary to Kugrupaga river from the west, 1 mile above the mouth of 'Taylor creek, near latitude $65^{\circ} 42^{\prime}$, longitude $164^{\circ} 50^{\prime}$. Prospector's' name, obtained by Gerdine, 1901.

Homestake; creek, Fairbanks region, tributary to Faith creek from the east, near latitude $65^{\circ} 25^{\prime}$, longitude $146^{\circ} 10^{\prime}$. Prospector's' name, from Gerdine, 1903.

Homestake; gulch, Seward peninsula, on west bank of Casadepaga river, near latitude $64^{\circ} 48^{\prime}$, longitude $164^{\circ} 20^{\prime}$. Prospectors' name, from Gerdine, 1905.

Hongkong; bend, in Kasilof river, Kenai peninsula, near latitude $60^{\circ} 20^{\prime}$, longitude $151^{\circ} 10^{\prime}$. Local name, from Moffit, 1904.

Honey; creek, tributary to Penny river from the east, in the Cape Nome mining region, Seward peninsula. Prospectors' name, published in 1900.

Hoochinoo, archipelago, village, etc.; see Kootznahoo.

Hoochitna. Allen, 1885, reports this to be the Indian name of the main stream of Koyukuk river at its source. Name found only in his text (p. 100), where it is written Hoochítna.

Hood; bay, indenting the western shore of Admiralty island, Chatham strait, Alexander archipelago, near latitude $57^{\circ} 25^{\prime}$. So called by Vancouver in 1794. There has been confusion of names and geographical representation in this vicinity. The Coast Survey has called this bay Hootz (from Khutz or Khudz, meaning bear).

Hood; point, at the southern end of Lindenberg peninsula, Duncan canal, Alexander archipelago. So named by Vancouver, 1793, after Admiral Alexander Arthur Hood, R. N., afterwards Lord Bridport.

Hood; point, on the northeastern shore of Killisnoo island, Chatham strait, Alexander archipelago. So named by Meade, 1869.

Hoodlum; creek, Seward peninsula, tributary to Cripple river from the east, near latitude $65^{\circ} 50^{\prime}$, longitude $163^{\circ} 35^{\prime}$. Prospector's' name, obtained by Mendenhall in 1901.

Hoodoo; dome, in the Rampart region, 50 miles east of Fort Hamlin, on the east bank of the North fork of Hess creek, near longitude $147^{\circ} 30^{\prime}$. Prospector's' name, reported by Lieutenant Erickson, U. S. A., 1902.

Hoodoo; gulch, 20 miles north of Nome, Seward peninsula, tributary to Nome river from the east, near latitude $64^{\circ} 44^{\prime}$, longitude $165^{\circ} 14^{\prime}$. Local name, from Gerdine, 1904.

Hoodoo, island, Prince William sound; see Flemming.

Hoof; hill, in I'yndall glacier, near Mount St. Elias. So called by Topham in the Alpine Journal (vol, 14), 1889.

Hook; point, on the western shore of Portage bay, Kupreanof island, Alexander archipelago. Presumably so named by Nichols, 1882.

Hoola-Hoola, river; see Hulabula.

Hoonah; post-office (established in 1901), at Kantukán, Hooniah harbor, Port Frederick. See Kantukan.

Hooniah; harbor, in Port Frederick, Chichagof island, Icy strait, Alexander archipelago, near longitude $136^{\circ} 27^{\prime}$. Native name, meaning cold lake, and variously spelled Fooniah, Hoonyah, etc. Has also been called. Port Frederick harbor.

Hooniah; island, on the west side of entrance to Port Frederick, south shore Icy strait, near longitude $135^{\circ} 30^{\prime}$. So named by Dickins, 1901. 
Hooniah; point and bluff, on the nopth side of entrance to Hooniah harbor, Port Frederick, Icy strait, Alexander archipelago, near longitude $135^{\circ}$ 27 '. So named by Dickins, 1901. 'This is Entraurce point of Symonds, 1880.

Hooniah; sound, Peril strait, indenting the southern shore of Chichagof island, Alexander archipelago. Name derived from a resident tribe of Indians, and variously spelled Hoonah, Hoonjah, Huna. The Sitka Indians are said to call it Shekak.

Hooniah; hot or warm springs, on the northern shore of Tenakee inlet, Chichagof island, Alexander archipelago. So called by Nichols in the Coast Pilot (1891, p. 163).

Hooniah, village; see Kantukan.

Hoonyah, island ; see Chichagof.

Hooper; bay, in the Yukon delta. Visited and named by Nelson in December, 1.878, after Capt. Calvin Leighton Hooper, of the United States Revenue Marine, well known for his investigations in Bering sea and the Arctic ocean.

Hooper; mountains, along the Arctic coast, between Cape Lisburne and Point Barrow. So named by Petrof, 1880, after Capt. C. L. Hooper, U. S. Revenue Marine. Apparently identical with the Meade river mountains of Ray in 1885.

Foorts; mountain (2,077 feet high), east of Yakutat bay, southeastern Alaska, near latitude $59^{\circ} 45^{\prime}$, longitude $139^{\circ} 32^{\prime}$. So called by McGrath, 1893 .

Hoosier; creek, tributary to Minook creek from the east. Prospectors' name, published by the Coast Survey in 1898.

Hoosnoff, archipelago, etc.; see Kootznahoo.

Hoot; island, south of Orr island, Sea Otter sound, Prince of Wales archipelago, near latitude $55^{\circ} 53^{\prime}$, longitude $133^{\circ} 23^{\prime}$. So named by Dickins, 1903-4.

Hootalinqua, river; see Teslin.

Hootchy-eye, lakes; see Hutshi.

Hootlanana, river; see Hutlina creek.

Hootlinana, creek; see Hutlina.

Hootz, bay ; see Hood.

Hope; creek, in the Fairbanks region, tributary to Faith creek from the north, near latitude $65^{\circ} 20^{\prime}$, longitude $146^{\circ} 20^{\prime}$. Prospectors' name, obtained by Gerdine, 1903 .

Hope; mining town and post-office, at mouth of Resurrection creek, Turnagain arm, Cook inlet, near longitude $149^{\circ} 45^{\prime}$. Called Hope City by the prospectors. The post-office was established in 1901 .

Hope; point (Point Hope), on the Arctic const, about 30 miles to the southward of Cape Lisburne. So named by Beechy, August, 1826, in compliment to Sir William Johnstone Hope. Called Hoffnung (hope) by German map makers, and Golofnin and Golovin by the Russians. Native name said to be Tikira, Tikera, Tigera, Tigara, or Figarok (the forefinger).

Hopkins; bridge, over Minook creek, about 8 .miles above its mouth. Local name, reported by Prindle, 1904.

Horace; mountain, on headwaters of Koyukuk river, near longitude $149^{\circ}$. Prospectors' name, reported by Schrader, 1899.

Horboon, rock; see Humpback.

Horboon vnutrennie; see Inner Humpback.

Horn; cape, near the entrance to Falmouth harbor, Nagal island, Shumagin group. Named by the fishermen prior to 1871 . 
Horn; cliffs (1,800 feet high), on the mainland, opposite noithern entrance to Wrangell strait, Alexainder archipelago. So called in the Coast Pilot (1883, p. 127).

Horn; island, the largest of the Ball group, Sitka sound, Alexander archipelago.

So named by United States naval officers, 1880. It was named Rogova or Rokhova (from Rog, horn) by Vasilief, 1809. Has also been printed Horney and Morne.

Horn; mountain (2,929 feet high), just back of Horn cliffs. So called by. Thomas, 1887.

Horn; point, the southern point of entrance to Port Etches, Prince William sound. So named by Portlock, 1787.

Horoshi pogodi, cape and mountain; see Fairweather.

Horse; island, west of Douglas island, Stephens passage, Alexander archipelago. Apparently so named by Mansfield, 1890.

Horse, island; see Cheval.

Horse; shoal, near Horse island, Stephens passage, Alexander archipelago. Named by Mansfield, 1890.

Horse Marine; lagoon, stream, and lake, southwestern coast of Kodiak, at the northeastern extremity of Olga bay, Alitak bay. So called in the local fisheries, and reported by Moser, 1900.

Horton; creek, tributary to headwaters of Fox river, Seward peninsula. Name from Barnard, 1900.

Hose; point, on the mainland, the north point of entrance to Fitzgibbon cove, Behm canal, southeastern Alaska. Named by the Coast Survey in 1891.

Hosford; creek, enstern Alaska, tributary to Charley river from the east, near latitude $64^{\circ} 55^{\prime}$, iongitude $143^{\circ} 30^{\prime}$. Prospectors' name, reported by Witherspoon, 1905.

Hosiana; river, tributary to the Xukon on the right bank opposite Beaver creek, about longitude $147^{\circ} 30^{\prime}$. Indian name, reported by Peters and Schrader, 1901. Edward's Track Chart of the Yukon, 1899, has He Beaver at the mouth of this river (may be the name of a.slough) and She Beaver (Ausana) on the opposite shore at the mouth of Beaver creek. Ausana may be another form of Hosiana.

Hostage; point, in Wrangell harbor, Alexander archipelago. Named Amanat (hostage) by Zarembo in 1834. Zarembo's sketch was published on Russian Hydrographic chart 1396 in 1848. Called Amanat point on United States Hydrographic chart 225.

Hosyekalcat, river; see Huslia.

Hot; springs, on Hot Springs bay, Sitka sound, Alexander archipelago. Name from the Russians.

Hot; springs, 20 miles northwest of Katmai, Alaska peninsula. Reported by Spurr and Post, of the Geological Survey, 1898.

Hot; spring, in the Kobuk valley at head of Reed river near latitude $67^{\circ} 20^{\prime}$, longitude $155^{\circ} 20^{\prime}$. Visited by Reed, of Stoney's party, 18s6. The native name is given as $\mathrm{Ah}$-lue-ga-wik.

Hotel; gulch, $4 \frac{1}{2}$ miles north of Nome, on the western slope of Newton peak, draining into Dry creek, near longitude $165^{\circ} 20^{\prime}$. Local name, published in 1904 .

Hotel, mountain; see Khotol.

Hotham; inlet, enst of Kotzebue sound, Arctic ocean. Named by Beechey, 1826, " in compliment to the Hon. Sir Henry Hotham, K. C. B., one of the lords of the Admiralty." 
Hotham; peak (1,300 feet high), south of Kobuk river, east of Hotham inlet, near latitude $66^{\circ} 45^{\prime}$, longitude $160^{\circ} 45^{\prime}$. So named by Stoney, 1885 .

Hotol, mountain; see Khotol.

Hot Springs; small bay, near Sitka sound, on the western shore of Baranof island, Alexander archipelago. . Named Kluchef or Kluchevoi (hot spring) by Vasilief, 1809, on account of the warm springs there. On British Admiralty chart 2337 this name, called Klucher and translated Marsh, is applied to the southwest end of Deep lake, and from this we have, on Coast Survey chart 8240 (ed. of 1898); one end of Deep lake named Marsh bay.

Hot Springs; bay, indenting the northeastern shore of Akutan island, Krenitzin group, eastern Aleutians, near longitude $165^{\circ} 51^{\prime}$. So named by Gilbert, 1901.

Hot Springs; creek, Seward peninsula, tributary to the headwaters of Serpentine river, near latitude $65^{\circ} 50^{\prime}$, longitude $164^{\circ} 40^{\prime}$. Prospector's' name, obtained by Gerdine, 1901.

Hotspur; island, between Annette and Duke islands, Gravina group, Alexander archipelago. Presumably so named by local pilots.

Houchnou, archipelago ; see Kootzuahoo.

Houghton; port, indenting the mainland, Frederick sound, southeastern Alaska. So named by Vancouver, 1794.

Hound; island, in the northern part of Keku strait, Alexander archipelago. So named by Moore, 1892. Erroneously Round island.

Hourigan; point, the southern point of entrance to Band cove, Kuiu island, Alexander archipelago. So named by Glass, 1881.

House; island, in Revillagigedo channel, between Foggy bay and Boca de Quadra, Alexander archipelago. So named by Nichols, 1883.

House; mountain, in California ridge, Gravina island, Alexander archipelago. So named by Nichols, 1883.

House, mountain; see Kings.

House; peak (6,001 feet high), on the mainland, east of Frederick sound, southeastern Alaska. So named by Thomas, 1887.

Howard; mountain (2,340 feet high), northwest of Port McArthur, Kuiu island, Alexander archipelago. So named by Felm, 1886.

Howard; point, on the mainland, near south end of Lynn canal, Alexander archipelago. Named by Mansfield, 1890, after Insign William Lauriston Howard, U. S. N., a member of his party.

Howe; point, on the southern shore of Mitkof island, Sumner strait, Alexander archipelago. Named by Vancouver, 1793. Erroneously Hove.

Howie; lake (Lake Howie), Seward peninsula, south of Goodhope bay, and on the western slope of Asses Dar's, near latitude $65^{\circ} 40^{\prime}$, longitude $163^{\circ} 20^{\prime}$. Prospector's' name, reported by Mendenhall, 1901.

Howkan; reef, in Howkan narrows, immediately in front of Howkan village. Named by Nichois, 1881. Has also been written How-kan.

Howkan; narrow strait, between Dall island and Long island, west of Cordova bay, Dixon entrance, near latitude $54^{\circ} 50^{\prime}$, longitude $132^{\circ} 50^{\prime}$. The narrowest part of the strait is called Howkan narrows. Has been written Howcan. Native word, published by the Const Survey in 1883.

Howkan; village of Haida Indians and post-office (established in 1884 under the name of Jackson and changed to Howkan in 1906), on Long island, Howkan narrows, Cordova bay, Alexander archipelago. At this village is the Jackson (Presbyterian) mission.

Howling; valley, Muir glacier, 20 miles above the front, Glacier bay, southeastern Alasiza. So named by Muir, 1890. . 
Hoyle; lake, draining to Ekolina river from the right, near latitude $63^{\circ}$, longitude $154^{\circ}$. So named by Herron, 1899.

Hoyt; creek, eastern Alaska, tributary to Flat creek from the east, near latitude $65^{\circ} 10^{\prime}$, longitude $143^{\circ}$. Prospectors' name, from sketch map compiled by Major Glassford, Signal Corps, U. S. A., 1905.

Huagin; river, in the St. Elias alps, said to be a lake outlet, debouching immediately north of Lituya bay. So called by Tebenkof, 1S49. Written Hawg-heen, i. e., Hawg river, by Moser, 1901. It is Rivière aux Saumons (Salmon river) of La Perouse, French edition, and, erroneously, Silmon in the English edition.

Hub; rock, in Port Chester, Annette island, Alexander archipelago. So named by Nichols, 1883.

Hub; rock, in Dry pass north of Tuxekan island, Prince of Wales archipelago, : near latitude $55^{\circ} 56^{\prime}$, longitude $133^{\circ} 18^{\prime}$. So named by Dickins, 1903-4.

Hubbard; glacier, near the head of Yakutat bay, southeastern Alaska. So named by Russell, 1890, after Gardiner Greene Hubbard, president of the National Geographical Society.

Hubbard; mountain (12,064 feet high) north of Yakutat bay, southeastern Alaska. So named by Russell, 1890, after Gardiner Greene Hubbard, president of the National Geographic Society.

Hubbard; peak (5,700 feet high), on the left bank of Kotsina river. So named on a manuscript map, made by prospectors in 1900 .

Hudson; bay, indenting the eastern shore of Chilkat inlet, at the head of Lynn canal, near latitude $59^{\circ} 09^{\prime}$, longitude $135^{\circ} 22^{\prime}$. Local navigators' name, reported by H. C. Fassett, Bureau of Fisheries, 1904.

Hudson; creek, 26 miles north of Nome, Seward peninsula, tributary from the west to Buffalo creek, at the headwaters of Nome river, near longitude $165^{\circ} 17^{\prime}$. Miners' name, reported by Gerdine, 1904.

Hudson Bay; creek, tributary to South fork Koyukuk river from the south, near latitude $67^{\circ}$. Prospector's' name, from Schrader, 1899.

Hudson Bay, inlet: see Excursion.

Hudsunoo, archipelago, etc.; see Kootznahoo.

Huff; creek, Seward peninsula, in Solomon River basin, tributary on north bank of Big Hurrah creek, near latitude $64^{\circ} 40^{\prime}$, longitude $164^{\circ} 12^{\prime}$. Prospectors' name, from a local map, 1901.

Huggins; island, 14 miles long, in Koyukuk river, near the mouth of Batza river, about latitude $66^{\circ}$, longitude $154^{\circ} 30^{\prime}$. So named by Allen, 1885, after Capt. Eli Lundy Huggins, U. S. A., for a long time a resident of the territory and a warm friend of Allen's expedition (Allen, p. 103). On his map 4 Allen calls this McQuisten island. This last, which should be McQuesten, has also been printed McQuister and McQuestion.

Hugh; point, the southernmost point of Glass peninsula, Admiralty island, Alexander archipelago. So named by Vancouver, 1794 .

Hughes; bar, in Koyukuk river, near Red mountain, latitude $66^{\circ} 20^{\prime}$, longitude $153^{\circ} 50^{\prime}$. Prospector's' name, reported 1900 .

Hugh Miller; glacier and inlet, west shore, near head of Glacier bay, southeastern Alaska. In 1879 Muir found one great glacier heading this inlet, which he named after the distinguished geologist, Hugh Miller. In 1892 its front had so far receded that Reid found its two branches converted into distinct glaciers. Retaining the name Hugh Miller for the larger branch at the head of the inlet he named the other Charpentler glacier. 
Huiak, island; see Shuyak.

Hulahula; river, on the Arctic coast, the most westerly of the two principal rivers between Barter and Turner rivers, near longitude $143^{\circ}$. Native name, reported by S. J. Marsh, a prospector, 1902, who wrote it Hoolahoola.

Hulitnak, river ; see Chulitna.

Hull; point, the eastern point of entrance to Port Moore, Elson bay, Arctic coast, just east of Point Barrow. So named by the British Admiralty, 1.853, after Master Thomas Hull, R. N., of H. M. S. Plover.

Humboldt; creek, Seward peninsula, tributary to Goodhope river from the west, near latitude $65^{\circ} 55^{\prime}$, longitude $164^{\circ}$. Prospector's' name, obtained by Mendenhall, 1901.

Humboldt; harbor, indenting the western shore of Popof island, Popof strait, Shumagin group, near longitude $160^{\circ} 30^{\prime}$. So named by Dall, 1872, after the Coast Survey schooner Humboldt.

Humbug; creek, in the Fortymile region, eastern Alaska, at the head of Hutchinson creek. Prospector's' name, published in 1905. Called Conference creek by Lieutenant Mitchell, Signal Corps, U. S. A., in 1902.

Humbug; point, on south end of Lidenberg peninsula, Wrangell strait, Alexander archipelago. So named by Meade, 1869.

Hume; island, in George inlet, Revillagigedo island, Alexander archipelago, near latitude $55^{\circ} 24^{\prime}$, longitude $131^{\circ} 21^{\prime}$. Local navigator's' name, reported by H. C. Fassett, Bureau of Fisheries, 1904.

Hump; island, in Cholmondeley sound, western shore Clarence strait, southeastern Alaska, near latitude $55^{\circ} 14^{\prime}$, longitude $132^{\circ} 07^{\prime}$. Called Pup by the Coast Survey, 1901, but H. C. Fassett, of the Bureau of Fisheries, 1904, says it is called Hump island by the local navigators.

Hump; island, in Clover passage, Behm canal, Alexander archipelago. So named by Clover, 1885.

FLump; island, north of Point Retreat, in Lynn canal, Alexander archipelago. So named by Meade, 1869 , from its appearance.

E.ump. (The) ; see Chariot.

Frumpback; bay, in the mainland, indenting the southern shore of Bradfield canal, Ernest sound, southeastern Alaska, near latitude $56^{\circ} 11^{\prime}$, longitude $131^{\circ} 54^{\prime}$. Local navigators' name, reported by H. C. Fassett, Bureau of Fisheries, 1904. This seems to be the same that Snow cilled Anan, 1886. See Anan.

Jumpback; rock (18 feet high), in Chiniak bay, Kodiak. Named Horboon (humpback) by Lisianski, 1804. Also written Gorbun. The Coast Survey, 1869, called it Humpback or Sugarloaf rock.

Eumphrey; point, on the Arctic coast, near the international boundary line. Named by Franklin, 1826, who has in his text Humphrys (p. 145) and Humphreys (p. 169). On his map it is Humphreys.

Hump Knoll; peak (3,116 feet high), on the mainland, near head of Thomas bay, southeastern Alaska. So named by 'Thomas, 1887.

Huna, sound; see Hooniah.

Hungarian; creek, tributary to South fork Koyuluk river, near longitude $150^{\circ}$. Prospectors' name, reported by Schrader, 1899.

Hungry; creek, Kenai peninsula, tributary to Resurrection creek, on the left bank, near its head. Miners' name, from Moffit, 1904.

Hungry; creek, tributary to Oregon creek from the south, Seward peninsula. Name from Barnard, 1000. 
Hungry Harbor; mining camp, in the Kantishna region, established in 1905 on Bearpaw river, 40 miles above its mouth. So called by the prospectors and reported by Prindle.

Hunker; creek, 15 miles northwest of Nome, Seward peninsula, a small tributary of New Eldorado creek from the north, near longitude $165^{\circ} 10^{\prime}$. Local name, from Gerdine, 1904.

Hunner; creek, on Seward peninsula, tributary to Kaviruk river from north, near latitude $65^{\circ} \cdot 20^{\prime}$, longitude $165^{\circ} 15^{\prime}$. Prospectors' name, reported by Gerdine, 1901.

Hunning, bay ; see Hanning.

Hunt; fork, in the Koyukuk region, branch of John river on the west, near latitude $68^{\circ}$, longitude $153^{\circ}$. Prospectors' name, obtained by Peters and Schrader, 1901.

Hunt; island, near western end of the Sandman reefs, south of Deer island and northeast of Sannak, near latitude $54^{\circ} 4 \bar{t}^{\prime}$, longitude $162^{\circ} 1 \tau^{\prime}$. So called by the Fish Commission in 1888. This may be Egg (Iachnoi) island of Tebenkof, 1849.

Hunt; peak $(3,494$ feet high), in the northeastern part of Kupreanof island, Alexander archipelago. Named by Thomas, 1887, after Ensign Henry J. Hunt, U. S. N.

Hunt; point, the western head of Rodgers harbor, on south shore of Wrangell island, Arctic ocean. So named by Berry in September, 18s1, after Ensign Henry Jackson Hunt, U. S. N., a member of his party.

Hunt; river, tributary to the Kobuk from the north, near latitude $67^{\circ} .15^{\prime}$, longitude $158^{\circ} 30^{\prime}$. So named by Stoney, 1885, probably after one of his party. He wrote the native name Kon-gon-wik.

Hunter; bay, in Prince of Wales island, opening into Cordova bay, Alexander archipelago, near latitude $54^{\circ} 52^{\prime}$, longitude $132^{\circ} 20^{\prime}$. Sounded by Moser, 1897.

Hunter; creek, tributary to Minook creek from the east, near latitude $65^{\circ} 30^{\prime}$, longitude $150^{\circ}$. Prospectors' name, reported by Spurr, Goodrich, and Schrader, 1896.

Hunter; creek, Seward peninsula, flowing north into Kotzebue"sound, near longitude $162^{\circ} 20^{\prime}$. Prospectors' name, reported by Witherspoon, 1903.

Hunter; creek, Seward peninsula, tributary to Kiwalik river firom the east, near latitude $65^{\circ} 45^{\prime}$, longitude $161^{\circ} 40^{\prime}$. Prospectors' name, obtained by Witherspoon, 1903.

Hunter's, point; see Bird.

Hurtle; creek, tributary to Tonsina lake. Name from Schrader, 1900.

Huskisson; mountain, in extreme northeastern Alaska. So named by Franklin, 1826, after the "president of the board of trade."

Huslia; river, tributary to the Koyukuk from the west, near longitude. $156^{\circ} 30^{\prime}$. Native name, reported by Allen, 1885, as Hussliakatna, on his map 1 and 4, and Husliakakat in his text (p. 105). See Kakat.

Hut; point, on the mainland, the north point of entrance to Walker cove, Behm canal, southeastern Alaska. So named by the Coast Survey in 1891.

Hut; point, on the northwestern coast of Douglas island, at entrance to Gastineau channel, Alexander archipelago. So named by Symonds, 1880. There were some Indian houses or huts on the point.

Hut; point, on the southern shore of Afognak island, Kodiak group. Named Zhila (hut, cabin, house) by Murashef, 1839-40.

Hutchinson; creek, tributary to North fork Fortymile river from the west, near latitude $64^{\circ} 25^{\prime}$, longitude $142^{\circ} 05^{\prime}$. Prospectors' name, reported by Signal Corps, U. S. A., 1902. Written also Hutchison. 
Hutchinson, creek ; see Quartz.

Hutchinson; hill (99 feet high), on Northeast point, St. Paul island, Pribilof group, Bering sea. Called Sealion by Dall, 1874, which may be the local name. Later it was called Hutchinson, after Hayward Malcolm Hutchinson, of the Alaska Commercial Company. Elliott speaks of it as the "volcanic nodule known as Hutchinson's hill."

Hutchinson; sunken reef, off Outer Spruce cape, Chiniak bay, Kodiak. Name published by the Coast Survey in 1881.

Hutchison, creek; see Hutchinson.

II utli, bay and glacier; see Le Conte.

Hutlina; creek, tributary from the east to Baker creek, which is a tributary of 'Tanana river, near latitude $65^{\circ} 55^{\prime}$, longitude $155^{\circ} 20^{\prime}$. Indian name, reported by Brooks, 1902, as Footlinana. Has been written Hootlanana and Futlinana, i. e., Hutlina river.

Hutshi; chain of lakes draining northward into Lewes river in longitude $137^{\circ}$. Native name, apparently first published by Glave in the Century, September and October, 1.892, where it is spelled Hootchy-Lye. It has been variously written Hootch Eye, Hootch-i, Futchi, Hotchi, Fuchai, etc. The Canadian Board on Geographic Names has adopted the above form, Hutshi.

Huxley; peak (11,907 feet high), in the St. Elias alps, southeastern Alaska. So named by Topham, 1886, after Prof. Thomas Henry Huxley.

Hyaks; creek, Arctic slope, tributary to Marsh fork Canning river from the west, near latitude $68^{\circ} 30^{\prime}$, longitude $147^{\circ}$ : So called by S. J. Marsh, a prospector, 1903 .

Hydah, cove; see Mission.

Hyden, canyon; see Heiden.

Hydra; island, near the southern coast of Alaska peninsula, north of the Semidi islands. Name published by 'Tebenkof in 1849 . On a manuscript Russian map, 1849, it is called Zatschra island. Apparently identical with Otter island of Coast Survey chart 8500 .

Iabloshnie, island; see Middle.

Iachnoi, cipe and island; see Egg.

Iuchnoi, islappd, Sandman reefs; see Hunt.

Iachnoi, island, Unalga pass; see Egg.

Iaitchnoi, bay; see Egg.

Iaklek, cape; see Aklek.

Ialktag, cape; see Yaktag.

Ianaliun, cape; see Bog.

Iantar, stream; see Amber.

Iantarni, bay; see Amber.

Icathliul, river; see Fish.

Icathluik, river; see Niukluk.

Ice; creek, 60 miles northeast of Knik arm, Cook inlet, on the west bank of Chickaloon creek, a northern tributary of Matanuska river, near latitude $62^{\circ} 10^{\prime}$, longitụde $148^{\circ} 20^{\prime}$. So named by John S. Bagg, guide of Glenn's expedition, 1898.

Ice; gulch, 15 miles north of Nome, Seward peninsula, a small tributary to Nome liver from the west, near longitude $165^{\circ} 18^{\prime}$. Local name, published in 1.900.

Ice; river, tributary to Copper river from the east; near Wood canyon. So named by Allen, 1885.

Ice; spit, off the northeastern shore of Wrangell island, Arctic ocean. So named by Berry, 1881. 
Iceberg; point, on the southeastern shore of Lemesurier island, Icy strait, Alexander archipelago. So named by Hanus, August, 1880. At that time much drift ice had stranded there.

Icehouse; point and lake, on the western shore of Woody island, St. Paul harbor, Kodiak. Named Pestchanoe (sandy) by Russian naval officers in 1808-1810. This is the lake from which the Kodiak Ice Company obtains its ice. On this spot Tebenkof, 1849 , shows a native village Aleksashkina, which he calls the Chiniak settlement. On the old Russian chart XVI, 1808-1810, the Aleut village of Aleksashkano is shown about a mile farther south.

Ice Water, river; see Soynai.

Ichock. Langsdorf (II, 234) gives this as the name of a creek southwest from Kukak bay. Not identified.

Icy; bay, in front of Malaspina glacier, St. Wlias alps, southeastern Alaska. So called by Vancouver in 1794. It is Lothianoi (icy) of Tebenkof, 1849.

Icy; bay, on the western shore of Prince William sound. So named by Vancouver, 1794.

Icy, bay ; see Palma.

ICy. Billings, in July, 1790, when off the entrance to Cook 'inlet, saw at a distance of 15 miles northwest, behind the Chugach islands, a glacier used by the traders as a landmark for entering Cook inlet and called by them "Ledeneaia Reka (Icy river)."

Icy; cape, the northern head of Icy bay, near Mount St. Elias. Called Ledianoi (icy) by Tebenkof, 1849.

Icy; cape, on the Arctic coast, about midway between Cape Lisburne and Point Barrow, near latitude $70^{\circ}$. So named by Cook, 1778 , "because it was much encumbered with ice." The Eskimo name is Ootookok, or, as we would write it, Utukok.

Icy, channel ; see Gastineau.

Icy; gulch, in Silverbow basin, about 2 miles east of Juneau, southeastern Alaska. Local name, reported by Peters, 1902.

Icy; passage, separating Pleasant island from the mainland, Icy strait, southeastern Alaska. Name published by the Coast Survey in 1891.

Icy; peak, near Kialagvik bay, on the south shore of Alaska peninsula. Name apparently derived from Tebenkof, 1849.

Icy; point, on the mainland coast, between Lituya bay and Cape spencer. Named Ledianoi (icy) by Tebenkof, 1849. Has also been called Cape Forrest.

Icy; reef, on the Arctic coast, near the international boundary. So named by Franklin, 1826.

Icy; strait, north of Chichagof island, joining Chatham strait and Cross sound, Alexander archipelago, near latitude $58^{\circ} 15^{\prime}$. So called by the Russians. See Cross sound.

Ida; creek, 15 miles north of Cape Nome, Seward peninsula, tributary to Bonita creek from the south, near longitude $165^{\circ} 10^{\prime}$. Local name. Has been called Moose and Morse.

Idagak, strait; see Udagak.

Idahc; bar, on Minook creek, Rampart region, between Hunter and Little Minook creèks. Prospector's' name, reported by Prindle, 1904.

Idaho; creek and bar, Seward peninsula-creek tributary to:Kuzitrin river from the north, near Coffee Dome mountain ; bar in Kuzitrin river, near latitude $65^{\circ} 12^{\prime}$, longitude $164^{\circ} 40^{\prime}$. Prospectors' name, obtained by Gerdine, 1901. 
Idaho; creek, in the Fairbanks region, tributary to McManus creek from the north, near latitude $65^{\circ} 25^{\prime}$, longitude $146^{\circ} 10^{\prime}$. Prospectors' name, reported by Gerdine, 1903.

Idaho; gulch, Seward peninsula, at head of Maston creek, near latitude $65^{\circ} 48^{\prime}$, longitude $166^{\circ} 10^{\prime}$. Prospector's' name, obtained by Gerdine, 1901.

Idaho; inlet, indenting the northern shore of Chichagof island, Cross sound, Alexander archipelago, near longitude $136^{\circ} 15^{\prime}$. So named by pilot W. E. George, after the steamer Idaho, which grounded here.

Idaho; peak (3,100 feet high), on Woronkofski island, Alexander archipelago. So named by Snow, 1886, after the steamship Idaho.

Idaho; rock, submerged, northeast side-Tongass narrows, Alexander archipelago, near latitude $55^{\circ} 19^{\prime}$. Local name, from the Coast Pilot of 1901 .

Idak; cape, the northeasternmost point of Umnak island, eastern Aleutians. Native name, from Kuritzien, 1849. Apparently it means outlet or exit. It is the northwestern head of Umnak strait.

Idaliuk; cape, on the northern shore of Umnak island, near its western end. Native name, from Kuritzien, 1849.

Idaliuk, cape; see Prominence.

Idalug; cape, on the northern shore of Amlia isiand, Andreanof group, middle Aleutians. Native name, from Tebenkof, 1849.

Ideal; cove, in Mitlof island, near the north end of Dry strait, Frederick sound, Alexander archipelago. Descriptive name, given by Thomas in 1887 . Nichols reports "excellent anchorage here for small vessels."

Idelfonso, point; see Ildefonso.

lden-noo, village; see Ei-dan-noo.

Ides Neck; narrow isthmus, separating Schulze cove from Peril strait, Baranof island, Alexander archipelago. So named by Coghlan, 1884.

Igagik, river and village; see Ugaguk.

Igak, bay ; see Ugak.

Igatskai, bay; see Ugak.

Ighiak, village; see Eyak:

Igiagagamute, Eskimo village; see Igiak.

Igiagiuk, lake; see Becharof.

lgiak, cape; see Ugyak.

Igiak; Eskimo village of two huts, near Cape Romanzof, Bering sea, about latitude $62^{\circ}$. Visited by Nelson in December, 1878. He reports its name to be Igragamiut (text, p. 665), and on the map Igiagamute. Petrof, 1880, has Igiagagamute. Written also Igiogagamut.

Igiogagamut, Eskimo village; see Igiak.

Igitkin; islạnd, near Great Sitkin, Andreanof group, middle Aleutians. Aleut name, from the Russians, written Igitkihn, Igitkilm, Igitkum, etc., and Egilka by Billings, 1790.

Igloo; creek, in western part of Seward peninsula, debouching near Cape Woolley. Name from Barnard, 1900. It is the Eskimo word for house.

Igloo; creek, tributary to Grantley harbor from the north, Seward peninsula. Eskimo name, meaning house, from Barnard, 1900.

Igloo; creek, tributary to American river from the east, Seward peninsula. Eskimo name, meaning house, from Brooks, $\bullet 1900$.

Igloo; creek, Seward peninsula, tributary to Goodhope river from the north, near latitude $65^{\circ} 45^{\prime}$, longitude $163^{\circ} 30^{\prime}$. Local name, reported by Gerdine, 1901.

Igloo; post-office (established in 1901), Seward peninsulạ, on Kuzitrin river, near its mouth; about latitude $65^{\circ} .10^{\prime}$, longitude $165^{\circ} 04^{\prime}$. The locality was called Mary's Igloo by the prospectors. 
Ignaliuk, Ignalook, island; see Little Diomede.

Ignatief, cape; see Mendenhall.

Ignatio, island; see St. Ignace.

Ignavik; Eskimo village, on the Arctic coast, 15 miles south of Cape Smyth, near latitude $71^{\circ}$. Native name from Jarvis, 1898.

Ignok; Eskimo village, on the right bank of Yukon river, near Koserefski. Petrof, 1880, calls it Ignokhatskamute and Ignokhatskomute. Raymond, 1869, has Ingekasagmi. Both name and village have disappeared from recent mâps.

Igognak, anchorage; see Eider.

Igognak, cape; see Kalekta.

Igokluk; slough, Yukon delta, a branch of Kwemeluk slough from the east, near latitude $62^{\circ} 27^{\prime}$, longitude $163^{\circ} 20^{\prime}$. Eskimo name, obtained by Putnam, 1899.

Igragamiut, village; see Igiak.

Iguik; creek, and very small Eskimo village at its mouth, on eastern shore of Norton sound, just north of the Unalaklik river. Native name, written on the Western Union Telegraph Expedition map, 1867, Igouik; by Dall, Egowik, and by Petrof, Igowik; also witten Igavik and Egawik.

Igushik; river, draining southward from Amanka lake to Nushagak bay, about latitude $59^{\circ}$, longitude $159^{\circ}$. Eskimo name reported by Tebenkof, 1849, as Iguzhak; by Petrof, 1880, as Igushek; by the Fish Commission, 1890, as Egashak; by the Coast Survey, 1897, as Egashik; by Spurr, 1898, as Egoushik or Crooked, and by Moser, 1900, Egashak or Snake. See Snake.

Igvak; cape, the western point of entrance to Fortage (Kanatak) bay, on the southern shore of Alaska peninsula, west from Kodiak. Native name, from the Russians. Erroneously Iswak.

Thack, bay ; see Ugak.-

I-im-tuck, river; see Lishtak.

Ijoot, cape; see Izhut.

$I k$, river; see Eek.

Ikak; Eskimo village, east of Naknek lake, Alaska peninsula. Native name, from the Russians. Petrof, 1880, calls it Ikkhagmute, i. e., Ikkak people. The Eleventh Census and Coast Survey call it Ukak. Population in 1880,162 .

Ilkaligvig-miut, village; see Cheenik.

Ikalu; low sandy islet, on the Arctic coast, abreast of Dease inlet. Eskimo name, from British Admiralty chart 593 (1830-1882), where it is written Ikalue.

Ikatan; bay, north of Ikatan peninsula, at the south end of Isanotski strait, Alaska peninsula. So called by Dall, 1880.

Ikatan; peninsula, projecting from the southeastern corner of Unimak island, at south end of Isanotski strait, Alaska peninsula, near latitude $54^{\circ} 43^{\prime}$, longitude $163^{\circ} 15^{\prime}$. Native name, variously written Ikatak, Ikatan, Ikatane, Ikatok, Ikatun, etc. Veniaminof says Ikatok or, properly, Ikatan.

Ikatan; point, on north shore Ikatan peninsula, being the south point of entrance to Ikatan bay. So designated by Westdahl, 1901.

Ikatlek; Eskimo village, on right bank of lower Yukon river, about 30 miles below Anvik. Nelson, who passed through it, in 1879, reports its name to be Ikatlegomute, i. e., Ikatlek people. Not shown on late maps.

Ikeutpak, river; see Fish. 
Ikhiak, lake and village; see Eyak.

Thhok, village; see Ikwok.

Ikiginak; high rocky islet, a few miles west of the westem end of Atka, middle Aleutians. Native name, from Tebenkof, 1849. Lutke calls it Nerpitchy (seal).

Ikikiktoik, village; see Kiktaguk.

lkiraaluk, channel; see Moore.

Ilkkiagamut, village; see Savonoski.

lkkugoak, river; see Ikugoak.

Iknetuk; Eskimo village, on the western shore of Golofnin bay, Norton sound. Called Kniktag-miut by the Russians as early as 1852. By Petrof, 1880, called Ignituk.

Iknetuk; point, nealr Golofnin bay, Norton sound. Native name, from Schrader, 1900.

Ikogmut; village of 350 Eskimos, and Russian Orthodox Church mission (Pokrovskaia mission), which appears to have been first occupied in or about 1843. For many years spoken of as The Mission. Shown on the maps with the designation. Mission, and now generally, Russian Mission, which seems to have supplanted the native name. It is on the north bank of the lower Yukon, near its southermmost bend and latitude $62^{\circ}$. Has been variously written Ekogmute, Ikogmint, etc. Probably from ikkok (a point), and so, point jolles.

Ikolik; point, on the western shore of Kodiak. Called Southwest point by Lisianski, 1805, and Tkolik by later Russians. Variously given as Ecolik, Ikalik, etc. Called also Seal cape.

Ikoum-unga-koverushika, St. George Island; see South hill.

Ikpikpuk, river; see Chipp.

Ilpikpung, river. Stoney's map has a west branch of Chipp river, 20 miles - above the mouth of Meade river, lettered Ik-pik-pung. The main river he calls Chipp or Ik-pik-puk.

Ilpilkpung, river; see Chipp.

Ikpiling. This Eskimo name appears on Ray's map, 1885, for some feature just east of the United States Signal Service station Utkiavi, near Point . Barrow, Arctic ocean.

Ilsiahtal, bay; see Anderson.

Ikti; cape, between Chignik bay and Mitıofania island, on the southern shore of Alaska peninsula. Native name, from the Russians. Has been written Itkhi and, accidental!y, Itkbi.

Iktigalik; naive village, of eight or ten houses, on right bank of the Unalaklik river, about 25 miles above its mouth. Native name, from Dall, 1866 .

Ikuak; Eskimo village, on right bank of the lower Yukon, near head of delta. Eskimo name, from Raymond, 1869, who wrote it Yukagamut. Tikhmenief, 1861, presumably quoting Zagoskin, writes it Ikuagmiut, i. e., Ikuak people. Apparently-identical with Ingahameh (also Ingahamé) of Petrof, 1880 . Population in 1880, 63 .

Ikugoak; river, northwestern Alaska, tributary to Selawik river from the east, near the Arctic circle and longitude $160^{\circ}$. Eskimo name, from Stoney: 1885, who wrote Ik-ku-go-ak.

Ikwok; native village southwestern Alaska, on Nushagak river, a few miles above Kakuak. Reported by Osgood, 1902, and written Ikwok and Ikhok.

Ilak, cape; see Ugyak.

Bull. 299-06 м-21 
Ilak; islet, in Kukak bay, Alaska peninsula, mentioned by Langsdorf (II, 234). Not identified.

Ilak; islet, southwest of Tanaga island, Andreanof group, middle Aleutians. Aleut name, given by Billings, 1790, as Illuk, and by Lutke, Tebenkof, and other Russians as Illiak. Has also been written Illakh.

Ildefonso; point, in San Alberto bay, Bucareli bay, Prince of Wales archipelago. Named Punta de San Yldefonso by Maurelle and Quadra, 1775-1779. Erroneously Idelfonso.

Iliamna; small bay, in the northwest corner of Kamisbak bay, southwestern shore of Cook inlet near latitude $59^{\circ} 40^{\prime}$. Local name, obtained by Osgood, 1902.

Iliamna; lake, largest in Alaska, a few feet above sea level, about 60 miles long and from 15 to 25 miles wide, between Bristol bay and Cook inlet. Named Shelekof by the Russians as early as 1802 , but now univers:1ly: known by its native name, Iliamna. Locally pronounced Lámna. According to Martin, Iliamna is " said to be the name of a mythical great blackfish, supposed to inhabit this lake, which bites holes in the bidarkas of bad natives." A Russian map of 1802 calls this Shelekof, while Clark lake, supposed to have been discovered in 1891, is shown and called Ilima lake.

Iliamna; pass and portage, between Iliamna bay, southwest shore of Cook inlet, and Iliamna lake, about latitude $59^{\circ} 40^{\prime}$. Local name, obtained by Osgood, 1902.

Iliamna; river, Alaska peninsula, tributary to Iliamna lake from the northeast, about latitude $59^{\circ} 50^{\prime}$, longitude $153^{\circ} 50^{\prime}$. Local name, reported by Osgood, 1902.

Iliamna; native village, Alaska peninsula, on the right bank of Iliamna river, 6 miles above Iliamna lake, near latitude $59^{\circ} 50^{\prime}$, longitude $153^{\circ} 50^{\prime}$. So described by Osgood, 1902. The Post Route maps, 1904 and 1905, locate this village on Jliamna bay.

Iliamna; volcano (12,066 feet high), on the west coast of Cook inlet. Native name, from the early Russian explorers. The Spanish explorers of the last century called it Volcan de Miranda.

Iliasik; group of islands on the southern shore of Alaska peninsula, near Belkofski. Native name, from the Russians. Veniaminof and Lutke have Eliazik and Tebenkof, Ialiasik. See also Inner Iliasik and Outer Iliasik.

Iliasik; strait, between the outer and inner Iliasik islands, south shore Alaska peninsula, western extremity; near latitude $55^{\circ}$, longitude $162^{\circ}$. So described by Moser, 1897.

Iliaviki, island; see Inner Iliasik and Outer Iliasik.

Iliazhek, island; see Inner Iliasik.

Ilin; bay, on the western shore of Chichagof island, Alexander archipelago. Named Ilina (Ilin's) by the Russians early in the century, after the Russian naval ofticer, Peter Iranovich Ilin.

Iliuk; lake, which is either an arm of Naknek lake or, possibly, a lake wholly separate from but near to it. On some Russian maps this name is applied to Naknek lake. Written also Illiak.

Iliuliuk; bay, the southeasterly arm of Unalaska bay, on the east side of: Amaknak ișland, near latitude $53^{\circ} 54^{\prime}$, longitude $166^{\circ} 30^{\prime}$. In this bay are Dutch barbor and Iliuliuk harbor. This is present usage, and was approved by the U. S. Board on Geographic Names April 5, 1905. 
Iliuliuk; Larbor, in Iliuliuk bay, Unalaska, just west of. town of same name. Veniaminof called this Gavanskitia (harbor) bay.

Iliuliuk; reef, at entrance to Iliuliuk harbor, Unalaska bay. Local natue, published by the Const Survey in 1900.

Iliuliuk; the chief town of Unalaska, eastern Aleutians. Founded by the "terrible" Solovief, between 1760 and 1770 , and named lliuliuk (Aleut for harmony or good understanding, or according to another interpretation, the curved beach). Population in 1890, 317. It is often called Unalaska. The spelling of the name has been Illiouliouk, Illuluk, etc. See Unalaska.

Iliutak; Eskimo village, on the eastern shore of Kuskokwim bay. Native namme, from Nelson, 1878-79, who wrote it Iliutagamute, i. e., lliutak people. Population 40 in 1880.

Ilivit; group of hills or mountains on right bank of the Yukon, south of Anvik. Native name, from the liussians. Not shown on recent maps.

Ilkognak; rock, between Kodiak and Whale islands, Kodiak group. Native naime, from Murashef, 1839-40.

Ilktugitak; cape, between Katmai and Kukak bays, on north shore of Shelikof strait. Native name, from the Russians.

$I l l a k$, island; see Ulak.

Illamna, volcano; see Iliamna.

Illiak, lake; see Iliuk.

Illiuk, lake; see Naknek.

Il-luit-kuk. This is given by the British Admiralty, 1853, as the Eskimo name of the low sandy islands in front of Elson bay, on the Arctic const, just east of Point Barrow.

Illuk, islet; see Ilak.

Ilmalianuk; cape, the western head of Inanudak bay, on the north shore of Umnak, eastern Aleutians. Native name given by Kuritzien, 1849, as Ilmalianok.

Ilput; islet, in the southeastern part of Sitka sound, Baranof island, Alexander archipelago. Apparently a native name, obtained by Vasilief, 1809, who wrote it Ilpiet. Has also been written Ilpit.

Iluiak, island; see Shuyak.

Imachuck, river; see Inmachuk.

Imaglin, island; see Little Diomede.

Imagnee; Aleut village, in Summer bay, on eastern shore of Unalaska bay, eastern Aleutians. Sarichef shows a settlement here, in 1790, which he calls Sinagnia. Veniaminof, however, calls the village and bay Imagninskoe. Imagnee is the local and, presumably, the native name. Population in 1830 was 32 .

Imagninskoe, bay; see Summer.

Imagru, port; see Clarence.

Imaklit, ișland; see Big Diomede.

Imakpiguak, bay; see Goodnews.

Imiak; Eskimo village, at outlet of Aleknagik lake, northwest from mouth of the.Nushagak. Native name, from Tebenkof, 1849.

Imnuchuk, river' see Inmachuk.

Imoktegokshuli. Eskimo village, on south shore of Seward peninsula, a little east of Nome. Petrof. in 1880 , reported its population as 30 , and its name. Imokhtagokshuk in his text (p. 11) and Imokhtegokshuk on his map. Both town and name have vanished:

Imourouk, basin and lake; see Imuruk. 
Impassable; island, one of the Necker group, Sitka sound, Alexander archipelago. Named Nepropusknoi (impassable) by Vasilief in 1809.' Hals also been called Neprop, which Kostrometinof translates not to be omitted.

Impniguk, Impnipuk, river; see Inmachuk.

Imuruk; basin, east of P'ort Clarence, Seward peninsula. Eskimo name, reported by Beechey, 1827, as Imau-rook. Variously written Imaourouk, Imaurook, Imurook, Imourouk, Imagazuk, and on a late map Cowvinik. Murdoch writes it Imau-ruk.

Imuruk; lake, Seward peninsula, the source of Kugruk river, which drains it to Kotzebue sound. It is about 75 miles northeast of Imuruk basin, near latitude $65^{\circ} 35^{\prime}$, longitude $163^{\circ} 10^{\prime}$. Eskimo name, written Emuruk by Mendenhall, 1901. Written also Imourouk.

Imuya; bay, just west of Kialagvik bay, on south shore of Alaska peninsula. Native name, from the Coast Survey.

Ina; gulch, in Fortymile region, on south bank of Slate creek, neil latitude $64^{\circ} 35^{\prime}$, longitude $142^{\circ} 40^{\prime}$. Prospector's' name, reported by Witherspoon, 1905.

Inalak. Small island, near Unalaska, not identified, perhaps Unalga. Name from Berg, 1823 (p. 59).

Inalin, island; see Big Diomede.

Inanudak; bay, indenting the northern shore of Umnak, eastern Aleutians. Native name from Veniaminof. There are some coves in this bay, one of which is probably the one called stepanofiskaia by Lutke. According to Grewingk, Lutke called Inanudak bay Stepanow bay, but this appears to be an error.

Inaru; river, in northern Alaska, flowing northeasterly and supposed to bebouch into Dease inlet. Crossed by Ray in March, 1883. The natives, he says in his text (p. 27), call it Ináru; on his map he calls it Kuabroo, and this name has been copied on Coast Survey and other charts.

Independence; creek, tributary to Sinuk river from the west, Seward peninsula. Name from Barnard, 1900.

Independence; creek, Seward peninsula, tributary to Quartz creek from west, near latitude $65^{\circ} 20^{\prime}$, longitude $164^{\circ} 45^{\prime}$. Prospectors' name, obtained by Gerdine, 1901.

Independence; creek, Seward peninsula, tributary from the south to Kugruk river and Kotzebue sound, near longitude $163^{\circ}$. Prospector's' name, obtained by Mendenhall, 1901.

Independence; creek, in the Birch Creek region, tributary to Mammoth creek from the right, near latitude $65^{\circ} 30^{\prime}$, longitude $145^{\circ} 15^{\prime}$. Prospectors' name, reported by Spurr, Goodrich, and Schrader, 1896.

Independence; creek, eastern Alaska, on the north bank of North fork Fortymile creek, near latitude $64^{\circ} 40^{\prime}$, longitude $142^{\circ} 20^{\prime}$. Prospectors' name, from sketch map compiled by Major Glassford, Signal Corps, U. S. A., 1905.

Independence; island, in Steamer bay, Etolin island, Alexauder archipelago. So named by Snow, 1886.

Index, island; see Guide.

Indiada; islet, in Port Santa Cruz, Suemez island, Prince of Wạles archipelago. Named Isleta de la Indiada by Maurelle and Quadra, 1775-1779.

Indian, bay; see Sumner.

Indian; channel of Chilkat river, " used in going up," near latitude $59^{\circ} \cdot 20^{\prime}$, longitude $135^{\circ} 48^{\prime}$. Name taken from the Coast Survey magnetic tables for 1902. Probably reported by Pratt, 1894. 
Indian; creek, tributary to Copper river from the north, between Chistochina and Slana rivers. Prospectors' name, obtatined by Schrader, 1903. According to Schrader the Indian name is Tetelna.

Indian; creek, on the north shore of 'Turnagain arm, Cook inlet, near latitude $61^{\circ} 05^{\prime}$, longitude $149^{\circ} 30^{\prime}$. Prospectors' name, from Glenn, 1898.

Indian; creek, tributary to Chickaloon bay, south shore of Turnagain arm, Cook inlet, near longitude $150^{\circ}$. Local name, from Recker, 1895. •

Indian; creek, tributary to the Susitna river from the north, near latitude $63^{\circ}$. So named by Muldrow, 1898.

Indian; creek, tributary to Goodpaster river from the north, near latitude $64^{\circ}$ $30^{\prime}$, longitude $145^{\circ}$. Prospector's' name, reported by Gerdine, 1903.

Indian; creek, tributary to Mosquito fork Fortymile creek from the left, near latitude $64^{\circ}$, longitude $143^{\circ}$. So called by Lieutenant Mitchell, signal Corps, U. S. A., 1902.

Indian, creak; see Tsadaka.

Indian, point; see Green.

Indian; point, the northern point of entrance to Naha bas, Behm canal, Alexander archipelago. So named by Clover, 1885. There are Indian graves on the point.

Indian; river, near Sitka, Baranof island, Alexander archipelago. Locally so called. It is Koloshanka and Koloshenka (Koloshian) of Russian charts.

Indian; river; Kenai peninsula, tributary to lustumena lake from the west, near longitude $150^{\circ} 20^{\prime}$. Local name, from Moftit, 1904.

Indian; rock, bare at lowest water, in Felice strait, Gravina group, Alexander: archipelago. So named by Nichols, 1883.

Indian; rock, in Security bay, Kuiu island, Alexander archipelago. So named by Meade, 1869 .

Indian; sunken rock, at mouth of Taiya inlet, Lynn canal, southeastern Alaska. So called by Nichols in the Coast Pilot (1.891, p. 203).

Indian; sunken rock, in middle anchorage of Sitka harbor, Sitka sound, Alexander archipelago. Name published by the Coast Survey in 1.881.

Indian Pass; creek, tributary to Yukon river from the east, midway between The Ramparts and Fort Hamlin, near latitude $65^{\circ} 40^{\prime}$, longitude $149^{\circ}$ 40'. Prospectors' name, reported by Lieutenant Erickson, U. S. A., 1902.

Indut, cape; see Izbut.

Inellen, island; see Big Diomede.

Inerskin, bay ; see Iniskin.

ingahameh, village; see Ikuak.

Ingakalik; island; off the south shore of Alaska peninsula, northeast of Sutwik island. Native name, from 'Tebenkof, 1849.

Ingekasagmi, village; see Ignok.

Ingekvak, island; see High.

Ingenstrem; rocks, just enst of the Semichi islands, western Aleutians. So named by the Russians after pilot Igenstrem, who visited the Andreanof group of islands, 1829, and twice wintered at Atka, correcting the chatrs of this general region. The name appears variously, Ingenstern, Ingenstrem, Ingenström, Inghestrom, etc.

Inger; Eskimo village, in southeast part of Nunivak island. Bering sea. Native name, from the Eleventh census, where it is written Ingeramiut (mountain village), from ingerrit (Kuskokwin) or ingrik (Yukon delta) meaning mountain and wiut meaning people.. Population in 1890, 35. 
Ingichuak; hill (525 feet high), in the Yukon delta northeast of Kusilvak mountain, near latitude $62^{\circ} 10^{\prime}$, longitude $164^{\circ} 07^{\prime}$. The Russians wrote it Ingichuak. On a late Coast Survey chart it is called Ingrikchoa. It is doubtless the Eskimo term ingrēchốa meaning hill, and might better be written Ingrichoa, from Ingrik (mountain) and choa, diminutive termination.

Ingichuk; eskimo village (of 8 , people in 1880), in the Yukon delta. Native name from Nelson, who visited it in December, 1878. Also has been written Ingechuk. Father Barnum writes this Ingrēechōa'mēūt (the hill folks), or, as we would write it, Ingrichoa.

Ingieguik, mountain; see Kusilvak.

Ingle; creek, tributary to Mosquito fork Fortymile creek from the north, near longitude $142^{\circ} 05^{\prime}$. Prospectors' name, from sketch map compiled by Major Glassford, Signal Corps, U. S. A., 1905.

Inglestat, point; see Bald Head promontory.

Inglikhakh, island; see Karpa.

Inglutalik; river, tributary to the head of Norton bay, Norton sound. An Eskimo name. Tebenkof, 1849, calls this river, or a stream which appear's to be this one, Inaktuli. The Western Union Telegraph Expedition map of 1867 calls a native village on this stream, Ingletalik. For the rest there has been hopeless confusion, Ingluealik, Inglucalik, Inglaliktalik, etc.

Ingoragayuk; native village, on the tundra, east of Bethel and Kuskokwim river. Eskimo name and description derived from Reindeer Report, 1901, p. 83 , where it is printed Ingoragayukemute.

Ingraham; bay, indenting the southeastern shore of Prince of Wales island. Clarence strait, Alexander archipelago, near latitude $55^{\circ}$, longitude $132^{\circ}$. So named by Dall, 1879 , after Joseph Ingraham, master of the brig Hope, of Boston, 1791-92, whose unpublished hydrographic notes of this region were used in compiling the Coast Pilot of 1883.

Ingraham; creek, $3 \frac{1}{2}$ miles northwest of Nome, Seward peninsula, tributary to Anvil creek from the east, near longitude $165^{\circ} 23^{\prime}$. Local name, published in 1903.

Ingraham; point, the north point of entrance to Ingraham bay, Clarence strait, Alexander archipelago. So applied by local navigators, and reported by H. C. Fassett, Bureau of Fisjeries, 1904.

Ingrakak; Eskimo village, 5 miles below Chukchuk, on the right bank of lower Yukon river, near latitude $61^{\circ} 50^{\prime}$, longitude $161^{\circ} 30^{\prime}$. Native name, from Coast Survey officer's, 1898, by whom it is written Ingrakaghamiut.

Ingrakaklak; Eskimo village; Yukon delta, on the right bank of Kwikluak pass, at its mouth, near latitude $62^{\circ} 37^{\prime}$, longitude $164^{\circ} 47^{\prime}$. Eskimo name, reported by Putnam, 1899, who wrote it Ingrakaklakamiut.

Ingram, creek; see Mitchell.

Ingrēchóă, hill; see Ingichuak.

Ingrechoumeut, Eskimo village; see Ingichuk.

Ingrichoa; hill; see Ingichuak.

Ingrichoa, Eskimo village; see Ingichuk.

Ingriguk, mountain; see Kusilvak.

Ingrilcchoa, hill; see Ingichuak.

Ingrikchun; slough, opening on the left bank of Yukon river 30 miles below Andreafski, near Ingichuak hill and latitude $62^{\circ} 10^{\prime}$, longitude $164^{\circ}$. Eskimo name, reported by Putnam, 1899. Probably some corm of ingrichoa, hill. 
Inian; cove and anchorage, on the northwest coast of Inian islands, Cross sound. The anchorage here, was discovered, charted, and named by Pratt, 1901.

Inian; islands, in Cross sound, southenstem Alaska, near latitude $58^{\circ} 15^{\prime}$, longltude $130^{\circ} 20^{\prime}$. So named by Dall, 1879. Have also been called Brian islands.

Inikla; island, one of the Sannak group, 3 miles sontheast of Sannak island, near latitude $54^{\circ} 21^{\prime}$, longitude $162^{\circ}, 29^{\prime}$. Native nime, reported by Westdahl, 1901.

Inischen, bay; see Iniskin.

Iniskin; bay, indenting the north shore of Kamishak bay, west shore Cook inlet, about latitude $59^{\circ} 40^{\prime}$, longitude $153^{\circ} 25^{\prime}$. Local name, written Enochkin by Martin, 1903 . Russian surname Inokhin, variously corrupted to Innerskin, Inniskin, Inerskin, Initskin, Inischen.

Initial; island, at entrance to Redoubt bay, Sitka sound, Alexander archipelago. Named Nachalnie (initial or beginning) by Vasilief in 1.809.

Initkilly; Iskimo village, on the Arctic coast, just east of Cape Lisburne, near the Corwin coal mines. Fskimo name, published by the Coast Survey in 1890 .

Initskin, bay; see Iniskin.

Inland; lake, a tidewater lake, the largest of three connecting with and just west of Selawik lake, latitude $66^{\circ} \cdot 30^{\prime}$, longitude $160^{\circ} 05^{\prime}$. Visited and named by Ensign Purcell, of Stoney's expedition, 1884. Cantwell, 1884, wrote the Eskimo name Emogarikchoit (little sea), and Stoney's map shows a village on its shores E-mug-ge-row-che-uk; evidently two independent attempts at the same name.

Inland, river; see Noatak.

Inlet; point, Port Chester, Annette island, Alexinder archipelago. Name published by the Coast Survey in 1896 .

Inlet; point, the northernmost point of Woewodski island, Wrangell strait, Alexander archipelago. So named by Dall, 1879.

Inlikak, island ; see Karpa.

Inmachuk; river, Seward peninsula, tributary to Kotzebue sound, just east of Cape Deceit, near longitude $162^{\circ} 45^{\prime}$. Eskimo name, written by Mendenhill, 1901, Ipnichuk. It has been written variously Imachuck, Imnuchuk, Innuchuk, etc. The Eskimo term is said to mean big cliffs. In that case Impnipuk or Impniguk maly more nearly represent it.

Inner; cape, on the western shore of Kizhuyak bay, northern coast of Kodiak. Named Vnutrennie.(inner) by Murashef, 1839-40.

Inner; point, on the southeastern shore of Kruzof isiand, Sitka sound, Alexander archipelago. Named Otmeloi vnutrennie (inner shoals) by Vasilief, 1809, to distinguish it from mother point called Shoals, and also Outer Shoals point. Shoals extend off both points. Lisianski, 1804, called it second point. It has also in late charts been called Rocky point.

Inner; rocks, in Chichagof harbor, Attu island, western Aleutians. So named by Gibson, July, 1855 .

Inner Humpback; rock, in St. Paul harbor, Kodiak. Named Horboon vnutrennie (inner humpback) by Russian naval officers, 1808-1810. This may be identical with High rock of the Const Survey in 1869 .

Inner Iliasik; island, near the southern shore of Alaska peninsula, off Relkofski. Native name, from the Russians, who wrote it Iliaviki and Iliazhek. This one is nearest the shore of the peninsula; the other, Outer Iliasik, is farther out. The group has, been called Iliasil islands. 
Inner Point Sophia; point, 2 miles inside Point Sophia, on the east side of entrance to Port Frederick, south shore Icy strait, near longitude $135^{\circ} 28^{\prime}$. So named by Dickins, 1901 .

Inner Signal; rock, off the eastern shore of Biorka island, eastern Aleutians, near longitude $166^{\circ} 05^{\prime}$. So called by Gilbert, 1901 . See The Signals.

Innerskin, bay; see Iniskin.

Inner Spruce; cape, at entrance to St. Paul harbor, Kodiak. Named Elovoi vautrennie (spruce inner) by the Russians, 1808-1810.

Inniskin, bay; see Iniskin.

Innoko; river, tributary to Shageluk slough, northeast from Anvik. Native name, from the Russians. Tikhmenief calls it Innoko or Shiltonato. Dall, 1866, calls it Innoko or Shageluk. Petrof calls it Innoko on his map and Innok in his text.

Innuchuk, river; see Inmachuk.

Inokitin, bay ; see Iniskin.

Inooktut, village; see Inuktut.

Inside; passage, from Clarence strait to Tongass nar"ows, between Vallenar point and Guard islands. So named by Clover, 1885.

Insignificant; ridge of mountains $(2,050$ feet high), near Port Chester, Annette island, Alexander archipelago. So named by Nichols, 1883.

Inuktut; deserted Eskimo village, Seward peninsula, at the mouth of Buckland river, near latitude $66^{\circ}$, longitude $161^{\circ}$. Visited by Bertholf in 1898, who wrote it Inooktut. 'This may be Kongik or Kongigamut of earlier maps, since abandoned.

Ioulalih, island; see Ụlak.

Ipewik; river, in northwestern Alaska, tributary to Kukpuk river, 30 miles east of Point Hope, near latitude $68^{\circ} 30^{\prime}$. Eskimo name, published, in 1890 , as Ippewik.

Ipnichuk, river; see Inmachuk.

Iphigenia; bay, on the western border of Prince of Wales archipelago, between Bucareli bay and Sumner strait, near latitude $55^{\circ} 40^{\prime}$, longitude $134^{\circ}$. So named by Davidson, in 1869 (Coast Pilot, p. 95), after the packet boat Iphigenia Nubiana, Capt. William Douglas, which was here in 1788.

Iphigenia; point, the eastern point of entrance to Port Caldera, Bucareli bay, Prince of Wales archipelago. Named Punta de Santa Efigenia by Maurelle and Quadra, 1775-1779.

Ipnot; Eskimo village, on the Arctic coast, near Cape Thomson, a little south of Point Hope. Name from Petrof, who wrote it Ip-Not and Ipnot, and reported a population, in 1880 , of 40 .

Ippewik, river; see Ipewik.

Trak, bay ; see Ugak.

Irene; creek, 7 miles northwest of Cape Nome, tributary to Nome river from the east, near longitude $165^{\circ} 13^{\prime}$. Local name, published in 1900 .

Irene; glacier, on the west bank of Taiya river, southeastern Alaska, near latitude $59^{\circ} 35^{\prime}$, longitude $135^{\circ} 22^{\prime}$. Name from Flemer, 1898 , but not hitherto published.

Irish; gulch, 15 miles north of Nome, Seward peninsula, at the head of Scotch gulch, on the east bank of Snake river, near longitude $165^{\circ} 23^{\prime}$. Miners' name, published in 1901.

Iron; creek, Seward peninsula, small tributary on west bank near head of Big Four creek, an east branch of Casadepaga river, near latitude $64^{\circ} 47^{\prime}$, longitude $164^{\circ} 05^{\prime}$. Frospector's' name, from Gerdine, 1905. 
Iron; creek, 20 miles north of Cape Nome, Seward peninsula, tributary to Flambean river from the west, nenr latitude $64^{\circ} 41^{\prime}$, longitude $165^{\circ} 05^{\prime}$. Name from Barnard, 1900. Gerdine, 1904, reports that the local name is Triple creek.

Iron; creek, tributary to Kruzgamepa river from the south, Seward peninsulat. Name from Barnard, 1900.

Iron; creek, 15 miles north of Nome, Seward peninsula, a small tributary of Nome river from the west, near longitude $165^{\circ} 18^{\prime}$. Local name, published in 1900.

Iron; creek, Seward peninsula, tributary to North fork Kougarok river from the south, near latitude $65^{\circ} 35^{\prime}$, longitude $164^{\circ} 25^{\prime}$. Prospectors' name, reported by Gerdine, 1901.

Iron; creek, Seward peninsula, tributary to Sullivan creek, which flows into Kotzebue sound, near latitude $66^{\circ}$, longitude $163^{\circ} 10^{\prime}$. Prospectors' name, obtained by Witherspoon, 1903.

Iron, island; see Chugul.

Irving, cape; see Muzon.

Irving; mountain (9,000 feet high), north of Malaspina glacier, st. Elias alps, southeastern Alaska. So named by Russell, 1890, after Roland Duer Irving, United States geologist. Has been erroneously printed Irvin.

Irving; peak ( 2,169 feet high), on the mainland, near Slocum inlet, southeastern Alaska. So named by Thomas, 1888.

Isaacs, point; see Bald Head.

Isabella; creek, 2 miles north of Fairbanks, tributary to Noyes slough from the north, near longitude $147^{\circ} 45^{\prime}$. Local name, from a local map, 1905.

Isanotski, bay; see Bechevin.

Isanotski; islands, in Bechevin bay, Isanotski strait, Alaska peninsula. Named Issanakh islands, by Dall, 1882.

Isanotski; point, on the eastern end of Unimak island, near entrance to Isanotski strait. So called by Tebenkof, 1849.

Isanotski; ridge of mountains, and peak or peaks, on eastern end of Unimak island, eastern Aleutians. Called Issanakski by Veniaminof, 1831.

Isanotski; strait, at the western end of Alaska peninsula, separating it from Unimak island, near longitude $163^{\circ} 22^{\prime}$. According to Veniaminof, the name is Issanakskie, a Russian adjective from the Aleut name isanak (bole, tear, rent). Lutke, 1836, says " not Issanotsky, as ordinarily called; the name of the strait is the same as that of the island Sannakh or Issannakh." On the early Russian charts it is Isanotskoi, Isanotzky, etc., and Lutke so uses it in 1828. It is usually called Isanotski and sometimes False Pass.

Isanotskoi, volcano; see Pogromnoi.

$I$-she-ik, lake; see Aishihik.

Ishiik, lake and village; see Aishihik.

Ishiuk; Eskimo village of 15 huts, northwest Alaska, at the source of the Etivluk river, one of the headwaters of Colville river, near latitude $68^{\circ}$, longitude $155^{\circ} 25^{\prime}$. Visited by Stoney, 1885 , who wrote Issheyul.

Ishut; creek, Seward peninsula, tributary from the northwest to Anikovik creek, about 5 miles northeast of York. Eskimo name, reported by Gerdine, 1901.

1sḯoot, mountain; see Iskut.

Iskoot, river; see Iskut. 
Iskut; mountain $(4,800$ feet high $)$, on the Canadian side of the international boundary, near the junction of Iskut and Stikine rivers. Indian name, written Skoot by Hunter, 1877. It has also been written Iskoot and Iskut. The Canadian Board on Geographic Names has adopted the form Iskut.

Iskut; river, in Canada, tributary to Stikine river from the east, Indian name, written Skoot and Iskoot. The Canadian Board on Geographic Names has adopted Iskut.

Island; creek, Kenai peninsula, on the right bank of Resurrection creek 2 miles above Palmer creek. Local nane, obtained by Moffit, 1904.

Island; creek, tributary to Yukon river from the north, about 20 miles below the mouth of Tozi river. Name published by the Coast Survey in 1898. This appears to be the stream called Sitzikunten by Dall (1.869), Newchuklicargut by Raymond (1869), and Nuchuklikakat by Petrof (1880).

Island; point, the north point of entrance to McLean arm, Prince of Wales island, Clarence strait, southeastern Alaska, near latitude $54^{\circ} 48^{\prime}$, longitude $131^{\circ} 57^{\prime}$. So called by local navigators and reported by Fassett, Bureau of Fisheries, 1904.

Island; point, at the southern side of entrance to Kasaan bay, Clarence strait, Alexander archipelago. So named by Dall, 1880.

Island; point, on Baranof island, near Southern rápids, Peril strait, Alexander archipelago. So named, 1884, by Coghlan, who shows an island off the point.

Island; point, on Lindenberg peninsula, Wrangell strait, Alexander archipelago. So named by Coghlan, 1884. There is an island off this point.

Island; point, on the western shore of Carroll inlet, Revillagigedo island. Named by the Coast Survey in 1891. There is an island off the point.

Island; point, the southeasternmost of Sitklan island, Tongass passage, Alexander archipelago. Descriptive name, given by Nichols, 1883. There is a small island off the point.

Island; slough, on the south side of Big island, Yukon river. Name published by the Coast Survey in 1898. Its native name, according to Zagoskin, 1.842-1844, is Notliagepia-ta.

Islands, Bay of; indenting the western shore of Adak island, middle Aleutians, near longitude $176^{\circ} 50^{\prime}$. Descriptive name, given by Dall, 1873.

Islands of the Four Mountalins; see Four Mountains.

Islet; cape, on the northern shore of Kodiak, in Kupreanof strait. Named Ostrovka (islet) by Murashef, 1839-40.

Islet; point, on the southern shore of Port Sinta Cruz, Suemez island, Prince of Wales archipelago. Named Punta de la Isleta (point of the islet) by Maurelle and Quadra, 1775-1779. There is an islet off the point.

Islets; point, in Bucareli bay, Prince of Wales archipelago. Named Punta de los. Islotillos (point of the barren islets) by Maurelle and Quadra, $1775-1779$.

Ismailof; island, in Halibut cove, Kachemak bay, Cook inlet. Named by Dall, 1880, after a Russian naval officer, Gerassiim Grigorovich Ismaïlof, who made explorations in Alaska in the last century. Cook calls him Erasim Greǵorieoff Sin Ismyloff, and Vancouver, Mr. Smyloff.

Issannakh, strait; see Isanotski.

Jssheyuk, Eskimo village; see Ishiuk.

Isthmus; bay, on the soathern shore of Chiniak bay, Kodiak. Named Përesheinoi (isthmus) by Russian naval officers, 1808-1810.

Isthmus; island, near Hot Springs bay, sitka sound, Alexander archipelago. Named Peresheechnoi (istbmus) by Vasilief, 1809. 
Isthmus; island, in Kalsin bay, Chiniak bay, Kodiak. Named Peresheechnoi (isthmus) by Russian naval ofticers, 1808-1810.

Isqual, cape; see Igvak.

Italio; river, a glacial stream on the southeastern const, 25 miles southeast of Yakutat, near longitude $139^{\circ}$. Name, from Moser, 19001 . 'This may be Akoi of 'Tebenkof.

Itkillik; river, tributary to the Colville, about 70 miles from its mouth. So described by IA. L. Bosqui, United States commissioner, who located on the Colville at the mouth of this river in December, 1902, and called the place Jarvis, after Capt. D. H. Jarvis, collector of customs, district of Alaska. The river is not shown on any map.

Itulilik; Eskimo village, on the right bank of Chulitna river, 68 miles above its junction with the Kuskokwim, near longitude $157^{\circ}$. Native name, written E-tu-le-lig-a-mute (Itulilik folks) on an unpublished map drawn by W. R. Buckman, who prospected the Chulitna valley in 1902-3.

Itvelik; river, on the Arctic slope, tributary to Colville river from the east, near latitude $70^{\circ}$, longitude $151^{\circ}$. Eskimo nime, reported by Peters and Schrider, 1901.

- Iukuk; bay, indenting the northeastern shore of Raspberty island, Kodiak group. Native name, from Murishef, 1839-40.

Iukuk, island; see Raspberry.

Iumkrarak; slough, Yukon delta, on the right bank of Kiwikluak pass, near latitude $62^{\circ} 43^{\prime}$, longitude $164^{\circ} 15^{\prime}$. Eskimo name, obtained by Putnam, 1899 , who wrote it Iumkraarak.

Iuri, point; see Urey.

Iuzhnie, cape ; see South.

Iuzhnie, point; see Southeast.

iuzhnoi, cape; see Trinity.

Iuzhnoi, point; see Harbor.

Ivakin; cape, the eastern point of entrance to Constantine harbor, Amchitka

$\dot{\infty}$ island, western Aleutians. So called by Tebenkof, 184.9 .

Ivan; barrabora or house belonging to one Ivan (John) on the divide between Unalaklik and the Yukon. Name from Dall, 1866. Since 1869 has appeared on maps as a village Ivan.

Ivan; small island, in Pavlof bay, Alaska peninsula. Presumably named Ivan (John) by the Russians. Name reported (or given) by Dall, 1880.

Ivanhoe; creek, Seward peninsula, at head of Big Four creek, an east branch of Casadepaga river, near latitude $64^{\circ} 47^{\prime}$, longitude $164^{\circ} 03^{\prime}$. Prospectors' name, from a locil map, 1901.

Ivanof; bay, indenting the soithern shore of Alaska peninsula, northeast of the Shumagin group. Named by Dall in 1880.4 cape near by was named Ivanof (John's) by Lutke, 1835.

Ivanof, cape; see Kupreanof.

Ivey; see Ivy City.

Ivy City; on the Yukon, 2 miles below Nation, near mouth of Fourth of July creek, about longitude $141^{\circ} 50^{\prime}$. Local nime, called Ivy City by Cantwell, 1900 , and Ivey on an unpublished map.

Iyak; native village, on the north side of Kobuk river, 5 miles below the mouth of the Pah, near latitude $\left(66^{\circ} 50^{\prime}\right.$, longitude $156^{\circ} 05^{\prime}$. Visited by Stoney's party in 1885 .

Iyoukeen; cove, on the northeastern shore of Chichagof island, Chatham strait, Alexander archipelago. Native name, reported by Davidson, 1869, as I-youk-een. 
Izawerknuk; river, Yukon delta, reported by Jarvis, 1897, as probably another Eskimo name for the Krichavak.

I:bavlenia, point; see Escape.

Izembek; bay, indenting the northern shore of Alaska peninsula near its western end, about longitude $162^{\circ} 45^{\prime}$. Named by Lutke, after Surgeon Karl Izembek, a member of his party. Lutke spells the name Izenbek and Isenbeck. Grewingk follows the spelling Isenbeck. The official list of the officers of the Moller, Captain Staniukovich commanding, on which ressel this surgeon serred, has Surgeon Karl lzembek. That list, in the Journal of the Russian Hydrographic Office for 1850 (vol. 8, p. 182), appears to have been carefully prepared and leads to the belief that the name should be written Izembek.

Izhiga; cove, in Inanudak bay, on the northern shore of Umnak, eastern Aleutians. Native name, from Veniaminof.

Izhut; bay, indenting the southeastern coast of Afognak island, Kodiak group. Apparently a native name, from Tebenkof, 1849. Variously given as Izhutskaia, Ujut, Uyut, etc. The Spaniards called it Puerto. de Solano (east wind). Izhut bay of 'Tebenkof is west of Pillar point; Izhut bay of the Russian-American Company's report for 1849 is a smaller bay east of Pillar point.

Izhut; cape, forming the western head of Izhut bay, Afognak island, Kodiak group. So called by Tebenkof, who identifies it with Whitsuntide of Cook, 1778, calling it Piati-desiat-nitzi (Pentecost, or Whitsuntide). It is Cape Shariepof of Murashef, 1839-40. The Russian-American Company's map of 1849 applies the name Izhutskoi to the western head of a small bay farther east. Thus we have Ijoot, Ishoot, Indut, Izhutskni, Pentecost, Piatidesiatniztzi, Shariepof, Shiripof, and Whitsuntide as names which have been applied to this cape.

Izhut; creek, tributary to Anikovik river from the north, in western part of Seward peninsula. Eskimo name, which has been published as Ishoot and Ishout.

Izigan; cape, on the southern shore of Unalaska, near its western end. So. called by 'Tebenkof, 1849 .

jabbertown, near Point Hope; see Coopers.

Jachach, cape; see Yakak.

sachlanissa, island; see Kochu.

Jack; bay, indenting the southeastern shore of Port Valdez, opposite Lowe point, Prince William sound. Named Jack's by Abercrombie, 1898, presumably after W. G. Jack, a prospector in this region.

Jack; creek, tributary at the headwaters of Nabesna river on the west. Probably a prospectors' name, reported by Schrader, 1902.

Jack; river, tributary to Cantwell river from the soutb, near latitude $63^{\circ} 30^{\prime}$. So named by Eldridge and Muldrow, of the Geological Survey, 1898, presumably after W. G. Jack, a prospector.

Jackass; islet, near the southeastern shore of Alun island, Krenitzin group, easteln Aleutians. So named by the Fish Commission in 1888.

Jackass; point, the southernmost point of Akun island, eastern Aleutians, near longitude $165^{\circ} 34^{\prime}$. So named by the Fish Commission in 1888 .

Jackpot; bay, on western side of Prince William sound. Local name, reported by Grant, 1905.

Jackpot; lakes and stream, southwestern coast Prince William sound, on the mainland, draining into the large bay, maybe Jackpot bay (above), west of the south end of Chenega island, near latitude $60^{\circ} 20^{\prime}$, longitude $148^{\circ} 30^{\prime}$. So named by the fisheries, reported and written Jack Pot and Jack-Pot by Moser, 1897 and 1901. 
Jacksina; creek and glacier; creek tributary to the headwaters of Nabesna river from the west, and glacier on the north side of Mount Jarvis. Name probably given by prospectors. Reported by Schrader, 1902, who says the native name is Di-bot-i-chit-in-da.

Jackson, bay ; see Sheep.

Jackson; cove, indenting the southern shore of Glacier island, Prince William sound. Name fiom Scluader, 1900.

Jackson; cove, indenting southern shore of Port Valden, Frince William sound, $3 \frac{1}{2}$ miles: west of Fort Liscum, near latitude $61^{\circ} 05^{\prime}$, longitude $146^{\circ} 30^{\prime}$. Tocal name, reported by Grant, 1905.

Jackson; creek, tributary to Bonanzil-river from the north, Seward peninsula. Name from Barnard, 1900.

Jackson; creek, tributary to the Yukon on the right bank, 6 miles above the mouth of the Tanana. Name taken from Edward's 'Track Chart of the Yukon, 1899.

Jackson; island, near the liead of Cordova bay, Alexander archipelago. So nimed by Dall in the Coast Pilot, 1883, after Rev. Sheldon Jackson. Jackson, in his Alaska $(1880$, p. 376), calls it Norcross island.

Jaclison, island; ' see Channel.

Jackson; point, south shore Port Valdez, three-fourths of a mile west of Fort Liscum, Prince William sound, near longitude $146^{\circ} 20^{\prime}$. Locil name, reported by Ritter, 19001 .

Jackson; point, the north point of entrance to Port Clarence, Bering strait. So named by Beechey, 1827, in compliment to Capt. Samuel Jackson, R. N.

Jackson; Presbyterian mission, and trading post at Howkan village, Long island, Cordova bay, Alexander archipelago. Rev. Sheldon Jackson, in his report for: 1886 (p. 19), says: "On the 22 d of August, 1881, I established a mission among them (Haidas) at the village of Howcan, placing Mr. James ID. Chapman in charge as a teacher. The station was called Jackson by the missionaries." A post-oftice called Jackson was established here in February, 1884, and the name changed to Howkan in February or March, 1906.

Jack; Wade, creek; see Wade.

Jnck Wade; post-office, iin the Fortymile region, established in 1902 and located on Wade creek, near latitude $64^{\circ} 10^{\prime}$, longitude $141^{\circ}: 30^{\prime}$.

Jacob; island, on the southern shore of Alaska peninsula, northeast of the Shumagins. Named St. Jacob by Woronkofski, 1837.

Jacob, island; see Yakobi.

Jacootat, bay; see Yakutat.

Jade; creek, tributary to the Kobuk from the north near Jade Mountain, about latitude $67^{\circ} 10^{\prime}$, longitude $158^{\circ} 10^{\prime}$. So named by Mendenhall and Reaburn, 1901.

Jade; mountain, or mountains (3,500 feet high), northwestern Alaska, - on the north bank of Kobuk river, near longitude $158^{\circ}$. Visited by Stoney in 1884 and again in 1886, when he succeeded in finding the jade from which the Eskimo made their ornaments. Name published by the Coast Survey in 1884. Cantwell, 1884, calls it the Ashiganok, or green-stone, mountain (p. 57).

Jadski; cove, indenting the northern shore of McHenry inlet, Ltolin island, Clarence strait, Alexander archipelago, near latitude $56^{\circ} 02^{\prime}$, longitude $132^{\circ} 26^{\prime}$. Local navigators' name, reported by Fassett, Bureau of Fisheries, 1904.

Jaichnoi, cape; see Egg.

Jaitschnoi, island; see Egg. 
Jakobia, island; see Chichagof.

Jakoiny, point; see Anchor.

Jambodinuk; creek, tributary to-Yentna river from the north, 19 miles below the Skwentna, neal latitude $62^{\circ}$, longitude $150^{\circ} 45^{\prime}$. Native name, Jam-bod-i-nook, obtained by Herron, 1899 .

James; island, in Ivanof bay, northeast of the Shumagius. So called by Dall. 1880.

James, island ; see Crow.

James; lake, on the southeast shore of Prince of Wales island 3 miles north of Port Johnson, Clarence strait, Alexander archipelago, near latitude $55^{\circ}$ $09^{\prime}$, longitude $132^{\circ} 02^{\prime}$. Local name, reported by Brooks, 1901.

Jamestown; bay, in the northeastern part of Sitka sound, Baranof island, Alexander archipelago. In 1879-80 the C. S. S. Jamestown was stationed in southeastern Alaska and for the most part was at Sitka, where her officers, especially Lieut. F. M. Symonds, navigating officer, and Master G. C. Hanus, engaged in surveying, and added materially to previous knowledge of Sitka sound and some other places. This bay or cove wits named after the ship and various islets in the sound after officers of the ship.

Jamestown; peak (2,940 feet high), on the mainland, northwest of Farragut bay, southeastern Alaska. Named by 'Thomas, 1887, after the U. S. S. Jamestoun, at one time stationed in Alaskan waters.

Jamestown; point, on left bank of Chilkat river. Named by United States naval officers, 1880 , after the U. S. S. Jamestown.

Jamieson; creek, Seward peninsula, tributary to Goodhope river from the north, near latitude $65^{\circ} 45^{\prime}$, longitude $163^{\circ} 40^{\prime}$. Prospectors' name, obtained by Mendenball, 1901 .

Jane; creek, near Bettles, tributary to Koyukuk river from the west, near latitude $67^{\circ}$, longitude $152^{\circ}$. Prospector's' nime, obtained by Peters and Schrader, 1901.

Janesville; mountain (2,620 feet high), east of Port Chester, Annette island, Alexander archipelatgo. So named by Nichols, 1883. Erroneously Janeville.

Japan, island; see Japonski.

Japonski; island, near Sitka, Sitka sound, Alexander archipelago. Named Japonski (Japanese) by the Russians. In 1805 the storm-drifted hulk of a Japanese junk went ashore on this coast. Its rescued sailors lived for at time on this islind; hence the name Japonski, i. e., Japanesc. Erroneously Jeponski; also has been written Japan and Yaponski.

Jarvis; creek, southeastern Alaska, tributary to Klehini river from the southwest, near the international boundary and latitude $59^{\circ} 25^{\prime}$, longitude $136^{\circ} 21^{\prime}$. Local name, obtained by Wright, 1903.

Jarvis; creek, tributary to Delta river from the east, near its junction with the Tanina, in about latitude $64^{\circ}$. So named by Glenn, 1898, perhaps after Lieut. David Fenry Jarvis, U. S. Revenue-Cutter Service.

Jarvis; mountain (12,230 feet high), 12 miles north of Mount Wrangell, southern Alaska. So named by Schrader, 1903, after Capt. D. H. Jarvis, collector cf customs, district of Alaska.

Jarvis; village, northern Alaska, 70 miles up Colville river, at the mouth of Itkillik river. So named and described by E. F. Bosqui, United States commissioner, who located there in December, 1902. Named after Capt. D. H. Jarvis, collector of customs, district of Alaska.

Jauncey; mountain $(3,654$ feet high), on the easteru shore of Portland canal. So named by Pender, 1868. 
Jaw; point, on Liesnoi island, the southwestern point of entrance to Woewodski harbor, Frederick sound, Alexander archipelago. So named by Mansfield, 1.889.

Jaw; point, on the mainland, east shore of Taku inlet, southeastern Alaska. So named by Mansfield, 1890.

Jeannette; island, northeast of the New Siberian islands, Arctic ocean. Discovered by .De Long, 1881, and named by him after his ship Jeannelte.

Jeannette; mountain, in the Augusta range, St. Elias alps, southeastern Alaska. So named by Russell, 1890.

Jefferson; creek, an affluent of Yukon river on the right bank at Circle, near longitude $144^{\circ}$. Local name, taken from a map in the Coast Survey archives drawn by E. F. Ball; a prospector, 1898.

Jelchitni, river, tributary to Chilkat river; see Bear creek.

Jellowa, island; see Spruce.

Jeltaliatschlkahin, river, tributary to Klelini river; see Little Boulder creek.

Jendustáliä, village; see Gan-te-gas-tali-leh.

Jenkins; peik (3,292 feet ligh), on the mainland, east of 'Thomas bay, southeastern Alaska. Named by Thomas, 1887, presumably after RearAdmiral Thornton Alexander Jenkins, U. S. N.

Jenkins; sunken rock, near the head of Chilkat inlet, Lynn canal, southeastern Alaska. So named by the Coast Survey in 1891.

Jennie M; slough, on the north bank of.Chena slougl, 3 miles east of Fairbanks, near longitude $147^{\circ} 50^{\prime}$. Local name, from Map of Location, Tanana Mines Railroad, 1904.

Jeponski, island ; see Japonski.

Jerome; creek; tributary to Solomon river from the west, Seward peninsula. Name from Barnard, 1900.

Jessie, creek; see Saint Michael.

Jesus MIary; cape, in Gulf of Esquibel, Prince of Wales archipelago. Named Punta de Jesus Maria by Maurelle and Quadra, 1775-1779.

Jet, island ; see Loon.

Jim; creek, tributary to Taylor creek from the east, Seward peninsula. Name from Brooks, 1900.

Jim; creek, eastern Alaski, on the south bank of Slate creek, tributary from the west to Nortli fork of Fortymile creek, about latitude $64^{\circ} 355^{\prime}$, longitude $142^{\circ} 40^{\prime}$. Prospectors' name, written Dim on a sketch map compiled by Major Glassford, Signal Corps, U. S. A., 1905.

Jim; river, draining into South fork Koyukuk river from the south, near longitude $151^{\circ}$. Prospector's' name, published by the Coast Survey in 1899 .

Jimtown; mining eamp, at mouth of. Jim river, near longitude $151^{\circ}$. Prospectors' name, reported by the Geological Survey in 1899.

Jockeálch, river, tributary to Klehini river; see Boulder creek.

Joe; creek, Seward peninsula, tributary to Quartz creek from the west, near latitude $65^{\circ} 22^{\prime}$, longitude $164^{\circ} 45^{\prime}$. Prospectors' named, obtained by Gerdine, 1901 .

Joe; gulch, 6 miles north of Nome, Seward peninsula, on the north slope of Newton peak, draining to Dexter creek, near longitude $165^{\circ} 18^{\prime}$. Local name, published in 1001.

Joe; island, in Clover passage, Behm canal, Alexander irchipelago. So named by Clover, 1885 .

Joe; islands, in the mouth of Klawak inlet, on the northeast side of Fish Egg island, Bucareli bay, Prince of $\mathrm{W}_{\text {alles }}$ archipelago, neür latitude $55^{\circ} 30^{\prime}$. Local name, obtained by Moser, 1897. 
Joe Bush; creek, north side of Tanana, in the Baker creek region, tributary to Pioneer creek from the northwest near its head, about longitude $150^{\circ}$. Prospectors'. name, reported by Prindle, 1904.

coe Wilson, creek; see Wilson.

Johann Bogoslow, island; see Bogoslof.

John; creek, Seward peninsula, 8 miles north of Grantley harbor, tributary from the west to North creek, near latitude $65^{\circ} 23^{\prime}$, longitude $166^{\circ}$. Prospectors' name, obtained by Gerdine, 1902.

John; creek, tributary to the South fork of the Koyukuk river from the north, near longitude $150^{\circ} 30^{\prime}$. Prospectors' name, obtained by Peters and Schrader, 1901.

John; island, near the southwest coast of Nagai island, Shumagins. So called by Dall, 1880 .

John; island, northeast of the Shumagins, in Ivanof bay, Alaska peninsuli. So called by Dall, 1880.

John; lake, $1 \frac{1}{2}$ miles north of Port Johnson, southeastern shore Prince of Wales island, Alexander archipelago, near latitude $55^{\circ} 08^{\prime}$, longitude $132^{\circ} 0 z^{\prime}$. Local name, reported by Brooks, 1901.

John; peak, on the mainland, east of Farragut bay, southeastern Alaska. So named by Thomas, 1887.

John; river, large tributary of the Koyukuk river from the north, near longitude $152^{\circ}$. Named, about 1898 , after John Bremner, pioneer prospector and explorer. Allen, 1885, explored the Koyukuk as far as the mouth of this river, which he named Fickett, after Private Fred w. Fickett, U. S. A., a member of his party. He wrote the Indian name Ascheeshna, which has also been written Ochesna and Oschesna. In 1899 Schrader and Gerdine erroneously put the name Totsenbetna on this river, and Fickett they applied to a stream, apparently a very small one, on the same side of the Koyukuk, 10 miles farther down. This doubtless is known to the miners by some other name. In 1901 Peters and schrader explored it and found the prospectors and miners knew it as John river. They adopted John, omitting Fickett from their map entirely. Schrader wrote the Indian name, Alchichna. Thus the river has had four names: the Indian name Ascheeshna or Alchichna ; Fickett river, given by Allen, 1885; Totsenbetna, erioneously by Schrader and Gerdine, 1899, and John river, given by the miners and so known locally.

John; rock, off Alaska peninsula, southeast of Belkofski. Presumably so named by the traders. Published by the Coast Survey in 1882.

Johns; creek, tributary to Solomon river from the west, Seward peninsula. Name from Barnard, 1900.

Johns; Indian house, near Mentasta lake, on trail between Tanana and Copper rivers. It is near the head of Slana river. So called by Lowe, 1898, from the name of its Indian occupant. Known as Johnnie's village.

Johns Hopkins; glacier, on the west side, near the head of Reid inlet, Glacier bay, southeastern Alaska. This is the second in şize of the three branches of the original Grand Pacific glacier of Muir. Named by Reid, 1892, after Johns Hopkins University. See Grand Pacific.

Johnson; bay, indenting the north shore of Sannak island between Unimak cove and Northeast harbor, near latitude $54^{\circ} 27^{\prime}$, longitude $162^{\circ} 38^{\prime}$. Called Johnsons by Westdabl, 1901, and probably a local name. 
Johnson; cove, indenting the southern shore of Moira sound, western shore Clarence strait, southeastern Alaska, near latitude $55^{\circ}$, longitude $132^{\circ}$ 05'. So called by local navigators, and reported by Fassett, Bureau of Fisheries, 1904.

Johnson; creek, on the mainland, north of Berners bay, eastern shore Lymn canal, soutbeastern Alaska, near latitude $58^{\circ} 50^{\prime}$. Prospectors' name, reported by Spencer and Wright, 1903.

Johnson; creek, Kenai peninsula, tributary to Trail lakes from the northeast. Local name, from Moftit, 1904.

Johnson; creek, Seward peninsula, on west bank Solomon river, 5 miles from the coast, near longitude $164^{\circ} 23^{\prime}$. Prospectors' name, from a local. map, 1904.

Johnson; creek, tributary to Casadepaga river,from the socth, Seward peninsula. Name from Barnard, 1900.

Johnson, creek; see Johnston.

Johnson; fork, on the eastern shore of Herendeen bay, Alaska peninsula, a left fork of Coal creek, which is tributary to Mine harbor. Prospectors' name, reported by Sidney Paige, of the Geological Survey, 1905.

Johnson, island; see Berry.

Johnson; mining camp, west of Council, in the Fish River mining region, north of Golofnin bay, Seward peninsula. Called Johnson City by the prospectors, and this name published by the Coast Survey in 1900 .

Johnson; mountain (6,000 feet high), near the head of Portland canal. So named by Pender, 1868 .

Johnson; port (Port Johnson), indenting the southeastern shore of Prince of Wales island, Clarence strait, Alexander archipelago, near latitude $55^{\circ}$ $07^{\prime}$, longitude $130^{\circ} 03^{\prime}$. Local name, published by the Coast Survey in 1901. Moser, 1901, wrote Johuson arm or inlet.

Johnson, river; see Yentna.

Johnson; river, tributary to Tanana irer from the soutl, near latitude $64^{\circ}$. Discovered and named by Allen, 1885, after Peder Johnson, a Sweçish miner, member of his party, of whom he speaks in high praise.

Johnsons, point; see Jobnstone.

Johnston; channel, eastern side of Herendeen bay, Alaska peninsula, near longitude $160^{\circ} 46^{\prime}$. So named by 'Tanner, 1899, after Ensign. Marbury Johnston, U. S. N., the officer of his ship who surveyed it.

Johnston; creek, in the St. Elias region, southern Alaska, 18 miles east of Cape Yaktag; erroneously Johnson. Named after Richard C. Johnston, who discovered petroleum in the Yaktag region, and one of the first to locate claims. Reported by Martin in 1903.

Johnston; creek, tributary to Feather river from the east, Seward peninsula. Name from Barnard, 1900.

Johnston; creek, Seward peninsula, tributary to Kaviruk river from the north, near latitude $65^{\circ} 25^{\prime}$, longitude $165^{\circ} 10^{\prime}$. Prospectors' name, obtained by Gerdine, 1901.

Johnston; hill, near the mouth of Naknek river, Bristol bay. Named Johnsston's by the Fish Commission in 1890 .

Johnstone; passage, separating Khantaak island from the mainland, Yakutat bay, southeastern Alaska. Named by Dall, 1879, after Master James Johnstone, R. N., one of Vancouver's officers.

Bull. 299-06 $\mathrm{M}-22$ 
Johnstone; point, on the northern shore of Hinchinbrook island, Prince William sound. Named by Davidson, in 1868, presumably after Master James Johnstone, R. N., of Vancouver's party, 1790-1795. Erroneously Johnsons and Johnston.

John's Village. The Yukon map, sheet 10, published at Ottawa in 1898, gives this name to a village on the upper Yukon near Eagle. It is Johnnie's village of Schwatka in 1883 .

Tolly; gulch, in the Copper River region, at the headwaters of Chititu creek. Prospector's' name, reported by Mendenhall, 1903.

Jones; creek, Seward peninsula, tributary on east bank Solomon river, near latitude $64^{\circ} 42^{\prime}$, longitude $164^{\circ} 16^{\prime}$. Prospectors' name, from a local map, 1904.

Jones; islands, on the Arctic coast, a little east of Colville river. Discovered and named by Dease and Simpson, 1837, after "Rev. David T. Jones, the faithful and eloquent minister at Red River." Renamed Thetis by Stockton, who, in 1.889, made a cruise along this coast in the U. S. S. Thetis.

Jones; river, tributary to the Kuskokwim from the right, near latitude $62^{\circ} 30^{\prime}$, longitude $154^{\circ}$. Named by Ferron, 1899, after Private Sam Jones, U. S. A., one of his party.

Jones, river; see Yahtse.

Jorosa; creek, 15 miles north of Nome, Seward peninsula, tributary from the north through Bangor creek to Snake river, near longitude $165^{\circ} 28^{\prime}$. Local name from Gerdine, 1904. Has been called Go!d creek.

Joseph; creek, and village at its moutb-creek tributary to Middle fork Fortymile creek from the north, near latitude $64^{\circ} 25^{\prime}$, longitude $143^{\circ} 10^{\prime}$. Prospectors' name, reported by Gerdine, 1903.

Josephine; gulch, 10 miles northeast of Nome, Seward peninsula, at the head of Buster creek, an east fork of Nome river, near longitude $165^{\circ} 11^{\prime}$. Local name, from Gerdine, 1904.

Jounakh, islet; see Unak.

Jualin; post-office (established in 1901), on east shore Lynn canal, near latitude $59^{\circ}$.

Jude; island (100 feet bigh), west of Unga, Shumagin group. 'Named by the Russians after the apostle.

Judy; hill (631 feet high), in the eastern. part of Gravina island, Alexander archipelago. So named by Clover, 1885 .

Jug; island, in Kalsin bay, Chiniak bay, Kodiak. Named Kubieshka (jug) by Russian naval officers, 1808-1810.

Jug; island, in the sonthern part of the Necker group, Sitka sound, Alexander archipelago. Named Kubieshka (jug) by Vasilief, 1809.

Jukchana, river'; see Yukon.

Jule-nog-a-mute, Eskimo village; see Julnok.

Julnok; Eskimo village, southwestern Alaska, on left bank of Chulitna river, 119 miles above its junction with the Kuskokwim, near longitude $157^{\circ}$. Native name written Jule-nog-a-mute on an unpublished map drawn by W. R. Buckman, a prospector, who wintered 40 miles above in 1902-3.

Jumbo; island, in Hetta inlet, southwestern coast Prince of Wales island, Alexander archipelago, near latitude $55^{\circ} 15^{\prime}$, longitude $132^{\circ} 40^{\prime}$. Local name, reported by Dickins, 1905. Called Deer island on Coast Survey chart 8100, 1904. 
Jumbo; mountain (Mount Jumbo), on the eastern shore, near the head of Hettal inlet, southwestern coast of Prince of Wales island, Alexander archipelago, near latitude $55^{\circ} 15^{\prime}$, longitude $132^{\circ} 35^{\prime}$. Local name, reported by Wright, 1905 .

Jumbo; mountain (3,333 feet high), on Douglas island, Alexander archipelago, about 2 miles south of Douglas. Local name, from Peters, 1902.

Jump; creek, Seward peninsula, tributary from the west to Candle creek, near latitude $65^{\circ} 52^{\prime}$, longitude $162^{\circ}$. Prospector's' name, obtained by Witherspoon, 1903.

Jumpoff; creek, in the Birch Creek region, tributary to Birch or to Grooked creek from the left, neir latitude $65^{\circ} 40^{\prime}$, longitude $144^{\circ} 30^{\prime}$. Prospectors' name, written also Jump Off. This may be the same as Quartz creek.

Juna, river ; see Yuison:

Junaska, island; see Yunaska.

June; creek, Seward peninsula, tributary from the west to Pannell river, near latitude $65^{\circ} 50^{\prime}$, longitude $163^{\circ} 05^{\prime}$. Prospector's' same obtained by Witherspoon, 1903.

Juneau; city, harbor, and island, southeastern Alaska, near latitude $58^{\circ} 18^{\prime}$, longitude $134^{\circ} 24^{\prime}$. " 'Two prospectors, Harris and Juneau, found mineral here, in 1.880 , and soon afterwards a camp was located." This camp, it is said, was named Harrisburg and the district Juneau. United States naval ofticer's reconnoitered the harbor about this time, and called the camp Rockwell, after Commander Charles H. Rockwell, U. S. N. Owing to the resulting confusion in names, the residents beld a town meeting and adopted the name Juneau. A post-ofice, called Juneau, was established here in April, 1881, and the town incorporater June 29, 1900. Population in $1899,1,253$; in $1900,1,864$.

Juneau; creek, tributary from the north to Kenai river, Kenai peninsula, near longitude $150^{\circ}$. Local name, from Mendenhall, 1898.

Juneau, creek; see Junior.

Juneau; creek, tributary to Walker fork Fortymile creek from the left, near latitude $64^{\circ}$, longitude $141^{\circ} 20^{\prime}$. Prospectors' name, taken from map in Coast Survey archives drawn by E. F. Ball, a prospector, 1898.

Juneau; island, in Gastineau channel, Alexander archipelago, 2 miles southeast of Juneau. Local name, from Peters, 1902.

Juneau; mountain (3,590 feet high), 1 mile north of Juneau, southeastern Alaska. Local name, obtained by Peters, 1902.

Junior; creek, tributary to Mills creek from the east, Kenai peninsula. Local .name from Becker, 1895. Moffit, 1904, salys this is an error: and should be Juneau.

Juno; mountain, in the western part of Revillagigedo island, Alexander archipelago. So named by Nichols, 1883.

Just; island, at entrance to Willard inlet, northeast of Dixon entrance. Name published by the Coast Survey in 1899.

Jute; bay, indenting the south shore of Alaska peninsula, 12 miles southwest of Cold Bay, near latitude $57^{\circ} 35^{\prime}$. Prospectors' name, reported by Martin, 1903.

Jute; -island, in the entrance to Cold bay, south shore Alaska peninsula. Prospectors' name, reported by Martin, 1004 .

Kaat1; river; tributary to Chilkat.river from the east. Native nime, reported by United States naval`ofticers, 1880. 
Kabakof; bay, indenting the southern coast of Atka, middle Aleutians. So named by the Russian-American Company's pilot Ingeustrem, about 1830.

Kabhalcher, cape; see Kaphalsek.

Kabuch; point, the southwesternmost point of Alaska peninsula, near latitude $54^{\circ} 49^{\prime}$, longitude $163^{\circ} 20^{\prime}$. Called Khaboutcha by Lutke, 1835, and Khabuch by Tebenkof, 1849. Apparently a native name. It is probably identical with Alaska cape of Billings, 1790.

Kabugachly, cape; see Kubugakli.

Kachel, island; see Middleton.

Kachel, island; see Katiuchali.

Kachemak; bay, indenting the eastern shore of Cook inlet, near latitude $59^{\circ}$ $30^{\prime}$, longitude $152^{\circ}$. It is Chugachik or Kachekmak of the Russians. Tikhmenief has Kachetmakskaia. Grewingk has Kotschekmaksky, and it has been often written Kachekmak, Katchemak, and Highcliff. According to Dall, ka means water, chek means cliff, and mak is an intensive suffix meaning high, great, large; translated it is Highcliff bay.

Kachiginskaia, bay ; see Kashega.

Kachkahin, river'; see Chilkoot.

Kach-khanna, island; see Wrangell.

Kadiak, bay; see Camp Coogan.

Kadiak, island, town, rock, etc. ; see Kodiak.

Kadin; island, on the southern edge of the Stikine flats, Sumner strait, Alexander archipelago. Named by the Russian surveying party on the Rynda, in 1863, "after the veteran pilot, M. M. Kadin, a native of the Aleutian islands, and who drew, at Sitka; the charts contained in Tebenkof's atlas."

Kadischle, glacier; see Norris.

Kalugin, islands; see Pavlof.

Kadugnal, cape; see Kudugnak.

Kaeulhuk; slough, Ukon delta, connecting Apoon pass and Okwega pass, less than 2 miles below their junction, near latitude $63^{\circ} 03^{\prime}$, longitude $163^{\circ}$ 37'. Eskimo name, so written by Faris, 1899.

Kaflia; bay, next soutbwest of Kukak bay, on the north shore of Shelikof strait. Named Kaflia (Dutch tile) by Vasilief in 1831. Lutke, 1835, wrote it Kafla. The native name is said to be Kokhia.

Kagai, island; one of the Shumagin group, which one not determined, was so called by Sarichef.

Kagak Unimak, islet; see Chernabura.

Kagalaska; island, immediately east of Adak island, Andreanof group, middle Aleutians. Lutke calls it Kagalaska, but 'Tebenkof and the Russian Hydrographic charts have Kagalaksa.

Kagalga, island; see Tigalda.

Kagalogh, point, St. George island; 'see Tolstoi.

Kagalus; cape, the southeastern point of Chugul island, near Great. Sitkin, Andreanof group, middle Aleutians. Perhaps a native name; from Tebenkof, 1849. Has also been wrịtten Kagalis.

Kagamil; volcanic island, one of the group of islands of the Four Mountains. Native name, from Sarichef, about 1790 . Has been variously written Chagamil, Khogamil, Kigamil, etc. Veniaminof calls it Kagamiliak, Several mummies in the Smithsonian Institution came from this island.

Kagata, lake; see Amanka. 
Kaghkaghamute, Eskimo village; see Kokok.

Kagigikak; cape, on the southern side of Adak island, Andreanof group, middle Aleutians. Aleut nitme from 'Tebenkof, 1849. Has been written Kagigikbnach.

Kagigun, islands; see Shumagin.

Kaguyak; bay, indenting the southern shore of Kodiak, immediately west of Two Feaded island. Called Alsentia bay by the Fish Commission in 1888.

Kaguyak; village, at Kaguyak bay, on the south shore of Kodiak. Native name, published by Petrof in the Tenth Census, 1880, where it is spelled Kaguiak. It may be identical with the Kaniag-miut of the RussianAmerican Company, in 1849. In 1868, the Const Survey published the name Alsentia for this village. Of the origin of this no trace has been found.

Kaguyak; village, on Svikshak baj, Shelikof strait, about 25 miles southwest of Cape Douglas. Lutke, 1835, salys (nautical part, p. 275), "Kaiayak river and Kaiayakak village in Svikhchak golfe. The Russians wrongly call this village Naouchkak." The bay was called Noakchak on manuscript map of the Western Union Telegraph expedition, 1867. Tebenkof, 1849, has Kaiaiak settlement, which has on many charts appeared as Kayayak. Prior to 1884 the Coast Survey charts had Kayayak, but since that date Kaguyak. The change appears to have been accidental and unfortunate, there being a Kaguyak on the southwest shore of Kodiak island. In the Eleventh Census, 1890, the vlllage is called Douglass, after Cape Douglas. Kaguyak seems to be the proper name for what is sometimes called Alsentia, on the southwest shore of Kodiak.

Ka-Hehe; salmon stream, on the western coast of Prince of Wales archipelago, in the vicinity of Tuxekan. So described by Moser, 1897. It may be the same as Sarhini, which see.

Kah-lu-look-ta-ark, lake; see Walker.

Kahltog, village; see Kaltag.

Kah Shakes; cove, in Revillagigedo channel, near the southern point of entrance to Boca de Quadra, southeastern Alaska. So named from Kah Shakes, the chief of an Indian village situated at the northern point of entrance.

- Kah Shakes; lake, lagoon, and stream. The lagoon extends 11 miles in an easterly direction from the northeastern end of Kah Shakes cove above, and receives at its head the waters of the stream which is the outlet of the la7ie. Written Kah-Shakes by Moser, 1901.

Kah Shakes; point, the southern point of entrance to Boca de Quadra, Revillagigedo channel, southeastern Alaska, near latitude $55^{\circ} 04^{\prime}$, Iongitude $131^{\circ}$. So applied by local navigators and reported by Fassett, Bureau of Fisheries, 1904.

Kah Shakes; Indian village "of half a dozen houses" on Kah Shakes cove, southeast Alaska. The Tenth Census, 1880, has two settlements on Itolin island, called Kash's village and Shake's village, population 49 and 38 , respectively. Evidently there is some confusion as to names here.

Kah Sheets; bay, indenting the southeastern shore of Kupreanof island, Sumner strait, Alexander archipelago, at entrance to Duncan canal, near latitude $56^{\circ} 30^{\prime}$, longitude $133^{\circ} 06^{\prime}$. Locil navigator's' name, reported by Fassett, Bureau of Fisheries, 1904. 
Kah Sheets; salmon stream and lake, southern shore Kupreanof island, Alexander archipelago, tributary to Kah Sheets bay (above). So called by the fisheries, probably after the Indian who claims the stream. Reported and written Kah-Sheets by Moser, 1897.

Kahsitsnah; bay, indenting the southern shore of Kachemak bay, Cook inlet. Native name, published by the Coast Survey in 1883.

Kahuntla; lake, on the west side of Katalla bay, near Controller bay, Gulf of Alaska, about longitude $144^{\circ} 30^{\prime}$. Native name, reported by Martin, 1903.

Kahurnoi, cape; see Kekurnoi.

I tiaiak, village; see Kaguyak.

Kaiakak; native village, on right bank of Yukon river, a little below Nulato. So called by Petrof, in 1880 , who reported a population of 124 at that date.

Kaiakishvig-miut, village; see Utukok.

Kaialik; Eskimo village, in the Yukon delta northeast of Hazen bay. Visited by Nelson in December, 1878 , who reports its name as Kaialigumiut, i. e., Kaialik people. Population in 1880 , 100; in 1890, 157. The Eleventh Census calls it Kailwigamiut (p. 164) and Kialigamiut, i, e.. people of Kialit mountains (p. 110). Jarvis, there in 1897, writes Kiyilieugamute.

Kaianak; cape, the western head of Vulcan cove, on south shore of Akutan island, Krenitzin group, eastern Aleutians. So called by Tebenkof, 1849. The Fish Commission, in 1888, called this South Head. Possibly this point is the Battery point of Veniaminof. See Battery.

Kaiashik, island; see Round.

Katashit, islands; see Walrus.

Ka aiasik; one of the Shumagins, not identified. Native name from Veniaminof, who says it is high and rocky. Lutke writes it Kassik.

Kaichali, island; see Kaiuchali.

Kai-gah-nee, strait; see Dixon entrance.

Kaigan; portage, between the heads of Cholmondeley sound, Moira sound, and Tliakaek bay, Prince of Wales island, Alexander archipelago. Called Kaigantsef on Russian Hydrographic chart 1493, and Kaigan by Dall in the Coast Pilot $(1883$, p. 85$)$. It is doubtful whether it exists as described.

Kaigani, cape; see Muzon.

Kaigani; harbors, South, Middle; and North, in Dall island, opening into Kaigani strait, near Dixon entrance, Alexander archipelago. So called by Etolin in 1833. Presumably a native name, often or generally written Kaigahnee. South Kaigani harbor was known, in 1799, as Taddiskey, a native name, or Taddy's core, a corruption of the former. Kaigani; point, the southern point of Long island, Cordova bay, Dixon entrance. Named Iuzhnoi (south) by Tebenkof, 1848. Has also been called Kaigan and U\%hnoi.

Kaigani; strait, the southern part of the strait between Long island and Dall island, Cordova bay, Dixon entrance. Native name, reported by Etolin, 1833, as Kaigan. Variously called Kaigahnee, Kaigan, Kaijani, etc.

Kaigani; village of Haida Indians, at Cape Muzon, Dixon entrance, Alexander archipelago.

Kailnvigamiut, village; see Kaialik.

Kaisana, island; see Kasiana. 
Kaiuchali; island, one of the Necker group, Sitka sound, Alexander archipelago. Apparently a native name, from Vasilief in 1809 . Has also been written Kaichali. Apparently a corruption of the Russian kachel, from kachat, to swing, rock, roll.

Kaiugnak; bay, west of Sitkalidak island, on the southern coast of Kodiak. So called by Tebenkof, 1849. Perhaps frrom the Aleut word kayuk, meaning berry.

Kainlik, bay; see Kujulik.

Kai-vik, river; see Ophir creek.

Kaiyuh; mountains, in western Alaska, between Innoko and Yukon rivers. Native name, from the names of a tribe of. Indians living in the region.

Kaiyuh, river; see Kaiyuh slough.

Kaiguh; șlough, on the left bank of Yukon river extending from 15 miles below to 60 miles below Nulato. Called Kaiyuh river on most majs. Tikbmenief, 1861, called it Kutulnakt. Dall (1866) has Káiyuh, and Raymond (1869) Kayuh for the mountains and Kaiyuh for the river. Rev. Julius Jettê, of Nulato, writes the name of the mountains Kayařthe letter r representing the guttural kh (Kayakh) and says that the river, so called, is properly a slough of the Yukon as above described, which receives an affluent river from the Kaiyuh region. This affuent, together with the part of the slough below its mouth, the Indians call Khotolno, i. e., Khotol river. The slough is here called Kaiyuh and the river Khotol. See Khotol river.

Kai-yılkh-pal-ik, island; see Kiukpalik.

kajulik, river; see Kejulik.

Kak; islet, at entrance to Chignik bay, Alaska peninsula. The native name, according to Tebenkof, is Kak or Kakh, which has also been written Katch. By the Coast Survey, 1875, is was called Rocky island.

liakagin, inlet; see Basket.

Kakachtoli; slough or pass, Yukon delta, one of the outlets of: Kwiguk pass on the north, near latitude $62^{\circ} 50^{\prime}$, longitude $164^{\circ} 46^{\prime}$. Eskimo name reported by Putman, 1899.

Kakanhini; river, southeastern coast of Alaska, on the west side of Dry bay, near longitude $138^{\circ} 40^{\prime}$. 'Tebenkof, 184', represented it as the most westerly of the 5 outlets of Alsek river, and wrote the Indian name Kakangina or Kakanhini (Kakan river). Moser, who made a reconnaissance here in 1901, found the Alsek to have only 3 brond outlets, and just west of these the Ko-kon-hee-ni (Stickleback), an outlet of Us-tay river. See also Dry bay.

Kakani; lake, immediately behind the beach in the St. Elias alpine region, between the Alsek delta and Yakutat bay. So called by Tebenkof, 1849. Apparently a native name. It is near Kakanhini river.

Kakat. This is an Indian word used in the interior of Alaska, and written variously, kakat, kaket, kargut, chargut, kaget, and chaget. It means mouth of a river and is found suffixed to many Indian names of rivers, especially those tributary to the great highways of travel, the Yukon, Tanana, and Koyukuk. Thus we have:

Batzakakat $=$ mouth of the Batza river.

Coskakat = mouth of the Cos (Cosna) river.

Daklikakat $=$ mouth of the Dakli river.

Flogatzakakat $=$ mouth of the Hogatza river.

Hosiakakat = mouth of the Hosia (Hosiana) river.

Husliakakat $=$ mouth of the Huslia river. 
Kakat-Continued.

Khotolkakat $=$ mouth of the Khotol river.

Tozikakat . = mouth of the Tozi river.

These, to the Indians, were names of localities and landmarks on the great rivers, but were often taken by explorers to be the names of the ricers themselves. The Indians called the rivers Cos-na, Hosia-ña, Khotol-no, the word na, no, or nu meaning river, and some names bave come down to us in both forms. It has been thought best in nearly all cases to drop the termination kakat and write Batza river, Huslia river, etc. The termination na has been omitted from some very long names, though in gerieral it has been retained.

Kakati; lake, on north bank of Stikine river, opposite mouth of Katete river, southeastern Alaska. Native name, reported by Hunter, 1877, as Kahkahtoi.

Kakatkusik, cape; see Sarichef.

Kake; post-office (established in 1904), northwestern part of Kupreanof island, Alexander archipèlago.

Kake, strait; see Kelsu.

Kake; village, in the northwestern part of. Kupreanof island, Alexander archipelago. It is the principal village of the so-called Kake Indians. Keliu (islands and strait) is apparently only another form of this same name. Meade, 1869, says the Indians bere are called the Kakes, Kekis, or Kehons, the terms being indifferently applied.

Kakhtul; river, west of Iliamna lake, tributary to Mulchatna river from the east, near latitude $60^{\circ}$, longitude $156^{\circ} 30^{\prime}$. Native name. Selanz, 1890, wrote Kokhtuli (Forest) river; while on the Census map, 1893, Kaklutut appeared. The Coast Survey, 1898, published Kabktut, and Osgood, in 1902, wrote Kakbtul.

Kalchvalga; island; see Kavalga.

Kallhvegina, stream; see Kakvi.

Kakidaguk; cape, the western point of entrance to Morzhovi bay, near west end of Alaska peninsula. According to Lutke it was called Kakhidagouk by Kudiakof in or about 1791 . Obviously this is the native name.

Kakka, village; see Makak.

Kakliaklia; native village, on right bank of the Koyukuk, at mouth of the Sukloseanti river. Name from Tikhmenief, 1861, who wrote it Kakliakliakakat, i. e., mouth of Kakliaklia river. Not found on recent maps.' '

Kaknu, lake; see Skilak.

Kaknu, river; see Kenai.

Kakogkakat, creek; see Medicine.

Kakovo; islet, in Whale bay, Baranof bay, Alexander archipelago. So named by the Russians as early as $\mathbf{1 8 5 0}$.

Kakuak; Eskimo village and river, on right bank of Nushagak river, about 60 miles above its mouth. Native name, from Petrof, 1880. On recent maps written Kakwok. Schanz, 1890, speaks of the Kakwok river at this place.

Kakuktahuk; 'pass, Yukon delta, opening into Apoon pass from the north, near latitude $63^{\circ} 05^{\prime}$, longitude $163^{\circ} 40^{\prime}$. Eskimo name, reported by Faris, 1899.

Kakul; narrows, the contracted part of Peril strait near its western end. So named by Moore, 1897. 
Kakul; point, between Fish bay and Neva strait, in eastern part of Salisbury sound, Alexander archipelago. So called by the Russians. Perhaps derived from Kekur. See Kekur.

Kakul; rock, Salisbury sound, three-eighths mile southwest of Point Kakul, the south point at western entrance to Peril strait, Alexander archipelago, near latitude $57^{\circ} 22^{\prime}$, longitude $135^{\circ} 42^{\prime}$. So nanied by Moore, 1896 .

Kakvi; glacial stream, in the Fairweather range, debouching a few miles north of Lituya bay. Tebenkof, 1849, on his chart 7, calls this Kakhvegina, and on his chart 8 Katagina. The word is apparently of Indian origin, the termination gina or hini meaning river.

Kakwan; point, on the northern bank of Stikine river, near Popof glacier. Native name, from Hunter, 1877.

Kakwok; see Kakuak.

Kalabri, islet; see Kalibri.

Kalchagamut, village; see Kaltshak.

Kal-e-gu-ri-che-ark, river; see Kaliguricheark and Reed creek.

Kalekta; bay, indenting the eastern shore of Unalaska, between Beaver and Unalaska bays, near latitude $54^{\circ}$, longitude $1.66^{\circ} 20^{\prime}$. Aleut name, from Sarichef, 1790. Also has been written Kalekhta, Kalekbtak, and Kaleakhta.

Kalekta; cape or promontory (500 feet high), on the eastern shore of Unalaska, between Unalaska and Kalekta bays. Aleut name, from Sarichef, 1790. Veniaminof also calls it Kalekta, but Lutke says the natives call it Igognak. The Fish Commission has called it Priest point.

Kalekta. Native village on Kalekta bay, Unalaska; was found by Sarichef, in 1790, and shown on his chart. Veniaminof describes it (about 1825) as composed of 3 huts (yourts) and 14 people. Not now in existence.

Kalga, cape; see South.

Kalgin; island, near the head of Cook inlet. Apparently a native name, reported by Wosnesenski about 1840. In Galiano's atlas, 1802, it is called Isla del Peligro (danger island). On a Russian map of 1802 it is called Kulgiak.

Kaliada, bay ; see Kiliuda.

Kaliakh; river, falling into the Gulf of Alaska, 20 miles west of Cape Yaktag, near longitude $143^{\circ}$. Probably it is the one lettered "small river" in Vancouver's atlas, 1798. Native name, from Tebenkof, 1849. Davidson, 1869 (Coast Pilot, p. 143), wrote Kaliekh. Martin, 1904, reports that J. L. McPherson, deputy mineral surveyor, wrote the Indian name of this stream Cultheeth; pronounced Kul-thee-é'th, or, as we would write it, Kúltbieth.

Kalialiaktna, river ; see Sukosleanti.

Kalibri; islet, at junction of Sukoi strait and Krestof sound, Alexander archipelago. So called by Vasilief, 1833. Apparently identical with Goloi (bare) island of Vasilief, 1899. Also written Kalabri.

Kalidge, point; see Collie.

Kaligagan; islet, one of the Krenitzin group, in Ugamak strait, between Tigalda and Ugamak, eastern Aleutians, near longitude $164^{\circ}$ 55'. Native name, from Tebenkof. The Fish Commission, 1888, called it Sealion.

Kalignak; native village, on one of the western tributaries of the Nushagak river. Eskimo name, from Petrof, 1880.

Kaliguricheark; river, northwestern Alaska, tributary to Kobuk river from the north, near longitude $159^{\circ} 15^{\prime}$. Eskimo name, written Kal-e-gu-ri-cheark by Stoney, 1886, but given by him to what is here called Reed creek. Written and located as above by Mendenhall, 1901. 
Kalik; river, Seward peninsula, flowing into the Arctic ocem, near longitude $164^{\circ} 50^{\prime}$. Eskimo name, obtained by Gerdine, 1901.

Kalinin; bay, indenting the northern shore of Kruzof island, Salisbury sound, Alexander archipelago. Named Kalinina (Kalinin's) by Vasilief, 1833, doubtless after Kalinin, pilot of the Russian ship Neva, who, with 34 others, was drowned January 9, 1813, near Mount Edgecumbe in the wreck of the Neva:

Kalinin; point, Salisbury sound, Alexander archipelago, the west point at entrance to Kalinin bay (above). Named Kalinina by Moore in 1.896 .

Kaliukluk; Eskimo village, on Nelson island, near Cape Vancouver, Bering sea. Visited by Nelson, December, 187S, and its nome reported by him as Kaliokhlogamute, i. e., Kaliukluk people.

Kalivinaguk; channel, connecting Baird inlet with Etolin strait and separating Nelson island from the mainland, Bering sea. Eskimo name, from Nelson, who crossed it December, 1878.

Kalla; native village, on the Kobuk, near latitude $66^{\circ} 50^{\prime}$, longitude $156^{\circ} 30^{\prime}$. Visited by Stoney, 1885, who wrote its name Kallamute.

K̇al-la-gu-nick, river, branch of the Kobuk; see Salmon.

Kal-lu-look-to-ark, lake; see Walker.

Kalsin; bay, in the soutbwestern part of Chiniak bay, Kodiak. Named Kalsinskaia by Russian naval ofticers, 1808-1810.

Kalsin; island, in Kalsin bay, Chiniak bay, Kodiak. Named Kalsinskoi by Russian naval officers, $1808-1810$.

Kalsin; reef, in Chiniak bay, Kodiak. Named by Russian naval officers in 1808-1810. It is Kalisin of the Coast Survey in 1869.

Kaltag; range of mountains, on the northern bank of the Yukon, between Nulato and the coast. So called by Petrof, 1880.

Kaltag; portage, over the Kaltag mountains, between the headwaters of the Unalaklik river and the Yukon. So called in Reindeer Report, 1900, p. 53.

Kaltag; river, tributary to the Yukon from the northwest, 35 miles below Nulato, near latitude $64^{\circ} 10^{\prime}$, longitude $158^{\circ} 40^{\prime}$. Probably local name. Reported by Cantwell in 1900 as Kaltag river, and apparently also as Rotokakat river.

Kaltag; telegraph station, on the Yukon, 40 miles below Nulato. So named by the Signal Corps, U. S. A., 1903.

Kaltag; native village, telegraph station, landing, and trading post, on the Xukon 40 miles below Nuląto. It is important as the river terminus of the winter trail between St. Michael and the Yukon valley, and as the point where the military telegraph line to St. Michael leaves Yukon river. Called Kaltág by the Russians. Petrof, 1880, shows two villages on the right bank, called Lower Kaltag and Upper Kaltag. Tikhmenief, 1861, writes it Kkhaltel ; and Raymond, 1869, Kahltog. Allen, 1885, speaks of "Kháltat's village, on an island in the middle of the river;" and Zane, of Stoney's expedition, 1886, speaks of a native living 34 miles below Nulato named Kaltaga.

Kalthagamute, village; see Kaltshak.

Kaltkhagamute, village; see Kaltshak.

Kaltshak; Eskimo village, on the right bank of the Kuskokwim, near longitude $161^{\circ}$. Eskimo name, reported by Petrof, 1880, as Kalthagamute and Kaltkhagamute, and by Spurr and Post as Kaltshagamut, i. e., Kaltshak people. 
Kaluiak; native village, on the southern shore of Chignik bay, Alaska peninsula. So given by Petrof, 1880, and the Fish Commission, 1888. The census of 1890 reports the only village existing in this locality to be oue on Mitrofania island. No name is applied to it.

Kalwatta; Indian village, on east side of Chilkat river, 5 miles below Klukwan. Native name, said to mean place of gulls, published Katkwaltu by the Const Survey in 1898.

Kamachi; point, the northern point of entrance to Wrangell harbor, Alexander archipelago. Apparently a native name, reported by Zarembo in 1834 . It appears on Zarembo's sketch on Russian Hydrographic chart 1396. Has also been called Point Hafuache.

Kamchatka, Sen of; see Bering.

Kame; glacial stream, debouching on the northwestern shore of Yakutat bay, southeastem Alaska. So named by Russell, 1891.

Kamegli; Eskimo village, on the right bank of Kuskokwim river, about 10 miles above Bethel. Its native name, according to Spurr and Post, who obtained it from missionary J. H. Kilbuck, 1898, is Kameglimut, i. e.. Kamegli people.

Kamenaia; peak, north of Silver bay, Baranof island, Alexander archipelago. Named Kamennaia (rocky) by the Russians.

Kamenistaia, bay; see Necker.

Kamenistic. This is the Russian adjective for stoney, covered with stones, from kamen (a stone or rock.) This word spelled Kamminista and Kamninista, is applied to a 'spot on St. Paul island, Pribilof group, Bering sea. Elliott, 1874, has Kamminista, Russian for rocky place.

Tamenistie, islets; see Rocky.

Kamenistie, point; see Rock.

Kamenoi; island, south of Middle island, Sitka sound, Alexander archipelago. Named Kamennoi (stony) by Vasilief, 1809.

Kamenoi; point, on the eastern shore of Kruzof island, in the northernmost part of Sitka sound, Alexander archipelago. Named Kamennoi (rocky) by Vasilief in 1809. Variously written Kamenni, Kamennie, Kamennoi, Kamenoi, Rock, and Rocky.

Kamerchluk; slough, Yukon delta, opening on the left bank of Apoon pass, near latitude $62^{\circ} 57^{\prime}$, longitude $163^{\circ} 47^{\prime}$. Eskimo name, obtained by Faris, 1899.

Kamieshatskoi, cape; see Douglas.

Kamishak; bay, in the southwestern part of Cook inlet, latitude $59^{\circ}$ to $60^{\circ}$. Native name, reported by the early Russians and variously spelled Kamiskuk, Kamieshatskaia, Kamiischatskaja, Kamychatskoi, Kamyshak, etc. Davidson, 1869, described it as limited on the north by Augustine island. The name is now generally applied to the whole bight in the middle of which Augustine island is situated. See also Bourdieus.

Kamishak, ișland ; see Shaw.

Kamishak; river, tributary to Kamishak bay, Cook inlet. Native name, reported by the early Russians.

Kamminista; see Kamenistie.

Kamvik, bay, on the southeast coast of Alaska peninsula, Shelikof strait, between Katmai bay and Cold bay. Name given Martin, 1904, by Nikolai Kalmakof of Katmai. It may be an error in transliterating Kashvik from the Russian. See Kashvik.

Kamyshak, bay; see Kamishak. 
Kanaga; island (1,392 feet high), one of the principal islands of the Andreanof group, middle Aleutians. Aleut name, from early Russian explorers. Probably identical with Kanaton island of Cook. Has also been written Konega and Konniaga.

Kanagunut; island, near Tongass harbor, Dixon entrance, Alexander archipelago. Native name, from Davidson, 1869, who wrote it Kan-na-gluu. nut. Also erroneously Kannagkhunut.

Kanak; island, in Controller bay, east of the mouth of Copper river. Native name, published by Tebenkof, 1849 .

Kanakalinguk; slough, Yukon delta, opening on the right bank of $x$ poon pass at Bill Moores or Konogkelyokamiut, near latitude $62^{\circ} 57^{\prime}$, longiturle $163^{\circ} 46^{\prime}$. Eskimo name published by the Coast Survey in 1509 as Konogtinok, and in 1901, as Kanakalinguk.

Kanakanak; Eskimo village, in the Nushagak enumeration district of the Eleventh Census, 1890; population, 53. Written also Kanaknek. According to Moser, 1897 , it is located just below the mouth of Wood river, on the west shore of Nushagak bay, and called also Chogiung.

Kanalku; bay, in Kootznahoo inlet, at the head of the middle arm, Admiralty island, Alexander archipelago. Native name, given by the Coast Survey, 1891, as Kanalkoo.

- Kanama, gulch; see Káanoma.

Kanata, cape and village; see Kanatak.

Kanata; river, the north fork of the Tiekel, northeast of Port Valdez, Prince William sound. Native name, from Rohñ, 1898.

Kanatak, bay; see Portage.

Kanatak; cape, between Portage bay and Cold bay, on the northern shore of Shelikof strait. Aleut name, from the Russians, supposed to mean snowy. Has been written Kanalak, Kanatah; and Kanata.

Kanatak; native village, at the head of 'Portage bay on the south side of Alaska peninsula, about latitude $57^{\circ} 30^{\prime}$, longitude $155^{\circ} 45^{\prime}$. Native name. reported by Osgood in 1902. Martin, 1903, says the local prounciation is Kanáta.

Kanaton, island; see Kanaga.

Kanauguk; river, near York, in western part of Seward peninsula. Native name, from Brooks, 1900, who wrote it Kanaugok.

Kandik; river, tributary to the Yukon from the north, near Iongitude $142^{\circ} 30^{\prime}$. Indian name reported by Spurr, Goodrich, and Schrader in 1896. Locally known as Charley creek. Charley village (Indian) is at or near its mouth.

Kane; islands, in the northern part of Neva strait, Alexander archipelago. Named, apparently by the Russians, after Captain Kane, an Americen pioneer trader on this coast at the beginning of the nineteenth century. Have also been called Kan islets.

Kane; peak (3,292 feet high), on Lindenberg peninsula, Kupreanof island, Alexander archipelago. Named by Thomas, 1887, presumably after the arctic explorer Elisha Kent Kane.

Kaneglilikamiut, Eskimo village; see Kanelik.

Kanektok; river, just south of the Kuskokwim river and tributary to Kuskokwim bay. According to Spurr, who uses Kanektok, its Eskimo name is Kwina or Kanètok (snowy).

Kanelik; pass or slough, Yukon delta, opening northeast from Kwemeluk slough to the northern part of Akularak pass, near latitude $62^{\circ} 30^{\prime}$, longitude $164^{\circ} 40^{\prime}$. Eskimo name, obtained by Putnam, 1899. Father Barnum, 1901 , wrote it Kănēlǐk. 
Kanelik; Eskimo village, Yukon delta, on the left bank of Kanelik pass, near latitude $62^{\circ} 34^{\prime}$, longitude $164^{\circ} 30^{\prime}$. Eskimo name, written by 1'utnam, 1899, Kanegklikamiut. Father Barnum, 1901, wrote Kănēlǐg'mēūt ; i. e., Kanelik. folks.

Kanewok, district; see York.

Kanga; bay, indenting the southeastern shore of Sitka sound, Baranof island, Alexander, archipelago. Name applied by Dall in the Coast r-ilot, $19 \$ 3$.

Kanga; islet, in the southeastern part of Sitka sound, Baranof island, Alexander archipelago. So named by Vasilief, 1809. It is an Asiatic name of the Mongolian gun.

Kangaiulouk, island ; see Spectacle.

Kangokakh; slough or pass, Yukon delta, one of the outlets of Kwiguk pass on the north, near latitude $62^{\circ} 50^{\prime}$, longitude $164^{\circ} 47^{\prime}$. Jiskimo name reported by Putuam, 1899. It is Kangokakh on Coast siuvey cluart 9370 , and Kangokakli on chart 9373, editions of i.90!.

Kóngusuk, river ; see Kvinguk.

Kaniat, bay; see Alitak.

Kaniek, river ; see Buckland.

Kaniek; small stream, tributary from the west to Kulukak bay, on north shore of Bristol bay. Native name, from 'Tebenkof, 1849.

Kanig-mfut, village; see Kaguyak.

Kanikluk; native village, on the northern shore of Prince William sound. Native name, reported by Fetrof, 1880, as Kanikhluk.

Kaniliak, island, one of the Shumagin group; which one not discovered. Name from Veniaminof and Lutke, who write it Khainiliakh.

Kaniugi, island; see Koniuji.

Kanoma; gulch, 7 miles north of Nome, Seward peninsula, at the head of Snow gulch, near longitude $165^{\circ} 23^{\prime}$. Local name, published in 1904 . Written also Kanama.

Kanoozhki, island ; see Koniuji.

Kanowock, mining district; see York.

Kantishna; post-office (established January, 1906), on the lower part of Kantishna river (below).

Kantishna; river, draining the north slope of Mount McKinley and tributary to Tanana river from the south, near longitude $150^{\circ}$. Recent maps differ by about one degree cf longitude in locating the confluence of this river with the Tanana. It is shown at about longitude $151^{\circ}$, where Allen, 1885, marked "Toclat," and near longitude $150^{\circ}$, as the river which Allen named Dugan. 'The weight of evidence supports the latter: contention. Herron, 1899, drew it into the Tanana, where Allen marked the "Toclat," and called it Toclat (Con-tay-th-no). He also wrote Con-tay-thno. Brooks, 1902, followed Herron and called it Toklat. Lieutenant Gibbs, U. S. A., 1902, and Reaburn, 1903, draw it to the Tanana, near longitude $150^{\circ}$, showing it to be the same which Allen called Dugan. Gibbs wrote Cantishna, and Reaburn, Kantishna. It is known as Kantishna river, Indian name, written also Cantishna, Cantisna, and Contaythno. A large east (pight) branch of the Kantishna, 60 miles up by steamboat, is known as Troklat river.

Kantukan; village of Hooniah Indians, Fooniah harbor, Port Frederick, Icy strait, Alexander archipelago. Name from the Coast Pilot (1883, p. 191), where it is written Kan-tu-kan. The post-office Hoonah was established here in 1901.

Kanuhnuktuili, slough; see Kanụnuk. 
Kanuktik; creek, tributary to Kanektok river from the southeast, about 60 miles above the mouth of the Kanektok, western Alaska. Native name, from Spurr and Post, of the Geological Survey, who passed its mouth September $4,1898$.

Kanulik; Eskimo village, near the mouth of Nushagak river, on left bank. Native name, from Petrof, 1880. Carmel mission and Nushagak postoffice are here.

Kanunuk; slough, Yukon delta, opening on the right bank of Apoon pass, a half mile above Kotlik, near latitude $63^{\circ} 02^{\prime}$, longitude $163^{\circ} 34^{\prime}$. Eskimo name, obtained by Faris, 1899, who wrote Kanubnuktuili.

Kanuti; village, and also a river tributary to the Koyukuk from the south, near the Arctic circle and longitude $153^{\circ}$. Native name, reported by Allen, 1.885, and by him wrịtten Konoótená, i. e., Kanuti river. This is old Man river of the prospectors.

Kaoechearl, river; see Kawichiark.

Kaoklovakamiat, Eskimo village; see Kwikluak.

Kaoledoly; slough, Yukon delta, a cut-off on the right bank between Kwikluak pass and Kwiguk pass, near latitude $62^{\circ} 45^{\prime}$, longitude $164^{\circ} 27^{\prime}$. Eskimo name, obtained by Putnam in 1899.

Kaoualita, island ; see Kaviatka.

Kaphalsek; cape, in Wrangell harbor, Alexander archipelago. Native name, reported by Zarembo, 1834, as Kap-khal-tsech. The name was published, in 1.848, on Zarembo's sketch of the harbor on Russian Hydrographic chart No. 1396. On United States Hydrographic chart 225, this point is called Kabhaicher.

Kapho; mountain (5,000 to 6,000 feet high), on the mainland, near head of Bradfield canal,. southeastern Alaska. Apparently a native name, obtained by Snow, 1886, and said to mean brothers.

Karablin, islet; see Ship.

Kąavaxarak, river; see Kaviavazak.

Kariltna; creek, tributary to Yentna river from the north, 20 miles below the Skwentna, near latitude $62^{\circ}$, longitude $150^{\circ} 45^{\prime}$. Indian name obtained by Ferron, 1899, who wrote it Car-ilt-nu, i. e., Karilt river.

Karlooch, village; see Karluk.

Karluk; cape, at mouth of Karluk river, on the northwestern shore of Kodiak. Native name, from the Russians. It is a precipitous mountain mass about 1,600 feet high, locally known as Karlnk head.

Karluk; lake or lakes, drained by the Karluk river, in the western part of Kodiak. Native name.

Karluk; reef, on the eastern shore of Cook inlet, between Kenai and Kasilof river mouths. Name published by the Coast Survey in 1900 .

Karluk; river, 30 miles long, draining Karluk lakes, in the western part of Kodiak. Native name.

Karluk; spit and lagoon, "a narrow shingle spit or bulkhead $* * *$ threefourths of a mile long" and the inclosed lagoon at the mouth of Karluk river, northwest coast of Kodiak. Local name, reported by Moser, 1897.

Karluk, strait; see Kupreanof. .

Karluk; village, at mouth of Karluk river, Kodiak. Native name, from the Russians. Lisianski, 1805, spells it Carlook and Karlooch. Shelikof, according to Coxe, called it Karluta. There are several canneries here, and the place is locally known as Karluk spit. A post-office called Karluk was established here in March, 1895.

Karlusi; rock, the largest of the Old Sitka rocks, Sitka sound, Alexander archipelago. So named by Vasilief in 1809. 
Kar-n'yer-nok, river; ; see Colville.

Karpa; island, the northeastermmost of the Shumagin group and at or near the entrance to Stepovak bay. Called Buldýr (hovel) by the Russians. The Aleut name is Inlikak, or, as Lutke writes it, Inglikbakh. Russian Hydrographic chart 1.379 (ed. of 1847 ) calls it Karpa (carp) island, while Tebenkof, 1849, calls it Tangimak. Tangik is the Aleut word for island and Tangidak for islet. Thus this island lias been called Boulder, Bouldyr (hovel), Inglikhakh, Iulíkak (perhaps from Ingliakun, whiskers), Karpa (carp) and Tangimak (islet?).

Karr; hills, back of Icy bay and near Mount St. Elias, southeastern Alaska. Named by Topham, 1888, presumably after Mr. Seton-Karr. Erroneously Carr.

Karson, creek, Seward penińsula ; see Kasson.

Karta; bay, at the heid of Kasaan bay, Prince of Wales island, Alexander archipelago. Called, in 1880, Kasaan anchorage (Coast Pilot, p. 85). Kasaan bay was then called Kartil, following the erroneous form on British Admiralty chart 2431. Later the charts adopted Kasaan for the large bay and retained Firta for this little bay at its head. Just east of it is the Baranovich fishery, the salmon fisliery of Philip Baranovich having been established here in about 1878 or earlier.

Kasuan, anchorage; see Karta bay.

Kasaan; bay, indenting the eastern shore of Irince of Wales island, Alexander archipelago, near latitude $55^{\circ} 30^{\prime}$, longitude $132^{\circ} 20^{\prime}$. Name of Indian origin, obtained by the Russians and variously written Casaan, Kasan, Kazarn, and even, by error, Karta.

Kasaan; peninsula, northeastern shore Prince of Wales island, separating Kalsaan bay from Clarence strait, Alexander archipelago. So named by Brooks, 1901.

Kasaan; point, the north point of entrance to Skowl arm of Kasaan bay, southeastern Alaska. So applied by local navigators, and reported by Fassett, Bureau of Fisheries, 1904.

Kasaan; post-office, on north shore of Kasaan bay, Prince of Wales island, Alexander archipelago; established in December, 1899.

Kasaan; village, of Haida Indians, on Skowl arm, Kasaan bay, Prince of Wales island, Alexander archipelago. Native name.

Kasatochi; island (1,018 feet high), northwest of the western end of Atka, middle Aleutians. Called Kassatotchy by Lutke, about 1830 , who says it is an extinct crater reported to contain a lake.

Kashaiak; Eskimo village, on the north bank of 'Tokiak river, near. mouth of Kashaiak river. Its native name, according to Spurr and Post, 1898, is Ḱashaiyágamut, i. e., Kashaiak people.

Kashaiak; river, tributary to Togiak river from the north, about 30 miles above the mouth of the latter. Native name, from Spurr and Post, who write it Kashíiyak.

Kashaw; river, tributary to the Kaskawulsh from the northeast, north of the St. Elias alps. Native name, from Brooks, 1900.

Kashega; bay, indenting the northern shore of Unalaski, eastern Aleutians. Named Koshiginskoi by Sarichef, 1792, supposedly after Yefim Koshigin, who wintered at Unalaska in 1763 . Has been variously written Kachiginskaia, Kasheega, Kashuga, Koshigin, etc.

Kashega; cape, between Kashegal and Pumicestone bays, on northern shore of Unaliska, eastern Aleutians. So called by Tebenkof, 1849 . 
Kashega; native village, in Kashega bay, on the northern shore of Unalaska. So called by Sarichef in 1792 . In 1831 it was the headquarters of the bidarshik or foreman of the Russian-American Company for the western half of Unalaska. Its population then was 41 ; in 1880,74 , and in 1890, 46. Has been called Kashigin and Koshigin.

Kashegelok; Eskimo village, on the right bank of Chulitna river, 157 miles above its junction with the Kuskokwim. Native name from manuscript map by W. R. Buckman, who wintered there in 1902-3 and who wrote it Kasheg-e-log-e-mute.

Kashevarof; group of islands, in Clarence strait, Alexander archipelago. Apparently so named by Dall in the Coast Pilot $(1883$, p. 89$)$.

Kashevarof; passage, separating the Kashevarof group of islands from Prince of. Wales island, Clarence strait, Alexander archipelago. Named by the Russians. Variously written Kashevarow, Kashevaroff and, erroneously, Kashvarow. It is an oft-recurring Russian family name.

Kashigaluk; Eskimo village, on Nelson island, Bering sea. Visited by Nelson December, 1878, and its name reported by him to be Kashigalogamute, i. e., Kashigaluk people.

Kashkak; Eskimo village, on the left bank of Chulitna river, 125 miles above its junction with the Kuskoliwim, near longitude $157^{\circ}$. Native name written Kash-skag-a-mute on an unpublished map drawn by W. R. Buckman, a prospector, who wintered 33 miles above in 1902-3.

Kash-skag-a-mute, Eskimo village; see Kasbkak.

Kashuga, bay ; see Kashega.

Kashunuk; river, in the Yukon delta, thougl!t to be one of the outlets of Yukon river, and so represented until recently. Native name, from Tebenkof, 1849, who wrote Kizhunak. Also has been written Kizhunok. Nelson. who crossed it in 1878, calls it Kashunuk, and Jarvis in 1897, Kashunak.

Kashunuk; Eskimo village, of 20 houses, in the Yukon delta, near the Kashunuk river. Eskimo name, from Nelson, who visited it December, 1878; and reported a population of 100 or 200. Petrof, 1880, writes Kashunok and reports a population of 125 . The Eleventh Census, 1890, calls it Kashunahmiut and gives a population of 232.

Kashutuk; Eskimo village, in the Yukon delta, near Andreafski. Eskimo name, from Nelson, who visited it December, 1878. Also bas been written Kashutok.

Kushvarou, passage ; near Kashevarof.

Kashvik; bay, immediately southwest of Katmai bay, Shelikof strait. Native name from Tebenkof, 1849.

Kasiak; cape, the western point of entrance to Sitkalidak strait, on the southeastern shore of Kodiak. So called by Tebenkof, 1849. Native name. Kasik is Aleut for seed and Kaiasik for high and rocky.

Kasiana; group of islands, in the northern part of Sitka sound, Alexander archipelago. So named by Vasilief, 1809. Erroneously Kaisana. It is a Russian family name.

Kasilof; cape, at mouth of Kasilof river, Cook inlet. The cape appears to have been named by Wosnesenski about 1840 . Also written Kassilow, Kussiloff, etc.

Kasilof, lake; see Tustumena.

Kasilof; river, on Kenai peninsula, draining Tustumena lake to Cook inlet, near latitude $60^{\circ} \cdot 20^{\prime}$. Apparently a Russian proper name, due to Wosnesenski about 1840. Variously written Kasilof, Kasilova, Kasilovka, Kussiloff, Kussilowa, etc. 
Kasilof; fishing village, at mouth of Kasilof river, Cook inlet. Upon or near the site of this village the Russian foreman Koloniin, 1786, began for. the Lebedef-Lastochkin Company a settlement by building two log houses surrounded by a stockade. This was called St. George, presumably after one of the ships of the company. The name Georgiefs kaia appears on the old maps.

Kaskawulsh; river, northeast of Yakutat bay, and tributary to the Alsek. Indian name, reported by Glave, 1890, who wrote Kaska Wurlch. Has been variously written Kaskarwurlch, Kaskarwulch, etc. The above form, Kaskawulsh, has been adopted by the Canadian Board on Geo graphic Names.

Kasnatchin, point; see Anchor.

Kasnyku; bay, on the eastern shore of Baranof island, Chatham strait, Alexander archipelago. Native name, reported by Moore, 1895.

Kasook; inlet and lake, on the northern shore of Cordova bay, Alexander archipelago. Apparently a native name from Moser, 1897.

Kassa; inlet, indenting the eastern shore of Cordova bay, Prince of Wales island, Alexander archipelago, 3 miles northwest of Shipwreck point, near latitude $54^{\circ} 56^{\prime}$, longitude $132^{\circ} 33^{\prime}$. Probably native name, so known to the pilots and reported by Dickins, 1905.

Kassatotchy, island; see Kasatochi.

Kassdeparka, river; see Casadepaga.

Kassik, island ; see Kaiasik.

Kassilof, river and village; see Kasilof.

Kasson; creek, tributary to Shovel creek from the east, Seward peninsula. Name from Barnard, 1900. Erroneously Karson.

Kataguni; island, one of the Chilkat islands, in Lynn canal, southeastern Alaska. Native name obtained by the Krause brothers, 1.882, and by them written Katagúne.

Katak. The Russian American map of 1849 shows an Alent settlement on Afognak bay, Afognak island, called Kattagmiut, i. e., Kat-tak people.

Katalla; bay, river, slough, town, and post-office, between Controller bay and the mouth of Copper river, southern Alaska. Written also Catalla and Catella. Indian name meaning bay, reported by Pratt and Martin, 1903. The post-office was established in 1904 and called Catalla.

Katch, islet; see Kak.

Katcheldat, river; see Yentna.

Kate; mountain (4,600 feet high), near Port Valdez, Prince William sound. So named by Abercrombie, 1898.

Kateekuk; island (300 feet high), one of the Semidi islands. Native name, obtained in 1874, by Dall, who wrote it Katee'khuk.

Kateel; river, tributary to Koyukuk river from the west, about 40 miles above mouth of the latter. Native name, reported by Allen, 1885, as Kateelkakat (on his map) and Koteelkákat (in his text, p. 105), i. e., mouth of. Kateel river. Has also appeared as Kotelkakat and Cotillakakat. See. Kakat.

Katelekaket, river; see Katilla.

Kates Needle; mountain (9,960 feet high), on the western bank of the Stikine, on the international boundary. Also called Kates Needles.

Katete; mountain $(4,170$ feet high $)$, near the Katete river. Native name, from Hunter, 1877, who has Kwah-tee-tah and Ka-té-té.

Katete; river, tributary to the Stikine river, from the southeast. Native name, published by the Coast Survey, 1883, as Kwahteetah and later as Kate-te and Kahtite.

Bull. $299-06 \mathrm{M}-23$ 
Kathal, 'mountain ; see Kathul.

Kathul; mountain, on north side of Yukon river, nearly opposite the mouth of Washington creek, near longitude $142^{\circ}$. Apparently an Indian name, obtained by Spurr, Goodrich, and Schrader, 1896. It has been written Cathul, Cathut, and Kathal.

Katilla; river, tributary to the Koyukuk, on the left bank, 4 miles above Dulbi river, and one-half mile below Kautas river, near latitude $65^{\circ} 30^{\prime}$ longitude $156^{\circ} 20^{\prime}$. Indian name, reported by Lieutenant Camden, R. C. S., in 1900, who wrote Katelekaket and Katillakakat.

Katiushkin. A small stream on Kenai peninsula, debouching in Cook inlet, near East Foreland, is on Wosnesenski's map (1840) in Grewingk (map 3), called Kantuitschike. The cape East Foreland is called Katiushkin on Russian Hydrographic chart 1378 (ed. of 1847).

Katlkulti, Indian village; see Kalwatta.

Katlatinchira; river, the chief tributary of Taiya river on the west, near latitude $59^{\circ} 37^{\prime}$, longitude $135^{\circ} 20^{\prime}$. Indian name, so written by Krause brother's, 1882 .

Katlian; bay, in the northeastern part of Sitka sound, Alexander archipelago. Named by Lisianski after Katlian or Kotlean, one of the native chiefs of Sitka in 1809. Has been called Katlianofa gulf, and Katliana or Kotleana (Katlian's or Kotlean's) bay.

Katmai; bay, indenting the northern shore of Shelikof strait, near latitude $58^{\circ}$, longitude $154^{\circ} 50^{\prime}$. Native name, from Vasilief, 1831-32; written Katmai and Katmaiskoi.

Katmai; creek, tributary to Katmai bay, Shelikof strait. Native name.

Katmai; village, on Katmai bay, Shelikof strait, northwest of Kodiak. This is one of the most important of the native villages. Population in 1880, 218 ; in $1890,132$.

Katnu; river, debouching on the northwestern shore of Cook inlet, immediately west of the West Foreland. Native name, from the Russians.

Katrina; river, tributary to the White from the west, in latitude $63^{\circ}$. This name has been adopted by the Canadian Board on Geographic Names. It is apparently an accidental corruption of the native word Katsiná, published by the Coast Survey in 1890. Katrina is reported to be the local usage.

Katschadélch, tributary of Chilkat river; see Clear creek.

Katschin, river; see Katzehin.

Katschlihthin, river; see Chilkoot.

Katselahin, river; see Kicking Horse.

Katselena, river; see Kotsina.

$\dot{K} a t \sin a$, river; see Katrina.

Katz; island, one of the Galinkin group, Sitka sound, Alexander archipelago. So named by United States naval ofticers in 1880, after Ensign Edward M. Katz, U. S. N.

Katzehin; river, on the mainland, tributary to Chilkoot inlet from the east, southeastern Alaska. Native name, variously written Chkazehīn (Krause), Katsehin (Coast Survey), Khatsehin, and, by error, Katschin. Apparently it is Katz-hini, i. e., Katz river.

Katzelena, river; see Kotsina.

Kauatka. One of the Shumagin islands, not identified, is called Kaouakhta by Lutke, who in turn obtained this name from Veniaminof. Veniaminof's notes, 1840, has the form Kauatka, meaning "long, narrow, and with some stony illaces." 
Kauk; river, northwestern Alaska, tributary to Eschscholtz bay from the east, neal latitude $66^{\circ} 15^{\prime}$. Lskimo name obtained by Mendenhall and Reaburn, 1901.

Kautas; river, draining from a lake, northward to Koyukuk river, near latitude $65^{\circ} 30^{\prime}$, longitude $156^{\circ} 20^{\prime}$. Native name, from Allen, 1885, who wrote it Cawtaskákat, i. e., mouth of the Kautas (river). This appears to be the one that was called Kotachikakat by Camden in 1900 .

Kavalga; island, one of the westernmost of the Andreanof group, middle Aleutians. Aleut name, from the Russians. Lutke and others write it Kalkhvalga, but Tebenkof hals Kavalga. Erroneously Ravalga.

Kavet; creek, northwestern Alaska, tributary to Kobuk river from the south, near latitude $67^{\circ} 10^{\prime}$, longitude $159^{\circ}$. Eskimo name, obtained by Mendenhall and Reaburn, 1901.

Kaviaial, bily; see Clarence, port.

Kaviak; Eskimo village, between Golofnin bay and Port Clarence. Called Kaviagamute on the map and Kayiazgamute in the text of the Tenth Census by Petrof, 1880 , who reports the population to be 200 . Kaviazagemut of Dall and the Coast Survey in 1869. Near it many maps, since 1869, show a river called Kaviavazak, a name said to be now unknown locally.

Kaviavazak; river, Seward peninsula, near the hend of Imuruk basin. Also written Karavaxarak. This name appeared on many maps between 1869 and 1898. It does not appear on the more recent maps and is said to be unknown locally. It may have been the Kuzitrin river or its branch, the Kougarok.

Kaviruk; swampy tract and small river at head of Imuruk basin, east of Grantley harbor, Seward peninsula, near latitude $65^{\circ} 1.5^{\prime}$, longitude $165^{\circ} 20^{\prime}$. An Eskimo word, apparently from some of the Franklin search parties about 1850, and spelled Cov-vee-arak. Has also been written Covearak. Billings, 1790, shows a river here called Kauveren on his chart and Ka-ooveren in his text. On a Russian chart of 1802 . it is called Kvuveren. Now called Marys river by the minets.

Kawanak; channel, Yukon flats, Bering sea ; and pass, Yukon delta, heading in Kwikpak pass, 3 miles above the head of Apoon pass and extending, on the left side and generally parallel to Kwikpak pass, 20 miles to Bering sea ; near latitude $63^{\circ}$, longitude $164^{\circ} 05^{\prime}$. Iskimo name, obtained by Putnam in 1899. Possibly from Eskimo Kāāwănè (Kauuwani) a little distance $u p ;$ i. e., a little distance from the Kwikpak.

Kawanera; point, prominent high ledge, at East rookery, northeastern const St. George island, Bering seal, near longitude $169^{\circ} 30^{\prime}$. Aleut name, written Kï'wï-nār'ii (seat lion's boat) by l'utnam, 1897.

Kawichiark; river, northern Alaska, tributary to Kugarak river and through it to Selawik river, near the Arctic circle and longitude $159^{\circ}$. Eskimo name obtained by Stoney, 1886, who wrote it Ka-o-e-che-ark.

Kawokhawik; pass or slough, Yukon delta at the mouth of Kwiguk pass, near: latitude $62^{\circ} 47^{\prime}$, longitude $164^{\circ} 50^{\prime}$. Eskimo name, obtained by Putnam, 1899, and written Kilwocbawik and Kawockawik.

Kayak; cape, the eastern head of Protection harbor, on south coast of Unalaska, eastern Aleutians, near longitude $166^{\circ} 34^{\prime}$. So called by Tebenkof, 1849 , perhaps from a real or fancied resemblance to the native skin boat. Called Mountain cape by the Fish Commission in 1888. 
Kayak; group of islets, at the southwestern end of the Galankin group, Sitka sound, Alexander archipelago. So named by Vasilief in 1809 . Kayak is the native name for their small skin-covered boats. The name has appeared as Kayaik, Kayaktch; and Kayatchi. Was also called Beardslee island by United States naval officers in 1880.

Kayak; island, on the southern border of Controller bay, Gulf of Alaska. This is the island which it is believed Bering saw and named St. Elias in 1741. Cook, in 1778 , saw and named it Kaye's island, after Rev. Dr. Kaye, dean of Lincoln. It has also appeared as Kay's island. The Spaniards Arteaga and Bodega, in 1779, called it Nuestra Señora del Carmen, whence the name Carmen island. The Russians called it Kayak from a fancied resemblance of its outlines to an Eskimo kayak or skin canoe. This has been written Kaiak and Kyak.

Kayak; post-office established in 1901 and abolished January, 1906, on Wingham island, southwest border of Controller bay, Gulf of Alaska.

Kayakh, mountains, river, and slough ; see Kaiyuh.

Kayakliut; cape, on the southern shore of Alaska peninsula, west of Kodiak. Native name, from Tebenkof, 1849. Also written Kayagliuk.

Kayaku, island; see Adak.

Kayar, mountains and river or slough; see Kaiyuh.

Kayayak, village; see Kaguyak.

Kay-e-ghlen, bay; see Whale.

Kaye's, island ; see Kayak.

Kayuk, river ; see Koyuk.

Kazakof; cape, forming the vestern point of entrance to Danger bay, on south shore of Afognak island, Kodiak group. So named by Murashef, 183940. Tebenkof applies this name, spelled Kazakofskie, to the eastern head of the bay. Its meaning is Cossack's.

Kazarn, bay ; see Kasaan.

Kazhgi-Igvat; cape, immediately north of Cape Douglas, Cook inlet. So called on Russion Hydrographic chart 1378 (edition of 1847). Obviously a Russian rendering of some native pbrase or name.

Kazhutak; slough and Eskimo village, on the left bank of Yukon river at the great bend, 25 miles below Andreafski, near latitude $62^{\circ} 05^{\prime}$, longitude $164^{\circ}$. Native name, obtained by Putnam, 1899. The name of the village he wrote Kazhutakamiut.

Kazili, island ; see Chisik.

Kchisakh. On United States Hydrographic chart 8, a cape, the southermmost point of Little Tanaga island, middle Aleutians, is called C. Kchisakh. This name has not been found on any chart of earlier date. Most of the names upon it are taken from Tebenkof's charts. In this case Tebenkof shows an islet which he calls Silak island, but does not name the cape. The hydrographic chart does not name the island, but calls the near-by cape C. Kchisakh. Perhaps this is the origin of the name.

Kchulach, point; see Kulah.

Keating; creek, tributary from the south to Mosquito fork of South fork Koyukuk river, near latitude $67^{\circ}$, longitude $150^{\circ}$. Prospectors' name, reported by Peters and Schrader, 1901.

Keating; range of mountains (3,000 feet high), in the western part of. Etolin island, Alexander archipelago. So named by Snow, 1886.

Kebethluk; Eskimo village, on the west side of Cape Nome, near latitude $64^{\circ}$ $30^{\prime}$, longitude $165^{\circ}$. Visited by Jarvis, 1898. The termination thluk means old, worn out. This may be an old trading place-kiputhluk. 
Kechumstuk; creek tributary to Mosquito fork Fortymile creek from the north, near latitude $64^{\circ} 05^{\prime}$, longitude $142^{\circ} 55^{\prime}$. Local name, reported in 1902 . Written also Ketchumstock.

Kechumstuk; range of hills, north of the Tanana, in longitude $142^{\circ}$ to $145^{\circ}$. Called Razor Back Divide by Wells in 1890 . On Coast Survey chart ' $\mathrm{T}$, editions of 1895 and 1896 , it is called Razor Back Divide, and on later editions and maps Ketchumstock Hills. Wells wrote the name of the tribe of Indians in this locality Kittschunstalk.

Kechumstuk; telegraph station, at the junction of Kechumstuk creek and Mosquito fork Fortymile creek. Named Ketchumstock by the Signal Corps, U. S. A., in 1903.

Keechatno, river; see Kichatna.

Keeghil, village; see Kijik.

Kee-Gili, creek, mountain and village; see Kijik.

Keejik, village; see Kijik.

Kee-Kluch, river; see Kiklukh.

Keeli' Khtagikh, island; see Kiliktagik.

Keene; channel, north of Keene island, Wrangell strait, Alexander archipelago. Named Keene's channel by Meade, 1869, after the pilot J. W. Keene.

Keene; island, in San Christoval channel, Bucareli bay, Alexander archipelago. Name published in the Coast Pilot (1891, p. 121).

Keene; island, in Wrangell strait, Alexander archipelago. Named Keene's island by Meade, 1869, after the pilot J. W. Keene.

Keene; rock or rocky patch, northwest of the middle channel into Sitka harbor, Sitka sound, Alexander archipelago. Named by the United States Navy, 1879, after pilot J. W. Keene, who reported it in that year.

Keete; inlet, in Nutkwa inlet, Cordova bay, Prince of Wales island, Alexander archipelago. Apparently a native name, from Moser, 1897.

Keetovaia, bay; see Whale.

Keewalik, river and mining camp; see Kiwalik.

Kegan; cove, lake, and salmon stream, Prince of Wales island, southern shore Moira sound, Clarence strait, southeastern Alaska, near latitude $55^{\circ}$, longitude $132^{\circ} 10^{\prime}$. Called by the fisheries, Kegan, the name of the Indian who claimed the salmon stream, and reported by Moser in 1897.

Kegezruk, creek ; see Kigezruk.

$K e g$-ich-tow-ik, native village; see Kiktaguk.

Kegilitowruk, village; see Kiktaguk.

Kegulik, river ; see Kejulik.

Kejachu, island; see Adak.

Kejulik; river, Alaska peninsula, tributary to Becharof lake from the east. Native name. According to Martin, 1904, it is pronounced Kĕ-jéw-lǐk, means clay or mud, and is written variously Kegulik, Kajulik, Kejulik, and Kujulik.

Kekoor, rock; see Second Kekur.

Kekour, rock; see Third Kekur.

Keku; group of islets, in the north end of Keku strait, Alexander archipelago. Native name, which has been written Kekou and Kiku.

Keku; strait, between Kuiu and Kupreanof islands, Alexander archipelago. A native name, which has been variously written Kake, Kiku, ete.

Kekur. This word, spelled-Kekoor, Kekour, Kekur, etc., is frequently found on Russian maps of Alaska and Eastern Siberia. It appears to be some native term adopted into the Russian and to mean any high isolated rock or rocky islet. Apparently it is an exact equivalent of the Spanish 
Kekur-Continued.

word Farallon. In the Journal of the Russian Hydrographic Office (1844, vol. 2, pp. 115-129) is a list of words in use by the seafaring folk (promieshlenniki) of the Archangel government. In this list occurs these two entries: Gurie (pyramid of rocks) ; Kelur, same as gurie, but oftener by this word is meant an isolated pillar-like rock. The word is in use in Nova Zembla. Paktusof, in 1833, speaks of Guria or Kekura. Petrof (Bancroft's History of Alaska, p..225) says, "This expedition fell in with a large party of savages, who had taken up a position on a Kekour," and then adds this explanation, "Such places, to which the Russians applied the Kamchatka name of Kekour, were often used by the natives as natural fortifications and places of refuge. War parties or hunting expeditions would leave their women and children upon such cliffs for safe-keeping till their return." In Wrangell's narrative, edited by Sabine, we find (p. 354) Kekury, Kekurnoi, or columns.

Kekur, cape; see Pillar.

Kekur; islet, near the entrance to Kalsin bay, Chiniak bay, Kodiak. Called Kekurnoi (pillar) by Russian naval officers, 1808-1810.

Kekur, rock; see First Kekur.

Kekur, rock; see Pinnacle.

Kelkurnie, cape; see Rocky.

Kekurnoi; cape, on the northern shore of Shelikof strait, between Katmai and Cold bays. By Tebenkof, 1849, it is called Kekurnoi, from Kekur (pillar), and by mistranslation this appears on current charts as Kahurnoi. It has been translated Pinnacle. Lutke, 1835, calls it Nelupaki or Neliupiaki, apparently a native name, while Russian Hydrographic chart 1379 has another native name, Nukakalkak.

Kell; bay, Affleck canal, Kuiu island, Alexander archipelago. Said to be so called by the Indians. Name reported by Helm, 1886.

Kellek, island; see Summit.

Kellett, island; see Wrangell.

Kelley, river; see Killey.

Kellogg; point, the northern point of entrance to Young cove, Howkan strait, Cordova bay. Alexander archipelago. Named by Sheldon Jacksorr after Miss Fannie E. Kellogg, a teacher at Sitka in 1878.

Kellogg; point, the western point of entrance to Dunbar inlet, Prince of Wales island, Alexander archipelago. Named by Dall, 1882, after Miss Fannie E. Kellogg, a teacher at Sitka in 1878.

Kelly; mountain (Mount Kelly), on the base of Lisburne peninsula, in northwestern Alaska, at headwaters of Pitmegea and Kukpuk rivers, near latitude $68^{\circ} 30^{\prime}$, longitude $163^{\circ} 30^{\prime}$. Supposed to be named after John W. Kelly, who lived in that region, and published by the Coast Survey in 1890.

Kelp; bay, indenting the northeastern shore of Baranof island, Chatham strait, Alexander archipelago. Often referred to as Deep bay, and in 1879 named Kelp bay by Dall in the Coast Pilot, published. in 1883 .

Kelp; bay, indenting the northwest shore of Tigalda island, Krenitzin group, eastern Aleutians, near longitude $165^{\circ} 10^{\prime}$. Descriptive name, from Gilbert, 1.901.

Kelp; island, near the southern shore of Düke island, Dixon entrance, Alexander archipelago. So named by Nichols, 1883.

Kelp; point, between Dewey and McHenry anchorages, on Etolin island, Clarence strait, Alexander archipelago. So named by Snow, 1886. 
Kelp; rocks, off Port Chester, Nichols passage, Alexander archipelago. So named by Nichols, 1883 .

Kempff; biay, indenting the southwestern shore of Alitak bay, Kodiak, 7 miles northeast of Cape Alitak. So named by Moser, 1900, after Ensign Clarence F. Kempff, U. S. N., a member of his party.

Kenachananak; Eskimo village, on the seashore east of Nunivak island, Bering sea. In the Eleventh Census, 1890, it is called Kenrachananaghamiut, i. e., Kenachananak people, described as composed of 8 dwellings and 181 people.

Kenai, bay ; see Cook inlet.

Kenai; lake, on Kenai peninsula, between Turnagain arm and Resurrection bay, and draining through Kenai river westward through Lake Skilak to Cook inlet, near latitude $60^{\circ} 25^{\prime}$, longitude $149^{\circ} 40^{\prime}$. On some mnsps called Second lake and probably Skiliamna. See also Skilak.

Kenai; mointains, forming the axis of Kenai peninsuli. Commonly so called. Name published in the Tenth Census, 1880. Grewingk, 1849, deriving his information from Wosnesenski, 1842 , gives the native name of these mountains as Trüüli; also written Trủủli.

Kenai; peninsula, between Cook inlet and Prince William sound. Native name, from the Russians. On early Russian maps the peninsula bears no name, but Cook inlet is called Kenaiskaia gulf. Billings, 1802, calls it Kanaiski land. Grewingk calls it Tschugatsk (Chugach) peninsula.

Kenai; river, on Kenai peninsula, draining skilak and Kenai lakes to Cook inlet, near latitude $60^{\circ} 30^{\prime}$. Native name Kaknu from the Russians; apparently first uised by Wosnesenski about 1840. Grewingk has called it Nik river, an abbreviation of Nikolas. Of late years it is commonly called Kenai river, and the Board on Geographic Names has adopted that name.

Kenai, strait ; see Shelikof.

Kenai; village and post-office, at mouth of Kenai river, on enstern shore of Cook inlet. A fortified post was established here by Grigor Konovalof, commanding the ship St. George, of the Lebedef-Laistochlkin Company, in August, 1791, and called fort or redoubt St. Nicholas or St. Nicolis or St. Nikolas. On a Russian map of 1802 it is called Pavlovskaia, i. e., Paul, and a manuscript note says fort De Pawlofsk. In the summer of 1869 there was a military post of the United States here called Fort Kenni, and by this name Kenai, a native name, the place is now linown. A post-office, Kenai, was established here in February, 1899.

Kenaiskischer, inlet; see Cook.

Kenasnow, archipelago, etc. ; see Kootznahoo.

Kenasnov, island; see Killisnoo.

Kenasnow; rocks, in Kootznahoo roads, Chatham strait, Alexander archipelago. Called Kootznahoo by Meade, 1869, and Kenasnow by Nichols, 1891.

Kendrick; bay, indenting the southeastern shore of Prince of Wales island, Clarence strait, Alexander archipelago, near latitude $54^{\circ} 52^{\prime}$, longitude $132^{\circ}$. Named by Iall, 1879, after Capt. John Kendrick, of the sloop Columbia, from Boston, who wintered at Nootki in 1.785-89.

Kendrick; islands, at entrance to Kendrick bay, Prince of Wales island, Clarence strait, southeastern Alaska. So called by local navigators, and reported by Fassett, Bureau of Fisheries, 1904.

Kennedy; point, the eastern point of entrance into Saook bay, Peril strait, Alexander archipelago. Named by Moore, 1895, after Surg. Robert Morris. Kennedy, U. S. N., a member of his party. 
Kennicott; glacier, on the southeastern flank of Mount Blackburn, forming the source of Kennicott river. So named by Gerdine, 1900, after Robert Kennicott.

Kennicott; pass, between Lakina river and Kennicott glacier. So named by Gerdine, of the Geological Survey, 1900.

Kennicott; river, tributary to the Nizina from the nortb. Local name, in memory of the Alaskan explorer and naturalist, Robert Kennicott, a pioneer on Yukon river, who died at Nulato, May 1.3, 1866.

Kennon; island, in the entrance to Chichagof harbor, 'Attu island, western Aleutians. So named by Gibson, July, 1855, after Lieut. Beverley Kennon, U. S. N.

Kentucky; creek, tributary to Igloo creek, from the south, Seward peninsula.

- Name from Brooks, 1900.

Kentucky; creek, tributary to Klokerblok river, from the south, Seward peninsula. Name from Baìnard, 1900.

Kenunimik; Eskimo village, on the right bank of the lower Yukon, 15 miles above Andreafski, near latitude $\left(62^{\circ}\right.$, longitude $163^{\circ}$. Native name, from the Coast Survey, 1898. Perhaps this is identical with Ankachak.

Keyizetka, river; see Kokolik.

Kern; creek, tributary to Turnagain arm of Cook inlet from the north, near latitude $61^{\circ}$, longitude $149^{\circ}$. Prospectors' name, from Herron, 1899.

Kernan; gulch, Copper River region, tributary to Blei gulch on the south side of Chititu creek. Prospectors' name taken from Map. of Nizina mining district, by George M. Esterly, of Valdez, 1902.

Kestrel; islet, on the north shore of Boca de Quadra, southeastern Alaska. ' So named by the Coast Survey in 1891 .

Ketavie, point; see Whale.

Ketchikan; post-office and village, on Revillagigedo island; in Tongass narrows, Alexander archipelago. The post-office was established in April, 1892. Also has been written Kichikan and Kitch-i-kan.

Ketchumstock; see Kechumstuk.

Ketchimville. This name is found on Nelson's map of 1878-79, published in the Proceedings of the Royal Geographic Society for 1882 (p. 712), and is applied to a post or fort on the mainland just south of St. Michael. Norton sound. It was copied on the census maps of 1880 , but is not found on later maps.

Ketlrachtü, point; see Battery.

Ketoy, island; see Whale.

Kettle; cape, on the southeastern shore of Umnak island, near Umnak pass, eastern Aleutians. Named Kotelnoi (kettle) by the Russians. The native name is Utmak, presumably from the Aleut, utman, (out of the middle).

Kevuleel, river; see Kivalina.

K.evulik, river; see Kivalina.

Kewalik, river and mining camp; see Kiwalik.

Key; reef, east of Kashevarof islands, Clarence strait, Alexander archipelago. So named by Snow, 1886.

Keyilktuk, village; see Kiyiktuk.

Keystone; canyon and telegraph station, on Lowe river 15 miles east of Valdez, Prince William sound. So named by Abercrombie, 1898, presumably after Pennsylvania, the Keystone state:

Keystone; creek, 15 miles northwest of Fairbanks, tributary to Goldstream creek, from the north, near longitude $148^{\circ}$. Prospectors' name, from a local map, 1905. 
Khaboutcha, point; see Kabuch.

Khabuch, point; see Kabuch.

- Khaigamute, village; see Nunaikak.

Khainiliakh, island; see Kaniliak.

Khaltselahin, river; see Kicking Horse.

Khantaak; island, in Yakutat bay, southeastern Alaska, near latitude $59^{\circ} 35^{\prime}$, longitude $139^{\circ} 45^{\prime}$. 'This is the native name of a wooden dish used for holding food. First applied by Tebenkof, 1849. Has been written Hantak and Khantak, and might better be written Kontog, to agree with the pronunciation.

Khatnotoutze, creek; see Medicine.

Khaz; bay, indenting the southwestern shore of Chichagof island, Alexander archipelago, near latitude $57^{\circ} 30^{\prime}$, longitude $136^{\circ}$. Apparently named Khaz (fag-end) by Tebenkof, 1849.

Khaz; head, southwestern shore of Chichagof island, a bold, bluff headland about 1,400 feet high, the northwestern end of a rugged peninsula, between Slocum arm of Khaz bay (above) and the sea. So named by Moore, 1897.

Khaz; point, the southern point of Khaz head (above). Local name, reported by Moore in 1897.

Khazamil, island ; see Kagamil.

Khazik, island; see Chisik.

Khiltat; river, tributary to Tanana river from the north, near longitude $144^{\circ}$ 30'. Named by Allen, 1885, after an Indian chief, Kheeltat.

Khitkhouk, cape; see Scotch Cap.

Khituk, cape; see Scotch Cap and Seal.

Khlebnikof; cape, between Chichagof harbor and Sarana bay, on the northern shore of Attu island, western Aleutians. So named by Etolin, 1827, presumably after the pilot, Andrei Khlebnikof, who made surveys about Kodiak in 1810. Also written Chlebnikoff.

Khlikaklulik, island; see Latouche.

Khodo'oye, mountain ; see Khotol.

Khoostoff, island; see Khwostof.

Khotol; mountain, "one of the higher peaks of Kaiyuh range about 25 miles southeast of Nulato." So described by Father Jetté of Nulato in 1904. Indian name which he wrote Hotol, Hotel by error, Ǩotol, and řotoldlela- $\check{\mathrm{R}}$ and $\mathrm{H}$ representing the guttural $\mathrm{Kh}$ (there being no sound $r$ in the Indian languages of that region, he uses the letter $r$ for this purpose)-and dlela meaning monntain. It is also called Khodo'oye--" the furtbermost going down" the river-by the Indians, but this name properly belongs to another mountain.

Khotol; river, on the southeast side of the Yukon, draining the Kaiyub region into Kaiyuh slough of the Yukon, 40 miles south of Nulato. According to Father Jetté of Nulato, the Indians call this river and the lower part of the slough, Khotolno, i. e., Khotol river. Tikhmenief, 1861, wrote this name Kutulnakt and gave it to Kaiyuh slough. See also Kaiyuh slough.

Khoudialcoff, islands; see Kudiakof.

Khromchenko, cape; see Etolin.

Kltagaliuk, island; see Hinchinbrook.

Kltullitno, river; see Chulitna.

Kihulukh, bay; see Kuluk.

Khun, river; see Kun. 
K.lunna, island; see Chichagof.

Khutsnoi, island; see Admiralty.

Kh $h$ tz-n' $h u$, archipelago, etc. ; see Kootznaboo.

Khwain; bay, indenting the eastern shore of Annette island, Felice strait, Alexander archipelago, near latitude $55^{\circ} 05^{\prime}$, longitude $131^{\circ} 22^{\prime}$. Name from local navigators, by Fassett, Bureau of Fisheries, 1904.

Khwostof; island (1,873 feet high), one of the Rat island group, western Aleutians. Apparently so named by Krusenstern, 1827, after Nikolai Alexandrovich Khwostof, a Russian naval officer who, with Davidof, mare explorations in Alaska, 1802-1804. According to Lutke the name was applied to a group of which Khwostof island was one. Variously written Khoostoff, Khvostoff, Khwostov, etc.

Kiactak, Kiactuk, lake and river ; see Kiaktak.

Kiakasia; river, tributary to Stikine river from the south, 3 miles below the mouth of Iskut river. Native name, published as Ki-ka-hry in 1868, and written Kiah-kah-seah by Hunter in $187 \overline{7}$.

Kiaktak; lake and river, northwestern Alaska, between Inland lake and Selawik lake, and draining into the latter, near latitude $66^{\circ} 30^{\prime}$, longitude $160^{\circ} 15^{\prime}$. Eskimo name obtained by Cantwell, 1884, who called the river Kiactuk or $F 8 x$ and the lake Kiactak. Stoney, 1885, shows a village on the shore of the lake, the name of which he writes Ki-go-ak-to-ak.

Kialagvik; bay, on the southeastern coast of Alaska peninsula, near Mount Bechatrof, about latitude $57^{\circ} 20^{\prime}$, longitude $156^{\circ}$. Native name, from the Russians, also written Kialagvit. Called on some maps Wide bay.

Kialegak; native village, now abandoned, and cape 5 miles northeast of Southeast cape, eastern end of St. Lawrence island, Bering sea. Native name, from Tebenkof, 1849, who wrote Kgallegak. Also has been written Krallegak. The above spelling, which seems more probable, is from Russian Hydrographic chart 1455 (ed. 1852).

Kiam; post-oftice (established November, 1905), Alexander archipelago, on eastern coast of Prince of Wales island, at head of McKenzie inlet, south shore Skowl arm of Kasaan bay, near latitude $55^{\circ} 20^{\prime}$, longitude $132^{\circ} 20^{\prime}$. Brooks, 1901 , reported a mine in this vicinity called Kiam.

Kiangolevik; slough or pass; Yukon delta, an outlet of Black river to the north, near latitude $62^{\circ} 25^{\prime}$, longitude $165^{\circ} 05^{\prime}$. Eskimo name, written Kiangolévic by Putman, 1899.

Kiavak; bay, west of Sitkalidak island, indenting the southern shore of Kodiak. So called by Tebenkof, 1849. Native word. Has been written Kiawak and Kiyavak. It is apparently identical with Naumliack bay and village of Lisianski in $\mathbf{1 8 0 5}$.

Kiavak; cape, at the south point of entrance to Kiavak bay, Kodiak. So called by Tebenkof, 1849.

Kiavak, passage; see Klawak.

Kichaiak; creek, northwestern Alaska, tributary from the east to Kobuk river, near its source, about latitude $67^{\circ} 05^{\prime}$, longitude $154^{\circ} 10^{\prime}$. Eskimo name, written Kit-chah-ee-yah and Kit-chah-ee-yak by Cantwell in 1885, and Kichaiakaka by Mendenball in 1901.

Kichak, village; see Kijik.

Kichatna; river, a large branch of the Yentna from the west, 10 miles above the Skwentna, near latitude $62^{\circ}$. Indian name. Explored by Herron in 1899 and written by him Kee-chat-no, i. e., Kichat river. 
Kichili, village; see Kijik.

Kichikan, village; see Ketchikan.

Kichzulili, bay ; see Kuzhulik.

Kicking Horse; river, tributory to the Chilkat river from the south, near its mouth, southeastern Alaska. So called on a recent railroad map. Its native name has been variously given as Chalzékahīn (Krause), Katsekahin (Nichols), Khaltsekahin (Coast Survey), Khalzekahin (Dall), etc. Apparentlty its native name sounds like Katsek-hini, i. e., Katsek river.

Kiellek, island; see Summit.

Kiestotnak, cape; see West Foreland.

Kietaguk, village; see Kiktaguk.

Kigalitowruk, native village; see Kikiktak.

Kigalga, island; see Tigalda.

Kigalgin; island, one of the group of islands of the Four Mountains, eastern Aleutians. Native name, from Veniaminof, about 1830. Not inhabited. Has been written Kigalga, "a name often recurring in the Aleutian islands."

Kigalgin, island; see Egg.

Kigalik; rendezvous village, at the limit of boat navigation, on the upper Chipp river, near latitude $69^{\circ} 20^{\prime}$, longitude $154^{\circ} 30^{\prime}$. It consisted of 30 tents and 150 Eskimos when visited by Ensign Howard, of Stoney's expedition, in May, 1886, on his way to Point Barrow. "At this place the last green brush was seen, 10 to 12 feet high."

Kigamil, island; see Kagamil.

Kiganin, island; one of the Shumagin group, not identified. Called Kiganghym by Lutke, who, in turn, obtained the name from Veniaminof. In a later publication Veniaminof calls it Kiganin.

Kigezruk; creek, in the extreme western part of Seward peninsula, debouching between capes York and Prince of Wales. Named after Kiviarzruk, a Prince of Wales Eskimo, who discovered gold here in June, 1899. Has been written Kiryarzark, Kiugaarzruk, and Kivyearzruk, and is now called, locally, Kigezruk.

Kightale Sichtunak, islands; see Trinity.

Kigluaik; range of mountains, in western part of Seward peninsula. Eskimo name, from Beechey, 1827, who wrote it Kig-low-aic. Has also been called Kiglowa, and by the miners Kiglo-white, Craggly-white, and Kreegly White. On some late local maps called Sawtooth.

Kigmil, cape; see Prince of Wales.

Ki-go-ak-to-alk; Eskimo viliage, northwestern Alaska, western shore of. Inland lake and eastern shore of Kiaktak lake, near latitude $66^{\circ} 30^{\prime}$, longitude $160^{\circ} 10^{\prime}$. Native name, so written by Stoney, 1885.

Kiguga; cape and cliff, on the northwestern coast of Adak island, Andreanof group, middle Aleutians. Aleut name, from Tebenkof, 1849.

Kigun; cape, the westernmost point of Atka, Andreanof group, middle Aleutians. Native name, from 'Tebenkof, 1849. Perhaps from the Aleut kiguk (diver or grebe).

Kigunak; cape, in Inanudak bay, on the northern coast of Umnak, eastern Aleutians. Native name, from Kuritzien, 1849.

Kigushimkada; cape, on the northern shore of Umnak, eastern Aleutians. Native name, from Kuritzien, 1849. 
Kijik; native village, on the west shore of Lake Clark, mountain near, and creek tributary to Lake Clark, about the middle of the west side, near latitude $60^{\circ} 30^{\prime}$, longitude $154^{\circ} 15^{\prime}$. Native name, reported by Osgood, 1902 ; and written Keejik and Keeghik. A village in the same position is called Nikhkak on the Coast Survey map of southwestern Alaska, 1898. Kichik of Petrof, 1880, is located on the other side of the lake. The Census enumerator for that district, 1900, reported a village Kichak. Kikhtak, island; see Kodiak.

Kikhtal, island; see Martin point and Martin islands.

Kikiktak; Eskimo village (trading rendezvous), at the mouth of Hotham inlet, Kotzebue sound. Population in 1880, 200. Eskimo name, from Petrof, 1880, who wrote it Kikiktagamute, i. e., island folks. It has been written variously Kikiktaruk, Kikitaruk, Kigaktowruk. Stoney, 1886, wrote Ki-ra-targ-ga-roak. Kotzebue post-office and reindeer station and a Friends' (Quaker) mission are located at or near this place.

Kikiktaruk, liskimo village; see Kikiktak and Kiktaguk.

Kikitaruk, native village; see Kikiktak.

Kiklukh; river, 8 or 9 miles east of Cape Suckling, Gulf of Alaska, near longitude $143^{\circ} 40^{\prime}$. Called Malaia Ugalenka (Little Coal or Coaly) by Tebenk of in 1849, and Little Ugalentz in the Coast Pilot of 1869. Martin, 1904, writes the Indian name Kee-kluch, and says the prospectors call it Eightmile creek.

Kiksc, island; see Kiska.

Kiktagaliuk; islets, at entrance to Cold bay, southeastern shore Alaska peninsular, near latitude $57^{\circ} 45^{\prime}$. Native name from the Russians. Has been written Tiktakaluk.

Kiktaguk; Eskimo village, on the southern shore of Norton sound, about 18 miles east of St. Michael. Dall, who visited it October 8, 1866, reports its name to be Kegiktówruk, a "word dèrived from Kikhtuk, meaning an island," and ruk or guk, augmentative; probably then big island. Tebenkof in 1849 calls it Kiektaguk, while Raymond in 1871 and the Coast Survey parties of 1898 call it Ikikiktoik and the hill near it Toik. It has been written Kikiktaruk, and recently Tlicketawik, Tlickearrik, etc.

Kiktak; Eskimo village, on a large island in Kuskokwim river, about 25 miles above Bethel. Native name, from Nelson, 1878-79, who wrote it Kikkhtagamute, i. e., island people. Kik-kh-ta or Kiktak is the native word, which has by corruption become Kadiak and Kodiak. Petrof in 1880 gives its population as 232 and its name Kik-khtagamute. The Eleventh Census gives a population of 119 and the name, Kikikhtagamiut.

Kiku, islet and village; see Kake.

Kikukalen, bay; see Erskine.

Kilbuck; range of mountains, east of the lower reach of Kuskokwim river, western Alaska. So named by Spurr, 1898, after Rev. John H. Kilbuck, a Delaware Indiain missionary and teaclier at Bethel.

Kiliatva; river, in St. Elias alpine region, debouching between the Alsek delta and Yakutat bay. Apparently a native name; published by Tebenkof in 1849.

Kiliktagik; island (750 feet high), one of the Semidi islands. Native name, obtained, in 1874, by Dáll, who wrote it Keeli'Khtagikh. 
Kilimantavie; Eskimo village, near Wainwright inlet, Arctic coast. 'Tiklnmenief, 1861, calls it Kilametagag-minit; Petrof, 1880, calls it Kolumakturook; Hydrographic chart 68 calls it Kelamantowruk, while later charts omit it or call it Kilimantavie. According to Murdoch this name is Kê-lếv-a-tow-tin (sling). Jarvis calls it Kilimantavie. (Reindeer: Report 1903 , p. 136.)

Kiliuda; bay, indenting the southeastern shore of Kodiak. Native name, reported by the Russians. Has been written Kiliouda, Kiliouk, Kiliuda, Kiluidinskoi, Kiliuk, Killuda, Kiluden, Kaliada, etc. Perhaps it is a corruption of Kiliak, an Aleut word meaning morning, or Kiliak (early in the morning), and uda ; (bay).

Kiliuda; native village, on the north shore of Kiliuda bay, Kodiak. Has been generally written Killuda.

Kiliugmiut, cape; see Kuliuk.

Kiliuluk, bay ; see Kuliliak.

Killai. Peterof, 1880, shows two native villages on the headwaters of Kuk river, northern Alaska, designated as Killaïmutes; i. e., Kilaï people.

Killarney; lake (Lake Killarney), 6 miles northwest of Fairbanks, near latitude $64^{\circ} 50^{\prime}$, longitude $147^{\circ} 55^{\prime}$. Local name, from. Map of Location, Tanana Mines railroad, 1905.

Killey; river, Kenai peninsula, a southern tributary of Kenai river, near longitude $150^{\circ} 40^{\prime}$. Local name from Moffit, 1904. Erroneously Kelley.

Killik; creek, northern Alaska, tributary to Colville river from the south, near longitude $153^{\circ} 30^{\prime}$. Eskimo name, obtained by Peters and Schrader, 1901.

Killisnoo; harbor and island, opposite Peril strait, in Chatham strait, Alexander archipelago, near latitude $57^{\circ} 28^{\prime}$. Corruption of some native word. Apparently only another form of Kootznahoo (Khutz-n'hu= bear fort). It is identical with Kenasnow island of Mealde in 1869. Speaking of this island and the harbor east of it, etc., Meade says: "The names Kenasnow and Koteosok are the Indian names of these places, and as such I have inserted them on my charts."

Killisnoo; post-oftice and native village, on Killisnoo island, Chatham strait, Alexander archipelago. The post-office was established here in July, 1884.

Killisnoo; reef, off: west end of Killisnoo island, Chatham strait, Alexander archipelago. Named Kenasnow by Meade, 1869. On late clarts changed to Killisnoo.

Killkuhn; creek, tributary to Kruzgamepa river from the eaist, Seward peninsulis, near latitude $65^{\circ}$, longitude $164^{\circ} 30^{\prime}$. So named by Brooks, 1900 , after his cook, Charles Kubn.

Killuda, village; see Kiliuda.

Kilokak; rocks, near Agripin bay, on the southern shore of Alaska peninsula. Native name, published by the Coast Survey in 1900.

Kiluidinslioi, bay; see Kiliuda.

Kimball; mountain $(9,000$ feet high), south of Tanana river, near longitude $144^{\circ} 40^{\prime}$. So named by Allen, 1885 .

Kimball; pass, west of the Copper river, in latitude $61^{\circ} 30^{\prime}$. Name from Abercrombie, 1898.

Kina; bay or cove, indenting the southern shore of Kasaan bay, between Coal bay and Twelvemile arm, Clarence strait, sontheastern Alaska, near latitude $55^{\circ} 30^{\prime}$, longitude $132^{\circ} 32^{\prime}$. Local navigators' name, reported by Moser, 1900. 
Kina; salmon streạn and lake; tributary to Kina bay, south shore Kasaan bay, Prince of Wales island. So called by the fisheries, and reported by Moser, 1897 and 1900.

Kinak; river, on the mainland, enst of Nunivak, draining from Dall lake, southward to Bering sea. Native name, from Nelson, 1878. According to J. H. Kilbuck, the word means face. Late maps show the Kinak river flowing not southward to the sea, but eastward to the Kuskokwim.

Kinak; Eskimo village, on right bank of the lower Kuskokwim. Visited by Nelson in January, 1879, who reported its native name to be Kinagamiut, i. e., Kinak people. Its population was at that time about 175 . Population in 1880,$60 ; 1890,257$. Kínak is said to be the Eskimo word for face.

Kinegnagmiut, village; see Razboinski.

Kinegnak; Eskimo village, of 76 people in 1890 , near Cape Newenham, Bering sea. Name from the Eleventh Census, where it is Kinegnagmiut in the text (p. 99) and Kniegnagamute on the map, i. e., Kinegnak people. King, cove; see Peterson bay and Salmon bay.

King George T'hird's archipelago. That part of the Alexander archipelago which lies west of Cbatham strait and south of Cross sound and Icy strait was named by Vancouver King George Third's archipelago. The name is obsolete.

King; island (700 feet high), in Bering strait. Discovered by Cook, August 6, 1778, and named by him King's islind, after Lieut. James King, a member of his party. Its native name, according to Nelson, is Ukiwuk, a name which has been given as Okiben, Oo-ghe-book, Oo-ghee-a-book, Ookivok, Oukivok, Ukivok, etc.

King; island, in Clover bay, western shore of Clarence strait, southeastern Alaska, near latitude $55^{\circ} \cdot 18^{\prime}$, longitude $132^{\circ} 10^{\prime}$. Local navigators' name, reported by Fassett, Bureau of Fisheries, 1904.

King; mountain $(1,204$ feet high $), 8$ miles north of Nome, Seward peninsula, near latitude $64^{\circ} 36^{\prime}$, longitude $165^{\circ} 20^{\prime}$. Local name, published in 1900 .

King; river, Seward peninsula, emptying into Bering sea 3 miles east of Cape York. Prospectors' name, reported by Collier in 1903.

Kingegan; Lskimo village; with population, in 1890 , of 488 , at or near Cape Prince of Wales, Bering strait. Beechey, 1827, says: "The natives have a village upon the lowland near the cape called Eidannoo, and another inland, named King-a-ghe." Dall says: "Known to natives as far south as Norton sound and to local navigators as King-é-gan." It has been written King-a-ghee, Kingigamute, King-a-khi, etc. See Wales.

Kinghiak, village; see Suworof.

Kings, bay, Prince William sound; see Nellie Juan.

Kings; cove, indenting the southern shore of Alaska peninsula, just west of Belkofski, near longitude $162^{\circ} 18^{\prime}$. Named King's cove by the Fish Commission in 1888.

Kings; creek, tributary to Matanuska river from the north, about 30 miles above the mouth of the Matanuska. So known locally. Presumably named after Al. King, one of Alaska's pioneer prospectors. Name published in 1899.

Kings; creek, in the Mount Wrangell district, tributary to Elliott creek on the north. Prospectors' name, reported by Mendenhall, 1903. 
Kings; mountain, on the left bank of Matanuska river, about 35 miles from Knik arm of Cook inlet. Named House mountain by Mendenhall, 1S98. Locally called Kings by the miners and prospectors, after Al. King, whose cabin was near it.

King Salmon; river, Alaska peninsula, draining the country between Becharof and Naknek lakes and tributary to Ugaguk river from the north, netr latitude $58^{\circ} 15^{\prime}$, longitude $157^{\circ}$. Descriptive name, reported by Osgood, 1902.

King Salmon; river, Alaska peninsula, tributary on the left bank of Ugaslik river, 10 miles above its mouth, near latitude $57^{\circ} 30^{\prime}$, longitude $157^{\circ} 30^{\prime}$. Local descriptive name, reported by Moser, 1900.

King Salmon; river, tributary to Tilichik river from the north, near latitude $60^{\circ}$, longitude $157^{\circ} 30^{\prime}$. Local name, obtained by Spurr and Post, 1898, from a trader, $\mathbf{A}$. Mittendorf.

Kings Cabin; home of Al. King, a prospector, at junction of Kings creek and Matanuska river.

Kings County; creek, Kenai peninsula, a southern tributary of Skilak lake, near longitude $150^{\circ} 30^{\prime}$. Prospectors' name, from Moflit, 1904 .

Kingsmill; point, on the northwestern shore of Kuiu island, at junction of Chatham strait and Frederick sound, Alexander archipelago. So named by Vancouver, in 1794, after Vice-Admiral Kingsmill, R. N.

King Solomon; creek, in the Fortymile mining district, tributary to O'Brien creek. Local name, obtained by Barnard in 1898.

Kiniaak, village; see Suworof.

Kinik, arm, river, etc. ; see Knik.

Kiniklik; village, on northern shore of Prince William sound. Native name, from Schrader, 1900, who wrote it Kinicklick.

Kink (The); bend, in North fork Fortymile creek, near latitude $64^{\circ} 20^{\prime}$, longitude $142^{\circ}$. Local descriptive name, The Kink, reported by Gerdine, in 1903.

Kinkaid; mountain, on the eastern shore of Sitka sound, Baranof island, Alexander archipelago. So named by the Coast Survey, presumably after C. A. Kinkaid, who was one of the first council elected at Sitka, shortly after the transfer of Alaska from Russia to the United States in 1867. It is the mountain of four stone pyramids of Vasilief in 1809.

Kinkutumina; small lake, 60 miles northwest of Mount McKinley, near 'Telida lake. Indian name, reported by Herron, 1899. The termination minat means lake.

Kinuiak, village; see Suworof.

Kiougilakh, cape; see Kíngilak.

Kipnuiak, river; see Black.

Kipniak; Eskimo village and Coast Survey tidal station, at mouth of. Black river, in the Yukon delta, near latitude $62^{\circ} 20^{\prime}$. Nelson, 1879 , reports its name to be Kipniaguk and Dall writes it phonetically Kip-nai-ăk. A late Coast Survey chart has Kripniyukamiut.

Kipniak, river; see Black.

Kipniyagok; river, Yukon delta, tributary on the left bank to Black river near its mouth, about latitude $62^{\circ} 20^{\prime}$, longitude $165^{\circ} 20^{\prime}$. Eskimo name written Kripniyagok by Putnam, 1899. This is the diminutive of $\mathrm{Kip}$ niuk or Kipnaiak, the Eskimo name of Black river (yagak, the young of animals), therefore Little Kipnaiak river. Eskimo kipnaiak means a curve. 
Kipunaiak, river; see Black.

Kiputhlik, Eskimo village; see Kebethluk.

Ki-ra-targ-ga-roak, native village; see Kikiktak.

Kirbas; island, immediately south of Spruce island, of the Necker group, Sitka sound, Alexander archipelago. So called by Vasilief, 1809.

Kirilof; bay, indenting the northern shore of Amchitka island, Rat Island group, western Aleutians. So named by Ingenstrem, 1830. Has been written Kirilovskaia, Kirloff, etc.

Kirinskaia, creek; see Sawmill.

Kirk; creek, Seward peninsula, flowing into Spafarief bay from the west, near latitude $66^{\circ}$, longitude $162^{\circ}$. Local name, reported by Witherspoon, 1903.

Kirk; point, the northern point of Foggy bay, Revillagigedo channel, Alexander archipelago. So named by Nichols in 1883. The point is almost an island at high water and in the Coast Pilot of 1883 was called an island.

Kirushkin; island, southwest of Japonski island, Sitka sound, Alexander archipelago. Named Kiriushlkin (smelt) by Vasilief, 1809.

Kiryarzark, river; see Kigezruk.

Kishnak, cape; see Seal.

Kishtak, point; see Martin point and Martin islands.

Kiska; harbor, indenting the eastern shore of Kiska island, Rat Island group, western Aleutians. Named Kyska by Dall, 1873.

Kiska; island, one of the principal islands of the Rat Island group, western Aleutians, near east longitude $177^{\circ} 30^{\prime}$. Perhaps this is St. Stephen island of Bering in 1741. Kiska or Keeska is, according to Dall, the Aleut word for gut. Variously written Kiksa, Kishka, Kyska, Küska, Kysa, etc., and often Great or Big Kiska to distinguish it from Little Kiska, near by.

Kismaliuk, bay; see Alimuda.

Kismit; creek, tributary to the Susitna on the left, about 17 miles above the mouth of Deshka river, near latitude $62^{\circ}$, longitude $150^{\circ} 05^{\prime}$. Indian name obtained by Learnard, of Glenn's expedition, 1898, and written Kismitno, i. e., Kismit river.

Kisselen; bay, at the head of Beaver bay, Unalaska, eastern Aleutians, near longitude $166^{\circ} 35^{\prime}$. Sarichef, 1792 , gives its Aleut name as Kisselen, but Veniaminof has Kissialiak. The Fish Commission, 1888, called it Worsham bay.

Kita; islet, in the southeastern part of Sitka sound, Baranof island, Alexander archipelago. Named Kita (whale) by Vasilief, 1809.

Kitagutak, island; see Ukolnoi.

Kitchaheeyah, river; see Kichaiak.

Kitchen; anchorage, in Belkofski bay, Alaska peninsula. So called by the Fish Commission in 1888.

Kitchikan, village; see Ketchikan.

Kite; island, in Boca de Quadra, near Vixen bay, southeastern Alaska. So named by the Coast Survey in 1891.

Kithraum; bay, lakes and stream, at the head of Dora bay, Cholmondeley sound, Alexander archipelago, near latitude $55^{\circ} 10^{\prime}$, longitude $132^{\circ} 15^{\prime}$. So named because "the stream is claimed and fished by an Indian, Kithraum." Reported by Moser, 1897.

Kitkoon, bay; see Kitkun.

Kitkuk, cape; see Scotch Cap. 
Kitkun; bay, indenting the south shore of Cholmondeley sound, Clarence strait, southeastern Alaska, near latitude $55^{\circ} 10^{\prime}$, longitude $132^{\circ} 10^{\prime}$. Written also Kitkoon. Native name, reported by Brooks, 1901.

Kitovi, island; see Whale.

Kitovi, point, St. Paul island; see Whale.

Kitovi; rookery (seal), near Whăle point, southern shore St. Paul island, Bering sea, near longitude $170^{\circ} 15^{\prime}$. Russian adjective, whale, written Ketavie by Elliott in 1872-74.

Kittens (The); two rocky islets, in the southern end of Lynn canal, near Funter bay, Admiralty island, Alexander archipelago. So named by Mansfield, 1890 :

Kittiwake, island; see Whale.

Kittschunstalk, hills; see Kechumstuk.

Kiugaarzruk, river; see Kigezruk.

Kiugilak; cape, on the southwestern shore of Great Sitka island, Andreanof group, middle Aleutians. Native name, apparently from North Pacific exploring expedition, 1855 , which wrote it Kiougilakh.

Kiukpalik; island, in the northeastern part of Shelikof strait. Native name from the Russians. Russian Hydrograpbic chart 1378, edition of 1847, has phonetically U-kai-yūkh-pal-iek, and Tebenkof, 1849, Kai-yukìpal-ik. It has appeared as Kaiuklipalik (1868), Kiukhpalik (1869), and Kiukpalik (1886).

$K i-u l-u k$, river; see Bonanza.

Kiunil; river, of doubtful existence, an affluent of the Yentna on the right, between the Skwentna and Kichatna, near latitude $62^{\circ}$, longitude $151^{\circ} 20^{\prime}$ Indian name, obtained by Ferron, 1899, who wrote Ki-un-ik.

Kivalenag-miut, cape; see Seppings.

Kivalina; river, of northwestern Alaska, debouching on the Arctic coast between Point Hope and Cape Krusenstern, near latitude $78^{\circ}$. Eskimo name, written by Stoney (1886) Kuveleek, by the Coast Survey (1890) Kevuleek, by Jarvis (1897). Kivalena. For the rest it has been written Kevulik, Kiveleena, Kivelow, Kiv-a-linyab, Kivilenya, etc.

Kivavak, bay; see Kiavak.

Kiveleena, river; see Kivalina.

Kivelow, river; see Kivalina.

Kiviarzruk, river ; see Kigezruk.

Kivvichaval, river; see Kvichivak.

Kivilenya, river; see Kivalina.

Kiwalik; mining camp, near mouth of Kiwalik river, on the south shore of Kotzebue sound, Seward peninsula. A post-office, Keewalik or Keewalick, was established bere in 1902 .

Kiwalik; mountain (2,440 feet high), Seward peninsula, west side of Kiwalik river, latitude $65^{\circ} 30^{\prime}$, longitude $162^{\circ} 08^{\prime}$. Local name, reported by Witherspoon, 1903.

Kiwalik; river, on Seward peninsula, tributary to Spafarief bay, Kotzebue sound, near longitude $162^{\circ}$. Eskimo name, published by the British Admiralty as early as $\mathbf{1 8 8 2}$, and probably earlier, as Kee-wa-lik. Written also Keewalick and Kewalik.

Kiyavak, bay ; see Kiavak.

Kiyiktuk; Eskimo village, northwest coast Seward peninsula, on or near Shishmaref inlet. Native name, reported to the Bureau of Education in 1900 , by W. T. Lopp, of Cape Prince of Wales, and written by him Keyiktuk.

Bull. $299-06 \mathrm{M}-24$ 
Kiyiliengaimute, native village; see Kaialik.

Kizhuchia; small stream, on the northern shore of Redoubt bay, Baranof island, Alexander archipelago. So called by Vasilief, 1809.

Kizhulil, bay; see Kujulik.

Kizhunak, river ; see Kasbunuk.

Kizhuyak; bay, indenting the northern shore of Kodiak and opening into Marmot bay. Named Shakmanof or Kizhuyakskaia by Murashef, 183940. Called Kizhuyak by Tebenkof, 1849.

Kizhuyak; cape, the western point of entrance to Kizhuyak bay, on north shore of Kodiak. Named Kizhutskoi by Murashef in 1839-40. Called Kizhuyak by Tebenkof, 1849. •

Klihalfel, village; see Kaltag.

Kkhulakh, point; see Kulak.

Klack-cet, river; see Klakset.

Kladbitsha, cape; see Graveyard.

Klaheela, river; see Klehini.

Klahini; river, tributary to Burroughs bay, Behm canal, Alexander archipelago. Native name, from the Coast Survey. Variously written Clahona, Klaheena, Klahena, etc., i. e., Kla river.

Klak; creek, tributary to Kanektok river from the south, about 40 miles east of Kuskokwim bay. Native name, obtained by. Spurr and Post, of the Geological Survey, 1898.

Klakas; inlet (unexplored), indenting Prince of Wales island and opening into Cordova bay, Alexander archipelago. Native name, from Moser in 1897. It may be identical with Tliakek bay of earlier maps.

Klakas; lake, in the southern part of Prince of Wales island, Alexander archipelago. Native name, from Moser, 1897.

Klakset; river, tributary to the Yukon on the right bank 10 miles below Nulato. Native name written Klack-cet on Edwards's Track chart of the Yukon, 1899.

Klakwan, village; see Klukwan.

Klamaskwaltin; native village, on the north bank of Yukon river, near the mouth of Kaiyuh slough. Native name Klamasqualttin, from the Coast Survey, 1898.

Klan; hill, on Sitklan island, Dixon entrance, southeastern Alaska. Native name being part of the word Sit-klān, reported by Nichols and published in 1889.

Klanachargut, creek; see Minook.

Klanakakat, creek; see Minook.

Klanooshana, river; see Ray and Chetaut.

Klatahina; river, tributary on the right bank of the Yukon at Nulato. Indian name, written Klatahenah by Cantwell, 1900. This may be the same as Klatkahatna, which see.

Klatassin, river; see Klotassin.

Klatena, river; see Klutina.

Klatkahatna; river, a little tributary of the Yukon from the northwest at Nulato. Written Klat-kahatna or "Stop a bit" river by Cantwell, 1900. See also Klatabina.

Klatsuta; river, tributary to the Yukon from the soutb, about 25 miles below the mouth of Tozi river. Native name, reported by Raymond (1869) as Klatsutachargut, by Petrof (1880) as·Klatsutachakat, and by Allen as Klatsutakakat, i. e., mouth of Klatsuta river.

Kla-u-ish-na, river; see Ray and Chetaut. 
Klawak; island, in Klawak inlet, near Klawak village, Prince of Wales archipelago. Local name, reported by Moser, 1897.

Klawak; inlet, opening into Bucareli bay, Prince of Wales archipelago, near latitude $55^{\circ} 30^{\prime}$. Corruption of some native word, obtained by the Russians. Variously written Klawack, Klawok, Kliavakhan, Tlevakh, Tlevak, etc., and erroneously Kiawak.

Klawak; lake and stream, falling into Klawak inlet from the east near Klawak village. Local name, from Moser, 1897.

Klawak, passage; see Dry pass.

Klawak; post-office and village, ou Klawak inlet, Prince of Wales archipelago. Variously written Klawock, Kliawak, Kliavakhan, Kiawak, Tlevak, Tlewalk, etc. Corruption of some native word, obtained by the Russians. The post-office here, Klawock, was established in February, 1884.

Klawak; reef, at entrance to Klawak inlet, Bucareli bay, Prince of Wales archipelago. So named by Moser, 1897.

Klawasi; river, tributary to Copper river, from the east, near Copper Center. Native name from Allen, 1885, who wrote it Klawasiná, i. e., Klawasi river. Has also been written Klawasena.

Klchakuk; 1Eskimo village, on the eastern shore of the Kuskokwim bay, just north of Goodnews bay. Sarichef, 1826 , has at this place the words Kchakuk bay, though no bay is shown. Petrof, 1880, shows a village which he calls Klchangamute or Kl-changamute, i. e., Klchank people.

Kleguchek; Eskimo village, on the right bank of Kuskokwim river, at its mouth. According to Spurr and Post, who obtained this information from missionary J. H. Kilbuck, 1898, its native name is Klegutshégamut, i. e., Kíleguchek people.

Klehini; river, tributary to the Chilkat from the west, in latitude $59^{\circ} 24^{\prime}$. Native name, reported by United States naral officers in 1880 as Kluheeny. Krause, 1882, spelled it Tlehíni. It has also appeared as Klaheela. The above form, Klehini, has been adopted by the Canadian Board on Geographic Names. Perbaps the same word as Klahini, which see.

Kletekhlinik; mountains, southeast of Skwentua river, near latitude $61^{\circ} 40^{\prime}$, longitude $152^{\circ} 45^{\prime}$. Indian name from Herron, 1899, who wrote it Clate-ech-li-nich.

Kletsan; creek, flowing northward to White river, near longitude $141^{\circ}$. Native name, reported by Hayes in 1891 as Klet-san-dek, or Copper creek, the termination dek meaning creek.

Kliarkof; island, one of the Siginaka group, Sitka sound, Alexander archipelago. Named Kliarkof (Clark) by Vasilief, 1809.

Kliavakhan, inlet and village; see Klawak.

Klihatalik; Eskimo village, western Alaska, on or near the headwaters of Anvik river. Native name, publisbed in 1905.

Klikalklik, island; see Latouche.

Klinch.ef, peak; see Kliuchef.

Klinkwan; Haida Indian village, near Hunter bay, Cordova bay, Alexander archipelago. Native name, from Moser, 1897.

Klinkwan; Haida Indian village, on the western shore of Long island, Cordova bay, Alexander archipelago. Native name, called Klinquan in the Eleventh Census, 1890, and Koianglas village by Sheldon Jackson in 1880.

Kliskon; mountain (3,830 feet high), northwest of Cook inlet, on the left bank of Yentna river, neaf latitude $62^{\circ} 25^{\prime}$, longitude $151^{\circ} 45^{\prime}$. Native name, obtained by Herron, 1899, who wrote it Tlis-kon. 
Kliuchef; mountain, near Hot Springs bay, Baranof island, Alexander archipelago. Named Kliuchevaia (hot springs) by Vasilief, 1809. Has been called Kliucheff or Springs mountain, a name recently transferred to another near-by peak and spelled Klinchet. Erroneously, Klinchef.

Kliuchef; volcano, in the northern part of Atka, middle Aleutians. Named Kliuchevskaia (springs) by the Russians, says Lutke, on account of the large number of warm springs on its western slope. Variousiy written Klioutchevskoi, Kljutschewskoj, etc.

Klochkof; rock, 2 or 3 miles eastnortheast (by compass) from the eastern end of Amlia island. Named after the pilot of the Russian-American company's ship Chirikof, who discovered it in 1818. It is Siuvich (sea lion) rock of the natives. A manuscript note in Davidson's copy of Sarichef's atlais indicates a rock awash here. The pilot Ingenstrem denies the existence of this rock.

Klokachef; island, at the northern point of entrance to Salisbury sound, Alexander archipelago. Name apparently first ised on British Admiralty chart 2337. . Has also been called Fortuna island and vincent island. Klokachef is a Russian family name.

Klokachef; point, the southwesternmóst point of Klokachef island, Salisbury sound, Alexander archipelago. So named by Vasilief, 1833. Has alsa. been called Olga point.

Klokachef, sound, see Salisbury.

Klokerblok; river, tributary to Niukluk river from the west, Seward peninsula. The local rendition of some native name, which is variously written Klokblok, Kluchablok, Kucheblok, Cushaback, etc.

Klondike; gold district, and river, tributary to the Yukon, from the east, near latitude $64^{\circ}$. This river was named Deer river by the Western Union Telegraph expedition in $\mathbf{1 8 6 7}$, and so appeared on various maps. Later it was called Raindeer and afterwards Reindeer. Ogilvie, writing September 6, 1896, from Cudahy, says: "The river known here as the Klondike;" and in a footnote says: "The correct name is Thron Duick." It has also been called Clondyke and Chandik or Deer.

Kloquán, village; see Klukwan.

Klotassin; river, tributary to the White, from the east, near latitude $62^{\circ} 30^{\prime}$. Native name, reported by Hayes in 1891. The above form, Klotassin, has been adopted by the Canadian Board on Geographic Names.

Kltagutan, lake; see Yanert.

Klu; river, tributary to the Chakina from the west. Apparently so called by the prospectors.

Kluane; lake and river, flowing therefrom to the Donjek river, near latitude $61^{\circ} 30^{\prime}$. Native name, reported by Hayes, in 1891, as Kluantu river, the termination tu meaning river. The name has also been written Kluahne. The above form, Kluane, as applied to both lake and river, has been adopted by the Canadian Board on Geographic Names. This is, doubtless, the lake called by Glave (Century, October, 1892, p. 877) Tloo Arny. Possibly, also, this may be Ta-ku-ten-ny-ee of Davidson.

Kluantu; see Kluane.

Kluchablok, river; see Klokerblok.

Kluchev, bay: see Hot Springs.

Kluchev, lake; see Deep.

Kluklats; small lake, 12 miles southwest of Lake Minchumina, near latitude $63^{\circ} 45^{\prime}$, longitude $152^{\circ} 15^{\prime}$. Indian name obtained by Herron, 1899 , who wrote it Klu-klats-o-domino and Klu-klats-o-dom-ino-mino or mina signifies lake. 
Klukwan; village, near the mouth of Chilkat river. Native name, said to mean the old town and first reported by naval officers, in 1880, as Chilkat or Klukquan. Krause, 1882, calls it Kloquán. Has also been written Klakwan. The above form, Klukwan, has been adopted by the Canadian Board on Geographic Names.

Klumma Gutta, glacier; see Taku.

Klumu Gutta, glacier; see Taku.

Klutina; glacier, extending from Valdez summit down inland to the headwaters of Klutina river. Native name, which has generally been written Kilutena.

Klutina; lake, about 40 miles north of Valder, Prince William sound. Native name, adopted by the several hundred earliest prospectors camped at the lake in the season of 1898 ; has also been called Abercrombie lake. Generally written Klutena.

Klutina; river, draining from Klutina lake, northeastward to Copper river. Native name, reported by Allen, 1885 , as Klatená, i. e., Klati river. Generally written Klutena.

Klutlan; glacier and river, draining from it northward to White river in longitude $141^{\circ}$. Native name, reported by Brooks in 1899 .

Kluvesna; creek, tributary to the Kotsina, from the north, draining from Kluvesna glacier. Native name, from manuscript map made by prospectors in 1900.

Kluvesna; glacier, on southern flank of Mount Wrangell. Native name, from the prospectors, 1900 .

Knakatnuk; Indian village, on the northern shore of Knik arm of Cook inlet. Native name, reported by Petrof in 1880.

Knapp, glacier, on Chilkat river. So named by the Leslie expedition in 1890, after the governor of Alaska.' Not found on any map.

Knecktakimut, village; see Chiukak.

Kneep, arm, river, etc. ; see Knik.

Knetena, river; see Nadina.

Knight; island, in Yakutat bay, southeastern Alaska, near latitude $59^{\circ} 43^{\prime}$, longitude $139^{\circ} 34^{\prime}$. So named by Vancouver, 1794. It is Dalnie (distant) island of Tebenkof, 1849. Has also been written Dalni.

Knight; island, in the western part of Prince William sound. Named Knights island by the Coast Survey in 1869 .

Knight Island; passage, between Knight island and the island next north, Prince William sound. Local name, reported by Grant, 1905.

Knik; arm, river, village, and post-office at the head of Cook inlet. Knik is the Eskimo word for fire. 'It has been printed Kinik, Kneep, Knick, Knnik, Kook, Knuyl, Kweek, etc. The post-office was established in June, 1905.

Kniktag-mint, village; see Ignituk.

Knob; mountain (4,250 feet high), near the eastern bank of Stikine river. So , named by the Coast Survey in 1895 .

Knolls, The; see Nichols.

Knot; point, the most southerly of the two points at the northeast end of. Haw-

- . kins island, Prince William sound, Gulf of Alaska, near latitude $60^{\circ} 35^{\prime}$, longitude $145^{\circ} 43^{\prime}$. So named by Moser, 1897 .

Knowles; creek, tributary to the Koyuk river from the north, Seward peninsula. So called by Peters, 1900.

Knowles; head, on the northeastern shore of Prince William sound, near lati- tude $60^{\circ} 41^{\prime}$, longitude $146^{\circ} 35^{\prime}$. Local name, reported by Moser, 1897. 
Knox; peak, in the Teocalli mountains, near headwaters of the Kuskokwim. So named by Spurr and Post, 189S.

Knuyk, arm, river, etc.; see Knik.

Kobakof; bay, on the southern coast of Atka, middle Aleutians. So named by the Russians. Called Kobakotshaia on Russian Hydrographic chart 1400.

Kobolunuk; Eskimo village or camp, on the right bank of the Yukon, 9 miles below Andreafski, about longitude $163^{\circ} 30^{\prime}$. Eskimo name, from Putnam, 1899, who wrote Cobolunuk.

Kobuk; river, northwestern Alaska, near the Arctic circle, tributary to Hotham inlet, Kotzebue sound. Eskimo name meaning big river and first written Kowuk by John Simpson in 1850; Dall, 1870, wrote Kowak, and Petroff, 1880, Kooak. Thoroughly explored by Stoney, 1883-1886, who wrote the Eskimo name Ku-buck, but suggested that it be called Putnam river in honor of Master Charles Flint Putnam, U. S. N., officer of the Rodyers who was carried to sea on the ice and lost in 1880 . Cantwell, who made hasty explorations of the river in the summers of 1884 and 1885 , put Koowak on his map and Kowak in his text. Allen, 1885, got the Koyukuk Indian name wbich he wrote Holoöatna, Holöatná, etc.; he wrote the Eskimo name Kowuk. It has also been written Kubuk, and Kuvuk. Now known generally to the miners, prospectors, traders, and missionaries as Kobuk river and the U. S. Board on Geographic Names has adopted that form.

Kochlogamute, Eskimo village; see Kokok.

Kochla, bay; see Kaflia.

Kochu; island ( 150 feet high), in .Chilkat inlet, Lynn canal, southeastern Alaska. Named Kochu by Lindenberg, 1838. It is Ventosa island of Meade in 1868. The native name is said to. be Gla-hūts, but the Krause brothers, 1882, report the native name to be Jachlanissa.

Kochuitno; Learnard, of Glenn's expedition, 1998, gives this as the Indian name of a tributary from the left to the Susitna, but is uncertain as to its location.

Kodiak; large island near Cook inlet: Discòvered by Stephen Glotof, a Russian fur liunter, who anchored in Alitak (Kaniat) bay, in the southwestern part of the island, on September 8, 1763. He learned from the natives that the island was by them called Kikhtak. (Banc. Hist., 141, 145.) Kíkhtŭk is the Innuit word for island. (Dall's Alaska, 532.) Petrof (Banc. Hist., 224) says: "Kikhtak or Kikhtowik is the Innuit word for island. At the present day (1886) the natives of the peninsula speak of the Kodiak people simply as Kikhtagamutes, islanders. The tribal name appears to have been Kaniag, and the Russian appellation now in use was probably ,derived from both." Martin Sauer, who wrote the account of Billings's expedition, 1785-1794, says (p. 174) : "Shelik of has called this island Kichtak as the original name of it, in which, however, he is mistaken, for Kichtak or Kightak is merely an island; they call the Trinity island Kightak Sichtunak, thus, Kightak Kadiak; and to my astonishment one of them called Alaska a Kightak or island." Cook in 1778 got the name Kodiak from the Russian Ismáilof (II, p. 504). This spelling was followed by Meares (1788), Vancouver (1794), and Langsdorf (1804), who has Kodiak, Kadjak, or Kuktak, i. e., Great Island (II, p. 58). The British Admiralty charts $260,278,787,2172,2460$, and 2558 followed the spelling Kodiak. Sauer, about 1790, has Kadiak (Billings's voyage, pp. 168-170), and so also 
Kodiak-Continued.

has Lutke, 1836 (Naut. part, p. 268). Dixọn, 1789, has Kodiac and Codiac (p. 145) ; Lisianski, 1804, has Cadiack. At the time of the purchase of Alaska the form Kodiak (pronounced Kód-dy-ak) was in.general use among Euglish speaking people, and the same form, Kodiak (pronounced Kăd-yák), was in general use among the Russians. Dall (Alaska, p. 529) says: "The Russian $O$ when not accented should be rendered in English by A; from the neglect of this (comes) Kódiak insend of Kadiák." Also, at p. 532, he says: "Kadiăk.-The name of the largest island south of Aliaska. It is a derivative, according to some authors, from the Russian Kídia, a large tub; more probably, however, it is a corruption of Kaniag, the ancient Innuit name. The inhabitants, according to Coxe, called themselves Kaniagist or Kaniagmut. This name is almost invariably misspelled by linglish authors as Kodiak, Codiac, Codiack, Kadiack, and in other similarly absurd ways. The above is the only correct spelling." Martin, 1904, was told by the Russian Alaskans that it is derived from the Aleut word for sea gull, which it resembles closely. The speliing of this name was submitted to the Board on Geographic Names in 1890 and the form Kaldiak adopted. Local usage has, however, remained Kodiak, both in form and pronunciation, while the pronunciation $K \hat{a}-d y-a k$ is often heard from the lips of those who have learned the name, not from hearing it, but from the printed page. Moser, in Report of the Fish Commission (1899, p. 19), says: "Though the present approved spelling of the name of this island is Kadiak, the company retains the former spelling Kodiak." The Board has therefore receded from the position taken in 1890 and adopted Kodiak. Martinez and Lopez de Faro in 1788 named the island Florida Blanca.

Kodiak; post-office at Kodiak village, established in August, 1888.

Kodiak; rock, near the entrance to St. Paul harbor, Kodiak. Named Kadiak by the Coast Survey.

Kodiak; town, on Kodiak island, one of the principal towns of Alaskit. The first Russian settlement on Kodiak was made by Shelikof at Three Saints bay. In or about 1792 the settlement was removed to this place, which was named St. Paul. It is popularly known as Kodiak. The post-office Kodiak was established here in August, 1888. In the Eleventh Census (p. 74) it is stated that "The place was selected as a central station and headquarters of the Russian fur-trading companies in the year 1789 on account of its good harbor and the close vicinity of good building timber. Previous to the establishment of New Archangel, or Sitka, on its present site, Kadiak was also the headquarters of the Russian-American Company. The Russians gave it the name of Parlovsky gavan (Pavlof's, i. e., Paul's harbor). and the natives and creoles of the island speak of it to the present day simply as gavan, or the harbor. The canonization into St. Paul is the result of faulty translation by our map makers."

The above is not wholly borne out by the record. The Russian Lisianski, on his map of 1805 , published in 1814, has St. Paul. Pavlof is the Russian for Paul: Early Russian charts have Pavlovski gavan, but Tebenkof, 1849, has gavan St. Pavla.

Kodogh; ravine, draining into Garden cove, southeast shore St. George island, Bering sea, near longitude $169^{\circ} 30^{\prime}$. Aleut word meaning gulch, written Ko' $\bar{o}^{\prime}$ ōgh by Putnam in 1897. 
Kogerchtek; Eskimo village, Yukon delta, on the western shore of Lake Koggan, visited by Jarvis, 1897, and by him written Kogerchtehmute.

Koggan; lake, in the Yukon delta, the source of Manopiknak river, near latitude $61^{\circ} 30^{\prime}$, longitude $163^{\circ} 30^{\prime}$. Eskimo name from Jarvis, 1897.

Kogish; mountain, on Prince of Wales island, Alexander archipelago, near latitude $55^{\circ} 42^{\prime}$, longitude $133^{\circ} 10^{\prime}$. Named by Dickins, $1903-4$, after an Indian chief who formerly lived at Tuxekan.

Kogiukhtuli, creek; see Swan river.

Kogiung; Eskimo village, at mouth of Kvichak river, Bristol bay. Native name reported, 1880, by Petrof, who spelled it Koggiung.

Kogok; river, debouching into Norton sound, about 1.5 miles southwest from St. Michael, near latitude $63^{\circ} 15^{\prime}$. Native name, obtained by the Coast Survey in 1898.

Kogoluktuk; river, northwestern Alaska, tributary to Kobuk river from the north, near latitude $67^{\circ}$, longitude $156^{\circ} 45^{\prime}$. Eskimo name written Kogo-luk-tuk by Stoney, 1885. El-yog-o-Iok-tok or Rocky river, of Cantwell, 1885 , is probably this one. It has been called Koguluk.

Kogrukluk; river, the middle fork at the head of Chulitna river, a south branch of the Kuskokwim, near longitude $157^{\circ}$. Eskimo name from an unpublished map made by W. R. Buckman, a prospector, in the winter of 1902-3. He wrote it Ko-gruk-luk.

Koguluk, river; see Kogoluktuk.

Kogweamnit; Eskimo village; see Eluktuk.

Kohlllux, village; see Koklux.

Kohlsaat; peak, in the Tordrillo mountains, near headwaters of the Kuskokwim. Named by Spurr and Post, 1898, after the Chicago newspaper man. Erroneously Kolsaat.

Koianglas, village; see Klinkwan.

Koichak, river ; see Kvichak.

Koidern; river, tributary to the white river from the south, near longitude $140^{\circ}$ $30^{\prime}$. . Native name, reported by Hayes, 1891.

Koikpak, river; see Koyuk.

Kok, rivèr, Arctic coast; see Kuk.

Koka; islet, in southeasteru part of Sitka sound, Baranof island, Alexander archipelago. A Finnish family name, applied by Vasilief in 1809.

Kokachatna, river; see Hogatza.

Kokachutna, river ; see Hogatza.

Kolkhla, bay; see Kaflia.

Kokhluk; slough or channel, Yukon delta, at the mouth of Kwikpak pass, near latitude $63^{\circ} 07^{\prime}$, longitude $164^{\circ} 32^{\prime}$. Eskimo name, written Kochluk by Putnam, 1899.

Kokhtuli, river ; see Kakhtul.

Kokinhenik; Indian village, island and slough, in Copper River delta, near latitude $60^{\circ} 20^{\prime}$, longitude $145^{\circ} 03^{\prime}$. Indian name, or possibly an Indian's name, reported by Moser, in 1897, as Coquenhena; Ritter, 1898, wrote. Kokinhenic and Kokin Henik.

Kolla, bay; see Kaflia.

Koklux; astronomical station, near Klukwan, Chilkat river, southeastern Alaska, occupied by Davidson, August 7,1869 , as a solar eclipse station, latitude $59^{\circ} 24^{\prime}$, longitude $135^{\circ} 53^{\prime}$. Native name from Davidson, who wrote it Kohklux.

Koko; Eskimo village, on the right bank of lower Yukon river, a little below Ikogmut. Name published by the Coast Survey, in 1898, as Kochkomut, i. e., Koko people. 
Kokok; Eskimo village, on the right bank of lower Yukon river, nenr the YukonKuskokwim portage and longitude $161^{\circ} 15^{\prime}$. Native name, from Raymond, 1869, who wrote it Kochkogamute, i. e., Kokok people. Has also been written Kaghlaghamute.

Kokolik; river, on the Arctic coast, debouching in the lagoon just back of Point Lay, near latitude $69^{\circ} 45^{\prime}$. Eskimo name from Jarvis, 1898. Collier, 1904, says he was given the name Kepizetka for this stream by the Eskimos about Cape Lisburne.

Kokolik; Eskimo settlement, at Point Lay, Arctic coast, near latitude $70^{\circ}$. Name published by the Coast Survey in 1899.

Kokomo; creek, in the Fairbanks region, tributary to Chatanika river from the south, near latitude $65^{\circ} 10^{\prime}$, longitude $147^{\circ} 10^{\prime}$. Local name, reported by Gerdine, 1903.

Ko-kon-hee-ni, river; see Kokanhini.

Kokrines; landing, trading post, and telegraph station, on the right bank of Yukon river, midway between the mouths of the Tanana and Koyukuk. near latitude $64^{\circ} 50^{\prime}$, longitude $154^{\circ} 50^{\prime}$. Local name, written variously Kokrines, Korkrines, Kolirine, Kokrein, Kokrine Station, Cochranes, and Kockrine. This seems to be at or near the location of Hakorcins, new station, of earlier maps.

Koksetna; river, southwestern Alaska, tributary from the north to Chulitna river, a tributary on the west side of Lake Clark. Indian name, published in 1905 .

Kolisulitapaga, creek; see Casadepaga.

Kolkiket; mountain, northwest of Togiak lake, in the Ahklun range. Native name, from Post, 1898, who wrote it Kolchichet. Not shown on any map.

Kolmakof; an old Russian trading post and stockade or redoubt, on the north bank of the Kuskokwim, about 200 miles above its mouth. Ivan Simonson Lukeen, a Russian creole, ascended the Kuskokwim in 1832 to this place, where he built a stockade, which was for a time known as Lukeen's fort. In 1841 it was partially destroyed by the Indians with fre, whereupon it was rebuilt by Alexander Kolmakof and took his name. Variously known since as Kolmakof redoubt, Kolmakorski, etc.

Kologho; bight, southwest of Garden cove, southeastern const St. George island, Bering sea, near longitude $169^{\circ} 32^{\prime}$. Aleut name, meaning choleed or full, written Kōōōghō by Putnam in 1897, who says that it is also called "Drăvnoí (Russian, wooded)" probably Drovyenoi (of firewood).

Koloshanka, river; see Indian.

Kolosh; island, in Flot Springs bay, Sitka sound, Alexander archipelago. So named by Vasilief., 1809.

Koloshian; island, one of the Siginaka group, Sitka sound, Alexander archipelago. Named Koloshenkin (Koloshian) by Vasilief, 1809.

Koloshshoi, cape; see Escape.

Kolsaat, peak; see Kohlsaat.

Kolumalkturuk, village; see Kilimantavie.

Komarof. Nelson, in 1878, shows a village bearing this name in the Yukon delta, near Kotlik. It is not shown on recent maps.

Komtok Hon, port ; see Frederick.

Konaton; river, tributary to the Yukon, from the north, a little above the mouth of Yuko or Soonkakat river. Name from Dall, 1869, who wrote it Konaton. Neither name nor river found on recent maps.

Konega, island; see Kanaga.

Konetz, point; see Dalnoi. 
Kongiganak; Eskimo village (of about 175 people in 1878 ), on north shore of Kuskokwim bay. Visited by Nelson in December, 1.878, and its native name reported by him as Kongiganagamiut, i. e., Kongiganak people.

Kongik; Eskimo village, on the Buckland river, Seward peninsula, reported by Petrof, 1880, as Kongigamute, i. e., Kongik people. The river, on which is this village, the Eskimos are said to call Konguk, Kunguk, or Kongak. Bartholf reports, 1898 , an abandoned village at the mouth of Buckland river called Inuktut by the Eskimos.

Konglah; old village site, on west end St. Paul island, Bering sea, near longitude $170^{\circ} 25^{\prime}$. Aleut name, from Elliott, 1872-74.

Kon-gon-wik, river; see Hunt.

Konguk, river; see Buckland.

Konicheskaia, volcano; see Conical.

Konioujii, island; see Big Koniuji.

Koniugi, island; see Big Koniuji.

Koniuji; island (1,113 feet high), off the northwestern shore of Atka, middle Aleutians. So called by the early Russians from the abundance there of crested auks (Simorhynchins cristatellus), called by the Russians Kanoozhki or Kanooskie. The Aleut name of this bird is Kunuliuk. The word Koniuji often apnears and is variously spelled Kaniugi, Koniouji, Koniouzhka, Canooskie, etc. See also Little Koniuji.

Koniuji; islet, in Little Raspberry.strait, between Whale and Kodiak islands. named by Murashef, 1839-40. The name is a corruption of the Aleut name Kun-u-liuk, meaning crested auk. Elliott spells it Canooskie.

Koniuji; strait, between Big and Little Koniuju islands, Shumagin group. Called Koniushi by Dall, 1872.

Konnekova, river; see Clear.

Konniaga, island; see Kanaga.

Konogkelyokamint; landing; see Bill Moores.

Konogtinok, slough; see Kanakalinguk.

Konootena, river and village; see Kanuti.

Konsina, river; see Tiekel.

Konstantina, harbor; see Constantine.

Kontog, island; see Khantaak.

Kooagamutes, villages; see Kobuk.

Kooak, river; see Kobuk.

Koog, river; see Kuk.

Koogrock, mining district, etc.; see Kougarok.

Koogroog, river; see Kugruk.

Kooguru, river ; see Canning.

Kook, bay; see Basket.

Kook; lake and stream, eastern shore Chichagof island, Chatham strait, Alexander archipelago, tributary to Basket bay; near latitude $57^{\circ} 45^{\prime}$. Called Kook (basket) by Moser, 1901. Kook is also the Indian name of Basket bay.

Kook, river; see Knik.

Kookpoowrook, river; see Kukpowruk.

Koolipuk, river; see Kukpuk.

Koolooguck, Eskimo village; see Kuluguk.

Koolvagavigamute, village; see Kulvagavik.

Koonthrashiloona, lake and river; see Kunthrashibuna.

Koopowra, river; see Kupowra.

Koosetrien, river; see Kuzitrin. 
Koot; Eskimo village, near Cape Etolin, Nunivak island, Bering sea. Native name, from the Eleventh Census. Population in 1890, 117.

Kootoark, 'river; see Kutoark.

Kootznahoo; archipelago, head, inlet, roads, and village, Admiralty island, Alexander archipelago. This word comes from an Indian word, Kंhutz$\mathrm{n}^{\prime} \mathrm{hu}$ (bear's fort). 'The totemic symbol of these Indians is a bear. Its obscure and difficult gutturals have produced great diversity of rendering. It has been called Hoochinoo, Hoosnoff, Houchnou, Hudsunoo, Kenasnow; Khutz-n'hu, Kootsnoo, Koutsnou, Kutznou, Koutznow, etc. An island near and the post-office bear the name Killisnoo, another form of this word. See Kenasnow and Killisnoo.

Loourovskaia, bay; see Kovurof.

I ooyak, slough; see Kuiak.

Korga, island; see Crow.

Korium-anyi, lake; see Govorushka.

Korkpowrook, river; see Kukpowruk.

Korkrines, landing, trading post, and telegraph station; see Kokrines.

Koronatsie, island; see Coronation.

Korovin; bay, indenting the northwestern shore of Atka, middle Aleutians. Presumably so named by the Russians, after Ivan Korovin, captain of the trading vessel Trinity, in these waters in 1762 . Written Korowinsky, Korovinskaia, etc.

Korovin; cape, the northern head of Korovin bay, Atka island, middle Aleutians. It is Korovei of Sarichef, in 1790 , and usually Korovinski.

Korovin; island, one of the Shumagin group. Named by the Russians, presumably after Ivan Korovin, one of the enrly Russian explorers, who,

- in command of the $S v$. Troitzkia (Holy Trinity), explored the Aleutian islands in 1762. Also called Korovinskoi and Korovin. The word is from the Russian Koróva (cow).

Korovin; strait, between Popof and Korovin islands, Shumagin group, near longitude $160^{\circ} 15^{\prime}$. Name published by the Coast Survey in 1903 .

Korovin; volcano (4,988 feet high), on the north end of Atka, middle Aleutians. Called Korovinskaia by Lutke about 1830.

Korovinski; deserted native village on Korovin bay, Atka island, middle Aleu. tians. Lutke calls it Nikolskoi. The village now appears to be abandoned, the natives having removed to Nazan bay, across the island.

Kosakuts; river, 20 miles northwest of Cape Yaktag, Gulf of Alaska, a branch of Kulthith river. Native name reported by J. L. McPherson, deputy mineral surveyor, 1903 , who wrote it Cosacoots.

Kosciusko; island, in the northwestern part of Prince of Wales archipelago, near latitude $56^{\circ}$. So named by Dall, 1879.

Kosera-anag, lake, St. George island; see Upper.

Koserefski; Indian village (population 350), on the left bank of the Yukon, near the mouth of Shageluk slough, about latitude $62^{\circ} 10^{\prime}$, longitude $160^{\circ}$. Called Leather village by Dall, 1866 , who reports this to be the Russian usage. Has appeared on various maps as Koserefski, Kosyrof, Kozerevsky, Kozyrof, etc. Holy Cross mission is opposite this place on the right bank.

Koserefsky; post-office, at Koserefski, on the Yukon, established in September, 1899 .

Koshigin, bay; see Kashega.

Koshotok, creek; see Casadepaga. 
Koskvicharok; mountains, on the right bank of the lower Yukon, 20 miles above Andreafski, near longitude $163^{\circ} 50^{\prime}$. Eskimo name, obtained by Putman in 1899.

Kostromitinof; cape, forming the eastern point of entrance to Danger bay, on the southern shore of Afognak island, Kodiak group. So named by Murashef in 1839-40. It is a Russian family name. The United States court interpreter at Sitka at the present time is George Kostrometinoff.

Kosyrof, village; see Koserefski.

Kotachikakat, river; see Kautas.

Ko-tag-lik-ark, river; see Helpmejack creek.

Kotelkakat, river; see Kateel.

Kotelnoi, cape; see Kettle.

Koteosok, harbor. The anchorage at east end of Killisnoo (Kenasnow of Meade) island was so called by Meade, 1869 . Has also been called Koteosok creek. The name appears to be obsolete.

Koteosok, island; see Killisnoo.

Kothlik; island, Yukon delta, at the mouth of Kwikpak pass, near latitude $63^{\circ}$ $07^{\prime}$, longitude $164^{\circ} 32^{\prime}$. Native name, reported by Putnam, 1899. Próbably Eskimo kwūthleek, meaning breeches.

Kotlik; small river, in the Yukon delta, opening on the right bank of Apoon pass, 6 miles above Pastol bay. This with the Little Kotlik openiug at the same point forms the kwu-tleek (breeches).

Kotlik; Eskimo village (population 31 in 1890), at the mouth of Kotlik river, 6 miles upstream from the Apoon mouth of the Yukon. An Eskimo name which, according to Nelson, means, breeches. It was, in 1878 , the fur-trading station for the district, and is still a small trading post. So named to designate the junction of two small streams. Kwī'-tlēk, trousers (Father Barnum).

Kotlo, river; see Preacher creek.

Kotory, islands; see Pribilof.

Kotsechekmaksky, bay; see Kachemak.

Kotsina; river, tributary; to Copper river from the left (east), just above the Chitina, near latitude $61^{\circ} 30^{\prime}$. Indian name, written Katzelena or Katselena by Abercrombie in 1898; written also Katselina. Schrader, 1900 , wrote the name Kotsina.

Kotsolcotana, river; see Buckland.

Kotusk, mountains; see Chilkoot.

Kotzebue; post-office (established in 1903), reindeer station, and Friends' (Quaker) mission, at entrance to Hotham inlet, Kotzebue sound. This is at or near Kikiktak.

Kotzebue; sound, on the northern shore of Seward peninsula, Arctic ocean. Discovered, explored, and named by Kotzebue in August, 1816. $\mathrm{He}$ says: "In compliance with the general wish of my companions, I called this newly discovered sound by my own name, Kotzebue's sound."

Kou, island; see Kuiu.

Kouboughakkhli, cape; see Kubugakli.

Kougarok; mining district and river, tributary to the. Kuzitrin from the north, in western part of Seward peninisula. Eskimo name, variously written Koogrock, Kougrok, Kugrock, Kugruk, Coogrock, etc., from Barnard and Brooks, 1900.

Kougarok; mountain (2,787 feet high), Seward peninsula; on the west side of Kougarok river, near latitude $65^{\circ} 40^{\prime}$; longitude $165^{\circ} 12^{\prime}$. Written Kugruk by Gerdine, 1901. 
Kougarok; mining town, Seward peninsula, on Kougarok river. Written Kugruk City by Gerdine, 1901. A post-office, Kugarok, was established here in July, 1905.

Kougrok, mining district, etc.; see Kougarok.

Koujalik, bay; see Kujulik.

Koujulik, bay ; see Kujulik.

Koukal, bay ; see Kukak.

Koukhat, cape; see Douglas.

Koulagayakh, island; see Kuliugiak

Koulakh, lake; see Kulik.

Koulichkow, bay; see Snipe.

Koulitzkoff, rock ; see Kulichkof.

Koulugmuit, cape; see Kuliuk.

Koumloun, cape ; see Kumliun.

Kousilvak Mouth, pass; see Kwemeluk.

Koutznow, archipelago, etc.; see Kootznahoo.

Kovrizhka; cape, forming the north head of Makushin bay, on the northwestern shore of Unalaska, eastern Aleutians. Sarichef, 1792, called it Hatan, perhaps from the Russian word hat (sea wall or dam), and the Russian Hydrographic charts have Hattan. Veniaminof calls it Ermoshkinskie and applies the name Kovrizhka to another point 12 miles farther south. It is Makushin cape (not Makushin point) of the Fish Commission, 1888. Kovrizbka is Russian for a small loaf or gingerbread cake.

Kovurof; bay, indenting the northern shore of Atka, middle Aleutians. So named by Ingenstrem or Lutke about 1830 . Lutke calls it Koourovskaia. Has also been called Kovurova.

Kowak, river; see Kobuk.

Kowuk, river; see Kobuk.

Kow-e-rok, village; see Kaviruk.

Koyana; creek, west of Golofnin sound, Seward peninsula. Name from Barnard, 1900 .

Koyuk; river, tributary to the head of Norton bay, Norton sound. An Eskimo name, given by Tebenkof as Kvieguk (river big), by the Western Union Telegraph Expedition map as Koikpak (river big), by the Seward map of 1867 as Koipak, and since then as Kayuk, Koyuk, Kuyuk, etc. 'As here used this name applies also to what has been called the Kanguksuk, or Left fork Kviguk (Koyuk). According to Brooks, 1900, this river is now locally known as Koyuk.

Koyuktulik; river, on the north shore of Norton bay, Norton sound, near longitude $162^{\circ} 25^{\prime}$. Eskimo name, reported by Gilbert in 1900 .

Koyukuk; mountain, on the north bank of Yukon river, just below the mouth of Koyukuk river. Called Koyukuk Sopka (peak) by Raymond. 1869. Zane, of Stoney's expedition, who passed it on the way to St. Michael in the winter of 1886, described it as " 5 miles below the mouth of the Koyukuk, 1,500 feet high" (presumably above the Yukon) and called it Be-ne-le-rah-cher (big mountain). On Stoney's map it is written Benelaracher.

Koyukuk; river, tributary to the Yukon from the north, a little above Nulato. Native name, reported by the Russians as Kuiuk and by the the Westeln Union Telegraph expedition, 1867, as Coyukuk. On Coast Survey maps called Kouiak, Koyoukuk, and Koyukuk. By Cantwell, Kuryukuk. According to Stoney, the Kobuk Eskimos call it Tug-ga-rag-ıwick. 
Koyukuk; small trading station of the Northern Commercial Company and telegraph station, on the Yukon, 2 miles below the mouth of Koyukuk river, near latitude $64^{\circ} 50^{\prime}$, longitude $157^{\circ} 40^{\prime}$. Terentief of Petrof was at or near this place.

Kozerevsky, village; see Koserefski and Holy Cross Mission.

Kozian, rock or shoal; see Cozian.

Kozyrof, village; see Koserefski.

Kradigy, hill or rocks; see Fox Castle.

Ir rinie, cape; see Last.

Krakankringa, St. George island; see Garden cove.

Krallegak, village; see Kialagak.

Krasnoi, cape; see Red.

Krasnoi Ribi, islets, etc.; see Redfish.

Krasnoriechnoi, cape; see Red river.

Kravaksarak; Lskimo camp, Yukon delta, on the right bank of Kwikpak pass, 8 miles above the head of Apoon pass, near latitude $62^{\circ} 50^{\prime}$, longitude $164^{\circ} 05^{\prime}$. Native name, reported by Faris, 1899, as Kravaksarakamiut; also written Kravaksarok.

Kravalisarok, pass; see Little Apoon.

Kreegly White, mountains; see Kigluaik.

Krenitzin; cape, the western end of Alaska peninsula, the northeast point of entrance to Isanotski strait, near longitude $163^{\circ} 25^{\prime}$. Named by Lutke, 1828; presumably after Peter Kuzmich Krenitzin, who explored in the Aleutian islands in 1768-69. Variously written Krenitsyn, Krenitzine, Krenytsin, etc.

Krenitzin; group of islands, between Unalaska and Unimak, eastern Aleutians, longitude $165^{\circ}-166^{\circ}$. So called by Tebenkof, prior to 1836 , presumably after Capt. Peter Kuzmich Krenitzin, who explored in this region in 1768. The principal islands of this group are Rootok, Akun, Akutan, Avatanak, Tigalda, Ugamak, and Unalga.

Kresta, cape; see Northwest Shoulder.

Kresta; point, at south end of Krestof island, Sitka sound; Alexander archipelago. Named Kresta (cross) by Vasilief, 1833.

Kresta, sound; see Cross.

Krestof, bay; see Winter anchorage.

Krestof; island, north of Sitka sound, Alexander archipelago. Named Krestof (cross) by the Russians. Krestof is a Russian family name.

Krestof; mountain, on Krestof island, north of Sitka sound, Alexander archipelago. Named Krestofskaia (cross) by Vasilief, 1809.

Krestof; port, indenting the eastern shore of Kruzof island; Alexander archipelago.' Called Mielkoi. (shoal) bay by Vasilief, 1809 . Also called Krestof (cross) very early by the Russians.

Krestof; sound, between Krestof, Kruzof, and Partofshikof islands, just north of Sitka sound, Alexander archipelago. So designated by Moore in 1897 and in recent Coast Survey publications. It constitutes a part of what Portlock, in 1787, called Hayward strait. It was called Krestof (cross) by Vasilief in 1833. Vasilief, sr., in 1809, applied the name Krestof to what is bere called Olga strait. See Hayward and OIga.

Krestofskoi, island; see Guide.

Kretakagamiut, Eskimo village; see Kritakak.

Kreuger; creek, Seward peninsula, tributary from the north to Arctic river, near longitude $166^{\circ} 03^{\prime}$. Prospectors' name, reported by Gerdine, 1901.

Kripniyagok, river; see Kipniyagok. 
Kripniyuk, river; see Black.

Kripniyukamiut, village; see Kipniak.

Krischa; ridge, south of the Takhini river, near. Chilkat inlet, Lynn canal, southeastern Alaska. Native name, is reported by the Krause brothers in 1882.

Krissey, island; see Rat.

Kritakak; Eskimo village, Yukon delta, on a small island in Kwikluak pass, near latitude $62^{\circ} 42^{\prime}$, longitude $164^{\circ} 20^{\prime}$. There is or was a Catholic mission on the right or left bank of the pass at this place. Eskinn

- name, written Kretakagamiut by Putnam in 1899.

Kritskoi; island, one of the Kudobin islands, on the northern shore of Alaska peninsula. So named by Lutke, 1828, who says that this island was erroneously called l'ŝle aux Loups (wolf) on his chart 14 .

Krivoi, island ; see Crooked.

Kriwoi; island, in Yakutat bay, southeastern Alaska. Named Kriwoi (crooked) by Tebenkof, 1849. Also written Krivoi. Has also been called Crooked island.

Krogh; lake, in southern part of Etolin island, Alexander archipelago. So named by snow, 1886 .

Krotahini; pass, between the valleys of Alsek and Chilkat rivers. Name published in the Coast Pilot, 1883.

Krotahini; river, tributary to Alsek river, southenstern Alaska. Native name, reported by the Krause brothers, in 1882, as Krotahini, i. e., Krota river.

Kroto, creek; see Deshka river.

Kroto; Indian village, on the right bank of the Susitna, 33 miles above its mouth, and just below the mouth of the Deshka. Native name, from Muldrow, 1898.

Krugloi; island, in Peril strait, opposite Hooniah sound, Alexander archipelago. Named Krugloi (round) by. Vasilief, 1833 ; by error, Kruoloi.

Krugloi; islands, in Salisbury sound, near entrance to Peril strait, Alexander archipelago. Named Krugloi (round) by Vasilief, 1.833 .

Krugloi, island; see Agattu.

Krugloi, island; see Round.

Krugloi, islet; see Mills.

Krugloi; point, the southernmost point of Halleck islind, north of Sitka sound. Named Krugloi (round) by Vasilief, 1809.

Krusenstern, island; see Little Diomede.

Krusenstern; promontory, constituting the northern point of entrance to Kotzebue sound, Arctic ocean, near latitude $67^{\circ} 08^{\prime}$, longitude $163^{\circ} 40^{\prime}$. So named by Kotzebue, August, 1816, after Admiral Adam Johann von Krusenstern, of the Russian navy. Has been written Kruzenstern.

Krutoi, cape ; see Steep.

Krutoi; island, in Yakutat bay, southeastern Alaska. Named Krutoi (steep) by Tebenkof,. 1849. Erroneously Krustoi.

Krutoi, point, on the western shore of Chilkat inlet, Lynn canal, southeastern Alaska. Named Krutoi (steep) by Lindenberg, 1838. The name is obsolete.

Kruzgamepa; river, on Seward peninsula, flowing into Kuzitrin river, and thence to Imuruk basin, near latitude $65^{\circ} 05^{\prime}$, longitude $165^{\circ}$. Local name, from the Eskimo; written Kruzgamapah or Kiruz-ga-ma-pa. Also sometimes called Pilgrim. Pronounced Ḱrooze-gay-máy-pah. 
Kruzof; island, one of the large islands of the Alexander archipelago, northwest . of Silka. Tebenkof, 1849, calls it by its native name, Tleekh. According to Grewingk (p. 93), Mount Edgecumbe was called St. Lazaro by Juan d'Ayala, in 1775, and the island became afterwards known as San Jacinto (St. Hyacinth). In 1787 Portlock named it Pitt island. Early Russian traders called it Sitka island. Lisianski, in 1805, named if Crooze "after our late Admiral" (p. 221, English edition). Grewingk, 1849, calls it Edgecumb or Krusow island. Kruzof (possessive of Kruze) has been selected and adopted, that being, in some of its variant. forms of Kruse, Krusoff, Kruzoff, Kruzow, etc., more frequently used.

Kruzof; point (Point Kruzof), north shore Kruzof island, Salisbury sound, Alexander archipelago, 1 mile northeast of Cape Georgiana. So named by Moore, 1896.

Kryci, islands; see Rat.

Kshaliuk; cape, on the northern shore of Umnak, eastern Aleutians. Native name, from Kuritzien, 1849.

Kuahroo, river; see Inaru.

$K u$-ah-r $u$, inlet; see Woody.

Kubiesluka, island; see Jug.

Kubugakli; cape, the south point of entrance to Katmai bay, Shelikof strait, Alaska peninsula. Native name, from the Russians. Variously written Kouboughakkhli, Kubugakhli, Kubugachly, etc.

Kubuk, river; see Kobuk.

Kucheblok, river; see Klokerblok.

Kucher; creek, northern Alaska, tributary to Colville river from the south, near longitude $155^{\circ} 15^{\prime}$. So named by Peters and Schrader, 1901.

Kudiakof; islands, in front of Izembek bay, on the northern shore of Alaska peninsula, near longitude $162^{\circ} 45^{\prime}$. The principal islands of the group, from west to east, are Glen, Operl, and Neumann. Tebenkof, 1849, calls them Chimiudi-apparently a native word, the ending uda meaning bay, and chim possibly from chimik-a species of marine fish found there. Dall, in 1882, named these islands Kudiakof, after Kudiakof, the surveyor, who in the autumn of 1791 was sent there from Unalaska in a baidarka by Captain Sarichef. He wintered on Unimak island, and in the following spring made a tour of the island in his baidarka, passing by Sannak and Deer islands. Variously written Chudoekow, Khoudiakoff, Khudiakoff, etc.

Kudobin; a string of low islands bordering the north shore of Alaska penininsula from Port Moller westward, of which the principal ones are Walrus, Kritskoi, and Moller. Called Khudobin by Dall, 1882, after Andrew Khudobin, one of the naval officers of Lutle's party.

Kudobin, peninsula ; see Deer islet.

Kudugnak; cape, the northern head of Nazan bay, Atka island, middle Aleutians. Native name, from Tebenkof, 1849. Has been written Kadugnak and Kudugnake.

Kuearuk; river, tributary to Fish river from the east, north of Golofnin sound; Seward peninsula. Name, from the Eskimo, published in 1900. Also called Right fork of Fish river.

Kue-che-ark, river; sèe Kuikcherk.

Kiue-ga-rack, river; see Kugarak.

Kugachuk, river; see Lane.

Kugalga, island; see Tigalda. 
Kugaluk; INskimo village, on Spafarief bay, Kotzebue sound, Seward peninsula. Population in 1880, 12. According to the Russians, in 1852, its name is Kualiug-miut, and according to Petrof, 1880, it is Kugalukmute, i. e., Kugaluk people.

Kugarak; river, northwestern Aliski, tributary to Selawik river from the north, near the Arctic circle and longitude $159^{\circ}$. Eskimo name, obtained by Stoney, 1886, who wrote Kue-ga-rack. Also written Kuegerak.

Kugarok, post-oflice; see Kougarok.

Kugidach-eIugutscha; see Pogromnoi volcano.

Kugirulkruk, river; see Noxapagil.

Kugrua; river, tributary to the Arctic ocean at the Seahorse islands. Native name, from English naval officers during the Franklin search expedition. Always hitherto has been written Cogrua. According to Murdoch, Kúg'ru is the Eskimo name of the whistling swan.

Kugruk, district, mountain, post-oftice, river, and town ; see Kougarok.

Kugruk; river, draining Imuruk lake and tributary to Kotzebue sound, Seward peninsula, a little east of Cape Deceit. Eskimo name, from Brooks, 1900. Has been written Koogroog, and translated Swan river.

Kugruk, river, Arctic coast of Seward peninsula; see Kugrupaga.

Fugrulkrm, river; see Noxapaga.

Kugrupaga; river, Seward peninsula, emptying into a lagoon on the Arctic coast, near longitude $166^{\circ} 45^{\prime}$. Eskimo name, reported Kugruk by Gerdine, 1.901.

Kuguklik; river, in western Alaska, a little north of Kuskokwim bay. Eskimo name, from Nelson, who crossed its mouth December, 1878.

Kügulik, bay; see Kuzhulik.

Kuguru, river; see Canning.

Kuguwik; Eskimo village, in the Kobuk valley, at the mouth of Kugarak river, just north of the Arctic circle, about longitude $159^{\circ}$. Native name, obtained by Stoney, 1885, and written by him Ku-gu-wik.

Kuiak; slough, about 2 miles southwest of western end St. Michael canal, near St. Michael, western Alaiska, about latitude $63^{\circ} 23^{\prime}$. Eskimo name, from the Const Survey, 1898, who wrote it Kooyak.

Kuik, river and village; see KKwik.

Kuik-anuik-puk; see Kuyikanuikpul.

Kuikcherk; river, northwestern Alaskal, tributary to Kobuk river from the south, near latitude $66^{\circ} 45^{\prime}$, longitude $155^{\circ}$. Eskimo name, so written by Mendenhall, 1901. Stoney, 1885, shows this stream without a name, but a little to the east, where Mendenball and Reaburn show no stream, he indicates one called Kue-che-ark-no doubt meant for the same native name.

Kuikli, village; see Kwik.

Kuilkluk; Eskimo village, on the left bank of the Kuskokwim, about 20 miles above Bethel. Native name, from Nelson, 1878-79, who wrote it Kuilkhlogamute, i. e., Kuilklok people. Petrof gives its population, in 1880, as 75, and its name Kuljkhlugamute in his text (p. 17) and Kuilkhlogamute on his map.

Kuimla, pass; see Krwemeluk.

Kuiu; island, one of the large islands of the Alexander archipelago. Native name, obtained by the Russians. Fas also been called Kou island,

Kuiu, lake and stream; see Alecks.

Bull. $299-06 \mathrm{M}-25$ 
Kuiuk, river ; see Koyukuk.

Kuiukta; bay, northeast of Mitrofania island, indenting the southern shore of Alaska peninsula. Nitive nime, from the Russians.

Kujulik; bay, on the southern shore of Alaska peninsula, immediately east of Chignik bay. Native niame, from the Russians. Pronounced Kee-zhúlik. It is Kizhulik of Tebenkof, 1849 ; has also been written Kaiulik, Koujalik, Kugulik, etc.

Kujulil, river; see Kejulik.

Kuk; river, tributary to Wainwright inlet, Arctic coast. Eskimo name, published by the Coast Survey, 1869, as Kook. Since then given indifferently as Kok or Koo. Hydrographic chart 68, edition of 1892, shows two rivers, one called Koo and the other Kee, and near their mouths, on Point Collie, a villige called Koogmute, i. e., river people. Tikhmenief, 1.861, calls this village Kululin. Koog river of the Eleventh Census maly be either this or Kukpuk river.

Kutia, rock; see Signals (The).

Kukak; bay, west of Afognak, on the northern shore of Shelikof strait. Native name, from early Russian explorers. Sometimes written Koukak. Langsdorf, 1813, wrote it as above, Kukak.

Kukak; Indian village, on Kukak bay. Lutke, 1835, has Koukak bay and village.

Kukaklek; lake, Alaska peninsula, between Iliamna and Naknek lakes; and draining through Alagnak river into the head of Bristol bay, near longitude $156^{\circ}$. Native name, from Tebenkof, 1849. Has been called Aliknuk.

Kukistan; cape, on the eastern shore of Cook inlet. Called Dolgoi (long) or Kukis-tan by Wosnesenski about 1840. Native name. The termination tan appears to mean point or cape.

Kulkan, harbor; see Portlock.

Kuklax; lake, near the water portage, between Yukon and Kuskokwim rivers. Raymond, in 1869, reported its native name as Kuklaxlekuhta-here followed part way: and called Kuklax.

Kukluktuk; Eskimo village, on the left bank of Kuskokwim-river, about 30 miles below Kolmakof. - Name from Petrof, 1880, who writes it Kokhlokhtoklpagamute.

Kukpowruk; river, tributary to the Arctic ocean, between Cape Lisburne and Icy cape, near latitude $69^{\circ} 20^{\prime}$. Eskimo name, published, in 1890 , as Kookpoowrook and Kookpowrook. Kuk in the dialect of the north- western Eskimo means river. It is probable that Kukpaurungmiut of the Eleventh Census refers to some village or people near or on this river.

Kukpuk; river, tributary to Marryat inlet, near Point Hope, Arctic ocean, about latitude $68^{\circ} 20^{\prime}$. Eskimo name, published by the Coast Survey, 1890, as Kookpuk (river big); also called Tigara (the index finger), the Eskimo name of Point Hope.

Kukuliak; native village and cape, on the northern shore of St. Lawrence island, Bering sea. Eskimo name, from Tebenkof, 1849. Erroneously Nukuliak.

Kukuyukuk. Raymond, 1869 , gives this as the name of a small river tributary to the Yukon from the south, about a dozen miles above the mouth of the Koyukuk. Name not found elsewhere.

Kukvak, cape; see Douglas. 
Kulak; point, the southern point of entrance to Tanaga bay, Tanaga island, middle Aleutians. Aleut name, from Tebenkof, 1849, who indicates the initial $\mathrm{K}$ as very hard. His spelling has been transliterated Kchulach; or, as it might be, Kkhulakl.

Kulgial, island; see Kalgin.

Kuliak; cape, west of Afognak island, on northern shore of Shelikof strait. Native name, from the Russians, who write it Kuliak and Kuliakuiak.

Kulichavak, river' see Kvichavak.

Kullichliof, bay; see Snipe.

Kulichkof; islet, east of Near island, in St. Faul harbor, Kodiak. Named Kulichkof (snipe) by the early Russians.

Kulichkof; islet, near the sonthern point of entrance to Kukak bay, Shelikof strait. - Named Kulichkof (snipe) by Vasilief, 1831.

Kulichkof; rock, off Burunof cape, Sitka sound, Alexander archipelago. Named Kulichkof (snipe) by Vasilief, 1809. Has been variously written Koulitzkoff, Kulichek, Kulitch, etc.

Kulik; lake, in the water portage between Yukon and Kuskokwim rivers. Called Kullik by Tikhmenief, 1861, and Koulakh by Raymond, 1.869 . Spurr and Fost, who passed here, 1898, make no mention of this, but call a lake in this vicinity Oknakluk.

Kuliliak; bay, indenting the southern shore of Unalaska, eastern Aleutians. Called by its Aleut name, Kuliliak (sorrow, anguish), by Sarichef, 1792 , and since spelled in many ways, as Kiliuluk, Kouliliak, Kullilak, etc.

Kulitnak, river; see Chulitna.

Kuliugiali. One of the Shumagins, not identified, is so called by veniaminof and Lutke. It is a native word, meaning round and rocky. Lutke writes it Koulagayakh.

Kullugmiut, cape; see Kuliuk.

Kuliuk; cape, between Uganik and Uyak bays, on the northern shore of Kodiak. Native name, from the Russians. Lisianski, 1805 , shows a village here called Koloock. Usually called Kuliug-miut (Kuliuk people) on maps and written Koulugmut, Kulinyemute, Kuliugmiut, Kümelmot, Kumolmot, Kiliugmiut, etc.

Kulkana, town or' station ; see Gulkana.

Kullukuk, bay, lake, etc.; see Kulukak.

Kulthieth, river; see Kaliakh.

Kulugaru, river; see Mende.

Kulugrua, river: see Meade.

Kuluguk; Eskimo village, between Ambler and Noatak rivers, near latitude $67^{\circ} 30^{\prime}$, longitude $156^{\circ} 30^{\prime}$. Visited by Ensign Howard, of Stoney's expedition in the spring of 1886. Stoney wrote it Koolooguck.

Kuluk; bay, indenting the eastern shore of Adak island, Andreanof group, middle Aleutians. Native name, from Tebenkof, 1849. Has also been written Khiulukh.

Kulukak; small shallow bay, indenting the northern shore of Bristol bay, about 35 miles northwesterly from Cape Constantine. Native name, from Tebenkof, 1849, who wrote it Kuliukak. Has also been written Koulóukak, Kouloulak, Kulluk, Kululuk, Kulutuk, etc. To a large open bay outside this bay a late Coast Survey chart applies the name Kululak, written also Kullukuk.

Kulukak; lake, draining to Kulukak bay, on north shore of Bristol bay. Native name, from Tebenkof, 1849, who wrote it Kuliukak. Perhaps this is identical with Oallek lake of Spurr in 1898. 
Kulukak; point, one of the points at entrance to Kulukak bay. Reported by Schanz, 1890, as Kullukuk.

Kululak, bay; see Kulukak:

Kulutuk, bay; see Kulukik.

Kulvagavik; Eskimo village, on the western side of Kuskokwim bay, Bering sea. Visited by Nelson January, 1879, and its native name reported by him to be Koolvagavigamiut, i. e., Kulvagavik people.

Kumelmot, cape; see Kuliuk.

Kumisili, cape and island; see Kumlik.

Kumlik; cape and island, on the southern shore of Alaska peninsula, northwest of Sutwik island. Native name, from the Russians. Erroneously Kumisik.

Kumliun; cape, the northern point of entrance to Chignik bay, Alaska peninsula. Native name, from the Russians. Variously written Koumloun, Kumlium, Kumtiak, etc. It may be identical with Foggy cape of Cook in 1778 .

Kumtiak, cape; see Kumliun.

Kun; river, in the Yukon delta, tributary to the head of Scammon bay, near latitude $61^{\circ} 50^{\prime}$. Native name, written Khun by the Coast Survey in 1898. Dall, 1869, wrote it Kun, and says it is Kun of the Innuit, and was named Maria Louisa by Captain Smith of the Western Union Telegraph expedition, about 1867.

Kunaiugiuk, island; see. Spectacle.

Kunakakvak. The Russian-American Company's map of 1849 shows a native village of this name near Karluk, on the north shore of Kodiak.

Kunakan, island; see Sitkalidak.

Kunayosh; creek, on the coast 8 miles southeast of Yakutat, tributary to Situk river, from the east. 2 miles above its mouth; near longitude $139^{\circ} 30^{\prime}$. Indian name, written Ku-na-yosh by Moser, 1901.

Kungitak; cape; see Reef.

Kungiugan. The south end of Big Koniuji island, Shumagin group, has the appearance of an island, and is by 'Tebenkof shown as a separate island with the native name Kungiugan. Dall gives the name as Kungagingan. Lutle calls one of the islands in the Shumagin group Kiganghym, which seems to be another rendering of this word.

Kung-uk, river ; see Buckland.

Kungyanook, river; see Colville.

Kunikakagi; island (perhaps a lump of ice now melted), in the delta of Alsek river, southeastern Alaska. So called by Tebenkof, 1849 (chart 7 ). Apparently a native name. In the Coast Pilot (1883, p. 205, footnote), it is spelled Kunakagi and applied to a river.

Kunk; creek and lake, eastern shore Etolin island, Alexander archipelago, tributary to Zimovia strait, from the west, latitude $56^{\circ} 17^{\prime}$. Probably an Indian name, written Kunk (Konke) by Moser, 1901.

Kunmik; cape, the northeastern point of entrance to Aniakchak bay, Alaska peninsula. Name published by the Coast Survey in 1899 .

Kunthrashibuna; lake and river, tributary to Lake Clark from the east, nearly opposite the mouth of Chulitna river, near latitude $60^{\circ} 30^{\prime}$, longitude $154^{\circ}$. Native name, reported by Osgood, 1902 (p. 13), and written by him Koonthrashiboona.

Kunuliuk, island; see Koniuji.

Kunuyu-tanan. One of the Shumagin islands, not identified, is called by Sarichef Kunujutanany (Phillips Voyages, VI, 15) and by Lutke KunuyouTanany, i. e., Kunuyu-big. 
linn-ya-nook, river ; see Colville.

Linpolrail, peak; see Cupola.

Kupowra; river, debouching on the Arctic coast, 40 miles east of Colville river, near longitude $148^{\circ} 50^{\prime}$. Eskimo name, reported in 1903 by $\mathrm{S}$. J. Marsh, a prospector, who wrote it Koopowra-ku, meaning river.

Kupreanof; harbor, between Paul and Jacob islands, off the southern shore of Alaska peninsula, northeast of the Shumagins, near longitude $159^{\circ}, 15^{\prime}$. So named by Woronkofski, in $\mathbf{1 8 3 7}$.

Kupreanof; island, one of the principal islands of the Alexander archipelago. So named by the Russians, after Capt. Ivan Andreevich Kupreanof., who succeeded Wrangell as governor of the Russian-American colonies in 1836. Variously spelled Kupreanoff, Kupreanovi, Kuprianow, etc.

Kupreanof; point, on the southern shore of Alaska peninsula, northeast of the Shumagins, near longitude $159^{\circ} 30^{\prime}$. Named Ivanof (John's) by Lutke, 1836, and afterwards Kupreanof by the Russians. Called Ivanoff, Ivanovsky, Kupreanoff, and St. John.

Kupreanof; strait, between Kodiak and Afognak islands. Named Karluk by Murashef, in 1839-40, Kuppreanof by the Russian-American Company's officers, in 1849, Sievernoi (northern) by Tebenkof, in 1849, and variously called North, Northern, Karluk, and Kupreanof.

Kursula; old village site on St. Paul island, Bering sea, on the southwest coast near Zapadni point, and longitude $170^{\circ} 22^{\prime}$. Local name, written Kursootah by Elliott, 1872-74.

Kurupa; creek, northern Alaska, tributary to Colville river from the south, near longitude $154^{\circ}$. Eskimo name, obtained by Peters and Schrader in 1901.

Kuryukuk, river ; see Koyukuk.

Kusawa; lake (elevation 2,700 feet), northwest of Chilkat pass, draining to lake Laberge. Native name, written Kūssooā by Krause in 1.882, Kūssūa by the Coast Survey in 1883, and Kusawah by the Canadian Geological Survey in 1898. Named Arliell by the Leslie Expedition, in 1890, a member of which wrote the Indian name Kusu $\mathrm{Ah}$. The above form, Kusawa, has been adopted by the Canadian Board on Geographic Names.

Kuselik; creek, debouching in Camden bay, Arctic coast, 15 miles west of Barter island, near longitude $144^{\circ} 45^{\prime}$. Eskimo name, reported by S. J. Marsh, a prospector, 1902, who wrote it Cooselik. Perhaps it were better written Kuslik.

Kushneahin; creek and lake, opening at Point Barrie, on the southwestern shore of Kupreanof island, Alexander archipelago, near latitude $56^{\circ} 27^{\prime}$. longitude $133^{\circ} 39^{\prime}$. Indian name, adopted by the fishertes, and reported by Moser in 1901. Written also Kusbneaheen.

Kushtaka; lake, glacier, and ridge, 15 miles northeast of Controller bay, Gulf of Alaska. Native name meaning demon or ghost: The natives believe that this lake is inhabited by evil spirits who often make the water boil, or in winter break up the ice. The cause of these phenomena is the escape of coal gas from the bottom of the lake through the water. In winter it accumulates under the ice, with increasing tension till the ice gives way, and is sometimes shot into the air. Nitive name and story from Martin, 1903, who wrote the name Kushtahkah. It has also been written Kushtabki.

Kushti; island, one of the Siginaka group, Sitka sound, Alexander archipelago. So named by Vasilief, 1809.

Kushukvag-mint, village; see Alitak.

Kusiloak, pass; see Kwemeluk.

Kusiloff, mount ; see Kusilvak. 
Kusilvak; island, one of the outer islands of the Yukon delta. Native name. Has also been written Kusalvak.

Kusilvak; mountain (2,449 feet high), in the Yukon delta, about 35 miles westerly from Andreafski, near latitude $62^{\circ}$, longitude $164^{\circ} 35^{\prime}$. . Apparently a native name, obtained by Dall, who, in 1870 , published the form Kúsilvak. Has also been written Kusiloff. Earlier Russian charts call it Ingieguk, doubtless for Eskimo ingriguk (big mountain). Tebenkof calls it Ingun.

Kusilvak Mouth; see Kwemeluk, pass.

Kuska, island; see Kiska.

Kuskok; Eskimo village, on the left bank of lower Kuskokwim river, near its mouth. Native name, from Nelson,. 1879, who wrote Kuskogamute. i. e., Kuskok people. Has also been written Kuskohkagamiut, Kuskokvagamute, etc. Population in 1880,24 ; in $1890,115$.

Kuskokwim; bay, at mouth of Kuskokwim river, Bering, sea. Eskimo name, from Ustiugof, who visited it in 1818 . Variously written Kouskokvim, Kuskoquim, etc. . The word Kuskokwim, according to missionary J. H. Kilbuck, is the genitive of Kuskokwik, the last syllable meaning river and the rest of doubtful meaning.

Kuskokwim; river, one of the large rivers of western Alaska; south of the Yukon. Eskimo name, apparently obtained by Ustiugof, 1818, and published in Sarichef's atlas, 1826. Eskimo name variously spelled. "The old Indian name for the Kuskokwim was Chin-ana, now obsolete except among the old Indians." (Herron, 1899, p. 45.). See also Echitna.

Kuskovak; Eskimo village, on the right bank of Kuskokwim river, near its mouth. Name from Nelson, who passed near it January, 1879, and who writes, it Kuskovakh.

Kuskulana;-glacier, on the southwestern slope of Mount Blackburn. So named by Gerdine, 1900.

Kuskulana; pass, between Chokosna and Kuskulana rivers. So named by Schrader, 1900.

Kuskulana; river, tributary to Chitina river from the enst, and draining from Kuskulana glacier. Nạtive name, from Rohn, 1899. Kuskulaná means Kuskula river.

Kuslina; creek, tributary to Copper river from the east, between the mouths of Kotsina and Cheshnina rivers. Native name, from Schrader, 1900.

Kussiloff, cape, river, village; see Kasilof.

Kussooa, lake; see Kusawa.

Kissoocichranuthini. The Krause brothers, 1882, report this to be the native description of the stream which drains Kusawa lake, southeastern Alaska. See also East.

Kustatan; Indian village (population 65 in 1880), on shore of Redoubt bay, Cook inlet. Native name, reported by Petrof in 1880. The last syllable, tan, means point or cape.

Kussua. river; ; see Kusawa.

Kusu Alh, lake; see Kusawa.

Kutchuma; group of islands, in northeastern part of Sitka sound, Alexander archipelago. Russian naval officers, in 1809, called this group Boidarkin, which has also appeared as Boidarka. Have also been called Kutchiuma. It is a corruption of Kuchumof, a Russian family name.

Kutenige; creek, tributary to Jockench river, Chilkat region, southenstern Alaska. Native name, reported by the Krause brothers, 1882, and by them written Kutenigé.

Kuththlatno, river; see Gisasa. 
Kutkan; island, in Sitka harbor, .Sitka sound, Alexander archipelago. Só named by the Russians, after a famous Indian chief who freed his slaves and embraced Christianity. Has also been written Kuch-kan and Kukh-kan. It has also been called Garden, Gull, Popof, and Stanovoi (rocky). The last name was given by Vasilief in 1809.

Kutkwutlu; Indian village, on the left bank of Chilkat river, near its mouth, southeastern Alaska. Katkwaltu or Kut-kwutlu is said to mean place of gulls. A Presbyterian missionary station called Willard (afterwards changed to Haines) was established at this village in 1881.

Kutlaku; lake and stream, Kuiu island, Alexander archipelago, on the south shore of South arm, Bay of Pillars, Chatham strait, near latitude $56^{\circ}$ $37^{\prime}$. Indian name, written Kutlakoo by Moser in 1900, who says they are also called Point Ellis stream and lake.

Lutlik, village and river; see Kotlik.

K.utloot, island; see South.

Kutmiut; Eskimo village or camp, Yukon delta, on the left bank of Kun river, near the head of Scammon bay, about latitude $61^{\circ} 50^{\prime}$, longitude $165^{\circ}$ 30'. Eskimo name, obtained by Putnam, 1899. See Kutten.

Kutmuknuk; channel, leading into Kwikluak and Kwemeluk passes; - in the Yukon delta, near latitude $62^{\circ} 35^{\prime}$. Eskimo name, from the Coast Survey, 1898.

Kutna; creek, tributary to Yentna river from the south, near latitude $61^{\circ} 45^{\prime}$, longitude $150^{\circ} 40^{\prime}$. Indian name obtained by. Herron in 1899, and by him written Cut-nu, i. e., Kut river.

Kutoark; river, northern Alaskal, tributary to Alatna river from the north, near latitude $67^{\circ} 40^{\prime}$, longitude $154^{\circ} 15^{\prime}$. Eskimo name, obtained by Stoney in 1886, and by him written Koo-to-ark. Written also Kutuark.

Kutsch-tazik-mutscha, lake; see Salamatof.

E.utsch-tschchamna. Grewingk, 1.550, following Wosnesenski, 1840, gives this as the native designation of a small lake on Kenai peninsula, near East Foreland. Perhaps Kutsch means lake, and the rest of this might be pronounced Shamna.

Kutten. Dall, writing in 1869 , says there is a native settlement in the Yukon delta, on the Kun river, about 10 miles from the head of Scammon bay, known as Kúttenmut (Kutten people). . See Kutmiut.

$K u t-t u k-\imath a u h$, island ; 'see Tongass.

ILutuarl, river; see Kutoark.

Kutuk, river ; see Pish.

Kutul; native village, on the right bank of the Yukon, about 50 miles above Anvik. Name from Nelson, 1878-79, who writes it Khutulkakat, i. e., mouth of Kutul river.

Kutulnakt, river; see Kaiyuh slough and Khotol river.

Kutuzof; cape, on the northern shore of Alaska peninsula, a little east of. Port Moller. Named Kutuzova (Kutuzof's) by Lutke, 1.828, presumably after Fagemeister's ship, the Kutuzof. 'I'his cipe and the one next east of it, Seniavine, have sometimes been confounded on the charts. It has been variously spelled Koutousoff, Kutuzoff, etc.

Ku $u k$, river ; see Mungoark.

Kuvul, river; see Kobuk.

K uyikanuikpul, Eskimo village; see Paimiut.

Kuy $u k$, river; see Koyuk.

Kuyukuk; lakes, near the south bank of the Yukon, drained by Kukuyukuk river. Name from Raymond, 1869. Not found on recent maps. 
Kuyuyukak; cape, on the southern shore of Alaska peninsula, northeast of Sutwik island. Native name, published by the Coast Survey in 1899.

Kuzitrin; river, Seward peninsula, flowing westward to Imuruk basin, near latitude $65^{\circ}, 10^{\prime}$, longitude $165^{\circ}$. Eskimo name, from Brooks, 1900. Locally written Koosetrien.

Kvichak; bay, southwestern Alaska, at the head of Bristol bay, near latitude $59^{\circ}$, longitude $157^{\circ}$. So named by Moser, 1901.

Kvichak; village and river, draining from Iliamna lake to Bristol bay. Native name, reported by the early Russians. Lutke, writing in 1828, says: "Kvitchak (river), called by Cook Bristol." Recently written Koichak.

Kvichavak; river, between Kuskokwim and Yukon rivers, tributary to the Kuskokwim from the west. Name from Nelson, who traveled along this sluggish stream in January, 1879, which he says is by the natives called Kivvichavak. Apparently identical with Ankitáktuk creek of Spurr and Post, of the Geological Survey, 1898, who obtained this name from missionary J. H. Kilbuck. Tikhmenief, 1861, calls it Kvinchagak. Has also been called Kulichavak, Kulichivak, and probably Izawerknuk.

Kvichpak, river : see Yukon.

Kvichvauk; pass, Yukon delta, opening into Apoon pass on the north, less than a mile above Kotlik; near latitude $63^{\circ} 04^{\prime}$, longitude $163^{\circ} 30^{\prime}$. Eskimo name, obtained by Faris, 1899.

Kvieguk, river; see Koyuk.

Kvigatluk; Eskimo village, in the Big Lake country, between the Yukon and Kuskokwim. Nelson, in 1879 , passed near it and reports its name to be Kvigathlogamute, i. e., Kvigatluk people.

Kviguk; Eskimo village, on north shore of Norton bay, at mouth of the Kviguk river. Eskimo name, from the Russians. 'Tikhmenief, 1861, has Kviegmiut and Kvieguk-miut, i. e., Kviguk people.

Kvikak; Eskimo village, on right bank of the Yukon, about 30 miles above Anvik. Native name, from Nelson, 1878-79, who wrote it Kvikhagamute, i. e., Krikah people.

Kivilh, river and village; see Kwik.

Iivinchagak, river' ; see Kvichivak.

Kvingak; small stream, tributary to the head of Norton bay, Norton sound. Eskimo name, frem Tebenkof, 1849. It appears to be identical with Kvienkak of Tikbmenief, 1861.

Kruveren, tract and river; see Kaviruk.

Kwahteetah, river ; see Katete.

Kwatahein; stream, Kuiu island, on the south shore of the South arm, Bay of Pillars, Chatham strait, about 4 miles inside Point Ellis. Indian name, reported by Moser in 1.900, who wrote "Quat-a-hein; or trout stream."

Kweek, arm, etc. ; see Knik.

Kweleluk; Eskimo village, in the Kuskokwim district, given in the Eleventh Census, 1890 (p. 164), as Quelelochamiut, i. e., Kivelelok people. Population in 1890, 112. Location unknown.

Kwemeluk; pass, in the Yukon deltil, south of Kwikluak pass and near latitude $62^{\circ} 30^{\prime}$. Eskimo name, from the Coast Survey, in 1898. The Russians wrote it Kuimlia. Tebenkof, 1849, called it Naulchi. It was called Kousilvak mouth by Raymond, 1869, and Kusilvak or Kusiloak later.

Kwichlimut, river; see Kwikli. 
Kwichlowak; pass, Yukon delta, just west of Okwega pass and probably opening into it, near latitude $63^{\circ} 08^{\prime}$, longitude $163^{\circ} 37^{\prime}$. Eskimo name obtained by Putnam in 1899. Probably the ch in this word represents a guttural and should be kh.

Kwiguk; pass and Eskimo village, Yukon delta. The pass is one of the outlets of Kwikluak pass on the north, near latitude $62^{\circ} 45^{\prime}$. The village is on the right bank of Kwikluak pass at the head of Kwiguk pass, near longitude $164^{\circ} 28^{\prime}$. Eskimo name, meaning big river, reported by Putnam, 1899, as Kweguk pass and. Kwegugamiut (big river folles) village.

Kwik. The Eskimo word for river. (Singular Kwik, dual Kweek, plural Kweet, or, according to Father Barnum, Kwǐq, Kwĭgūk, Kwëgut).

Kwik; river, and Eskimo village, north shore of Norton bay, Seward peninsula, near latitude $64^{\circ} 45^{\prime}$, longitude $161^{\circ} 45^{\prime}$. Called Kuik by Jarvis in 1897 and Peters in 1900. Written also Quick. It is the Isskimo word for river. Earlier maps call the village Kvikb.

Kwik; river, flowing from the Malaspina glacier into Yakutat bay, southeastern Alaska. So called by Tebenkof, 1849. Has also been called the Grand Wash.

Kwik; Eskimo village, on the western side of Bald Head, Norton bay, Norton sound. On a recent map called Isaacs, from the name of a person living there.

Kwik; Eskimo village, northeast of Bald Head, on the northern shore of Norton bay, Norton sound. Called Kvikh by Petrof, 1880. On a late map called Kuikli.

Kwik; Eskimo village, on the right bank of the Kuskokwim, about 10 miles above Bethel. Nelson, 1878-79, reports its native name to be Kwigamute, i. e., river people. Petrof, 1880 , follows this spelling. Spurr and Post in 1898, following Missionary Kilbuck, wite Kwẹgamut.

Kwik; Eskimo village, on the southern shore of Nunivak island. Native name, from the Eleventh Census, which spells it Kiveegamute on the map and Kwigamiut in the text (p. 164).

Kwikak; ISskimo village, on the outer coast of the Yukon delta, 7 miles south of the mouth of Black river, near latitude $62^{\circ} 15^{\prime}$. Native name, from the Coast Survey, 1898, who give it as Kiwikágamint.

Kwikak; Eskimo village, on the left ( ? right) bank of the Kuskokwim, about 25 miles below Kalchaganut. It is apparently identical with Kwigalogamute of Petrof in 1880. Missionary Kilbuck, according to Spurr, 1898, writes it Queékagamut, and it was published by the Geological Survey as Kwikagamut, i. e., Kwikak people.

Kwikalablok; river, a south branch of Unalaklik river, western Alaska, near latitude $63^{\circ} 45^{\prime}$. Eskimo name, published Quichalabloch in 1900. See also South river.

Kwilhitak, pass; see Kivikiuak.

Kivililliuak, pass; see Kwikluak.

Kwikli; river, tributary to the Kuskokwim from the east, a little above Bethel. Its Eskimo name, according to Spurr and Post, who obtained it from Missionary J. H. Kilbuck, in 1898, is Kwiklimut, i. e., Kwikli people.

Kwikloaklok; Eskimo village or ca解, on the left bank of the Yukon, 8 miles below Andreafski, near longitude $163^{\circ} 30^{\prime}$. Eskimo name, obtained by Putnam, 1899.

Kwiklok, pass ; see Kwikluak.

Kwiklokchun; pass or channel, Yukon delta, connecting the mouths of Kwikluak and Kwemeluk passes, near latitude $62^{\circ} 33^{\prime}$, longitude $164^{\circ} 51^{\prime}$. Eskimo name, obtained by Putnam, 1899. 
Kuitilouvak, pass ; see Kwikluak.

Kwikluak; pass, Yukon delta, by far the largest outlet of the Yukon, near latitude $62^{\circ} 40^{\prime}$. It is about $50^{\circ}$ miles long and is the most southerly of the main outlets. Lskimo name. 'lebenkof, 1849, has Kivikhliuak and Kwikbltak; Raymond, 1869, called it American mouth, and the Coast Survey, 1899-1901, Kwiklok and Kwiklowak.

Kwikluak; Eskimo village, Yukon delta, on the left bank of Kwikluak pass. near latitude $62^{\circ} 36^{\prime}$, longitude $164^{\circ} 45^{\prime}$. Eskimo name, written by Putnam, 1899, Kaoklorakamiut, probably Kwikluak folks.

Kwikpak; pass, one of the mouths of the Yukon river, near latitude $63^{\circ}$. Eskimo name. Kwik means river (dual Kiweek, plural Kweet) and puk means big, large. Variously written Kwikhpak, Kwikhsak, etc.

Kwikpak, river; see Yukon.

Kwikpak; Eskimo village, Yukon delta, on the right bank of Kwikpak pass, near latitude $63^{\circ} 03^{\prime}$, longitude $164^{\circ} 25^{\prime}$. 'This is Old Kwikpakamiut of some maps.

Kwikpakak; slough, Yukon delta, opening on the left bank of Kwikpak pass, 3 miles above the head of Kawanak pass, near latitude $62^{\circ} 52^{\prime}$, longi.tude $164^{\circ} 10^{\prime}$. Eskimo name, reported by Faris in 1899.

Kwikpak Crossing; pilots' name for the junction or rather the bar or channel at the junction of the Kwikpak and Apoon passes, Yukon delta; latitude $62^{\circ} 55^{\prime}$, longitude $164^{\circ}$.

Kwiktalik; mountain (1,200 feet high), on Seward peninsula, between Golofnin and Norton bays, north shore of Norton sound. Native name (meaning river-abonnding place perhaps), from Peters, 1900. Also written Quiktalik.

Kwikuk; slough, Yukon delta, opening on the right bank of Kwikpak pass, 10 miles below the head of the delta, near latitude $63^{\circ} 40^{\prime}$, longitude $163^{\circ}$ 55'. Eskimo name, reported by Faris, 1899.

Kwimlilthla; slough, Yukon delta, opening on the left bank of Akularak pass, near latitude $62^{\circ} 29^{\prime}$, longitude $164^{\circ} 15^{\prime}$. Eskimo name, obtained by Putnam, 1899.

Kwina, river; see Kanektok.

Kwinak; Eskimo village, on the eastern shore of Kuskokwim bay, at the mouth of Kanektok river, Bering sea. So given by Sarichef, 1826, and Teisen. kof, 1849. Petrof, 1880, writes it Quinehahamute, or omitting the termination mate, meaning people, it would be Quene-ă-ăk. Variously written Quinhágamute, Quinehaba, Quinhagak, Kwinhagak, etc.

Kwinhagak, village; see Kwinak.

Kwiniuk; mountain, Seward peninsula. Native name, from the prospectors, who write it Quinnehuk.

Kwiniuk; river, east of Golofnin bay and tributary to north shore of Norton bay. Eskimo name, written Quinnehuk, Quinnelhock, etc., by the prospectors.

Kwisnon. Raymond, 1869, shows a westerin tributary of Tozi river called Quisnon. Name not found elsewhere.

Kwiyadik; creek, tributary to Kinskokwim river, just south of Kanektok river, western Alaska. Native name, ofjtained by Spurr and Post, of the Geological Survey, 1898, and by them written Quiyáidik.

Kyak, island; see Kayak.

Kygane, cape; see Muzon.

Kygmil, cape; see Prince of Wales.

Kyska, harbor, etc.; see Kiska.

Kytlek, island; see South. 
Lab; reef, between Cat and Mary islands, Revillagigedo channel, Alexander archipelago. Name published in the Coast rilot (1891, p. 98).

Labandera; reef, in the entrance to Port Sinta Cruz, Suemez. island, Prince of Wales archipelago. Named La Labandera (the washerwoman) by Maurelle and Quadra in 1775-1779.

Labouchere; bay; indenting the northeastern coast of Prince of Wales island, and opening into Sumner strait, Alexander archipelago. Named by the traders after the Hudson Bay Company steamer Labouchere. Has also been called a port and a harbor.

Labouchere, bay; see Highfield anchorage.

Labouchere, harbor; see Pyramid.

Labouchere; island, at entrance to Labouchere bay, Sumner strait, Alexander archipelago. Called ship island by Helm, 1.886.

Labouchere, island; see Pyramid.

Labouchere; mount, west of Chilkat inlet, near Pyramid harbor, southeastern Alaska. So named by Meade, 1869, after the Fudson Bay Company's steamer Labouchere, which in turn was named after a Mr. Labouchere, of the Hudson Bay Company.

Labret, river; see Tutuksuk.

Lacey; island, in Cordova bay, Alexander archipelago, just enst of Jackson island, at entrance to Tlevak strait, near latitude $55^{\circ}$, longitude $132^{\circ} 45^{\prime}$. Pilots' name, from Dickins, 1905.

La Chaussée. From the northern point of entrance to Lituya bay there extends a spit called by La Perouse la chaussée (the road). On the English edition of Lal Perouse's chart 19, this is designated as "Road to the fishery and morai" (burial place).

Lachina, river; see Lakinia.

Lackie; gulch, 10 miles north of Cape Nome, Seward peninsula, draining into Osborn creek from the west, near longitude $165^{\circ} 05^{\prime}$. Local name, published in 1904.

Ladds; fishing station, at mouth of Chuitna-river, near head of Cook inlet. Apparently a local name, in use in 1895 . It is at or near the site of an Indian village called Chuitna.

Latirones, Islas de; see Robber.

Ladue; creek, tributary to White river from the west, near longitude $140^{\circ}$. Presumably named after a prospector, Lal Due, who wintered on the Yukon in 1884-85.

lagartos, Rio; see Bering river.

Lagoon; creek, Seward peninsula, debouching on the coast of Bering sea, hetween York and Cape Prince of Wales, near longitude $167^{\circ} 53^{\prime}$. Name from Gerdine, 1.901.

Lagoon; point, on the northern shore of Alaska peninsula, west of Port Moller, near longitude $161^{\circ} 30^{\prime}$. So named by Dall in 1882 . Fossibly identical with Rozhnof of Lutke in 1828 .

Lagoon; rookery (seai), on the south const of St. Paul island, Bering sea, just north of St. Paul village. Loca1 name, from Elliott, 1872-1874.

La Grand Platcan; see Grand Plateau.

Laida. This is a Kamchatkan word meaning shoal, and was adopted by the Russians in the American possessions.

Laidcnnoj, point; see Anchor.

Laja. An islet with rocks about it near San Fernando island, Bucareli bay, Prince of. Wales archipelago, was nimed by Maurelle and Quadra, 1775-1779, la Lajal (the thin flat stone). 
Lake; bay, between Prince of Wales island and Stevenson island, Kashevarof passage, Clarence strait, Alexander archipelago, near latitude $56^{\circ} 02^{\prime}$, longitude $132^{\circ} 58^{\prime}$. Local name, reported by Moser in 1897 .

Lake; creek, in the Copper River region, draining Trout lake into Middle fork Chistochina river near its source, about latitude $63^{\circ} 08^{\prime}$, longitude $144^{\circ}$. $40^{\prime}$. Descriptive name, given by Gerdine in 1902.

Lake; creek, in the Copper River region, tributary to Nizina river from the south, between Dan and Chititu creeks. Prospectors' name, taken from map of Nizina mining district, made by George M. Esterly, of Valdez, 1902.

Lake; creek, tributary to Chandlar river from the east, near longitude $148^{\circ} 30^{\prime}$. Presumably a descriptive name, from Schrader, 1899.

Lake; dune, on Northeast point, St. Paul island, Bering sea, between Cross hill and Big lake, near longitude $170^{\circ} 08^{\prime}$. Descriptive name, from Duffield, 1897.

Lake; hill (282 feet high), on St. Paul island, Pribilof group, Bering sea, near longitude $170^{\circ} 15^{\prime}$. Presumably a local name, published by the Coast Survey in 1875 .

Lake, point; see Aiak.

Lake Bay; small fishing village, on the northeastern shore of Prince of Wales island, Alexander archipelago. It is near Stevenson island, in Kashevarof passage. So called in the Eleventh Census, 1890.

Lakina; river, tributary to Chitina river from the north, near longitude $143^{\circ}$. Native name, from Rohn, 1899, who wrote it Lachina. Pronounced Lắk-i-ná.

Lamar; gulch in the Copper River region, tributary to Blei gulch, on the south side of Chititu creek. Prosectors' name, taken from map of Nizina mining district, by George M. Esterly, of Valdez, 1902.

Lamb; island, on the eastern side of Afognak bay, south shore Afognak island, near latitude $58^{\circ}$, longitude $152^{\circ} 42^{\prime}$. Local name, reported by Moser, 1900.

Lancashire; rocks, on the southern shore of Kachemak bay, Cook inlet. Named by Dall, 1880, after the English yacht Lancashire Witch (Sir Thomas Hesketh, owner), which visited Cook inlet that year.

Landlock; post-office (established October, 1905), on Landlocked bay, Prince William sound.

Landlocked; bay, on the northeastern shore of Prince William sound. Local descriptive name, published in 1898, by the Geological Survey.

Landmark; conspicuous gap in the foothills of the Alaskan mountains, near the head of Delta river, longitude $146^{\circ}$. Descriptive name, by Mendenhall, of the Geological Survey, 1898.

Landslip; point, on the western shore of Portland canal, near its head. Descriptive name, given by Pender in 1868.

Lane; islet, in Danger passage, between Mary and Duke islands, Gravina group, Alexander archipelago. So named by Nichols, 1883.

Lane; river, Seward peninsula, tributary to Goodhope bay from the southwest. Prospectors' name, reported by Gerdine, 1901. This river has been called by its Eskimo name Kugachuk.

Lanes Landing; on Kuzitrin river, Seward peninsula, near latitude $65^{\circ} 12^{\prime}$, longitude $164^{\circ} 50^{\prime}$. Local name, reported by Gerdine, 1901.

Lanin, cape ; see Lapin.

La Perouse; glacier, in the southern part of the St. Elias alps. So named by Dall, 1874, after J. F. G. de La Perouse. 
La Perouse; mountain (10,740 feet high); in southern part of the St. Elias alps, near latitude $58^{\circ} 33^{\prime}$, longitude $137^{\circ} 05^{\prime}$. So named by Dall, 1874, after Jean François de Galaup de la Perouse, the celebrated and unfortunate French navigator, who explored this const in 1786.

Lapin; cape, forming the eastem head of Ulilia bay, on northern shore of Unimak, eastern Aleutians, near longitude $164^{\circ} 05^{\prime}$. 'Tebenkof called this Lanin, but it has usually been written on American charts Lipin. Capt. Ivan Savich Lapin was a fur trader in this region, in 1762, and is an authority on the early history of the Aleutian islands. Perhaps the name Lanin is derived from the Russian word lan (deer). On most modern charts the name is misplaced, being applied to Mordvinof and Cave.

Larch; bay, near the south end of Baranof island, Alexander archipelago. Named Listvinichnaia (larch) by the Russians.

Large; island, in Nazan bay, Atka, middle Aleutians. Named Bolshoi (large) by the Russians. Erroneously Bomchoi.

Large, Isle du; see Navy.

Larger, arm, Whale bay ; see Great.

Larratita, islet or reef; see Larzatita.

Larsen; bay, indenting the western shore of Uyak bay, on northern shore of Kodiak. So called in the Eleventh Census, 1890. Locally known as Larsen bay.

Larzatita; islet or reef, in San Christoval channel, Bucareli bay, Prince of Wales archipelago, called by Maurelle and Quadra, 1775-1779, Larzatita, according to the English edition of plate 26 in the plates accompanying La Perouse's voyage. On the old Russian copy of this it is Larratita.

Las Animas, island and point; see Animas.

Iascano; islands. This name appears to have been applied by the Spaniards, 1788 , to some of the islets in Unimak pass.

Las Hermanas, islands; see Hazy.

La Spray; creek, 25 miles north of Cape Nome, Seward peninsula, tributary to the headwaters of Flambeau river from the north, near latitude $64^{\circ} 45^{\prime}$, longitude $165^{\circ} 10^{\prime}$. Local name, from Gerdine, 1904 .

Las Puercas, islets; see Sows (The)

Las Ranas, islets and rocks; see Frogs (The).

Last; cape, on the northern shore of Afognak bay, near mouth of Afognak river. . Named Krainie (the very last) by Murashef, 1839-40. Near by he has Posliedni (last) cape.

Last Chance; creek, just south of Port Clarence, Seward peninsula. Name from Barnard, 1900.

Last Chance; creek, 20 miles north of Nome, Seward peninsula, tributary to North fork Snake river from the west, near longitude $165^{\circ} 2 S^{\prime}$. Name from Barnard, 1900. Has been called West fork of Snake river.

Last Chance; creek, Seward peninsula, tributary to Turner creek, which is a tributary of Noxapaga river, near latitude $65^{\circ} 35^{\prime}$, longitude $164^{\circ} 30^{\prime}$. Prospector's' name, reported by Gerdine, 1901.

Last Chance; creek, tributary to the Yukon from the east, near Eagle. Prospector's' name, published by the Geological Survey in 1899.

Last Chance; creek, enstern Alaska, on the south bank of Seventymile creek, near latitude $65^{\circ}$, longitude $142^{\circ} 15^{\prime}$. Prospectors' name, from sketch map compiled by Major Glassford, Signal Corps, U. S. A., 1905. 
Last Chance; gulch, in the Copper River region, at the headwaters of Chititu creek. Prospector's' name, taken from map of Nizina mining district by George M. Esterly, of Valdez, 1902.

Last Timber; cape, on the southern shore of Raspberry island, Kupreanof strait, Kodiak group. The descriptive name Posliednaho liesy (last of the woods) was given by Murashef, 1839-40.

Late; point, the south point of Windfall island, Seymour canal, Alexander archipelago. So named by Mansfield, 1.889.

Latourche; Island, in the southwestern part of Prince William sound. So called by Vancouver in his atlas, 1798. Portlock, 1787, called it Foot island, possibly from a fancied resemblance to a human foot. The native name is reported to be Klikaklik or Klikaklit, also spelled Khlikakblik.

Latouche; point, the eastern point of entrance to Disenchantment bay, Yakutat bay, southeastern Alaska. Named Latouche by Puget, of Vancouver's party, in 1794: It was called Punta de la Esperanzal (hope point) by Malaspina, in 1791, perhaps in allusion to bis hope of here finding the famous Northwest paissilge.

Latouche; post-office (established June, 1905), on Latouche island, Prince William sound.

Lauder; point, the southern point of entrance to Whale bay, Baranof island, Alexander archipelago. So named by Dixon, 1787. Has also been called South point.

Lauf; islands, in Rodman bay, Peril strait, Alexander archipelago. So named by Moore, 1895 .

Launch; cove, at Southern rapids, Peril strait, Baranof' island, Alexander archipelago. So called by Coghlin, 1884 .

Laura; mountilin $(-7,527$ feet high), on the mainland, east of Stikine river. Name published by the Coast Survey in 1895 .

Laurada; creek, 8 miles northwest of Cape Nome, Seward peninsula, tributary to Nome river from the east, near longitude $165^{\circ} 12^{\prime}$. Prospector's' name, published in 1900.

Lava; creek, Sevard peninsula, tributary to Kiwalik river from the east, near latitude $65^{\circ} 50^{\prime}$, longitude $161^{\circ} 40^{\prime}$. So'called by Witherspoon, 1903.

Lava; islet, near Kruzof island, in entrance to Sitka'sound, Alexander archipelago. So named by Vasilief, 1809.

Lava; point, on the west side of Alutan island, Krenitzin group, eastern Aleutians, near latitude $54^{\circ} 10^{\prime}$, longitude $166^{\circ} 05^{\prime}$. Called Flat Top by Moser, 1897, and Lava by the Const Survey in 1902.

Lavelle Young; creek, in the upper Koyukuk region, tributary to Dietrich river from the east; near latitude $68^{\circ}$, 'longitude $150^{\circ}$. Prospectors' name, reported by Feters and Schrader, 1901.

Lavinia; point, on the northwestern shore of Chichagof island, Cross sound, Alexander archipelago. So named by Vancouver, 1794.

Lawrence; creek, 1.3 miles east of Cape Yaktag, Gulf of Alaska, near longitude $142^{\circ}$. Named after Lawrence E. Barber, one of the first to locate oil lands in the Yaktag region in 1897. Local name, from Martin, 1903.

Lawrence; creek and valley, Alaska peninsula; on the southeastern shore of Herendeen bay, near longitude $160^{\circ} 38^{\prime}$. So:named by Tanner, 1890 .

Lawson; creek, on Douglas island, tributary to Gastineau channel, one-half mile northwest of Douglas. Local name, reported by Peters in 1902.

Lay; point, on the Arctic coast, between Capie Lisburne and Icy cape. So named by Beechey, 1826, after George Tradescant Lay, the naturalist of bis expedition. On Tikhmenief's map this is called Sloistie (in layers). 
Lazaref; cape, a headland 1,100 feet high, on the southenstern shore of Unimak island, eastern Aleutians. So named by Lutlie, 1828, who says that Kudiakof, 1791, reported its native name as Touliouliaga.

Lazaref; peak (1,100 feet high), on the southeastern shore of Unimak Island, 3 miles northeast of Cape Lazaref. So called by Westdahl, 1901.

Lazaro; mountain $(1,767$ feet high), on the south end of Duke island, Dixon entrance. Named st. Lazaro by Douglas in June, 1789. Usage has shortened the name to Liarilro.

Lazy; bay, southwestern shore of Alitak bay, southwestern shore Kodiak, 4 Imiles inslde Cape Alitak. Local name, reported by Moser, 1900.

Leader; island, In the entrance to Ivanof bay, Alaska peninsulat. Named Fro. rodnik (leader) by Woronkofski, 1837.

Leading; point, on Frince of Wales island, in southeastern part of Cordova bay, Alexander archipelago. So named by Moser, 1896."

Leading, point; see Harrison.

Leadville; mountain (1,797 feet high), neall Port Chester, Annette island, Alexander archipelago. So named by Nichols, 1883.

League; point, on the mainland, Stephens passage, Alexander atchipelago. So named by Meade, 1868.

Leather, village; see Koserefski.

Leask; cove, at the head of George inlet, Revillagigedo island, southeastern Alaska, near latitude $55^{\circ} 30^{\prime}$, longitude $131^{\circ} 30^{\prime}$. Local navigator's' name, reported by Fassett, Bureau of Fisheries, 1904.

Lebarge; river, tributary to the Yukon river from the north, about 40 miles above the mouth of the Koyukuk. So named by Dall, 1869, after his friend and companion, familiarly called Mike Lebarge. Its native name, according to Dall, is Miskuntl'kakat.

Lebelevs7i, islands; see Pribilof.

Lebiazhe, Jake; see Swan.

Le Conte; bay, in the mainland, east of Mitkof island, southeastern Alaska, near latitude $56^{\circ} 45^{\prime}$. So named by Thomas, 1887 , presumably after Joseph Le Conte, professor of geology in the University of Californla. Has been called Leconte, Hutli, and Thunder. The native name is Hutli, the Tlingits' mythical thunder bird, the flapping of whose wings produces the thunder.

Le Conte; glacier, at head of Le Conte bay, southeastern Alaska. So named by Thomas, 1887, presumably after Prof. Joseph Le Conte. Has been written Leconte. Native name is Hutli(the Thunderer), and from this it is often called Thunder glacier.

Ledge; islet, is Funter bay, Admiralty island, Alexander archipelago. So named by Mansfield, 1890.

Ledge; point, on the mainland, the south point of entrance to Walker cove, Behm canal. So named by the Coast Survey in 1891.

Ledge; point, the southwestern point of entrance to Nakat inlet, southenstern Alaska. Descriptive name, given by Nichols in 1883.

Ledianoi, cape; see Icy.

Leduc; river, on the mainland, tributary to the Chickamin river, southeasterm Alaski. Name published by the Coast Survey in 1898. Also written Le Duc.

Lee; creek, in the Fortymile region, eastern Alaska, tributary from the south to Gold creek, an atfluent of Mosquito fork Fortymile creek, near latitude $64^{\circ} 10^{\prime}$, longitude $142^{\circ} 30^{\prime}$. Name from Lieutenant Mitchell, Signal Corps, U, S. A., in 1902. 
Lee; gulch, 3 miles northwest of Cape Nome, Seward peninsula, tributary to to Hastings creek from the east, near longitude $165^{\circ} 05^{\prime}$. Local name, published in 1.904 as Lee's.

Lee; mountain, Alaska peninsula, on the western .side of the southeastern extremity of Becharof lake. Named after J. H. Lee, a pioneer prospector, by J. L. McPherson, deputy mineral surveyor.

Lees; point, the eastern point of entrance to Anchor passage, Behm canal, Alexander archipelago. So named by Vancouver, 1793.

Leesia, bay; see Aleutkina.

Leesoffskaia, bay; see Aleutkina.

Leesy, cape and islet; see Fox.

Left; cape, the wester'n head of Kiliuda bay, Kodiak. Named Lievoi (left hand) by the Russians. It is on the le't hand as one enters the bay.

Left; fork of Coal creek, Alaska peninsula, tributary to Mine harbor, eastern shore Herendeen bay, near longitude $160^{\circ} 40^{\prime}$. Descriptive name, reported by Sidney Paige, of the Geological Survey, 1905.

Left, fork of Casadepaga; see Willow creek.

Left; fork of Dexter creek, 6 miles north of Nome, Seward peninsula, draining the north slope of the divide between Anvil peak and Newton peak, near longitude $165^{\circ} 20$. Local name, published in 1901.

Left; fork of Elk creek, on the left bank of Nome river, 13 miles northwest of Cape Nome, near longitude $165^{\circ} 15^{\prime}$. Local name, published in 1904.

Left; fork of Diry creek, $3 \frac{1}{2}$ miles northeast of Nome, Seward peninsula, near longitude $165^{\circ} 18^{\prime}$. Name from Gerdine, 1904. Has been called Newton Gulch No. 2.

Leg; island, west from Latouche island, Prince William sound. So named by Dixon, 1787.

Legma; island, one of the Necker group, Sitka sound, Alexander archipelago. So named by Vasilief, 1809. Legma is Aleut for calm.

Leila; small lake, near the headwaters of Matanuska river, about latitude $62^{\circ}$. So named by Glenn, 1898.

Leisnoi, island; see Liesnoi.

Lemesurier; island, near entrance to Glacier bay, Icy strait, southeastern Alaska, about latitude $58^{\circ} 17^{\prime}$, longitude $136^{\circ} 05^{\prime}$. So named by Dall, 1879 , after the officer who commanded one of Vancouver's boats during the exploration and survey of Cross sound in 1794.

Lemesurier, island; see Misery.

Lemesurier; point, the extreme northeastern point of Kayak island, Controller bay, Gulf of Alaska, near Jongitude $144^{\circ} 10^{\prime}$. Named Point le Mesurier by Vancouver in 1794. The Spaniards called it Punta de Navia. Has been written Mesurier point.

Lemesurier; point, at the junction of Ernest sound and Clarence strait, Alexander archipelago. Named by Vancouver, 1793, after Le Mesurier, a member of his party. Sometimes it has been written Mesurier. It is Misery point of the local navigators, probably because more easily pronounced and entered in the log.

Lemly; rock and group of rocks, off Lemesurier point, at the junction of Ernest sound and Clarence strait, Alexander archipelago. So named by Clover, 1885, presumably after Capt. Samuel Conrad Lemly, Judge-AdvocateGeneral, U. S. N. Erroneously Lemley.

Lemon; creek, on the mainland, southeastern Alaska, about 5 miles northwest of Juneau, tributary to Gastineau channel. Local name, reported by Peters in 1902. 
Lemon; point, the north point of entrance to Port McArthur, Kuiu island, Alexander archipelago. So named by Helm, 1886.

Lemon Creek; glacier, southeastern Alaska, about 4 miles northeast of Juneau, at the head of Lemon creek. Local name, reported by Peters in 10)(2.

Lena; cove, indenting the mainland, in Favorite channel, Stephens passage, southeastern Alaska, on the north side of Lena point below. Name published by the Coast Sulvey in 1893 .

Lena; point, on the mainland, near southern entrance to Favorite chamnel, Stephens palssage, southeastern Alaska, near latitude $58^{\circ} 24^{\prime}$. So named by Beardslee, 1880 .

Lenard; harbor; indenting the eastern shore of Cold bay, near Belkofski, Alaska peninsula, about longitude $162^{\circ} 20^{\prime}$. Apparently so named by the Fish Commission in 1888.

Lenard; sunken rock, 30 miles southwest of Sannak island, near latitude $54^{\circ}$, longitude $163^{\circ} 13^{\prime}$. So named by the Fish Commission in 1888 .

Lennan; shoal, off south end of Dolgoi island, near Belkofski. So named by Dill, 1880.

Lennox; island, near the eastern point of entrance to Izembek bay, Alaska peninsuli. So named by the Fish Commission in 1888.

Leo; anchorage, in Fortuna strait, Salisbury sound, west end of Chichagof island, Alexander archipelago. Surveyed and so named by Coghlan, 1884, presumably after the schooner Leo.

Leo; creek, tributary from the west to Trembly creek, an affluent of Dietrich river, about latitude $68^{\circ}$, longitude $150^{\circ}$. Prospector's' name, reported by Peters and Schrader, 1901.

Leo; mountain (Mount Leo) in western Aliska, on the left bank of upper Anvik river, near latitude $63^{\circ} 30^{\prime}$. Prospectors' name, published in 1900.

Leo; point (Point Leo), southwestern shore Chichagof island, Salisbury sound, Alexander archipelago-the eastern point at the southern entrance to Fortuna strait and Leo anchorage (above). So named by Moore, 1896.

Leontovich; cape, the western point of entrance to Gerstle bay, on north shore of Alaski peninsula, between Hort Moller and lzembek bay. Named by Lutke, 1828 , after Lieut. Alexander Leontovich, I. N., a member of his party. Has also been called Leon cape and Starling cape.

Leora; mountain (Mount Leora), east of Norton sound, near Eaton. Name reported by Doctor Gambelf, superintendent of Eaton Reindeer station, in 1900. Not found on any map.

Leroy.

- Name from Barnard, 1900.

Leskoff. cape: see Lieskof.

Leslie; glacier: and pass at the head of Chilkat river. So named by the Leslie expedition in 1890 . This name bas not been seen on any map.

Lesnoi, island, islet, shoal; see Liesnoi.

Lesser, arm, Whale bay; see Small.

Letnikof; cove, on the eastern shore of Chilkat inlet, Lynn canal, southeastern Alaska, near latitude $59^{\circ} 10^{\prime}$, longitude $135^{\circ} 23^{\prime}$. So named by Lindenberg, 1838 ; written also Litnekof.

Letushkwin, village; see Old Kootznahoo.

Levashef, port or harbor' see Port Levashef.

Level; island, at entrance to Duncan canal, Sumner strait; Alexander archipelago. Descriptive name, given by Snow in 1886. At high water it becomes two islands.

Bull. 299-06 $\mathrm{M}-26$ 
Level; mountain, on. Revillagigedo island, near Tongass narrows, Alexander archipelago. So named by Nichols, 1883.

Lewes; river, one of the aftluents of the upper Yukon. In 1847 or 1848 Robert Campbell, of the Hudson Bay Company, descended this river and named it Lewes. Fresent usage appears to regard the Yukon as beginning at the junction of the Lewes and Pelly rivers at Fort Selkirk. Often written Lewis. The form Lewes has been adopted by the Canadian Board on Geographic Names.

Lewis; cape, on the Arctic coast, between Point Hope and Cape Lisburne, near latitude $68^{\circ} 40^{\prime}$. So named by Beechey, 1826, presumably after $\mathrm{Mr}$. Charles Lewis, who accompanied him as a volunteer.

Lewis; Jow islet, west from Alava point, Revillagigedo channel, Alexander archipelago. Apparently so named by Iocal pilots. Near it is Walker island, and there has been confusion between these names. Called Side island in the Coast Pilot (1883, p. 77)

Lewis; peak, in the McKinley range, near latitude $62^{\circ} 10^{\prime}$, longitude $153^{\circ}$. So named by Herron, 1899.

Lewis; point, on Gravina island, Tongass narrows, Alexander archipelago. Named, presumably, by local pilots about 1880 .

Lewis; reef, off Lewis point, Tongass narrows, Alexander archipelago. So named by local pilots.

Lewis, river; see Lewes.

Lgun, rock; see Liar.

Liakik, bay; see Three Saints.

Liakik; cape, forming the eastern point of entrance to Three Saints bay, Kodiak. So called by Tebenkof, 1849. Perhaps from Liak, the Aleut name for the black-footed goose.

Liar; rock, the westermmost of the Eckholms group, Sitka sound, Alexander archipelago. Nimed Lgun (liar) by the Russians, 1809. Has also been called False rock.

Liard; river, tributary to the Mackenzie, from the west. Has also been called Mountain river. The above name, Liard, lats been adopted by the Canadian Board on Geographic Names.

Libbey; glacier; tributary to Agassiz glacier, St. Elias alps, southeastern Alaska. Named by 'Topham, 1888, after Prof. William Libbey, jr., of Princeton

- college. Erroneously Libby.

Libby; island, 5 miles westward of Cape Spencer, mainland coast, southeastern Alaska, at west side of entrance to Graves harbor, near latitude $58^{\circ}$ $15^{\prime}$, longitude $136^{\circ} 40^{\prime}$. "It is a good-sized wooded island, probably 300 feet high." So described in the Coast Pilot of 1901.

Libby; river, tributary to the headwaters of Niukluk river, Seward peninsula. Name from Barnard, 1900. Presumably so named after Daniel B. Libby, of the Western Union Telegraph expedition, 1866.

Liberty; fork, of O'Brien creek, in the Fortymile mining district. Local name, obtained by Barnard in 1898 .

Liberty Cap; see Battery point.

Lida; island, and anchorage, near the northwestern point of Caton island, Sannak group, about longitude $162^{\circ} 30^{\prime}$. So called by the Fish Commission in 1880.

Lidrejana, bay; see Andrew.

Liebes; cove, indenting the south shore of St. Michael bay, western Alaska, near latitude $63^{\circ} 27^{\prime}$, longitude $161^{\circ} 58^{\prime}$. Name given or reported by the Coast Survey parties, $1898-1900$. 
Liebigstag; river, tributary to Copper river from the east, near liltitude $62^{\circ}$. So called by Allen, 1885 , after an Indian chief living at or near its mouth. Apparently identical with Chetaslina.

Liesistoi, islet; see Wooded.

Lieskof; cape, on the northern shore of Alaska peninsula, northwest of Pavlof: bay. Named Lieskova (Lieskof's) by Lutke, 1S28, after Lieut. Arcadie Lieskof, I. N., a member of his party. Has been written Leskoff, I.ieskoff, Liskoff, etc. Apparently identical with Garfield point of the Fish Commission in 1888.

Liesnoi, cape; see Wooded.

Liesnoi; island, between Woewodski and Eliza harbors, Frederick sound, Alexander archipelago. Named Liesnoi (woody) by Zalrembo, 1838.

Liesnoi; island, in Krestof harbor, Kruzof island, Alexander archipelago. Named Liesnoi (woody) by Vasilief, 1809.

Liesnoi; islaud, northwest of Wrangell, in Sumner strait, Alexander archipelago. Named Liesnoi (woody), by the Rynda party, 1863. The island is low and wooded. Has been printed erroneously Leisnoi.

Liesnoi; island, one of the Necker group, Sitka sound, Alexander archipelago. Named Liesnoi (wooded) by Vasilief, 1809, who has a North Liesnoi and a South Liesnoi. Has also been erroneously written Lusnoi.

Liesnoi, island; see Makhniti.

Liesnoi, island (I. ydiak); see Woody.

Liesnoi; islet, $r$. L L pelago. Lamed Liesnoi (woody) by Vasilief, 1809.

Liesnoi; islet, near Southern rapids, Peril strait, Alexander archipelago. Named Liesnoi (woody) by Vasilief, 1833. Has also been written Lesnoi.

Liesnoi; shoal, near Southern rapids, Peril strait, Alexander archipelago. So named by Coghlan, 1884.

Lietnik; cape, in Kizhuyak bay, north coast of Kodiak. Named Lietnika (summer village) by Murashef, 1839-40.

Lietnik, cape, on the western shore of Afognak bay, Afognak island, Kodiak group. Named Lietnika (summer village) by Murashef, 1839-40. Moser, 1900 , reports Lipsett as the natme of this point. See Lipsett.

Lietnil;; see Afognalk and Litnik.

Lievoi, cape; see Left.

Lighter; creek, an arm of Davis creek, in Kootznahoo inlet, Admiralty island, Alexander archipelago. So named by Meade, who, in 1869, opened a coal mine here.

Lighthouse, island; see signal.

Lighthouse; rocks, southwest of the Semidis. So named by Dall, 1874. Tebenkof, 1849, calls it Namdak crag or pinnacle. Also called Namtschak.

Lightning; creek, Seward peninsula, tributary to Casadepaga river from the east, near latitude $64^{\circ} 53^{\prime}$, longitude $164^{\circ} 13^{\prime}$. Prospectors' name, from Gerdine. 1905.

Lignite; creek, tributary to Yukon river from the south, neal longitude $143^{\circ}$ 15'. Name from Collier, 1902.

Lignite; creek, a right branch of Cantwell river, near latitude $63^{\circ} 55^{\prime}$, longitude $149^{\circ}$. Descriptive name, from Brooks, 1902 .

Lillian; creek, 10 miles northeast of Nome, Seward peninsula, tributary to Buster creek from the north, near longitude $165^{\circ} 157^{\prime}$. Name from Birnard, 1900.

Lilly; lake, 10 miles north of and tributary to Klutina lake. So named by Abercrombie, 1898. Also written Lily. 
Lime; creek, tributary to the Niukluk river from the south, in the Eldorado mining district, Seward peninsula. Local name, published by the Geological Survey in 1900. Called Bear creek on a recent local map.

Lime; creek, Seward peninsula, tributary on south bank of East fork Solomon river, near latitude $64^{\circ} 42^{\prime}$, longitude $164^{\circ} \quad 05^{\prime}$. Prospectors' name, from a local map, 1904.

Lime; point, the western point of entrance to Nutkwa inlet, Prince of Wales island, Alexander archipelago. Name from Moser, 1897.

Limestone; butte (3,700 feet high), eastern Alaska, east of. North fork Fortymile creek and south of Champion creek, near latitude $64^{\circ} 45^{\prime}$, longitude $141^{\circ} 50^{\prime}$. Prospectors' name, from sketch map compiled by Major Glassford, Signal Corps, U. S. A., 1905.

Limestone; creek, tributary to Bettles river from the north, near longitude $149^{\circ} 30^{\prime}$. Descriptive name, from Schrader, 1899.

Limestone; creek, tributary to Clear creek from the east, on south slope of Mount Wrangell. Apparently a local name, reported by Schrader in 1900.

Limestone; gap, in the Talkeetna mountains, between the headwaters of Bubb and Hicks creeks. So named by Glenn, 1898 .

Limestone; inlet, in the mainland, opening into Stephens passage, southeastern Alaska. Descriptive name, given by Meade in 1869 . On the north shore are some high limestone bluffs.

Limestone Bluffs; mountain, on the nortli shore of Limestone inlet, Stephens passilge, 'southeastern Alaska. So named by Meade, 1869, who says: "From a remarkable-looking streak on the side of the mountain forming the west side of the inlet I called it Limestone Inlet and the mountain Limestone Bluff."

Lina, bay; see Lituya.

Lincoln, cape; see Mordvinof.

Lincoln; channel, between Sitklan and Kannaghunut islands, Dixon entrance. Presumably named, 1869, after the U. S. revenue cutter Lincoln.

Lincoln; island, north of Point Retreat, in Lynn canal, Alexinder archipelago. So named by Meade, 1869 .

Lincoln; mountains (6,200 feet high), near the head of Portland canal. Ap- parently so named by the Coast Survey. Erroneously Licoln.

Lincoln; open bay, on the nortbwestern shore of St. Paul island, Pribilof group, Bering sea. Name published by the Coast Survey in 1890. Designated as Lincoln bight on a recent Coast Surrey chart.

Lincoln; peak $(4,894$ feet high), on the mainland, north. of Frederick sound, southeastern Alaska. So named by Thomas, 1887, after President Abraham Lincoln.

Lincoln; rock, awash at lowest water, southeast of Kashevarof passage, in Clarence strait, Alexander archipelago. Named by Snow, 1886, after President Lincoln. This rock has been reserved for light-house purposes by Executive order dated January. 4, 1901.

Lind; island, in northwestern part of Prince William sound. So named because a Mr. Lind has a fox ranch on this island. So says Grant, 1905. It is probably the same island that is elsewhere called Pond. See Pond.

Linda; bar, in the Yukon, between Fort Yukon and Circle at Thirtysixmile crossing (36 miles below Circle?). Named after the steamer Linda wrecked or stranded here. River pilots' name, taken from Edwards' Track Chart of the Yukon, 1899. 
Linda Vista; creek, Seward peninsula, in Solomon River valley, tributary on south bank of Big Hurrah creek, neai latitude $64^{\circ} 38^{\prime}$, longitude $164^{\circ}$ 15'. Prospector's' name, from a local map, 1904.

Lindblom; creek, 9 miles north of Nome, Seward peninsula, tributary to Snake river trom the east, near longitude $165^{\circ} 27^{\prime}$. So named after Erick $\mathrm{C}$. Lindblom, one of the first to stake claims near Nome in 1898. Erroneously Lindbloom.

Lindeman; lake, near Chilkoot pass, in the Yukon drainage basin. Named by Schwatka, 1883, after Dr. Moritz Lindemin, vice-president of the Bremen Geegraphical Society.

Lindenberg; harbor, indenting the southern shore of Chichagof island, Peril strait, Alexander archipelago. So named by vasilief, 1833.

Lindenberg; head, the eastern head of Lindenberg harbor, Feril strait, Alexander archipelago. Name apparently first applied by Moore, 1895.

Lindenberg; peninsula, constituting the eastern part of Kupreanof island, Alexander archipelago. The Russians called its eastern side Lindenberg shore or coast, after $G$. Lindenberg, who explored and surveyed in the Alexander archipelago in and about 1838. Dall, in the Coast Pilot. 1883 , applied the name to the peninsula.

Lindentuerg, point; see Glacier.

Line; island, at entrance to Whiting harbor, Sitka sound, Alexander archipelago. So named by United States naval officers, 1880 .

Linnet; islet, near Spruce island, of the Necker group, Sitka sound, Alexander archipelago. Named Chechotkin (linnet) by Vasilief, 1809.

Lion; creek, Seward peninsula, Solomon River drainage, tributary on south bank of Big Hurrah creek, near latitude $64^{\circ} 38^{\prime}$, longitude $164^{\circ} 12^{\prime}$. Prospectors' name, from a local map, 1904.

Lion; point, on the eastern shore of Portland canal, near its head. So named by the Coast Survey as early as 1891 .

Lion; reef, on the Arctic coast east of Colville river. So named by Franklin after his boat Lion, which grounded upon it, August 7, 1826.

Lipsett; point (Point Lipsett), Afognak island, Kodiak group, on the western shore of Afognak bay, near latitude $58^{\circ}$, longitude $152^{\circ} 47^{\prime}$. Local name, reported by Moser, 1900 . See Lietnik cape.

Lisburne; cape (1,400 feet high), on the Arctic coast of Alaska, near latitude $68^{\circ} 53^{\prime}$. Discovered and so named by Cook, August 21, 1778. Erroneously Lisburn and Lisbon. The Eskimo name is Wévok, Wevuk, or Webuk, which is also the name of the village there and the name of Cape Thompson ; Cape Lisburne being Webuk Unasiksuk (far) and Cape Thompson, Webuk Konikto (near).

Lisburne; hills, a range of hills, 1,000 to 2,000 feet high, extending southwesterly from Cape Lisburne, near latitude $68^{\circ} 40^{\prime}$. So named by Collier, 1904.

Lisburne; peninsula, northwest coast of Alaska, latitude $68^{\circ}$ to $69^{\circ}$. Name proposed and used by Collier, 1904.

Liscome; bay, on the southern shore of Dall island, Dixon entrance. A bay in this vicinity, not exactly identified, was named Fort Liscome by Ingrabam in 1792.

Liscum, fort ; see Fort Liscum.

Lisefskaia, bay; see Camp Coogan.

Lishtak; river, the left fork, near the head of Chulitna river, a large southern tributary of the Kuskokwim, near longitude $157^{\circ}$. Native name, from 'Tikhmenief, 1861. Another native name is said to be I-im-tuck. 
Lisianski; peninsula, between Katliana bay and Nakwasina passage, Baranof island, Alexander archipeligo. So named by Dall in the Coast Pilot of 1883.

Lisianski; point, the north point of entrance to Katliana bay, Sitka sound, Alexander archipelago. Named by Dall, in the Coalst Pilot of 1883, after Capt. Iuri Fedorovich Lisianski, I. N., who was at Sitka in 1804.

Lisianski; small bay, on the southeastern coast of Kodiak, northwest of Sitkalidak island. Name given by the Fish Commission in 1888.

Lisianski; strait, separating Yakobi island from Chichagof island, Alexander archipelago, near latitude $58^{\circ}$, longitude $136^{\circ} 20^{\prime}{ }^{\circ}$. So named by Dall, 1879, in the Const Pilot, after Capt. Iuri Fedorovich Lisianski, upon whose chart of 1814 it first appears. Has been written Lisiansky

Liskoff, cape; see Lieskof.

Litnelkof, cove; see Letnikof.

Litnil, bay, lake, river' ; see Afognak.

Litnik; Indian village, on Afognak bay, Afognak island. This name is found on a map made by the Fish Commission in 1889, and is apparently the Afognak of other maps. According to Moser, 1900, it is the Russian word Elitnik or Lietnik, meaning a place where fish are cured, or a summer village, and is also the local name of Afognak bay. On Moser's chart of Afognak bay, 1900,. Litnik village is placed at the head of the bay 5 miles north of Afognak.

Little; bay, indenting the northeastern shore of Akun island, Krenitzin group, eastern Aleutians, near longitude $105^{\circ} 35^{\prime}$. So named by the Fish Commission in 1888. Called Rïecheshni bay by Veniaminof, 1830 .

Little; canyon, on the Stikine river, British Columbia.

Little; cove, at head of Middle bay, Chiniak bay, Kodiak. Named Mielkoi (very small) by Russian naval officer's, 1808-1810.

Little; creek, tributary to Red bay, Prince of 'Wales island, Alexander archipeliggo. So named by Helm, 1886.

Little; creek, 3 miles northwest of Nome, Seward peninsula, tributary to Anvil creek from the east, near longitude $165^{\circ} 27^{\prime}$. Local name, obtained by the Geological Survey in 1899. Rich placers were discovered on this creek in 1904.

Little, glacier; see Popof.

Little; gulch, 5 miles northeast of Nome, Seward peninsula, on the northeast slope of Newton peak, draining into Extra Diry creek, near longitude $165^{\circ} 17^{\prime}$. Local name, published in 1904 .

Little; gulch, 9 miles north of Nome, Seward peninsula, on the east bank of Glacier creek, near longitude $165^{\circ} 20^{\prime}$. Local name, published in 1904 .

Little; gulch, 25 miles north of Nome, Seward peninsula, on the west bank of Nome river, near longitude $165^{\circ} 13^{\prime}$. Miners' name, réported by Gerdine, 1904.

Little; island, at entrance to Deep bay, Peril strait, Alexander archipelago. Named Malie (little) by Vasilief, 1833.

Little; island, in southern part of Lynn canal, Alexander archipelago. So named by Symonds, 1880 .

Little; islands, west of Unga and north of Wosnesenski island, near entrance to Pavlof bay, Alaska peninsula. So called by Dall, 1882.

Little; mountain, on the south bank of the Yukon, near the moutl of Koyukuk river. So named by Allen, 1885.

Little; river, about 1 mile west of Cape Ugat, on northern coast of Lodiak. So called by Moser, 1897. 
Iittle; rock (10 feet above bigh water), near north end of Duke island, in Revillagigedo channel, Alexander archipelago. Presuibbly so named by local pilots about 1880 .

Little Afognak; bay and village, southeastern coast Afognak island, Kodiak group, northeast of Afognak bay. Mentioned by Moser, 1900, but not found on any map.

Little Anvil; creek, just east of Topkok river, Seward peninsula. Name from Barnard, 1900. Called also Silverbow creek.

Little Apoon; pass, Yukon delta, a cut-off on the right bank, connecting Apoon pass below its junction with Kwikpak pass, with Kiwikpak palss above the mouth of Kawanalk pass, near latitude $62^{\circ} 53^{\prime}$, longitude $164^{\circ}$. Called Kravaksarok or Little Aproon by Faris, 1899.

Little Black; river, northeastern Alaska, tributary to Porcupine river from the west, 10 miles above Fort Yukon; near latitude $66^{\circ} 30^{\prime}$, longitude $144^{\circ}$. Name published by the Coast Survey in 1890. See also Black and Rat.

Little Blanche; creek, tributary to Seventymile creek from the south, about 10 miles from Eagle, on the Yukon. Prospectors' name, from Barnard, 1898. Called also Rock creek.

Little Boulder; creek, in the Chilkat region, tributary to Klehini river from the north, 3 miles below Porcupine creek, near longitude $136^{\circ} 08^{\prime}$. Prospectors' name, reported by Wright, 1903. Krause brothers (1882) wrote the Indian name Teltakatschkabin or Jeltakatschkahin, and Flemer (1898) wrote it Teltakhatskahin.

Little Branch; bay, indenting the southwestern shore of Baranof island, Alexander archipelago. Named Maloi Strelka (little arrow, i. e., little offshoot) by the Russians.

Little Charley, creek; see Kandik river.

Little Chena; river, in the Fairbanks region, tributary to Chena river from the north, near latitude $65^{\circ}$, longitude $147^{\circ}$. Local name, from Gerdine, 1903.

Little Daisy; creek, Seward peninsula, tributary to Goodhope river from the south, near latitude $65^{\circ} 45^{\prime}$, longitude $163^{\circ} 55^{\prime}$. Prospectors' name, reported by Gerdine, 1901.

Little Delta, creek; see Mahutzu.

Little Derby; creek, debouching on the south shore of Seward peninsula, 64. miles west of Cape Nome, near longitude $165^{\circ} 12^{\prime}$. Local name, from Gerdine, 1904.

Little Diomede; island, one of the Diomede group, in Bering strait. Commonly known as the Little Diomede. Sauer and, after him, Lutke give its name as Imaglin. Beechey, 1830, has Kruzenstern (Igna-look), while Tebenkof, 1849, calls it Ignaliuk. In the Alaska purchase treaty, 1867, Little Diomede island and Fairway rock, presumably, are grouped as "the islands of Krusenstern or Ignalook." Beechey named this island, 1826, after the Russian admiral, Krusenstern.

Little East; rookery (seal) on the north shore St. George island, Bering sea, near longitude $169^{\circ} 31^{\prime}$. Called Little Eastern rookery by Elliott in 1872-73, and Little Last by Stauley-Brown (1891) and Duffield in 1897.

Little Eastern, rookery; see Little East.

Little Eldorado; creek, in the Rampart region, tributary from the north to Quail creek a branch of 'Troublesome creek. Prospectors' name, obtrined by Prindle in 1904.

Little Fort; island, on the southeastern shore of Shuyak island, Kodiak group. Named Maloi Krieposti (little fort) by the Russian-American Company, 1849. 
Little Garfield; creek, Seward peninsula, tributary to Noxapaga river from the west, near latitude $65^{\circ} 30^{\prime}$, longitude $164^{\circ} 20^{\prime}$. Local name, reported by Gerdine, 1901.

Little Gavanski; island, immediately opposite Starrigavan bay, Sitka sound, i Alexander archipelago. Named Gavanski menshoi (little harbor) by Vasilief, 1809. Has also been called Little island.

Little Gold; creek, eastern Alaska, a north branch of Gold creek, Salcha River drainage, near latitude $64^{\circ} 50^{\prime}$, longitude $145^{\circ} 40^{\prime}$. Prospectors' name, reported by Witherspoon, 1905.

Little Goose, island; see Goose.

Little Granite; creek, eastern Alaska, on the south bank of Seventymile creek, near latitude $64^{\circ} 55^{\prime}$, longitude $142^{\circ}$ ' $20^{\prime}$. Prospectors' name, from sketch map compiled by Major Glassford, Signal Corps, U. S. A., 1905.

Little Hog, river; see Little Hogatza.

Little Hogatza; river, tributary to the Koyukuk, on the right bank, $1 \frac{1}{2}$ miles below Hogatza river, near latitude $66^{\circ}$, longitude $155^{\circ} 30^{\prime}$. River pilots' name, reported as Little Hogatsikakat and Little Hog by Lieutenant Camden, R. C. S., 1900.

Little Hurrah; creek, tributary to Big Hurrah creek from the south, Seward peninsula. Name from Barnard, 1900.

Little Indian; creek, Kenai peninsula, tributary to Chickaloon bay, south shore Turnagain arm, Cook inlet, near longitude $149^{\circ} 50^{\prime}$. Local name, from Becker, 1895.

Little Joe; gulch, 15 miles northwest of Nome, Seward peninsula, on the right bank of New Eldorado creek, an affluent of Osborn creek, near longi-, tude $165^{\circ} 10^{\prime}$. Miners' name, from Gerdine, 1904 .

Little Kayak; local name for Wingham island.

Little Kings, creek; see Young.

Little Kiska; island, just east of Kiska, Rat island group, western Aleutians. So called by Lutke. See Kiska. .

Little Koniujï; island, between Big Koniuji and Simeonof islands, Shumagin group, near longitude $159^{\circ} 20^{\prime}$. Now occupied as a blue-fox farm. So named by the Russians. According to Veniaminof this is Tangimak island of the Aleuts. Lutke writes it Tounghimik. See also Koniuji.

Little Kotlik; river, Yukon delta, the westerly of the two small river's opening on the right bank of Apoon pass at Kotlik, near latitude $63^{\circ} 02^{\prime}$, longitude $163^{\circ} 33^{\prime}$. From Eskimo kwa-tleek (breeches). So called by Faris, 1899.

Jittle Malamute; river, in the Koyukuk region, tributary to Alatna river. Mentioned by Lieutenant Camden (Operations of the U. S. revenue steamer Nunivali, 1899-1901, p. 247). Not found on any map.

Little Minook; creek, tributary to Minook creek from the east, near latitude $65^{\circ} 30^{\prime}$, longitude $150^{\circ}$. Prospectors' name, reported by spurr, Goodrich, and Schrader, 1896.

Little Minook Junior; creek, in the Rampart region, tributary from the east to Minook creek, about 5 miles above its mouth. Local name, reported by Prindle, 1904.

Litile Naked, island; see Peak and Storey.

Little Nitchawak; river, 8 miles northwest of Controller bay, tributary to Nitchawak river from the east, near longitude $144^{\circ}$. Local name, from Martin, 1903.

Little Polovina; hill, in the northeastern part of St. Paul island, Pribilof group, Bering sea. Presumably the local name. Name published by the Coast Survey in 1875. Polovina is Russian for halfuay. 
Little Polovina; rookery, on the eastern shore of St. Paul island, Bering sea, $1 \frac{1}{8}$ miles northeast of Halfway point, near longitude $170^{\circ} 09^{\prime}$. Written Little Polavina by Elliott, 1873-74.

Little Queenie; creek, 8 miles north of Fairbanks, on the south bank of Goldstream creek, a mile below Engineer creek, near longitude $147^{\circ} 45^{\prime}$. Prospectors' name, from a local map, 1905.

Little Rapids; islet, in Southern rapids, Feril strait, Alexander archipelago. - So named by Coghlan, 1884.

Ljttle Raspberry; island, between .Afognak and Kodiak, Kodiak group. Named Maloi Malinovoi (little raspberty) by Murashef, 1839-40.

Little Raspberry; strait, between Whale and Kodiak islands, Kodiak group. Named Maloi Malinovoi (little raspberry) by Murashef, 1839-40.

Little River; slough, in the eastern part of Copper river delta. Fisheries name, reported by Moser, 1897.

Little Rose; island, one of the Opasni islands, in Northern rapids, Peril strait, Alexander archipelago. So named by Coghlan, 1884.

Little Salmon; river or creek, tributary to Tsirku river from the north, near longitude $136^{\circ}$. Local name, obtained by Wright, 1903. The 'Isirku is now called by the miners, Salmon river.

Little Sitkin; island (3,585 feet high), between Kiska and Semisopochnoi islands, Rat island group, western Aleutians. So called by the Russians. Lutke, 1835, calls it Little or Western Sitkin. Also has been written Little Sitchin.

Little Smith; island, just southwest of Smith island, Prince William sound. Local name, reported by Grant, 1905.

Iittle Sonnickson, creek; see Falls:

Little Specimen; gulch, 6 miles north of Nome, Seward peninsula, on the north side of Anvil peak, near longitude $165^{\circ} 23^{\prime}$. Local name, publisbed in 1904.

Little Strêlli, arm of Whale bay; see Small.

Little Susitna; stream, entering head of Cook inlet, between Susitna river and Knik arm. Local name, published by the.Coast Survey in 1898.

Little Tanaga; island, east of Adak island, Andreanof group, middle Aleutians. Called Tannak on Russian Hydrographic chart 1400, edition of 1848; Tanaga by Tebenkof, 1849; and Little Tanaga by the North Pacific exploring expedition, 1855, doubtless to distinguish it from the larger Tanaga island, about 70 miles west of this one. Native name.

Little Tanana; river or slougb, on the right bank of the Tanana, nenr longitude $143^{\circ} 30^{\prime}$. So called by Lieutenant Mitchell, Signal Corps, U. S. A., 1902.

Little Tok; river; in the Mount Wrangell region, tributary from the south to 'Tok river, near latitude $63^{\circ} 04^{\prime}$ ', longitude $143^{\circ} 26^{\prime}$. Local name, reported by Schrader, 1902 . Called also Little Tokio.

Little Ugalenka, river; see Kiklukh.

Little Ugalentz, river; see Kiklukh.

Little Whale; bay, indenting the southwestern coast of Baranof island, in or near Whale bay, about latitude $56^{\circ} 40^{\prime}$. So called by the fisheries, and reported by Moser, 1897. It may be the bay that is otherwise called Small arm of Whale bay. See Small.

Little Zapadni; rookery (seal), on the western shore of English bay, southwestern coast of St. Paul island, Bering sea, near longitude $170^{\circ} 20^{\prime}$. Local name, reported by Duffield in $\mathbf{1 8 9 7 .}$ 
Lituya; bay, in southern part of the St. Elias alps, southeastern Alaşka, near longitude $137^{\circ} 40^{\prime}$. This name is of Indian origin and was obtained and used by the Russians. The Indian word is thought by Dall to be H'lit-tu-yúh, accented on the last syllable. Lisianski, 1805, wrote it L'tooa bay, and 'Tebenkof writes it Ltua. Russian Hydrographic chart 1378 has Altua bay or Port Frantsuzof. Out of these has come Ltuya, Alituya, Altona, and Lina. La Perouse surveyed the bay, 1786, and named it Fort des França is and to the whalemen it has been known as Frenchman's bay. The name Skecter has also been applied to it under: a. misapprehension.

Lituya; mountain (11,832 feet high), in the Fairweather range, southeastern Alaska. Name published by Tebenkof, 1849.

Lively; group of islands, in Tlevak strait, near Tlevak narrows, Alexander archipelago. So named by Dall, 1882, after the steam launch of the Hassler. Sheldon Jackson has calied this group Voorhees isles.

Lively; sunken rock, in Port Chester, Annette island, Alexander archipelago. Named by Nichols, 18̧83, after the Hassler's steam launch Lively.

Livingston; creek, tributary to Feather river from the east, Seward peninsula. Name from Barnerd, 1900.

Livingstone; creek, eastern Alaska, on the south bank of Seventymile creek, near latitude $64^{\circ} 55^{\prime}$, longitude $142^{\circ} 05^{\prime}$. Prospectors' name, and so spelled on sketch map compiled by Major Glassford, Signal Corps, U. S. A., 1905.

Lizard; cove, indenting the eastern shore of Pearse island, just south of Lizard point, Fortland inlet, Canada, near latitude $54^{\circ} 50^{\prime}$, longitude $130^{\circ} 15^{\prime}$. Name of point (below) applied by local navigators to cove, and reported by Fassett, Bureiu of Fisheries, 1904.

Lizard; point on the southeastern shore of Pearse island, Portland inlet. So named by Pender, 1868 . Erroneously Lizzard.

Loaf; ridge of mountains (2,200 feet high), on the mainland, northeast of Dixon entrance. So called by Nichols, 1883.

Lobos, Isla de los; see Sealion rocks.

Lockenuck, river; see Alagnak.

Lockwood; mountains, northwestern Alaska, south of the headwaters of Kobuk river, between the Kobuk and Koyukuk rivers, and lying across the Arctic circle, near longitude $156^{\circ}$. So named by Stoney in 1885 .

Lockwood; peak $(3,510$ feet high) in the northeastern.part of Kupreanof island, Alexander archipelago. Named by Thomas, 1887, after Lieut. James Booth Lockwood, U. S. A., who perished at Cape Sabine in 1883.

Lockwood; point, on Woewodski island, Wrangell strait, Alexander archipelago. So named by Meade, 1869 . It was called Poverotni (turning) by Lindenberg in 1838.

Lode, point, on the right bank of Chilkat river, near its mouth. . Named Zhila. (lode, also hut) by Lindenberg, 1838. The name is obsolete.

Lofika; hut, of an Indian named Lofka, where the earliest American travelers on the Yukon used to spend a night. Called Lofka, Lofka's, and Lofka's barrabora (hut). It was on the right bank of the Yukon and due east from St. Michael.

Log; point, on Liesnoi island, Woewodski harbor, Frederick sound, Alexander archipelago. So named by Mansfield, 1889.

Logan; creek, small tributary on south bank of upper Yukon, near longitude $142^{\circ} 05^{\prime}$. Prospector's' name, reported by Witherspoon, 1905. It appears to be the stame creek which Collier, 1902, called Glenn. See Glenn. 
Logan; mountain $(19,539$ feet high), in the St. Elias region. So named by Russell, in 1890, in honor: of Sir William Edmond Logan, " founder and long director of the Geological Survey of Canada." The name bas been adopted by the Canadian Boand on Geographic Names.

Logan; point, on the eastern shore of Portland canal. So named by Pender, 1868.

Loghry; creek, in the Fortymile region, eastern Alaska, a small tributary of Hutchinson creek at its head, near latitude $64^{\circ} 15^{\prime}$, longitude $142^{\circ} 20^{\prime}$. So named by Lieutenant Mitchell, Signal Corps, U. S. A., 1902.

Lohtianoi, point; see Glicier.

Lohtianoi, sound; see Cross.

Lomas; cape, on the western shore of Port Caldera, Bucareli bay, Prince of Wales archipelago. Named Cabo de las Lomas (cape of the hillocks) by Maurelle and Quadra, 1775-1779.

Lomavik; Eskimo village, on the left bank of the lower. Kuskokwim. Name from Nelson, 1879, who wrote it Loma vigamute, i. e., Lomavik people.

Lone; creek, Seward peninsula, tributary from the south to Igloo creek, an affluent of. American river, near longitude $165^{\circ} 25^{\prime}$. Prospectors' name, reported by Gerdine, 1900 .

Lone, island, Prince William sound; see Long.

Lone; small islet, in Glacier bay, southeastern Alaska. Descriptive name, given by Reid in 1892 .

Lone; mountain $(2,142$ feet high), near Barlow cove, on northern end of Admiralty island, Alexander archipelago. So called by Meade in 1869. On a recent Coast Survey chart called Barlow mountain.

Lone; rock, south entrance to Fillisnoo harbor, Hood bay, Admiralty island,

1 Alexander archipelago, near latitude $57^{\circ} 28^{\prime}$. So named by Meade, 1869 .

Lone; rock, in or near Port Wrangell, Alaska peninsula. Named Odinakoi (isolated or lone) by Vasilief', 1832.

Lone Baldy; mountain, between Katalla bay and the Copper river delta, near longitude $144^{\circ} 30^{\prime}$. Descriptive name, from Nartin, $190 \%$.

Lone BButte; creek, Seward peninsula, tributary to Serpentine river from the south, near latitude $65^{\circ} 50^{\prime}$, longitude $165^{\circ} 10^{\prime}$. Local name, reported by Gerdine, 1901.

Lone Tree; islet, near entrance to Whitewater bay, Chatham strait, Alexander archipelago. So called by Nichols in the Coast Pilot (1891, p. 157).

Long; arm of Moser bay, extending to the northeast, western shore of Revillagigedo island, Naba bay, Bebm canal, southeastern Alaska, near latitude $55^{\circ} 35^{\prime}$, longitude $131^{\circ} 38^{\prime}$. Descriptive name, from local navigators, and reported by Fassett, Bureatu of Fisheries, 1904.

Long. A sunken bank or reef, called by the Russians Dlinnaia (rather long), and lying near Pamplona rock, Gulf of Alaska, is shown on Russian Hydrographic chart 1378 (1.847).

Long; bay, indenting the north shore of Prince William sound, between Columbia and Unakwik bays, near longitude $147^{\circ} 10^{\prime}$. Local name, reported by Schrader, 1900.

Long; beach, in Mitrofania bay, Alaska peninsula. So callea by the Fish Commission in 1888.

Long; glacier; on the southern flank of Mount Wrangell and tributary to Kotsina creek from the north. So named by Schrader, 1900, from its shape.

Long; island, on the western shore of Cordova bay, Dixon entrance. Named Dolgoi (long) by the Russians. 
Long; island, in Kootznahoo inlet, Admiralty island, Alexander archipelago. Descriptive name, given by Meade in 1869.

Long; island, in northeastern part of Sitka sound, Baranof island, Alexander archipelago. Named Dolgoi (long) by Vasilief in 1809 . Has also been called Dolgay.

Long; island, in Port Frederick, Chichagof island, Alexander archipelago, near longitude $135^{\circ} 28^{\prime}$.: So named by United States naval officers, 1880 .

Long; island, in Kasaan bay, Prince of Wales island, Alexander archipelatgo, near latitude $55^{\circ} 30^{\prime}$; longitude $132^{\circ} 20^{\prime}$. Named by the Coast Survey in 1880 .

Long; island, 2 miles long and one-half mile wide, in the northwestern part of Prince William sound, about 70 miles soutbwest of Valdez and 10 miles west of Naked island. Has been occupied since 1896 for the propagiltion of blue foxes. Local name, from Schrader, 1900. Galled also Lone island.

Long; island, in Chiniak bay, near Kodiak. Now occupied by the Senidi Propagating Company for raising blue foxes. Named Dolgoi or Goloi (long or bare) by the Russians in 1809. Lisianski, 1804, called it Barren island.

Long, island, Sannak group; see Clifford.

Long; mountain, Unalaska island, on the peninsula between Unalaska bay and Kalekta bay, near longitude $166^{\circ} 23^{\prime}$. Descriptive name, used by the Harriman expedition, 1899.

Long; peak (about 2,500 feet high), on Wrangell island, Arctic ocean. Climbed by Lieutenant Berry, 1881, and its height measured by aneroid barometer. Capt. Thomas Long, of the whaling bark Nile, measured its height in 1867 and obtained the result 2,480 feet. Named Long peak by the Hydrographic Office in (or before) 1879 and Berry's peak by the same office in 1881.

Longfellow; peak ( 2,955 feet high), on the mainland, near Port Snettishaim, southeastern Alaska. Named by Thomas, 1888, after the poet, Henry Wadsworth Longfellow.

Lookout; mountain, about 800 to 1,000 feet above the river, on west bank of Koyukuk river, near latitude $67^{\circ}$. So named by Allen, who ascended it August, 1885.

Lookout; point, on the mainland, Stephens passage, Alexander archipelago. So named by Meade, 1869 .

Lookout; point, on the south shore of Security bay, Kuiu island, Alexander archipelago. So named by Meade, 1869.

Lookout; point, the eastern point of Caton island, Sannak group, near latitude $54^{\circ} 23^{\prime}$, longitude $162^{\circ} 21^{\prime}$. So called by the Coast Survey in 1900 .

Loon; island, one of the Middle islands, Sitka sound, Alexander archipelago. Named Gagarin (loon) by Vasilief, 1809. Also called Jet by a mistranslation. Has also been written Gagari (diver).

Loon; point, in Eliza harbor, Frederick sound, Alexander archipelago. So named by Mansfield, 1889.

Loon; rock, in the passage between Hinchinbrook and Hawkins islands, Prince William sound, near iatitude $60^{\circ} 29^{\prime}$, longitude $146^{\circ} 17^{\prime}$. So called by Ritter, 1903.

Isoper; creek, in the Tanana valley, tributary to Preacher creek from the south, near latitude $65^{\circ} 40^{\prime}$, longitude $145^{\circ} 40^{\prime}$. Prospectors' name, reported by Gerdine, 1903. 
Lopp; lagoon, just north of Cape Prince of Wales, Seward peninsula. So named by Brooks, 1900, after Rev. William Thomas Lopp, of Indiana, a missionary to the Eskimo, who began work here in 1890 .

Lorus, harbor ; see Dora.

Lord; islands, in Dixon entrance, near Cape Fox. So named by Fender, 1868. Lord; rock, near Lord islands, Dixon entrance, south of Cape Fox. Named by Nichols, 1883.

Lords, harbor ; see Dora.

Lorentz; river, tributary to the Tanana from the south, near longitude $150^{\circ} 30^{\prime}$. Named by Allen, 1885, after Mr. Lorentz, of the Alaska Commercial Company, chief trader for the Yukon country. On some maps it is Lorenz.

Loring; post-office and fishing village, on Naha bay, west side of Revillagigedo island, Alexander archipelago. The post-office was established here November, 1885.

Los Coronalos, islands; see Coronados.

Los Hermanos, islands; see Hazy.

Los Mondragones, islets; see Fish Egg.

Lost, creek, near Yakutat bay; see Thaghian.

Lost; creek, Seward peninsula, in Solomon River basin, tributary on nortly bank of Kasson creek, near latitude $64^{\circ} 42^{\prime}$, longitude $164^{\circ} 23^{\prime}$. Prospectors' name, from a local map, 1904.

Lost; creek, Seward peninsula, in Niukluk valley, tributary to American creek from the southeast, near latitude $64^{\circ} 52^{\prime}$, longitude $164^{\circ} 25^{\prime}$. Prospector's' name, from Gerdine, 1905.

Lost; creek, 6 miles northeast of Nome, Seward peninsula, tributary from the west to Nome river, near longitude $165^{\circ} 13^{\prime}$. Local name, published in 1900 .

Lost; creek, 25 miles north of Nome, tributary to Stewart river from the south, near longitude $165^{\circ} 20^{\prime}$. Local name, from Gerdine, 1904.

Lost; creek, tributary to Klokerblok river from the south, Seward peninsula. Name from Barnard, 1900.

Lost; creek, tributary to Tubutulik river from the east, Seward peninsula. Frospector's' name, from Peters, 1900.

Lost; creek, tributary to Yukon river from the south, near longiturle $148^{\circ}$. Prospectors' name, reported by Lieutenant Erickson, U. S. A., 1902.

Lost; gulch, in the Copper River region, on the south side of Chititu creek. Prospectors' name, reported by Mendenhall, 1902.

Lost; harbor, indenting the western shore of Akun island, Krenitzin group, eastern Aleutians, near longitude $165^{\circ} 36^{\prime}$. So named by Gilbert, 1901.

Lost; river, Seward peninsula, rising in the York mountains and emptying into Bering sea, 10 miles east of Cape York, near longitude $167^{\circ} 10^{\prime}$. Local name, reported by Collièr, 1903.

Lothianoi, bay ; see Icy.

Lothianoi, inlet; see Taku.

Louden; telegraph station, on the right bank of Yukon river, 48 miles above the mouth of the Koyukuk, at, near, or opposite Zakatlatan. So named by the Signal Corps, U. S. A., 1903.

Louisa; creek, Seward peninsula, tributary to Kougarok river from the enst, near latitude $65^{\circ} 30^{\prime}$, longitude $164^{\circ} 40^{\prime}$. Prospectors' name, reporter by Gerdine, 1.901.

Louisa; point, on the mainland, at south end of Favorite channel, Stephens passage, southeastern Alaska. So named by Beardslee, 1880. 
Louise; cove, south shore Peril strait, just inside western entrance, near latitude $57^{\circ} 22^{\prime}$, longitude $135^{\circ} 40^{\prime}$. Presumably a local name, from Moore, 1896. Called also Rodman cove.

Louise; lake (elevation 2,200 feet), on the Copper River plateau, in about latitude $62^{\circ} 30^{\prime}$, and in the Susitna drainage system. So called, 1898, by Glenn, who indicates that this is its local name.

Louise, point; see New Eddystone.

Louisville; creek. Seward peninsula, tributary from the south to Igloo creek, a branch of American river, near longitude $165^{\circ} 15^{\prime}$. Prospectors' name, reported by Gerdine, 1901.

Love; islet, one of the Japonski group, Sitka sound, Alexander archipelago. So named by United States naval officers, 1880, after a Mr. Love, employed on the Jamestoun at Sitka in that year.

Low; bluff, on the northern shore of Amchitka isliand, western Aleutians. So designated by the North Pacific exploring expedition of 1855.

Low; cape, on the southwestern shore of Kodiak. Named Nizmennoi (low) by Tebenkof, 1849. Has also appeared as Nizmenno point.

Low; cape, the western head of Kizhuyak bay, Kodiak. Named Nizmennie (low) by Murashef, 1839-40.

Low, cape; see Narrow.

Low, cape; see 'Tonki.

Low; hill ( 407 feet high), in the northern part of St. Paul island, Pribilof group, Bering sea, near longitude $170^{\circ} 18^{\prime}$. Name from Elliott; 1873-74.

Low; island, between Spruce and Kodiak islands. Nimed Nizmennie (low) by Murasbef, 1839-40.

Low; island, off Shoals point, in entrance to sitka sound, Alexinder archipelago. Named Nizmennoi (low.) by Vasilief, 1809.

Low No. 1; island, southwest of Deer island, near Belkofski. So called by the Fish Commission in 1888.

Low No. 2; island, southwest of Deer island, near Belkofski. So called by the Fish Commission in 1.888.

Low; point, the eastern point of entrance to St. John harbor, Zarembo island, Alexander archipelago. So named by Snow, 1886.

Low; point, on east side of Portage bay, Alaska peninsula. Name published by the Hydrographic Office in. March, 1893.

Low; point, Alaska peninsula, on the north shore of Mine harbor, southeastern shore Herendeen bay; near longitude $160^{\circ} 41^{\prime}$. Descriptive name, given by Tanner, 1890 .

Low; point, on the eastern shore of Unimak, eastern Aleutians. Called Nizmennoi (low) by Tebenkof, 1849.

Low; point, on the eastern shore of Bay of Waterfalls, Adak island, middle Aleutians. Descriptive name, given by Gibson in 1855 .

Lowe; point (Point Lowe) on northwest shore of Port Valdez, Prince William sound, near longitude $146^{\circ} 32^{\prime}$. Sso named by Abercrombie in 1898, after Lieut. Percival G. Lowe, U. S. A., a member of his party.

Lowe; river, entering head of Port Valdez; Prince William sound, near latitude $61^{\circ} 05^{\prime}$, longitude $146^{\circ} 10^{\prime}$. So named by Abercrombie, 1898, after Lieut. Percival G. Lowe, U. S. A., a member of his party.

Lowell, islind ; see Renard.

Lowell; point, on the west shore of Resurrection bay, Kenai peninsula, 2 miles south of Seward, near latitude $60^{\circ} 04^{\prime}$, longitude $149^{\circ} 27^{\prime}$. Local name, reported by Denson, of the Coast Survey, 1905. 
Lowenstern; cape, the eastern point of entrance to Shishmaref inlet, Seward peninsula, Arctic ocean. Named Löwenstern by Kotzebue, August, 1816.

Lower; lake, near St. Paul, Kodiak, draining to Shahafka cove. Called Dolgoi (long) by the Russians, 1808-1810, but by Tebenkof, 1849, called Nizhni (lower).

Lowe River; telegraph station, 2 miles east of Port Valde\%, Prince William sound, southern Alaska. So named by the Signal Corps, U. S. A., 1900.

Lower Kootznahoo, bay; see Whitewater.

Lower N̦ushagak, river; see Nushagak bay:

Lower Ramparts; gorge, in Yukon river, between the mouths of the Dall and Tanana rivers. Apparently so called by Dall, 1884. See also Ramparts.

Lower Ramparts; gorge or cinyon, in Porcupine river, about 75 miles above Fort Yukon. So called by the Coast Survey in 1895.

Lowrie; island, near Forrester island, off the west coast of Prince of Wales archipelago. So named by Dall, 1879, after Captain Lowrie, of the snow Captain Cook, in 1786, who was perhaps the first English-speaking navigator to visit Queen Chirlotte islands, and possibly the first who saw this islanda.

Lozi-koket; Indian village, on the left bank of the Yukon, opposite the mouth of Melozi river, near latitude $64^{\circ} 40^{\prime}$, longitude $155^{\circ} 30^{\prime}$. Name takeu from Edwards' 'Track Chart of the Yukon, 1899.

L'tooa, bay ; see Lituya.

Ltu , bay ; see Lituya.

Lucan; point, southeast side Crross sound and west side of Port Althorp, Alexander archipelago. So named by Vancouver, 1794. See also Column.

Luce; island, one of the Kutchuma group, Sitka sound, Alexander archipelago. So named by United States naval officers, 1880, after a Mr. Luce, employed on the Jamestoun at Sitka in that year. See also Emgeten.

Lucia; glacier, northwest of Yaliutat bay, in the St. Elias alps, southeastern Alaska. So named by Mark Brickell Kerr, 1890, after his mother.

Lucile; small lake, about 10 miles north of Knik : $11 \mathrm{~m}$, Cook inlet. So named by Glenn, 1898. Written Lucile on his map and Lucille in his text. Martin, 1905, reports that locally the prospectors and others call it Wassilla's lake, after the chief of the Kink Indians who lives there, and suggests that Lucile may have been an attempt at Wassilla.

Luck; point, on Prince of. Wales island, Clarence strait, Alexander archipelago. So named by Snow, 1886 .

Lucky; cove, indenting the southern shore of Revillagigedo island, Revillagigedo channel, 3 miles northwest of Point Alava, near latitude $55^{\circ} 1.3^{\prime}$, longitude $131^{\circ} \mathbf{1 5}$. Local natvigators' name, reported by Fassett, Bureau of Fisheries, 1904.

Lucky; creek, Seward peninsula, tributary to Harris creek, which in turn is tributary to North fork Kougarok river, near latitude $65^{\circ} 40^{\prime}$, longitude $164^{\circ} 25^{\prime}$. Prospectors' name, reported by Gerdine, 1901.

Lucky; gulch, eastern Alaskil, on the enst bank of Fourth of July creek, an aftluent of the Yukon river from the south, near longitude $141^{\circ} 50^{\prime}$. Prospectors' name, reported by Lieutenant Erickson, U. S. A., 1902.

Lucky Strike; creek, tributary to Blnestone river from the north, Seward peninsula. Name from Barnard, 1900.

Lucy; port (Port Lucy), in southwestern shore of Chatham strait, Baranof island, Alexander archipelago, near latitude $56^{\circ} 20^{\prime}$, longitude $134^{\circ} 40^{\prime}$. So called and described in the Coast Pilot of 1901. 
Lukanin; open bay, on the southern shore of St. Paul island, Pribilof group, Bering sea. Usually written Lukannon. Elliott says it derives its name from "one Lakannon, a pioneer Russian, who distinguished himself with one Kaiecov, a countryman, by capturing a large number of seil-otter's at that point, and on Otter island, in 1787-88." Petrof (Banc. Hist., p. 183) says that Ivan Lukanin was the peredovchik (senior officer:) with Ismailof.

Lukanin; hill, point, and rookery, on the southeastern coast of St. Paul island, Bering sea, near longitude $170^{\circ} 15^{\prime}$. Local name, which Elliott, 1872-74, wrote Lukannen.

Lukeen's Fort; see Kolmakot'.

Lull; point, the northern point of entrance to Kelp bay, Chatham strait, Alexander archipelago, near latitude $57^{\circ} 17^{\prime}$, longitude $134^{\circ} 49^{\prime}$. Named by Dall, 1883, after Capt. Edward Phelps Lull, U. S. N., hydrographic inspector, Coast Survey.

Lulu; peak, in southern part of the St. Elias alps, southeastern Alaska. Name published by the Coast Survey in 1889.

Lung; island, Sumner strait; near the south end of Duncan canal, Kupreanof island, Alexander archipelago. So named by Thomas, 1887.

Lurvey; creek, southeastern Alaska, on the mainland, 2 miles east of Juneau, tributary to Gold creek from the northeast. Local name, reported by. Spencer and Wright, 1903.

Lusnoi, island; see Liesnoi.

Lutke; cape (a cliff 538 feet high), forming the southern hend of Unimak bay on south shore of Unimak island, eastern Aleutians, near longitude $164^{\circ} 20^{\prime}$. Veniaminof (1831) calls this Siuchi (sea lion), and is followed by Tebenkof (1849). The Russian Hydrographic charts (1847) call it Lutke, while the Fish Commission (1888) calls it Promontory.

Lyman; anchorage, a bight in the western shore of Clarence strait, Kasian peninsula, Prince of Wales island, Alexander archipelago, near latitude $55^{\circ} 33^{\prime}$, longitude $132^{\circ} 17^{\prime}$. Named by the Coast Survey after Charles .Lyman, second watch officer of the Coast Survey steamer Gedney, engaiged in Coast Filot work in 1900, and described in the Coast Pilot of 1901. Said also to be called Port Hadley.

Lyman; point, the eastern poitn at the entrance to Lyman anchorage (above). So named and described in the Coast pilot of 1901.

Lyman; rock, awash at lowest tides, on the west side of Lyman anchorage (above). So named and described in the Coast Pilot of 1901.

Lynch; cape, on the western shore of Heceta island, Alexander arrhipelago. So named by the local pilots. Not shown on existing charts. Name published by Nichols in the Coast Pilot (1891, p. 122).

Lynn; canal, the great northern arm of Alexander archipelago. It was explored and so named by Vancouver, 1794. Has also been called Lymn channel.

Lynn; creek, 6 miles north of Nome, Seward peninsula, tributary to Snake river from the east, near longitude $165^{\circ} 28^{\prime}$. Local name, obtained by the Geological Survey in 1899.

Lynn Brothers; group of islands, in St. James bay, Lynn canal, Alexander archipelago. Named The Brothers by Meade, 1868, and since modified to Lynn Brothers.

Lynn Sisters; two small islands, in the southern part of Lynn canal, Alexander archipelago. Called The Sisters by Meade, 1868, and modified to Lynn Sisters in the Coast Pilot in 1883. 
Iynx; creek, on the west bank of East fork Sixmile creek, Kenai peninsula, about 16 miles southeast of Sunrise, Cook inlet. Local name, reported by Mendenhall; 1899.

Iynx; creek, Seward peninsula, tributary from the southeast to Lopp lagoon, on the Arctic coast, near latitude $65^{\circ} 42^{\prime}$. So called by Gerdine, 1901 .

Lynx; creek, in the Rampart region, tributary to Hess creek from the south, near latitude $65^{\circ} 30^{\prime}$, longitude $149^{\circ} 30^{\prime}$. Prospectors' name, from Lieutenant Erickson, U. S. A., 1902.

Lynx; mountain, in the Rampart region, southenst of Rampart (city), near latitude $65^{\circ} 20^{\prime}$, longitude $149^{\circ} 40^{\prime}$. Prospectors' name, reported by Prindle, 1905.

Lyre; point; on the eastern shore of Port Refugio, Bucareli bay, Prince of Wales archipelago. Named Punta de Lira (lyre point) by Maurelle and Quadra, 1775-1779.

Mab; island, near Bridget cove, Lynn canal, Alexander archipelago. So named by Mansfield, 1890 .

Mabe; gulch, 6 miles northeast of Nome, Seward peninsula, on the south bank of Lost creek, a tributary of Nome river from the west, near longitude $165^{\circ} 14^{\prime}$. Local name, published in 1904.

Mabel; creek, Seward peninsula, tributary to Mascot creek from the east, near latitude $65^{\circ} 30^{\prime}$, longitude $164^{\circ} 25^{\prime}$. Prospector's' name, reported by Gerdine, 1901.

Mabel; island, in Hassiah inlet, Cordova bay, Alexander archipelago, near latitude $55^{\circ}$, longitude $132^{\circ} 38^{\prime}$. Name from Dickins, 1905 .

Mabel; island, in Dewey anchorage, Clarence strait, Alexander archipelago. So named by Snow, 1886. Erroneously Mable.

McAdam; creek, tributary to Tisuk river, from the north, Seward peninsula. Name from Barnard, 1900.

McArthur; peak (2,239 feet high), near Port McArthur, Kuiu island, Alexander archipelago. So named by Heln, 1886, after the Coast Survey steamer McArthur.

McArthur; port, near the southern entrance to Affleck canal, Kuiu island, Alexander archipelago, latitude $56^{\circ} 05^{\prime}$, longitude $134^{\circ} 05^{\prime}$. Named by Helm, 1886, after the Coast Survey steamer McArthur, under his command.

McArthur; reef, in Sumner strait, off the mouth of Clarence strait, Alexander archipelago. So named by the Coast Survey, after its surveying steamer McArthur.

McBride; glacier, part of the Muir glacier. Called Second North tributary by Reid, 1890, and later McBride, after H. McBride, a member of bis party.

McCartey; point, the southernmost point of the Bronaugh islands, off Dall Head, Gravina island, Alexander archipelago. So named by Nichols, 1883. Also erroneously McCarty.

IMcCarthy; creek, tributary to Kennicott river from the east. Prospectors' name, reported by the Geological Survey in 1899.

McClellan; flats, at head of Chilkat inlet, Lynn canal, Alexander archipelago. So named by naval officers, after Lieut. Edward P. McClellan, U. S. N., who visited the locality in 1880 .

McClellan; group of islets, forming part of the Galankin group, Sitka sound; Alexander archipelago. So named by - United States naval officers, 1880, after Lieut. E. P. McClellan, U. S. N.

Bull. $299-06 \mathrm{M}-27$ 
McClellan; rock, near Lindenberg harbor, Peril strait, Alexander archipelago. Named by United States naval officers, 1880, after its discoverer, Lieut. E. P. McClellan, U. S. N. Erroneously McLellan.

McCullough; rock, in Dixon entrance, west of Zayas island. Reported by Captain McCullough, of the Hudson Bay Company steamer Otter, and named after him by the Coast Survey in 1883. Erroneously McCollough.

McDermott; creek, tributary to Yukon river from the east 10 miles above the Ramparts, near latitude $65^{\circ} 30^{\prime}$, longitude $149^{\circ} 50^{\prime}$. Prospectors' name, reported by Lieutenant Erickson, U. S. A., 1902.

McDoel; peak (6,000 feet high), near headwater's of -Kuskokwim river, in latitude $62^{\circ}$. So named by Post, of the Geological Survey, 1898.

McDonald; bar, a bench on Minook creek, Rampart region, about 9 miles above its mouth. Prospectors' name, reported by Prindle, 1904. Erroneously Macdonald.

McDonald, bay; see Yes.

McDonald; creek, 5 miles east of Nome, Seward peninsula, tributary to Nome river from the north, near longitude $165^{\circ} 15^{\prime}$. Name from Barnard, 1900.

McDonald; islands, opposite the north end of Wrangell strait, in Frederick sound, Alexander archipelago. Named by Thomas, 1887, after Ensign John Daniel McDonald, U. S. N., a member of his party.

McDonald; lake, Cleveland peninsula, near the bead of Yes bay, Behm canal, southeastern Alaska, near latitude $55^{\circ} 57^{\prime}$, longitude $131^{\circ} 50^{\prime}$. So known to the fisheries, and reported by H. C. Fassett, Bureau of Fisheries, 1904.

McDonald; sunken rock, in the broad part of Frederick sound, at junction with Stevens passage, Alexander archipelago, near latitude $57^{\circ} \mathbf{2 5}$, longitude $133^{\circ} 37^{\prime}$. Name published by the Coast Survey, 1895 or earlier.

McDonough; peak (2,700 feet high), in southeastern part of Douglas island, Alexander archipelago. So named by the Coast Survey in 1893.

McFarland; group of islands, on the enstern shore of Tlevak strait, north of Dunbar inlet, Alexander archipelago. Named by Dall, 1882, after Mrs. A. R. McFarland, a missionary and teacher, who began work in Alaska in 1877. Sheldon Jackson has named them Hill islets.

McFarland, islet; see Village.

McFarland; point, on Dall island, opposite Howkan village, Cordova bay, Alexander archipelago. Named by Sheldon Jackson, after Mrs. A. R. McFarland, a missionary and teacher, who began work in Alaska in 1877.

McGinnis; creek, on the mainland, eastern shore Favorite channel, Lynn canal, tributary to Montana creek, from the east, near latitude $58^{\circ} 25^{\prime}$. Prospectors' name, reported by Spencer and Wright, 1903 .

McGrath; mountain (6,179 feet high), on the mainland, on north side of Iskut river. So named by the Coast Survey, after John Edward McGrath.

McHenry; anchorage, in Etolin island, opening into Clarence strait, Alexander archipelago. Named by Snow, 1886, after John McHenry, a member of his party.

McHenry; inlet, in Etolin island, opening into Clarence strait, Alexander archipelago. Named by Snow, 1856, after John McHenry, a member of his party.

McHenry; sunken ledge, at entrance to Union bay, Cleveland peninsula, Alexander archipelago. So named by Clover, 1885. 
McKenzie; inlet, and rock at its entrance, southern shore Skowl arm Kasaan bay, Clarence strait, southeastern Alaska, near latitude $55^{\circ} \cdot 24^{\prime}$, longitude $132^{\circ} 20^{\prime}$. So called by local navigators, and reported by Brooks, 1901.

McKinley; creek, Seward peninsula, tributary from the northeast to Grantley harbor. Prospectors' name, obtained by Gerdine, 1901.

McKinley; creek, in the Birch Creek region, tributary to Preacher creek from the south, near latitude $65^{\circ} 30^{\prime}$, longitude $146^{\circ}$. Prospectors' name, reported from Gerdine, 1903.

McKinley; creek, tributary to Middle fork Fortymile creek from the south, near latitude $64^{\circ} 20^{\prime}$, longitude $143^{\circ}$. Prospectors' name, reported by Gerdine, 1903.

McKinley; creek, tributary to Walker fork Fortymile creek from the left, near latitude $64^{\circ}$, longitude $141^{\circ} 20^{\prime}$. Prospectors' name, taken from map in Coast Survey archives, drawn by E. F. Ball, a prospector, 1898.

McKinley; creek, in the Fortymile region, tributary to O'Brien creek from the east, near latitude $64^{\circ} 25^{\prime}$, longitude $141^{\circ} 15^{\prime}$. Prospector's' name, reported by Frindle, 1903.

McKinley; creek, in the Porcupine gold district. Prospectors' name, published in 1900.

McKinley; lake, just north of or in edge of delta of the Copper river, 3 miles north of Alaganik. Local name, from Gerdine, 1900.

Mc.Kinley; mountain (20,300 feet high), near the headwaters of Kuskokwim river. Name published by the Coast Survey in 1897. Also called Bulshaia, a corruption of the Russian word for $b i g$, and Traleika by the natives of Cook inlet, also meaning big. It was named McKinley by a prospector, Dickey, who published an account of it in the New York Sun, January 24, 1897. See also Foraker.

McKinley; range, defined by Herron, 1899, as that part of the Alaska range which includes Mount McKinley, and which extends southwest from the Chulitna-Cantwell divide, near longitude $149^{\circ}$.

McKin].ey; river, fork of Kantishna river, draining the north and northeast slopes of Mount McKinley, near longitude $151^{\circ}$. Named McKinley fork by Brooks, 1902, and now known as McKinley river.

McKinley; mining town, on Kantishna river, 40 miles above Bearpaw, and 50 miles north of Mount McKinley, near latitude $63^{\circ} 45^{\prime}$, longitude $151^{\circ}$. Established in the summer of 1905 , and reported by Prindle.

McLean; arm, jndenting the southeastern shore of Prince of Wales island, about 6 miles worth of Cape Chacon, near latitude $54^{\circ} 47^{\prime}$, longitude $132^{\circ}$. Named by Clover, 1885, after Ensign Walter McLean, U. S. N., a member of his party.

McLean; point, the southern point of entrance to McLean arm, Prince of Wales island, southeastern Alaska. Name so applied by local navigators, and reported by H. C. Fassett, Bureau of Fisheries, 1.904.

McLellain, rock; see McClellan.

McMahon; creek, eastern Alaska, on the left bank of Butte creek, an affluent of North fork Fortymile creek from the northeast, near latitude $64^{\circ} 40^{\prime}$, longitucle $142^{\circ}$. Prospectors' name, from sketch map compiled by Major Glassford, Signal Corps, U. S. A., 1905.

McIManus; creek, in the Fairbanks region, tributary to Chatanika river at its source, near latitude $65^{\circ} 12^{\prime}$, longitude $146^{\circ} 20^{\prime}$. Prospector's' name, reported by Gerdine, 1903. 
MCNair, island; see Grand.

MeNairy; point, the south point of entrance to Steamboat bay, Frederick sound, Alexander archipelago. So named by 'Thomas, 1887.

McNamara, point; see Macnamara.

McNeil; creek, Kenai peninsula, tributary from the north to Kachemak bay, about 10 miles northeast of Homer. Local name, reported by Dall in 1895.

McPherson; point, not shown on any map and not identified, on the Arctic coast somewhere east of Point Barrow. Named by Dease and Simpson, 1837, after M. McPherson.

McQuesten, island; see Fuggins.

McTavish; point, on the western shore of Dease inlet, Arctic coast. Name from British Admiralty chart 593 (1830-1882).

Macartney; point, the northeastern point of entrance to Keku strait, Kupreanof island, Alexander archipelago. So named by Vancouver, 1794.

Mackay; inlet, immediately east of Dease inlet, on the Arctic coast. Named M'Kay's inlet by Dease and Simpson, 1837, after one of their guides, James M'Kay, a Scotchman, who had served with Sir. George Back in 1834.

Mackenzie; point, at the head of Cook inlet. Named by Vancouver, 1794, "after the Right Hon. James Stuart Mackenzie." Erroneously Mackinzie.

Mackenzie; river, in Canada, named after its first explorer, Alexander Mackenzie.

Mackenzie; small bay, between Dease inlet and Point Barrow, Arctic ocean. So named by Dease and Simpson, 1837, after Chief Factor Roderick Mackenzie, of the Hudson Bay Company.

Macklin; creek, Seward peninsula, tributary to Kougarok river from the east, near its source, about latitude $65^{\circ} 45^{\prime}$, longitude $164^{\circ} 50^{\prime}$. Prospectors' name, reported by Gerdine, 1901.

Macks, bay; see Tanaskan.

Macks Head; promontory, Sanborn harbor, Nagai. island, Shumagins. Local name, from the Coast Survey.

Macks Head; small rounded island, off northern point of entrance to Sanborn harbor, Nagai island, Shumagins. Local name, reported by Dall in 1872. The point behind it has also been called Mack's Head.

Macleod; harbor, on the northwestern coast of Montague island, Prince Willam sound. Named McLeod's by Portlock, 1787, after one of his officers.

Macleod; point, in Smith bay, on the Arctic coast, between Cape Halkett and Tangent point. Named M'Leod by Dease and Simpson, 1837, after A. R. M'Leod.

Macmillan; mountains (3,500 feet high), and river, tributary to Pelly river from the east, near latitude $63^{\circ}$. Sometimes written McMillan. The spelling Macmillan has been adopted by the Canadian Board on Geographic Names.

Macnamara; point, on Zarembo island, the northeast point of entrance to Clarence strait, Alexander archipelago. So named by Vancouver, 1793, after Captain Macnamara, R. N. Often written McNamara.

Macooshino, village; see Makushin.

Madan; point, on the mainland, in Eastern passage, Alexander archipelago. So named by Vancouver, 1793.

Made; creek, 13 miles north of Cape Nome, Seward peninsula, tributary to Osborn creek, from the east, near longitude $165^{\circ} 07^{\prime}$. Name from Gerdine, 1904. 
Madeira; creek, Seward peninsula. Name from Brooks, 1901.

IMadison; creek, eastern Alaska, on south bank of Seventymile creek, near latitude $64^{\circ} 50^{\prime}$, longitude $142^{\circ} 50^{\prime}$. Prospectors' name, from sketch map compiled by Major Glassford, Signal Corps, U. S. A., 1905.

Madison; gulch, 10 miles north of Nome, Seward peninsula, on the eastern slope of Mount Brynteson, draining into the head of Glacier creek from the west, near longitude $165^{\circ} 21^{\prime}$. Local name, published in 1904.

Madison; peak (2,507 feet high), on the mainland, near Port Snettisham, southeastern Alaska. So named by Thomas, 1888, after President James Madison.

Madre de Dios; island, in Bucareli bay, Prince of Wales archipelago. Named Isla de la Madre de Dios (island of God's mother) by Maurelle and Quadra, 1775-1779. Has also been written erroneously Madre de Deos.

Madzaheen; cove, northwestern shore of Hassler harbor, Annette island, Alexander archipelago, near latitude $55^{\circ} 14^{\prime}$, longitude $131^{\circ} 28^{\prime}$. Native name, gotten from local navigators, by H. C. Fassett, Bureau of Fisheries, 1904.

Magdalena; cape, the north point of entrance to Port Bazan, Dall island, Prince of Wales archipelago. Either this cape or Cape Muzon was named Cabo de Santa Maria Magdalena.by. Perez, 1774.

Magdalena, Isla de la; see Hinchinbrook.

Magnet; creek, Seward peninsula, on north coast Norton sound, 6 miles east of Solomon river, near longitude $164^{\circ} 13^{\prime}$. Prospectors' name, from a local map, 1904.

Magnet; creek, Seward peninsula, tributary to North fork Kougarok river from the north, near latitude $65^{\circ} 35^{\prime}$, longitude $164^{\circ} 40^{\prime}$. Local name, reported by Gerdine, 1901.

Magnet; creek, Seward peninsula, tributary from the west to Pannell river, which is a tributary of Inmachuk river, near latitude $65^{\circ} 45^{\prime}$, longitude $163^{\circ} 05^{\prime}$. Prospectors' name, obtained by Witherspoon, 1903.

Magnolia; creek, tributary to Igloo creek from the north, Seward peninsula. Name from Brooks, 1900.

Magnolia; gulch, 18 miles north of Nome, Seward peninsula, on the east bank of Grouse creek, at the headwaters of Snake river, near longitude $165^{\circ} 21^{\prime}$. Local name, from Gerdine, 1904.

Magoun; islands, between Krestof and Kruzof islands, Alexandèr archipelago. Named by the Russians, after a Captain Magoun, who traded on this coast in early times. Has also been written Magun.

Mahid; island, one of the Necker islands, Sitka sound, Alexander archipelago. Named Ma-id by Vasilief in 1809. Is often written Maid. Pronounced Mắh-id.

Mahlo; valley, and river flowing through it, at east end of Klutina lake. Named by Abercrombie, 189S, after Emil Mahlo, a member of his party.

Mahtkwingak; pass or slough, Yukon delta, opening on outer shore, 14 miles northeast of Kwikpak mouth, near latitude $63^{\circ} 12^{\prime}$, longitude $164^{\circ} 20^{\prime}$. Eskimo name, reported by Putnam in 1899 as Mahtkweengak. Erroneously Malitqweengak.

Mahutzu; river, tributary to the Tanana from the south, near longitude $146^{\circ}$ $30^{\prime}$. Native name, reported by Peters and Brooks, 1898. It has since been named Russel creek, and it is reported that the prospectors are calling it Little Delta creek.

Maiachnoi, island; see Signal.

Maid, island; see Mahid.

Main, lake and valley; see Endicott. 
Main, river; see Nushagak.

Maiogagaluk; Eskimo village, northwestern Alaska, in Navy pass, 30 miles southwest of Chandler lake, near latitude $68^{\circ}$, longitude $154^{\circ}$. Visited by Stoney, 1886, who wrote the name My-og-arg-a-look and My-o-ga-agal-uk.

Major; cove, on the southeastern shore of Norton sound. Called Major's cove by Dall, 1866, because it was the first point at which Major Kennicott landed with his party after setting out from St. Michael.

Makak; Eskimo village, on the right bank of Yukon river, between Anvik and Koserefski. Called Makka by 'Tikhmenief, 1861. Raymond (1869) calls it Makagamute, i. e., Makak people, and Petrof (1880) Makeymute. Population in 1880, 121.

Makaka; point, the northwestern point of Hawkins island, Prince William sound. Apparently a native name, reported by Abercrombie in 1898.

Makhnale, rock; see Black.

Makhnati; island, at southern entrance to western channel into Sitka harbor, Sitka sound, Alexander archipelago. Named Makhnatie (rough or shaggy) by Vasilief, 1809. Has also been called Liesnoi (wooded) island.

Makhnati; islet, in Whale bay, Baranof island, Alexander archipelago. Named Makbnatoi (rough or shaggy) by the Russians.

Makhnati; submerged rock, in Sitka sound, $2 \frac{1}{2}$ cables from a beacon on Makbnati island. So named by the Coast Survey in 1883. Has also been called Beacon, rock.

Maklau; river, southwestern Alaska, tributary on the left bank of Wood river, 10 miles from its mouth, near longitude $158^{\circ} 30^{\prime}$. Local name, maybe Eskimo, reported by Moser, 1900.

Malcnashka, bay; see Sycamore.

Malknashka, cape; see Rocky.

Maknashkina, cape; see Miller.

Makrovskoi, bay; see Pumicestone.

Makushin; bay, indenting the northwestern shore of Unalaska, eastern Aleutians. Presumably so called by Krenitzin and Levashef, 1768-69. Coxe, in bis account of their voyage, published in 1780, has on an accompanying map Makyshinskaia bay. Written Makushi, Makushinskoi, etc.

Makushin; cape, on the northern shore of Makushin bay, Unalaska. Called Makushi by Tebenkof, 1849. It is Makushin point (not cape) of the Fish Commission in 1888.

Makushin, cape; see Kovrizhka.

Makushin; valley, beginning at Broad bay, in Unalaska bay, and stretching inland. So called by Davidson, 1869. Dall called it Glacier valley in 1873.

Makushin; native village, on the northern shore of Makushin bay, Unalaska. Sarichef, 1792, shows this village, which he calls Makushinskoe settlement. Lisianski, 1805, has Macooshino settlement. Veniaminof, 1831, says it was the headquarters of the Russian-American Company's bidarshik or foreman, and that it contained 6 huts (yourts) and 35 natives. Population in 1880, 62 ; in 1890, 51.

Makushin; active volcano (5,691 feet high), on Unalaska, eastern Aleutians, near latitude $53^{\circ} 52^{\prime}$, longitude $166^{\circ} 50^{\prime}$. Sarichef, 1792 , designates it as ognedieshutshaia gora (burning mountain). By Kotzebue, about 1825, it is called Makuschkin volcano. According to Grewingk, quoting Sarichef, its native name is Aigägin, which appear's to be from the 
Makushin-Continued.

Aleut word Aigak (big). Coxe writes it Ayaghish, and Grewingk, Ajägisch. Postels, 1835, called it Wesselow, i. e., Cheerful mountain. It is near Cape Cheerful.

Malaia Ugalenta, river; see Kiklukh.

Malalolic, creek; see Melatolik.

Malaspina; glacier, on the flanks of the St. Elias alps, immediately north of Yakutat bay. This was named Malaspine plateau by Dall, 1874, who did not then get near enough to recognize its true character. In 1880 , however, it was approached nearer and its true character seen. Since that time it has been called the Malaspina glacier. In 1886 the New York Times expedition applied the names Agassiz and Great Agassiz, also Guyot and Great Guyot, to glaciers now regarded as parts of this one.

Malaspina; island, of doubtful existence, on the southeast side of Bucareli bay, east of Suemez island, Prince of Wales archipelago. So named by Dall, 1879, after Capt. Don Alessandro Malaspina, the distinguished and unfortunate Italian navigator, who, in the service of Spain, explored and surveyed on the northwest coast of America in 1791.

Malaspina; mountain, in the St. Elias alps, near Mount St. Elias. So named by Dall, 1880, after the unfortunate Malaspina, who was in Yakutat bay in 1791. Dall suggests that this may be identical with Piton (Peak) of La Perouse in 1786.

Malchatna, river; see Mulchatna.

Malcolm; river, on the Arctic coast, near the internatioual boundary line. Named Sir Pulteney Malcolm river by Franklin in 1826.

Male; point, the southwestern extremity cf Fillmore island, Alexander archipelago. So named by the Coast Survey in 1891.

Maley Roukav; see Small.

Malie, island; see Little.

Malinof, island and strait; see Raspberry.

Malinovoi, cape; see Raspberry.

Malinovskoi, cape; see Nuniliak.

Malitgweengak, pass or slough; see Mahtkwingak.

Malmesbury; port, on the western side of Kuiu island, Chatham stralt, Alex. ander archipelago. So named by Vancouver, 1794 .

Maloi Krieposti, island; see Little Fort.

Maloi Malinovoi, island and strait; see Little Raspberry.

Maloi Strelka, bay; see Little Branch.

Mamalus; islet, in Moser bay, western shore Revillagigedo island, Naha bay, Behm canal, southeastern Alaska, near latitude $55^{\circ} 35^{\prime}$, longitude $131^{\circ} 40^{\prime}$. Native name, meaning dead, so called by local navigators, and reported, 1904, by H. C. Fassett, Bureau of Fisheries, who wrote it Mamaloose.

Mammce, bluffs and hills; see Einahnuto.

Mammoth; creek, in the Birch Creek region, tributary to Crooked creek, from the southwest, near latitude $65^{\circ} 30^{\prime}$, longitude $145^{\circ} 10^{\prime}$. Prospectors' name, reported by Spurr, Goodrich, and Schrader, 1896.

Mammoth; mountains (3,500 to 5,500 feet high) on the right bank of Yukon river, and extending across the international boundary from Fortymile creek to Kandik river, and thence northwesterly. Name proposed by Spurr's party, of the Geological Survey, in 1896, on account of the abundance of the fossil remains of the elephant or mammoth in this region. 
Mammoth; river, on Seward peninsula, tributary to Kotzebue sound, immediately east of Cape Deceit. So named by Petrof, 1880, from the occurrence of mammoth bones in the vicinity.

Mammoth House; see Miller House.

Manby; glacial stream, from Malaspina glacier, debouching near Manby point, Yakutat bay, southeastern Alaska. So named by Russell, 1891.

Manby; point, the northwestern point of entrance to Yakutat bay, southenstern Alaska. So named by Vancouver, 1794, after a member of his party. Apparently identical with Pte. de la Boussole of La Perouse in 1786. It is St. Elias of Malaspina in 1792, and Bolshoi (great) point of Tebenkof in 1849 .

Mandarin; rock, at head of Zachary bay, Unga island, Shumagin group. So named by Dall, 1872.

Mangoak; river, northwestern Alaska, tributary to Selawik lake, from the southeast, near latitude $66^{\circ} 30^{\prime}$, longitude $160^{\circ} 20^{\prime}$. Eskimo name, obtained by Stoney, 1886, and written Man-go-ak.

Manila; creek, 20 miles north of Nome, Seward peninsula, tributary from the west to Hobson creek, an affluent of Nome river, near longitude $165^{\circ} 17^{\prime}$. Name from Barnard, 1900.

Manila; creek, tributary to Solomon river from the west, Seward peninsula. Name from Barnard, 1900.

Manila; creek, tributary to Middle fork Fortymile creek from the south, near latitude $64^{\circ} 20^{\prime}$, longitude $142^{\circ} 40^{\prime}$. Prospectors' name, reported by Gerdine, 1903.

Manillaratsita; creek, tributary to Koyukuk river from the right, between the Gisasa and the Yukon, near latitude $65^{\circ}$, longitude $157^{\circ} 30^{\prime}$. Indian name, Manillaratsitah, published in 1902 .

Manillaratsita; mountains, on northwest sịde of the confluence of Yukon and Koyukuk rivers, near latitude $65^{\circ}$, longitude $157^{\circ} 30^{\prime}$. Indian name, published in 1902.

Manker; valley, near foot of Klutina lake, through which flows Manker creek. So named by Abercrombie, 1898.

Mankomen; lake and valley, in the Copper River region, near the source of the East fork Chistochina river, about latitude $63^{\circ}$, longitude $144^{\circ} 30^{\prime}$. Indian nạme, applied by prospectors and reported by Mendenhall, 1902.

Manna; creek, -Seward peninsula, debouching in Lopp lagoon, on the Arctic coast. Native name, reported by Gerdine in 1901.

Manning; point, on the Arctic coast near or on Barter island. So named by Franklin, 1826.

Man of War; peak, on the mainland, west of Farragut bay, southeastern Alaska. So named by Thomas, 1887 .

Manokinak, river; see Manopiknak.

Manopiknak; river, in the Yukon delta, one of the outlets of Yukon river. Eskimo name from Nelson, 1878, who in his text writes Manopiknak and Manokinak and on his map Manokinak. Has also been written Manokinok.

Mansfield; lake, 7 miles north of Tanana crossing, draining southward to the Tanana, near longitude $143^{\circ} 30^{\prime}$. So named by Wells, 1890 , after Lieut. Commander Henry Buckingham Mansfield, U. S. N.

Mansfield; peninsula, forming the northern part of Admiralty island, Alexander archipelago. So named by the Coast Survey, 1893, after Lieut. Commander Henry Buckingham Mansfield, U. S. N., who made surveys in the Alexander archipelago in 1889-1891.

Mantalik, creek; see Mentalik. 
Mantasna, lake, mountains, etc. ; see Mentasta.

Manzanita; cove, indenting the eastern shore of Wales island, Portland canal, Canada, near latitude $54^{\circ} 45^{\prime}$, longitude $130^{\circ} 26^{\prime}$. Descriptive name published by the Coast Survey in 1901.

Manzanita; island, in Behm canal, northwest from the entrance to Rudyerd bay. So named by the Coast Survey in 1891.

Manzanita; peak (3,959 feet high), in the eastern part of Mitkof island, Alexander archipelago. So named by Thomas, 1887 .

Maple; point, on the eastern shore of Portland canal. So named by Pender, 1868.

Marabilla; island and point, in Gulf of Esquibel, Prince of Wales archipelago. Named Ysla y Punta de la Marabilla by Maurelle and Quadra, 1775-1779.

Marble; creek, opening on the east side of Shakan strait, northwestern shore of Prince of Wales island, near latitude $56^{\circ} 10^{\prime}$, longitude $133^{\circ} 27^{\prime}$. Local name obtained by Dickins, 1903-4.

Marble; island, on the north side of Sea Otter sound, Prince of Wales archipelago, neal latitude $55^{\circ} 58^{\prime}$, longitude $133^{\circ} 27^{\prime}$. So named by Dickins, 1903-4. Has been called Fox island.

Marble; islet, in the southern part of Affleck canal, Kuiu island, Alexander archipelago. So namied by Snow, 1886, "from its formation."

Marble; two small bare islets, in Glacier bay, southeastern Alaska. So called by the Coast survey, 1883, on account of the rocks of which they are composed.

Marble; point, Alaska peninsula, on the eastern shore of Herendeen bay, onehalf mile north of Shingle point, near longitude $160^{\circ} 45^{\prime}$. Descriptive name, given by 'Tanner, 1890 .

Marble Bluffs; locality on the western shore of Admiralty island, Chatham strait, Alexander archipelago. Descriptive name of local origin, published by the Coast Survey in 1883.

Maria; creek, Seward peninsula, tributary from the south to Kugrupaga river, near latitude $65^{\circ} 50^{\prime}$, longitude $166^{\circ} 23^{\prime}$. Prospectors' name, reported by Gerdine, 1901.

Maria; point, the northern point of entrance to Port Asumcion, Bucareli bay, Prince of Wales archipelago. Named Punta de Maria Josefa by Maurelle and Quadra, 1775-1779.

Maria Louisa, liver; see Kun.

Marie; creek, tributary to Walker fork Fortymile creek from the right, near latitude $64^{\circ}$, longitude $141^{\circ} 30^{\prime}$. Prospectors' name, taken from map in Coast Survey archives drawn by E. F. Ball, a prospector, 1898 .

Marie; lake (Loch Marie), on the northern shore of Windham bay, Frederick sound, southeastern Alaska, near latitude $57^{\circ} 35^{\prime}$. Prospector's' name, reported by spencer and Wright, 1903.

Marie; point (Point Marie), the south point of entrance to Ushk bay, Chichagof island, Peril strait, Alexander archipelago, near latitude $57^{\circ} 33^{\prime}$, longitude $135^{\circ} 34^{\prime}$. So named by Moore in $\mathbf{1 8 9 5 .}$

Marine, Port de la; see Real Marina.

Mariner; creek, tributary to Canyon creek from the west, in the Fortymile mining region; latitude $64^{\circ} 15^{\prime}$, longitude $151^{\circ} 10^{\prime}$. Local name, obtained by Barnard in 1898 . See Merriam.

Marion; creek, tributary to American creek from the east, in the Eagle mining region. Local name, obtained by Barnard in 1898.

Marion; creek, tributary to Middle fork of the Koyukuk from the east, near longitude $150^{\circ}$, Prospector's' name, reported by Schrader in 1899. 
Marks; creek, eastern Alaska, at head of Flat creek, near latitude $65^{\circ}$, longitude $143^{\circ}$. Prospectors' name, from sketch map compiled by Major Glassford, Signal Corps, U. S. A., 1905.

Marmion; island, at junction of Gastineau channel and Steplens passage, Alexander archipelago. So named by Dall in the Coast Pilot, 1883.

Marmot; bay, between Afognak and Kodiak. It was named Whitsuntide by Cook in 1778. Called Evershichie (marmot) by Tebenkof, 1849. The word Evrashka comes from Siberia. Kotzebue says (I, 229): "An animal in many respects similar to the squirrel ; but it is much larger and lives in the earth; it is called in Siberia Gewraschka. The Americans (in Kotzebue sound) call it 'Tschikschi." Chí-gìk', according to Nelson, is the Eskimo name of Parry's spermophile, so that Chigik and Tschilschi seem to be two renderings of the same Eskimo word. Veniaminof gives the Koloshian name of Evrashka as Tsalk and the Aleut name as Ulnik.

Marmot; island, east of Afognak island, Kodiak group. Now occupied as a fox farm. Named Evrashichie (marmot) by the early Russians. It is Isla de Camacho of Maurelle and Quadra (1779), and St. Hermogenes of Billings (about 1790) and of Galiano (1802). "The only land animals (on this island) are the foxes and myriads of ground squirrels (spermophilus) upon which the foxes prey for their subsistence. These rodents are called yevrashka in Russian. This word our map makers erroneously translated marmot, and thus misnamed the island." (Eleventh Census, p. 73.)

Marmot; river, tributary to Portland canal from the east, near its head. So named by Pender, 1868.

Marmot; strait, between Marmot and Afognak islands. Named Evrashichichie (marmot) by the Russians, 1849.

Maroonitch; old village site, on north shore of St. Paul island, Pribliof group, Bering sea. Name from Elliott, 1873-74, who says: "Site of a pioneer village, established by one Maroon." Written also Marunich.

Marr; butte (3,000 feet high), near junction of Delta and Tanana rivers. So named by Glenn, 1898, after Private Marr, a member of his party.

Marr; mountain $(2,447$ feet high), near the south end of Cleveland peninsula, Alexander archipelago. Named by the Coast Survey, 1886, after Robert Athelston Marr, then subassistant, Coast Survey.

Marr; mountain, on north bank of Porcupine river, near Lower Ramparts. So named by the Coast Survey as early as 1895 .

Marryat; inlet, immediately north of Point Hope, Arctic coast. Discovered by Lieutenant Belcher, R. N., 1827, and named by Beechey, "after his [Belcher's] relation, Captaín Marryat, R. N." Called Marriet by Tikhmenief.

Marsden; point, on the northwestern shore of Admiralty island, Chatham strait, Alexander archipelago. So named by Vancouver; 1794.

Marsh, bay; see Hot Springs.

Marsh; fork, the left fork of Canning river, Arctic slope, near latitude $69^{\circ}$, longitude $147^{\circ}$. So named in this dictionary after S. J. Marsh, a prospector, who explored and sketched it in 1903. After the manner of prospectors who term the branches right, and left in ascending, Marsh called it Right fork.

Marsh; island, southeast of the Kashevarof group of islands, in Clarence strait, Alexander archipelago. Named by Snow, 1886, after Ensign Charles Cariton Marsh, U. S. N., a member of his party. 
Marsh; lake, northeast of Chilkoot pass, on headwaters of Lewes river. Named, in 1883, by Schwatka, after Prof. Othniel Charles Marsh, of Yale College. This name has been adopted by the Canadian Board on Geographic Names.

Marsh; peak, on the mainland, near head of Thomas bay, southeastern Alaska. Named by Thomas, 1887, presumably after Prof. O. C. Marsh, of Yale College.

Marsh; point, the eastern point of entrance to Cordova bay, Dixon entrance, Alexander archipelago. Named by Clover, 1885, after Ensign Charles C. Marsh, U. S. N., a member of his party.

Marsh; point, the western point of entrance to Wainwright inlet, Arctic coast. So named by Beechey, 1826, after his purser, George Marsh.

Marshall; creek, tributary to Matanuska river from the north, just below the Chickaloon. So named by Mendenball, 1898, after a prospector, W. H. Marshall.

Marshull; creek, tributary to Yukon river from the south, 4 or 5 miles below Rampart (city), near longitude $150^{\circ} 20^{\prime}$. Prospectors' name, taken from Edwards's Track Chart of the Yukon, 1899.

Marshall; islet, near the entrance to Silver bay, Sitka sound, Alexander archipelago. So named by Únited States naval officers, 1.880 .

Marshall; mountain (5,200 feet high), on the eastern shore of Klutina lake. So named by Abercrombie, 1898.

Marshall; mountain (4,500 feet high), on the eastern shore of Portland canal. Named Marshal by Pender, 1868.

Marshall; pass, in the Chugach mountains, east of Valdez, between the headwaters of Lowe and Tasnuna rivers. So named by Abercrombie, 1898.

Marshall; peak (3,017 feet high), on the mainland, near Port Snettisham, southeastern Alaska. Named by Thomas, 1888, after Chief Justice John Marshall.

Marten; arm, of Boca de Quadra, southeastern Alaska. So named by the Coast Survey in 1891.

Marten, river; see Martin.

Martin; small creek, on the south shore of Seward peninsula, 2 miles southeast of Nome, near longitude $165^{\circ} 20^{\prime}$. Local name, published in 1904 .

Martin; harbor, a small arm of Korovinski bay, Atka island, middle Aleutians. Named Pestchanaia (sandy) by Ingenstrem, about 1830, and called Sand, Peschani, etc. Locally known as Martin's harbor, after Capt. Martin Klinkofström, of the Russian-American Company's service, who first entered and afterwards used it.

Martin, island ; see Gravel.

Martin; low sand island, in front of Elson bay, Arctic coast, just east of Point Barrow. So named by the British Admiralty in 1853 . It may be identical with Doctor island of later charts.

Martin; islands, two small islands, near Point Martin, on the west side of Katalla bay, Gulf of Alaska, near latitude $60^{\circ} 10^{\prime}$, longitude $144^{\circ} 33^{\prime}$. Tebenkof, 1849, shows one island here which he names Kikhtak. By this name as well as Kishtak, they have been sometimes called. Davidson, Coast Pilot, 1869, p. 149, quotes from some source Anglicé island. They are locally known as Fox or Martin islands.

Martin; point, " the northwest point of Controller's bay, which, after Sir Henry Martin, I called Point Martin." So described and named by Vancouver, 1794. "The two rocky islets lying off" this point, mentioned by Van- 
Martin-Costinued.

couver, are now known locally as Martin or Fox islands. Tebenkof, 1849 , shows only one small island, which he names Kikhtak; from this the point has been called Kikhtak and Kishtak.

Martin; point, on the Arctic coast, a little east of Camden bay. Named Point Sir Henry Martin by Franklin, 1826.

Martin; river, debouching on eastern margin of Copper River delta, near longitude $144^{\circ} 45^{\prime}$. Local name written Marten by Moser, 1897.

Martin; rock, in Port Chester, Annette island, Alexander archipelago. So named by Nichols, 1883.

Martin River; glacier, a large glacier at the head of Martin river, 25 miles north of Controller bay, Gulf of Alaska, near longitude $144^{\circ} 15^{\prime}$. Local name, reported by Martin in 1903.

Marunich, St. Paul island; see Maroonitch.

Marvine; glacier, tributary to the Malaspina glacier, in the St. Elias alps, southeastern Alaska. Named by Russell; 1890, after the geologist, Archibald Robertson Marvine.

Mary, bay; see Shelikof.

Mary; creek, tributary to Controller bay from the north, near longitude $144^{\circ}$ 20'. Local name, from Pratt, 1903. Called also Mary's.

Mary; gulch, 6 miles north of Nome, Seward peninsula, at the head of Mountain creek, a tributary to Snake river from the east, near longitude $165^{\circ} 25^{\prime}$. Local name, published in 1904.

Mary; island, north of Duke island, in Revillagigedo channel, Alexander archipelago, near latitude $55^{\circ} 05^{\prime}$, longitude $131^{\circ} 14^{\prime}$. Named by W. E. George, pilot, in 1880 (Coast Pilot, 76). Erroneously St. Mary island, on British Admiralty chart 2431, edition of 1882.

Mary; island, in the Sannak group, 2 miles south of Sannak island, near lattude $54^{\circ} 20^{\prime}$, longitude $162^{\circ} 33^{\prime}$. So named by Westdahl, 1901.

Mary; point (Point Mary), the northern point of entrance to Shelikof bay, Kruzof island, Alexander archipelago, near latitude $57^{\circ} 10^{\prime}$, longitude $135^{\circ} 50^{\prime}$. So named by Moore, 1897.

Mary; port (Port Mary), in Shelikof bay, Kruzof island, Alexander archipelago. So named by Vancouver, 1794 . See Shelikof bay.

Mary Island; anchorage, in the northern end of Mary island, Revillagigedo channel, Alexander archipelago. Local name, published by the Coast Survey in 1883.

Mary Island; light-house reservation, in northeastern part of Mary island, Revillagigedo channel, Alexander archipelago. Reserved for lighthouse purposes by Executive order dated January 4, 1901.

Marys, river; see Kaviruk.

Mary's Igloo; see Igloo.

Mascot; creek, Seward peninsula, tributary from the northwest to Magnolia creek, on the north bank of Igloo creek, near latitude $65^{\circ} 30^{\prime}$, longitude $165^{\circ} 20^{\prime}$. Prospectors' name, reported by Gerdine, 1901 .

Mascot; creek, Seward peninsula, tributary to Noxapaga river, near its mouth, about latitude $65^{\circ} 25^{\prime}$, longitude $164^{\circ} 20^{\prime}$. Prospectors' name, reported by Gerdine, 1901.

Mascot; creek, tributary on the right to Seattle river, an affluent of North fork Koyukuk river, about latitude $67^{\circ} 30^{\prime}$, longitude $150^{\circ} 40^{\prime}$. ' Miners' name, reported by Peters and Schrader, 1901.

Mashik; native village, at Port Moller, Alaska peninsula. Native name, reported by Petrof, 1880, who wrote it Mashikh. 
Mason; narrows, in the Tanana river, near longitude $146^{\circ}$. So named, 1885 , by Allen, in honor of Prof. Otis Tufton Mason, of the Smithsonian Institution.

Massacre; bay, indenting the southenstern shore of Attu island, western Aleutians. Named Ubiennoi (massacre) by Davidof, about 1802, presumably to commemorate the wanton massacre here of 15 natives by Cossack fur hunters, in $\mathbf{1 7 4 5}$, under Alexai Bieliaef. Lutke wrote it Oubiennaia, and Grewingk has Subienna.

JMassacre; brook, flowing from a lake into Massacre harbor, Attu island, western Aleutians. Name from Grewingk, 1850, who has Subienna, apparently an error for Ubienna (massacre).

Mastic; sunken rock, in Revillagigedo channel, near entrance to Thorne arm, Alexandel archipelago. Named after the vessel Mastick, which struck upon it July, 1882. Is now usually written Mastic and has been, erroneously, Mystic.

Mastodon; bank, a caving bank of - Koyukuk river, on the left, between the Dagitli and Kateel rivers, near latitude $65^{\circ} 25^{\prime}$, longitude $157^{\circ} 15^{\prime}$. It contains mastodon remains, and is called Mastodon bank or Stinik bank by the river pilots.

Mastodon; fork, of Lagle creek, in the Birch Creek region, draining the northwest side of Mastodon dome, near latitude $65^{\circ} 27^{\prime}$, longitude $145^{\circ} 22^{\prime}$. Prospectors' name, reported by Spurr, Goodrich, and Schrader, 1896.

IMastodon; post-office (established in 1902), and creek, in the Birch Creek region. The creek is tributary to Mammoth creek from the left, near latitude $64^{\circ} 30^{\prime}$, longitude $145^{\circ} 15^{\prime}$. Gold was discovered on this creei in 1894-the first in the Birch Creek field. Prospector's' name, reported by Spurr, Goodrich, and Schrader, 1896.

Mastodon Dome; mountain, in the Birch Creek region, 4,400 feet high, near latitude $65^{\circ} 25^{\prime}$, longitude $145^{\circ} 20^{\prime}$. Prospector's' name, reported by Spurr, Goodrich, and Schrader, 1896.

Maston; crekek, Seward peninsula, tributary from the southeast to Kugrupaga rive near latitude $65^{\circ} 51^{\prime}$, longitude $166^{\circ} 24^{\prime}$.

Matanuska; glacier, near the source of Matanuska river. So named by Mendenhall, 1898.

Matanuska; river, tributary to Knik arm, Cook inlet. Native name, published by the Coast Survey in 1897. Has also been written Matanooski. Martin, 1905, was told by old traders in the region that the Russians called this river Mednoviska, probably meant for, or a corruption of, Mednorechka (Copper river).

Matanuska; native village, on the eastern shore of lake on Copper River plateau. Native name, obtained by Glenn in 1898 .

Matheson; creek, tributary from the left to Atwater creek, affluent to South fork Fortymile creek, near latitude $64^{\circ}$, longitude $141^{\circ} 50^{\prime}$. Prospector's' name, taken from map in the Coast Survey archives drawn by $\mathrm{E}$. F. Ball, a prospector, 1898.

Matson; creek, Seward peninsula, tributary on south bank of East fork Solomon river, near latitude $64^{\circ} 42^{\prime}$, longitude $164^{\circ} 12^{\prime}$. Prospectors' name, from a local map, 1904.

Matwi, island; see St. Matthew.

Maud, lake; see Sirkwet.

Mauneluk; river, northwestern Alaska, tributary to Kobuk river from the north, near latitude $66^{\circ} 45^{\prime}$, longitude $156^{\circ} 15^{\prime}$. Eskimo name, written Mau-ne-luck by Stoney, 1885. 
Maurelle; islands, in Iphigenia bay, Prince of Wales archipelago. So named by Dall, 1879, after the Spaniard Don Francisco Antonio Maurelle, who made surveys in this region in 1775 and 1779 .

Maurice; creek, tributary to Walker fork Fortymile creek from the right, near latitude $64^{\circ} 05^{\prime}$, longitude $141^{\circ} 20^{\prime}$. Prospectors' name, from Ball's map, 1898, in Coast Survey archives.

Maury; peak $(5,566$ feet high), on the mainland, between Thomas bay and Port Houghton, southeastern Alaska. Named by the Coast Survey, 1895, after Capt. Matthew Fontaine Maury, U. S. N.

Mayastetchinoi, island; see Signal.

May; creek, Seward peninsula, tributary to Bear creek near its source, about latitude $65^{\circ} 40^{\prime}$, longitude $161^{\circ} 05^{\prime}$. Prospectors' name, reported by Witherspoon, 1903.

May; gulch, in the Copper River region, on the north side of Young creek, which is tributary to Nizina river. Prospector's' name, taken from map of Nizina mining district by George M. Esterly, of Valdez, 1902.

Mayer; peak $(6,100$ feet high), near the head of Klutina lake. So named by Abercrombie, 1898. Has also been written Meyer.

Maynard; hill (380 feet high), on the western part of St. George island, Bering sea, near longitude $169^{\circ} 41^{\prime}$. So called by Stanley-Brown, 1891, probably after Lieut. Washburn Maynard, U. S. N., with Elliott in 1874. Putnam gives Ēgănŭt'a-kōverūshka' (Aleut-Russian, hill near the high bluff). Russian kovrishka (a little loaf) used by the Aleuts to mean hill.

Mayo; bend, in Koyukuk river, about 10 miles below the mouth of Allen river. So named by Allen, 1885 . Erroneously Mays on a late chart.

Mayoral; cove, behind St. Ignace island, Bucareli bay, Prince of Wales archipelago. Named Puerto Mayoral (Steward port) by Maurelle and Quadra, 1775-1779.

Maysil; cape, on the western shore of Port Refugio, Bucareli bay, Prince of Wales archipelago. Named Cabo Maysil by Maurelle and Quadra, 17751779.

Meade; glacier, east of Chilkoot inlet, Lynn canal, at the head of Katzehin river. So named by the Coast Survey, presumably after Rear-Admiral Richard Worsam Meade, U. S. N., who surveyed in southeastern Alaska - $\quad$ in 1868 and 1869.

Meade, mountains; see Hooper.

Meade; point, on the northwestern shore of Kuiu island, between Security and Saginaw bays, Alexander archipelago. Named by the Coast Survey, after Rear-Admiral R. W. Meade, U. S. N.

Meade; river, of northern Alaska, explored by Ray in April, 1883, and by him named Meade. Its Eskimo name, according to Murdoch, is Kulúgrua, which has been printed Kol u gru'a, and, by error, Cogtua.

Meares; passage, between Suemez and Quadra islands, near Bucareli bay, Alexander archipelago. So named by Dall in the Coast Pilot (1883, p. 97). Called Sea Otter bay by Lisianski, after Meares (?), Ingraham, and other early traders.

Meares, port; see Prisoners cove.

Medicine; creek, tributary to Yukon river from the north, about 15 miles below Lower Kaltag. Raymond, 1869, calls it Takaltski ; Tikhmenief, 1861, Kakogkakat, i. e., Kakog mouth. A native village at its mouth is called by Petrof, 1880, Khatnotoutze; he gives its population as 115. 
Medicine; lake, in the Birch Creek region, draining into Crooked creek from the right, near latitude $65^{\circ} 30^{\prime}$, longitude $144^{\circ} 40^{\prime}$. Prospectors' name, reported by Spurr, Goodrich, and Schrader, 1896.

Mednorechlia, river; see Matanuska.

Mednoviska, river; see Matanuska.

Medvedniliova, bay; see Bear.

Medvetcha, creek; see Sawmill.

Medviednik, cape; see Bear.

Medviezhi, island; see Woewodski.

Medviezhia, cove; see Bear.

Meiklejohn, entrance; see Hinchinbrook.

Meiklejohn; pass (4,500 feet high), one of the passes between Copper and Tanana rivers. It lies between Tok river and Wagner lake. Named by Lowe, 1898, after Hon. G. D. Meiklejohn, Assistant Secretary of War.

Melanson; lake, near Port Chester, Annette island, Alexander archipelago. So named by the Coast Survey in 1897.

Melatolik; creek, outer shore Yukon delta, 20 miles south of Black river; near latitude $62^{\circ} 05^{\prime}$. Eskimo name, Melatolic, obtained by Putnam, 1899. Erroneously Melalolic. This may be Muganolowik of Dall, which see.

Meli, point; see Green.

Melkowadia, point; see Shallows.

Mellen; rock, in Cordova bay, Alexander archipelago, in entrance to Hetta inlet, near latitude $55^{\circ} 02^{\prime}$, longitude $132^{\circ} 42^{\prime}$. So called by Dickins 1905 .

Mellish; cabin, on shore of Knik arm of Cook inlet. So called, 1898, after its owner, Henry Mellish. Has also been written Melishe's.

Melnichnoi, cape; see Miller.

Melozi; landing and telegraph station, on Yukon river, at the mouth of. Melozi river, 133 miles below Fort Gibbon.

Melzoi; river, tributary to the Yukon from the north, between the mouths of Koyukuk and Tanana rivers. Native name, reported by the Western Union Telegraph expedition, 1867, as Melozecargut and usually written Melozikakat. See Kakat.

Melozikakat; mountains, between Melozi and Koyukuk rivers, about longitude $154^{\circ}$. So called by Lieutenant Camden, Revenue-Cutter Service, 1900. These mountains or some of them were called Peloziklella by the Coast Survey, 1898. See Peloziklella.

Melsing; creek, tributary to Niukluk river from the north, in the Eldorado mining district, Seward peninsula. Local name, published in 1900, after

L. Melsing, a miner.

Memtrelegamute, village; see Mumtrelek.

Mena-kak-a-shah, lake; see Minakak.

Mendenhall; cape, the southernmost point of Nunivak island, Bering sea. Named Ignatief by Tebenkof, 1849, after Lieut. Ivan Ignatief, I. N., who accompanied Shishmaref in the Blagonamierennie (good-intent) 181 - 1822. Recently renamed Mendenhall by the Coast Survey.

Mendenhall; glacier, on the mainland, northwest of Juneau, southeastern Alaska, near latitude $58^{\circ} 25^{\prime}$. So named by the Coast Survey, 1892, after Prof. Thomas Corwin Mendenhall, its Superintendent.

Mendenhall; river, tributary to Takhini river, southeastern Alaska. So named presumably by the Leslie expedition, 1890 , after Superintendent T. C. Mendenhall, Coast Survey. 
Mendenhall; river, on the mainland, southeastern Alaska, draining Mendenhall glacier into the northwest end of Gastineau channel, Stephens passage, Alexander archipelago, near latitude $58^{\circ} 23^{\prime}$, longitude $134^{\circ} 35^{\prime}$. So called by Spencer and Wright, 1903.

Mendilkalcat, river; see Mentokakat.

Menefee; anchorage, at the entrance to Moira sound, Clarence strait, Alexander archipelago. Named by Clover, 1885, after Ensign Daniel Preston Menefee, U. S. N., a member of his party. Has been written erroneously, Menafee.

Menefee; inlet, in Etolin island, opening into Ernest sound, Alexander archipelago. Named by Snow, 1886, after Ensign D. P. Menefee, U. S. N., a member of his party. Has also been written, erroneously, Menafee and Menefes.

Mene-liak-o-shah, lake; see Minakạk.

Menendez. The western part of Copper river delta was called Ensenada de Menendez by the Spaniards in 1788.

Menshikof; cape, on the northern shore of Alaska peninsula, near the mouth of Ugashik river. Named Menshikova (Menshikof's) by Lutke, 1828. Has often been written Menchikoff.

Mentalik; creek, tributary to Yentna river from the north, 10 miles below the Skwentna, near latitude $62^{\circ}$, longitude $151^{\circ}$. Native name. Post obtained the name, 1898, through J. Madison, a resident of Cook inlet, as Mantalik.

Mentanontli; lake and river, between the Yukon and Koyukuk, near longitude $152^{\circ}$. Native name, reported by Allen in 1885 . On his map 4 it is Mentantlekakat lake and river; and in his text (p. 97, etc.) it is Mentanóntlekákat river and Tatatontly lake. See Kakat.

Mentasta; lake, mountain range, pass (2,300 feet high), and trail, between Copper and Tanana rivers. Native name, reported by Allen in 1885. Schrader says this is a corruption of the Indian name Mantasna, the termination na meaning river.

Mentasta; telegraph station, at Mentasta pass, 112 miles northeast of Copper Center. Named Mentasta or Mentasta Pass by the Signal Corps, U. S. A., 1902.

Mentokakat; native village, on the south bank of Yukon river, about 20 miles above the mouth of Melozi river. Native name, reported by Petrof in 1880. Population in 1880,20 . Late maps omit the village and show a stream called Montekakat creek, Mendikakat river, etc., i. e., mouth of Monte river or creek. Zagoskin, 1842-1844, gives the name of the river: as Minkotliatno.

Menzies cape; see Ommaney.

Menzies', strait; see Chatham.

$M e-o k-n e-o z-d o k$, Indian village; see Miokniozdok.

Mercier. Petrof, in his map in the Tenth Census, 1880, shows a place called Mercier station on the north bank of the Yukon; about 40 miles below the mouth of the Tanana. Name not found elsewhere.

Mer d'Ormante, sea; see Bering.

Merk; cape, the western point of Hall island, Bering sea. Named Merka (Merk's) by Tebenkof, 1848, presumably after Dr. Karl Merck (or Merk), surgeon and naturalist in the Billings expedition, 1785-1794.

Merriam; creek, in the Fortymile region, tributary to Canyon creek from the left, near latitude $64^{\circ} 15^{\prime}$, longitude $141^{\circ} 10^{\prime}$. Prospectors' name. This may be identical with Mariner creek of Barnard. 
Merry Christmas; creek, Fortymile region, tributary to Slate creek on north . bank, near latitude $64^{\circ} 40^{\prime}$, longitude $142^{\circ} 35^{\prime}$. Prospectors' name, reported by Witherspoon, 1905 .

Mertz; islet, in bight on the northern shore of Long island, Sitka sound, Alexander archipelago: Named by United States naval ofticers, 1880, after Lieut. Albert Mertz, U. S. N.

Mesa; creek, in the Wrangell mountains, on the west side of Mount Gordon, tributary to Jacksina creek, on the right. So named by Schrader, 1902, from the fact that its source is in the lava mesa of the locality.

Meshagak, bay, river, trading post.; see Nushagak.

Meshik; river and lake, Alaska peninsula, tributary to Port Heiden, near longitude $158^{\circ} 30^{\prime}$. Presumably Eskimo name, adopted by the fisheries, and published Mishik by the Geological Survey in 1905 .

Meshik; Eskimo village, Alaska peninsula, on the north shore of Fort Heiden. near longitude $158^{\circ} 40^{\prime}$. Native name, published Mishik by the Coast Survey in 1902.

Mesquatilla; mountains, on the north bank of Yukon river, between the mouths of Melozi and Tozi rivers. Native name, from Raymond, 1869.

Mesurier, point; see Lemesurier.

Metlakatla; post-office and Indian village, at Port Chester, Annette island, Alexander archipelago. Called Port Chester and Metlakatla. Metlakatla is the name of a group of Tsimpsean or Chimsyan Indians that founded the village. It has been variously spelled Metlahcatlah, Metlahkahtla, Metlakatla, etc. The name of the post-office established here in October, 1888, was spelled Metlakahtla, and changed to Metlakatla in 1.904 .

Prior to 1887 there was a village of Metlakatla Indians about $\mathbf{1 5}$ miles south of Port Simpson, on the western shore of Chimsyan peninsula, British Columbia, where the Scotch missionary, William Duncan, had lived and successfully labored for many years. Owing to disagreement with the established church, Duncan and his Indians, 1887, abandoned their village, which thereafter became known as Old Metlakatla, and founded the present Metlakatla, which was at first called New Metlakatla, and is sometimes still so called and sometimes Port Chester village. As to this Capt. D. D. Gaillard, Corps of Engineers, U. S. A., who surveyed and built storehouses in Portland canal, in 1896, says (Senate Doc. No. 19, Fifty-fourth Congress, second session, p. 4) :

"The largest settlement in the region under discussion is at New Metlakahtla (Port Chester), where there is a store, a cannery, a sawmill, and about 850 Christian Indians who, in 1887, to obtain greater religious liberty, abandoned their village in British Columbia and followed their devoted missionary, Mr. William Duncan, to their present abode, upon arrival at which it is said that they hoisted the United States flag and formally transferred their allegiance from Canada to the United States. By act of Congress, approved March 3, 1891, the body of lands known as Annette Islands was set apart as a reservation 'for the use of the Metlakiahtla Indians and those persons known as Metlakahtlans who have recently emigrated from British Columbia to Alaska, and such other Alaskan natives as may join them,' etc."

Mexico; point, on Prince of Wales island, in Cordova bay, Alexander archipelago. So named by Moser in 1897.

Meyer, peak ; see Mayer.

Bull. 299-06 .M-28 
Meyers; island, in the unnamed bay on the east side and 2 miles south of Lemesurier point, eastern shore, Clarence strait, southeastern Alaska, near latitude $55^{\circ} 44^{\prime}$, longitude $132^{\circ} 16^{\prime}$. Local navigator's' name, reported Myer by H. C. Fassett, Bureau of Fisheries, 1904.

Meyers; stream, Cleveland peninsula, entering the unnamed bay on the east side of Lemesurier point, near latitude $55^{\circ} 45^{\prime}$, longitude $132^{\circ} 15^{\prime}$. So called because it is "fished by Mr. Meyers," and reported by Moser, 1900.

Mice; islands, in Behm canal, opposite entrance to Rudyerd bay, southeastern Alaska. So named by the Coast Survey in 1901.

Michigan; creek, in the Koyukuk region, tributary to Wild river from the north, near latitude $67^{\circ} 20^{\prime}$, longitude $151^{\circ} 10^{\prime}$. Prospectors' name, reported by Peters and Schrader, 1901.

Michigan; creek, eastern Alaska, on the left bank of Yukon river at Nation (city), near longitude $141^{\circ} 50^{\prime}$. Prospectors' name, reported by E. F. Ball in 1898, and by Lieutenant Erickson, U. S. A., 1902.

Mid; rock (25 feet high), between Cat and Dog islands, Gravina group, Alexander archipelago. So named by Nichols, 1883.

Middle; anchorage, between the Indian village at Sitka and Japonski island, Sitka sound, Alexander archipelago. There are three anchorages, Eastern, Middle, and Western. Descriptive appellation.

Middle; arm, of Kelp bay, Baranof island, Chatham strait, Alexander archipelago, near latitude $57^{\circ} 20^{\prime}$, longitude $135^{\circ}$. So named by Moore, 1895 .

Middle; arm, of Three Arm bay, Adak island, middle Aleutians. Descriptive name, given by Gibson in 1855 .

Middle; bay, an arm of Chiniak bay, Kodiak. Named Srednaia (middle) by the Russians.

Middle; bay, indenting the northern shore of Unalaska, between Kashega bay and Chernofski harbor. Given the descriptive name Srednaia (middle) by Veniaminof, 1840. The Fish Commission used this name Middle in 1888. Sarichef used the name Alimuda for this place, a name which belongs to the bay next east of it.

Middle; cape, on the northern coast of Kodiak, near Spruce island. Named Srednie (middle) by Murashef, 1839-40.

Middle; channel, leading into Sitka harbor, Sitka sound, Alexander archipelago. Named srednie (middle) by the Russians.

Middle; fork of Fortymile, near latitude $64^{\circ} 30^{\prime}$. Descriptive name, given by prospectors. It has been called Granite fork and, the upper part, Two White Men creek.

Middle; fork, Chandlar river. Descriptive name, from Schrader, 1899.

Middle; fork, Koyukuk river. Descriptive name, from Schrader, 1899.

Middle; hill, on St. Paul island, Bering sea, on the eastern shore of English bay, south coast, near longitude $170^{\circ} 17^{\prime}$. Name from Duffield, 1897.

Middle; island, in Shakan bay, Sumner strait, Alexander archipelago. So named by Helm, 1886.

Middle; island, the principal island of the Middle Island group, in northern part of Sitka sound, Alexander archipelago. Named Sredni (middle) by Vasilief, 1809. By later Russians called Iablosbnie (apple) and afterwards variously called Iablosh or Middle.

Middle; island, in Chiniak bay, near Kalsin bay, Kodiak. Named Srednie (middle) by Russian naval officers, 1808-1810.

Middle; islands, in the Kashevarof group, Clarence strait, Alexander archipelago. So named by Snow, 1886 .

Middle; group of islands, in northern part of Sitka sound, Alexander archipelago. Name not heretofore used. 
Middle, islands; see Vitskari.

Middle; mountain, on the eastern side of Annette island, Alexander archipelago. So named by Nichols, 1883.

Middle; mountain, on the mainland, east of Stikine river and near the international boundary. Name published by the Coast Survey in 1895.

Middle; peak (1,90ึs feet high), near Chichagof harbor, on Attu island, western Aleutians. So named by Gibson, July, $185 \overline{ }$.

Middle; point, on the southern shore of Sawmill cove, Howkan strait, Cordova bay, Alexander archipelago. So named by Sheldon Jackson, 1880.

Middle; point, on Baranof island, between Northern and Southern rapids, Peril strait, Alexander archipelago, near latitude $57^{\circ} 26^{\prime}$, longitude $135^{\circ} 34^{\prime}$. Named Srednie (middle) by Vasilief, 1.833. Has been called Mid and Sredni.

Middle; point, between Zaikof bay and Rocky bay, northeast end of Montague island, Prince William sound, near latitude $60^{\circ} 20^{\prime}$, longitude $147^{\circ}$. Descriptive name, given by Westdahl, $1.902 .$. .

Middle; point, on the north shore of Olga bay, Alitak bay, southwestèrn coast of Kodiak. Local descriptive name, reported by Moser, 1.900.

Middle; point, between East and Volcano bays, northeast of Belkofski, on south shore Alaska peninsula. Presumably a local name, reported by Dall, 1880.

Middle; point, on the west end of Unimak island, eastern Aleutians, about midway between Cape Sarichef and Scotch Cap, near latitude $54^{\circ} 29^{\prime}$, longitude $164^{\circ} 54^{\prime}$. So designated by Gilbert, 1901.

Middle; point, the north point of entrance to Chapel cove, Bay of Waterfalls, Adak island, middle Aleutians. Named by United States naval officers, 1.893.

Middle, point; see Bear cape.

Middle; reef, in Alitak bay, southwestern coast of Kodiak. Descriptive name. from Moser, 1900.

Middle; rock, in the Necker group of islands, Sitka sound, Alexander archipelago. Named Srednie (middle) by Vasilief, 1809.

Middle; rock, in Bay of Waterfalls, Adak island, middle Aleutians. Descriptive name, given by Gibson in 1855 .

Middle, rock; see Prolewy.

Middle; rocks, in the middle of the entrance to Chichagof harbor, Attu island, western Aleutians. So named by Gibson, July, 1855.

Middle; shoal, immediately east of Turner point, Port Mulgrave, Yakutat bay, southeastern Alaska. So called by Dall in the Coast Pilot (1883, p. 208).

Middle Chugach, island; see Pearl.

Middle Glacier; creek, tributary from the north to Chinitna bay, Cook inlet, near latitude $59^{\circ} 50^{\prime}$, longitude $153^{\circ} 10^{\prime}$. Name from Martin, 1904 .

Middle Point; rock, bare at low water, in Peril strait, 300 yards west of Middle point (above). So described in the Coast Pilot of 1901.

Middle Station; trading post, on the Nushagak river at the mouth of the Mulchatna. Local name, obtained in 1898 by Spurr and Post from trader A. Mittendorf.

Middleton; island, in the Gulf of Alaska, near longitude $146^{\circ}$. So called by vancouver in his atlas. The Spaniards, in 1791, . called it Isla de Hijosil. Tebenkof calls it Achek or Ochek, and some Russian charts Kachek or Kochek. . The earliest name applied is Atchaka or Achakoo, apparently the native name. 
Middy; point, the northeast point of Ham island, Revillagigedo channel, Alexander archipelago. So named by Nichols, 1883.

Midnight; creek, Seward peninsula, on the east side of Midnight mountain (below), tributary to Taylor creek from the north, near latitude $65^{\circ} 45^{\prime}$, longitude $164^{\circ} 30^{\prime}$. Prospectors' name, reported by Gerdine, 1901.

Midnight; mountain near headwaters of Kougarok river, ${ }^{D}$ Seward peninsula. Name from Brooks, 1900.

Midun; island (150 feet high), near Deer island, in the Sandman reefs, northeast of Sannak, near latitude $54^{\circ} 52^{\prime}$, longitude $162^{\circ} 13^{\prime}$. So called by Dall, 1880: Presumably a local name.

Midway; island, in Redfish bay, Baranof island, Alexander archipelago. So named by Moser, 1897.

Midway, island ; see Hague rock.

Midway; islands, between Holkham bay and Port Snettisham, in Stephens passage, Alexander archipelago. So named by Meade, 1869. These islands were reserved for light-house purposes by Executive order dated January $4,1901$.

Midway; islands, on the Arctic coast, east of the mouth of Colville river. So named by Stockton, 1889, from the circumstance that they are about midway between Lion reef proper and Return reef.

Midway; point, on Glass peninsula, Stephens passage, Alexander archipelago. So named by Mansfield, 1889 .

Midway; reef, at the eastern entrance to Peril strait, Alexander archipelago. So named by Dall in the Coast Pilot (1883, p. 167).

Midway; reef, in Mine harbor, Herendeen bay, Alaska peninsula, near longitude $160^{\circ} 41^{\prime}$. Descriptive name, given by Tanner, 1890 .

Midway; rock (awash at highest water), in southern part of Wrangell strait, Alexander archipelago. Descriptive name, given by Meade, 1869. Lindenberg, 1838, called it Polivnoi (awash).

Midway; rock, near the Southern rapids, Peril strait, Alexander archipelago. Named Srednie (middle) by Vasilief, 1833.

Mielloi, bay; see Krestof harbor.

Mielloi, cove; see Little.

Mieshak; cove, on south shore of Alaska peninsula, between Cold and Portage bays. So called by the Russians.

Miesofski, point; see Black.

Miesofskoe, lake; see Round.

Miga; cape, on the northwest shore of Kanaga island, Andreanof group, middle

Aleutians. So called by Tebenkof, 1849. Miga is the genitive of the Russian mig (wink, twinkling of an eye, no time).

Mike; point, southeastern shore Cleveland peninsula, between Wadding and Raymond coves, Behm canal, southeastern Alaska, near latitude $55^{\circ} 37^{\prime}$, longitude $131^{\circ} 53^{\prime}$. Local navigators' name, reported by H. C. Fassett, Bureau of Fisheries, 1904.

Mike Hess, creek; see Hess.

Mikhailovskaia, bay; see Alimuda.

Mikischkin, point; see East Foreland.

Milavanof, river; see Chvilnuk.

Miles; canyon, in Lewes (formerly Yukon) river, between lakes Marsh and Laberge, often spoken of as the Great canyon of the Yukon. Schwatka, who passed through it and its rapids on a raft, July 2, 1883, named it after his department commander, Gen. Nelson Appleton Miles, U. S. A.

Miles; glacier, near mouth of Copper river. So named by Allen, 1885, after Gen. Nelson A. Miles, U. S. A. 
Miles; pass, between the headwaters of Copper and Tanana rivers. So named by Allen, 1885, after Gen. Nelson A. Miles, U. S. A.

Milifores, Punta de los; see Thousand Flowers.

Millvie, point; see Rock.

Mill; lake, near St. Paul, Kodiak, draining to Popof bay. At the mouth of the stream draining from it, Tebenkof, 1849, shows a melnitza (mill).

Mill; reef, in Howkan strait, northwest from Howkan village, Cordova bay, Alexander archipelago. So named by Sheldon Jackson, 1880. There is (or was) a sawmill near this place.

Millard; trail, about 90 miles long, from Copper Center to Mentasta pass along the western slopes of mounts Drum and Sanford. Prospectors' name. Some 60 or 70 miles of this trail were cleared, under the direction of Mr. B. F. Millard, in or about 1898.

Miller; cape, the eastern head of Sycamore bay, north const of Kodiak. Named Maknashkina by Murashef, 1839-40. Tebenkof, 1849, calls it melnichnoi (relating to a mill), perhaps by reason of a mill in the adjacent bay. It has been called Millers cape by the Coast Survey.

Miller, cape; see Popof.

Miller, coalmine; see Pioneer.

Miller; creek, in the Fairbanks region, tributary to Fish creek from the north, near latitude $65^{\circ} 05^{\prime}$; longitude $147^{\circ}$. Prospectors' name, reported by Gerdine, 1903.

Miller; creek, in the Birch Creek region, tributary to Mammoth creek from the left, near latitude $65^{\circ} 30^{\prime}$, longitude $145^{\circ} 20^{\prime}$. Named after $O$. C. Miller, a prospector, who discovered gold here in 1894 . Reported by Spurr, Goodrich, and Schrader, 1896.

Miller; creek, tributary to Sixtymile creek from the west, near longitude $141^{\circ}$. Local name, from Abercrombie, 1898.

Miller; creek, in the Fortymile region, tributary to Dome creek from the right, near latitude $64^{\circ} 25^{\prime}$, longitude $141^{\circ} 10^{\prime}$. Prospector's' name, from Ball's map (unpublished), 1898, in Coast Survey archives.

Miller; glacier, southeastern coast of Alaska, 22 miles east of Yakutat, and immediately west of Yakutat glacier, near longitude $139^{\circ}$. So named by Moser, 1901, after Ensign Cyrus R. Miller, U. S. N., a member of his party.

Miller; gulch, in the Chistochina region, on the north side of Slate creek. Named by prospectors after Jack Miller, who first found gold here, and reported by Mendenhall, 1902.

Miller; island, northwestern shore of Alitak bay, Kodiak, at southern entrance to Moser bay. So named by Moser, 1900, after Ensign Cyrus R. Miller, U. S. N., a member of his party.

Miller; lake, at head of North arm, Moria sound, Prince of Wales island, Alexander archipelago. So named by Clover, 1885 , perhaps after his wife. Has been printed erroneously Mitten and Mitter.

Miller; lake, Annette island, Alexander archipelago, on the east side of Tamgas harbor and draining into the head of 'Tamgas lake, near latitude $55^{\circ} 04^{\prime}$. So named by Moser, 1901, probably after Ensign C. R. Miller, U. S. N., a member of his party.

Miller House; road house or tavern, in the Birch Creek region, near the junction of Mammoth and Miller creeks, about latitude $65^{\circ} 30^{\prime}$, longitude $145^{\circ} 10^{\prime}$. Local name, reported by Gerdine, 1903. Spurr's map, 1896, has Mammoth House at this place.

Millerton; village, in the Nushagak enumerating district of the Eleventh Census, 1890 , containing a population of 165 . Location not discovered. 
Millisville; town or settlement, on the northwestern shore of Tustumena lake, Kenai peninsula, near longitude $150^{\circ} 25^{\prime}$. Local name, obtained by Moffit, 1904.

Mills; creek, tributary to Canyon creek from the east, Kenai peninsula. Prospectors' name, from Becker, 1895.

Mills; islet, in Krestof sound, north of Sitka sound, Alexander archipelago, between Double island and Polnoi island. Named Krugloi (round) by Vasilief in 1809. Renamed Mills by Moore, 1897, after a prominent merchant at Sitka.

Milne; point, somewhere on the Arctic coast, east of Colville river. So called by Dease and Simpson, 1837, in their narrative (p. 129). Location not discovered.

Milroy; creek, Seward peninsula, tributary from the north to Hannum creek, which is a tributary of Inmachuk river; near latitude $65^{\circ} 45^{\prime}$, longitude $163^{\circ} 20^{\prime}$. Prospectors' name, reported by Mendenhall, 1901.

Milton; creek, Seward peninsula, in Casadepaga drainage basin, tributary to Birch creek from the east, near latitude $64^{\circ} 48^{\prime}$, longitude $164^{\circ} 09^{\prime}$. Prospectors' name, from Gerdine, 1905.

Mina; creek, Seward peninsula, tributary from the east to Kugruk river, which flows into Kotzebue sound, near latitude $65^{\circ} 45^{\prime}$, longitude $162^{\circ} 20^{\prime}$. Prospectors' name, reported by Witherspoon, 1903.

Minakak; lake, north of Kobuk river, drained by Beaver river, near latitude $67^{\circ} 10^{\prime}$, longitude $155^{\circ} 25^{\prime}$. Eskimo name, written Mena-kak-a-shah and Mene-kok-o-shah by Cantwell, 1885.

Minchumina; lake, about 60 miles northwest of Mount McKinley, near latitude $64^{\circ}$, longitude $152^{\circ}$. Indian name, Min-chu-min-a, i. e., Minchu lake, obtained by Herron in 1899 .

Mine; harbor, in Ferendeen bay, Alaska peninsula. So called by the Fish Commission in 1890 ; called also Coal harbor. A coal mine was opened here in $\mathbf{1 8 8 8 .}$

Mine; point, in Kootznahoo inlet, Admiralty island, Alexander archipelago. So named by Meade, who opened a coal mine near this point in 1869.

Mineral; creek, tributary to Port Valdez,. Prince William sound, from the north, near longitude $146^{\circ} 20^{\prime}$. Presumably a local name; published in 1898 .

Mineral; creek, 12 miles north of Nome, Seward peninsula, tributary to Nome river from the east, near latitude $64^{\circ} 40^{\prime}$, longitude $165^{\circ} 17^{\prime}$. Miners' name, reported in 1900 .

Mineral; lake, southeastern shore Prince of Wales island, draining into Nowiskay cove, at the head of North arm Moira sound, Alexander archipelago, near latitude $55^{\circ} 09^{\prime}$, longitude $132^{\circ} 12^{\prime}$. Prospector's' name, reported by Brooks, 1901. It is said to be often called Nowiskay lake.

Mineral; point, on the southern shore of San Antonio bay, Bucareli bay, Prince of Wales archipelago. Named Punta de Mineral by Maurelle and Quadra, 1775-1779.

Miners; bay, in Unakwik inlet, Prince William sound. Local name, reported by Glenn in 1898.

Miners; cove, in Gastineau channel, near the town of Juneau. Local name, published by Dall in the Coast Pilot (1883, p. 171), where it is written Miner's.

Mliners; lake, and river, on the north shore Prince William sound, near the head of Unakwik inlet, on the east side, and draining into Miners bay, near longitude $147^{\circ} 15^{\prime}$. Fisheries name, reported by Moser in 1897 and 1901. 
Miners; point, on the eastern shore of Portland canal. Name published by the Coast Survey in 1897.

Minerva; mountain, in the southwestern part of Revillagigedo island, Alexander archipelago. So named by Nichols, 1883 .

Minett; islet, in Jamestown bay, Sitka sound, Alexander archipelago. So named by United States naval officers, 1880, presumably after Lieut. Henry Minett, U. S. N.

Miniatulik; river, on the north shore of Norton bay, Norton sound, near longitude $162^{\circ} 20^{\prime}$, Eskimo name, reported by Gilbert, 1900. Neechuck, on a map published in 1900 , appears to be this river.

Mink; bay, indenting the southern shore of Boca de Quadra, southeastern Alaska. So named by the Coast Survey in 1891.

Mink; point, name given by Moser, 1897 , to the point between what he describes as the South and East arms of West Uganik bay, Kodiak, near latitude $57^{\circ} 45^{\prime}$, longitude $153^{\circ} 30^{\prime}$.

Minnehaha; creek, Seward peninsula, tributary to Spafarief bay from the soutbwest, near latitude $66^{\circ}$, longitude $162^{\circ}$. Prospectors' name, reported by Mendenball and Reaburn, 1901.

Minnesota; creek, Seward peninsula, in Solomon River basin, tributary on east bank of Penny creek, near latitude $64^{\circ} 40^{\prime}$, longitude $164^{\circ} 22^{\prime}$. Prospector's' name, from a local map, 1901.

Minnie; creek, tributary to South fork Kuzitrin river from the south, near latitude $65^{\circ} 25^{\prime}$, longitude $163^{\circ} 45^{\prime}$. Prospector's' name, reported by Gerdine, 1901.

Minnie; creek, tributary to Middle fork Koyukuk river, on the left bank, near latitude $67^{\circ} 30^{\prime}$, longitude $150^{\circ} 15^{\prime}$. Prospector's' name, reported by Peters and Schrader, 1901. Schrader and Gerdine, 1899, called it, erroneously, Wiseman creek, which is the name of a tributary near by on the right bank.

Minook; creek, tributary to Yukon river from the enst, 2 miles above Rampart (city), near longitude $150^{\circ}$. Apparently identical with Klanachargut (Klana-kakat) river of Raymond, 1869. Has been spelled Mynook and Munook. Named after John Minook, alias Ivan Pavlof, half Russian, half Eskimo, miner and interpreter at Fort Reliance.

Mint; river, tributary to Lopp lagoon, Seward peninsula. Name from Brooks, 1900.

Mintok; lake, somewhere in the region south of Minook creek, draining to the 'Tanana jiver. Native name, from Raymond, 1869, who spells it Mintokh.

Minx; islands, at head of Thorne arm, Revillagigedo island, Alexander archipelago. So named by the Coast Survey in 1891.

Miolcniozdok; Indian village, on the right bank of Yukon river, 15 miles above Kokrimes, near longitude $154^{\circ} 10^{\prime}$. Indian name written Me-ok-ne-ozdok on IEdwards' Track Chart of the Yukon, 1899. It seems to be at or near the location of Hakorcins old station.

Miraballes; point, in eastern part of Bucareli bay, Prince of Wales archipelago. Named Punta de Miraballes (point of white plums) by Maurelle and Quadra, 1775-1779.

Miranda, volcano; see Iliamna.

Mirando, Volcan de; see Redoubt volcano.

Mirror; creek, tributary to Chisana river from the east, near latitude $62^{\circ} 30^{\prime}$. Descriptive name, given by Peters and Brooks, 1898.

Mirror; slough, near mouth of Martin river, east side Copper River delta. Local name, reported by Martin, 1904. 
Misery; island, near Lemesurier point, Clarence strait, southeastern Alaska, near latitude $55^{\circ} 45^{\prime}$, longitude $132^{\circ} 17^{\prime}$. Corruption of Lemesurier by local navigators, reported by H. C. Fassett, Bureau of Fisheries, 1904.

Mishik, river and village; see Meshik.

Miskuntl'kakat, river; see Lebarge.

Mission; cove, just north of Howkan village, Cordova bay, Alexander archipelago. So named by Dall, 1882. Has also been named Hydah by Sheldon Jackson.

Mission; creek, tributary to Port Clarence from the north, Seward peninsula. Name from Barnard, 1900.

Mission; creek, Seward peninsula, tributary from the south to Arctic river, near longitude $165^{\circ} 43^{\prime}$. ' Prospectors' name, reported by Gerdine, 1901.

Mission; creek, in the Eagle mining district, tributary to Yukon river from the west at Eagle. Local name, published in 1898. Its native name, as obtained by Schwatka in 1883 , is Tatotlinda.

Mission; creek, tributary to Mosquito fork Fortymile creek from the south, near longitude $142^{\circ}$. Prospectors' name, from sketch map compiled by Major Glassford, Signal Corps, U. S. A., 1905.

Missionary; range of mountains (2,500 to 2,800 feet high), east of Portage baý, on Lindenberg peninsula, Kupreanof island, Alexander archipelago. So named by Thomas, 1887.

Mission Warehouse, village; see Shiniak.

Missouri; creek, in the Fortymile region, tributary to Champion creek from the left, near latitude $64^{\circ} 30^{\prime}$, longitude $142^{\circ}$. Prospectors' name, taken from Ball's map (unpublished), 1.898, in Coast Survey archives.

Mist; harbor, indenting the eastern shore of Nagai island, Sbumagin group. Name published by the Coast Survey in 1882.

Mitchell; bay, in Kootznahoo inlet, Admiralty island, Alexander archipelago. So named by Meade, 1869, after his classmate, Lieut. Commander John Gardner Mitchell, U. S. N.

Mitchell; creek, Seward peninsula, tributary on north bank of East fork Solomon river, near latitude $64^{\circ} 42^{\prime}$, longitude $164^{\circ} 14^{\prime}$. Prospectors' name, from a local map, 1904.

Mitchell; creek, Seward peninsula, flowing northeast to Agiapuk river, near longitude $165^{\circ} 43^{\prime}$. Prospector's' name, reported by Gerdine, 1901. Erroneously Mitchel.

Mitchell; creek, in the Fortymile region, eastern Alaska, tributary to Kechumstuk creek from the northeast, near latitude $64^{\circ} 05^{\prime}$, longitude $142^{\circ} 40^{\prime}$. Called Ingram creek by Lieutenant Mitchell in 1902, and Mitchell creek by the Signal Corps, U. S. A., 1905.

Mitchell, island; see Wingham.

Mitchell; pass (4,700 feet high), in the Fortymile region, eastern Alaska, between the headwaters of Mitchell creek and Lee creek. So named by the Signal Corps in 1902, after Lieut. William Mitchell, Signal Corps, U. S. A.

Mitchell; point, on the southern shore of Kupreanof island, Sumner strait, Alexander archipelago. So named by Vancouver, 1793, after Capt. William Mitchell, R. N.

Mitchell; post-office and trading post, on the upper Yukon, near the mouth of Fortymile creek. The post-office was established in 1892, and discontinued in 1895 . Mir. L. N. (Jack) McQuestin was postmaster. In 1890 the population was reported to be 238 .

Mitchell; sunken rock, in Middle channel, Sitka harbor, Sitka sound, Alexander archipelago. So named by. United States naval officers, 1880. 
Mite; cove, anchorage (contracted) and small island, in Lisianski strait, on the eastern shore of Yakobi island, Alexander archipelago, near longitude $136^{\circ} 27^{\prime}$. So named by Pratt, 1901 .

Mitkof; large island, off the mouth of Stikine river, Alexander archipelago. Named by the Russians after a Captain Mitkof. Variously written Mitgoff, Mitkoff, etc.

Mitletukeruk; Eskimo village, on the Arctic coast of Seward peninsula, at northeast end of Lopp lagoon, near latitude $65^{\circ} 50^{\prime}$. Native name, obtained by Gerdine, 1901.

Mitrofania; bay, northeast from the Shumagins, indenting the south shore of Alaska peninsula. So named by the Fish Commission in 1888.

Mitrofania; harbor, in Mitrofania bay; Alaska peninsula. So named by the Fish Commission in 188s.

Mitrofania; island, west of the Semidi islands, and near the south shore of Alaski peninsula, near longitude $158^{\circ} 45^{\prime}$. So named by the Russians, who wrote it Mitrofania and St. Mitrofania. Has also been written Mitrofa.

Mitten, lake; see Miller.

Mizofek, point; see Black.

Mlkleet-o-kumen-ah, mountain; see Schwatka.

Mock; creek, tributary from the left to Atwater creek, affluent to South fork Fortymile creek, near latitude $64^{\circ}$, longitude $141^{\circ} 50^{\prime}$. Prospectors' name, taken from Ball's map (unpublished), 1898, in Coast Survey archives.

Moffet; cove, at east end of Izembek bay, on the north shore of Alasika peninsulit. Named by Dall in 1882. The Fish Commission, 1888, show this cove divided into two parts, one called Sloss bay, the other Neumann bay.

Moffet; point, the eastern point of entrance to Izembek bay, on north shove of Alaska peninsula. Named by Lutke, 1828, after Midshipman Samuel Moffet, a member of his party. Has been called Neumann by the Fish Commission.

Mogilnoi; island, soutbwest of Japonski island, Sitka sound, Alexander archipelago. Named Mogilnoi (grave) by Vasilief in 1809. Has also been called Shell island.

Mogul; creek, tributary to Seventymile creek from the soutb. Local name, obtained by Barnard, 1898.

Mohican; cape, the westernmost point of Nunivak island, Bering sea. Named Boil by Tebenkof, 1849, after Lieut. Roman Boil, who was in the party of Vasilief when Nunivak was discovered by Vasilief in 1821 . Recently called Cape Mohican by the Coast Survey.

Moira; bare rock ( 50 feet high), at entrance to Moira sound, Clarence strait, Alexander archipelago. So named by Clover, 1885.

Moira; sound, indenting the soutbeastern shore of Prince of Wales island, Clarence strait, Alexander archipelago. Named by Vancouver, 1793, "after the noble Earl of that title."

Molkrovskoi, bay; see Punicestone.

Mokrovskoi, cape; see Spray.

Molchatna, river; see Mulchatna.

Mole; harbor, in Seymour canal, Admiralty island, Alexander archipelago. So named by Mansfield, 1889.

Moller; island, one of the Kudobin islands, on north coast of Alaska peninsula, near Port Moller and longitude $161^{\circ} 15^{\prime}$. So named by Dall, 1882. Also written Möller. 
Moller; port (Port Moller), on the northern shore of Alaska peninsula, near longitude $160^{\circ} 35^{\prime}$. Partially explored by Staniukovich of Lutke's party, in 1828, and named after his vessel, Moller.

Mondragones (Los), islets; see Fish Egg.

Money; creek, Seward peninsula, tributary to Aurora creek, which is a tributary to West fork Noxapaga river, near latitude $65^{\circ} 38^{\prime}$, longitude $164^{\circ}$ 15'. Prospectors' name, reported by Gerdine, 1901.

Money; creek, in the Fortymile region, tributary to Mission creek from the right, near latitude $64^{\circ} 45^{\prime}$, longitude $141^{\circ} 30^{\prime}$. Prospector's name. This may be identical with Cripple creek of Barnard.

Monolith; point, on the western side of Portage bay, Alaska peninsula. Name published in Hydrographic Office Notice to Mariners No. 48, 1893.

Montague; island, in entrance to Prince William sound. Named Montagu by Cook in 1778. The native name Tsukli was also used by the Russians. The usual spelling Montague has largely superseded the original spelling Montagu.

Montague; peak, northeastern end of Montague island, Prince William sound, near Zaikof point. So called by Westdahl, 1903.

Montague; point, on the northeastern end of Montague island, Prince William sound, near latitude $60^{\circ} 22^{\prime}$, longitude $147^{\circ}$. So called by Westdabl, 1902.

Montana; creek, and basin at its head, on the mainland, southeastern Alaska, eastern shore of Favorite channel, Lynn.canal, tributary to Mendenhall river from the northwest, near latitude $58^{\circ} 25^{\prime}$. Prospector's' name, reported by Spencer and Wright, 1903.

Montana; creek, tributary on the left to Susitna river, about 3 miles above the mouth of Deshka river, near latitude $62^{\circ} 10^{\prime}$, longitude $150^{\circ} 05^{\prime}$. Prospector's' name, reported by Glenn, 1898.

Montana; creek, Seward peninsula, small tributary of Solomon river, on west bank near its head. About latitude $64^{\circ} 46^{\prime}$, longitude $164^{\circ} 20^{\prime}$. Prospectors' name, Montana Creek No. 1, from a local map, 1904.

Montana; creek, Seward peninsula, tributary from the east to Kugruk river, which flows into Kotzebue sound, near latitude $65^{\circ} 50^{\prime}$, longitude $162^{\circ}$ $20^{\prime}$. Prospectors' name, reported by Witherspoon, 1903.

Montana; creek, in the Fairbanks region, tributary to McManus creek from the north, near latitude $65^{\circ} 25^{\prime}$, longitude $146^{\circ} 05^{\prime}$. Prospector's' name, reported by Gerdine, 1903.

Montana; creek, in the Rampart region, tributary from the west to Minook creek, about 5 miles above its mouth. Prospectors' name, reported by Prindle, 1904.

Montana; creek, 7 or 8 miles west of Eagle, tributary to Mission creek from the right, near latitude $64^{\circ} 45^{\prime}$, longitude $141^{\circ} 25^{\prime}$. Prospectors' name. This may be identical with Colorado creek of Barnard and Boulder creek of Spurr, Goodrich, and Schrader.

Montana; creek, eastern Alaska, on the north bank of Seventymile creek, near latitude $64^{\circ} 55^{\prime}$, longitude $142^{\circ} 40^{\prime}$. Prospectors' name, from sketch map compiled by Major Glassford, Signal Corps, U. S. A., 1905.

Montana; creek, tributary to Fortymile creek from the south, near latitude $64^{\circ} 15^{\prime}$, longitude $141^{\circ} 30^{\prime}$. Prospectors' name, obtained by Barnard, 1898. Has also been called Waller creek.

Montauk; point and camp, on the left bank of Yukon river, 12 miles above Nation, near longitude $141^{\circ} 30^{\prime}$. Prospectors' name, reported by Cantwell, 1900. 
Monte Cristo; creek, draining the north slope of Mount Gordon, and tributary to the headivaters of the Nabesna river from the west. Prospectors' name, reported by Schrader, 1902, who says the native name is Na-un-da.

Monte Cristo; creek, 30 miles north of Cape Nome, Seward peninsula, a north fork of Sulphur creek, which is tributary to Nome river from the east near longitude $165^{\circ} 10^{\prime}$. Miners' name, reported by Gerdine, 1904.

Montelikat, creek; see Mentokakat.

Monument; creek, Seward peninsula, small tributary on east bank of Casadepaga, near latitude $64^{\circ} 47^{\prime}$ longitude $164^{\circ} 23^{\prime}$. Prospectors' name, from a local map, 1.901.

Monument; creek, 8 miles north of Nome, Seward peninsula, tributary to Snake river from the west, near longitude $165^{\circ} 28^{\prime}$. Name from Barnard, 1900.

Mronument; creek, Seward peninsula, tributary to North fork Kougarok river from the south, near latitude $65^{\circ} 35^{\prime}$, longitude $164^{\circ} 35^{\prime}$. Prospectors' name, reported by Gerdine, 1901.

Monument; mountain, Seward peninsula, 7 miles north of Kiwalik mountain, near latitude $65^{\circ} 35^{\prime}$, longitude $162^{\circ} 10^{\prime}$. Prospectors' name, reported by Witherspoon, 1903 .

Monument; point, rocks, and river, on eastern side of Kruzof island, Alexander archipelago. Named Monumentalnoi (monument) by Vasilief, 1809.

Monument; rock (1,300 feet high); 9 miles northwest of Nome, Seward peninsula, on the right bank of Snake river, near latitude $64^{\circ} 35^{\prime}$, longitude $165^{\circ} 34^{\prime}$. Prospectors' name, published in 1.904.

Moonlight; creek, tributary to Grantley harbor from the north, Seward peninsula. Name from Barnard, 1900.

Moonlight; creek, 20 miles north of Cape Nome, Seward peninsula, tributary to Eldorado river from the west, near longitude $165^{\circ}$. Name from Barnard, 1900.

Moonlight; creek, Seward peninsula, tributary from the east to Anikovik creek, about 6 miles northeast of York. Prospectors' name, reported by Gerdine, 1901.

Moonlight; creek, Seward peninsula, tributary from the south to Humboldt creek, which is an aftluent of Goodhope river, near latitude $65^{\circ} \mathbf{5 5}$, longitude $164^{\circ}$. Prospectors' name, reported by Mendenhall, 1901.

Moonlight; creek and springs, 4 miles north of Nome, Seward peninsula, tributary to Little creek from the north, near longitude $165^{\circ} 25^{\prime}$. Local name, published in 1904 .

Moonlight; creek, Seward peninsula, small tributary on west bank of Casadepaga, near latitude $64^{\circ} 47^{\prime}$, longitude $164^{\circ} 27^{\prime}$. Prospectors' name, from Gerdine, 1905.

Moonshine; creek, Seward peninsula, in Casadepaga drainage basin, tributary to Birch creek from the northwest, near latitude $64^{\circ} 49^{\prime}$, longitude $164^{\circ}$ 10'. Prospector's' name, from Gerdine, 1905.

INoore; channel, leading through some low sandy islands to Port Moore, Arctic coast, near Point Barrow. So named by the British Admiralty, 1853, after Commander Thomas E. L. Moore, R. N. Its Eskimo name was given by the British as Ik-ke-rá-luk. Ray calls it, 1885, Ikiraaluk.

Mroore; creek, tributary from the south to Mosquito fork of South fork Koyukuk river, near latitude $67^{\circ} 05^{\prime}$, longitude $149^{\circ} 40^{\prime}$. Prospectors' name, reported by Peters and Schrader, 1901. 
Moore; island, in Koyukuk river, near latitude $67^{\circ}$. So named by Allen, 1885 .

Moore; mountains, on the southern border of Chichagof island, Alexander archipelago. So named by the Coast Survey, 1895, after Lieut. Commanders Edwin King Moore and William Irwin Moore, U. S. N.

Moore; nunatak, in the Agassiz glacier, near southeastern end of the Chaix hills, St. Elias alps. So called by Russell, 1S91, presumably after Will C. Moore, a member of his party, who was drowned in landing at Icy bay on June 6, 1891.

Moore; port, at Point Barrow. So named, 1853, after Commander Thomas E. L. Moore, R. N., of the Franklin search expedition.

Moorovskoy, bay; see Pumicestone.

Moose; creek, tributary to Canyon creek from the south, Kenai peninsula. Local name, from Becker, 1895.

Moose; creek and pass, Kenai peninsula; creek tributary to Trail lakes from the northwest, and pass at its head, leading to Quartz creek. Local name, from Moffit, 1904.

Moose; creek, Kenai peninsula, on the left bank of Resurrection creek, 14 miles miles above Hope city. Locil name, from Moffit, 1904.

MIoose; creek, 100 miles northwest of the head of Cook inlet, draining southward from Simpson pass into Happy river, a branch of the Skwentna, near longitude $153^{\circ}$. So named by Brooks, 1902.

Moose; creek, in the Kantishna region, a large left fork of Bearpaw creek, nenr latitude $64^{\circ}$, longitude $150^{\circ}$. Name given by prospectors in 1905, and reported by Prindle.

Moose; creek, tributary to Chena slough, on the north bank of the Tanana river, near latitude $64^{\circ} 40^{\prime}$, longitude $147^{\circ}$. Local name, reported by Gerdine, 1903.

Moose, creek, tributary to Chatanika river; see Vault.

Moose; creek, tributary to Fairbanks creek from the north, near latitude $65^{\circ} 05^{\prime}$, longitude $147^{\circ} 20^{\prime}$. Local name, obtained by Gerdine, 1903 .

Moose, creek, Seward peninsula; see Ida.

Moose; creek, in the Fairbanks region, tributary to Goldstream creek from the north, near latitude $64^{\circ} 55^{\prime}$, longitude $147^{\circ} 55^{\prime}$. Local name, from Map of Location, Tanana Mines Railroad, 1.904.

Moose; creek, tributary to Seventymile creek from the north, near latitude $65^{\circ} 55^{\prime}$, longitude $141^{\circ} 35^{\prime}$. Prospectors' name, reported by Gerdine, 1903.

Moose; creek, tributary to Fortymile creek from the south, at the international boundary, near latitude $64^{\circ} 15^{\prime}$. Local name, reported by Spurr, Goodrich, and Schrader, of the Geological Survey, 1896.

Moose, creek; see 'Tsadaka.

Moose, creek; see Nation river.

Moose; river, Kenai peninsula, a northern tributary of Kenai river, near longitude $150^{\circ} 45^{\prime}$. Local name, from Moffit, 1904.

Moose Camp; place, on the northern bank of Klutina river, about 10 miles above its mouth. Name from Abercrombie, 1898.

Moosehorn; mountain (5,000 feet high), near the international boundary and latitude $63^{\circ}$. So named by Peters and Brooks, 1898.

Moosehorn; rapids, in Kasilof river, Kenai peninsula, near the outlet of Tustumena lake. Local name, from Moffit, 1904.

Mop; point, at the head of Thorne arm, Revillagigedo island, Alexander archipelago. So named by the Coast Survey in 1891. 
Moran; creek or gulch, Seward peninsula, on east bank of Solomon river, 5 miles from the coast, near longitude $164^{\circ} 23^{\prime}$. Prospectors' name, from a local map, 1904.

Mordvinof; cape, the northwestern head of Unimak island, eastern Aleutians, between OKsenof bay and Urilia bay, near longitude $164^{\circ} 30^{\prime}$. Named Mordvinova (Mordvinof's) by Staniukovich in 1828. Lutke uses Noïsalk or Mordvinof. Apparently Noisak is the native name. Veniaminof (1831) calls it Oksenof or Mordvinof, and Tebenkof (1849) calls it Mordvinof or Oksenof. The Fish Commission, 1888, called it Lincoln.

Mordvinof, cape; see Lapin.

Morgan; cape, the southwesternmost point of Akutan island, Krenitzin group, eastern Aleutians, near longitude $166^{\circ} 03^{\prime}$. So named by the Fish Commission in 1888.

Morjevskoi, peak; see Walrus.

Morjovi, island; see Hall.

Morjovi, rookery; see Morzhovoi.

Morkovskoi, bay; see Pumicestone.

Morne, island; see Horn.

Morning Call; creek, 30 miles north of Cape Nome, Seward peninsula, tributary to Grand Central river from the south, near longitude $165^{\circ} 06^{\prime}$. Name from Barnard, 1900.

Morozovs7ie, bay; see Cold.

Morris; creek, draining the eastern slope of Simpson pass, to the right bank of Kichatna river. So named by Herron, 1899.

Morris; reef; in Chatham strait, at eastern entrance to Peril strait, Alexander archipelago. Named by United States naval officer's, in 1880, after William Gouverneur Morris, United States collector of customs at Sitka.

Morse; cove, in Ray anchorage, eastern shore of Duke island, Gravina group, Alexander archipelago. So named by Nichols, 1883, presumably after Fremont Morse, a member of his party.

Lorse, creek; see Ida.

Morse; glacier, part of the Muir glacier, southeastern Alaska. Named by Reid, 1892, after J. F. Morse, one of his companions in 1890. In Reid's first publication of this (Nat. Geog. Mag., 1892, vol. 4, map) the glacier is called West tributary (of Muir glacier).

Morse, island; see Bendel.

Morse; rock (awash at low water), near Hemlock island, Port Chester, Annette island, Alexander archipelago. So named by the Coast Survey, presumably after Mr. Fremont Morse, of the Coast Survey.

Morskoi; breaker, about half a mile westerly from Sea rock, at entrance to Salisbury sound, Alexander archipelago. Named Morskoi (sea) by Moore, 1897.

Morskoi, cape; see Hinchinbrook.

Morskoi, cape; see Ocean.

Morskoi, cape; see Phipps.

Morskoi, islet; see Navy.

Morskoi, rock; see Sea.

Morton; fort, at mouth of Kobuk river, Hotham inlet, Arctic ocean. This name, Fort Morton, was published by the Coast Survey in 1898.

Morzhovoi; bay, indenting the southern shore of Alaska peninsula, near its western end, latitude $55^{\circ}$, longitude $163^{\circ}$. Named Morzhovoi (walrus) by the Russians. Its Aleut name is Adamagan. Has been variously written Morjevskaia, Morshevoi, Morshovoi, Morzovia, etc. 
Morzhovoi, island; see Hall.

Morzhovoi, island; see Walrus.

Morzhovoi, islet; see Shaiak.

Morzhovoi; peninsula, in Isanotski strait, western end of Alaska peninsula, separating Traders cove from Bechevin bay, near latitude $54^{\circ} 56^{\prime}$, longitude $163^{\circ} 20^{\prime}$. Name from Westdabl, 1901. He received it from Capt. J. L. Fisher, who sailed through Isanotski strait in 1898.

-Morzhovoi; rookery, on the eastern side of Northeast point, St. Paul island, Bering sea, near longitude $169^{\circ} 57^{\prime}$. Local name, Russian (walrus), written Morjovi by Duffield, 1897 .

Morzhovoi; native village, at western end of Alaska peninsula. Named Morzhovoi (walrus) by the Russians. Variously spelled. There are or were two villages, one called Old Morzhovoi, the other, New Morzhovoi, being about 12 miles apart. Old Morzhovoi was at the head of Morzhovoi bay; New Morzhovoi is on Traders cove, which opens into Isanotski strait. The Greek church here is named Protassof, and Petrof, 1880, called the settlement Protassof.

Moser; bay, in Behm canal, indenting the western shore of Revillagigedo island, Alexander archipelago, near latitude $55^{\circ} 34^{\prime}$, longitude $131^{\circ} 40^{\prime}$. Named by the Coast Survey, 1886, after Commander Jefferson Franklin Moser, U. S. N.

Moser; bay, northwestern shore Alitak bay, Kodiak. Named after Commander Jefferson F. Moser, U. S. N., who in command of the Fish Commission steamer Albatross made a reconnaissance of Alitak bay in 1900.

Moser; glacier, southeastern coast of Alaska, 20 miles east of Yakutat, near longitude $139^{\circ}$. So named by the Fish Commission, after Commander Jefferson Franklin Moser, U. S. N., who in command of the Albatross made a reconnaissance in this region in 1901.

Moser; island, near head of Hooniah sound, Chichagof island, Alexander archipelago. So named by the Coast Survey, 1899, after Lieut. Commander Jefferson Franklin Moser, U. S. N.

Moser; island, in Naha bay, at mouth of Moser bay, Behm canal, southeastern Alaska. So applied by the local navigators, and reported by H. C. Fassett, Bureau of Fisheries, 1904.

Moses; point, the western point of entrance to Hanus bay, Peril strait, Alexander archipelago. Named by Moore, 1895, after Asst. Engineer Stanford Elwood Moses, a member of his party.

Moses; rock, off south shore of Alaska peninsula, Unga strait, near longitude $161^{\circ} 10^{\prime}$. Local name, reported by Moser, 1897.

Mosman; inlet, in Etolin island, opening into Clarence strait, Alexander archipelago. So named by Dall, 1879, after Alonzo Tyler Mosman, of the Coast Survey, who made surveys in Alaska in 1867.

Mosquito; creek, tributary to Tonsina river from the south. Name from Schrader, 1900.

Mosquito; creek, tributary to Fish river from the east, Seward peninsula. Prospectors' name, of obvious origin.

Mosquito; flats, on the left bank of Mosquito fork Fortymile creek, near latitude $64^{\circ}$, longitude $143^{\circ}$. So called by Lientenant Mitchell, Signal Corps, U. S. A., 1902.

Mosquito; fork, South fork Fortymile creek, near latitude $64^{\circ}$, longitude $142^{\circ}$. Prospector's' name, published by the Coast Survey in 1890.

Mosquito; fork, South fork Koyukuk river, near longitude $150^{\circ}$. Prospectors' name of obvious origin; from Schrader, 1899. 
Moss; cape, on the southern shore of Alaska peninsula, a little east of Belkofski. Presumably a local name, reported by Dall, 1880. Erroneously Mosk.

Moss; creek, 60 miles northeast of Knik arm, Cook inlet, on the west bank of Chickaloon creek, a northern tributary of Matanuska river, near latitude $62^{\circ} 10^{\prime}$, longitude $148^{\circ} 20^{\prime}$. So named by guide John $\mathbf{S}$. Bagg, of Glenn's expedition, 1898.

Moss; creek, Alaska peninsula, tributary to Mine harbor, southeastern shore Herendeen bay, just south of Coal creek, near longitude $160^{\circ} 40^{\prime}$. Descriptive name, reported by Sidney Paige, of the Geological Survey, 1905.

Moss; creek, or gulch, 8 miles northwest of Cape Nome, Seward peninsula, tributary to Nome river from the east. Prospectors' name, published in 1900 .

Moss; island, in Douglas bay, Sumner strait, Alexander archipelago. So named by Thomas, 1887 .

Moss; mountain (1,631 feet high), east of Tamgas harbor, Annette island, Alexander archipelago. So named by Nichols, 1883.

Moss; point, on the western shore of Tamgas harbor, Annette island, Alexander archipelago. Name published by the Coast Survey in 1891.

Moth; point, at entrance to Thorne arm, Revillagigedo island. So named by the Coast Survey in 1891.

Mound; hill (1,956 feet high), near the southern end of Revillagigedo island, Alexander archipelago. So named by Nichols, 1883.

Mound; point, the northwestern point of entrance to Karta bay, Prince of Wales island, Alexander archipelago. So named by Clover, 1885.

Mountain, bay; see Uniktali.

Mountain; cape, on Raspberry island, Kupreanof strait, Kodiak group. Named Gorie (mountain) by Murashef, 1839-40.

Mountain, cape; see Kayak.

Mountain; cape (500 or 600 feet high), Nagai island, Shumagin group. Named Golova (mountainous) by T'ebenkof, 1849 .

Mountain; creek, 7 miles north of Nome, Seward peninsula, tributary to Snake river from the east, near longitude $165^{\circ} 27^{\prime}$. Prospectors' name, published in 1.900.

Mountain; creek, 20 miles north of Nome, Seward peninsula, tributary to Stewart river from the south, near longitude $165^{\circ} 28^{\prime}$. Name from Barnard, 1900 .

Mountain; glacier, on the mainland, near head of Thomas bay, southeastern Alaska. So named by Thomas, 1887.

Mountain; point, on Lindenberg peninsula, Wrangell strait, Alexander archipelago. Apparently so called by Coghlan, 1884. In the Coast Pilot, 1883, this is called Cove point. Apparently identical with Waterfall (vodopada) cape of Lindenberg,. 1838, or possibly Krutoi (steep) of Lindenberg.

Mountain; point, on Revillagigedo island, near north end of Annette island, Alexander archipelago. So named by Nichols, 1883.

Monntain, river; see Liard.

Mountain; slough, in the extreme western margin of Copper River delta, $1 \frac{1}{2}$ miles west of the mouth of Eyak river, near latitude $60^{\circ} 28^{\prime}$, longitude $145^{\circ} 40^{\prime}$. Local name, reported by Moser, 1897, and Ritter, 1898.

Mountain City: mining camp, now deserted, established in 1899 on the right bank of Koyukuk river, near Red mountain, about latitude $66^{\circ} 20^{\prime}$, longitude $153^{\circ} 50^{\prime}$. 
Mountain Head; point, near Southern rapids, Peril strait, Baranof island, Alexander archipelago. So named by Coghlan, 1884.

Mount Little; island, in Yukon river, just above mouth of the Koyukuk. So named by Allen, 1885.

Mud; bay, indenting the eastern shore of Kruzof island, Kruzof sound, Alexander archipelago, near latitude $57^{\circ} 11^{\prime}$, longitude $135^{\circ} 37^{\prime}$. Descriptive name, published by the Coast Survey in 1900 .

Mud; bay, indenting the northern shore of Chichagof island, Icy strait, Alexander archipelago, near longitude $136^{\circ}$. So named by Hanus, 1880 .

Mud; bay, indenting the southern shore of Chignik bay, Alaska peninsula. Locally so known. There is an extensive mud flat at its head. Also called Doris bay.

Mud; creek, tributary to Red bay, Prince of Wales island, Alexander archipelago. So named by Helm, 1886.

Mud; creek, Seward peninsula, in Casadepaga drainage basin, tributary to Ruby creek from the south, near latitude $64^{\circ} 48^{\prime}$, longitude $164^{\circ} 17^{\prime}$. Prospector's' name, from Gerdine, 1905.

Mud; glacier, on the western bank of Stikine river, near the international boundary: Called Dirt glacier by Hunter, 1877. On late maps Mud glacier.

Muerta; island, in Port Real Marina, Bucareli bay, Prince of Wales archipelago. Named Ysla del Muerto (island of the dead) by Maurelle and Quadra, $17 \dot{75}-1779$.

Muffin; islands, in the entrance to Ernest sound, Alexander archipelago. So named by Snow, 1886.

Muganolowik; shallow stream, in Yukon delta, debouching between Scammon bay and the mouth of Black river. Eskimo name from Dall, who wrote it Muganólowik. By the Western Union exploring parties, 1865-1867, this was called Pope's river, after Frank L. Pope, of that expedition. See Melatolik.

Muir; glacier, at head of Muir inlet, Glacier bay, southeastern Alaska, near: latitude $58^{\circ} 55^{\prime}$, longitude $136^{\circ} 10^{\prime}$. Named in about 1880 , after John Muir.

Muir; inlet, at head of Glacier bay, southeastern Alaska. Name published in the Coast Pilot (1883, p. 189). Named after John Muir.

Muisofski, island; see St. Lazaria.

Mukacharni; hill or mountain (1,700 feet high), north of Grantley harbor, Seward peninsula: Name from Beechey, 1827, who wrote it Muck-achar-ne.

Mukialik; Eskimo camp, or maybe a slough, on the left bank of the Yukon, at the great bend, 23 miles below Andreafski, near latitude $62^{\circ} 05^{\prime}$, longitude $163^{\circ} 55^{\prime}$. Native name, obtained by Putuam, 1899 . .

Muklultulik; river, on the north shore of Norton bay, Norton sound, near Iongitude $162^{\circ} 15^{\prime}$. Eskimo name, reported by Gilbert, 1900 .

Mulchatna; river; tributary to the headwaters of Nushagak river; also Eskimo villages on same. Written Molchatua by Petrof, 1880. Has been often written Malchatna and Mulchutna. Here written Mulchatna to conform to the reported local pronunciation.

Muldrow; glacier, 25 miles northeast of Mount McKinley, drained by McKinley river into Kantishna river, near latitude $63^{\circ} 20^{\prime}$; longitude $150^{\circ} 30^{\prime}$. So named by Brooks, 1902, after Robert Muldrow, of the Geological Survey. 
Mule; rock (awash at high water), in entrance to Tamgas harbor, Annette island, Alexander archipelago. So named, presumably by. Nichols; 1883.

Mulgrave; hills or mountains, north of Kotzebue sound, between Noatak river and the. sea. Cook, in August, 1778, named a point in this vicinity Mulgrave, back of which were "hills of a moderate height." Beechey, coming nearer, 1826, saw that these hills were farther inland than Cook supposed, and called them the Mulgrave range.

Mulgrave; port, in Yakutat bay, southeastern Alaska, near latitude $59^{\circ} 34^{\prime}$, longitude $139^{\circ} 47^{\prime}$. Visited, sketched, and named by Dixon, 1787, " in honor of the Right Honourable-Lord Mulgrave." It was called Rurik harbor by Khromchenko, 1823, presumably after the Russian-Amẹrican Company's brig Rurili.

Mulligan; creek, tributary to Eldorado river from the east, Seward peninsula. Nime from Barnard, 1900.

Mummy; bay, indenting the southwestern shore of Knight island, Prince William sound. Locil name, reported by Grant, 1905.

Mummy; island, in Orca channel, Prince William sound, near latitude $60^{\circ} 28^{\prime}$, longitude $146^{\circ}$. Local name, reported by Ritter, 1899 .

Mumtrak; Eskimo village, at head of Goodnews bay, Bering sea. Population in 1890, 162. Name from Petrof, 1880, who spelled it Mumtrahamute. Variously given Mumtrahahamut, etc.

Mumtrelek; Eskimo village, on left bank of the lower Kuskokwim. Bethel Mission is at this place. First reported by Fetrof, 1880, as Mumtrekllogamute, and variously written Mumtrelegamut, Mumtreckhlagamute, etc. Mumtrelega-mut (smokehouse people) was so called from the fact that here a peculiar house for smoking fish was first erected.

Munday; peak (4,000 feet high) and creek, in the St. Elias region, southeastern Alaska, 17 miles east of Cape Yaktag. So named by .J. L. McPherson, deputy mineral surveyor, after Charles F. Munday, one of the first to locate petroleum lands in the Yaktag region, 1897.

Mungoark; river, tributary to Eschscholtz bay, from the east, Seward peninsula. Called Kuuk on British Admiralty chart 593. (ed. of 1882) and Mungoark on a recent map.

Munina, village; see Ninilchik.

Munook, creek; see Minook.

Munoz; point, the westernmost point of Khantaak island, Yakutat bay, southeastern Alaska. Named Muñoz by Malaspina, 1791. It is Southwest point of Tebenkof, 1849 .

Munsatli; mountains (2,000 feet high), on the kit bank of the upper Kuskokwim (East fork), near latitude $63^{\circ} 30^{\prime}$, longitucie $152^{\circ} 30^{\prime}$. Indian name, obtained by Herron, 1899 , who irrote it viun-sat-lee.

Murder; cove, at the south end of Admiralty sland, Alexander archipelago. So named by Meade, 1869 , on account of the murder here, by the natives, of a small party of traders

Murdo; islet, in Port Chester, Annette island, Alexander archipelago. So named by Nichols, 1883 .

Murphy; cove, in Graves harbor, southeastern Alaska, near latitude $58^{\circ} 15^{\prime}$, longitude $136^{\circ} 40^{\prime}$. "The southern one on the east side, just inside the entrance." So described in the Coast Pilot of 1901.

Murpinys Crack; a small indentation, on the north shore of Sannak island, $1 \frac{1}{4}$ miles east of Acherk harbor, near latitude $54^{\circ} 29^{\prime}$, longitude $162^{\circ} 47^{\prime}$. Local name, reported by Westdahl, 1901.

Bull. $299-06 \mathrm{M}-29$ 
Murray, cape; see Nunez.

Murre; point, in Kiliuda bay, Kodiak. Named Arie (a sea bird, the arrie or murre or guillemot, Pallas's murre, Uria lomvil arra) by Tebenkof, 1849.

Murre; rocks, near Yukon harbor, Big Koniuji island, Shumagin group. Named by Dall, July, 1874. There were clouds of murres in this vicinity at that time.

Musatchie Nose; see Chacon, cape.

Muse; island, in Gambier bay, Admiralty island, Alexander archipelago. So named by Mansfield, 1889 .

Mushukli, island; see Turnagain.

Muskoieika. Raymond, 1869 , shows a native village on the right bank of the Yukon, about 65 miles above Anvik, bearing this appellation. Both place and name have vanished from recent maps.

Mussel; point, in Redfish bay, Baranof island, Alexander archipelago. Named Mussle by Moser, 1897.

Mussel; point, on San Fernando island, Bucareli bay, Prince of Wales archipelago. Named Punta. Almejas (mussel point) by Maurelle and Quadra, $1775 ; 1779$.

Mute. Eskimo word for people; variously written miut, mute, and mut, and suffixed to the name of the people. Thus, Ak-mute, Pai-mute, etc.

Mutnaia; small stream, on Kenai peninsula, debouching at Anchor point, Cook inlet. Named Mutnaia (muddy) by Wosnesenski about 1840 .

Muzon; cape, the southernmost point of Dall island, Dixon entrance. It is highly probable that this is Cabo de Muñoz or Muñoz Goosens or Muñoz Gorens of Caamaño, in 1792, and that Vancouver, in copying from Caamaño, transposed two letters, making Muzon. In this form it has come into general use and is well established. Dixon, 1787, called it Cape Pitt, and about the same time it was named Irving by Douglas. Tebenkof, 1848, called it Kaigani, evidently the native name which has also been written Caiganee, Kygane, etc.

Myak; remarkable crag (471 feet high) in front of the bluff, on the north shore of St. George island, Bering sea, near longitude $169^{\circ} 43^{\prime}$. Aleut name, meaning pile of rocks, cairn, or landmark, from Duffield and Putnam, 1897.

Myer, island and stream; see Meyers.

Myers; fork, of Chicken creek, which is a tributary of Mosquito fork Fortymile creek, near latitude $64^{\circ} 06^{\prime}$, longitude $142^{\circ}$. Prospector's' name, reported by Spurr, Goodrich, and Schrader, 1896.

Myhote; river, debouching on the coast of the Gulf of Alaska. Name from the Land Office map of Alaska, 1898. This is one of many streams shown on maps as converging to the same delta, near longitude $143^{\circ}$. Kaliakh river is another of them. Probably native name. See Chiwaki.

Mynook, creek; see Minook.

My-og-arg-a-look, Eskimo village; see Maiogagaluk.

Myrtle; creek, Seward peninsula, a small tributary on west bank of Casadepaga, near latitude $64^{\circ} 50^{\prime}$, longitude $164^{\circ} 20^{\prime}$. Prospectors' name, from Gerdine, 1905.

Myrtle; creek, 25 miles north of Cape Nome, Seward peninsula, tributary to the headwaters of Flambeau river from the north, near latitude $64^{\circ} 45^{\prime}$, longitude $165^{\circ} 07^{\prime}$. Local name, from Gerdine, 1904.

Myrtle; creek, tributary from the north to Slate creek, a branch of Middle fork Koyukuk river, near latitude $67^{\circ} 15^{\prime}$, longitude $150^{\circ}$. Prospectors' name, reported by Schrader, 1899. 
Myrtle; lake, draining into the head of Niblack anchorage, Moira sound, southeastern shore Prince of Wales island, Alexander archipelago, near latitude $55^{\circ} 05^{\prime}$, longitude $132^{\circ} 07^{\prime}$. Local name, reported by Brooks, 1901 .

Mystery; creek, 7 miles northeast of Nome, Seward peninsula, on the right bank of Nome river, tributary to Helen creek, near longitude $165^{\circ} \mathbf{1 7}^{\prime}$. Local name, published in 1904.

Mystery; creek, Seward peninsula, tributary to Cripple river, from the east, near latitude $65^{\circ} 50^{\prime}$, longitude $163^{\circ} 30^{\prime}$. Prospector's' name, reported by Gerdine, 1901.

Mystery; creek, tributary to Niukluk river from the north, in the Eldorado mining district, Seward peninsula. Local name, published in 1900 .

Mystery; creek, tributary to Shovel creek from the west, Seward peninsula. Name from Barnard, 1900.

Mystic, rock; see Mastic.

$\mathrm{Na}, \mathrm{No}, \mathrm{Nu}$. An Indian word meaning river; much used in interior Alaska and added as a final syllable to the names of rivers; as Tanana, Chitina, etc.

Nabesna; glacier on the northeast slope of the Wringell mountains, at the head of Nabesna river, near latitude $62^{\circ}$, longitude $143^{\circ}$. So called by Schrader, 1902.

Nabesna; river, one of the principal tributaries of the upper Tanana. According to Allen (p. 136), "The natives of the upper Tamana cill that river Nabesna." Peters and Brooks, 1898, say that this use, mentioned by Allen, is locally obsolete, and they apply the name not to the main stream, but to a principal tributary, near longitude $142^{\circ}$.

Nachalnie, island; see Initial.

Nachalnie, point; see Entrance.

Nachgelssit; glacier, on the southern side of Klehini river, at the head of Jarvis creek, southeastern Alaskit. Native name, from the Krause brotbers, 1882, who write it Nachgelssit.

Nachk, bay ; see Flat.

Nachlezhnia, bay; see Camp Coogan.

Nachlezhnoi; island, south of Middle island, Sitka sound, Alexander archipelago. Named Nachlezhnoi (chief) by Vasilief, 1809 .

$N$ achliuagimiut, Lskimo village; see Nakhliwak.

Nackchamili, island; see Nakchamik.

Nadezhda; group of islets, in the western part of Krestof sound, Alexander archipelago. Named Nadezhda. (hope) by Vasilief, 1833, after Krusenstern's vessel.

Nadina; glacier, on the southwestern slope of Mount Drum and drained by Nadina river (below). So named by Gerdine and Mendenhall, 1902.

Nadina; river, tributary to Copper river from the left (northeast), near latitude $61^{\circ} 50^{\prime}$, Indian name written Knetena by Abercrombie in 1898, and Knetina in the first edition of this dictionary. Gerdine and Mendenhall, 1902, wrote Nadina.

Naducha; islet, on the southwestern edge of the Sandman reefs, northeast of Sannak. Called Nadoutcha by Lutke and Nadoucha by Dall. Nada is the Aleut word for west, from which word the name of this western islet is obviously derived.

Naerie; rock, at entrance to Hot Springs bay, Sitka sound, Alexander archipelago. So named by Vasilief, $180 \dot{9}$.

Nagai; island, one of the largest of the Shumagin group. Native name, from early Russian explorers. Has also been witten Nagay.

Nagai; rocks, off the western shore of Chirikof island. So named by Kashevarof about 1830 . Erroneously Naga and Nagau. 
Naghaikhlavigamute, village; see Nakolkavik.

Naginak; cove, at head of Anderson bay, Makushin bay, Unalaska. Native name from Veniaminof, 1840.

Nagnek, river; see Naknek.

Naguchchik; see Nagukchik.

Nagukchik; locality, Yukon delta, on the right bank of Apoon pass, 4 miles below old Fort Hamilton, near latitude $62^{\circ} \mathbf{5 5 ^ { \prime }}$, longitude $163^{\circ} 48^{\prime}$. Eskimo name, written Naguchchik by Faris, 1899.

Nagxamil, island; see Nakchamik.

Naha; bay, indenting the western shore of Revillagigedo island, Behm canal, Alexander archipelago, near latitude $55^{\circ} 35^{\prime}$, longitude $131^{\circ} 40^{\prime}$. Native name. Dall in the Coast Pilot $(1883$, p. 75$)$ says, "known as Naha bay."

Naha; lakes, and salmon stream, at head of Naha bay, Revillagigedo island. So known to the fisheries, and reported by Moser in 1897 and 1900.

Vatuatatilton, Indian village; see Nahochatilton.

Nahihmud; native village, in Kiluden bay, on southern coast of Kodiak. Was called Nahimood by Lisianski, 1804. Presumably a native name.

Nahochatilton; Indian village, on Yukon river, 40 miles above the Koyukuk, near longitude $156^{\circ} 45^{\prime}$. Native name reported by Collier, 1902, and may be meant for the same Indian name as Notaloten of the Eleventh Census. Written also Nahoclatilten and Nahatatilton. Louden telegraph station is located here.

Nahoclatilten, Indian village; see Nahochatilton.

Nahsayvernia, point; see North.

Nahtuk, river; see Nuluk.

Nahwazuk, lake; see Salmon.

Nakalilok; bay, indenting the southern shore of Alaska peninsula, northeast of Sutwik island. Native name, from Russian Hydrographic chart 1379 (ed. of 1.847), where it is written Nakkhalilok.

Nakat; harbor, about 3 miles northeast of Port Tongass, Dixon entrance. So named by Nichols, 1.888 .

Nakat; inlet, northeast of Dixon entrance. Local name, of Indian origin. Nichols says in the Coast Pilot (1891, p. 79), "The body of water between Cape Fox and Tongass is sometimes called Nakat Inlet, but that name really applies only to the inlet proper," whose soutbwest point of entrance is Ledge point. See also Fillmore.

Nakat; mountain (2,921 feet high), on the mainland, northeast of Dixon entrance. So named by Nichols, 1883.

Nakchamik; island, near the entrance to Chignik bay, Alaska peninsula. Native name, from the Russians. 'Variously written Nackchamik, 'Nagzamik, etc.

Naked; island, at the south end of Lynn canal, near Funter bay, Admiralty island, Alexander archipelago. Descriptive name, given by Mansfield in 1890 .

Naked; island, the largest of the Naked islands, Prince William sound. Called also Big Naked.

Naked; islands, three of them, Naked, Peak, and Storey, in the northern part of Prince William sound. Local name, from Abercrombie, 1898. Occupied since 1895 for the propagation of blue foxes.

Nakh, bay; see Flat. · .

Nakhliwak; Eskimo village, Yukon delta, on Chaniliut slough, right bank Apoon pass, $1 \frac{1}{2}$ miles from the mouth, near latitude $63^{\circ} 02^{\prime}$, longitude $163^{\circ} 25^{\prime}$. Native name, written Nachliwagimiut by Faris in 1899. 
Naknek; lake, between Becharof and Iliamna lakes, Alaska peninsula. Native name, from Lutke, 1.828. According to Vasilief, its native name is Akulogak. Has also been called Illiuk lake. Petrof, 1880, named it Walker, after Gen. Francis A. Walker, superintendent of the 'Tenth Census.

Naknek; river, draining from Naknek lake westward to Bristol bay, Bering sea, near latitude $58^{\circ} 45^{\prime}$. Native name, from Lutke, 1828. Irroneously Naknik.

Nalinek, village; see Suworof.

Nakochna; river, tributary to the Kichatna from the left, near latitude $62^{\circ}$, longitude $152^{\circ}$. Indian name, obtainẹd by Herron, 1899, who wrote it Na-koch-nu.

Nakolkavik; Eskimo village, on the left bank of the Kuskokwim, near its. mouth. Its native name, according to Nelson, 1878-79, is Naghaikhls: vigamute, and according to Spurr and Post, 1898, getting their: inform: tion from missionary Kilbuck, Nacholchavigamut, i. e., Nakolkatvik people. Petrof wrote Naghaikhlavigamite on his map and Naghikhlavigamute in his text (p. 17). Population in 1880, 193.

Nakwasina; island, one of the Siginaka-group, Sitka sound, Alexander archipelago. Named Nakwasinskoi by Vasilief, 1809.

Nakwasina; parsage, separating Halleck island from Baranof island, Alexander archipelago. It was called Nakwasinskaia gulf by Vasilief, 1809, and has also been written Noquashinski and Little Noquashinski bay. According to George Kostrometinoff this is from the Russian nakwashina (fermented).

Naluktchvak, cape; see Providence.

Namalak, crag; see Lighthouse rocks.

Nameless; cape, on the western shore of Kenai peninsula. Called Besimenny (without a name) by Wosnesenski about 1840 .

Nameless; islet, in the southern part of: the Necker group, Sitka sound, Alexander archipelago. Named Beziemiannoi (nameless, anonymous) by Vasilief, 1809.

Namtschak, rocks; see Lighthouse.

Nanana, river; see Cantwell.

Nancy Lee; creek, 15 miles north of Cape Nome, Seward peninsula, tributary 'to Osborn creek firom the east, near longitude $165^{\circ} 09^{\prime}$. Prospectors' name, published in 1.904.

Nandell; Indian villạge, on Tetling river, near Wagner lake, about 20 miles from the Tanana river. Visited by Allen, 1885 , who found a village of four houses and 86 people, presided over by the chief Nandell. Has been called Nandell's and, by error, Nandellas.

Naniwuknuk; lake. Yukon deltal, drained by Azun river, near latitude $61^{\circ}$, longitude $164^{\circ}$. Eskimo name, probably from nanvak, meaning lakc, reported by Jarvis, 1897. This is near Shokfaktolik lake or it may be the same.

Nannuk; lagoon, on the coast of St. Lawrence island, 20 miles from Gambell (Cape Chibukak). Eskimo name, reported in 1904 by Dr. E. O. Campbell, missionary on St. Lawrence island, who wrote it Nan nook.

Nanushuk; river, northern Alaska, tributary to Anakturuk river from the east,

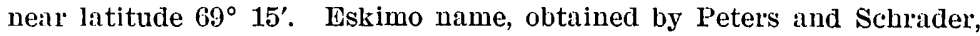
1901. 
Nanvaranak; slough, on the right bank of Yukon river, 60 miles below Andreafski, near latitude $62^{\circ} 45^{\prime}$, longitude $163^{\circ} 55^{\prime}$. New Fort Hamilton is situated on this slough. Eskimo name, so written by Faris, 1899. Has also been written Nanvaranok and Nanvarnok.

Nanvogaloklak; Eskimo village, in the Big Lake country. Visited by Nelson in January, 1879, who reported its native name to be Nanvogalokblagamute, i. e., Nan-vog-a-lok-lak people. Erroneously Nauvogalokhlagamute in text of Tenth Census. In Eleventh Census, 1890, called Nunavoknakchlugamiut. Population in 1880, 100; in 1890, 107.

Naouchlialk, village; see Kaguyak.

Naouchlagamut, village; see Nauklak.

Napai; Eskimo village, on the northern bank of the Kuskokwim, a little above Kolmakof. Spurr and Post obtained from Doctor Romig, 1898, the name Napaimut, i. e., Napai people, as the Eskimo name of this place.

Napaiskak; Eskimo village, on the left bank of the Kuskokwim, about 4 miles below Bethel. According to Nelson, 1878-79, its native name is Napaskiagamute, and according to missionary Kilbuck, 1898, it is Napaiskágamut, i. e., Napaiskak people.

Napakiak; Eskimo village, on the right bank of the Kuskokwim, about 10 miles below Bethel. Nelson, 1878, reports the native name as Napahaiagitmute, and this is copied by Petrof and the Hydrographic Office. Spurr and Post, 1898, following missionary Kilbuck, write Napachiakáchagamut, i. e., Napakiakachak people.

Napaklulik; Eskimo village, northwestern Alaska, on the. Mangoak river. southeast of Selawik lake, near latitude $66^{\circ} 20^{\prime}$, longitude $160^{\circ} 20^{\prime}$. Native name, written Nah-park-lu-lik by Stoney, 1886.

Na-park-lu-lik, Eskimo village; see Napaklulik.

Napean; point, the southwestern point of entrance to Eliza harbor, Admiralty island, Frederick sound, Alexander archipelago. Named by Vancouver, in 1794, who, in the text of his original edition of 1798 , spells it Nipean. It occurs, there four times, always spelled Napean. On his chart, on the French copy of it, and in the $8^{\circ}$ edition of 1801 it is Nepean, and this form has gained wide usage; variously corrupted to Nepen and Nepken.

Napoleon; creek, tributary from the east to South fork Fortymile creek, near latitude $64^{\circ} 05^{\prime}$. Prospector's' name, from Spurr, Goodrich, and Schrader, 1896.

Napoleon; point, in Yukon delta, on right bank of the Kwikpak pass; was so called by Raymond in 1869. Not identifiable on recent charts.

Naringolapak; slough or cut-off, Yukon delta, on the right bank of Kwikluak pass, 10 miles below the head of the delta, near latitude $62^{\circ} 38^{\prime}$, longitude $164^{\circ} 01^{\prime}$. Eskimo name, obtained by Putnam, 1899.

Naroam-anyi, lake; see-Atka.

Narosigak; Eskimo village, Yukon delta, on the left bank of Kwemeluk pass, at Nioklakowik slough, latitude $62^{\circ} 32^{\prime}$, longitude $164^{\circ} 57^{\prime}$. Native name, written Narosigagamieut, i. e., Narosigak people, by Putnam, 1899.

Narrow; cape, the northwestern point of Unga island, Shumagin group. Named Tonkie (narrow) by the Russians.

Narrow; cape, the nortbern point of entrance to Ugak bay; on eastern shore of Kodiak. Named Tonkie (narrow) by the Russians. It was named Hollings by Meares, 1788. It has been called Low, Narrow, Tonkeye, etc. 
Narrow; creek, tributary to Red bay, Prince of Wales island, Alexander archipelago. So named by Helm, 1886.

Narrow; passage, in Behm canal, separating Rudyerd island from Revillagigedo island. So named by the Const Survey in 1891.

Narrow; point, on Prince of Wales island, in Clarence strait, opposite mouth of Ernest sound, Alexander archipelago. Named Tonkie (narrow) by the Russians. Has also been written 'Tonkey.

Narrow; point, on the right bank of Chilkat river, near its mouth. Named Tonkie (narrow) by Lindenberg in 1838 . The name is obsolete.

Narrow, point; see Tonki.

Narrow; strait, between Kodiak and Spruce islands, Kodiak group. Named Uzenkoi (narrow) or Elovoi (spruce) by Murashef, 1830-40. Moșer, 1899 , writes Úsinka narrows.

Narrows; mountain (2,940 feet high), in the eastern part of Annette island, Alexander archipelago. So named by Nichols, 1883. It is near Tongass narrows, whence the name.

Narrows (The); passage, near the eastern shore of Cordova bay, Alexander archipelago, just north of Leading point, near latitude $54^{\circ} 48^{\prime}$. So named by Moser, 1897 .

Narrows (The); passage, in Orca bay; southeastern. part of Prince William sound, near latitude $60^{\circ} 37^{\prime}$, longitude $145^{\circ} 45^{\prime}$. So named by Moser, 1897.

Narrows (The); passage, connecting Alitak bay and Olga bay, southwestern coast of Kodiak. So described by Moser, 1.900.

Narrows; point, on the southern shore of Whale island, Kodiak group. Named Uekosti (narrows) by Murashef, 1839-40.

Narrows; two peaks (2,750 and 2,759 feet high), at the northern entrance to Wrangell strait, Lindenberg peninsula, Alexander archipelago. So named by Thomạs, 1887.

Nasanki, harbor; see Pavlof.

Nasikan, island; see Two Headed.

Natagehin. The Krause brothers, 1882, report Natagehin to be the native name of a small stream near Krotahini pass, southeastern Alaska.

Natat; creek, in the Copper River region, tributary to Slana river from the east. near its junction with Copper river. Indian name, obtained by Schrader, 1903.

Natazhat; mountain range, north of Mount St. Elias. Native name, reported by Hayes, 1891, as Nat-azh-at.

Natcheek, village; see Nuchek.

Nateekin; bay, indenting the southwestern shore of Unalaska bay, eastern Aleutians, near longitude $166^{\circ} 31^{\prime}$. Called Natiekinskaia by Veniaminof and known locally as Nateelin bay.

Nateekin; Aleut village, at Nateekin bay, in Unalaska bay. Sarichef shows a village here, 1792, which he calls Natieka settlement. Veniaminof, 1830, calls it Natiekinskoe, and says it consists of two buts (yourts) and 15 people.

Nathlie; mountain, east of Copper river, between Drum and Sanford mountains. So named by Abercrombie, 1898. Perhaps it should be Nathalie.

Nation; mining camp, on left bank of the Yukon, opposite and a few miles below the mouth of Nation river, near latitude $65^{\circ} 10^{\prime}$, longitude $141^{\circ}$ 40'. Locally called Nation City. Reported by Cantwell, 1900.

Nation; point, the western point of entrance to Egg harbor, Coronation island, Alexander archipelago. So named by Snow, 1886. 
Nation; river, tributary to the Yukon from the north, near the international boundary. This is the river called by its Indian name Tahkandit in the first edition of this dictionary. It is well known to the miners of that region as Nation river.

Natsina, river; see White.

Natulten, village; see Notaloten.

Naugvili, village; see Suworof.

Naukati; bay or inlet, on the western shore of Prince of Wales island, Tuxekan passage, near latitude $55^{\circ} 52^{\prime}$, Iongitude $133^{\circ} 10^{\prime}$. Indian name, from Dickins, $1908-4$, who wrote Naukatee.

Nauklak; Eskimo village, in the interior of the eastern part of Alaska peninsula, on the trail from Kamishak bay, Cook inlet, to Naknek lake, and about 15 miles east of the latter. According to Spurr and Post, who obtained their information, in 1898 , from the chief of Savonoski, its native name is Naouchlagamut, i. e., Nauklak people.

Naulchi, river; see Kwemeluk.

Naumliack, bay; see Kiavak.

Naunda, creek; see Monte Cristo.

Navil, point; see Lesmesurier.

, Navy; islet, near Port Wrangell, Alaska peninsula. Named Morskoi (sea) by Vasilief, 1832. Lutke has Isle du Large and the Coast Survey, 1869, Navy islet.

Navy; peak (3,734 feet high), near McHenry inlet, Etolin island, Alexander archipelago. So named by Snow, 1886.

Nazan; bay, indenting the eastern shore of Atka island, Andreanof group, middle Aleutians, near longitude $174^{\circ}$. Apparently so named by Tebenkof. Lutke calls it East bay.

Nazan; bay, indenting the southern shore of Little Tanaga island, Andreanof group, middle Aleutians. So named by Tebenkof, 1849.

Nazidak, island; see Two Headed cape.

Neak, creek; see Niak.

Nel-liluk, river; see Niukluk.

Near; cape, on the northwestern shore of Whale island, Kodiak group. Named Blizhnie (near) by Murashef, 1839-40.

Near; island, in St. Paul harbor, Kodiak. Named Blisnie and Bliskie (near or close) by the early Russians. Lisianski, 1804, calls it Close island. Dall (Harriman expedition, vol. 4, p. 125) apparently calls this island Pogibshi (perishing).

Near; island (600 feet high), near the sontheastern shore of Nagai island, Shumagin group. Named Blizhnie (near) by the Russians.

Near; group of islands, the westernmost of the Aleutian chain, and hence nearest, of all the Aleutians, to Asia. The early Russian explorers, accordingly, called them Blizbnie (near) islands. Langsdorf has (II, 13) Plishnie ostrowa or nearest islands. Have also been called Blijnie or Rat islands. Berg says Bering called them Deception islands, but Lutke says he finds no warrant for this in Bering's journal. Variously written Blijni, Blijnies, etc.

Near; point, on the western shore of Piper island, Fish bay, Peril strait, Alexander archipelago. So named by United States naval officers, 1880.

Nearer, point; see Blizhni.

Nechraje, rock; see Eldred.

Neck; point, on the north side of entrance to Spasskaia bay, sonth shore of Icy strait, Alexander archipelago, near longitude $135^{\circ} 19^{\prime}$. So named by Dickins, 1901. 
Necker; bay, indenting the western shore of Baranof island, Alexander archipelago. Called Port Necker by La Perouse, 1786. Called Kamenistaia (rocky or stony) by the Russians. Has been called Rocky, Stone, and Stony.

Necker; islands, near the southern entrance to Sitka sound, Baranof island, Alexander archipelago. So called in the Coast Pilot, 1883, and attributed to La Perouse, 1786. La Perouse's chart 16 shows Port Necker in this place and chart 17 Port Neker for the same place.

$\lambda^{\top} e c k e r$, isles; see Guibert.

Nedostatka; islet, in the northern part of Krestof sound, Alexander archipelago. Named Nedostatka (want) island by Vasilief, 1833.

Neechuck, river ; see Miniatulik.

Needle; peak (1,700 feet high), near the center of: Coronation island, Alexander archipelago. So named by Snow, 1886.

Needle; peak, near the head of Bay of Waterfalls, Adak island, middle Aleutians. Descriptive name, given by Gibson, 1855 .

Needle; rock, near the northwestern shore of Amaknak island, Unalaska bay, near longitude $166^{\circ} 32^{\prime}$. Descriptive name, given by Dall, 1874 .

Needles; mountain ( 7,000 feet high), on right bank of the Tanana river, near latitude $62^{\circ}$. Descriptive name, given by Peters and Brooks, 1898.

Neelcaluecha, lake; see Nikawiṇa.

Neekaweena, lake; see Nikawina.

Neenana; see Cantwell river and Nenana telegraph station.

Neets; bay, in Behm canal, indenting the northwestern shore of Revillagigedo island, Alexander archipelago. So named by the Coast Survey in 1891.

Negheling, river; see Nogheling.

Negro; cape, in the eastern part of Bucareli bay, Prince of Wales archipelago. Named Cabo Negro (black cape) by Mavrelle and Quadra, 1775-1779.

Negsue; creek, tributary to Penny river from the east, in the Nome mining region, Seward peninsula. Prospectors' name, published in 1900.

Negvelnuk, river; see Golsova.

Nehlutahalik, slough or creek; see Nelutahalik.

Nekula; gulch, 7 miles north of Nome, Seward peninsula, at the head of Anvil creek, near longitude $165^{\circ} 21^{\prime}$. Local name, published in 19003 . Written also Nikkala.

Nelakamiut, Dskimo village; see Nilak.

Nellie; gulch, in the Copper River region, on the south side of Chititu creek. Prospector's' name, reported by Mendenhall, 1903.

Nellie; gulch, 6 miles north of Nome, Seward peninsula, at the head of Mountain creek, a tributary of Snake river, near longitude $165^{\circ} 26^{\prime}$. Local name, published in 1904.

Nellie Juan, cape; see Aspid.

Nellie Juan; port, indenting the western shore of Prince William sound. Discovered and named, 1857, by Samuel Applegate, after his schooner, Nellie Juan. This spelling is from Applegate's map, where it is also written Nell Juan and sometimes Nelly Juan. 'The local name is said to be Kings bay.

Nelson; bay, an open bight, west shore Chatham strait, at junction with Frederick sound, Alexander archipelago, near latitude $56^{\circ} 57^{\prime}$, longitude $134^{\circ} 43^{\prime}$. So called and described in the Coast Pilot of 1901.

Nelson, creek; see Hammond.

Nelson; island, at the head of Hooniah sound, Peril strait, Alexander archipelago. So named by Moore, 1895, but not hitberto published. 
Nelson; island, on the western coast of Alaska, northeast of Nunivak island, Bering sea. So named by Gannett, 1880, after Edward William Nelson, who spent about five years in this region as an observer for the United States Signal Service and collector for the Smithisonian Institution.

Nelson; lagoon, on the northern shore of Alaska peninsula, a little west of Port Moller. So nạmed by Dall, 1882, after Mr. E. W. Nelson.

Nelson; point, in Behm canal, on the mainland, the southern point of entrance to Smeaton bay. So named by Vancouver, 1793, after Lord Nelson.

Neltushkin; Indian village, on Admiralty island, north shore Whitewater bay, Chatham strait, Alexander archipelago, near latitude $57^{\circ} 15^{\prime}$, longitude $134^{\circ} 35^{\prime}$. Native name, reported by Moore, 1895.

Nelupali, cape; see Kelurnoi.

Nelutahalik; slough or creek, Yukon delta, on the right bank of Apoon pass, 3 miles from its mouth, near latitude $63^{\circ} 03^{\prime}$, longitude $163^{\circ} 28^{\prime}$. Eskimo name, obtained by Faris, 1899 , and written by him Nehlutahalik.

Nemeth, creek; see Nemod.

Nemod; creek, tributary to South fork Koyukuk river from the south, near longitude $150^{\circ} 15^{\prime}$. Prospectors' name, printed Nemetin by the Coast Survey, 1899, and written Nemod by Peter's and Schrader, 1901.

Nenana, river; see Cantwell.

Nenana; telegraph station, on the Tanana river, opposite the mouth of Cantwell river, the Indian name of which is Nenana. Written also Neenana. So named by the Signal Corps, U. S. A., in 1903 . This station is at or near the Indian village Tortella.

Nenevok; lake, between the headwaters of Togiak and Kanektok rivers, western Alaska. Native name, from .Spurr and Post, of the Geological Survey, who camped on its shore September 10, 1898. They give the name as Nenevókuk adding " Nenevok=lake with descriptive ending."

Neniltschils, cape; see Ninilchik.

Nepean, point; see Napean.

Nepovorotni; group of rocks, south of Japonski island, Sitka sound, Alexander archipelago. Named Nepovorotnoi (not turning) by Vasilief, 1809. Entering Sitka harbor by Middle channel, these rocks, on the port hand, are not to be turned around. The course is to be kept for about a mile farther, when one reaches Povorotnoi (turning) island, around which one turns to the anchorage. Has also been written Nepoverotni.

Neprop, island; see Impassable.

Nepropusknoi, island; see Impassable.

Nerelna; creek, tributary to Chitina liver from the south. Native name, from a manuscript map made by prospectors, 1900.

Nerpichi; islets, south of Middle island, Sitka sound, Alexander archipelago. Named Nerpichi (seal) by Vasilief, 1809.

Nerpichie, bay, etc. ; see Seal.

Nerpitchy, islet; see Ikiginak.

Nesbitt; point, the southermmost point of Zarembo island, Alexander archipelago. So named by Vancouver, 1793. Has also been written Nesbit, this form being found in the $8^{\circ}$ edition of Vancouver (vol. 4, p. 245).

Nesbitt; reef, off Point Nesbitt, Clarence strait, Alexander archipelago. So named by -Snow, 1886.

Nesbonglok; Eskimo village, 22 miles northwest of Bethel, in the Big Lake. country. Native name written Nesboangloakmut by Dr. C. O. Lind, in

- Reindeer Report, 1904, p. 72.

Netne; lake, near Tyonek, at head of Cook inlet. Name published by the Coast Survey in 1898. 
Neukluk, river; see Niukluk.

Veumann, bay and point; see Moffet.

Neumann; island, the easternmost of the Kudiakof islands, Izembek bay, north shore Alaska peninsula, near longitude $162^{\circ} 35^{\prime}$. So named by the Fish Commission, 1888, after Mr. Rudolph Neumann, of the Alaska Commercial Company. .

Neva; bay, 3 miles north of Cape Edgecumbe, on the western const of Kruzof island, Alexander archipelago, near latitude $57^{\circ} 03^{\prime}$. So named by officers of the Russian-American Company about 1849 .

Neva; small creek, Seward peninsula, tributary to Kougarok river from the east, near latitude $65^{\circ} 30^{\prime}$, longitude $164^{\circ} 40^{\prime}$. Prospector's' name, reported by Gerdine, 1901.

Neva; island, east of the Parker group, Sitka sound, Alexander archipeligo. So named by Vasilief in 1809 . Has also been called Nevi. Named after the ship Neva.

Nevia; point, at junction of Nakwasina passage and Neva strait, on Baranof island, Alexander archipelago, near latitude $57^{\circ} 14^{\prime}$, longitude $135^{\circ} 33^{\prime}$. Apparently so named by Dall in the Coast Pilot, 1883 .

Neva; strait, separating Baranof island from Partofshikof island, Alexander archipelago. Named by Lisianski, 1804, after his ressel; called Olga strait by Vasilief in 1809. It then included what has been termed Olga strait. The present Neva channel is the Olga strait of the Russian chart of 1809; but not of Tebenkof.

Nevada; creek, in southern part of Douglas island, Alexander archipelago, tributary to Gastineau channel. Local name, reported by Peters, 1.902.

Neva Point; reef, in Krruzof sound, Alexander archipelago, extending 200 yards south-southeast from Neva point (above). So described in the Const Pilot, 1901.

Nevski; group of islets, south of Japonski island, Sitka sound, Alexander archipelago. Presumably named by the Russians, 180:, after the war ship Neva, which was at Sitka in 1804.

New, harbor; see Baralof.

Nenó Archangel, town; see Sitka.

Neu Balaam; see Uzinki.

Nenberry, river; see Teslin.

Teu Bogoslof. island; see Grewingk.

New Bonanza; c̀reek, 16 miles northwest of Cape Nome, Seward peninsula, tributary to Bonita creek, at the head of Osborn creek, near longitude $165^{\circ} 12^{\prime}$. Local name, published in 1904.

New-chill-o-ukat; point formed by the confluence of Yukon and Tanana rivers, near latitude $65^{\circ} 15^{\prime}$, longitude $152^{\circ}$. Indian name, reported by Herron, 1899.

Venchulili. Allen, 1885, shows a river tributary to the Yukon from the north, near longitude $153^{\circ}$, which he calls Newchuklikakat, i. e., Newchukli mouth. Late maps have in this vicinity two streams, called Birch creek and Island creek. The latter seems to be the Newcbukli of Allen.

New Eddystone; islands, in Behm canal, near entrance to Rudyerd bay, Alexander archipelago. Apparently so named by the British Admiralty about 1865 .

New Eddystone; point, in Behm canal, the south point of entrance to Rudyerd bay, Alexander archipelago. So named on the Russian charts. The point is a short distance from New Eddystone rock. On a late Coast Survey chart the point is called Louise. 
New Eddystone; rock, in Behm canal, between Smeaton and Rudyerd bays, Alexander archipelago. So named by Vancouver, 1793, from its resemblance to the Light-House rock off Plymouth, England.

New Eldorado; creek, 15 miles northeast of Nome, Seward peninsula, tributary from the north to Osborn creek, aflluent to Nome river, near latitude $64^{\circ} 40^{\prime}$, longitude $165^{\circ} 09^{\prime}$. Prospectors' náme, from Barnard, 1900 .

Newell; sunken rock, in Port Chester, Annette island, Alexander archipelago. So named in the Coast Pilot (1891, p. 93).

Newenham; cape, on the mainland, the northern point of entrance to Bristol bay, Bering sea, near latitude $58^{\circ} 40^{\prime}$, longitude $162^{\circ}$. So named by Cook, July 16, 1778. The natives call it Black, on account of its color, and Tebenkof has Newenham followed by chernoi (black) in parenthensis.

New Fort Hamilton; supply depot of the North American Transportation and Trading Company, on the right bank of Kwikpak pass, at the mouth of Nanvaranak slough, Yukon delta, 20 miles above (Old) Fort Hamilton, and 15 miles below the head of Yukon delta, near latitude $62^{\circ} 44^{\prime}$, longitude $163^{\circ} 55^{\prime}$.

Newicargut, island; see Nowi.

New Morzhovi, village; see Morzhovoi.

New Russia, colony; see Glory of Russia.

Newton; creek, Seward peninsula, tributary from the north to American river, near longitude $165^{\circ} 45^{\prime}$. Local name, reported by Gerdine, 1901.

Newton; glacier and mountain (13,774 feet high), near Mount St. Elias, southeastern Alaska. So named by Russell, 1890, after Henry Newton, author of a report on the geology of the Black Hills of Dakota.

Newton; gulch, $3 \frac{1}{2}$ miles northeast of Nome, Seward peninsula, on the south slope of Newton peak, draining into Dry creek, near longitude $165^{\circ} 19^{\prime}$. Name from Barnard, 1900.

Newton; peak (1,144 feet high), 5 miles northeast of Nome, Seward peninsula, near latitude $64^{\circ} 33^{\prime}$, longitude $165^{\circ} 18^{\prime}$. Local name published in 1904 . Called also Newton rock and Dry Creek mountain.

Newton, rock; see Newton peak.

Newton Gulch No. 2; see Left fork.

Newyear; gulch, 7 miles north of Nome, Seward peninsula, on the north bank of Anvil creek, near its source, about longitude $165^{\circ} 22^{\prime}$. Local name, published in 1904. Written also New Years.

New York; creek, north side of Tanana river, flowing west from near the head of Minook creek, near latitude $65^{\circ}$, longitude $150^{\circ} 10^{\prime}$. Prospectors' name, reported by Prindle, 1904.

Niak; small creek and native camping place, on the Arctic coast, 5 or 6 miles south of Cape Lisburne, near latitude $68^{\circ} 45^{\prime}$. Eskimo name, reported by Collier, 1904. Written also Neak.

Niblack; anchorage, in Moira sound, Prince of Wales island, Alexander archipelago, near latitude $55^{\circ} 03^{\prime}$, longitude $132^{\circ} 05^{\prime}$. So named by Clover, 1885, after Ensign Albert Parker Niblack, U. S. N.,' a member of his party. Erroneously Niblick on British Admiralty chart 2431.

Niblack; islands, in Ernest sound, Alexander archipelago. So named by Snow, 1886, after Ensign A. P. Niblack, U. S. N., a member of his party.

Niblack; point, on Cleveland peninsula, in Clarence strait, Alexander archipelago. So named by Clover, 1885 , after Ensign A. P. Niblack, U. S. N., a member of his party. Erroneously Niblick point. 
Niblack; post-office (established in 1901.) and mining camp, on Niblack anchorage, Prince of Wales island, Alexander archipelago.

Nichawak; mountain, a few miles northeast of Controller bay and river tributary to Bering river near its mouth. Indian name, reported by Martin, 1903. Written also Nitchawak and Nitchavak.

Nicholas, settlement; see Korovinski.

Nichols; bay, indenting the southern end of Prince of Wales island, Dixon entrance. So named by the Coast Survey, 1880, after Commander Henry Ezra Nichols, U. S. N.

Nichols; group of islands, in Tlevak strait, opposite Breezy bay, Alexander archipelago. So named by Dall, 1882, after Commander H. E. Nichols, U. S. N., who reconnoitered this region in 1881 . Near them are "The Sentinels" or Sentinel islands. Coast Survey chart 713 , published in 1883 , calls the whole group Sentinel islands.

Nichols; hills (280 feet high), at mouth of Nushagak river. So named by the Fish Commission, 1890, presumably after Commander H. E. Nichols, U. S. N. Erroneously Nicholls. Locally known as The Knolls.

Nichols; mountain, near Mount St. Elias. So named by the New York 'Times expedition, 1886, after Commander H. E. Nichols, U. S. N.

Nichols; passage, between Annette and Gravina islands, Gravina group, Alexander archipelago. Called Nichols pass in the Coast Pilot (1883, p. 79), after Commander H. E. Nichols, U. S. N.

Nichols Bay; cannery (now burned and abandoned), in Nichols bay, at the southern end of Prince of Wales island, Alexander archipelago. So called in the Eleventh Census, 1890.

Nicholson; rocks, north of Makhnati island, Sitka sound, Alexander archipelago. So named by United States naval officers, 1880.

Nickle; creek, Seward peninsula, tributary from the south to North creek, an affluent of American river, near longitude $165^{\circ} 58^{\prime}$. Prospectors' name, so written by Gerdine, 1901.

Niegieklik, river; see Clear.

Niekta, cape; see Prince of Wales.

Nigaluk; Eskimo village, near the mouth of Colville river, Arctic coast. Native name, published as early as 1867 , and probably earlier.

Niga To, river; see Yukon.

Nigelius; point, on the western shore of Carroll inlet, Revillagigedo island, Alexander archipelago, near latitude $55^{\circ} 34^{\prime}$, longitude $131^{\circ} 21^{\prime}$. Local navigators' name, maybe of Indian origin, reported by $\mathrm{H}$. C. Fassett, Bureau of Fisheries, 1904.

Nigeruk; creek, northwestern Alaska, tributary to Kobuk river from the south, near longitude $159^{\circ} 30^{\prime}$. Eskimo name, obtained by Mendenhall, 1901.

Nights Lodging; cape, on the southern shore of Afognak island, Kodiak group. Named Nochlega (night's lodging) by Murashef, 1839-40.

$N i k$, river; see Kenai.

Nikawina; lake, on Chulitna river, about 30 miles west of Lake Clark, near latitude $60^{\circ} 30^{\prime}$, longitude $155^{\circ} 30^{\prime}$. Native name reported by Osgood, 1902, who wrote it Neekaweena. Written also Neekahueena.

Nikhlkak, village; see Kijik.

Nikkala, gulch; see Nekula.

Nikolai; bay and creek, on the south shore of Tustumena lake, Kenai peninsula, near latitude $60^{\circ} 05^{\prime}$, longitude $150^{\circ} 45^{\prime}$. Local name, from Moffit, 1904 . 
Nikolai; creek, tributary to McCarthy creek from the east. So called by the prospectors, after the Indian chief, Nikolai.

Nikolai; house, on Nizina river, south bank, near the mouth of the Chitistone. Name of an Indian chief, reported by Hayes, 1891, who says "Nicolai, or Scolai, as the Yukon Indians call him."

Nikolai, islands; see Green.

Nikolaief; anchorage and small village, near Belkofski, Alaska peninsula. Called Nikolaievsky by Petrof, 1880, and Nicoloffsky by the Fish Commission. Presumably named by the Russians after T'sar Nikolas.

Nikolas, rock or shoal; see Cozian.

Nikolsli, cape; see Tanak.

Nikolski; native village, on the northern shore of Umnak, opposite Driftwood bay. So called by the Russians as early as 1830 . Veniaminof speaks of it as Riecheshnoe (river), now called Nikolski. Population in 1834, 83 ; in 1880,127 ; in 1890 , about 100 . Lutke writes it Retchechnoi and Petrof, Nikolsky.

Nikolskoi, village; see Korovinski.

Nikonda; creek, tributary at the headwaters of the Nabesna river on the east. Native name, reported by Witherspoon, 1902.

Nilak; Eskimo village, Yukon delta, on the left bank of Kwikluak pass, near latitude $62^{\circ} 35^{\prime}$, longitude $164^{\circ} 47^{\prime}$. Native name, written Nelakimiut by Putnam, 1899 .

Nil Desperandum; gulch, 6 miles northeast of Nome, Seward peninsula, on the north bank of Lost creek a tributary of Nome river from the west, near longitude $165^{\circ} 14^{\prime}$. Prospectors' name, published in 1903.

Nillioka, river; see Tolovana.

Nimiuk; point, on the west side of Hotham inlet, opposite the delta of Kobuk river, near latitude $66^{\circ} 45^{\prime}$, longitude $162^{\circ}$. It is almost directly east and on the opposite side of the peninsula from Cape Blossom. Eskimo name, written - Nimyuk by Stoney, 1884, who says it signifies the cottonwood tree. Ninook or Ninvok is cottonwood, according to John W. Kefly's vocabulary.

Nimiuk; Lskimo village of 2 huts, northwestern Alaska, on Kutoark river, near latitude $67^{\circ} 45^{\prime}$, longitude $154^{\circ} \cdot 15^{\prime}$. Visited by Stoney, 1886, who wrote its name Nimyuk. It is the Eskimo name of the cottonwood tree.

Nimiuk; Eskimo village, northwestern Alaska, on the upper Noatak river, near Riley pass, about latitude $67^{\circ} 50^{\prime}$, longitude $155^{\circ} 50^{\prime}$. Written Nimyuk by Stoney, 1885, who says it signifies cottonwood, and that the village had 30 inhabitants.

Nimyık; see Nimiuk.

Nin; ridge, on the left bank of Kichatna river, an eastern tributary of the Yentna, near longitude $152^{\circ}$. Indian name, obtained by Herron, 1899.

Ninagiak; island, in Hallo bay, Shelikof strait. Native name, from Tebenkof, 1849.

Ninilchik; cape and river, on the eastern shore of Cook inlet. So called by 'Tebenkof, 1849. Wosnesenski, about 1840 , calls the cape Neniltschik or Sunit and the river Chnik-Chnak.

Ninilchik; rock or rocks, on the eastern shore of Cook inlet, between Kasilof and Ninilchik river mouths. Native name, from Tebenkof, 1849.

Ninilchik; village of 81 people (1890), on eastern shore of Cook inlet, south of the Kasilof river mouth. Late maps show a fishery bere. A small Russian settlement was made here early in the century. Petrof (Tenth Census, VIII, p. 27) says: "A number of 'colonial citizens,' or superannuated employés of the old Russian Company were ordered to settle 
Ninilchik-Continued.

some fifty or sixty years ago (1830 or 1820) at Ninilchik, and their descendents live there still." On Wosnesenski's map in Grewingk, about 1840, the place is called Munina and the near-by cape Neniltschik or Sunit.

Ninuan-I'ugat, lake; see Becharof.

Ninuluk;- creek, northern Alaska, tributary to Colville river from the south, near longitude $153^{\circ}$. Eskimo name, obtained by Teters and Schrader, 1901.

Nioklakowik; slough, Yukon delta, opening into the mouth of Kwemeluk pass on the south bank, neir latitude $62^{\circ} 32^{\prime}$, longitude $164^{\circ} 57^{\prime}$. Native name, obtained by Putnam, 1899.

Nipple; mountain, in California ridge, Gravina island, Alexander archipelago. So named by Nichols, 1883.

Nipple, mountain ; see Dixon.

Nipples (The); two mountains (2,450 and 2,900 feet high), near Shakan bay, on Kosciusko island, Alexander archipelago, near latitude $56^{\circ} 07^{\prime}$, longitude $133^{\circ} 27^{\prime}$. Called Shakan nipples in the Coast Pilot of 1883 (p. 101). Usually called The Nipples.

Niprohodni, bay; see No Thorofare.

Nisling; river, tributary to the White river from the east, near longitude $140^{\circ}$. Native name, reported by Hayes in 1891.

Nismeni; cove, at north end of Baranof' island, Feril strait, Alexander archipelago. So named by Moore, 1895.

Nismeni; lake, on the border of Malaspina glacier. Tebenkof shows such a lake just behind Point Riou (Nismeni of Tebenkof), which he calls Nizmennie (low).

Nismeni; point, the northernmost point of Baranof island, Peril strait, Alexander archipelago. Named Nismeni (low or low lying) by Vasilief, 1833. Has also been written Nismenna and Nizmennie.

Nitak; Indian village, on Knik arm of Cook inlet. Native name, reported by Petrof, 1880, as Nitakh.

Nitchawak, mountain and river; see Nichawak.

Nitzutalina; river, 50 miles north of Mount McKinley, outlet of Lake Minchumina and tributary to the Kantishna river from the west, near latitude $64^{\circ}$, longitude $151^{\circ}$. Indian name, written Nitz-u-tal-ee-na by Herron, 1899.

Niukluk; river, in Seward peninsula; tributary to Golofnin sound. An Eskimo name, now used locally and variously written Nea-kluk, Neukluk, Neukeluk, etc. The Western Union Telegraph Expedition map of 1867 calls it Icatbluik. In 1869 it was called Fish river, apparently by Dall, and has since borne this name on most maps till quite recently. The Russians, as early as 1852, called it Ikiut-pak (Ikiut-big) or Big Ikiut of the Eskimos. See also Eaton.

Niunak, island; see Chernobour.

Nixon; shoal, Peril strait, Alexander archipelago, near latitude $57^{\circ} 28^{\prime}$, longitude $135^{\circ} 32^{\prime}$, "a flat mostly bare at low water, which projects 200 yards from the mouth of a stream on the northeast side thiree-fourths mile north of Opasni islands." So described in the Coast Pilot of 1901.

Nizhni, lake; see Lower.

Nizina; glacier and river, tributary to the Chitina. Native name, reported 1891, by Hayes. who spells it Nizzenab, i. e., Nizi river.

Nizina; post-office (established in May, 1905), in the Nizina River valley, eastern Alaska. 
Nizkoi, island; see Crooked.

Nizmennia, point; see Shoals.

$\mathrm{N} i z m e n n o i$, cape, island, etc.; see Low.

Nizmennoi, point; see Riou.

Noalen, river; see Nogheling.

Noatak; river, in northwestern Alaska, tributary to Hotham inlet. Called Inland river by Beechey. Sometimes called Noatok, Noatuk, Nunatok, and Notoark. The prevailing modern usage is Noatak, as here given.

Noatak; Eskimo village, on the lower part of the Noatak river, northwestern Alaska. Called Noatagamutes, i. e., Noatak peoples. Petrof, 1880, shows two villages and labels them Noatagamutes; Stoney calls one of these Shu-quck.

Nob; mountain, near George inlet, Revillagigedo island, Alexander archipelago. So named by Nichols, 1883.

Nobhill; creek, Seward peninsula, in Solomon River drainage basin, tributary on south bank of Kasson creek, near latitude $64^{\circ} 42^{\prime}$, longitude $164^{\circ}$ 23'. Prospectors' name, Nob Hill, from a local map, 1904.

Nocadero, strait; see Trocadero.

Nochlega, cape; see Night's Lodging.

Nocotocargut, creek; see Beaver and Birch.

Nogamut; Eskimo village, on the right bank of the Chulitua river, 139 miles above its junction with the Kuskokwim, near longitude $157^{\circ}$. Native name written Noga-mute on a manuscript map made by W. R. Bùckman, a prospector, who wintered 20 miles above in 1902-3.

Nogheling; river, Alaska peninsula, ' 25 or 30 miles long, draining Lake Clark into Iliamna lake, near latitude $60^{\circ}$, longitude $155^{\circ}$. Native name written Noghelin by Schanz in 1890, and Nogheling on the census map, 1893. Written also Negheling and said to be pronounced, by the whites, Noấlen.

Nohoolchintna. Allen, 1885, gives this name to what. is now called South fork Koyukuk river and to a native village on the right bank about 3 miles above its mouth. See South fork Koyukuk.

Nohtalohton, village; see Notaloten.

Noisak, cape; see Mordvinof.

Noisy; islands, near the northwestern shore of Kodiak. Called Sodomniia (noisy) by Tebenkof, 1849. A cape near it was called Noisy cape by the Coast Survey in 1867. Has also, on one chart, been called Zotschomnia.

Nöitoc, river; see Noatak.

Nokogamiut; Eskimo village, Yukon delta, at the mouth of Kwikpak pass, near latitude $63^{\circ} 02^{\prime}$, longitude $164^{\circ} 32^{\prime}$. Eskimo name, obtained by Faris, 1899.

Nokol-ot-nah, river; see Nulato.

Nokrot; Eskimo village, 30 miles southwest of St. Michael, near Cape Romanof, on south shore of Norton sound, near latitude $63^{\circ} 10^{\prime}$. Native name, obtained by the Coast Survey, 1898, and published as Nokrotmiut, i. e., Nokrot people.

No Man; creek, tributary to Casadepaga river from the east, Seward peninsula. Name from Barnard, 1900.

Nome; cape, on the northern shore of Norton sound, Seward peninsula, near latitude $64^{\circ} 21^{\prime}$, longitude $165^{\circ}$. Named Tolstoi (blunt or broad) by Tebenkof, 1833. Russian Hydrographic chart 1455, published in 1852, calls it Sredni (middle), adding Tolstoi as a synonym. The name Nome first appears on British Admiralty charts, after the Franklin 
Nome-Continued.

search expeditions, and was given by Kellett, 1849. Sir William Wharton, hydrographer to the British Admiralty, writing in April, 1901, says:" The name Cape Nome, which is off the entrance to Norton bay, first appears on our charts from an original of Kelletts in 1849 . I suppose. the town gets its name from the same source, but what that is we have nothing to show." Prof. George Davidson says that this nameless cape on the original sheet bore the memorandum "? Name" which the draftsman interpreted to be $C$. Nome.

Nome; creek, in the Fairbanks region, tributary to Chatanika river from the north, near latitude $65^{\circ} 20^{\prime}$, longitude $146^{\circ} 45^{\prime}$. Prospectors' name, reported by Gerdine, 1903 .

Nome; mountains, in the Nome mining region, in southern part of Seward peninsuli. Local name, published in 1900.

Nome, peninsula; see Seward.

Nome; river, in the Nome mining region, Seward peninsula. Name published in 1900 .

Nome; town, post-office, and telegraph station, near Cape Nome, on the southern shore of Seward peuinsula. Local name. Schrader and Brooks, who visited it in October, 1899, speak of the "thriving young city of Nome, first called Anvil City, now officially, Nome." Gold was found here in June, 1898, and on October 18, 1898, the Cape Nome mining district was organized. The post-office was established in June, 1899, and the town incorporated April 9, 1901. It is the northwestern terminus of the U. S. Military Telegraph. Fopulation in 1900, 12,488.

honapeklonulk; see Old Fort Hamilton.

Noobooa, island ; see Barter.

Noocheek, village; see Nuchek.

Noocleet, cape and village; see Denbigh and Nuklit.

Nook-hook-keen, creek; see Nukhukkin.

Nook (The); cove, indenting the eastern shore of Tigalda island, Krenitzin group, eastern Aleutians. So named by the Fish Commission in 1888.

Nook (The), village; see Teller.

Nookmut, station; see Teller.

Nooluk, river; see Nuluk.

Noon; point, the easternmost point of Pleasant island, Icy strait, Alexander archipelago, near latitude $58^{\circ} 20^{\prime}$, longitude $135^{\circ} 32^{\prime}$. Name published by Dall, 1883 , in the Coast Pilot:

Noon; point, the southernmost point of Jacob island, northeast of the Shumagin group. Named Poludennie (noon) by Woronkofski, 1837.

Noonarbook, islind; see Big Diomede.

Nootowulitoy, like; see Nutuvukti.

Noowook, point; see Barrow.

Noovool, settlement; see Nuwuk.

Noquashinski, passage; see Nakwasina.

Norcross, island; see Jackson.

Nordenskiold; river, tributary to Lewes ricer from the south, near longitude $.136^{\circ}$. Named by Schwatka, in 1883, after Baron Nils Adolf Erik von Nordenskiold, the celebrated Swedish arctic explorer.

Norfolk, sound ; see Sitka.

Noriega; point, on the southern shore of San Juan Bautista island, Bucareli bay, Prince of Wales archipelago. Named Punta Noriega by Maurelle and Quadra, $1775-1779$.

Bull. $299-06 \mathrm{M}-30$ 
Norma; bay, indenting the western shore of Izembek bay, north shore Alaska peninsula, near longitude $162^{\circ} \cdot 57^{\prime}$. So named by the Fish , Commission in 1888 .

Norris; glacier, on the west side of Taku inlet, southenstern Alaska. Named in 1886, after Dr. Basil Norris, U. S. N. The native pame is Kadischle. Named Windom by the Coast Survey, 1890, in honor of the Iate Secretary of the Treasury.

Nor-talh-rok-tah, lake; see Nuturukti.

North; anchorage, on the northern shore of St. George island, Pribilof group, Bering sea. Local nime.

North; arm, Bay of Pillars, Kuiu island, Chatham strait, Alexander archipelago. Name published by the Coast Survey in 1899.

North; arm, Fooniah sound, Chichagof island, Alexander archipelago. So named by the Coast Survey in 1899 .

North; arm, Moira sound, Clarence strait, Alexander archipeligo. So named by the Coast Survey in 1894.

North; arm, Three Arm bay, Adak island, middle Aleutians. Descriptive name, given by Gibson in 1855 .

North; bay, in Dall island, opening into Tlevak strait, Alexander archipelago. So named by Nichols, 1881.

North; bay and point, on the northern shore of Stuart island, Norton sound. So named by the Coast Survey in 1898.

North; bay, on the northern shore of St. Paul island, Pribilof group, Bering sea. Name published by the Coast Survey in 1890 .

North; cape, between Necker and Whale bays, on the western shore of Baranof istand, Alexander archipelago, near latitude $56^{\circ} 40^{\prime}$. So named by the Russians.

North; cape, the northernmost point of Spruce island, Kodiak group. Named Sievernoi (north) by Murashef, 1839-40.

North; cape, the northernmost point of Atka, middle Aleutians. Named Sievernoi (north) by Tebenkof, 1849.

North; cape, the northernmost point of Kanaga isliand, middle Aleutians. So named by Gibson, 1855 .

North; cape, on the northern coast of St. Lawrence island, Bering sea. Named Sievernoi (north) by the Russians. Erroneously Siepermo.

North, cape; see Afognak.

North, cape; see Hall.

North, cape; see Stag.

North; creek, Seward peninsula, tributary from the south to Agiapuk river, near longitude $165^{\circ}$ 52'. Prospectors'. name, reported by Gerdine, 1901.

North; creek, tributary to South fork Koyukuk river from the east, near longitude $147^{\circ}$. Name published by the Coast Survey in 1899 .

North; flat, in Wrangell strait, Alexander archipelago. Called Wrangell North Flat by Meade, 1869 .

North; fork, Snake river, 20 miles north of Nome, Seward peninsula, near longitude $166^{\circ} 25^{\prime}$. So described by Barnard; 1900 .

North; fork, Fox creek, 25 miles north of Cape Nome, Seward peninsula, near longitude $165^{\circ} 03^{\prime}$. Descriptive name from Bernard, 1900.

North; fork, Hess creek, in the Rampart region. Prospectors' name, reported by Lieutenant Erickson, U. S. A., 1902.

North; fork, Preacher creek, eastern Alaska, near latitude $65^{\circ} 45^{\prime}$, longitude $146^{\circ}$. Descriptive name, given by prospectors and reported by Witherspoon, 1905. 
North; fork, Birch creek, eastern Alaska. Local name, published by the Coast Survey in 1899.

North; fork, Fortymile cleek, 25 miles west of the international boundary, near latitude $64^{\circ} 15^{\prime}$. Local designation, published by the Coast Survey in 1890. Presumably in use as early as 1.886 .

North; fork, Koyukuk river, hear longitude $151^{\circ}$. Prospectors' name, reported by Schrader, 1899. 'This is probably the river the Indians call Hokotena.

North, harbor ; see Coal.

North; hill (422 feet high), on the northern coast of St. Paul island, Pribilof group, Bering sea. Presumably a local name, published by the Coast Survey in 1875 .

North; island and rock, at the head of Orca bay and Orca inlet, Prince William sound, Gulf of Alaska, near latitude $60^{\circ} 37^{\prime}$, longitude $145^{\circ} 40^{\prime}$. So named by Moser, 1897.

North; island, at entrance to Port McArthur, Kuiu island, Alexander archipelago. So nimed by Helm, 1886.

North; island, in the southern part of Lynn canal, Alexander archipelago.' So named by Beardslee, 1880 , or possibly by Meade, 1869 .

North; island, in Whitewater bay, Admiralty island, Alexander archipelago. So named by Glass, 1881.

North, island; see Raspberry.

North; ledge, in the southern end of Lynn canal, near Funter bay, Alexander archipelago. So named by Mansfield, 1890.

North; ledge, in Wrangell strait, Alexander archipelago. So named by Meade, 1869.

North; passage, connecting Eliza harbor with Woewodski harbor, Admiralty island, Alexander archipelago. So named by Mansfield, 1889 .

North; passage, in Icy strait, on the north side of Lemesurier island, Alexander archipelago, near longitude $136^{\circ} 05^{\prime}$. Name published by the Coast Survey in 1904.

North; point, the north point of Fish Egg island, at south point of entrance to Klawak inlet, Bucareli bay, Prince of Wales archipelago, near latitude $55^{\circ} 30^{\prime}$. So named by Moser, 1897.

North; point, on Lindenberg peninsula, Wrangell strait, Alexander archipelago. So named by Dall, 1879 .

North; point, on north side of entrance to Kelp bay, just inside Point Lull, Chatham strait, Alexander archipelago, near latitude $57^{\circ} 17^{\prime}$, longitude $134^{\circ} 50^{\prime}$. Descriptive name, given by Moore, 1895.

North; point, at entrance to Mitchell bay, Kootznahoo inlet, Admiralty island, Alexander archipelago. So named by Meade, 1869.

North; point, on the northern shore of St. Faul island, Pribilof group, Bering sea. Local name, from the Russian Sievernoi (north). A late Coast Survey map has Severnoye, while Iilliott, 1874, wrote it Nabsayvernia, which he translates "on the north shore."

North; river, near Eaton, a branch (nortb branch) of Unilaklik river. So called by the missionaries and herders at Eaton.

North; rock, at northern point of entrance to lliuliuk harbor, Unalaska bay. So named by Dall, 1871.

North; sunken rock, in Dixon entrance, just north of and near West Devil rock. Name published by the Coast Survey, 1886, but appears to be now obsolete. 
North; rookery, on north shore St. George island, Bering sea, near longitude $169^{\circ}$ 34'. Local name. According to Putnam, the Aleut name is Älg:̈ininitōrōlog (place where the seals do not go up).

North, strait; see Kupreanof.

North Bronaugh; island, in Nichols passage, Alexander archipelago. So called by Nichols in the Coast Pilot (1891, p. 95).

Northeast; arm of Uganik bay, Kodiak, indenting the eastern shore of the western branch of that bay. So described by Moser, 1897.

North East, arm; see Nunatak fiord.

Northeast; bluff, on the northern shore of Attu island, western Aleutians. So named by Gibson, 1855.

Northeast; cape, the easternmost point of St. Lawrence island, Bering sea. So called by Tebenkof, 1849. It is Cape Anderson of Russian Hydrographic chart 1455 (ed. of 1852 ), thus preserving the name which, in 1778, Cook gave to St. Lawrence island. Krusenstern in his Hydrographic Memoirs named this Shishmaref (Chichmareff), after Captain Shishmaref, who surveyed the shore of the island in 1821 .

Northeast; creek, on the Arctic slope, eastern Alaska, a tributary on the right bank of Canning rivër, near latitude $69^{\circ}$, longitude $146^{\circ}$. So named by Marsh, 1903.

Northeast; harbor, between Karluk and Ugak bays, on the northern shore of Kodiak. So called by Moser, 1899.

Northeast; harbor, indenting the southwestern shore of Little Koniuji island, Shumagin group. Local name, published by Dall in 1875.

Northeast; harbor, indenting the northeast shore of Sannak island, and on the east side of Northeast point, near latitude $54^{\circ} 27^{\prime}$, longitude $162^{\circ} 35^{\prime}$. So named by Westdahl, 1901.

Northeast; point, the northernmost point of Khantaak island, Yakutat bay, southeastern Alaska. So named by Tebenkof, 1849.

Northeast; point, the northeasternmost point of Sannak island. So called by Dall, 1880.

Northeast; point, the northeasternmost point of St. Paul island, Pribilof group, Bering sea. Local name. Tikhmenief, 1862, calls it Vostochnie (east) point.

Northerly; island, in St. John harbor, Zarembo island, Alexander archipelago. So named by officers of the U. S. S. Adams, 1884.

Northern; rapids, in Peril strait, Alexander archipelago. Called Perwie porogi (first rapids) by the Russians and often spoken of as the First or Northern rapids.

Northern, strait; see Kupreanof.

North Foreland; cape, on the northwestern shore of Cook inlet. So named by Vancouver, 1794.

North Fork; telegraph station, at the crossing of the North fork Fortymile creek. So named by the Signal Corps, U. S. A., 1903.

North Green; rock, in Wrangell strait, Alexander archipelago.' So called by Nichols in the Coast Pilot (1891, p. 132).

North Head; point, the northern point of entrance to Coal harbor, Unga island, Shumagin group. So named, presumably, by the Western Union Telegraph expedition, 1865 .

North Head; the north point of Akutan island, eastern Aleutians, near longitude $165^{\circ} 56^{\prime}$. Called Sigak cape by 'Tebenkof, 1849. Called North Head by the Fish Commission, 1888, and said to be locally so known.

North Heal; see Ulakta Head. 
North Inian; pass, connecting Cross sound with Icy strait, on the north side of Inian islands, near longitude $136^{\circ} 25^{\prime}$. . So named by Pratt, 1.901.

North Marble, islet, Glacier bay; see Marble.

North Olga; lake and stream, on the north shore of Olga bay, Alitak bay, Kodiak, tributary to Cannery cove. Descriptive name, reported by Moser, 1.901.

North Passage; point, the northern point of entrance to Freshwater bay, Chichagof island, Chatham strait, Alexander archipelago. It was named North by Meade, 1869.

North Passage; rock, near Stockdale harbor, Prince William sound. So named by Vancouver, 1794 .

North Point; ledge, in Wrangell strait, Alexander archipelago. So called by Nichols in the Coast Pilot (1891, p. 131).

North Point; a mountain (5,600 feet high) enstern Alaska, 15 miles south of Seventymile creek, near latitude $64^{\circ} 50^{\prime}$, longitude $142^{\circ} 10^{\prime}$. Prospector's' name, reported by Witherspoon, 1905.

North Point Baker; see Baker:

North Quadra; mountain (2,353 feet high), on the mainland, just north of entrance to Boca de Quadra. So named by Nichols, 1883.

North Semidli, island; see Aghiyuk.

North Star; creek, 30 miles north of Nome, Seward peninsula, tributary to Windy creek from the east, near longitude $165^{\circ} 25^{\prime}$. Name from Barnard, 1900 .

Northumberland; cape, the southernmost point of Duke island, Gravina group, Alexander archipelago. Named by Vancouver, 1793, "in honor of that illustrious family."

Northumberland, island; see Duke.

. Northuest, cape, 'Tanaga island; see Sajaga.

Northwest, cape, Unimak island; see Sarichef.

Northwest; harbor, indenting the northern shore of Little Koniuji island, Shumagin group. So called by the fishermen. This may be the Agugum uda (God's bay) of the Aleuts.

Northwest; island, one of the Inian group, Cross sound, Alexander archipelngo. Apparently so named by Dall in the Coast Pilot (1883, p. 186). Has also been written North-west.

Northwest; point, the northwesternmost point of St. Paul island, Pribilof group, Bering sea. This may be the Zapadnie (west) point of: Tebenkof, 1849. Name published by the Coast Survey in 1.890 .

Northwest, point; see Chibukak.

Northwest; shoal, lying northeast of the anchorage in Port Mulgrave, Yakutat bay, southeastern Alaska. Called .Northwestern by Dall in the Coast Pilot (1883, p. 208).

Northwest Shoulder; cape, on the rrorthwestern shore of Attu island, western Aleutians. So called by the North Pacific exploring expedition, 1855 . Tebenkof, 1849, calls it Kresta (cross) cape.

Norton; bay, in the northeastern part of Norton sound, Bering sea. Name published by the Coast Survey in 1884 .

Norton; sound, in the northeastern part of Bering sea, latitude $64^{\circ}$. Discovered by Cook in September, 1778, and by him named Norton "in honour of Sir Fletcher Norton (afterwards Lord Grantley), speaker of the Fouse of Commons." Sometimes called Norton bay. The designation Norton bay is now generally applied to the northeastern arm of Norton sound.

Nor-to-rol-tee, lake; see Nutuvukti. 
Norutak; lake, near the Arctic circle, drained by Kobuk river; latitude $66^{\circ} 50^{\prime}$, longitude $154^{\circ} 30^{\prime}$. Native name, reported by Cantwell, 1885, as Noru-tak. Stoney, 1886, called it Now-get-to-ark (Gull lake). .

Nose; point, in Behm canal, on the northwestern shore of Revillagigedo island. Named by the Coast Survey in 1891 . Brow and Chin points are near by.

Nosovskoi; native village, on the western end of Unimak island, eastern Aleutians, about 6 miles northwest from Scotch Cap. So called by Lutke, 1828.

Notaloten; village (of 15 people), on north bank of the Yukon, about 20 miles above the mouth of 'the Koyukuk. A native name, reported in the Tenth Census (1880) as Natulaten, in the Eleventh Census (1890) as Notaloten, and on Coast Survey chart 3093 (ed. of 1898) as Nohtalohton.

Notch; creek, tributary to Cross creek, itself a tributary of the Chisna on the west. Name applied by Schrader in 1902, being a contraction of the Indian name Not-chit-in-da.

Notch; mountain (1,879 feet high), on the southern end of Revillagigedo island, Alexander archipelago. So named by Nichols, 1883.

Not-chit-in-da, creek; see Notch.

No Thorofare; bay, indenting the eastern shore of Sitka sound, Baranof island, Alexander archipelago. Named Niprohodni (no thorofare) by Vasilief, 1809. It is Poroshki bay of Tebenkof, which name has also been written Boroshki and Paroshki.

No Thorofare; island, in Wrangell strait, Alexander archipelago. Called No Thoroughfare by Nichols in the Coast Pilot (1891, p. 131).

No Thorofare; point, on Woewodski island, Wrangell strait, Alexander archipelago. Named No Thoroughfare by Meade, 1868. Has also been written No-thoroughfare.

Notliagepia-ta, slough; see Island.

Notmoltowoak, river; see Ambler.

Notoark, river; see Noatak.

Notokakat, river; see Dall.

Nouchagak, river, etc.; see Nushagak.

No Use; ledge, in Swanson harbor, Icy strait, near southwest entrance to Lynn canal, Alexander archipelago. So named by the Coast Survey in 1890.

Has also been written No-use.

Novarassi, colony; see Glory of Russia.

Novastoshnah, rookery; see Vostochnie.

Novie Balaam, village; see Uzinki.

Novikakat, river; see Nowi.

Nowiskay; cove and salmon stream, at head of north arm Moira sound, western shore Clarence strait, southeastern Alaska, near latitude $55^{\circ} 08^{\prime}$, longitude $132^{\circ} 10^{\prime}$. So called by the fisheries, after the Indian who claimed the stream. Written Nowisk-Kay by Moser, 1897.

Nowislay, lake; see Mineral.

Novy, islands; see Pribilof.

Nowell; point, on the western shore of Prince William sound. So named by Vancouver, 1794. Has also been printed Nowall.

Nowgettoark, lake; see Norutak.

Nowi; island, mountains, village, and river tributary to the Yukon from the south, about 100 miles below the mouth of the Tanana river, near latitude $64^{\circ} 50^{\prime}$, longitude $154^{\circ} 10^{\prime}$. Native name, first reported by the Western Union Telegraph expedition, 1867, as Newicargut, the termina- 
Nowi-Continued.

tion cargut, now written kakat, meaning mouth of a river. (See Kakat.) Petrof, in 1880 , wrote the name Noyakakat, now usually written Nowikakat or Novikakat.

Now-tow-vuck-toy, lake; see Nutuvukti.

Nowuk, Eskimo village; see Nuwuk.

Noxapaga; town or camp, on Noxapaga river, Seward peninsula, nenr latitude $65^{\circ} 30^{\prime}$, longitude $164^{\circ} 15^{\prime}$. Local name, reported by Gerdine, 1901.

Noxapaga; river, Seward peninsula, tributary to Kuzitrin river from the north, near longitude $164^{\circ}$. Eskimo name, reported by Gerdine, 1901. Brooks, 1900, obtained another Eskimo name, Kugrukruk or Kugirukuk, for this river.

Noyalialkat, island ; see Nowi.

Noyes; creek, Seward peninsula, tributary to Cottonwood creek, an affluent of Goodhope river from the north, near latitude $65^{\circ} 42^{\prime}$, longitude $163^{\circ}$ 20'. Prospectors' name, reported by Mendenball, 1901.

Noyes; island, off Bucareli bay, Prince of Wales archipelago. So named by Dall, 1879, after Mr. William M. Noyes, of the Coast Survey party employed in Alaska, 1873-1880.

Noyes; slough, a branch of Chena slough, 1 mile north of Fairbanks, near longitude $147^{\circ} 45^{\prime}$. Local name, from map of Tanana Mines Railroad, 1904.

Noyes Roadhouse; tavern or locality, on Yukon river, 30 miles below Nation. Name taken from Gerdine's map, 1903.

Nuasuknan; high bluff, being a " noted landmark visible for many miles around," on Meade river, nortbern Alaska. Native name from Ray, who passed it March 29, 1883. Ray writes it Nŭa-suk-nan.

Nubbins; mountitin, in northern part of Annette island, Alexander archipelago. So named by Nichols, 188 .

Nubble; point, the western point of entrance to Kahsitsnah bay, Kachemak bay, Cook inlet. Descriptive name, given by Dall, 1880.

Nuchek; harbor, in Port Etches, Prince William sound. Native name, from the early Russians. Chernof, 1830, calls Port Etches, as here used, Nuchek bay, and what is here called Nuchek harbor he calls Constantine harbor. Portlock, 1787, cilled this Brooks harbor.

Nuchek; village, on Nuchek harbor, Port 1Etches, Hinchinbrook island, Prince William sound. Native name, adopted by the Russians at an early day and variously spelled Natcheek, Noocheek, Nutschek, etc. The Russians built here, in or about 1793, a stockaded post, called Fort Konstantine or Konstantinovsk. On a Russian chart of 1802 it is called fort and harbor of [illegible] Konstantine and Helenil. It was visited by Vancouver in June, 1794, and was not in existence in June, 1792. Dall's Alaska (p. 318) gives the date 1798, which appears to be an error for 1793.

Nuchek, island; see Finchinbrook.

Nuchel, port; ; see Etches.

Nuchusala; mountains, northeast of Lake Minchumina, at the head of East fork Kuskokwim, near latitude $64^{\circ} 15^{\prime}$, longitude $151^{\circ}$. Indian name, obtained by Herron, 1899.

Nuck-vuck-to-trk, river; see Ambler.

Nucleet, cape and village; see Denbigh and Nuklit.

Nudre-wok, lake; see Selby. 
Nudruvukpuk; Eskimo village, northwestern Alaska, on western shore of Chandler lake, near latitude $68^{\circ} 15^{\prime}$, longitude. $153^{\circ}$. Native name, obtained by Stoney, 1886, who wrote Nu-dru-vuk-puk.

Nuestra Señora del Carmen; see Kayak.

Nugget; creek, on the mainland, southeastern Alaska, on the eastern edge of Mendenhall glacier, near latitude $58^{\circ}$ ' $25^{\prime}$. Prospector's' name, reported by Spencer and Wright, 1903.

Nugget; creek, in the Chilkat valley, tributary to Tsirku river from the north, near latitude $59^{\circ} 19^{\prime}$, longitude $136^{\circ} 10^{\prime}$. Prospector's' name, reported by Wright, 1903.

Nugget; creek, in Copper river basin, tributary to Kuskulana river from the north. So named, 1900, by Gerdine, who found a large block of native copper near it.

Nugget; creek, 35 miles north of Cape Nome, Seward peninsula, tributary to Grand Central river from the south, near longitude $165^{\circ} 10^{\prime}$. Name from Barnard, 1900 .

Nugget; creek, tributary to Oregon creek from the east, Seward peninsula. Name from Barnard, 1900.

Nugget; creek, Seward peninsula, tributary from the east to Arctic river, near latitude $65^{\circ} 51^{\prime}$. Prospectors' name, reported by Gerdine, 1901.

Nugget; creek, 13 miles northwest of Fairbanks, tributary on the south bank of Goldstream creek, near longitude $148^{\circ}$ : 'Prospectors' name, from a local map; 1905.

Nugget; creek, in the Fairbanks region, tributary to Little Chena river from the north, near latitude $64^{\circ} 55^{\prime}$, longitude $147^{\circ} 20^{\prime}$. Prospectors' name, reported by Gerdine, 1903.

Nugget; creek, tributary to Middle fork Koyukuk river, near latitude $67^{\circ} 30^{\prime}$, longitude 150 . . Prospectors' name, reported by Peters and Schrader, 1901.

Nugget; creek, eastern Alaska, on south bank of Seventymile creek, near latitude $65^{\circ}$, longitude $142^{\circ} 20^{\prime}$. . Prospectors' name, reported by witherspoon, 1905.

Nugget; gulch, southeastern Alaska, on the mainland, 2 miles. east of Juneau and on the south bank of Gold creek. Local name, reported by Spencer and Wright, 1903.

Nugget; gulch, in the Copper River region, at the headwaters of Chititu creek. Prospectors' name, reported by Mendenhall, 1903.

Nugget; gulch, 15 miles northwest of Nome, Seward peninsula, on the left bank of New Eldorado creek, tributary to Nome river, through Osborn creek, near longitude $165^{\circ} 08^{\prime}$. Miners' name, from Gerdine, 1904.

Nugget; gulch, in the Fairbanks region, on the right bank of Pedro creek, near latitude $65^{\circ}$, longitude $147^{\circ} 30^{\prime}$. Prospectors' name, reported by rrindle, 1903.

Nugget; gulch, on the left bank of Fortymile creek, near Bonanza bar, about latitude $64^{\circ} 15^{\prime}$, longitude $141^{\circ} 12^{\prime}$. Prospectors' name, obtained by Spurr, Goodrich, and Schrader, 1896.

Nugget; gulch, in Eagle City mining district, near headwaters of American creek. Miner's name, obtained by Barnard, 1898.

Nugnugaluktuk; river, Seward peninsula, tributary from the west to Goodhope bay, Kotzebue sound. Eskimo name, obtained by Witherspoon, 1903.

Nugukachuk; river, Yukon delta, tributary to Azun river from the left, near latitude $61^{\circ}$, longitude $164^{\circ}$. Eskimo name, reported by Jarvis, 1897. 
Nuhkahllanny, mountain; see Gold.

Nuh-luk, river; see Nuluk.

Nuka; bay, indenting the southern shore of Kenai peninsula, Gulf of Alaska. Apparently a native name. Publisbed by the Russians, 1847, and perhaps earlier:

Nukchulahchakak; creek, tributary to the Yukon from the north, a little bolow Nulato. Native name, published by the Coast Survey in 1898.

Nukhukkin; creek, said to be the outlet of a system of three lakes, debouching at the head of an indentation on the southenstern coast of Alaska, about 4 miles nortli of Cape Spencer; near longitude $136^{\circ} 45^{\prime}$. Indian name, reported by Moser, 1901, and written by him Nook-Look-keen.

Nu-lilac-i-yat, village; see Nuklukayet.

Nuklit, cape; see Denbigb.

Nuklit; Eskimo village, on the enstern shore of Norton sound, immediately behind Cape Denbigh. Name from Tebenkof, 1849. It is the Eskimo name of Cape Denbigh. Written also Nucleet and Noocleet.

Nukluk; creek, tributary to Kanektok river from the south, about 30 miles east of Kuskokwim bay. Native name, Núk-luk, obtained by. Spurr and Post, 1898.

N $u k l u k$ kayet, station; see Walker.

Nuklukayet; village, on the north bank of Yukon river, just below the mouth of the Tanana. Many maps place it on north bank at mouth of the Tozi. The maps are confused and contradictory as to its site. Perhaps it has occupied two sites. Cantwell says that the Tanana station of the Northern Commercial Company about midway between Fort Gibbon and St. James Mission is on the site of this old village. Population in 1880,$29 ;$ in 1890,120 . Native name, variously spelled. Dall spells it Nuklukahyêt; Petrof, Nuklukaiet. Also written Nuklakyet, Nuklukyet, Nu-klac-i-yat, etc. See also Tuklukyet.

Nuklunek; mountain, at headwaters of Kanektok river, western Alaska. Native name, obtained by Spurr and Post, of the Geological Survey, who passed near it September 7, 1898. Pronounced Nu-klú-nek.

Nukshak; cape, forming the southwestern point of entrance to Hallo bay, on north shore of Shelikof strait. Native name, from the Russians, which has been printed Nuchtschak and Nukhshak.

Nukuliak, cape, St. Lawrence. Island; see Kukuliak.

Nulato; river, tributary to the Yukon from the north, at Nulato. Tikhmenief., 1861, calls it Nulata. It has been written Nokol-ot-na. The natives, according to Cantwell, call it Klat-kahatna (stop a bit river).

Nulato; trading post, village, post-office (established in 1901), telegraph station, and steamboat landing on the right bank of Yukon river, about 100 miles from Norton sound and 550 miles by river from the ocean, near latitude $64^{\circ} 45^{\prime}$, longitude $158^{\circ}$. Population in 1900,281 . Founded by the Russian, Malakof, who built a blockhouse and stockade near here in 1838. Shortly after, in his absence, this was burned by the Indians. It was rebuilt in 1842 by Lieutenant Zagoskin of the Russian navy. He was shortly afterwards succeeded by one Vasili Derzhavin, whose many acts of cruelty led to the massacre of the entire garrison by the Koyukuk Indians in 1851 . In later years the post was moved 2 miles farthel upstream to its present site. Nulato is, and always has been, the great trading center for the natives of the Koyukuk valley. The Roman Catholic mission of St. Peter Claver is located at Nulato. 
Nuleargowik; river, northwestern Alaska; tributary to Selawik river from the east, near the Arctic Circle and longitude $160^{\circ}$. Eskimo name, meaning deer-mating place or deer-mating time, from nulea (wife). Reported by Stoney in 1886 . Erroneously Nuteargowik.

Nuloktolok; Eskimo village, in the sonthern part of Nelson island, Bering sea, visited by Nelson, December, 1878, and its name reported by him as Nuloktolgamute. Petrof writes it Nulokhtologamute, i. e., Nuloktolok people.

Nuluk; river, Seward peninsula, debouching in a lagoon on the Arctic coast, near latitude $65^{\circ} 55^{\prime}$. Eskimo name, written Nooluk by Gerdine, 1901.

Nuluk; river, northwestern Alaskil, tributary to the upper Alatna river rrom the northeast, near latitude $67^{\circ} 30^{\prime}$, longitude $154^{\circ}$. Eskimo name. Called Nub-luk R. (Owl R.) on Stoney's map, 1886. Written also Nahtuk.

Nünachăra ğămut; Eskimo village in the Big Lake country, northwest of Bethel. Reported by Dr. C. O. Lind, Reindeer Report, Bureau of Education, 1904, p. 69. May be the same as Nunochok.

Nunachik; pass or slough, Yukon delta, cpening on the right bank of rittle Apoon pass and connecting it with Apoon pass at old Fort Hamilton, near latitude $62^{\circ} 53^{\prime}$, longitude $163^{\circ} 55^{\prime}$. Eskimo name obtained by Faris, 1899.

Nunaikak; Eskimo village, on the right bank of the Yukon, opposite the mouth of Shageluk slough. Name from Raymond, 1869, who wrote it Nunaikagamute. May be identical with Khaigamute, or perhaps Ookagamute of Petrof, 1880. Both name and place have vanished from recent maps.

Nunaktak; Eskimo village, on the right bank of the Yukon, about 30 miles above Anvik. Native name, from Nelson, 1878-79, who wrote it Nunakhtagamute, i. e., Nunaktak people.

Nunamekrok; Eskimo village, Yukon delta, at the mouth of Kwemeluk pass, on the left bank, near: latitude $62^{\circ} 32^{\prime}$, longitude $164^{\circ} 50^{\prime}$. Native name. writen Nunamekrokamiut by Putnam, 1899.

Nunamiut; native village, on the shore of Three Saints harbor, Kodiak. Elroneously Ziatitz. See Three Saints harbor.

Nunamiut, harbor; see 'Three Saints.

Nunapikloak; creek, near the foot of the mountains east of Pastolik bay, and north of Pastolik river, near latitude $63^{\circ}$. Name reported by Dr. C. 0 . Lind, of the Bureau of Education, in Reindeer Report for 1.904, p. 58, who gives its meaning "plenty crooked." Father Barnum, however, gives the word Nunapik, literally nuna (land) pik (real), real land, i. e., solid land in distinction from swamp or.marsh.

Nunapililurok, village; see Fort Hamilton (Old).

Nunapithlugak, village; see Fort Hamilton (Old).

Nunaria, settlement; see Sedaru.

Nunatak; fiord, in Russell fiord, Yakutat bay, extending east from Russęll fiord to the front of Nunatak glacier. So called by the Harriman expedition, 1899. Moser, 1901, called it North East arm.

Nunatak; glacier, on the east side of Russell fiord, Yakutat bay, southeastern Alaska. So named by Russell, 1891, because of a rounded butte of bare rock, a nunatak, rising through it.

Nunatok, river; see Noatak.

Nunava. This Eskimo name appears on Ray's map, 1885, for some feature just west of the United States signal station Utkiavi, Arctic coast. 
Nunavakanuk; lake, Yukon delta, drained by Black river, near latitude $62^{\circ}$ $15^{\prime}$, longitude $164^{\circ} 45^{\prime}$. Wskimo name, obtained by Putnam, 1899. Eskimo nanvak means lake.

Nunez; point, the southeast point of Bean island, near Cape Chacon, Dixon entrance. Named by Caamaño, 1792. Vancouver, following Caamaño, has on his chart Punta de Nuñez. It is Cape Murray of some of the early traders.

Nunez; rocks or reef, bare at half tide, off Nunez point, Dixon entrance. So named by the Coast Survey, 1885. Has also been written Nuñez.

Nunigvaial. Crooked island, in the northern part of Bristol bay, is shown by Sarichef, 1826, as composed of two islands, the northern one being designated by its Eskimo name Nunigvaiak. Tebenkof, 1849, calls it Nunaliugak.

Nunit, island; see Chernobour.

Nuniliak; cape and summer village, on the southwestern shore of Afognak island, Kodiak group. The cape was called Malinovskoi (raspberry) by Murashef, 1839-40, who gives Nuniliak as the native name. A village here he calls the Malinorskie lietnik (Raspberry summer village). Tebenkof calls the settlement Nunalik.

Nunivak; island, on the eastern shore of Bering sea, near latitude $60^{\circ}$, longitude $166^{\circ}$. Discovered by the Russian naval ofticer Vasilief, July 21, 1821, and named by him after his ship Otkritie (discovery). Etolin and Khromchenko, in ships of the Russian-American Company, found this island at about the same time. Speaking of this, Lutke says the native name Nunivak (he writes Nounivak) has been properly retained on the charts, and he adds had this course been followed in similar cases much confusion and embarrassment would have been avoided. Has been variously written Nounivak, Nounivok, Nunivack, Nuniwak, Nuneevack, etc.

Nunochok; Eskimo village, in the Big Lake region. Visited by Nelson in January, 1879, who reports its native name to be Nunochogmute, i. e., Nunochok people. Population in 1880,40 ; in 1890,135 . Spelled Nunochogamute in the Terth Census (text, p..11) and Nunachanaghamiut in the Eleventh Census (p. 164). Nŭnachărạ gămut is given as the name of the same village or one near it.

Nurukomarot; channel, Yukon delta, leading northward from the mouth of

- Kwikluak pass, near latitude $62^{\circ} 40^{\prime}$, longitude $164^{\circ} 50^{\prime}$. Eskimo name, obtained by Putnam, 1899.

Nushagak; bay, southwestern Alaska, opening into Bristol bay, on the north shore, between Protection point and Etolin point, and extending northward 30 miles to the junction of Nushagak and Wood rivers, near latitude $58^{\circ} 30^{\prime}$, longitude $158^{\circ} 30^{\prime}$. So called by Tebenkof, 1849 . Called also Lower Nushagak. river.

Nushagak, lake; see Tikchik.

Nushagak; river, tributary to the head of Bristol bay. Native name, reported by the early Russian explorers as Nushegak and Nushagak. Lutke, 1828, writes it Nouchagak. Apparently it is the river which Cook, 1778, named Bristol. According to Schanz, 1890, the Eskimo name of the river is Tablekuk, while to the local fisheries it is the Main river.

Nushagak; trading post and post-office, at mouth.of Nushagak river. The Russians established a trading post at the mouth of the Nushagak, in 1818 or 1819, and called it Alexandrovsk, perhaps after Alexander Baranof, under whose orders the post was established. Variously called since 
Nushagak-Continued.

then redoubt or fort and spelled Alexander, Alexandrovsk, Alexandrovski, etc., and erroneously Alexandra. Now generally known as Nushagak. Has been written Meshagak. Above this place $1 . \frac{3}{8}$ miles, at a place called Kanulik, is the Moravian mission, Carmel, and Nushagak post-office (established August, 1899).

Nushakantna, river; see Toklat.

Nutavuliti, lake; see Nutuvukti.

Nuteargowik, river: see Nuleargowik.

Nutkwa; inlet and lagoon, on the northeastern shore of Cordova bay, Alexander archipelago, Native name given as Nutqua by Moser in 1897. Tliakek bay of enrlier charts may have been this inlet.

Nutuvukti; lake, northwestern Alaska, draining into Kobuk river from the north, near its source, about latitude $67^{\circ}$, longitude $154^{\circ} 55^{\prime}$. Eskimo name, reported by Stoney, 1885 , as Now-tow-vuck-toy; by Cantwell, 1885, as Nor-to-rok-tee and Nor-tah-rok-tah ; and by Mendenball, 1901, as Nutavukti. Has also been written Noctowucktoy.

Nut-vuck-to-wo-ark, river; see Ambler.

Nutzotin; range of mountains, near the headwaters of Tanana river. Named by Peters and Brooks, 1898, after a tribe of Indians in the region.

Nuviukhaktalik; slough, opening from Apoon pass to Tatalinguk pass, Yukon delta, near latitude $63^{\circ} 03^{\prime}$, longitude $163^{\circ} 27^{\prime}$. Eskimo name, obtained by Faris, 1899.

Nuwaynyuk, river, village, etc.; see Golsovia.

Nuwuk, point; see Barrow.

Nuwuk; Eskimo settlement, at Point Barrow. Nu-wuk or Noowook means the point. "The assemblage of winter huts at Point Barrow is so named by the Eskimo." Variously written Noowook, Noo-wook, Noo'wooh, Nowuk, etc. Population in 1853, 309.

Nychta, cape; see Prince of Wales.

Oallek, lake; see Kulukak and Ualik.

Oalligamut, village; see Ualik.

Obernoi; point, on the eastern shore of Captains bay, Unalaska bay, near longitude $166^{\circ} 34^{\prime}$. Called Obernoi (üpper) by Dall, 1872. Presumably it was locally so known.

Obetavannaia; open bay, between Banner and Korovin bays, on northwestern coast of Atka. So called by Lutke about 1830.

Obgorieli, islet, point, etc. ; see Burnt.

O'Brien; creek, 13 miles north of Nome, Seward peninsula, draining through Willow creek into Osborn creek, near longitude $165^{\circ} 10^{\prime}$. Local name, from Gerdine, 1904.

O'Brien; creek, tributary to Fortymile creek from the north. Miner's' name, reported by Spurr's party, 1896.

O'Brien; creek, tributary to Klokerblok river from the south, Seward peninsula. Name from Barnard, 1900.

Obsechki; islet, in the eastern part of Sitka sound, Baranof island, Alexander archipelago. Named Obsechki (miss fire) by Vasilief, 1809. Has also been written Obsetchka and Obsetchki.

Observation; island, at entance to Steamer bay, Clarence strait, Alexander archipelago. So named by Snow, 1886 , whose astronomical station was on this island near its north end,

Observation; island, 2 miles northwest of Orca, Orca inlet, Prince William sound, near latitude $60^{\circ} 35^{\prime}$, longitude $145^{\circ} 40^{\prime}$. So named by Moser, 1897. 
Observation; point, on the northeastern shore of Stuart island, Norton sound. So named by the Coast Survey in 1898 .

Observation; rock, in the inner arm of Nakat inlet, southeastern Alaska. So called by Nichols in the Coast Pilot (1891, p. 79). Not named on any chart.

Observatory, island; see Pylamid.

Observatory, point; see Tent.

Obsielatushie, point; see Drying.

Ocalee, spit; see Okalee.

Ocean; cape, the southern point of entrance to Yakutat bay, sontheastern Alaskal, near longitude $139^{\circ}$. 50'. Named Morskoi (ocean or sea) by Tebenkof, 1849. It is doubtless identical with Cape Phipps of earlier charts. See Phipps.

Ocean; creek, debouching between York and Cape Prince of Wales, Seward peninsula. Name from Brooks, 1900.

Ocean; point, on left bank of 'Colville river', about latitude $70^{\circ}$. So named by Peters and Schrider, 1901.

ochek, island; see Middleton.

Ochesna, river ; see John.

Ochsakieen, creek; see Oksa.

O-co-mon-e-look, native village; see Okomoneluk.

O'Connor; creek in the Fairbanks region, tributary to Goldstream creek from the north, near latitude $64^{\circ} 55^{\prime}$, longitude $147^{\circ} 50^{\prime}$. Prospectors' name, reported by Gerdine, 1903.

O'Connor; glacier and river, on upper waters of Alsek river, northeist of Yakutat bay. So named by Peter's, 1899, and written Oconnor.

0'Connor's Roadhouse; in the Fairbanks region; on the north bank of Goldstream creek, near longitude $147^{\circ} 40^{\prime}$. Name from Map of Location, Tanana Mines Railroad, 1904.

0.con-0-ne-look, native village; see Okomoneluk.

Octalee, spit; see Okalee.

Octillee, spit; see Okalee.

Odd Fellows, cape; see Starichkof.

Odgovigamut, village; see Uknavik.

Odiak; cannery, of the Alaska I'acker's Association, about 3 miles south of Orca, Prince William sound. Apparently this is only another rendering of some native word which is written Eyak, Ighiak, etc. See Eyak.

Odiak; channel, leading from the head of Orca bay across Orca inlet to Odiak, Frince William sound, Gulf of Alaska. Local nime, from Moser,.1897.

Odiak, lake and river; see Eyak.

Odinakoi, rock; see Lone.

Offield; creek, Seward peninsula, in Solomon River basin, tributary on south bank of Coal creek, near latitude $64^{\circ} 44^{\prime}$, longitude $164^{\circ} 07^{\prime}$. 1'rospector's' name, from a local map, 1904.

offield; creek, Seward peninsula, tributary from the northeast to Grantley harbor. Prospector's' name, reported by Gerdine, 1901.

Ogavik, native village; see Uknavik.

Ogliuga; island, at the western end of the Andreanof group, middle Aleutians. It is Ogloga of Lutke. This with Skagul island constitutes the Delarof islands of Lutke. Has also been written Ogliouga.

Oglodak; islet, off the western end of Atka, middle Alentians. So called by Lutke about 1830. Also has been wiitten Oglodok, Ogmodak, and Ogmodakh. This would seem to come from the Aleut word Agligalk (albatross). 
Ogowinagak; Eskimo village, on the northern shore of Norton bay. Native name, from Petrof, 1880, who reported its population as 20, and its name Ogowinagak in his text (p. 11) and Ogowinanagak on his maps.

O'Hara; bay, on the outer coast of Chichagof island, Alexander archipelago, in the broad sound south of Point Urey, near latitude $57^{\circ} 53^{\prime}$. Not found on any map. So called by the fisheries, and reported by Moser, 1897.

Ohio; creek, tributary to Jackson creek from. the north, Seward peninsula. Name from Barnard, 1900.

Oil; bay, indenting the north shore of Kamishak bay, southwest shore of Cook inlet, near latitude $59^{\circ} 40^{\prime}$, longitude $153^{\circ} 20^{\prime}$. Local name, from Martin, 1903.

Oil; creek, 5 miles east of Cape Yaktag, Gulf of Alaska, near longitude $142^{\circ} 15^{\prime}$. Prospectors' name, reported by Martin, 1904.

Oil; creek, tributary to Katalla slough, Gulf of Alaska, near longitude $144^{\circ} 30^{\prime}$. Local name, reported by Martin, 1904.

Oil; creek, 6 miles sonthwest of Cold bay, Alaska peninsula, tributary to Dry bay, near latitude $57^{\circ} 40^{\prime}$, longitude $155^{\circ} 30^{\prime}$. Local name, from Martin, 1904 .

Okaganak; Eskimo village, on the left bank of the Kuskokwim, about 85 miles above Bethel. Native name, from Nelson, 1879, who wrote it Okhaganak.

Okalee; channel, between Kanak and Wingham islands, Controller bay, Gulf of Alaska, near longitude $144^{\circ} 1^{\prime}$. So named by Pratt, 1903.

Okalee; spit, on the south side of Controller bay, Gulf of Alaska, extending west from Cape Suckling, near latitude $60^{\circ}$, longitude $144^{\circ}$. Reported by Martin, 1903 , who wrote it Ocalee. Written also Octalee and Octillee.

Oliben, island ; see King.

Okivalki, rock; see Tairway.

Ollashok, river; see Alatna.

Oklune, mountains; see Ahklun.

Oknagamut; Eskimo village, on the north bank of Kuskokwim river, above Kalchagamut. Eskimo name, from Nelson, 1879, who wrote it Okhogamute, i. e., Okok people. Has also been written erroneously Okhagamute. Coast Survey charts have Oknagamut, and this is the name, according to missionary Kilbuck. It is said to mean village on the other side. Pronounced Ook-nă-gá-mūte. Has also been written Oh-hagamiut. Population in 1880,130 ; in $1890,36$.

Oknakluk; lake, on the water portage between Yukon and Kuskokwim rivers.

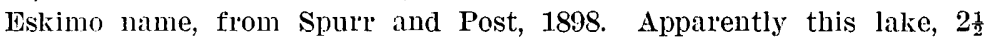
miles long and 4 feet deep, is the one called Ookaht on Coast Survey chart 3092.

Oknavigamut, village; see Uknavik.

Okomoneluk; Eskimo village, northwestern Alaska, in Navy pass, 15 miles southwest of Chandler lake, near latitude $68^{\circ}$, longitude $153^{\circ} 45^{\prime}$. Visited by Stoney, 1886, who wrote $\mathrm{O}$-co-mon-e-look and $\mathrm{O}$-con-o-ne-look.

Olvonchatelnie, cape; see Termination.

Okpfauchakuk; slough, Yukon delta, opening on the left bank of Kwikpak pass, 12 miles below the head of the delta, near latitude $62^{\circ} 42^{\prime}$, longitude $163^{\circ} 58^{\prime}$. Eskimo name, repórted by Faris, 1899.

Olipilitalik, village; see Opilitulik.

Oksa; creek, tributary to the Stikine from the east, near Little Canyon. Native name, from late Const Survey charts, where it is written Ochsakieen, Och-sa-ki-een, and Oksakiin. The termination seems to be a variant form of hini (river:), so often occurring in this region. 
Oksenof; bay, on the northwestern coast of Unimak island, eastern Aleutians, near longitude $164^{\circ} 35^{\prime}$. Called Oksenova (Oksenof's) by Veniaminof, 1831.

Oksenof, cape; see Mordvinof.

Okshokwewhik; pass, Yukou delta, opening on the coast of Bering sen, 20 miles west of Apoon mouth, near latitude $63^{\circ} 12^{\prime}$, longitude $163^{\circ} 50^{\prime}$. Eskimo name, reported by Putnam, 1899. Written also Okshokwhewhik.

Oksukfeok; river, somewhere in Yukon delta. Location not determined. Name from Eleventh Census, 1890 (p. 110).

Okwatatalik; slough, Yukon delta, opening on the west bank of Aproka pass, near latitude $62^{\circ} 45^{\prime}$, longitude $164^{\circ} 08^{\prime}$. Eskimo name, obtained by . Putnam, 1899.

Okwega; pass, 8 miles long, opening into the Apoon pass, Yukon delta, from the north, near latitude $63^{\circ} 05^{\prime}$, longitude $163^{\circ} 35^{\prime}$. So called by the Coast Survey in 1898 .

Olai, mountains; see Alai.

Old Andreafski, fort; see Andreafski.

Old, river ; see starichkof.

old Crow; river, tributary to the Porcupine from the north, crossing the international boundary line near latitude $68^{\circ}$. So called by the Coast Survey in $\mathbf{1 8 9 5}$.

Old Glory; creek, Seward peninsula, tributary from the west to Pannell river, a branch of Inmachuk river, near latitude $65^{\circ} 50^{\prime}$, longitude $163^{\circ} 10^{\prime}$. P'rospectors' name, reported by Mendenhall, 1901.

Old Harbor; small harbor, on the eastern shore of Makushin bay, Unalaska. The present settlement of Makushin is on its shores. It is so called, says Veniaminof, because a Russian ship wintered here in 1761 . Tebenkof; probably erroneously, applies the name to a harbor or open. bay on the south shore of Unalaska, nearly opposite the head of Beaver bay.

Old Harbor, bay; see Old Sitka.

Old Harbor; Kodiak; see Three Saints.

Old Johnson; lake and stream, on the north shore of Moira sound, Frince of Wales island, neâl latitude $55^{\circ}$, longitude $132^{\circ} 10^{\prime}$. So called by the fisheries, and reported by Moser, 1897.

Old Kootznahoo. Formerly a populous Indian village stood on the northern side of Chaik bay, on the western coast of Admiralty island, Alexander: archipelago. Its native name, according to Dall (Coast Pilot, 1883, p. 175), was Letusblwin. Now generally referred to as Old Kootznahoo.

Old Kuilpalamiut, Eskimo village; see Kwikpak.

Oldman; creek, eastern Alaska, on the north bank of Mosquito fork Fortymile creek, near longitude $142^{\circ} \cdot 15^{\prime}$. Prospectors' name, from sketch map compiled by Major Glassford, Signal Corps, U. S. A., 1905.

Old Man; island, in the eastern part of Bucareli bay, Prince of Wales archipelago. Named Isla del Viejo (island of the old [one]) by Maurelle and Quadra, 1775-1779.

Old Man, river: see Kanuti.

Old Man; rocks, two rocks (the higher about 60 feet), off the northwest shore of Egg island and opposite the south point of entrance to Beaver inlet, Unalaska island, near longitude $166^{\circ} 05^{\prime}$. So named by Gilbert, 1901 .

Old Morzhovoi, village; see Morzhovoi.

Olds; mountain (4,460 feet high), on mainland, $4 \frac{1}{2}$ miles northeast of Juneau. Local name, reported by Peters, 1902. 
old Sitka; Larbor, in Starrigavan bay, Sitka sound, Alexander archipelago. It was on the shores of this harbor that the first Russian settlement was planted, by Baranof, 1799. Here be built the fort Archangel Gabriel, which the natives destroyed in 1802 . Thereupon this site was abandoned for the present site of Sitka, and henceforward this place is referred to as the old harbor (starri-gavan). Vasilief; 1809, calls this Starri-gavan (old harbor) bay.

Old Sitka; rocks, in entrance to Starrigavan bay, Sitka sound, Alexander archipelago. Name published by the Coast Survey in 1891.

old Tom; salmon stream, Prince of Wales island, southeastern Alaska, on the south shore of Skowl arm, Kasaan bay, 1 mile west of McKenzie arm, near latitude $55^{\circ} 24^{\prime}$, longitude $132^{\circ} 23^{\prime}$. So called by the fisheries, and described by Moser, 1897.

old Tyonek; see Tyonek.

Old Village, salmon stream and lake; see Thoms.

old Woman; mountain, on the west side of Yukon river, between Kaltag and Unalaklik. Local name (Old Womans), published in 1901. Vesolia, Old Woman, and Sugarloaf may be different names for the same mountain.

Old Woman; telegraph station, on Unalaklik river, 50 miles above Unalaklik, near Old Woman mountain. So named by the Signal Corps, U. S. A., 1903.

Ole; creek, in Fortymile region, eastern Alaska, on west bank of Independence creek; near latitude $64^{\circ} 40^{\prime}$, longitude $142^{\circ} 20^{\prime}$. Prospectors' name, reported by Witherspoon, 1905.

Oleny, island; see Deer.

Olga; bay, an arm of Alitak bay, indenting the western shore of Kodiak. Presumably so named by the Russians. Name published by the Eleventh Census, 1890. Olga is a Russian feminine proper name.

Olga; islands, in Dolgoi harbor, Dolgoi island, near Belkofski. Local name, reported by Dall, 1880.

Olga; point, the northernmost point of Krestof island, Alexander archipelago. So named by the Russians.

Olga, point; see Klokachef.

Olga; rock, off Alaska peninsula, southeast of Belkofski. Name reported by Dall, 1880.

Olga; rock, off entrance to Salisbury sound, Alexander archipelago. So named by Moore, 1897.

Olga; strait, separating Halleck island from Krestof island, Alexander archipelago. So named by Vasilief, 1833. It has also been called Krestof (cross) strait, having been so named by Vasilief, sr., 1809.

Olga, strait; see Neva and Salisbury.

Olive; cove, indenting the northeastern shore of Etolin island, Zimovia strait, Alexander archipelago, near latitude $56^{\circ} 12^{\prime}$, longitude $132^{\circ} 19^{\prime}$. Local navigator's' name, reported by H. C. Fassett, Bureau of Fisheries, 1904.

Oliver; inlet, in the northern coast of Admiralty island, Stephens passage, Alexander archipelago. So named by Mansfield, 1890.

o-loo-kok, river; see Wloyukuk.

Olsen; bay, on the outer coast of Chichagof island, Alexander archipelago, in the broad sound south of Point Urey, near latitude $57^{\circ} 53^{\prime}$. Not found on any map. So called by the fisheries, and reported by Moser, 1897.

Olsen; island, near mouth of Unakwik bay, Prince William sound. So named because a Mr. Olsen has a fox ranch here. Local name, reported by Grant, 1905. 
Omalik; creek (an east branch of Fish river), mountain, and silver and lead mines, in the Fish River region, Seward peninsula, near latitude $65^{\circ}$, longitude $163^{\circ}$. Eskimo name, which has been given as Omilak and Omalik, and might perhaps be better written Umalik. The creek has been called Green river.

Omalik; mining camp, Seward peninsula, near Omalik creek. Prospectors' name, reported by Witherspoon, 1903.

Omega; creek, tributary to American river from the east, Seward peninsula. Name from Brooks, 1900.

Omega; small creek, draining the southern slope of the divide between Tanana river and the headwaters of Minook creek, near latitude $65^{\circ}$, longitude $150^{\circ} 15^{\prime}$. Prospectors' name, reported by F'rindle, 1904.

Ommaney; cape, forming the southern point of Baranof island, Alexander archipelago. So named by Colnett in 1789. La Perouse, 1786, named it Chirikof, after the distinguished Russian navigator. Malaspina, 1791, called it P'unta Oesta de la Entrada del Principe. The traders, 1796-1799, called it Menzies cape, and Lisianski, 1804, South cape.

Onatzino, cape; see Dangerous.

Onega, creek ; see Oniga.

Oneida; submerged rock, 7 miles southwest of Sannak island, near latitude $54^{\circ} 21^{\prime}$, longitude $162^{\circ} 55^{\prime}$. So called by Westdahl, 1901 .

One Tree; rock, in Redfish bay, Baranof island, Alexander archipelago. So named by Moser, 1897.

Ong-u-tuk, river; see Solomon.

Onieda, creek ; see Oniga.

Oniga; creek, 16 miles north of Cape Nome, Seward peninsula, tributary from the east to Bonita creek, near longitude $165^{\circ} 13^{\prime}$. Local name, apparently of Eskimo origin, published in 1901. Written also Onega and Onieda.

- Onihitsk; native village, on the eastern end of Sitkalidak island, near Kodiak. So called by Lisianski, 1805 .

Onihitsk, settlement; see Anihitsk.

Onklat; creek, between Yakutat and the head of Russell fiord, tributary to Situk river from the west, neal: longitude. $139^{\circ} 30^{\prime}$. Indian name, written On-klat by Moser, 1901.

Onman, cape; see Romanof.

Onokovuk, creek; see Anikovik.

Onslow; island, at junction of Clarence strait and Ernest sound, Alexander archipelago, near latitude $55^{\circ} 53^{\prime}$, longitude $132^{\circ} 22^{\prime}$. So named by the Coast Survey in 1887.

Onslow; point, in Clarence strait, the southwestern point of entrance to Ernest sound, Alexander archipelago. So named by Vancouver, 1798. Drroneously Onelow. Has also been called Onslow rock.

Doagalga, island; see Ugamak.

Doallikh, village; see Ualik.

Oobakagainute, village; see.Unakak.

Ooganok, bay; see Uganik.

Oogashik, village; see Ugashik:

Oo-ghe-book, island; see King.

Oo-ghe-e-ak, rock; see Fairway.

Ooglamie, village; see Utkiavi.

Oogovigamute, village; see Ugovik.

Oohack, bay; see Ugak.

Oohaiack, village; see Akhiok.

Bull, $299-06 \mathrm{M} \longrightarrow 31$ 
Oohaiack, village; see Uhaiak.

Oohanick, island; see Uganik.

oohaskeck, village; see Uhaskek.

Oohiack, bay; see Uyak.

Oo-innalitagowik, village; see Uinuk.

Oolkagamute, village; see Nunaikak.

Ookagamute, village; see Ukak.

Dokaht, lake; see Oknakluk.

Ookakhl, lake; see Ukak.

Ookamok, island; see Chirikof.

Oolakaiya, hill; see Ulakaia.

Oomanak, island; see Umnak.

Oonalagamute, village; see Umnak.

Oonakhtolik, village; see Ungalik.

Oonalakleet, river; see Unalaklik.

Oonalaklik, village; see Unalaklik.

Oonalashka, island; see Unalaska:

Oonalgi, island; see Unalga.

Oonangashik, village; see Unangashik.

Oone-agun, islands; see Four Mountains.

Oonella, island; see Unalga.

Oonemak, island; see Unimak.

Ootkeavie, village; see Utkiavi.

Ootokok, river; see Utukok.

Ootookok, cape; see Icy.

Ootookok, river; see Utukok.

Ootoo-kok, village; see Utukok.

Oowik, pass or slough; see Uwik.

Opasnaia, bay, cape, etc.; see Danger and Dangerous.

Opasni; group of islands, in Northern rapids, Peril strait, Alexander archipelago. Named Opasnie (perilous or dangerous) by Vasilief, 1833.

Opatulik, river, Seward peninsula; see Cache.

Open; bay, on the southern shore of Unalaska, east of Kashega bay, near latitude $53^{\circ} 30^{\prime}$, longitude $166^{\circ} 50^{\prime}$.. Descriptive name, given by the Fish Commission in 1888 .

Open; bight, indenting the north shore of Akutan island just east of North head, Krenitzin group, eastern Aleutians, near longitude $165^{\circ} 55^{\prime}$. Descriptive name, from Gilbert, 1901.

Open; . rock, in the Kasiana group of islands, Sitka sound, Alexander archipelago. Named Atkritoi (open, i. e., uncovered or discovered) by Vasiliec, 1809.

Operl; island, one of the Kudiakof islands, Izembek bay, northern shore Alaska peninsula, near longitude $162^{\circ} 47^{\prime}$. So named by the Fish Commission in 1888.

Ophir; creek, tributary to Niukluk river from the north, in the Eldorado mining district, Seward peninsula. Local name, published in 1900. According to Brooks the Eskimo name is Kai-vik.

Ophir; gulch, in the Mount Wrangell district, tributary to Elliott creek on the north. Prospectors' name, reported by Mendenball, 1903.

Opiktulik; Eskimo village, on the northern shore of Norton sound, 40 miles east of Nome. Petrof reported its population in 1880 as 12 , and its name Okpiktolik, in his text (p. 11) and Okpiktalik on his maps. A local map, 1900, calls it Opiktulik, i. e., Opik region. Has been written Opiktillik and Apiktalluk. 
Orange; hill, in the Mount Wrangell region, at the foot of Nabesna glacier, near latitude $62^{\circ} 14^{\prime}$, longitude $142^{\circ} 54^{\prime}$. So named by Schrader, 1902, "from its orange red color, due to mineralization of the rock."

Oratia; mountain (7,300 feet high), near the headwaters of Kanektok river, western Alaska. So named by Spurr and Post, of the Geological Survey, who passed near it September, 1898.

Orca; bay, indenting the eastern shore of Prince William sound, Gulf of Alaska, near latitude $60^{\circ} 35^{\prime}$, longitude $146^{\circ}$. Called Pto. Cordoval on chart 2 of Vancouver's atlas (1798), a name either given by Vancouver or adopted by him from the Spaniards. On May 2, 1906, the U. S. Board on Geographic Names, named this bay Orca to avoid confusion with Cordova bay, Dixon entrance.

Orca; cannery, of the Pacific Steam Whaling Company, and post-office (established in December, 1894) on the eastern shore of Orca inlet, Prince William sound. Named after one of the company's vessels.

Orca; channel, leading from the head of Orca bay to Orca, Prince William sound, Gulf of Alaska. So named by Moser, 1897.

Orca; inlet, on the southeast side of Hawkins island, southeastern part of Prince William sound, Gulf of Alaska, near latitude $60^{\circ} 30^{\prime}$, longitude $145^{\circ} 50^{\prime}$. So named by Mosel, 1897 .

Orca; point, on the southern shore of Boca de Quadra. So named by. the Coast Survey in 1891.

Oregon; creek, 16 miles northwest of Nome, Seward peninsula, tributary to Cripple river from the east, near latitude $64^{\circ} 40^{\prime}$, longitude $165^{\circ} 40^{\prime}$. Name from Barnard, 1900 .

Oregon; creek, Seward peninsula, tributary to Mystery creek, an affluent of. Cripple river, near latitude $65^{\circ} 50^{\prime}$, longitude $163^{\circ} 30^{\prime}$. Prospectors' name, reported by Gerdine, 1901.

Orel, shoal; see Pamploina.

Orevilla, Punta de: see Whitshed cape.

Orieshik (Hazel), island; see Egg.

or-kim-ya-nool, river; see Colville.

Orlova; native settlement, at Esgle harbor, Ugak bay, Kodiak. Named Orlova - (Orlof's) by the Russians and "erroneously renamed St. Orloff in our Coast Survey maps. It is now popularly known only by the name of the bay," i. e., Eagle Harbor.

Orobultulak, creek; see Cache.

Oro Fino; gulch, Seward peninsula, jn Solomon Rivel drainage basin, on north bank of Adams creek, near latitude $64^{\circ} 43^{\prime}$, longitude $164^{\circ} 29^{\prime}$. Prospectors' name, from a local map, 1904.

Orphan; creek, Seward peninsula, tributary on north bank of East fork Solomon river, near latitude $64^{\circ} 42^{\prime}$, longitude $164^{\circ} 07^{\prime}$. Prospector's' name, from Gerdine, 1905.

Orphan; creek, in the Rampart region, tributary to Troublesome creek from the southeast, near latitude $65^{\circ} 20^{\prime}$, longitude $149^{\circ} 40^{\prime}$. Prospectors' name; reported by Prindle, 1904.

Orphans; creek, Arctic slope, tributary to Canning river from the east, near latitude $69^{\circ} 30^{\prime}$, longitude $147^{\circ}$. So named by S. J. Marsh, a prospector, 1902-03.

Orr; island, Sea Otter sound, Prince of Wales archipelago, near latitude $55^{\circ} 57^{\prime}$, longitude $133^{\circ} 25^{\prime}$. So named by Dickins, 1903-04, after Capt. Cyrus Orr, of Shakan. 
Orzenoy; caunery (established in 1889) on western shore of Stepovak bay, Alaska peninsula. So called by Moser in his report, 1899 (text, p. 171), but on his map Ozernoi. Apparently from the Russian adjective Ozernoi, meaning lake.

Osar; glacial stream, debouching northeast of Manby point, on the northern shore of Yakutat bay, southeastern Alaska, near latitude $59^{\circ} 45^{\prime}$, longitude $140^{\circ} 10^{\prime}$. So named by Russell, 1891. McGrath, 1892, called this stream, or one of its mouths, or one near it, Forney river, which name was published in the Coast Survey magnetic declination tables for 1902 .

Osborn; mountain (4,700 feet high), in the Kigluaik mountains, Seward peninsula. Name from Barnard, 1900.

Osborn; creek, tributary to Nome river from the east, in the Nome mining region, Seward peninsula. Also written Osborne. Prospectors' name, published in 1900.

Oschesul, river; see John.

Oserski, bay; see Redoubt.

Oshibki, island; see Error.

Osier; island, at south point of entrance to Russell fiord, Disenchantment bay, Yakutat bay, southeastern Alaska. , Named by Russell, in 1891. "It is covered with a dense growth of willows, hence its name."

Oskawalit; river, tributary to Kuskokwim river from the east, near longitude $158^{\circ}$. Native name, pronounced ŏs-ka-wắ-lit, obtained by Spurr and Post, 1898, from A. Lind, a trader.

Ossipee; channel, between Bushy and Shrubby islands of the Kashevarof group, Clarence strait, Alexander archipelago. Named by the Coast Survey, in 1895 , after the U. S. S. Ossipee.

Osten; island, in Carroll inlet, Revillagigedo island, Alexander archipelago, near latitude $55^{\circ} 25^{\prime}$, longitude $131^{\circ} 20^{\prime}$. Local navigators' name, reported by H. C. Fissett, Bureau of Fisheries, 1904.

Ostovia, island; see Otstoia.

Ostraia, mountain; see Barometer.

Ostrovki, cape; see Islet.

Ostrovki, islands; see Pribilof.

Otai, mountain; see Alai.

Otcheredin, point ; see Acheredin.

Otkiancik, village; see Utkiavi.

Otma, island; see Attu.

Otmeli, cape, etc.; see Shoal.

Otmeloi; island, in Yakutat bay, southeastern Alaska. Named Otmeloi (shoal) by Tebenkof in 1849. There is a shoal extending off from the island. Also called Shoals island.

Otmeloi vnieshnie, point; see Shoals.

otmeloi vnutrennie, point; see Inner.

Otok-kok, village; see Utukok.

Otrubistoi, cape; see Bluft.

Otstoia; island, opposite Hooniah sound, in Peril strait, Alexander archipelago. Named Otstoia (off-lying) by Vasilief in 1833. Also called Ostovia and sometimes translated distant. George Kostrometinoff calls this Otstoi (shelter).

Otter; bay, indenting the southern shore of Alaska peninsula, northwest from the Shumagin group. It is Bobrovoi (beaver) bay of Tebenkof, 1849, and Otter bay of later charts. On some charts Otter bay is shown as a small bay indenting the western shore of Portage bay. 
Otter; cove, indenting the southeistern shore of Unimak island on the west side of Ikatan peninsula, near longitude $168^{\circ} 20^{\prime}$. So designated by Westdahl, 1901.

Otter; creek, in the Kantishna region, on the east (right) bank of Bearpaw. creek, near latitude $64^{\circ}$, longitude $150^{\circ}$. Name given by prospectors. 1905 , and reported by Prindle.

Otter; creek, 3 miles east of Nome, Seward peninsula, tributary to Nome river from the north, at its mouth, near lougitude $165^{\circ} 18^{\prime}$. Prospectors' name, published in 1900 .

Otter; island, one of the Pribilof group, Bering seil. So called by the Russians, as early as 1816, and probably enrlier. Kotzebue has, in the Innglish text, Bober. Lutke calls it Bobrovi (des loutres), and the Russian charts generally Bobrovoi (sea otter). Beechey called it Sea Otter and Sea-otter. Now well known as Otter island.

Otter, island; see Hydra.

Otter; point on the north shore of Unimak island, near the eastern end, about longitude $163^{\circ} 44^{\prime}$. Local name, published by the Coast Survey in 1.902.

Otter; sound, in the western part of Prince of Wales archipelago. Meares, 1788 , named some body of water in this vicinity and which can not now be iclentified with certainty; "Sea-Otter Harbour," which he writes Sea-otter, Sea Otter, and on his charts calls it harbour and sound. In the Coast Pilot of 1869 , by Davidson, this is called Otter sound.

Otter; strait, between Bird and Chernobour islands, Shumagin group. So nimed by Dill in 1.882 .

Otters, Sea of ; see Rering. .

Ottoway; valley, on the north border of Klutina lake. So named by Abercrombie in 1898 .

Otul:ah, river and village; see Utukok.

Otumgwilut; creek, tributary to Kanektok river from the north, abont 50 miles east of Kuskokwim bay, western, Alaska. Native name, obtained by Spurr and Fost, of the Geological Survey, 1898, and by then written Otúmgwilute.

Otviesnoi, cape; see Upright.

Oubeloi, islet; see Ubiloi.

Oubiennaia, bay; see Massacre.

Oudagakh, strait; see Udagak.

Ouegakh, island; see Uegak.

Ouehtock, island; see Rootok.

Ougadaki, harbor; see Dutch.

Ougatchik, river; see Ugashik.

Ougavik, Eskimo village; see Ugovik.

Ouglovaia, village; see Uglovaia.

Ougnagok, harbor; see Delarof.

Oukalinka; river, northwestern Alaska, tributary to Kugarak river, a branch of Selawik river, near latitude $66^{\circ} 45^{\prime}$, longitude $158^{\circ}$. Iaskimo name, written Ou-ka-lim-ka-gru-gra by Stoney, 1886.

Oukamok, island; see Chirikof.

Oukivok, island; see King.

Ouknadol, island; see Hog.

Ouliaga, island; see Uliaga.

Oulidalko. An island, not identified, somewhere between Adak and Great Sitkin islands, middle Aleutians, is so called by Lutke.

Oumakh, island; see Umak. 
Ounalakleet, village; see Unalaklik.

Ounalashka, island; see Unalaska.

Ounalga, island and pass; see Unalga.

Ounga, island; see Unga.

Öunga, pillars; see Hibahibgik.

Oungaklitalik, river; see Ungalik.

Ourand; mountain (4,300 feet high), between Valdez glacier and Klutina lake. So named by Abercrombie, 1898.

Ousercli, point; see Zeal.

Outer; point, the eastern point of entrance to Wachusett cove, Freshwater bay, Chatham strait; Alexander archipelago. So named by Glass, 1881.

Outer; point, the westernmost point of Douglas island, Stephens passage, Alexander archipelago: So named by Symonds, 1880 .

Outer; rock, 30 feet high and bare, off the entrance to Khaz bay, southwestern shore Chichagof island, Alexandler archipelago, near latitude $57^{\circ} 33^{\prime}$, longitude $136^{\circ} 09^{\prime}$. Descriptive name, given by Noore, 1897 .

Outer; rock, in Nazan bay, Atka, middle Aleutians. Called Vnieshnie (outer) by Tebenkof, 1849 .

Outer Iliasik; island, off the southern shore of Alaska peninsula, near Belkofski. Name from the Russians, who wrote it Iliaviki and Big Iliazhek. See Iliasik and Inner Iliasik.

Outer Signal; rock, off the eastern shore of Biorka island, eastern Aleutians, near longitude $166^{\circ} 03^{\prime}$. So named by Gilbert, 1901 .' See The Signals.

Outlet; cape, on the northern shore of Kodiak, being the point where vessels pass out from Kupreanof strait into Shelikof strait. Named Viekhodia (passage out) by Murashef, 1839-40.

Overhang; point, in Redfish bay, Baranof island, Alexander archipelago. So named by Moser, 1897.

Owen; mountain, east of Seward glacier, in the St. Elias alps, southeastern Alaska. So named by Russell, 1890, after David Dale Owen, United States geologist.

Owen; shoal ( $3 \frac{1}{2}$ fatboms water), about 10 miles northeast from Point Barrow, Arctic ocean. So called after Captain Owen, of the whaling $\mathrm{sh}_{1}$ ? Mary and Helen. Published on United States Hydrographic Office chart 1189, in 1890. Hydrographic notice 7 of 1890 (p. 80 ) has a statement from Capt. Everett Smith, of the steam whaler Balena, that this shoal does not exist.

Oweruk, creek ; see Aueruk.

Owl; creek, 22 miles north of Cape Nome, Seward peninsula, tributary to Fox creek from the south, near longitude $165^{\circ}$. Local name, from Gerdine, 1904.

Owl; creek, 40 miles east of Fort Hamlin, on the Yukon, and probably tributary to Lost creek, near longitude $148^{\circ}$. Prospectors' name, reported by Lieutenant Erickson, U. S. A., 1902.

Owl; creek, in the Fortymile region, tributary to Cherry creek from the west, near latitude $64^{\circ}$; longitude $141^{\circ}$. Prospector's name, reported by Gerdine, 1903 .

Owl; island, south of Orr island, Sea Otter sound, Prince of Wales archipelago, near latitude $55^{\circ} 53^{\prime}$, longitude $133^{\circ} 25^{\prime}$. So named by Dickins, $1903-4$.

Owl, river: see Nuluk.

Ox; point, on the mainland, in Port Snettisham, at mouth of Whiting river, southeastern Alaska. So named by Thomas, 1888.

Oxide; creek, trilutaly to Ophir creek, near its headwaters, Seward peninsula. Nane from Baruard, 1900. 
Oyak; native village, on the eastern shore of Kuskokwim bay, just north of the mouth of Kanektok river. Native name, obtained by Spurr and Post, 1898, from the missionary John H. Kilbuck, who gives it as Oyágamut, i. e., Oyak people.

Ozerskoi, station; see Redoubt.

Pablof, harbor; see Paivlof.

Pacific; shoal, off Cape Hallett, Arctic ocean. Reported by Captain Knowles, of the whale ship Pacific, prior to 1889 , and named Pacific by the Hydrographic Office.

Pacific; ocean. This is the South sea or Great South sea of the old navigators and Vostochnie (eaistern) ocean of the Russians. Named irar del Sur (South sea) by Balboa in 1513, and Pacific by Magellan in 1521.

Pack, river; see Ambler.

Paddy; bay, on western side of Prince William sound. Local name, reported by Grant, 1905.

Fagoobnoy, strait; see Peril.

Fagomawik, slough or pass; see Bugomowik.

Fah; rapids, in Kobuk river, just above Pah village. This name has been so applied on some maps, but is probably due to misinterpretation of Cantwell's map.

Pah; river, tributary to Kobuk river from the south, about 300 miles from its mouth. It lies across the Arctic Circle, near longitude $156^{\circ} 20^{\prime}$. It was traversed by Zane, of Stoney's expedition, in 1886, on a trip to St. Michael and return, and called Par river by Stoney, aftei the village Pah at its morith. Cantwell, 1885, wrote its Isskimo name Cliok-waychok and Shok-ah-bok-shegiak, which he says has "reference to the rapid current."

Pah; Eskimo village, northwestern Alaska, on Kobuk river, at the mouth of Pah river', near latitude $66^{\circ} 45^{\prime}$, longitude $156^{\circ} 05^{\prime}$. Eskimo name, so written by Cantwell, 1885; Stoney, 1885, wrote Par and said it means door, because by this river is the route from the Kobuk to the Yukon country.

- It is, however, the same as pai of the Eskinio farther south, and pan or pan-a of the Point Barrow Eskimo; and, like the Indian word kakat, means the mouth of a river, or the confluence of two rivers.

Paimut; see Bimiut.

Paimiut; slough, on the left bank of the Yukon, nearly opposite the Bskimo village of the same name, near latitude $62^{\circ} 10^{\prime}$, longitude $160^{\circ} 10^{\prime}$. Written F'imute on Edwards's Track Chart of the Yukon, 1899.

Paimiut; a native village of 50 inhibitants on the right bank of the Yukon, 38 miles above Russian Mission, near latitude $62^{\circ} 10^{\prime}$, longitude $160^{\circ} 10^{\prime}$.

- Raymond, 1869 , calls an Eskimo village at or near this place Kuyikanuikpul. Other maps have copied this. I'etrof, 1880, wrote Paimute; Nelson, 1900, Paimut; and others Pimute. "The circular hatch of the native canoe or kaiyak is termed pī. *** The word pì means also the mouth of a river or stream. *** $*$ Pimēunt is the name of several villages situated at the junction of streams." (Father Bainum, Essentials of Innuit, pp. 308-309.)

Paimute; Eskimo village, on the right bank of Kuskok wim river, about 25 miles above Bethel. Eskimo name; from the Russians, who wrote it Paimut, i.: e., mouth-of-the-river folks. Population in 1880, 30. Omitted from recent maps. Tikhmenief, 1861, placed it on the left bank of the river.

Pajara; creek, tributary to Eldorado river from the east, Seward peninsuli. Name from Barnard, 1900. 
Pakenham; point, in Port Wells, Prince William sound. So named by Vancouver, 1794.

Pakwil, Eskimo village; see Pawik.

Palenoi, point; see Fired.

Palisade; point, on San Fernando island, Bucareli bay, Prince of Wales archipelago. Named Punta de la Empalizada (point of the palisade) by Maurelle and Quadra, 1775-1779.

Palisades; bluffs, on the south bank of the Yukon, about 40 miles below the mouth of the Tanana. So called by Allen, 1885.

Palm; point, a minor point on Point Martin, being the western point of entrance to Katalla bay, Gulf of Alaska. Local name, reported by Martin, 1903, descriptive of some spruce trees on this point blown by the wind into shapes which, from a distance, resemble palms.

- Palma; bay, on the mainland coast, a little north of Cross sound. Named Bahia de Palma by Malaspina, 1791. Has also been called Icy bay.

Palmer; creek, tributary to Resurrection creek from the east, Kenai peninsula. Local name, from Becker, 1895 . On one map this is erroneously shown tributary to Fresno creek.

Palmers Store; trading place, on the shore of Knik arm of Cook inlet. Local name, published in 1899 .

Palmetto; point, on the south shore of San Juan Bautista island, Bucareli bay, Prince of Wales archipelago. Named Punta del Palmito (Palmetto point) by Maurelle and Quadra, 1775-1779.

Palo Cano; point, on San Fernaildo island, San Alberto bay, Bucareli bay, Prince of Wales archipelago. Named Punta del Palo Cano (point of the white pole) by Maurelle and Quadra, 1775-1779.

Palomas, Ysla de; see Pigeon island.

Palonoi; point, on the mainland, very near Point Rothsay, at mouth of Stikine river. Named Palonoi (fired) by Basargin, of the Rynda party, 1863.

l'altus, point; see Halibut.

Pamiek; lake, draining through Wood river to Nushagak bay. Native name, from Tebenkof, 1849 . It is Akuliukhpak of Petrof, 1880.

Pamplona. The Spaniard Arteiga reyorted that on July 16, 1779, he saw at the distance of a miie the appearance of a bajo (bank or shoal). This. shoal, in the Fairweather ground off Mount St. Elias, he placed upon his chart with the name Bajo Pamplona. Vancouver refers to it as Roco Pamplona of the Spaniards. Tebenkof says that Talin, mate of the Russian vessel Orel (eagle) saw it, 1794, and named it Orel, after his ship. Recent charts omit it altogether, it having been searched for and not found.

Pancacke, creek; see Slate.

Pankof; breaker, 4 miles northeast of Cape Pankof (below). So designateci by Westdahl, 1901.

Pankof; cape, the southeastern point of Ikatan peninsula, near Isanotski strait, Alaska peninsula, about datitude $54^{\circ} \cdot 40^{\prime}$, longitude $162^{\circ} 34^{\prime}$. Named Pankova (Pankof's) by the Russians. Also written Pankoff.

Pannell, creek; see Pinnell river.

Papin, river; see Parantulik.

Papka; Eskimo village, on the north shore of Kuskokwim bay, near the mouth of Kuskokwim river. Accordiag to Spurr and Post, who obtained their: information from missionary J. H. Kilbuck, in 1898 , its native name is Papkamut, i. e., Papka people. 
Paps (The); two small rounded hills, on the southern side of the entrance to Lituya bay, southeastern Alaska. Name published in 1875 on Coast Survey chart 742. Descriptive name. First use of the name not discovered.

Par, rapids ; see Pah.

$P a r$, river and village; see Pah.

Paradise; flats, at head of Saook bay, Peril strait, Alexander archipelago. So named by Moore, 1895.

Paralihotnia, bay; see Steamer.

Paralysis; point, separating Band cove from Security bay, Kuiu island, Alexander archipelago. Called South point by Meade in 1869, and Paralysis point by 'Glass in 1881.

Paramanof; bay, indenting the northwestern shore of Afognak island, Kodiak group. Named by the Russians. Apparently a proper name. Has also appeared as Paramano and Paramonofskaia.

Paramanof; cape, the western point of entrance to Paramanof bay, Afognak island, Kodiak group. Named by the Russians. The native name is Tanak; perhaps from tanak, the Aleut word for big.

Parantulik; river, Seward peninsula, tributary of Fish river from the west, which in turn is tributary to Golofnin bay, near latitude $65^{\circ}$, longitude $163^{\circ} 20^{\prime}$. Local name, derived from the Eskimo. 'The termination tulik. is said to mean place or region. It has been called Papan, Papin, and some alleged lakes at its head Paran. Called by the miners Pargan, Pargon, and Paragon.

Pargan, river; see Parantulik.

Parida; island, in San Alberto bay, Bucareli bay, Prince of Wales archipelago. Named Parida (woman just delivered of a child) by Maurelle and Quadra, 1775-1779.

Paris; creek, near Douglas, -Douglas island, Alexander archipelago. Local name, published by the Coast Survey in 1893.

Parker, creek; see Poker:

Parker; group of islands, near the western channel into Sitka harbor, Sitka sound, Alexander archipelago. So named by United States naval officers, 1880 .

Parker; point, on the west shore of Admiralty island, Chatham strait, Alexander archipelago. So named by Vancouver, 1794.

l'arlor, harbor; see Pavlof.

I'aroshki, bay; see No Thorofare.

Parsons; peak (5,500 feet high), near head of Taiya inlet, southeast Alaska. So named by the Coast Survey in 1897 .

Partennoi; point, on the western shore of Chichagof island, near entrance to Ilin bay, Alexander archipelago. So named by mate Ilin early in the nineteenth century.

Partof; bay, indenting the southern shore of Umnak, near Vsevidof volcano. Called Partovaia (party) by Kuritzien, 1849. Veniaminof and Lutke call it Glubokoi (deep) bay.

Partof; point, the extereme southeastern point of Partofshikof island at junction of Neva strait and Krestof sound, Alexander archipelago, near latitude $57^{\circ} 14^{\prime}$, longitude $135^{\circ} 34^{\prime}$. Name so applied by Moore, 1897 .

Partofshikof; island, between Baranof and Kruzof islands, Alexander archipelago. Named Partofshikof (party) by the Russians. Variously written Partoffschilioff, Partovstchikoff, etc.

Party; cape, the northwestern point of Shuyak island, Kodiak group. Named Partie (party) by the Russian-American Company, 1849. 
Pasco; creek, tributary to Middle fork of the Koyuluk from the south, near latitude $67^{\circ}$. Prospector's' name, from Schrader, 1899.

Paso; point, in Umnak strait, near the western end of Unalaska, eastern Aleutians. So named by the Fish Commission in 1888.

Pass; creek, tributary to the Kotsina from the south. Descriptive name, given by Schrader, 1900 .

Pass; creek, Kenai peninsula, tributary from the west to Canyon creek, a branch of Sixmile creek, near latitude $60^{\circ} 45^{\prime}$, longitude $149^{\circ} 30^{\prime}$. Local descriptive name, reported by Moffit in 1904.

Pass; creek, Kenai peninsula, tributary from the east to Resurrection creek, near latitude $60^{\circ} 50^{\prime}$, longitude $149^{\circ} 40^{\prime}$. Local descriptive name, reported by Becker in 1895.

Passage; canal, or arm, in the northwestern párt of Prince William sound, from which there is a portage to Turnagain arm of Cook inlet, about latitude $60^{\circ} 47^{\prime}$, longitude $148^{\circ} 20^{\prime}$. Called Passage by Vancouver in 1794. Has recently, been called Portage bay.

Passage; group of islands, at entrance to Middle channel into Sitka harbor, Sitka sound, Alexander archipelago. Named Prokhoda (passage) by Vasilief, 1809. Has also been written Prokodi. Tebenkof calls them Goloi (bare).

Passage; island, in Graham harbor, Cook inlet. So named by Portlock, 1786.

Passage; island, northeast from Sannak, between Deer island and the Sandman reefs. So called by the Fish Commission in 1888.

Passage; islet and point, in Mitchell bay, Kootznahoo inlet, Admiralty island, Alexander archipelago. So named by Meade, 1869.

Passage; islet between Kodiak and Spruce islands, Kodiak group. Named Prikboda (passage) by .Tebenkof, 1849.

Passage; rock, near the entrance to Tongass harbor, Alexander archipelago. So named by Nichols in the Coast. Pilot (1891, p. 79).

Passage; sunken rock, in the entrance to Lituya bay, southeastern Alaska. So named by Dall, 1874.

Pastol; open bay, between St. Michael and the main mouth of the Yukon, near latitude $63^{\circ} 10^{\prime}$.: Eskimo name, from the Russians, 1852 . Also written Pastole, Pastoli, and Pastolik.

Pastoliak; river, tributary to Pastol bay, Norton sound, western Alaska, near latitude $63^{\circ}$, longitude $163^{\circ} 13^{\prime}$. Eskimo name, from Tebenkof, 1849.

Pastoliak; Eskimo village, on the right bank of Postoliak river, a few miles above its mouth, on southern shore of Norton sound. Native name, from Tebenkof, 1849. It is, or rather was, for it is not shown on late maps, a few miles north of Pastólik, with which it should not be confounded. Dall writes it Pastoliák.

Pastolik; river, tributary to Pastol bay, at the Apoon mouth of the Yukon, western Alaska, near. latitude $63^{\circ}$, longitude $163^{\circ} .20^{\prime}$. Called Pastol by Tebenkof, 1849. Eskimo name, pronounced Pas-tố-lik.

Pastolik; Eskimo villạge, on the right bank of Pastolik river, a few miles above its moutb. Population in 1890, 113.

Pathfinder, channel; see Avatanak strait.

Patterson; bay, Hooniah soụnd, Chichagof island, Alexander archipelago, southeastern Alaska. Name published by the Coast Survey in 1900.

Patterson; bay, on the southeastern shore of Baranof island, Chatham strait, Alexander archipelago, near latitude $56^{\circ} 35^{\prime}$, longitude $134^{\circ} 40^{\prime}$. Named by the Coast Survey, after its surveying steamer Patterson. 
Patterson; creek, Seward peninsula, tributary to Candle creek from the west, near latitude $65^{\circ} 50^{\prime}$, longitude $162^{\circ}$. Prospectors'. name, reported by Witherspoon, 1903.

Patterson; creek, on the north bank of the Tanana at Harper bend, 20 miles above its mouth, near longitude $151^{\circ} 30^{\prime}$. So named by Lieut. George $\mathrm{S}$. Gibbs, Signal Corps, U. S. A., 1902, probably after H. W. Patterson, who was associated with him in making a map of the Tanana.

Patterson; glacier, on the mainland, east of Frederick sound, southeastern Alaska. So named by Dall, 1879, after Carlile Pollock Patterson, the then Superintendent of the Coast Survey.

Patterson; island, in the entrance to Kasaan bay, Clarence strait, Alexander archipelago. So named by Clover, 1885 , after the Coast Survey steamer Patterson.

Patterson; peaks (4,746 and 4,848 feet high), near Patterson glacier, southeastern Alaska. So named by Thomas, 1887.

Patterson; point, west shore Chatham strait, being the north point at entrance to Patterson bay (above). So described in the Coast Pilot of 1901.

Paul; island, off the southern shore of Alaska peninsula, northeast of the Shumagins. Named St. Paul by Woronkofski, 1837.

Paul; lake, draining into Port Johnson, southeastern shore Prince of Wales island, Alexander archipelago, near latitude $55^{\circ} 08^{\prime}$, longitude $132^{\circ} 05^{\prime}$. Local name, reported by Brooks, 1901.

Pauline; creek, Seward peninsula, tributary to Holtz creek from the east, near latitude $65^{\circ} 32^{\prime}$, longitude $162^{\circ}$. $30^{\prime}$. Prospectors' name, reported by Witherspoon, 1903.

Pavlof; bay, indenting the southern shore of Alaska peninsula, west of the Shumagins. Named Pavlofskie (Paul) by the Russians. Variously spelled. Its Aleut name is Tachik or Tatschik.

Pavlof; harbor, indenting the northern coast of Sannak, near longitude $162^{\circ} 45^{\prime}$. Called Pavloff by the Fish Commission in 1888. Also designated "Cove."

Pavlof; harbor, in Freshwater bay, Chichagof island, Chatham strait, Alexander archipelago. Named Pavlof (Paul) by Tebenkof, 1849. Has also been called. Pablof and, erroneously, Parlor. Its native name is said to be Nasanki. Meade, 1869, made a sketch of it and published it with the name Freshwater bay. This name Freshwater is now applied to the whole inlet and Pavlof to the anchorage within it. See Freshwater:

Pavlof; group of islands, near Belkofski, consisting of Long, Goloi (bare), Ukolnoi (coal), Poperchnoi (crosswise), and Wosnesenski. Its Aleut name, according to Veniaminor, is Kadugin (narrow).

Pavlof; villagè, at Selenie point, Pavlof bay, Alaska peninșula. Called Pavlovsk by Petrof, 1880.

Pavilof; active volcano, on the Alaskan peninsula, west of the Shumagins, near longitude $162^{\circ}$ : Named Pavlof (Paul or St. Paul) by the Russians.

Paviovskaia, village; see Kenai.

Pavlovski, town; see Kodiak.

Pawik; Eskimo village, on the eastern side of Bristol bay, Bering sea. Also written Pawig. The name Pawik was obtained by Spurr and Post, 1898, from Fritz Blando, a resident. Apparently this is the Pakwik of the Eleventh Census, 1890.

Paxson; creek and flats, on the north side of the Tanana, near longitude $143^{\circ} .30^{\prime}$. So called by Lịeutenant Mitchell, Signal Corps, U. S. A., 1902. 
Peabody; mountains (4,000 to 5,000 feet high), on the western shore of Portland canal. So named by Pender, 1868.

Peacock; ereek, tributary to the Kotsina from the south. Apparently a prospector's name, reported by Schrader, 1900.

Peak; island, one of the Naked islands, Prince William sound, north of Naked island, near latitude $60^{\circ} 45^{\prime}$, longitude $147^{\circ} 20^{\prime}$. Occupied as a bluefox farm. Local descriptive name, published in 1900 . Either this island or Storey island is called also Little Naked.

Peak; point, on the north shore of St. Matthew island, near its eastern end. Named Pik (peak) by. Sarichef in his atlas of 1826.

Peaked; island, off the western end of Attu island, western Aleutians. Apparently so named by Gibson, 1855.

Peard; cliff, on the southern shore of Peard bay, Arctic coast. Presumably so called by the British Admiralty as early as 1855 .

Peard; open bay, on the Arctic coast, between the Seahorse islands and Point Barrow. Named by Beechey, August, 1826, after his first lieutenant, George Peard. Often written Pearl and on one chart Pedrl.

Pearl, bay ; see Peard.

Pearl; island, one of the Chugach islands, near Cape Elizabeth, Kenai peninsula. Occupied by the Alaska Fox Company for the propagation of blue foxes. Local name, ręported by the Harriman expedition, 1899 (vol. 2, p. 360). Called also Middle Chugach island.

Pearl; point, in the eastern part of Bucareli bay, Prince of Wales archipelago. Named Punta de Perlas (point of pearls) by Maurelle and Quadra, 1775-1779.

Pearse; canal, north of Pearse island, Alexander archipelago. So named by Pender, 1868.

Pearse; island (British), at mouth of Portland canal, Alexander archipelago, near latitude $54^{\circ} 50^{\prime}$, longitude $130^{\circ} 20^{\prime}$. So named by Pender, 1868.

Peavey; mining camp, on Peavey slough, on the right bank of the Koyukuk, near the Arctic circle and longitude $152^{\circ}$. It is also called Peavy and Peavy Trading Post.

Peavey; slough, on the right bank of the Koyukuk, just above the Arctic circle, near longitude $152^{\circ}$. Peavey mining camp is located on this slough. Local name, published in 1902.

Pedersen; point, the southeastern point of Moser island, Hooniah sound, Peril strait, Alexander archipelago. Name, till now unpublished, given by Moore in $\mathbf{1 8 9 5 .}$

Pedersen, point; see Suworof cape.

Pedrl, bay ; see Peard.

Pedro; creek, in the Fairbanks region, tributary to the headwaters of Goldstream creek, near latitude $65^{\circ}$, longitude $147^{\circ} 30^{\prime}$. Named after Felix Pedro, who discovered gold on this creek in 1902-the first in the Fairbanks field.

Pedro Dome; mountain, in the Fairbanks region, near latitude $65^{\circ}$, longitude $147^{\circ} 30^{\prime}$. Local name, reported by Gerdine, 1903.

Feerleshin, mountain ; see Pereleshin.

Peirce; cape; a little east of Cape Newenham, on the north shore of Bristol bay. Named Peirce, 1869, by the Coast Survey, after Prof. Benjamin Peirce, then Superintendent of the Coast Survey. Tebenkof calls it Peschera (cave) point. Perbaps it is Calm point of Cook in 1778 . See Galm.

Peirce; mountain (more than 2,000 feet high), on the northern part of Nagai island, Shumagin group. So called by Dall, 1872, after Prof. Benjamin Peirce, then Superintendent of the Coast Survey. 
Peisar; island, in the southeastern part of Sitka souud, Baranof island, Alexander archipelago. Named Peisar (writer) by Vasilief, 1809. Pronounced Pé́-sar.

Peklawik; river, Yukon delta, an aftluent of Black river on the right bank, near latitude $62^{\circ} 18^{\prime}$, longitude $164^{\circ} 55^{\prime}$. Eskimo name, obtained by. Putnam in 1899.

Pektotolik; slough, Yukon delta, opening on the left bank of Kwikluak pass, 12 miles below the head of the delta, near latitude $62^{\circ} 40^{\prime}$, longitude $164^{\circ}$ 07'. Eskimo name, obtained by Putnam in 1899.

Pelenga, point; see Azimuth.

Peligro, Isla del; see Kalgin island.

Pellew; point, on the northern shore of Prince William sound. So named by Vancouver, 1794 .

Pelly; mountains (5,000 to 7,000 feet high), lake, and river, Yukon, Canada. Named after a former governor of the Hudson Bay Company.

Pelly, mountains; see Romanzof.

Peloziklella; mountains, on the north bank of Yukon river, near mouth of Melozi river. Name published by the Coast Survey in 1898. Perhaps this should be Melozidlela, i. e., Melozi mountain. See also Melozikakat mountains.

Peluk; creek, just south of Port Clarence, Seward peninsula. Native name, from Barnard, 1900.

Peluk; creek, on the south shore of Seward peninsula, $1 \frac{1}{2}$ miles east of Nome, near longitude $165^{\circ} 20^{\prime}$. Native name, published in 1904 .

Peluk; creek, tributary to Noxapaga river from the north, Seward peninsula. Native name, from Brooks, 1900.

Penelope; creek, tributary to Casadepaga river from the south, Seward peninsula. Name from Barnard, 1900.

Penguin; creek, on the north side of Turnagain arm, Cook inlet, a left branch of Bird creek, near latitude $61^{\circ}$, longitude $149^{\circ} 35^{\prime}$. Local name, reported by Herron, 1899.

Penilkl, islet; see Pinnacle.

Peninsula; island ( 800 feet high), near the northwestern shore of Big Koniuji island, Shumagin group. So named by Dall, 1875.

Peninsula (The); isolated hill, neil east bank of Copper river, just north of Bremner river. Șo named by Abercrombie, 1898.

Peninsula; point, on Revillagigedo island, south side of Ward cove, Tongass narrows, Alexander archipelago, near latitude $55^{\circ} 23^{\prime}$, longitude $131^{\circ}$ 44'. Local name, given by the pilots.

Peninsula; ridge of mountains, on the mainland, between Boca de Quadra and Dixon entrance, southeastern Alaska. So named by Nichols, 1883.

Peninsula Bluff; cape, the northern point of entrance to Albatross anchorage, Portage bay, Alaska peninsula. So named in 1893.

Peninsular; point, on the southeastern shore of Chichagof island, opposite Kootznahoo, Chathaim strait, Alexander archipelago. This name, which is descriptive, first appears in the Coast Pilot of 1891 (p. 162).

Pennock; island, at the south end of Tongass narrows, Alexander archipelago. So named by the pilot W. E. George.

Pennock; reef, off the northwestern end of Pennock island, 'Tongass narrows, Alexander archipelago. So named by Dall, 1883. Called also Pennock Island reef.

Penny; creek, tributary to Solomon river from the north, Seward peninsula. Name from Barnard, 1900. 
Penny; river; in the Nome mining region, Seward peninsula. Local name, given by prospectors in 1898 . Was also called by Schrader No Name river.

Pentecost, cape; see Izbut.

Pepper; point, the southern point of entrance to Port Asumcion, Bucareli bay; Prince of Wales archipelago. Named Punta de la Pimienta (pepper point) by Maurelle and Quadra, 1775-1779.

Percebes; point, the easternmost point of San Juan Bautista island, 'Bucareli bay, Prince of Wales archipelago. Named Punta de Percebes by Maurelle and Quadra, 1775-1779.

Percy; group of islands, at junction of Felice and Clarence straits, Alexander archipelago. So named by Dall in the Coast Pilot ( 1883, p. 83$)$.

Percy; point, the westernmost point of the Percy islands, Clarence strait, Alexander archipelago. So named by Vancouver, 1793.

Perdidos, Rio de los; see Copper river.

Peregrebni; cape, in Kizhuyak bay, on the northern coast of Kodiak. Named Peregrebnie (passable, i. e., a point which can be rowed past) by the Russians.

Peregrebni, islands ; see Barren.

Peregrebny, island; see Wosnesenski.

Pereleshin; mountain, on the mainland, east of the Stikine river and near the international boundary. Native name, from the Coast Survey. Has been written Peerleshin and Pereleshin, i. e., Pereles river.

Perenosa, point; see Portage:

Perenosnaia, bay or creek; see Portage.

Peresheechnai, island; see Isthmus.

Perevainoy, inlet; see Carry.

Perevalnie; islet, at the north end of Shuyak island, Kodiak group. Named Perevalnie (wallowing) by the Russians. It has been translated Portage.

Perewumno, inlet; see Carry.

Perez, Entrada de; see Dixon Entrance.

Perignak; Eskimo summer camp, on the western shore of Elson bay, near Point Barrow. Native name, from English naval officers in the Franklin search expeditions, 1849-1853, who wrote it Pergniák. Ray, 1885, writes it Perignax.

Peril; strait, separating Baranof island from Chichagof island, Alexander archipelago. This strait derives its name from the circumstance that on its shores, in 1799, a large number of Aleuts (said to be 150) perished from eating poisonous mussels. Lisianski, who reports this story, calls it Pagoobnoy. or Pernicious strait. The later Russian charts call it Pogibshie (peril or perisbing) strait.

Perkinsville; railroad station and mining camp, 4 miles north of Nome, Seward peninsula, near longitude $165^{\circ} 2 \overline{5}^{\prime}$. Name from Gerdine, 1904.

Perpendiculaire, cape; see Upright.

Pernicious, strait; see Peril.

Perrier, pass; see Chilkoot.

Perry, creek; Seward peninsula, tributary from the west to Pinnell river, which is a branch of the Inmachuk river; near latitude $65^{\circ} 50^{\prime}$, longitude $163^{\circ} 05^{\prime}$. Prospectors' name, reported by Witherspoon, 1903.

Perry; island, in the northwestern part of Prince William sound, near Point Culross. Local name, published by the Coast Survey; 1900. Has been occupied since 1897 as a blue-fox farm by "Kendall \& Steamy," and was called Stamie island by Schrader, 1900. See Stamie. 
Perwie porogi; see Northern rapid.

Peschani; point, on the northeastern shore of Duffield peninsula, Peril strait, Alexander archipelago. Named Peschani (sandy) by Vasilief, 1833. Has also been called Pestchani, Sandy, and, by mistranslation, Stony.

Peschani, island ; see Galankin.

Peschani, point; see Halibut.

Peschanie, cape, etc.; see Sand.

Peschanie, island; see Pyramid.

Peschera, cape; see Peirce.

Pesiak, island; see Gravel.

Pestchanaia, harbor; see Martin.

Pestchanay, bay; see Sandy.

Pestchanoe, point and lake; see Icehouse.

Pestchani, island; see Pyramid.

Pestriakof. The Russian-American Company map of 1849 shows a village on the south shore of Spruce island, Kodiak group, called Pestriakova (of eider duck) settlement.

Pestriakof, anchorage; see Eider.

Pestsovaia, bay; see Blue Fox.

Pete Dahl; slough, in the Copper river delta, between Alaganik slough and Castle Island slough, near latitude $60^{\circ} 23^{\prime}$, longitude $145^{\circ} 23^{\prime}$. Local name, reported by Moser, 1897.

Petelin; mountain, near Katmai bay, Alaska peninsula. So named by Spurr and Post, 1898, after missionary A. Petélin.

Peter. Johnson; stream, southeastern shore Prince of Wales island, Alexander archipelago, on the north shore of Port Johnson and draining. Paul, James, and John lakes, near latitude $55^{\circ} 05^{\prime}$, longitude $132^{\circ} 03^{\prime}$. So called by the fisheries, and reported by Moser, 1897.

Peters, glacier; see Hanna.

Peters; point (Point Peters), the sonthern point of Deer island, Ernest sound, Alexander archipelago, near latitude $56^{\circ}$, longitude $132^{\circ}$. Name obtained from local navigators by Fassett, Bureau of Fisheries, 1904 .

Petersburg;. Post-office, at north end of Wrangell strait, on north end of Mitkof island, Alexander archipelago. Established March, 1899.

Peterson; bay, indenting the southeastern shore of Sannak island, near longitude $162^{\circ} 37^{\prime}$. So called by the Fish Commission in 1888. Perhaps this is identical with King cove of Dall in 1880.

Peterson; creek, on the eastern shore of Favorite channel, Lynn canal, southeastern Alaska, near latitude $58^{\circ} 30^{\prime}$. Prospectors' name, reported by Spencer and Wright in 1903.

Peterson; creek, tributary to Turnagain arm of Cook inlet from the north, near latitude $61^{\circ}$, longitude $149^{\circ}$. Local name, from Herron, 1899.

Peterson, creek ; see Slate.

Peterson; island, 3 miles south of Peterson bay, south shore of Sannak island. So named by Westdahl, 1901.

Petitski, island; see Bird.

Petkas Point, native village; see Pitkas Point.

Petmegea, river; see Pitmegea.

Petrel; island, one of the Chiachi islands, off southern shore of Alaska peninsula. So named by Dall, 1875.

Petrel; point, on the western shore of Portland canal. So named by the Coast Survey in 1895.

Petrie's, strait ; see Shelikof: 
Petrof; falls, Nogheling liver, Alaska peninsula, a few miles above Iliamna lake, near latitude $60^{\circ}$, longitude $155^{\circ}$. Name from Osgood, 1902 (pp. 11, 12), who wrote it Petroff.

Petrof; point, the westernmost point of Sannak island, near latitude $54^{\circ} 30^{\prime}$, longitude $162^{\circ} 50^{\prime}$. Named Petrova (Petrof's) by Tebenkof in 1849.

Petsika; creek, tributary to Koyukuk river on the right bank, 4 or 5 miles above Dagitli river, near latitude $65^{\circ} 30^{\prime}$, longitude $156^{\circ} 40^{\prime}$. Probably Indian name, written Ptseka on an unpublished chart of the Koyukuk, made by Lieutenant Camden, U. S. R. M., 1900.

Peulik; mountain, between Becharof lake and the Ugashik lakes, Alaska peninsula, near latitude $58^{\circ}$, longitude $156^{\circ}$. Called Smoky mountain or Mount Peulik by Osgood, 1902. Peulik is said to be Aleut for smoking or smoking mountain.

Phaier-veder, mountain; see Fairweather.

Phelan; creek, tributary to Delta river from the east. So named by Glenn, 1898.

Philadelphia; mountain, near George inlet, Revillagigedo island, Alexander archipelago. So named by Nichols, 1883.

Philkhtulik, lake; see Pilktulik.

Phipp; point, on the northwestern shore of Wales ișland, Dixon entrance. 'So named by the Coast Survey in 1891.

Phipps; peninsula, at the southern entrance to Yakutat bay, southeastern Alaska. Dixon, in 1787, named some point on its shore for Hon. Constantine John Phipps, Baron Mulgrave. (See Coast Pilot, p. 206.) There has been some confusion in the application of this name, it being the same as Carrew and Morskoi (ocean or sea) of some charts. Has been misprinted Phips.

Phipps, point; see Carrew.

Phoebe; creek, tributary to Bettles river from the east, near longitude $149^{\circ}$. Prospector's' name, from Schrader; 1899.

$P i$, island; see Pye.

Piatidesiatnitzi, cape; see Izhut.

Pick; river, northwestern Alaski, tributary to Kobuk river from the south, near latitude $66^{\circ} 45^{\prime}$, longitude $157^{\circ}$. Called Pick or She-kluck-she-uck by Stoney, 1886.

Pickarts; coal mine, on the right bank of Yukon river, 12 miles above Nulato near latitude $64^{\circ} 50^{\prime}$, longitude $158^{\circ}$. Local name, after Frank Pickarts, the owner, published in 1899. Lrroneously Picketts.

Pickarts; creek, tributary to Koyukuk river from the north, near Arctic City. Named, 1899, after Pickarts, of the firm of Pickarts, Bettles \& Pickarts, owners of the trading post Bergman.

Picketts, coal mine; see Pickarts.

Piedras, Isla de; see Rocky island.

Piedras; point, the eastern point of entrance to Rurik harbor, Khantaak island, Yakutat bay. Named Punta de las Piedras (point of rocks) by Malaspina, 1791.

Piedras Blancas, rocks; see White.

Pietmielctaligmiut, village; see Pikmiktalik.

Pigeon; island, in Port Real Marina, Bucareli bay, Prince of Wales archipelago. Named Ysla de Palomas (island of pigeons) by Maurelle and Quadra, 1774-75.

Pigot; point, the western point of entrance to Port Wells, Prince William sound. So named by Vancouver, 1774. Erroneously Piqot.

Pik, point; see Peak. 
Pikmiktalik; river, 25 miles southwest of St. Michael, western Alaska, near latitude $63^{\circ}$ 15'. Eskimo name, from the Russians, who wrote it Pietmiektalik.

Pikmiktalik; Eskimo village, near the mouth of Pikmiktalik rivel, about 25 miles to the southwest of St. Michael, western Alaska. Native name, from the Russians, who wrote it.Pietmiektaligmiut. Nelson wrote it Pikmiktalik. The termination talik or tulik means place or region where anything abounds.

Pile; island, at the head of Mitchell bay, Kootznahoo inlet, Admiralty island, Alexander archipelago, near latitude $57^{\circ} 30^{\prime}$, longitude $134^{\circ} 25^{\prime}$. Local name, reported by Wright in 1903.

Pilgrim, river; see Kruzgamepa.

Pilktulik; lake, on the portage between the Yukon and Kuskokwim rivers. Raymond, 1869, reports its name as Philkh Tulik (Philk region) and later maps write Philkhtulik.

Pillar, bay; see Pillars, Bay of.

Pillar; cape, in Kizhuyak bay, on north coast of Kodiak. Named Kekurnoi (pillar) by the Russians.

Pillar, cape; see Bold.

Pillar; cape, the eastern point of entrance to Izhut bay, on the southeastern shore of Afognak island, Kodiak group. This may be Cape Whitsunday of Cook in 1778. Called by the Russians Kekur (pillar).

Pillar; hill or mountain (1,491 feet high), very near the town of Kodiak. A note on the old Russian chart made by Russian naval officers in 1808-1810 says: "On (this) mountain a pillar rises 150 fathoms above sea level." On the Coast Survey chart of 1869 this hill was called Pillar mountain.

Pillar; point, on the eastern shore of Wrangell island, Arctic ocean. So named by Berry, 1881, who shows a rock near it.

Pillar; rock, northwest from Kiska, Rat island group, western Aleutians. The Russians designated it as Viesokie kamen (high rock) ; Tebenkof, 1849, calls it Stolb (pillar), and the North Pacific exploring expedition, 1855, called it Pillar rock.

Pillars, Bay of; bay, indenting the western shore of Kuiu island, Chatham strait, Alexander archipelago. Descriptive name, published by Dall in the Coast Pilot (1883, p. 120).

Pillars (The); high rocks, off the southern shore of Umnak, eastern Aleutians. Local name, from the Russians.

Pillsbury; point, in Kootznahoo inlet, Admiralty island, Alexander archipelago. So named by Meade, 1869, after Lieut. Commander John Elliott Pillsbury, U. S. N., a member of his party.

Pilot; creek, a tributary of Chatanika river from the south, near latitude $65^{\circ} 05^{\prime}$, longitude $147^{\circ} 25^{\prime}$. Local name, reported by Gerdine, 1903.

Pilot; point, on the southeastern shore of Hemlock island, Port Chester, Annette island, Alexander archipelago. So named by the Coast Survey in 1896.

Pilot; rock, southwestern side of entrance to Resurrection bay, Kenai peninsula, near latitude $59^{\circ} 44^{\prime}$, longitude $149^{\circ} 28^{\prime}$. So named by the U. S. Board on Geographic Names, June 6, 1906.

Pilot Station; Eskimo village, Alaska peninsula, on the right bank of Ugashik river, 6 miles above its mouth, near latitude $57^{\circ} 30^{\prime}$. "An Eskimo formerly lived in the village who piloted vessels through the channel, hence the name, Pilot Station." (Moser, 1900.)

Pimeut, Eskimo village; see Paimiut.

Bull. 299-06 $\mathrm{M}-32$ 
Pimienta, Punta de la; see Pepper point.

Pimute, Eskimo village and slough; see Paimiut.

Pin; peak (1,300 feet high), on the northwestern shore of Coronation island, Alexander archipelago. So named by Snow, 1886.

Pin; peaks, on the mainland, east of Frederick sound, southeastern Alaska. So named by Thomas, 1887.

Pin; point, on Liesnoi island, at entrance to Eliza barbor, Frederick sound, Alexander archipelago. So named by Mansfield, 1889.

Pinal, Punta del; see Pinegrove point.

Pine; creek, tributary to Red bay, Prince of Wales island, Alexander archipelago. So named by Helm, 1886.

Pine; creek, just east of mouth of Solomon river, Seward peninsula. Name from Barnarö, 1900.

Pine; creek, tributary to Niukluk riyer from the south, in the Eldorado mining district, Seward peninsula. Local name, published in 1900. Has also been called Foster creek.

Pine; island and point, in Port Real Marina, Bucareli bay, Prince of Wales archipelago. Named Punta y Ysla del Pino by Maurelle and Quadra, 1775-1779.

Pine, island ; see Spruce.

Pine; point, the eastern point of entrance to Red bay, Prince of Wales island, Alexander archipelago, near latitude $56^{\circ} 20^{\prime}$, longitude $133^{\circ} 16^{\prime}$. So named by Helm, 1886.

Pinegrove; point, on San Fernando island, Bucareli bay, Prince of Wales archipelago. Named Funta del Pinal (pine grove) by Maurelle and Quadra, 1775-1779.

Pinekl, islet; see Pinnacle.

Pine Tree; islet, in Sawmill cove, Howkan narrows, Alexander archipelago. So named by Sheldon Jackson, 1880.

Pingingaluk; river, northern Alaska, tributary to headwaters of Alatna river from the north, near latitude $67^{\circ} 30^{\prime}$, longitude $154^{\circ}$. Eskimo name, obtained by Stoney, 1886, who wrote it Ping-ing-a-look. Erroneously Ringingaluk.

Pingolee; low sandy island, off the mouth of Dease inlet, Arctic ocean. Apparently so named by the British Admiralty.

Pingoshugarun, village; see Pinoshuragin.

Pinguk; river, Seward peninsula, flowing northwest and debouching in a lagoon on the Arctic coast, near latitude $65^{\circ} 50^{\prime}$. Eskimo name, obtained by Gerdine, 1901.

Pinik, islets; see Punuk.

Pinnacle, cape; see Kekurnoi.

Pinnacle; volcanic islet (930 feet high), south of St. Matthew island, Bering sea. Descriptive name, given by Cook in 1778. Variously Pinekl, Penikl, Pinacle, etc. Lutke calls it Île des Tours (towers) or Îles des Flêches (spires).

Pinnacle; mountain, 30 miles northeast of Knik arm, Cook inlet, on south bank of Matanuska river, near latitude $61^{\circ} 40^{\prime}$, longitude $148^{\circ} 40^{\prime}$. Local name, reported by Martin, 1905.

Pinnacle; pass, in the St. Elias alpine region. Descriptive name, given by Russell in 1890.

Pinnacle; peak, Alaska peninsula, at the head of Herendeen bay, near longitude $160^{\circ} 45^{\prime}$. Descriptive name, published by the Coast Survey in 1900. 
Pinnacle; point, on the northwestern shore of Nagai island, Shumagin group. It is the north head of the nameless bay at the head of which is Sanborn harbor. So called by Dall, 1872. Descriptive name.

Pinnacle; sunken rock, near Cape Fox, in Dixon entrance. Shown on British Admiralty charts and in 'Tebenkof's atlas. Called Pinnacle rock on Hydrographic chart 225. Its existence is denied by local navigators.

Pinnacle; rock, off Entrance point, Hooniah harbor, Port Frederick, Alexander archipelago. So named by United States naval officers, 1880.

Pinnacle; rock, in entrance to Pavlof harbor, Freshwater bay, Chatham strait, Alexander archipelago. So named by Meade, 1869.

Pinnacle; rock, off Cape St. Ilias, south end Kayak island, Controller bay, Gulf of Alaska, near longitude $144^{\circ} 33^{\prime}$. So described by Pratt, 1903.

Pinnacle; rock, in the Chiachi group of islands, off south shore of Alaska peninsula. So named by Dall, 1875.

Pinnacle; rock, in Chignik lagoon, Chignik bay, Alaska peninsula. So named by Moser, 1897.

Pinnacle; rock, on the southwestern edge of the Sandman reefs, northeast of Sannak. Designated as Kekur (pillar) by Tebenkof, 1849; as Pinnacle by Dall, 1.880, and later called Pinnacle rock.

Pinnacle, rock; see Second Priest.

Pinnacle; rock, on the southern shore of Akun island, Krenitzin group, eastern Aleutians, near longitude $165^{\circ} 34^{\prime}$. Descriptive name, from Gilbert, 1901.

Pinnacle Pass; cliff, forming the north wall of Pinnacle pass, St. Elias alps, southeastern Alaska. So named by Russell, 1890.

Pinnacles. Between Unga island, Shumagin group, and Wosnesenski island, Tebenkof shows some rocks called Kekuri (pillars). These appear on Còast Survey chart 806 (1.882), with the designation Pinnacles, but are not found on later charts.

Pinnell; river, Seward peninsula, the principal tributary of Inmachuk river, on the right bank, 15 miles south of Kotzebue sound, near longitude $163^{\circ}$. Named after Jesse Pinnell, a miner of Nome, and reported by the Geological Survey parties in 1901. Erroneously Pannell.

Pinoshuragin. Petrof, 1880, shows a native village of this name (population 29) on the Seahorse islands. On British Admiralty chart 593 (ed. of 1882 ) it is called Pingoshugarun.

Pinta; cove, on the eastern side of Point Adolphus, south shore of Icy strait, Alexander archipelago, near longitude $135^{\circ} 46^{\prime}$. ' So named by Dickins, 1901.

Pinta; head, on Baranof island, near Southern rapids, Peril strait, Alexander archipelago, So named by Coghlan, 1884, after the U. S. S. Pinta.

Pinta; mountain (5,000 feet high), northeast of Yakutat bay, southeastern Alaska. So named by Russell, 1891, after the U. S. S. Pinta.

Pinta; peak, on the mainland, near Farragut bay, southeastern Alaska. So named by Thomas, 1887, after the U. S. S. Pinta.

Pinta; rock, at the entrance to Port Frederick, south shore Icy strait, Alexander archipelago, near longitude $135^{\circ} 27^{\prime}$. So named by Dickins, 1901.

Pinta; rocks, off Cape Bendel, Frederick sound, Alexander archipelago. Named by the Coast Survey, after the U. S. S. Pinto.

Pinusuk; island ( 850 feet high), one of the Chiachi group, on southern shore of Alaska peninsula. Native name, obtained by Dall, 1875 .

Pio; point, at head of Woewodski harbor, Frederick sound, Alexander archipelago. So namẹ by Mansfield, 1889. 
Pioneer; coal mine, on the right bank of the Yukon, 25 miles above Rampart (city), near longitude $150^{\circ}$. Local name. Cantwell, 1900, called it Pioneer and in one place. Tom Drew mine; Collier, 1902, called it Drew mine, and adds: "Has been known as the Pioneer mine and the Miller mine."

Pioneer; creek, flowing southwest from near the headwaters of Minook creek to Baker flat, along Tanana river, near latitude $65^{\circ}$, longitude $150^{\circ} \cdot 10^{\prime}$. Prospectors' name, reported by Prindle, 1904.

Pioneer; gulch, 15 miles north of Nome, Seward peninsula, on the west bank of Snake river at its head; near latitude $64^{\circ} 42^{\prime}$, longitude $165^{\circ} 25^{\prime}$. Miners' name, reported by Gerdine, 1904.

Pipe; spit, the innerr point on south side of entrance to Hotham inlet, Kotzebue sound, near latitude $66^{\circ} 55^{\prime}$, longitude $162^{\circ} 10^{\prime}$. Descriptive name, given by Stoney, 1885 .

Piper; island, at entrance to Schulze cove, Fish bay, Peril strait, Alexander archipelago. So named by United States naval officers, 1880. Family name.

Piqot, point; see Pigot.

Pirate; cove, on the northeastern shore of Popof island, Shumagin group. Local name, based on the reputation of the place. In use as early us 1880.

Pirate; point, on the southeastern shore of Pearse island, Portland inlet. So named by the Coast Survey in 1891.

Pirate; peak .(3,289 feet high), on the mainland, near Thomas bay, southeastern Alaska. So named by Thomas, 1887, after his steam launch.

Pirie; point, on the eastern shore of Portland canal. So named by Pender, 1868.

Pisa Tower; rock, near the entrance to Chichagof harbor, Attu island, western Aleutians. So named by Gibson, July, 1855.

Pish; river, Seward peninsula, tributary to Goodhope bay from the southwest. Native name, reported by Witherspoon, 1903, as Pish or Kutuk.

Piskuk; mountain peak, near the head of Togiak river, western Alaska. Eskimo name, obtained by Spurr and Post, of the Geological Survey, who passed near it September 13, 1898. They write it Pískuk.

Pitak; island, one of the Necker group, Sitka sound, Alexander archipelago. So called by Vasilief, 1809.

Pitkas; bar, gold bearing, on Birch creek at the junction of Harrison creek. Discovered in $1893 . \quad$ Reported by Schrader, 1896.

Pitkas Point; native village of 75 Eskimos, and branch trading post, on the right bank of Yukon river, at the mouth of Clear river, 2 miles below Andreafski, near latitude $62^{\circ} 05^{\prime}$, longitude $163^{\circ} 30^{\prime}$. Called Petka's Point by the Coast Survey in 1898 . "The trader is a half-breed Russian named Pitka, and his store is a branch of the Northern Commercial Company's station at Andreafski." (Cantwell, 1900.)

Pitmegea; river, tributary to the Arctic ocean, at Cape Sabine, about latitude $69^{\circ}$. Eskimo name, published in 1890 . Has been written Petmegea and Pitmigea.

Pitmiktalik, native village; see Pikmiktalik.

Piton, mountain; see Malaspina.

Pitt, cape; see Muzon.

Pitt; island, in Hooniah harbor, Port Frederick, Icy strait, Alexander archipelago, near longitude $135^{\circ} 30^{\prime}$. So named by United States naval officers, 1880. In Hydrographic Office notice 97, 1880, it is called Harbor island. 
Pitt, island; see Kruzof.

Pitt; point, the eastern point of entrance to Smith bay, east of Point Barrow, Arctic coast. So named by Dease and Simpson, 1837.

Pittsburg; creek, tributary to Middle fork Fortymile creek from the north. near latitude $64^{\circ} 30^{\prime}$, longitude $142^{\circ} 50^{\prime}$. Prospectors' name, reported by Gerdine, 1903.

Placer; creek, Seward peninsula, tributary to Goodhope river from the south, near latitude $65^{\circ} 45^{\prime}$, longitude $163^{\circ} 50^{\prime}$. Prospectors' name, reported by Gerdine, 1901.

Plain; mountain (2,035 feet high), in California ridge, Gravina island, Alexander archipelago. So named by Nichols, 1883.

Platte, islet; see Flat.

Platinum; creek, in the Mount Wrangell region, tributary to Nabesna river from the west. So named by prospectors who found what they supposed to be platinum in the creek gravels. Reported by Schrader, 1903.

Plavezinnoi, lake; see Tazlina.

Pleasant; bay, indenting the eastern sbore of Admiralty island, Seymour channel, Alexander archipelago, near latitude $57^{\circ} 38^{\prime}$, longitude $134^{\circ}$. Local navigators' name, reported by Fassett, Bureau of Fisheries, 1904.

Pleasant; creek, eastern Alaska, on the north bank of Seventymile creek, near latitude $65^{\circ}$, longitude $142^{\circ}$. Prospectors' name, from sketch map compiled by Major Glassford, Signal Corps, U. S. A., 1905.

Pleasant; island, in Icy strait, southeastern Alaska, near latitude $58^{\circ} 20^{\prime}$, longitude $135^{\circ} 35^{\prime}$. So named by Dall, 1879 .

Pleasant Camp; locality, on the Dalton trail, in Porcupine gold district, southeastern Alaska. Local name, from Bróoks, 1900.

Pleasant Island; reef, on the south shore of Pleasant Island, Icy strait, Alexander archipelago. So named by Dickins, 1902.

Pleveznie, lake; see Tazlina.

Plies, Islas des; see Sannak islands.

Plishnie, islands; see Near.

Plover; supposed island, in the Arctic ocean, near Herald island. Reported and named by Kellett, 1849, after H. M. S. Plover. Perhaps some part of Wrangell island was seen by Kellett and given this name. The island does not exist and does not appear on modern maps. See Wrangell.

Plover; point, the western point of entrance to Port Moore, in Elson bay, Arctic coast, just east of Point Barrow, near longitude $156^{\circ} 16^{\prime}$. So named by the British Admiralty, 1854, after H. M. S. Plover.

Plover; rock, small and bare, off the entrance to South arm, Kelp bay, Chatbam strait, Alexander archipelago, near latitude $57^{\circ} 19^{\prime}$, longitude $134^{\circ} 56^{\prime}$. So named by Moore, 1895 .

Plume, creek ; tributary to Seventymile; see Flume.

Poa; islet, off the south shore of Akun island, in Avatanak strait, eastern Aleutians, near longitude $165^{\circ} 30^{\prime}$. Tebenkof, 1849, calls it Tumannoi (foggy). Called Poa by the Fish Commission in 1888. Foa is the name of a genus of grasses.

Pocket; island, at the northern end of Dry strait, Alexander archipelago. So named by Thomas, 1887.

Podsopochni; cape, on the northern shore of Atka ișland, near Kovurof bay. It is near a volcanic peak (sopka), and was therefore designated by Lutke, about 1830 , Podsopochni (under the peak) cape.

Pogakhluk, lake; see Amanka. 
Pogibshi; anchorage, Peril strait, Alexander archipelago, on the northeastern side of Pogibshi point (below). Described in the Coast Pilot of 1901.

Pogibshi, island, Kodiak harbor; see Near.

Pogibshi; point, on the northern shore of Baranof island, Peril strait, Alexander archipelago, near latitude $57^{\circ} 30^{\prime}$, longitude $135^{\circ} 33^{\prime}$. Named Pogibshi (perilous or dangerous) by vasilief, 1833.

Pogibshie, strait; see Peril.

Pogoreshapka; Eskimo village, on the right bank of lower Yukon river, about 20 miles below Koșerefski. Name from Petrof, 1880, who gives its population as 121. Near it is Dagorashapka mountain of Raymond. Pogoreshapka appears to be Russian for burnt hat.

Pogoreshapka, mountain; see Dagorashapka.

Pogromni; native village, 7 or 8 miles northeast from Cape Sarichef, on the northern shore of Unimak island, eastern Aleutians. So called by Lutke, 1828. It is near Pogromni volcano.

Pogromni; volcano (6,500 feet high), in the western part of Unimak island, eastern Aleutians, near latitude $54^{\circ} 34^{\prime}$, longitude $164^{\circ} 41^{\prime}$. Named Pogromnoi (destroying, desolation) by Sarichef in 1790. Variously spelled Pogromnia, Pogrumnoj, Pogromskaia, Progromnoi, etc. Also called Isanotskoi or Devastation. The native name, according to Grewingk, is Kugidach-Jagutscha.

Pogromnoi, cape; see Sarichef.

Pogromnoi, cape; see Shishkof.

Point Barrie; yillage and salmon salting station, on the southernmost point of Kupreanof island, Alexander archipelago. Local designation. Name published in the Eleventh Census, 1890.

Point Ellis, lake and stream; see Kutlaku.

I'oint Ellis; village and cannery, "at the head of a bay opening into Chatham strait, about 3 miles from the south point of Kuiu island." The cannery was brought "from Freshwater bay on Baranof island," and established here in 1890 . See Ellis.

Point Lockwood; rock and beacon, 200 yards north of Point Lockwood, western shore Wrangell narrows, Alexander archipelago, near latitude $56^{\circ} 34^{\prime}$. Name from the Coast Pilot of 1901.

Point ${ }^{\circ}$ Retreat; peninsula. The northern part of Admiralty island was so designated on Coast Survey chart 728, published in 1885, but has not since been used.

Pointer; peak, on Lindenberg peninsula, Kupreanof island, Alexander archipelago. So named by Thomas, 1887. Perhaps it is a pointer for the northern entrance to Wrangell strait.

Poison; cove, in Chichagof island, Peril strait, Alexander archipelago. So named by Meade, 1869, in commemoration of the death of 150 Aleuts, somewhere in the vicinity, 1799, from eating poisonous mussels.

Poison; rocks, opposite Povorotni point, Peril strait, Alexander archipelago. So called by Dall in the Coast Pilot, who says that these " are the rocks from which Baranof's Aleuts, in 1799, picked the poisonous mussels which caused the death of over 100 persons.

Pok; native village, on the right bank of Koyukuk river, near its mouth. Native name from Tikhmenief, 1861, who wrote it Pokkakat, i. e., mouth of the Pok river. Not found on recent maps.

Poker; creek, at the head of Walker fork Fortymile creek, near latitude $64^{\circ} 03^{\prime}$ and the international boundary. Prospectors' name, reported by Spurr, Gocdrich, and Schrader, of the Geological Survey, 1896. Erroneously Parker. 
Pokoinaia, harbor; see Quiet.

Polar; creek, Seward peninsula, tributary to Bear creek from the west, near latitude $65^{\circ} 35^{\prime}$, longitude $161^{\circ}, 10^{\prime}$. Prospector's' name, reported $\mathrm{ky}$ Witherspoon, 1903.

Polar, sea; see Arctic ocean.

Polar Bear; acreek, Seward peninsula, tributary to Cripple river from the southwest, near latitude $65^{\circ} 50^{\prime}$, longitude $163^{\circ} 40^{\prime}$. Prospectors' name, reported by Gerdine, 1901.

Pole; anchorage, for small vessels, Sumner strait, Alexander archipelago, on the northeast side of Cape Pole (below). So described in the Cotist Pilot of 1901.

Pole; cape, on the western end of Kosciusko island, Sumner strait, Alexander archipelago, near latitude $55^{\circ} 57^{\prime}$, longitude $133^{\circ} 49^{\prime}$. Named by Vancouver, 1793, after Captain Pole, R. N.

Polivnoi; rock, near the southern entrance to Umuak pass, eastern Aleutians. Kuritzien, 1849, designates it as a rock awash (kamen polivnie.).

Polivnoi, rock; see Midway.

Polivnoi; rocks, in Woewodski harbor, Frederick sound, Alexinder archipelago. Named Polivnoi kamen (washed-over rock) by Zarembo, 1838.

Polivnoi, rocks; see Surf.

Polk; inlet, at the head of Skowl arm, Kasian bay, Clarence strait, southeastern Alaska, near latitude $55^{\circ} 24^{\prime}$ ', longitude $132^{\circ} 27^{\prime}$. Navigators' name, reported by Fassett, Bureau of Fisheries, 1904 .

Polk; island, on the west shore of Clarence strait, southeastern Alaska, near latitude $55^{\circ}$, longitude $132^{\circ}$. So called by local navigators, and reported by H. C. Fassett, Bureau of Fisheries, 1904.

Polnoi; islet, in Kiestof sound, north of Sitka sound, Alexander archipelago. Named Polnoi (full) by Vasilief, 1833. Renamed Brady, by Moore, 1897.

Polovina; cliffs and rookery, on the southeastern coast St. Paul island, Bering sea, on and near Fialfway point, about longitude $170^{\circ} 10^{\prime}$. Local name, called Polavina by Eliott, 1873-74, and Polavina point by StanleyBrown, 1891. Russian polovinnoi (half way).

Polovina; hill (470 feet high), on the eastern side of St. Paul island, Pribilof: group, Bering sea. It is near Halfway (polovinnoi) point. Local name. Written Polavina, Foluvina, etc.

Polovina Cliffs; rookery, St. Paul island, northeast of Halfway point, south shore, near longitude $170^{\circ}: 10^{\prime}$. Local name, reported by Duffield, 1897 .

Polovinnoi, point; see Halfivay.

Poltava; island, in or near Port Wrangell, Alaska peninsula. So named by Vasilief, 1832. Usually written Pultava.

Poltishi; low foothill, on the left bank of Kantishna river, near latitude $62^{\circ} 10^{\prime}$, longitude $151^{\circ} 45^{\prime}$. Native name, reported by Herron, 1899 , and written by him rol-tish-ee.

Poludcnnie, point; see Noon.

Pomeroy; mountain, between Oil bay and Iniskin bay, Cook inlet, near latitude $59^{\circ} 37^{\prime}$, longitude $153^{\circ} 25^{\prime}$. Prospectors' name, reported by Martin, 1903.

Pond; bay, in Dall island, Kaigani strait, Alexander archipelago. So named by Dall, 1882. It is Sinclair cove of Sheldon Jackson in 1880.

Pond; bay, indenting the northern shore of Duke island, Gravina group, Alexander archipelagro. Named by Nichols, 1883, presumably after Ensign Charles Fremont Pond, U. S. N., a member of his party. 
Pond; creek, tributary to Imuruk basin from the south, Seward peninsula. Name from Barnard, 1900.

Pond; island, in Kelp bay, Chathan strait, Alexander archipelago, the largest of several low, wooded islands on the south side, near latitude $57^{\circ} 17^{\prime}$, longitude $134^{\circ} 53^{\prime}$. Descriptive name, given by Moore, 1895 , from the two ponds thereon.

Pond; island, in Prince William sound, 70 miles southwest of Valdez. Occupied since 1897 as a fox ranch by A. W. Lind, Ell-amar, Alaska. Not discovered which island is meant.

Pond; reef, in northern entrance to Tongass narrows, Alexander archipelago. Name published in the Coast Pilot $(1883$, p. 81$)$.

Pond; rock (awash at low water), in Howkan narrows, Cordova bay, Alexander archipelago. Named by Nichols, 1881, after Ensign C. F. Pond, U. S. N., a member of his party.

Ponte; point, on Woodchopper island, Kootznaboo inlet, Admiralty island, Alexander aíchipelago. Named by Meade, 1869, after a Mr. Ponte, an expert on coal, employed on board the U. S. S. Saginaw.

Pool; creek, in the Fairbanks region, tributary from the east to Smith creek, at the head of Chatanika river, near latitude $65^{\circ} 15^{\prime}$, longitude $146^{\circ}$

15'. Prospectors' name, reported by Gerdine, 1903.

Poo-wowa-luk, Eskimo village; see Powoeluk.

Pop; mountain, in central part of Annette island, Alexander archipelago. So named by Nichols, 1883. Erroneously Top.

Pop; point, at head of Thorne arm, Revillagigedo island, Alexander archipelago. So named by the Coast Survey in 1891.

Poperechnoi; island, off the southern shore of Alaska peninsula, west of the Shumagin group. Named Poperechnoi (crosswise) by the Russians. The Aleut name is Kuiagdak. Variously written Poperetchny, Poperesbnoi, etc.

Poperechnoi, island; see Broad.

Poperechnoi, island; see Crosswise.

Poplar; point, at west end of San Juan Bautista island, Bucareli bay, Prince of Wales archipelago. Named Punta de los Alamos (point of the poplars) by Maurelle and Quadra, 1775-1779.

Popof; bay, on the northeast coast of Kodiak, near St. Paul harbor. Named Popofskaia by Murashef, 1839-40. Has also been called Popoff or Priest bay. Vasili (William) and Ivan (John) Popof were pioneer traders and fur hunters in Alaska in 1762-63.

Popof; cape, on the western shore of Popof bay, Kodiak island. Named Popofskie by Murashef, 1839-40. Popof is a Russian proper name. This may be identical with Miller (melnichnoi) cape of Tebenkof.

Popof; glacier, on north bank of Stikine river, near its mouth. Called First or Little glacier by Hunter in 1877. Apparently named Popof by the Rynda party in 1863 .

Popof; island, in St. Paul harbor, Kodiak. So named by the Russians in 1808-1810.

Popof; island, one of the principal islands of the Shumagin group. Named Popovskoi by the early Russians. Popof is a Russian proper name, often written Popoff.

Popof, island; see Kutkan.

Popof; reefs, in Popof strait, Shumagins. Named Popoff by Dall, 1872.

Popof; rock (42 feet high), near the northern shore of Popof island, Shumagins. Named Popoff by Dall, 1872. 
Popof; strait, separating Unga and Popof islands, Shumagin group. Surveyed and named by Dall, 1872.

Popof Head; point (500 feet high), the southern point of Popof island, Shumagins. Local name, published in 1872, and perhaps derived from Vasili and Ivan Popof, traders and fur hunters here in 1762-63.

Porcupine; creek, tributary to Steamer bay, on Etolin island, Alexander archipelago. So named by Snow, 1.886:

Porcupine; creek, mining camp, and gold district, in the Chilkat region, on the south bank of Klehini river, southeastern Alaska, near the international boundary, about longitude $136^{\circ} 15^{\prime}$. Prospectors' name, reported by Flemer, 1898. Krause brothers, 1882, wrote the Indian name of this creek, or the glacier at its head, or both, Tlachkahiniku.

Porcupine; creek, Kenai peninsula, tributary to Turnagain arm, Cook inlet, near latitude $61^{\circ}$, longitude $149^{\circ} 40^{\prime}$. Local name, from Moffit, 1904 .

Porcupine; creek, in the Birch Creek region, tributary to Crooked creek from the west, near latitude $65^{\circ} 30^{\prime}$, longitude $145^{\circ} 20^{\prime}$. Prospectors' name, reported by Spurr, Goodrich, and Schrader, of the Geological Survey, in 1896.

Porcupine; creek, tributary to Middle fork Koyukuk river from the north, near longitude $150^{\circ} 30^{\prime}$. Prospectors' name, reported by Schrader, 1899. See Porcupine creek, following.

Porcupine; creek, tributary to South fork Koyukuk river from the north, near latitude $68^{\circ}$. Published by the Coast Survey in 1899. Perhaps this creek is identical with the previous one.

Porcupine; hill, on the west-bank of Skagway liver, 7 or 8 miles above Skagway, southeastern Alaska. So named by John Nelson, 1898, and not hitherto published:

Porcupine; island, in Kenai lake, Kenai peninsula. So called by Mendenball, 1898.

Porcupine; point, on the northeastern shore of Prince William sound. So named by Abercrombie, 1898.

Porcupine; post-office (established in 1901), in the Porcupine gold district, near Chilkat river, southeastern Alaska.

Porcupine; river, in northeastem Alaska, tributary to the Yukon. Old name, probably given by factors of the Hudson Bay Company.

Porcupine; river, tributary to the Stikine from the east; near the international boundary line. Name published by the Coast Survey in 1891 .

Porcupine Dome; mountain, in the Birch Creek region at the head. of Porcupine creek, near latitude $65^{\circ} 30^{\prime}$, longitude $145^{\circ} 30^{\prime}$. Prospectors' name, reported by Spurr, Goodrich, and Schrader, of the Geological Survey, 1896.

Porcupine House; road house or tavern, in the Birch Creek region, near the junction of Porcupine and Mammoth creeks, about latitude $65^{\circ} 30^{\prime}$, longitude $145^{\circ} 10$. Reported by Spurr, Goodrich, and Schrader, of the Geological Survey, 1896.

Porfia; cape, at entrance to Port Santa Cruz, Suemez island, Prince of Wales archipelago. Named Cabo de la Porfia (cape of the dispute) by Maurelle and Quadra, 1775-1779.

Poroga, island; see Rapids.

Poroshli, bay; see No Thorofare.

Porpoise; harbor, indenting the western shore of Nagai island, Shumagins. Name derived from the small schooner Porpoise, which wintered there some time prior to 1871 . 
Porpoise; islands, off the mouth of Excursion inlet, Icy strait, Alexander archipelago, near latitude $58^{\circ} 20^{\prime}$, longitude $135^{\circ} 28^{\prime}$. So named by United States naval officers, 1880.

Porpoise; islets, in the entrance to Port Etches, Prince William sound. Named Ptichi (bird) by Chernof,'1830, and. Porpoise or Bird islands by the Coast Survey in 1869.

Porpoise; point, on the northern shore of Boca de Quadra, southeastern Alaska. So named by the Coast Survey in 1891.

Port; mountain; on Wales island, Alexander archipelago. So named by Nichols, 1888.

Portage; arm, of Kelp bay, Baranof island, Chatham strait, Alexander archipelago, near latitude $57^{\circ} 21^{\prime}$, longitude $134^{\circ} \tilde{\mathrm{s}} 5^{\prime}$. So named by Moore, 1895.

Portage; bay, at head of Hetta inlet, Cordova bay, Alexander archipelago, near latitude $55^{\circ} 17^{\prime}$, longitude $132^{\circ} 35^{\prime}$. There is a portage from here to Cholmondeley sound. Local descriptive name, reported by Dickins, in 1905 .

Portage; bay, indenting the northern shore of Kupreanof island, Alexander archipelago, near latitude $57^{\circ}$, longitude $133^{\circ} 20^{\prime}$. Called Perenosnaia (portage) bay by the Russians. Meade, in 1869, calls it Perenosnaya creek. Has also been called Portage harbor. Presumably there is a portage from its head to the head of Duncan canal.

Portage, bay, Prince William sound; see Passage canal.

Portage; bay, indenting the northern shore of Afognak island, Kodiak group. Named Perenosnaia (portage) by the Russian-American Company, 1849.

Portage; bay, indenting the southern shore of Alaska peninsula, immediately north of the Shumagins, near longitude $160^{\circ} 35^{\prime}$. A short portage connects it with Herendeen bay. Named Perenosnaia, (portage) by the Russians.

Portage; bay, on the southern shore of Alaska peninsula, west from Kodiak, from which there is a portage to Becharof lake. Named Perenosnoi (portage) by Tebenkof, 1849. Earlier Russian charts use the native name Kanatak. Osgood (p. 20) says this bay ought to be called Kanatak.

Fortage, bay in Kuskokwim bay; see Chagvan.

Portage; cove, indenting the northwestern shore of Revillagigedo island, Behm canal, Alexander archipelago, near latitude $55^{\circ} 46^{\prime}$, longitude $131^{\circ} 03^{\prime}$. Local navigators' name, reported by Fassett, Bureau of Fisheries, 1904.

Portage; cove, near head of Chilkoot inlet, Lynn canal, Alexander archipelago. Called Portage bay by the traders. From it there is a short portage between Chilkat and Chilkoot inlets.

Portage; creek, Kenai peninsula, draining Portage glacier into the head of Turnagain arm of Cook inlet. Local name, from Mofit, 1904.

Portage; creek, tributary to Susitna river from the north, near latitude $63^{\circ}$. So named by Muldrow, 1.898 .

Portage; creek, tributary to headwaters of Skwentna river in the Tordrillo range. So named by Spurr and Post, 1898.

Portage; creek, tributary to American river from the north, Seward peninsula. Name from Brooks, 1900.

Portage; creek, Seward peninsula, tributary to North fork Kougarok river from the south, near latitude $65^{\circ} 35^{\prime}$, longitude $164^{\circ} 30^{\prime}$. Prospectors' name, reported by Gerdine in 1901.

Portage; creek, on the right bank of Anvik river, western Alaska, near latitude $63^{\circ} 10^{\prime}$. Prospectors' name, published in 1900 . 
0

Portage; creek, eastern Alaska, small tributary on north bank of Birch creek, near latitude $65^{\circ} 20^{\prime}$, longitude $144^{\circ} 45^{\prime}$. Prospector's' name, reported by Witherspoon, 1905.

Portage; creek, eastern Alaska, 30 miles southwest of Circle, tributary on south side of Crooked creek, near latitude $65^{\circ} 30^{\prime}$, longitude $144^{\circ} 35^{\prime}$. Prospector's' name, reported by Witherspoon, 1905 .

Portage; creek, tributary to Middle fork Fortymile creek from the north, near latitude $64^{\circ} 30^{\prime}$, longitude $142^{\circ} 40^{\prime}$. Prospectors' name, reported by Gerdine, 1903.

Portage; creek, tributary to South fork Koyukuk river from the north, near longitude $150^{\circ}$. Prospectors' name, reported by r'eters and Schrader, 1901.

Portage, creek, tributary to Lake Clark; see Akhtidung.

Portage; glacier, on Kenai peninsula, between Passage canal and Turnagain arm of Cook inlet. So called by Mendenhall, 1898.

Portage, islet; see Perevalnie.

Portage; two small islets, near the entrance to Portage bay, Kupreanof island, Alexander archipelago. Called Perenosnaya (portage) by Meade, 1869 .

Portage; mountain (1,400 feet high), 15 or 20 miles west from the outlet of Lake Clark, near latitude $60^{\circ} 10^{\prime}$, longitude $155^{\circ} 30^{\prime}$. Local name, reported by Osgood, 1902.

Portage; mountains (3,500 feet high), near head of Portage bay, Kupreanof island, Alexander archipelago. So named by Thomas, 1887.

Portage; point, east of McClellan flats, Chilkat inlet, Lynn canal, Alexander archipelago. The western end of the portage across Seduction tongue to Haines is near this point.

Portage; point, in Kelp bay, separating Portage arm (above) from Middle arm, Baranof island, Chatham strait, Alexander archipelago. So named by Moore, 1895 .

Portage; point, the eastern point of entrance to Dry Spruce bay, on northern shore of Kodiak. Named Perenosa (portage) by Murashef, 1839-40.

Portage; river, on the west coast of Kodiak. So designated by the Fish Commission in 1888. Tebenkof has the word Perenos (portage) here.

Portage; valley, Alaska peninsula, at the head of Herendeen bay, near longitude $160^{\circ} 40^{\prime}$. Descriptive name, given by Tanner, 1890 .

Port Chester, village; see Metlakatla.

Port Clarence. The Eleventh Census, 1890, gives the population of Port Clarence as 485 . This does not appear to refer to any particular settlement or village, though it has sometimes been so used.

l'ort des Français; see Lituya bay.

Porter; peak (4,798 feet high), on the mainland east of Thomas bay, southeastern Alaska. Named by Thomas, 1887, after Admiral David Dixon Porter, U. S. N.

Port Gravina; settlement, $3 \frac{1}{2}$ miles northwest of Ketchikan, on northeast shore of Gravina island, Tongass narrows, Alexander' archipelago, near latitude $55^{\circ} 22^{\prime}$. Local name, from the Coast Pilot of 1901.

Portillo; channel, in Bucareli bay, Prince of Wales archipelago. Named Canal del Portillo (passage canal) by Maurelle and Quadra, 1775-1779.

Portland; canal, in southeastern Alaska, through which ruus the boundary line between Alaska and British Columbia. Named Portland's canal, 1793, by Vancouver, who says: "The distance from its entrance to its source is about 70 miles, which, in honor of the noble family of Bentinck, I name Portland's canal." The canal is here regarded as terminating at Point Ramsden. 
Portland; inlet, east of Dixon entrance, separating Pearse island from the mainland of British Columbia. Dall, in the Coast Pilot (1883, p. 57), says: "The broader portion (of Portland canal) on modern charts is often denominated Portland inlet, the name of Portland canal being then restricted to that part of it of contracted width which lies to the westward of Observatory inlet.". $\cdot$

Portland; island ( $206 \cdot$ feet high); near the northern end of Stephens passage, Alexinder archipelago.; So :named by Beardslee, 1880.

Portland; point, on the northeastern coast of Pearse island, at southern end of Portland canal, Alexander archipelago.

Port Levashef; port or harbor, at head of Captains bay, Unalaska, Eastern Aleutians. Named after Capt. Lieut. Michael Levashef, who wintered in Captains bay, September 18, 1768, to June 6, 1769, and, after his vessel, called the bay St. Paul harbor. In 1790, Sarichef surveyed in this locality, and, after Levashef, named it Captains harbor. Krusenstern, 1827, says of this place that it is properly called Captains, but to distinguish it from others it will be convenient to call it Port

- Levacheff. The bay has generally been called Captains, and Port Levashef is the harbor at its head.

Portlock; bank, nọrtheast of Kodiak. So named, 1888, by the Fish Commission, after Capt. Nathaniel Portlock.

Portlock; harbor, on the western coast of Chichagof island, Alexander archipelago. This name was given, $\mathbf{1 7 8 7}$, by Capt. Nathaniel Portlock, an English fur trader, who published a sketch of it in 1789. The Spaniards translated it Bahia de Puerto Lock (bay of Lock harbor). Nichols, in the Coast Pilot (1891, p. 189), regards it as identical with Kukkan of the Indians.

Posliedni; cape, on northern shore of Afognak bay, Afognak island. Named Posliedni (last) by Murashef, 1839-40. Near by he has Krainie (the very last).

Possession; point, on Kenai peninsula, at head of Cook inlet. Named by Cook, 1778, who here "displayed the flag and took possession of the river and country in His Majesty's name." Tebenkof, 1849, indicates a settlement, (naseleniia) here.

Post; creek, tributary to Niukluk river from the north, Seward peninsula. Name from Barnard, 1900.

Post; river, tributary to the Kuskokwim from the left, near latitude $62^{\circ} 20^{\prime}$, longitude $153^{\circ} 30^{\prime}$. So named by Brooks, 1902, after W. S. Post, of the Geological Survey, who with Spurr ascended the Kuskokwim in 1898.

Potainikof; cape, on the northwestern coast of Atka, middle Aleutians. A reef, with islets and rocks above and below water, extends off the point for about 2 miles. Potaïnik is Russian for a hidden or secret place and in the colonies was applied to a rock which never uncovered, but revealed itself by breakers in heavy weather. At such times they said "The Potainik is playing."

Pot; creek, Seward peninsula, tributary from the west to Cripple river, near latitude $66^{\circ}$, longitude $163^{\circ} .45^{\prime}$. Prospectors' name, reported by Witherspoon, 1903.

Potato; creek, Seward peninsula, tributary to Candle creek from the west, near latitude $65^{\circ} 48^{\prime}$, longitude $162^{\circ} 10^{\prime}$. Prospectors' name, reported by Witherspoion, 1903. 
Potato; creek, Seward peninsula, tributary to Lopp lagoon on the Arctic coast, near Cape Prince of Wales. Local name, reported by Geidine, 1901.

Potato; mountain (1,370 feet high), on Seward peuinsula, about 15 miles northeast of Cape Prince of Wales, near latitude $65^{\circ} 40^{\prime}$, longitude $167^{\circ} 35^{\prime}$. Name published by the Coast Survey in 1900. Apparently this is Conical hill of Beechey, 1827. Called also Cone hill.

Potato; point, in Valdez narrows, Prince William sound. So called by Abercrombie, 1898.

Pouale, bay ; see Cold.

Poul; creek, 15 miles east of Cape Yaktag, Gulf of Alaska, near longitude $142^{\circ}$. Named after Angel Poul, one of the first to locate oil lands near: Cape Yaktag in 1897, and reported by Martin in 1903.

Poul; point, on the north shore of Bering lake, 8 miles north of Controller bay, - Gulf of Alaska, near latitude $60^{\circ} 13^{\prime}$, Iongitude $144^{\circ} 14^{\prime}$. Prospectors' name, reported by Martin, 1905.

Poundstone; rock, in the southern part of Lyun canal, Alexander archipelago. Named by Mansfield, 1890, after Ensign Homer Clark 'Poundstone, U. S. N., a member of his party.

Poverotni, point; see Lockwood.

Poverotnie, point; see Vanderbilt.

Poverty; creek, eastern Alaska, on the east bank of Charley river, which is affluent to the Yukon fron the south, near longitude $143^{\circ}$. Prospectors' name, from sketch map compiled by Major Glassford, Signal Corps, U. S. A., 1905.

Poverty; island, off the south end of Long island, Chiniak bay, Kodiak. Named Ubezhitsha (? poverty) by Russian naval officers, 1808-1810.

Povorotni; island, in Peril strait; Alexander archipelago. Named Povorotni (turn or turnabout) by Vasilief in 1833 . Has also been written Povero and Poverotni; also called Turnabout. It is Return island of Meade, 1869. For a long time, 1835-1875, it was conspicuously marked by a canoe, marking the burial place of a family of Sitka Indians who died of measles in 1835. From this it derived the local name of Canoe island.

Povorotni, island; see Turnabout.

Povorotni; point, the northeast point of entrance to Redoubt bay, Sitka sound, Alexander archipelago. Named Povorotnoi (turiabout) by Vasilief, 1809. Also has been called Povorot, Poverotnoi, and Turnabout.

povorotni, point; see Turner.

Povorotnoi, point; see Protection.

Pow; island, in Hassler harbor, Revillagigedo channel, Alexander archipelago. So named by Nichols, 1882.

Powell; creek, Seward peninsula, small tributary on west bank of Casadepaga river, near latitule $64^{\circ} 50^{\prime}$, longitude $164^{\circ} 20^{\prime}$. Prospector's' name, from Gerdine, 1905 .

Powell; gulch, at the headwaters of Chisna river: Named by prospectors, after A. M. Powell, engineer and pioneer in the Copper River country. Reported by Mendenhall, 1903.

Powell; peak $(2,655$ feet high), on the mainland, near Thomas bay, southeastern Alaska. Named by Thomas, 1887, after Maj. John Wesley Powell, then Director of the United States Geological Survey.

Powell; peak, on the northwestern shore of Klutina lake. So named by Abercrombie, 1898. 
Powers; creek, draining Sumdum glacier, on the eastern shore of Holkham inlet, Stephens passage, Alexander archipelago, near latitude $57^{\circ} 46^{\prime}$. Prospectors' name, reported by Spencer and Wright, 1903.

Powers; creek, in the Fortymile region, tributary to Dome creek from the right, near latitude $64^{\circ} 25^{\prime}$, longitude $141^{\circ} 10^{\prime}$. Prospectors' name, taken from a manuscript map in the Coast Survey archives drawn by E. F. Ball, 1898.

Powoeluk; Eskimo village, at Southwest cape, St. Lawrence island, Bering sea. Population in 1904, 19. Native name, published by the Bureau . of Education (1900) as Powoeluk and (1904). Pöō wö'wā lŭk.

Pratt; mountain, on the mainland, west of the Stikine river. Named by the Coast Survey, after John Francis Pratt, assistant, Coast and Geodetic Survey.

Pravoi, cape, Kodiak; see Right.

Pravoi, point; see Right Hand.

Praznik; island, in St. Paul harbor, Kodiak. Has been occupied as a fox farm, but not so at present. Named Rocky by Lisianski, 1804 . Russian naval officers, 1808-1810, named it Prazdnichnoi (holiday or picnic). It has also been called Holiday island.

Preacher; creek, tributary to Birch creek from the south, near latitude $66^{\circ}$, longitude $145^{\circ} 30^{\prime}$. " Named by pioneer prospectors after the Rev. R. McDonald, chaplain of the Hudson Bay Company and missionary to the Indians, who first reported the occurrence of placer gold in the basin of this stream." (Maddren, Smithsonian Miscell. Coll., vol. 49, 1905, No. 1584, p. 9.) Published by the Coast Survey in 1895 . Called Kotlo river by Dall, 1870.

Preble; peak (5,028 feet high), on the mainland, near Thomas bay, southeastern Alaska. Named by Thomas, 1887, after Rear-Admiral George Henry Preble, U. S: N.

Pribilie; island, at the north end of Krestof sound, Alexander archipelago, the largest of the Sound group. Named Pribilie (profitable) by Vasilief, 1833. See Sound islands.

Pribilof; group of islands in Bering sea, composed of two larger ones, St. Paul and St. George, and two smaller ones, Otter and Walrus. Often called the Fur Seal islands. They were "discovered in 1786 by the pilot Pribilof and then called Novy (new); afterwards Lebedevski, from the name of the owner of the vessel which discovered them. Shelikof called them Zouboff (after the then Russian minister of the interior). Later they were called Kotovy (fur seal) from the immense number of these animals found there, and Sieverny (north) from their relation to Unalaska. Sarichef on his map named them Pribilof, after their discoverer." (Lutke 336-337). In the colonies they were, under the Russians, usually called Ostrovki (the little islands). . St. George was first seen and landed upon June $\frac{12}{1}, 1786$. Hunters wintered there, and the next year, on June 29, in the morning, they saw St. Paul. On visiting it they found the copper handle of a sword, a clay pipe, and fireplaces-proofs of prior visits by parties unknown. Often now'called The Seal Islands.

Price; island, near the entrance of Gambier bay, Admiralty island, Alexander archipelago. So named by Mansfield, 1889.

Priest, bay; see Popof.

Priest, point; see Kalekta. 
Priest; rock, near Cape Kalekta, the eastern head of Unalaska bay, eastern Aleutians, near longitude $166^{\circ} 23^{\prime}$. Locally so called from fancied resemblance to a Russian priest." Lutke says (p. 281) "The broken-down cliffs and isolated rocks sometimes take the most fantastic forms; as, for example; the one just in front of Cape Kalekta exactly resenbles an old man having his head inclined and his arms crossed on his breast." .

Frince; creek, tributary to Caribou creek. So called by H. H. Hicks, guide of Captain Glenn's expedition in 1898. Not identified and name not found on any map.

Prince; shoal, on the northeast side of Rurik harbor, Yakutat bay, southeastern Alaska. So named by Harber, 1892.

Prince Ernest's, sound ; see Ernest.

Prince of Wales; archipelago, between Dixon entrance and Sumner strait, southeastern Alaska. Named "The Prince of Wales's Archipelago" by Vàncouver, 1793.

Prince of Wales; cape, at the western end of Seward peninsula, Bering strait, being that point of North America which approaches nearest to Asia. So named by Cook, August 9, 1778. The Eskimo name is reported to be Niekta, also written Nychta. Billings, 1.790, calls it Prince of Wales or Kigmil or Kygmil. It is said to have been named Gwozdef by Bering in 1728. Now universally known as Cape Prince of Wales.

Prince of Wales; island, the largest island of Prince of Wales archipelago, in Alexander archipelago. The earliest use of this name appears to be in the treaty between Great Britain and Russia of February $\frac{28}{16}, 1825$.

Prince of Wales; passage, in the southwestern part of Prince William sound. So named, 1787, by Hayward, of Portlock's vessel.

Prince of Wales; shoal, off Cape Prince of Wales, Bering strait. So called by the Coast Survey in 1890.

Princess; bay, indenting the sontheastern shore of Revillagigedo island, Behm canal, Alexander archipelago, near latitude $55^{\circ} 23^{\prime}$, longitude $131^{\circ}$. Local navigators' name, reported by Fassett, Bureau of Fisheries, 1904.

Princess; rock, in Caton harbor, Sannak islands, near longitude $162^{\circ} 27^{\prime}$. So called by Westdahl, 1901.

Princess Head; cliff, on the eastern shore of Unalaska bay, eastern Aleutians, near longitude $166^{\circ} 24^{\prime}$. So called by Dall, 1871 .

Prince William; sound, indenting the northern shore of the Gulf of Alaska. Named Prince William's by Cook, 1778. The Russians called it Chugach gulf or Prince William sound.

Prisoners; cove, on the southern shore of Middle Kaigani harbor, Kaigani strait, near Dixon entrance. Named Prisoners cove (plieunaia gavantza) by Etolin in 1833 . Some persons indentify this, probably erroneously, with Port Meares of Douglas.

Pritchard; rocks, in the Galankin group, Sitka sound, Alexander archipeligo. So named by United States naval officers, 1880. Called Pritchard shoals in Hydrographic notice 5 of 1880.

Problem; gulch, Seward peninsula, in Solomon River basin, on southwest bank of Mystery creek, a west branch of Shovel creek, near latitude $64^{\circ} 39^{\prime}$, longitude $164^{\circ} 28^{\prime}$. Prospectors' name, published in 1900 .

Proctor; islands, in Dixon entrance, near the soutbwestern shore of Willes island. Originally they were included in the group called Boston islands. Named by Nichols, 1891.

Progromnoi, volcano; see Pogromni.

Prolchoda, islands, etc.; see Passage. 
Prolewy; point, the northwestern point of entrance to Wrangell strait, Alexander archipelago, near latitude $56^{\circ} 50^{\prime}$, longitude $132^{\circ} 56^{\prime}$. Named Pro: lewy (strait) by Lindenberg, 1838. It is Proliva point of Meade's sketch, 1869 .

Prolewy; rock, in Southern rapids, Peril strait, Alexander archipelago. Prolewy is the Russian word for strait. This name seems to have been first applied by Coghlan in 1884.

Prolewy; rock, off Prolewy point, Wrangell strait, Alexander archipelago. So called by Coghlan, 1884. It is Middle rock of Meade in 1868.

i'romezhutochnie, cape; see Between.

Prominence; cape, on the southern shore of Unalaska, between Open and Usof bays, near longitude $166^{\circ} 46^{\prime}$. So named by the Fish Commission in 1888. Its native name is given by Tebenkof as Idaliuk.

Promisla; bay;"indenting the southern shore of Krestof island, Sitka sound, Alexander archipelago. Named Promisla (business) by Vasilief, 1833. Bozhie promisla means God's business, which a Russian dictionary translates Providence. Thus this bay has been called Providence. Kostrometinoff translates this furs.

Promontory, cape; see Lutke.

Promontory; cove, indenting the southern shore of Unimak island, eastern Aleutians, $2 \frac{1}{2}$ miles north of Cape Lutke, near latitude $54^{\circ} 31^{\prime}$. So named by the Fish Commission in 1888.

Promontory; Lill (1,130 feet high), on the southern shore of Unimak island, 8 miles west of Cape Lutke, near longitude $164^{\circ} 31^{\prime}$. Descriptive name, published by the Coast Survey in 1902.

Propastchy, point, St. George island; see Sealion.

Propastchy-koverushka, St. George island; see Sealion hills.

Prospect; creek, 10 miles north of Nome, Seward peninsula, tributary to Snake river from the east, near longitude $165^{\circ} 2 \bar{\tau}^{\prime}$. Local name, published in 1900.

Prospect; creek, 13 miles north of Cape Nome, Seward peninsula, a right branch of Discovery creek, near longitude $165^{\circ} 03^{\prime}$. Name from Gerdine, 1904.

Prospect; point, on the eastern shore of Port Snettisham, Stephens passage, Alexander archipelago. So named by Thomas, 1888 .

Protassof. The Russian orthadox church at Morzhovoi is called Protassof in the Tenth Census, 1880, and Eleventh Census, 1890. Petrof in the Tenth Census called the town Protassof; accidentally Protasso on his map.

Protection; bay, between Old harbor and Three Island bay, indenting the southeastern shore of Unalaska, eastern Aleutians, near longitude $166^{\circ}$ $35^{\prime}$. So named by the Fish Commission in 1888 .

Protection; point, on the western shore of Nushagak bay. Named Povorotnoi (turn) by Tebenkof, 1849. The coast line bends or turns at this point. Renamed Protection by the Fish Commission in 1890.

Protection; port, in the northwestern part of Prince of Wales island, opening into Sumner strait, Alexander archipelago. So named by Vancouver, who in $\mathbf{1 7 . 9 3}$ here rode out a beavy gale, and, "grateful for such an asylum," named it Port Protection.

Providence, bay ; see Promisla.

Providence; cape, on the southern shore of Alaska peninsula, west of Kodiak. Named Providenia (providence) by Vasilief in 1831. His skin boat (bidarka) was wrecked here and he narrowly escaped drowning. The Aleut name of the cape is Naluktchyak. 
Providence; cape, in the eastern part of Unalaska, eastern Aleutians. Not identified. So named by Cook, 1778 (II, 527) ; also so called by Sauer on Billings's track chart and also in Galiano's atlas, 1802.

Providence; point, the northern point of entrance to Estrella bay, Bucareli bay, Prince of Wales archipelago. Named Punta de la Providencia by Maurelle and Quadra, 1775-1779.

Provoduik, island ; see Leader:

Prudhoe; bay, on the Arctic coast east of the mouth of Colville river. So named by Franklin in 1826.

Pryor; island, on the western shore of Alitak bay, Kodiak, on north side of entrance to Kempff bay. Name from Moser, 1900.

Ptarmagan, gulch, on Birch creek; see Ptarmigan creek.

Ptarmigan; creek, tributary from the south to the 'Isina or south fork of 'Tiekel river, about 25 miles east of Valdez. Name from Schrader, 1900.

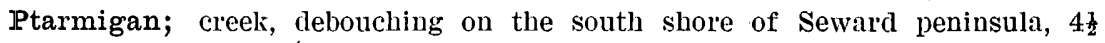
miles west of Cape Nome, near longitude $165^{\circ} 08^{\prime}$. Local name, from Gerdine, 1904.

Ptarmigan; creek, Seward peninsula, Casadepaga drainage, tributary on south bank of Willow creek, near latitude $64^{\circ} 49^{\prime}$, longitude $164^{\circ} 28^{\prime}$. Prospectors' name, from a local map, 1901.

Ptarmigan; creek, Seward peninsula, tributary to Candle creek from the west, near latitude $65^{\circ} 45^{\prime}$, longitude $162^{\circ} 10^{\prime}$. Prospectors' name, reported by Witherspoon in 1903.

Ptarmigan; creek, Seward peninsula, tributary to Kuzitrin river from the north, near latitude $65^{\circ} 15^{\prime}$, longitude $164^{\circ} 57^{\prime}$. P'ospectors' name, reported by Gerdine, 1901.

Ptarmigan; creek, tributary to the headwaters of Birch creek, near latitude $65^{\circ} 28^{\prime}$, longitude $145^{\circ} 30^{\prime}$. Prospectors' name, reported as Ptarmagan gulch by Schrader, 1896 .

Ptarmigan; gulch, in the Birch Creek region, on the left bank of Harrison creek, near latitude $65^{\circ} 20^{\prime}$, longitude $145^{\circ}$. Prospectors' name, reported by Spurr, Goodrich, and Schrader, of the Geological Survey, 1896.

Ptarmigan; small lake, near and to the east of Kenai lake, Kenai peninsula. Name from Mendenhall, 1.898.

Ptarmigan; valley, and creek therein, tributary to Kuskokwim river, near its source. So named by Spurr and Post, 1898.

Ptichi, islets; see Porpoise.

Ptichie, cape, island, etc.; see Bird.

Ptseka, creek; see Petsika.

Puale, bay; see Cold.

Puffin; bay, indenting the southern end of Baranof island, Alexander archipelago. Named Toporkof (puffin) by the Russians. Has also been written Toporknff and Toporkov.

Puffin; islet, near St. Paul, in Chiniak bay, Kodiak. Named Toporkof (puffin) by Russian naval officers, $1808-1810$.

Puffin; islet, near the southwestern end of Sitkalidak island, off southeastern shore of Kodiak. Named Toporkof (puftin) by Tebenkof, 1849.

Puffin; islet, near Chamisso island, Kotzebue sound, Arctic ocean. So named by Beechey, July, 1826.

Puffin; point, the south point of entrance to Puftin bay, Baranof island. Alexander archipelago. Named Toporkof (puffin) by the Russians,

Bụll. 299-06 M-33 
Puffy; creek and slough, on the eastern shore of Controller bay. Named after McIver Forbes Morrison McIver-Campbell, head of Clan McIver, Scotland, nicknamed by his intimate friends "Puffy." Local name from Martin, 1904.

Puffy, creek; see Edwardes.

Puget; cape, on the southeastern coast of Kenai peninsula. Named by Vancouver, 1794, after Lieut. Peter Puget, R. N., of his party.

Puget; cove, about 5 miles northeast of Port Mulgrave, Yakutat bay, southeastern Alaska. So named by Dall, 1879, after Lieut. Peter Puget, R. N., one of the companions of Vancouver, who was in this vicinity in 1794.

Puguviliak; native village, near Southwest cape, St. Lawrence island, Bering sea. Native name, from Tebenkof, 1849. Erroneously Pugupiliak.

Puk or Pak. Eskimo for big; thus, Kwikpak, river big.

Pulizzi; island, on the east side of Spasskaia bay, south side Icy strait, Alexander archipelago, near longitude $135^{\circ} 17^{\prime}$. So named by Dickins, 1901 .

Fultara, island; see Poltava.

Pumicestone; bay, indenting the western shore of Unalaska, eastern Aleutians. Named Mokrovskoi (wet) by Sarichef, 1792, and since variously given as Morkovskoi, Moorovskoy, etc. In 1888 it was named Pumicestone by the Fish Commission. Its native name is given by Veniaminof as Aliuksul, perhaps from the Aleut word Aliuk (river otter).

Punch; hill (1,885 feet high), near south end of Gravina island, Alexander archipelago. So named by Nichols, 1883 .

Punchbowl; cove, indenting the southern shore of Rudyerd bay, Behm canal, Alexander archipelago. Named by the Coast Survey in 1891.

Punishment;. point, near St. Ignace island, Bucareli bay, Prince of Wales archipelago. Named Punta de Castigo (punishment point) by Maurelle and Quadra, 1775-1779.

Punuk; islets, near the eastern end of St. Lawrence island, Bering sea. Eskimo name, from Tebenkof. Erroneously Pinik.

Pup (The); island, at south point of Betton island, Clover passage, northern entrance to Behm canal, southeastern Alaska, near -latitude $55^{\circ} 30^{\prime}$, longitude $131^{\circ} 50^{\prime}$. Local navigators' name, reported by H. C. Fassett, Bureau of Fisheries, 1904.

$P u p$, island; see Hump.

Pup; island, off the entrance to Port Camden, Keku strait, Alexander archipelago. So named by Moore, 1892.

. Puppets (The); two hills (1,987 feet high), at the southern end of Gravina island, Alexander archipelago. Punch and Judy are near by. Named by Nichols, 1883.

Purcell; peak (2,800 feet high), south of Selawik river, near latitude $66^{\circ} 15^{\prime}$, longitude $157^{\circ} 40^{\prime}$. So named by Stoney after Ensign J. L. Purcell, U. S. N., a member of his expedition in 1884, also a member of his' expedition in 1885 , but invalided home from Bering sea.

Purple; mountain (2,447 feet high), near Port Chester, Annette island, Alexander archipelago. So named by Nichols, 1883.

Pusco; creek, tributary to Middle fork Koyukuk river from the south, near longitude $150^{\circ} 30^{\prime}$. Name so reported by Peters and Schrader, 1901.

Pushki, island; see Cannon.

Pustiia, island; see Empty. 
Pustoi; islet, near Ship island, in Umnak strait, eastern Aleutians. Called Pustoi (barren or desert) by Kuritzien, 1849. Lutke calls it Tanghinakh, perhaps intended for Tangidak; the Aleut word for islet. The name Tanginak applies to Ship island.

Putmikwa; slough, Yukon delta, connecting Kwiguk and Alakanuk passes, near latitude $62^{\circ} 45^{\prime}$, longitude $164^{\circ} 43^{\prime}$. Eskimo name, obtained by Futiin, 1899.

Putnam; peak (3,887 feet high), on Lindenberg peninsula, Kupreanof island, Alexander archipelago. So named by Thomas, 1887, after Master Charles Flint Putnam, U. S. N., a member of Berry's party in Bering strait in 1880. Putnam was driven to sea on an ice floe in Bering strait and perished.

P.utnam, river; see Kóbuk.

Puzzle; gulch, Seward peniusula, in Solomon River basin, on north bank of: Mystery creek, a west branch of Shovel creek, near latitude $64^{\circ} 19^{\prime}$, longitude $164^{\circ} 27^{\prime}$. Prospector's' name, from a local map, 1904.

Pybus; bay, indenting the southeastern shore of Admiralty island, Frederick sound, Alexander archipelago. So called by Mansfield, 1889.

Pybus; point, the eastern point of entrance to Pybus bay, Admiralty island, Frederick sound, Alexander archipelingo. So named by Vancouver, 1794.

Pye; islands, near Nuka bay, off the southern coast of Kenai peninsula, Gulf of Alaska. Named Fye's by Fortlock, 1786, and variously written Fi, Pies, Pyes, etc.

Pyke; point, on the eastern shore of Port Bainbridge, Prince William sound. So named by Vancouver, 1794.

Pyramid; harbor, at the head of Chilkat inlet, southeastern Alaska, near latitude $59^{\circ} 10^{\prime}$, longitude $135^{\circ} 28^{\prime}$. 'The Hudson Bay Company employees called this place Labouchere bay, after the steamer of that name. Meade, 1869, called it Pyramid Island harbor. It is now commonly known as Pyramid hatbor. The native name was reported by the Krause brothers in 1882, and is obscurely engraved on their map. It appears to be Tichtinigé.

Pyramid; island, at the head of Chilkat inlet, Lynn canal, southeastern Alaska, $1 \frac{1}{2}$ miles northeast of Pyramid harbor 'above). Descriptive name, given by Meade in 1869. Lindenberg, 1838, called it Peschanie (sandy). Has also been called Farewell through an erroneous translation of Peschani (proshaite $=$ farewell). Has also been called Stony, another translation of Feschani. It has been occupied by the Coast Survey as an astronomical station and called Observatory island. The native name, according to the Krause brothers, 1882, is Chlacbatsch, which Dall writes Shla-hatch.

Pyramid; mountain (2,100 feet high̆), near Iliuliuk, Unalaska, eastern Aleutians, about longitude $166^{\circ} 32^{\prime}$. Descriptive name, published by the Coast Survey in $\mathbf{1 8 7 5}$.

Pyramid; peak, on Kosciusko island, near the head of Davidson inlet, Frince of Wales archipelago, about latitude $56^{\circ} 03^{\prime}$, longitude $133^{\circ} 22^{\prime}$. Descriptive name, given by Dickins, 1903-4.

Pyramid; peak (4,068 feet high), on the northeastern shore of Glacier bay, southeastern Alaska. Descriptive name, from Reid, 1892.

Pyramid, point; see Green.

Quadra, bay; see Boca de Quadra.

Quadra, island; see Dall. 
Quadra; lake and stream, on the western shore of Mink arm, Boca de Quadra, southeastern Alaska, near latitude $55^{\circ} 04^{\prime}$. So named by the fisheries, and reported by.Mosei, 1897.

Quadra; point, the northern point of entrance to Boca de Quadra, Revillagigedo channel, southeastern Alaska, near latitude $55^{\circ} 05^{\prime}$, longitude $131^{\circ}$. Old name, so applied by local navigators and reported by Fassett, Bureau of Fisheries, 1904.

Quail; creek, in the Rampart region, tributary to Troublesome creek from the west. Prospectors' name, reported by Prindle, 1904.

Quartz; creek, in the Copper river region, tributary to Chisna river at its source. Prospectors' name, reported by Mendenhall, 1903.

Quartz; creek, tributary to the Tonsina river, just below Tonsina lake. Prospectors' name, from Roln, 1899.

Quartz; creek, emptying into Kenai lake, near the foot, Kenai peninsula, about latitude $60^{\circ} 30^{\prime}$, longitude $149^{\circ} \cdot 40^{\prime}$. Prospectors' name, reported by Mendenhall, 1898.

Quartz; creek, tributary from the south to Turnagain arm of Cook inlet, near longitude $149^{\circ} 05^{\prime}$. Local name, reported by Becker, 1895 .

Quartz; creek, tributary to Solomon river from the south, Seward peninsula. Name from Barnard, 1900.

Quartz; creek, debouching nearly opposite Sledge island, Seward peninsula. Name from Barnard, 1900.

Quartz; creek, tributary to Goose creek from the south, Seward peninsula. Name from. Barnard, 1900.

Quartz; creek, tributary to Kougarok river from the west, Seward peninsula. Name from Brooks, 1900 .

Quartz; creek, tributary to Penny river from the east, in the Nome mining region, Seward Peninsula. Prospector's' name, published in 1900. It is Hutchinson creek of a recent local map.

Quartz; creek, Seward peninsula, tributary to Independence creek, an affluent of Kugruk river and Kotzebue sound, near latitude $65^{\circ} 35^{\prime}$, longitude $162^{\circ} 20^{\prime}$. Prospector's' name, reported by Witherspoon, 1903.

Quartz; creek, Seward peninsula, tributary to south fork Serpentine river, near latitude $65^{\circ} 45^{\prime}$, longitude $165^{\circ} 20^{\prime}$. Prospector's' name, reported by Gerdine, 1901.

Quartz; creek, 25 miles north of Nome, Seward peninsula, tributary from the north to Stewart river at its source, near latitude $64^{\circ} 50^{\prime}$, longitude $165^{\circ} 18^{\prime}$. Local name, reported by Gerdine, 1904.

Quartz; creek, Seward peninsula, tributary to Kiwalik river from the east, near latitude $65^{\circ} 35^{\prime}$, longitude $161^{\circ} 40^{\prime}$. Prospectors' name, reported by .Wither'spoon, 1903.

Quartz; creek, tributary to Yukon river on the right bank, 2 miles below Rampart (city), near longitude $150^{\circ} 40^{\prime}$. Prospectors' name, published in 1899.

Quartz; creek, eastern Alaska, Salcha River drainage, tributary on south bank of Gold creek, near latiticle $64^{\circ} 50^{\prime}$, longitude $145^{\circ} 40^{\prime}$. Prospectors' name, reported by Witherspoon, 1905.

Quartz; creek, tributary to Birch creek from the northwest, near latitude $65^{\circ} 40^{\prime}$, longitude $144^{\circ} 30^{\prime}$. Prospectors' name, reported by Prindle, 1904. Jump Off creek, appearing on an unpublished map of 1898 , is either the same creek or one near it. 
Quartz; creek, eastern Alaska, tributary to Boundary creek from the southeast, near latitude $64^{\circ} 40^{\prime}$, and the international boundary. Prospectors' name, from sketch map compiled by Major Glassford, Signal Corps, U. S. A., 1905.

Quartz; creek, tributary to Chandlar river from the west, near latitude $68^{\circ}$. Prospector's' name, published by the Geological Survey in 1901.

Quartz; gulch, southeastern Alaska, on the mainland, 2 miles east of Juneau, on the south bank of Gold creek. Local name, reported by Spencer and Wright, 1903.

Quartz; gulch, 6 miles north of Nome, Seward peninsula, on the north bank of Anvil creek, near its source, about longitude $165^{\circ} 23^{\prime}$. Local name, published in 1904.

Quartz; point, on Goose island, the western point of entrance to Mud bay, Icy strait, Alexander archipelago, near longitude $136^{\circ}$. So called by Dall in the Coast Pilot $(1883$, p. 190$)$. The place is marked by large masses of white quartz, resembling ice.

Quartz; point, in Coal harbor, Unga island, Shumagin group. So named by Dall, 1872.

Quartz; rock, near the entrance to McHenry anchorage, Clarence strait, Alexander archipelago. So named by Snow, 1886.

Quartz Creek; mining camp, Seward peninsula, latitude $65^{\circ} 20^{\prime}$, longitude $164^{\circ} 40^{\prime}$. Local name, reported by Gerdine, 1901. This is apparently the location of Dahl post-office.

Quat-a-hein, stream ; see Kwatahein.

Quay; peak (5,000 feet high), near Port Valdez, Prince William sound. So named by Abercrombie, 1898, after Hon. Matthew Stanley Quay, of Pennsylvania.

Queekagamut, village; see Kwikak.

Queen; creek, 15 miles north of Controller bay, Gulf of Alaska, the left branch óf Car'bon creek, near latitude $60^{\circ} 23^{\prime}$, longitude $144^{\circ} 07^{\prime}$. Prospector's' name, reported by Martin, 1903 .

Queen; creek, tributary to Kougarok river from the east, near latitude $65^{\circ} 35^{\prime}$, longitude $164^{\circ} 40^{\prime}$. Prospectors' name, reported by Gerdine, 1901.

Queen; inlet, at the head of Glacier bay. Named by Reid, 1892, after the steamship Queen, the first ship ever taken to the upper part of Glacier bay.

Queens; creek, in the Mount Wrangell region, tributary to Elliott creek from the north. Prospectors' name, reported by Mendenhall, 1903.

Queer; island, in Chiniak bay,,Kodiak. Named Chudnoi (queer; odd, strange) by Russian naval officers, 1808-1810.

Quemabo, cape; see Quemado.

Quemado; cape, on the western shore of Suemez island, Bucareli bay, Prince of Wales archipelago. Named by Maurelle and Quadra, 1775-1779. It is Quemabo on La Perouse's copy (English edition, 1798) of Maurelle and Quadra, but this appears to be an error for Quemado (burnt).

Quetoth, river; see Dultoth.

Quichalabloch, river; see Kwikalablok.

Quick, river; see Kwik.

Quiet; harbor, in Etolin island, opening into Stikine strait, Alexander archipelago. Named Poliöinaia (quiet) by the Russians. Has been called Pokoinay and Quiet bay.

Quiktalik, mountain; see Kwiktalik. 
Quincy; gulch, 9 miles northwest of Cape Nome, Seward peninsula, draining the north slope of Army peak into Osborn creek, near longitude $165^{\circ} 10^{\prime}$. Name from Gerdine, 1904.

Quinehahamute, village; see Kwinak.

Quinhagak, post-office (established February, 1906), southwestern Alaska, on

- the eastern shore of Kuskokwim bay, Bering sea, near. latitude $60^{\circ}$. See Kwinak. .

Quinhagak, village; see Kwinak.

Quinnehuk, mountain; see Kwiniuk.

Quinnelhock, river; see Kwiniuk.

Quito Suenos. The Spaniards Maurelle and Quadra, 1775-1779, have on their chart in Portillo channel, Bucareli bay, Prince of Wales archipelago, this name Quito Suenos (sleeping obstacle), or, as one may suppose, a sunken reef. Just south of it is Sheer-off-there (alargate-alla) rock and just north of it the Eye Opener (abree-el-ojo).

Quitoway, island; see Whale.

Quiyaidik, creek; see Kwiyadik.

Rabbit; creek, Seward peninsula, a west branch of Pine creek, on coast of Norton sound, near longitude $164^{\circ} 20^{\prime}$. Prospectors' name, from a local map, 1904.

Race; island, in Kootznaboo inlet, Admiralty island, Alexander archipelago. So named by Meade, 1869.

Race; point, the northernmost point of Annette island, and the eastern point of entrance to Annette bay, Annette island, Alexander archipelago. Presumably a descriptive name, given by local pilots about 1875-1880.

Face, reef ; seè Walden rocks.

Radcliffe; glacier, tributary to Harvard glacier, at the head of College fiord, Port Wells, Prince William sound. So named by the Harriman expedition, in 1899, after Radcliffe college, the woman's annex to Harvard University.

Ragged; cove, in Prince of Wales island, opening into Kashevarof passage, Clarence strait, Alexander archipelago. So named by Snow, 1886 . Erroneously Rugged cove.

Ragged; mountain. A mountain spur between Katalla bay and river on the east, and the Copper River delta on the west, terminating at Point Martin, Gulf of Alaska, near longitude $144^{\circ} .30^{\prime}$. So called by Martin, 1903.

Rainbow; creek; in the Mount Wrangell district, a tributary of Elliott creek on the north. Prospector's' name, réported by Mendenball, 1903.

Rainbow; creek, on the north shore of Turnagain arm, Cook inlet, near longitude $149^{\circ} 40^{\prime}$. Prospector's' name, from Becker, 1895 .

Rainbow; creek, 35 miles north of Cape Nome, Seward peninsula, tributary to Grand Central river from the north, near longitude $165^{\circ} 05^{\prime}$. Name from Barnard, 1900.

Rainbow; creek, tributary to Quartz creek from the east. Name from schrader, 1900.

Rainbow; glacier, on the mainland just north of Davidson glacier, Chilkat inlet, Lyun canal. Name published by the Coast Survey in 1893.

Raindeer, river; see Klondike.

Rainy; pass, in McKinley range, 10 miles southwest from Simpson pass, near latitude $62^{\circ} 10^{\prime}$, longitude $153^{\circ}$. Discovered and so named by Brooks, 1902 .

Rakof, inlet; see Crawfish.

Rakovoi; bay, in Whale bay, Baranof island, Alexander archipelago. Named Rakovoi (shell) by the Russians. Has also beẹl called shell bay. 
Ralkagak; Eskimo village, in the lower Kuskokwim valley, near Bethel. Name published by the Bureau of Education in 1903 (Reindeer Report, p. 106). Not found on any map.

Ralph; lake, in the lower Matanuska valley. So named by Mendenhall, 1898.

- Not shown on map and not,identified.

Ralston; island, in southern part of Lynn canal, Alexander archipelago. So named by Meade, in 1869, after Mr. William C. Ralston, banker, in San Francisco. This island has been reserved for light-house purposes by Executive order dated January 4, 1901.

Rampart; small creek, tributary to Yukon river from the south at Rampart (city), near longitude $150^{\circ} 10^{\prime}$. Local name taken from Edwards' Track Chart of the Yukon, 1899.

Rampart; mountains, on south bank of the Yukon, just above the mouth of the Tanana. So called by Raymond in 1869. T'he Western Union Telegraph Expedition map of 1867 applies this name to mountains farther up the river.

Rampart; mining town, post-office, and telegraph station (population about 400 ), on the south shore of the Yukon, in the Lower Ramparts, near the mouth of Minook creek. Called Rampart City by the miners. A postoffice called Rampart was established here November, 1898.

Rampart House; an Indian village and probably a trading station, situated on the right bank of the Yukon, 6 miles above Dall river. It is apparently the place lettered Shaman or Shaman's on some maps.

Rampart House; trading post of the Hudson Bay Company, now discontinued, on Porcupine river, northeastern Alaska and Yukon territory. This post was first located on the right bank of the Porcupine opposite the mouth of Salmon Trout river. This proved to be in Alaska about 35 miles below the international boundary. It was therefore moved farther up the Porcupine and located on the right bank immediately east of the international boundary. The former site is now called old Rampart House and the latter New Rampart House.

Ramparts; "This is a name introduced by the northern fur traders to designate a contracted, walled, or canyon-like valley and has been applied by them to similar physiographic features on the Mackenzie, Porcupine and Yukon rivers. On the Porcupine [and Yukon], Upper and Lower Ramparts are differentiated and the portions of the valley so named are very picturesque." (Maddren, Smithsonian Miscell. Coll., vol. 49 , No. 1584 , p. 11, 1905.)

Ramparts; gorge or canyon, in Yukon river, beginning a few miles above the mouth of Tanana river and extending up river about 100 miles. The designation Lower Ramparts has been applied to all of it, and also to a part, the most picturesque part, some 30 miles above Minook creek. The Upper Ramparts are described by Schwatka as beginning at Old Fort Selkirk on the Yukon and extending some 400 miles downstream.

Ramparts; (Upper and Lower), canyons on Porcupine river. The Lower Ramparts extend 25 miles from the Yukon flats to the valley of Coleen river. The Upper Ramparts, about 60 miles long, extend from the valley of the Coleen to a point about 25 miles east of the international boundary.

Ramsden; point, at the junction. of Portland canal and Observatory inlet. Named by Vancouver, 1793, after "Mr. Ramsden, the optician."

Ranch; point, at the Indian village Gan-te-gas-tak-heh at head of Chilkat inlet, southeastern Alaska. So named by United States naval officers, 1880 . Has also been written Ranche. 
Rancheria; island, in the eastern part of Bucareli bay, Prince of Walès archipelago. Named La Rancheria (the farm) by Maurelle and Quadra, - 1775-1779.

Randsburg; creek, 4 miles northwest of Cape Nome, Seward peninsula, tributairy to Hastings creek from the north, near longitude $165^{\circ} 03^{\prime}$. Miner's' name, from Gerdine, 1904. Published also as Ransburg.

Range; creek, on Baranof island, debouching in Northern rapids, Peril strait, Alexander archipelago. So named by Coghlan, 1884.

Range; island, in the northern entrance to Popof strait, Shumagins. So named by Dall, 1872.

Range; islet, in Red bay, Prince of Wales island, Sumner strait; the most southerly of the islands in the entrance to Red bay. So described in the Coast Pilot of 1901.

Range; islet, in Coal harbor, Shumagins. . So named by Dall, 1872.

Range; point, N. by W. $\frac{1}{2}$ W., 3 miles distant from Jaw point, Taku inlet, southeastern Alaska. So called by Nichols in the Coast Pilot (1891, p. 153).

Range; point, the southern point of entrance to Fish bay, Peril strait, Alexander archipelago. So named by Coghlan, 1884.

Range; point, in Chichagof: harbor, Attu island, western Aleutians. So named by Gibson, July, 1855.

Rankin, island; see Corlies.

Ransburg, creek; see Randsburg.

Rapid; river, tributary to Porcupine river from the north, near the international bounflary. Possibly identical with Sucker river of the Coast Survey in 1890 ; on recent maps Rapid river.

Rapid City; mining town, northern Alaska, on Alatna river, near latitude $67^{\circ}$. Miners' name, reported by Mendenball and Reaburn, 1901.

Rapids; island, in Southern rapids, Peril strait, Alexander archipelago. Named Poroga (rapids) by Vasilief, 1833.

Rapids; point, on Chichagof island, near Northern rapids, Peril strait, Alexander archipelago. Name apparently first used by Dall in the Coast Pilot (1883, p. 163):

Rasbinik, village; see Razboinski.

Rasp; ledge, at northern entrance to Mole harbor, Seymour canal, Admiralty island, Alexander archipelago. So named by Mansfield, 1889.

Raspberry; cape, the westernmost point of Malinof island, Shelikof strait. Named Malinovoi (raspberry) by Murashef, 1839-40, who applied it to a point about $1^{-}$mile southeast of the point here described. The Russian-American Company map of 1849 applies the name as here used. It is Strawberry point of Coast Survey chart 8500 (ed. of 1900).

Raspberry; island, between Afognak and Kodiak. Called Malinof, or Sievernoi (raspberry or north) by Murashef, 1839-40. Lisianski, in 1804, called it North island. Tebenkof, 1849, calls it Bolshoi Malinof (big raspberry). There is a Little Raspberry island near by. The native nanre is Iukuk, as given by the Bussian-American Company, 1848 .

Raspberry; strait, separating Raspberry and Afognak islands, Kodiak group. Named Malinovoi (raspberry) by Murashef, 1839-40.

Rat; island, between Amchitka and Kiska, Rat Island group, western Aleutians. Called by the Aleuts Ayugadak and by the Russians Krisi (rat). Billings (1790) has Krissey, and Arrowsmith (1790) has Rats. Grewingk has Agadak, with Ajugadach as the more exact form. 
Rat; group of islands, in the western part of the Aleutian chain, immediately east of the Near island group. The group comprises the chain from Amchitka to Buldir, inclusive. Amchitka and Kiska are the principal islands of the group. Called Kryci (aux rats) by Lutke and usually called Krysi or Rat islands.

$R a t$, islands ; see Near.

Rat; islet (17 feet high), near the entrance to Funter bay, Admiralty island, Alexander archipelago. So named by Mansfield, 1890 .

Rat; lake, on the south bank of and very near Porcupine river,. in longitude $144^{\circ}$. Name published by the Coast Survey in 1890.

Rat; river, tributary to Porcupine river from the east, about 50 miles above Fort Yukon. Called Little Black by the Coast Survey in 1890, and Big Black and also Rat by the Coast Survey in 1898. See Black and Little Black.

Ratkovsky, village; see Afognak.

Ratmanof, island; see Big Diomede.

Ratz; harbor, on the western shore of Clarence strait, opposite Dewey anchorage, Alexander archipelago. So named by 'Tebenkof, 1848.

Ratz; point, north of Ratz harbor, on the eastern side of Prince of Wales island, Alexander archipelago. So named by Snow, 1886.

Ratzel; range of mountains or peaks, on the headwaters of Birch creek. So named by Schwatka, 1853, after Prof. Frederick Ratzel, of Munich. Porcupine Dome and Mastodon Dome are in this group.

Ravalga, island; see Kavalga.

Raven; bay, indenting the southern shore of Unalaska, immediately east of Eagle bay. So named by the Fish Commission in 1888.

Raven; creek, tributary to the headwaters of Yukla creek, north of 'Turnagain arm, Cook inlet. Local name, from Mendenhall, 1.898.

Raven; creek, in the Rampart region, tributary from the east to Lynx creek, an affluent of Hess creek, near latitude $65^{\circ} 30^{\prime}$, longitude $149^{\circ} 20^{\prime}$. Prospector's' name, reported by Lieutenant Erickson, U. S. A., 1902.

Raven; islet, northwest of Spruce island, in the Necker group, Sitka sound, Alexander archipelago. Named Halkin (daw or jackdaw) by Vasilief, 1809 .

Raw; point, on the eastern shore of Portland canal. Name published by the Coast Survey in 1891.

Ray; anchorage, on the eastern shore of Duke island, Gravina group, Alexander archipelago. So named by the Coast Survey, 1893, after Lieut. Whitmul P. Ray, U. S. N. Erroneously Bay.

Ray; river, tributary to the Yukon from the north, about 50 miles above Rampart, near longitude $150^{\circ}$. So named by Allen, 1885 , after Capt. Patrick Henry Ray, U. S. A. The maps show two rivers in this vicinity, about 10 miles apart, and the most westerly of the two is the one which Allen named Ray. Raymond (1869) called it Atonisuk, and Schwatka has it Atonisonik. These are presumably native names, but Cantwell (1900) gives the Indian name as Kla-u-ish-na, and Lieutenant Erickson called it Klanooshana (Salt creek) and applied the name Ray river to the stream 10 miles above. Collier (1902) called the lower one Salt river and put Ray river on the stream. 10 miles above. The upper or most easterly river is one which Dall calls Tseetoht; Raymond, Chetaut; Schwatka, Che-taut; and Petrof, Chetaht. The tendency at the present time is to represent this as the larger of the two rivers and call it Ray, and to call the lower and most westerly Salt creek or river. See Chetaut. 
Raymond; cove, indenting the southeastern shore of Cleveland peninsula, Behm canal, southeastern Alaska, near latitude $55^{\circ} 38^{\prime}$, longitude $131^{\circ}$ $52^{\prime}$. Local navigators' name, reported by Fassett, Bureau of Fisheries, 1904.

'Razboinski; Eskimo village, on lower Yukon river, right bank, near head of the delta. Its native name is Kinegnagmiut, i. e., Kinegnak people, and by the Russians called Razboinnitski (robber). Variously written Rasbinik, Razboiniksky, Razboinitskaya, etc.

Razed Fort; cape, near the southeastern point of entrance to Nakwasina passage, Baranof island, Alexander archipelago. Named Vierublennoi Kriepostnoi (cut-down stockade) by Vasilief, 1809. Perhaps the Russians here destroyed one of the native strongholds.

Razorback, divide; see Kechumstuk Hills.

Razrishenie, cape; see Decision.

Razuvirenie, bay; see Disenchantment.

Read; island, in Farragut bay, Frederick sound, Alexander archipelago. Named by Thomas, 1887, presumably after Ensign Maurice L. Read, U. S. N., a member of his party.

Ready Bullion; creek, on the northeastern shore of Douglas island, Alexander archipelago. Presumably a miners' name, in use prior to 1890 .

Ready Bullion; creek, 9 miles west of Fairbanks, on the north bank of Esther creek, tributary to Cripple creek from the north, near longitude $148^{\circ}$. Prospectors' name, from a local map, 1905.

Real Marina; port, in Bucareli bay, Prince of Wales archipelago. Named Puerto de la Real Marina (port of the royal navy) by Maurelle and Quadra, 1775-1779.

Red; bay, in northern end of Prince of Wales island, opening into Sumner strait, Alexander archipelago, near latitude $56^{\circ} 20^{\prime}$, longitude $133^{\circ} 18^{\prime}$. Named Red (krasnaia) by the Russians.

Red; bluff, on the western shore of Akutan island, Krenitzin group, eastern Aleutians, near longitude $166^{\circ} 06^{\prime}$. Descriptive name, from Gilbert, 1901.

Red; bluffs (393 feet high), on the south shore of St. George island, Bering sea, near longitude $169^{\circ} 38^{\prime}$. Descriptive name, from Stanley-Brown, 1891.

Red; cape, the western point of entrance to Massacre harbor, Attu island, western Aleutians. Named Krasnoi (red) by Sarichef, 1790.

Red; cove, on southern shore of Popof island, Shumagins. Local and descriptive name, published in 1875 . On or near this cove Tikhmenief indicates a colonial settlement.

Red; mountain, in Muir glacier, southeastern Alaska. So named by Reid, 1890.

Red; mountain (3,800 feet high), in the northern part of Etolin island, Alexander archipelago. Apparently a local name, published by Dall in the Coast Pilot (1883, p. 94), and perhaps earlier.

Red; mountain (2,404 feet high), near Port Chester, Annette island, Alexander archipelago. So named by Nichols, 1883.

Red; mountain, on the north bank of the Koyukuk, near longitude $154^{\circ}$. Descriptive name, given by Allen in $\mathbf{1 8 8 5}$.

Red; river, on the western coast of Kodiak, 6 miles north of Ayakulik river. Named Krasnaia (red) by Tebenkof, 1849.

Red; river or creek, in the eastern part of Unimak, draining from a lake into St. Catherine cove. Called Krasnaia (red) by Veniaminof, 1840.

Red, river; see Ayakulik. 
Red; rock, in Chapel cove, Bay of Waterfalls, Adak island, middle Aleutians. So named by United States naval officers, 1893.

Red; rock (about 20 feet high), near the head of Niblack anchorage, Clarence strait, Alexander archipelago. So named by Nichols, 1891.

Red Bay; mountain (2,843 feet high), near the head of Red bay; Prince of Wales island, Alexander archipelago. It was named False Mount Calder by Nichols, 1881 (Coast Pilot, p. 105).

Red Bluff; bay, on the southeastern shore of Baranof island, Chatham strait, Alexander archipelago. So named by Moore, 1895.

Red Cliff; point, the south point of entrance to Manzanita bay, eastern shore of Wales island, Portland inlet, Alexander archipelago. Descriptive name.. given by Pender, 1868.

Redfish; bay, indenting the southwestern shore of Raranof ișland, Alexander archipelago, near latitude $56^{\circ} 15^{\prime}$, longitude $134^{\circ} 52^{\prime}$. Named Krasnol Ribi (redfish, a kind of salmon) by the Russians in 1847. Also called Krasnoi (red) bay.

Redfish; breaker, off Redfish cape, Baranof island, Alexander archipelago. So named by Moser, 1897.

Redfish; cape, the western point of entrance to Redfish bay, Baranof island, Alexander archipelago. . Named Krasnoi Ribi (redfish) by the Russians, 1847.

Redfish; islets, near Redfish bay, Baranof island, Alexander archipelago. Named Krasnoi Ribi (redfish) by the Russians, 1847.

Red Head; promontory, forming the western point of entrance to Port Gravina, Prince William sound, near latitude $60^{\circ} 40^{\prime}$, longitude $146^{\circ} 27^{\prime}$. So called by Abercrombie, 1898. Moser, 1897, called it Cone point.

Red Head; bluff cape, on the northern shore of Attu island, western Aleutians. Presumably a descriptive appellation; given by the North Pacific exploring expedition in 1855 .

Red Mountain; creek, in the Copper River region, tributary to Chisna river on the east. Prospector's' name, reported by Mendenhall in 1903.

Redoubt; bay, in Sitka sound, Baranof island, Alexander archipelago. Lisianski, in 1804, called this 'Tyon's (chief's) bay. Tebenkof calls it Redoubt bay from the fishing station, called The Redoubt, at its head. Later it has been called Oseriski (lake) bay. Its head is only a few yards from Deep lake.

Redoubt; bay, on the western shore of Cook inlet, near Redoubt volcano. Name published by the Coast Survey in 1869.

Redoubt (The); fishing station, at outlet of Deep lake, sitka sound, Baranof island, Alexander archipelago. Usually spoken of as The Redoubt. Has also been called Ozerskoi (lake) redoubt and Dranisbnikof settlement. Also erroneously Oserki.

Redoubt, mountain ; see Dranishnikof.

Redoubt, trading post; see Nushagak.

Redoubt; volcino $(11,270$ feet high), on the western shore of Cook inlet. It is an active volcano and was by the Russians called Viesokaia (high) and also Goreloi (burning) ; also written Goryalaya. Its native name, according to Grewingk, is Ujakushatsch. . Sometimes written Redoùte. The Spaniards, 1779, called it Volcan de Mirando. Generally known as Redoubt volcano.

Red River; cape, on the northeastern shore of Unimak island, forming the northwest point of entrance to Isanotski strait. Called Krasnoi-riechki (red river) by Veniaminof, 1831. 
Redrock; creek, tributary to Sixtymile creek from the north, near the international boundary. Local name, published by the Coast Survey in 1898.

Redstone; mountains, applied to the plateau or escarpment on the north side of Noatak river, about latitude $68^{\circ}$, longitude $160^{\circ}$, by McLenegan, 1885, on account of its color.

Redstone; river, northwestern Alaska, tributary to Ambler river from the north, near latitude $57^{\circ} 10^{\prime}$, longitude $157^{\circ} 45^{\prime}$. Descriptive name, given by Stoney, 1885, who wrote the native name E-vel-she-ark and Evesheark.

Redwood; bay and creek, bay in north shore Controller bay, on east side Point Hey, and creek tributary thereto from the northwest, near longitude

- $144^{\circ} 20^{\prime}$. Named by J. L. McPherson, deputy mineral surveyor, after Dr. Boverton Redwood, geologist, of London, England.

Redwood; mining camp, in the Controller Bay region, near Redwood bay and creek (above). Prospectors' name, reported by Martin, 1905.

Reechnoi, point; see Rothsay.

Reed, creek, northwestern Alaska, tributary to Kobuk river from the north, near longitude $159^{\circ} 45^{\prime}$. Named Reed liver by Stoney, 1884-1886, after a member of his party, although he had named another branch of the Kobuk 5 degrees farther east, Reed river. He gave the Eskimo name, Kal-e-gu-ri-che-ark, but Mendenhall, 1901, found that this name belongs to an affuent 16 miles farther up.

Reed; river, northwestern Alaska, tributary to Kobuk river from the north, near latitude $67^{\circ}$, longitude $155^{\circ}$. Named after Ensign M. L. Reed, U. S. N., of Stoney's expedition, who explored it in 1886. Stoney gives the Eskimo name as An-ne-lag-ag-ge-rack or An-e-la-gag-e-rack. Cantwell, 1885, wrote Ung-ee-let-ar-geeak and Ung-ee-le-ganjiak.

Reed Grass; point, on the northern shore of San Antonio bay, Bucareli bay, Prince of Wales archipelago. Named Punta de Carrizales (reed grass point) by Maurelle and Quadra, 1775-1779.

Reef; bight, indenting the western shore of Akutan island, Krenitzin group, eastern Aleutians, near longitude $166^{\circ} 07^{\prime}$. So named by Gilbert, 1901.

Reef; cape, on. the southern shore of Unalaska, between Open and Raven bays. So named by the Fish Commission in 18s8. A reef extends off the point. Tebenkof, 1849, called it by its Aleut name, Kungitak.

Reef; harbor, near Grave point, on the northeastern shore of Duke island, Gravina group, Alexinder archipelago. So named by Nichols, 1882.

Reef; island, on the western shore of Portland canal, in latitude $55^{\circ} 05^{\prime}$. So called by Nichols in the Coast Pilot (1891, p. 76).

Reef; islands, near the entrance to False Lead, in Tlevak strait, Cordova bay, Alexander archipelago. So named by Nichols, 1881.

Reef; point, north of Hassler harbor, on Annette island, Revillagigedo channel, Alexander archipelago. So named by Nichols, 1882.

Reef; point, the southeastern point of Young island,:Tlevak strait, Cordova bay, Alexander archipelago. Descriptive name, given by Nichols in 1881.

Reef; point, on the southwestern coast of Woronkofski island, Alexander archipelago. So named by Snow, 1886.

Reef; point, the north point of entrance to Port Real Marina, Bucareli bay, Prince of Wales archipelago. Named Punta del Arricife (reef point) by Maurelle and Quadra in 1775-1779. Erroneously Arrecite.

Reef; point, on the eastern side of Portage bay, Alaska peninsula. So called in Hydrographic Office notice 48, published in 1893.

Reef; point, the southernmost point of St. Paul island, Pribilof group, Bering sea. Local name, published by the Coast Survey in 1875. 
Reef; rock and shoal, in Redfish bay, Baranof island, Alexander archipelago. So named by Moser, 1897.

Reef; rookery, on Reef point, St. Paul island. Local name, reported by Elliott, $1872-1874$.

Refuge; cove, just north of Ward cove, on eastern shore of Jongass narrows, Alexander archipelago. Perhaps so named by local pilots. Name published by the Coast Survey in 1886.

Refuge; inlet, on the Arctic const, a little west of Point Barrow. So named by Beechey in 1826. Its Eskimo name, according to Murdoch, is Wal-apai ; according to Ray's vocabulary, Wál-ăk-pa; according to sheldon Jackson, Walakpat.

Refugio; port, in Bucareli bay, Prince of Wales archipelago. Named Puerto del Refugio (port of refuge) by Maurelle and Quadra, 1775-1779. Variously called Port Refuge, Port Refugio, and Puerto del Refugio.

Regal; glacier, on eastern flank of Regal mountain. So named by Schrader, 1900 .

Regal; mountain (13,400 feet high), in longitude $143^{\circ}$, east-southenst from Mount Wrangell. So named by Rohn, 1899.

Reid; bay, in Kúu island, Sumner strait, Alexander archipelago. Named by Helm, 1886. Perhaps the intention was to name it after Ensign Maurice Lance Read, U. S. N., a member of Helm's party. Has been written Reid, Reid's and Reids.

Reid; glacier, on the southwest side of Reid inlet near its head, Glacier bay, southeastern Alaska. This is the smallest and most southerly branch of the original Grand Pacific glacier of Muir and was so named by the Harriman expedition, 1899, after Prof. Harry Fielding Reid. See Grand Pacific.

Reid; inlet, at head of Glacier bay, southeastern Alaska. Named after Prof. Harry Fielding Reid, who visited Glacier bay, in 1890 and 1892, and studied its glaciers. The statement in the Sixteenth Annul Report Geological Survey, Part I, p. 423, that it was named by the U. S. Boarri on Geographic Names is an error.

Reindeer; creek, Seward peninsula, tributary to Kugruk river, south of Kotzebue sound, near longitude $162^{\circ} 30^{\prime}$. Prospectors' name, reported by Mendenball, 1901.

Reindeer; creek, Seward peninsula, tributary to Clifford creek, which is an affluent of Goodhope bay, near latitude $66^{\circ}$; longitude $163^{\circ} 30^{\prime}$. Local name, obtained by Geological Survey parties in 1901.

Reindeer; creek, Seward peninsula, tributary from the northeast to Schlitz creek, which is a tributary of Serpentine river, near latitude $65^{\circ} 50^{\prime}$, longitude $164^{\circ} 45^{\prime}$. Prospector's' name, reported by Gerdine, 1901.

Reindeer; hills, on the peninsula forming the south head of Norton bay, Norton sound. Local name, from Peters, 1900.

Remedios; point, the western point of entrance to Port Dolores, Bucareli bay, Prince of Wales archipelago. Named Punta de los Remedios (point of the remedies) by Maurelle and Quadra, 1775-1779.

Remedios, Puerto de los; see Salisbury sound.

Renard; islind (1,558 feet high), in Resurrection bay, Kenai peninsula, near latitude $59^{\circ} 55^{\prime}$, longitude $149^{\circ} 20^{\prime}$. So named by the U. S. Board on Geographic Names, June 6, 1906. Hamilton, of the Geological Survey, 1904, reported Lowell as the name of this island and Denson, Coast Survey, 1905, reported Fox. Presumably both local names.

Rendu; inlet and glacier, at head of Glacier bay, southeastẹrn Alạska, So named by Reid, 1892, after a French glacialist, 
Renshaw; point, on the southern shore of Alaska peninsula, north of the Shumagins. So named by Dall, 1880.

Rescue; roadstead, on the eastern shore of Sullivan island, Lynn canal, Alexander archipelago. So named by Meade, 1869, in memory of his rescue of six persons from the Anerican schooner Louisa Downs, wrecked here in 1867 .

Research; creek, eastern Alaska, on the south bank of the Yukon, at the head of Fisher creek, near latitude $65^{\circ}$, longitude $142^{\circ} 40^{\prime}$. Prospector's' name, from sketch map compiled by Major Glassford, Signal Corps, U. S. A., 1905.

Reshimosti; island, south of Japonski island, Sitka sound, Alexander archipelago. Named Reshimosti (resolution) by Vasilief in 1809. Has also been written Retchimosti and Roshimosti.

Resurrection, arm; see Turnagain.

Resurrection; bay, indenting the southeastern shore of Kenai peninsula, near latitude $60^{\circ}$, longitude $149^{\circ} 20^{\circ}$. It is Port Andrews of Portlock in 1787. Baranof, 1792, selected this spot for al shipyard and called it Voskresenskaia. 'This word means resurrection, and also Sunday. Here was built and launched, in 1794, the Phœnix, the first vessel built in what is now Alaska.

Resurrection; cape, the eastern point of entrance to Resurrection bay,, on southern shore of Kenai peninsula. Name published by the Coast Survey in 1869. It is Point Barwell of Portlock in 1787.

Resurrection; creek, Kenai peninsula, tributary to Turnagain Arm of Cook inlet from the south; near latitude $61^{\circ}$, longitude $149^{\circ} 40^{\prime}$. Local name, reported by Becker in $\mathbf{1 8 9 5}$.

Resurrection; fort or post or stockade, built by Baranof at Resurrection bay in 1792. Sometimes called Fort Resurrection.

Resurrection; river, tributary to the head of Resurrection bay, Kenai peninsula. Named Resurrection creek by Glenn, 1898 .

Retaliation; point, on northeastern shore of Security bay, Kuiu island, Alexander archipelago. So named by Neade, who in February, 1869, destroyed two Indian villages here because of the murder by the Indians "of two white men under circumstances of great brutality."

Retreat; point, the northernmost point of Admiralty island, Alexander archipelago. Named by Whidbey in July, 1794, in commemoration of his

- retreat by reason of the hostile behavior of the natives. Called Otstuplenie (retreat) by the Russians. 'This point has been reserved. for light-house purposes by Executive order dated January 4, 1901.

Retreat; supposed reef; near Point Retreat; was so called in the Coast Pilot (1883, p. 172), but according to present information it does not exist.

Return; point, in Sycamore bay, north coast of Kodiak. Called Povorotnie (turn), in 1839-40, by Murashef, whose surveys ended near this point.

Return; reef, on the Arctic coast, east of mouth of Colville river. So named by Franklin, 1826. This reef marks the western limit of Franklin's explorations.

Reverdy; mountains (4,000 to 5,000 feet high), near the head of Portland canal, southeastern Alaska. Apparently so called by Pender, 1868. Nichols in the Coast Pilot $(1891$, p. 78 ) calls them Reverdy Johnson mountains.

Revilla; post-office, at Ward cove, Tongass narrows, Revillagigedo island, southeastern Alaska; established in May, 1900, and discontinued in 1.901.

Revillagigedo; channel, leading northward from Dixon entrance and separating the Gravina group from the mainland. So called after the adjacent island. Has been written Revilla Gigedo. 
Revillagigedo; island, in southeastern part of Alexander archipelago, separated from the mainland by Behm canal. So named by Vancouver, 1793, after Don Juan Vicente de Guemes Pacheco de Pedilla, Count of Revilla Gigedo and viceroy of Mexico 1789-1794.

Rex; creek, Seward peninsula, tributary to Goodhope bay from the south, near longitude $1.33^{\circ}$. Prospector's' name, reported by Mendenhall and Reaburn, 1901.

Rex; creek, southeast side of Alaska peninsula, falling into the head of Dry bay, near latiturs $62^{\circ} 25^{\prime}$. Prospectors' name, reported by Martin, 1903.

Rex; gulch, in the Copper. River region, on the north side of Chititu creek. Prospectors' name. First appeared on map of Nizinafinining district by George M. Esterly, of Valdez, 1902.

Reynard; point (Point Reynard), the north point at entrance to Douglass bay, southwest shore Hooniah sound, Peril strait, Alexander archipelago, near latitude $56^{\circ} 40^{\prime}$, longitude $135^{\circ} 42^{\prime}$. Named by Moore, 1895, after the Coast Survey steam launch Reynard.

Rhode Island; small creek draining the southern slope of the divide between 'Tanana river and the headwaters of Minook creek, near latitude $65^{\circ}$, longitude $150^{\circ} 10^{\prime}$. Prospector's' name, reported by Prindle, 1904.

Ribni, point; see Fish.

Rice; mountain (5,646 feet high), near headwaters of Kanata river. Name from Schrider, 1900.

Rich; mountain (6,000 feet high), in the Tordrillo range, on headwaters of Kuskokwim river. So named by Spurr and Fost, 1898.

Richardson; creek, in the Rampart region, tributary to Hess creek from the south, near latitude $65^{\circ} 30^{\prime}$, longitude $149^{\circ}$. Prospectors' name, reported by Lieutenant Erickson, U. S. A., 1902.

Richmond; gulch, 10 miles north of Nome, Seward peninsula, on the eastern

- slope of Mount Brynteson, draining into the head of Glacier ereek from the west, near longitude $165^{\circ} 21^{\prime}$. Local name, published in 1904.

Richter; creek, tributary to Niukluk river from the south, Seward peninsula. Name from Barnard, 1900. Perhaps identical with Slate creek. See Slate.

Ricord. Beechey mentions, August, 1826, a cape near Cape Thompson, on the Arctic coast, called Ricord by the Russians. Not found on any map.

Ridge; hill (493 feet high), in the western part of St. Paul island, Pribilof group, Bering sea. Name published by the Coast Survey in 1875 . Called Dot hill by Stanley-Brown in 1891.

Ridge; point, the eastern point of entrance to Hot Springs bay, northeast shore of Akutan island, Krenitzin group, eastern Aleutians, near longitude $165^{\circ} 48^{\prime}$. Descriptive name, from Gilbert, 1901.

Ridgewall. On Elliott's map of St. Paul island, Pribilof group, Bering sea; this word appears on a low ridge or spur in the southwestern part of the island.

Ridgeway; creek, Seward peninsula, Casadepaga drainage, tributary on south bank of Willow creek, near latitude $64^{\circ} 48^{\prime}$, longitude $164^{\circ} 25^{\prime}$. Prospectors' name, printed Ridgewood on a local map, 1901.

Ridgewood, creek; see Ridgeway.

Rieba, bay; see Fish.

Riebnie, point; see Fish.

Riecheshni, bay; see Little. 
Riecheshni. A hamlet of 5 huts (yourts) containing 37 natives existed, in 1830, says Veniaminof, on Riecheshni bay (now called Little bay), on the northeastern shore of Akun island, Krenitzin group, eastern Aleutians.

Riecheshnoe, village; see Nikolski.

Riecheshnoi, cove;' see Akun.

Right; cape, the eastern head of Kiliuda bay, southeastern shore of Kodiak, near latitude $57^{\circ} 15^{\prime}$. Named Pravoi (right hand) by the Russians. It is on the right hand as one enters the bay.

Right, fork of Banner creek; see Slate creek.

Right, fork of Canning river; see Marsh fork.

Right, fork of Fish river; see Kuearuk.

Right Hand;-point, the western point of entrance to Kulukak bay, on the northern shore of Bristol bay. Named Pravoi (right hand) by Tebenkof, 1849.

Riley; cape, on the eastern shore of Port Clarence, Bering strait. Apparently so named by Beechey, 1827, or possibly by Trollope, 1854. On late maps this name has been moved north from its original place and applied to the southern point of entrance to Grantley harbor.

Riley; pass, northwestern Alaska, between Ifoatak and Colville valleys, near latitude $68^{\circ}$, longitude $155^{\circ} 30^{\prime}$. So named by Stoney, 1885, after an Eskimo interpreter in bis paity-Ounalook-whom they nicknamed "Riley."

Riley Camp; mining camp, on Kobuk river, near longitude $157^{\circ}$. "Some miner's wintered there in 1900." Reported by Mendenhall and Reaburn, 1901.

Rimrock; creek, Kenai peninsula, a left branch of Resurrection creek, 5 miles above Hope city. Local name, from Moffit, 1904.

Ring; creek, tributary to the rigbt fork of Bluestone river, Seward peninsula. Name from Baruard, 1900 .

Ring; islet, at entrance to Jamestown bay, Sitka sound, Alexander archipelago. So named by United Státes naval officers, 1880, after Paymaster James . Andrew Ring, U. S. N.

Ringingaluk, river; see Pingingaluk.

Riobo; point, on the southern shore of San Juan Bautista island, Bucareli bay, Prince of Wales archipelago. So named by Maurelle and Quadra, 17751779.

Riou; point, in front of Malaspina glacier, St. Elias alpine region, southeastern Alaska. So named by Vancouver, 1794, and by him applied to the southeastern point of entrance to Icy bay. It is Nizmennoi (low) point of Tebenkof, 1849, and Rio of Russian Hydrographic chart 1378 .

Rip; rock, in passage between Hawkins and Hinchinbrook islands, Prince William sound, near latitude $60^{\circ} 27^{\prime}$, longitude $146^{\circ} 18^{\prime}$. So named -by Ritter, 1900.

Jiiph, cape; see Shakmanof.

Ripinski; mountain (Mount Ripinski, 3,540 feet high), on Chilkat peninsula, southeastern Alaska, $1 \frac{1}{2}$ miles northwest of Haines mission, near latitude $59^{\circ} 15^{\prime}$, longitude $135^{\circ} 30^{\prime}$. Local name, after $\mathrm{Mr}$. Ripinski, of Haines mission, and published by the Coast Survey in 1897. The name is misplaced on Coast Survey chart 8303 . Krause brothers, 1882, wrote the Indian name of this bill Geissen.

Rishenia, cape; see Decision.

River; islet, at head of Taku inlet, southeastern Alaska. So named by Meade, 1869. The island is not shown on recent maps. 
River; point, on the restern shore of Portland canal, southeastern Alaska. Name published by the Coast Survey in 1891.

River; point, in Port Snettisham, Stephens passage, Alexander archipelago. So named by Thomas, 1888.

Rivermouth; cape, near mouth of Afognak river, Afognak bay, Afognak. Named Ustia rieki (mouth of river) by Murasbef, 1839-40.

Road; island, on the northern shore of Redoubt bay, Sitka sound, Alexander archipelago. Named Dorozhnoi (fit for traveling) by Vasilief, 1809.

Roadstead; island, at the entrance to Security bay, Kuiu island, Alexander archipelago. So named by Meade, 1869.

Roaring. Coxe in his Russian Discoveries (3d ed., 1787, b. 210) says that Krenitzin and Levashef, in 1768-69, found two burning mountains on Unalaska, one called Ayaghish. (Makushin) the other (by the Russians) Roaring mountain.

Roaring; glacier, on the west shore, near the head of Harriman fiord, Port Wells, Prince William sound, Gulf of Alaska. Descriptive name, given by the Harriman expedition; 1899, and suggested by the noise of ice masses tumbling down the steep slope at the top of which the glacier terminates.

Rob; point (Foint Rob), the southwestern point of Krestof island, Hayward strait, Sitka sound, Alexander archipelago, near latitude $57^{\circ} 09^{\prime}$, longitude $135^{\circ} 33^{\prime}$. Probably a local name, reported by Moore, 1897.

Robber; islands, in the eastern part of Bucareli bay, Prince of Wales archipelago. Named Yslas de Ladrones (islands of robbers) by Maurelle and Quadra, 1775-1779.

Robe; lake, near Valdez, Prince William sound. Proper name, given by Abercrombie, 1898.

Robe; river, draining from Robe lake to Port Valdez. Proper name, given by Abercrombie, 1898.

Robert; creek, tributary to Bettles river from the east, near longitude $149^{\circ}$. Prospector's' name, from Schrader, 1899.

Robert; islands, at south point of entrance to Port Foughton, Frederick sound, Alexander archipelago. So named by Nichols, 1882.

Roberts; mountain, southeastern Alaska, about 3 miles southeast of Juneau. Local name, reported by Peters, 1902.

Robert Lincoln; mountain, on the northern side of Nelson island. Apparently so named by Nelson, 1878, after Hon. Robert Lincoln, then Secretary of War.

Robertson; mountain (7,950 feet high), on the mainland, east of the Stikine river. Name published by the Coast Survey in 1895.

Robertson; river, tributary to the Tanana from the west, near longitude $144^{\circ}$. So named, 1885, by Allen in honor of Sergt. Cady Robertson, U. S. A., a member of his party.

Robin, island; see St. Lazaria.

Robinson; creek, in the Fortymile region, tributary to Wade creek from the southeast, near latitude $64^{\circ} 10^{\prime}$, longitude $141^{\circ} 30^{\prime}$. Prospectors' name, reported by Prindle, 1903...

Robinson; hills, flanking the Malaspina glacier on the west. So named by

- Russell, 1891, after Lieut. L. L. Robinson, U. S. R. M., who was drowned in landing at Icy bay, June $6,1891$.

Robinson; mountain, on the Arctic coast, near the international boundary line. So named by Franklin, 1826, after the Right Elon. Mr. Robinson, "now Lord Goderich," chancellor of the exchequer.

Roca Pamplona; see Pamplona.

Bull. 299-06 $\mathrm{M}-34$ 
Rochanoff, lake; see Becharof.

Rock; creek, tributary to Kotsina from the south. Prospectors' name, reported by Gerdine in 1900 .

Rock; creek, tributary to Slate creek from the south, Seward peninsula. Name from Baruard, 1900.

Rock; creek, 8 miles north of Nome, Seward peninsula, tributary to Snake river from the east, near longitude $165^{\circ} 27^{\prime}$. Prospector's' name, published in 1900.

Rock; creek, 25 miles north of Cape Nome, Seward peninsula, a main fork of Fox creek, an affluent of Eldorado river, near longitude $165^{\circ} 05^{\prime}$. Local name, from Gerdine, 1904.

Rock; creek, Seward peninsula, tributary to Serpentine river on the north, near latitude $65^{\circ} 55^{\prime}$, longitude $165^{\circ}$. Prospectors' name, reported by Gerdine, 1901.

Rock; small creek, on Seward peninsula, tributary to Taylor creek from the south, near latitude $65^{\circ} 40^{\prime}$, longitude $164^{\circ} 40^{\prime}$. Prospector's' name, reported by Gerdine, 1901.

Rock; creek, south shore Sewarà peninsula, on east bank of Solomon river, 4 miles from the coast, near longitude $164^{\circ} 22^{\prime}$. Prospectors' name, from a local map, 1904.

Rock; creek, Seward-peninsula, in Solomon River basin, tributary on south bank of Coal creek, near latitude $64^{\circ} 44^{\prime}$, longitude $164^{\circ} 14^{\prime}$. ' Prospectors' name, from a local map, 1901.

Rock; creek, Seward peninsula, tributary on west bank Topkok river, near longitude $164^{\circ}$. Prospectors' name, from a local map, 1904.

Rock; creek, eastern Alaska, tributary to Preacher creek from the southeast, near latitude $65^{\circ} .45^{\prime}$, longitude $145^{\circ} 30^{\prime}$. Prospectors' name, reported by Witherspoon, 1905.

Rock; creek, tributary to Goodpaster river from the north, near latitude $64^{\circ} 30^{\prime}$, longitude $144^{\circ} 30^{\prime}$. Prospectors' name, reported by Gerdine, 1903.

Rock; creek, tributary to Seventymile creek; see Little Blanche.

Rock; creek, tributary to Mosquito fork Fortymile creek from the left, near latitude $64^{\circ} 05^{\prime}$, longitude $142^{\circ} 40^{\prime}$. So called by Lieutenant Mitchell, Signal Corps, U. S. A., 1902.

Rock; island, in the Yukon at the lower entrance to the Ramparts, near latitude $65^{\circ} 15^{\prime}$, longitude $151^{\circ}$. River pilots' name, taken from Edwards' Track Chart of the Yukon, 1899.

Rock; islet, off the Sandman reefs, southeast of Belkofski. Designated as Rock by the Fish Commission, in 1888, and later called Rock islet.

Rock; islet, 130 feet high, near the southern shore of Unimak island, about 2 miles west of Cape Lazaref, near longitude $163^{\circ} 38^{\prime}$. Descriptive name, reported by Westdahl, 1901.

Rock; point, on the western shore of Portland canal, southeastern Alaska. So called by the Coast Survey.

Rock; point, near entrance to Carroll inlet, Revillagigedo island, Alexander archipelago. So named by the Coast Survey in 1891.

Rock; point, on Mitkof island, Wrangell strait, Alexander archipelago. So named by Meade, 1869. It is Mielkie (shallow) of Lindenberg in 1838.

Rock; point, on Gravina island, about 2 miles westerly from Ward cove, Tongass narrows, Alexander archipelago. So, called by Dall in the Coast Pilot (1883, p. 81). Off this point extends Rosa reef.

Rock; point, midway between Pogibshi point and Otstoia island, on northern. shore of Baranof island, Peril strait, Alexander archipelago. Named Kamenistie (rocky) by Vasilief, 1833. 
Rock; point, 1 mile inside Point Highfield, north end Wrangell island, Eastern passage, Alexander archipelago, near latitude $56^{\circ} 29^{\prime}$, longitude $132^{\circ}$ 21.'. Local navigator's' name, reported by Fassett, Bureau of Fisheries, in 1904.

Rock; point, the eastern point of entrance to Sanford cove, Holkham bay, Stephens passage, Alexander archipelago. So named by Mansfield, 1.859.

Rock; point, on the northeastern coast of St. Michael island, Norton sound. So named by the Coast Survey in 1898.

Rock; point, northwestern coast of Kodiak, described by Moser, 1897, as the "southern point of entrance to Northeast Arm" of the west branch of Uganik bay, near latitude $57^{\circ} 50^{\prime}$, longitude $153^{\circ} 30^{\prime}$.

lrock, point; see Kamenoi.

Rocker; gulch, on the south shore of Seward peninsula, 1 mile southeast of Nome, near longitude $165^{\circ} 22^{\prime}$. Local name, published in 1904.

Rockfish; cove, in Neets bay, Behm canal, Alexander archipelago. So named by the Coast Survey in 1891.

Rock Island Point; locality, on Koyukuk river, 34 miles below Red mountain. Name taken from the Northern Commercial Company's folder for 1.905.

liocks; point, on the south shore of Alaska peninsula, bètween Sannak and the Shumagins. Not identified. So designated on Billings's track chart.

Rockwell, camp, city, harbor, etc.; see Juneau.

Rockwell; island, one of the Galankin group, Sitka sound, Alexander archipelago. Named by United States naval officers, 1880, after Commander Charles H. Rockwell, U. S. N.

Rocky; bay, in Etolin island, opening into Clarence strait, Alexander archipelago. So named by Snow, 1886.

Rocky; bay, in northeast end of Montague island, Prince William sound, near latitude $60^{\circ} 20^{\prime}$, longitude $147^{\circ}$. Probably local name, reported by Westdahl, 1.902.

Rocky, bay; see Necker.

Rocky; cape, the western head of sycamore bay, on north coast of Kodiak. Named Kekurnie (rocky) by Murashef, 1839-40. 'Tebenkof, 1849, calls it Maknashka.

Rocky; cove, indenting the southern shore of Biorka island, Sitka sound, Alexander: archipelago. So named by Symonds, 1879.

Rocky; creek, Seward peninsula, Casadepaga drainage, tributary on north bank of Willow creek, near latitude $64^{\circ} 49^{\prime}$, longitude $164^{\circ} 24^{\prime}$. Prospector's' name, from Gerdine, 1905.

Rocky, creek, Nome river; see Rocky Mountain.

Rocky; island, in San Christoval channel, Bucareli bay, Prince of Wales archipelago. Named Ysla de Piedras (island of rocks) by Maurelle and Quadral, $1.755-1.779$.

Rocky; island, in Kalsin bay, Chiniak bay, Kodiak. Named Utesistoi (rocky or cliffy) by Russian naval officers, 1808.

Rocky; island, north shore Afognak bay, Kodiak group, near latitude $58^{\circ} 02^{\prime}$, longitude $152^{\circ} 47$. Descriptive name, from Moser, 1901.

Rocky, island; see Kak.

Rocky; islet ( 54 feet high), off Swanson harbor, at eastern entrance to Icy strait, Alexander archipelago, near latitude $58^{\circ} 10^{\prime}$, longitude $135^{\circ} 02^{\prime}$. So nmmed by Symonds in 1880, or possibly by Meade in 1869 .

Rocky; islet, between Kodiak and Spruce islands, Kodiak group. Named Kamenistie (rocky) by Murashef, 1839-40. 
Rocky; islet, in western anchorage, St. Paul harbor, Kodiak. Called Utichi (rocky) on an undated old Russian chart.

Rocky; group of islets, in Marmot bay, Kodiak group. Named Kamenistie (rocky) by Murashef, 1839-40.

Rocky; mountains, constituting the main divide between the Arctic and the Pacific drainages. Described by Schrader, 1901, as the Alaska extension of the main chain of the United States. See Endicott mountains.

Rocky; point, between Chaik and Whitewater bays, Admiralty island, Chatham strait, Alexander archipelago. So named by Meade, 1869.

Rocky; point, in Whitewater bay, Admiralty island, Alexander archipelago. So named by Glass, 1881.

Rocky; point, the southwestern point of Long island, Kootznahoo inlet, Admiralty island, Alexander archipelago. So named by Meade, 1869.

Rocky; point, on the eastern shore of Chilkat inlet, near the present village of Chilkat. Named Utesistie (rocky) by Lindenberg, 1838. The name is obsolete.

Rocky; point, near entrance to Port Valdez, Prince William sound. So named by Abercrombie, 1898.

Rocky; point, the southern point of entrance to Dutch harbor, on Amaknak island, Unalaska bay, eastern Aleutians, near longitude $166^{\circ} 32^{\prime}$. Descriptive name, given by Dall, 1873.

Rocky; point, on the southern shore of Uyak bay, Kodiak island, between Cape Uyak and Bear island. Descriptive name, from Moser, 1897.

Rocky; point, the western point of entrance to Golofnin bay, Norton sound. Named Kamennoi (rocky) by Khromchenko, 1821, because of a bare flat rock near it. It has recently been called Fergusson point by the prospectors and traders-sometimes called The Promontory and Stony cape.

Rocky, point; see Inner.

Rocky, point; see Kamenoi.

Rocky, point; see Tonki.

Rocky, river; see Kogoluktuk.

Rocky Bottom; creek, northern Alaska, tributary to Alatna river. Prospectors' name, reported by Lieutenant Camden, 1900. Not found on any map.

Rocky Mountain; creek; 20 miles north of Nome, Seward peninsula, tributary to Nome river from the east, near longitude $165^{\circ} 12^{\prime}$. Local name, from Gerdine, 1904. It is apparently the same that is called Rocky creek on a local map of 1900 .

Rocky Patch; a shoal in Eastern channel, Sitka sound, near latitude 57 $02^{\circ}$, longitude $135^{\circ} 18^{\prime}$. Descriptive name, published by the Coast Survey in 1900.

Rocky Reef; point, near the western entrance to Kupreanof strait, Kodiak group. Called Kamenistoi laidie (rocky bank) by Murashef, 1839-40.

Rocky River; point, on the north shore of Unimak island, at the mouth of Shishaldin river, near longitude $163^{\circ} 50^{\prime}$. Name published by the Coast Survey in 1902.

Rodgers; harbor, on the southern shere of Wrangell island, Arctic ocean. Surveyed and named in September, 1881, by Master Charles F. Putnam and Ensign George M. Stoney, of the U. S. S. Rodgers.

Rodgers; point, southwest from Emmons island, on shore of Chichagof island. in northern angle of Peril strait, Alexander archipelago. So named by Moore, 1895, presumably after Augustus Ferdinand Rodgers, assistant, Coast Survey. Erroneously Rogers. 
Rodgnoff, cape; see Rozhnof.

Rodiac. This name was applied by the Spaniards, 1788 , to one of the Shumagins. Apparently it is a blunder for Kodiac, now written Kodiak.

Rodman; bay, indenting the northern shore of Baranof island, Peril strait, Alexander archipelago. Named by Moore, 1895, after Lieut. Hugh Rodman, U. S. N., a member of bis party.

Rodman, cove; see Louise.

Rodman; glacier, southeastern coast of Alaska, 35 miles southeast of Yakutat, near longitude $138^{\circ} 40^{\prime}$. So named by Moser, 1901, after Lieut. Hugh Rodman, U. S. N., a member of his party.

Rodman; peak (3,140 feet high), on the mainland, near Thomas bay, southeastern Alaska. So named by Thomas, 1887, after Lieut. Hugh Rodman, U. S. N.

Rodman; post-office (established in 1901), on Rodman bay, north shore Baranof island, Alexander archipelago.

Rodman; reach, a narrow arm of Alitak bay, southwestern coast of Kodiak, extending southwest, inside 'Tanner head, from Lazy bay to Cape Alitak. So named by Moser, 1900, after Lieut. Hugh Rodman, U. S. N., one of his party.

Rodney; cape, on the southwestern shore of Seward peninsula, Bering sea. Discovered and so named by Cook, August 5, 1778 .

Rodney; creek, just west of Cripple river, Seward peninsula. Name from Barnard, 1900.

Rodney; mountain, on the south shore of Seward peninsula, 15 miles northwest of Nome and 25 miles southeast of Cape Rodney, near longitude $165^{\circ}$ 52'. Local name, published in 1904 .

Roe; point, in Behm canal, near the entrance to Smeaton bay, Alexander archipelago. So named by the Coast Survey in 1891 .

Rogers; creek, tributary to the Yukon river from the south, 20 miles above Dall river, near longitude $148^{\circ} 40^{\prime}$. Prospector's' name, reported by Lieutenant Erickson, U. S. A., 1902, as Roger creek.

Rrogova, island; see Horn.

Rohn; glacier, tributary to Nizina glacier from the west, on the eastern flank of Regal mountain. Named by the Geological Survey, 1901, after Oscar Rohn, who crossed it in $\mathbf{1 8 9 9 .}$

Rohn; river, tributary to the Kuskokwim from the east, near latitude $62^{\circ}$. So named by Spurr, in 1898, after Oscar Rohn, a member of his party. Herron went down this river in 1899 and called it Tateno or Tate-no, which be says is the native name.

Rolchova, island; see Horn.

Rokovoy, bay; see Crawfish inlet.

Rolling Ground. In Sitka Sound, Alexander archipelago, " in the space between Biorka and Vitskari islands; a more or less heavy swell is nearly always experienced, even when the water is smooth in other parts of the sound." Hence this designation the Rolling Ground.

Romania; point, on the western shore of Port Refugio, Bucareli bay, Prince of Wales archipelago. Named Punta de Romania by Maurelle and Quadra, $1775-1779$.

Romanof; point, on the southern shore of Norton sound, between St. Michael and the mouth of the Yukon. Apparently this is Point Shallow-Water of Cook, 1778. To distinguish it from Shoal Ness of Cook, another point to the southward, Lutke proposed to call it Cap-Nord du hautfond, i. e., Northern Cape Shoal Water. Lutke says its native name is 
Romanof-Continued.

Asiatchak. Tebenkof, 1849, calls it Aziachak, and the Russian Hydrographic Office, 1852, Aziachagiak (otmeloi=shoal). This Russian word Otmeloi (shoal) has been transliterated back into English and appeared as Onman. The name Romanoff may be a local name. The first mention of it found is in Dall's Alaska (p. 119).

Romanzof; cape, on the mainland, in Bering sea, the westernmost point of the Yukon delta. So named by Shishmaref in 1821 . It was in the same year independently named Romanzof by Kromchenko and Etolin, in both cases after Count Rumiantsof, a name which has been variously written Romantsof, Romanzof, Roumiantsoff, etc.

Romanzof; mountains ( 8,000 to 10,000 feet high), in northeastern Alaska, near the Arctic coast. Named by Franklin, 1826, "after the late Count Romansoff, Chancellor of the Russian Empire." Has been variously spelled Romantzoff, Roumiantzoff, etc. Apparently these mountains are identical with those named Pelly by Dease and Simpson in 1837, "after the public-spirited governor of the Hudson's Bay Company." Schrader, 1899, applies the name to mountains considerably farther soutb.

Romig; mountain (about 2,500 feet high), in the Kilbuck range, western Alaska, about 30 miles east-southeast of Bethel. So named by Spurr and Post, 1898, after the missionary Dr. Joseph Herman Romig.

Romp; iṣland, near the entrance to Gambier bay, Admiralty island, Alexander archipelago. So named by Mansfield, 1889.

Rookery; islands, off Point Macnamara, Clarence strait, Alexander archipelago. So named by Snow, 1886 .

Roosevelt; lagoon, at the head of Naha bay, western shore Revillagigedo island, Behm canal, southeastern Alaska, near latitude $55^{\circ} 36^{\prime}$, longitude $131^{\circ}$ 37'. Local navigators' name, probably after the President, reported by Fassett, Bureau of Fisheries, 1904.

Root; glacier, near Kennicott glacier, in longitude $143^{\circ}$. So namèd by Robn, 1899.

Rootok; island, near west end of Avatanak island, Krenitzin group, eastern Aleutians, about longitude $165^{\circ} 30^{\prime}$. Native name, spelled Aiaktak by Veniaminof and Aektok by Lutke and Tebenkof. Also called Goloi (bare) by the Russians. Krusenstern spells it Ouektock, while the Fish Commission, 1888, calls it Rootok. Also has been called Goly. Apparently identical with Aiaiepta of Krenitzen and Levashef in 1768 . This island has been. reserveci for light-house purposes by Executive order dated January 4, 1901. In that order it is called Rootok island. The spelling Rootok apparently arose accidentally from Aektok and has become established.

Rootok; strait or pass, separating Rootok island from Avatanak island, Krenitzin group, eastern Aleutians. Also called Aektok.

Rope; cliff, on the western border of Agassiz glacier, St. Elias alps. So named, 1890 , by Russell, who, with his party, scaled it by means of a rope.

Rope; creek, a tributary on the south shore of Bering lake, 5 miles north of Controller bay, Gulf of Alaska, near latitude $60^{\circ} 15^{\prime}$, longitude $144^{\circ} 14^{\prime}$. So called by the prospectors, because a rope has been hung to aid travelers over a falls in the creek. Reported by Martin, 1905 .

Rosa; reef, off Rock point, in northern part of Tongass narrows, Alexander archipelago. Name published by the Coast Survey in 1899.

Rosalia; point, on San Fernando island, Gulf of Esquibel, Prince of Wales archipelago. Named Punta de Santa Rosalia bv Maurelle and Quadra. 1775-1779. 
Rosary; island, in San Christoval channel, Bucareli bay, Prince of Wales archipelago. Named Ysla del Rosario (Rosary island) by Maurelle and Quadra, 1775-1779.

Rosary; point, the south point of entrance to Port Santa Cruz, Suemez island, Prince of Wales archipelago. Named Puntal del Rosario (point of the rosary) by Maurelle and Quadra, 1775-1779.

Rose; channel, in Northern rapids, Peril strait, Alexander archipelago. So named by Coghlan, 1884, after the little steamer Rose.

Rose; creek, tributary to Middle fork Koyukuk river from the east, near longitude $150^{\circ} 30^{\prime}$. Prospectors' name, from Schlader, 1899.

Rose; inlet, in Dall island, Tlevak strait, Alexander archipelago. So named by Dall, 1882.

Rose, island; see Hinchinbrook and Seal rocks.

Rose, point; see Cliff.

Rose. Dease and Simpson, 1837, spenk of a Point Rose (p. 163) near: Point Barrow. The name is not shown on their map. Perhaps this is an error: for Ross and applies to some point at or near their Ross bay.

Rose; rock, in Middle channel, Sitka harbor, Sitka sound, Alexander archipelago. Named by United States naval officers, 1880, presumably after: the little steamer Rose.

Rose; rock, covered at high water, Kootznahoo inlet, Admiralty island, Chatham strait, Alexander archipelago, near latitude $57^{\circ} 30^{\prime}$, longitude $134^{\circ} 30^{\prime}$. So named by Moore, 1895.

Rose Channel; rock, in Northern rapids, Peril strait, Alexander archipelago.

- So named by Coghlan, 1884.

Rose Island; rock, bare at low water, 200 yards off the east shore of Big Rose island, Adams channel, Northern rapids, Peril strait, Alexander archipelago, near latitude $57^{\circ} 27^{\prime}$, longitude $135^{\circ} 32^{\prime}$. So described in the Coast Pilot of 1901. Called also Adams Channel rock.

Ross; bay, on the Arctic coast, between Dease inlet and Point Barrow. So named by Dease and Simpson, 1837, after a personal friend. Also called Ross's in their map.

Ross; creek, tributary to Yukon river from the south, 1.8 miles above the mouth of Dall river; near longitude $148^{\circ} 50^{\prime}$. Prospectors' name, reported by Lieutenant Erickson, U. S. A., 1902.

Rothsay; point, on the mainland, at mouth of Stikine river. So named by Vancouver, 1793. Also called Reechnoi (river) by the Ryndu party in 1863 .

Rotokakat, river; see Kaltag.

Rotol, Rotoldlela, mountain; see Khotol.

Round; hill (1,647 feet high), just west of Nakat inlet. So named by Nichols, 1883.

Round; island, Cordova bay, Alexander archipelago, on the southwestern margin of the Barrier islands, near latitude $54^{\circ} 47^{\prime}$, longitude $132^{\circ} 32^{\prime}$. Descriptive name, from Dickins, 1905.

Round; island, at entrance to Hunter bay, Cordova bay, Prince of Wales island, near latitude $54^{\circ} 52^{\prime}$, longitude $132^{\circ} 24^{\prime}$. So named by Moser, 1897 .

Round; island, near entrance to Thorne arm, in Revillagigedo channel, Alexander archipelago. So named by Nichols, 1.883 .

Round; island, at entrance to Security bay, Kuiu island, Alexander archipelago. So named by Meade, 1869 .

Round; island, on the southern side of Redoubt bay, Sitka sound, Alexander archipelago. Named Krugloi (round) by Vasilief., 1809. 
Round; island, north shore Salisbury sound, one-half mile east of Krugloi islands, at entrance to Peril strait, near latitude $57^{\circ} 22^{\prime}$, longitude $135^{\circ}$ 43'. "Wooded, 200 feet high, dome-shaped top." Descriptive name, from Moore, 1896.

Round; island (427 feet high), in entrance to Coal harbor, Unga island, Shumagins. Descriptive name given, presumably, by the Western Union Telegraph expedition in 1865.

Round; island, the southeasternmost of the Walrus island group, in northern part of Bristol bay. Supposed to be the island so named on account of its shape by Cook, July 12, 1778. Tebenkof calls it. Krugloi (round) and gives its native name as Kaiashik. Sarichef, 1826, calls it Walrus island and gives its native name as Kaiashik.

Round, island, see Hound.

Round, island; see Walrus.

Round; islet (or islets), in Holkham bay, Stephens passage, Alexander archipelago. So named by Meade, 1869.

Round; islet, in Kasaan bay, Prince of Wales island, Alexander archipelago. Local name, published in the Coast Pilot $(1883$, p. 86 (i).

Round; islet, in western anchorage of St. Paul harbor, Kodiak. Named Krugloi (round) by Russian naval officers, 1.808-1810.

Round; islet, 40 feet high, on the southern shore of Beaver inlet, Unalaska island, at the eastern entrance to Amugul bay, near longitude $166^{\circ} 23^{\prime}$. Descriptive name, given by Gilbert, 1901.

Round; islet, near the southern shore of Ugamak island, Krenitzin group, eastern Aleutians, near longitude $164^{\circ} 47^{\prime}$. So called by Gilbert, 1901 .

Round; knob (80 feet high), south coast St. Paul island, Bering sea, on the narrow neck between St. Paul village and Reef point, near longitude $170^{\circ} 16^{\prime}$. Descriptive name, from Duffield, 1897.

Round; lake, near St. Paul, Kodiak. Named Krugloe (round) by Russian naval ofticers, 1808-1810. Tebenkof, 1849, calls it Miesofskoe (cape).

Round; mountain, in the northwestern part of Annette island, Alexander archipelago. So named by Nichols, 1883.

Round; mountain, on the left bank of Koyukuk river, 5 miles below the mouth of Kanuti river, near latitude $66^{\circ} 30^{\prime}$, longitude $153^{\circ} 15^{\prime}$. River pilots' name, reported in 1900 , but not heretofore published.

Round; point, on the eastern shore of Portland canal. So named by Pender in 1868.

Round; point, on the southeastern shore of Zarembo island, Stikine strait, Alexander archipelago. So named by snow, 1886.

Round; point, one-fourth mile west of Flag point, on the south shore Whitewater bay, Admiralty island, Chatham strait, Alexander archipelago, near latitude $57^{\circ} 14^{\prime}$, longitude $134^{\circ} 36^{\prime}$. So named by Moore, 1895 .

Round, point; see Glazenap.

Round; rock (40 feet high), off Pybus bay, Frederick sound, Alexander archipelago. So named in the Coast Pilot (1891, p. 143).

Round; rock, one of the Nagai rocks, near Chirikof island. So named by Dall, 1874.

Roundabout; mountain (1,000 feet high), on the right bank of Kuskokwim river, in latitude $63^{\circ}$. So named by Spurr and Post, 1898.

Roundabout; mountain, on north side of Koyukuk river, near latitude $65^{\circ} 30^{\prime}$, longitude $156^{\circ} 30^{\prime}$. So named by Schrader and Gerdine, 1899 .

Round Head; the eastern point of entrance to Seredka bay, eastern shore Akun island, Krenitzin group, eastern Aleutians, near longitude $165^{\circ} 24^{\prime}$. So named by Gilbert, 1901 . 
Round Hill; island, western shore Alitak bay, Kodiak, at entrance to Kempff. bay. Name from Moser, 1900.

Roundtop; mountain, near east end of Unimak island, eastern Aleutians, near latitude $54^{\circ} 45^{\prime}$, longitude $163^{\circ} 35^{\prime}$. Called Dome by Moser in 1897, and Round Top by the Coast Survey in 1902 .

Rousseau; range of mountains (3,500 to 4,000 feet high), on western side of Portland canal, southeastern Alaska. So named by Pender, 1868.

Rover; creek, Seward peninsula, small tributary on east bank Casadepaga river, near latitude $64^{\circ} 47^{\prime}$, longitude $164^{\circ} 22^{\prime}$. Prospectors' name, from Gerdine, 1905. It is apparently the same that is called slate on a local map, 1901.

Rowand; point, on the Arctic coast, east of Point Barrow. So named by Dease and Simpson, 1837, after a friend.

Rowland; gulch, Copper River region, at the headwaters of Chititu creek. Frospectors' name, taken from map of Nizina mining district, by George M. Esterly, of Valdez, 1902.

Roxas, Puerto de; see Ugak bay.

Rozhnof; cape, on the northern shore of Alaska peninsula, on west side of Port Moller, and Ferendeen bay, near longitude $161^{\circ}$. Named Rozhnof by Lutke, 1828, who wrote it (in French) Rojnoff. Has been written Rodgnoff. The original Rozhnof is now Lagoon point (of Coast Survey charts), and the name Rozhnof has been transferred to a point farther east.

Rubber Boot; lake and stream, western coast Prince William sound, on the north side of the entrance to the small bay immediately north of Point Nowell, near latitude $60^{\circ} 30^{\prime}$, longitude $148^{\circ}$. So called by the fisheries, and reported by Moser, 1897.

Rubetz, village; see Afognak.

Lubia, bay; see Fish.

Ruby; creek, tributary to Bluestone river from the west, Seward peninsula. Name from Barnard, 1900.

Ruby; creek, tributary to Casadepagi river from the east, Seward peninsula. Name from Barnard, 1900.

Ruby; creek, Seward peninsula, tributary from the south to Igloo creek, a branch of American river, near longitude $165^{\circ} 24^{\prime}$. Prospector's' name, reported by Gerdine, 1901.

$R u b y$; creek, on the right bank of Anvik river, western Alaska, near latitude $63^{\circ} 15^{\prime}$. Prospector's' name, published in 1900 .

Ruby; creek, 20 miles northeast of Fairbanks, on the south side of Chatanika river, one-fourth mile below Cleary creek, near latitude $65^{\circ} 05^{\prime}$, longitude $147^{\circ} 35^{\prime}$. Prospector's' name, from a local map, 1905.

Ruby; creek, tributary to Minook creek from the west. Prospectors' name, published by the Coast Survey in 1898 .

Ruby; creek, eastern Alaska, on the west bank of Slate creek, tributary from the west to North fork Fortymile creek, about latitude $64^{\circ} 40^{\prime}$, longitude $142^{\circ} 45^{\prime}$. Prospectors' name, from sketch map compiled by Major Glassford, Signal Corps, U. S. A., 1905.

Ruby; gulch, Copper River region, at the source of Chistochina river. Prospector's' name, reported by Mendenhall, 1903.

Ruby; gulch, 10 miles northwest of Cape Nome, draining from the southeast, through Hazel creek, into Nome river, near longitude $165^{\circ} 10^{\prime}$. Local name, published in 1904 .

Rudder; point, on Bennett island, Arctic ocean. So named by De Long, 1881. 
Rudolph; creek, 15 miles north of Nome, Seward peninsula, tributary from the east to the headwaters of Snake river, near longitude $165^{\circ} 23^{\prime}$. Miners' name, published in 1900 .

Rudyerd; bay, in the mainland, debouching into Bebm canal, southeastern Alaska. Named· by Dall, 1879, after the English engineer Rudyerd, who rebuilt the Eddystone light-house after its destruction in 1703.

Rudyerd; island, in Behm canal, southwest from the entrance to Smeaton bay. So named by Dall, 1879, after the English engineer Rudyerd.

Rufus, creek, Nome river; see Sufus.

Rugged, cove; see Ragged.

Ruggcd, island; see Makhnati.

Rugged; island (1,488 feet high), in entrance to Resurrection bay, Kenai peninsula, near latitude $59^{\circ} \overline{\mathrm{a}} 1^{\prime}$; longitude $149^{\circ} 24^{\prime}$. Descriptive name, given by the U. S. Board on Geographic Names, June 6,1906 .

Ruhamah; mountain (5.460 feet high), near head of Disenchantment bay, southeastern Alaska. Named Ruhama by Russell, 1891, "in honor of Miss Ruhama Scidmore, the author of a charming book on journeys

- in Alaska." As Miss Scidmore spells her name Rubamah (not Ruhama), and as it was named in her honor, her own spelling is here followed.

Ruins; point, the southern point of entrance to Shipley bay, Sumner strait, Alexander archipelago. So named by Dall, 1879, on account of a ruined Indian village there.

Rukavitsie; cape, on southern shore of Unimak island, "near which are two rocky pillar's and some shoals, affording tolerable anchorage." So described by Veniaminof, 1840, and called Rukavitsie, gloves or mittens, probably from some fancied resemblance to those articles. The Coast Survey chart 8860 locates it on the east side of Unimak bay, near longitude $164^{\circ}$.

Rulby; creek, tributary to Sinuk river from the east, Seward peninsula. Name from Barnard, 1900.

Rurik; harbor, indenting the southeastern shore of Khantaak island, Yakutat bay, southeastern Alaska. Two harbors indent the southeastern shore of Kbantaak island. One of these is Port Mulgrave, the other, as here used, is Rurik harbor: Khromichenko, 1823, surveyed both and gave the name Rurik to the whole, the name being that of a brig belonging to the Russian-American Company. This name is now restricted to the harbor immediately northeast of Port Mulgrave.

Rush; hill (665 feet high), on west end of St. Paul island, Bering sea, the highest of the Einahnuhto hills, near longitude $170^{\circ} 24^{\prime}$. StanleyBrown, 1891, gave the name Rush to the Einahnubto hills, probably after the U. S. revenue cutter Richard Rush. The Coast Survey, 1898, used the name as above.

kush, hills; see Einahnuhto.

Rush; point, west of Beardslee islands, Glacier bay, southeastern Alaska. Apparently so called, 1892 , by Reid, on account of the ceaseless rush of tidal flow past it.

Rush; point, the western head of Zapadni bay, on soufhern shore of St. George island, Pribilof group, Bering sea. Name published by the Coast Survey in 1898. Presumably named after the U. S. revenue cutter Richard Rush.

Rush; rock, near Umga island, between Sannak island and Alaska peninsula. So called by Dall, 1880, presumably after the U. S. revenue cutter.Richard Rush. 
Russel, creek; see Mahutzu river.

Russell; creek, tributary to Snake river from the west, Seward peninsula. Name from Barnard, 1900.

Russell; fiord, an arm of Disenchantment bay, soutbeastern Alaska. This extensive arm of Disenchantment bay was discovered and sketched by Prof. I. C. Russell in 1891, and is here named after him.

Russell; glacier, in or near Skolai pass, at the head of White river. So named by Hayes, 1891, after: Prof. Israel Cook Russell.

Russell; mountain (Mount Russell, 11,850 feet high), in the McKinley range, 35 miles southwest of Mount McKinley, near latitude $62^{\circ} 47^{\prime}$, longitude $151^{\circ} 53^{\prime}$. So named by Brooks, 1902, after Prof. I. C. Kussell.

Russian; creek, tributary to Yulion river from the south, 3 miles below Rampart (city), near longitude $150^{\circ} 15^{\prime}$. Name taken from Edwards' Track Chart of the Yukon, 1899.

Russian; harbor, at southwestern end of Kodiak island, behind Geese islands. So named by the Fish Commission in 1888. The name is derived from Tebenkof, who slows here "Russian lodge."

Russian, island; see Bamdoroshni.

Russian; point, the southern point of Grabam harbor, Cook inlet. Called Russian Pt. by Portlock, 1786.

Russian; reef, off Whitewater bay, Chatham strait, Alexander archipelago. So named by Meade, 1869. A Russian vessel is silid to have struck upon it.

Russian; river, Kenai peninsula, a southern tributary of. Kenai river, between Kenai and Skilak lakes, near longitude $150^{\circ}$. Local name, from Moffit, 1904.

Russian Mission; see Ilogmut.

Rusty Gold; creek, in the Fairbanks region, tributary to Chatanika river from the south, near latitude $65^{\circ} 10^{\prime}$, longitude $147^{\circ} 20^{\prime}$. Prospectors' name, reported by Gerdine, 1903.

Ruth; island, in Thomas bay, Alexander archipelago. So named by Thomas, 1887.

72ut7ovs7iy, village; see Afognak.

Rutland; island, low and sandy, on the Arctic coast, near Point Barrow. Apparently so named by the British Admiralty, 1855.

Ryan; creek, just east of Topkok river, Seward peninsula. Name from Barnard, 1900.

Ryan; creek, eistern Alaska, on the right bank of Butte creek, an affluent of North fork Fortymile creek from the northeast, near latitude $64^{\circ} 40^{\prime}$, longitude $142^{\circ}$. Prospectors' name, from sketch map compiled by Major Glassford, Signal Corps, U. S. A., 1905.

Ryan; creek, eastern Alaska, on the west bank of the North fork Fortymile creek, near latitude $64^{\circ} 40^{\prime}$, longitude $142^{\circ} 15^{\prime}$. Prospectors' name, from sketch map compiled by Major Glassford, Signal Corps, U. S. A., 1905.

Tiyan, creek; see Colorado.

Rynda; anchorage, at southeastern edge of the Stikine flats, Sumner strait, Alexander archipelago. Called Rynda anchorage or Port Rynda by Dall in the Coast Pilot, 1883 , after the Russian corvette Rynda, which anchored here and sounded out the place in 1863.

Rynda; island, in the Stikine flats, Sumner strait, Alexander archipelago. Named by the Russians after the corvette Rynda, which made surveys in this region in 1863. 
Rynda; mountain (3,700 feet high), on the mainland, east of the flats at mouth of Stikine river. So called by Hunter, 1877.

Sabachi, point; see Dog.

Sabine; cape, on the Arctic coast, east of Cape Lisburne. So named by Beechey, 1827 , presumably after Gen. Sir Edward Sabine.

Sacharowskaja, bay; see Zachary.

Sachem; island, in Saginaw bay, Kuiu island, Alexander archipelago. So named by Moore, 1892.

Sachine, strait, etc.; see Shakhine.

sachsaiya, glacier; see Saksaia.

Sadatanak; island, near the southern shore of Atka, middle Aleutians. Native name from Tebenkof, 1849.

Saddle; mountain, on the mainland, east of Stikine river, near international boundary. Name published by the Coast Survey in 1891.

Sadie; cove, indenting the southern shore of Kachemak bay, Cook inlet. So named by Dall, 1880, after Sarah Eldred, wife of Marcus Baker.

sadlidok, island; see Sitkalidak.

Safa; islands, in Pearse inlet, at entrance to Wales harbor, southeastern Alaska. So named by Nichols, 1891.

Safety; point and rock, in Niblack anchorage, Clarence strait, Alexander archipelago. So named by Clover, 1885.

Safety; port (Port Safety), immediately east of Cape Nome, on the northern shore of Norton sound. Surveyed and named by the Coast Survey in 1899. A post-office, Safety, established here in September, 1900, was discontinued in 1903.

Safety; telegraph station on Port Safety, 24 miles east of Nome, connected by wireless telegraph with St. Michael, 107 miles across Norton sound.

Sagak; cape, the westernmost point of Umuak island, eastern Aleutians. Aleut name, from Veniaminof. It means sleep. Lutke calls it Sigak.

Sagamtushik; cape, on the sonthern shore of Umnak island, near Vsevidof volcano. Native name, from Kuritzien, 1849.

Sagchudak; islet, near the southern shore of Atka, middle Aleutians. Native namie, from Tebenkof, 1849. Has been written sagtchudakb.

Saghadellautan, village; see Zakatlatan.

Sagigik; island, off the southern shore of Amlia island, near its eastern end, Andreanof group, middle Aleutians. Native name, from Tebenkof, 1849. Perhaps from the Aleut sígik (a point or sharp edge).

Saginaw; bay, indenting the northwestern shore of Kuiu island, Frederick sound, Alexander archipelago. So named by Meade, 1869, after his ship, the U. S. S. Saginaw.

Saginaw; channel, separating Sbelter and Lincoln islands from the northern end of Admiralty island, Alexander archipelago. So named by Meade, 1869, after his ship, the U. S. S. Saginaw, the first man-of-war to pass through it.

Saginaw; ledge of rocks, in Mitchell bay, Kootznahoo inlet, Admiralty island, Alexander archipelago. So named by Meade, 1869, after his vessel, the U. S. S. Saginaw.

Saginaw; point, near Kootznahoo inlet, Admiralty išland, Alexander archipelago. So named by Meade, 1869, after his vessel, the U. S. S. Saginan.

Sahjek, creek; see Sajek.

Sail; island, off False Point Pybus, Frederick sound, Alexander archipelago. Named Ship island by Meade, 1869, and on later charts called Sail.

sail, rock, near Bogoslof; see Ship.

Saina, river and telegraph station; see Tsina. 
Saint Abram, islands; see Semichi.

Saint Agnes; point, on the eastern shore of St. Ignace island, Bucareli bay, Prince of Wales archipelago. Named Punta de S. Ines (St. Agnes point) by Maurelle and Quadra, 1775-1779.

Saint Albans; point, the eastern point of entrance to Affleck canal, Kuiu island, Alexander archipelago. So named by Vanconver, $\mathbf{1 7 9 3 .}$

Saint Andrean, islands; see Andreanof.

Saint Augustine; cape, in Gulf of Esquibel, Prince of Wales archipelago. Named Cabo de San Augustin by Maurelle and Quadra, 1775-1779.

Saint Augustine; cape, the southern point of entrance to Augustine bay, Dall island, Prince of Wales archipelago. Named Cabo de San Agustin by Maurelle, 1775.

Saint Augustine; mountain; see Augustine.

Saint Barnabas, cape; see Barnabas.

Saint Bartholomew, cape; see Bartolome.

Saint Boniface; point, the southern point of entrance to Port San Antonio, Bucareli bay, Prince of Wales archipelago. Named Punta de San Bonifacio by Maurelle and Quadra, 1775-1779.

Saint Catherine; cove, indenting the northeastern shore of Unimak island and opening into Isanotski strait near its norther'm end, about latitude $55^{\circ}$, longitude $163^{\circ} 30^{\prime}$. So named by Dall, 1882, after Krenitzin's vessel, the galiot St. Catherine. Krenitzin wintered in this vessel in Isanotski strait, 1768-69.

Saint Chrysostom; harbor, on the eastern shore of Cook inlet, just north of Kenai. Translated and called Zlatousta (golden mouthed) by Tebenkof, 1849.

Saint Demetrius, is!ands ; see Diomede.

Saint Diamed, islands; see Diomede.

Naint Diomede, islands; see Diomede.

Saint Dionysius; redoubt or fort, Wrangell harbor, Alexander archipelago. By order of Baron Wrangell a log stockade or fortified post was built in Wrangell harbor, 1834, by Lieut. Dionysius Zarembo to prevent encroachments by the Hudson Bay Company. Zarembo called it Redoubt St. Dionysius. Also it has been called St. Dionicio, St. Dionysi, and Dionysius. A few years ago remains of this abandoned and ruined stockade were still to be seen.

Saint Elias; cape, the southern end of Kayak island, near Controller bay. So named by Bering in 1741. Vancouver, 1794, named it Hamond, after Sir Andrew Snape Hamond, which name the Russian charts write Famon, and others Hammond. The spaniards (1779) called it P. de Cañas (point of reeds), and applied Cavo de San Elias to Cape Suckling.

Saint Elias, cape; see Sitkagi.

Saint Elias; mountain (18,024 feet high), in southeastern Alaska. Discovered by Bering on St. Elias day, July $\frac{27}{16}, 174.1$, and so named by him. The native name is reported by Topham to be Yahtse-tah-shah.

Saint Elias, point; see Manby.

Saint Elias Alps; great mountain range, extending from Cross sound northwesterly to Mount St. Elias and beyond. This name appears to have been first applied by Dall, 1874.

Saint Elizabeth, cape; see Elizabeth.

Saint Etienne, island; see Agattu.

Saint Felix, point; see Felix, cape. 
Saint George; island, one of the Pribilof group, Bering sen, near latitude $56^{\circ}$ $35^{\prime}$, longitude $169^{\circ} 30^{\prime}$. Discovered Tune ; 1786, by Pribilof and named after his ship, George or St. George. Now universally called St. George.

Saint George; rock or rocks, in Chiniak bay, Kodiak. Name published by the Coast Survey in 1881.

Saint George; village, on St. George island, Pribilof group, Bering sea. Local name.

Saint Hermogenes; cape, the easternmost point of Marmot island, Kodiak group. Cook, 1778, identified this as the point named St. Hermogenes by Bering in 1741.

Saint Hermogenes, island; see Marmot.

Saint Ignace; island, in Bucareli bay, Prince of Wales archipelago. Named St. Ignace of St. Ignácio by Maurelle and Quadra, 1775-1779.

Saint Ines, point; see St. Agnes.

Saint Isidor; point, in San Nicolas canal, Bucareli bay, Prince of Wales archipelago. Named Punta de San Ysidoro by Maurelle and Quadra, 17751779.

Saint Jacob, island; see Jacob.

Saint James; bay, in the mainland, on western shore of Lynn canal, Alexander archipelago. Name published by the Coast Survey in 1889 .

Saint James; mission, on north bank of the Yukon, opposite the mouth of Tanana river. This Episcopalian mission was established in 1891, by Rev. J. L. Prevost, about 3 miles above the mouth of the Tozi rivel, but has since been moved to its present site 13 miles farther up. The trading post near the old site was called Fort Adams.

Saint Jean Bogosloff, island; see Bogoslof.

Saint John, cape; see Kupreanof.

Saint John; harbor, in Zarembo island, opening into Sumner strait, Alexander archipelago. Apparently this name was first applied by Dall in the Coast Pilot (1883, p. 106).

Saint John; point, Zarembo island, Sumner strait, Alexander archipelago. So named by Vancouver, 1793.

Saint John; rock, south coast St. Paul island, Bering sea, on the narrow neck between St. Paul village and Reef point, near longitude $170^{\circ} 17^{\prime}$. Local name, reported by Duffield, 1897 .

Saint John Baptist; bay, indenting the western shore of Baranof island, Neva strait, Alexander archipelago. Named Cv. Ioanna Predtechi (St. John the Baptisto) by Vasilief, 1833. Sometimes called Baptist bay and St. John bay or gulf.

Saint John's, hill, St. Paul island ; see C'ross.

Saint Joseph; island, in Arriaga passage, Gulf of Esquibel, Prince of Wales archipelago. Named Ysla de San Josep by Maurelle and Quadra, 17751779.

Saint Lawrence; large island, in the northern part of Bering sea, near latitude $63^{\circ} 30^{\prime}$, longitude $170^{\circ}$. Discovered by Bering on St. Lawrence day, August $\frac{21}{16}, 1728$, and named by him St. Lawrence. Muller (Voyages, 1761, p. 3) says: "They heard of an island which was said to lie somewhat farther, at no great distance from the continent; to this they gave the name of St. Lawrence, on account of its being the 10th of August, that saint's day, when they passed by it, without observing anything upon it besides cottages of fishermen." By early Russians also called Sind, after Lieutenant Sind, who passed somewhere near it in 1766 . 
Saint Lawrence-Continued.

Cook passed east of this island in 1778 and his expedition to the west of it in 1779. Its eastern end he named Anderson island, after Dr. William Anderson, surgeon on the Discovery, on the supposition that it was a separate island. Later, according to Beechey, he found that it was part of what we now call st. Lawrence island, but owing to his death the correction was not made in his published account. The main body of the island Cook called Clerke's island, after Capt. Charles Clerke of the Discovery, and its western end, shown as a separate island, he calls St. Laurence and St. Lawrence (he uses both forms), taking the name from Bering. According to Billings the Chukchi call this island E-oo-vogen. On his chart he calls it Eivoogiena or Clerks, adding Sinde island of the Russians, while Sarichef, who accompanied Billings, has St. Lawrence or Eivugen, and this is followed on Russian Hydrographic charts. Kotzebue says the natives call it Tschibocki. This name is preserved in the name of its northwestern cape, Chibukak. Now universally known as St. Lawrence island.

Saint Lazaria, cape; see Edgecumbe.

Saint Lazaria; island, near the southern end of Kruzof island, Sitka sound, Alexander archipelago. So called by Vasilief, 1809, presumably to retain the name supposed to bave been given by Chirikof, 1741, to Edgecumbe cape and mountain, and by some even applied to Kruzof island as a whole. Has also been called Muisofski (cape) island. It was called Robin islaud by Dixon, 1787.

Saint Lazaro, mountain ; see Lazaro.

Saint Leonard; point, on the western shore of St. Ignace island, Bucareli bay, Prince of Wales archipelago. Named Punta de San Leonardo by Maurelle and Quadra, 1775-1779.

Saint Mary, island ; see Mary.

Saint Mary; point, the northern point of entrance to Berners bay, Lynn canal, Alexander archipelago. Named St. Mary's by Vancouver, 1794.

Saint Matthew; island, in Bering sea. Discovered and so named by Sind iu August, 1766. Cook saw it September 23, 1778, and says that afterwards he found it was wholly unknown to the Russians. Accordingly, he named it Gore's, after Lieut. John Gore, a member of his party. Billings, about 1790, calls it Matwi or Gores island. Kotzebue has St.. Matwey (Choris island). It is now universally known as St. Matthew island.

Saint Michael; bay, on which is situated St. Michael, Norton sound, Bering sea. Discovered and described by Tebenkof in 1.831, and, after him, named Tebenkof by Lutke in 1.836. On late charts called St. Michael bay.

Saint Michael; canal, hill (472 feet high), islaud, military reservation, postoffice (established in September, 1897), and town, Norton sound, Bering sea, near latitude $63^{\circ} 30^{\prime}$. A stockaded post was established here by the Russians, 1833, and, according to Zagoskin, named after .Capt. Niichael Dmitrievich Tebenkof, afterwards governor of the Russian-American colony. It was called Redoubt St. Michael or Michaelovski. The native name is Techek (the bay).

Saint Michael; creek, 8 miles northwest of Cape Nome, Seward peninsula, tributary from the southeast to Osborn creek, near longitude $165^{\circ} 08^{\prime}$. Local name, published in 1901. Called also Jessie creek.

saint Mitrofania, island; see Mitrofania. 
Saint Nicholas. An unexplored opening on the eastern shore of Bucareli bay, Prince of Wales archipelago, was named Puerto de San Nicolao by Maurelle and Quadra, 1775-1779.

Saint Nicholas; canal or channel, in western part of Bucareli bay. Named Canal de St. Nicholas by Maurelle and Quadra, 1775-1779. Has also been called San Nicolo.

Saint Nicholas, fort ; see Kenai.

Saint Orlof, village; see Orlora and Eagle harbor.

Saint Patrick; creek, 5 miles northwest of Fairbanks, tributary to Cripple creek, near longitude $147^{\circ} 55^{\prime}$. Local rame, from map of location, Tanana Mines Railroad, 1904.

Saint Paul; harbor, the principal harbor of Kodiak, near latitude $57^{\circ} 47^{\prime}$, longitude $152^{\circ} 24^{\prime}$, and often called Kodiak harbor.

Saint Paul, harbor; ; see Port Levashef.

Saint Paul; island, the principal island of the Pribilof group, Bering sea, near latitude $57^{\circ} 10^{\prime}$, longitude $170^{\circ} 15^{\prime}$. Discovered June 29,1786 (o. s.) (St. Peter and St. Paul's day of the Julian calendar), by Pribilof, and named by him St. Peter and St. Paul, a name soon abbreviated to St. Paul.

Saint Paul, island; see Paul.

Saint Paul, town; see Kodiak.

Saint Paul; village, on St. Paul island, Pribilof group, Bering sea. Local name.

Saint Philip; island, in Gulf of Esquibel, Frince of Wales archipelago. Named Ysla de San Felipe by Maurelle and Quadra, 1775-1779.

Saint Sebastian; point, in the eastern part of Bucareli bay, Prince of Wales archipelago. Named Punta de San Sebastian by Maurelle and Quadra, $1775-1779$.

Saint Sergis; mountains, southwestern Alaska, between the Yukon and Kuskokwim rivers, near latitude $62^{\circ}$, longitude $159^{\circ}$. Name published in 1905.

Saint Simeon، A fort or stockade called St. Simeon, located on Cape Suckling, Controller bay, is shown on a Russian map of 1802.

Saint Stephens, island; see Kiska.

Saint Theresa; point, in San Nicolas canal, Bucareli bay, Prince of Wales archipelago. Named Punta de Santa Theresa by Maurelle and Quadra, 1775-1779.

Saint Thomas; point, in Portillo channel, Bucareli bay, Prince of Wales archipelago. Named Punta de San Thomas (St. Thomas point) by Maurelle and Quadra, 1775-1779.

Sajaka; cape (7,108 feet high), the northeasternmost point of 'Tanaga island, Andreanof group, middle Aleutians. Tebenkof, 1849, calls this Northwest cape. Hydrographic chart 8, embodying the results of the North Pacific exploring expedition of 1855, has Sajaga, the origin or meaning of which I have not discovered. A late Coast Survey chart has Sajaca.

Sajek; creek, at the headwaters of Volkmar river, an affluent of the Tanana from the north, near latitude $64^{\circ} 20^{\prime}$, longitude $143^{\circ}$. Probably an Indian name, reported in 1898 by E. F. Ball, a prospector, who wrote Sahjek (Bear creek).

Sajelklakat, river; see Sozhekla.

Sakataloden, village; see Zakatlatan.

saledelontin, village; see Zakatlatan.

Salileliageta, creek; see Baker.

Saks; cove, in the mainland, opening into Behm canal, Alexander archipelago. So named by the Coast Survey in 1891. 
Saksaia; glacier, in the Chilkat region at the head of Glacier creek, an affluent on the south bank of Klehini river, near latitude $59^{\circ} 20^{\prime}$, longitude $136^{\circ}$ 25'. Indian name, written Saxaeja by the Krause brother's in 1882 , and Sachsaiya by Flemer in 1898.

Salamatof; lake, near East Foreland, Kenai peninsula. This name is from Grewingk, 1850, who, following Wosnesenski, 1840, calls this Salamatowa or Kutsch-tazik-mütscha lake. Salamatof is a Russian proper name and the otber the native appellation.

Salamatof; shoal, off the northern end of Kanaga island, Andreanof group, middle Aleutians. Russian family name, from Tebenkof, 1849.

Salawik, lake; see Selawik.

Salcha; river, tributary to the Tanana river from the east, near longitude $147^{\circ}$. Native name, reported by Peters and Brooks, of the Geological Survey, 1898, and spelled Salchacket and Salchaket. Presumably this is Salchakakat, i. e., mouth of Salcha river. Transformed to Salt Jacket by some of the prospectors.

Salcha; telegraph station on the Tanana at confluence with Salcha river. So named by the Signal Corps, U. S. A., 1902. The Indian name is Salchaket of Salchakakat, i. e., mouth of the Salcha river.

Saldovia, bay ; see Seldovia.

Salisbury; point, the southeastern point of entrance to Gastineau channel, Stephens passage, Alexander archipelago. So named by Vancouver, 1794, after the bishop of Salisbury. See Bishop.

Salisbury; sound, between Chichagof and Kruzof islands, Alexander archipelago, near latitude $57^{\circ} 22^{\prime}$. So called by Portlock, 1787. It is the Puerto de los Remedios, of Maurelle, 1775; Bay of Islands, of Cook, 1778; Klokachef sound, gulf, or strait, of Vasilief and others; and Olga strait, of Tebenkof, 1849.

Salmo; point, the northeasternmost point of Hawkins island, Prince William sound. Named by Abercrombie, 1898, after the little steamer Salmo. Called Hawkins point by Moser in 1897.

Salmo; rock, near eastern shore of Cook inlet, at mouth of Kenai river. Name reported by the Coast Survey parties in 1905 .

Salmo, sound; see Unakwik inlet.

Salmon; bay, opening into Clarence strait near its northern end, Prince of Wales island, Alexander archipelago. So named by Snow, 1886.

Salmon; bay or cove, indenting the northern shore of Silver bay, Sitka sound, Alexander archipelago, near latitude $57^{\circ} 03^{\prime}$, longitude $135^{\circ} 13^{\prime}$. Named Seldovaia (herring) by the Russians. This has been translated Salmon and the place called Salmon bay.

Salmon; bay, indenting the southeastern shore of Sannak island, just east of Peterson bay. So called by the Fish Commission in 1888. Perhaps this is identical with King cove of Dall, 1880.

Salmon; creek, tributary to Red bay, Prince of Wales island, Alexander archipelago. So named by Helm, 1886.

Salmon; creek, on the mainland, 3 miles northwest of Juneau, southeastern Alaska. Presumably a local name.

Salmon; creek, entering Port Valdez from the south, 4 miles west of Fort Liscum, Prince William sound, near longitude $146^{\circ} 26^{\prime}$. Local name, reported by Grant, 1905.

Salmon; creek, tributary to Resurrection river and Resurrection bay, Kenai peninsula. Local name, from Mendenhall, 1898.

Salmon; creek, Alaska peninsula, tributary to Becharof lake from the east. Local name, reported by Martin, 1903.

Bull. 299-06 $\mathrm{M}-35$ 
Salmon; lake, near head of Resurrection bay, Kenai peninsula, drained by Salmon river. Local name, from Mendenhall, 1898.

Salmon; lake, Seward peninsula, 35 miles north of Cape Nome, draining to Port Clarence, through Kruzgamepa river, near latitude $64^{\circ} 54^{\prime}$, longitude $165^{\circ}$. Name from Barnard, 1900. Its Eskimo name is said to be Nahwazúk (salmon).

Salmon; point, on the western shore of Portland canal, near its head. Name published by the Coast Survey about 1891.

Salmon; river, tributary to head of Portland canal, southeastern Alaska. So named by Pender, 1868 :

Salmon; river, tributary to the Stikine from the south, about 7 miles from Rothsay point. So called by Hunter, 1877.

Salmon, river, on west bank of Chilkat; see Tsirku.

Salmon; river, debouching on the north shore of Icy strait, 7 miles east of Glacier bay, near longitude $135^{\circ} 45^{\prime}$. So called by Dickins, 1902 .

Salmon; river, nortbwestern Alaska, tributary to Kobuk river from the north, near latitude $67^{\circ} 15^{\prime}$, longitude $159^{\circ} 30^{\prime}$. Called Salmon or Kal-la-gunick by Stoney, 1884-1886, and Salmon by Mendenhall, 1901.

Salmon, river; see Sheenjek.

Salmon; run, tributary to Sanborn harbor, Nagai island, Shumagins. So called by Dall, 1872.

Salmon, sound, Prince William sound; see Unakwik inlet.

Salmon Bay; village and fishery, at. Salmon bay, Prince of Wales island, Alexander archipelago. The fishery was established prior to 1890 .

Salmonberry; cove, in Chichagof island, near southwestern entrance to Peril strait, Alexander archipelago. So named by Coghlan, 1884.

Salmon Creek; valley, lying between Klutina and Lily lakes, on the northwest. So called by Schrader, 1898.

Salmon Trout; river, tributary to the Porcupine from the east, near the international boundary line. So called by the Coast Survey in 1895 .

Salt; creek or river, tributary to Yukon, river from the north, about 50 miles above Rampart. Prospector's' name, reported in 1899. See also Ray and Chetaut.

Salt; island, near the northern shore of Atka, middle Aleutians. Named Solenoi (salted) by Lutke, about 1830, and variously written Salennoj, Soleni, Soleny (salée), etc.

Salt; lagoon, at the head of Kitkun bay, on the southern shore of Cholmondeley sound, Clarence strait, southeastern Alaska, near latitude $55^{\circ} 10^{\prime}$, longitude $132^{\circ} 10^{\prime}$. Descriptive name, from local navigators by $\mathrm{H}$. C. Fassett, Bureau of Fisheries, 1904.

SaIt; lagoon, at the head of George inlet, Revillagigedo island, Alexander archipelago, near latitude $55^{\circ} 33^{\prime}$, longitude $131^{\circ} 28^{\prime}$. Local navigators' name, reported by H. C. Fassett, Bureau of Fisheries, 1904.

Saltery; cove, on the southern shore Skowl arm, Kasaan bay, Clarence strait, southeastern Alaska, near latitude $55^{\circ} 24^{\prime}$, longitude $132^{\circ} 20^{\prime}$. Local navigators' name, reported by H. C. Fassett, Bureau of Fisheries, 1904.

Salthidack, island; see Sitkalidak.

Salt Jacket, river; see Salcha.

Sam; creek, tributary to the Yukon river from the south, near latitude $65^{\circ} 20^{\prime}$, longitude $142^{\circ} 50^{\prime}$. 'Prospectors' name, reported by Lieutenant Erickson, U. S. A., 1902.

Sam; peak (2,583 feet high), in eastern part of Mitkof island, Alexander archipelago. So named by Thomas, 1887. 
Samalga; island, off the southwestern end of Umnak island, eastern Aleutians, longitude $169^{\circ} 05^{\prime}$. Now occupied for the propagation of blue. foxes. Native name, from Sarichef, 1790. In 1764 , says Veniaminof, there was on this island a settlement containing not less than 400 people.

Saimganoodha, bay; see English.

Samganuda, bay; see English.

Samlalogh; ridge (kaia), extending obliquely across the west end of St. George island, Bering sea, near longitude $169^{\circ} 40^{\prime}$ to $169^{\circ} 45^{\prime}$. Aleut nime, written Sämlälōch'-kīyä' (ridge where eggs are gathered) by Putnam, 1897. Samlalogh-kiya, on Coast Survey map 3224, 1898.

Samoilof, island; see Scraggy.

Samovar; hills, back of Malaspina glacier, in the St. Elias alps, southeastern Alaska. So named by Russell in 1890 . Samovar is the Russian name of the utensil used by them for making tea.

Sampson; creek, 16 miles north of Nome, in the Nome mining reglon, Seward peninsula, tributary to Nome river from the east, near longitude $165^{\circ}$ 17'. Local name, in compliment to Admiral William Thomas Sampson, and published in 1900 .

Samuel; point, the westernmost point of Killisnoo island, Chatham strait, Alexander archipelago. So named by Vancouver in 1794. Has been misplaced on the charts and also erroneously printed Samuels.

Sanachno, cape; see West.

San Adrian; islet, in Port Refugio, Bucareli bay, Prince of Wales archipelago. This name appears on the old Russian chart which was copied from the Spanish, but does not appear on the English edition of that chart by La Perouse (1798, pl. 26).

San Ageda, point; see Agueda.

Sanaguich; river, Seward peninsula, flowing north to Shishmaref inlet, near longitude $165^{\circ} 37^{\prime}$. Eskimo name, reported by Gerdine, 1901 .

San Alberto; bay, in Bucareli bay, Prince of Wales archipelago. Called Seno de San Alverto by Maurelle and Quadra, 1775-1779. Aiso has been called San Alberti and San Alberto.

San Antonio; point, in Port Refugio, Bucareli bay, Prince of Wales archipelago. Named Punta de San Antonio (point of St. Anthony) by Maurelle and Quadra, 1775-1779.

San Antonio; point, on the northern shore of San Juan Bautista island, Bucareli bay, Prince of Wales archipelago. Named Punta de San Antonio by Maurelle and Quidra, 1775-1779.

San Antonio; port, in Baker island, Bucareli bay, Frince of Wales archipelago. Called Puerto de San Antonio by Maurelle and Quadra, 1775-1779.

San Bitoriana; point, on the northeastern shore of St. Ignace island, Bucareli bay, Prince of Wales archipelago. Named Punta de San Bitoriana by Maurelle and Quadra, 1775-1779. Called San Batoriano on an old Russian chart.

Sanborn; harbor, indenting the western shore of Nagai island, Shumagins. This harbor derived its name from the schooner. $J$. D. Sanborn, commanded by Capt. William Morse, who discovered it May, 1866.

San Carlos, island; see Forrester.

Sancho; creek, tributary to Yukon river from the south, 8 miles above Rampart rapids, and 33 miles below Rampart (city), near longitude $150^{\circ} 50^{\prime}$. Name taken from Edwards' Track Chart of the Yukon, 1899. It is apparently the same creek as Shevlin creek of the Coast Survey in 1898. See also Shevlin and Shefflin. 
San Christoval; channel, in Bucareli bay, Prince of Wales archipelago. Named Canal de San Christoval by Maurelle and Quadra, 1775-1779.

San Clemente; islet, in Portillo channel, Bucareli bay, Prince of Wales archipelago. Named Ysla de San Clemente by Maurelle and Quadra, 17751779.

San Come; point, in the eastern part of Bucareli bay, Prince of Wales archipelago. Named Punta de San Come by Maurelle and Quadra, 1775-1779.

Sand; bay, indenting the eastern shore of Stephens passage, Alexander archipelago, between Point Lookout and Point Astley, near latitude 57 $40^{\prime}$. Local name, reported by Spencer and Wright, 1903.

Sand; cape, at head of Kizhuyak bay, north coast of Kodiak. Named Peschanie (sandy) by Murashef, 1839-40.

Sund, barbor; see Martin.

Sand; island, near Table island, in Hood bay, Chatham strait, Alexander archipelago. So called by Nichols in the Coast Pilot $(1891$, p. 157).

Sand; island, east of Cape Whitshed at mouth of the Copper river. So called by Moser, 1899.

Sand, island; see Sumdum.

Sand; islands, two islands, on the outer side of Scammon bay, Yukon delta, near latitude $62^{\circ}$, longitude $166^{\circ}$. So called by. Dall in 1869 . Late maps distinguish the two islands as North Sand island and South Sand island.

Sand; islet, in McHenry anchorage, Clarence strait, Alexander archipelago. Apparently so designated by Snow or Helm, 1886.

Sand; point, on the northern shore of Whitewater bay, Admiralty island, Alexander archipelago. So named by Glass, 1881 .

Sand; point, the westernmost point of Popof island, Shumagins. Descriptive name, given by Dall, 1872.

Sand; spit, in Holkham bay, Stephens passage, Alexander archipelago. So called by the Coast Survey in 1895 .

Sanders, creek, Seward peninsula; see Saunders.

Sandfly; bay, on the western shore of Portland canal. So named by Pender, 1868 , for obvious reasons.

Sandford, cove; see Sanford.

Sandman; reefs, south of́ Belkofski, western end Alaska peninsula, near latitude $54^{\circ} 15^{\prime}$, longitude $162^{\circ} 15^{\prime}$. So called by Dall, 1880, after Captain Sandman, of the Alaska Commercial Company, to whom he was indebted for much information about the locality.

Sandpoint; fishing village and post-office, at Humboldt harbor, on Popof island, Shumagins. Locally known as Sand Point. The post-office was established here in March, 1891, and called Sandpoint.

Sandy; bay, indenting the southwestern shore of Baranof island, Alexander archipelago. Named Peschanaia (sandy) by the Russians.

Sandy; bay, indenting the southern shore of Sannak island, just. northwest of Peterson bay, near longitude $162^{\circ} 40^{\prime}$. Descriptive name, by Westdahl, 1901.

Sandy; bight, near the mouth of Red bay, Prince of Wales island, Alexander archipelago. So designated by Helm, 1886.

Sandy; cove, on the eastern shore of Glacier bay, southeastern Alaska. So named by Reid, 1892 .

Sandy; cove, near the mouth of Deep inlet, Sitka sound, Baranof island, Alexander archipelago. Named Pestchania (sandy) by Vasilief, 1809.

Sandy; cove, indenting the eastern shore of Little Koniuji island, Shumagin group. So named by Dall, 1874. 
Sandy; cove, on the northeast shore of Akutan island, Krenitzin group, eastern Aleutians, near longitude $165^{\circ} 48^{\prime}$. Descriptive name, by Gilbert, 1901.

Sandy; creek, tributary to American river from the east, Seward peninsula. Name from Brooks, 1900.

Sandy; point, the northwestern point of entrance to Twelvemile arm, Kasaan bay, Prince of Wales island, Alexander archipelago. So named by Clover, 1885.

sandy; point, on the right bank of the Chilkat river, about 7 miles above its mouth. Named Peschanie (sandy) by Lindenberg, 1838. The name is obsolete.

Sandy; point, in Alitak bay, southwestern coast of Kodiak, the northeastern point of Tanner head and the southern point of entrance to Lazy bay. Descriptive name, given by Moser, 1900.

Sandy; point, on the north shore of Olga bay, Alitak bay, soutbwestern coast of Kodiak. Local descriptive name, reported by Moser, 1900.

Sandy, point; see Anchorage.

Sandy, point; see Peschani.

Sandy; river, in the western part of Unimak, eastern Aleutians. This descriptive name, Peschanaia (sandy) was published by Veniaminof in 1840.

San Elias, cape; see St. Elias and Suckling.

San Felipe, Isla de; see St. Philip.

San Fernando; island, in Bucareli bay, Prince of Wales archipelago. So named by Maurelle and Quadra, 1775-1779.

Sanford; cove, in Endicott arm of Holkham bay, Stephens passage, Alexander archipelago, near latitude $57^{\circ} 41^{\prime}$, longitude $133^{\circ} .28^{\prime}$. So named by Mansfield, 1889, after Lawson Sanford, a member of his party. Erroneously Sandford.

Sanford; mountain (13,500 feet high), east of and near Copper river, in longitude $144^{\circ}$. So named by Allen, 1885 , in honor of the Sanford family, his "great-grandfather being Reuben Sanford."

Sanford; river, tributary to Copper river from the east, in the vicinity of Mount Sanford. So named by Allen, 1885, after his anecstors.

San Francisco; creek, 39 miles north of Cape Nome, Seward peninsula, tributary to headwaters of Eldorado river, near longitude $165^{\circ}$. Name from Barnard, 1900 .

San Francisco; island and point, in St. Nicholas canal, Bucareli bay, Prince of Wales archipelago. Named Punta y Ysla de San Francisco by Maurelle and Quadra, 1775-1779.

Sanganoac, Paso de; see Akutan pass.

Sango; creek; Seward peninsula, tributary from the south to Arctic river, near longitude $165^{\circ} 47^{\prime}$. Name from Gerdine, 1901.

San Jacinto, island; see Kruzof.

San Jose; creek, tributary to Eldorado river from the east, Seward peninsula. Name from Barnard, 1900.,

San Jose; point, the northern point of entrance to Port Santa Cruz, Suemez island, Prince of Wales archipelago. Named Punta de San Jose (point of St. Joseph) by Maurelle and Quadra, 1775-1779.

San Juan Bautista; island, in Bucareli bay, Prince of Wales archipelago. Named Ysla de San Juan Bautista (island of St. John the Baptist) by Maurelle and Quadra, 1775-1779.

San Juanito; islet or rock, in Bucareli bay, Prince of Wales archipelago. Named San Juanito by Maurelle and Quadra, 1775-1779. 
Sankin; bay, indenting the southern shore of Alaska peninsula, near its westernmost point, about longitude $163^{\circ} \cdot 18^{\prime}$. So called by Dall, 1880 , taking the name from the near-by island Sankin.

- Sankin; island, near the southern entrance to Isanotski strait, Alaska peninsula. Called Sankik and Sankin by the Russians. Apparently a native name.

San Lorenzo; island, in Arriaga passage, Gulf of Esquibel, Prince of Wales archipelago. Named Ysla de San Lorenzo (St. Lawrence island) by Maurelle and Quadra, 1775-1779.

Sannak; bank, southeast from Sannak island, near latitude $54^{\circ} 15^{\prime}$, longitude $162^{\circ}$. Called Sannakh by the Fish Commission in 1888.

Sannak; group of islands, the largest island in the group, and reefs on the southwest side of the group, south of the west end of Alaska peninsula, near latitude $54^{\circ} 25^{\prime}$, longitude $162^{\circ} 30^{\prime}$. Cook was becalmed off this group June 21, 1778, and in three hours caught more than 100 halibut weighing from 20 to 100 pounds each. Hence he gave the name Halibut island. Galiano's atlas (1802) has Islas des Plies. Except for these two names the island has been uniformly known as Sannak, spelled in many ways, Sanak, Sanuak, Sannakb, Sannacb, etc.

Sannak; mountain and peak (1,700 feet high), at western end of Sannak island. Cook in 1778 called this Halibut-head.

San Nicolo, canal or channel; see St. Nicholas.

San Pablo; point, on the eastern end of San Juan Bautista island, Bucareli bay, Prince of Wales archipelago. Named Punta de San Pablo (point of St. Paul) by Maurelle and Quadra, 1775-1779.

San Pasqual; point, on San Fernando island, Gulf of Esquibel, Prince of Wales archipelago. Named Punta de San Pasqual by Maurelle and Quadra, $1775-1779$.

San Pedro; island, in Arriaga passage, Gulf of Esquibel, Prince of Wales archipelago. Named Ysla de San Pèdro (island of St. Peter) by Maurelle and Quadra, 1775-1779.

San Rafael; point, on the southeastern shore of St. Ignace island, Bucareli bay, Prince of Wales archipelago. Named Punta de San Rafael by Maurelle and Quadra, 1775-1779.

San Roque; point, the eastern point of entrance to San Antonio bay, Bucareli bay, Prince of Wales archipelago. So named by Maurelle and Quadra, 1775-1779.

San Silbestre, Punta de; see Silvester point.

Sanson; point, on the southeastern shore of Bucareli bay, Prince of Wales archipelago. Named Punta San Son by Maurelre and Quadra, 1775-1779.

Santa Agueda, point: see Agueda.

Santa Anna; bay or inlet, point, and cannery, on the western shore Cleveland peninsula, Seward passage, Ernest sound, southeastern Alaska, near latitude $56^{\circ}$, longitude $132^{\circ}$. Local name, published in the Coast Pilot of 1901 .

Santa Buenabentura, Punta de; see Ventura point.

Santa Catalina, island; see Forrester.

Santa Cristina, island; see Forrester.

Santa Cruz; creek, Seward peninsula, an east branch of Cache creek, on the coast of Norton sound near longitude $164^{\circ} 10^{\prime}$. Prospectors' name, from a local map, 1904.

Santa Cruz; port, in Suemez island, Bucareli bay, Prince of Wales archipelago. Named Puerto de la Santa Cruz (port of the holy cross) by Maurelle, 1779. 
Santa Gertrudis; point, in Gulf of Esquibel, Bucareli bay, Prince of Wales archipelago. It is said to have been so named, about 1790 , by the Spaniards, after the Spanish man-of-war Santa Gertrudis. Has also been called St. Gertruda.

Santa Lucia; islands and point, in San Christoval channel, Bucareli bay, Prince of Wales archipelago. Named Punta y Yslas de San Lucia by Maurelle and Quadra, 1775-1799.

Santa Rita; island, in Port Real Marina, Bucareli bay, Prince of Wales archipelago. Named Ysla de Santa Rita by Maurelle and Quadra, 1775-1779.

Santa Rosa; point, west of St. Ignace island, Bucareli bay, Prince of Wales archipelago. Named Punta de Santa Rosa by Maurelle and Quadra, 1775-1779.

San Vacinto, mountain; see Edgecumbe.

San Ysidoro, Punta de; see Saint Isidor point.

Saook; bay, indenting the northern shore of Baranof island, Peril strait, Alexander archipelago. Has also been written Sa-ook. Native name, reported by Moore in 1895.

Saook; point, the western point of entrance to Saook bay, Peril strait, Alexander archipelago. So named by Moore, 1895.

Sapozhkovo, river; see Buskin.

Sarana; bay, indenting the southern shore of Akutan island, Krenitzin group, eastern Aleutians, near longitude $164^{\circ} \mathbf{5 7 ^ { \prime }}$. So called by Veniaminof about 1830 .

Sarana; bay, in Korovinski bay, Atka, middle Aleutians. So named by Lutke about 1830. Sarana is the Russian name of the Kamchatkan lily, the roots of which are eaten by the natives. Also written Saranna and Sarannaia.

Sarana; bay, indenting the northern shore of Attu island, western Aleutians. Local name, given by the Russians. Lutke, 1836, writes it Sarannaia. Sarani is the Russian name of the Kamchatkan lily, and also of a liquor made from it. It is often written Saranna.

Sarana; brook, flowing from a lake into (?) Sarana bay, Attu island, western Aleutians. Called Saraina by Grewingk, 1850.

Sarana; islet, off the southern end of Outer Iliasik island, in the Sandman reefs. Named Saranna by the Russians. Variously written Saranna, Saranoy, etc.

Saranac; peak (2,683 feet high), on the mainland, near Farragut bay, southeastern Alaska. Named by Thomas, 1887, after the U. S. S. Saranac, lost in Seymour narrows, June, 1875.

Saranac; rock, off the northern end of Woronkofski island, Sumner strait, Alexander archipelago. The U. S. S. Saranac is said to have struck upon it, whence the name, published in the Coast Pilot. $(1883$, p. 93$)$.

Sar-du-loten, Indian village; see Yakatlatan.

Sargent; bay, indenting the eastern shore of Revillagigedo island, Behm canal, Alexander archipelago, near latitude $55^{\circ} 34^{\prime}$, longitude $130^{\circ} 58^{\prime}$. Local navigators' name, reported by H. C. Fassett, Bureau of Fisheries, 1904.

Sar-Hene, salmon stream ; see Sarhini.

Sarhini; salmon stream, western shore Prince of Wales island, Alexander archipelago, 8 miles south of Sarkar inlet, near latitude $55^{\circ} \mathbf{5 5 ^ { \prime }}$. So described by Moser, 1901, who wrote Sar-Hene. Indian name, used by the fisheries. It may be the same that Moser called Kah-Hehe in 1897. 
Sarichef; cape, the westernmost point of Unimak island, eastern Aleutians, near latitude $54^{\circ} 36^{\prime}$, longitude $164^{\circ} 56^{\prime}$. So named by Lutke, 1828, after Admiral Gavrila Andreivich Sarichef. Tebenkof calls it Northwest cape. Also has been written Saritchey, Sarytcheff, etc. According to Veniaminof, its native name is Kakatkusik (?dry). Veniaminof calles it Pogromnoi First, or the west-southwest cape of Unimak, and the next one to the northeast, Shishkof, he calls Pogromnoi Second. This point was set apart for light-house purposes by Executive order dated January 4, 1901. In that order it is called Saritchey.

Sarichef; island, at entrance to Shishmaref inlet, on the northern shore of Seward peninsula. Named by Kotzebue, 1816, who says: "I named the narrow island after our worthy vice-admiral, Saritscheff." Variously written Saritscheff, Sarytschef, etc.

Sarichef; strait, between Hall and St. Matthew islands, Bering sea. Sarichef anchored in this strait in 1791. It was afterwards named for him by the Russians.

Sarkar; inlet, lake, and salmon stream, western shore Prince of Wales island, Alexander archipelago, near latitude $56^{\circ} 03^{\prime}$. Indian name, so applied by the fisheries, and written Sar-Kar by Moser in 1897 and 1901.

sarutschew, volcano; see Sergief.

Sarytcheff, peninsula and volcano; see Sergief.

sasak, cove; see Sisek.

Sasedni; island, on the southern side of Whiting harbor, Sitka sound, Alexander archipelago. Named Sasedni (neighbor) by Vasilief, 1809.

Sasmik; cape, the southernmost point of Tanaga island, middle Aleutians. Presumably an Aleut name, from Tebenkof, 1849. Has also been written Sasmikh.

Satanna, cape; see Bird.

Saturday; creek, 3 miles north of Nome, Seward peninsula, tributary to Wonder creek, a branch of Center creek, near longitude $165^{\circ} 23^{\prime}$. Local name, published in 1904.

Saturday; creek, Seward peninsula, tributary from the west to North creek, near latitude $65^{\circ} 23^{\prime}$. Prospectors' name, reported by Gerdine, 1901.

Saüluktoucikh. One of the Shumagins (which one is not known) was so called by Lutke (p. 267) in 1836. Sarichef called it (as printed in Phillips's Voyages, VI, 15) Saluluktussich.

Saunders; creek, 4 miles northwest of Cape Nome, Seward peninsula, tributary to Hastings creek from the north, near longitude $165^{\circ} 06^{\prime}$. Name from Barnard, 1900. Has been written Sanders.

Savaovik; river, debouching on the Arctic coast, 90 miles east of Colville river, near Anxiety point and longitude $147^{\circ}$. Eskimo name, obtained lig S. I. Marsh, a prospector, $1902-3$, who wrote Saviovic on his map.

Saviovic, river; see Savaovik.

Savonoski; Eskimo village, on the eastern shore of Naknek lake, Alaska peninsula. Name from Spurr and Post, who obtained it, 1898, from Rev. A. Petelin. Has also been written Savanóski. Of it Spurr says: "Ikkhagamut or Savonoski, as it is now commonly called."

Saw; peaks $(5,124$ feet high), on the mainland, east of Frederick sound, southeastern Alaska. So named by Thomas, 1887.

Saw; point, at entrance to Eliza harbor, Frederick sound, Alexander archipelago. So named by Mansfield, 1889.

Saw; ridge of mountains, in the southern part of Revillagigedo island, Alexander archipelago. Descriptive name, given by Nichols in 1883. 
Sawanukto; river, debouching on the Arctic coast, 60 miles east of Colville river, near Anxiety point and longitude $148^{\circ} 15^{\prime}$. Eskimo name, obtained by S. J. Marsh, a prospector, 1902-1903.

Sawmill; bay, indenting the western, shore of.Port Valdez, nearly opposite Jack bay, about latitude $61^{\circ} 02^{\prime}$, longitude $146^{\circ} 41^{\prime}$. Local name, reported by Ritter of the Const Survey, 1902.

Sawmill; camp, on beadwaters of Klutina river. Called Saw Mill by Abercrombie in 1.898 .

Sawmill; cove, in Dall island, Howkan strait, Alexander archipelago. So named by Nichols, 1881. Sheldon Jackson named this cove Ham, after Mrs. J. M. Ham, who contributed funds for the erection of a sawmill here in 1882.

Sawmill; creek, tributary from the east to Berners bay, eastern shore Lynn canal, southeastern Alaska, near latitude $58^{\circ} 46^{\prime}$. Prospectors' name, reported by Spencer and Wright, 1903.

Sawmill; creek, tributary to Silver bay from the north, Baranof island, Alexander archipelago. On a Russian manuscript map in the Coast Survey it is called Kirinskaia bay or Sawmill creek. On a late Coast Survey map it is Medvetcha, a name obviously from the Russian word for bear. Tebenkof's chart 38 of 1850 shows a pilnoi zavod (sawmill) here.

Sawmill; creek, tributary to Klutina river from the southeast, near its headwaters. So called by Abercrombie, 1898 .

Sawmill; creek, Kenai peninsula, tributary to Turnagain arm of Cook inlet from the south, near longitude $149^{\circ} 15^{\prime}$. Local name, from Herron, 1899.

Sawmill; spit, ọ the south shore of Port Valdez, Prince William sound, $2 \frac{1}{2}$ miles west of Fort Liscum, near longitude $146^{\circ} 23^{\prime}$. Local name, reported by Ritter, 1901.

Sawtooth, mountains; see Kigluaik.

Sawyer; glaciers, on the mainland, at head of Tracy arm of Holkham bay, southeastern Alaska. So named by Mansfield, 1889.

Saxaeja, glacier; see Saksaia.

Saxman; settlement or village, 2 miles southeast of Ketchikan, on northeastern shore of Tongass narrows, Revillagigedo island, Alexander archipelago, near latitude $55^{\circ} 19^{\prime}$, longitude $131^{\circ} 36^{\prime}$. Local name, from the Coast Pilot of 1901.

Sbichsak, bay; see Swikshak.

Scachlitak, island; see Sitkalidak.

Scald; point, the western point of entrance to Snug cove, Gambier bay, Admiralty island, Alexander archipelago. So named by Mansfield, 1889.

Scales (The); apparently a camp in Chilkoot pass. Reported by Flemer in 1898.

Scammon; bay, in the Yukon delta, Bering sea, on the north side of Cape Romanzof, near latitude $61^{\circ} 50^{\prime}$. So named by Dall, 1870, after Capt. Charles M. Scammon, U. S. R. M.

Scenery; cove, in Thomas bay, southeastern Alaska. Descriptive name, given by Thomas, 1887.

Schachun, rock; see Shakun.

Schakhin, strait; see Shakhine.

Schelikoff, harbor; see Three Saints.

Schiefflin; creek, tributary to Yukon river on the right bank, 20 miles above the mouth of the Tanana, near longitude $151^{\circ} 15^{\prime}$. Shevlin creek is 20 miles farther up and on the left bank. Edward and Eff Schieffin, the discov- 
Schiefflin-Continued.

erers of gold at Tombstone, Ariz., organized a large party and prospected on the Yukon about here in 1882-83. (Goodrich, Eighteenth Ann. Rept. U. S. Geol. Survey, pt. 3, p. 111.) Written Shefflin on Edwards' Track Chart of the Yukon (1899) and by Cantwell (1900); Sheflin by Collier, 1902.

Schilkossean; island, one of the Chilkat islands, Lynn canal, southeastern Alaska. Native name, reported by the Krause brothers in 1882, and by them written Schikosseán.

Schikuk, island; see Sullivan.

Schkague, river and town; see Skagiway.

Schkaliakh, point; see Thatcher.

Schley; creek, tributary to Nome river from the east, in the Nome mining region, Seward peninsula. Named by the prospectors, after Admiral Winfield Scott Schley, U. S. N., and name published in 1900.

Schley; creek, eastern Alaska, a small affluent of the Yukon, on the left bank, near latitude $65^{\circ} 15^{\prime}$, longitude $142^{\circ}$. Prospectors' name, found on an unpublished map in the Coast Survey archives, drawn by E. F. Ball, a prospector, 1898.

Schlitz; creek, Seward peninsula, tributary to headwaters of Serpentine river, near latitude $65^{\circ} 50^{\prime}$, longitude $164^{\circ} 50^{\prime}$. Prospectors' name, reported by Gerdine, 1901.

Schnuna, river; see Shuna.

Schönwetterberg, mountain; see Fairweather.

Schooner; rock, Prince William sound, off Zaikof point, Montague island, on the west side of Hinchinbrook entrance, near latitude $60^{\circ} 18^{\prime}$, longitude $146^{\circ} 52^{\prime}$. Descriptive name, reported by Westdahl, 1902.

Schoonhoven, creek; see Boulder.

Schroeder, point; see Spruce.

Schujek, island; see Shuyak.

Schulze; cove, in, Fish bay, Peril strait, Alexander archipelago. Named by United States naval officers, 1880, after Paul Schulze, of Portland, Oreg. president of the Northwest Trading Company. Erroneously Shulze.

Schulze, glacier; see Taku.

Schulze; head, the western head of Schulze cove, Fish bay, Baranof island, Alexander archipelago. So named by Coghlan, 1884.

schumachinskaia. One of the Shumagin islands (which one is not known) was so called by Langsdorf (Voyage, II, 54).

Schuna, river; see Shuna.

Schunachtuli, island; see Shaws.

Schwan; glacier, tributary to Tasnuna river from the south, between Valdez and Copper river. So named by Abercrombie, 1898, after Col. Theodore Schwan, U. S. A.

Schwatka; mountain (9,000 feet high), on the south side of Yukon river and west side of Beaver creek, near latitude $66^{\circ}$, longitude $146^{\circ} 30^{\prime}$. Named by Lieutenant Erickson, U. S. A., 1902, after Lieut. Frederick Schwatka, U. S. A. He reported the Indian name Mkleet-o-kumen-ah (mountain with lake on top).

Schwatka; mountains, northwestern Alaska, between Kobuk and Noatak rivers, near latitude $67^{\circ} 30^{\prime}$, longitude $156^{\circ}$. So named by Stoney, 1885-86, presumably after Lieut. Frederick Schwatka, U. S. A.

scolai, pass; see Skolai.

Scookuk, village; see Chiukak. 
Scotch; gulch, 8 miles northwest of Cape Nome, Seward peninsula, draining from the north into Saint Michael creek, near longitude $165^{\circ} 07^{\prime}$. Local name, published in 1904.

Scotch; gulch, 15 miles north of Nome, Seward peninsula, tributary from the eaist to the headwaters of Snake river, near longitude $165^{\circ} 23^{\prime}$. Miners' name, Scotch-Irish, published in 1900 . See Irish.

Scotch Cap; cape, a headland 420 feet high, the southwesternmost point of Unimak island, eastern Aleutians, 5 miles west of Seal cape near longitude $164^{\circ} 47^{\prime}$. Its native name is Hibahíbgik, according to Veniaminof, who adds that it constitutes the very end of Unimak, and near it are high and rocky pillars. From this point the natives set out to cross Unimak pass. Called Kitkhuk by Tebenkof, 1849. Variously written Khitkhouk, Khitkouk, Khituk, Kitkuk, etc. Called Scotch cape by the Fish Commission, in 1888, and Scotch cap by same, in 1890 . So called from its resemblance to a scotch cap or bonnet when seen in profile. This cape was reserved for light-house purposes by Executive order dated January 4, 1901.

Scotch Cap; light-house, on the southwestern shore of Unimak island, about 2 miles east of Scotch Cap.

Scotch-Irish, creek; see Scotch gulch and Irish gulch.

Scotland; sunken rock, between Karpa and Korovin islands, Shumagin group. Named by Dall, 1875, after the fishing schooner Scotland, which reported it in 1871.

Scott; peak (3,249 feet high), on Lindenberg peninsula, Kupreanof island, Alexander archipelago. Named by Thomas, 1887, after Gen. Winfield Scott, U. S. A.

Scott; point, on south side of entrance to Ingraham bay, southeast shore Prince of Wales island, Clarence strait, southeastern Alaska, near latitude $54^{\circ}$ $57^{\prime}$, longitude $131^{\circ} 58^{\prime}$. So called by local navigators, and reported by H. C. Fassett, Bureau of Fisheries, 1904.

Scott; point, the western head of Mackenzie bay, near Point Barrow, Arctic coast. So named by Dease and Simpson, 1837.

Scottie; creek, tributary to the Tanana from the east, near the international boundary. Named by Peters and Brooks, 1898, after a member of their party.

Scraggy; islands, at northern end of Neva strait, in Salisbury sound, Alexander archipelago. Named Samoilof by Vasilief, 1833, after one of the early Russian explorers. Has been shortened on some maps to Samoi. Have also been called Scraggy, and such is reported to be local usage.

Scraggy; island, on the west side of entrance to Port Frederick, south shore Icy strait, Alexander archipelago, near longitude $135^{\circ} 29^{\prime}$. So named by Pratt'in 1901.

Scraggy, island; see Fivemile.

Scraggy; point, Salisbury sound, the northeast point of Kruzof island, Alexander archipelago, three-fourths mile west of Scraggy islands (above). Name applied by Moore, 1896.

Screen; group of islands, near the western shore of Etolin island, in Clarence strait, Alexander archipelago. So named by Dall, 1879.

Scrub; island, in Port Chester, Annette island, Alexander archipelago. So named by Nichols, 1883.

Scud; river, tributary to Stikine river from the east, in the vicinity of the international boundary. Name published by the Coast Survey in 1891 . 
Scull; islet (50 feet high), in Young bay, Stephens passage, Alexander archipelago. Named Scull island by Meade, 1869. Has also been written Skull.

Sea; rock, off Cape Georgiana, at entrance to Salisbury sound, Alexander archipelago. Named Morskoi (sea) by Vasilief, 1833. Morskoi breaker is just west of it.

Seaforth; mining camp, on South fork Koyukuk river, near longitude $151^{\circ}$. Prospectors' name, from Schrader, 1899.

Seagull; six rocky islets, between Unalga and Akutan, in Akutan pass, eastern Aleutians. Locally known as Chaiki (gull) rocks. The name Chaichi (gull). was published by Tebenkof in 1849. Called Gull rocks by Dall, 1871, who established a tide gage upon one of them. See Unalga island.

Seahorse; islands, low and sandy, on the Arctic coast, a little east of Point Belcher. Named Sea Horse by Beechey in August, 1826.

Seal; bay, indenting the northeastern coast of Afognak island, Kodiak group. Named Nerpichie (seal) by the Russians.

Seal; cape, the eastern point of entrance to Coal bay, on the southern shore of Alaska peninsula, northwest from Unga island. Named Nerpichie (seal) by the Russians.

Seal; cape, the southern point of Unimak island, eastern Aleutians, near longitude $164^{\circ} 39^{\prime}$. Called Kishnak by Tebenkof, 1849. The native name of the cape next west from this is, according to Tebenkof, 1849, Kitkhuk, and by transposing or confusing names this is often called Khituk. The Fish Commission, 1888, called it Seal cape, and it is said to be now locally so known.

Seal, cape; see Ikolik.

Seal; cove, on the eastern shore of Chilkat inlet, Lynn canal, southeastern Alaska. Named Nerp (seal) by Lindenberg, 1838.

Seal; cove, between Dall bay and Bostwick inlet, southeastern shore Gravina island, Nichols passage, Clarence strait, southeastern Alaska, near latitude $55^{\circ} 10^{\prime}$, longitude $131^{\circ} 03^{\prime}$. Local navigators' name, reported by Brooks, 1901.

Seal; island, Prince William sound, 5 or 6 miles east of the north end of Knight island, near latitude $60^{\circ} 30^{\prime}$, longitude $147^{\circ} 20^{\prime}$. Name published by the Coast Survey in 1899.

Seal, island, near Atka; see Ikiginak.

Seal; islands, fringing the northern shore of Alaska peninsula, just west of Heiden bay. Named Nerpichoi (seal) by Tebenkof, 1849 .

Seal; islets, near Seal bay, off the northeastern coast of Afognak island, Kodiak group. Named Nerpichie (seal) by the Russians.

Seal; lake, St. George island, Bering sea, on east end near north shore and longitude $169^{\circ} 31^{\prime}$. So called by Duffield in 1897. According to Putnam the Aleut name is Än'ím-äl'gerā (seal lake).

Seal; rock, near Katmai, Alaska peninsula. Name obtained by Spurr and Post in 1898, from Rev. E. Petelin. It appears to be an isolated rock on the land.

Seal; submerged rock, reported at the southeastern margin of Sannak shoals, Sannak islands, near latitude $54^{\circ} 18^{\prime}$, longitude $162^{\circ} 35^{\prime}$. So described by Westdahl, 1901.

Seal; rock, near Cape Newenham, Bristol bay. So named by the Fish Commission in 1890.

Seal; rocks, in Portland canal, near its head. So named by Pender, 1868. 
Seal; rocks, in Hinchinbrook entrance, Prince Williau sound, near latitude $60^{\circ}$ $10^{\prime}$, longitude $146^{\circ} 47^{\prime}$. Called Rose island by Meares in 1788, and Triste (dismal) by the Spaniards the same year. It is Siuchi (sea lion) of the Russians and Seal rocks of recent charts.

Seal; rocks, near Chiswell island, off Kenai peninsula, Gulf of Alaska. Named Siuchi (sea lion) by the Russians and erroneously translated Seal, the name by which it is designated on current maps and charts.

Seal; rocks, off the western end of Kodiak. Named Siuchi (sea lion) by Tebenkof, 1849. Have been called Zufutch, an attempted transliteration of Siuchi (sea lion).

Sealed; passage, Felice strait, between Percy and Duke islands, Gravina group, Alexander archipelago. Apparently a local and descriptive name, published by the Coast Survey in $\mathbf{1 8 8 5}$.

Sealer; creek, tributary to Cripple creek from the west, in the Nome mining region, Seward peninsula. Local name, published in 1900.

Sealevel; mining camp, at head of 'Thorne arm, Revillagigedo island, Alexander archipelago. A post-office established here in April, 1900, was discontinued in June, 1905.

Sealion, cape, on southern coast of Unimak; see Lutke.

Sealion; cove, indenting the northwestern shore of Kruzof island, Alexander archipelago, near latitude $57^{\circ} 18^{\prime}$. Named Siuchia guba (sea lion gulf) by Vasilief, 1833. Also written Siouchi, Sioutchi creek, etc.

Sealion; hills, two hills North Sealion and South Sealion, 645 and 679 feet high, respectively, on the eastern end of St. George island, Bering sea, near longitude $169^{\circ} 30^{\prime}$. So called by Stanley-Brown in 1891. According to Putnam the Aleuts call the north hill Alōgh'-kōverrūshkia (middle hill) ; and the south hill 'Tūg'ŭnā'rarō'lōgh-kōverūishkä' (hill near Tugunararo$\operatorname{logh}$ ), or, in Russian, Propastchy-Koverushka (bill near PropastchyPropastchy and Tugunararologh being names for Sealion point and Koverushka (Russian, Kovrishka meaning a little loaf) used for hill.

Sealion, islet; see Kaligagan.

Sealion; point, near the northeastern end of St. Paul island, Pribilof group, Bering sea. Presumably a local name. Published by the Coast Survey in 1875 . Has also been called Sealion Neck.

Sealion; point, on the southeastern shore of St. George island, Pribilof group, Bering sea. So called because sea lions haul out here. Name published by the Coast Survey in 1875. According to Putnam, called in Russian Propastchy (perished), because dead sea lions have been found here, and in Aleut, Tùg'únā'rarō'lōgh (dead sea-lion place).

Sealion; rock, at entrance to Puffin bay, Baranof island, Alexander archipelago. Named Siuchi (sea lion) by the Russians.

Sealion; rock, near the eastern end of Akun island, eastern Aleutians. Called Sivoutchy (des lions marins) by Lutke, 1836.

Sealion; rock, a few miles west of the western end of Atka, middle Aleutians. Called Sivoutchy (du lion marin) by Lutke about 1830. Not shown on any map.

Sealion; rock, between Rat and Little Kiska islands, Rat island group, western. Aleutians. So called by Lutke, about 1830, who writes Sivoutchi (du lion marin).

Sealion; rock, near Reef point, on the southern shore of St. Paul island, Pribilof group, Bering sea. Named by the Russians. Lutke has Sivoutchi (du lion marin). 
Sealion; rocks, off the northwestern coast of Kruzof island, Alexander archipelago, at south side of entrance to Sealion cove. Called Islas de los Lobos and Islas de Lobos (wolves, probably meaning seals, lobos marinos) by the Spaniards, 1.774-1791. Named Suichi (sea lion), by Vasilief, 1833. Also writtè Siouchi, Sioutchi, etc.

Sealion; rocks, south of Unga, Shumagins. Named Siuchi (sea lion) by the Russians. Have also been called Seal rock.

Sealion; rocks, near eastern shore of Afognak island, Kodiak group. Named Siuchi (sea lion) by the Russians about 1849 .

Sealion; rocks, in the Sandman reefs, southwest of Iliasik island. Called Sivuchie (sea. lion) by Veniaminof and Siwutschy (see löwen) by Grewingk, 1849.

Sealion; rocks, off the northern side of Amak island, near west end of Alaska peninsula, Bering sea. Named Siuchi (sea lion) by Lutke, 1828.

Sea Otter; bank, northeast of Middleton island, Gulf of Alaska. Name published by the Coast Survey in 1869.

Sea Otter; bank or reef, in Shelikof strait, a short distance southwesterly from Cape Douglas. Named Bobrof (sea otter) by the Russians. Also Bobrovoi, Bobrow, Bohrow, etc. Has also been translated Beaver.

Sea Otter; bay, indenting the southern shore of Atka, middle Aleutians. Called Bobrovaia (sea otter) by Lutke about 1830.

Seu Otter, bay; see Meares passage.

Sea Otter; cove, in Wrangell harbor, Alaska peninsula. Called Port Bobrovoi (des loutres) by Lutke.

Sea Otter; harbor, between Baker and Noyes islands, Bucareli bay, Prince of Wales archipelago. This place may be the one so named by Meares, 1788. The identity is doubtful.

Sea Otter; island, east of Shuyak island, Kodiak group. Named Bobrovie (sea otter) by the Russians. Has been erroneously translated Beaver. Variously written Bobrow, Bohrow, etc.

Sea Otter, island; see Otter.

Sea Otter; islet, between Kanaga and Tanaga islands, Andreanof group, middle Aleutians. Billings, 1790, says it was called Bobrovie (sea otter) from the number of these animals that formerly held their resting place upon it. This name Bobrovie, variously written Bobroff, Bobrow, Bobrovy, etc., and translated Beaver, has been applied to this islet. Tebenkof adds the word valga, which seems to be the Aleut name; another islet soutbwest from this bearing the name Kavalga.

Sea Otter; islets, north of Shuyak island, Kodiak group. Named Bobrovie (sea otter) by the Russian-American Company.

Sea Otter. A group of sunken rocks, south of Augustine island, Cook inlet, are indicated with a query (P. D.) on a map of Cook inlet by Dall, 1895 .

Sea Otter; sound, on the western border of Prince of Wales archipelago, about 30 miles north of Sea Otter harbor, in Bucareli bay. This also may be the Sea Otter harbor of Meares in 1788. Also called Otter sound.

Sea Otters, bay; see Beaver.

Seat, island; see East Clump.

Seaton; bay. In the Eleventh Census (p. 25) we read: "Nearly opposite New Eddystone rock, on the east side of the channel (Behm canal) is Seaton bay. It is about 2 miles wide, and extends into the mainland a distance of 15 miles." This appears to refer to Rudyerd bay, or perhaps it is an error for Smeaton bay. Seaton bay not found on any chart.

Seattle; bar, at junction of Eureka and Pioneer creeks in the Baker Creek region, north side of Tanana river. Prospectors' name, reported by Prindle, 1904. 
Seattle; creek, tributary to Turnagain arm of Cook inlet from the soutb, Kenai peninsula, near longitude $149^{\circ} 10^{\prime}$. Local name, from Becker, 1895.

Seattle; creek, draining the south slope of the divide between Tanana river and the headwaters of Minook creek, near latitude $65^{\circ}$, longitude $150^{\circ} 10^{\prime}$. Prospector's' name, reported by Prindle, 1904.

Seattle; creek, tributary to Kruzgamepa river from the south, Seward peninsula. Name from Barnard, 1900.

Seattle; creek, tributary to Wesley creek from the south, Seward peninsula. Name from Barnard, 1900.

Seattle; creek, 15 miles north of Nome, Seward peninsula, tributary from the east to the head of Snake river, near longitude $165^{\circ} 23^{\prime}$. Miners' name, published in 1900 .

Seattle; creek, 7 miles north of Cape Nome, Seward peninsula, tributary to Fox lake from the west, near longitude $165^{\circ}$. Named from Barnard, 1900.

Seattle, creek; see Discovery.

Seattle; mountain (10,000 feet high), near the head of Yakutat bay, southeastern Alaska. Named by Russell, 1890, after the city of Seattle. Has also been called Bozman.

Seattle; river, tributary. on the left. bank to North fork Koyukuk river, near latitude $67^{\circ} 30^{\prime}$, longitude $150^{\circ} 40^{\prime}$. Prospector's' name, reported by Peters and Schrader, 1901.

Seattle, Jr.; creek, in the Baker Creek region, on the north side of the Tanana, tributary to Pioneer creek from the northwest. Prospector's' name, reported by Prindle, 1904.

Seattle Point; locality, on Koyukuk river, Midway between Hogatza and Dulbi rivers. Name taken from the Northern Commercial Conpany's folder for 1905 .

Sebree; island, in Muir inlet, Glacier bay, southeastẹrn Alaska. So named, in or about 1890, after Commander Uriel Sebree, U. S. N. ' It is Headland island of Reid in 1891 (Am. Geologist, 1891, vol. 8, map, p. 228).

Sebree; peak, in the eastern part of Mitkof island, Alexander archipelago. Named by Thomas, 1887, after Commander Uriel Sebree, U. S. N.

Seclusion; harbor, in Kuiu island, Keku strait, Alexander archipelago. So named by Moore, 1892.

Second; lake, on Kenai peninsula, draining into Skilak or Kaknu or Kenai lake. Name published by the Coast Survey in 1898. The existence of this lake is doubtful. See Ben lake and Kenai lake.

Second; narrows, in Redfish bay, Baranof island, Alexander archipelago. So named by Moser, 1897.

Second, point; see Inner.

Second, rapids; see Southern.

Second Kekur; an isolated rock or rocky islet, off the southwestern coast of Baranof island, Alexander archipelago. Also written Kekoor and Kekour. See Kekur.

Second Priest; pinnacle rock, at the southern point of entrance to Summer bay, Unalaska bay, near longitude $166^{\circ} 28^{\prime}$. Locally so called, the similar pinnacle rock off Cape Kalekta, about 7 miles north of this, being known as Priest rock. On the charts this Second Priest rock is merely designated Pinnacle. This rock has been reserved for light-house purposes by Executive order dated January 4, 1901. In that order it is called Pinnacle.

Secret; creek, on south coast of Seward peninsula, Norton sound, 5 miles east of Solomon river, near longitude $164^{\circ} 1^{\prime}$. Prospectors' name, Secret Ravine creek, on a local map, 1904, and Secret creek, by Gerdine, 1905. 
Security; bay; indenting the northwestern shore of Kuiu island, Alexander archipelago. Descriptive name, given by Meade, 1869, who in that year visited and made a reconnaissance of it.

Security; roads, at entrance to Security bay, Kuiu island, Alexander archipelago. So named by Meade, 1869.

Sedaghur, island; see Biorka.

Sedanla, cape; see Umshaliak.

Sedanka. Sarichef, 1792 , shows a native settlement at Umshaliuk cape, on the north shore of Unalaska. It does not appear on later maps.

Sedanka, village; see Biorka.

Sedaru; Eskimo settlement, on the Arctic coast, at Point Belcher. Name from Ray, 1885. Has also been called Sedard, Sedaro, Sezaro, and may be identical with Atnik. According to Murdoch, 1883, it is Sedáro or Sedáru. Also called Nunaria on some charts. See also Atnik.

Seduction; island, off Seduction point, Lynn canal, Alexander archipelago. So named by Dall, 1880.

Seduction; point, on the mainland, in northern part of Lynn canal, Alexander archipelago. Named by Vancouver, 1794. Has also been called Seduction Tongue. Tebenkof translates it Soblazna (seduction).

Seer-kwet, lake; see Sirkwet.

Seer-lcwet, river; see Takbini.

Seethah; old village site, on St. Paul island, Bering sea, on southwest point, near longitude $170^{\circ} 25^{\prime}$. Local name, from Elliott, 1872-1874.

S'eetien, island; see Great Sitkin.

Seet-oht, river; see Chetaut.

See-tuck, river; see Situk.

Seevooluk, cape and Eskimo village; see Chibukak and Gambell.

Seguam; island $(2,098$ feet high), the easternmost of the Andreanof group, middle Aleutians. . Native name, from Sarichef, about 1790. Variously written Segouam, Siguam, Signam, and, by error, Genunam and Tenounam. Has also been called Goreli (burnt).

Seguam; pass, about 15 miles wide, between Amlia and Seguam islands, Andreanof group, middle Aleutians. So called by Lutke, 1830.

Segula, island; see Chugui.

Sekulmun; lake, in latitude $61^{\circ} 30^{\prime}$, longitude $137^{\circ} 30^{\prime}$. Apparently a native name, which has also been spelled Sekulman. The above form, Sekulmun, has been adopted by the Canadian Board on Geographic Names.

Selawik; lake, a tidewater lake connecting with Hotham inlet, near Kotzebue 'sound, northwestern Alaska, about latitude $66^{\circ} 30^{\prime}$, longitude $161^{\circ}$. Native name, presumably from some of the Franklin search expeditions, about 1850. Written Salawik, Selawik, Silawik, etc. According to John Murdoch it is pronounced Sílawik.

Selawik; river, tributary to Selawik lake. Has also been written Sal-a-wik and Selawick.

Selby; lake, near the Arctic circle, drained by the Kobuk river. Explored and named by Stoney, 1884. This is Nudre-wok or Nud-re-wok lake of Cantwell, 1885.

Seldevaia, cove; see Herring.

Seldovia; bay, indenting the southern shore of Kachemak bay, Cook inlet. Called Seldevoi (herring) by Tebenkof, 1849. Variously written Saldovia, Soldovoi, etc. The native name appears to be Chesloknu, and was published by the Coast Survey, following Dall, 1883. Erroneously Chestoknu. 
Seldovia; point, the eastern point of entrance to Seldovia bay, Kachemak bay, Cook inlet. Called Soldovoi by.Dall, 1883, the bay having been called Seldovoi (herring) by Tebenkof.

Seldovia; post-office and village, at Seldovia bay, Cook inlet. The name is derived from the name of the bay. The post-office was established here November, 1898.

Selenia, point; see Settlement.

Selenie; lake, on the northern shore of Graham harbor, Cook inlet. The Coast Survey atlas of harbor charts (1869, map 6) has a sketch of "Port Graham from Archimandritoff's Survey," on which appears Celenic lake: This is obviously a mistaken rendering of the Russian word selenie (settlement).

Selenie; point, on eastern shore of Pavlof bay, Alaska peninsula. Tebenkof shows a settlement (selenie) at this point, whence the name Selenie, given by Dall in 1880. This village was called Pavlovsk by Petrof, 1880.

Selezneva, bay, cape and village; see Duck.

Selfridge; bay, on the southern coast of Wrangell, island, Arctic ocean. Perhaps this is a synonyin for Doubtful harbor of Berry in 1881.

Selin; creek, eastern Alaska, on the west bank of Charley river, which is affluent to the Yukon, from the south; near longitude $143^{\circ}$. Prospectors' name, from sketch map compiled by`Major Glassford, Signal Corps, U. S. A., 1905.

Seltathin, tributary of Klehini river; see Glave creek.

Seltathinschokschage. The Krause brothers, 1882, report Seltat-hî́n-schok-schage to be the native name of a mountain peak near the headwaters of the Klehini river, southeastern Alaska.

semenoffsky, island; see Simeonof.

Semichi; islands (818 feet high), just east of Attu, western Aleutians. Discovered by the early Russians and named Semichi, from the Russian Semik, says Dall, the feast on the seventh Thursday after Easter, on which day they were discovered. Perhaps they are St. Abram of Bering in 1741. Coxe, 1780, calls them Shemya. Variously written Semitsch, Semitschi, etc.

Semida. Langsdorf, 1813, calls the Semidi islands Eudocia (Ewdokijefftian), and one of the group, not identified, Semida. which name, spelled Semidi, is now applied to the group. According to Sauer (Billings's Voyage, 200), the largest of the group is Simedan or Simedün. See Chowiet.

Semidi; a group of about seven small islands, off Alaska peninsula, southwest from Kodiak, near longitude $156^{\circ} 50^{\prime}$; thought to have been discovered by Bering in August, 1741, and named Tumannoi (foggy). Either this group or the adjacent Chirikof island was identified by Cook, 1778, with Bering's Foggy islands. Billings, 1802, calls them Simedan, and in the Spanish atlas of Galiano, 1802, appears the name Isla Fogoi. About the beginning of the century the group received from the Russians the name of Eudoxia or Eudocia, which has appeared under the forms Ewdokijefftian and Evdokeevskies. On old Russian charts they are called Semidi or Eudokierskie. In 1868 they were called by the Coast Survey Seven islands. Sem is the Russian numeral seven. By a blunder in transliteration they were once called Zumik.

Semidin, island; see Chowiet.

Bull. $299-06 \mathrm{M}-36$ 
Semisopochnoi; island (3,112 feet high), one of the Rat island group, northeast of Amchitka, western Aleutians. The descriptive name, Semisopochnoi (seven peaks), was given, apparently by Sarichef, about 1790 . It has been variously written Semisopotchny, Semi Soposhna, Semisopokh, Island of the seven mountains, 7 .Mountains, etc.

Senati; native village, on the right bank of Yukon river, "just below Rampart Rapids." So called by Raymond, in 1869, who says it was the first native village met with on the Yukon in descending from Fort Yukon. It was occupied by Senati, an old Kutchin, and his people. Raymond called it Senati's village.

Seniavin; cape, on the northern shore of Alaska peninsula, a little east of Port Moller. So named by Lutke, 1828, after his vessel. Also written Seniavine.

Sentinel; hill, northern Alaska, on the west side of Colville river,-near latitude $70^{\circ}$. So named by Peters and Schrader, 1901.

Sentinel; island, in southern part of Lynn canal, Alexander archipelago. Apparently so named by Meade, 1869. This island was reserved for lighthouse purposes by Executive order dated January 4, 1.901.

Sentinel; peak (4,250 feet high), at head of Glacier bay. So named by Reid, 1892.

Sentinel; peak $(2,024$ feet high), on Kabuch point, at the southwestern extremity of Alaska peninsula, near longitude $163^{\circ} 20^{\prime}$. Descriptive name, reported by Westdahl, 1901.

Sentinel; point, on the southern shore of Port Snettisham, Stephens passage, Alexander archipelago. So named by Thomas, 1888.

Sentinel; rock, near the Western channel into Sitka harbor, Sitka sound, Alexander archipelago. So named by United States naval officers, 1879.

Sentinels (The); group of five islets in Tlevak strait, west of the Nichols group, Alexander archipelago. Called Sentinel islands by Nichols, 1881.

Sentinels (Three); three peaks, western Alaska, on the headwaters of Unalaklik river, near latiture $63^{\circ} 50^{\prime}$. Prospectors' name, published in 1900 .

Seookuk, Eskimo village; see Chiukak.

Seppings; cape, on the Arctic const, between Point Hope and Cape Krusenstern. Named Seppings by Beechey, 1827 . Has also been written Sepping. The Eskimo village here has been called Cape Sepping, and also Kivalinagmiut.

Serebrenikof, arm or bay; see Silver bay.

Seredka; open bay, on the southeastern shore of Akun island, Krenitzen group, eastern Aleutians, near longitude $165^{\circ} 30^{\prime}$. Called Seredkinskoi (middle) by Veniaminof, who says a village of 2 huts (yourts), containing 16 people, existed here in 1830 .

Sergief; bay, indenting the southern shore of Atka island, middle Aleutians. Called Sergieff and Sergheieff by Lutke. A Russian family name.

Sergief; island, at mouth of Stikine river. So named by the Rynda party, 1863, after a member of the party, who was drowned at Sergief rapid in the Sitkine.

Sergief; peninsula and volcano, on northwestern coast of Atka, middle Aleutians. So called by Lutke about 1830. Has been called Sarytcheff peninsula. Grewingk has Vulkan Sarütschew and Sergejewsky-Rerg.

Sergief; rapid, in Stikine river: So named by the Rynda party, who lost a man of that name at this place.

Sergius; channel, Sềrgius narrows, Southern rapids, Peril strait, Alexander archipelago. Name so applied by Moore, 1895. 
Sergius; narrows, in Southern rapids, Peril strait, Alexander archipelago. Apparently so named by Coghlan, 1884.

Sergius; point, on Chichagof island, in Southern rapids, Peril strait, Alexander archipelago. Apparently so named by Coghlan, 1884.

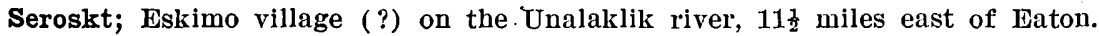
Probably native name, found in Reindeer Report for $1900^{\circ}$ (p. 75), Bureau of Education.

Serpentine; glacier, tributary to Harriman fiord, Port Wells, Prince William sound. Descriptive name, given by the Harriman expedition, 1899.

Serpentine; river, Seward peninsula, tributary to Shishmaref inlet, from the southeast. Descriptive name, reported by Gerdine, 1901. It was explored and named by Charles McLennan, a prospector; 1900.

Settlenent; point, Afognak bay, Afognak. Named Selenia (settlement) by the Russians.

Setuk, river and village; see Situk.

Seven, islands; see Semidi.

Seven-Mile, point; see Uyak cape.

Seven Sisters (The); group of rocky islets off the northwestern shore of Hinchinbrook island, Prince William sound.' So called by Abercrombie, 1898.

Seventeenmile; island, in Yukon river, 12 miles above Fort Yukon, about longitude $145^{\circ}$. Name taken from Edwards' 'Track Chart of the Yukon, 1899.

Seventymile; creek, tributary to Yukon river from the west, near latitude $65^{\circ}$. Prospector's' name, published in 1898 by the Coast Survey. The creek is about 70 miles below old Fort Reliance.

Seventymile; mining camp, on Yukon river, left bank, 5 miles above mouth of Seventymile creek. Prospectors' name.

Sevenuka; creek, northwestern Alaska, tributary to Alatna river from the north, near longitude $153^{\circ} 30^{\prime}$. Eskimo name, reported by Mendenhall and Reaburn in 1901.

Severnoye, point, St. Paul island; see North.

Sevidow, islets; see Vsevidof.

Seward; creek, tributary to Mission creek from the west, in the Eagle mining region. Local name, published in 1899.

Seward; glacier, tributary to Malaspina glacier, in the St. Elias alps, southeastern Alaska. So named by Russell, 1890, after the Hon. William Henry Seward, who negotiated the purchase of Alaska by the United States.

Seward. The southeastern part of Wrangell island was, in 1879 , named Seward island by Dall, then writing the Coast Pilot. Surveys since made show that this supposed island does not exist.

Seward; mountains (about 4,000 feet high), west of Portland canal. So named by Pender, 1868.

Seward; passage, in Ernest sound, separating Deer island from Cleveland peninsula. So named by Snow, 1886.

Seward; peninsula, of western Alaska, between Kotzebue and Norton sounds. It has been so designated on maps and in the texts of several publications since the gold excitement of 1898, this having been suggested by Governor Brady in compliment to Hon. William H. Seward. The name Kaviak was proposed by Dall, 1869, who in his Alaska (p. 268) says: "The great peninsula inclosed by the waters of Norton Bay and Sound, Bering Strait, the Arctic Ocean, and Kotzebue Sound it is proposed to 
Seward-Continued.

call the Káviak Peninsula, from the native name of Kavi-iák and the Káviak Innuit, who inhabit it." This name Kaviak appears to have never come into use. It has not been found on any map. The names Sumuer peninsula and Nome peninsula were also proposed and published in 1900 .

Seward; town and post-office (established in 1904), on Resurrection bay, southwestern shore Kenai peninsula.

Seward City, camp and landing, Lynn canal; see Comet.

Sewiliow, volcano; see Vsevidof.

Sextant; point, the western point of entrance to Tamgas harbor, Annette island, Alexander archipelago. So named by Nichols, 1883.

Seymour; canal, indenting Admiralty island from the south, Alexander archipelago. Called Seymour's channel by Vancouver, 1794.

Sezaro, village; see Sedaru.

Sfaganuk; Eskimo village, on the mainland, east of Nunivak island, Bering sea. Visited by Nelson in December, 1878, and its name reported in his text to be Sfoganugamiut. On his map it is Sfaganugamute, i. e., Sfaganuk people.

Shag, bay; see Urilia.

Shag; islet, near the northwestern shore of Shuyak island, Kodiak group. Named Urili (shag or cormorant, Graculus bicristatus) by the RussianAmerican Company, 1849.

Shag; rock, at head of Sanborn harbor, Nagai island, Shumagins. So named by Dall, 1872.

Shag; rocks, in Kupreanof strait, Kodiak group. Named Urilie (shag) by the Russians.

Shagak; bay, indenting the western shore of Adak island, Andreanof group, middle Aleutians. Aleut name from Tebenkof, 1849. Has also been written Chagakh.

Shageluk; native village, on the northern bank of the Shageluk slough. So called by Dall in 1866. Tikhmenief, 1861, shows several villages here bearing long names, none of them resembling this one. They are Kushichagat, Tizhgelede, Tiegozhitno, Intenleiden, Kuingshtetakten, and Inselnostleide. None of them appear on modern maps. Petrof, 1880 , calls them collectively the Chageluk settlements.

Shageluk; slough, on left bank of the Yukon and joining it near Holy Cross mission. So written by Dall, 1866 . Tikhmenief, 1861, wrote it Chageliuk; Petrof, 1880, Chageluk; and Raymond, 1869, Shagelook.

Shagulik; island, off the southern shore of Alaska peninsula, northeast of Sutwik island. Native name, from the Russians.

Shahafka; cove, in St. Paul harbor, Kodiak, near latitude $57^{\circ} \mathbf{4 7}^{\prime}$, longitude $152^{\circ} 24^{\prime}$. Named Peschanoi (sandy) by the Russians, 1808-1810, but by Tebenkof, 1849, called Shahafka. Has been written Chagafka.

Shaiak; islet, east of and near Cape Peirce, on north shore of Bristol bay. Sarichef, 1826, calls it Molzhevoi (walrus) and adds the native name Shaiak. Tebenkof also calls it Shaiak.

Shakan; bay, indenting the northwestern shore of Prince of Wales island and opening into Sumner $\cdot$ strait, Alexander archipelago, near latitude $56^{\circ} 10^{\prime}$, longitude $133^{\circ} 30^{\prime}$. Name of Indian origin, and written Shakan, Shakaan, and Shukan. Sachine and Shakhine are probably only other renderings of the same word.

Shakan; islet, at southern point of entrance to Shakan bay, Prince of Wales archipelago, near latitude $56^{\circ} 08^{\prime}$, longitude $133^{\circ} 38^{\prime}$. Native name. 
Shakan; strait, in Shakan bay, separating Hamilton island from Kosciusko island, Alexander archipelago. Also written Shakaan.

Shakan Nipples; see Nipples (The).

Shakan; Indian village, post-oftice (established in June, 1886), and sawmill, Kosciusko island, Alexander archipelago. In the Jleventh Census $(1890$, p. 34$)$ we read "Chican, about 60 miles north of Klawak," and also "Sawmill and about a dozen houses built some 10 years ago." Originally known as Hamiltons Mill.

Shakes; mountain, in the southern part of Etolin island, Alexander archipelago. So named by Snow, 1886, after Shakes, an Indian chief.

Shakine; supposed strait or passage, in western part of Prince of Wales archipelago, connecting Sea Otter sound and Bucareli bay. Variously written Shakhine, Sachine, Schakhin, etc. Native name, from the Russians. Apparently only another form of the word Shakan.

Shakmanof, bay ; see Kizhuyak.

Shakmanof; cape, near Spruce island, on the northeastern shore of Kodiak. Named Shakmanof by Murashef, 1839-40. Tebenkof, 1849, calls it Riph (reef) point and also Cape Chiniak.

Shaktolik; bay, in the eastern part of Norton sound. Called by the natives Chacktoole, according to Cook, 1778; and Shaktol, Shaktoli, and Shaktólik by the Russians. Into it flows Shaktolik river, and on its shore is the Eskimo village Shaktólik.

Shaktolik; Eskimo village, at mouth of Shaktolik river, Norton sound. Native name. Has also been written Shaktolit. Population in 1880,60 ; in 1890,38 .

Shaktolik; hills, or mountains, near the Shaktolik river, east of Norton sound. So called by Dall in his Alaska (pp. 24, 152, etc.).

Shaktolik; river, tributary to eastern part of Norton sound. Liskimo name, from Tebenkof, 1849 .

Shakun; rock, in Shelikof strait, near Swikshak bay. Native name, from the

... Russians: Has been written Schachun and Schakhun.

Shaliakh, point; see Thatcher.

shallow, bay; see Dry.

Shallow-loater, point; see Romanof.

Shallows; point, the northeastern point of Whale island, near Kodiak. Named Melkowadia (little water) by Murashef, 1839-40. Called Dolphin point by Moser, 1900. See Dolphin.

Shaman; island, off the western end of Douglas island, Stephens passage, Alexander archipelago. So named by Mansfield in 1890. Shaman means an Indian medicine man or doctor.

Shaman. A place on the north bank of Yukon river, at mouth. of Dall river, about 10 miles above the trading post Fort Famlin, near longitude $149^{\circ} 06^{\prime}$; is called Shamans Village on late charts. There is no village at this place. Shaman, the Siberian term for sorcerer, was introduced by the Russians to designate the native medicine man.

Shaman; point, in Wrangell harbor, Alexander archipelago. So named by Zarembo, 1834. Zarembo's sketch was published, 1848, on Russian Hydrographic chart No. 1396. Called Zhemani on United States Hydrographic chart 225 .

Shantatalik; small stream, tributary, from the north, to Tustumena lake, Kenai peninsula. Native name, from Wosnesenski, 1840, given by Grewingk as Tschantatalich. Perhaps it is Shanta-tulik, Shanta region.

Shapka; island (700 feet high), one of the Chiachi group, on southern shore of Alaska peninsula. Named Shapka (hat) by the Russians. 
Shariepof, cape; see Izhut.

Sharp; ledge, in Swanson harbor, Icy strait, near entrance to Lynn canal, Alexander archipelago. So named by the Coast Survey in 1890 .

Sharp; mountain (1,227 feet high), north of Cape Fox, Dixon entrance. So named by Nichols, 1883.

Sharp; peak (5,900 feet high), north of Valdez glacier. So named by Abercrombie, 1898.

Sharp; point, on Revillagigedo island, in Behm canal, west of Smeaton island. So named by the Coast Survey in 1891.

Sharp; point, at entrance to Eliza harbor, Frederick sound, Alexander archipelago. So named by Mansfield, 1889.

Sharp; point, on northern shore of Port Snettisham, Stephens passage, Alexander archipelago. So named by Thomas, 1888 .

Shasheki, pass; see Chilkoot and White.

Shashgat; bay, apparently an arm of Igak bay, Kodiak; was so called by Lisianski, in 1805 (Voyage, pp. 184-185).

Shasta; small creek, on the southern shore at the eastern end of Karluk lagoon, near the outlet of Karluk river, southwestern coast of Kodiak, near latitude $57^{\circ} 30^{\prime}$. Local name, and so described by H. C. Fassett, of the U. S. Fish Commission, in 1900.

Shasta; creek, tributary to Harris creek, which in turn is a tributary to North fork Kougarok river, near latitude $65^{\circ} 41^{\prime}$, longitude $164^{\circ} 30^{\prime}$. Prospectors' name, reported by Gerdine, 1901.

Shaw, bay ; see Urilia.

Shaw; creek, debouching on the north bank of Tanana river, near longitude $146^{\circ} 20^{\prime}$. It is the principal tributary between Goodpaster and Salcha rivers. Called Thompson by Lieutenant Gibbs, of the Signal Corps, U. S. A., 1902 ; but Prindle reports it, 1904-5, known to the miners as Shaw creek.

Shaw; island, near Cape Douglas, Cook inlet. Named Shaw's by Vancouver, 1794. Called Kamishak by Tebenkof, 1849. The Aleut name is Shunaktuli, which Grewingk writes Schunachtuli.

Shaw; islands, on the west side of Idaho inlet, Icy strait, Alexander archipelago, near longitude $136^{\circ} 15^{\prime}$. So named by Dickins, probably after E. V. Shaw, a member of his party in 1902 .

Shayak; island, in Marmot bay, between Afognak and Kodiak. So called by Tebenkof, 1849. See also Hog.

Shea; creek, Seward peninsula, Casadepaga drainage, tributary to Birch creek from the east, near latitude $64^{\circ} 50^{\prime}$, longitude $164^{\circ} 08^{\prime}$. Prospectors' name, from Gerdine, 1905.

She Beaver; see Beaver creek, Beaver slough and Hosiana river.

Shed; mountain $(2,620$ feet high), between Nakat inlet and Willard inlet, southeastern Alaska. So named by Nichols, 1883.

Shedden; point, one of the points of entrance to Refuge inlet, just west of Point Barrow. Apparently so named by British naval officers engaged in the Franklin search expeditions, 1849-1853.

Shee-gar-rik-puk, river; see Squirrel.

Shee-lee-lie-tok, river; see Squirrel.

Sheenjek; river, tributary to the Porcupine from the north, near longitude $144^{\circ} 30^{\prime}$. Late Coast Survey charts call it Salmon river, and earlier ones give Sheenjek or Salmon. Name apparently first published in 1895.

Sheep; bay and point, north shore of Orca bay, Prince William sound, near latitude $60^{\circ} 40^{\prime}$, longitude $145^{\circ} 56^{\prime}$. Probably a local name from Moser, 1897, who called the bay Sheep or Jackson. 
Sheep; creek, on the mainland, 4 miles southeast of Juneau, southeastern Alaska, and tributary to Gastineau channel, near latitude $58^{\circ} 15^{\prime}$, longitude $134^{\circ} 20^{\prime}$. Local name, published in the Coast Pilot (1891, p. 152).

Sheep; creek, 25 miles northeast of Controller bay, Gulf of Alaska, near latitude $60^{\circ} 28^{\prime}$, longitude $143^{\circ} 45^{\prime}$. Prospector's' name, reported by Martin, 1905 .

Sheep; creek, tributary to Kotsina river from the south. Prospectors' name, reported by Gerdine, 1900.

Sheep; creek, on the east side of Copper River delta, between Miles glacier and Martin river, near latitude $60^{\circ} 30^{\prime}$, longitude $144^{\circ} 45^{\prime}$. Local name, reported by Martin, 1905.

Sheep; creek, in the Copper River region, tributary to Chitistone river from the east. Prospectors' name, reported by Schrader, 1903.

Sheep; creek, tributary to Dietrich river from the east, near latitude $68^{\circ}$, longitude $150^{\circ}$. Prospector's' name, reported by Schrader, of the Geological Survey, 1899, and erroneously applied to Trembley creek, a nearby tributary on the opposite bank. Has also been called David creek.

Sheep; creek, in the Talkeetna mountains, northeast of Cook inlet, tributary on the east bank of Chickaloon creek, a north branch of Matanuska river ; near latitude $62^{\circ} 20^{\prime}$, longitude $148^{\circ} 20^{\prime}$. So called by Glenn, 1898 .

Sheep; creek, tributary from the east to the head of Kachemak bay, Cook inlet, near latitude $59^{\circ} 45^{\prime}$. Local name, from Stone, 1904.

Sheep; creek, in the Kantishna region, at the head of Glen creek on the east (right) bank of Moose creek. So named by prospectors, 1905, and reported by Prindle.

Sheep; creek, 12 miles northwest of Fairbanks, tributary on the south bank of Goldstream creek, near longitude $148^{\circ}$. Prospector's' name, from a local map, 1905.

Sheep; creek, eastern Alaska, tributary on south bank of Birch creek, near latitude $65^{\circ} 20^{\prime}$, longitude $144^{\circ} 35^{\prime}$. Prospectors' narne, reported by Witherspoon, 1905.

Sheep; creek, in the Fortymile region, tributary to Yukon river from the west, 10 miles below Seventymile creek, near latitude $65^{\circ}$, longitude $141^{\circ} 20^{\prime}$. Prospectors' name, reported by Cantwell, 1900.

Sheep; creek, tributary to Robert creek, near the headwaters of the Koyukuk. Prospectors' name, reported by Schrader, 1899.

Sheep; gulch, north side Chichokna river, on the western slope of Mount Wrangell, near latitude $62^{\circ}$, longitude $144^{\circ} 28^{\prime}$. Prospectors' name, reported by Gerdine, 1902.

Sheep; gulch, in the Copper River region, at the headwaters of Chititu creek. Prospectors' name. First appears on map of Nizina mining district by George M. Esterly, of Valdez, 1902.

Sheep; island, one of the Galankin group, Sitka sound, Alexander archipelago. Named Barani (sheep) by Vasilief, 1809. Has been written Barani and Baranie.

Sheep; lake, north shore St. Paul island, Bering sea, near longitude $170^{\circ} 12^{\prime}$. Local name, reported by Stanley-Brown, 1891.

Sheep; mountain $(4,286$ feet high), about 4 miles southeast of Juneau, southeastern Alaska. Local name, reported by Peters, 1902.

Sheep Camp; mining camp, near the head of Talya river, southeastern Alaska. Reported by Flemer, 1808. 
Sheep Creek; flat, bare at ordinary low water, extending one-third the distance across Gastineau channel, from the mouth of Sheep creek (above). So described in the Coast Pilot of 1901.

Sheep Creek; settlement, on the north side of Gastineau channel, at the mouth of Sheep creek (above). Local name from the Coast Pilot of 1901.

Sheer-off-there; rock, in Portillo channel, Bucareli bay, Prince of Wailes archipelago. Named Alargate-alla (sheer-off-there) by Maurelle and Quadra, $1775-1779$.

Sheffin, creek; see Schiefflin.

Sheflin, creek; see Schieftlin.

Shekak, sound; see Honiah.

Shekesti; point, the southern point of entrance to Wrangell harbor, Wrangell island, Alexander archipelago. So called by Zarembo, 1834. On United States Hydrographic chart 225.it is Zhekiski.

she-kluck-she-uck, river; see Pick.

Sheklukshuk; range, northwestern Alaska, just east of Waring mountains, south of Kobuk river, near the Arctic circle and longitude $157^{\circ}$. Eskimo name, reported by Mendenhall, 1901.

Shekt; islet, in Wrangell harbor, Alexander archipelago. Apparently a native name, reported by Zarembo in 1834. Zarembo's sketch of Wrangell harbor, whereon this name appears, was published in 1848 on Russian Hydrographic chart 1396 . On Hydrographic chart 225 this is called Shake island.

Sheldon, island; see Channel.

Shelikof; bay, indenting the western shore of Kruzof island, Alexander archipelago. Named by the Russians after Grigori Ivianovich Shelikof, founder of the Russian-American Company. It is the Port Mary of Vancouver, 1794. Called Mary bay on some charts, and Puerto de Guadalupe in Galiano's atlas, 1802. Has been mistranslated Silk bay. Present usage applies the name Shelikof to the whole bay and restricts the name Mary to a cove or small bight within the bay.

Shelikof, harbor; see Three Saints bay.

Shelikof, lake; see"Iliamna.

Shelikof; strait, separating Kodiak from the mainland. So called by the Russians in the last century after Grigori Ivanovich Shelikof. Cook, who saw its northeastern end, in 1778, called it Smokey bay on account of the smoke seen on Point Banks, and its southwestern end Whitsuntide bay. Meares traversed it in August, 1786, and named it Petrie's strait, after William Petrie. The Spaniards, 1788, called it Canal de Flores. The Russians usually called it Aliaskinskoi or Shelikof, although it appears on an official map of 1802 as Kenai strait. And finally Shelikof: has been written Chélékhoff, Helikoff, Shelikhoff, etc.

Shell, bay; see Rakovoi.

Shell; creek, tributary to Skwentna river from the north, near longitude $151^{\circ}$ $30^{\prime}$. So named by Spurr, 1898, after P. G. Shell, who prospected in this region in 1887 .

Shell; hills (1,500 to 1,700 feet high), on the north bank of Skwentna river, about 60 miles north of Cook inlet. So named by Spurr, 1898, after P. G. Shell, who prospected in this region in 1887.

Shell, island; see Mogilnoi.

Shelter; bay, on the northwestern shore of Hinchinbrook island, Prince William sound. Name published by the Coast Survey in 1900.

Shelter; island, at junction of Stephens passage and Lynn canal, Alexander archipelago. So named by Meade, 1869. 
Shelter; islet, near the southern end of Long island, Chiniak bay, Kodiak. Named Ubezhitza (shelter) by Russian naval officers, 1808-1810.

Shelter; point, the eastern point of Killisnoo island; Hood bay, Chatham strait, Alexander archipelago. So named by Meade, 1869 .

Shemya, islands; see Semichi.

Shepard; creek, 15 miles north of Nome, Seward peninsula, a small tributary of Nome River from the west, near longitude $165^{\circ} 18^{\prime}$. Local name, from Gerdine, 1904.

Shepard, creek; see Upland.

Shepherd; creek, in the Controller Bay region, tributary to Bering lake from the north, near latitude $60^{\circ} 20^{\prime}$, longitude $144^{\circ} 10^{\prime}$. Named, 1899, after F. H. Shepherd, a mining engineer of Nanaimo, British Columbia. Reported by Martin, 1903.

Shepherd; creek, tributary to Snake river from the west, in the Nome mining region, Seward peninsula. Local name, published in 1900. Flas also been written Shepard.

Sheridan; creek, Seward peninsula, tributary to Bear creek from the east, near latitude $65^{\circ} 35^{\prime}$, longitude $161^{\circ}$. Prospector's' name, reported by Witherspoon, 1903.

Sheridan; glacier, terminating on Copper River delta, near latitude $60^{\circ} 30^{\prime}$, longitude $145^{\circ} 15^{\prime}$. So named by Abercrombie, 1884, after Gen. Phil. H. Sheridan, U. S. A.

Sheridan; peak (3,514 feet ligh), on Lindènberg peninsula, Kupreanof island, Alexander archipelago. Named by Thomas, 1.887, after Gen., Philip Henry Sheridan, U. S. A.

Sheridan, river; see Glacier.

Sherman; creek, on the mainland, southeastern Alaska, debouching on the eastern shore of Lynn canal, at Point Sherman, near latitude $58^{\circ} 52^{\prime}$. Prospector's' name, reported by Spencer and Wright, 1903.

Sherman; peak (3,984 feet high), on Lindenberg peninsula, Kupreanof island, Alexander archipelago. Named by Thomas, 1887, after Gen. William Tecumseh Sherman, U. S. A.

Sherman; point, on the eastern shore of Lynn canal, Alexander archipelago. Named by Meade, 1869, after Gen. William Tecumseh Sherman, U. S. A. This point was reserved for light-house purposes by Executive order dated January 4, 1901.

Sherman; sunken rock, off Sherman point, Lynn canal, Alexander archipelago. So named by Mansfield, 1890.

Sheshalek; Eskimo village, on the northern shore of Kotzebue sound, north of the mouth of Noatak, river. Reported by Petrof, 1880, as Sheshalegamute, i. e., Sheshalek people: Stoney names a village in the same place She-sur-are-lick. See also Anyok. Population in 1880, 100.

She-sur-are-lick, native village; see Sheshalek.

Shevenak; Eskimo village, on the left bank of Kuskokwim river, near its mouth. Native name, from Nelson, 1878-79, who wrote it Shevenagamute, i. e., Shevenak people. Petrof, 1880 , gives its population as 58, and its name Shovenagamute in his text (p. 17) and Shevenagamute on his map. Population, in 1890, 62, and spelling Shovenagamiut.

Sheolin; creek, tributary to Yukon river from the south, between the Ramparts and mouth of the Tanana. Goodrich says probably named after the Schiefflin brothers, who prospected that region in 1882-83. See also Sancho and Schiefflin.

Shiganik, island; see. Wingham. 
Shilgi; islet, southeast from Sitkin island, middle Aleutians. Name from the Russians. Identity of the island doubtful.

shiltonato, river; see Innoko.

Shinagrua; Eskimo village, on the Arctic coast; east of Point Barrow. The name appears on Coast Survey map 20, of 1869, and presumably on earlier maps, but is not shown on recent maps.

Shingle; island at entrance to Totem bay, Sumner strait, Alexander archipelago. So named by Helm, 1886.

Shingle; point, Alaska peninsula, on the eastern shore Herendeen bay, 8. miles south of Point Divide, near longitude $160^{\circ} 45^{\prime}$. Descriptive name, given by Tanner, 1890 .

Shingnek; creek, northwestern Alaska, tributary on the north bank of Kobuk river, near longitude $157^{\circ} 20^{\prime}$. Eskimo name, written Shung-nack by Stoney in 1885, and Shingnek by Mendenhall in 1901.

Shiniak; native village, on the eastern shore of Kuskokwim bay, north of the

- Kanektok river mouth. It is usually Shiniagamute, i. e., Shiniak people. Name Shiniagmiut, published in Sarichef's 'atlas, 1826. At this place is located a mission warehouse and on some maps appears as Warehouse, on others, Mission Warebouse.

Ship; bay, indenting the western shore of Resurrection bay, Kenai peninsula, 5 miles south of the town of Seward. Local name, from Moffit, 1904.

Ship; cove, in Port Conciusion, Baranof island, Alexander archipelago. . Named by Vancouver, 1794, who moored his ships here.

Ship; island, near shore of Cleveland peninsula, Clarence strait, Alexander archipelago. So named by Baker, 1880, on account of its appearance from the south. A rock near it has been called Ship rock and the point behind it Ship point and Ship Island point (Coast Pilot, p. 87, and map, p. 72).

Ship, island; see Error.

S'hip, island; see Labouchere.

Ship, island; see Sail.

Ship; islands, eastern, shore-Cordova bay, Alexander archipelago, between Kassa inlet and Shipwreck point; near latitude $54^{\circ} 55^{\prime}$, longitude $132^{\circ}$ 34'. Name from Dickins, 1905.

Ship; islet, between Davison and Sextant points, near entrance to Tamgas harbor, Annette island, Alexander archipelago. Named Karablin (ship) by Etolin, 1833. .

Ship; high rock or islet, in Umnak pass, eastern Aleutians. Called Karablin (ship) by the Russians. Lutke calls it a high rock, which the Russians of the country call the ship and the Aleuts Tanghinakh. Veniaminof has Ship (tanginak). See also Pustoi.

Ship; rock, in the vicinity of Bogoslof island, Bering sea. An island with rocks about it is shown on the track chart of Krenitzin and Levashef, 1768, in Coxe, 1780. On Billing's track chart, published by Sauer in 1802, is shown an islet in this vicinity, and near it the name Ship I. A rock, resembling a ship, near the site of Bogoslof, was described by. Cook in 1786. Cook (vol. 2, p. 526) describes it as an "elevated rock like a tower," but gives it no name in his text. In 1884, according to Cantwell, it was 87 feet high and stood on a spit connecting old and new Bogoslof. It fell between 1887 and 1890, and has disappeared.

Shipinskaia, river; see Sturgeon. 
Shipley; bay, in Kosciusko island, and opening into Sumner strait, Alexander archipelago, near latitude $56^{\circ} 05^{\prime}$, longitude $133^{\circ} 35^{\prime}$. Named by Snow, 1886, after Ensign John Harry Shipley, U. S. N., a member of his party.

Shipwreck; point, on the northeastern shore of Cordova bay, Alexander archipelago. So named by Moser, 1897.

Shtrokaia, bay; see Broad.

Shishaldin; small river, on the north shore of Unimak, near longitude $163^{\circ} 50^{\prime}$, " abounding in redfish," says Veniaminof, 1840 ( $\mathrm{I}, 215)$.

Shishaldin; volcano $(9,387$ feet high), on Unimak island, eastern Aleutians, - near latitude $54^{\circ} 45^{\prime}$, longitude $163^{\circ} 58^{\prime}$. Seen and named by Sarichef on June 18, 1790, who gives, according to Grewingk, Agajedan as its native name. According to Veniaminof, its native name is Sisaguk. Variously written Chichaldinskoi, Shushaldinskaia, etc. Its height as measured by Lutke in 1828 was 1,400 toises (8,953 English feet). Kotzebue found its height to be 5,525 English feet, according to Lutke, or 7,154 according to Grewingk. Tebenkof gives 8,755 feet and the Coast Survey 9,387 feet for its height.

Shishaldinski, village; see Sisaguk.

Shishkof, cape; see Lapin.

Shishkof, point; see Cave.

Shishmaref; cape, the southernmost point of Hall island, Bering sea. Named Shishmareva (Shishmaref's) on Russian Hydrographic chart 1455 (ed. of 1852), after Capt. Lieut. Glieb Semeonovich Shishmaref, who accom: panied Kotzebue, 1815-1818.

Shishmaref, cape; see Northeast.

Shishmaref; inlet, indenting the northern shore of Seward peninsula, Arctic ocean. So named by Kotzebue in August, 1816, after Lieutenant Shishmaref, who accompanied him in his explorations in 1816 . Variously written Chichmareff, Schischmareff, etc.

Shisloiso; hills, in the upper Kuskokwim region, on the southwest side of Lake Minchumina, near latitude $64^{\circ}$, longitude $152^{\circ}$. Native name written by Herron, 1899, Shiss-loy-so, probably from the Indian word shis (bear).

Shisnona; river, in the Kuskokwim region, a right branch of the Chedotlothna, near latitude $63^{\circ}$, longitude $153^{\circ}$. Indian name, probably from shis (bear), written by Herron (1899) Shissnona.

Shiss-loy-so, hills; see Shisloiso.

Shissnona, river; see Shisnoua.

Shitando, river; see Fortymile creek.

Shitna, creek; see Chitna.

Shitnak, cape and village; see Chitnak.

Shkagway, river and town; see Skagway.

Shketlina, point; on the southwestern shore of Seduction tongue, Lynn canal, southeastern Alaska. Apparently a native name, reported by Lindenberg in 1838.

Shkin, island; see Skin.

Shla-hatch, island; see Pyramid.

Shnu, river; see Shuna creek.

Shoal; bay, indenting the northwestern shore of Little Koniuji island, Shumagin group. So named by Dall, 1874.

Shoal; bay, near entrance to Sanborn harbor, Nagai island, Shumagins. So named by Dall, 1872. Descriptive name. 
Shoal; cape, on the northern coast of Kodiak, in Narrow strait. Named Otmeli (shoal) by Murashef, 1839-40.

Shoal; cape, on the southern shore of Afognak island, Kodiak group. Named Otmieloi (shoal) by Murashef, 1839-40.

Shoal; cove, indenting the western end of Alaska peninsula and opening into Isanotski strait, near latitude $54^{\circ} 57^{\prime}$, longitude $163^{\circ} 15^{\prime}$. So named by Dall, 1880.

Shoal; cove, indenting the western shore of Carroll inlet, Revillagigedo island, Alexander archipelago, near latitude $55^{\circ} 26^{\prime}$, longitude $131^{\circ} 17^{\prime}$. Local descriptive navigator's' name, reported by H. C. Fassett, Bureau of Fisheries, 1904.

Shoal; point, near Southern rapids, Peril strait, on Chichagof island, Alexander archipelago. So named by Coghlan, 1884.

Shoal; point, on the eastern side of McClellan flats, at month of Chilkat river, southeastern Alaska. Named Otmelie (shoal) by Lindenberg, 1838. This name is obsolete.

Shoal Ness. Cook, 1778, so named some point near the mouth of the Kuskokwim, just what one does not appear. Perhaps it was Cape Avinof.

Shoals, island; see Otmèloi.

Shoals; point, the southeastern point of Kruzof island, in entrance to Sitka sound, Alexander archipelago. This cape has borne many names. Dixon, 1787, called it White's point, and Lisianski, in 1804, First point. The early Russians, after Lisianski, called it Otmeloi (shoals) point, and to distinguish from another shoals point a few miles farther: within the sound they called it Otmeloi vnieshnie (outer shoals). So it appears as Shoals point, Point of Shoals, and Outer point of Shoals. Tebenkof, 1850, calls it Nizmennia (low) point.

Shoalwater; passage, in Behm canal, separating Winstanley island from the mainland, southeastern Alaska. So named by Dall, 1879.

Shockum; mountains, 15 miles north of Controller bay, Gulf of Alaska, near latitude $60^{\circ} 22^{\prime}$, longitude $144^{\circ}$. So named after an Indian, who writes his name thus, and reported by Martin, 1905.

Shoe; island, in Tlevak strait, Cordova bay, Alexander archipelago. So named. by Nichols, 1881, by reason of its shape. (Coast Pilot, p. 68.)

Shoe; rock, in Tlevak strait, Cordova bay, near Shoe island (above), about latitude $54^{\circ} 57^{\prime}$, longitude $132^{\circ} 45^{\prime}$. So called by Dickins, 1905 .

Shok-ah-bok-shegial, river; see Pah.

Shokfaktolik; one of the numerous lakes in the Kuskokwim tundra, about 25 miles northwest of Bethel; also a native village there. . Name obtained by Spurr and Post, 1898, from missionary Helmick; spelled Tșokfachtoligamut by Post and Chokfaktoligamute by Spurr. In the Eleventh Census it is called Chokfoktoleghagamiut, i. e., Shokfak region people. Chokagtaligamute may be another rendering of this village name, which see. The lake is near or identical with Naniuknuk lake.

Shokum; creek, $12 \frac{1}{2}$ miles east of Cape Yaktrg, Gulf of Alaska, and one-half mile west of Lawrence creek, near longitude $142^{\circ}$. Indian name, reported by Martin; 1904.

Shoo Fly, rock; see Eye Opener.

Short; arm of Kendrick bay, on south shore Clarence strait, southeastern Alaska; near latitude $54^{\circ} 52^{\prime}$, longitude $132^{\circ} 04^{\prime}$. So described by local navigators, and reported by $\mathrm{H}$. C. Fassett, Bureau of Fisheries, 1904.

Short; bay; indenting the mainland, on north shore of Behm canal. Called Short inlet by Dall, 1879 (Coast Pilot, p. 73). 
Short; creek, tributary to Red bay, Prince of Wales island, Alexander archipelago. So named by Helm, 1886.

Short; creek, 25 miles north of Nome, Seward peninsula, tributary to Stewart river from the north, near longitude $165^{\circ} 22^{\prime}$. Local name, from Gerdine, 1904.

Short; creek, 25 miles north of Nome, Seward peninsula, tributary from the northwest to Dorothy creek, a west branch of Nome river, near longitude $165^{\circ} 15^{\prime}$. Miners' name, reported by Gerdine, 1904:

Short; passage, between Smeaton island and Revillagigedo island, in Behm canal; Alexander archipelago. Named by the Coast Survey in 1891.

Short; point, just within the entrance to Smeaton bay, on its southern shore, Alexander archipelago. So named by the Coast Survey in 1891.

Shorty; creek, tributary to the headwaters of the Alsek. Named by Brooks, 1899.

Shotcoaluk, Eskimo village; see Shotkoluk.

Shotkoluk; native village, on the Noatak river, northwestern Alaska, near latitude $67^{\circ} 55^{\prime}$, longitude $156^{\circ} 30^{\prime}$. Visited by Ensign Howard, of Stoney's party, in the spring of 1886 . Stoney wrote Shotcoaluk and Shot-koal-uik.

Shoup; bay, indenting the north shore of Port Valdez, Prince William sound. near latitude $61^{\circ} 07^{\prime}$, longitude $146^{\circ} 32^{\prime}$. Local name, reported by Grant, 1905.

Shoup; glacier, at the head of Shoup bay, north shore Port Valdez, Prince William sound. Local name, reported by Abercrombie, 1898. Called also Canyon Creek glacier.

Shovel; creek, tributary to Solomon river from the west, in the Bonanza mining district, Seward peninsula. Local name, published in 1900.

Shovenagamute, village; see Shevenak.

Show, gulch; see Snow.

Shrimp; bay, in Behm canal, indenting the northwestern shore of Revillagigedo island. So named by the Const Survey in 1891.

Shrubby; island, one of the Kashevarof group, Clarence strait, Alexander archipelago. So called by Dall in the Coast Pilot (1883, p. 90).

Shtilia, point; see Calm.

Shuck; river, on the south shore, near the head of Windham bay, eastern shore Frederick sound, southeastern Alaska, near latitude $57^{\circ} 34^{\prime}$, longitude $133^{\circ} 20^{\prime}$. 'This name, written also Chuck and applied to one or more mining camps, was published by the Coast Survey in 1891 .

Shuck, camp; see Chuck.

Shuitna, river; see Chuit.

Shukwuk; Eskimo village, northwestern Alaska, on the left bank of Noatak river, near latitude $67^{\circ} 45^{\prime}$, longitude $163^{\circ}$. Native name written Shu-quck by Stoney, 1885. This is one of the villages which Fetrof, 1880 , includes under the general name Noatagamutes. See Noatak.

Shumagin; bank, near the Shumagin islands. So named by the Fish Commission in 1888.

Shumagin; large group of islands, west of Kodiak and south of Alaska peninsula. So named by Bering, after one of his silors, who died of scurvy and was buried here, August 30, 1741. Sometimes written Choumagin and Choumaghin. According to Veniaminof, the Aleut name is Kaggiun. Golofnin says the Aleuts call them Unga, from the name of the largest of the group.

Shuna; creek, tributary from the northwest to Copper river, near Chistochina and latitude $62^{\circ} 35^{\prime}$, longitude $144^{\circ} 21^{\prime}$. Indian name, written Schnuna, i. e., Shnu river, by Allen, 1885 . Gerdine, 1902, wrote Schuna creek. 
Shunaltuli, island; see Shaw.

Shungnak; post-office (established in 1903), northwestern Alaska, on Kobuk river, near longitude $156^{\circ}$. Eskimo name. It seems to be where Stoney located the Eskimo village of Sulukpowik, and 60 or 70 miles above Shingnek creek.

shung-nack, river; see Shingnek.

Shupwik; Eskimo village, northwestern Alaska, on eastern shore of Inland lake, near latitude $66^{\circ} 30^{\prime}$, longitude $160^{\circ}$. Native name, reported by Stoney, 1885.

Shu-quck, Eskimo village; see Shukwuk and Noatak.

Shushaldenskaia, volcano; see Shishaldin.

S'hu-shuk-to-ark, river; see Squirrel.

Shuyak; island, north of Afognak, off mouth of Cook inlet. Native name, from the earliest Russian explorers. It has had many spellings, Chouyak, Chuyak, Iluiak, Huiak, Schujek, Shooiack, etc.

Shuyak; strait, between Shuyak and Afognak islands. Native name, from early Russian explorers.

Sichtunak, strait; see Sitkinak.

Sidankin, village; see Biorka.

Side, island; see Lewis.

Sidney; creek, tributary to Cripple river from the south, near its mouth. - Seward peninsula. Name from Barnard, 1900. Witherspoon, 1899, called this Sealer creek.

Siepermo, cape; see North.

Sievernoi, cape; see Afognak.

Sievernoi, cape, etc.; see North.

Sievernoi, island; see Raspberry.

Sievernoi, passage; see Whale.

Sievernoi, point; see Akun Head.

Sievernoi, strait; see Kupreanof.

Sigak, cape; see North Head.

Sigak, cape; see Sagak.

Sigdak, island; see Great Sitkin.

Siginak, island; see Biorka.

Siginaka; group of -islands, in the northernmost part of Sitka sound, Alexander archipelago. So called by the Russians.

Siginaka; island, one of the Siginaka group, Sitka sound, Alexander archipelago. Named Siginaki by Vasilief in 1809 . Has also been written Siginak.

Signal; island, on eastern side of Western channel into Sitka harbor, Sitka sound, Alexander archipelago. Named Maiachnoi (signal) by Vasilief in 1809 , on whose chart is shown a maiak (light-house). Has also been called Lighthouse, Mayastetchnoi, and Signal Light island.

Signal; mountain, in western part of Revillagigedo island, Alexander archipelago. So named by Nichols, 1883.

Signal, point; see. Yellow.

Signals (The); three separate small rocks off the eastern shore of Biorka island, eastern Aleutians, near latitude $53^{\circ} 48^{\prime}$, longitude $166^{\circ} 05^{\prime}$. The one nearest the shore, known as the Inner Signal, is 180 feet high. The most northerly, called the Outer Signal, is 50 feet high. The third, one-fourth mile east of the Outer Signal, is 10 feet high. So described by Gilbert, 1901 . 
Signals (The); pinnacle rocks (kekuri), near southern entrance to Akutan pass, eastern Aleutians. Called Kuka (Cook's) pillar by Tebenkof, 1849. The Fish Commission, in 1888, called them The Signals.

Sigoola, island; see Chugul.

Siguam, island; see Seguam.

Sigalidok, island; see Sitkalidak.

Sikarnoi, mountain; see Sugarloaf.

Sikonsina; pass, in the Mentasta mountains, at the head of the slana river. Indian name, so applied by prospectors, and reported by Schrader, 1903.

Silak; islet, in the strait between Little Tanaga and Kagalaska islands, Andreanof group, middle Aleutians. Name from Tebenkof, 1849.

Silk, bay; see Shelikof.

Sillokh, lake; see Skilak.

Silnaho Techenia, cape; see Tiderip.

Silok; creek, tributary to Tanana river from the south, near longitude $147^{\circ}$. This stream was called Delta creek by Allen, 1885. To avoid confusion with Allen's Delta river, and because the exact locality of his Delta creek is not clear, this change bas been introduced by the Geological Survey. Apparently a native name, which has also been spelled Silokh. It is reported, 1905, that the prospectors have given the name Delta - creek to a stream 25 miles above this one and 5 or 6 miles below Delta river.

Silver; bay, opening into Sitka sound, Baranof island, Alexander archipelago, near latitude $57^{\circ} 02^{\prime}$, longitude $135^{\circ} 14^{\prime}$. Locally so called from the occurrence of silver near it. It was called Serebrenikof arm or bay by the Russians.

Silver; creek, 20 miles north of Nome, Seward peninsula, tributary from the north to Goldbottom creek, near longitude $165^{\circ} 23^{\prime}$. Local name, from Gerdine, 1904.

Silver; creek, 25 miles north of Nome, Seward peninsula, tributary to Stewart river from the north, near longitude $165^{\circ} 25^{\prime}$. Local name, from Gerdine, 1904.

Silver; gulch, in the Fairbanks region, on the north bank of Goldstream creek, a mile above Engineer creek, near longitude $147^{\circ} 40^{\prime}$. Local name, from Map of Location, Tanana Mines Railroad, 1905.

Silver; lake (elevation 4,200 feet), on the divide between the Alsek and Yukon watersheds, Alaska. According to the Krause brothers the native name is Danaaku; according to Dall, Dana-aka.

Silver; point, on the northeastern shore of Sitka sound, Baranof island, Alexander archipelago. Apparently so named by United States naval officers, 1880.

Silverbow; basin, in valley of Gold creek, 3 miles east of Juneau, southeastern Alaska. Local name, Silver Bow, published by Nichols in the Coast Pilot (1891, p. 150).

Silverbow, creek; see Little Anvil.

Silver Salmon; bay, indenting the northwestern shore of Olga bay, Alitak bay, southwestern coast of Kodiak. Local name, reported by Moser, 1900.

Silivertip; creek, Kenai peniṇsula, tributary from the west to East fork Sixmile creek. Local name, from Moffit, 1904.

Silvester; point, on the northwestern shore of St. Ignace island, Bucareli bay, Prince of Wales archipelago. Named Punta de San Silbestre by Maurelle and Quadra, 1775-1779. 
Simedan, islands; see Semidi.

Simeonof; harbor, indenting the western shore of Simeonof island, Shumagin group. Surveyed and named by Dall, 1872.

Simeonof; island, the easternmost of the Shumagin group. Now occupied as a blue-fox farm. Named Seménorskie (Simon) by the Russians. Lutke applies the name to the southeastern group of the Shumagins, and this one he calls Taghinak. The native name is Tiakinak. Variously called Semenoffsky, Simeonovski. Also called Tachkinach, Takh-kiniakh; Takhinak, Tikhiniak, etc.

Simmons; point, the south point of entrance to Copper harbor eastern shore Hetta inlet, Cordova bay, Alexander archipelago, near latitude $55^{\circ} 12^{\prime}$, longitude $132^{\circ} 40^{\prime}$. Name from Dickins, 1905 .

Simonof; islet, in Highfield anchorage, at north end of Wrangell island, Alexander archipelago. Apparently so named by the British Admiralty, 1865, and by the Russians, at about the same time, Observation islet. Has been written erroneously Simanoff.

Simonton; point, between Nakat harbor and Nakat inlet, Dixon entrance. So named by Nichols, 1883.

Simpson; bay, on the northern shore of Orca bay, Prince William sound, near latitude $60^{\circ} 40^{\prime}$, longitude $145^{\circ} 50^{\prime}$. Local name, reported by Moser, 1897.

Simpson; cape, the western head of Smith bay, on the Arctic coast, east of Point Barrow. Named Cape George Simpson by Dease and Simpson, 1837, in honor of Governor Sir George Simpson, of the Hudson Bay Company. On their map called Cape Governor Simpson.

Simpson; cove, at Collinson point, on the Arctic coast, east of Point Barrow.

Simpson; mountain (5,200 feet high), east of Klutina lake. So named by Abercrombie, 1898.

Simpson; pass $\left(3,600\right.$ feet high), in the McKinley range, near latitude $62^{\circ}$, longitude $153^{\circ} 30^{\prime}$. Discovered and named by Herron, 1899 .

Simpson; peak (5,271 feet high), on the mainland east of Frederick sound, southeastern Alaska. So named by Thomas, 1887.

Simpson; sunken rock, in Eastern channel into Sitka harbor, Sitka sound, Alexander archipelago. Discovered and named by H. M. S. Devastation, 1862 .

Sinagmia, village; see Imagnee.

Sinaru; locality and small stream, debouching just west of Refuge inlet, on the Arctic coast. Called Sinarua by British naval officers, 1849-1853. Ray, who explored it in April, 1883, with a native guide, writes it Siñaru in his text and Singaroo on his map. Jarvis established his reindeer camp here in the spring of 1898 , and writes it Sinra. Written also Sinragahroo.

Sinbad; point, on the northern shore of Suloia bay, Chichagof island, Peril strait, Alexander archipelago, near latitude $57^{\circ} 24^{\prime}$, longitude $135^{\circ} 39^{\prime}$. Name published by the Coast Survey in 1900 .

sinclair, cove; see Pond bay.

Sinclair; lake and river, in northernmost Alaska, debouching between Dease inlet and Smith bay, east of Point Barrow. So named by Dease and Simpson, 1837, after George Sinclair, a half-breed and guide, who had served with Sir George Back in 1834.

Sind, island; see St. Lawrence.

Sindsha, island ; see Hall.

Sinerazat, Eskimo village; see Sinrazat.

Singaroo, river; see Sinaru. 
Sinitsin; cove, indenting the northern shore of Kruzof island, south side Salisbury sound, Alexander archipelago, 1 mile eastward of Sinitsin island (below). Name so applied by Moore, 1896.

Sinitsin; island, on the southern shore of Salisbury sound, Alexander archipelago, near latitude $57^{\circ} 21^{\prime}$, longitude $135^{\circ} 46^{\prime}$. Named, 1833 , by Vasilief, after Lieut. Nikolai Sinitsin, of the Russian Navy, who accompanied Hagemeister on the Krotkoi, 1828-1830. Has been erroneousiy written Sinits.

Sinnyuli. This Eskimo name appears on Ray's map of 1885 for some feature a little east of the Signal Service station Utkiavi, near Point Barrow, Arctic coast.

Sinr $a$, river ; see Sinaru.

Sinragahroo, locality; see Sinaru.

Sinrazat; Eskimo village, on the northwest coast of Seward peninsula, near latitude $66^{\circ}$, longitude $167^{\circ}$. Visited by Jarvis in 1898 . Written also Sinerazat.

Sinrock, river and village; see Sinuk.

Sinuk; river, near Cape Rodney, Seward peninsula, about longitude $166^{\circ}$. Eskimo name, from Barnard, 1900. It has been written Sinook, Sinrock, and synrock.

Sinuk; Eskimo village, at the mouth of Sinuk river, Seward peninsula, 6 miles southeast of Cape Rodney. Native name, from Barnard, 1900. Petrof, 1880 , has an Eskimo village on the north shore of Port Clarence called Siniogamute, i. e., Siniok people.

Siouchi, bay; see Sealion.

Siouchi, islets; see Sealion.

Sirkwet; lake, a small lake in the Chilkat region, on the upper Takhini river above Kusawa lake. Indian nime, reported by the Leslie expedition, 1890 , and written Cirquet, Seer-quett, and Seer-kwet. Wells, the leader of the expedition named it Lake Maud.

Sirkwet, river; see Takhini.

Siroi; point, on Baranof island, Peril strait, Alexander archipelago. Named Siroi (wet) by Vasilief, 1833.

Sirr; village or locality, on Koyukuk river, near the junction of North and Middle forks. Name from Peters and Schrader, 1901.

Siruk; creek, northern Alaska, tributary to Alatna river from the south, near: latitude $66^{\circ} 45^{\prime}$, longitude $153^{\circ} 30^{\prime}$. Apparently an Eskimo name obtained by Mendenhall, 1901. Written also Sirurk.

Sirurk, creek; see Siruk.

Sisaguk; native village (in about 1830) on the northern shore of Unimak. This is the native name. The Russians called it Shishaldinski.

sisaguk, volcano; see Shishaldin.

Sischu; mountain, on the right bank of the upper: Kuskokwim, Last Fork, near latitude $64^{\circ}$. Native name, from Heron, 1899.

Sisek; cove, on the south shore of Beaver bay, in Biorka island, Unalaska, eastern Aleutians, near longitude $166^{\circ} 11^{\prime}$. Aleut name, from Sarichef, 1792. Perhaps this should be Sasak, the Aleut name of the parroquet ank. Sisik is the Aleut word for the numeral 100 .

Sishimkiak, island; see sitymkan.

Sister; three islands, at high water,. about 1 mile south of Kelp island, Dixon entrance. Named Twin islands by pilot W. E. George and so published in the Coast Pilot (1883, p. 77). The name Sister islands, published by the Coast Survey, 1885, has come into general use.

Bull. $299-06$ M -37 
Sisters; islands, in Icy strait, Alexander archipelago, near latitude $58^{\circ} 10^{\prime}$, longitude $135^{\circ} 15^{\prime}$. So called by United States naval officers, 1880 .

Sisters; a small island, among the Sannak reefs, Sannak islands, near latitude $54^{\circ} 20^{\prime}$, longitude $162^{\circ} 41^{\prime}$. Descriptive name, from Westdahl, 1901.

Sisters .(The), islands; see Lynn Sisters.

Sisters (The), islands; see Twin.

Sisters (The); two peaks (1,308 and 1,325 feet high), about 12 miles southeast of St. Michael, Norton sound. So named by the Coast Survey in 1898.

Sisters; reef and ledge, 1 mile west of Sisters islands, Icy strait, Alexander archipelago. So named by Dickins, 1901.

Sisters (The); two large rocks, about 2 miles off the eastern shore of Cook inlet, and about 6 miles below Kasilof; near latitude $60^{\circ} 20^{\prime}$. So described by Moser, 1897.

Sitak, glacial stream; see Situk.

Sithanak, island; see Biorka.

Sitka; city, the capital and one of the chief towns of Alaska, near latitude $57^{\circ}$. Baranof, 1799, visited Sitka sound and began the construction of a fortified post, which he called Fort Archangel Gabriel. This fort, located on what is now known as Old harbor; was completed the following spring. In May, 1802, the natives attacked this fort and drove out its inmates, killing all the officer:s and 30 men. The Indians then fortified themselves near by and held their post till 1804, when it was bombarded and captured by the Russians. Thereupon a new fort was constructed by the Russians and called Fort Archangel Michael. This was located on the site of the governor's house or castle (since burned) in the present town of Sitka. The town which grew up around it was called by the Russians New Archangel (Novo Arkhangelsk) or Sitka. This native. word Shitka or Sitka, of unknown meaning, has been variously written Schitcha, Sitcha, Sitki, etc. The post-office at Sitka was established in October, 1885. Population in 1890, 1,190; in 1900, 1,396.

Sitka; harbor, in Sitka sound, Baranof island, Alexander archipelago, near latitude $57^{\circ}$.

Sitka, island; see Baranof.

Sitka, island; see Kruzof.

Sitka; point, on the southern shore of Kruzof island, Sitka sound, Alexander archipelago. What is now called Cape Edgecumbe was called Sitka point by Russian naval officers, 1809. The present usage retains both names, Edgecumbe for the southwest point of Kruzof island, and Sitka for the inner angle of that point.

Sitka; sound, on the western shore of Baranof island, Alexander archipelago, near latitude $57^{\circ}$. First visited by Bodega and Maurelle in August, 1775, and by them called Insenada del Susto (bay of terrors). Dixon, who visited and made a sketch of it in June, 1787, called it Norfolk sound, which name was adopted by Vancouver. The native name, according to the Frenchman Marchand, who was here in 1791 or 1792 , is Tchinkitanay bay. The Russians who began settlement here in $\mathbf{1 7 9 9}$ obtained from the natives the name Shitka, a name which, modified to Sitka, has come into general use.

Sitkagi; bluffs, in the vicinity of Sitkagi point of early maps. So named by Russell, 1891, who says "there is now no cape at that locality, but rather a slight recession in the coast line." 
Sitkagi; cape, in front of Malaspina glacier; St. Elias alpine region, southeastern Alaska. Apparently a native name, applied by Tebenkof in 1849. Perhaps identical with Cape St. Elias of Russian Hydrographic cha:t 1378.

Sitkalidak; island, near the southern coast of Kodiak. Behind this island the Russians made their first settlement on Kodiak, 1784, at Three Saints bay. The name is a corruption of some native word or phrase which has appeared in many forms. Billings calls the island Kunakan or: Kukan, while Galiano's atlas, 1802, has Isla de Soto (forest island): For the rest we have variant forms of the above. Lisianski, 1805, has Salthidack, while Langsdorf, who accompanied his expedition, has Sachlidok, Sadlidok or Scachlitak. The early Russian chaits have Saklidok and Siaklidok, while Tebenkof, 1849, has Satklidak and Siatklidak. The Russian-American Company map of 1849 has Saklidok, with Shagitak as an alternative form. It has also appeared as Saklidov and even as Zatchlitschak.

Sitkalidak; strait, between Kodiak and Sitkalidak islands. Corruption of some native name, obtained by the Russians.

Sitkinak; island, one of the Trinity islands, off the southwestern end of Kodiak. Native name, from the early Russians. Has been written Sichtunak, Sikhinak, Sitchinak, Sitcknak, Sithoonack, Sitkinak, Sitkınak, etc.

Sitklan; island, southwest of 'Tongass passage, Dixon entrance. Native name, reported by Davidson, 1869, as Sit-klan.

Sitkoh; bay, in Chichagof island, eastern entrance to Peril strait, Alexander archipelago. Native name, published in the Coast Pilot (1883, p. 178).

Sitkun; pass, between South fork Koyukuk river and Slate creek, an affluent of Middle fork, near latitude $67^{\circ} 10^{\prime}$, longitude $150^{\circ}$. Name from Feters and Schrader, 1901.

Sitnazuak; Eskimo village, on the southern shore of Seward peninsula, a little west of Cape Nome. Petrof, in 1880, called it Chitnashuak_and gave its population as 20 . On a recent local map it is called Sitnazoak.

Sittakanay; river, tributary to Taku river from the east, southeastern Alaska. Native name, published by the Coast Survey in 1895 .

Situk; glacial stream, on the coast of the St. Elias alps, debouching a few miles southeast of Yakutat bay, near longitude $139^{\circ} 30^{\prime}$. Indian name, written Sitak by Tebenkof (1849), Setuk by Glave (1890), See-tuck by Moser (1901), and Setuk by the Yakutat and Southern Railway.

Situk; Indian village, about 15 miles east of Yakutat, visited by Russell in September, 1.891, who reports its name as Setuck.

s'itymkan. One of the Shumagin islands, not identified, is so called by Iutke. who took it from Veniaminof. In Veniaminof's later publication it is called Sishimkak.

siuchi, cape; see Georgiana.

Siuchi, cape ; see Lutke.

siuchi, rocks, etc.; see Seal.

Siuvich, rock; see Klochkof.

sivernoi, passage; see Whale.

Sivoutchy, rock; see Sealion.

Sivukuk, cape and Eskimo village; see Chibukak and Gambell.

sivóash, inlet; see Tenakee. 
Sixmile; creek, Kenai peninsula, tributary to Turnagain arm of Cook inlet from the south, near longitude $149^{\circ} 30^{\prime}$. Local name, obtained by Becker, 1895.

Sixtymile; butte, near Dennison fork Fortymile creek, about latitude $63^{\circ} 45^{\prime}$, longitude $142^{\circ} 30^{\prime}$. Prospector's' name, reported by Spurr, Goodrich, and Schrader, 1896.

Sixtymile; creek, tributary to Yukon river from the west, near longitude $140^{\circ}$. Local name.

Skagul; island, one of the westernmost of the Andreanof group, middle Aleu- tians. Aleut name, from the Russians. Lutke writes Skakhoul and Tebenkof Skagul. Also written Skagule. This with Ogliuga iṣland and adjacent islets and rocks constitute the Delarof islands of Lutke.

Skagway; river and town, at head of Taiya inlet, southeastern Alaska. Native name, said to mean "home of the north wind," and variously written. The Krause brothers, 1882, write it Schkagué. Nichols, 1891, wrote it Shkagway. Has also been written Skagwa; Skaguay, etc. The above form.. has also been adopted by the Canadian Boärd on Geographic Names. The post-office was established here in November, 1897. There is also a military post here, called by the military authorities Skaguay.

Skan; bay, indenting the northern shore of Unalaska, eastern Aleutians. Called. Skan bay by Sarichef, 1792. Called Twin bay by. the Fish Commission, 1888, a descriptive term, the bay being double. Veniaminof regards this as lying within Makushin bay and calls it Starichkof.

Skatalis, village; see Alaganil.

Slecter, bay; see Lituya.

Skeleton; islet, very near the eastern shore of Wrangell island, Arctic ocean. So named by Berry, 1881.

Skilak; lake, on Kenai peninsula, drained by the Kenai river. Apparently a native name, reported by Wosnesenski about 1840. Variously written Sillokh, Skilakh, Skillokh, etc. Also called Kaknu and Kenai.

Skilak; village, néar Skilak lake, on Kenai peninsula. Native náme, from Petrof, 1880 , who spelis it Skilakh.

Skilakh, lake; see Tustumena.

Stikiliamna; lake, on Kenai peninsula, tributary to Skilak lake. So called on Russian Hydrographic chart 1378 (ed. of 1847). Though out of position, this is probably Kenai lake. See Kenai.

Skin; island, near entrance to Cholmondeley sound, Clarence strait, Alexander archipelago. "Probably named by the traders." It is Shkin island of Russian Hydrographic chart 1493 (ed. of 1853).

Skipwith; reefs, in the eastern side of Afognak bay, Kodiak group, near latitude $58^{\circ}$, longitude $152^{\circ} 42^{\prime}$. Locall name, reported by Moser; 1900 .

Skirt; point, on Revillagigedo island, in Behm canal, between Rudyerd bay and

- Walker cove, Alexander archipelago: So called by the Coast Survey in 1891.

Skolai; pass (about 5,000 feet high), creek tributary to the headwaters of the Nizina river, and mountains between the headwaters of White, Nizina, and Chitina rivers. Spelled variously Scolai, Scoloi. Scolai is the name by which the Copper River chief, Nicolai or Scolai, is known among all the Yukon natives. (Hayes, Nat. Geog. Mag., vol. 4, 135.)

Skookum; creek, tributary to Gold run from the south, 'Seward peninsula. Name from Barnard, 1900. Skookum or Skoo-koom is a Chihalis Indian word, adopted in the Chinook jargon with the general meaning very. It means ghost, evil spirit, demon, etc. Skookum tumtum means brave; skookum chuck, a rapid, etc. 
Skookum; creek, Seward peninsula, tributary to Noxapaga river, through Turner creek, near latitude $65^{\circ} 35^{\prime}$. longitude $164^{\circ}, 15^{\prime}$. Prospectors' name, reported by Gerdine, 1901.

Skookum; creek, tributary to headwaters of North fork Kougarok river; near latitude $65^{\circ} 40^{\prime}$, longitude $164^{\circ} 22^{\prime}$. Prospectors' name, reported by Gerdine, 1901.

Skookum; creek, north side of Tanana river, tributary to Pioneer creek from the northwest. Prospector's' name, reported by Prindle, 1904.

Skookum; gulch, 16 miles northwest of Cape Nome, Seward peninsula, draining to Bonita creek at the head of Osborn creek, near longitude $165^{\circ} 13^{\prime}$. Miner's' name, published in 1901.

Skookum; river, tributary to Klokerblok river from the west, Seward peninsula, Name from Barnard, 1900.

Skookum Chuck; tide rip, in Tlevak narrows, Cordova bay, Prince of Wales island. Chinook name, published by the Coast Survey in 1905.

Skookum Chuck; tide rip, on the south side of Cholmondeley sound, Clarence strait, southeastern Alaska, near latitude $55^{\circ} 10^{\prime}$, longitude $132^{\circ} 10^{\prime}$. So called by local navigators, and reported by $\mathrm{H}$. C. Fassett, Bureau of Fisheries, 1904.

Shoot, river; see Iskut.

Skotnik, mountain; see Barometer.

Skowl; arm, of Kasaan bay, Clarence strait, Alexander archipelago. Called Skoivl bay, 1880, after an Indian chief of that name then living there.

Skowl; island, Kasaan bay, Alexander archipelago. The island now known by this name forms Skowl point, the south point of entrance to Skowl arm, near latitude $55^{\circ} 25^{\prime}$, longitude $132^{\circ} 16^{\prime}$. Compare map in the Coast Pilot (1883, p. 72) with later ones.

Skowl; point, the southern point of entrance to Skowl arm, Kasaan bay, Clarence strait, Alexander archipelago. So named by Dall, 1880.

Skull; cliff ( 70 feet high), in Peard bay, west of Point Barrow, Arctic coast. So named by English naval ofticers connected with the Franklin search expeditions, $1849-1853$.

Skull, islet; see Scull.

skvortzova, village; see Starling.

Skwentna; river, tributary to the Yentna from the west, which in turn is tributary to the Susitna. Native name, from Spurr and Post, 1898. Has also been written Squentna, i. e., Squent or Skwent river.

Slab; point, on the western shore of Portland cinal. So named by Pender, 1868.

Sladen; creek, in the Copper River region, tributary from the southwest to Bubb creek, an affluent of Tazlina river, near latitude $62^{\circ} 15^{\prime}$, longitude $147^{\circ} 45^{\prime}$. So named by Glenn, 1898 .

Slag; point, on the eastern shore of Behm canal, just north of Winstanley island, Alexander archipelago. Name published by the Coast Survey in 1891.

Slana; river, draining from Suslota lake to Copper river. Native name, reported by Allen, 1885, as Slaná, i. e., Sla river. Has also been written Slahna.

Slate; creek, on the south side of Windham bay, Frederick sound, southeastern Alaska, tributary to Shuck river from the west. Prospectors' name, reported by Spencer and Wright, 1903.

Slate; creek, in the Copper River region, tributary to Chistochina river at its source. Prospectors' name, reported by Mendenhall, 1903.

Slate; creek, tributary from the south to Turnagain arm of Cook inlet, about 6 miles east of Sunrise. Local name, reported by Moffit, 1904. 
Slate; creek, 12 miles north of Nome, Seward peninsula, tributary from the north to Banner creek, an affluent of Nome river, near longitude $165^{\circ}$ 20'. Local name, published in 1901. Called also. Right fork.

Slate; creek, 15 miles north of Nome, Seward peninsula, a small tributary from the west to Nome river, near longitude $165^{\circ} 18^{\prime}$. Local name, published in 1900.

Slate; creek, 25 miles north of Nome, Seward peninsula, a tributary to. Stewart river from the north, near longitude $165^{\circ} 20^{\prime}$. Local name, from Gerdine, 1904.

Slate; creek, tributary to Fish river from the west, Seward peninsula. Name from Peter's, 1900.

Slate; creek, tributary to Fox river from the south, Seward peninsula. Name from Barnard, 1900.

Slate; creek, tributary to Niukluk river from the south, in the Eldorado mining district, Seward peninsulit. Local name, publisbed in 1900 . May be identical with Beattie, Bennet, Coffee, Enright, Pancake, Peterson, or Richter of a local map.

Slate; creek, tributary to Sunset creek from the south, Seward peninsula. Name from Barnard, 1900.

Slate, creek; tributary to Casadepaga; see Rover.

Slate; creek, in the Rampart region, tributary to Minook creek from the west, about 12 miles above its mouth. Prospectors' name, reported by Prindle, 1904.

Slate; creek, tributary to Mosquito creek from the south. Name from Schrader. 1900.

Slate; creek, tributary to North fork Fortymile creek from the west, near latitude $64^{\circ} 40^{\prime}$, longitude $142^{\circ} 10^{\prime}$. Prospectors' name, reported by Gerdine, 1903.

Slate; creek, tributary to Middle fork Koyukuk river from the east, near latitude $67^{\circ} 15^{\prime}$, longitude $150^{\circ} 15^{\prime}$. Prospectors' name, published in 1899.

Slate; island, in Revillagigedo channel, near entrance to Boca de Qüadra, Alexander archipelago. So named by Vancouver, 1793, " being entirely composed of that rock."

Slate; islets, at entrance to Crawfish inlet, Baranof island, Alexander archipelago. Named Aspid (slate) by the Russians.

Slate, point; see Aspid.

Slaughter; island, connected with the shore at low water, being the north point (near Point Mary), at. entrance to Shelikof bay, Kruzof island, Alexander archipelago, near latitude $57^{\circ} 10^{\prime}$, longitude $135^{\circ} 50^{\prime}$. So named by Moore, 1897 .

Slavarassi, colony; see Glory of Russia.

S'lava Rossie, bay; see Tanaga.

Sledge; creek, 10 miles north of Nome, Seward peninsula, tributary to Snake river from the west. Name from Barnard, 1900.

Sledge; island, off the coast of Seward peninsula, west of Cape Nome. So named by Cook, wbo landed upon it August 5, 1778. He says: "We found, a little way from the shore where we landed, a sledge, which occasioned this name being given to the island." According to Sauer the native name is Ayak. Beechey (Voyage, 1826, p. 291) gives the same, Ayak, as the native name and adds: "It is singular that this island, which was named Sledge Island by Captain Cook, from the circumstance of one of these implements being found upon it, should be called by a 
Sledge-Continued.

word signifying the same thing in the Esquimaux language." This native name has been variously written Ajak, Asiak, Asshiak, Ayak, Aziak, Azjiak, etc. .

sileepy, sea ; see Bering.

Slide (The); bluff, just east of Karluk spit, on the northern shore of Kodiak. So called by Moser, 1897.

S'lide, point; see Eva.

Slide Ridge; mountains, in western part of Revillagigedo island, Alexander arçhipèlago. So named by Nichols, 1883.

Slim; island, near entrance to Nakat inlet, Alexander archipelago. So named by Nichols, 1883.

Slim, point; see Thin.

Slime; bank, off the northern coast of Unimak island, eastern Aleutians. So named by the fishermen on account of the abundance of. jelly fish. Reported by Tanner in 1890 .

Slims; river, tributary to Kluane lake, near latitude $61^{\circ}$, longitude $138^{\circ} 30^{\prime}$. Name from Peters, 1899.

Slocum; arm of Khaz bay, and point, southwest shore Chichagof island, southeastern Alaska, near latitude $57^{\circ} 30^{\prime}$, longitude $136^{\circ}$. So named by Moore, 1897.

Slocum; inlet, in mainland, near the north end of Glass peninsula, Stephens passage, Alexander archipelago. Named by Thomas, 1888, after Ensign George Ralph Slocum, U. S. N., a member of his party.

Slocum; point (Point Slocum), Chichagof island, Alexander archipelago, on the outside of the peninsula separating Slocum arm of Khaz bay from the ocean, near latitude $57^{\circ} 28^{\prime}$. So named by Moore, 1897 .

Sloistie, point; see Lay.

Slope; glacier, 25 miles northeast of Controller bay, Gulf of Alaska, near latitude $60^{\circ} 28^{\prime}$, longitude $143^{\circ} 48^{\prime}$. Descriptive name, given by prospectors, and reported by Martin, 1905.

Slope; hill (475 feet high), on St. Paul island, Bering sen, just west of Bogoslof hill, near longitude $170^{\circ} 18^{\prime}$. So called by Stanley-Brown, 1891 .

S'loss, bay; see Moffet cove.

Sluice; creek, tributary to Jim river from the east, near longitude $149^{\circ}$ : Prospectors' name, published by the Coast Survey in 1899 .

Small; arm, of Whale bay, Baranof island, Alexander archipelago. Called Maley roukav (little sleeve) by the Russians. See also Little Whale bay.

Small; bay, indenting the northwest shore of Beaver inlet, Unalaska island, near longitude $166^{\circ} 27^{\prime}$. So described by Gilbert, 1901 .

Small; glacier, on the mainland, east of Frederick sound, southeastern Alaska. So called by Thomas, 1887.

Smallwood; creek, in.the Fairbanks region, tributary to Nugget creek from the northeast, near latitude $64^{\circ} 55^{\prime}$, longitude $147^{\circ} 10^{\prime}$. Prospectors' name, reported by Gerdine, 1903 .

Smeaton; bay, in the mainland, debouching into Behm canal, Alexander archipelago. Named by Dall, in 1879 (Coast Pilot, p. 72, footnote), after the English engineer Smeaton who, in 1759 , rebuilt the Eddystone lighthouse after its destruction by fire in $\mathbf{1 7 5 5}$.

Smeaton; island, near Smcaton bay, in Behm canal, Alexander arcbipelago. Named by Dall, 1879. 
Smith; bay, on the outer coast of Chichagof island, Alexander archipelago, in the broad bight south of Point Urey, near latitude $57^{\circ} 53^{\prime}$. Not found on any map. So called by the fisheries, and reported by Moser, 1897.

Smith; bay, on the Arctic coast, between Dease inlet and Colville river mouth. Named E. Smith's by Dease and Simpson, 1837, after E. Smith, chief factor of the Hudson Bay Company.

Smith; cape, in the Yukon delta; on the south shore of Scammon bay, 6 miles east of Cape Romanzof, near latitude $61^{\circ} 50^{\prime}$, longitude $165^{\circ} 55^{\prime}$. So named by Dall, 1869 , presumably after Capt. E. E. Smith, a wéll-known whaling master in the region at that time.

Smith; creek, Seward peninsula, tributary to Inmachuk river from the west, near Cape Deceit. Prospectors' name, reported by. Mendenliall and Reabu'n, 1901.

Smith; creek, in the Fairbanks region, tributary to Chatanika river at its source, near latitude $65^{\circ} 15^{\prime}$, longitude $146^{\circ} 25^{\prime}$. Prospector's' name, reported by Gerdine, 1903 .

Smith; creek, tributary to Fortymile creek from the south; 2 or 3 miles from the international boundary. ' Local name, "Smith creek of Spurr, 1896 ; and of Abercrombie's map, 1898. Erroneously' called. Davis by Barnard, in 1898.

Smith; glacier, tributary from the west to College fiord, Port Wells, Prince Wil: liam sound. So named by the Harriman expedition, 1899, after Smith college.

Smith; island, south of Japonski island, in 'Sitkà sound, Alexander archipelago. So named by United States nával ofticers, 1880.

Smith; island, in central part of Prince William sound, between and a little east of Knight and Naked islands. Has been occupied since 1898 for the propagation of blue foxes.' Name from 'Schrader, 1900. 'Called also Smiths.

Smith; lake, 5 miles northwest of Fairbanks, near latitude $64^{\circ} 50^{\prime}$, longitude $147^{\circ} 50^{\prime}$. Local name, Smiths, taken from Map of Location, Tanana Mines Railroad, 1904.

Smith; river, in northernmost Alaska, debouching near Cape Halkett, Arctic ocean. Named William Smith by Dease and Simpson, 1837, after William Smith, secretary to the Hudson Bay Company.

Smiths Bridge; on Taiya rivel, southeastern Alaska, 5 miles above Dyea. Name from Flemer, 1898.

Smokey, bay; see Shelikof.

Smokehouse; cove, indenting the eastern shore of Chilkat inlet, at the head of Lynn canal, sontheastern Alaska, near latitude $59^{\circ} 10^{\prime}$, longitude $135^{\circ}$. 22'. Local navigator's' name, reported by H. C. Fassett, Bureau of Fisheries, 1904.

Simoky, mountain; see Peulik.

Smoky; point, Bristol bay, southwestern Alaska, the north point at entrance to Ugashik river, near latitude $57^{\circ} 30^{\prime}$. Local name, reported by Moser, 1900.

Smooth; mountain (1,899 feet high), in Dall ridge, Gravina island, Alexander archipelago. . So named by Nichols, 1883.

Smuggler; cove, on the west side of Annette island, opening into Nichols passage, Alexander archipelago. Named by Nichols, 1883. Also written Smuggler's and Sn: agglers. 
Smugglers; cove, indenting the southeastern shore of Cleveland peninsula, Behm canal, immediately south of Helm bay, southeastern Alaska, near latitude $55^{\circ} 35^{\prime}$, longitude $131^{\circ} 57^{\prime}$. Name in use by local navigators, and reported by Brooks, 1901 .

Smyth; cape, on the Arctic cöast, just west of Point Barrow, near latitude $71^{\circ}$ 18'. So named 'by Beechey in August, 1826, "in compliment to" William Smyth, onè of his officers. Sometimes, erroneously; Smith and Smythe.

Snag; point, in Alaganik slough, Copper River delta, near latitude $60^{\circ} 25^{\prime}$, longitude $145^{\circ} 17^{\prime}$. Descriptive name, from Ritter, 1898 .

Snag; point, southwestern Alaska, on the west side of Nushagak bay, at mouth of Wood river, near latitude $59^{\circ}$, longitude $158^{\circ} 30^{\prime}$. Local descriptive name, reported by Moser, 1901.

Snag; river, tributary to White river from the west, near longitude $140^{\circ} 30^{\prime}$. Descriptive name, given by Peters and Brooks, 1898.

Snail; point, in Behm canal, the southern point of entrance to Spacious bay. Named by the Coast Survey in 1891.

Snail; point, on the western shore of Sin Fernando island, Bucareli bay, Prince of Wales archipelago. Named Punta del Caracol (snail point) by Maurelle and Quadra, 1775-1779.

Snail; rock (40 feet high), in Revillagigedo channel, between Boca de Quadra and Fogggy bay, Alexander archipelago. So named by Nichols, 1883.

Snake; island, in Gulf of Esquibel, Prince of Wales archipelago. Named 18 Culebra (the snake) by Maurelle and Quadra, 1775-1779.

Snake; river, tributary to Nushagak bay from the west, near latitude $59^{\circ}$, longitude $158^{\circ} 45^{\prime}$. Local name, from Spurr and Post in 1898 , 'apparently suggested by the tortuous course of the stream. Moser, 1900, gives Sỉake as an alternative for Igushik river. See Igushik.

Snake; river, in the Nome mining region, Seward peninsula, near longitude $165^{\circ} 30^{\prime}$. Local name, given in 1898 ; presumably suggested by the tortuous course of the stream.

sneedee, mountain; see Snidi.

Snettisham; port (Port Snettisham), and post-office (established "in June, 1900) : port indenting the mainland coast in Stephens passage, Alexander archipelago. So named by Vancouver, 1794 .

Sriider; peak, immediately south of Mount Drum, near latitude $62^{\circ} 05^{\prime}$, long1tude $144^{\circ} 40^{\prime}$. Prospectors' name, reported by Gerdine, 1903.

Snidi; mountain, 40 miles northwest of Cook inlet, and soutl of Skwentna river, near latitude $61^{\circ} 30^{\prime}$, longitude $152^{\circ}$. Native name from Ferron, 1899, who wiote Sueedee. This probably is the same as Beluga mountain of the Geological Survey, 1898. See Beluga.

Snip; islands, in Behm canal, opposite the entrance to. Walker cove, Alexander archipelago. Named by the Coast Survey in 1891.

Snipe; bay, indenting the southwestern coast of Baranof island, Alexander archipelago. Named Kulichkof' (snipe) by the Russians. Has been written Kulitch, Kulitchok, Koulitchkow, and Kulichkof.

Snipe; island (20 feet high), between Annette and Duke islands, Gravina group, Alexander archipelago. So named by Nichols, 1883.

Snipe; island, in Thorne arm, Revillagigedo island, Alexander archipelago. So named by the Coast Survey in 1891.

Snipe; point, the westernmost point of Bell island, Behm canal, Alexander archipelago. So named by the Coast Survey in 1891. 
Snipers; point, Kenai peninsula, south shore Turnagain arm of Cook inlet, on east side of mouth of Sixmile creek, near longitude $149^{\circ} 30^{\prime}$. Local name, Sniper's, reported by Herron in 1899.

Snow; creek, debouching near Cape York, Seward peninsula, Bering strait. Local name, published by the Coast Survey in 1900.

Snow; creek, tributary to Skookum river from the north, Seward peninsula. Name from Barnard, 1900.

Snow; gulch, 7 miles north of Nome, Seward peninsula, draining into Glacier creek from the south, near longitude $165^{\circ} 24^{\prime}$. Local name, publislied in 1903.

Snow; mountains, on north bank of Koyukuk river, between Allen and John rivers. So named by Allen, 1885 .

Snow; passage, in Clarence strait, between Zarembo ișland and the Kashevarof group of islands, Alexander archipelago. Named by the Coast Survey, 1886, after Lieut.-Commander Albert Sidney Snow, U. S. N., who in that year made surveys in this region.

Snow; river, tributary to the head of lienai lake, Kenai peninsula, near latitude $60^{\circ} 20^{\prime}$, longitude $149^{\circ} 20^{\prime}$. Local name, from Mendenhall, 1898 .

Snowball; creek, tributary to Dutch creek from the north, in the Eldorado mining district, Seward peninsula. Local name, published in 1900.

Spow Cap; mountain (5,078 feet high), on the west bank of Stikine river, near Great Glacier. Descriptive name, published by the Coast Survey in 1895.

Snow Dome; mountain peak (3,300 feet.high), in Muir glacier, soutbeastern Alaska. So named by Muir, 1882.

Snowshoe; creek, tributary to Penny river from the west, in the Nome mining region, Seward peninsula. Prospectors' name, published in 1900 .

Snowshoe; creek, Seward peninsula, tributary to South fork Serpentine river from the west, near latitude $65^{\circ} 55^{\prime}$, longitude $165^{\circ} 20^{\prime}$. Prospectors' name, reported by Gerdine, 1901.

Snowslide; gulch, about 1 mile east of. Juneau, southeastern Alaska. Local name, reported by Peters, 1902.

Snow Tower; mountain (7,100 feet high), near Whiting river, southeastern Alaska. Name published by the Coast Survey in 1895.

Snowy; mountain, on and near the north end of Admiralty island, Alexander archipelago: So named by Dall in the Coast Pilot (1883, map, p. 182).

Snowy; mountain (5,577 feet high), on the mainland, about 6 miles east of Stikine river. Name published by the Coast Survey in 1895.

Snug; anchorage, a little north of Tolstoi bay, Clarence strait, Alexander archipelago. Descriptive name, given by Clover in 1885.

Snug; cove, in Gambier bay, Admiralty island, Alexander archipelago. So named by Mansfield, 1889.

Snug; cove, "in the passage connecting Olga bay with Alitak bay," on 'western coast of Kodiak. Locally known as Snug harbor. A cannery was built here in 1889 .

Snug; harbor, in Security bay, Kuiu island, Alexander archipelago. Descriptive name, given by Meade in 1869 .

Snug; harbor, on the western shore of Cook inlet, near Iliamna peak. Name published by the Coast Survey in 1898 , and applied to an alleged anchorage on the north side of Chisik island at entrance to Tuxedni harbor. It is a misnomer and has been removed from the chart. See Tuxedni.

Snug; harbor, in the exireme western part of Moser bay, Alitak bay, Kodiak. So named by the fisheries, and reported by Moser, 1900 . 
Snug Corner; cove or bay, near the southern point of entrance to Port Fidalgo, Prince William sound, near latitude $60^{\circ} 44^{\prime}$, longitude $146^{\circ} 36^{\prime}$. Descriptive name, given by Cook, 1778.

Soapstone; point, the northernmost point of Yakobi island, Alexander archipelago. So named by ${ }^{\circ}$ Dall, 1880 , on account of its greenish appearance, resembling soapstone.

Soblazna, point; see Seduction.

Soda; creek, tributary to South fork Fortymile creek from the west. Prospector's' name, from B Barnard, 1898.

Sodtomniia, islands; see Noisy.

Sofia; gulch, 8 miles north of Nome, Seward peninsula, on the left bank of Rock creek, a branch of Snake river from the east, near longitude $165^{\circ} 25^{\prime}$. Local name, published in 1904.

Softuk; bar, on the south side of Martin River flats, Copper River delta, near longitude $144^{\circ} 37^{\prime}$. Probably a native name, reported by Pratt, 1903.

Sohjeklakakat, river; see Sozhekla.

Sokolof; island, westerly from Wrangell, in Sumner strait, Alexander archipelago. Named by the Russians, presumably after Mr. Alexander Sokolof, a Russian who has written extensively on Alaskan topies.

Solano, Puerto de; see Izhut bay.

Soldovoi, bay; see Seldovia.

Solenoi, island; see Salt.

Solo; creek, in the Fairbanks region, tributary to Fish creek near its source, about latitude $65^{\circ}$, longitude $147^{\circ} 20^{\prime}$. Prospectors' name, reported by Gerdine, 1903.

Solomon; creek and gulch, on the south shore of Port Valdez, Frince William sound, near longitude $146^{\circ} \mathbf{1 5}$. Local name, from Schrader and Ger-

, dine, 1900.

Solomon; creek, on the south side of Midnight mountain, Seward peninsula, a tributary to Taylor creek from the north, near latitude $65^{\circ} 45^{\prime}$, longitude $164^{\circ} 35^{\prime}$. Prospectors' name, reported by Gerdine, 1901.

Solomon; post-office (established in 1902), on the north shore of Norton sound, 30 miles east of Nome, Seward peninsula.

Solomon; river, in the Bonanza mining district, Seward peninsula. Local name, published in 1900. Brooks says the Eskimo name is Ong-u-tuk.

Solovarika;'Islet, southwest from Deer island, near Belkofski. Not identified. Called Solovarikha by Lutke, 1836.

Soluka; creek, tributary to Katmai creek, near longitude $155^{\circ}$. Native name, obtained by Spurr and Post, of the Geological Survey, from Rev. A. Petelin, 1898, and written Solúka.

Sombrero; islet, in northern part of Bucareli bay, Prince of Wales archipelago. Named Sombrero (hat) by Maurelle and Quadra, 1775-1779.

Sorneone; creek, 9 miles north of Nome, Seward peninsula, tributary to Snake river from the west, near longitude $165^{\circ} 28^{\prime}$. Local name, published in 1903.

Somerset; river, a small stream on the east side of Knight island, Prince William sound. So called by the fisheries, and.so described by Moser, 1897.

Sonickson; creek, tributary to Seventymile creek from the south. Local name, obtained by Barnard, of the Geological Survey, 1898. Called also Falls creek.

Sonora; creek, debouching nearly opposite Sledge island, Seward peninsula. Name from Barnard, 1900.

Soo City; mining camp, on South fork Koyukuk river, near longitude $151^{\circ}$. Prospectors' name, reported by Schrader, of the Geological Survey, 1899. 
Soo-look-pow-vuck-to-ark, river; see Sulukpowik.

Sönkakat, river; see Yuko.

Soonkakat; village, and river, tributary to the Yukon from the south, a little above Nulato. Petrof, 1880 , uses Soonkakat as the name of the village. Allen, 1885, calls a stream which appears to be identical with this the Yukokakat. See Kakat.

Sophia; point, the enstern point of entrance to Port Frederick, Icy strait, Alexander archipelago, near longitude $135^{\circ} 24^{\prime}$. So named by Vancouver, 1794.

Sopka, mountain; see Koyukuk.

Sorenson; mountain (Mount Sorenson, 5,620 feet high), eaștern Alaska, at head of Seventymile creek, near latitude $65^{\circ}$, longitude $143^{\circ}$. Prospectors' name, from sketch map compiled by Major Glassford, Signal Corps, U. S. A., 1905. Written also Sorensen.

Sorrels; creek, in the Fairbanks region, tributary to Little Chena river from the north, near latitude $65^{\circ} 05^{\prime}$, longitude $146^{\circ} 55^{\prime}$. Prospectors' name, reported by Gerdine, 1903.

Sosiego, Punta del; see Tranquil point.

Sosnovoi, island ; see Fir.'

Soto; bight, on the northern coast of Unimak, eastern Aleutians. So named by the Fish Commission in 1888.

Soto, Isla de; see Sitkalidak island.

Souchoi, channel ; see Dry strait.

Sọuhoi, inlet; see Sukoi.

Soukhoi, strait; see Dry.

Soukhoi, strait; see Sukoi, inlet.

Soukoi, inlet; see Sukoi.

Soule; glacier; in the Seward mountains, west of Portland canal, southeastern: Alaska. So named by the Coast Survey in 1897 .

Soulima, river; see Ugashik.

Sound; islands, good sized, wooded, in Krestof sound, at south entrance to Neva strait, Alexander archipelago, near latitude $57^{\circ} 13^{\prime}$, longitude $135^{\circ} 33^{\prime}$. Name from Moore, 1897. Vasilief, 1833, called the largest island of the group Pribilie (profitable); according to Dall's Coast Pilot (1983, p. 155), the group was called Pribieli by the Russians. See Pribilie.

Soundon, island; see Sumdum.

Sourciough; creek, debouching just south of Port Clarence, and near Cape Douglas, Seward peninsula. Name from Barnard, 1900.

Sourdough; creek, tributary to Skookum creek from the north, Seward peninsula. Name from Barnard, 1900.

Sourdough; creek, in the Fairbanks region, tributary to Chatanika river from the north, near latitude $65^{\circ} 20^{\prime}$, longitude $146^{\circ} 30^{\prime}$. Prospectors' name, reported by Gerdine, 1903.

South; arm, of Cholmondeley sound, western shore, Clarence strait, southeastern Alaska, near latitude $55^{\circ} 10^{\prime}$, longitude $132^{\circ} 20^{\prime}$. Local descrintive name, reported by Brooks, 1901.

South; arm, of Kendrick bay, southeastern shore Prince of Wales island, Clarence strait, southeastern Alaska, near latitude $54^{\circ}, 50^{\prime}$, longitude $132^{\circ} 03^{\prime}$. So called by local navigators, and reported by H. C. Fassett, Bureau of Fisheries, 1904.

South; arm, of Moira sound, western shore Clarence strait, southeastern Alaska, near latitude $55^{\circ}$, longitude $132^{\circ} 10^{\prime}$. Deșcriptive name, from local navigator's, by H. C. Fassett, Bureau of Fisheries, 1904. 
South; arm, of Bay of Pillars, Kuiu island, Chatham strait, Alexander archipelago. Name published by the Coast Survey in 1899 .

South; arm, of Hooniah sound, Chichagof island, Alexander archipelago. Name published by the Coast Survey in 1899.

South; arm, of Kelp bay, Baranof island, Chatham strait, Alexander archipelago. So named by Moore, 1895.

South; arm, of Uganik bay, Kodiak, being the southern extension of the west .... branch of that bay. So described by Moser, 1.897.

South; arm, of Three Arm bay, Adak island, middle Aleutians: Descriptive name, given by Gibson in 1855 .

South; bay, Dall island, Tlevak strait, Alexander archipelago. So called by Dall in the Coast Pilot $(1883$, p. 69$)$.

South, cape, Deer island; see Fawn, point.

South; cape, the southeastern point of Spruce island, Kodiak group. Named Vkhodal or Iuzhnie (entrance or south) point by Murashef, 1839-40.

South; cape, the southern point Whale island, Kodiak group. Named Iuzhnie (south) by Murashef, 1839-40.

South; cape, the southernmost point of Chirikof island. So called by Dall, in 1874.

South, cape; see Ommaney.

South, cape; see Trinity.

South; flat, in Wrangell strait, Alexander archipelago. Called Wrangell South Flat by Meade, 1869.

South; fork, Chulitna river, which is tributary to Clark lake, near latitude $60^{\circ}$ $10^{\prime}$, longitude $155^{\circ} 40^{\prime}$. Descriptive nilme, from Osgood, 1902.

South; fork of Butte creek, Seward peninsula, on west bank of Solomon river, near latitude $64^{\circ} 43^{\prime}$, longitude $164^{\circ} 20^{\prime}$. Descriptive name, given by prospectors and reported by Gerdine, 1905 .

South; fork, Quail creek, a tributary from the west to Troublesome creek, in the Rampart region. Descriptive name, reported by Prindle, 1903.

South; fork, Hess creek, in the Rampart region. Prospectors' name, reported by Lieutenant Erickson, U. S. A., 1902.

South; fork, Birch creek, eastern Alaska. Name published by the Coast Survey in 1895 .

South; fork Fortymile creek, near the international boundary. Local designation, published by the Coast Suivey in 1898. Presumably in use as early as 1886.

South; fork, Koyukuk river, near the Arctic circle. Local name, published by the Coast Survey in 1899. Apparently identical with Nohoolchintal of Allen in 1885 .

South; harbor, the southernmost of Kaigani harbors, Dall island, Alexander archipelago. "Known in 1799 as Taddiskey, a native name, or Taddy's cove, a corruption of the former:" (Coast Pilot, 1883, p. 66.)

South; hill ( 668 feet high), on St. George island, Bering sea, near longitude $169^{\circ}$ $36^{\prime}$. So called by: Duffield, 1897. Putnam obtained the Aleut-Russian

- name Īkoum'-ūng:a'-kōverūshkä' (hill near the fox trail). Russian kovrishka (a little loaf) used to mean hill.

South; island, at entrance to Port McArthur, Kuiu island, Alexander archipelago. So named by Helm, 1886.

South; island, west from the entrance to Port Snettisham, in Stephens passage, Alexander archipelago. So named by Mansfield, 1889.

South; island (250 feet high), one of the Semidi islands. Named Iuzhnie (south) by the Russians. The native name is Kutloot. Lutke, 1835, has Kytlek. 
South, island; see Biorka.

South; islet, off Aiak cape, on the southwestern shore of Unalaska. So named by the Fish Commission in 1888.

South; ledge, in Wrangell strait, Alexander archipelago. So named by Meade, 1869.

South; passage, into Eliza harbor, between Liesnoi and Admiralty islands, Frederick sound, Alexander archipelago. So named by Mansfield, 1889.

South; passage, the contracted part of Cleveland passage, at its south end, Frederick sound, Alexander archipelago. Apparently so named by Nichols, 1891.

South; passage, in Icy strait, on the south side of Lemesurier island, Alexander archipelago, near longitude $136^{\circ}$. $05^{\prime}$. Name published by the Coast Survey in 1904.

South; point, on the northern shore of American bay, Howkan strait, Cordova bay, Alexander archipelago. So named by Sheldon Jackson, 1880.

South; point, on the northeastern shore of Christmas island, Security bay, Alexander archipelago. So called by Glass, 1881.

South; point, on the south side of entrance to Kelp bay, Baranof island, Chatham strait, Alexander archipelago. Descriptive name, given by Moore, 1895.

South; point at entrance to Mitchell bay, Kootsnahoo inlet, Admiralty island, Alexander archipelago. So named by Meade, 1869.

South; point, the southwestern point of the Kodiak group. So called by Lisianski, 1805.

South, point, Lituya bay; see Harbor.

South, point; see Kaigani.

South, point; see Lauder.

South, point; see Paralysis.

South, point; see Zapadni.

South; river, northwestern Alaska, probably a branch of Unalaklik river, near Waton. Local name, from Reindeer Report, 1903 and 1904. Not found on any map.

South; rock, on the south side of South Inian pass, southeastern Alaska, $1 \frac{1}{4}$ miles east of Point Lavinia, on the east side of Cross sound, near longitude $136^{\circ} 18^{\prime}$. So named by Pratt, 1901 .

South; rock, about one-tenth of a mile off the north shore of Observation island, Orca inlet, Prince William sound. So named by Moser, 1897.

South; submerged rock, on the south margin of Sannak reefs, Sannak islands, near latitude $54^{\circ} 18^{\prime}$, longitude $162^{\circ} 42^{\prime}$. Descriptive name, from Westdahl, 1901.

South, sea; see Pacific ocean.

South Amaknak; rocks, off the southern end of Amaknak island, in Captains bay, Unalaska bay, near longitude $166^{\circ} 33^{\prime}$. So named by Dall, 1873.

South Craig; point, on the eastern shore of Zarembo island, Alexander archipelago. This name first appears in the Coast Pilot $(1883$, p. 94), where it is called South Craig island.

Southeast; cape, the southeastern point of St. Lawrence island, Bering sea. So named by Tebenkof, 1849.

Southeast; cove, in the south end of Wrangell island, Ernest sound, Alexander archipelago. So named by Snow, 1886 .

Southeast, glacier; see Adams.

Southeast; point, the southernmost point of Knight island, Yakutat bay, southeastern Alaska. So named by Tebenkof, 1849.

Southeast, point; see Cascade. 
Southeast; shoal, southeast from Turner point, Port Mulgrave, Yakutat bay, southeastern Alaska. Called Eastern by Dall, 1883; Southeastern by Nichols, 1891; and Southeast by Harber, 1892.

Southerly; island, in St. John harbor, Zarembo island, Alexander archipelago. So named by officers of the U. S. S. Adams, 1884.

Southern; glacier, between Port Dick and Tutka bay, on Kenai peninsula. So named by Dall, 1880.

Southern; rapids, in Peril strait, Alexander archipelago. Called Vtorie porogi (second rapids) by the Russians, and often spoken of as the Second or Southern rapids.

South Green; rock, in Wrangell strait, Alexander archipelago. So called in the Coast Pilot (1891, p. 132).

South Head, Akutan island; see Kaianak.

South Head, point; see Battery.

South Inian; pass, between Cross sound and Icy strait, on the south side of Inian islands, near longitude $136^{\circ} 20^{\prime}$. So named by Pratt, 1901 .

South Marble, islet, Glacier bay ; see Marble.

South Olga; lakes and stream, southwestern shore of Olga bay, Alitak bay, southwestern coast of Kodiak. Local nome, reported by Moser, 1900.

South Passage; point, the southern point of entrance to Tenakee inlet; Chichagof island, Chatham strait, Alexander archipelago. Called South point by Meade, 1869.

South Passage; rock, near Port Chalmers, Prince William sound. So named by Vancouver, 1794.

South Quadra; mountain (1,764 feet high), on the mainland, southeast of entrance to Boca de Quadra. So named by Nichols, 1883.

South Semidi, island; see Chowiet.

South Vallenar; point, on Gravina island, the south point of entrance to Vallenar bay, Clarence strait, Alexander archipelago. So named by the Coast Survey in 1886.

Southwest; bay, indenting the western shore of English bay, southern coast St. Paul island, Bering sea, near longitude $170^{\circ} 20^{\prime}$. Called S. W. bay by Stanley-Brown, 1891.

Southwest, bay, St. George island; see Zapadni.

Southwest; cape, the southwestern point of St. Lawrence island, Bering sea. So called by Tebenkof, 1849. Dr. E. O. Campbell, the missionary on St. Lawrence island, calls the native village on this cape Pōō wóo wā lŭk. Population in 1904, 19.

Southwest, cape; see Cleare.

Southwest; cove, in Etolin island, opening into Ernest sound, Alexander archipelago. So named by Snow, 1886.

Southwest; end of Unalaska, eastern Aleutians. Called Southwest kenetz (end) by Tebenkof, $1 \$ 49$.

Southwest; island, one of the Inian group, Cross sound, Alexander archipelago. Apparently so named by Dall in the Coast Pilot (1883, p. 106).

Southwest; peak (1,960 feet high), near Chichagof harbor, on Attu island, western Aleutians. So named by Gibson, July, 1855.

Southwest; point, the southwesternmost point of St. Paul island, Pribilof group, Bering sea. Called Zapadnie. (west) by the Russians, and Southwest on recent charts.

South Zelonoi, point; see False Green.

Soutkhvik, island; see Sutwik.

Souvoroff, cape; see Suworof. 
Sows (The); group of rocky islets, in the entrance to San Antonio bay, Bucareli bay, Prince of Wales archipelago. Named Las Puercas (the sows) by Maurelle and Quadra, 1775-1779.

Soynai; river, tributary to Stikine river from the north. Named Soynai (ice water) by the Russians, 1863 .

Sozhekla; river, tributary to the Koyukuk from the north, near longitude $151^{\circ}$. Native name, reported in 1885 , by Allen, who writes it Sohjeklakákat in his text (p. 99) and Sajeklakat on his map (4). It has also been written Sajahlakat.

Spacious; bay, in Behm canal, indenting the eastern shore of Cleveland peninsula. Named by Dall, 1879, from Vancouver's description of it as a "spacious bay."

Spafarief; bay, indenting the southeastern shore of Kotzebue sound, Seward peninsula. Named Spafarief's by Kotzebue, August, 1816.

spanberg, cape; see Espenberg.

Spanish; islands, at the western entrance to Sumnel: strait. Alexander archipelago. So named by La Perouse, 1786. The name was applied ratber indefinitely by La Perouse to a group of islands then very little known. Dall in the Coast Pilot, 1883, applies the name to Coronation and Warren islands with some associated islands and rocks. The name is now still further restricted to a small group of islands between Coronation and Kuiu islands.

Sparkle; creek, 12 miles north of Nome, Seward peninsula, tributary to Nome river from the east, near longitude $165^{\circ} 16^{\prime}$. Prospector's' name, published in 1900.

Sparrow; creek, 13 miles north of Cape Nome, Seward peninsula, a small tributary of Prospect creek, a branch of Discovery creek from the west, near longitude $165^{\circ} 05^{\prime}$. Name from Gerdine, 1904.

Sparrow; islet, one of the Necker group, Sitka sound, Alexander archipelago. Named Vorobinoi (sparrow) by Vasilief, 1809.

Spasskaia; bay, on the northern shore of Chichagof island, Icy strait, Alexander archipelago, near longitude $135^{\circ} 20^{\prime}$. The literal meaning is " of the Church of Our Saviour," but the place was named by the Russians in the early part of the century, presumably after Gregori Spasskaia, a Russian hydrographer. Has been variously written Spaska, Spaskaia, Spaskaia bay, Port Spaskai, etc.

Spasskaia; island, northeast of Spasskaia bay, Icy strait, Alexander archipelago. Named Spaskai by Meade, 1869.

Specimen; gulch, 6 miles north of Nome, Seward peninsula, on the north slope of Anvil peak, draining into Anvil creek from the east, near longitude $165^{\circ} 22^{\prime}$. Local name, published in 1901 .

Spectacle; island (1,000 feet high), between Nagai and Big Koniuji islands, Shumagin group. Descriptive name, given by fisbermen, and reported by Dall, 1872. Perhaps this is the Kunaiugiuk island of Veniaminof (I, 255, 265), which is described as "long with two hills." Lutke spells it Kangaiulouk.

Speel; point, at mouth of Speel river, Port Snettisham, Stephens passage, Alexander archipelago. So named by Thomas, 1888.

Speel; river, tributary to head of Port Snettisham, southeastern Alaska. So named by Thomas, 1888.

Spellacy; gulch, northern Alaska, on the left bank of Koyukuk river, 10 miles below the mouth of Kanuti river, near latitude $66^{\circ} 20^{\prime}$, longitude $153^{\circ}$ 20'. Prospectors' name, reported by Lieutenant Camdẹn, Revenụue Cutter Service, 1900. 
Spencer; cape, the northwestern point of entrance to Cross sound, Alexander archipelago, near latitude $58^{\circ} 12^{\prime}$, longitude $136^{\circ} 38^{\prime}$. Named by Vancouver, 1794, "in honour of Lord Spencer." It is called Punta de Villaluenga on the general map in De Mofras' atlas, 1845 .

Spencer; point, the south point of entrance to Port Clarence, Bering strait. So named by Beechey, September, 1827, "in compliment to the Honourable Captain Robert Spèncer," R. N.

Spicer; creek, tributary to the Yukon on the right bank, 9 miles above the mouth of the 'Tanana. Prospector's' name, published in 1899.

Spike; island, Orca inlet, near Odiak, Prince William sound. So called by Moser, 1897.

Spike; rock, near Keene island, in Wrangell strait, Alexander archipelago, about latitude $56^{\circ} 36^{\prime}$. So named by the Coast Survey in 1881 .

Spike Rock; shoal, Wrangell strait, Alexander archipelago, extending 100 yards northward from Spike rock (above). So described in the Coast Pilot of 1901.

Spine; mountain (1,987 feet high), on Annette island, Alexander archipelago. So named by Nichols, 1883.

Spire; island, near the northern end of Annette island, in Revillagigedo channel, Alexander archipelago, near latitude $55^{\circ} 16^{\prime}$, longitude $131^{\circ} 30^{\prime}$. So named by the Const'Survey in 1882.

Spire Island; reef, in Revillagigedo chamel, Alexander archipelago. onefourth mile northeast of Spire island (above). So described in the Coast Pilot of 1901.

Spirit; mountain (3,000 feet high), near left bank of Copper river, in latitude $61^{\circ}$ $20^{\prime}$. So called by Allen, 1885, because the natives people it with an imaginary Mighty Spirit. .

Spirlin, island; see Biorka.

Spirkin, strait; see Udagak.

Spit; point, on the eastern shore of Portland canal. Apparently so named by Pender, 1868.

Spit; point, on the eastern shore of Carroll inlet, Revillagigedo isiand, Alexander archipelago. So named by the Coast Survey in 1891.

Spit; rock, off the southern coast of St. Matthew island, Bering sea. So named by Dall or Elliott, 1874.

Spithead; the south end of the spit in front of Dutch harbor, Unalaska bay, near latitude $53^{\circ} 54^{\prime}$, longitude $166^{\circ} 32^{\prime}$. So named by Dall, 1871.

Spitz; islet, south of Mitrofania island, on southern shore of Alaska peninsula. Named Spitz (sharp pointed) by Tebenkof, 1849.

Split; creek, 5 miles north of Controller bay, Gulf: of Aliska, near latitude $60^{\circ}$ $15^{\prime}$, longitude $144^{\circ} 20^{\prime}$. S So called by prospectors because the stream divides, one part flowing to Bering lake and the other to Katalla river. Reported by Martin, 1905.

Split; creek, Seward peninsula, tributary to Bear creek from the west, near latitude $65^{\circ} 32^{\prime}$, longitude $161^{\circ} 05^{\prime}$. Descriptive name, given by prospectors, and reported by Witherspoon, 1903.

Split; island, near Dewey anchorage, in Clarence strait, Alexander archipelago. Descriptive name, given by Snow, 1886.

Splits (The); locality, eastern Alaska, at junction of Salcha river and its North fork, near latitude $64^{\circ} 40^{\prime}$, longitude $145^{\circ} 20^{\prime}$. Prospector's' name, reported by witherspoon, 1905.

Split Top; mountain $(2,100$ feet high), on the eastern side of Unalaska bay, Unalaska, eastern Aleutians, near longitude $166^{\circ} 25^{\prime}$. Descriptive name, given by Dall, 1871 .

Bull. $299-06 \mathrm{M}-38$ 
Split Top; mountain (2,098 feet high), near head of Bay of Waterfalls, Adak island, middle Aleutians. Descriptive name, given by Gibson, 1855.

Spoon Knoll; bill, on the mainland, east of Farragut bay, southeastern Alaska. So named by Thomas, 1887 .

spornago, point; see Tidemeeting.

Spot; mountain $(1,807$ feet high), in California ridge, Gravina island, Alexander archipelago. So named by Nichols, 1883.

Spray; cape, between Skan and Pumicestone bays, on north shore of Unalaska, eastern Aleutians. So named by the Fish Commission in 1888. It was named Mokrovskoi (wet) by Sarichef in 1792. 'Tebenkof calls it Morkovskoi.

Spray; island, in Thomas bay, Frederick sound, Alexander archipelago. So named by Thomas, 1887.

Spruce; cape, the southwestern point of Spruce island, Kodiak group. Named Elovoi (spruce) by Murashef, 1839-40.

Spruce; cape, the western point of entrance to Chiniak bay, Kodiak, Named Elovoi vneshnie (spruce outer) by the early Russians. Called Elovoi (spruce) by Tebenkof, 1849.

Spruce; creek, tributary to the head of Windham bay, eastern shore Frederick sound, southeastern Alaska, near latitude 57. 35'. Prospectors' name, reported by Spencer and Wright, 1903.

Spruce; creek, in the Kantishna region, on the east (right) bank of Moose creek, near latitude $63^{\circ} 30^{\prime}$, longitude $150^{\circ} 30^{\prime}$. So named by prospectors in 1905 , and reported by Prindle.

Spruce; creek, Seward peninsula, tributary to Holtz creek, near latitude $65^{\circ}$ $30^{\prime}$, longitude $162^{\circ} 35^{\prime}$. Prospectors' name, reported by Witherspoon, 1903.

Spruce; creek, just south of Port Clarence, Seward peninsula. Name from Barnard, 1900.

Spruce; creek, tributary to the Casadepaga river from the south, Seward peninsula. Name from Barnard, 1900.

Spruce, creek, Seward peninsula; see Cache.

- Spruce; island ( 84 feet high), off Pybus bay, Frederick sound, Alexander archipelago. Named Yelowy (spruce) by Zarembo, 1838. Erroneously Yellowy.

Spruce; island, between Afognak and Kodiak. Lisianski, in 1804; calls it Pine island and Langsdorf, Jellowa (fir). Variously called Elow, Elovoi, Yelovoi, etc.

spruce, island; see Elovoi.

Spruce; point, on the eastern shore of Wrangell strait. Alexander archipelago. Named Schroeder by Meade, 1869, after Lieut. Seaton Schroeder, U. S. N., a junior officer on the Saginaw in 1868-69. It is Spruce point of Lindenberg in 1838.

Spuhn; island (246 feet high); at western entrance to Gastineau channel, southeastern Alaska. So named by Beardslee, 1880, after Mr. Carl Spuhn, of the Northwest Trading Company.

Spuhn; point, on Spuhn island, at west end of Gastineau channel, Alexander archipelago. Said to have been so " named by the United States Navy in 1881." This seems to be an error. Apparently it was first so called in the Coast Pilot (1883, p. 173).

Spuhn point; see Zimovia.

Spurr; glacier, in longitude $143^{\circ}$. near Skolai pass. Named after Josiah Edward Spurr, of the Geological Survey, by Rohn, in 1900. 
Spurr; mountain (Mount Spurr, 10,925 feet high), 40 miles west of the head of Cook inlet, near latitude, $61^{\circ} 18^{\prime}$, longitude $152^{\circ} 15^{\prime}$. So nimed by Brooks, 1902, after J. E. Spurr, of the Geological Survey. Hatay moun- . tain. of Herron, 1899, may be this one.

Spurt; point, on the northern shore of Thomas bay, Frederick sound, Alexander archipelago. So named by Thomas, 1887.

Square; bluff, on the northern shore of Amchitlit island, western Aleutians. So designated by the North Pacific exploring expedition in 1855 .

Square; cove, Admiralty island, Chatham strait, Alexander archipelago. Descriptive name, given by Baker in 1880 .

Square; island, in Behm canal, at mouth of Spacious bay, Alexander archipelago. Descriptive name, given by the Coast Survey in 1891.

Square; island, in Tlevak strait, north of Long. island, Alexander archipelago. Descriptive name, given by Nichols in 1881.

Squaw; creek, tributary to the Yukon, on the right bank, opposite Rampart (city), near longitude $150^{\circ} 10^{\prime}$. Local name, published in 1899 .

Squaw; creek, tributary to South fork Koyukuk river from the east, near latitude $67^{\circ}$. Prospector's' name, reported by Schrader, 1899 .

Squaw; gulch, in the Birch Creek region, on left bank of Farrison creek, near latitude $65^{\circ} 15^{\prime}$, longitude $145^{\circ}$. Prospector's' name, reporterl by Spurr, Goodrich, and Schrader, of the Geological Survey, 1896.

Squaw; gulch and creek, tributary to Canyon creek from the west, in the rortymile mining district, near latitude $64^{\circ} 10^{\prime}$, longitude $141^{\circ} 10^{\prime}$. Local name, obtained by Spurr, Goodrich, and Schrader, 1896.

Squantna, river; see Skwentna.

Squirrel; creek, Seward peninsula, șmall tributary of Casadepaga on east bank, near latitude $64^{\circ} 46^{\prime}$, longitude $164^{\circ} 28^{\prime}$. Prospectors' name, from Gerdine, 1905. Apparently called Dewey on a local map, 1901.

Squirrel; island, in Prince William sound, "situated north of Knight island," occupied as a fox farm since 1897. So described in Report of Secretary of the Interior, for 1903, p. 282, by Jas. W. Witten. Not found on any map.

Squirrel; river, northwestern Alaska, tributary to Kobuk river from the north, near latitude $67^{\circ}$, longitude $160^{\circ} 30^{\prime}$. Cantwell, 1884, called it Sheeleelictok or Squirrel; in 1885, he wrote Shee-lee-lie-tok and Shee-garrik-puk or Squirrel. Stoney, 1883-1886, called it Squirrel or Shu-shukto-ark. Mendenhall, 1901, called it Squirrel river.

Srednaia, bay, etc.; see Middle.

Sredni, island; see Middle.

Sredni, point; see Middle.

Ssergoit, river; see Takhini.

Ssittiaje, glacier; see Davidson.

Stachin, river; see Stikine.

Stachtan Nitada. According to Cook, 1778, this name had appeared on "modern maps" als a name of a part of the continent of America, the part we now call Alaska. But he could not find that this name was locally known to either natives or Russians.

Stack; island, southern shore Naha bay, western shore Revillagigedo island, Behm canal, southeastern Alaska, near latitude $55^{\circ} 34^{\prime}$, longitude $131^{\circ} 41^{\prime}$. Local navigator's' name. Probably 'after Capt. $R$. Stack, a local seaman, reported by F. C. Fassett, Bureau of. Fisheries, 1904.

Stag; point, the northeastermmost point of Deer island, near Belkofski, about latitude $55^{\circ}$, longitude $162^{\circ} 15^{\prime}$. So named by Dall, 1880 . Called North cape by the Fish Commission in 1888. 
Stagarok; Eskimo village, on the eastern shore of Nushagak bay, southwestern Alaska, on Clark point, near latitude $58^{\circ} 50^{\prime}$. Eskimo name, written Stugarok by Moser in 1897, and Stagarok in 1900. Also called Clark Point Village.

Staines, river; see Canning.

Stairway, glacier; see Surprise.

Stamie, island, in northwestern part of Prince William sound, near Point Culross. Name from Scbrader, 1900. Also called Perry island. See Perry.

Staneys; island, in Tuxekan passage, Prince of Wales archipelago, near latitude $55^{\circ} 49^{\prime}$, longitude $133^{\circ} 12^{\prime}$. Named by Dickins, 1903-4, after an Indian chief.

Staneys Cone; mountain (2,760 feet high), on Prince of Wales island, southeast of Davidson inlet, near latitude $55^{\circ} 44^{\prime}$, longitude $133^{\circ} 09^{\prime}$. Named by Dickins, $1903-4$, after an Indian chief.

Stanhope; island, near the western shore of Etolin island, Clarence strait, Alexander archipelago. So named by Dall, 1879.

Stanhope; point, the southern point of Stanhope island, Clarence strait, Alexander archipelago. So named by Vancouver, 1793.

Stanovoi, island; see Kutkan.

Stanton, narrows; see Valdez.

Star; creek, in the Fortymile region, tributary to Champion creek from the left, near latitude $64^{\circ} 30^{\prime}$, longitude $141^{\circ} 45^{\prime}$. Prospectors' name, found on map in Coast Survey archives, drawn by E. F. Ball; a prospector, 1898 .

Star; gulch and creek, tributary to American creek from the east, in the Eagle mining region. Local name, obtained by Barnard, 1898.

Star; lake, Revillagigedo island, Alexander archipelago, on east shore Thorne arm, at its head, near latitude $55^{\circ} 24^{\prime}$, longitude $131^{\circ} 10^{\prime}$. Local name, reported by Brooks, 1901.

Star; mining camp, at junction of Seventymile creek and Yukon river, near the international boundary. Locally known as Star City. Also written Starr. A post-office, named Star, was established here in November, 1898 , and discontinued in 1902.

Star; rock, bare at low water, in Funter bay, Admiralty island, Alexander archipelago. So named by Mansfield, 1890 .

Staraya Artil; rookery (seal), on the north shore of St. George island, Bering sea, near longitude $169^{\circ} 36^{\prime}$. Russian name, Staraya Artel (old camp). Written Starry Ateel by Elliott (1872-1874), Starry Arteel by StanleyBrown, and Staraya Artil by Duffield.

Starboard; cape, the eastern head of Kiliuda bay, Kodiak. Named Pravoi (right or starboard) by the Russians. It is on the right hand as one enters the bay.

Starichkof, bay; see Skan.

Starichkof; cape, on the eastern shore of Cook inlet. Apparently named Starichkof (an old codger) by Wosnesenski, about 1840, who gives the native name as Stuk 'Talj Chak. Spelled Staritschkow by Grewingk.

Starichkof; cape, the south head of Makushin bay, on north shore of Unalaska, eastern Aleutians. Named Starichkof (an old codger or old fellow) by Tebenkof in 1849. The Fish Commission, 1888, called it Odd Fellows. Could this have arisen from an error in translation?

Starichkof; reef, extending off Eigg point, on northwestern shore of Atka, middle Aleutians. Called Staritchkoff (old codger) by Lutke. 
Starichkof; river, on the western side of Kenai peninsula. Name published by Tebenkof in 1849. It has been translated old river. The native name appears, according to Wosnesenski, 1840, to be Stuk Talj Chak. .

Starichkof, native village, shown by Sarichef, 1792, under the name Akmagan, near Starichkof cape, on north shore of Unalaska. Veniaminof calls it Starichkof and says it continued to exist down to 1805 .

Starik; Eskimo village, on the left bank of Yukon river, above the head of the delta, near longitude $163^{\circ}$. Called Starry (old) Kiwikhpak by Dall, 1869. Petrof, 1880, writes it Starikvikhpak and gives its population as 90. The Coast Survey, 1898 , has Starikvihpak.

Starikvikhpak, Eskimo village; see Starik.

Sturling, cape; see I.eontovich.

Starling; native village, in the western part of Spruce island, Kodiak group. Named Slivortzova (Starling's) by 'Tebenkof, 1849.

Sturr, mining camp; see Star.

Starrigavan; bay, in the northeastern part of Sitka sound, Alexander archipelago. On a harbor in this bay was the site of the first Russian settlement in these parts, in 1799. After its destruction by the Indians, 1802, the Russians made a new settlement on the site of the present town of Sitka. Thereupon the old place was and still is referred to as Starrigavan or Old harbor bay. See also Old Sitka harbor.

Sturrigavan, harbor; see Three Saints.

Starry, village; see Starik.

Starry Arteel, rookery; see Staraya Artil.

Station; island, at entrance to Funter bay, Admiralty island, Alexander archipelago, near latitude $58^{\circ} 15^{\prime}$, longitude $134^{\circ} 55^{\prime}$. So named by Mansfield in 1890 . His astronomical station was near this island.

Station; island, south of Mitkof island, in Sumner strait, Alexander archipelago, latitude $56^{\circ} 08^{\prime}$, longitude $133^{\circ} 38^{\prime}$. So named by Nichols, 1881 .

Station; islet; at south point of entrance to Shakan bay, Prince of Wales island, Alexander archipelago. So named by Helm, 1886.

Station; point, about 1 mile south of Wrangell, on Wrangell island, Zimovia strait, Alexander archipelago, near latitude $56^{\circ} 27^{\prime}$, longitude $132^{\circ} 23^{\prime}$. So named by Snow, 1886, who had an astronomical station at this place. This seems to be Graveyard point of Coast Survey magnetic declination tables for 1902 , p. 271.

Station; point, on Glass peninsula, southwest of Limestone inlet, Stẻphens passage, Alexander archipelago. So named by Mansfield, 1889.

Staunch; point, the eastern point of entrance to Windfall harbor, Seymour canal, Alexander archipelago. So named by Mansfield, 1889.

Steamboat; bay, indenting the mainland coast in northern arm of Frederick sound, Alexander archipelago. So named by Thomas, 1887.

Steamboat; creek, tributary to Niukluk river from the east, Seward peninsula. Name from Barnard, 1900.

Steamboat; creek, in the Fairbanks region, tributary to Pedro creek from the north, near latitude $65^{\circ}$, longitude $147^{\circ} 30^{\prime}$. Prospector's' name, reported by Gerdine, 1903.

Steamer; bay, in the western part of Etolin island, Alexander archipelago. Named Parakhotnia (steamer) by the Russians.

Steamer; knoll (2,033 feet high), near Steamer bay, Etolin island, Alexander archipelago. So named by Snow, 1886. 
Steamer; point, the northern point of entrance to Steamer bay, western shore of Etolin island, at junction of Stikine and Clarence straits, Alexander archipelago, near latitude $56^{\circ} 13^{\prime}$, longitude $132^{\circ} 43^{\prime}$. Name so used by local navigators, and reported by H. C. Fassett, Bureau of Fisheries, 1904.

Steamer; rocks, on the western shore of Etolin island, 2 miles south of Steamer bay, Clarence strait, Alexander archipelago, near latitude $56^{\circ} 08^{\prime}$, longitude $132^{\circ} 43^{\prime}$. Name so used by local navigators, and reported by H. C. Fassett, Bureau of Fisheries, 1904.

Stebbins; village, near St. Michael, Norton sound. So called on Coast Survey chart 9380 , published in 1900 . On Coast Survey chart 9370 , published in 1899, is it called Atroic or Stebbins. See also Stephens, cape.

Steele; creek, tributary to Fortymile creek from the south. Local name, obtained by Barnard, 1898. Spurr, 1896, wrote it Steel.

Steele; point (Point Steele, 237 feet high), the southenstern point at the eastern end of Hinchinbiook island, Prince William sound, near latitude $60^{\circ} 20^{\prime}$, longitude $146^{\circ} 10^{\prime}$. So named by Portlock in 1787. Vancouver, 1794, named it Bentinck. Often written Steel. Both names are used on the latest charts and applied to different capes. See Bentinck.

Steele Creek; mining camp, on Fortymile creek, at the mouth of Steele creek, near latitude $64^{\circ} 05^{\prime}$, longitude $141^{\circ} 20^{\prime}$. Frospectors' name, reported by Prindle, 1903 .

Steep; cape, on the northwestern shore of Afognak island, Kodiak group. Named Krutoi (steep) by the Russians. Called Kruto, Krutoi, and Krutoy.

Steep; creek, 20 miles north of Nome, Seward peninsula, tributary from the north to Goldbottom creek, near longitude $165^{\circ} 23^{\prime}$. Local name, from Gerdine, 1904.

Steep; mountain (2,045 feet high), near the head of Bay of Waterfalls, Adak island, middle, Aleutians. So named by Gibson, 1855. Has also been called steep Top.

Steep; point, on the western shore of Portland canal, southeastern Alaska. So named by Pender, 1868.

Steeple; peak (2,136 feet high), on the mainland near Taku harbor, Stephens passage, southeastern Alaska. So named by Thomas, 1888.

Stella; creek, tributary to Cripple river from the south, Seward peninsula. Name from Barnard, 1900.

Stepanof; cove, on the northern coast of Umnak, perhaps in Inanudak bay. So called by Lutke. See Inanudak.

Stephens; cape, the northwestern point of St. Michael island, opposite Stuart island, southern coast of Norton sound, Bering sea, near latitude $63^{\circ} 32^{\prime}$, longitude $163^{\circ} 19^{\prime}$. So named by Cook in September, 1778. In the mouths of the Russians this became. Stefens and even Stebbins. Perhaps this is Tchuk of the natives.

Stephens, cove; see Tee harbor.

stephens, creek; see Stevens.

Stephens; creek, tributary to head of Klutina lake, latitude $61^{\circ} 30^{\prime}$. Presumably so named by Lowe, 1898, after Sherman C. Stephens, a member of his party.

Stephens; bill (331 feet high), on Cape Stephens, near St. Michael, Norton sound. So named by the Coast Survey in 1898. Native name said to be Chinéeklk. 
Stephens; pass, narrow strait, between Stuart island and St. Michael island, south shore of Norton sound, near latitude $63^{\circ} 32^{\prime}$, longitude $162^{\circ} 20^{\prime}$. Local name, published by the Coast survey in 1900.

Stephens; passage, between Admiralty island and the mainland to the east, Alexander archipelago. Called Stephens's passage by Vancouver, 1.794.

Stephens; point, on the mainland, in Favorite channel, Lynn canal, Alexander archipelago. Apparently so named by Beardslee, 1880.

Stepovak; bay, indenting the southern part of Alaska peninsula, near the Shumagins. Named Stepovakho (Stepof's) bay by the Russiaus. F'roper name. Has been written Stepovakho and Stepowoj. Tebenkof, 1849, calls it Zakbarof (Zachary) bay.

Sterling; creek, eastern Alaska, Cbarley River drainage, tributary to Beverly creek from the northwest, near latitude $65^{\circ} 05^{\prime}$, longitude $143^{\circ} 50^{\prime}$. Prospector's' name, reported by Witherspoon, 1905.

Stetson; creek, tributary to Cooper creek, Kenai peninsula. Local name, from Mendenhall, 1898.

Stevens; creek, tributary to the Yukon from the south, 18 miles below Rampart (city), near longitude $150^{\circ}$. Prospectors' name, published in 1899. Written also Stephens.

Sterens; gulch, 8 miles northwest of Cape Nome, Seward peninsula, on the east bank of Nome river, near longitude $165^{\circ} 12^{\prime}$. Name from Gerdine, 1904.

Stevenson; island, in Kashevarof passage, Clarence strait, Alexander archipelago. So named by Snow, 1886.

Stewart; creek, Seward peninsula, Casadepaga drainage, tributary to Birch creek from the northwest, near latitude $64^{\circ} 50^{\prime}$, longitude $164^{\circ} 10^{\prime}$ Frospectors' name, from Gerdine; 1905.

Stewart; island, south of Japonski island, Sitka sound, Alexander archipelago. So named by United States naval officers, 1880 .

Stewart; peak, on the mainland, near Thomas bay, southeastern Alaska. So named by 'Thomas, 1887 .

Stewart; port, on the eastern shore of Cleveland peninsula, opening into Behm canal. Named by Vancouver, 1793, after Mate John Stewart, of his party, "who made a very good survey of it."

Stewart; river, 20 miles north of Nome, Seward peninsula, tributary to Sinuk river from the east, near longitude $166^{\circ} 30^{\prime}$. Name from Barnard, 1900.

Stewart; river, tributary to the upper Yukon. So named, 1850, by Robert Campbell, of the Hudson Bay Company. Named after his friend and assistant clerk, James G. Stewart, son of Hon. John Stewart, of Quebec. Stewart (James G.) crossed this river on the ice in the winter of 1849.

Stewart; sunken rock, in Security bay, Kuiu island, Alexander archipelago. Name published by the Coast Survey in 1891.

stick, village; see Chief Stephen.

stickleback, river; see Kakanhini.

Stiernfeld, island; see Turner.

Stikiné; river, in southeastern Alaska and British Columbia. A name of Indian origin, meaning great river, and which has been variously written Stachin, Stachine, Stahkin, Stah-keena, Stakeen, Stickeen, Stikeen, etc., and erroneously Francis river and Pelly river. The above form Stikine has been adopted also by the Canadian Board on Geographic Names. 
Stikine; strait, separating Zarembo islands from Etolin and Woronkofski islands, Alexander archipelago. Named by the Russians and written Stakhinski, Stachinski, etc.

Still; harbor, in Whale bay, Baranof island, Alexander archipelago. Named Tikhaia (still) by the Russians. Has also been called Tichai and Tichaia.

Stillwater; anchorage, in Kootznahoo inlet, Admiralty island, Alexander archipelago. Descriptive name, given by Meade, 1869.

Stillwater; creek, draining Kushtaka lake, and glacier, and tributary to Bering river, 12 miles northeast of Controller bay, near longitude $144^{\circ}$. Local name, reported by Martin, 1903.

Stink, bank; see Mastodon.

Stiphan, Indian village; see Chief Stephen.

Stockade; point, the eastern point of entrance to Taku harbor, Stephens pas sage, Alexander archipelago. So named by Meade, 1869 . On the point was a ruined blockhouse and stockade built by the Hudson Bay Company in 1840-41.

Stockdale; harbor, on the western const of Montague island, Prince William sound. Named Stockdale's by Portlock, 1787.

Stockholm; bay and point, on the south shore of Olga bay, Alitak bay, southwestern coast of Kodiak. Local name, reported by Moser, 1900.

Stolb, cape; see Bold.

Sitolb, rock; see Pillar.

Stone, bay; see Necker.

Stone; creek, tributary to Nabesna river from the east. So named by Schrader in 1902, "from the conspicuity and size of its barren stony delta."

Stone; islands, in entrance to Ernest sound, Alexander archipelago. Named by Snow, 1886, after Mr. J. C. Stone, a member of his party.

Stone; islet, at the south end of Davis creek, in Admiralty island, Alexander archipelago. The name is used by Nichols, in the Coast Pilot (1891, p. $160)$.

Stone; rock (20 feet high), about 3 miles north of Cape Chacon, Dixon entrance. So named by Clover, 1885.

Stonehouse; creek, in Fortymile mining district, tributary to Chicken creek, which is tributary to Mosquito fork from the north. Prospectors' name, from Barnard, 1898.

Stoney; mountain and glacier, in the Tordrillo range. So named by Spurr, 1898, in honor of Commander George Morse Stoney, U. S. N., who explored the Kobuk region, 1883-1886.

Stony, cape, Golofnin bay; see Rocky point.

Stony; creek, Seward peninsula, tributary to the headwaters of Turner creek, which is a tributary of Noxapaga river, near latitude $65^{\circ} 35^{\prime}$, longitude $164^{\circ} 25^{\prime}$. Prospectors' name, reported by Gerdine, 1901 :

Stony, island; see Pyramid.

Stony, point; see Peschani.

Stony, point, St. Paul island; see Tonki.

Stop; island, in Portage bay, Kupreanof island, Alexander archipelago. So named by Nichols, 1882. Beyond this island there is an extensive mud flat and shoal water.

Stopford; point, on the eastern shore of Portland canal. So named by Pender, 1868. 
Storey; island, one of the Naked islands, in Prince William sound. Called (erroneously) Story by Abercrombie, 1898, after Mr. Walter Storey, agent of the Alaska Packers' Association. Either this island or Peak island is also called Little Naked.

Storey; slough, one of the passes through the delta of the Copper river. Local name, from Ritter, 1898. Erroneously Story.

Storm; islands, in Fanshaw bay, Frederick sound, Alexander archipelago. So named by Thomas, 1887 .

Stoss; cape, near the head of Russell fiord, Disenchantment bay, southeastern Alaska. So named by Russell, 1891.

Stout; island, in Koyukuk river, near Double Point mountain. So named by Allen, 1885.

Strait; bay, indenting the southern shore of Beaver inlet, Biorka island, eastern Aleutians, near longitude $166^{\circ} 17^{\prime}$. So named by Gilbert, 1901 .

Strait; cape, on the northeastern shore of Lindenberg peninsula, Kupreanof island, Alexander archipelago. Called Cape of the Straits on English charts prior to 1880 . On late charts called Cape of the Strait.

Strait; island, off Port Protection, in Sumner strait, Alexander archipelago. So named by Helm in 1886. Called Barrie by Dall in the Coast Pilot (1883, p. 104).

Stranger; river, on the onter coast of Chichagof island, Alexander archipelago, tributary to the broad sound immediately south of Point Urey, near latitude $57^{\circ} 53^{\prime}$. So called by the fisheries, and reported by Moser, 1897.

Strauss; sunken rock, near south end of Shelter island, Stephens passage, Alexander archipelago. So named by the Coast Survey in or prior to 1891 .

Strawberry; harbor, indenting the northwest shore of Controller bay on the south side of Point Hey, near latitude $60^{\circ} 10^{\prime}$, longitude $144^{\circ} 20^{\prime}$. Local name, from Pratt, 1903.

Strawberry; hill, on eastern end of Hinchinbrook island, Prince William sound, near longitude $146^{\circ} 05^{\prime}$. Local name, reported by Ritter, 1899 .

Strawberry; point, on the west side of Strawberry harbor, Controller bay. Cave point is 3 or 4 miles west of this. Local name, from Martin, 1903.

Strawberry, point; see Raspberry, cape.

Strawberry; pond, about 3 miles southwest of Port Mulgrave, Yakutat bay, southeastern Alaska. Named Laguna de las Frezas (dung lake) by Malaspina, 1791. In Spanish frezas means-dung, fresas means strawberry. Perhaps frezas is a clerical error for fresas. I prefer to think so and make this change.

Strawberry; reef, on the eastern side of Copper River delta, 'Gulf of Alaska, near latitude $60^{\circ} 13^{\prime}$, longitude $144^{\circ} 45^{\prime}$. So named by Ritter, 1898 .

Streets; island (10 feet high), in Clarence strait, just north of entrance to Kasaan bay, Alexander archipelago. - So named by Clover, 1885.

Streets; lake, in the western part of Etolin island, draining to head of Rocky bay, Alexander archipelago. Named by Snow, 1886, after Passed Âsst. Surg. Thomas Hale Streets, U. S. N., a member of his party.

Strelna; creek, tributary to the Kuskulana from the north, near its moutb. Native name in local use, 1900.

Stripe; mountain (2,300 feet high), west of and near mouth of Portland canal. So named by Pender, 1868.

Strogonof; point, the southern point of entrance to Heiden bay, on northern shore of Alaska peninsula. Named Strogonova (Strogonof's) by Lutke. Has also been written Strogonoff, Strogonov, etc. 
Stuart; canal or passage, across Stuart island, Norton sound. So named by the Coast Survey in 1898.

Stuart; creek, in the Copper River region, tributary to the 'Tsina river, near: latitude $61^{\circ} 15^{\prime}$. Probably so named by the U. S. Army expedition under Captain Abercrombie in 1899.

Stuart; creek, tributary to Tonsina river from the west, near its mouth. Name from Schrader, 1900.

Stuart; creek, tributary to Fairview creek from the south, Seward peninsula. Name from Barnard, 1900.

Stuart; island, in Norton sound, western Alaska. Discovered and named Stuart's by Cook in September, 1778.

Stuart; mountain or hill (483 feet high), on Stuart island, Norton sound. So named by the Coast Survey in 1898 .

Stuck; mountalin, neil Copper river, latitude $61^{\circ} 57^{\prime}$; longitude $146^{\circ} 30^{\prime}$. Named Stuick by Abercrombie, 1898.

studenaja, bay; see Cold.

stugarok, Eskimo village; see Stagarok.

Stu-hee-nook, creek; see Stubinuk.

Stuhinuk; creek, southeastern Alaska, one of the outlets of Ustay river, 40 miles southeast of Yakutat, near longitude $138^{\circ} 40^{\prime}$. Indian name, written Stu-hee-nook by Moser, 1901. It seems to correspond with Gines or Hines river of 'Tebenkof, 1849.

Stuk-Talj-Chak, river; see Starichkof.

Stulchena, bay; see Cold.

Sturgeon; river, on the northern coast of Kodiak, near Karluk. Named Shipinskaia by Tebenkof, 1849. Called Sturgeon river by the Fish Commission in 1888 .

Sturgess; island, in Glacier bay, southeastern Alaska. Name published in British Admiralty chart 2431 (ed. of 1890).

Stuver; creek, in the Copper River region, tributary to Chisana river from the west. So named by Witherspoon, 1902, after Chas. H. Stuver, a member of the party.

Stuver; mountain, northern Alaska, on the east side of Anaktuvuk river, near latitude $68^{\circ} 15^{\prime}$. So named by Peters and Schrader, 1901, after Charles H. Stuver, a member of the expedition.

Styleman; point, the northern point of entrance to Port Snettisham, Stephens passage, Alexander archipelago. Named by Vancouver, 1794.

Styx; river, in the Tordrillo range, tributary to Kuskokwim river from the east, near its source. So named by Spurr and Post, 1898.

Subienna, bay; see Massacre.

Succosleanty, river; see Sukosleanti.

Suchilnoi, islet; see Sushilnoi.

Sucho Emnik, bay and peninsula; see Dry Spruce.

Sucker; river, tributary to the Porcupine from the north, near the international boundary line. So called by the Coast Survey in 1890 .

Sucker, river; see Rapid.

Suckling; cape, the eastern point of entrance to Controller bay. So named by Cook in 1778. Translated Cabo Chupador (sucking bottle) in Malaspina's narrative, 1791. It was named Cabo de San Elias by Maurelle and Quadra, 1779.

Suckqwan, village; see Sukkwan.

Sudak; cape, the northeasternmost point of Tanaga island, Andreanof group, middle Aleutians. Called Sudak (perch-pike) by Tebenkof, 1849. Has also been written Sudakh. 
Sudden; creek, northern Alaska, tributary to Alatna river. Prospectors' name, reported by Lieutenant Camden, Revenue-Cutter Service, in 1900. Not found on any map.

Suemez; island, in Bucareli bay, Prince of Wales archipelago. So named by the Spaniards, $1775-1792$.

Sufus; creek, 7 miles northwest of Nome, Seward peninsula, a small tributary of Nome river from the west, near longitude $165^{\circ} 15^{\prime}$. Local name, published in 1900 as Rufus.

Sugarloaf; island, about 14 miles northwest of Cape Spencer, at entrance to Dixon harbor, southeastern Alaska. Name published by the Coast Survey in 1889.

Sugarloaf; island, one of the Barren islands, in entrance to Cook inlet. So called by Dixon, 1787 (Voyage, p. 69).

Sugarloaf, island, Resurrection bay ; see Hive.

Sugarloaf; mountain $(5,259$ feet high), on the mainland, east of the stikine river and near the international boundary. Name published by the Coast Survey in 1895:

Sugarloaf; mountain, on south shore of Silver bay, Sitla sound, Alexander archipelago, near latitude $57^{\circ} 02^{\prime}$, longitude $135^{\circ} 14^{\prime}$. Probably local name, published by the Coast Survey in 1900 .

Sugarloaf; mountain, on the west side of Iniskin bay, Cook inlet, near latitude $59^{\circ} 43^{\prime}$, longitude $153^{\circ} 30^{\prime}$. Descriptive name, reported by Martin, 1904.

Sugarloaf, mountain, near Unalaklik river, between Norton sound and Kaltag, on the Yukon. Local name, found in the Reindeer Report for 1900. It may be the same as Vesolia mountain or old Woman mountain.

Sugarloaf; mountain (1,350 feet high), on the southeastern coast of St. Matthew island, Bering sea. Named Sikarnoi golovie (sugarloaf), says Lutke, 1836 , on account of its appearance.

Sugarloaf; peak, southwestern shore of Kodiak, southeast of Karluk lagoon; near mouth of Karluk river, about latitude $57^{\circ} 30^{\prime}$. Local name, reported by H. C. Fassett, U. S. Fish Commission, 1900.

Sugarloaf; peak, on Alaska peninsula. near the heal of Bristol bay. So named by the Fish Commission in 1890 .

Sugarloaf; peak (1,060 feet high), on the north end" of Kanaga island, middle Aleutians. So named by Gibson, 1855.

Sugarloaf; peak (1,760 feet high), on the southern edge of Semisopochnoi island, Rat island group, western Aleutians. Apparently so named by the North Pacific exploring expedition, 1855.

Sugarloaf; rock, near cape Whitshed, at entrance to Prince William sound. So called by Moser, 1897.

Sugarloaf, rock; see Humpback.

Sulihoi, bay; see Dry.

Sukhoi, bay, near Cape Douglas ; see Dry.

Sukhoi, river; see Blind.

Sukhoi Elnik, bay; see Dry Spruce.

Sukkwan; island or (?) peninsula, in the northern part of Cordova bay, Alexander archipelago. So written by Moser, 1897.

Sukkwan; narrows, in Sukkwan strait, northern part of Cordova bay. Local name, published by the Coast Survey in 1905 .

Sukkwan; strait, in the northern part of Cordova bay, Alexander archipelago, near latitude $55^{\circ} 10^{\prime}$, longitude $132^{\circ} 50^{\prime}$. So written by Moser, 1897 .

Sukkwan; Indian village, on the north shore of Cordova bay, Alexander archipelago. Has also been written Suckqwan. 
Suklik; island (200 feet high), one of the Semidi islands. Native name obtained, 1874, by Dall, who wrote it Su'khlikh.

Sukoi; inlet, partly dry at low water, separating Kruzof and Partofschikof islands and uniting Krestof and Salisbury sounds. This constitutes the northern and chief part of the strait named Hayward's by Portlock in 1787. It was called Sukoi (dry) by the Russians, a name which has appeared as Dry, Souchoi, Souhoi, Soukhoi, Soukoi, etc.

Sukoi; islets, north of the northern entrance to Wrangell strait, in Frederick sound, Alexander archipelago. Called Soukhoi (dry) by Meade, 1869. Has also been written Souchoi.

Sukosleanti; river, tributary to the Koyukuk from the west, near its mouth. Native name, reported, 1885, by Allen, who writes it Succoslëanty in text (p. 106) and Succoslcanty on his map. Tikhmenief, 1861, shows this stream and calls it Kalialiaktna.

suktu, creek; see Usuktu river.

Sukwanila; mountains, on north bank of the Yukon river, a little above Melozi river. Called Suyanyilla by the Western Union Telegraph expedition, 1867, and Suquonilla by Raymond in 1869. Apparently these are the mountains called on late Coast Survey maps Tohtanyilla.

Sulima, river; see Ugashik.

Sullivan; creek, Seward peninsula, tributary to Kotzebue sound, near longitude $163^{\circ}$. Prospectors' name, reported by Mendenhall, 1901.

Sullivan; island, in Lynn canal, southeastern Alaska. So named by Meade, 1869, after the master of the American schooner Louisa Downs, wrecked here in 1867. According to the Krause brothers, 1882, its native name is Schikúk.

Sullivan; locality, Seward peninsula, 20 miles southwest of Port Clarence. A post-office was established here in 1902 and discontinued in 1905.

Sullivan; mountain (2,142 feet high), on the eastern shore of Gravina island, Alexander archipelago. So named by the Coast Survey in 1886.

Sullivan; point, on the western shore of Kuiu island, Chatham strait, Alexander archipelago: So named by Vancouver, 1794.

Sullivan; point, Kootznahoo inlet, Chatham strait, Alexander archipelago, the north point at entrance to the southerly arm, leading to Favorite bay. So named by Moore, 1895 .

Sullivan; rock (150 feet high), south of Sullivan island, in Lynn canal, Alexander archipelago. Named by the Hydrographic Office in 1869.

Suloia; bay, indenting the southern shore of Chichagof island, Peril strait, Alexander archipelago. Named Suloia (porridge) by the Russians. George Kostrometinoff, United States court interpreter at Sitka, writes this Sulovoi (ripple).

Suloia; islet, in Suloia bay, Peril strait, Alexander archipelago. So named by Coghlan, 1884.

Suloia; point, opposite Fish bay, on Chichagof island, Peril strait, Alexander archipelago. So named by the Russians.

Suloia; sunken rock, in Suloia bay, Peril strait, Alexander archipelago. So named by Coghlan, 1884.

Su-look-pow-wick, native village; see Sulukpowik.

Sulphur; creek, 30 miles north of Cape Nome, Seward peninsula, tributary to Nome river from the east, near longitude $165^{\circ} 12^{\prime}$. Name from Barnard, 1900.

Sulphur; springs, on Bell island, Behm canal, Alexander archipelago. So named by the Coast Surrey, 1891. 
Sulukpowik; river, outlet of Lake Selby, and tributary to Kobuk river from the north, near latitude $66^{\circ} 45^{\prime}$, longitude $155^{\circ} 45^{\prime}$. Visited by Stoney, 1884, and its Eskimo name written by him Soo-look-pow-vuck-to-ark and Su-look-pow-vuck-to-ark, from sulukpowik, the name of a small fish.

Sulukpowik; Eskimo village, on upper Kobuk river, at outlet of Lake Selby, near: latitude $66^{\circ} \cdot 45^{\prime}$, longitude $156^{\circ}$. Eskimo name of a small fish plentiful there, which Stoney, 1884, wrote Su-look-pow-wick, Soo-lookpow-vuck, and Su-luk-pow-wuk. The post-office, Shungnak, is situated at or near this place.

Sulzer; post-office (established in 1901) and settlement, near head of Hetta inlet, Cordova bay, Prince of Wales island, about latitude $55^{\circ} 15^{\prime}$, longitude $132^{\circ} 40^{\prime}$.

Sum Dum, bay; see Holkham.

Sumdum; glacier, and mountain (6,690 feet high), on the mainland, near Holkham bay, Stephens passage, southeastern Alaska, near latitude $57^{\circ} 45^{\prime}$. Native name, representing the booming of the falling and rising icebergs, written Soundon by Meade, 1869 ; also written Sum Dum.

Sumdum; island, in Endicott arm of Holkham bay, Stephens passage, Alexander archipelago. Called Sand island by Meade, 1869, and said to be known locally as Fox island, because it is occupied as a fox ranch. Has also been written Soundon.

Sumclum; post-office, in Sanford cove, Holkbam bay; southeastern Alaska. Established November, 1897.

Summer; bay, indenting the eastern shore of Unalaska bay, eastern Aleutians. Veniaminof calls this Imagninskoe. Davidson, 1869, called it Indian bay; and Dall, 1871, Summer bay, which is believed to be its local name.

Summit; creek, Chilkat valley, southeastern Alaska, tributary to Tsirku river: from the north, near latitude $59^{\circ} 20^{\prime}$, longitude $136^{\circ} 02^{\prime}$. Prospectors' name, reported by Wright, 1903.

Summit; creek, tributary at the head of Canyon creek from the west, Kenai peninsula. Local name, reported by Mendenhall, 1898.

Summit; creek, 22 miles north of Cape Nome. Seward peninsula, tributary to Eldorado river from the west, near longitude $165^{\circ}$. Name from Barnard, 1900.

Summit; glacier $(5,700$ feet high $)$, on the mainland, east of Le Conte bay, southeastern Alaska. So named by Thomas, 1887 .

Summit; gulch, on the south side of Young creek, a tributary of Nizina river. Prospectors' name. First appear's on map of Nizina mining district, by George M. Esterly, of Valdez, 1902.

Summit; island, on the north shore of Bristol bay, just east of Togiak bay. So called by the Fish Commission in 1890 . Sarichef, 1826, calls it by its Eskimo name, Kellek. Tebenkof calls it Kielkek.

Summit; lake near the source of Gulkana river, a tributary of Copper river. Name taken by Mendenhall, 1903, from map by Powell, a Valdez engineer.

Summit; lake, at the source of the western branch of Tebay river, which is tributary to the Chitina. Descriptive name, given by Schrader and Spencer, 1900.

Summit; peaks (5,800 feet high), at head of Valdez glacier. So named by A bercrombie, 1898. 
Summit; railroad station and mining camp, 6 miles north of Nome, Seward peninsula, near longitude $165^{\circ} 21^{\prime}$. Local name, Summit Station, published in 1903.

Summit; telegraph station, on the divide between Goodpaster river and Middle fork Fortymile creek, near latitude $64^{\circ} 30^{\prime}$, longitude $143^{\circ} 40^{\prime}$. So named by the Signal Corps, U. S. A., 1903.

Sumner, glacier: ; see Turner.

Sumner; island, northwest from Port Protection, in Sumner strait, Alexander archipelago. So named by Helm, 1886.

Sumner; mountains, in the southern part of Mitkof island, Alexander archipelago. So named by Thomas, 1887.

Sumner, peninsula ; see Seward.

Sumner; strait, extending from the mouth of the Stikine river to the Pacific, between Prince of Wales archipelago and other islands on the south and Kupreanof and other islands on the north. Named by Dall, 1875, after Hon. Charles Sumner.

Sunby; creek, 8 miles north of Nome, Seward peninsula, draining the northeast slope of King mountain to Nome river, near longitude $165^{\circ} 18^{\prime}$. Local name, published in 1903 . Written also sundby.

Sunday; gulch, in the Copper River region, on the north side of Chititu creek. Prospectors' name. First appears on majp of Nizina mining district by George M. Esterly, of Valdez, 1902.

Sundby, creek; see Sunby.

Sun Golovine, bay and sound; see Golofinin.

Sunit, cape; see Ninilchik.

Sunny; cove and point, northern shore Cholmondeley sound, Prince of Wailes island, western shore Clarence strait, southeastern Alaska, near latitude $55^{\circ} 15^{\prime}$, longitude $132^{\circ} 16^{\prime}$. Local navigators' name, reported by Brooks, 1901.

Sunny; cove, indenting the western shore of Taku inlet, southenstern Alaska, near latitude $58^{\circ} 18^{\prime}$, longitude $134^{\circ} 08^{\prime}$. Local navigator's' name, reported by Moser, 1900 .

Sunny; mountain $(4,400$ feet high $)$, near the outlet of Klutina lake. So named by Abercrombie, 1898.

Sunnyside; mining camp and landing, on the southern shore of Holkham bay, Stephens passage, Alexander archipelago, just inside Point Astley, near latitude $57^{\circ} 42^{\prime}$, longitude $133^{\circ} 37^{\prime}$. Local name, reporter by Spencer and Wright, 1903.

Sunrise; creek, Seward peninsula, tributary to Agiapuk river from the south, near longitude $166^{\circ} 04^{\prime}$. Prospector's' name, reported by Gerdine, 1901.

Sunrise; mining town and post-office (establisbed in June, 1899), on south shore of Turnagain arm of Cook inlet, at mouth of Sixmile creek. Kenai peninsula, near longitude $149^{\circ} 30^{\prime}$. Founded in 1895 or 1896 , and called Sunrise City.

Sunset; creek, tributary to Turnagain arm of Cook inlet from the south, just west of Sixmile creek. Local name, from Mendenhall, 1898.

Sunset; creek, tributary to Gold run, from the south, Seward peninsula. Name from Barnard, 1900.

Sunset; creek, tributary to Grantley harbor from the north. Seward peninsula. Name from Barnard, 1900.

Sunset; creek, tributary to Snake river from the north, near Nome, Seward peninsula. Name from Barnard, 1900 .

Sunset; island ( 404 feet high), near Windham bay, Frederick sound, Alexander archipelago. So named by Meade, 1869 . 
Sunset; pass, in the Franklin mountains, northeastern Alaska, "leading from the head of Kuselik creek to the head of Barter river," near latitude $69^{\circ} 30^{\prime}$, longitude $145^{\circ}$. So described by S. J. Marsh, a prospector, 1902.

Sunshine; creek, Seward peninsula, in Casadepaga valley, tributary to Canyon creek from the north, neir latitude $64^{\circ} 52^{\prime}$, longitude $164^{\circ} 21^{\prime}$. Prospectors' name, from a locil map, 1901.

Sunshine; village or camp, on Klehini river, near Chilkat river. Prospectors' name, from Brooks, 1900.

Surf; bay, indenting the southwestem shore of Akun island, Krenitzin group, easter'n Aleutians, near longitude $165^{\circ} 37^{\prime}$. So named by Gilbert, 1901.

Surf; point, the western point of entrance to Port Alice, Dividson inlet, Prince of: Wales archipelago, near latitude $55^{\circ} 50^{\prime}$, longitude $133^{\circ} 38^{\prime}$. So named by Dickins, 1903-4.

Surf; rock, near Middle channel into Sitka harbor, Sitka sound, Alexander archipelago. Called Polivnoi (surf washed) by the Russians in 1809. Also, they used Burun (breakers) to designate it. Thus it has been called Bolivnoi (by erior), Burun, Polivnoi, and surf.

Surge; small bay, indenting the western shore of Yakobi island, Alexander archipelago. Apparently so named by Dall in the Coast Pilot (1883, p. 185 ).

Surprise; creek, tributary to the Kotsina from the north. Prospectors' name, reported by Gerdine, 1900.

Surprise; creek, tributary to Topkok river from the west, Seward peninsula. Name from Barnard, 1900.

Surprise; creek, Seward peninsula, small tributary on west bank near head of Big Four creek, Casadepaga drainage, near latitude $64^{\circ} 48^{\prime}$, longitude $164^{\circ} 05^{\prime}$. Prospectors' name, from a local map, 1904.

Surprise; glacier, tributary to Harriman fiord, Port Wells, Prince William sound. Called Surprise glacier, also the Stairway, by the Harriman expedition, 1899 .

Surprise; gulch, 12 miles north of Cape Nome, Seward peninsula, draining into Osborn creek from the east, near longitude $165^{\circ} 06^{\prime}$. Local name, from Gerdine, 1904 .

Surprise; harbor, at the south end of Admiralty island, Alexander archipelago. So named, presumably, by Meade, 1869 .

Surprise; point, on island in mouth of Nakat inlet, southeastern Alaska. So named by Nichols, 1888 .

Survey; mountains (2,916 feet high), in the northern part of Mitkof island, Alexander archipelago. So named by Thomas, 1887.

Survey; point, 1 mile northeast of Higgins point, the southern point of entrance to Clover passage, northern entrance to Behm canal, southeastern Alaska, near latitude $55^{\circ} 28^{\prime}$, longitude $131^{\circ} 50^{\prime}$. Name from local navigators, reported by H. C. Fassett, Bureau of Fisheries, 1904.

Survey; point, the eastern point of entrance to Tamgas harbor, Annette island, Alexander archipelago. So nimed by Nichols, 1883.

sushetna, river, mountain, village; see Susitna.

Sushilnoi; islet, in the Sandman reefs, northeast of Sannak. Named Sushilnoi (drying-ground, drying place) by the Russians. Erroneously Sushitnoi. Veniaminof has Chishelnoi (cleaning).

Sushitna, river, mountain, village; see Susitna.

Susitna; mountain $(4,280$ feet high $)$, about 15 miles north of the mouth of the Susitnat river, near latitude $61^{\circ} 30^{\prime}$, longitude $151^{\circ} 45^{\prime}$. Apparently a local name, published Sushitna by the Geological Survey in 1900. 
Susitna; river, tributary from the north to Cook inlet. Native name, Sushitna, i. e., Sushit river. Variously written Suchitna, Sushetna, Sushitna, Susitna, etc.

Susitna; Indian village, near the mouth of Susitna river, Cook inlet. Petrof, 1880 , writes it Sushetno and shows two villages, Susbetno (first, village), with population 44, and Sushetno (second village), with population 46. 'The Eleventh Census, 1890, has Sushitna village, with population 142 .

Suskaralogh; point, on the north shore near the west end of St. George island, Bering sea, $1 \frac{1}{4}$ miles east of Dalnoi point, near longitude $169^{\circ} 45^{\prime}$. Aleut name, reported by Duffield, 1897. Putnam wrote Sŭskär $\bar{a}^{\prime} \operatorname{lōgh}$ (place where they get whales).

Suskita; channel, of Koyukuk river, about 47 miles long, on the right (north), side of Treat island, near latitude $66^{\circ}$, longitude $156^{\circ}$. The channel on the left side is called the Cutoff. River pilots' name, reported by Lieutenant Camden, Revenue-Cutter Service, 1900.

Suskita; mountains, on the right bank of Koyukuk river, between Dakli and Hogatza rivers, near latitude $66^{\circ}$, longitude $156^{\circ}$. Indian name, adopted by the river pilots, and reported by Lieutenant Camden, Revenue-Cutter: Service, 1900.

Suslositna; creek, in the Mentasta mountains, tributary to Slana river from the east, 7 miles above Suslota creek. Indian name, reported by Schrader, 1903.

Suslota; creek, tributary to Slana river. Native name, reported by Allen in 1885. In his text it is printed Suslota, and also (apparently erroneously ) Sustota. The termination ta is doubtless what Hayes wrote to or too, meaning creek.

Suslota; lake, in the Copper River valley, drained by the Suslota creek (above). Name from Wither'spoon, 1902.

Suslota; pass (about 4,000 feet high), between the Copper and Tanana rivers. So called by Schrader, 1899.

Suspiro; capé, in Bucareli bay, Prince of Wales archipelago. Named Suspiro (sigh) by Maurelle and Quadra, 1775-1779.

Susto, Ensenada del; see Sitka sound.

sutchum, island; see Sutwik.

Sutkum, island; see Sutwik.

Sutro; creek, tributary to Fox river from the soutb, Seward peninsula. Name from Barnard, 1900.

Sutter; creek, Seward peninsula, tributary from the west to Buck creek, near latitude $65^{\circ} 38^{\prime}$. Prospectors' name, reported by Collier, 1903.

Sutter; creek, eastern Alaska, on the south bank of Seventymile creek, near latitude $64^{\circ} 55^{\prime}$, longitude $142^{\circ} 05^{\prime}$. Prospectors' name, from sketch map compiled by Major Glassford, Signal Corps, U. S. A., 1905.

Sutwik; island, off the southern shore of Alaska peninsula, north of the Semidi

- group, near longitude $157^{\circ}$. Native name, from the Russians, who have Sutkum and Sutwik. Langsdorf, 1813, has Sutchum and the Russian charts Sutkhwik. Variously written Soutkhvik, Soutvik, Sutchum, Sutchwik, Sutkhum, Sutkwik, and Zutchwik. Petrof, in the Tenth Census, 1880, calls the island Sutkhum, and in his text (p. 28) the village Sutkhoon. In the Eleventh Census, 1890, the island is called Sutwik and the village Sutkum.

Sutwik; native village, on Sutwik island. 
Suworof; cape, at mouth of Naknek river, near head of Bristol bay, Bering sea, about latitude $58^{\circ} 45^{\prime}$, longitude $157^{\circ} 05^{\prime}$. Só named by Staniukovich, of the corvette Moller; in 1828, whose reconnaissince of the Alaska peninsula ended here. Spelled Souvoroff, Suvoroff, etc. Russian proper name. It is apparently this cape or some point on it that Moser, 1900, calls Pedersen point.

Suworof; village, at mouth of Naknek river, Bristol bay, Bering sea. So called by the Russians, presumably after Cape Suvorof, near by. Its native name appears to be Kinghiak or Kiniak, which has also ippeared as Kinuiak. Sarichef calls it the Aleut village Naugvik; called also Naknek.

Suyanyilla, mountains; see Sukwanila.

Svensen; sunken rock, in the eastern part of Peril strait, Alexander arclipelago. Named Svenson by Moore, 1895 ; here changed to Svensen, the usual spelling of this Swedish proper name.

Svetchnilioff, harbor and point; see Sviechniliof.

Sviechnikof; harbor or port, indenting the southern shore of Amlia island, Andreanof group, middle Aleutians. Surveyed and presumably named by Chernof, 1832. May be a family name. Sviechnik is Russian for tallow chandler. The name has been written svetchnikoff, Sbieznikof, and even Souchikova.

Svieshlakof; island, in Kalsin bay, Chiniak bay, Kodiak. So named by the Russians.

Svilhchak, bay; see Swikshak.

Svinoi, island; see Hog.

Swamp; point, on the eastern shore of Portland canal: So named by Pender, 1868.

Swan; island, in Seymour canal, Admiralty island, Alexander archipelago. So named by Mansfield, 1890 .

Swan; lake, near Sitka, Baranof island, Alexander archipelago. Named Lebiazhe (swan) by Vasilief, 1809.

Swan; small lake, $1^{\circ}$ west of outlet of Lake Clark, drained by Swan river (below). Local name, reported by Osgood, who visited it in 1902.

Swan; river, tributary from the northeast to Kaktul river, in affluent of the Mulchatna from the east, near latitude $60^{\circ}$, longitude $156^{\circ}$. Local name, obtained by Spurr and Post, 1898, from Trader A. Mittendorf. They represented it as tributary to the Mulchatna. It is apparently the stream for which Schanz, 1891, reported the Eskimo name Kogiukhtuli.

Suan, river; see Kugruk.

Swanport; anchorage and post, opposite Valdez, in Fort Valde\%, Prince William sound. Local name, published in 1899 .

Swanson; creek, Seward peninsula, north of Grantley harbor, and flowing east to Allene creek, a branch of North creek. I'rospectors' name, reported by Gerdine, 1901.

Swanson; harbor, at junction of Lynn canal, Chatham strait, and Icy strait, Alexander archipelago, near latitude $58^{\circ} 12^{\prime}$, longitude $135^{\circ} 05^{\prime}$. So named by Meade, 1869.

Swedania; point, on the southern shore of Alaska peninsula, north of the Shumagins. Named Swedania (meeting place) by the Russians.

Swede; gulch, on the south side of Young creek, a tributary of Nizina river. Prospectors' name. First appears on map of Nizina mining district, by Geo. M. Esterly, of Valdez, 1902.

Bull. $299-06 \mathrm{M}-39$ 
S'wedish Meadows. This name appeared on an unpublished chart of the Coast Survey (numbered 1000) for some features in Revillagigedo channel, Alexander archipelago.

Sweetbrier; creek, Seward peninsula, Solomon river drainage, tributary on west bank of Shovel creek, near latitude $64^{\circ} 42^{\prime}$, longitude $164^{\circ} 25^{\prime}$. Prospectors' name from a local map, 1904.

Sweetcake; creek, tributary to Ophir creek from the north, Seward peninsula: Name from Barnard, 1900.

Sweetheart; falls, in Port Snettisham, Stephens passage, Alexander archipelago. So named by Thomas, 1888.

Subetlaretchka, river; see Clear.

Swikshak; bay, on the northern shore of Shelikof strait, about 25 miles southwest of Cape Douglas, Alaska peninsula. Native name, which Lutke, 1835, writes Svikhchak. Has been written Sbichsak and Swikschak.

Swinoi, island; see Hog.

Switch; creek, in the Birch Creek district, tributary to Deadwood creek from the south, near latitude $65^{\circ} 30^{\prime}$, longitude $144^{\circ} 50^{\prime}$. Prospector's' name; reported by Prindle, 1903.

Switch; fork, of Chicken creek from the left, in the Fortymile region, near latitude $64^{\circ} 05^{\prime}$, longitude $142^{\circ}$. Prospectors' name, taken from a map in the Coast Survey archives, drawn by E. F. Ball, a prospector, 1898.

Sword; point, in Portillo channel, Bucareli bay, Prince of Wales archipelago. Named Punta de Espada (sword point) by Maurelle and Quadra, 17751779.

Syble; point, on the mainland, the eastern point of entrance to Yes bay, Alexander archipelago. So named by the Coast Survey in 1891.

Sycamore; bay, indenting the northern shore of Kodiak. Named Chernteshef (perhaps from Cherniechie, sycamore) by the Russians, 1808-1810. Tebenkof calls it Maknashka and the Coast Survey, Devils bay.

Sykes; point, the southern point of entrance to Behm canal, Alexander archipelago. Named by Vancouver, 1793, after a member of his party.

Sylburn; harbor, on the western side of Annette island, opening into Nichols passage, Alexander archipelago. So named by Nichols, 1883.

Sylva; creek; near the head of Windham bay, Frederick sound, southeastern Alaska, tributary to Shuck river, from the east. Prospectors' name, reported by Spencer and Wright, 1903.

Symonds; bay, in Biorka island, Sitka sound, Alexander archipelago. Named after Lieut. Frederick Martin Symonds, U. S. N., who, with Master G. C. Hanus, U. S. N., surveyed it in 1879 .

Symonds; point, on Admiralty island, near north end of Stephens passage, Alexander archipelago. Named by Coghlan, 1884, after Lieut. F. M. Symonds, U. S. N., who made surveys in this vicinity in 1880 .

Synrock, Synrok, Synrook; see Sinuk.

T'aaltsug, bay ; see Dry.

Taaltsug; river, one of the five rivers in the delta of the Alsek, southeastern Alaska. Apparently a native name, published by Tebenkof, 1849.

Taapkuk; Eskimo village (population 42 in 1880), at Cape Espenberg, Kotzebue sound. Eskimo name, from Petrof, 1880, who writes it Ta-apkuk.

Table; island, in Hood bay, Admiralty island, Alexander archipelago, near latitude $57^{\circ} 27^{\prime}$. So named by Meade, 1869 .

Table; mountain (2,438 feet high), a prominent landmark on the southern shore of Whitewater bay, southeastern shore Admiralty island, Chatham strait, Alexander archipelago, near latitude $57^{\circ} 13^{\prime}$. So described in the Coast Pilot of 1901. 
Table; mountain (6,000 feet high), on the headwaters of Koyukuk river, in latitude $68^{\circ}$. Descriptive name, given by Schrader in 1899 .

Tachat; river, tributary to the Kuskokwim from the north, near latitude $63^{\circ}$. Native name, from Spurr and Post, 1898, who wrote it Tachatna, i. e., Tachat river:

T'achiki, bay; see Pavlof.

Tachilni; cape, the eastern point of entrance to Morzhovoi bay, on the southern shore of Alaska peninsula, near its western end, about longitude $162^{\circ}$ 54'. Named Tochilnoi (grinding to an edge, sharpening, whetting) by Tebenkof, 1849. Its Aleut name according to Lutke (p. 272), who obtained it from Kudiakof, 1791, is Animatchoutchkok.

Tachilni; mountains, between Cold and Morzhovoi bays, at western end of Alaska peninsula. Named Tachelhey by the Fish Commission, 1.888, the name being obviously derived from Cape Tachilni, near by. Tebenkof calls the cape Tochilnoi. It has been given Tachilnoi by Dall, Tachelhey by the Fish Commission, and Tachethey by the Coast Survey.

Tachlinach, island; see Simeonof.

I'achshilit, creek; see Takshilik.

I'achti, island; see Takli.

'l'a-clik, landing; see Tklik.

'T'acou, harbor; see Taku.

I'addiskey, harbor; see Kaigani and south.

Tadluk; cipe, on the southern shore of Atka island, middle Aleutians. Native name, from Tebenkof, 1849.

Tadrandile, river; see Chandlar.

Tag; rock or rocky islet, one of the Delarof islands, near western end of the Andreanof group, middle Aleutians. Aleut name, from Tebenkof, who writes it Tagachalugis, or, as we may divide it, Ta-gach-al-u-gis. This has been written Tagatchalgise by the Hydrographic Office and Tagachalgise by the Coast Survey. This large name of a small feature is here. curtailed to 'Tag.

Tagadak; islet, east of Adak, and south of Great Sitkin, Andreanof group, middle Aleutians. Aleut name, from Tebenkof, 1849. Tagádak is Aleut for new, fresh, etc. Has also been written Tagadakb.

Tagagawik; river, northwestern Alaska, tributary to Selawik river from the south, near latitude $66^{\circ} 30^{\prime}$, longitude $159^{\circ}$. Eskimo name, obtained by Stoney in 1886, who wrote Tag-gag-a-wik.

I'agalack, bay; see Dakavak.

Tagalak; island, between Atka and Great Sitkin, middle Aleutians. Native name, from Billings's track chart, 1790-1792. (Not to be confounded with Tagadak, a small island about 10 miles west of this one). Has also been written Tagalakh.

Tagamak, islet; see Chernabura.

Tag-gag-a-wit, Eskimo village; see Tagagawik.

Taghinak, island; see Simeonof.

Tagish; lake and post-office, east of Bennett lake, Yukon district, Canada. Named Bove, 1883, by Schwatka, after Lieutenant Bove, of the Italian navy, but by Doctor Dawson called Tagish. The native name, according to Ogilvie, is Takone. The above name, Tagish, has been adopted by the Canadian Board on Geographic Names.

Tagumanik; creek, tributary to the eastern part of Norton sound. Native name, from the Western Union Telegraph Expedition map of 1867. 
Taguta. Raymond, 1869, shows a native village on the north bank of the Yukon, about 15 miles below the mouth of the Kaiyuh slough, called Tagutakaka, which appears to be intended for Taguta-kakat, i. e., Taguta river. Neither name nor village appears on recent maps.

Tahini; river, tributary to Chilkat river from the north, or rather it is the upper part of Chilkat river, near latitude $59^{\circ} 30^{\prime}$. Native name, reported by the Krause brothers in 1882. Name omitted from recent maps.

Tahini, river; see Takhin.

Tahlkandit; river, tributary to the Yukon from the northeast, near the international boundary. Native name, published by the Coast Survey, in 1890, as Tahkandik. Now known as Nation river. See Nation.

Tahkeena, river; see Takhini.

Tahko, lake; see Teslin.

I'ahko, pass; see Taku.

Tahlekuk, river; see Nushagak.

Tahneta; pass, between the headwaters of the Matanuska and Tazlina rivers Nátive name, from Mendenhall, 1898.

Tahnohlialony, village; see Tanakot.

Taigud; islands, on the south side of Redoubt bay, Sitka sound, Alexander archipelago. So called by Vasilief, 1809.

Taiya; inlet, at head of Chilkoot inlet, southeastern Alaska, near latitude $59^{\circ}$ $20^{\prime}$, longitude $135^{\circ} 20^{\prime}$. An Indian word, variously written Ty ̈̈a and Tya (Meade, 1869), Dejiih (Krause, 1882), Dayay (Schwatka, 1883), Dyea and Taiya by various authorities. The above form has been adopted for the inlet and the river which flows into it at its head.

Taiya; river, tributary at the head of Taiya inlet (above).

Taiyasanka; harbor, in front of Ferebee glacier, at the head of Lynn canal, southeastern Alaska. Native name, reported by the Krause brother's, in 1882, as Dejühssánke. Iichols (1891) writes it Taiya Sahnka.

Takahola; lake, northern Alaska, on the west side of, and tributary to Alatna river, near latitude $67^{\circ} 20^{\prime}$, longitude $154^{\circ}$. Eskimo name, written Ta-kahoela and Ta-ka-heo-la by Stoney, who saw it in 1886.

Takaiak; mountain, about 25 miles southeast of Nulato. Native name, from Tikhmenief, 1861. Not found on any recent map. Near it Tikbmenief shows a summer village called Takaiaksa.

Takaltski, creek; see Medicine.

Takamgia; point, the northeast point of North rookery, north shore St. Genrge island, near longitude $169^{\circ} 34^{\prime}$. Aleut name, reported by Duffield, 1897 .

Takanis; bay, indenting the western shore of Yakobi island, Alexander archipelago. Native name, from Tebenkof, 1849. Usually written Takhanis, sometimes Thakanis.

Takatz; bay, on the eastern coast of Baranof island, Chatham strait, Alexander archipelago, near latitude $57^{\circ} 10^{\prime}$, longitude $134^{\circ} 45^{\prime}$. Native name, reported by Moore, 1895.

Takatz; islands, in Takat bay (above), Chatham strait, Alexander archipelago. Name so applied by Moore, 1895.

T'akauangha, island; see Tanaga.

Takchuk; entrance, to a narrow strait leading from Grantley harbor to Imuruk basin, Seward peninsula. Beechey visited this in August, 1827, described it, and says it is called Tokshook by the natives. Lutke writes it Tokchouk. Beechey says there was an Eskimo village on its shores. Dall,. 1869, locates a village here called Taksumut. By Petrof, 1880, this is called 'Taksomute and located farther east. 
Takhanis, bay; see Takanis.

T'alihanis, cape ; see Bingham.

Takhin; mountain ridge, between Takhin river and Chilkat lake, southeastern Alaska. The native name of this ridge was reported by the Klause brothers, in 1882, to be T'akhinschă.

Takhin; river, tributary to the Chilkat from the west, near head of Lynn canal. Native name, reported by United States naval officers, 1880 , as Takheen. Krause's map of 1882 has 'Takhin. Has also been called Tahini and 'Taklini. The above form, Takhin, has been adopted by the Canadian Board on Geographic Names.

Takhini; river, a left branch of Lewes river, on which is Kusawa lake. Native name, reported in 1883 by Schwatka, who writes it Tahk-heen-a. According to Schanz, 1890, the Chilkat Indians call this river Seer-kwet (Sirkwet), written also Cirquet, and know nothing of the name Takhini. This is the name which Krause brothers, 1882, wrote Ssergoít, and applied to that part of the river above Kusawa lake. The above form, Takhini, has been adopted by the Canadian Board on Geographic Names.

Takiketak; Eskimo village, on the eastem shore of Kuskokwim bay. Name from Nelson, 1878-79, who wrote it Takikatagamute, i. e., 'Takiketak people. Population in 1880, 21.

Talilek, cipe; see Aklekg.

Takli; island, between Katmai and Kukak bays, on north shore of Shelikof strait. Native name, from the Russians, who wrote it Takali and Takhli Erroneously Tachli and Tachti.

Takome, lake; see Tagish.

Takshak; ILskimo villige, on right bank of lower Yukon river, near Razboinski. Name from Dall, 1869. Usually written Takshagemut, i. e., Takshak people.

Takshak, village; see Chukchuk.

Takshilik; creek, tributary to Kanektok river from the south, about 30 miles above the Kanektok's mouth. Native name, from Post, 1898, who wrote it Táchshilik.

T'aksumut, village; see Takchuk.

Taku; chitinel, off the Yukon delta, leading into Kwikluak and Kwemeluk passes, near latitude $62^{\circ} 30^{\prime}$, longitude $165^{\circ} 20^{\prime}$. So named by Putuam, 1.899, probably after the Coast Survey steamer $T a k u$.

Taku; glacier, at the head of Taku inlet, southeastern Alaska, near latitude $58^{\circ} 30^{\prime}$, longitude $134^{\circ} 05^{\prime}$. So known locally and to geologists, tourists, and navigators. It was çhristened Schulze in 1883, after Paul Schulze, president of the Northwest Trading Company, and Foster in 1890, by the Coast Survey, after Hon. Charles Foster, Secretary of the Trensury. The Indian name, according to Miss Scidmore, is Klumū Gutta, Klumma Gutta, or Sitth Klumū Gutta (the spirit's home).

Taku; harbor, indenting the mainland in Stephens passage, Alexander archipelago. A native name, first applied by Vasilief in 1848. Variously written Taco, Tacou, Takou, etc.

Taku; inlet, opening into Stephens passage, southeastern Alaska. Native nime, variously written, Taco, Tacou, Tahko, etc. It is Lothianoi (icy) arm of Tebenkof, 1849. Has also been called Glacier inlet.

Taku; lake, draining into 'laku harbor. So called by Thomas, 1888.

Taku; mountain (2,170 feet high), on the mainland, near Taku larbor, Stephens passage, southeastern Alaska. 'So called by Thomas, 1888. . 
Taku; pass, into the interior by way of the Taku river. Local name, first applied by Vasilief, 1848. Variously written Taco, Tahko, Takou, etc.

Taku; point, on the eastern shore of Taku inlet, southeastern Alaska.

Taku; river, of British Columbia and southeastern Alaska, tributary to the head of Taku inlet.

Taku; village, at head of Taku harbor, Stephens passage, Alexander archipelago. Has appeared on charts as Taku settlement and Takou villages.

Ta-ku-ten-ny, lake and river; see Kluane.

T'a-tcu-ten-ny-ee, lake and village; see Aishihik.

Takwaklanuk; slough, Yukon delta, opening on the right bank of Kwikluak pass, 13 miles below the head of the delta, near latitude $62^{\circ} 41^{\prime}$, longitude $164^{\circ} 05^{\prime}$. Eskimo name, obtained by Putnam in 1899 .

Talbiksok; river, tributary to the lower Yukon from the south, near or at the Yukon-Kuskokwim portage. Native name, from Raymond, 1869, who wrote it Talbiksokh. Variously written Talbigsak, Talbiksak, etc.

Talkeetna; mountain range, north of Cook inlet, between the Matanuska and Susitna rivers. The name Talkeetna was proposed by Eldridge, 1898, and published in his report, where he says the last syllable is often pronounced no. Talkeet-na or Talkeet-no means Talkeet river. Written Talkutna by Mendenhall.

Talkeetna; river, north of Cook inlet, tributary to the Susitna from the east, near latitude $62^{\circ}$. Native name, from Eldridge and Muldrow, 1898, who wrote Talkeetna, i. e., Talkeet river; said to mean river of plenty.

ralkutna, river and mountains; see Talkeetna.

Tall Tree; point,.in Sawmill cove, Howkan strait, Cordova bay, Alexander archipelago. So named by Sheldon Jackson, 1880.

Talnika, point; see Willow.

Talsekwe; river, tributary to Taku river from the north, near the international boundary line, southeastern Alaska. Native name, given by the Coast Survey, 1895, as Taltakay ; in 1898, as Tolusque (or possibly Slocah) ; and in 1899, as Tallsaykway.

- Tralsona, creek and town; see Tulsona.

Tamgas; harbor, indenting the southern shore of Annette island, Alexander archipelago, near latitude $55^{\circ} 03^{\prime}$, longitude $131^{\circ} 32^{\prime}$. Surveyed and so called by Etolin, 1833. 'Presumably a native name, identical with Tongass, but kept in this form to prevent confusing the two places.

Tamgas; lake, on Annette island, eastern shore Tamgas harbor, Alexander archipelago. So called by the fisheries, and reported by Moser in 1901.

Tamgas; mountain (3,684 feet high), in the southeastern part of Annette island, Alexander archipelago. So named by Nichols, 1883.

Tamgas; reef, in Felice strait, Gravina group, Alexander archipelago. So named by Nichols, 1883.

Tan. This is said to be the native name for cape or point as used by the Indians about Cook inlet. It is added as a final syllable. Thus, Kukistan, i. e., Kukis cape.

Tana; glacier and river, tributary to the Chitina from the south. Native name, from a manuscript map made by prospectors in 1900 .

T'anaak, cape; see Paramanof.

Tanada; creek and lake, tributary to Copper river from the east, near longitude $143^{\circ} 30^{\prime}$. Apparently a native name, reported by Peters, of the Geological Survey, 1899.

Tanada; peak, 27 miles northeast of Mount Wrangell, and immediately south of Tanada lake. So named by Witherspoon, 1902. 
Tanadak; island, one of the westernmost of the Andreanof group, middle Aleu. tians. Aleut name, from Tebenkof, 1849. Has also been written Tanadakb. Perhaps it means crab place.

Tanadak; islet, east of and near Little Kiska, Rat island group, western Aleutians. Aleut name, from Lutke. Also written Tanadakh.

Tanadak; islet, near the eastern end of Amlia island, Andreanof group, middle Aleutians. Native name, from Tebenkof, 1849.

Tanaga; bay, indenting the western shore of Tanaga island, Andreanof group, middle Aleutians. So called by Sarichef, 1790. Tebenkof, 1849, called this Slava Rossie (Glory of Russia) bay, after the ship Glory of Russia, commanded by Billings, in whose company Sarichef was. So it appears on late maps as Glory of Russia bay.

Tanaga; island (6,975 feet high), one of the principal islands of the Andreanof group, middle Aleutians. Aleut name, from early Russian explorers. Lutke has Tanaga or Taniaga, and Grewingk indicates that the native name is Takawangha. Has also been written Tannagil.

T'anaga, island; see Little Tanaga.

Tanak; cape, the northermmost point of Umnak, eastern Aleutians. Veniaminof calls this cape Egorkovskoi, "noteworthy. for the enormous blocks thrown out by the explosion of Tulik volcano in 1817." The native village Egorovskoi, located here at that time, was destroyed, the natives, however, being absent. The village was rebuilt in Inanudak bay and is, presumably, the Nikolski village of to-day. Kuritzien, 1849 , calls this Tanak, the Aleut word for place and the Kodiak word for water.

Tanakh-angounalih, island; see Chuginadak.

T'anakihotlihaiak, village; see Tanakot.

Tanaklak; island, south of Great Sitkin, Andreanof group, middle Aleutians. Aleut name, from Tebenkof, 1849. Has also been written Tanakblakh.

Tanakot; native village, on north bank of the Yukon, near mouth of the Melozi river. Population in 1880, 52. The Tenth Census (1880) gives as the name of a town near this locality Tanakhotkhaiak. On later maps it appears as Tahnohkalony.

Tanana; glacier, in latitude $62^{\circ}$, longitude $142^{\circ} 30^{\prime}$. So named by the Geolog. ical Survey in 1.898 .

Tanana; post-office (established in September, 1898), on north bank of Yukon river, at mouth_of the Tanana. At this place is the new St. James Mission, and Fort Gibbon is a few miles below.

Tanana; river, of central Alaska, tributary to the Yukon; literally Tanan-na, i. e., Tanan river, and said to mean river of the mountain men. According to Allen its upper part is called Nabesna by the natives. It was known to the traders of the Hudson Bay Company as Gens des Buttes. Has been variously written Tananah, Tannanah, Tennanab, etc., but it is now universally known as the Tanana.

Tanana; trading station of the Northern Commercial Company, on the north bank of Yukon river, near the mouth of the Tanana: This station is located 1 mile above Weare, on the site of the old Indian village of Nuklukayet, and below St. James mission. Going upstream comes Fort Gibbon, Weare, Tanana station, and St. James mission. The distance from the fort to the mission is 3 or 4 miles. Tanana post-office is either here or at Weare.

Tanana Crossing; telegraph station, on the Tanana river, near longitude $133^{\circ}$ $30^{\prime}$.

T'ananei, village; see Chilkoot. 
Tanani; Indian village, just north of Haines, near head of Chilkoot inlet, southeastern Alaska. Native name, reported by the Krause brothers in 1882.

Tanaskan; bay, indenting the southern shore of Beaver bay, Unalaska, easteru Aleutians, neạr latitude $53^{\circ} 43^{\prime}$, longitude $166^{\circ} 29^{\prime}$. Aleut name, from Sarichef, 1792, who wrote it 'Taneska. Veniaminof, however, writes it Tanaskan. It means vegetable garden. It is Macks bay of the Fish Commission, 1888.

Tangent; peak (2,449 feet high), on the mainland, west of Farragut bay, southeastern Alaska. So named by Thomas, 1887.

Tangent; point, the eastern point of entrance to Dease inlet, east of Point Barrow, Arctic ocean. So named by Dease and Simpson in 1837, who say "The land *** turned sharply off to SSW., forming an acute angle well termed Point 'Tangent."

Tanghinalk, islet; see Pustoi.

Tangik; islet, near the eastern shore of Akun island, Krenitzin group, eastern Aleutians, near longitude $165^{\circ} 30^{\prime}$. So called by Tebenkof, 1849. Tangik is Aleut for island. Called Waverly island by the Fish Commission, 1888.

Tangimak, island; see Karpa.

Tangimak, island; see Little Koniuji.

Tanginak; islet (200 feet high), east of Akun island, in Unimak pass, eastern Aleutians, near longitude $165^{\circ} 19^{\prime}$. Native name, from Tebenkof, 1849. Perhaps it is simply the Aleut Tangidal (islet). The Fish Commission, 1888, called it Breed island. Has also been called Propagation island.

Tangle; lakes, at source of the Delta river, near longitude $146^{\circ}$. So named by Mendenhall, 1898 .

Tanglefoot; small bight, at Karluk head, on north shore of Kodiak. A cannery was built on the beach here in 1893. Locally known as Tanglefoot bay.

Tanignag-miut, settlement; see Aleksasbkina.

Tanis; glacial stream, in the St. Elias alps, a little north of the mouth of the Alsek. So called by 'Tebenkof, 1849. Apparently a native name. See Ustay.

Tannak, island; see Little Tanaga.

Tanner; hẹa, a high peninsula, 4 miles long. in Alitals bay, southwestern shore of Kodiak, extending northeast from Cape Alitak. So named by Moser in 1900, probably after Lieutenant-Commander Zera Luther Tanner, U. S. N., who commanded the Fish Commission steamer Albatross in Alaskan waters, 1888 to 1893 , inclusive.

Tano, island; see Chuginidak.

Tanogtukan; lake, on the north coast of St. George island, Bering sea, near Staraya Artil rookery and longitude $169^{\circ} 36^{\prime}$. Aleut name, written 'Tănōgtŭk'ăn-än' yi (old village lake) by Putnam in 1897. So called from the ruins of an old village near.

Tantallon; point, the southeastern point of Douglas island, Stephens passage, Alexander archipelago. So named by Dall in the Coast Pilot (1883, p. 171).

Tanunak; Eskimo village, at Cape Vancouver, Nelson island, Bering sea. Name from Nelson, who visited it in December, 1878. Usually written Tununak and sometimes Tununuk. Is also called Dununak in the Eleventh Census. Father Barnum, who established a mission here in 1891, since abandoned, writes Tununa. 
Taoatin; mountain, on the right bank of the Yukon, near Kaltag. Name published by the Coast Survey in 1898.

Tapirag, mountain; see Fourpeaked.

Tapor, point; see Hatchet.

Tar; stream, on the southwestern const of Prince of Wales island, southeastern Alaska, south of Hunter bay. Called Tar by the fisheries, and so described by Moser in 1897.

Taral; creek, tributary to Copper river from the enst, at Taral. Locally called Taralna, i e., Taral river.

Taral; village (of 2 houses in 1885), on left bank of Copper river, a little below the mouth of the Chitina; also creek tributary to the Copper from the east, at this village. Native name, reported as Tarál by Allen, 1885.

Taranovokovik; pass or channel, Yukon delta, connecting the mouths of Kwikluak and Kwemeluk passes, near latitude $62^{\circ} 33^{\prime}$, longitude $164^{\circ} 50^{\prime}$. Eskimo name, obtained by Putnam in 1899, and written Taranovokckovik.

Tarasof; bay, indenting the eastern shore of Makushin bay, Unalaska. It is immediately east of Old Harbor. So called by Veniaminof, 1840.

Target; islet, in Mitchell bay, Kootznahoo inlet, Admiralty island, Alexander archipelago. Named by Meade, 1869, in commemoration of the target practice had there.

T'arpluwa; Eskimo village, on the coast, north of Cape Prince of Wales, Seward peninsula. Reported by Lieutenant Bertholf, Revenue-Cutter Service, 1897 , but not found on any map.

Tasekpuk; lake, on the Arctic coast, about 80 miles enst of Point Barrow, near longitude $153^{\circ}$. In Ray's vocabulary it is written Tăs' yôk poñ, while Jarvis writes Tesukpuk. Eskimo name, the termination puk or pung meaning big and Tasyuk, inclosed vater, or bay.

Tashalich; river, 8 miles east of Cape Suckling, Gulf of Alaska, near longitude $143^{\circ} 45^{\prime}$. Native name, from Martin, 1904, who wrote it 'Tash-a leach.

Tashuk, bay; see Elson.

Tastina, river; see Tazlina.

Taslinamna; lake, a few miles east of Kenai, on the Kenai peninsula. Native name, from Wosnesenski, about 1840. Perhaps the termination amna means lake (mina).

Tasmuna; river, tributary to the Copper from the west, opposite Bremner river, about 55 miles from the coast. Native name, from Allen, 1885, who wrote it Tasnuná; i. e., Tasnu river.

Tasuk, bay; see Elson.

T'asyulk, bay ; see Elson.

T'asyukpung, lake; see Tasekpuk.

T'atatontly, lake; see Mentanontli.

Tratchek, Eskimo village; see Techek.

Tatchik, bay and sound; see Golofnin.

Tatena, river; see Dadina.

Tateno, river, tributary to Kuskokwim ; see Rohn.

Tatitlek; narrows, northeastern shore Prince William sound, between Bligh island and the mainland, near latitude $60^{\circ} 52^{\prime}$, longitude $146^{\circ} 40^{\prime}$. So called by Ritter, 1903, who wrote it Tatitlack.

Tatitlek; village, on Tatitlek narrows, northeastern coast of Prince William sound. Native name, which has been spelled Tatikhlek, Tatilack, Tatitlak, etc. According to Gerdine it is pronounced Tay-tét-lěk. Formerly it stood at the head of Gladhaugh bay, but "some years ago" was moved to its present site near Copper mountain. 
Tatlalinguk; pass, 4 miles long, Yukon delta, opening into the north side of Apoon pass, $1 \frac{1}{2}$ miles below Kotlik, near latitude $63^{\circ} 03^{\prime}$, longitude $163^{\circ} 30^{\prime}$. Eskimo name, obtained by Faris in 1899 .

Tatlathna; river, a large affluent of the East fork of Kuskokwim river, on the left, near longitude $153^{\circ}$. Native name, obtained by Herron, 1899, who wrote it Tatlathno, na or no meaning river.

Tatonduk; river, crossing the international boundary, and tributary to the Yukon from the northeast. Indian name, written Tatondu and Tatonduc by Spurr's party, 1896. The Canadian Board on Geographic Names bas adopted the form here given.

Tatoosh; islands and rocks, in northern entrance to Behm canal, east of Betton island, Alexander archipelago. Islands so named by the Coast Survey in 1886 and since applied to the rocks by local navigators.

Tatoosh; point, the northwestern point of Betton island, 2 miles north of Tatoosh islands, northern entrance to Behm canal, Alexander archipelago, near latitude $55^{\circ} 32^{\prime}$, longitude $131^{\circ} 48^{\prime}$. Name so applied by local navigators, and reported by H. C. Fassett, Bureau of Fisheries, 1904 .

Ta-toot-lee, butte; see Boundary.

Tatotlinda, creek; see Mission.

Tatshenshini; river, tributary to the Alsek river. Native name, reported in 1882, by Krause as Tatschanzhini and variously spelled. The above form, Tatshenshini, has been adopted by the Canadian Board on Geographic Names.

Tava; island, one of the Necker island group, Sitka sound, Alexander archipelago. Named Tava (tent) by Vasilief, 1809. According to George Kostrometinoff, United States court interpreter at Sitka, Tava is Aleut for enough.

Tawah; inlet and stream, on Phipps peninsula, south shore De Monti bay, Yakutat bay, near longitude $139^{\circ} 45^{\prime}$. Indian name, written Ta-wah by Moser in 1901. This is the stream which on the charts is usually named Ankau creek. According to Moser the Tawah and Ankau have the same source. The Tawah flows west into De Monti bay and the Ankau flowing east debouches on the coast; 9 miles southeast of Ocean cape.

Taxlina, river; see Tazlina.

Taylor; bay, north shore Cross sound, southeastern Alaska, near latitude $58^{\circ}$ $15^{\prime}$, longitude $136^{\circ} 30^{\prime}$. Named by Dall in the Coast Pilot $(1883, \mathrm{p}$. 186), after Mr. C. H. Taylor, of Chicago, who visited it prior to 1883.

Taylor; creek, tributary to the Kougarok river from the east, Seward peninsula. Name from Brooks, 1900.

Taylor; islands, on the eastern shore of Taylor bay, Cross sound, southeastern Alaska. So named by Pratt, 1901.

Taylor; lagoon, 5 miles west of Topkok head, south shore Seward peninsula, near longitude $164^{\circ} 10^{\prime}$. Prospectors' name, Taylor's, published in 1904.

Tazimina; river, tributary to Lake Clark from the east, near its outlet and latitude $60^{\circ} 10^{\prime}$, longitude $154^{\circ} 30^{\prime}$. Indian name obtained by Osgood, 1902, who wrote Tazimeena. The Indian word mina means lake.

Tazlina; glacier, at source of Tazlina river. Called Taxlina by Mendenhall, 1898, who took the name from Allen's map of 1885. Allen used the native name Tezlina for the river in his text and the same, though obscurely printed, on his map. Tazlina means Tazli river. 
Tazlina; lake, on Tazlina river. Serebrenikof, in 1848, ieported the name of this lake as Plavezhnoi. From this has come Pleveznie of some maps. This lake, which is drained by the Tazlina river, is now known locally as Tazlina.

Tazlina; river, tributary to the Copper from the west, near latitude $62^{\circ} 03^{\prime}$. Corruption of an Indian name, given as Tlieshitna by Serebrenikof, in 1848, and by Allen, in 1885, as Tezliná, i. e., Tezli river. The usage of miners and prospectors is Tazlina. Has been written Taxlina and Tazlena.

Tchakhikh, cape; see Chakik.

T'chakoch, stream; see Chakok.

Tchaseni, point; see Chasina.

Tchegoulak, island; see Herbert.

Tchernobour, islet; see Chernabura.

Tchernoboury, islet; see Chernabura.

Tchiboukoukak, cape and native village; see Chibukak and Gambell.

Tolibukak, cape and village; see Chibukak and Gambell.

Tchighinagal, bay and mountain; see Chiginagak.

Tchigul, island; see Chugul.

Tchillkat, inlet, peak, etc. ; see Chilkat.

Tchineyak, cape; see Chiniak.

Tchintitanay, bay; see Sitka sound.

T'chirikoff, island; see Chirikof.

T'chitchagow, cape; see Chichagof.

Tchitnak, village; see Chitnak.

T'chougatskoi, mountains; see Chugach.

T'choughinadokh, island; see Chuginadak.

Tchougoulak, island; see Chugul.

T'chougoule, island; see Chugul.

Tchougoulok, island; see Chugul.

Tchounol, cape; see Chunak.

I'chuk, cape; see Stephens.

T'chuna, cape; see Chunu.

T'Click, landing; see Tklik.

Tear; islet, one of the Ball group, Sitka sound, Alexander archipelago. So named by United States naval officers, 1880.

Tebay; river, tributary to the Chitina from the south, about 30 miles above its mouth. So called by Allen, 1885, who says that Tebay is the Indian name of a variety of sheep.

Tebenkof; bay, indenting the western coast of Kuiu island, Chatham strait, Alexander archipelago. Named Tebienkof bay by Dall, 1879; after Capt. Michael Dmitrievich Tebienkof or 'Tebenkof, governor of the Russian-American colonies $1845-1850$. This name has been variously

. transliterated Tebenkoff, Tebenkov, Tebienkoff, etc. Called also Kon bay.

Tebenkof, bay; see St. Michael.

Tebenkof; mountain (4,100 feet high), east of Yakutat bay, southeastern Alaska. Named by Russell, in 1890, after Capt. Michael Dmitrievich Tebienkof or Tebenkof, governor of the Russian-American colonies 1845-1850. Both the forms Tebienkof and Tebenkof have been much used.

Tebooktolic, river; see Tubutulik. 
Techek; the native name of the Eskimo village at St. Michael, tĕchĕk, the bay, Written also Tatchek. Compare with Tashuk, Tasyuk, 'Tasek, etc., of the northern Eskimo.

Tee; harbor, indenting the mainland in Favorite channel, Lynn canal, Alexander archipelago. Named Stephens cove by the Coast Survey in 1897 . Called Tee harbor by the local navigators from its resemblance to the letter $\mathrm{T}$.

Tee-at-iolkwik. Dall, writing in 1869 , gives this as the native name of a stream in the Yukon delta a little north of Black river.

Tefaknak; Eskimo village, of 10 houses, in the delta between the Kuskokwim and Yukon rivers. Called Tefaknaghamiut, i. e., Tefaknak people, in the Eleventh Census, 1890. Population, 195.

T'eikhell, river; see Tiekel and Uranatina.

T'eikhell, telegraph station; see 'Tiekel.

Telegraph; bill, about $1 \frac{1}{2}$ miles north of St. Paul village, St. Paul island, Pribilof group, Bering sea. Presumably a local name, published by the Coast Survey in $\mathbf{1 8 7 5}$.

Telemitz; islet, one of the Sannak group, 3 miles south of the eastern end of Sannak island, near latitude $54^{\circ} 21^{\prime}$, longitude $162^{\circ} 31^{\prime}$. . So named by Westdahl, 1901.

Telida; Indian village and lake, in the upper Kuskokwim region, on the right bank of Tatlathna river, near latitude $63^{\circ} 30^{\prime}$, longitude $152^{\circ} 30^{\prime}$. Indian name reported by Herron, 1899, may be from telia (fish).

Telitzototel; river, in the Kuskokwim region, a right branch of the Hitzikolok, near latitude $63^{\circ} 15^{\prime}$, longitude $153^{\circ}$. Indian name, obtained by Herron, 1899, who wrote Tel-itz-o-to-lel-no; no means river.

Teller; creek, Seward peninsula, tributary to South Fork of Serpentine river from the west, near latitude $65^{\circ} 50^{\prime}$, longitude $165^{\circ} 20^{\prime}$. Prospectors' name, reported by Gerdine, 1901.

Teller; reindeer station, Grantley harbor, Seward peninsula. Established by Sheldon Jackson, 1892, and named by him after Hon. Henry Moore Teller, Secretary of the Interior. Afterwards moved to north shore of Port Clarence. Now there is a town and post-office (established in April, 1900) on the spit forming the south point of entrance to Grantley harbor. 'This place is called locally and by " the old-timers" The Nook, a name derived from the Eskimo. Beechey, 1827 , says the natives call it Nooke, or, as we would now write it, Nuk. Dall (1869) wrote Nookmut and Petrof (1880) Nookmute, i. e., Nook people.

Teltakhatskahin, river; see Little Boulder creek.

Temnie, island; see Dark.

Tenakee; inlet, indenting the northeastern shore of Chichagof island. Native name, adopted by the Coast Survey in 1869. A portage 150 yards long is said to connect its head with Port Frederick. Variously designated as a canal, channel, inlet, and passage and named Berry, Blind, Siwash, and Tenakee.

Tenakee; post-office (established in 1903), eastern shore Tenakee inlet, Chichagof island, Alexander archipelago.

Tenas; creek, tributary to Copper river from the east. Chinook name, meaning little, given by the prospectors.

Tenas; gulch, in the Copper River region, at headwaters of Chititu creek. Prospectors' name, reported by Schrader, 1902. Tenas is a Chinook word meaning small.

Tenazie; peak, near the international boundary line, on the headwaters of old Crow river, near latitude $68^{\circ}$. So called by the Coast Survey in 1895 . 
Ten Fathom; anchorage, in Redfish bay, Baranof island, Alexander archipelago. So called by Moser, 1897.

T'ennanah, river; see Tamana.

Tenounam, island; see Seguam.

I'enrarum-anyi, St. George island; see Bear lake.

Tent; mountain (7,100 feet high), on the mainland, at head of Tracy arm, Holkham bay, southeastern Alaska. Name published by the Coast Survey in 1895 .

Tent; point, on the western shore of Tamgas harbor, Annette island, Alexander archipelago, near latitude $55^{\circ} 04^{\prime}$, longitude $131^{\circ} 32^{\prime}$. So named by Nichols in 1883. His observation tent was erected at this point. Called also Observatory point.

Teocalli; mountains, on the right bank of Kuskokwim river, near lititude $62^{\circ}$. So named by Spurr, 1898 , from fancied resemblance to the Aztec temples.

Terbilon; island, near Woodhouse point, Biorka island, Sitka sound. So named by Vasilief in 1809 .

Terentief; station, on north bank of Yukon river, a little below mouth of the Koyukuk. Called Terentief's station by Petrof, 1880, presumably after: its owner or occupant. Population in 1880, 15. See Koyukuk.

Teresa; creek, southeastern slope Alaska peninsula, tributary to Cold bay, near latitude $57^{\circ} \cdot 45^{\prime}$. Local name, after the schooner T'eresa, the wreck of which lies at its mouth. Reported by Martin, 1903.

Termination; cape, on the northern shore of Kodiak, near Spruce island. Named Okonchatelnie (termination) by Murashef, 1839-40.

Termination; point, on the northern shore of Alaska peninsula, very near its west end. Called Granichnoi (termination, boundary) by Tebenkof, 1849.

Termination; point, the northeastern point of Long island, Kootznahoo inlet, Admiralty island, Alexander archipelago. So named by Meade, 1869.

Termination; rock, near Termination point, Alaska peninsula. So named by Dall, 1880.

Terrace; mountain (6,000 feet high), west of and near Klutina lake. So named by Abercrombie, 1898.

Terrace; point, of mountain separating the Atrevida and Lucia glaciers, St. Elias alps, southeastern Alaska. So named by Russell, 1890.

Terra Cotta; mountains, on left bank of Kuskokwim river, near latitude $62^{\circ}$. So named by Spurr, 1898, "from their superb and peculiar coloring."

Teslin; lake, and river tributary to the upper Yukon; often called Hootalinqua or Teslin. On early charts mistakenly called the Tahko. It is the Newberly river of Schwatka. The above form, Teslin, hats been adopted also by the Canadian Board on Geographic Names.

T'estigos (Los), islets; see Witnesses (The).

Tesukpuk, lake; see Tasekpuk.

Tetahina, river; see Bremner.

Tetelna, creek, tributary to Copper river; see Indian.

Tetling; river, tributary to the Tanana from the south, near longitude $142^{\circ}$. So called by Lowe in 1898 .

Tetling; village (two houses), on Tetling river. Named, 1885, by Allen, after an Indian. Lowe, who visited it in 1898, calls it Tetlings and says it is composed of four log houses on the right bank of Tetling river. Its chief was David.

Teufelsberg, mountain; see Devil. 
Tevelma; creek, northern Alaska, tributary to Colville river from the south, near longitude $155^{\circ} 15^{\prime}$. Eskimo name, obtained by Peter's and Schrader, 1901.

Texas; creek, tributary to Canyon creek from the south, Seward peninsula. Name from Barnard, 1900.

Texas; creek, eastern Alaska, tributary to Fish creek, an affluent to North fork Fortymile creek from the south, near latitude $64^{\circ} 25^{\prime}$, longitude $142^{\circ}$ 35'. Prospectors' name, from sketch map compiled by Major Glassford, Signal Corps, U. S. A., 1905.

Tezlina, glacier; see Tazlina.

Thaghian; creek, a branch of Ankau creek, 7 miles southeast of Yakutat. Indian name, reported by Moser, 1901, as Tha-ghe-an. Called also Lost creek.

Thakanis, bay ; see Takanis.

Thanksgiving; creek, draining south to Baker flat, along the Tanana river, near latitude $65^{\circ}$, longitude $150^{\circ} 15^{\prime}$. Prospectors' name, reported by Prindle, 1904.

Thanksgiving; creek, eastern Alaska, tributary on south bank of the Yukon, near longitude $143^{\circ} 40^{\prime}$. Prospectors' name, reported by Witherspoon, 1905:

Thatcher; point, forming the southern point of eastern entrance to Peril strait, Alexander archipelago. So named by Meade, 1869, after Rear-Admiral Henry Knox Thatcher, U. S. N. It is Coleman point of Homfray in 1867. The native name is reported to be Shkaliakh or Schkaliakh.

Thekonda, creek; see Cooper.

Theodore; point, the southernmost point of Yakobi island, Alexander archipelago. Named Theodor by Dall, 1879, after Capt. Urey Feodorovich Lisianski, the first one to show any of the details of this region. It is Cape Cross of some charts.

Theodore; river, tributary to Cook inlet, near its head. Name published by the Geological Survey in 1898.

Theresa; creek, Seward peninsula, tributary to Independence creek, an affluent of Kugruk river and Kotzebue sound, near latitude $65^{\circ} 35^{\prime}$, longitude $162^{\circ} 20^{\prime}$. Prospector's' name, reported by Witherspoon, 1903.

Thetis; coal mine, on the Arctic coast, at Cape Sabine, east of Cape Lisburne. So named after the U. S. S. Thetis, which coaled here in 1889 .

Thetis; creek, northwestern Alaska, debouching on the Arctic coast, 8 miles west of Cape Sabine, near longitude $165^{\circ}$ : The so-called Thetis coal mine is near its mouth. So called by Peters and Schrader, 1901.

Thetis, islands ; see Jones.

Thick, point; see Broad.

Thin; point, the western point of entrance to Cold bay, near western end of Alaska peninsula, about longitude $162^{\circ} 34^{\prime}$. Named Tonkoi (narrow) by Tebenkof, and variously called Slim, Thin, Tonki, etc.

Thin Point; cannery, established in 1889 at Thin point, the western point of entrance to Cold Bay, Alaska peninsula.

Thin Point; cove, on the southern shore of the Alaska peninsula, immediately west of Thin point. Name published by the Coast Survey in 1902.

Third Kekur; isolated rock or rocky islet, off the southwestern coast of Baranof island, Alexander archipelago. Also written Kekour and Kekoor. See Kelkur.

Thirtyfivemile; bar, in Yukon river. May be that distance below Circle. River pilot's name, taken from Edwards' Track Chart of the Yukon, 1899 , where it is written 35 Mile. 
Thirtymile; river, tributary to the Yukon from the north; about that distance above Circle. Local name, reported by Collier, 1902.

Thirtysixmile Crossing; channel, in Yukon river, at Linda bar. May be 36 miles below Circle. River pilots' name.

Thistle; creek, tributary to Feather river from the north, Seward peninsula. Name from Barnard, 1900.

Thistle; ledge, near Point Lookout, Stephens passage, Alexander archipelago. Name published by the Coast Survey in 1895 . Discovered in 1893 by Otto J. Klotz, and named by him after his steamer.

Thistle; rock (10 feet above high water), near Cape Fox, in Dixon entrance. So named by Nichols, 1883: Erroneously Whistle on one chart.

Thomas; bay, indenting the mainland coast, northeast of Kupreanof island, Alexander archipelago. Named by the Coast Survey, 1887, after Lieut. Commander Charles Mitchell Thomas, U. S. N., who surveyed it in that year.

Thomas, bay; see Clover.

Thomas; cape, the westernmost point of Wrangell island, Arctic ocean. Discovered by Capt. Thomas Long, of the New London whaling bark Nile, August 14, 1867, and by him named Thomas, after the seaman who first reported the lind.

Thomas; creek, Seward peninsula, tributary to Candle creek from the west, near latitude $65^{\circ} 50^{\prime}$, longitude $162^{\circ} 05^{\prime}$. Prospectors' name, reported by Witherspoon, 1903 .

Thomas; creek, Seward peninsula, tributary to Goodhope river ${ }^{\circ}$ from the north, near latitude $65^{\circ} 42^{\prime}$, longitude $163^{\circ} 25^{\prime}$. Prospectors' name, reported by Mendenhall, 1901.

Thomas; creek, eastern Alaska, small tributary on north bank of Birch creek, near lạtitude $65^{\circ} 20^{\prime}$, longitude $145^{\circ}$. Prospectors' name, reported by Witherspoon, 1905.

Thomas; island, in Helm bay, western shore Behm canal, southeastern Alaska, near latitude $55^{\circ} 36^{\prime}$, longitude $131^{\circ} 57^{\prime}$. Local navigator's' name, reported by H. C. Fassett, Bureau of Fisheries, 1904.

Thomas; mountain (5,400 feet high), near Port Valdez, Prince William sound. Named by Abercrombie, 1898, presumably. after Gen. George Henry Thomas, U. S. A.

Thomas; rock, off the southeastern end of Raspberry island, between Afognak and Kodiak islands, near latitude $58^{\circ}$. Local name, reported by Moser, 1900 .

Thompson; cape, the northernmost point of Big Koniuji island, Shumagin group. So called by Dall, 1880.

Thompson; cape, on the Arctic coast, a few miles southeast of Point Hope. "A high cape," says Beechey, August, 1826, "which I named after Mr. Deas Thomson, one of the Commissioners of the Navy." In his text Beechey spells it Thomson, but on his map Thompson. Near it Beechey adds Cape Ricord of the Russians. The Eskimo name is Webuk or Wevok, which is also the name of Cape Lisburne, distinguished as Webuk Unasiksuk (far) for Cape Lisburne and Webuk Konikto (near) for Cape Thompson.

Thompson; creek, 25 miles north of Nome, Seward peninsula, tributary from the south to Stewart river at its source, near latitude $64^{\circ} 50^{\prime}$, longitude $165^{\circ} 18^{\prime}$. Local name, reported by Gerdine, 1904.

Thompson; creek, 9 miles north of Nome, Seward peninsula, tributary to Snake river from the west, near longitude $165^{\circ} 28^{\prime}$. Local name, published in 1901. 
Thompson; creek, tributary to Klokerblok river from the north, Seward peninsula. Name from Barnard, 1900.

Thompson; creek, tributary to Port Clarence from the north, Seward peninsula. Name from Barnard, 1900.

Thompson; creek, tributary to Walker fork Fortymile creek from the right, near latitude $64^{\circ}$, longitude $141^{\circ} 20^{\prime}$. Prospector's' name, from map in Coast Survey archives drawn by E. F. Ball, a prospector, in 1898.

Thompson, creek; see Shaw.

Thompson, island; see Galankin.

Thoms; salmon stream and lake, Wrangell island, Alexander archipelago, drain- $\quad$ ing into a rocky bay near the southern end of Zimovia strait on the east side, about latitude $56^{\circ} 10^{\prime}$, longitude $132^{\circ} 10^{\prime}$. Called Old Village stream by Moser in 1897, and Thoms (Aw-aw) in 1900; "better known as Thoms."

Thomson; pass (2,330 feet high), east of Valdez, Prince William sound. Named by Abercrombie, 1898, after Hon. Frank Thomson, of Pennsylvania. On his map it is spelled Thompson.

Thomson; point, on the Arctic coast,'near Flaxman island. So named by Franklin, 1826. It is Thomson in his text and Thompson on his map.

Thoms Place; a bight on the southwestern shore of Wrangell island, Zimovia strait, Alexander archipelago, near latitude $56^{\circ} 10^{\prime}$, longitude $132^{\circ} 07^{\prime}$. Local name, reported by Moser, 1900.

Thorne; arm, indenting the southern shore of Revillagigedo island, Alexander archipelago, near latitude $55^{\circ} 40^{\prime}$, longitude $132^{\circ} 30^{\prime}$. " Named in 1880 , by the Coast Survey, after Capt. Charles Thorne, long in command of the steamer California in these waters."

Thorne; bay, indenting the eastern shore of Prince of Wales island, Clarence strait, Alexander archipelago. Named, 1891, after Frank Manley Thorme, Superintendent of the Coast Survey.

Thorne; head, on the north side of entrance to Thorne bay, Clarence strait, southeastern Alaska. So applied by local navigators, and reported by H. C. Fassett, Bureau of Fisheries, 1904.

Thorne; island, in Kashevarof passage, Clarence strait, Alexander archipelago. So named by Snow, 1886, presumably after F. M. Thorne, then Superintendent of the Coast Survey.

Thornton; mountain, near Point Higgins, in western part of Revillagigedo island, Alexander archipelago. So named by Nichols, 1883.

Thorp; creek, Seward peninsula, small tributary on east bank of Casadepagil river, near latitude $64^{\circ} 53^{\prime}$, longitude $164^{\circ} .12^{\prime}$. Prospectors' name, from a local map, 1901.

Thousand Flowers; point, on southern shore of San Juan Bautista island, Bucareli bay, Prince of Wales archipelago. Named Punta de los Miliflores (point of a thousand flower's) by Maurelle and Quadra, 17751779.

Three Arm; bay, indenting the western shore of Adak island, Andreanof group, middle Aleutians. Descriptive name, given by Gibson, 1855. Also called West or Three Arm bay.

Three Brothers; rocks, in entrance to Narrow strait, Kodiak. Named Tre Brata (three brothers) by Murashef, 1839-40.

Three Finger; point, the southern point of Albatross anchorage, Portage bay, Alaska peninsulit. So called in Hydrographic Office notice 48, 1893.

Three Hill; island . 1,300 feet high), near Port Althorp. in Cross sound. Alexander archipelago, near latitude $58^{\circ} 10^{\prime}$, longitude $136^{\circ} 24^{\prime}$. Descriptive name, given by Dall, 1880. Also written Threehill and Three-hill, 
Three Island; bay, between Usof and Protection bays, on southeastern shore of Unalaska, eastern Aleutians, near longitude $166^{\circ} 40^{\prime}$. Descriptive name, given by the Fish Commission in 1888.

Threemile; arm of Keku strait, Kuiu island, Alexander archipelago. So named by Moore, 1892 .

Threemile; creek, tributary to north shore of Cook inlet, between North Foreland and mouth of Beluga river. Name applied by Spurr, 1898.

Threemile; salmon stream, western coast Prince of Wales island, debouching on the north shore of Klawak lake, 3 miles from its outlet, near latitude $55^{\circ} 27^{\prime}$. Local descriptive name, written Three-mile by Moser in 1897.

Three Pillar; cape, in Kizhuyak bay, north coast of Kodiak. Named Trekh Kekurnie (three rocky pillars) by Murashef, 1839-40.

Three Rivers (Valley of); in northeast Alaska, at the head of,Firth river, near: latitude $68^{\circ} 40^{\prime}$ and the international boundary. Descriptive name, given by Turner, 1890 .

Three Snints; bay, behind Sitkalidak island, on the southeastern coast of Kodiak. Usually so called. Three Saints harbor is on the western shore of this bay. Tebenkof calls this bay Liakik, perhaps from liak, the Aleut name for the black-footed goose.

Three Saints; harbor, on the western shore of Three Saints bay, on the southeastern shore of Kodiak. Here, on August 3, 1784, arrived Shelikof, from Okhotsk, in the ship Three Saints, and established the first Russian settlement on Kodiak, naming it after his vessel. A few years later the settlement was moved to St. Paul, Kodiak. The place is often referred to as Old Harbor or Starri-gavan. Langsdorf in his Voyage (pp. 88,91 ) calls it Schelikoff harbor. A native village there is called Nunamiut. This name Three Saints bas, by a curious transformation, become Ziatitz on some maps. The Russian verb sviatit, to sunctify, whence sviatoi, a'saint, was written in Englisb, 1849, by the Russian skipper Archimandritof Zfiatit\%. The manuscript map. on which this appeared contains many words familiar to the student of the locality, but which are recognized with difficulty owing to the novel orthography: This manuscript map of Kodiak was publisbed by the United States Hydrographic Office in 1869 . On that map we have "Hr. of 3 Saints and Zfiatitz." One more change and we bave-on late charts-Ziatitz as the name of the native village Nunamiut.

Three Tree; point, $2 \frac{1}{2}$ miles southwest of Orca, Frince William sound, near latitude $60^{\circ} 33^{\prime}$, longitude $145^{\circ} 43^{\prime}$. Local name, reported by Gírant, 1905.

Throat; river, northwestern Alaska, the nortbwestern outlet of Inland lake, into Selawik river, near the Arctic circle and longitude $160^{\circ}$. Called Eegyak or Throat river by Cantwell, 1884.

Thron Duick, river; see Klondike.

Thumb; cove, indenting the eastern shore of Resurrection bay, Kenai peninsula, near latitude $60^{\circ}$, longitude $149^{\circ} 20^{\prime}$. So named by the U. S. Board on Geographic Names, June 6, 1906.

Thumb; point, on the southwestern shore of Liesnoi island, Eliza harbor, Frederick sound, Alexander archipelago. So named by Mansfield, 1889.

Thunder, bay and glacier; see Le Conte.

Thunder; falls, in Le Conte bay, soutbeastern Alaska. Descriptive name, given by Thomas in 1887 .

Bull. $299-06 \mathrm{м}-40$ 
Thunder; mountain (3,080 feet high), on the mainland, north of Le Conte bay, southeastern'Alaska. So named by Thomas, 1887.

Thunder; point, on the northern shore of Le Conte bay, southeastern Alaska. So named by Thomas, 1887 .

Thurston; creek, eastern Alaska, on the south bank of Seventymile creek, near its mouth, about latitude $64^{\circ} 55^{\prime}$, longitude $141^{\circ} 20^{\prime}$. Prospector's' name, from sketch map compiled by Major Glassford, Signal Corps, U. S. A., 1905 .

Tiakinak, island; see Simeonof.

Tianna. Immediately in front of the St. Elias alps and a little south of Yakutat bay is the place where Meares anchored in August, 1788, and which he called Tianna's Bay and also Tianna's Roads, after a native chief from the Hawaiian islands who accompanied him. Has been misprinted Diana Roads.

Tichai, harbor; see Still.

I'ichtinige, harbor; see Pyramid.

Tick; shoal, off the south point at entrance to Puget cove, Yakutat bay, southeastern Alaska. So named by Harber, 1892.

Tidal; inlet, on the northeastern shore of Glacier bay, southeastern Alaska. So named by Reid, 1890, who established a tidal station here.

Tide; island, off the north end of the Kashevarof group, Clarence strait, Alexander archipelago. So named by Snow, 1886.

Tidemeeting; point, in Kupreanof strait, Kodiak group. Named Spornaho Techenial (of contending currents) by Murashef, 1839-40.

Tiderip; cape, on the northern end of Afognak island, opposite Shuyak island. Named Silnaho 'Techenia (of strong currents) by the Russian-American Company, 1849 .

Tidgituk; islet, southwest of and near Tanaga island, middle Aleutians. Aleut name, from Tebenkot. who wrote it Tidgituk. Has also been written Tidgatukb.

Tiedeman; island, in Seymour canal, Alexander archipelago. So called by Dall in the Coast Pilot (1883, p. 129).

Tielagag-miut, village; see Tigara.

Tiekel; river, tributary to Copper river from the west, opposite the mouth of Dewey creek. Called Konsiná by Allen, 1885. Allen applies this name Tiekel (spelled Tiekhell on his map 2 and Zeikhell in his text, p. 46) to anotler river farther north, now known as Uranatina. Tiekel river is called by Abercrombie, 1898, Konsena or Tsaina. This last name, spelled 'T'sina, is now applied to the South fork of the Tiekel. The Signal Corps, U. S. A., has named a telegraph station. on Kanata river (south fork of Tiekel) Teikhell.

Tiekel; telegraph station on Kanata river, which is the south fork of Tiekel river, 58 miles northeast of Valdez. Named Teikbell by the Signal Corps in 1902.

Tieschenni, river; see Chistochina.

Tigalda; bay, indenting the northern shore of Tigalda island, Krenitzin group, eastern Aleutians. So named by the Fish Commission in 1888.

Tigalda; island (1,200 to 1,800 feet high), one of the Krenitzin group, eastern Aleutians, near longitude $165^{\circ}$. Native name, from Veniaminof. Kudiakof, 1791, wrote it Kigalga; Krenitzin and Levashef, 1768, have Kagalga and Kugalga. Has also been written Tigalga, Tigaida, Coogalga, Coagalga, and erroneously Croyalgu.

Tigara, river; see Kukpuk. 
Tigara; Lskimo village, at Point Hope, Arctic ocean. Tikbmenief, 1861, wrote Tiekagag-miut, which on Russian Hydrographic chart 1495, becomes Tiekaga. Petrof, 1880, wrote Tikirak, and reports a population in that year of 276. In Ray's vocabulary, 1883, it is written Tǐk-ě-rá (index finger). John W. Kelly's Eskimo vocabulary, publisbed by the Bureau of Education, gives Figarok as the name of this village. In the Eleventh Census it is spelled Tikera, and Herendeen gives Tik-i-rah as the name of Point Hope and Tik-i-ráh-mún, the name of the-village. Lieutenant Bertholf, 1898, wrote Tigera, and on Hydrographic chart 68, 1904, it is Tig-a-ra. Dr. John B. Driggs, missionary at Point Hope, writes the name Tig-a-rah; and Collier, of the Geological Survey, says that this represents the local pronunciation. It is also the Eskimo name of Point Hope, and all authorities agree means the index finger, or is derived from the name of that member. The latter Father Barnum writes Ťkók ; and Kelly, 'T́́keh or Tíkek.

Tigera, village; see Tigara.

Tiginagal, bay and mountain; see Chiginagak.

Tikchik; lake, and river draining it into Nushagak river from the northwest, near latitude $60^{\circ}$, longitude $159^{\circ}$. On the older maps this iake is always called Nushagak. Native name, reported by Schanz in 1890.

Tikchik; mountain, a conspicuous landmark on the right bank of the Nushagak river, near the mouth of Tikchik river. Reported by Osgood, 1902.

Tikchik; Eskimo village, on the north shore of Tikchik lake. Native name, from Petrof, 1880.

Tilitra, Eskimo village; see Tigara.

Tikizat; Eskimo village, at Cape Krusenstern, Arctic ocean. Eskimo name, from Petrof, 1880, who reported a population in that year of $\mathbf{7 5}$.

Tiktakaluk, islets; see Kiktagaliuk.

Till; creek, northern Alaska, tributary to John river from the east, near latitude $68^{\circ}$, longitude $152^{\circ} 15^{\prime}$. Name from Peters and Schrader, 1901 .

Tillman; mountain between Mount Wrangell and Copper river. So located and named by Allen, 1885, in honor of Prof. Samuel Escue Tillman, of the United States Military Academy. He gave its height as 15,500 feet. There is no such mountain in this position and it is now known that the mountain Allen really saw was Mount Wrangell which he failed to recognize from this point of view.

Tilted; hills, on the west shore of Cook inlet, extending from Chinitna bay to Iniskin bay, near latitude $59^{\circ} 45^{\prime}$. So named by G. C. Martin, 1903, from "topograpic forms due to outcrop of resistant monoclinal beds."

Timber; creek, Seward peninsula, tributary to Koyuk river from the south, near latitude $65^{\circ} 20^{\prime}$, longitude $162^{\circ} 10^{\prime}$. Prospector's' name, reported by Witherspoon, 1903.

Timber; knob, on Heceta island, Prince of Wales archipelago, near latitude $55^{\circ}$ $45^{\prime}$, longitude $133^{\circ} 35^{\prime}$. So named by Dickins, 1903-4.

Tin; creek, Seward peninsula, tributary from the east to Lost river, near latitude $65^{\circ} 27^{\prime}$. Name from Collier, 1903.

Tina; creek, Seward peninsula, tributaly to Mascot creek from the west, near latitude $65^{\circ} 30^{\prime}$, longitude $164^{\circ} 25^{\prime}$. Prospectors' name, reported by Gerdine, 1901.

Tin City; mining camp and post-office (established in April, 1905), Seward peninșula, near Cape Prince of Wales, Prospectors' name, reported by Gerdine, 1901. 
Tinhorn; gulch, Birch Creek legion, at the head of Boulder creek, near latitude $65^{\circ} 25^{\prime}$, 'longitude $145^{\circ} 05^{\prime}$. Prospectors' name, reported by Spurr, Goodrich, and Schrader, of the Geological Survey, 1896.

Tin Kettle; creek, in the Fortymile region, tributary to Franklin creek from the south, near latitude $64^{\circ} 10^{\prime}$, longitude $141^{\circ} 50^{\prime}$. Prospectors' name, from Prindle, 1903.

Tiokpit; mountain (2,000 feet high), about 60 miles east of Kuskokwim bay. Native name, obtained by Spurr and Post, of the Geological Survey, who passed by it September 5, 1898. They wrote Tióchpit.

Tired; mountain (1,824 feet high), in central part of Annette island, Alexander archipelago. So named by Nichols, 1883.

Tishou, river; see 'Tisuk creek.

Tisku, river; see Tsirku.

Tisuk; creek, in western part of Seward peninsula, debouching near Cape Douglas. Native name, from Barnard, 1900. Has also been written Tissook, and Tishou river.

Titukilsk; native village, on the eastern shore of Cook inlet. Name from Petrof, 1880 .

Tiurpa; islet, near Spruce island, of the Necker group, Sitka sound, Alexander archipelago. So called by Vasilief, 1809.

Tiznik, bay; see Chignik.

Tkhalka, island; see Hinchinbrook.

Tklik; landing (native village, perhaps, or locality), on the right bank of Yukon river, 26 miles below Andreafski. Written Ta-clik on Edwards' Track Chart of the Yukon, 1899; and 'T'Click by Cantwell in 1900.

Tlachkahiniku, river, branch of Klehini; see Porcupine creek.

Tlatek; Eskimo village, on right bank of the Yukon, about 35 miles above Andreafski. Name from Raymond, 1869, who wrote it Tlatekamute, i. e., Tlatek people.

Tleekakeela, river; see Tlikakila.

Tleelkh, islands ; see Kruzof.

Tlegan, bay; see Dry.

Tlegan; the southernmost of the five rivers in the delta of the Alsek, southeastęrn Alaska. So called by Tebenkof, 1849. Apparently a native name.

Tlegon; river, tributary to Innoko river from the east, near latitude $64^{\circ}$. Called Tlegon by Tikhmenief, 1861, and Thlegon by Petrof, 1880.

Tlehini, river; see Klehini.

Tlehonsiti, harbor ; see Tongass.

T'lekhonsiti. "A broad open bight in which vessels have anchored in 18 to 25 fathoms at the south end of Lincoln channel is now usually known as Tlekhonsiti Harbor:" (Coast Pilot, 1891, p. 80.)

Tlevak; narrows. The contracted part of Tlevak strait is known as Tlevak narrows.

Tlevak; strait, in the southwestern part of Prince of Wales archipelago. Has been written Tlevalk, Tlevach, Tlevakhan, etc. "The name Tlevaak strait appears to be due to Tebienkoff, and may have its origin in the same root as the name of Klahwak settlement and Tlevakhan guif farther north." (Dall in Coast Pilot, 1883, p. 69.)

Tlevakh, inlet; see Klawak.

I'Tewak, village; see Klawak.

Tliakek; bay, indenting the northern shore of Cordova bay, Prince of Wales archipelago. Name published in Coast Pilot of 1883, now obsolete. It may have been either Klakas, Nutkwa, or Hetta inlet. 
Tlicketarrik, Tlicketawik, Eskimo village; see Kiktaguk.

Tlieshitna, river; see Tazlina.

Tlikakila; river, tributary to the head of Clark lake from the northeast, near: latitude $61^{\circ}$, longitude $153^{\circ} 30^{\prime}$. Native name, obtained by Osgood, 1902, who wrote it Tleekakeela.

T'liskon, mountain ; see Kliskon.

T'loo-Arny, lake; see Kluane.

I'maktogmiut. 'Tikhmenief's map of 1861 shows an Eskimo village on the eastern shore of Norton sound, east of Besboro island, called Tmaktogmiut. Neither name nor village has been found on any other map.

To, Toe, Too, or Tu; Indian name for water; used in the Copper river country. It is appended to the name; thus, Chiti-to = copper water.

Toatut; Eskimo village, on Cape Espenberg. It contained two huts and 20 people when visited by Jarvis in the winter of 1897-98. John W. Kelly's Eskimo Vocabulary has Togotet as the Eskimo name of. Cape Espenberg.

Toboggan; glacier, near Harriman fiord, Port Wells, Prince William sound. So named by the Harriman expedition, 1899.

T'ochilnoi, cape; see Tachilni.

I'oclat, river; see Kantishna and Toklat.

Todd; creek, eastern Alaska, on the east bank of Charley river, which is affuent to the Yukon from the south; near longitude $143^{\circ}$. Prospector's' name, from sketch map compiled by Major Glassford, Signal Corps, U. S. A., 1905.

Togiak; bay, northeast of Hagemeister island, indenting the northern shore of Bristol bay. Eskimo name, given by Tebenkof, 1849, as Tugiak. Sarichef's atlas of 1826 , sheet 3 , gives the same spelling for the lake. Now generally written Togiak. Also, erroneously, Togaik.

Togiak; Eskimo village, on the eastern shore of Togiak bay, north shore of B1:istol bay, Bering sea. Eskimo name, written by Sarichef, 1826, Tugiatak, and by Tebenkof, 1849, Tugiak. Commonly written Togiak. Petrof, 1880, reported two villages, one on the eastern shore, Togiak, and another at the head of the bay, which he wrote Togiagamute, i. e., Togiak people.

Togiak; lake, drained by the Togiak river. Eskimo name, from Sarichef's atlas of 1826 , sheet 3 , where it is written Tugiak. Tebenkof also has 'Tugiak. Now commonly written Togiak.

Togiak; river, draining from Togiak lake to Togiak bay, on the northern shore of l3ristol bay. Eskimo name, written Tugiak by Sarichef and Tebenkof. Now commonly written Togiak.

Togotet, cape and Eskimo village; see Espenberg and Toatut.

T'o-go-tit-nuk, river; see Dakli.

I'ohtankella; mountain (3,000 feet high), on north bank of Yukon river, between - the mouths of Melozi and Tozi rivers. Native name, from the Coast Survey, 1898.

T'ohtanyilla, mountain; see Totanilla.

Tohtanyilla, mountains; see Sukwanila.

T'ohvunnukakat, creek; see Birch.

Toik; hill (520 feet high), on the south shore of Norton sound. Eskimo name, from the Coast Survey, 1898 .

Tok; native village, on an island at junction of the Koyukuk and Yukon, rivers. Name from 'Tikhmenief, 1861, who writes it Tok-kakat, i, e., Tok mouth. Not found on recent maps. 
Tok; river, tributary to the Tanana from the south, near longitude $143^{\circ}$. Native name, reported by Allen, 1885, as Takái. Written 'Tokio by Wells in 1890. According to Peters and Brooks, of the Geological Survey, this name, pronounced Tōk, is in general use by both whites and Indians.

T'ok-Hehe, Tok-Hene, salmon stream; see Tokhini.

Tokhini; salmon stream; eastern shore Kosciusko island, Prince of Wales archipelago, near latitude $56^{\circ} 08^{\prime}$. Indian name, adopted by the fisheries; reported Tok-Hehe by Moser in 1897, and Tok-Hene in 1901.

Tokichitna; river, a right branch of the Chulitna, draining the middle part of the southeastern slope of the McKinley range, near latitude $62^{\circ} 35^{\prime}$, longitude $150^{\circ} 30^{\prime}$. Indian name, reported to Brooks, 1902, by George Aberbardt, a prospector.

Toklat, river; see Kantishna.

Toklat; river, large east (right) branch of the Kantishna, about 40 miles south of the Tanana, near latitude $64^{\circ} 15^{\prime}$, longitude $150^{\circ} 15^{\prime}$. Indian name, said to mean dishwater, reported by Reaburn in 1903; written also Toclat.

Toklat; river, tributary to the Tanana from the south, about 50 miles above the mouth of the latter. This may be identical with Nushakantna of Petrof, 1880, or, as is more likely, with Tutlut river, also of Petrof. Name from Allen, 1885, who wrote it Toclat and says it means dish water. See also Toklat river (above) and Kantishna.

Tokolokna; river, an affluent of the Yentna on the right, between Skwentna . and Kichatna rivers, near latitude $62^{\circ}$, longitude $151^{\circ} 30^{\prime}$. Indian name, from Ferron, 1899, who wrote it To-ko-loch-nu, i. e., Tokolok river.

T'okshook, entrance; see Takchuk.

Tokun; lake, and creek tributary thereto, 15 miles north of Controller bay, and drained by Martin river. Native name, from Martin, 1903.

Tolovana; river, tributary to the Tanana from the north, between Chena river and Baker creek. Called Nilkoka by Peters and Brooks in 1898, and Tolovana by Brooks in 1902. Indian name. The upper portion of this river, in the Fairbanks mining region, is called Chatanika river, which see.

Tolovana; telegraph station and post-office (established in August, 1905), on Tanana river, at confluence with Tolovana river, 117 miles above Fort Gibbon. So named by the Signal Corps, U. S. A., 1903, and spelled variously Tolovana, Tolavana, and Tolovano.

Tolstoi; bay, Clarence strait, Prince of Wales island, Alexander archipelago. So called by Nichols, 1882 . Its eastern point of entrance had been previously named Tolstoi (broad) by the Russians. Also written Tolstoy.

Tolstoi; cape, the eastern head of Kovurof bay, on north shore of Atka, middle Aleutians. Presumably named Tolstoi (broad) by Ingenstrem in 1829.

Tolstoi, cape; see Broad.

I'olstoi, cape; see Burunof.

Tolstoi, cape; see Chiniak.

Tolstoi; island, at entrance to Tolstoi bay, in Clarence strait, Prince of Wales island, Alexander archipelago. So called by Nichols, 1882.

Tolstoi; point, on the eastem shore of Norton sound. So called by the Russians and name published by Dall in 1869. (Alaska, p. 20, and Coast Survey chart 20 of 1869). This is the earliest use found of this name in print. 
Toistoi; point, the easternmost of St. George island, Pribilof group, Bering sea. Called Vostochnoi (east) by. Tebenkof, 1849. Locally known as Tolstoi (broad) point. According to Putnam, the Aleut name is Käg:i'logh, stern of sluip.

Tolstoi; point, the eastern point of entrance to Seal bay, on northeastern coast of Afognak island, Kodiak group. Named Tolstie (broad) by the Russians.

Tolstoi; point, the eastern point of entrance to Tolstoi bay, Prince of Wales island, Alexander archipelago. Named Tolstoi (broad) by the Russians.

Tolstoi; point, the southeastern point of entrance to English bay, on south shore of St. Paul island, Pribilof group, Bering sea. Named Tolstoi (broad) by the Russians.

Tolstoi; point, the south head of Tolstoi bay, on Prince of Wales island, Clarence strait, Alexander archipelago. Named Tolstoi (broad) by the Russians. Has also been called Broad, Tolstoy, and Thick.

Tolstoi; rookery, St. Paul island, Bering sea, on 'Tolstoi point (above), Local name, reported by Elliott in 1872-74.

Tolstoi Bay; fishing station; on the east side of Prince of Wales island, Alexander archipelago. So called in the Eleventh Census. The station was not located on 'Tolstoi bay, but on Thorne bay; at first near its mouth and later toward its bead.

Tolusque, river; see Talsekwe.

Tom; creek, in the Fairbanks region, tributary to Gilmore creek from the south, near latitude $65^{\circ}$, longitude $147^{\circ} 30^{\prime}$. Prospectors' name, reported by Gerdine, 1903.

Tomasagnu; river, of northernmost Alaska, tributary to Dease inlet from the east. Native name, published on British Admiralty chart 593 (ed. of 1882).

Tomato; creek, eastern Alaska, on the south bank Mosquito fork Fortymile creek, near longitude $142^{\circ} 10^{\prime}$. Frospectors' name, from sketch map compiled by Major Glassford, Signal Corps, U. S. A., 1905.

Tombstone; bay, on the western shore of Portland canal, southeastern Alaskin. So named by Pender, 1868.

T'om Drew, coal mine; see Pioneer.

Toms Ranch; Indian village, in Security bay, Kuiu island, Alexander archipelago. Destroyed by Meade, 1869. Erroneously Tonis Rianche.

Tondustek, village; see Gan-te-gas-tak-heh.

Tongass, fort; see Fort Tongass.

Tongass, harbor ; see 'Tamgas.

Tongass; Indian tribe and village, on 'Tongass island, Alexander' archipelago.

Tongass; island, 4 miles east of Cape Fox, Dixon entrance. Native name, also written Tongas, etc. It is Kut-tuk-wab island of the Coast Survey atlas of Harbor Charts in Alaska, 1869.

Tongass; narrows, in strait separating Revillagigedo island from Graviua island, Alexander archipelago. So named by local pilots about 1878-1880, The name appears to be applied to the narrower part of 'Tongass passage or to the whole passage indifferently.

Tongass; passage, between Sitklan and Wales islands, near eastern end of Dixon entrance, Alexander archipelago. Local name.

Tongass; point, on the eastern shore of Tongass island, near the old military barracks. So called by Nichols in the Coast Pilot $(1891$, p. 80$)$. 
Tongass; port, between Tongass island and the mainland, Dixon entrance; called indiscriminately harbor and port. Nichols says in the Coast Pilot. (1891, p. 79) : "Port Tongass is a small barbor," etc. The Russians who used this harbor called it Tlehonsiti. Erroneously transliterated in one case as Tlechopcity. The name has been written Tongas, Tomgas, etc., but the present usage is Tongass.

Tongass; reef, north of Tongass island. So called by Nichols in the Coast Pilot (1891, p. 79).

Tongue; point, long and narrow, on the northern shore of Bristol bay, opposite Hagemeister island. So called by the Fish Commission in 1890.

Tongue; point, the south head of Jack bay, Port Valdez, Prince William sound. So called by Abercrombie, 1898.

Tonka; cannery, eastern shore Kupreanof island, Wrangell strait, Alexander archipelago. Name from the Coast Pilot of 1901. A post-office established here 1902, was abolished in 1905.

Tonki, cape, Kodiak; see Narrow.

Tonki; cape, on the eastern coalst of Afognak island, Kodiak group. Named Tonkie (narrow) by the Russians.

Tonki, point, Clarence strait; see Narrow.

Tonki; point, on the southeastern shore of St. Paul island, Pribilof group, Bering sea. It is the northeast point of Luikanin bay. Locally called Tonki (narrow). Has also been called Tonkie Mees (cape), Narrow, Rocky, and Stony.

Tonkie, cape; see Narrow.

Tonkoi, point; see Thin.

Tonowek; bay, in western part of Prince of Wales archipelago. Apparently a native name, obtained by the Russians. Has also been written Tonoek.

Tonsina; lake, at source of Tonsina river. Native name from Schrader, 1900.

Tonsina; river, tributary to the Copper from the west, near latitude $62^{\circ}$. Native name, reported by Allen, 1885, who called it Tonsina creek on his map and Konsiná creek in his text (p. 58). It has, since 1885, been called Tonsena and Archer or Tonsina, i. e., Tonsi river.

Tonsina; post-office (established in 1904), and telegriph station, on Tonsina river, 20 miles above its confluence with Copper river, near latitude $61^{\circ} 40^{\prime}$. So named by the Signal Corps, U. S. A., 1902.

Tontatin; mountain, between Skwentna and Yentna rivers, near latitude $62^{\circ}$, longitude $151^{\circ} 30^{\prime}$. Native name, from Her'ron, 1899. Shell hills of Spurr and Post are probably the same.

Tonzona; river, tributary to Kuskokwim from the east, 15 miles above the mouth of East fork, near latitude $63^{\circ}$, longitude $164^{\circ}$. Indian name, obtained by Herron, 1899.

Toogamak, bay; see Unimak.

Toogedach, isTand ; see Tugidak.

Too Good; creek, tributary to Kotsina river from the soutl. Apparently so named by the prospectors. Name reported by Gerdine, 1900.

Tookhlagamute, village; see Tuklak.

Tooksook, channel and Eskimo village; see Tuksuk.

Toolitzkakat, river; see Chetlechuk.

Too-look-sook, river ; see Tutuksuk.

Tooloouk, Eskimo village; see Tuluuk.

Tooluka-anahamute, village; see Tuluka.

Tootooksook, river; see Tutuksuk.

Top, mountain; see Pop. 
Topanika; place, on the eastern shore of Norton sound, where sandstone bluffs begin (as one goes east). Called Topánika by Dall, 1869. On the Western Union Telegraph Expedition map of 1867 called Topanica. Somewhat north of this Petrof, 1880, shows an Eskimo village of 10 people called Tup-hamikva. Possibly this is the same name.

Topkok; cape, the western head of Boat harbor, on northern shore of Norton sound, Bering sea. Locally called 'Topcock, a local rendering of an Eskimo name given by Petrof, 1880, as Tupka-ak.

Topkok; Eskimo villige, at Boat hatrbor, on the northern shore of Norton sound, Bering sea. Native name, from Petrof, 1880 , who writes it Tupka-ak. The local spelling and pronunciation is 'lopcock.

Topkok; river; tributary to Boat harbor, between Cape Nome and Golofnin sound, Seward peninsula. Called Topcock by Schrader and.Brooks, in 1899, and Topkok by Barnard in 1900. Locally known as Topcock, a corruption of some Eskimo word which Petrof, in 1880, wrote Tupka-ak.

Topkok Head; bluff point, at mouth of lopkok river, Seward peninsula. So called by Barnard, 1900 .

Topnotch; creek, Seward peninsula, Solomion River drainage, tributary on , north bank of Kasson creek, near latitude $64^{\circ} 42^{\prime}$, longitude $164^{\circ} 24^{\prime}$. Prospectors' name, from a local map, 1901.

Toporkof, bay and point; see Puffin.

Tordrillo; range of mountains, northwest of Cook inlet, between the headwaters of Kuskokwim and Skwentna rivers. So named by Spurr, 1.898.

Torno, cape; see Black.

Torrent; inlet, on the Arctic coast, in Peard bay. So called on British Admiralty chart 593 (ed. of 1882 ).

Torsar; island, one of the Necker group, Sitka sound, Alexander archipelago. So named by Vasilief, 1809 .

Tortella; Indian village, on south side of Tanana river, a short distance above the mouth of Cantwell river. Native name, reported by Brooks and Reaburn, 1902. Written also Tortilli. Nenana telegraph station is near this place, on the north bank.

Tortilli, Indian village; see Tortella.

Tose Kargut, river; see Tozi.

Totanilla; mountains, on the north bank of Yukon river, a little above the Melozi. Corruption of some native designation. Called Tohtanyilla on recent Coast Survey charts. Written also Totankella. Perhaps it is identical with Hohonilla of earlier charts or Holtkagelia of Zagoskin, $1842-1844$.

Totankella, mountain; see Totanilla.

Totem; bay, in the southern shore of Kupreanof island, Sumner strait, Alexander archipelago. So named by the Coast Survey, in 1886, "on account of the detached pillars of rock on its western shore, which resemble the Indian totem poles."

Toti; islet, in the eastern part of Bucareli bay, Prince of Wales archipelago. So named by Maurelle and Quadra, 1775-1779.

Totoilon; mountains, in the McKinley range, at the head of the Yentna drainage basin, near latitude $62^{\circ}$, longitude $153^{\circ}$. Native name, from Herron, 1899, who wrote it To-toy-lon.

To-toy-lon, mountains; see Totoilon.

Tots-an-tee-ash, lake; see Dezadeash.

Totschunda; creek, tributary to Nabesna river on the west, near latitude $62^{\circ}$ $30^{\prime}$, longitude $142^{\circ} 50^{\prime}$. Indian name, reported by Schrader, 1902. 
T'otsenbetna, river; see Wild and John.

Tougidak, island; see Tugidak.

T'oujajak. Langsdorf, in 1814 (Voyage, II, 235), gives this as the name of a native village in Kukak bay, Alaska peninsula.

T'oulaksagamut, village; see Tuluksak.

Touliouliaga, cape; see Lazaref.

Tounak, island; see Chernobour.

Tounghimik, island; see Little Koniuji.

Tournay; mountain (5,532 feet high), on the eastern shore of Portland canal. So named by Pender, 1868.

Tours, Ile des; see Pinnacle islet.

Tower; bluff, on Tanana river, near longitude $144^{\circ}$. So named by Allen, 1885. Tower Bluff; rapids, in the 'Tanana, near the above. So named by Allen, 1885. Towhead; mountain (4,858 feet high), between Tana and Chitina rivers. So named by Schrader, 1900.

Townsend; point, on the southern shore of Admiralty island, Frederick sound, Alexander archipelago. Named Townshend and Townsend by Vancouver, 1794. On map 12 of his atlas it is Townshend; in his text ( $8^{\circ}$ ed., vol. 5, p. 445 ) it is Townsend. Perhaps identical with Brightman of recent charts. See Brightman.

- Towshécargut, river; see Tozi.

Toyonok, village; see Tyonek.

Tozer; creek, Seward peninsula, tributary from the northeast to Don river, near latitude $65^{\circ} 26^{\prime}$, longitude $166^{\circ} 49^{\prime}$. Name repòrted by Gerdine, 1901 .

Tozi; river, tributary to the Yukon from the north, near longitude $152^{\circ} 30^{\prime}$. Native name, reported by the Western Union Telegraph expedition, 1867, as Towshecargut. Raymond, 1869, wrote it Tosekargut, and Allen, 1885, Tozikakat. See Kakat.

Track; rock (covered at high water), near the entrance to Tongass harbor, Alexander archipelago. So named by Nichols, 1883.

Tracy; arm, of Folkham bay, Stephens passage, southeastern Alaska. So named by Mansfield, 1889, after the Hon. Benjamin Franklin Tracy, Secretary of the Navy.

Tracy; island, near southern shore of Wales island, Dixon entrance, Alexander archipelago. Named by the Coast Survey, in 1891, after Hon. B. F. Tracy, Secretary of the Navy.

Traders, bay; see Trading.

Traders; cove, indenting the extreme western end of Alaska peninsula, in Isanotski strait, near latitude $54^{\circ} 55^{\prime}$, longitude $163^{\circ} 20^{\prime}$. New Morzhovoi village is situated on this cove. Local name, published by the Coast Survey in 1882 .

Traders; group of islands, west of Thatcher point, at eastern entrance to Peril strait, Alexander archipelago. Named Traitors (not Traders) by Meade in 1869. The statement in the Coast Pilot (1883, p. 167) that Meade gave the name Traders is not borne out by his chart (U. S. Hydrographic 225). On that chart the name is Traitors This error has been accepted and followed in recent Coast Survey publications. The name Traitors has vanished. Traders remains and is applied (on Coast Survey chart 8283) as here given and on Coast Survey chart 8050 to a large island or peninsula south of these.

Trading; bay, on the northwestern shore of Cook inlet. So named by Portlock, who in August, 1786, anchored and traded here.

Trail; creek, tributary to Kenai lake from the north, Kenai peninsula. Local name, reported by Mendenhall in 1898. 
Trail; creek, tributary to Cold bay, Alaska peninsula, near latitude $57^{\circ} 45^{\prime}$, longitude $155^{\circ} 30^{\prime}$. Prospectors' name, reported by Martin in 1903.

Trail; creek, Seward peninsula, tributary from the north to Cottonwood creek, an affluent of Goodhope river, near latitude $65^{\circ} 42^{\prime}$, longitude $162^{\circ} 05^{\prime}$. Prospector's' name, reported by Mendeṇball in 1901.

Trail; creek, in the Fortymile region, tributary to Dome creek from the left, near latitude $64^{\circ} 25^{\prime}$ and the international boundary. Prospector's' name, from map in Coast Survey archives drawn by E. F. Ball, a prospector, 1898.

Trail; lakes, Kenai peninsula, on Trail creek, draining into Kenai lake from the north, near latitude $60^{\circ} 30^{\prime}$, longitude $149^{\circ} 20^{\prime}$. Local name, from Moffit, 1904.

Traitors; cove, in Behm canal, indenting the western shore of Revillagigedo island, Alexander archipelago. So named by Vancouver, 1793, to commemorate an attack on his surveying party by a band of Indians coming from this cove.

Traitors, islands ; see Traders.

Traleika; range of high mountains, west of the Susitna river. Spurr suggests this Indian word, spelled by him Traleyka and meaning high mountains, as the name of the range. According to Eldridge, Traleyka is the Susitna Indian name for Mount McKinley.

Tramp; point, in Behm canal, northwest from New Eddystone rock, Alexander archipelago. So named by the Coast Survey in 1891 .

Tramway; bar, on Middle fork Koyukuk river, near longitude $150^{\circ} 30^{\prime}$, Gold producing bar located and named in the spring of 1899 .

Tranquil; point, the western point of entrance to Port Caldera, Bucareli bay, Prince of Wales archipelago. Named Punta del Sosiego (point of tranquillity) by Maurelle and Quadra, 1775-1779.

Trap; creek, Seward peninsula, tributary to head of East fork Solomon river, near latitude $64^{\circ} 42^{\prime}$, longitude $164^{\circ} 04^{\prime}$. Prospectors' name, from a local map, 1904.

Trap; islet, near the northern end of Bold island, in Revillagigedo channel, Alexander archipelago. So called by Dall in the Coast Pilot (1883, p. 78).

Trap; point, on the mainland, on eastern shore of Behm canal, north of: Walker cove. So named by the Coast Survey in 1891.

Travers; creek, Kanai peninsula, on the north shore of Kachemak bay, Cook inlet, 3 miles inside Anchor point. Local name from Stone, 1904.

Treadwell; mines, town, and post-office (established in 1902), on Douglas island, about 1 mile southeast of Douglas. Gold was discovered here in 1881 and shortly afterwards the mine was acquired by John Treadwell, for whom it is named. The town Treadwell was incorporated March 16, 1901 ; population in $1900,522$.

Treasure; creek, in the Fairbanks region, tributary to Chatanika river from the south, near latitude $65^{\circ} 05^{\prime}$, longitude $147^{\circ} 45^{\prime}$. Prospectors' name, reported by Gerdine, 1903.

Treat; island, in Koyukuk river, near latitude $66^{\circ}$, longitude $156^{\circ}$. So named by Allen, 1885, after his classmate, Lient. Charles Gould Treat, U. $\mathbf{s}$. A.

Treble; mountain (4,000 to 5,000 feet high), near the head of Portland canal. Descriptive name, given by Pender in 1868.

Tree; mountain (2,700 feet high), in the Muir glacier, southeastern Alaska. So named by Muir, 1892. 
Tree; point, on the mainland, near junction of Revillagigedo channel and Dixon entrance, southeastern Alaska. It is about 4 miles northwesterly from Cape Fox and just north of Boat harbor. It has been reserved for lighthouse purposes by Executive order dated January 4, 1901. Name täken from that order. Light station in operation in 1904.

Tree; point, the north end of Pearse island, Portland canal, Alexander archipelago. So named by Pender, 1868.

Treeless; island, an islet between Afognak and Kodiak islands, near the eastern shore of Whale island, about latitude $57^{\circ} 57^{\prime}$. Descriptive name, given by Moser in 1900. It was. described Nizmennie kamennie (low rocky) by Murashef, $1839-40$.

Trembley; creek, tributary to Dietrich river, an affluent of Middle fork Koyukuk river, near latitude $68^{\circ}$, longitude $150^{\circ}$. This was erronèously named Sheep creek by Schrader and Gerdine, 1899.

Tretiakof; cape, on the southeastern shore of Shuyak island, Kodiak group. Named by the Russian-American Company, 1849.

Triangle; islet, in Queen inlet, at head of Glacier bay, southeastern Alaska. So named by Reid, 1892, on account of its shape.

Tributary; creek, Seward peninsula, Solomon River drainage, tributary to Big Hurrah creek from the east, near latitude $64^{\circ} 39^{\prime}$, longitude $164^{\circ} 10^{\prime}$. Local descriptive name, from a local map, 1904.

Trident; bay, indenting the southeastern shore of Akun island, Krenitzin group, eastern Aleutians, near longitude $165^{\circ} 32^{\prime}$. So named by Gilbert, 1901.

Trilby; creek, Seward peninsula, tributary from the south to Windy creek, near latitude $65^{\circ} 34^{\prime}$, longitude $165^{\circ} 27^{\prime}$. Prospectors' name, reported by Gerdine, 1901.

Trilby; creek, Seward peninsula, on the east bank of Solomon river, tributary to Big Furrah creek from the north. Prospectors' name, reported by Schrader and Brooks, 1899, but misapplied by them to East fork Solomon river.

Trilby, creek; see East fork Solomon river.

Trinidad, cape; see Trinity.

Trinity; cape, the southwestern point of Kodiak. Named by Cook, 1778. So called by the English and early Russians. Tebenkof, 1849, following Lisianski, 1805, calls it Iuzhnoi (south), and thus it has appeared as South and Utchno. Has also been called Trinidad. According to Petrof the native name is Aliulik. Perhaps it is Aliuliuk, the Alent word for thimble.

Trinity; creek, tributary to-Sinuk river from the east, Seward peninsula. Name from Barnard, 1900.

Trinity; islands, off the southwestern end of Kodiak. Named by Cook, $177 \dot{8}$. It is Trinidad island of Galiano's atlas, 1802. It is 'Troitza (trinity) of the Russians. According to Sauer, 1790 (Billings, p. 174), the native name is Kightak Sichtunak, i. e., Siktunak island.

Trinity; islands, a group of small islands off the west shore of Sannak island, and north of Clifford island, near latitude $54^{\circ} 26^{\prime}$, longitude $162^{\circ} 52^{\prime}$. Probably a local name, reported by Westdahl in 1901.

Triplet; rocks, near Cape Morgin. the southwestern point of Akutan island, Krenitzin group, eastern Aleutians, near longitude $166^{\circ} 03^{\prime}$. Descriptive name, from Gilbert, 1901.

Tripple; creek, 5 miles northeast of Nome, Seward peninsula, tributary from the west to Nome river, near longitude $165^{\circ} 14^{\prime}$. Local name, published in 1900. 
Tripple; creek, 17 miles north of Cape Nome, Seward peninsula, tributary from the west to Flambeau river, near longitude $165^{\circ} 05^{\prime}$. Local name, from Gerdine, 1904.

Tripple, creek, Seward peninsula; see Iron.

Triste; island, in Port Real Marina; Bucareli bay, Prince of Wales archipelago. Named Ysla Triste (sorrowful island) by Maurelle and Quadra in 17751779 .

Triste, island; see Seal rocks.

Trocadero. An unexplored strait, in eastern part of Bucareli bay, Prince of Wales archipelago, was named Canos del Nocadero by Maurelle and Quadra, 1775-1779. Apparently this is an error for 'Trocadero. Also. called Frocadero.

Trogshak; Eskimo village, Yukon delta, on the eastern bank of Akularak pass, near latitude $62^{\circ} 38^{\prime}$, longitude $164^{\circ}$. 15'. Eskimo name, obtained by Putnam in 1899, and written Trogshagamiut, i. e., Trogshak folks.

Troitz; island, from Russian Troitsa, the Trinity; the largest of the Trinity $\cdot$ islands, in the Sannak group, near longitude $162^{\circ} 52^{\prime}$. Probably local name, reported by Westdahl, 1901.

Troitza, islands; see Trinity.

Trollop; point, the nortuern point of entrance to Smeaton bay, Behm canal, Alexander archipelago. So named by Vancouver, 1793.

Troublesome; creek, tributary to Hess creek from the south; near latitude $65^{\circ}$ $30^{\prime}$, longitude $149^{\circ} 10^{\prime}$. Prospectors' name, reported by Lieutenant Erickson, U. S. A., 1902.

Trout; creek, "soutbwestern shore Etolin island, Clarence strait, Alexander archipelago, on the east side of the east inlet at the head of McHenry inlet; near latitude $56^{\circ} 02^{\prime}$, longitude $132^{\circ} 21^{\prime}$. So called by the fisheries, and reported by Moser, 1900.

Trout; creek, 17 miles north of Controller bay, tributary to Stillwater creek from the north, near longitude $144^{\circ}$. Local name, from Martin, 1903.

Trout; creek, tributary to Tonsina river from the northwest, nearly opposite the mouth of Bernard creek. Name from Schrader, 1900.

Trout; creek, tributary to Bear river from the west, Seward peninsula. Name from Barnard, 1900.

Trout; creek, 16 miles north of Nome, Seward peninsula, a small tributary to Nome river from the west, near longitude $165^{\circ} 18^{\prime}$. Local name, published in 1903.

Trout; creek, Seward peninsula, debouching in the lagoon along the Arctic coast, near latitude $66^{\circ} 05^{\prime}$, longitude $116^{\circ} 35^{\prime}$. Prospectors' name, reported by Gerdine, 1901.

Trout; creek, eastern Alaska, on the left bank of Yukon river, near longitude $141^{\circ} 30^{\prime}$. Prospectors' name, reported by Lieutenant Erickson, U. S. A., 1902.

Trout; hill ( 893 feet high), near Port Chester, Annette island, Alexander archipelago. So named by Nichols, 1883.

Trout; lake, near Port Chester, Annette island; Alexander archipelago. So named by the Coast Survey in $\mathbf{1 8 9 7 .}$.

Trout; lake, on northwestern coast of Wrangell island, Alexander archipelago. So named by Snow, 1886.

Trout; small lake, near headwaters of Middle fork Chistochina river, to which it drains, near latitude $63^{\circ} 08^{\prime}$, longitude $144^{\circ} 42^{\prime}$. Prospectors' name, reported by Gerdine, 1902 . 
Truax; range of hills, east of Golofnin bay, Seward peninsula: Name from Schrader, 1899.

Trubitsina, cape; see Edgecumbe.

Trunk; island, off the north point of entrance to Helm bay, Behm canal, Alexander archipelago. So named by the Coast Survey in 1886.

Trü̈ili, mountains; see Kenai.

Tsa; cove, near the head of George inlet, Revillagigedo island, Alexander archipelago. So named by the Coast Survey in 1891.

Tsadaka; creek, tributary to the Matanuska from the north, about 20 miles above the mouth of the latter. Native name, obtained by Glenn, 1898, who indicates that it is the Indian word for moose. Locally called Moose.

I'sahagajuk, river; see Chaiagaguk.

T'saina, river ; see 'Tiekel.

I'sammana; old village site, northwestern part of St. Paul island, Bering sea, near longitude $170^{\circ} 23^{\prime}$. Probably native name from Elliott, 1872-1874, who wrote "Tsammanah."

Tsaritsa; sunken rock, in Eastern channel into Sitka harbor, Sitka sound, Alexander archipelago. So named by the Russians, after one of their vessels which struck upon it. Usually written Tsaritza.

I'schantatalich, stream; see Shantatalik.

T'schastiji, islets; see Chastie.

Tschechina, island; see Sitkin.

Tschechovla, island; see Chugul.

Tscherikow's island; see Chirikof.

Tschibocki, island; see Saint Lawrence.

Tschibocki, point; see Chibukak.

'Tschichkalansk, point; see Chikalan.

I'schilkut, lake; see Chilkoot.

'fschilkat, peak and lake; see Chilkat.

I'schilkathin, river; see Chilkat.

I'schillkat, inlet; see Chilkat.

I'schitschagoff, harbor; see Chichagof.

Tischugatsk, peninsula; see Kenai.

Tschuiou, Tschuiow, bay and river; see Chuiu.

T'see'toht, river; see Chetaut.

'I'sholkfachtoligamut, lake; see Shokfaktolik.

i'shugidi, island; see Herbert.

I'shugulla, island; see Chugul.

T'silkat, inlet, river, etc.; see Chilkat.

Tsina; river, tributary to the Tiekel from the west. It is the south fork of Tiekel river. Native name, Tsee-na, i. e., Tsee river, from Geological Survey parties in 1900. It is Tsaina of Schrader, 1898, and said to be China of Abercrombie, 1898. Pronounced Tsế-na. See Tiekel.

Tsina; telegraph station, on Tsina river, 34 miles northeast of Valdez. Named Saina by the Signal Corps, U. S. A., 1902.

Tsirku; river, tributary to the Chilkat from the west, near its mouth. Native name, given by Krause, 1882, as Zirkú. Variously written Tisku, Tsirku, etc. Brooks, 1899, called it Salmon river, which is said to be the local name.

$T$ si-u, river' see Tsivat.

Tsivat; river, debouching on the coast of the Gulf of Alaska, 25 miles east of Cape Suckling, near longitude $143^{\circ} 15^{\prime}$. Native name, from Tebenkof, 1849. Martin, 1904, reports the Indian name as Tsi-u. 
Tsogliakten; native village, on left bank of the Koyukuk, a few miles above its mouth. Native name, from Tikbmenief, 1861. Not found on recent maps.

Tsonagoliakten; native village, on left bank of the Koyukuk, a few miles above its mouth. Native name, from Tikhmenief, 1861. Not found on recent maps.

I'sukli, island; see Montague.

T'sumbonda, creek; see Bond.

Ttunaiskysch, bay; see Cook, inlet.

Tubutulik; river, Seward peninsula, tributary to north shore of Norton bay. Eskimo name, from Tebenkof, 1849, who writes it Tubuktulik. On late maps Tubutulik, and this is used on prospectors' stakes and said to be local usage. Tikbmenief, 1861 , has a village here called Tubuktuligmiut, i. e., Tubuk region people. Written also Tebooktolic.

I'u-ca-omina, lake; see 'Tukomina.

'T'uchan T'an, point; see East Foreland.

Tuchidok, island; see Tugidak.

Tuchu; pillar rock, near the eastern coast of Akun island, Krenitzin group, eastern Aleutians. So called by Tebenkof, 1849. Perhaps from the Russian tucha (cloud).

Tuck; creek, in the Mentasta mountains; tributary to Beal creek from the west, near longitude $143^{\circ}$. So named by Witherspoon, 1902, being a nickname for one of the party.

'Tuckfield; whaling station, 15 miles northeast of Point Hope, Arctic coast, at entrance to Marryat inlet. Local name, Tuckfield's, reported by Collier in 1903.

Tug; gulch, 10 miles northeast of Nome, Seward peninsula, on the north bank of Lillian creek, near longitude $165^{\circ} 13^{\prime}$. Local name, published in 1904.

Tugamak, bay; see Unimak.

T'ugat, lake; see Becharof.

Trug-ga-rag-a-uvick, river; see Koyukuk.

I'ugiak, bay ; see Togiak.

Tugidak; island, one of the'Trinity islands, southwest from Kodiak. Native name, from the early Russians. Variously written Toogedach, Toogidach, Toohidack, Tougidak, Tougidok, Tuchidok, Tuchidock, Tugedak, Tugijak, etc. It means moon or lunar month.

I'ugunararologh, St. George island; see Sealion point.

Tugunararologh-koverushka, St. George island; see Sealion bills.

T'ukalat. Spurr and Post, deriving their information, in 1898, from J. Madison, a resident of Cook inlet, give Tukalatna, i. e., Tukalat river, as the name of one of the tributaries of Yentna river. Not shown on any map.

Tukamiut; Eskimo village, on the right bank of the Yukon, 13 miles below Andreafski, near longitude $164^{\circ} 40^{\prime}$. Eskimo name, obtained by Putnam, 1899 .

Tuklak; Eskimo villige, on right bank of the Kuskokwim, a little below the Yukon-Kuskokwim portage. Native name, from Nelson, 1879, who wrote it Tookhlagamute, $i$. e., Tuklak people. Population in $1880,92$. Not shown on late maps.

T'uklukyet; village, on right bank of Yukon river, at mouth of the Tozi, about 15 miles below Nuklukayet. Perhaps this form is an error for Nuklukayet. The maps are confused and contradictory as to this. 
Tukomina; small lake, south of Lake 'Minchumina, near latitude $63^{\circ} 45^{\prime}$, longitude $152^{\circ}$. Indian name, from Herron, 1899, who wrote it Tu-ca-omina. Mina is Indian for lake.

Tuksuk; channel, connecting Imuruk basin and Grantley harbor, Seward peninsula, near latitude $65^{\circ} 12^{\prime}$, longitude $166^{\circ}$. Name from Barnard, 1900 . Also written Toolssook.

Tuksuk; Eskimo village, on Tuksuk channel, Seward peninsula. Written also Tooksook.

Tukukapak; Eskimo village, Yukon delta, on the east bank of Akulaiak pass, near latitude $62^{\circ} 36^{\prime}$, longitude $164^{\circ} 18^{\prime}$. Eskimo name, obtained by Putnam, 1899.

Tukusitnu, harbor; see Tuxedni.

T'ukuzit, harbor ; see Tuxedni.

Tulik; cape, on Umnak island, in Umnak pass, eastern Aleutians. Called Tulikskoi by Veniaminof. Native name, from Tulik volcano, near by.

Tulik; native village on Umnak island, in Umnak pass. Native name, from Veniaminof. In 1831 there were but two villages on Umnak island, this one and Riecheshnoi, which together had a population of 109 . Kuritzien shows a village here in 1849 . Veniaminof gives the population in 1834 as 26 , in 3 huts (yourts).

Tulik; volcano, on the eastern end of Umnak island, eastern Aleutians. Called Tulikskoi by the Russians from the Aleut word Tulik, a cleft, crack, fissure, etc. It is also the Eskimo word for place, region, etc.

Tuliumnit; point, the southern point of entrance to Chignik bay, Alaska peninsula. Native name, from the Russians. It is "a high-turreted or castellated point called Tuliumnit Point or Castle Cape," or Castle point.

Tulsona; creek, tributary to Oopper river from the north, between Gakona and Chistochina rivers. Indian name, adopted by the whites, and reported by Mendenhall, 1902.

Tulsona; town or camp, in the Copper River region, on Tulsona creek. Called Talsona by the Signal Corps, U. S. A., 1903.

Tuluga; river, northern Alaska, tributary to Anaktuvuk river from the west; near latitude $69^{\circ}$. Eskimo name, obtained by Peters and Schrader, 1901.

Tuluka; Eskimo village, on the right bank of Kuskokwim river, about 30 miles below Kolmakof. Part of a native name, reported by. Petrof, 1880, as Toolukaanahamute on his map and Toolooka-anahamute in his text (p. 16). Population 59 in 1880. Not shown on recent maps.

Tuluksak; Eskimo village, on left bank of Kuskokwim river, about 40 miles above Bethel. Petrof, 1880, writes the name Tuluksak. Spurr, 1898, writes it Toulakságamut.

Tu-lu-shu-lit-na, river; see Hayes.

Tuluuk; Eskimo village of 10 houses and 70 inhabitants, on upper Colville river. near the mouth of the Etivluk, about latitude $68^{\circ} 15^{\prime}$, longitude $156^{\circ}$ $30^{\prime}$. Visited by Ensign Howard, of Stoney's expedition, in the spring of 1886. Stoney wrote the name Tooloouk and Too-loo-uk.

Tumannoi, island; see Chirikof.

Tumannoi, islands; see Hazy.

Tumble; creek, in the Mount Wrangell district, north of Mount Jarvis, and tributary to Jacksina creek. Name given by Schrader, 1902, descriptive of the torrential character of the stream.

Tungulik. One of the Shumagin islands, not identified, is so called by Veniaminof $(1,255)$ and by Lutke.

l'uniak, bay, cape, etc. ; see Chiniak. 
Tuniakpuk; Eskimo village, on left bank of Togiak river, about 10 miles above its mouth. Population in 1880, 137. Not shown on recent maps. Name Tuniak-pak, i. e., Big Tuniak, from Petrof, 1880, who wrote Tuniakhpuk, on his map, and Tunniakhpuk in his text (p. 17).

Tunis; mountain, on left bank of Kuskokwim river, near latitude $62^{\circ} 20^{\prime}$. So named by Spurr and Post, 1898.

I'ununa, native village; see Tanunak.

T'ununak, village; see Tanunak.

T'ununuk, native village; see Tanunak.

Tunurokpak; chamnel of the Yukon, on the left, at the head of the delta, near latitude $62^{\circ} 30^{\prime}$, longitude $163^{\circ} 55^{\prime}$. Eskimo niame, obtained by P'utn:m, 1899, which may mean big slough.

Tunutuk; creek, northwestern Alaska, tributary to Kobuk river from the-soutla, near latitude $67^{\circ}, 10^{\prime}$, longitude $158^{\circ} 30^{\prime}$. Eskimo name, obtained by Mendenhall, 1901.

I'upka-ak, cape, river, village; see Tiopkok.

'f'upoi, point; see Blunt.

Turbot; point, on east shore of Baranof island, Chatham strait, Alexander archipelago; the north point at entrance to Takat\% bay. So named by Moore in 1895.

Turk; creek, at the head of Walker fork Fortymile creek, tributary on the right bank of Clierry creek, near the international boundary and latitude $64^{\circ}$. Prospectors' name, reported in 1898.

Turn; island, near the eastern shore of Cordova bay, Alexander archipelago. So named by Moser, 1897.

Turn; point, in Kootznaboo inlet, Admiralty island, Alexander archipelago. So named by Meade, 1869 .

Turn; point, in Tlevak narrows, Dall island, Alexander archipelago. Appaently a local name, published by Dall in the Coast Pilot $(1883$, p. 69$)$.

Turn; point, on Mitkof island, Wrangell strait, Alexander archipelago. Descriptive name, given by Nichols in 1881. It is Cone point of Meade in 1869 .

Turn; point, on the western shore of Fortland canil. So named by Pender in 1868.

Turn; point, the southern point of entrance to Hunter bay, Cordova bay, Alexander archipelago. So named by Moser in 1897.

Turn; point, on the west shore of Tuxekan island, Sea Otter sound, Prince of Wales archipelago, near latitude $55^{\circ} 50^{\prime}$, longitude $133^{\circ} 21^{\prime}$. So named by Dickins, $1903-4$.

Turn; point, on the northern shore of Kodiak. Named Povorota-(turn or tack) by Tebenkof, 1849. Perhaps this is identical with Course (kursal) point of Murashef in 1839-40.

Turn; rock, in the western part of Sukkwan strait, Cordova bay, Prince of Wales island, near latitude $55^{\circ} 08^{\prime}$, longitude $132^{\circ} 54^{\prime}$. Name published by the Coast Survey in 1905 .

Turnabout; island, off the northwestern end of Kupreanof island, in Frederick sound, Alexander archipelago. Named Povorotni (țurnabout) by the Russians. See also Fovorotni.

Turnagain; arm, of Cook inlet, on the northeru shore of Kenai peninsula. Called Turnagain river by Cook, 1778, and Turmagain arm by Vancouver in 1794. By the Russians called Vozvrashenia (return). Also has been called Resurrection.

T'urnagain, island; see Fire.

Bull. $299-06 \mathrm{M}-41$ 
Turner; creek, tributary to the Noxapaga river from the west, Seward peninsula. Name from Brooks, 1900.

Turner; glacier, near the head of Yakutat bay, southeastern Alaska. So named by Russell, 1891, after John Henry Turner, of the Coast Survey, who was engaged in Alaskan surveys, 1888 to 1892. Russel, 1.890, had called this Dalton glacier, after John Dalton, a well-known frontiersman. By the Coast Survey it was called Duffield glacier, after the Superintendent, and later by the same Survey called sumner or Dalton glacier.

Turner; island, between Big Koniuji and Nagai islands, Shumagin group. Has been called stiernfeld and also Turner, both names being given by the Coast Survey.

Turner; lake, tributary to Taku inlet, southeastern Alaska. Name published by the Coast Survey in 1895 .

Turner; mountain (5,953 feet high), on the mainland, near Iskut river. Named by the Coast Survey, 1895, after J. H. Turner, of the Coast Survey.

Turner; point, on Khantalak island, the western point of entrance into Port Mulgrave, Yakutat bay, southeastern Alaska. So named by Dixon, 1787, after his mate, James Turner. It is Turni of Tebenkof, and by mistranslation Povorotni (turning) on Russian Hydrographic chart 1378.

Turner; river, debouching on the Arctic coast, at the international boundary. Named, 1894, by Frederick Funston (now brigadier-general, U. S. A.) in honor of John Henry Turner, of the Coast Survey, who was the first white man to pass firom the valley of the Porcupine to Herschel island.

Turning; islet, around which one turns from Middle channel into Sitka harbor, Alexander archipelago. Named Pororotnoi (turning) by the Russians.

Turret; point, the eastern point of entrance to Bay of Waterfalls, Adak island, middle Aleutians. So named by Gibson, 1855 .

Tuscarora; rock, at entrance to Iliuliuk harbor, Unalaska bay, eastern Aleutians, near longitude $166^{\circ} 32^{\prime}$. Local name, published by the Coast Survey in 1.900 .

Tusik; cape, on the southern shore of Kanaga island, Andreanof group, middle Aleutians. So called by Tebenkof, 1849 . Has also been written Tusich. 'T'uska, bay ; see Tutka.

Tustumena; lake, on Kenai peninsula, drained by the Kasilof river. An Indian name, the termination mena or mina meaning lake. Reported by Wosnesenski about 1.840 . On Russian Hydrographic chart 1378 (ed. of 1847) it is called Chustielena. Has also been called Kasilof and by misapplication, Skilakh.

Tutagvak, inlet; see Wainwright.

- Tutka; bay, indenting the southern shore of Kachemak bay, Cook inlet. Called Tutk by Tebenkof in 1849 ; called also Utka (duck) and Duck. Apparently a mative name. Has been written Tutka, Tutke, and on recent charts Tuski.

Tutlut; native village, on the south bank of the Tanana, at mouth of the Tutlut river. Native name, from Petrof, 1880.

I'utlut; river, tributary to the Tanana from the south, about 100 miles above the mouth of the Tanana. Native name, from Petrof. 1880. Apparently this is Toklat river of Allen, 1885. See Toklat.

Tutlut, river; ; see Cantwell.

Tuttle; creek, tributary from the northeast to Kugrupaga river, near latitude $65^{\circ} 53^{\prime}$, longitude $166^{\circ} 28^{\prime}$. Prospector's' name, reported by Gerdine, 1901. 
Tutuksuk; river, northwestern Alaska, tributary to Kobuk river from the north, near longitude $159^{\circ} 15^{\prime}$ '. Stoney, 1886 , called it Labret or 'Toolook-sook river; Mendenhall, 1901, wrote Tootooksook, and says it means river of caribou pelts, from tutu or: tootoo, caribou.

Tuxedni; harbor, on the western shore of Cook inlet, near Iliamna volcano. Native name, given by Tebenkof, 1849, as Tukuzit, and by Eichwald. 1871, as Tukusitnu. The native name, according to Dall, is 'Tūk-sed'-ni. Fas been called snug bararbor.

Tuxekan; island, on the east side of Sea Otter sound, Prince of Wales archipelago, near latitude $55^{\circ} 50^{\prime}$, longitude $133^{\circ} 15^{\prime}$. So nimed by Dickins, $1903-4$.

Tuxekan; passage, between Tuxekan island and Prince of Wales island. So named by Dickins, 1903-4.

Tuxekan; winter village of the Hanega Indians, in Gulf of Esquibel, Prince of Wales archipelago. Later maps show it 25 miles fartber north on Tuxekan passage. Name published by the Coast Survey, in 1895, as Tuxeau and corrected to Tuxecan in 1899 .

Twelve Fathom; strait, separating Little Koniuji and Simeonof islands, Shumagin group. So called by the fishermen. Named from its depth.

Twelvemile; arm, of Kasaan bay, Frince of Wales island, Alexander archipelago. So called by Clover, who surveyed it in 1885 . It had previously been called Eighteenmile arm.

Twelvemile; bar, in the Yukon, about that distance below Circle, near latitude $66^{\circ}$, longitude $144^{\circ}$. River pilots' name, reported by Cantwell in 1900.

Twelvemile; camp, on the headwaters of Klutina river. So named by Abercrombie, 1898 . It is about 12 miles from Klutina lake.

Twelvemile; creek, tributary to the headwaters of Birch creek from the west, near latitude $65^{\circ} 25^{\prime}$, longitude $144^{\circ} 50^{\prime}$. Prospector's' name, reported by Gerdine, 1.903.

T'welvemile, creek; see Excelsior.

Twelvemile; creek, in the Fortymile mining district, tributary to Walker fork vrom the north. Prospectors' name, from Barnard, of the Geological Survey, 1898.

Twelvemile; creek, tributary to Middle fork Koyukuk river from the north, near longitude $150^{\circ} 30^{\prime}$. Local name, from Schrader, 1899 .

T'uelvemile Cache; see Twelvemile House.

Twelvemile House; tavern or locality, on Birch creek, 12 miles southwest of Circle (city). Local name, reported by Gerdine, 1903. Spurr's malp, 1896, has the name Twelvemile Cache at this point.

Twenty Fathom; bank, off Kasaan bay, Clarence strait, Alexinder archipelago. So cilled by the Coast Survey in 1895 or earlier.

Twentymile; creek, on right bank of Yukon river, 20 miles above Rampart (city), near longitude $150^{\circ}$. Frospectors' name, reported by Lieutenant Erickson, U. S. A., 1902.

Twentymile; point, on the north bank of Yukon river, 20 miles below Circle (city), near longitude $144^{\circ} 20^{\prime}$. River pilots' name, reported by Lieutenant Erickson, U. S. A., 1902.

Twentymile; river, draining Glenn lake into Turnagain arm of Cook inlet, near latitude $61^{\circ}$, longitude $149^{\circ}$. Local name, from Glenn, $189 \mathrm{~s}$.

Twenty-two Mile; large island, in the Yukon, about that distance below Rampart, near longitude $150^{\circ} 40^{\prime}$. River pilots' name.

T'win, bay; see Skan. 
Twin; creeks, in the Fairbanks region, at the head of Pedro creek, near latitude $65^{\circ}$, longitude $147^{\circ} 30^{\prime}$. Prospectors' name, reported by Gerdine, 1903.

Twin; creek, tributary to Fortymile creek from the north, near Bonanza bar. Miners' name, obtained by Barnard, of the Geological Survey, 1898.

Twin; glacier, on the mainland, on north side of Taku inlet, southeastern Alaska. Name published by the Coast Survey in 1895.

I'win; glaciers, at head of College fiord, Port Wells, Prince William sound. Descriptive name, given by Glenn in 1898. See Harvard and Yale.

Twin; glaciers, north of Tidal inlet, Glacier bay, southeastern Alaska. Descriptive name, given by Reid in 1890 .

Twin; islands, between Mary and Revillagigedo islands, Revillagigedo channel, Alexander archipelago. So named by Pilot W. E. George about 1880. Have also been called The Sisters.

T'win, islands; see Sister.

Twin; islet, between Praznik and Near isiands, St. Paul harbor, Kodiak. Named Dvoinoi (twin) by Russian naval ofticers, 1808-1810.

Twin; lakes, two small lakes 13 miles northwest of Cape Nome, Seward peninsula, on the left bank of Nome river, near latitude $64^{\circ} 35^{\prime}$, longitude $165^{\circ} 15^{\prime}$. Local name, published in 1903 .

Twin; mountain (1,165 feet high), 15 miles north of Nome, Seward peninsula, on the west bank of 'Snake river, near latitude $64^{\circ} 40^{\prime}$ ', longitude $165^{\circ}$ '28'. Local descriptive name, from Gerdine, 1904.

Twin; mountain (5,660 feet high), easterin Alaska, on left bank of Charley river, neal latitude $65^{\circ} 05^{\prime}$, longitude $143^{\circ} 30^{\prime}$. Prospector's' name, reported by Witherspoon, 1905.

Twin; pealss, the higher of the two is 2,680 feet, on Prince of Wales island, southeast of Davidson inlet, near latitude $55^{\circ} 45^{\prime}$, longitude $133^{\circ} 10^{\prime}$. So named by Dickins, 1903-4.

Twin; peaks, two conical peaks, about 1,200 feet high, southwestern coast of Kodiak, on Drake heald, Alitak bay, 5 miles northeast of Cape Alitak. Locil descriptive name, reported by Moser in 1900.

Twin; peaks ( 6,557 feet high), on the mainland, east of Frederick sound, southeaster'n Alaska. Descriptive name, given by Thomas in 1887.

Twin; point, southwest from the entrance to Port Snettisham, on Glass peninsula, Stephens passage, Alexander alchipelago. Descriptive name, given by Mansfield in 1889.

Twin; point, on the nortbwest coast of Kruzof island, Alexander archipelago, between Point Amelia and Cape Georgiana, near latitude $57^{\circ} 16^{\prime}$. Descriptive name, given by Moore in 1897 , but not hitherto published.

Twin Buttes; mountain, in the Fairbanks region, near latitude $65^{\circ} 10^{\prime}$, longitude $147^{\circ}$. Local descriptive name, reported by Gerdine in 1903.

Twin Mountain; creek, 15 miles north of Nome, Seward peninsula, tributary from the north to Boulder creek, an affluent of Snake river, near latitude $64^{\circ} 45^{\prime}$, longitude $165^{\circ} 30^{\prime}$. Name from Barnard, 1900 .

Twins; islets (100 and 300 feet high), on the southern edge of Walrus Island group, in northern part of Bristol bay, Bering sea. So named by the Fish Commission in 1890.

Twins; two recky islets, off the southeastern coast of Nagai island, Shumagin group. Local name, reported by Dall in 1872.

Truins; see Hanin rocks.

Twins (The); islets, south part of Ball group, at eastern entrance to Sitka harbor, Sitka sound, Alexander archipelago. Named Droini bratef (twin brother's) by Vasilief, 1809. Has also been called Eutrance island. 
Twins (The); two islets (226 and 239 feet high), off Hobart bay, Frederick sound, Alexander archipelago. Descriptive name, given by Meade in 1869.

Two Headed; island, neall the south end of Kodiak. Named Two-headed point by Cook in 1778. Variously called a cape or point and written TwoHeaded, Double Feaded, etc. According to Sauer, 1802, the native name is Nasikan. Variously written Nasiktak, Nazikak, etc.

Two Moon; bay, indenting the south shore of Fort Fidalgo, eastern shore Prince William sound, near latitude $60^{\circ} 45^{\prime}$, longitude $146^{\circ} 30^{\prime}$. Jocal name, reported by Grant, 1905. Named Bowie by Ritter in 1901, probably after William Bowie, of the Coast Survey, one of his party.

Two Tree; island, north of Vank island, Sumner strait, Alexander archipelago. Descriptive name; given by Meade in 1869 .

'J'uo White Men, creek; see Middle fork Fortymile.

Tyee; mountain, near the head of Bradfield canal, Alexander archipeligo. Named by Snow in 18S6. Native word, meaning chief or head man.

Tyndall; glacier, tributary to Malaspina glacier, near Mount St. Elias, southenstern Alaska. Named by the New York 'Times expedition of 1886 after Prof. John Tyndall.

Tyonek; Indian village, post-office, and store of the Alaska Commercial Company, near head of Cook inlet. Native name (from tyon, chief, and ok, the diminutive, little chicf), reported by P'etrof, 1880 , and by him spelled Toyonok. A few miles sontluwest is Tyonek station or Old Tyonek: The post-office Tyoonok was established near here in June, 1897, and its name changed to Tyonok in 1905 .

Tyonick, village; see Tyonek.

I'yon's, bay; see Redoubt.

Tyrena; creek, eastern Alaska, tributary to 'Trout creek, on the south bank of the Yukon, near latitude $65^{\circ}$, longitude $141^{\circ} 40^{\prime}$. Prospectors' name, from sketch map compiled by Major Glassford, Signal Corps, U. S. A., 1905.

T'yya, inlet; see Taiya.

Tzahavak; native village, on the eastern shore of Kuskokwim bay, Bering sea. Name from Petrof, 1880, who wrote it Tzahavagamute, i. e., Tzahavak people. Erroneously Tzaharagamute.

Ualik; lake, about 10 miles north of Kulukak bay, on the northern shore of Bristol bay, Bering sea. Spelled Oallek by Spurr in 'Twentieth Annual Report, United States Geological Survey (pt. 7 , map 10, p. 134) on the authority of missionary. Wood. Apparently this is Kuluką lake of Tebenkof. See Kulukak.

Ualik; native village, on the western shore of Kulukak bay, Bristol bay, Bering sea. Given by Petrof, 1880, as Ooallikh and by Spurr and Post as Oallígamut, i. e., Oallik people.

Ubeahitsha, island; see Poverty.

Ubezhit $\approx$ a, islet; see Shelter.

Ubi; island, in Bucareli bay, Prince of Wales archipelago. Named Ysla Ubi by Maurelle and Quadra, 1775-1779.

Ubiennoi, bay; see Massacre.

Ubiloi; islet, in Krestof sound, Alexander archipelago. Named Ubiloi (vacant) island by Vasilief in 1833. . It is "Oubeloi (low)" of British Admiralty chart 2337. Kostrometinoff translates Oubeloi as ebb-tide.

vcomude; native settlement, in Kiliuda bay, Kodiak. Native name, so given by Lisianski in 1805 . Apparently this is what would now be written Ukomuda, i. e., Ukom bay. 
Uda. Aleut word meaning bay. It is appended to the name; thus, Alimuda means Alim bay.

Udagak; bay, indenting the western shore of Udagak strait, Unalaska island, eastern Aleutians. So called by Gilbert, 1901.

Udagak; straiț, between Biorka and Unalaska islands, eastern Aleutians, near latitude $53^{\circ} 45^{\prime}$, longitude $166^{\circ} 18^{\prime}$. Its native name, Udágak, was used by Sarichef in 1792, and thereafter till 1849, when Tebenkof published the name Spirkin. Biorka island be called Spirkin island. Lutke wrote it Oudagakh, and it has been written Idagak.

Udak; cape, on the southern shore of Umnak island, forming the western head of Driftwood bay. Aleut name, meaning uliali, dried fish. Name from Kuritzien, 1849.

Udakhta, harbor; 'see Dutch.

Udakta; post-office at Dutch harbor, Unalaska, eastern Aleutians. Established in May, 1899.

Udamak; cove, at head of Anderson bay, Makushin bay, Unalaska. Native name, from Veniaminof, 1840.

Udamat; bay, in Beaver bay, indenting the northern shore of Biorka island, eastern Aleutians, near longitude $166^{\circ} 13^{\prime}$. Native name, from. Sarichef, 1792. Called Gull bay by the Fish Commission in 1888.

Uegak; island, the largest of the Vsevidof group, on the southern shore of Umnak, eastern Aleutians. Native namc, from Kotzebue, 1816; written Ouegakh by Lutke.

Uekosti, point; see Narrow.

Ugadaga; bay, indenting the northern shore of Beaver bay, Unalaska, eastern Aleutians, near longitude $166^{\circ} 25^{\prime}$. Aleut name, given by Sarichef, 1790 , as Ugadagan, and by Veniaminof as Ugadága. A creek flowing into the head of this bay was called by Langsdorf (II, 29) Ugadachan.

Ugaguk; rapids, in Ugaguk river, at the outlet of Becharof lake. Reported by Osgood, 1902.

Ugaguk; river, Alaska peninsula, draining westward from Becharof lake to Bristol bay. An Eskimo name, said to mean swift, reported by Lutke, in 1828, as Ougagouk and by later Russians as Ugaguk or Igagik, and since variously written Agouyak, Igiagik, Egegak, Ugiagik, etc. Martin, 1904, says that the nime of this river and the village at its mouth. is pronounced locally Igagik; that Ugaguk is obsolete excepting on Government maps.

Ugaguk; xillage, at mouth of Ugaguk river, Alaska peninsula. Has generally been written Igagik and often Egegak.

Ugaiak, cape; see Ugyak.

Ugaiushak; island, on the south shore of Alaska peninsula, nortl of the Semidis. Native name, from the Russians. Variously written Ugaiuscha, Ugaiuschak, Ugajutchak, etc.

Ugak; bay, indenting the southeastern shore of Kodlak. Native name, from early Russian explorers. Igak is a Kodiak word, meaning evil spirit or devil. The Russians wrote it Igak and Ugak. It has been called Dgak, Igak, Iagkskie, Igatskai, Ihack, lrak, Oohack, and Ugak. The Spaniards called it Puerto de Roxas.

Ugak; island, near entrance to Ugak bay, on southeast coast of Kodiak. Native name, reported by the Russians, who spelled it Igak, Ugak, etc. Ugak is said to be the local usage. 
Ugak; islet, near: Cape Chiniak, in entrance to Chiniak bay, Kodiak. Langsdorf says, in 1814. (Voyage II, 56), that Cape Chiniak "is bounded to the north by two small islands, one of which, in the language of the country, is called Giniak, the other Ugak."

Ugalek; bay, indenting Biorka island, on south shore of Unalaska, eastern Aleutians. Aleut name, from Sarichef, 1792.

Ugalgan, island; see Egg.

Ugalohan, island; see ligg.

Ugamak; biy, on the southern shore of Ugamak island, Krenitzin group, eastern Aleutians. So called by Gilbert, 1901.

Ugamak; island, one of the Krenitzin group, eastern Aleutians, near longitude $164^{\circ} 50^{\prime}$. Native name, from Veniaminof. Also written Ugamok, Ugomok, and Ukamak. This island wals reserved for light-house purposes by Executive order dated January 4, 1901. In that order the name is written Ugamok.

Ugamak; strait, separating Ugamak and Tigalda islands, Krenitzin group, eastern Aleutians. Called Ugamakskie by Veniaminof about 1830.

Ugamol, island; see Chirikof.

Uganik; bay, indenting the northern shore of Kodiak, near latitude $57^{\circ} 45^{\prime}$, longitude $153^{\circ} 30^{\prime}$. Petrof, 18S0, wrote it Ooganok. Moser, 1897, divides it into what he calls East and West Uganuk bays.

Uganik; cape, the eastern point of entrance to Uganik bay, on northern coast of Kodiak. Native name, from Tebenkof, 1849: Moser, 1897, called it Bast point.

Uganik; island, on the northern shore of Kodiak. Native name, from Lisianski, 1805, who spells it Oohanick. Tebenkof, 1849, has Uganik, which has usually been erroneously transliterated, Uganuk.

Uganik; spit, name given by Moser, 1897, to a wide shingle beach at the north point of entrance to what he describes as East arm of West Uganik bay. He wrote Uganuk.

Uganik; native village, at head of Uganik bay. Shown by Lisianski, 1805, who spells it Oohanick.

Ugashik; lakes (two), on Alaska peninsula, south of Becharof lake, and drain- ing into Bristol bay through Ugashik river. Nativè name, reported by Osgood, 1.902.

Ugashik; native village, at mouth of the Ugashik river, Alaska peninsulä. Reported by Petrof, 1880, and by him written Oogashik. Has also been written Oogahik.

Ugashik; river, debouching on the northwestern shore of Alaska peninsula. Staniukovich, in the corvette Moller, 1828, was the first to report the existence of this river, which in his journal is called Soulima. Lutke, however, called it, at the same time, by its native name, which in French he wrote Ougatchik. Thus the river has borne two names, each of them variously written Soulima, Sulima, Oogahik, Oogashik, Ugatschik, Ugazhak, etc. According to Grewingk there are two rivers.

Ugat; cape, the western point of entrance to Uganik bay, on the northern coast of Kodiak. Native name, from 'Tebenkof, 1849. Moser, 1897, called it West point.

Ugavigamiut, village; see Uknavik.

Jgazluak, river; see Ugashik.

Ugidak; rock or rocky islet, one of the Delarof islets, at western end of the Andreanof group, middle Aleutians. Aleut name, from Tebenkof., 1849. Has also been written Ugidakh. . 
Ugiiak, rock; see Fairway.

Ugiu-ug, village; see Biorka.

Uglaamie, village; see Utkiavi.

Uglovaia; Eskimo village, on the right bank of lower Yukon river; between Ikogmute and Razboinski. Visited by Nelson in January, 1879, and its name given by him as Ouglovaia.

Uglovaia, mountain ; see Corner.

Ugolnoi, island; see Charcoal.

Ugolnoi, island; see Ukolnoi.

Ugolnoi, point; see Coal.

Ugovik; Eskimo village, on right bank of Kuskokwim river, about 30 miles

Above' Bethel. Name from Nelson, 1879, who wrote it Oogovigamute, i. e., Ugovik people. The Eleventh Census lats Ugavigamiut and the Coast Survey has Odgovigamut. It has been written Ougavik. Population in 1880,206 ; in 1890,57 .

Uguagivil, lake; see Becharof.

Zlguiug, village; see Beaver.

Ugushtu, island; see Crooked.

Ugushtu, island; see Ushagat.

Ugyak; cape, the southern point of entrance to Kukak bay, Shelikof strait. Variously written Igiak, Ilak, Ugaiak, Ugiak. The local pronounciation, according to Dall, is U-gai-yak. Native word, from early Russian explorer's.

Uhaiak; native village, on the southwestern coast of Kodiak, which Lisianski, 1804, wrote Oohaiack.

Uhaskek; native village, on the southeastern coast of Kodiak, between Gull and Dangerous capes. Written Oohaskeck by Lisianski in 1.804.

Uhler; creek, tributary from the east to South fork Fortymile creek, near latitude $64^{\circ} 10^{\prime}$. Prospectors' name, reported by Spurr, Goodrich, and Schrader, 1896.

Uiak, bay ; see Uyak.

Uinuk; Eskimo village, on the south shore of Seward peninsula, at mouth of Nome river. Petrof, 1880 , reported its. population as 10 and its name as 0o-innakhtagowik. Since then it bas appeared as Ooinukhlagowik, Ooinuklagowik, etc.

Uito; hill, in the upper Kuskokwim region, on the south side of Lake Minchumina, near latitude $64^{\circ}$, longitude $152^{\circ}$. Native name, obtained by Herron in 1899, who wrote it U-it-oh.

Ujah, islet; see Uyak.

Ujalkushatsch, volcano; see Redoubt.

Ujut, bay; see Izhut.

U-kai-y'uhkh-pal-iek, island; see Kiukpalik.

Ukak; lake, on the water portage between Yukon and Kuskokwim rivers. Called Ookakhl or Oakakhl by Raymond, in 1869, and Ookakhl and Ookaklit by the Coast Survey, 1898.

tjkak, village; see Ikak.

Ukak; Lskimo village, in the Yukon delta, on shore of Hazen bay. Visited by Nelson in December, 1.878 , and its name reported by him as Ookagamiñt, i. e., Ukak people. Petrof, 1880, calls it Ookagamute and reports its population as 25 , and Jarvis, there in 1897 , writes it Ukogamute: Petrof shows two villages bearing this nlame, (1) the one here described, (2) a village on the right bank of the Yukon near Koserefski.

Ukamok, island; see Chirikof. 
Ukawutni; river, tributary to the Yukon from the north, about 30 miles above the mouth of Melozi river. Native name, from Dall, who has Ukawatne on his map and Ukawitni in his text (Alaska, p. 282).

Ulatatel, island; see Guide.

Ukivol, island; see King.

Ukivok; Eskimo village, on King island, in Bering sea. Said to contain about 40 dwellings partly excavated in the side of a ravine and built up with stone walls. See also King island. Native name written variously, Ookivok, Ovkevok, Ukivak, Ukivok, Ukivuk, Ukiwuk, etc.

Okinuk, island; see King.

Uknavik; Eskimo village and mission, on right bank of Kuskokwim river, about 10 miles below the Kuskokwim-Yukon portage. Its Eskimo name, according to Spurr and Post, who obtained it from missionary Kilbuck, in 1898, is Olinavigamut, for which the suggested meinning is, village on the other side of the village on the other side people. It has been written Ogavik.

Uknodol, island; see Hog.

Ukogamute, Eskimo village; see Ukak.

Ukolnoi; island, near entrance to Favlof bay, Alnska peninsula, west of the Shumagins: Named Ukolnoi (stone coal) by the Russians. The Alent name is Kitagutak. Has alsọ been written Ugolnoi and Youkolny.

Ukshivik; Eskimo village, at Lisianski halbor, on the southwestern shore of Kodiak. Called Ukshivikag-mint, i. e. Ukshivik people, on the RussianAmerican Company map of 1849 . Written also Ukshivikak. Ukshi'vik means a vinter village from Ukshuk (winter), and vik, the locative termination.

$\tau_{\text {-zuk; }}$ bay, in Raspberry island, Kodiak group. Native name, from the Russians.

Ulach, island; see Ulak.

Ulaga, islands; see Four Mountains.

Ulak; island, southwest from Tanaga, Andreanof group, middle Aleutians. Native name, from Sarichef, 1790. who wrote it Illak. Variously written Ioulaklk, Ulach, Ulakh, Youlak, etc. Apparently it is Ulak of the Aleuts, meaning house, or everybody's house.

Ụlak; islet, near Great Sitkin island, Andreanof group, middle Aleutians. Aleut name, from. Tebenkof. It means house for everybody. Has been written Ulakh. Apparently identical with Uliadak island of liussian Hydrographic chart 1400.

Clalihtat, harbor; see Dutch.

Ulakaia; hill ( 946 feet high), eastern part of St. George island, Bering sea, near longitude $169^{\circ} 34^{\prime}$. Aleut name, written Ahluckeyak, and Ahlucheyak by IElliott, 1872-1874; Oolakaiya by Stanley-Brown in 1891; and $\bar{U} 1^{\prime}$-äkĩy:i' by Putnam in 1897. 'The meaning is high, honse, according to Putnam; and a rough back-bone, according to Elliott. Written Alukeyak in the first edition of this dictionary.

Ulakta Head; (900 feet high) the precipitous north end of Amaknak in Unalaski bay, near longitude $166^{\circ} 30^{\prime}$. Called Ulakbta Head by Davidson in 1867, a name derived from Udakta (now Dutch) harbor, the change from Udakta to Ulakta being apparently accidental. Has also been called. North Head.

Clanach, cape; see Chlanak.

Ularakartha; point, north coast St. George island, Bering sea, near east end of Wast rookery, about longitude $\lambda 69^{\circ} 29^{\prime}$. Aleut name, meaning point opposite house, and written Ūl' äräk ïrthä' by Putnum in 1897. 
Uliadak; islet, near Great sitkin, Andreanof group, middle Aleutians. This name appears with a query on Russian Hydrographic chart 1400 . There is confusion in the representation of the islands here and resulting uncertainty as to the application of the name. See Ulak.

Uliaga; island, the northernmost of the islands of the Four Mountains, eastern Aleutians. Native name, from Sarichef, about 1790 . Variously written Ouliaga, Oulliaghin, etc. Veniaminof writes it Uliagan, and adds that, in 1764, there was in its southeastern part a small settlement of quarrelsome, thieving people, which, at the request of the Umnak Aleuts, Glotof exterminated.

Ulinoi; island, in Redoubt bay, Sitka sound, Alexander archipelago. Called Ulinnoi by Vasilief, 1809.

Ulloa; canal, leading south from Bucareli bay, Prince of Wales archipelago, near latitude $55^{\circ} 15^{\prime}$, longitude $133^{\circ} 15^{\prime}$. Apparently so named by the Spaniards in about 1792 . "Ulloa canal appears to have derived its name from being supposed to communicate with Cordova bay, the land north of Cordova bay being styled Isla Ulloa in Galiano's Atlas." (Coast Pilot, 1883, p. 97.)

Ulokat; hills, lower Yukon, extending southwest from Kusilvak mountains, 45 miles west of -Andreafski, near latitude $61^{\circ} \mathbf{5 7}$, longitude $164^{\circ} 40^{\prime}$. Fiskimo name, reported by Putnam in 1899.

Ulukuk; hills, river, and native village, on Unalaklik river, 20 miles east of Norton sound. Native name, from Dall, 1866. Also written Alookuk and Alukuk.

Umak; island, between Great Sitkin and Little Tanaga islands, Andreanof group, middle Aleutians. Aleut name, from the Russians. Has been written Oumakh, Umakh, and Yunakb.

Umakalookt , river; see Black.

Umanangula; bluffs ( 300 feet high), along the south coast of St. George island, Bering sea, between Red bluffs and Cascade point, near longitude $169^{\circ}$. $36^{\prime}$. Aleut name, written Ūmăn'ăngūl' a, can not be seen (that is, from certain places) by Putnam in 1897.

Umanangula; lake, on St. George islind, Bering sea, near the southern coast and longitude $169^{\circ} 3 \tau^{\prime}$. Aleut name, obtained by Putnam in 1897, and 'written Ūmăn' ăngū' lan-ăn' yi = lake near Umanangula (anyi means lake).

Umga; islet ( 250 feet high), between Sannak and Alaska peninsula, near longitude $162^{\circ} 45^{\prime}$. So called by the Russians.

Umla; island, one of the Sannak group, 4 miles southeast of Sannak island, near latitude $54^{\circ} 21^{\prime}$, longitude $162^{\circ} 28^{\prime}$. Native name, reported by Westdahl in 1901.

Umnak; bay, near Umnak pass, on the coast of Unalaska or maybe Umnak islind, eastern Aleutians. Reported by Gilbert, 1901. Not found on any map.

Ümnak; islant, one of the principal islands of the eastern Aleutians, west of Unalaska island, near longitude $168^{\circ}$. Native name. Cook, 1778 , wrote Oomanak; Sauer, 1790, has Oomnak; Coxe, taking the name from Krenitzin and Levashef, 1768, wrote Umyak: Has also been written Oumnak, Oumnakh, Amnak, Amnuk, etc.

Umnak; pass, separating Umnak and Unalaska islands, eastern Aleutians. Native name, from the Russians. 
Umnokalukta; fishing village, cn Black river, a south branch of the Kobuk. Eskimo name, reported by Cantwell in 1885, as Um-nok-a-luk-ta.

Um-ok-a-look-tok, river; see Black.

Umshaliuk; cape, the western head of Kashega bay, on north shore of Unalaska. Native name, from Sarichef, 1792. On this cape, in 1792, was Sedanka village. 'Tebenkof, in 1849 , called the cape Sedanka and, in 1888, the Fish Commission called it Hague.

Umyak, island; see Umnak.

Unak; islet, south of Great Sitkin, Andreanof group, middle Aleutians. Aleut name, from Tebenkof, 1849. It means wound, sore. Has also been written Jounakh.

Unak, river; see Unuk.

Unakak; Eskimo village, in the Yukon delta, near Hazen bay. Nelson, who visited it in December, 1878 , reports its name to be Oonakagamute, i. e., Unakak people. Petrof, 1880, calls it Oonakagamute and reports its population as 20 .

Unakserair; river, northern Alaska, tributary to Alatna river from the north, near longitude $154^{\circ} 30^{\prime}$. Eskimo name, obtained by Mendenhall, 1901.

Unaktolik, Eskimo village; see Ungalik.

Unakwik; inlet, indenting the northern shore of Prince William sound. Aprparently a native name, reported by Glenn, in 1898, as Unaquig, and by Abercrombie as Unaquick. According to Moser, 1897 and 1901, it is called Salmo sound by the fisheries. Erroneously Salmon.

IJnalaklcet, post-office and village; see Unalaklik.

Unalaklik; river, of western Alaska, tributary to eastern end of Norton sound. Eskimo name, variously written Oonalakleet, Ounalaklik, Unalalklik, etc. Tebenkof, 1849, has Unalaklit, and Russian Hydrographic chart. 1455, published in 1852, has Unalaklik or Tsetseka. The Western Union Telegraph lixpedition map of 1867 has inalachleet.

Unalaklik; Eskimo village, town, post-office, and telegraph station, on the eastern shore of Norton sound, at mouth of the Unalaklik river. Population in 1880,100 ; in 1890,175 ; in 1900 , 241. A post-oftice, Unalakleet, was established here in 1902, and it was connected with the military telegiaph, in 1903. Variously written Oonalaklik, Ounalakleet, Unalachleet, etc.

Unalashka, bay; see Unalaska.

Unalashka. The Fish Commission, in 1888, called the roadstead east of Amaknak island Unalashka harbor.

Unalaska; bay, indenting the northeastern shore of Unalaska island, eastern Aleutians, near latitude $54^{\circ}$, longitude $166^{\circ} 30^{\prime}$. The three arms at the head of the bay are now called, respectively: the eastern one, Iliuliuk bay; the one on the west, Nateekin bay; and the middle or most. southerly arm, Captains bay. Capt. Lieut. Michael Levashef wintered in the arm or branch now called Captains bay, September 18, 1768, to June 6,1769 , and named that arm St. Paul harbor, after his vessel. In 1\$27, Krusenstern called the western part (west of Amaknak) Baie dia Capitaine, and the eastern part (east of Amaknak) Baie de Illiuliuck. Veniaminof, in 1840, applied the name Captains to the whole bay, in memory of Levashef's visit. The Coast Survey, 1867, following Davidson, called the whole, Unalaska bay, and in 1875, following Dall, Captains bay. The Fish Commission in 1888, called it Unalashka ; and the same, written Unalaskil, is recent Coast Survey usage. It is now geneially called Unalaska bay.

Unalaska, harbor; see Iliuliuk. 
Unalaska; island, the largest and most important island of the eastern Aleutians. Discovered by the Russians in or about 1760. The Rev. Father Veniaminof, who lived here ten years, about 1820 to 1830 , and spoke the Aleut language, says the Aleuts called this islaud A'-u-an Alakska or Na'-u-an Alakska, i. e., this here Alakskia. Cook, 1778, wrote it Oonalashka, as also did Sauer, 1790. Sutrichef, 1790, wrote it Unalashka, while Lutke, 1828, has Ounalachka, a contraction of the true name Nagounalaska. Petrof silys Agunalaksh, the Aleut name of Unalaska.

Inalaska; post-office, at Iliuliuk village, Unalaska, eastern Aleutians. Established in November, 1892, and discontinued in 1905 .

Unalaska, town; see Iliuliuk.

Unalga; cove, on the northwest side Unalga island, eastern Aleutians. So described by Gilbert, 1901.

Unalga; island, in Akutan pass between Akutan and Unalaska islands, eastern Aleutians, near latitude $54^{\circ}$, longitude $166^{\circ} 10^{\prime}$. Native name, published in this form by Coxe, in 1780, who took it from Krenitzin and Levashef, 1768. Apparently this is Oonella of Cook in 1778. It is Oonalgi of Billings and Ounalga of Lutke. 'This island and the adjacent rock:; were reserved for light-house purposes by Executive order dated January 4, 1901. TIIte adjacent rocks, here called Gull rocks, were in that order called Seal Gull rocks.

Unalga; island, one of the westernmost of the Andreanof group, middle Aleutians. Aleut name, from the Russians. Russian Hydrographic chart 1400 of 1848 calls it western Unalga.

Unalga; pass, separating Unalga and Unalaska islands, eastern Aleutians. So called by Veniaminof. Lutke wrote it Ounalga.

Unalishagvak; cape, west of Karluk, on the northern shore of Shelikof strait. Native name, from the Russians. Variously spelled Unalischachwak, Unalischaglak, Unaltschaswak, Unalishogvalk, etc.

Unana; mountain peak (4,600 feet high), on the eastern side of Russell ford, southeastern Alaska. Apparently a native name, published by Russell in 1893.

Unangashik; native village, at Heiden bay, on the north shore of Alaska peninsula. Native name, from Petrof, 1880 , who wrote it Oonangashik.

Vnaquick, inlet; see Unakwik.

Unaquig, inlet; see Unakwik.

Unarilda; river, tributary to the Koyukuk from the south, at Treat island, near latitude $66^{\circ}$. So called by Allen, 1885.

Unaska, island; see Yunaska.

Unastal, island; see Guide.

I?natlotly; " a very high cut bank of clay" on the north bank of Koyukuk river, just below the mouth of the Alatna. So described by Allen, 1885. Indian name. A later wap has the word village here.

Unavikshak; islet, near the entrance to Chignik bay, Alaska peninsula. Native name, from the russians.

Uncle Sam; creek, Seward peninsula, const of Norton sound, tributary at head of Pine creek, near longitude $164^{\circ} 20^{\prime}$. Prospectors' name, from a local map, 1904.

Uncle Sam; creek, tributary to Fortymile creek from the north, at the international boundary. Local name, obtained by Barnard in 1898 .

Uncle Sam; mountain (1,298 feet bigh), Seward peninsula, 4 miles from coast of Norton sound, near longitude $164^{\circ} 16^{\prime}$. 'Prospectors' name, from Gerdine, 1905. 
Unga; cape, the southeastern point of Ungil island, Shumagins. So named by the Fish Commission in 1888.

Uinga, harbor; see Delarof.

Unga; islind, the largest of the Shumagin group, near latitude $55^{\circ} 15^{\prime}$, longitude $160^{\circ} 45^{\prime}$. Native name, from the Russians. Has also been written Ounga.

Vnga, islands; see Shumagin.

Unga; post-office, at Delarof harbor, Unga island, Shumagin group. Established August, 1.894.

Unga; reefs, in Popof strat, Shumagins. So nimed by Dall, 1872.

Unga; strait, separating the Sbumagin islands from Alaska peninsula. So named by Dall, 1872.

Ungaktalik; lake, near and connected with Nushagak lake. Native name, from Tebenkof, 1849. It means Ungalk region.

Ungalik; river, tributary to the enstern shore of Norton bay, Norton sound. Eskimo name, given by Petrof. 1880, as Oungalilitalik, by the Coast Survey as Ungaliktolik and Unoktolik, and by other's as Unaktolik, i. e., Ungalik region.

Ungalik; Eskimo village, on the eastern shore of Norton bay, at mouth of the Ungalik river. Petrof, 1880 , reported its population as 15 and its name as Oonakhtolik. On late Const Survey charts it is Unoktolik and on a local map Ungaliktalik. Written also Ungwaktolik and Unoctolik.

t/ng-ee-let-ar-geeak, river; see Reed.

Ungulungwak; mountain, on the left bank of the lower Yukon, 35 miles northwest of Andreafski, $T$ or $S$ miles northwest of Ingichuak mountain, near latitude $62^{\circ} 15^{\prime}$, longitude $164^{\circ} 15^{\prime}$. Eskimo name, reported by Putnam, 1899.

ingwaktolik, Eskimo village; see Ungalik.

Unigun, islands; see Four Mountains.

Uniktali; bay, indenting the northwestern shore of Beaver bay, Unalaska, eastern Aleutians, near longitude $166^{\circ} 30^{\prime}$. Aleut name, which Sarrichef, 1792, wrote Unietkalen and Veniaminof, Uniktalia. Apparently from the Aleut word Unaktak (broken). It is Mountain bay of the Fish Commission in 1888 .

Unimak; bay, indenting the southern shore of Unimak island, eastern Aleutians. Its native name is Tugamak, which las been. written Toogamak, Tougamak, and Tougoumak.

Unimak; cove, indenting the north shore of Sannak island, between Favlof har roor and Johnson bay, near: latitude $54^{\circ} 27$, longitude $162^{\circ} 40^{\prime}$. Nime reported by Westdihl, 1901.

Unimak; island, immediately west of Alaska peninsula, eastern Aleutians; near longitude $164^{\circ}$. Native name, which Cook, 17is, wrote Oonemak. Variously written Oonimak, Ounimak, etc.

Unimak; pass, between Unimak island and other islands to the west, near longitude $165^{\circ}$. One of the principal passes through the eastern Aleutians.

Union; bay, in Cleveland peninsula. at junction of Clarence strait and Ernest sound, Alexander archipelago, near latitude $55^{\circ} 45^{\prime}$, longitude $132^{\circ} 12$ '. So called, prior to 1880 , on some unpublished charts.

Union; mining camp, on the South fork Koyukuk river, 2 miles above its mouth, near longitude $152^{\circ}$. Called Union City by the prospectors and miners in 1899. 
Union; gulch, 10 miles northeast of Nome, Seward peninsula, on the north bank of Buster creek, an east branch of Nome river, near longitude $165^{\circ} 13^{\prime}$. Local name, publisbed in 1904.

Union; point, between Union bay and Vixen inlet, western shore Cleveland peninsula, Ernest sound, southeastern Alaska. Name so applied by the local navigators and reported by F. C. Fassett, Bureau of Fisheries, in 1904.

Unishka; island, on the south side of Redoubt bay, Sitka sound, Alexander archipelago. So called by Vasilief, 1809.

Unklakat; river, tributary to the Yukon, 47 miles below the mouth of Tozi river. So described by Cantwell, 1900. Not found on any map.

Unlucky; islet, in the eastern part of Bucareli bay, Prince of Wales archipelago. Named La Desgraciada (the unlucky) by Maurelle and Quadra,. 17751779.

Unnatak; native summer fishing camp, on Kobuk river, near the mouth of Ambler river, about latitude $67^{\circ}$, longitude $158^{\circ}$. Eskimo name, obtained by Cantwell in 1885, and written Un-nah-tak, but not shown on his map.

Unoctolik, Eskimo village; see Ungalik.

Unoktolik, river and village; see Ungalik.

Unsuzi; mountain (2,000 feet high), north of Lake Minchumina, on the left bank of Last fork Kuskokwim river, near latitude $64^{\circ}$, longitude $152^{\circ}$. Native name, given by Herron, 1899, as Un-suz-ee.

Unuk; river, tributary to Burroughs bay, soutbeastern Alaska. Native name, from the Coast Survey. "The correct name of this river," writes M. W. Gorman, " is Junuk or Junock."

Uphoon, pass; see Apoon.

Upland; creek, tributary to Nome river from the west, in the Nome mining region, Seward peninsula. Local name, published in 1900 . It is Shepard creek on a recent map.

Up-nut, creek ; see Aniliovik.

Upper; lake, near St. Paul, Kodiak. It drains to Lower lake and thence to Shabafka cove. Called verkhnie (upper) by 'Tebenkof, 1849.

Upper; lake, near the northeastern coast of St. George island, Bering sea, near longitude $169^{\circ} 31^{\prime}$. Local name. According to Putnam, the Aleut name is Kōs'ërä-ïn'ïg, meaning upper lakẹ.

Upper Camp, creek; see Camp.

Upper Chulik. The Eléventh Census, 1890 (p. 114), speaks of two Eskimo villages on the eastern coast of Nunivak island together containing 62 people and called Chuligmiut and Upper Chuligmiut, i. e., Chulik people.

Upper Ramparts; gorge or canyon, in Porcupine river, about 20 miles from the international boundary line. Aiso see Ramparts.

Upright; cape, the easternmost point of St. Matthew island, Bering sea. So named by Cook in 1778. Perpendiculaire of Lutke and Otviesnoi (upright) of the Russians. Erroneously Upwright.

Uranatina; river, tributary to the Copper from the west, about 10 miles north of Tiekel river. Native name, from Abercrombie in 1898. It is Teikbell river of Allen in 1885 . See Tiekel.

Urey; point, the westerumost point of Chichagof island, Alexander archipelago. So named by Dall in the Coast Pilot (1883, p. 184), after Capt. Iuri or Urey Feodorovich Lisianski, who was the first to indicate it. Urey, sometimes written Iuri, is the Russian for George. 
Urilia; bay, on the norther'n coast of Unimak, eastern Aleutians. Named Urilia (shag or cormorint) by Tebenkof, 1849. The Fish Commission, in 1888, called this Shaw bay. Perhaps this is an error for shag.

Urilie, rocks; see Shag.

Urilof; island, in southern part of the Necker group, Sitka sound, Alexander archipelago. Named Urielof by Vasilief, 1809.

Ursus; cove, in the western shore of Kamishak bay, Cook inlet, near latitude $59^{\circ} 33^{\prime}$. Local name, Bear cove, reported by Martin, 1904 . On June 6, 1906, the U. S. Board on Geographic Names renamed it Uısus.

U. S.; gulch, on the left bank of Uhler creek, an affuent of South fork Fortymile creek, near latitude $64^{\circ} 10^{\prime}$, longitude $141^{\circ} 4: 0^{\prime}$. Prospectors' name, reported in 1898 .

Uscrdic, point; see Zeal.

Usgik, islet; see Uski.

Ushagat; island, one of the Barren islands at entrance to Cook inlet. Native name, given by Tebenkof as Ushagat and Ugushtu. Has also been called Ugutchtu and Ushugat.

Usher; rock, on the west side of the Western channel into Sitka harbor, Sitki sound, Alexander archipelago. Named by United States naval officers, 1879, after Lieut. Nathaniel Rielly Usher, U. S. N., then on duty at Sitka.

Ushk; bay, indenting the southern shore of Chichagof island, Peril strait, Alexander archipelago, near latitude $57^{\circ} 34^{\prime}$, longitude $135^{\circ} 36^{\prime}$. Presumably a native nime, reported by Moore, 1.895 .

Ushk; point, the north point at entrance to Ushk bay (above). So named by Moore, 1895.

Usinka, narrows; see Narrow strait.

Tjsinka, village; see Uzinli.

Uski; islet, in the western anchorage St. Paul harbor, Kodiak. Named Uskoi by the early Russians. Perhaps from usgik, the Alent word for willow.

Uskosti, point; see East.

Usof; bay, indenting the southeastern shore of Unalaska,. eastern Aleutians, near latitude $53^{\circ} 30^{\prime}$, longitude $166^{\circ} 45^{\prime}$. Named Usova (Usof's) by Tebenkof, 1849. Called Whalebone bay by the Fish Commission in 1888.

Ustay; glacial stream, on the southeastern coast, 40 miles southeast of Yakutat, tributary to Akwe river from the east, near longitude $138^{\circ} 40^{\prime}$. Indian name, written Us-tay by Moser, 1901. The stream so lettered by Moser seems to include both the Akwe and Tanis of 'Tebenkof. See Akwe and Tanis.

Ustia, cape; see Entrance.

Ustia Rieka, cape; see Rivermouth.

Ustiugof; shoal or bank, off Constantine point, at mouth of the Nushagak river, Bristol bay, Bering sea. So nimed by 'Tebenkof, after a $\mathrm{Mr}$. Ustiugof, of whose surveys in this region, in 1818, Tebenkof: speaks in commendation.

Usuktu; river, of northern Alaska, tributary to Meade river from the east. Name from Ray, who passed it in April, 1883, and'reports its native name to be Usuuktu and Usâktu in his text and Esuktu on his map. It has since been written Suktu.

Utah; creek, tributary to Mission creek from the west, in the Eagle mining region. Local name, reported by, Barnard in 1898. 
Utakaht; slough, Yukon delta, on the right bank of Kwikluak pass, near latitude $62^{\circ} 43^{\prime}$, longitude $164^{\circ} 20^{\prime}$. Eskimo name, obtained by Putnam, 1899.

Utalug; cape, on the southeastern coast of Atka, opposite Amlia, middle Aleutians. Native name, from Tebenkof, 1849. Perbaps from the Aleut utak (big finger or thumb).

Utchno, cape; see Trinity.

Utes; cape, on the southern shore of Nazan bay, Atka, middle Aleutians. Named Utes (cliff or escarpment) by Tebenkof, 1849.

Utes; cape, somewhere in the vicinity of Boat harbor, on northern shore of Norton sound, Bering sea. Called Utes (cliff, escarpment) by Tebenkof, 1833. Not found on late maps.

Utes, cape; see Escarpment.

Utesistoi, island; see Rocky.

Utichi, islet; see Calming.

Utichi, islet; see Rocky.

Utinoi, islet; see Duck.

Utka, bay; see Tutka.

Utkiavi; Eskimo village, and Government station at Cape Smyth, near Point Barrow, latitude $71^{\circ}, 18^{\prime}$. 'This word, or something like it, is said to be the Eskimo name for Cape Smyth, and means the cliffs. The difficulty in getting at the native names of places is well illustrated in this case. Three members of the Signal Service party which spent two years here, and two, at least, of whom acquired a speaking knowledge of the Eskimo language, give these three forms: Ooglamie (and Uglaamie), Ootkeavie, and Utkiaving (Utkiawiñ). As for others, they have used Otkiawik, Otkiovik, Ootivakh, Ootkieawie, Ootkeavic, and Government station.

Utmak, cape; see Kettle.

Utukok; cape; see Icy.

Utukok; river, debauching in the lagoon along the Arctic coast, 15 miles south of Icy cape, near latitude $70^{\circ}$. Eskimo name, reported by Jarvis, 1898, who wrote it Ootokok and Ootookok. This is said to be the Eskimo name of Icy cape.

Utukok; Eskimo village, on the Arctic coast, at or near Icy cape. Eskimo nime, from Petrof, 1880, who wrote it Otok-kok. Has also been written Ootookok, and in John W. Kelly's rocabulary this is given as the Eskimo name of Icy cape. Russian Hydrographic chart 1495, dated 1854, shows a settlement here called Kaiakishvig-miut. According to Murdoch, the name is Ṓ-tu-káh [mun]. Population 50, in 1880.

Uwik; pass or slough, opening on the outer shore of Yukon deita, 22 miles noitheast of Kiwikpak mouth, near latitude $63^{\circ} 15^{\prime}$, longitude $164^{\circ} 10^{\prime}$. Eskimo name, obtained by P'utnam, 1899, who wrote Oowik.

Uyak; anchorage, behind Bear and Harvester islands, on west shore of Uyak bay, north shore of Kodiak. So called by Moser, 1897. Native name.

Uyak; bay, indenting the northwestern coast of Kodiak, near latitude $57^{\circ} 40^{\prime}$, longitude $153^{\circ} 50^{\prime}$. Native name, from the Russians. Lisianski, 1805, spells it Oohiack, and the village Ooiatsk. Petrof, 1880, writes it Ooiak. Has also been written Uiak.

Uyak; cape, the western point of entrance to Uyak bay, on northwest coast of Kodiak. Native name. Locally called Serenmile point. Lisianski, 1805 , calls it West point.

Uyak; islet, in Nazan bay, Atka, middle Aleutians. Native name, from Tebenkof, 1849. Has also been written Ujah. 
Uyak; village, and post-office (established in 1901), on Uyak anchorage, Uyak bay, northwestern coast of Kodiak island.

U? zenkoi, strait; see Narrow.

Uzinki; village, on Spruce island, Kodiak group. The location of this village is not shown. It may be identical with Novie Balạam (New Balaam) of the Russian-American Company map of 1849 . The village takes its name from Uzinkie, the Russian adjective for narron. Has also been written Oozinkie and Usinka.

Valdez; glacier, northeast of Valdez, Prince Wivilliam sound. So called by Abercrombie, 1898.

Valdez; narrows, the contracted part of the entrance to Port Valdez, Prince William sound. So called by Abercrombie, 1898. Also called Stanton narrows by Abercrombie the same year.

Valdez; port, indenting the northeastern shore of Prince William sound. According to Vancouver it was called Puerto de Valdes by Fidalgo in 1790 .

Valdez; summit, the highest point on the trail over Valdez glacier into the interior. So called by the 3,000 (more or less) prospectors who used it in 1898 .

Valdez; town, at head of Port Valdez, Prince William sound. Captain Glenn, writing in 1898 , indicates that it was then called Copper City, but now Valdez. A post-office, called Valdez, was established here in July, 1899, and the town was incorporated July 1, 1901. Population 1900, 315.

Vallenar; bay, in Clarence strait, at north end of Gravina island, Alexander archipelago. So named by Nichols, 1883.

Vallenar; point, the northernmost point of Gravina island, separating Tongass narrows from Clarence strait. Named by Vancouver, 1798, after Señor Higgins de Vallenar, President of Chile. Higgins, or rather O'Higgins of Ballenagh, Ireland; became naturalized in Chile and in place of O'Higgins of Ballenagh became Higgins de Vallenar.

Vallenar; rock, off Vallenar point, at the northern entrance to Tongass narrows. So named by Nichols, 1885 .

Vancouver; cape, high and bold, on the mainland, northealst of Nunivak island, Bering sea. Discovered by Etolin, in 1821, and by him named after Capt. George Vancouver.

Vancouver; islet, in Dixon entrance, very near Cape Northumberland, Duke island. Apparently a local name, published by the Coast Survey in 1885 .

Vancouver; mountain (15,666 feet high), in the st. Elias alps, southeastern Alaska. Named by Dall, in 1874, after the great English navigator, Capt. George Vancouver.

Vandeput; point, the western point of entrance to Thomas bay, Frederick sound, Alexander archipelago. So named by Vancouver, 1794.

Vanderbilt; point, on the northern bank of Chilkat river, near its mouth, southeastern Alaska. Named by United States naval officers, 1880, after Capt. J. M. Vanderbilt, captain of the trading steamer Favorite. It is apparently identical with Povorotni (turnabout) of Lindenberg in 1838.

Vanderbilt; reef, in the southern part of Lynn canal, Alexander archipelago. Discovered by Capt. J. M. Vanderbilt, of the Northwestern Trading Company's steamer Favorite and named after him by United States naval officers, 1880.

Vank; island, west of Wrangell, in Sumner strait, Alexander archipelago. So named by the Russians.

Tankahini, bay; see Dry.

Bull. 299-06 $\mathrm{M}-42$ 
Vankahini; one of five rivers in the delta of Alsel river, sontheastern Alaska. So called by Tebenkof in 1849 (chart 7 ). Apparently a native name, the termination hini meaning river. Has also been written Vankagina.

Van Sant; cove, indenting the southern shore of Kosciusko island, Davidson inlet, Prince of Wales archipelago, near latitude $55^{\circ} 59^{\prime}$, longitude $133^{\circ}$ 32'. Named by Dickins, 1903-4, after the superintendent of the Holbrook fishery.

Vasilief; bank, off Povorotni point, Sitkal sound, Baranof island, Alexander archipelago. Named Vasilief (Williams) by the Russians, 1809, after one of their naval officers. Has also been written Vasilevka.

Vasilief; bay, indenting the southern shore of Atka, middle Aleutians. So named by Lutke, after the pilot Vasilief, about 1830 .

Vasilief, cape; see Corwin.

Vasilief; rock, south of Biorka island, Sitka sound, Alexander. archipelago. Named Vasilief (Williams) by the Russians, 1809. Proper name. Has also been called Vasileva (Basil's or William's).

Vasilief; shoal (with 4 feet at low water),-in Chiniak bay, Kodiak, lying between the south ends of Long and Woody islands. Named by Russian naval officers, 1808-1810.

Vasilief; sunken reef, in the entrance to Chiniak bay, Kodiak. Discovered and named Vasilief by Russian naval ofticers, 1808-1810. Variously called Vasilief, Wasilieff, Williams, etc.

Vaskin; cape, on the northern coast of Unimak, eastern Aleutians. So called by Veniaminof, 1840.

Vassar; glacier, tributary from the west to College fiord, Port Wells, Prince William sound. So named by the Harriman expedition, 1899, after Vassar College.

Vault; creek, 15 miles north of Fairbanks, tributary to Chatanika river from the south, near latitude $65^{\circ} 05^{\prime}$, longitude $147^{\circ} 40^{\prime}$. On Gerdine's map of 1903 this is lettered Moose creek, but on a later local map it is called Vaùlt creek.

Vavilof, bay; see Baralof.

Vcevidofski, volcano; see Vsevidof.

Vegas; islands, in Sealed passage, on the northwestern shore of Duke island, Gravina group, Alexander archipelago. So named by Nichols, 1883.

Venetia; creek; tributary to Eldorado river from the east, Seward peninsula. Name from Barnard, 1900.

Vennevkar, creek; see Vernal.

Ventosa, island; see Kochu.

Ventura; creek, Seward peninsula, Casadepaga drainage, tributary to Alma creek at head of Birch creek, near latitude $64^{\circ} 48^{\prime}$, longitude $164^{\circ} 09^{\prime}$. Prospectors' name, from Gerdine, 1905.

Ventura; point, on San Fernando island, San Alberto bay, Bucareli bay, Prince of Wales archipelago. Named Punta de Santa Buenabentura by Maurelle and Quadra, 1775-1779.

Verde; island and point, in Port Refugio, Bucareli bay, Prince of Wales archipelago. Named Punta y Ysla Verde (green point and island) by Maurelle and Quadra, 1775-1779.

Verdure; point, on the western shore of Portland canal. So named by Pender 1868.

Verkhnie, lake; see Upper.

Vernal; creek, tributary to Wrangell harbor, Alexander archipelago. Named Veshnevka (vernal) by Zarembo, 1834. On hydrographic chart 225 it is called Vennevkar. 
Verstovia; mountain (3,216 feet high), about 3 miles from Sitka, Baranof: island, Alexander archipelago. Named by Vasilief in 1.809. Verstovaia is the adjective form of verst, the Russian unit for long distance, equal to 3,500 feet. The mountain is nearly 1 verst high.

Very; inlet, indenting the mainland on the eastern shore of Revillagigedo channel, southeastern Alaska, near latitude $54^{\circ} 57^{\prime}$, longitude $130^{\circ} 55^{\prime}$. Local navigator's' name, reported by H. C. Fassett, Bureau of Fisheries, 1.904.

Veseelovskoi, cupe; see Cheerful.

Veselofski, cape; see Cheerful.

Vesoki, island; see High.

Vesolia; mountain peak, in western Alaska, in the divide between Norton sound and Yukon river. Called Vesolia Sopka (cheerful peak) by the Russians. See Old Woman and Sugarloaf.

Veta; mountain (Mount Veta, 5,720 feet high), in the Fortymile region, eastern Alaska, near latitude $64^{\circ} 15^{\prime}$, longitude $143^{\circ}$. Prospector's' name, from sketch map compiled by-Major Glassford, Signal Corps, U. S: A., 1905.

Vexation; point, on Kupreanof island, Wrangell strait, Alexander archipelago. So named by Meade, 1.869 , in memory of the annoyance experienced, at this point, in taking the Saginaw through Wrangell strait.

Vexation Point; rock, off Vexation point, Wrangell strait, Alexander archipelago. So named by Nichols, 1881.

Vichnefski; rock, off St. John harbor, in Sumner strait, Alexander archipeligo. Apparently so named by the Russians.

Victoria; creek, tributary to Coal creek from the north, Seward peninsulit. Nime from Barnard, 1900.

Victoria; creek, tributary to Igloo creek from the south, Seward peninsula. Nime from Brooks, 1900.

Victoria; creek, the left branch of Beaver creek, 100 miles east of Rampart, near latitude $66^{\circ}$, longitude $146^{\circ}$. Frospectors' name, reported by Lieutenint Erickson, U. S. A., 1902. Calted also Golden creek.

Victory; creek, Kenai peninsula, tributary to Kenai lake from the east, near its southeastern extremity. Prospectors' name, from Moftit, 1904.

Viedrin; island, one of the Siginaka group, Sitka sound, Alexander: archipelago. So named by Vasilief, 1809.

Viejo, lsla del; see Old Man island.

Viekhoda, cape; see Outlet.

Vierublennoi Kriepostnoi, cape; see Razed Fort.

Viesoluta, volcano, etc.; see Redoubt.

Viesoki; rock, near Hot Springs bay, Sitka sound, Alexander archipelago. Named Viesokoi (high) by Vasilief, 1809. Has also been called High Rock and Visokoi.

Viesolie, rock; see Pillar.

Viesolooi, island; see High.

View; cove, Tlevak strait, indenting the eastern coast of Dall island, Alexander archipelago. So named by Nichols, 1881.

Viking; sunken rock, in Rerlfish bay, Baranof island, Alexander archipelago. So named by Moser, 1897.

Village; see Unatlotly.

Village; cove, indenting the westem end of Alaska peninsula, Isanotski strait. latitude $55^{\circ} 04^{\prime}$, longitude $163^{\circ} 15^{\prime}$. Old Morzhovoi village is located on this cove. Name published by the Coast Survey in 1882.

Village; cove, near St. Paul village, St. Paul island, Pribilof group, Bering sea. Local name. 
Village; islands; in Zimovia strait, opposite a deserted Indian village, whence the name, given by Snow in 1886.

Village; islands, a group of high rocky islets, off the western shore of Uganik bay, Kodiak, near Uganik village, about latitude $57^{\circ} 50^{\prime}$, longitude $153^{\circ} 35^{\prime}$. So named by Moser, 1897 .

Village; islet (peninsula at low water), in. Felice strait, near north end of Duke island, Alexander archipelago. So named by Nichols, 1882, who found an Indian village here containing 15 bouses.

Village; islet, near Howkan village, Cordova bay, Alexander archipelago. So named by Dall in 1882. Was also named McFarland by Sheldon Jackson, 1880 .

Village; peninsula, a rocky head (island at high water) on the western shore of Uganik bay, near Uganik village. So named by Moser, 1897.

Village; point, in Port Chester, Annette island, Alexander archipelago. It is at this point, named by Nichols, 1883, that the town of New Metlakatla has been built.

Village; point, on the western edge of McClellan flats, Chilkat inlet, southeastern Alaskia. Named by United States naral officers, 1880 . It was called Wodopada (waterfall) cape by Lindenberg in 1838.

Village; point, the north point of entrance to Chaik bay, Admiralty island, Chatham strait, Alexander archipélago. So named by Meade, 1869, who. on his chart (United States Hydrographic 225) shows the Indian village "Old. Kootznahoo" near. it. The native name of this village is given by Dall in the Coast Pilot (1883, p. 175) as Letushkwin.

Village; reefs, off Graveyard point, west shore Afognak bay, soutlieastern coast Afognak island, Kodiak group, near latitude $58^{\circ}$. Local name, reported by Moser, 1900.

Village; rock, in Kootznahoo inlet, Admiralty island, Alexander archipelago. So named by Meade, 1869.

Village; shoal, extending southeast from Pyramid point, north side of Port Mulgrave, Yakutat bay, southeastern Alaska, near latitude $59^{\circ} 34^{\prime}$, longitude $139^{\circ} 47^{\prime}$. So named by Harber, 1892.

Villaluenga, Punta de; see Spencer cape.

Villard; glacier, on the northern flank of Villard mountain, near Chilkoot inlet, southeastern Alaska. Apparently so named by Dall, 1883, after Henry villard.

Villard; mountain (5,100 feet high), on the mainland, near junction of 'Taiya and Chilkoot inlets, southeastern Alaska. Apparently so named by Dall, 1883, after Henry Villard.

Vinasale; old trading post, on the upper Kuskokwim. Population in 1890, 140. Local name, from Spurr, who visited it August 1, 1898, and found it deserted. Also written Vinasáhle and Vinisahle.

Fincent, island; see Hogan.

Tincent, island; see Klokachef.

Vinegar; creek, Seward peninsula, tributary on north bank of East fork Solomon river, near latitude $64^{\circ} 42^{\prime}$, longitude $164^{\circ} 16^{\prime}$. Prospectors' name, from a local map, 1904.

Viola, creek, near Nome; see Violet.

Violet; creek, 10 miles northwest of Cape Nome, Seward peninsula, draining from the northeast through Hazel creek into, Nonie river, near longitude $165^{\circ} 12^{\prime}$. Local name, published in 1904. Erroneously Viola.

Virgin, bay ; see Gladhaugh. 
Virgin; creek, on the north side of Turnagain arm of Cook inlet, a left branch of Glaciel creek, near latitude $61^{\circ}$, longitude $149^{\circ} \cdot 05^{\prime}$. Miners' name, reported by Herron, 1899.

Virgin; peak (3,750 feet high), in the northeastern part of Stolin island, Alexander archipelago. So named by Snow, 1886 .

Virginia; creek, tributary to ${ }^{\circ}$ Igloo creek from the south, Seward peninsula. Name from Brooks, 1900.

Virginia; creek, Seward peninsula, in Solomon River basin, tributary on west bank of Shovel creek, near latitude $64^{\circ} 43^{\prime}$, longitude $164^{\circ} 26^{\prime}$. Prospectors' name, from a local map, 1904.

Virginia; creek, Seward peninsula, tributary from the north to Garfield creek, an affluent of Kuzitrin river, near latitude $65^{\circ} 30^{\prime}$, longitude $164^{\circ} 25^{\prime}$. Prospectors' name, reported by Gerdine, 1901.

Virginia; gulch, Copper River region, at headwater's of Chititu creek. Named by prospectors, and first appears on map of Nizina mining district by. George M. Esterly, of Valdez, 1902.

Virublennoi; island, southwest of Japonski island, Sitka sound, Alexander archipelago. Named Virublennoi (trees cut down, i. e., cleared) by Vasilief in 1809 .

Visokoi, rock; see Viesoli.

Vitskari; island, and rocks, in Sitka sound, Alexander archipelago. So named by Vasilief in 1809. Lisianski, in 1804, called them Middle islands. According to George Kostrometinoff, United States' court interpreter at Sitka, this means (captain) Witz's chastisement.

Vixen; bay, indenting the southern shore of Boca de Quadra, Alexander archipelago. So named by the Coast Survey, in 1.891, presumably after one of its steam launches.

Vixen; inlet, on the western shore of Cleveland peninsula, opening into Ernest sound, Alexander archipelago, near latitude $55^{\circ} 50^{\prime}$, longitude $132^{\circ} 05^{\prime}$. So named by Snow; 1886, presumably after the steam launch Viacn.

Vixen; islands, Hooniah sound, Peril straịt, Alexander archipelago, a group of four islands, onè-half mile northwest of Emmons island, near latitude $57^{\circ} 37^{\prime}$, longitude $135^{\circ} 35^{\prime}$. So named by Moore in 1895 , after the Coast Survey launch Vixcn.

Vixen; point, the north point of entrance to Vixen inlet, Ernest sound, southeastern Alaska. Name so applied by local navigators and reported by F. C. Fassett, Bureatu of Fisheries, 1904.

Vlchoda, cape; see South.

Pnieshnic, rock; see Outer.

Vodopad; river, tributary to the head of Silver bay, Baranof island, Alexander archipeligo, near lititude $56^{\circ} 59^{\prime}$, longitude $135^{\circ} 07^{\prime}$. So called on Const and Geodetic Survey chart 8340 (ed. of 1898). The Russian charts have the word vodopad or Wodopad (water fall) in this place, one of: them indicating a height of 350 feet.

Voevodskago, island; see Woewodski.

Volcano; bay, indenting the northeastern shore of Makushin bay, Unalaska. So named by the Fish Commission in 1888. Sarichef's mal, of 1792, as also Tebenkof's, 1849, shows the village of Makushin on this bay. The present Makushin village is abont 4 miles south of this place.

Volcano; bay, indenting the southern shore of Alaskil peninsula, neal Pavlof: volcano. So called by Dall, 1880 ; perhaps a local name.

Volcano; point, south of Pavlof volcano, Alaska peninsula. So named by Dall in 1880 .

Volchie, island; see Wolf point. 
Volga; island, near Middle channel into Sitka harbor, Sitka sound, Alexander: archipelago. So named by the Russians.

Volkmar; river, tributary to the Tanana from the northeast, near latitude $64^{\circ}$, longitude $145^{\circ}$. 'This river was named Goodpaster by Allen, 1885. The tributary 20 miles farther down the Tanana, he named Volkmar, in honor of Col. William Jefferson Volkmâr, U. S. A. Later explorers inadvertently transposed these names, one for the other, and usage has thus estriblished them.

Voorhees, islands; see Lively.

Vorobinoi, islet; see Sparrow.

Voronie, island; see Crow.

Voronkowski, island; see Woronkofski.

Vosnesenski, island; see Wosnesenski.

Voss; creek, tributary from the west to South fork Fortymile creek. Local name, published by the Geological Survey in 1899.

Vostochnie, channel; see Bastern.

Vostochnie; locality and rookery, Northeast point, St. Paul island, Bering sea, near longitude $170^{\circ} 06^{\prime}$. Called Novastoshnah (of recent growth) by Elliott, 1874, who derives it from the Russian novaite, and says it is so called "because this locality in pioneer days was an island to itself; and it has been annexed recently to the mainland of St. Paul." Vostochnie is Russian for east.

Vostochnie, point; see I̦̣așt.

Vostochnie, point; see Northeast.

Vostochnoi, cape; see Last.

Vostochnoi, point; see Tolstoi.

Vozvrashenia, arm; see 'Turnagain.

Vsevidof; group of six islets, with some rocks and shoals, lying on the south side of and near to Umnak, eastern Aleutians. Called Sevidow, Sevidovskaia, Vsevidow, etc., by the Russians, perhaps after Andrëi Vsevidof, a Russian fur trader, who was in the Aleutian islands in 1747 .

Vsevidof; volcano $(8,800$ feet high), near the middle of Umnak island, eastern Aleutians. So called by Veniaminot and possibly by earlier Russians. The name has been variously spelled Sewidow, Vcevidofski, Wsewidow, etc.

Vulcan; cove, indenting the southern shore of Akutan island, Krenitzin group, eastern Aleutians, near longitude $164^{\circ} 50^{\prime}$. So named by the Fish Commission in 1888. The fire of Vulcan is much in evidence in this island.

Vulcan; creek, tributary to the Tubutulik river from the west, southeast of Omalik mountain, Seward peninsula. Prospectors' name, from Peters, 1900 .

Vulcan; point, the eastern point of entrance to Vulcan cove, Akutan island, eastern Aleutians. So named by the Fish Commission in 1888.

Vulcan Point; mountain, between Vulcan creek and Tubutulik river, Seward peninsula. Local name, from Peters, 1900.

Wachusett; cove, in Freshwater bay, Chichagof island, Chatham strait, Alexander archipelago. Surveyed and named by the U. S. S. Wachusett, Commander Henry Glass, U. S. N., commanding in 1881.

Wachusett; peak, on the mainland, near Farragut bay, southeastern Alaska. So named by Thomas, 1887 , after the U. S. S. Wachusett, at one time stationed in Alaskan waters. 
Wadding; cove, indenting the southeastern shore of Cleveland peninsula, Behm canal, just north of $\mathrm{Helm}$ bay, near latitude $55^{\circ} 37^{\prime}$, longitude $131^{\circ} 55^{\prime}$. Name given by local navigator's, and reported by H. C. Fassett, Bureau of Fisheries, 1904.

Wade; creek, Seward peninsula, tributary from the west to Kugruk river, which flows to Kotzebue sound, nenr longitude $163^{\circ}$. Prospector's' name, reported by Mendenhall, 1901.

Wade; creek, tributary to Walker fork from the north, in the Fortymile mining district. Prospectors' name, published by the Geological Survey in 1899. Presumably named after the prospector Jack Wade.

Wagner; lake (elevation 1,900 feet), draining through Tetling river to the Tanana. Named by Lowe, 1898, after Col. Arthur Lockwood Wagner, assistant adjutant-general, U. S. A.

Wainwright; inlet, on the Arctic coast, near Point Belcher, and latitude $70^{\circ}$ 35'. So named by Beechey in August, 1826, after Lieut. John Wainwright, R. N., a member of his party. According to the Russians it is Tutagvalk of the natives.

Wait; creek, in the Mount Wrangell district, tributary to Jacksina creek from the west. So named by Schrader, 1902, because he was delayed a week here by bad weather.

Waite; island, in Koyulkuk river, near latitude $66^{\circ} 15^{\prime}$, longitude $154^{\circ}$. So named by Allen, 1885, after Chief Justice Morrison Remick Waite.

Waiting; anchorage, north side of Thorne island, Kashevarof passage, Clarence strait, Prince of $W$ ales archipelago, near latitude $56^{\circ} 09^{\prime}$, longitude $133^{\circ}$ $03^{\prime}$. Local navigator's' name, reported by H. C. Fassett, Bureau of Fisheries, 1904.

Waklarok; slough, Yukon delta, on the left bank of Kwemeluk pass, near its moutb, about latitude $62^{\circ} 32^{\prime}$, longitude $165^{\circ}$. Eskimo name, obtained by Putuam, 1899 .

Waklarok; Eskimo village, Yukon delta, on Waklarok slough (above). Native name, written Waklarokamiut, i. e., Waklarok folks, by Putnam in 1899.

Walakpa; Eskimo camp, on the Arctic coast, at Refuge inlet, near latitude $71^{\circ}$ 07 . So written by Ray in 1883 . Murdock wrote Wal-a-pai, and others Walakpat. See Refuge inlet.

Walalipat; see Walakpa and Refuge inlet.

Wal-a-pai, inlet and camp; see Refuge and Walakpa.

Walden; point, the northern point of Annette island, Nichols passage, Alexander archipelago, southeastern Alaskia, near latitude $55^{\circ} 16 i^{\prime}$, longitude $131^{\circ} 35^{\prime}$. Local navigators' name, reported by H. C. l'assett, Bureau of Fisheries, 1904.

Walden; rocks, at northeastern end of Nichols passage, Alexander archipelago. Apparently so named by Nichols, 1883 . Called Race reet' in Coast Pilot (1883, p. 79), this name being taken from local pilots.

Waldron; creek, tributary on the left (southeast) bank of Yukon river, 5 miles below Fort Hamlin, near hatitude $65^{\circ} 50^{\prime}$, longitude $149^{\circ}$. Prospectors' name, reported by Lieutenant Erickson, U. S. A., 1902.

Wales; harbor, on the northwestern shore of Wales island, Alexander archipelago. Name published by the Coast Survey in 1891.

Wales; island, at the mouth of Portland inlet. So named by Pender, 1868.

Wales; passage, between Wales and Pearse islands, Alexander archipelago. So named by the Coast Survey in 1891.

Wales; point, the southernmost point of Wales island, at entrance to Portland inlet, Alexander archipelago. So named by Vancouver, 1793. 
Wales; post-office (established in 1902), on Cape Prince of Wales, Seward peninsula. The Eskimo village here is Kingegan, and here also is a Congregational mission, a reindeer station, and a Government school. See Kingegan.

Walker; cove, in the mainland, opening into Behm canal, southeastern Alaska. So named by Vancouver, 1793 , on his chart, but not mentioned in his text.

Walker; fork, of South fork Fortymile creek on the east, near the international boundary and latitude $64^{\circ}$. Prospectors' name, reported by Spurr, Goodrich, and Schrider, 1896.

Walker; island, south of Cone point, Revillagigedo channel, Alexander archipelago. Apparently so named by local pilots. Lewis and Walker islands are near together and their names have been confounded. The western is Lewis, the eastern Walker.

Walker, lake; see Naknek.

Walker; lake (Lake Walker), northwestern Alaska, the source of Kobuk river, near latitude $67^{\circ} 10^{\prime}$, longitude $154^{\circ} 30^{\prime}$. Discovered by Cantwell in 1885, who wrote the Eskimo name variously, Car-loog-ah-look-ta, Carloog-ah-look-tak, Car-loog-ah-look-tah, Cur-loog-ah-look-tah, and gave its meauing, Big Fish. lake. Stoney, 1885, wrote it Kal-lu-look-to-ark, Kab-lu-look-to-ark, and gave the same meaning. The name Lake Walker seems to have been giren by Stoney.

Walker; point, "broad and wooded," the eastern point of entrance to Murder cove, Frederick sound, Alexander archipelago. Called Cirroll by Nichols in the Coast Pilot, 1891, and Walker by the Coast Survey, in 189S. Since the surveys of 1897 this point has been called Walker, the name Carroll being applied to an island about 3 miles to the east of it.

Walker; station, on north bank of Yukon river at the mouth of Tozi river, about longitude $152^{\circ} 15^{\prime}$ - a collection of $\log$ cabins which were the winter quarters of the crews of a number of ressels in 1898 .

Walkerville; village, near or in the Porcupine gold district. Name published by the Geological survey in 1900.

Wall; creek, a right tributary of Mosquito fork Fortymile creek, near its head, about latitude $64^{\circ}$, longitude $143^{\circ}$. So 'called by Lieutenant Mitchell, Signal Corps, U. S. A., 1902.

Wallace; reef, in Felice strait, Alexander archipelago. So named by Harber in 1893.

Wallace; rock ( 1 foot below low water), in Cordova bay, Alexander archipelago. So called by Moser in 1897 .

Waller, creek; see Montana.

Wall Street; creek, tributary to South fork Fortymile creek. Prospectors' name, published by the Geological Survey in 1899. Called also Well Creek.

W.alnut; creek, tributary to Fairbanks creek from the north, near latitude $65^{\circ} 05^{\prime}$, longitude $147^{\circ} 10^{\prime}$. Prospectors' name, reported by Gerdine in 1903.

Walpole; point, the south point of entrance to Poit Houghton, Frederick sound, Alexander archipelago. So named by Vancouver, 1794.

Walrus; bight, near Northeast point, St. Paul island, Bering sea, on the north side of Sealion point, near longitude $170^{\circ} 06^{\prime}$. So called by Duftield, 1897. 
Walrus; island, east of St. Paul island, Pribilof group, Bering sea. Named Morzhovoi (walrus) by the early Russians. Sarichef (about 1790) has Morzhovoi, and Lutke (about 1830) morjovi (des morses).

Walrus; island, the easternmost of the Kudobin islands, near Port Moller; Bristol bay, Bering sea. So called by Dall, 1882. See also Wolf point. Walrus, island, see Round.

Walrus; islands, in northern part of Bristol bay, Bering sea. Sarichef's atlas, 1826 (sheet 3), applies this name to an island called by the natives Kaiashik, and which 'Tebenkof identifies with Round island of Cook. Tebenkof; whom we here follow, calls the whole group Morzhovia (walrus).

Walrus; peak (2,927 feet high), near east point of entrance to Morzhovoi bay, at western end of Alaska peninsula, about longitude $162^{\circ} 51^{\prime}$. Called Morjevskoi (walrus) by Lutke, 1835 .

Walter; island, in Port Houghton, Frederick soúnd, Alexander archipelago. So named by Nichols, 1882.

Walter; port (Port Walter), southwest shore Clarence strait, Baranof island, Alexander archipelago, near latitude $56^{\circ} 23^{\prime}$, longitude $134^{\circ} 40^{\prime}$. So called and described in the Coast Filot of 1901.

Wanda; island, between Sannak island and Caton island, immediately east of Finneys island, near latitude $54^{\circ} 25^{\prime}$, longitude $162^{\circ} 31^{\prime}$. Name from Westilahl, 1901.

Warburton; island, in Nichols passage, off. Port Chester, Alexander archipelago. So named by Nichols, 1883.

Ward; cove, in 'Tongass narrows, indenting the shore of Revillagigedo island, Alexinder archipelago, near latitude $55^{\circ} 25^{\prime}$, longitude $131^{\circ} 4 x^{\prime}$. Named after W. W. Waud, of Portland, Oreg., who established a saltery bere in 1883 or: 1884, and was drowned near here in March, 1892 . In print the cove has alwilys been called Ward.

Ward; mountain, in the southwestern part of Revillagigedo islind, Alexander archipelago. So named by Nichols, 1883.

Warde; point, on Cleveland peninsula, the south point of entrance to Bradfield caual. So named by Vancouver, 1798.

Warehouse, mission; see Shiniak.

Waring; mountains, northwestern Alaska, south of Kobuk river, near latitnde $67^{\circ}$, longitude $159^{\circ}$. So named by Stoney, 1886.

Waring; point, the northeasternmost point of Wrangell island, Arctic ocean. Named Waring's by Berry, 1.881, after Lieut. Howard Scott Waring, U. S. N., a member of his party.

Warm; creek, tributary to Goldbottom creek from the east, Seward peninsula. Name from Barnard, 1900.

Warm Chuck; salmon stream, western coast Prince of Wales archipelago in the vicinity of Tuxekan. So described by Moser in 1897. Local name.

Warm Spring; bay, in Baranof island, northwest of Point Gardner, Chatham strait, Alexander archipelago, near latitude $57^{\circ} 05^{\prime}$, longitude $134^{\circ} 45^{\prime}$. So named by Moore, 1895 .

Warm Spring; mountain (3,370 feet high), on the eastern bank of Stikine river, near Great glacier. Name published by the Coast Survey in 1895 .

Warren; channel, connecting Iphigenia bay and Sumner strait, and separating Warren island and Kosciusko island, Prince of Wales archipelago, near latitude $55^{\circ} 55^{\prime}$, longitude $133^{\circ} 50^{\prime}$. So named by Dickins, $1903-4$.

Warren; cove, indenting the southeastern shore of Warren island, Iphigenia bay, Prince of Wales archipelago, near latitude $55^{\circ} 52^{\prime}$, longitude $133^{\circ} 52^{\prime}$. So named by Dickins, 1903-4. 
Warren; island, at the southeastern point of entrance to Sumner strait, Alexander archipelago, near latitude $55^{\circ} 55^{\prime}$, longitude $133^{\circ} 55^{\prime}$. So named by Vancouver, 1793, after Sir John Borlase Warren.

Warren, islands; see Spanish.

Warren; peak $(2,200$ feet high), on Warren island, Sumner strait, Alexander archipelago. So named by Snow, 1866 .

Wart; point, in Behm canal, northwest from entrance to Rudyerd bay. So named by the Coast Survey in 1891.

Washington; bay, indenting the western shore of Kuiu island, Chatham strait, Alexander archipelago. Named published by the Coast Survey in 1899.

Washington; creek, tributary to Sinuk river from the east, Seward peninsula. Name from Barnard, 1900.

Washington; creek, 20 miles north of Cape Nome, Seward peninsula, tributary to Flambeau river from the east, near longitude $165^{\circ} 03^{\prime}$. Prospector's' name, published in 1900 .

Washington; creek, Seward peninsuli, tributary to Inmachuk river from the east, near latitude $65^{\circ} 55^{\prime}$, longitude $163^{\circ}$. Prospector's' name, reported by Witherspoon, 1903 .

Washington; creek or river, tributary to the Yukon from the south, near longitude $142^{\circ}$. Local name, erroneously lettered Charlie creek on a Coast Survey map of 1898 .

Washington; creek, tributary to Seventymile creek from the north. Local name, obtained by Barnard, 1898. Called also Bear gulch.

Washington; creek, tributary on the left to Seattle river, an aftluent of North fork Koyukuk river, near latitude $67^{\circ} 30^{\prime}$, longitude $150^{\circ} 30^{\prime}$. Miner's' name, reported by Peters and Schrader, 1901.

Washington, glacier; see Barry.

Washington; gulch, 8 miles northwest of Cape Nome, Seward peninsula, on the east bank of Nome river, near longitude $165^{\circ} 12^{\prime}$. Local name, reported in 1903.

Washington; peak (3,557 feet high), on the mainland, south of Port Houghton, southeastern Alaska. So named by the Coast Survey in $\mathbf{1 8 9 5}$.

Wasilieff, reef; see Vasilief.

Wasp; point, on Revillagigedo island, Behm canal, northwest from Smeaton island, Alexander archipelago. Named by the Coast Survey in 1891.

Wassilla's, lake; see Lucile.

Watch; islets, forming part of the Kasiana group, Sitka sound, Alexander archipelago. Named Bedennoi (watch), by Vasilief, 1809. These are the Apple islands of Coast Survey chart 8240 .

Waterfall, cape; see Mountain point.

Waterfall; creek, 20 miles north of Nome, Seward peninsula, tributary to Last Chance creek from the north, near longitude $165^{\circ}, 30^{\prime}$. Name from Barnard, 1900.

Waterfall; peak $(3,403$ feet high), on the mainland, near Thomas bay, southeastern Alaska. So named by Thomas, 1887. Near it are cascades.

Waterfall, point; see Village.

Waterfall Head. Near the southeastern point of St. George island, Pribilof group, Bering sea, is a waterfall, and at this place Elliott's map of 1873-74 has this name Waterfall Head, a little south of which is Southeast point. A later Coast Survey map of the region shows a different shàpe and has but one name, and that Cascade point. See Cascade.

Waterfalls; bay of, indenting the south shore of Adak island, middle Aleutians. Descriptive name, given by Gibson in $\mathbf{1 8 5 5}$. 
Watering; creek, in Port Santa Cruz, Suemez island, Prince of Wales archipelago. Named Rio de la Aguada (watering-place river) by Maurelle and Quadra, 1775-1779.

Waters; point, on the eastern shore of Port Bainbridge, Prince William sound. Named by Vancouver, 1794.

Watkins; point, on the western shore of Cleveland peninsula, Seward passnge, Ernest sound, southeastern Alaska, near latitude $55^{\circ} 57^{\prime}$, longitude $132^{\circ} 02^{\prime}$. Local navigators' name, reported by H. C. Fassett, Bureau of Fisheries, 1.904.

Watson; creek, Seward peninsula, Casadepaga drainage, tributary to Birch creek from the east, near latitude $64^{\circ} 49^{\prime}$, longitude $164^{\circ} 08^{\prime}$. Prospectors' name, from Gerdine, 1905.

Waud, cove; see Ward.

Waverly, island; see Tangik.

Wayanda; ledge, in Southern rapids, Peril strait, Alexander archipelago. So named after the $\mathrm{U}$. S. revenue cutter Wayanda, which once touched upon it. Sometimes, erroneously, Wyanda. Fas also been called Eureka ledge, after the steamer Eurela, which struck upon it April $26,1883$.

Wayanda, rock; see California.

Weare; trading station of the North American Trading and Transportation Company on the north bank of Yukon river, a few miles below the mouth of the Tanana. Probably named after Ely E. Weare, President of that company. Near this place is the post-office Tanana, established in September, 1898, St. James Episcopal mission, and the military post Fort Gibbon.

Weasel; cove, indenting the north shore of Boca de Quadra, southeastern Alaska. So named by the Coast Survey in 1891.

Webber; creek, eastern Alaska, on the south bank of Yukon river, near longi' tude $143^{\circ} 40^{\prime}$. Prospector's' name, reported by Lieutenant Erickson, U. S. A., 1902.

Weber; point, on the eastern shore of Kuskokwim bay, Bering sea. Named by the missionaries after Rev. Ernest L. Weber, Moravian missionary, in western Alaska.

Webster; lake, on Northeast point, St. Paul island, Bering sea, near longitude $170^{\circ} 07^{\prime}$. Name from Duffield, 1897. Elliott's map and other's show a house near, called Webster's house.

Webster; peak $(3,254$ feet high), on the mainland, near Port Snettisham, southeastern Alaska. 'So named by Thomas, 1888, after the distinguished American statesman Daniel Webster.

Webster; point (Point Webster), on the eastern shore of Cordova bay, southwestern shore Prince of Wales island, Alexander archipelago, near latitude $54^{\circ} 59^{\prime}$, longitude $132^{\circ} 39^{\prime}$. Name from Dickins, 1905 .

Webuk, cape; see Lisburne and Thompson.

Webuk, Eskimo village; see Wevol.

Wedge; cape, the northermmost point of Nagai island, Shumagins. Named by Dall, 1872.

Wedge; cape, the south point of entrance to Chapel cove, Bay of Waterfalls, Adak island, middle Aleutians. Descriptive name, given by United States naval officers, 1893.

Wedge; glacier, near the head of Harriman fiord, Port Wells, Prince William sound. Descriptive name, given by the Harriman expedition in 1899. 
Wedge; islands, in Clarence strait, southeastern shore Prince of Wales island, Alexander archipelago, near latitude $55^{\circ} 09^{\prime}$. So named by Vancouver, in 1793 , on account of the shape.

Wedge; point, on the northwestern shore of Woronkofski island, Stikine strait, Alexander archipelago, near latitude $56^{\circ} 25^{\prime}$, longitude $132^{\circ} 32^{\prime}$. Descriptive name, from local navigators, reported by H. C. Fassett, Bureau of Fisheries, 1904.

Wedge; point, on the southwestern shore of Adak isliand, Andreanof group, middle Aleutians. Descriptive name, given by Gibson in 1855.

Weedy; shoals, in Zachary bay, Unga island, Shumagins. So named by Dall, 1872.

Welcome; point, the southernmost point of Bird island, Shumagin group. Immediately east of it is Point Farewell, the last land seen when homeward bound. Name published by the Coast Survey in 1882 .

Well, creek; see Wall Street.

Wellesley; glacier, tributary from the west to College fiord, Port Wells, Prince William sound. So named by the Farriman expedition, 1899, after Wellesley College.

Wellesley; lake, near the international boundary. So named by Hayes, 1891, after Wellesley College.

Wellesley; mountain, between the Tanana and White rivers, near latitude $62^{\circ}$ $30^{\prime}$. So named by Peters and Brooks, 1898, after Wellesley College.

Wells; port (Port Wells), in northwestern part of Prince William sound. So named by Vancouver, 1794.

Werlick; island, in Sealed passage, near Hotspur island, bẹtween Duke and Annette islands, Alexander archipelago. So named by the Coast Survey in 1886 .

Weshrinarin; creek, an affluent of the Yukon on the left bank below Washington creek, near longitude $143^{\circ}$. This name, written Weshrinearine, was found on a map in the Coast Survey archives made by E. F. Ball, a prospector, in 1898 . It may be the Indian name of one of the many small tributaries in this vicinity described here under other names.

Wesley; creek, tributary to Tisuk river from the east, Seward peninsula. Name from Barnard, 1900.

Wessels; sunken reef, about 18 miles north from Middleton island. Discovered by John Wessels, master of the schooner Kodiak, October 25, 1881, and reported to George Davidson and by him to the Coast Survey Office.

West; arm, of Kendrick bay, Clarence strait, southeastern Alaska, near latitude $54^{\circ} 53^{\prime}$, longitude $132^{\circ} 05^{\prime}$. So called by local navigators, and reported by H. C. Fassett, Bureau of Fisheries, 1904.

West; arm, Chölmondeley sound, western shore Clarence strait, southeastern Alaskil, near latitude $55^{\circ} 15^{\prime}$, longitude $132^{\circ} 20^{\prime}$. So called by local navigators, and reported by Brooks in 1901 .

West; arm, of Moira sound, southwestern shore Clarence strait, southeastern Alaska, near latitude $55^{\circ}$, longitude $132^{\circ} 15^{\prime}$. Descriptive name, obtained from local navigators by F. C. Fassett, Bureau of Fisheries, 1904.

West, bay; see Three Arm.

West; breaker, 6 miles west of Petrof point, Sannak island, near latitude $54^{\circ}$ $29^{\prime}$, longitude $163^{\circ}$. So described by Westdahl, 1901.

West; cape, on the northwestern coast of Spruce island, Kodiak group. Named Zapadnie (west) by Murashef, 1839-40. 
West; cape, the westernmost point of Deer island, near Belkofski, about latitude $54^{\circ} 55^{\prime}$, longitude $162^{\circ} 26^{\prime}$. So named by the Fish Commission in 1885.

West; cape, the westermmost point of St. Law rence island, Bering sea. Named Zapadnie (west) by Tebenkof, 1849. By error of transliteration has been witten Sanachno and Sanakno.

West; channel, north of Sitla sound, connecting Hayward strait, Fort Krestof in Kruzof island, and Krestof strait, near latitude $57^{\circ} 09^{\prime}$, longitude $135^{\circ} 35^{\prime}$. 'Descriptive name, published by the Coast Survey in 1900.

West; cove, in northwest shole of Stepovak bay, Alaska peninsula, just north of Blunt point, near longitude $160^{\circ}$. So called by the Harriman expedition, 1899.

West; creek, tributary to Shovel creek from the west, Seward peniusula. Name from Barnard, 1900.

West, fork, Snake river ; see Last Chance creek.

West; fork, Chandar river, near latitude $67^{\circ} \mathbf{1 5}^{\prime}$. Local name, from Schrader, 1899.

West; hill (265 feet high), on Stuart island, Norton sound. So named by the Coast Survey in 1898.

West; island, in Koyukuk river, near longitude $157^{\circ}$. So named by Allen, 1885, " in honor of Lieut. Barrington King West, U. S. A., my classmate and special friend."

West; island, one of the Kashevarof group, Clarence strait, Alexander archipelago. So namied by Snow, 1886 .

West; peak (1,976 feet high), near: Chichagof harbor, on Attu island, western Aleutians. So named by Gibson, July, 1855.

West; peak (5,600 feet high), near Valdez, Prince William sound. So named by Abercrombie, 1898 .

West; point, near anchorage on west shore of Chirikof island, Alexander archipelago. Named by Dall, 1874 .

West; point, the western point of entrance to Portage bay, Kupreanof island, Alexander archipelago. So named by Nichols, 1882.

West; point, at entrance to Chichagof cove, Stepovak bay, south shore Alaska peninsula. Descriptive name, given by the Harriman expedition, 1899.

West; point, on the west side of Uganik bay, Kodiak, at the entrance to the west branch. So described by Moser, 1897 .

West; point, the western point of entrance to Chernofski harbor, Unalaska. So named by the Fish Commission in 1888 .

West; point, on the southeastern coast of: Seward peninsula, a little east of Point Rodney. Apparently a local designation, published in 1900.

West, point; see Uyak.

West; rocks, in Dixon entrance, 5 miles southwest from Cape Northumberland. So named by Nichols, 1883.

West; spit, at south end of Cleveland passage, Frederick sound, Alexander archipelago. Apparently so named by Nichols, 1891.

West Anchor; cove, indenting the southwestern shore of Ikatan peninsula, near south end of Isanotski strait, Unimak island. So called by the Fish Commission in 1888.

West Caipe Lazaref; see Aksit.

Westdahl; peak (5,075 feet high), in the southwestern part of Unimak island, about 4 miles southeast of Pogromni volcano, near latitude 54. $31^{\circ}$, longitude $164^{\circ} 39^{\prime}$. Named by Supt. O. H. 'Tittmann, of the Coast Survey, after Ferdinand Westdahl, who determined its geographic position in 1901. 
West Devil; rock, a dangerous sunken reef in Dixon entrance, 10 feet out at low water, 14 miles east of Cape Chacon. Found by Capt. James Carroll in the Idaho, November 23, 1883. See also East Devil.

Western; anchorage, in Sitka harbor, north of Japonski island, and between Channel rock and Harbor rock, Sitka sound, Alexander archipelago. Local name.

Western; channel, leading into Sitka harbor, Sitka sound, Alexander archipelago. Named Zapadnie (western) by the Russians.

West Foreland; cape, on the northwestern shore of Cook inlet. So named by Vancouver, 1794. It is Zapadnie (west) cape of the Russians, by whom the native name is reported to be Kiestotank.

West Francis; sunken rock, in Southern rapids, Peril strait, Alexander archipelago. Discovered and named by Coghlan, 1884, after pilot E. H. Francis, who was the first person to obtain soundings on it.

West Georgia. The coast region between Point Barrow and Cape Lisburne, Arctic ocean, was so called by Beechey in 1827. Apparently this name. has never come into use.

West Glacier; creek, tributary to Chinitna bay, Cook inlet, near latitude $59^{\circ}$ $50^{\prime}$, longitude $153^{\circ} 45^{\prime}$. Local name, reported by Martin in 1904.

West Head; point, the northwestern point of entrance to Popof strait, Shumagin islands. So named by Dall, 1872.

West Konetz, point; see Dalnoi.

West Kussua, lake; see Kusawa.

West Mill; rock, north of Sawmill cove, in. Howkan strait, Cordova bay, Alexander archipelago. So named by Nichols, 1881.

West Nagai; strait, between Nagai and Andronica islands, Shumagin group. So called by Dall, 1874.

West Point; a mountain ( 5,920 feet high), eastern Alaska, on upper Salcha river, near latitude $64^{\circ} \mathbf{5 7}$, longitude $143^{\circ} 40^{\prime}$. Name, from Witberspoon, 1905.

Wests; peak, on the western shore of Klutina lake. So named by Lowe, 1898. West Uganuk, bay; see Uganik.

Wet; gulch, 20 miles north of Nome, Seward peninsula, on the east bank of Hobson creek, a tributary of Nome river, near longitude $165^{\circ} 16^{\prime}$. Local name, published in 1904 .

Wet; gulch, 6 miles north of Nome, Seward peninsula, on the northwest slope of Newton peak, draining to the left fork of Dexter creek, near longitude $165^{\circ} 20^{\prime}$. Local name, from Gerdine, 1904.

Wevok, Wevuk, cape; see Lisburne and Thompson.

Wevok; Eskimo village, on the Arctic coast, near Cape Lisburne. Eskimo name, published by the Hydrographic Office in 1890. Has also been written Wevuk and Webuk.

Whale; bay, indenting the southwestern shore of Baranof island, Alexander archipelago. Named Keetovaia (whale) by the Russians. The native name is reported to be Kay-e-ghlen. It is Port Guibert of La Perouse, in 1786, and Fort Banks of some authorities.

Whale; bay, just southwest of Chenega ìsland, southwestern shore Prince William sound, near latitude $60^{\circ} 15^{\prime}$. Local name, reported by Grant, 1905 .

Whale; bay and point, northeastern shore of Caton island, Sannak group, near latitude $54^{\circ} 24^{\prime}$, longitude $162^{\circ} 23^{\prime}$. So named by Westdahl, 1901.

Whale; creek, tributary to Port Wells from the east, Prince William sound. So named by Glenn, 1898. 
Whale; island, one of the Galankin group, Sitka sound, Alexandel: archipelago. Named Kitovie (whale) by Vasilief in 1809 . This name has appeared as Quitoway and Whalebone.

Whale; island, the northern one of the two Martin islands, at Martin point, Gulf of Alaska, near longitude $144^{\circ} 33^{\prime}$. Local name, reported by Martin, 1905 .

Whale; island, between Afognak and Kodiak. Called Govorushechie (redlegred kittiwake, a species of gull) or Kitoi (whale) by Murashef in 1839-40. This usage was followed by Tebenkof and the Russian-American Company, 1849. Has also been called Ketoy. Called Whale by Moser, 1897, which seems to be the local usige.

Whale; island, east of and near St. Michael island, Norton sound, Bering sea. So called by the Coast Survey in 1898 .

Whale; island, at Elson bay, near Point Barrow, Arctic ocean. Apparently so named by the British Admiralty in 1855.

Whale, islet; see Kita.

Whale; passage, separating Thorne island from Prince of Wales island, Clarence strait, Alexander archipelago. So named by Snow, 1886.

Whale; passage, between Whale island and Kodiak island, near: latitude $57^{\circ}$ $55^{\prime}$, longitude $152^{\circ} 45^{\prime}$. So described by Moser, 1897. Called Sievernoi (northern) by Murashef, 1839-40.

Whale; point, on the eastern shore of Smeaton island, Bebm canal, Alexander archipelago. So called by the Coast Survey in 1891.

Whale; point, the western point of Lukanin bay, St. Paul island, Pribilof group, Bering sea. Called "Ketavie (of a whale)," says Elliott, because "a large right whale was stranded there in (?) 1849." Written also Kitovi.

Whale; rock ( 15 feet above high water), northeast of Duke island, Revillagigedo channel. Alexander archipelago. Presumably so named by local pilots ibout 1880 .

Whale; rock, Davidson inlet, Frince of Wales archipelago, near latitude $55^{\circ}$ $51^{\prime}$, longitude $133^{\circ} 41^{\prime}$. Named by Dickins, 1903-4.

Whalebone, bay; see Usof.

Whalebone; cape, between Usof and Three Island bays, on southeaster'n coast of Unalaska, near latitude $53^{\circ} 30^{\prime}$, longitude $166^{\circ} 44^{\prime}$. So named by the Fish Commission in 1888.

Whalebone, island; see Whale.

Whalehead; island, Davidson inlet, Prince of Wales archipelago, near latitude $55^{\circ} 52^{\prime}$, longitude $133^{\circ} 41^{\prime}$. Named Whale Head by Dickins, 1903-4.

Whaley; point, the northernmost point of Revillagigedo island, Behon canal, Alexander archipelago. So named by Vancouver. 1793.

What Cheer; bar, a gravel bench on Pioneer creek, one of the headwater's of Baker creek, on the north bank of the Tanana, near longitude $150^{\circ}$. Prospectors' name, reported by Frindle, 1904.

Whidbey; point, on the western shore of Lynn canal, southenstern Alaska. So named by Davidson, in 1867 , after Lieut. Joseph Whidbey, R. N., who was one of Vanconver's principal assistants during his explorations and surveys in this region, 1792-1795. Meade, 1867, called it Grant point. Erroneously Whidby.

Whipple; mountain (6,033 feet high), between Iskut and Katete rivers, on the international boundary, and about 7 miles from the Stikine. So named by Hunter in 1877 . Erroneously Wipple. 
Whiskey; bay, indenting the northernmost end of Pearse island, Alexander archipelago. Local name, published by Nichols in the Coast Pilot (1891, p. 76$)$.

Whistle, rock; see Thistle.

White; bluff, on the eastern shore of Portland canal. Name published by the Coast Survey in 1894.

White; bluff, on the north shore of Ugaguk river, just inside Cape Chichagof, Bristol bay. Local descriptive name, reported by Moser, 1900.

White; cliff, of snow, on the southern side of Newton glacier, St. Elias alps. So called by Russell, 1891.

White; cliff, on southwestern shore of Heceta island, Alexander archipelago. Apparently a local descriptive name; not shown on existing charts. Name published by Nichols in the Coast Pilot (1891, p. 122).

White; creek, Kenai peninsula, on the left bank of Resurrection creek, 12 miles above Hope (city). Local name, from Moffit, 1904.

White; glacier, near Muir inlet, Glacier bay, southeastern Alaska. Desceiptive name. given by Reid in 1890 .

White; gulch, at head of Port Dolores, Bucareli bay, Prince of Wales archipelago. Called Arroyo blanco (white gulch) by Maurelle and Quadra, $1775-1779$.

White; gulch, Copper River region, on the headwaters of Chititu creek. Prospectors' name, first published on. map of Nizina mining district by George M: Esterly, of Valdez, 1902.

White, island; see Error.

White; mountain, near the head of Golofnin sound, Seward peninsula. Local nime, published in 1900 .

White; mountains, on the mainland, west of Lynn canal, southeastern Alaska. So named by symonds, 1880 .

White; mountains, between the Yukon and Tanana rivers, between the headwaters of Beaver and Preacher creeks, near latitude $65^{\circ} 45^{\prime}$, longitude $147^{\circ}$. Local name, reported by Prindle. 1905.

Whice; pass (2,886 feet high), at the head of Skagway river, southeastern Alaska. So named by Osilvie, 1887, after the Hon. Thomas White, minister of the interior (of Canada). Perhaps identical with Shasheki of Dall, in the Coast Pilot (1883, p. 200).

White; point, in northern entrance to Keku strait, Kupreanof island; Alexander archipelago. Apparently a'local :name, published by the Coast Survey in 1891.

White; point, on the eastern shore of Portland canal. So named by Pender, 1868. Just north of it are some white cliffs.

White; point, the westernmost point of Duke island, Gravina group, Alexander archipelago. So. named by Nichols, 1883.

White, point; see Shoals.

White; reef, in Revillagigedo channel, at entrance to Boca de Quadra, south- * eastern Aliska. Descriptive name, given by Nichols in 1883.

White; river, on the western shore of George inlet, Revillagigedo island, southeastern Alaska, near latitude $55^{\circ} 27^{\prime} ;$; longitude $131^{\circ} 33^{\prime}$. Local navigators name, reported by H. C. Fassẹtt, Bureau of Fisheries, 1904.

White; river, a glacial stream, debouching 'on the coast of the Gulf of Alaskal,

$\because 8$ miles east of Cape raktig, near longitude $142^{\circ} 10^{\circ}$. So named by prospectors in 1897 , and reported by Martin, 1903. 
White; river, in Alaska and Canada, tributary to the upper Yukon. Discovered, 1850, by Robert Campbell, of the Hudson Bay Company, and by him named White on account of its color. The "Stick" Indians call it, says Schwatka (Military Reconnaissance, p. 29), Yukokon Heenab, i. e.; Yukokon river, and the Chilkats by another name meaning Sand river.

White; rock (120 feet high), at entrance to Moira sound, Clarence strait, Alexander archipelago. So named by Clover, 1885.

White; rock (15 feet high), at southern entrance to Duncan canal, Sumner strait, Alexander archipelago. So named by Snow, 1886, on account of its "very white" color.

White; rock, in Dixon entrance, 1 mile soutl of Cape Northumberland. Name published by the Coast Survey in 1894 .

White, rock; 'see Bieli.

White; rock, north of Hayes point, Chatham strait, Alexander archipelago. The descriptive name, Bieloi (white), was published by 'Tebenkof in 1849.

White; rocks, in Portillo channel, Bucareli bay, Prince of Wales archipelago. Called piedras blancas (white rocks) by Maurelle and Quadra, 1.7751779.

White Cliff; island, on the east side of Davidson inlet, Prince of Wales archipelago, near latitude $55^{\circ} 55^{\prime}$, longitude $133^{\circ} 29^{\prime}$. Descriptive name, applied by Dickins, 1903-4.

White Cliff; point, the most southerly• point of Moser island, Hooniah sound, Alexander archipelago. Descriptive name, given by Moore in 1895, not hitherto published.

White Eye; camp, or native village, or may be an Indian's hut, on Yukon river, 30 miles below Fort Yukion. Name published in 1899. Written also White Eye's Camp.

Whitefish; creek, an affluent of Yukon river on the left bank, opposite Nulato, near longitude $158^{\circ}$. Name, White Fish, found on map in Coast Survey archives drawn by E. F. Ball, a prospector, 1898

Whitestone; cove, indenting the western shore of Baranof island, Neva strait, on the east side of Whitestone narrows (below). Name published by the Coast Survey in 1900.

Whitestone; point, in Neva strait, Baranof island, Alexander archipelago. Name published by Dall in the Coast Pilot (1883, p. 156).

Whitestone; rock, in Neva strait, Alexander archipelago. Local name, alleged to be descriptive. First published in about 1880 .

Whitestone Narrows; contracted place in southern part of Neva strait, Alexander archipelago, near latitude $57^{\circ} 15^{\prime}$, longitude $135^{\circ}$. $34^{\prime}$. So named by Meade, 1869 .

Whitewater; bay, indenting the southwestern shore of Admiralty island, Chatham strait, Alexander archipelago. Descriptive name, given by Meade in 1869. Said to be known locally as Lower Kootznahoo.

Whiting; harbor, on the western side of Japonski island, Sitka sound, Alexander archipelago. So named by United States naval officers, 1880, presumably after Commodore William Danforth Whiting, U. S. N.

Whiting; point, in Port Snettisham, Stephens passage, Alexander archipelago. So named by Thomas, 1888, after Passed Asst. Surg. Robert Whiting, U. S. N., a member of his party.

Bull. $299-06 \mathrm{M}-43$ 
Whiting; river, of southeastern Alaska, flowing into Stephens passage. Named by Thomas, 18s8, after Passed Asst. Surg. Robert Whiting, U. S. N., a member of his party:

Whitney; mountain, near Mount St. Elias. Was so named by the New York Times expedition, of 1886, after Hon. William Collins Whitney.

Whitney; island, near Fanshaw bay, Frederick sound, Alexander archipelago. So named by Thomas, 1887, presumably after Hon. William C. Whitney, Secretary of the Navy.

Whitshed; point, near the mouth of Conper river, about longitude $146^{\circ}$. Named Witshed by Vancouver, 1794, after Captain Witshed, R. N. Thus it appears in the text of the original $4^{\circ}$ edition of Vancouver's voyage, but in the accompanying atlas and in the text of the $8^{\circ}$ edition of 1801. it is called Whitshed, after Captain Whitshed. Whitshed appears to be in general use. Has been erroneously printed Whitshet. The Spaniards, 1779, called it Punta de Orevilla.

Whitsunday, cape; see Pillar.

Whitsuntide, bay; see Shelikof strait.

Whitsuntide, cape; see Izhut.

Whymper, creek; see Hess.

Whymper; point, in the Yukon delta, a little south of, Cape Romanzof. So named by Dall, 1869, after Mr. Frederick Whymper, one of his companions in the Western Union telegraph expedition, 1S65-1867.

Wickersham; creek, eastern Alaska, tributary on north bank of Gold creek, Salcha River drainage, near latitude $64^{\circ} 50^{\prime}$, longitude $145^{\circ} 40^{\prime}$. Prospectors' name, reported by Witherspoon, 1905.

Wide, bay; see Kialagvik.

Wilby; island, in Port Chalmers, Prince William sound. Named Wilby's island by Portlock, 1787, presumably after William Wilbye, assistant trader on his voyage. Portlock gives both spellings.

Wild; creek, tributary to Koyukuk river from the north, near longitude $151^{\circ}$ $30^{\prime}$. Allen, 1885, was told by the Indians that the next large branch above the Ascheeshna (which he named Fickett and which is now called Joln river), where his exploration ended, was called Totzenbetna, or Totzunbetna. They, however, exaggerated the distance, or he misunderstood them, so he sketched it on his map far out of its true position. In 1899 Schrader and Gerdine called this Hokotena, and put Totsenbetna on John river, the next river below. In 1901 Peters and Schrader reported that the miners and others now call it Wild creek. The name Hokotena, however, was retained on their map. Totzunbetna is said to mean wild water or wild river, and Hokotena probably properly belongs to the next branch above, now generally called North fork.

Wild; island, southeast of Long island, Sitka sound, Alexander archipelago. Named Dikoi (wild) by Vasilief, 1809.

Wilder; creek, tributary from the west to Delta river, near latitude $63^{\circ} 30^{\prime}$. So named by Glenn, 1898.

Wildhorse; creek, Kenai peninsula, a left branch cf Resurrection creek, 1 mile above Hope (city). Local name, from Moffit, 1904.

Wilkes; peak (3,156 feet high), in Wilkes range of mountains, southeastern Alaska. So named by Thomas, 1887 .

Wilkes; range of mountains, on the mainland, north of and near mouth of Stikine river, southeastern Alaska. So named by Thomas, 1887, after Rear-Adn:iral Charles Wilkes, U. S. N. 
Wilkins; creek, Seward peninsula, tributary from the east to Maston creek, near latitude $65^{\circ} 50^{\prime}$, longitude $166^{\circ} 19^{\prime}$. Prospectors' name, reporter by Gerdine, 1901.

Willard; inlet, northeast of Dixon entrance, southeastern Alaska. So named by the Coast Survey in 1891.

Willard; missionary station, at the Indian village Kutkwutlu, near the mouth

- of Chilkat river, southeastern Alaska. Established prior to 1883.

William; small lake, southeastern shore Prince of Wales island, Alexander archipelago, on the north side of Port Johnson, near latitude $55^{\circ} 07^{\prime}$. Local name, reported by Moser, 1901. There is a cluster: of four lakés here, named, respectively, Paul, James, John, and William, all drained by Peter Johnson stream into Port Johnson.

William Henry; bay, on the west shore of Lynn canal, Alexander archipelago. Name adopted by Meade, 1869, from the Hudson Bay trader's.

Williams; coal mine, on the right bank of the Yukon, below Kaltag, near latitude $64^{\circ}$, longitude $159^{\circ} 10^{\prime}$. Probably the name of the owrier, reported by Collier, 1902.

Williams; island, at mouth of Nushagak river, Bristol bay, Bering sea. Called William's by the Fish Commission in 1890.

Williams, point; see Craven.

Williams, reef; see Vasilief.

William Smith, river; see Smith.

Willis; creek, tributary to Feather river from the north, Seward peninsula. Name from Barnard, 1900.

Willoughby; cove, on the south shore of Lemesurier island, Icy strait, Alexander archipelago, near longitude $136^{\circ} 03^{\prime}$. Surveyed and named by Hanus, 1880, after Richard G. Willoughby, an Alaskan pioneer.

Willoughby; island $(1,545$ feet high), in Glacier bay, southeastern Alaska. Named by United States naval officers, 1880, after Richard G. Willoughby, an Alaskan pioneer.

Willow; creek, Copper River region, tributary to Chisna river from the east. Prospectors' name, reported by Mendenhall, 1903.

willow; creek, Kenai peninsula, on the right bank of Resurrection creek, $2 \frac{1}{2}$ miles above Palmer creek. Local name, from Moffit, 1904.

Willow; creek, in the Kantishna region, on the east (right) bank of Moose creek, near latitude $63^{\circ} 30^{\prime}$, longitude $150^{\circ} 30^{\prime}$. So named by prospectors in 1905 , and reported by Prindle.

Willow; creek, tributary from the west to Penny river, in the Nome mining region, Seward peninsula. Prospectors' name, published in 1900.

Willow; creek, Seward peninsula, tributary on west bank of Solomon river,

- near latitude $64^{\circ} 43^{\prime}$, longitude $164^{\circ} 20^{\prime}$. Prospectors' name, from a local map, 1904.

Willow; creek, Seward peninsula, a west branch of Casadepaga river, near latitude $64^{\circ} 49^{\prime}$, longitude $164^{\circ} 20^{\prime}$. Called Left fork by Barnard, 1900, who placed the name Willow on a tributary farther up and on the east bank. It is Alert creek on a local map of 1900 .

Willow; creek, tributary to Port Clarence from the east, Seward peninsula. Name from Barnard, 1900.

Willow; creek, Seward peninsula, tributary from the north to Crosljy creek, .near latitude $65^{\circ} 52^{\prime}$; longitude $166^{\circ} 15^{\prime}$. Prospector's' name, reported by Gerdine, 1901.

Willow; creek, Seward peninsula, tributary to Candle creek from the west, near latitude $65^{\circ} 50^{\prime}$, longitude $162^{\circ} 05^{\prime}$. Prospectors' name, reported by Witherspoon, 1903. 
Willow; creek, 17 miles north of Nome, Seward peninsula, a small tributary to Nome river from the west, near longitude $165^{\circ} 18^{\prime}$. Local name, published in 1900.

Willow; creek, 12 miles north of Cape Nome, tributary to Osborn creek from the west, near longitude $165^{\circ} 08^{\prime}$. Local name, reported by Barnard, 1900.

Willow; creek, in the Rampart region, tributary to Troublesome creek from the east, near latitude $65^{\circ} 30^{\prime}$, longitude $149^{\circ} 15^{\prime}$. Prospector's' name, reported by Lieutenant Erickson, U. S. A.; 1902.

Willow; creek, eastern Alaska, on southeastern side of Preacher creek, tributary to Rock creek from the southwest, near latitude $65^{\circ} 40^{\prime}$, longitude $145^{\circ} 30^{\prime}$. Prospector's' name, reported by Witherspoon, 1905.

Willow; creek, in the Fortymile region, tributary to Gold creek from the north, near latitude $64^{\circ} 10^{\prime}$, longitude $142^{\circ} 20^{\prime}$. Prospectors' name, reported in 1898 .

Willow; creek, northern Alaska, tributary to Anaktuvuk river from the east, near latitude $68^{\circ} 45^{\prime}$. Name from Peters and Schrader, 1901.

Willow; island, at mouth of the Unuk river, Alexander archipelago. So named by the Coast Survey in 1889.

Willow; point, on the western shore of Kizhuyak bay, north coast of Kodiak. Named Talnika (willow) by Murashef, 1839-40. Elliott spells it Talneek, and says all creeping willows are so designated by the Russians.

Wilson; arm, of Smeaton bay, Behm canal, southeastern Alaska, near latitude $55^{\circ} 20^{\prime}$, longitude $130^{\circ} 40^{\prime}$. Local navigators' name, reported by $\mathrm{H}$. C. Fassett, Bureau of Fisheries, 1904.

Wilson; cove, indenting the soutbwestern shore of Admiralty island, Alexander archipelago. Name published by the Coast Survey in 1896.

Wilson; creek, tributary from the west, to North fork Fortymile creek. Prospectors' name, published by the Geological Survey in 1899. Called also Joe Wilson.

Wilson; creek, tributary on the north bank of Willow creek, a left fork of Casadepaga river, seward peninsula. Name from Barnard, 1900.

Wilson; creek, tributary to South fork Koyukuk river from the north, near longitude $150^{\circ} 15^{\prime}$. Prospectors' name, reported by the Geological Survey in 1899 .

Wilson; islands, on western edge of the Stikine flats, Sumner strait, Alexander archipelago. So named by Thomas, 1887.

Wilson; point, north shore Orca bay, Prince William sound, near latitude $60^{\circ} 38^{\prime}$, longitude $145^{\circ} 40^{\prime}$. So named by Abercrombie in 1898 .

Wilson; point, on the eastern side of Portage bay, Alaska peninsula. Name published in Hydrographic Office notice 48, 1893.

Wilson; point, the south point of entrance to Wilson cove, Admiralty islaud, Alexander archipelago. Name published by the Coast Survey in 1896.

Wimbledon; point, the western point of entrance to Dundas bay, Cross sound, Alexander archipelago, near latitude $58^{\circ} 18^{\prime}$, longitude $136^{\circ} 23^{\prime}$. So named by Vancouver, 1794. Erroneously Winbledon on some charts, and Wimbleton.

Wind; point, on the northwestern shore of Thomas bay, Frederick sound, Alexander archipelago. So named by 'Thomas, 1887.

Windfall; creek, and lake, on the mainland, eastern shore of Lynn canal, near Herbert glacier and latitude $58^{\circ} 30^{\prime}$. Prospectors' name, reported by Spencer and Wright, 1903. 
Windfall; harbor, on the western shore of Clarence strait, southeastern Alaska, near latitude $55^{\circ} 36^{\prime}$, longitude $132^{\circ} 20^{\prime}$. Local navigators' name, reported by H. C. Fassett, Bureau of Fisheries, 1904.

Windfall; harbor, Admiralty island, Seymour canal, Alexander archipelago. So named by Mansfield, 1889.

Windfall; island, in Seymour canal, Admiralty island, Alexander archipelago. So named by Mansfield, 1889.

Windham; bay, indenting the mainland, coast, Frederick sound, southeastern Alaska, near latitude $57^{\circ} 34^{\prime}$, longitude $133^{\circ} 30^{\prime}$. So named by Dall in the Coast Pilot (1883, p. 129).

Windham; mining camp and post-office (established in 1904), southeastern Alaska, at the head of Windham bay (above).. Name published by the Coașt Survey, 1901.

Windham; mountain (3,263 feet high), on the mainland, north of Windham bay, soutbeastern Alaska. So named by Meade, 1869.

Windham; point, on the mainland coast, the north point of entrance to Windham bay, and the southeastern point of entrance to Stephens passage, southeastern Alaska. So named by Vancouver, 1794.

Windom, glacier; see Norris.

Windy; bay, indenting the north shore of Hawkins island, Orca bay, Prince William sound, near latitude $60^{\circ} 34^{\prime}$, longitude $145^{\circ} 55^{\prime}$. So called by Ritter, 1900 .

Windy; cove, on the north side of Cape Romanzof, Yukon delta, near latitude $61^{\circ} 50^{\prime}$, longitude $166^{\circ} 04^{\prime}$. So named by Putnam, 1899 .

Windy; creek, tributary to right fork of Bluestone river from the south, Seward peninsula. Name from Barnard, 1900.

Windy; creek, 25 miles north of Nome, Seward peninsula, tributary to Stewart river from the north, near longitude $165^{\circ} 27^{\prime}$. Local name, from Gerdine, 1904.

Windy; creek, 30 miles north of Nome, Seward peninsula, tributary to the headwater's of Sinuk river from the north, near latitude $64^{\circ} 55^{\prime}$, longitude $165^{\circ} 26^{\prime}$. Name from Barnard, 1900.

Windy; creek, tributary to Kougarok river from the west, Seward peninsula. Name from Brooks, 1900.

Windy; creek, Seward peninsula, tributary from the south to Budd creek, a left branch of American river, near longitude $165^{\circ} 33^{\prime}$. Prospectors' name, reported by Gerdine, 1901.

Wingham; island, east of and near the mouth of Copper river, and on the west side of Controller bay, near longitude $144^{\circ} 20^{\prime}$. So named by Vancouver, 1794. It is Mitchell's island of Portlock and Meares, 1787-88, and Los dos Hermanos (the two brothers) of the Spaniards. The native name, according to Tebenkof, is Shiganik. Often called Mitchell's or Wingham island and Little Kayak.

Winnebago; creek, Seward peninsula, tributary on west bank of Solomon river, near latitude $64^{\circ} 42^{\prime}$, longitude $164^{\circ} 18^{\prime}$. Prospectors' name, from Gerdine, 1905.

Winner; creek, tributary to Glacier creek from the east, near head of Turn- again arm, Cook inlet, about latitude $61^{\circ}$, longitude $149^{\circ}$. Local name, from Mendenball, 1898.

Winona; creek, Seward peninsula, tributary to Noxapaga iriver, through Skookum and Turner creeks, near latitude $65^{\circ} 35^{\prime}$, longitude $164^{\circ} 15^{\circ}$. Prospectors' name, reported by Gerdine, 1901. 
Winslow; point, the eastern point of entrance to Mary island anchorage, Mary island, Alexander archipelago. So named, prior to 1883 , by local pilots, by whom the name was applied to the west point of entrance, now called Giant point. See Giant.

Winstanley; island, in Behm canal, between Smeaton and Rudyerd bays, Alex. ander archipelago. Named by Dall, 1879, after the English engineer Winstanley, who built the first Eddystone light-house in 1696-1699, and who lost his life there in 1703 .

Winter; anchorage, in St. Paul harbor, Kodiak. So called by Lisianski in 1804. It is the Krestof (cross) bay of Russian naval officers in 1808-1810.

Winter; creek, Seward peninsula, tributary to Kaviruk river from the east, near latitude $65^{\circ} 20^{\prime}$, longitude $165^{\circ}$. Prospectors' name, reported by

$\therefore$ Gerdine, 1901.

Winter; harbor, indenting the northwestern shore of Pearse island, Pearse canal. So named by the Coast Survey in 1891.

Winter; island, at the liead of Afognak bay, Kodiak group, near latitude $58^{\circ}$ $03^{\prime}$, longitude $152^{\circ} \cdot 49^{\prime}$. Local name, reported by Moser, 1900.

Winthrop; spur, of mountain on north bauk of the Koyukuk, near longitude $156^{\circ}$. Also called Point Winthrop. Name from Schrader, 1899.

Wipple, mountain; see Whipple.

Wiseman; creek, tributary to Middle fork Koyukuk river, on the west or right bank, near latitude $67^{\circ} 30^{\prime}$, longitude $150^{\circ}$. Prospectors' name, reported by Schrader, 1899, who erroneously gave the name to Minnie creek on the left bank.

Wislow; islet and cape, on the northern shore of Unalaska, 4 miles west of Cape Cheerful, near longitude $166^{\circ} 43^{\prime}$. . So called by the Fish Commission in 1888. Perhaps this is an error for Winslow.

Witnesses (The); two islets, in San Alberto bay, Bucareli bay, Prince of Wales archipelago. Named Los Testigos (the witnesses) by Maurelle and Quadra, 1775-1779.

Wloyukuk; river, tributary to the Kuskokwim from the south, a little above Kolmakof. Native name, obtained by Spurr and Post, in 1898, from trader A. Lind. Has since been written O-loo-kok.

Wodehouse, point; see Woodhouse.

Wodopada, point; see Village.

Woewodski; harbor, indenting the southern śbore of Admiralty island and opening into Frederick sound, Alexander archipelago, near latitude $57^{\circ} 10^{\prime}$, longitude $134^{\circ} 15^{\prime}$. Named by Zarembo, in 1838, after Stepan Vasilivich Woewodski, director of the Russian-American colonies, 1854-1859.

Woewodski; island, between Duncan canal and Wrangell strait, Alexander archipelago. Named by the Russians, 1848, after Capt.-Lieut. Stepan Vasilivich Woewodski, chief director of the Russian-American colonies, 1854-1859. Variously written Woewodsky, Voevodskago, etc. Lindenberg, in 1838, called part of this Medviezhi (bear).

Woedsky; post-office (established in 1902), on Woewodski island, Alexander archipelago.

Wolasatux; Indian hut, on left bank of Yukon river, a few miles below Nulato. Wolasatux was a young man who escaped massacre at Nulato in 1851. This place took its name from him. Erroneously Wolsatux.

Wolcot; mountain (Mount Wolcot, 5,300 feet high), in the Fortymile region, eastern Alaska, near latitude $64^{\circ} 40^{\prime}$, longitude $141^{\circ} .40^{\prime}$. Prospectors' name, from sketch map compiled by Major Glassford, Signal Corps, U. S. A., 1905.

Woleet, river; see Wulik. 
Wolf; creek, Kenai peninsula, on the left bank cf Resurrection creek, 8 miles above Hope (city). Local name, from Moffit, 1904.

Wolf; creek; in the Fairbanks region, tributary to Cleary creek from the east, near latitude $65^{\circ} 05^{\prime}$, longitude $147^{\circ} 25^{\prime}$. Prospectors' name, reported by. Gerdine, 1903.

Wolf; creek, eastern Alaska, tributary on south bauk of Birch creek, near latitude $65^{\circ} 15^{\prime}$, longitude $145^{\circ}$. Frospectors' name, reported by Witherspoon, 1905.

Wolf; creek, tributary to Mission creek from the south, 4 miles west of Eagle. Local name, obtained by Spurr's party in 1896.

Wolf, island; see Kritskoi.

Wolf; point, the ealsternmost point of Walrus island, near entrance to Port Moller, Alaski peninsula. The island of which this is the eastern point was named Volchie (wolf) by Lutke, 1828 , but is now known as Walrus island. The point was named Wolf by Dall in 1.882.

Woif; rock, off the west coist of Prince of Wales archipelago. So named by

- Vancouver in 1794. Meares, 1788, called it Forrester's island (chart, p. 1) and the Spaniards, 1774-1779, Isla Rasa (flat island).

Wolff; peak, south of Nount Drum. So named by Schrader, 1898, after Prof. John. Eliot Wolff, of Harvard University. The peak which Schrader described and named does not exist. The mountain which he thought he saw in this position was afterwards identified as Mount Sanford.

Wolftrap; rocks, in Yukon river and creek tributary to it from the north, 25 miles below Rampart (city) and 10 miles above the rapids, near longitude $150^{\circ} 45^{\prime}$. River pilots' name, written Wolf-trap on Edwards' Track Chart of the Yukon, 1899.

Wolley, cape; see Woolley.

Wolverine; creek, Kenai peninsula, a right-hand tributary of Quartz creek, which flows into Turnagain arm, Cook inlet. Local name, from Moffit, 1904. .

Wolverine; mountain $\left(4,640^{\circ}\right.$ feet high), southeast of the Ramparts of the Yukon, near latitude $65^{\circ} 20^{\prime}$, longitude $150^{\circ}$. Prospectors' name, reported by Brooks, 1902.

Womens; bay, an arm of Chiniak bay, Kodiak. Named Babia (women) by Russian naval officers, 1808-1810.

Wonder, creek ; see Center.

Wonder; creek, $2 \frac{1}{2}$ miles north of Nome, Seward peninsula, tributary to Center creek, from the east, near longitude $165^{\circ} 23^{\prime}$. Local name, from Gerdine, 1904.

Wood; canyon, on Copper river, a little below the mouth of the Chitina. Named Wood's by Allen, $\cdot 1885$, "in honor of Col. Henry Clay Wood, U. S. A."

Wood; glacier, at the head of Geikie inlet, on the west shore of Glacier bay, southeastern Alaska. So named by Reid, 1892, "after Lient. Charles Erskine Scott Wood, who seems to have been the first white man to enter Glacier bay." He was there in 1877. See also Geikie.

Wood, island; see Woody.

Wood; point, the southeastern point of entrance to Thomas bay, Frederick sound, Alexander archipelago. So named by Thomas, 1887 .

Wood; point, on the south shore of Norton sound, 10 miles east of St. Michael bay, near longitude $161^{\circ} 40^{\prime}$. Local name, published in 1904.

Wood; river, draining from Aleknagik lake to Nushagak bay. Apparently a local name, applied by the Fish Commission in 1890. In Sarichef's atlas (18.26, sheet 3 ) it is called Aliagnagik and by Tebenkof. 1849, Aleknagek. 
Wood; spit, in Holkham bay, Stephens passage, Alexander archipelago. So named by Mansfield, 1889.

Woodchopper; creek, tributary to Yukon river from the south, below Coal creek, near latitude $65^{\circ} 20^{\prime}$, longitude $143^{\circ} 15^{\prime}$. Local name, reported by Collier, 1902.

Woodchopper; island, in Kootznahoo inlet, Admiralty island, Alexander archipelago. So named by Meade, 1869 .

Woodcock; point, the north head of McLeod harbor, Montague island, Prince William sound. So named by Portlock, 1787, after Joseph Woodcock, a student who accompanied him on his voyage.

Wooded; cape, on the southwestern shore of Spruce island, Kodiak group. Named Liesnoi (wooded) by Murashef, 1839-40.

Wooded; islands, near Montague island, Prince William sound. Described by Vancouver, 1794, and apparently named by the Coast Survey in 1869.

Wooded; islet, off the northwestern shore of Spruce island, Kodiak group. Named Liesistoi (wooded) by Murashef, 1839-40.

Wooden; islet, near Cape Ommaney, Chatham strait, Alexander archipelago. Named by Vancouver, 1794, after Isaac Wooden, a member of his party, who fell overboard and was drowned in its vicinity.

Woodhouse; point, the southern point of Biorka island, Sitka sound, Alexander archipelago. Vancouver, 1794, gave this name to the "southeast point of a spacious opening whose northwest point was formed by Cape Edgecumbe, and which comprised Dixon's Norfolk Sound. From the bearings and distance given by Vancouver it seems evident that he applied the name to some part of the high land immediately to the westward of the western part of Crawfish Inlet, which, from his distance from the shore and the consequent invisibility of many of the low islets of the Necker group, appeared like the southeastern headland of the sound. His text and charts are in accord on this question. As early as 1818 , however, bearing in mind the intention rather than the erroneous location, the name was applied on the chart of Sitka, and by Russian naval officers and forming No. XIX of the old Russian series, to the south point of Biorka Island, which has since been known by the name of Woodhouse." Has also been written, erroneously, Wodehouse.

Woods; creek, tributary to the headwaters of Canyon creek, in the Fortymile mining region. Local name, obtained by Barnard in 1898.

Woodworth; glacier, tributary to Tasnuna river, between Port Valdez and Copper river. Named by Schrader, 1898, after Mr. Jay Backus Woodworth, of Harvard University.

Woody; inlet, in Peard bay, Arctic coast. So called on British Admiralty charts. According to John Murdoch, its native name is Ku-áh-ru.

Woody; island, off Vexation point, in Wrangell strait, Alexander archipelago. Named Liesnoi (woody) by Lindenberg, 1838.

Woody; island, near St. Paul, Chiniak bay, Kodiak. Named Liesnoi (woody) by Lisianski in 1804. Often called Wood island.

Woody, islet; see Liesnoi.

Woody; point, the north point of entrance to Whitewater bay, Admiralty island, Alexander archipelago. So named by Meade, 1869.

Wooleek, river; see Wulik. 
Woolley; cape, on the westeru shore of Seward peninsula, a little south of Port Clarence. Named Woolley by Beechey, 1826. Has also been written Wolley and Wooly.

Wooly Head; precipitous bluff (about 2,000 feet bigh), on the western shore of Nagai island, Shumagin group. So named by the fishermen, prior to 1871 , on account of the violent gusts of wind, called Woolies, experienced there. This word is supposed to be (a) either a Patagonian word for a violent local gust or (b) to come from the white foam on the water, resembling washed wool, which the wind produces.

Woronkofski; island, between Wrangell and Zarembo islands, Alexander archipelago. Named by the Russians, after Lieutenant Woronkofski, of the Russian navy, who in 1836 explored the southern shore of Alaska peninsula. Variously written Voronkowski, Voronkoffski, etc.

Woronkofski; point, the northernmost point of Woronkofski island, Alexander archipelago. So named by Dall, 1879.

Woronzof; point, at head of Cook inlet. Named by Vancouver, 1794, "after His Excellency the Russian ambassador at the British court."

Worsham, bay ; see Kisselen.

Worthington; glacier, about 15 miles east of Valdez and tributary to Ptarmigan creek. Name from Schrader, 1900.

Wosnesenski, cape; see Kasilof.

Wosnesenski; glacier, on Kenai peninsula, near Kachemak bay, Cook inlet. So named by Dall, 1880, after Elias G. Wosnesenski, of the St. Peter'sburg Academy of Sciences, who made collections and observations in this region in 1842-1844.

Wosnesenski; island, off the southern shore of Alaska peninsula and west of Unga island, Shumagin group. Veniaminof and Lutke called it Peregrebny, in Aleut, Unatkuyuk, meaning crested or serrated. Later it was called Vosnesenski, after Elias G. Wosnesenski, who in 1842-1844, explored and collected, for the St. Petersburg Academy of Sciences, in western Alaska. This name has had many spellings, Vossnessensky, Wossnessensky, Wosnesensky, and even Vozoychenski.

Wosnesenski; native village, on Wosnesenski island. A chapel, costing $\$ 1,500$, was erected in this village by the natives and dedicated under the name of Ascension.

Wrangell; cape, the westernmost point of Attu island, western Aleutians. So called by Lutke, 1836, after Baron von Wrangell.

Wrangell; harbor, near the north end of Wrangell island, Alexander archipelago. Surveyed, in 1834, by 'Capt. Lieut. Dionysius Feodorovich Zarembo and by him named after Capt. Adolph Karlovich Etolin, who, in 1840 , became director of the Russian-Ameriçan colony. The harbor has been variously called Etolin harbor, Port Wrangell, and Wrangell harbor. The last appears to be the prevailing usage at present and is here adopted.

Wrangell; island, Alexander archipelago. Named by the Russians after Admiral Baron Ferdinand Petrovich von Wrangell. Erroneously spelled Wrangle and Wrangel. The spelling of this word Wrangell forms the subject of a special note in Baer and Helmersen's Beitrage, etc. (vol. 1, p. 328), in which it is stated that while different persons of the name have adopted different modes for spelling it, the individual here referred to, one of the most eminent of that noble and distinguished family, invariably spelled his own with two l's. According to Tebenkof, the native name is Kach-khanna. 
Wrangell; island, off the northern shore of Siberia, northwesterly from Bering strait. The existence of this land was reported by natives, in March and April, 1823, to Baron von Wrangell, who then made an unsuccessful search for it. It was first clearly seen and its shore delineated by Capt. Thomas Long, of the New London whaling bark Nile, in August, 1867 , and by him called Wrangell's Land. From that date to 1881 it was shown on maps as the south end of a tract extending indefinitely northward and, by some, thought to connect with Greenland across the north pole. Its insular character was established by Berry, in 1881, and since that time it has borne the name. Wrangell island. Possibly Plover island of Kellett, in 1849, may be some peak of this island seen from afar.

Wrangell; island, one of the Necker group, Sitka sound, Alexander archipelago. Has been erroneously printed Wrangle. Was named Big Wrangell by Vasilief, in 1809, and another near by was called Little Wrangell.

Wrangell; mountain (14,000 feet high), east of Copper river, near latitude $62^{\circ}$. Named by the Russians after Baron von Wrangell, whose branch of the family always used the double "l." Erroneously Wrangle. Grewingk speaks of it both as Mount Wrangell and Chechitno peak.

Wrangell; mountains, of which Mount Wrangell is the highest peak, lying north of Chitina river, west of Nizina river, and in the great bend of - Copper river. So defined by Schrader, 1901.

Wrangell; peak, on the mainland $(3,800$ feet high), near the mouth of Stikine river. So called as early as 1887 and perhaps earlier. Erroneously Wrangel.

Wrangell; port, on the southern shore of Alaska peninsula, west of Kodiak, near longitude $156^{\circ} 30^{\prime}$. Surveyed by Vasilief, 1831, and named after the then director of the Russian-American colonies, Baron von Wrangell.

Wrangell; strait, connecting Sumner strait with Frederick sound and separating Mitkof island from Kupreanof and Woewodski islands, Alexander archipelago. Named by the Russians after Vice-Admiral Baron von Wrangell.

Wrangell; town, on the northern end of Wrangell island, Alexander archipelago, near latitude $56^{\circ} \cdot 28^{\prime}$, longitude $132^{\circ} 23^{\prime}$. Often called Fort Wrangell. The Russians built a stockaded post here, in 18:34, to resist encroachments by the Hudson Bay Company and named it Redoubt St. Dionysius. The United States established a military post here, in 1867, which was maintained with interruptions until May, 1877, and then abandoned. This post was called Fort Wrangell. Often misspelled Wrangle and Wrangel. A post-office was established here in October, 1885, called Fort Wrangell, and changed to Wrangell in 1902.

Wrangell Narrows. The contracted part of Wrangell strait was so designated by the pilots, a name published by the Hydrographic Office in 1869.

Wrangell North Flat; see North.

Wrangell South Flat; see South.

Wright; glacier, on the mainland, left bank of Taku rirer, southeastern Alaska, near latitude $58^{\circ} 30^{\prime}$, longitude $133^{\circ} 30^{\prime}$. So named by Hayes, 1891, after Prof. George Frederick Wright, of Oberlin College.

Wright, island; see Aston.

Wright; mountain (4,944 feet high), near Muir inlet, Glacier bay, southeastern Alaska. So named by Reid, 1890, after Prof. George Frederick Wright, who spent some time in this vicinity in 1886. 
Wright; point, on the southeastern shore of Dease inlet; Arctic coast. Name from British Admiralty chart 593 (1830-1882).

Wsewidow, volcano; see Vsevidof.

Wulik; river, tributary to the Arctic ocean, between Point Hope and Cape Krusenstern. An Eskimo name, given by Stoney, 1886, as Woleek, by the Coast Survey, in 1890, as Woleek, and by the Hydrographic Office as Wooleek.

Wyanda, ledge; see Wayanda.

Wyvill; reef, northeastern side Neva strait, Alexander archipelago, near latitude $57^{\circ} 16^{\prime}$, longitude $135^{\circ} 35^{\prime}$; " extends to mid-strait and bares about 9 feet at its highest point." Probably local nane, reported by Moore, 1897.

Yacherk; Eskimo village, on Igushik river, near Amanka lake, about 25 miles west of Nushagak. Native name, from Spurr, of the Geological Survey, 1898, who wrote it Yachérgamut; i. e., Yacherk people.

Yachtshilagamut, village; see Yakchilak.

Yacotat, bay ; see Yakutat.

Yagal, cape; see Yakak.

Yaganuda; bay or bight, on the southwest coast of St. George island, Bering sea, just east of Dalnoi point, near. longitude $169^{\circ} 466^{\prime}$. Aleut name, obtained by Putnam, 1897, and written Yäg'ăn-ūdii', wooded bay.

Yageltaliek, bay; see Alitak.

Yagodnoi, island; see Berry.

Yahna, river; see Yana.

Yahtse; glacial stream, from Malaspina glacier, debouching in Icy bay, southeastern Alaska, near longitude $141^{\circ} 15^{\prime}$. Native name, given as Yahtsé or Yahtse-tah. Has also been called Jones river. Late maps show two rivers; called East Yahtse and West Yahtse, respectively.

Yahtse-tah-shah, mountain; see St. Elias.

Yaichnia, islets; see Guibert.

Yaitchni, cape; see Egg.

Yaitchny, islets; see Guibert.

Yakaio, cape; see Yaktag.

Yakak; cape, the southwesternmost point of Adak island, Andreanof group, middle Aleutians. Aleut name, from Tebenkof, 1849. Veniaminof gives Yagak as the Aleut word for firewood or driftwood. The name has been written Jachach.

Yakatag, Yakataga, cape; see Yaktag.

Yakchilak; Eskimo village, on Kuskokwim river, left bank, near its mouth. Nitive name, reported by Spurr and Post, of the Geological Survey, in 1898, as Yachtshilágamut, i. e., Yakchilak people.

Yaklek, cape; see Aklek.

Yakobi; island, the northwesterumost of the Alexander archipelago, near latitude $58^{\circ}$. So named by Lisianski, 1804, presumably in honor of Gen. Ivan Yakobi. Also written Jacob, Jacobi, Jacobieff, etc. See also Cinichagof.

Yakobi; rock, near Cape Bingham, the southenst point of entrance to Cross sound, southeastern Alaska, near latitude $58^{\circ} 05^{\prime}$. So named by Pratt, 1901.

Takorni, point; see Anchorage. 
Yaktag; cape, near Mount St. Elias, southeastern Alaska. Apparently a native name, first applied by Tebenkof as Yaktaga in 1849. Has also appeared as Iaktag, Yakaio, and Yakiao. Martin says now (1904) the common local spelling and pronunciation is Yăk'atăg; sometimes Yakataga, pronounced Yăkătay'ga.

Yaktag; river, 3 miles west of Cape Yaktag, Gulf of Alaska, near longitude $142^{\circ} 30^{\prime}$. Local name, reported by Martin in 1903.

Yakutat; bay, in the St. Elias region, southeastern Alaska, near longitude $140^{\circ}$. Visited by La Perouse, 1786, who called it Baie de Monti. In the same year Portlock named it Admiralty bay: The Spaniards a little later, following Portlock, called it Almiralty and Almirantazgo. Lisianski, 1805, called it Jacootat and Yacootat. On the supposition that the bay was visited by Bering, in 1741, it has been called by his name. Usage has, however, settled upon the native name Yakutat.

Yakutat, colony ; see Glory of Russia.

Yakutat; glacier, between Dry and Yakutat bays, southeastern Alaska. Name published by the Coast Survey in $\mathbf{1 8 9 5}$.

Yakutat; roads, northern part of De Monti bay, Yakutat bay, on southeast side of Khantaak island. So called by Harber, 1892.

Yakutat; post-office (established in March, 1898) and village, on the southeastern shore of Yakutat bay, southeastern Alaska. Native name.

Yakutskalitnik; native village on right bank of the Yukon, at the mouth of Auto river. Name from Raymond, 1869. Not found on recent maps.

Yale; creek, tributary to Igloo creek from the north, Seward peninsula. Name from Brooks, 1900.

Yale; glacier, tributary to the head of College fiord, Port Wells, Prince William sound. So named by the Harriman expedition in 1899. Near it to the westward is Harvard glacier of the same expedition. These two were called Twin glaciers by Captain Glenn in 1898.

Yalik; native village, on Nuka bay, Kenai peninsula. Native name, reported by Petrof in 1880 .

Yamani; islets, off the entrance to Necker bay, Baranof island, Alexander archipelago. Named Yamani (full of pits or holes) by the Russians as early as 1850 .

Yana; glacial stream, from the Malaspina glacier, debouching near Icy bay and longitude $141^{\circ}$. Native name, reported by Russell in 1891. The termination na means river. Has also been printed Yahna.

Yanaliun, cape; see Bog.

Yancarnie; bay, indenting the southern shore of Alaska peninsula, north of Sutwik island. Name published by the Coast Survey in 1900.

Yanert; lake, northeastern Alaska, 20 miles southwest of Fort Yukon, on the right bank of Birch creek, near the Arctic Circle and longitude $146^{\circ}$. Named Yanert by Lieutenant Erickson, U. S. A., after William Yanert, an ex-soldier, who made explorations in this region in 1902. Kltagutan lake, of Petrof, 1880, is presumably meant for its Indian name.

Yanert; fork, a right branch of Cantwell river, near its source, about latitude $63^{\circ} 40^{\prime}$, longitude $148^{\circ} 30^{\prime}$. So named by Brooks, 1902, after Sergt. William Yanert, U. S. A., of Glenn's expedition, who penetrated to this point in 1898. Erroneously Yannert. 
Yanert Hole; a mountain, probably with a crater in the top, in the Rampart region, 40 miles southeast of Fort Hamlin, on the east bank of Crater creek, near latitude $65^{\circ} 40^{\prime}$, longitude $147^{\circ} .50^{\prime}$. So named by Lieutenant Erickson, U. S. A., after William Yanert, who made explorations in this region in 1902 .

Yangimak, island; see Little Koniuji.

Yankee; cove, indenting the eastern shore of Lynn canal, southeastern Alaska, near latitude $58^{\circ} 35^{\prime}$. Local name, reported by Spencer and Wright, 1903.

Yankee; point, on the western shore of Portland canal, near its head. Name published by the Coast Survey in 1897 .

Yankee; river, tributary to Mint river; in western part of Seward peninsula. Local name, from the prospectors.

Yankee Basin; mining camp, on the mainland southeastern Alaska, at the bead of Cowee creek, south shore Berners bay, eastern shore Lynn canal, near latitude $58^{\circ} 37^{\prime}$. Prospector's' name, from the Coast Pilot of 1901.

Yannert, creek; see Yanert fork.

Yantnu, river; see Yentna.

Yaponski, island; see Japonski.

Taram-anatuulug; rocky point at west end of East rookery, northeast coast of St. George island, Bering sea, near longitude $169^{\circ} 30^{\prime}$. Aleut name, written Yär'äm-ïnätī'ūlùg (narrow point) by Putnam in 1897.

Yarboro; inlet, on the Arctic coast, east of the mouth of Colville river: Named Yarborough by Sir John Franklin, August, 1826.

Yasha; island, at junction of Chatham strait and Frederick sound, Alexander archipelago. Named Yasha (Jakey, diminutive of Jacob) by the Russians. This island has been reserved for light-house purposes by Executive order dated January 4, 1901.

$Y a s n i$, island; see Andronica.

Yeastly or Egg. Raymond, in 1869, thus calls an island in the Yukon delta, near the head of Kwikpak pass. Not identified on recent charts.

Yeatman; mountain (Mount Yeatman, 5,690 feet high), on the west bank of Taiya river, southeastern Alaska, near latitude $59^{\circ} 33^{\prime}$, longitude $135^{\circ}$ $23^{\prime}$ So named by Flemer in 1898 , but not hitherto published.

Yedno, river; see Yentna.

Ycluk, cape and village; see Ekuk.

Yelchthini, river, Chilkat valley; see Bear creek.

Yellow; hill (554 feet high), near Metlakatla, on Annette island, Alexander archipelago. So named by Nichols in 1883.

Yellow; hills, on St. Lawrence island, Bering sea. So called by Mr. V. C. Gambell, who with his wife taught the school on the island from 1894 to 1898 .

Yellow; point, on Baranof island, near Northern rapids, Peril strait, Alexander archipelago. Named Zholti (yellow) by Vasilief, 1833 .

Yellow; point, on the eastern shore of Tamgas harbor, Annette island, Alexander archipelago. Has also been called signal point.

Yellow; rock, south side Kelp bay, Chatham strait, Alexander archipelago"the northernmost of the islands west of Pond island"-near latitude $57^{\circ} 18^{\prime}$, longitude $134^{\circ} 54^{\prime}$. Descriptive name, given by Moore, 1895 .

Yellow; rocks, two in number ( 20 feet high), in Dixon entrance, 7 miles southeast from Cape Northumberland. So named by Nichols, 1883, by reason of their color: . 
Yellow Cedar; bay, on the north side of Hawkins island, in eastern part of Prince William sound. So called in Twentieth Annual Report Geological Survey (part 7, p. 406). . Not shown on any maps. Presumably it local name.

Yellowstone; creek, tributary to Port Clarence from the east, Seward peninsula. Name from Barnard, 1900.

Yellowstone; creek, eastern Alaska, on the south bank of Seventymile creek, near latitude $64^{\circ} 55^{\prime}$, longitude $142^{\circ} 10^{\prime}$. Frospectors' name, from sketch map compiled by Major Glassford, Signal Corps, U. S. A., 1905.

Yellowy, island; see Spruce.

Yelovoi, island; see Spruce.

Yelowoi, island; see Elovoi.

Yendestaka, village; see Gan-te-gas-tak-heh.

Yenlo; mountain (about 3,885 feet high), on north bank of Yentna river, 60 miles north-northwest from the mouth of Susitna river, near latitude $62^{\circ}$, Iongitude $151^{\circ} 20^{\prime}$. So called by . Spurr and Post, of the Geological Survey, 1898.

Yentna; river, tributary to the Susitna from the northwest, about 25 miles above the mouth of the latter.' Native name. Spurr: and Post, 1898. report that it is known to the natives as Katcheldat or Yentna. Glenn, 1898, writes it Yentna. Lieutenant Learnard with Glenn, 1898, says it is called Yantnu (Yadno) by the Indians, and Johnson, by some whites-the name of the first white man to ascend it.

Yes; bay, Cleveland peninsula, Alexander archipelago. Native name, spelled . Yās, Yāas, Yes, and Yess. Named McDonald by Dall, 1879, and of ten called McDonald or Yes bay. Yãs is Tlinket for mussel.

Yes Bay; native village and cannery, at Yes bay, Alexander archipelago. The fishery was established here in 1886.

Yokuchargut, creek ; see Hess.

York; cape, in Bering strait; about 10 miles southeast of Cape Prince of Wales. So named by Beechey in August, 1827, "in honor of His Royal Highness."

York; mining camp, at Cape York, Seward peninsula. The post-office established here in April, 1900, was discontinued in 1902.

York; creek, Seward peninsula, tributary from the south to Pinguk river, near latitude $65^{\circ} 46^{\prime}$. Local name, reported by Collier, 1903.

York; mining district, in the extreme western part of Seward peninsula. Called the Kanowock, or York mining district.

York; group of islands, in Alexander archipelago, of which the principal ones are Etolin, Seward, Woronkofski, Wrangell, and Zarembo. Named Duke of York's islands by Vancouver in September, 1793, after the Duke of York, a name since shortened to York.

York; mountains, Seward peninsula, north and east of Cape York. Local name, reported by Gerdine, 1901.

Youcon, river; see Yukon.

Youkolny, island; see Ukolnoi.

Youlal, island; see Ulak.

Younaska, island; see Yunaska.

Young; bay, indenting the northern shore of Admiralty island, Stephens passage, Alexander archipelago, near latitude $55^{\circ} 10^{\prime}$, longitude $134^{\circ} 40^{\prime}$. Apparently so named by Dall in the Coast Pilot (1883, p. 172):

Young; cove, in Dall island, Howkan strait, Cordova bay, Alexander archipelago. So named by Sheldon Jackson, 1880, after Rev. Samuel Hall Young, a missionary, who began work at Wrangell in 1878. 
Young; creek, tributary to Nizina river from the south. So named by Gerdine: 1900 , after Robert Young, a member of his party.

Young; creek, tributary to Kings creek from the west, which latter is in turn tributary to the Mantnauska river about 30 miles above its mouth. So named by Glenn, 1898, after Corporal Young. a member: of his party. Called also Little Kings by the prospectors.

Young; island, at entrance to View cove, Tlevak strait, Cordova bay, Alexander archipelago. So named by Dall, 1S82, after Rev. S. Hall Young.

Young, island; see Corlies.

Young; island, in Foyukuk river, 10 miles above the mouth of the Huslia river, near latitude $66^{\circ} 50^{\prime}$, longitude $156^{\circ} 20^{\prime}$. River pilots' name, reported by Lieutenant Camden, Revenue-Cutter Service, 1900.

Joung; marsh, in Fritz cove, Donglas island, Alexander archipelago. Called Young's marsh by Symonds, 1880. Later charts do not show. any marsh here.

Young; mountain (5,260 feet high), between Lynn canal and Glacier bay, southeastern Alaska. Named by Reid, 1892, after Rev. S. Hall Young.

Young; point, the eastern point of entrance to Auke cove, Stephens passage, Alexander archipelago, at the east end of Young bay above, near latitude $58^{\circ} 12^{\prime}$, longitude $134^{\circ} 33^{\prime}$. So named by Vancouver in 1794 .

Young; sunken rock, in Zimovia strait, near north end of Etolin island. Discovered by Rev. S. Hall Young, 1882, and named after him by the Coast Survey.

Youp-nut, creek; see Anikovik.

Yugnat; rocks, off the northern point of entrance to Kukak bay, Shelikof strait. Apparently a native name, from Vasilief, 1831.

Inkagamut, village; see Ikuak.

Tukagamut, village; see Ingahameh.

Yukamak; island, southwest of Kodiak. See Chirikof.

Yukla; creek, tributary from the east to Knik arm, Cook inlet, near latitude $61^{\circ} 15^{\prime}$, longitude $149^{\circ} 40^{\prime}$. Native name, obtained by Mendenhall, 1.898. Has also been called Yukla-hina river.

Yulla-hitna, river; see Yukla creek.

Yuko; river, tributary to the Yukon from the soutl, about 40 miles above the mouth of the Koyukuk. Native name, reported, 1.861, by Tikbmenief. who wrote it Yukukakat, i. e., Yuku river; see Kakat. Has also been written Yukokargut and appears to be identical with Soonkakat of recent maps. See Soonkakat.

Yukolialat. Petrof in the Tenth Census, 1880, gives this as the name of a settlement, of 6 people, on the north bank of Yukon river, at the mouth of the Yuko or perhaps Soonkakat river.

Yukolion, river; see White.

Yukon; flats, in the valley of the Yukon, extending 200 miles from the mouth of the Dall to Circle (city).

Yukon; harbor, indenting the southeastern shore of Big Koniuji island, Shumagin group. So named by Dall, 1874, after the Coast Survey schooner Yukon.

Yukon; hills or mountains (1,000 to 2,500 feet high), between the Yukon and Koyukuk river's, central Alaska. Called Yukon mountains by Dall, 1869.

Yukon; island, on the southern shore of Kachemak bay, Cook inlet. So named by Dall, 1880, after the Coast Survey schooner Yukon. Now occupied by parties engaged in raising blue foxes. 
Yukon; island, in Yukon river, at mouth of the Koyukuk. So named by Allen, 1885.

Yukon; principal river of Alaska. The headwaters of this river were known to traders of the Hudson Bay Company early in the 19th century. Its lower part was explored by the Russians in 1837-38. Derzhabin founded the Russian post Nulato in 1841, and McMurray, the English post Fort Yukon in 1847. The Eskimo name of the river, by which it was long known, is Kwik-pak (river big). Variously spelled Kvichpak, Kvikhpakh, etc. The Indian name is Yukon, variously written Youcon, Yucon, etc., while one tribe of Indians, according to Allen, call it Nigato, i. e., Niga river. Grewingk also gives the names Jukchana and Juna, i. e., Jukcha river and Ju river. The form Yukon has also been . adopted by the Canadian Board on Geographic Names.

Yukutzcharkat, creek; see Hess.

Yukwonilnuk; river, tributary to the Kuskokwim from the north, near longitude $158^{\circ}$. Native name, obtained by Spurr and Post, in 1898, from trader A. Lind.

Yunalch, island; see Ümak.

Yunaska; volcanic island $(2,864$ feet high), in the group of islands of the Four Mountains, eastern Aleutians. Veniaminof includes it in that group. Native name, from Sarichef, about 1790. Variously written Junaska, Unaska, Younaska, etc.

Zachary; bay, indenting the north shore of Unga island, Shumagin group. Named Zakharefskaia by the Russians, after a Russian named Zakharef. Variously spelled Sacharowskaja, Zakhareffskaia,- etc. Called also Coal bay.

Zaikof; bay, in the north end of Montague island, Prince William sound. Named by the Russians, presumably after Stepan Kosmovich Zaikof, who was chief of the trading post St. Nicholas (Kenai) in the 18th century.

Zaikof; point, the northeasternmost point of Montague island, Prince William sound. So named by Davidson, 1868.

Zakatlatan; village (population 39), on north bank of the Yukon, near longitude $156^{\circ} 30^{\prime}$. In the Tenth Census a village called Zakatlatan is located here on the south bank. In the Eleventh Census we have Sakataloden, supposed to be the same place. On late maps it is Saghadellautan. Raymond, 1869, has Sakedelontin. Edwards' 'Track Chart of the Yukon, 1899, shows a place on the north bank called Sardu-loten. The telegraph station, Louden, is on the north bank at or near here.

Zakhareffskiaia, bay; see Zachary.

Zakharof, bay; see Stepovak.

Zakritoi, bay; see Banks harbor.

Zaliva, point; see Bay.

Zane; pass, between the valleys of Kobuk and Koyukuk rivers, by way of Pah and Dakli rivers, near the Arctic circle and longitude $156^{\circ} 30^{\prime}$. Named after Ensign A. V. Zane, U. S. N., a member of Stoney's Expedition, who went over this route from Kobuk river to St. Michael and return in the winter of $1885-86$.

Zanes; cliff, on the western end of Wrangell island, Arctic ocean. So named by Berry, 1881.

Zapadni; open bay, on the southwest shore of St. George island, Pribilof group, Bering sea. Called Zapadni (west) by the Russians and locally so known. It is Southwest bay of some charts. . 
Zapadni; point, the western point of entrance to English bay, on the south shore of St. Paul island, Pribilof group, Bering sea. Locally known as Zapadni (west). Has been called South point on several charts. Zapadni rookery is on this point. Has also been written Zapadnie.

Zapadni; rookery, on Zapadni bay, southwest coast St. George island, Bering sea, near longitude $169^{\circ} 40^{\prime}$. Local name, written Zapadnie by Elliott, $1872-1874$.

Zapadni; rookery, southern coast St. Paul island, Bering sea, on Zapadni point, western shore Inglish bay, near longitude $170^{\circ} 20^{\prime}$. Local name, written Zapadnie (west) by Elliott, 1872-1874.

Zapadnie, cape; see West.

Zapadnie, point; see Northwest.

Zapadnie, point; see Southwest.

Zapadni Reef; roókery, southern coast St. Paul island, Bering sea, on north shore of English bay, near longitude $170^{\circ} 19^{\prime}$. Local name.

Zarembo; island, between Clarence, Stikine, and Sumner straits, Alexander archipelago. Named by the Russians, after Capt.-Lieut. Dionysius Feodorovich Zarembo. Has also been written Zaremba.

Zatchlitschak, island; see Sitkalidak.

Zatschra, island; see Hydra.

Zayas; island, in eastern part of Dixon entrance. Named Isla de Zayas by Caลmaño, 1792.

Zdluiat; Indian village, on Knik arm of Cook inlet. Native name, reported by Petrof, 1880.

Zeal; point, the south point of entrance to St. John Baptist bay, Neva strait, Baranof island, Alexander archipelago. Named Userdie (zeal) by Vasilief, 1833. Also written Ouserdi.

Zeaman; gulch, 9 miles northwest of Cape Nome, Seward peninsula, draining the north slope of Army peak into Osborn creek, near longitude $165^{\circ}$ 10'. Local name, published in 1904.

$Z e i k h s l l$, river; see Tiekel.

Zelonie, point; see December.

Zelonoi, point, rocks, etc.; see Green.

Zenobia; sunken rock, near Eastern channel into Sitka harbor, Sitka sound, Alexander archipelago. Named by the Russians after the ship Zenobia, which struck upon it in 1855 .

Zharof, island; see Egg.

Zhekiski, point; see Shekesti.

Zhemani, point; see Shaman.

Zhila, cape; see Blunt point.

Zlitia, cape; see Head.

Zhila, point; see Hut.

Zhila, point; see Lode.

Zholti, point; see Yellow.

Zhuravlina, cove; see Crane.

Ziatitz, harbor; see Three Saints.

Ziatitz, village; see Nunamiut.

Zimovia; point, on the north bank of Chilkat river, near its mouth. Named. Zimovia (winter) by Lindenberg in 1838. It appears to be identical with the Spuhn point of naval officers in 1880 .

Bull. 299-06 $\mathrm{M} \longrightarrow-44$ 
Zimovia; strait, separating Wrangell island from Etolin and Woronkofski islands, Alexander archipelago. Named Zimovia (winter) by the Russians.

Zirku, rivèr ; see Tsirku.

Zlatousta, harbor ; see Saint Chrysostom.

Zokneda; lakes, two small lakes, between Tanada lake and Copper river, and draining into Copper river from the west, near latitude $62^{\circ} 25^{\prime}$. Indian name, reported by Schrader in 1902, who says the western one is commonly known as Lake Billy.

Zolotoi; bay and sands (" a reach of very beautiful drifting sand"-Elliott), southern coast St. Paul island, Bering sea, on the northwest side of Reef point, near longitude $170^{\circ} 17^{\prime}$. Called Zolotoi (golden) by the Russians, and written Zoltoi by Elliott, 1872-1874.

Zoltoi, bay and sands; see Zolotoi.

Zotschominia; islands; see Noisy.

Zouboff, islands; see Pribilof.

Zubof; rock, awash at lowest tides; in The Basin, three-eighths of a mile southwest of Crow island, Kelp bay, Chatham strait, Alexander archipelago, near latitude $57^{\circ} 17^{\prime}$, longitude $134^{\circ} 55^{\prime}$. Russian surname, written Zuboff by Moore in 1895.

Zufutch, rocks; see Seal.

Zumik, islands; see Semidi.

Zutchwik, islands; see Sutwik. 